\title{
THE GENERA OF THE
}

\section{EUPATORIEAE (ASTERACEAE)}




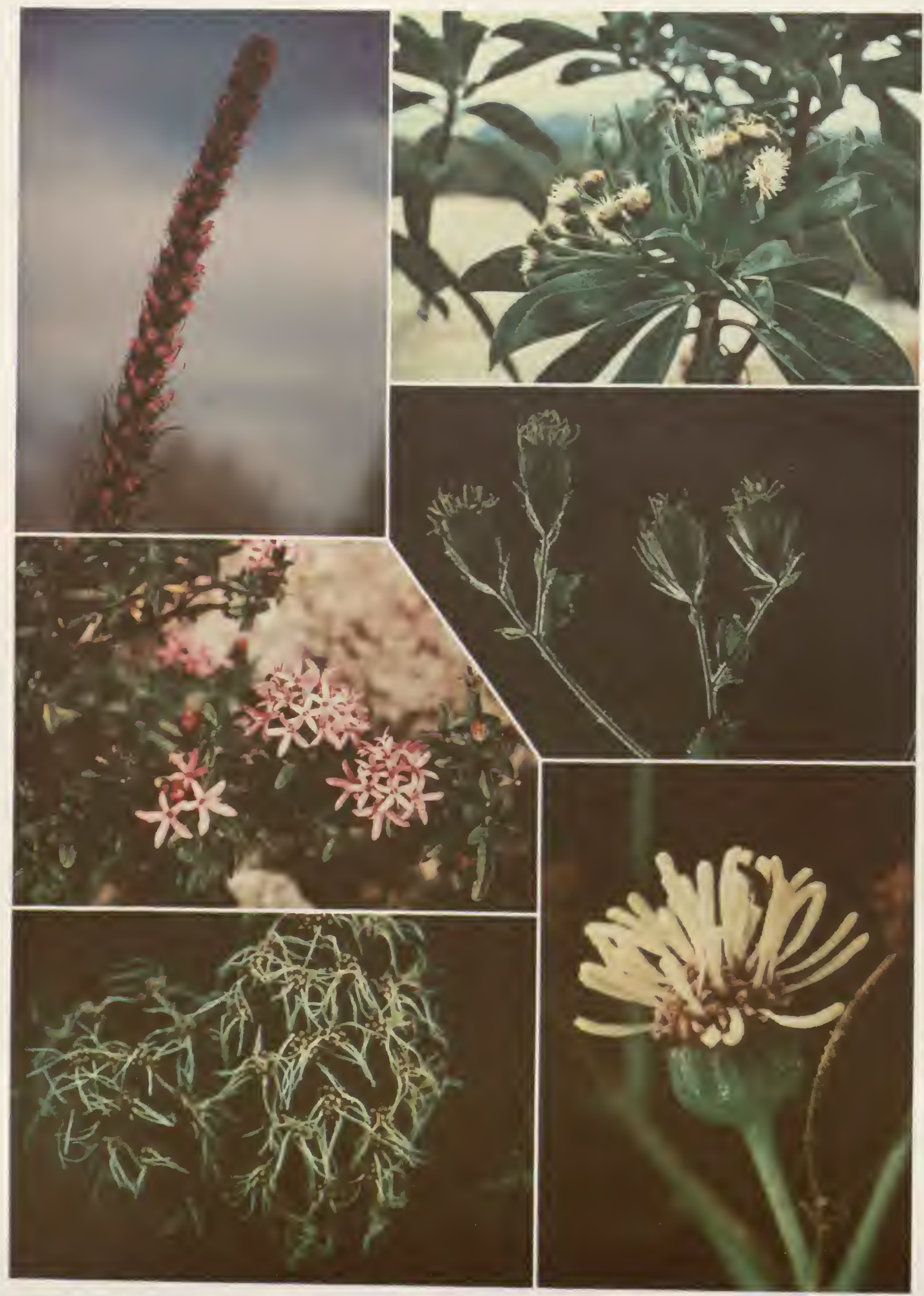

FrontisPiEcE. Top left: Liatris spicata (L.) Willd., United States. Top right: Morithamnus crassus R. King, H. Robinson \& G. Barroso, Bahia, Brazil. Middle left: Revealia macrocephala (Paray) R. King \& H. Robinson, Guerrero, Mexico. Middle right: Pseudokyrsteniopsis perpetiolata R. King \& H. Robinson, Guatemala, from greenhouse plant. Lower left: Grosvenoria hypargyra (B. Robinson) Morithamnus by Scot Mori Rever. Lower right: Adenostemma platyphyllum Cass., Ecuador, from greenhouse plant. Photographs of Natural History. 


\title{
Araall Reluniar A 11,1959 \\ THE GENERA OF THE EUPATORIEAE (ASTERACEAE)
}

\author{
Robert Merrill King and Harold Robinson
}
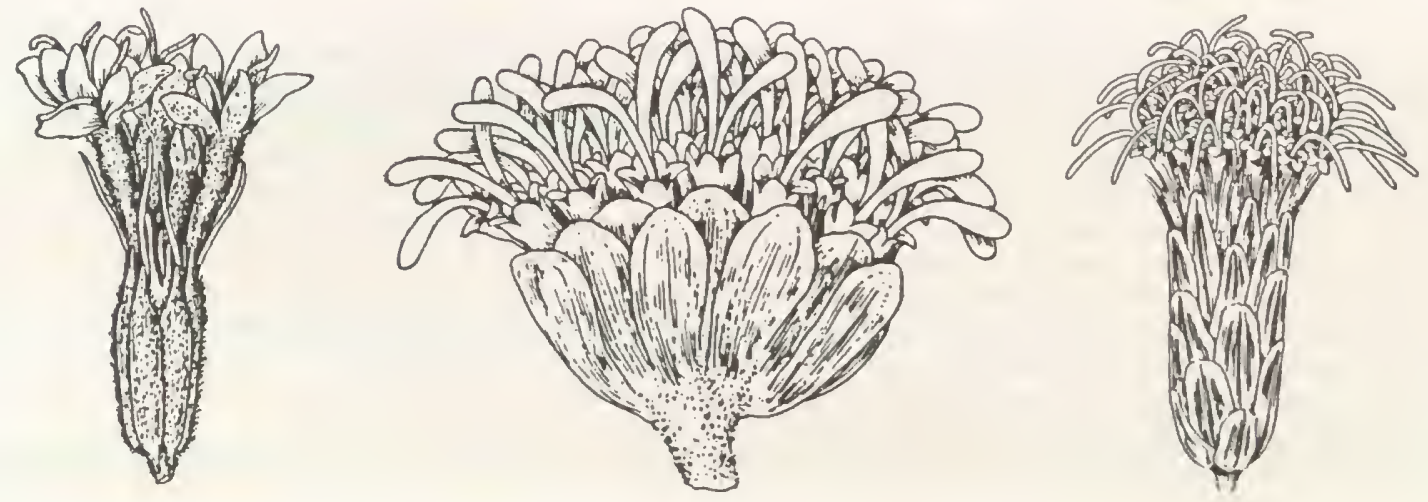

粘

1987 


\section{MONOGRAPHS IN SYSTEMATIC BOTANY \\ from the Missouri Botanical Garden}

Volume 22. October 1987.

ISSN 0161-1542

Authors' address:

Department of Botany, National Museum of Natural History, Smithsonian Institution, Washington, DC 20560.

Acknowledgements:

Many people are thanked for their contributions to this study. Most of the drawings were prepared by Regina O. Hughes (Smithsonian Institution) and Jack Schroeder (Stillpond, Maryland). Four plates and cover design were prepared by Alice Tangerini (Smithsonian Institution). The nomenclator was prepared by Edward Kaun, Dolores Kaun (both of Baltimore, Maryland), and David Bridge (Smithsonian Institution). We wish to thank Cheryl Bauer (Missouri Botanical Garden) for the careful editing of this manuscript.

The project has also been helped by the following individuals: L. Aristeguieta (Instituto Botánico, Caracas, Venezuela), V. Badillo (Universidad Central de Venezuela, Maracay, Venezuela), G. M. Barroso (Jardim Botanico, Rio de Janeiro, Brazil), Deborah Bell (Smithsonian Institution), J. Beaman (Michigan State University, East Lansing), L. Earl Bishop (Seattle, Washington), F. Bohlmann (Berlin, West Germany), D. Breedlove (California Academy of Sciences, San Francisco), R. D. Brettell (Smithsonian Institution), A. L. Cabrera (Instituto de Botánica Darwinion, San Isidro, Argentina), M. Canoso (Gray Herbarium, Harvard University), A. Clewell (Tallahassee, Florida), A. Cronquist (New York Botanical Garden), José Cuatrecasas (Smithsonian Institution), W. D'Arcy (Missouri Botanical Garden), H. Dawson (Randallstown, Maryland), C. Dodson (Missouri Botanical Garden), Lodi Earl (Baltimore, Maryland), G. Eiten (Universidade de Brasília, Brasilia), R. Ferreyra (Universidad Nacional Mayor de San Marcos, Lima), V. Funk (Smithsonian Institution), T. Filgueiras (Instituto Brasilero de Geografica e Estatistica, Brasília), A. Gómez-Pompa (Instituto Nacional de Investigaciones sobre Recursos Bióticos, Xalapa, Mexico), E. E. Hutton (Elkins, West Virginia), H. H. Iltis (University of Wisconsin, Madison), C. Jeffrey (Royal Botanic Gardens, Kew), J. J. Jiménez (Dominican Republic), V. Krantz (Smithsonian Institution), A. Lourteig (Laboratoire de Phanérogamie, Paris), D. Lellinger (Smithsonian Institution), R. Liesner (Missouri Botanical Garden), C. Marticorena (Universidad de Concepción, Concepción, Chile), S. Mori (New York Botanical Garden), R. McVaugh (University of Michigan, Ann Arbor), C. Nelson (Universidad Autónoma de Honduras, Tegucigalpa, Honduras), K. Parker (Smithsonian Institution), A. M. Powell (Sul Ross State University, Alpine, Texas), P. H. Raven (Missouri Botanical Garden), J. Russell (Baltimore, Maryland), J. Rzedowski (Instituto Politécnico Nacional, Mexico), A. Sessions (Smithsonian Institution), L. H. Shinners (Southern Methodist University, Dallas, Texas), J. Steyermark (Missouri Botanical Garden), and R. Wunderlin (University of South Florida, Tampa).

We also thank the curators of the following herbaria, who generously loaned us material for our study: A, B, BR, C, CAS, ENCB, F, FI, G, GDC, GH, K, L, LP, M, MEXU, MICH, MO, NY, P, RB, S, SMU, UB, UC, VEN, and WIS.

This project has been supported by grants to R. M. King from the following organizations: American Philosophical Society (Penrose Fund), National Geographic Society, National Science Foundation (GB 20502 A 1, GB 20502 A 2, BMS 70-00537, DEB 77-13457).

The cover illustration: Heads of Stevia, Adenostemma, and Chromolaena

Copyright (C) 1987 by the Missouri Botanical Garden All rights reserved.

Printed in the United States of America by

Allen Press, Inc., Lawrence, Kansas. 
This volume is dedicated to the three most important and able synantherologists of the 20th century in North America, Benjamin Lincoln Robinson, Sidney Fay Blake, and José Cuatrecasas. 

TABLE OF CONTENTS

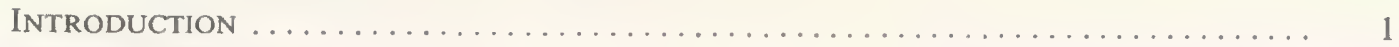

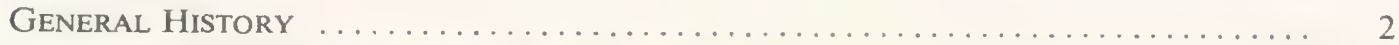

Chemistry and Cytology of the EupatorieaE $\ldots \ldots \ldots \ldots \ldots \ldots \ldots \ldots \ldots$

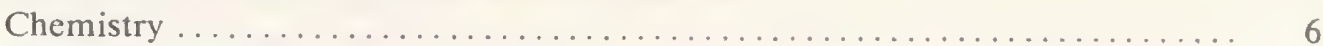

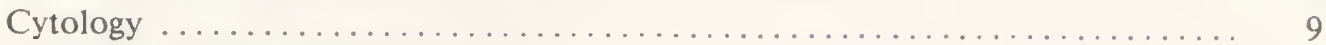

The RElationship of THE EUPATORIEAE $\ldots \ldots \ldots \ldots \ldots \ldots \ldots \ldots \ldots \ldots \ldots \ldots \ldots \ldots \ldots$

The Structure of the EupatorieaE $\ldots \ldots \ldots \ldots \ldots \ldots \ldots \ldots \ldots \ldots \ldots \ldots \ldots$

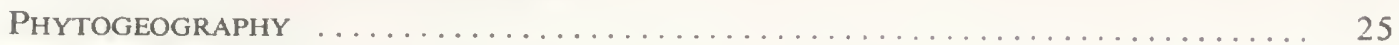

Keys to the Genera of the EupatorieaE $\ldots \ldots \ldots \ldots \ldots \ldots \ldots \ldots \ldots \ldots \ldots$

Artificial key to the genera of the Eupatorieae ..................... 30

Key to the subtribes of the Eupatoricae $\ldots \ldots \ldots \ldots \ldots \ldots \ldots \ldots \ldots . \ldots . \ldots . \ldots 4$

Key to the genera of the Eupatorieae in Mexico .................. 45

Key to the genera of the Eupatorieae in the West Indies ............... 48

Key to the genera of the Eupatorieae in Colombia . . . . . . . . . . . . . . . . . 49

Key to the genera of the Eupatorieae in Brazil $\ldots \ldots \ldots \ldots \ldots \ldots \ldots \ldots \ldots \ldots . . \ldots 1$

Treatment of the Subtribes and Genera of the Eupatorieae $\ldots \ldots \ldots \ldots \ldots \ldots .56$

Accepted sequence of the subtribes and genera of the Eupatorieae ......... 56

Subtribe I. Adenostemmatinae $\ldots \ldots \ldots \ldots \ldots \ldots \ldots \ldots \ldots \ldots \ldots \ldots$

Key to the genera of the subtribe Adenostemmatinae. 1. Adenostemma. 2. Sciadocephala. 3. Gymnocoronis.

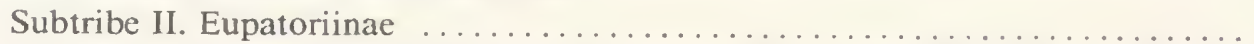

Key to the genera of the subtribe Eupatoriinae. 4. Eupatorium. 5. Austroeupatorium. 6. Stomatanthes. 7. Hatschbachiella.

Subtribe III. Disynaphiinae

Key to the genera of the subtribe Disynaphiinae. 8. Acanthostyles. 9. Rau linoreitzia. 10. Disynaphia. 11. Campovassouria. 12. Grazielia. 13. Symphyopappus.

Subtribe IV. Gyptidinae

Key to the genera of the subtribe Gyptidinae. 14. Gyptis. 15. Gyptidium. 16. Urolepis. 17. Barrosoa. 18. Dasycondylus. 19. Diacranthera. 20. Conocliniopsis. 21. Bejaranoa. 22. Prolobus. 23. Trichogonia. 24. Trichogoniopsis. 25. Platypodanthera. 26. Neocuatrecasia. 27. Vittetia. 28. Litothamnus. 29. Bahianthus. 30. Morithammus. 31. Agrianthus. 32. Arrojadocharis. 33. Lasiolaena. 34. Stylotrichium. 35. Bishopiella. 36. Campuloclinium. 37. Macropodina. 38. Conoclinium. 39. Tamaulipa. 40. Lourteigia.

Subtribe V. Ageratinae ................................. 136

Key to the genera of the subtribe Ageratinae. 41. Acritopappus. 42. Radlkoferotoma. 43. Ageratum. 44. Phania. 45. Phalacraea. 46. Blakeanthus. 47. Scherya. 48. Ascidiogyne. 49. Cavalcantia. 50. Teixeiranthus. 51. Gardnerina. 52. Ellenbergia. 53. Guevaria. 54. Ferreyrella. 55. Piqueriella. 56. Piqueriopsis. 57. Piqueria. 58. Stevia. 59. Metastevia. 60. Carphochaete. 61. Cronquistia. 62. Revealia. 63. Macvaughiella. 64. Microspermum. 65. Iltisia. 
Subtribe VI. Trichocoroninae

Key to the genera of the subtribe Trichocoroninae. 66. Trichocoronis. 67. Shinnersia. 68. Sclerolepis.

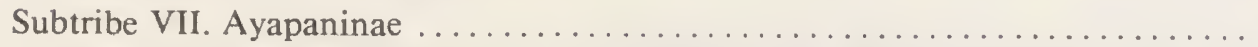

Key to the genera of the subtribe Ayapaninae. 69. Ayapana. 70. Ayapanopsis. 71. Polyanthina. 72. Gongrostylus. 73. Heterocondylus. 74. Condylidium. 75. Gymnocondylus. 76. Alomiella. 77. Monogereion. 78. Parapiqueria. 79. Lepidesmia. 80. Isocarpha.

Subtribe VIII. Alomiinae

Key to the genera of the subtribe Alomiinae. 81. Brickellia. 82. Barroetea. 83. Phanerostylis. 84. Brickelliastrum. 85. Flyriella. 86. Ageratella. 87. Asanthus. 88. Malperia. 89. Pleurocoronis. 90. Alomia. 91. Dyscritogyne. 92. Kyrsteniopsis. 93. Pseudokyrsteniopsis. 94. Steviopsis. 95. Carminatia. 96. Dissothrix. 97. Austrobrickellia. 98. Pseudobrickellia. 99. Goyazianthus. 100. Leptoclinium. 101. Planaltoa. 102. Crossothamnus. 103. Helogyne. 104. Condylopodium.

Subtribe IX. Liatrinae

Key to the genera of the subtribe Liatrinae. 105. Liatris. 106. Litrisa. 107. Trilisa. 108. Carphephorus. 109. Garberia. 110. Hartwrightia.

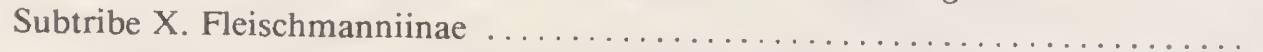

Key to the genera of the subtribe Fleischmanniinae. 111. Fleischmannia. 112. Sartorina.

Subtribe XI. Critoniinae

Key to the genera of the subtribe Critoniinae. 113. Critonia. 114. Critoniadelphus. 115. Urbananthus. 116. Adenocritonia. 117. Antillia. 118. Ciceronia. 119. Eupatorina. 120. Fleischmanniopsis. 121. Viereckia. 122. Koanophyllon. 123. Eupatoriastrum. 124. Sphaereupatorium. 125. Bishovia. 126. Nothobaccharis. 127. Santosia. 128. Grisebachianthus. 129. Lorentzianthus. 130. Chacoa. 131. Idiothamnus. 132. Mexianthus. 133. Neohintonia. 134. Peteravenia. 135. Critoniella. 136. Aristeguietia. 137. Asplundianthus. 138. Austrocritonia. 139. Badilloa. 140. Grosvenoria. 141. Corethamnium. 142. Castanedia. 143. Imeria. 144. Malmeanthus. 145. Hughesia. 146. Ophryosporus. 147. Cronquistianthus. 148. Steyermarkina. 149. Neocabreria. 150. Uleophytum. 151. Amboroa. 152. Tuberostylis.

Subtribe XII. Praxelinae

Key to the genera of the subtribe Praxelinae. 153. Praxelis. 154. Chromolaena. 155. Eupatoriopsis. 156. Lomatozona. 157. Praxeliopsis. 158. Eitenia. 159. Osmiopsis.

Subtribe XIII. Hebecliniinae

Key to the genera of the subtribe Hebecliniinae. 160. Hebeclinium. 161. Amolinia. 162. Bartlettina. 163. Decachaeta. 164. Erythradenia. 165. Guayania. 166. Matudina. 


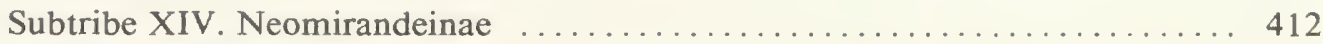

167. Neomirandea.

Subtribe XV. Mikaniinae ............................ 416

168. Mikania.

Subtribe XVI. Oxylobinae ........................... 425

Key to the genera of the subtribe Oxylobinae. 169. Ageratina. 170. Oxylobus.

171. Piptothrix. 172. Jaliscoa. 173. Pachythamnus. 174. Spaniopappus. 175.

Standleyanthus. 176. Kaunia. 177. Jaramilloa.

Subtribe XVII. Hofmeisteriinae

178. Hofmeisteria.

Subtribe XVIII. Oaxacaniinae ............................. 453

Key to the genera of the subtribe Oaxacaniinae. 179. Oaxacania. 180. Carterothamnus.

Literature Cited ........................................ 459

NOMENCLATOR OF THE EUPATORIEAE $\ldots \ldots \ldots \ldots \ldots \ldots \ldots \ldots \ldots \ldots \ldots \ldots \ldots \ldots$

INDEX TO GENERA . . . . . . . . . . . . . . . . . . . . . . . . . 575

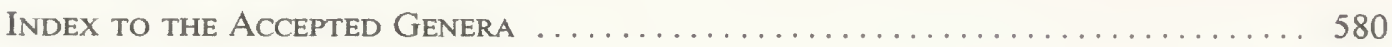





\section{INTRODUCTION}

The tribe Eupatorieae forms a major part of the family Asteraceae in the Neotropical Region and has some elements ranging naturally into North America as far as Canada and into the Eastern Hemisphere. Some members of the Eupatorieae native to the Neotropical Region, that have been introduced into the Pacific islands and the Old World tropics, have become widely distributed and have sometimes proven to be troublesome weeds. On the basis of traditional concepts, the tribe has been known to include nearly 2,000 species representing approximately $10 \%$ of the family Asteraceae and one of every 150 species of flowering plants.

In spite of the large element of the world's flora involved, the Eupatorieae has remained a poorly understood tribe. The members of the tribe mostly lack striking features, and the more obvious features seem highly erratic in distribution in the tribe. Many traditional genera have been distinguished, but only Mikania, Stevia, Brickellia, Ageratum, and Adenostemma, having considerable numbers of species, have proven to be phyletic to any great degree. Even some of the above concepts were very incomplete, while most other traditional segregates of any size have proven totally aphyletic.

The traditional concept of Eupatorium has proven particularly defective, and the concept of the genus has been allowed to degenerate in this century to roughly include most Asteraceae lacking rays, with flowers not yellow, with leaves usually opposite, and with the pappus capillary. As such, in general identification, the name Eupatorium has been applied to plants in many cases where use of the terms "Asteraceae" or "Compositae" was more appropriate. Under the field name Eupatorium have been found many Vernonieae, especially those with opposite leaves, many Astereae such as Baccharis, Inuleae such as Pluchea, and Heliantheae such as Schistocarpha and Neurolaena.

When more accurately applied, the traditional concept of Eupatorium could be regarded as a residuum of the tribe after other genera were removed and thus could be regarded as phyletic in the broadest sense. Other genera such as Piqueria and Alomia, however, were totally aphyletic, consisting of elements related to totally different elements of $E$ patorium. The aphyletic and simplistic concepts of genera of the Eupatorieae of the first half of this century were unresponsive to monography, and size of the group prevented any effective detailed studies except within geographical subdivisions. The tra- ditional system ultimately failed in its only possible reason to exist, providing a basis for identification. Previously described species were frequently redescribed from new areas or misrepresented in collections and floristic treatments, while many undescribed species remained unrecognized under incorrect names. The traditional concept was inevitably even more useless as a basis for cytological and chemotaxonomic studies.

Starting in 1966, and more continuously since 1970, the present authors have provided a series of partial revisions of the Eupatorieae, and an early overview of the revised concept of the tribe was presented in the symposium on the Biology and Chemistry of the Compositae (H. Robinson \& King, 1977). The overall project of revising the Eupatorieae has proven vastly more complex than first expected and would probably not have been undertaken if the problems had been foreseen. A final problem has been the obvious success of the tribe in many of the least explored areas of the Neotropics and the continuing arrival in recent years of unexpected and previously undescribed elements that are often distinct at the generic level even by traditional standards.

The revised concept of the Eupatorieae accepts 103 new generic concepts, including some raised from infrageneric levels. Many additional genera such as Ageratina, Ayapana, and Campuloclinium have been resurrected from the synonymy of the traditional concept of Eupatorium. Ultimately 180 genera are accepted in the tribe, genera which we consider to represent the most workable taxonomic units of the tribe, being reasonably equivalent phyletically to what are recognized as genera in other tribes of the Asteraceae such as the Heliantheae. Given continuing botanical progress and fuller understanding of the tribe, we believe there was a degree of inevitability to the presently accepted genera. The only thing that is regarded as particularly unusual about the present treatment is the extent to which the progress from the most poorly understood tribe of the Asteraceae to one of the best understood tribes of the family has been compressed into such a short time. It has resulted in a certain degree of "cultural shock" among various other students of systematic botany. It should be noted that the present concept is aimed at accurate solutions, but it is not a simple solution. The tribe has been found to be extremely complex, and the present treatment is only as simple as that complexity allows. 


\section{GENERAL History}

Botanists and naturalists in Europe have been familiar since earliest times with the one member of the tribe Eupatorieae that is native and common in that area, and by the time that Tournefort established the name Eupatorium in 1700, he was able to cite a number of additional relatives from North America and the West Indies. The illustrations and comments of Tournefort seem to emphasize the lack of any but tubular flowers in the heads, the unequal bracts of the involucre, the long capillary pappus, and in one illustration, the long rather straight branches of the style. The Tournefort name, $E u$ patorium, was adopted by Linnaeus in 1753 and 1754 in his Species Plantarum and Genera Plantarum which serve as the starting point of botanical nomenclature.

In the works of Linnaeus, two Eupatorian genera were established, Eupatorium and Ageratum. Both shared discoid heads with tubular hermaphroditic flowers, unequal to subequal involucral bracts, and long erect style branches. Ageratum differed from Eupatorium primarily by the pappus of awns rather than bristles. Nevertheless, one of the three species placed in Ageratum by Linnaeus was A. altissima which has a capillary pappus and is intimately related to the Eupatorium aromaticum L. of the same work. The Linnaean concept of Eupatorium included 14 species mostly from North America, the type, E. cannabinum, from Europe, and a few from tropical America. Included were members of the presently recognized genera Ageratina, Conoclinium, and Mikania. In addition, there was one species from Ceylon now placed in Vernonia. One other member of the Eupatorieae described in Species Plantarum was Verbesina lavenia $\mathrm{L}$. from Ceylon, which is now placed in the genus Adenostemma. The Linnaean placement of the latter was based on a very imperfect specimen described by Ray (1704).

In the period following Linnaeus and extending into the time of Cassini's contributions to Cuvier's Dictionnaire (1817-1830), many presently recognized genera of the Eupatorieae were described, including Critonia P. Browne (1756), Kuhnia Linnaeus (1763, = Brickellia Elliott, nom. cons.), Adenostemma J. R. Forster \& G. Forster (1776), Liatris Gaertner ex Schreber (1791), Piqueria Cavanilles (1794), Stevia Cavanilles (1797), Mikania Willdenow (1803), Carphephorus Cassini and Sclerolepis Cassini (1816b), Gyptis Cassini and Trilisa Cassini (1820b), Isocarpha R. Brown (1817) and
Alomia Humboldt, Bonpland \& Kunth (1818). The genus Ageratina of Spach (1841) represented the same entity as two earlier illegitimate names, Batschia Moench (1794) and Kyrstenia Necker (1790). Microspermum Lagasca was described in 1816 , but was not recognized as a member of the Eupatorieae until the mid-twentieth century because of its heads with ray-like peripheral flowers.

There had been a tendency to associate most of the elements of the Eupatorieae with each other through the time of Humboldt, Bonpland, and Kunth in 1818 , but it was Cassini (1819a) who formally recognized the tribe Eupatorieae along with other basic tribes in his classification.

In the Dictionnaire des Sciences Naturelles, Cassini $(1820 c)$ characterized the Eupatorieae as follows:

L'ovaire est oblong, non comprimé, un peu épaissi de bas en haut, arrondi au sommet; ordinairement prismatique, à cinq faces limitées par cinq arêtes saillantes; quelquefois cylindracé, avec cinq ou dix nervures; il est glabre, ou garni de poils, ou parsemé de globules substipités. Cet ovaire est ordinairement porté sur un pied plus ou moins grand, et de forme diversifiée, souvent articulé avec le corps. Le placentaire est ordinairement très-élevé. Le fruit mûr est ordinairement de couleur noire. L'aigrette, rarement nulle ou coroniforme, est ordinairement composée de squamellules uni-bisériées, libres ou entregreffées inférieurement, filiformes ou paléiformes.

Le style androgynique a ses branches longues, colorées comme la corolle, peu divergentes pendant la fleuraison; leur partie inférieure, un peu arquée en dehors, est courte, grêle, demi-cylindrique, bordée deu deux très-petits bourrelets stigmatiques; leur partie supérieure, un peu arquée en dedans, est longue, épaisse, subcylindracée, souvent élargie supérieurement, toujours arrondie au sommet, couverte de collecteurs papilliformes ou glanduliformes. La base du style est souvent velue.

Les étamines ont l'article anthérifere quelquefois épaissi; l'appendice apicilaire arrondi au sommet (nul dans le piqueria, denticulé dans quelques stevia); les appendices basilaires nuls ou presque nuls.

La corolle staminée est régulière, mals telle- 
ment diversifiée du reste qu'elle ne peut fournir à cette tribu aucun autre caractère général. Celle des Stevia et de quelques autres eupatoriées est remarquable par les poils qui garnissent sa surface intérieure.

In the comments that followed, Cassini emphasized the discoid heads with uniformly bisexual tubular flowers, the rarely paleaceous receptacle, the uniseriate to biseriate or imbricate involucral bracts, the usually opposite leaves, the mostly herbaceous habit, and the reddish, white, or bluish rather than yellowish flowers. The primary character of the tribe was considered to be the form of the style. The Eupatorieae was noted as being mostly American.

The Eupatorieae was placed between the Adenostyleae and the Vernonieae in Cassini's table of the tribe $(1818 \mathrm{c})$. The Adenostyleae was also discussed with the Eupatorieae in later entries by Cassini $(1823 a)$, and the two were evidently considered closely related. The relationship to the Vernonieae, which shared the same general form of heads and the same flower colors, was never emphasized, apparently because of the recognition of the fundamental differences in style and anther structure.

Cassini in a later entry in the Dictionnaire (1823a) treated the Eupatorieae in some detail and recognized three subgroups. The first section, Agerateae, had a reduced pappus and five-ribbed achenes. Included were Stevia, Ageratum, Alomia, Sclerolepis, Adenostemma, and Piqueria. The second section, Archetypae, had a full-length capillary pappus and five-ribbed achenes. It contained ? Arnoglossum Raf., Mikania, Batschia, Gyptis, and Eupatorium. The third section, Liatrideae, had a capillary or plumose pappus and ten ribs on the achene. The genera were Coleosanthus Cass. (= Brickellia), Kuhnia, Carphephorus, Trilisa, Suprago Gaertner (= Liatris), and Liatris. Arnoglossum, included on the basis of inadequate information, belongs to the Senecioneae.

The treatment of the Compositae by Lessing (1831), when he was 22 years of age, combined many of the tribes of Cassini that shared heads with ray and disk flowers and yellow corollas. The basic revision did not affect the Eupatorieae, which remained intact but was adulterated with some Senecioneae and Heliantheae. Formal subtribes were first established by Lessing and were as follows. Subtribe I, Alomieae, had homogamous heads with bisexual flowers and calvous achenes. The genera were Isocarpha, Alomia, and Piqueria. Subtribe II, Agerateae, had similar heads with a short, paleaceous, aristate, or coroniform pappus. Included were $\mathrm{Coe}$ lestina Cass. (= Conoclinium), Stevia, Ageratum, Paleolaria Cass. (= Palafoxia of the Heliantheae), Carelia Less., Sclerolepis, and Adenostemma. Subtribe III, Eupatorieae, had heads similar to the preceding with a capillary pappus, and it contained Shawia J. R. Forster (= Olearia of the Astereae), Kuhnia, Eupatorium, Mikania, Adenostyles (Senecioneae), Liatris, and Carphephorus. Subtribe IV, Tussilaginae, had heads that were heterogamous, often subdioicous, and it contained Homogyne Cass., Tussilago Cass., Nardosmia Cass., Petasites Gaertner, and Adenocaulon Hook. The last group is mostly Senecioneae with Adenocaulon now placed in the Mutisieae.

DeCandolle (1836) followed the general design of Lessing with the addition of a number of new genera. The tribe Eupatorieae was subdivided as follows. Subtribe I. Eupatorieae. Capitula homogama, with three divisions. Div. I. Alomieae. Pappus nullus, with genera Orsinia Bertol. (= Inula), Piqueria, Alomia, Phalacraea DC., Gymnocoronis DC., and Isocarpha. Div. II. Agerateae. Pappus paleaceous aut partim squamellatus, contained Coelestina, Ageratum, Anisochaeta DC. (Mutisieae), Adenostemma, Sclerolepis, Phania DC., Stevia, Palafoxia (Heliantheae), Carelia Less., and Agrianthus DC. Div. III. Adenostyleae. Pappus setosus scaber aut plumosus, including Kuhnia (with sect. Trichogonia DC.), Clavigera DC. (= Brickellia), Liatris (including Suprago and Trilisa), Carphephorus, Decachaeta DC., Chromolaena DC., Ooclinium DC. (= Praxelis Cass.), Conoclinium DC., Hebeclinium DC., Campuloclinium DC., Bulbostylis DC. (= Brickellia), Critonia, Eupatorium, Nothites Cass. (= Stevia), Mikania, Adenostyles (Senecioneae). Subtribe II. Tussilagineae. Capitula heterogama aut dioica, containing two divisions. Div. I. Petasiteae. Flores foeminei tubulosi, included Homogyne, Nardosmia, Petasites, and Adenocaulon, following Lessing's treatment closely. Div. II. Eutussilaginae. Flores foeminei ligulati, contained the remaining genera, Tussilago, Celmisia Cass., Alciope DC., and Brachyglottis J. R. Forster. Of these last, all are Senecioneae except Celmisia, which is Astereae. The number of recognized genera of the Eupatorieae was the highest of any time during the nineteenth century. Even so, Eupatorium had a total of 294 species and Mikania contained 111 species.

Ageratina and Ayapana were named shortly thereafter by Spach (1841).

The final significant contributions in the history 
of the Eupatorieae during the nineteenth century were the treatment of the family by Bentham (in Bentham \& Hooker, 1873) and the closely matching treatment by Hoffmann (1890-1894) in Engler and Prantl. The most notable feature of the treatments was the restoration of many of the tribes of Cassini. In the Eupatorieae, the most significant feature was the synonymization of many genera. The Bentham classification of the tribe can be summarized as follows.

Subtribus 1. Piquerieae. Antherae apice truncatae exappendiculatae. Achaenia costis 5 angulata, secundariis evanidis. Included genera were Piqueria, Phania, Decachaeta, Ophryosporus Meyen, Helogyne Nutt., Gymnocoronis, and Adenostemma.

Subtribus 2. Agerateae. Antherae appendiculatae. Achaenia costis 5 angulata, secundariis evanidis. The subtribe contained Sclerolepis, Alomia, Trichocoronis A. Gray, Tuberostyles Steetz, Carelia, Aschenbornia Schauer. (= Calea of the Heliantheae), Ageratum, Schaetzellia Schultz-Bip. (= Macvaughiella), Stevia, Dissothrix A. Gray, Fleischmannia SchultzBip., Hofmeisteria Walp., Carminatia, Trichogonia (DC.) Gardner, Brachyandra Philippi, Leptoclinium Benth., Agrianthus, Symphyopappus Turcz., Eupatorium, and Mikania.

Subtribus 3. Adenostyleae. Anterae appendiculatae. Achaenia costis secundariis conspicuis 10-rarius 7-8-costata. Included genera were Kanimia Gardner, Adenostyles (Senecioneae), Brickellia, Carphechaete A. Gray, Kuhnia, Liatris, Trilisa, and Carphephorus.

The system of Hoffmann (1890-1894) was based closely on that of Bentham and differed primarily by the addition of a few genera, Podophania Baillon in subtribe 1, Apodocephala Baker (= Vernonieae), Ageratella A. Gray, and Lomatozona Baker in subtribe 2, and Barroetea A. Gray and Garberia A. Gray in subtribe 3.

In both treatments, the naturalness of the Eupatorieae was restored to some extent, but both treatments suffered from comparatively inadequate insight in primarily Neotropical groups such as the Eupatorieae. Bentham and Hoffmann both placed the Eupatorieae adjacent to the Vernonieae in their sequence and, with or without intention, fostered the idea of close relationship between the two tribes in the minds of many subsequent botanists.

In the present century, B. Robinson produced numerous papers dealing with the Eupatorieae, including treatments of Eupatorium sensu lato, Stevia, and Mikania for many countries, and a treatment of Eupatorium in Standley's Trees and Shrubs of Mexico. B. Robinson (1913a) summarized the then existing generic concepts in the tribe, but indicated, "Further study, especially of the larger genera, may well reveal profitable generic segregations not as yet clear. This is especially likely to be the case among the numerous and as yet imperfectly known South American members of the tribe. It is also by no means improbable that when these are more satisfactorily represented in herbaria some new and more convincingly natural re-adjustment of generic lines will become possible."

The genus Adenostyles was excluded from the tribe by B. Robinson (1913a) and relationship suggested to the Senecioneae, a position more completely affirmed many years later by Toman, Harmatha, and Novotny (1968). Three Eupatorian genera placed in the Adenostylinae by Bentham were renamed the Kuhniinae, and a new subtribe, Adenostemmatinae, was established for Adenostemma, Gymnocoronis, and Hartwrightia A. Gray ex S. Watson. Robinson considered but excluded from the tribe two genera, Isocarpha and Lepidesmia Klatt, that should not have been excluded, and in $1922 c$ he described a new genus, Dyscritothamnus, in the tribe which proves to be a member of the Heliantheae (H. Robinson, 1981).

During the present century, since the time of $\mathrm{B}$. Robinson's key up until 1970, isolated studies of Eupatorieae have continued. Gaiser (1953, 1954), in a study of particular interest, surveyed the subtribe Kuhninnae as delimited by $\mathrm{B}$. Robinson $(1913 a)$ and suggested that at least four very distinct elements were involved. Genera have continued to be added to the tribe including Ciceronia Urban (1925), Stylotrichium Mattfeld (1923), Arrojadocharis Mattfeld (1930, for Arrojadoa Mattfeld, 1923), Sciadocephala Mattfeld (1938), Planaltoa Taubert (1896), Spaniopappus B. Robinson (1926a), Uleophytum Hieronymus (1906), Eupatoriopsis Hieronymus (1893), Praxeliopsis G. Barroso (1949), Ferreyrella and Iltisia S. F. Blake (1958), Amboroa Cabrera (1956), Ellenbergia Cuatrecasas (1964), Ascidiogyne Cuatrecasas (1965), Piqueriopsis R. King (1965), Carterothamnus R. King (1967a), and Cronquistia R. King (1968). In describing Ferreyrella and Iltisia, S. F. Blake (1958) mentioned the genus Microspermum Lagasca which was then placed in the Helenieae. The position of the latter in the Eupatorieae has finally been confirmed by H. Rob- 
inson and King (1977), but not in the position transitional to the Heliantheae that was suggested by Rzedowski (1970).

At the time of the initiation of the present study, everything regarding the tribal limits of the Eupatorieae was either resolved or had at some time been questioned. Also, many of the most common species were well recognized and defined. In contrast, the groupings of species within the tribe were almost entirely artificial. For example, Eupatorium was a residual concept, while Piqueria and Alomia both contained three or more elements related to totally different parts of the tribe; part of Ageratum was included in Alomia; and Fleischmannia, on the basis of its pappus, contained species of Hofmeisteria and Ageratina, but excluded over 70 species related to the type species.

The present study has benefitted from the return to microscopic techniques in a form commonly used in bryology (King \& Robinson, 1970i) and was formally initiated in a nomenclatorial survey of generic names then known to have been used in the tribe (King \& Robinson, 1969c). Over a hundred new genera have been described in a series of publications (King \& Robinson, 1970-1986), including one, Eupatoriadelphus not retained in this study. A few traditional genera have been placed in synonymy, namely Kanimia in Mikania (King \& Robinson, $1980 \mathrm{~m}$ ) and Kuhnia in Brickellia (following Shinners, 1971). The general outline of the presently accepted subtribal classification was first presented in the symposium on the Biology and Chemistry of the Compositae (H. Robinson \& King, 1977). One treatment using the revised generic concepts has been presented in the Flora of Panama (King \& Robinson, 1975y). 


\section{Chemistry ANd Cytology of The Eupatorieae}

Extensive data on the chemistry and the chromosomes of the Eupatorieae have accumulated during recent decades, and some of this is useful in the systematic study of the tribe.

\section{CHEMISTRY}

As in the case of most groups of plants, initial knowledge of the chemistry of the Eupatorieae comes from various general observations and uses of the plants accumulated since early historical times. Members of the tribe have not proven to have significant economic uses, but some uses, sometimes doubtful, have been claimed. A number of these are mentioned by Dominguez (1977) in his review of the chemistry of the tribe. He cites the use of Eupatorium cannabinum in India to cure jaundice, scurvy, fomenting sores, and ulcers and in Italy for homeopathic medicine. Tamaulipa is used as an astringent for poultries, and Mikania species of the cordiformes group are used to cure snakebites in South America and South Africa. Ageratum conyzoides is used for relief of abdominal pain.

Dominguez also cites the use of oleoresin from Trilisa odoratissima as a fixative in perfumery and the use of the dried leaves as a flavor additive to tobacco. Chromolaena odorata is used in India as a fish-poison, and label data indicates the species is also used in this way in tropical America, where the plant is native. Chromolaena collina and several Brickellia species are said to have medicinal uses in Mexico. Dominguez ultimately cites cytotoxic and antileukemic properties demonstrated for several sesquiterpene lactones from four species of Eupatorium and Liatris provincialis and cytotoxic effects of polyhydroxylated flavonoids in Eupatorium semiserratum and $E$. cuneifolium.

A number of additional effects and uses of members of the Eupatorieae have been recorded. Poisonous properties of the White Snakeroot, Ageratina altissima, as the cause of "milk sickness" (Hass, 1970) derive from benzofurans, which are widely distributed in the tribe. Regarding Ageratina sternbergiana of Peru, Weberbauer recorded that the fresh roots, softened in lukewarm water, are employed as an abortive, and that a tea prepared from the leaves is used for kidney and bladder problems (B. Robinson, 1919b: 83). Stevia rebaudiana has long been known as a source of a strong sweetener and possible sugar substitute (Fletcher, 1955; Soejarto et al., 1982, 1983), a glycoside that Dominguez (1977) cites as
300 times sweeter than sucrose. More recently the extracts of the plant have been cited for their potential as a contraceptive (Mazzei Planas \& Kuć, 1968). We have been informed that the extracts involved have since proven to be potential carcinogens (J. Duke, pers. commun.), but most recent evidence indicates that it is the aglycone, Steriol, rather than the sweetening agent Stevioside that is mutagenic (Pezzuto et al., 1983). Leaves from Austroeupatorium inulaefolium have also been used for fertility control in Uruguay (Esteves et al., 1981), and leaves of Liatris have been used as a substitute for vanilla (Atkinson \& Curtis, 1971).

Early in the last century, Arruda da Camara (H. Koster, 1816) described Koanophyllon tinctorium, also known as the Paraguay Indigo, as a potential dye plant. The plant has proven non-competitive as a source of indigo, but it is systematically interesting that, according to label data, another member of the same genus, $K$. albicaule, has been used in Belize as the source of a green dye.

It is primarily during the present century that the chemical substances of the Eupatorieae and other Asteraceae have begun to be structurally identified and accurately compared with chemicals in other groups of plants. Much of this is reviewed in the series of papers in the symposium on the Biology and Chemistry of the Compositae (Hegnauer, 1977; Herz, 1977; Sørensen, 1977; Harborne, 1977; Dominguez, 1977), and in a book on the naturally occurring acetylenes by Bohlmann et al. (1973). Reports of chemical constituents of the Eupatorieae have greatly increased in the period of years since the symposium (Bohlmann et al., 1977-1982), but much of the correlative study based on these results remains to be done. Some of this is discussed by Gage (1985). It is notable that none of the studies of the chemistry of the Eupatorieae involve macromolecules. The tribe was not one of the eight in which the plastocyanin amino acid sequences were studied by Boulter et al. (1978), and cytochrome $c$ sequences are known in the family from only the Heliantheae (Boulter et al., 1972). Only secondary metabolites have been studied in the Eupatorieae. The salient features of the chemistry of the tribe are reviewed here.

The Eupatorieae are one of the two tribes in the Asteraceae producing pyrrolizidine alkaloids. These compounds are able to cause liver damage when eaten by mammals. The form of pyrrolizidine al- 
kaloids in the two tribes is not the same. In the Senecioneae, the molecule is a diester forming a ring of the same type as found in the legume genus Crotalaria. In the Eupatorieae, the pyrrolizidine alkaloids are monoesters of the same type that is found in the family Boraginaceae (Hegnauer, 1977). We do not regard the alkaloids in the two tribes as reflecting any special relationship between them. The alkaloids in the Eupatorieae were originally recorded in the genus Eupatorium. More recent reports in Conoclinium coelestinum (Herz et al., 1981), Trichogonia gardneri (= Trichogoniopsis adenantha), two species of Adenostemma, Chromolaena maximilianii, and various Brazilian species of "Eupatorium" (Brown, 1984) show evidence of occurrence throughout the diversity of the tribe. Although Herz et al. (1981) report failure to find the alkaloids in two species of Ageratina, Everist (1974) has cited an unidentified pyrrolizidine alkaloid from adventive Ageratina in Australia. As shown by Brown (1984) and suggested by Vichnewski et al. (1985), the alkaloids are concentrated in the flower heads, especially the nectaries. The study by Brown cites the Eupatorieae as a major source of pyrrolizidine alkaloids (PA) obtained during pollination by mature Ithomiine butterflies: “. . . the original distasteful models in neotropical mimicry complexes." Brown (1984) further states that "flowerheads of several abundant Brazilian species of Eupatorium contain $1-4 \%$ of a single isomer of PA (k-o) and the corresponding $\mathrm{N}$-oxide, some of which are now in advanced clinical testing as antitumor agents."

A number of flavonoids and related compounds are known from the Eupatorieae, as shown by Dominguez (1977). The only report of flavonoids of the aurone or chalcone type in the tribe is from the leaves of Chromolaena odorata (Bose et al., 1973). All the flowers of the tribe Eupatorieae studied by King and Krantz (1975) indicated presence of UV absorbing flavonoids supposedly of the yellow flavonol type that has been reported from the tribe (Harborne, 1977), and there is no evidence of UV reffectance. It is notable that no flavonoids that produce any noticeable yellow coloration are present in the flowers of the tribe. Related compounds, the anthocyanins, are responsible for the reddish and bluish colors that are characteristic of the tribe. The only attempt to use the flavonoids at the generic level is the recent study of Flyriella (Mabry et al., 1981), where this relative of Brickellia was found to have these compounds more like members of the subtribe Eupatoriinae.
Among the phenolics of the Eupatorieae there are a number of essential oils of special note. The chromenes show an interesting distribution in the tribe, being reported from members of the subtribes Eupatoriinae (Bohlmann et al., 1980d, 1981e), Ageratinae (Dominguez, 1977), and Gyptidinae (Bohlmann et al., 1980e, 1981g, 1981l, 1981n, 1982c). Such compounds apparently inhibit the maturation of insects that develop on the plants (Bowers et al., 1976; Miller, 1980). Coumarins occur in seven subtribes (Dominguez, 1977; Bohlmann et al., 1980a, $1980 f, 1982 b, 1982 f, 1982 i)$. Related compounds with a five-sided secondary ring, the benzofurans, are responsible for the poisonous effects of many Eupatorieae such as "milk sickness" or "trembles." Benzofurans are particularly common in the tribe, being less common in the tribe Astereae, and rather rare in most other tribes. The presence of benzofurans in Isocarpha reinforces the placement of that genus in the Eupatorieae rather than the Heliantheae (Bohlmann et al., 1977a).

Monoterpenes, in the form of thymol derivatives, occur sporadically in the Eupatorieae. They occur in Bishovia boliviensis (Bohlmann et al., 1979d), where they may be associated with the long-stalked gland-tipped hairs; they are found in Mikania offcinalis and $M$. purpurascens, two species with erect habits from the Planalto of Brazil, which have many small sessile glandular punctations; and they appear common in Kaunia, from the Andes, including two species that have distinct sessile glands and one, $K$. saltensis, lacking evident glands. Thymol derivatives also occur in Eupatorium, the Liatrinae (Dominguez, 1977), and a number of species of Ageratina subgenus Neogreenella from Mexico.

Sesquiterpenes have been reported widely in the tribe. The acyclic forms have been reviewed by $\mathrm{H}$. Robinson et al. (1979). Acyclic sesquiterpenes are potentially present in all plants, but the Eupatorieae and Anthemideae are the only members of the Asteraceae with particularly notable elaborations of these compounds, and the elaborations are different in the two tribes. The molecules in the Eupatorieae do not form ketones or furans as in the Anthemideae, and they do form angeloyloxy esters rather than acetates. Within the Eupatorieae, esterification with angelic acid is common at the C-4 position, and it occurs at the $\mathrm{C}-5$ position only in various species of Brickellia.

Sesquiterpene lactones are particularly bitter compounds and in the Eupatorieae seem to be associated with the larger short-stalked capitate glands. 
Herout (1974) and Herz (1974, 1977) have arranged the common types of sesquiterpene lactones according to the chemical pathways, and they have shown that most of the secondarily elaborated forms such as the eremophilanolides, ambrosanolides, and helenanolides, are restricted to the advanced members of the subfamily Asteroideae, above the level of the Eupatorieae. The Eupatorieae produce, with few exceptions, only germacranolides, eudesmanolides, and guaianolides. The one apparent exception of a secondarily elaborated form is the ambrosanolide Stevin reported from Stevia ovata (Rios et al., 1967). The rearranged guaianolides of Lasiolaena santosii (Bohlmann et al., 1981l) are also regarded as being the "third level of biogenetic complexity," (Gage, 1985) though of a structure not matched closely in other tribes. The presence of secondarily elaborated eremophilanolides in Adenostyles was part of the evidence for excluding the genus from the Eupatorieae and confirming its position in the Senecioneae (Toman et al., 1968).

Cadinene derivatives, another type of sesquiterpene, are common in Chromolaena (Bohlmann et al., $1979 c, 1982 f$ ), and they may be responsible for some of the biological activity that has been noted in the genus.

Diterpenes have been reported from many Eupatorieae. The acyclic diterpenes have become elaborated in Lasiolaena (Bohlmann et al., 1982c) and Stylotrichium (Bohlmann et al., 1981n) of the Gyptidinae, with forms having secondary alcohols and acetates. The latter of the two genera also forms ketones. Additional forms occur in Disynaphia (Bohlmann et al., 1981d) and Mikania (Bohlmann et al., $1981 o, 1982 k)$, one of the latter having a furan group.

The active ingredient of the sweet shrub of Paraguay, Stevia rebaudiana, is the ent-kaurane diterpene glycoside, stevioside (Vis \& Fletcher, 1957). Various ent-kaurane derivatives are reported from a few other groups in the tribe, but seem particularly common in Mikania (Dominguez, 1977; Bohlmann et al., 1981o, 1982h). Kolavane derivatives are common in the Eupatorieae, especially among Brazilian species of Acritopappus (Bohlmann et al., 1980g), Bahianthus (Bohlmann et al., 1981 a), Goyazianthus (Bohlmann et al., 1981 $i$ ), Koanophyllon (Bohlmann et al., 1981p), and Symphyopappus (Bohlmann et al., 1981 h), and also in Liatris (Bohlmann et al., $1981 j$ ) and Hartwrightia (Bohlmann et al., 1981b) in eastern North America. Labdane derivatives of similar structure are even more widely distributed in the tribe. The forms of both types of compounds become particularly complex in the genus Acritopappus (Bohlmann et al., $1980 \mathrm{~g}$ ). Many of the species having the kolavane and labdane derivatives are notable for the viscid surfaces of their stems and leaves, and the lack of the compounds in one species of Acritopappus is correlated with a lack of viscid surfaces (Bohlmann et al., 1982b).

Carotenoids would naturally occur in all members of the Eupatorieae in at least their vegetative parts, but it is a characteristic of the tribe that they do not occur in the corollas or styles of the flowers in any form that produces a yellow color. Carotenoids are often present in anthers and pollen (Goodwin, 1980), however, and it is possible that carotenoids are involved in the yellow color of the pollen that is noticeable on the styles of many members of the subtribe Alomiinae.

Hegnauer (1977) has stated that seed oils of the family sometimes contain characteristic fatty acids. Nevertheless, little has been said of this biologically basic group of compounds in the Eupatorieae. Notable exceptions are the reports of a number of prostaglandin-like fatty acids in two species of Chromolaena, C. morii (Bohlmann et al., 1981h, 1982a) and $C$. chaseae (Bohlmann et al., 1982f).

Polyacetylenes are highly developed in the Asteraceae and a few other families such as the Apiaceae, and they have been part of the basis for recent speculation by chemotaxonomists regarding relationships between the two families (Mabry \& Bohlmann, 1977). This has been countered to some degree by Cronquist (1977). Regarding the polyacetylenes in the Asteraceae, Sørensen (1977) states that they are physiologically very active compounds against other organisms. Hegnauer (1977) mentions nematicidal, antibiotic, and in the case of ichthyotherol the fast-acting poisonous qualities of the polyacetylenes. The polyacetylenes are derived from the fatty acid, oleic acid, by the reduction of the degree of saturation to the level of triple bonds. In the basic polyacetylene form there are apparently three triple bonds, but some members of the group develop more. The common pentaynene has five such triple bonds, and one of its thiophene derivatives shows the products of six such bonds. The creation of such bonds requires input of energy, and polymerization or reactions with oxygen and sulfur release energy. Thus, the compounds tend to be unstable and break down rather soon after the death of the plant, which 
makes analysis of plants from remote areas difficult. It is these chemicals that often cause fresh material of Asteraceae to burn so easily.

Acetylenic compounds are found in the Asteraceae in two basic forms. Hegnauer (1977) indicates that the polymerization of highly unsaturated acetylenes produces the phytomelanin seen in the achene walls of only two tribes of the Asteraceae, the Eupatorieae and Heliantheae. Sørensen (1977) indicates that most polyacetylenes in the family are stored in the resin canals, where they are sometimes reddish colored, apparently because of acetylenes with a 1,2-dithiin-ring. Actual observations of flowers compared to reports of 1,2-dithiins would suggest the various colors of the canals are not so simple. Reddish or purplish color has been noticed in the canals of some Eupatorieae.

Bohlmann et al. (1973) have provided a review of the polyacetylenes known in the plant kingdom up to about ten years ago. All records from the Eupatorieae were of pentaynene and its derivatives. Pentaynene was reported from species now placed in the subtribes Adenostemmatinae, Eupatoriinae, Gyptidinae, Disynaphiinae, Ageratinae, Liatrinae, Alomiinae, Mikaniinae, and Oxylobinae. A thiophene and a dithiin are reported for only Mikania. The reports of a thiophene ester related to the dehydromatricariaester in Liatris are based on Atkinson and Curtis (1971), but these reports of an anthemidean type polyacetylene in the Eupatorieae seem anomalous, and they have not been verified.

In the possession of the pentaynene pathway, the Eupatorieae are like all tribes of the subfamily $\mathrm{Ci}$ chorioideae and like the basal elements of the subfamily Asteroideae up through the Inuleae and Calenduleae. Contrary to some theoretical considerations, it is this higher energy pathway of the polyacetylenes that seems to be more primitive among extant Asteraceae.

Raphids, which are presumably formed of calcium oxalate, are found in most Asteraceae. They occur in various parts of the plants, but have been surveyed most completely in the floral parts as a result of the many microscopic examinations of the reproductive structures of the family. Raphids are most common in the achenes, being present in all tribes where phytomelanins are absent. Of the two tribes with phytomelanins, the Eupatorieae and the Heliantheae, the latter has raphids in the achenes of the two subtribes in which phytomelanins are absent (H. Robinson, 1981), and it also has raphids commonly present in cells of the corolla or even the anther. The Eupatorieae is the only tribe totally lacking any well-formed raphids, rarely showing a few needle-like crystals in some cells of the corolla in a few species such as Cronquistianthus kalenbornianus.

\section{CYTOLOGY}

The chromosome data has been reviewed recently by $\mathrm{R}$. King et al. (1976). The base number for the tribe has been shown to be 10 , and this number has more recently been proposed as the base number for the entire subfamily Asteroideae (H. Robinson et al., 1981). This base number is found in most subtribes of the Eupatorieae, including most of the genera.

Within the Eupatorieae there are a number of exceptions to the base number of 10 , and it is these groups which require special notice. It is significant that the exceptions include comparatively few genera, but that many of the genera are distinctive and contain numerous species. These derived groups seem to have been produced mostly through aneuploid loss, or polyploidy, or a combination of both. Two groups, Acritopappus of the Gyptidinae and the Brickellia group in the Alomiinae, have an aneuploid loss to $x=9$. The groups clearly represent separate occurrences of such chromosome loss. Increases of chromosome number to $n=16-19$ are apparent in the subtribes Hebecliniinae, Neomirandeinae, Mikaniinae, Oxylobinae, Hofmeisteriinae, and Oaxacaniinae. These are assumed to represent at least two separate instances of polyploid increase followed by aneuploid loss. Such a pattern of polyploid increase followed by aneuploid loss appears common in other groups of Asteraceae such as the Heliantheae and Vernonieae (H. Robinson et al., 1981). In the case of the subtribe Hebecliniinae, the base of 10 is present within the subtribe, and in the case of the Oxylobinae some members of the subtribe seem to have higher polyploidy derived from multiples of 20. In the Oxylobinae, most of the species of Ageratina have a chromosome number stabilized at $x=17$ while the presumably more derived genus Oxylobus has stabilized at $x=16$.

In the Neomirandeinae, the single genus Neomirandea has two elements which differ in structure as well as in chromosome number. The members of the subgenus Critoniopsis which are all epiphytic, have a base of $x=17$. The members of typical NeOmirandea which contains some secondarily terres- 
Adenostemmatinae $5 \quad \underline{10}$

Eupatoriinae

Disynaphiinae

Gyptidinae

Ageratinae

Trichocoroninae

Ayapaninae

Alomiinae

Liatrinae

Fleischmanniinae

Critoniinae

Praxelinae

Hebecliniinae

Neomirandeinae

Mikaniinae

Oxylobinae
10

15

10

10

9 10 느는 12

15

10

9 $\underline{10}$

10

$4 \quad 10$

10

10

10

$\underline{16}$
20

30

$20 \quad 25$

30

20

20

30

20

30

20

20

29

$17 \quad \underline{20} 2425$

$16 \underline{17} 18 \quad \underline{19} 20$

$\underline{16} \underline{17}$

ca 40

51

\section{Hofmeisteriinae}

Oaxacaniinae $\underline{18} \underline{19}$

$\underline{18}$ FIGURE 1. Distribution of chromosome numbers in the Eupatorieae according to subtribes. Higher polyploids, primarily in the
Praxelinae and Oxylobinae, are omitted.

trial species, have numbers of $n=20$, ca. 24 and 25.

In the small subtribe Trichocoroninae, with three aquatic or subaquatic genera, there is apparently a base number of $x=15$. The derivation of the number is not clear. Other examples of $n=15$ in the tribe are in hybrids between different ploidy levels in Eupatorium and Ageratum which have a base of $x=10$.

The only example in the tribe of apparent aneuploid increase is in some of the subtribe Ageratinae.
Members of the genera Stevia, Cronquistia, Carphochaete, Piqueria, and Microspermum show $n=$ 11 or 12 and Macvaughiella has a tentative count of $n=\mathrm{ca}$. 13. As a result of evidence from the Heliantheae $(H$. Robinson et al., 1981) regarding the rarity of aneuploid increase in the family, we would now interpret the above series as derived from a single aneuploid increase to $n=12$ with some subsequent reductions to $n=11$.

A generalized scheme of the chromosome numbers in the tribe is presented in Figure 1. As men- 
tioned above, many of the groups that have distinctive chromosome numbers are also among the most readily defined taxonomically. Most of these have been recognized as genera in the traditional systems of classification, Ageratina being the outstanding exception. The groups involved do not differ by particularly extreme structural or chemical specializations, but they seem less subject to intergradation. The difference in chromosome number appears to reduce perceptibly the similarity of detail, presumably through reduction in the amount of hybridization. The different chromosome numbers and geographical separation seem to be the primary isolating mechanisms in the tribe.

Certainly, among the Eupatorieae having the common base number $x=10$ and similar geography, there is evidence of hybridization. There are examples such as Osmiopsis where characters seem directly traceable to two totally distinct phyletic stocks, in this case Chromolaena of the Praxelinae and Koanophyllon of the Critoniinae. The distribution of characters elsewhere in the tribe suggests that Osmiopsis is not unique, and we believe that such intergeneric hybridization is common in the family. Experimental hybrids have been produced between genera of both Eupatorieae and Heliantheae by Powell, the latter being reported (1972). Although such evidence is not generally recognized, it now seems obvious that successfully evolving groups of plants such as the Asteraceae owe part of their success to processes that complicate the taxonomy of the groups, such as intergeneric hybridization (H. Robinson, 1983). Such hybrids probably do not often perpetuate themselves to form new evolutionary lines, but those that succeed have a profound effect on the long-range evolution of a family such as the Asteraceae. An overview of the family gives the impression of a highly reticulating evolution at least at the formative stages of the family and its various subgroups.
As a result of the partial isolating effect of chromosome numbers, we can see the pattern found in the Eupatorieae in the Alomiinae, where general characters of the corolla shape and style distinguish a broad group, but many secondary features are shaped with other subtribes. Within the Alomiinae, the small group including Brickellia, Phanerostylis, and probably Barroetea, when it is known, having the distinct chromosome number $n=9$, have distinctive acyclic sesquiterpene (H. Robinson et al., 1979) and flavonoid (Mabry et al., 1981) chemistry.

A few additional features of the chromosomes of the Eupatorieae have been noted in the literature. Grant (1953) reported two size classes of chromosomes among members of the tribe in eastern North America. Species recognized in the present treatment as Eupatorium, had chromosomes 2.5-6.5 $\mu \mathrm{m}$ in length. Species treated here as Ageratina and $\mathrm{Co}$ noclinium had chromosomes $1.5-3 \mu \mathrm{m}$ long. Gaiser $(1953,1954)$ noted that there was a karyotype variation in the Brickellia series correlated with habit. Karyotypes including some long chromosomes were characteristic of shrubby species. Karyotypes with only medium length or short chromosomes occurred in comparatively herbaceous plants.

Two types of chromosome specialization have been noted among the weedy members of the Eupatorieae. The reduction to $n=4$ in Fleischmannia microstemon, in a genus with a base of $x=10$, has been noted by H. Baker (1967) and reviewed by R. King et al. (1976). The triploid nature of two weedy species of Ageratina, A. adenophora and A. riparia, with resulting irregular meiosis and apomixis, has also been discussed by R. King et al. (1976). Irregular meiosis and apomixis are common in many other members of the Eupatorieae, especially in the subtribe Praxelinae. 


\section{The RELATIONSHIPS OF THE EUPATORIEAE}

The present study, with its strong emphasis on microscopic features, in conjunction with work by the junior author on other tribes of the Asteraceae, has resulted in strong opinions regarding the phyletic position of the Eupatorieae in the family (Fig. 2). These opinions conflict with the widely accepted views of relationships based on more superficial aspects of the various Asteraceae. It is therefore initially necessary here to discuss what the relationships of the Eupatorieae are not, before attempting to determine what they are. As indicated below, the Eupatoricae are not closely related to the Vernonieae as implied by many authors including Carlquist (1976), and they are not derived from the Heliantheae as suggested by Cronquist (1955). It is the present view that the Eupatorieae represent a basal off-shoot of the subfamily Asteroideae, being fully within the Asteroideae, but retaining some ancestral features shared with the Cichorioideae.

The Eupatorieae and the Vernonieae both have discoid heads with reddish or purplish flower color, and they are among the many tribes in which most species have a capillary pappus. It is because of these obvious similarities that most authors have placed the two tribes adjacent to each other in their classifications. Even Cassini (1818c), who was well aware of the technical differences, placed the two tribes next to each other on one side of his chart of the tribes in the Dictionnaire des Sciences Naturelles. The association was maintained through Lessing (1832), DeCandolle (1836), Bentham and Hooker (1873), and Hoffmann (1890-1894) with the tribes distinguished by the differences in their styles. Even as the style differences are cited, there has been little tendency recently to use the styles in actual practice. The tendency to ignore the floral details reached a peak in this century with two instances when style details were erroneously assigned to the Eupatorieae and Vernonieae on the basis of their assumed relationship. Cronquist in Gleason (1952) described the style branches of the Vernonieae as having stigmatic surfaces only near the base, the condition that is found in the Eupatorieae. Carlquist (1976) credited the Eupatorieae with having stigmatic hairs covering the entire inside surface of their style branches as in the Vernonieae. It scems to have been Poljakov (1967) who first clearly showed that the Eupatorieae and Vernonieae were not closely related to each other, though the Eupatorieae were treated inexplicably by Poljakov as a subtribe Ageratinae of the Astereae. Independently, H. Robinson and Brettell (1973) in a study of the relationship of $U r$ sinia proposed an alignment similar to that of Poljakov with the Vernonieae as one of a series with the Liabeae, Cardueae (as Cynareae), Mutisieae, Lactuceae (as Cichorieae), and Arctotideae having styles with a single stigmatic area covering the inside surface of the branches, anthers with bases projecting well below the point of attachment, anther appendages mostly flat, lobes of the disk corollas long and narrow, and including all lophate, psilate or otherwise modified forms of pollen in the family. The remaining tribes, including the Eupatorieae, were seen to have two distinct stigmatic lines, anthers with pollen-bearing parts not extending much below the point of attachment, pollen with regularly distributed spines, and all examples in the family of short lobes on the disk corollas, keeled anther appendages, and sterile unbranched styles. The differences cited by $\mathrm{H}$. Robinson and Brettell have shown a number of exceptions on the basis of further studies, but appear to remain valid as indicators of a basic division in the family. Wagenitz (1976) refined the concept with the addition of a number of characters, the most significant, the presence of laticiferous cells or ducts in many tribes of the Vernonieae-Lactuceae series. Carlquist (1976) formalized the use of the subfamily names Cichorioideae and Asteroideae for the two series of tribes, but erroneously placed the Eupatorieae in the Cichorioideae.

H. Robinson (1977) presented a direct comparison of the two tribes Eupatorieae and Vernonieae, and reiterated the basic subfamily characters by which they differ. Additional characters cited were the T-shaped hairs, glands on the anther appendages, scorpioid cymes, weaker thickenings on the walls of the endothecial cells, larger pollen grains mostly over $40 \mu \mathrm{m}$, and raphids in the cells of the achene walls in the Vernonieae, none of which occur in the Eupatorieae. The discoid heads and similar flower colors shared by the two tribes were considered superficial and potentially subject to selection pressures by pollinators.

More recent observations continue to emphasize the differences between the tribes. The leaves of the Eupatorieae are often trinervate, but rarely those of the Vernonieae. Both tribes can show differentiated peripheral flowers in the heads, but in the Eupatorieae the differentiation is most often in the corolla 


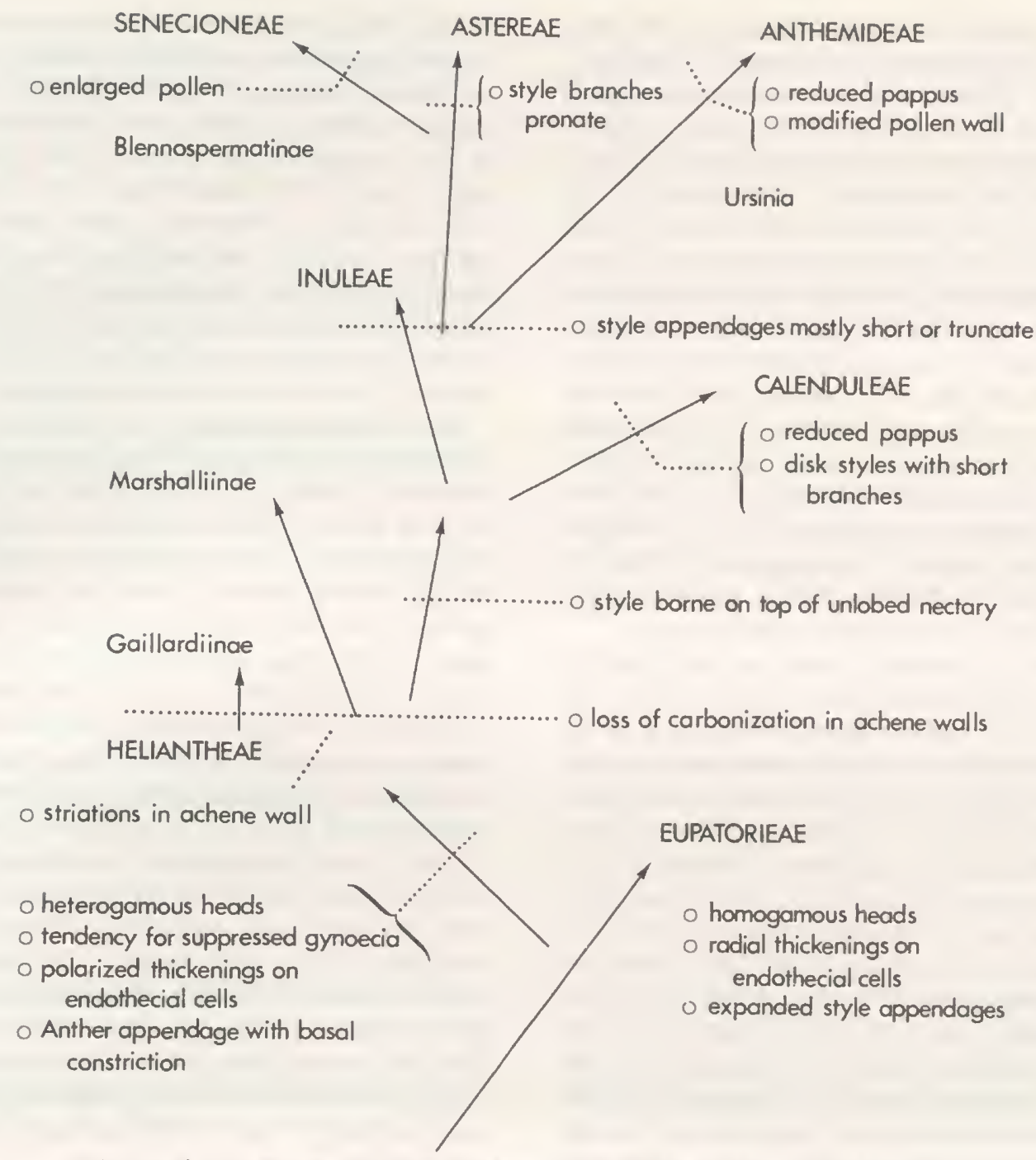

Ancestral Asteroideae with paired stigmatic lines, spinulose pollen, carbonized achene walls, anther appendages without constricted bases, gynoecia always fertile.

Figure 2. Schematic representation of relationships in the subfamily Asteroideae (from H. Robinson, 1981).

form, in the Vernonieae there is sometimes marked differentiation in the achenes (H. Robinson, 1979, Heterocypsela). It is also notable that one of the characters held in common by the tribes, the capillary pappus, is considered the primitive form in the family by $\mathrm{H}$. Robinson (1981).

On the basis of the foregoing, the Eupatorieae is considered to belong to the subfamily Asteroideae, with the tribes Heliantheae, Inuleae, Calenduleae, Astereae, Anthemideae, and Senecioneae, but there remains the problem of the position of the Eupatorieae within that subfamily. Cronquist's (1955) views on the ancestral position of the Heliantheae in the family are still widely accepted (Cronquist, 1977; Turner, 1977), and can be analyzed within the context of the two subfamily concept. The Cronquist concept can be considered partially nullified by the foregoing subfamily alignment and is further nullified by the artificiality of some of the tribal concepts accepted by Cronquist. Further problems arise from the realization from detailed studies that no tribe is sufficiently generalized to be ancestral to any other. The most important considerations, however, are those evident from the present study of the 
Eupatorieae and the concurrent studies of the Heliantheae by H. Robinson (1981) and H. Robinson et al. (1981). Cronquist (1955) argues the primitiveness of the Heliantheae mostly on the basis of a series of characters that seem pre-selected for their occurrence in the Heliantheae. Two characters that have a stronger theoretical basis are the five-parted pappus which more closely resembles the calyx from which it is supposedly derived, and the presence of paleae which represent the bracts that would subtend each flower in any compound inflorescence. Regarding the pappus, the capillary form proves to be much more widely distributed in the Heliantheae than realized by Cronquist, and is regarded as primitive in that tribe and in the family by $\mathrm{H}$. Robinson (1981). The paleaceous receptacle in its most highly developed form seems to be specialized within the Heliantheae (H. Robinson, 1981), and in its less specialized form it occurs in the Eupatorieae.

A number of characters can be interpreted as showing the Eupatorieae more primitive than the Heliantheae, and some of these are indicated in the accompanying diagram of the Asteroideae phylogeny that is accepted here. The heads of the Eupatorieae are discoid with all flowers bisexual. Those cases of differentiated peripheral flowers such as Microspermum and Praxeliopsis involve no loss of anthers. Cronquist (1955) has suggested that such heads represent a loss of rays in the Asteraceae, and that radiate heads are primitive in the Asteraceae. While Cronquist may be correct, there is no real evidence of radiate ancestry for the Eupatorieae, and Cronquist's arguments are the opposite of his assumptions in the same paper regarding the direction of evolution in the pappus. In a related character, there are no suppressed gynoecia in the Eupatorieae. Such non-functional gynoecia are restricted in the Asteraceae to a few genera of the tribe Mutisieae and to the tribes of the Asteroideae above the level of the Eupatorieae. Such gynoecia occur to some extent in all the tribes of the advanced Asteroideae, either within heterogamous heads or in male heads of dioecious species.

The Eupatorieae and Heliantheae are the only tribes of the Asteraceae having phytomelanins in the wall of the achene. The resulting black layer in the Eupatorieae is uninterrupted or only interrupted along the ribs. In the Heliantheae the achene walls have specialized lines interrupting the phytomelanin which are referred to as striations by H. Robinson (1981). Such striations are sufficiently widely distributed in the Heliantheae to be considered basic to that tribe, being found in many subtribes of both the paleaceous and epaleaceous series.

The endothecial cells of the Eupatorieae are the most consistently radial in their design of any tribe in the Asteraceae. As a result, they most closely approximate the ancestral functional form found in most families of flowering plants with functional valves. In contrast, the endothecial cells of the $\mathrm{He}$ liantheae are almost all polarized with reduced numbers of thickenings. As such, the endothecial cells of the Heliantheae are specialized, and the few radial forms in the tribe seem to be secondarily derived.

The anther appendages of the Eupatorieae are flat and broad with cells not divergent, or are sometimes reduced or lacking. In this respect the appendages are like those of most members of the subfamily Cichorioideae. In the Heliantheae, with few exceptions, and in all other tribes of the Asteroideae, the anther appendages are constricted at the base. In most Heliantheae the appendages are expanded above the base with diverging cell patterns. The condition of the Cichorioideae and the Eupatorieae seems to be primitive in the Asteraceae, with the constricted appendages being specialized in the $\mathrm{He}$ liantheae and other advanced Asteroideae.

There is one final character that may reflect a more primitive position for the Eupatorieae. Paired separate stigmatic lines are basic to the subfamily Asteroideae, and no tribe shows these separated lines more consistently than the Eupatorieae. In the Eupatorieae there are often glands in the space between the lines, a condition not found in any other tribe. There are no reversions to a single continuous stigmatic surface as in some Heliantheae, Senecioneae, and Inuleae.

There is some indication that the space between the stigmatic lines is developmentally related to the origin of the style appendage. In female flowers of many advanced Asteroideae, there is no appendage, and the stigmatic lines connect across the apex of the style. It is in the Eupatorieae that the stylar appendage reaches its highest development, often becoming the most prominent and colorful part of the inflorescence. While such a style appendage is specialized in itself, it is, nevertheless, the least efficient of the mechanisms adopted by the Asteraceae for the prevention of self-pollination, and it seems unlikely that it would have evolved from any form that was as efficient as that in the advanced Asteroideae such as the Heliantheae and the remaining tribes.

The Eupatorieae are considered here to be like all 
other tribes of the family, being too specialized to serve as the ancestor of any other tribe. However, the point of departure of the Eupatorieae is believed to be below the point of divergence of the Helian- theae from the remaining Asteroideae, and close to the point of divergence of the Asteroideae and $\mathrm{Ci}$ chorioideae. 


\section{The Structure of the EupatorieaE}

Members of the Eupatorieae are mostly perennial herbs or shrubs, a few such as Fleischmannia microstemon, $F$. sinclairii, and Brickellia diffusa are annuals, and some species of Critonia and Kaunia are small trees. Six genera, Mikania. Tuberostyles, Neomirandea, Gongrostylus, Hughesia, and Standleyanthus, have developed an epiphytic habit. In Neomirandea some species appear to have reverted to deep humus substrates, and they have extensive prop-root systems. One of the later species, N. panamensis, is an arborescent perennial herb up to 13 $\mathrm{m}$ tall.

The stems of the Eupatorieae differ from those of some tribes such as the Senecioneae, and resemble those of the Heliantheae by the position of the resin ducts between the vascular bundles rather than directly outside of them (Col, 1904). The pith may be solid, but is often fistulose. The condition is often stable within genera (Matudina versus Eupatoriastrum). Chambering of the pith is often prominent, and the septae can persist in considerably enlarged stems (Neomirandea). Solereder (1908) suggested possible anomalous secondary growth in Mikania, but Carlquist $(1965,1966)$ who reviewed the stem anatomy found no unique features in the vascular tissue of the tribe. According to Carlquist, the vessel elements are short and broad with large intervascular pits in the liana Mikania cordifolia, and the strands of axial parenchyma have cells as long as wide. Narrow vessels and prominent growth rings are found in a more xeric type such as Brickellia. Carlquist (1965) indicates that width of rays, presence or absence of procumbent cells in addition to erect ones in rays, relative height of rays, and notably short and narrow or wide and long vessel elements, might be useful in distinguishing species.

The Eupatorieae is one of the few basically opposite-leaved tribes of the Asteraceae. Some scattered groups in the tribe have strictly alternate leaves (most of Decachaeta, one species of Guevaria, Chromolaena stachyophylla, and members of the Liatrinae). Among the opposite-leaved genera, the upper leaves and bracts of the inflorescence often become alternate. Almost all the upper leaves are alternate in Neohintonia, and alternate branching of the inflorescence is characteristic of Austroeupatorium and some species of Heterocondylus. The opposite-leaved condition is perpetuated into the inflorescence in most species of Chromolaena and many other genera, and is seen in the head structure of Mikania and some Ophryosporus. True verticillate-leaved species include many members of $M i$ kania and Neomirandea costaricensis. The verticillate leaves of some Eupatorium and Sclerolepis seem developmentally related to the sessile or subsessile lobed or tripartite forms found in related species. Basal rosettes are characteristic of the Liatrinae, and are found to a lesser extent in other isolated genera such as Eupatorina, Bishopiella, $\mathrm{Ci}$ ceronia, Antillia, and Gyptis.

The leaves are variable in form from sessile to long-petiolate, but as in all members of the family, there is at least a minimal wing on the petiole and between any segments which reflects a basically sessile and simple form. Variation in the petiole occurs in all groups of the tribe, but sessile leaves or broadly winged petioles are particularly common in the Ayapaninae, and long petioles are particularly common in the Hebecliniinae.

Leaf blades are predominantly simple, ovate, or elliptical types with variations from entire to strongly dissected. Dissection may involve broad lobes (Carterothamnus, some Hofmeisteria, one Lomatozona), linear lobes (Acanthostyles and some Eupatorium) or bipinnatifid blades (Gyptis pinnatif$d a$ ). The most dissected lobes in the tribe occur in the calcicolous Eupatorina of Hispaniola. In Grazielia gaudichaudiana, the blade varies from finely serrate to bipinnatifid (Malme, 1933: 42, fig. 7). Venation of the blades may be palmate or pinnate, but there is a strong tendency for a trinervate condition from near the base. The venation varies within many genera. Ducts occur along the veins in many genera (especially prominent in Morithamnus). Only in Critonia are vesicles prominent in the areoles between the veins, where in some members they form translucent or even lens-like spots.

The inflorescence of the Eupatorieae is usually a flat-topped or dome-shaped corymbose panicle. Central heads may mature slightly after the peripheral ones, but more often they mature first. The cymose sequence is often reflected in the structure of the branching and is either restricted to the branches as in Condylidium or may extend to the whole inflorescence as in Ageratum. The cymose maturation is particularly notable in Liatris where the apical heads of the spicate inflorescence mature first. Heads in extreme cases may be sessile in rounded clusters (Neohintonia, Mexianthus, Sphaereupatorium) or may be single and large on long pe- 
duncles (Hofmeisteria and Brickellia monocephala). The major groups of Mikania have been classically distinguished by their corymbose, thyrsoid, and racemose or spicate inflorescence branches.

The involucre of the Eupatorieae is traditionally characterized as imbricate, subimbricate, or eximbricate. The three types prove to be subject to considerable interpretation, and there is an additional type found in the Adenostemmatinae. The imbricate form has been restricted in the past to groups called the "Cylindrocephalae" and some members of the Critoniinae with a cylindrical involucre of strongly overlapping bracts in many series of gradually increasing lengths. The distinctive appearance derives from the fact that the bracts of some genera dehisce rather than spread on drying. Many members of the tribe show the same cylindrical appearance when alive. Within the imbricate group is a truly natural element, the Praxelinae, in which all the involucral bracts are completely deciduous. The relationship includes a few genera such as Praxelis which do not usually have cylindrical involucres and which are not in the traditional Cylindrocephalae. The subimbricate involucre has bracts progressively longer in overlapping series, but at least the outer bracts spread at maturity and do not fall. Examples are common in the Critoniinae, Ayapaninae, Alomiinae, Hebecliniinae, and Fleischmanniinae. The eximbricate form has bracts of subequal lengths which spread at maturity and at most a few inner ones are deciduous. Examples are most common in the Gyptidinae, Ageratinae, and Oxylobinae. The involucral types may vary considerably within genera, although general trends may be evident through whole groups at the subtribal level. The involucre of the Adenostemmatinae is distinct from all others in the tribe by the indistinct non-articulate bases of the bracts, and by the partial fusion of many of the members.

The receptacle varies in shape and in cellular differentiation. The most distinctive form occurs in the Adenostemmatinae where the tissue between the individual achene scars is not sclerified and where the whole structure is able to change shape. The scars shift in position as the receptacle matures. In most other Eupatorieae the surface between the achene scars is completely sclerified and often forms distinct ridges or in some such as Piptothrix areolare forms short spines. In the extreme sclerified condition, most species of Hebeclinium have no central pith in the receptacle. Receptacles of many Eupatorieae have paleae arising from junctures between the flowers. The paleaceous species are rarely closely related to each other (Eupatoriastrum, Matudina, Idiothamnus, one species of Gyptidium, several species of Chromolaena, some Ageratum, Jaliscoa, Blakeanthus, Ferreyrella, Isocarpha, Lepidesmia, Parapiqueria, and Acritopappus). Such forms seem to represent an erratic capacity in the Eupatorieae for revival of this suppressed structure. The paleae of two genera, Oaxacania and Carterothamnus, seem to represent a very different form where each palea is closely paired with a flower and when pulled from the head carries a flower with it. Receptacles of many Eupatorieae have hairs or small chaff. Such hairs are more common, but not entirely consistent, in the Hebecliniinae. Some other comparatively unrelated genera such as Urolepis of the Gyptidinae and Polyanthina of the Ayapaninae also have prominent hairs. In Neomirandea and Neocabreria, the presence or absence of receptacular hairs is correlated with hairs on the inner surface of the corolla. The shape of the receptacle in the tribe is usually flat or slightly convex. A low-conical shape occurs in many members of the Gyptidinae and Ageratinae, and in one species of Aristeguietia in the Critoniinae. A high-conical to columnar shape occurs in Praxelis and Eupatoriopsis in the Praxelinae and Isocarpha in the Ayapaninae.

The heads of the Eupatorieae may contain from one flower to many hundred flowers. The genera having clusters of single-flowered heads (Mexianthus and Neohintonia) are both members of the Koanophyllon relationship in the Critoniinae, but they nevertheless show many differences in other details. Other genera with small numbers of flowers may have the number fixed, and in Stevia with five, Mikania with four, and Piqueria with three to five, the number is identical to the number of involucral bracts. The highest number with such floret-number stability seems to be 20 which occurs in six of the seven species of Lourteigia. The extremely high flower numbers occur in various distantly related groups such as Polyanthina of the Ayapaninae, Eupatoriastrum of the Critoniinae, and Hofmeisteria of the Hofmeisteriinae.

Corollas are whitish, reddish, or bluish, but so far as known, never yellowish in the Eupatorieae. References to yellowish flowers on label data in many Alomiinae seems to derive from the yellowish pollen that often coats the surface of the large style branches. All flowers are perfect and fertile. True rays are lacking, but peripheral flowers may be differentiated. The peripheral corollas are slightly zy- 
gomorphic in Bartlettina tuerckheimii and Ferreyrella peruviana, and the outer lobes or outer part of the limb are greatly expanded in Praxeliopsis and Microspermum. The peripheral flowers are differentiated by lack of a pappus in some species of Trichogonia and Fleischmannia. Differentiation of flowers in the heads of many Stevia was shown to follow a definite sequence by B. Robinson (1930d). He noted the usual pattern of heterocarpy involving an idiocarp with a partly or completely reduced pappus in the flower subtended by the outermost bract. The remaining adelphocarps are usually alike, but sometimes differences occur in the second or third achene according to a two-fifths sequence around the circle of flowers.

Corollas of the tribe are funnelform to tubular with or without a distinct basal tube. The base of the corolla is fused to the top of the achene in Teixeiranthus. The throat of the corolla is narrow and appears as a continuation of the basal tube in $\mathrm{CO}$ rethamnium. The upper part of the corolla is somewhat constricted in most members of the Alomiinae. There are five lobes except in the minute species of the oligotypic genera Iltisia and Piqueriopsis which have four lobes. The lobes are characteristically short with the exceptions of deeply cut narrow lobes in some species of Mikania, Neomirandea, and Steyermarkina. The lobes are usually without stomata, but these occur in some species of Stomatanthes of Africa and South America, and in four species of Eupatorium in North America. The cells of most corollas are narrow with obvious sinuous vertical walls, but some species of Mikania and most species of Neomirandea have large quadrate cells with mostly straight walls. The species with such cells seem to be restricted to moist and often epiphytic habitats. Corolla cells never contain obvious druses or other complex raphids, but rarely very simple crystals are seen. The inside surface of the corolla is usually glabrous, but Stevia, Steyermarkina, Neocabreria, some Neomirandea, some $\mathrm{He}$ beclinium, and others have hairs. Papillae on the inner surface in Eitenia are sometimes long and hair-like along the veins. In Gardnerina there are hairs restricted to the area of the insertion of the filament. In Cronquistianthus korthalsianus the inner surface of the corolla near the base of the anther has a pair of crests formed by invaginations of the inner surface. In Mikania houstoniana and its close relatives there is a characteristic wrinkling of the inner surface where the inner layer of cells expands more than the outer layer of the corolla.
The filaments are usually inserted above a slightly to strongly narrowed tube. In Urbananthus, Teixeiranthus, and Isocarpha megacephala, the insertion is near the base. In Praxeliopsis the filaments are reduced to short collars inserted just below the bases of the spreading lobes. In Polyanthina the corollas are so narrow that the insertions of the filaments are staggered at various levels.

The lower part of the filament is usually elongate and smooth. In various genera such as Phania, Praxeliopsis, or some Cronquistianthus the collar is mounted almost directly on the corolla. In a few genera such as Piqueria and Ellenbergia, the lower filament is papillose or pubescent.

The anther collar shows more variation in the Eupatorieae than in any other tribe of the Asteraceae (Fig. 3). Cells in the lower part are usually short, and those of the upper part elongate. The intercellular walls are usually thin or show slight nodular thickenings. In Ageratina, Hebeclinium, and Neomirandea and various of their relatives the collars are elongate with great numbers of quadrate cells, and there are usually few ornate thickenings on the walls. Fleischmannia shows the opposite extreme with few or no quadrate cells and with very prominent transverse annular thickenings that cover the outer walls. In the Praxelinae the lower part of the collar is usually enlarged with very short cells where the direction of the annular thickenings varies between cells often being oblique or vertical. The pattern of thickenings of the collar cells in its extreme forms is taxonomically useful, members of the Gyptidinae, Ageratinae, and Fleischmanninae having strongly annulate thickenings and the Hebecliniinae and Oxylobinae having almost none. In the Critoniinae there is variation in some genera. Prominent annular thickenings in the collar are known in a few genera outside of the Eupatorieae such as Chrysactinium of the Liabeae, Adenocaulon of the Mutisieae, and Pinillosa of the Heliantheae.

The stamens remain included in the corolla in most members of the tribe, but are characteristically exserted in Mikania, and are partially exposed in the deeply lobed species of Neomirandea and Steyermarkina.

Endothecial cells of the tribe are almost all subquadrate with nodular thickenings evenly distributed on horizontal and vertical walls. The cells tend to be more elongate in a few genera such as Ageratina. In Carphochaete and Hofmeisteria the cells may be elongate and some horizontal walls have fewer thickenings. Thickenings on the en- 


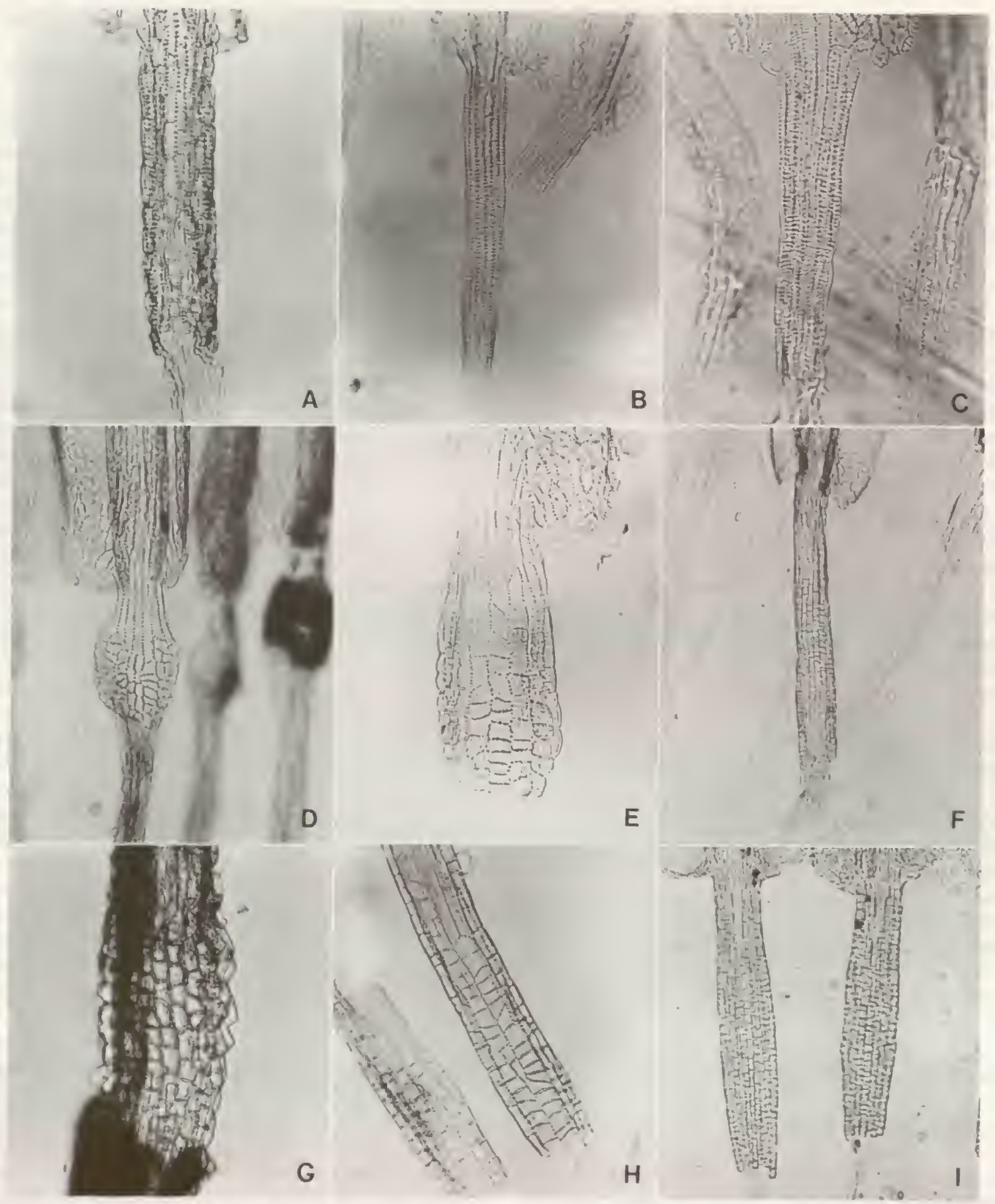

FtGURE 3. Anther collars. - A. Trichogonia menthaefolia Gardner, $\times 145 .-$ B. Fleischmannia cookii (B. Robinson) R. King \& H. Robinson, × 135. - C. Fleischmannia gentryi R. King \& H. Robinson, $\times 210 .-$ D. Praxelis asperulacea (Baker) R. King \& H. Robinson. $\times 100 .-$ E. Chromolacna chasei (B. Robinson) R. King \& H. Robinson, $\times 190 .-F$. Bartettina breedlovei R. King \& H. Robinson, $\times 100 .-$ G. Mikania cyanosma Urban \& E. Ekman, × 160. - H. Ageratina cardiophylla (B. Robinson) R. King \& H. Robinson, $\times 220 .-$ I. Spaniopappus bucheri (B. Robinson) R. King \& H. Robinson, $\times 140$. 
dothecial cells of most other tribes differ from those of the Eupatorieae by being polarized. The Vernonieae, Munnozia subgenus Kastnera of the Liabeae, and isolated genera such as Dahlia, Lasthenia, Pinillosa, the members of the Ambrosiinae, most members of the Rudbeckiinae, and some species of $\mathrm{Me}$ lampodium in the Heliantheae have similar radial thickenings, but these differ from those of the Eupatorieae in details.

The anther appendage in the Eupatorieae is flat with two layers of cells. It is often hollow in the mature state. A pair of flanges on the inner surface may be present as extensions of the inner valves of the anther thecae, and between the flanges there is sometimes a prominent groove that may end in an apical emargination. In some genera such as $D i$ acranthera, Trichogoniopsis, and some Ophryosporus the retuse appendage may be divided into two completely separate lobes. The appendage is usually oblong-ovate, but seems to show strong predisposition to reduction in the tribe. The appendage is shortened or lacking in such genera as Adenostemma of the Adenostemmatinae, Ciceronia, Ophryosporus, and Koanophyllon of the Critoniinae, Praxeliopsis of the Praxelinae, Decachaeta of the Hebecliniinae, Ageratella of the Alomiinae, Gongrostylus of the Ayapaninae, Diacranthera of the Gyptidinae, many genera such as Phania, Ellenbergia, Piqueria, Phalacraea, Piqueriopsis, and Ascidiogyne of the Ageratinae, and two species of the isolated genus Hofmeisteria. The appendage is unusually indurated in one species of Microspermum, and is unusually lobed and narrowed in some Praxelis. The appendage is characteristically rather obovate with a crenulate distal margin in Stevia and Metastevia. In Lasiolaena morii, the mature appendage is very fragile and deciduous (King \& Robinson, 1979f).

The nectary surrounds the style base and the style is fully immersed in most genera of the Eupatorieae. There is some elevation of the style in a few genera such as Praxeliopsis, Ageratina, and Carphochaete. This contrasts with such tribes as the Heliantheae where the nectary is usually strongly lobed and the style base is never completely immersed, or the more advanced Asteroideae such as the Astereae and Senecioneae where the style base is seated on top of the nectary. In all cases, the nectary has stomates which seem to function as secretory pores. The surface of the nectary is usually glabrous, but has hairs on the tip in Sciadocephala amazonica. The only other known example of a pubescent nectary in the family is in one species of Eremanthus in the Vernonieae.

The style furnishes the most important distinguishing characters of the tribe, especially the pubescent bases, the consistency of separation of the stigmatic lines, and the great enlargement of the style appendages. Outside of the Eupatorieae, hairs are known on the style base only in three genera, Arnica, Chaenactis, and Chamaechaenactis, in the subtribe Chaenactidinae of the Heliantheae ( $\mathrm{H}$. Robinson, 1981). In the Eupatorieae such pubescence is common, and hairs on the style are characteristic of some groups such as the Eupatoriinae and many genera of the Alomiinae. Pubescence on the style base is variable within some genera such as Ayapanopsis, Heterocondylus, and Isocarpha of the Ayapaninae. The occurrence of hairs on the style is widely distributed in the tribe, and the potential for such hairs seems basic to the tribe. Hairs occur on the shaft of the style in some Adenostemma species and in Stylotrichum, and both hairs and slender stalked glands are seen on the style shaft in Sartorina of the Fleischmaniinae.

The style base of the Eupatorieae may bear a node or enlargement independently of the presence of hairs (Fig. 4). Such basal nodes are often sharply defined and are usually constant within genera or groups of genera. Nodes are particularly prominent in Gongrostylus and other Ayapaninae and in many Alomiinae. Praxeliopsis of the Praxelinae has a welldeveloped node in a subtribe where stylar nodes are otherwise lacking. A node is present in most Oxylobinae and is absent in the Critoniinae. The node is usually absent in the Gyptidinae, but occurs in a few genera (including Dasycondylus and all but one species of Campuloclinium). The node in the Eupatorieae does not seem to function as in many Heliantheae where it enlarges belatedly and helps break the base of the corolla away from the achene.

The style branches have stigmatic lines consistently separated and usually restricted to the basal half (Cassini, 1813; Chamberlain, 1891). The stigmatic lines are close together on the inner surface and reach near the tip in one genus, Carphochaete. In most members of the tribe the lines are widely separated, and in many genera from various subtribes there are glands on the inner surface between the lines, or above on the appendage. Glands have not been seen on the inner surface of the style branches in any other tribe of the Asteraceae. Glands on the outer surface of the style branches are known 


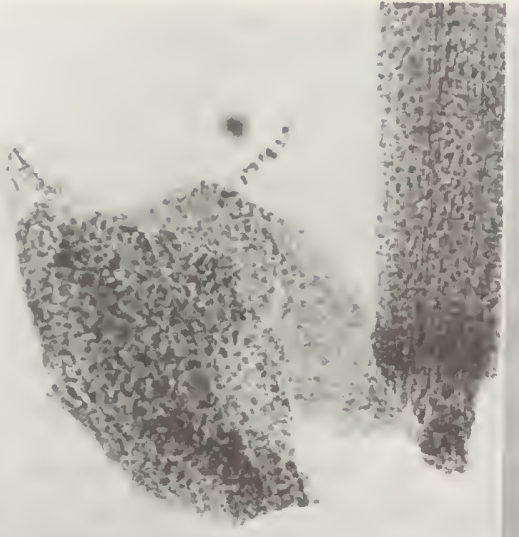

A

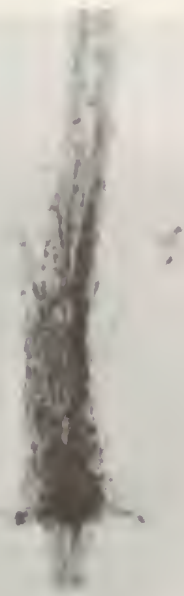

B

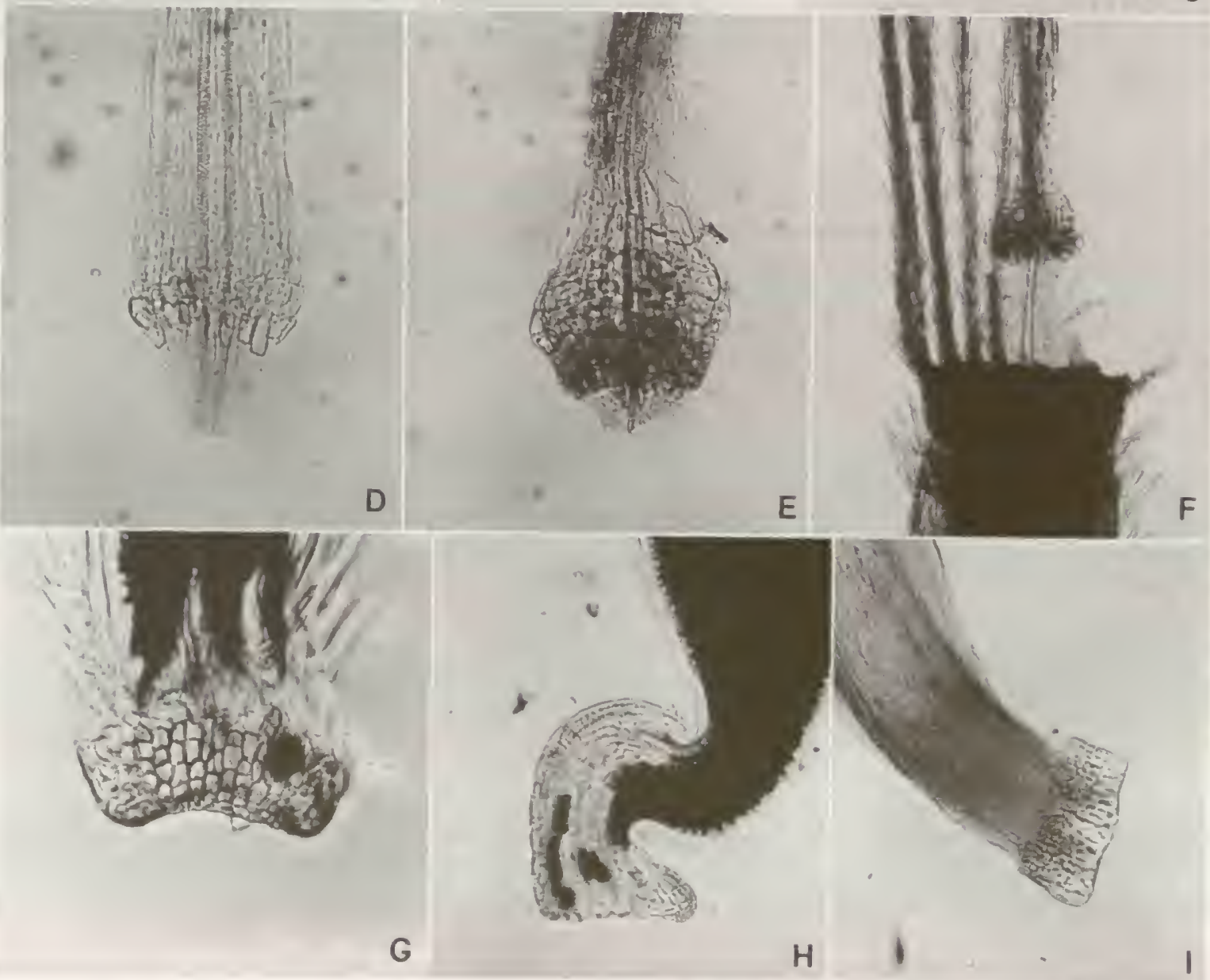

Figure 4. Style bases and carpopodia.-A. Sciadocephala amazonica R. King \& H. Robinson, style base showing part of originally surrounding nectary with hairs, $\times 95 .-B$. Austrocupatorium imulaefolium (H.B.K.) R. King \& H. Robinson, $\times 55 .-$ C. Brickellia peninsularis Brandegee, $\times 100 .-D$. Ageratina camachensis (Hieron.) R. King \& H. Robinson, $\times 110 .-$ E. Ageratina vernalis (Vatke \& Kurtz) R. King \& H. Robinson, × 200. -F. Agerarina cardiophylla (B. Robinson) R. King \& H. Robinson, showing style only partially immersed in nectary and fragile pappus, $\times 90 .-$ G. Trichogonia villosa (Sprengel) Schultz-Bip., $\times 160 .-$ H. Piqueria trinervia Cav., carpopodium, ×85.-1. Ayapanopsis vargasii R. King \& H. Robinson, carpopodium with basal row of enlarged cells, $\times 60$. 
in a few other tribes, Stokesia of the Vernonieae, and a few members of the Ecliptinae of the Heliantheae, but such glands are found in only a few members of the Eupatoricae such as Stylotrichum and some species of Mikania. The style appendage is quite short in Brickellia diffusa of the Alominae and Carphochaete of the Ageratinae due to the elongation of the stigmatic lines. There is also a tendency for short spreading appendages in Ayapana, Lepidesmia, and Isocarpha of the Ayapaninae, which has contributed to the placement of some of these in the Heliantheae by some authors (B. Robinson, 1913a; Badillo, 1944b; Stuessy, 1977). In all other Eupatoricae, the appendage is at least as long as the stigmatic region, and in some it is strongly pigmented, lending much of the visible color of the inflorescence. Styles in the Eupatorieae are often at least as prominent as the rays in some Astereae, and they apparently function in a manner equivalent to colored rays or bracts. Style appendages of many Eupatorieae are somewhat flattened, with or without a clavate tip. The Alomiinae are distinct in the manner in which the thickened appendages are not flattened. Rather abruptly expanded clavate style tips are found in some Critoniinae such as Fleischmanniopsis and Critoniadelphus, and can be used to distinguish Ophryosporus from the genus Mikania which it sometimes resembles. Very large fusiform clavate tips are found on the styles of Gongrostylus of the Ayapaninae. Terete filiform style appendages are found in Hebeclinium of the Hebecliniinae and Critoniella and Castenedia of the Critoniinae.

The achenes of the Eupatorieae are usually prismatic with five ribs. Brickellia, Liatris, and the Kanimia part of Mikania have up to ten ribs, but these genera do not form a related group as treated by Bentham and Hooker (1873). The genera with flattened, mostly two-ribbed achenes such as Macvaughiella, Oaxacania, and Eupatoriopsis are also of diverse relationships in the tribe. The genus Lourteigia is unique in the tribe by the extreme constriction of the achene below the pappus. The surface of the achene may have biseriate hairs, capitate glands, various combinations of these, or may be glabrous. The characteristically biseriate hairs may be parted from near the base or even uniseriate in members of the Liatrinae.

Internally, the walls of the achenes in the Eupatorieae lack crystals. Such crystals are prominent in all other tribes of the family except the Heliantheae, and they are present in some members of the latter tribe. The achene walls have black or carbonized resin-like deposits in the mature state in most genera of the Eupatorieae, and the deposits are formed around minute projections which appear as small pores. The punctations that result are usually randomly distributed, but are often in transverse rows in members of the Gyptidinae and Disynaphiinae. The punctations are unusually sparse in Piqueria, and carbonization and punctations seem to be entirely lacking in Sartorina. The only other tribe with such carbonized deposits associated with pitting is the Heliantheae (sensu H. Robinson, 1981). Many of the latter can be distinguished from the Eupatorieae by the presence of numerous clear longitudinal striations in the wall. The outer layers of the achene wall in the Eupatorieae expand at maturity to form a rind in the genus Tuberostyles and in some species of Mikania. In the type species of Ascidiogyne, the outer layer is expanded to form a large fluid-filled sac around the achene.

The carpopodium represents, in part, the abscission zone at the base of the achene, and it has a great variety of structure in the Eupatorieae (Fig. 5). It proved to be a particularly useful taxonomic character in the initial revisional study of the tribe by the present authors (King \& Robinson, 1966). Many genera have distorted bases with sinuous traces and differentiated cells higher in one side, such as $P i$ queria, Ageratum, Alomia, Flyriella, Condylidium, and Cronquistianthus, but in the first two genera listed the character varies between species. Guayania, Brickellia, and Praxelis are examples where the basal opening is turned to one side. Eupatorium, Conoclinium, and Sartorina are among the genera with the carpopodium poorly differentiated or undifferentiated. Cell shapes produce elongate surface patterns in Pleurocoronis or many series of short cells as in Hofmeisteria. The cell walls may be thin as in Ageratina, Trichogonia, and Barrosoa, or thick as in Fleischmannia. In Ayapana, Polyanthina, Ayapanopsis, and Gongrostylus of the Ayapaninae the lowermost row of cells is much enlarged and differentiated. The cells above the carpopodium may collapse at maturity leaving a marked upper edge on the carpopodium as in Fleischmannia and Campuloclinium, or the carpopodium may be structurally continuous with the ribs of the achene as in Barrosoa and Dasycondylus of the Gyptidinae and many members of the Hebecliniinae.

The ovule in the Eupatorieae has a single lobe at the lower end. The surface cells of the lobe are often sclerified, but the ovule is unsclerified in some genera such as Ayapana and Isocarpha. The cells of the 

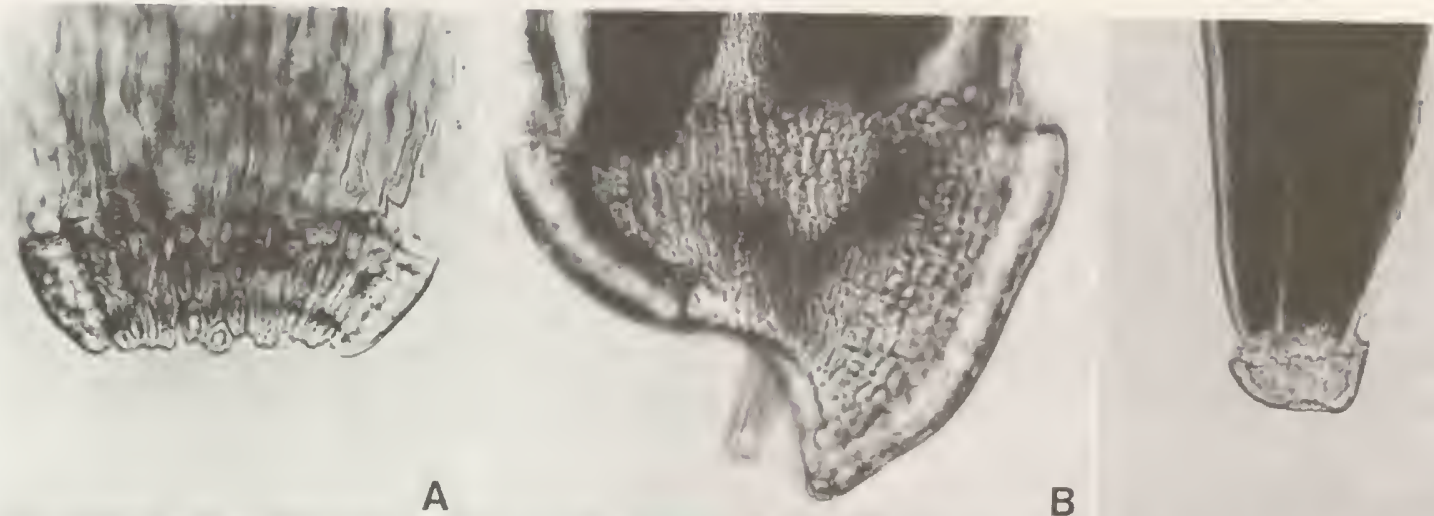

A

B

C

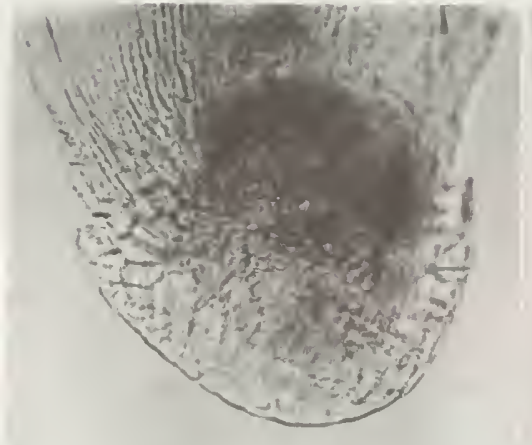

D

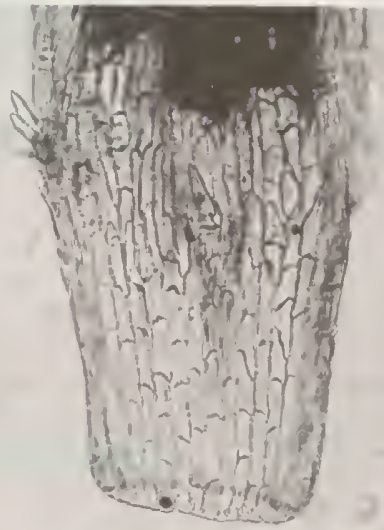

E
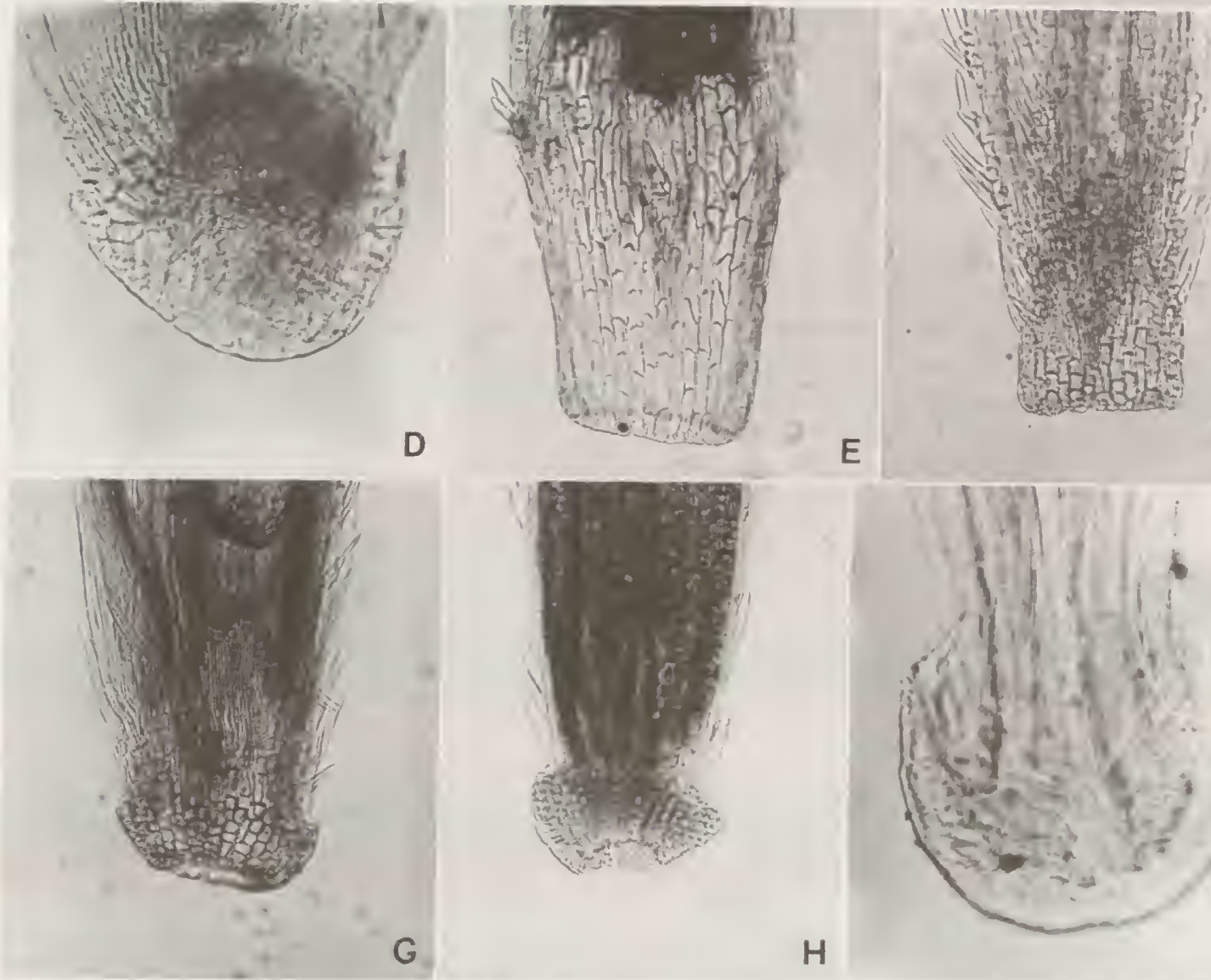

G

$\mathrm{H}$

FIgure 5. Carpopodia. - A. Brickelliastrum fendleri (A. Gray) R. King \& H. Robinson, $\times 140 .$, B. Phanerostylis coahuilensis (A Gray) R. King \& H. Robinson, ×160.-C. Fleischmannia guatemalensis R. King \& H. Robinson, $\times 85 .-D$. Praxelus asperulacea (Baker) R. King \& H. Robinson, $\times 140$. - E. Ageratina apollinairei (B. Robinson) R. King \& H. Robinson, $\times 200 .-$ F. Ageratina costaricensis R. King \& H. Robinson, × 180.-G. Ageratina brevipes (DC.) R. King \& H. Robinson, ×180. - H. Hofmeisteria schaffneri (A. Gray) R. King \& H. Robinson, $\times 110 .-$ I. Pleurocoronis pluriseta (A. Gray) R. King \& H. Robinson, $\times 190$.

ovule surface never have thickenings of the type found in many Heliantheae (H. Robinson, 1981).

The pappus of the Eupatorieae is usually formed of many capillary bristles in one series, a form that is considered primitive to the tribe. The pappus may be reduced to ten or five bristles, as in Hofmeisteria or some Fleischmannia, and it is reduced to five scales, a crown, or may be completely absent in 
Ageratum and other genera. Individual species of some genera such as Koanophyllon, Spaniopappus, Morithamnus, and Arrojadocharis may have the pappus reduced or lacking. Pappus elements of Pleurocoronis, Malperia, and some Hofmeisteria are differentiated with scales above the flattened surfaces of the achene and awns above the ribs. There is a tendency for pappus setae to be congested and forming a partial second row in some genera such as Mikania and Aristeguietia. In the tribe only one species of Asanthus has the pappus characteristically multiseriate with over a hundred bristles.

The outer surfaces of the pappus setae are sometimes flattened as in Brickellia and some closely related genera. Carminatia, some species of Brickellia, and a few species of Helogyne of the Alomiinae, and Liatris of the Liatrinae have a plumose pappus. In Helogyne the bristles of some species have vascular traces reaching about half the length of the bristles. The tips of the pappus bristles are usually narrow with sharp apical cells. In various members of the Eupatoriinae, Gyptidinae, and Disynaphiinae, the apical cells are rounded apically to bulbous. The tips of the pappus bristles are extremely enlarged in the genus Amboroa.
Pollen in the Eupatorieae is echinate, becoming almost smooth in one genus, Hofmeisteria. Some members of the tribe have notably short spines and seem to be primarily wind pollinated (Grashoff \& Beaman, 1970; Sullivan, 1975). Pollen size on the average is perhaps smaller than that of any other tribe. In the Eupatorieae the pollen of most genera as measured in fresh preparations in Hoyer's solution is $18-25 \mu \mathrm{m}$ in diameter. Size may vary between related species in the Adenostemmatinae. In one of the distinctive generic-pairs in the tribe, pollen of 13-17 $\mu \mathrm{m}$ diameter has been recorded in Carterothamnus and $25 \mu \mathrm{m}$ diameter in the related Oaxacania (King \& Robinson, 1970e). The largest pollen in the tribe, reaching ca. $35 \mu \mathrm{m}$, is found in Carphochaete.

In internal structure the exine is caveate, the condition that is most common in the subfamily Asteroideae and which occurs sporadically in the $\mathrm{Ci}$ chorioideae. Internal foramina are well developed in the columellae, a condition that is almost completely restricted to members of the subfamily Asteroideae (Skvarla et al., 1977). 


\section{PHYTOGEOGRAPHY}

Previous to the present study, only the most general phytogeographical conclusions were possible regarding the Eupatorieae. These included the recognition of the predominantly Neotropical distribution of the tribe, and the identification of the distinctive genera Adenostemma and Mikania as two of the members that had entered the Eastern Hemisphere. General ranges of a few other distinctive genera such as Stevia and Liatris were known, and a number of small genera of limited distribution were accepted. A more meaningful understanding of the geography of the Eupatorieae has had to await the present detailed revision of the tribe at the subtribal and generic level. Some of the results have been included in the treatment of the tribe in the symposium on the Biology and Chemistry of the Compositae (H. Robinson \& King, 1977), and in the Boletin de la Sociedad Argentina de Botanica issue honoring Dr. A. L. Cabrera ( $\mathrm{H}$. Robinson \& King, 1980). Also, during the extensive taxonomic revisions of the authors, the phytogeographic aspects have been consistently noted, and the classic Arcto-Tertiary distribution of Eupatorium sensu stricto (King \& Robinson, 1970u) was among the most significant of the initial discoveries.

The near restriction of the Eupatorieae to the Western Hemisphere clearly reflects the Neotropical origin that is assumed for the tribe. In its Neotropical or at least Western Hemisphere origin, the Eupatorieae parallels in various degrees the origins of two other tribes, the Heliantheae and the Liabeae. In the case of the Eupatorieae, the elements that have reached to Eastern Hemisphere include the pantropical Adenostemma with their sticky achenes highly adapted for distribution, Mikaniae of the widely distributed, scandent cordiformes group, and two genera of the subtribe Eupatoriinae which seem to have been favored for distribution by their geography. The case in the Heliantheae is somewhat parallel, with the pantropical Coreopsidinae noted for the barbed awns on their achenes which are highly adapted for distribution, and other elements such as the Melanthera and Sigesbeckia elements being either sticky or widely occurring. The Heliantheae show more intrusions into the Eastern Hemisphere, but their endemic elements in the Old World such as Fitchia and Guizotia can still be placed reasonably close to the New World groups, the Coreopsidinae and Milleriinae, from which they arose. The tribe Liabeae furnishes a different type of compar- ison, having never extended its range beyond the Neotropical Region. The example of each of the other two tribes is significant. It is of interest that the Heliantheae, which is the only close relative of the Eupatorieae, would share the basically Western Hemisphere distribution. The comparatively unrelated Liabeae is instructive primarily through an analysis of the probable reason for its restricted distribution.

The poor representation of the Eupatorieae in the Eastern Hemisphere may have led previous students of the Asteraceae to the erroneous conclusion that the Eupatorieae was a tribe of comparatively recent origin, and the more restricted distribution of the Liabeae might have led to similar erroneous beliefs about that tribe. In both tribes there is ample evidence of age as great or essentially as great as other tribes of the Asteraceae, and both probably date back to the seemingly explosive expansion of the family during the Miocene that has been proposed on the basis of pollen evidence (Raven \& Axelrod, 1974). Certainly, in the case of the Eupatorieae, there is ample evidence of many waves of dispersal and subsequent counter-dispersal within various independent elements of the tribe, many of these dispersals covering distances equal to or exceeding the distances to the Eastern Hemisphere. We contend that the causes of the comparative restriction of the Eupatorieae and Liabeae must be sought elsewhere. In this the example of the two genera in the subtribe Eupatoriinae reaching the Eastern Hemisphere seems most instructive.

For general purposes, one might recognize three basic corridors for distribution between the two hemispheres, the Bering corridor, the South Atlantic, and the Antarctic. Though the Eupatorieae have reached Chile in the form of at least three subtribes, it seems obvious that the Antarctic corridor has not been available to the tribe. Of the two remaining corridors, it seems notable that both have been used by the Eupatorieae, and genera involved in different corridors are members of the same subtribe, the Eupatoriinae. Part of the answer to this seems to lie in a geographic reality of the Western Hemisphere that reflected in what we have called the "Eastern Complex" of the Eupatorieae (H. Robinson \& King, 1980). The subtribes Eupatoriinae, Gyptidinae, and Disynaphiinae form a related group that seems concentrated in both eastern South America, primarily Brazil, and eastern North America. In eastern South 
America the group as represented by Stomatanthes with a naturally favored position for distribution to Africa, and in the north it seems that such eastern elements actually are favored over western elements in distribution over the Bering corridor. Though not initially evident, it seems that Eupatorium sensu stricto entered Asia across the Bering Strait without crossing to the west of the Rocky Mountains or to the southern ranges of Alaska. The genus is not now known northwest of Alberta, Canada in North America. The success of the particular subtribe Eupatoriinae over others of the Eastern Complex might lie in a resistance to more extreme environmental conditions such as might be encountered in longdistance transport. Such resistance seems to be exemplified by the genus Eupatorium of the subtribe, which extends farther northward in to the erroneously named North Temperate Zone than any other member of the tribe.

It is notable that those elements of the Eupatorieae which are widely distributed in, but primarily restricted to the western parts of North and South America, seem to have no access to the Eastern Hemisphere. It is further notable that the tribe Liabeae is restricted to precisely these areas, and probably originated in the area that is now the central Andes, in what was then probably the most isolated part of the Americas (H. Robinson, 1983).

The primary geographical fact of the Eupatorieae is its near restriction to the Western Hemisphere, but the second most significant geographical fact is the extent to which the tribe has prospered in that hemisphere. Not only widely distributed species, but numerous distinctive endemics are distributed in all the major areas inhabited by the tribe; genera of the Liatrinae in the southeastern United States, elements of the Alomiinae, Oaxacaninae, Hofmeisteriinae, Ageratinae, Trichocoroniinae, and Oxylobinae centering in Mexico; elements of the Critoniinae and the Neomirandeinae in Central America; elements of the Critoniinae in the West Indies; genera of the Critoniinae, Ayapaninae, and Oxylobinae from the Andes; and numerous elements of the Gyptidinae, Eupatoriinae, Disynaphiinae, Praxelinae, Ageratinae, and Ayapaninae in Brazil. It is the capacity for the Ageratinae and Ayapaninae to produce isolated endemics in the remote and poorly explored savanna outliers along the southern edge of the Amazon Basin that has complicated the completion of the present study. It seems clear that the tribe has been well established and has become thoroughly diversified throughout its range to an extent that a point of origin within that range is not clearly evident. Some elements in northern Mexico seem to show truncated ranges, suggesting that the tribe was probably more abundantly represented farther to the north in western North America in pre-Pleistocene times (H. Robinson \& King, 1980).

Other phytogeographic conclusions regarding the Eupatorieae involve various individual elements of the tribe. The most important of these elements is that referred to here as the Eastern Complex. The Complex includes three subtribes, the Disynaphiinae which is restricted to eastern South America, and the Eupatoriinae and Gyptidinae which are both disjunct between eastern South America and eastern North America. Only specialized members of the Eupatoriinae, in Eupatorium section Traganthes, intrude into the intervening more tropical areas of the West Indies. The distribution pattern seems to reflect the basic physiographic realities of the Western Hemisphere where both continents have extensive geologically aged eastern parts and western parts dominated by younger cordilleras. Members of the Eastern Complex are notable for their specializations for savanna and scrub habitats which are common in the eastern parts of both continents. The three subtribes overlap geographically with other Eupatorieae such as the Praxelinae that also show adaptations to the savanna habit, but the three subtribes of the Eastern Complex share some structural and chemical trends, such as rounded apical cells on the pappus setae and presence of chromenes, which suggest the three are related in a larger major phyletic element of the tribe. Even if the character trends mentioned derive from intergeneric hybridization between three more basically distinct stocks, the phytogeographic pattern remains valid for some of the genetic traits.

The Gyptidinae is the largest element in the Eastern Complex, and seems to have undergone an explosive radiation in the area of Brazil. A few representatives of the subtribe have intruded into more western parts of North and South America, Conoclinium and Tamaulipa in Mexico, Lourteigia and Conocliniopsis in the Colombian and Venezuelan Andes, and Neocuatrecasia along the eastern escarpment of the Andes in Peru and Bolivia. Because of the specialization of the subtribe for terrestrial and often savanna habitats, the area of eastern Brazil northward into Bahia represents the isolated extreme of the available habitat, and many of the most extreme forms of the subtribe occur in the area of Bahia. This is in contrast to the situation in such 
genera as Mikania where many common scandent forms reach Bahia from across the Amazon Basin to the north.

At least one subtribe, the Ageratinae, seems to represent a derivative of the Eastern Complex that has its center of distribution to the west in Central America and the Andes. Ageratum and many other genera of the subtribe are structurally close to the Gyptidinae, and chromenes like those seen in the Gyptidinae are reported for Ageratum. The Ageratinae tend to differ by the variously defective pappus, but some defective though never squamose forms are also present in the Gyptidinae in such genera as Arrojadocharis, Agrianthus, and Morithamnus, so that the character alone would not be given much credence. It is the basically different geographic distribution in combination with the pappus that marks the subtribe.

The two subtribes, Fleischmanniinae and Oxylobinae, which are mostly restricted to the mountainous western parts of North and South America, furnish the most striking contrast to the Eastern Complex. It is notable that the two western subtribes include species that closely resemble each other superficially, but that structural details and chromosome numbers of the two subtribes indicate that there is no close relationship. Both the Fleischmanniinae and Oxylobinae have ranges extending essentially unbroken from North America to the Andes of Argentina. Distinctive genera of the latter subtribe are found in both areas, suggesting that the distribution pattern antedated the existence of the land connection. Within the Oxylobinae, there is evidence of more recent migrations between North and South America, with Oxylobus extending from Mexico south as far as Colombia, and typical Ageratina which is concentrated in Mexico extending south as far as Chile. As with the Eastern Complex, north-south migrations within similar physiographic regions seem common, but east-west migrations are severely limited.

The tendency for the Eupatorieae to differ between Eastern and Western groups is also shown to some extent by the subtribe Alomiinae. The genus Brickellia is common in Mexico and the southwestern United States with one weedy species widely distributed throughout the Neotropical Region. A number of smaller genera of the group also occur in Mexico, and some show limited or truncated ranges suggesting previous wider distributions to the north. Less commonly recognized are the numerous elements of the subtribe in eastern South America, such as Dissothrix, Leptoclinium, Planaltoa, and Austrobrickellia. These genera seem to represent an older migration pattern between western North America and eastern South America. It is within South America that the east-west pattern is evident in the subtribe, with only the divergent elements, Crossothamnus and Helogyne among the older elements occurring within, and west of, the Andean cordillera in Peru and Chile.

The possible effect of intergeneric hybridization and introgression has been alluded to in the discussion of the Eastern Complex. Such effects are suspected again in the Alomiinae as indicated in the chapter on chemistry and cytology, and as evidenced by the corolla form in typical Alomia. Nevertheless, the distinctive tubular corolla and expanded style of the Alomiinae reflect the basic phyletic and phytogeographic pattern of the subtribe. Effects of hybridization actually seem to be seen most clearly in the tribe in the West Indian members of the two subtribes Critoniinae and Praxelinae. The two subtribes share a strong tendency for deciduous involucral bracts, the Praxelinae being particularly distinct among Asteraceae by losing all the bracts at maturity. Both subtribes are distributed throughout the Neotropical Region, and some rather intermediate forms can be found in the West Indies and less commonly in Mexico. These northern forms related to the Praxelinae might initially be regarded as relicts of a more primitive element of the subtribe. However, an overview of both subtribes presents a totally different picture. The Critoniinae are concentrated in the more tropical parts of the Western Hemisphere including Central America, the West Indies, and northwestern South America. The Praxelinae has most of the genera and all but a comparatively few species restricted to Brazil and adjacent areas. Though the Praxelinae may possess some traces of older Critoniinae and Gyptidinae introgression, the Brazilian members form a very marked group with a series of well-defined characters. Reexamination of some of the intermediate elements in the West Indies, especially the genus Osmiopsis, shows the characters of the Praxelinae and of Koanophyllon of the Critoniinae mixed in various combinations that we can only interpret as secondary from various hybrid swarms. It is notable that Osmiopsis appears to be viable and persisting, as are the other intermediates, but it is also notable that there is no evidence of continuing production of hybrid swarms. It is our present interpretation that the Praxelinae started in eastern South America 
where isolation from other elements of the Eupatorieae, including some Critoniinae, was stabilized through mostly species level sterility barriers. Expansion of the range of the Praxelinae northward into the West Indies is seen to have brought the subtribe into contact with members of the Critoniinae that were comparatively naive in their sterility barriers toward the new entrants. The period of naivete seems to have passed, but its progeny remain. The example is considered here as only the most obvious or recent of a series of similar events in the history of the tribe, resulting from expansions of previously geographically isolated groups into the same areas. There is ample evidence that the phenomenon is not restricted to the Eupatorieae, but that it is also common in the Heliantheae (H. Robinson et al., 1981). Senecioneae (H. Robinson \& Brettell, 1974), and at one time occurred in the Liabeae (H. Robinson, 1983). In the latter case, the comparative lack of such hybridization has been suggested as a contributing factor to the comparatively limited success of the tribe $(H$. Robinson, 1983).

In spite of the suspicion that hybridization may be a major factor in the successful explosive evolution of the Asteraceae, and perhaps many other families of flowering plants, the characters continue to reflect valid phytogeographic patterns that can be studied and can reveal major historical facts about the groups involved. But it is also important to realize that such hybridization does not occur so often that large genera and generic complexes cannot be maintained among the plants and recognized by botanists.

It is the phytogeographical complexities in the Eupatorieae within subtribes and even genera that adds to the impression of considerable age for the tribe. The Hebecliniinae are basically a group occurring in northern South America, Central America, and Mexico, with one weedy species found throughout the Neotropical Region. The subtribe has two different numbers that show different geographical distributions. Decachaeta, Matudina, and part of Bartlettina have $n=16$ while the rest of Bartlettina and Hebeclinium have $n=10$. The elements with $n=16$ are restricted to Mexico and Central America while all South American elements and all known samples of Hebeclinium regardless of geography have $n=10$. The Neomirandeinae are restricted to the most tropical parts of Central America and the northern Andes where they seem adapted to the moist forests as epiphytes and sec- ondary terrestrials in humus. The group seems to owe its diversity in the restricted area to the seasonality of the species with staggered flowering periods. The Oaxacaniinae consists of two genera in restricted areas of Mexico, Oaxacania, a local endemic in an area southeast of Mexico City, and Carterothamnus which is endemic to a small area in southern Baja California. The two isolated genera give the impression of relicts. The pair of genera is of special interest because of the possession of the most highly developed paleae in the tribe, and the possibility that they represent the most primitive surviving element in the Eupatorieae. It does not seem likely that any of the above subtribes really reflects the origins of the tribe, but it does seem probable that each reflects elements of the tribe that originated in different parts of the American tropics and in different environmental regions, some dating back to the time a few million years ago when Mexico, the Chiapas-Guatemala region, the Costa Rican region, and the northern Andes were separated by water (Matthews, 1980).

Not all disjunct distributions are correlated with sufficient structural differences to be interpreted as relictual. There are a few erratic distribution patterns in the Eupatorieae that seem comparatively recent and worthy of special note. The genus Guevaria is restricted to the Andes of Ecuador and Peru and the closely related genera Ferreyrella and Ellenbergia are endemic to Peru. It seems anomalous, therefore, to find a closely related genus Piqueriopsis in a totally remote locality in Michoacan, Mexico, and another close relative, Piqueriella even farther away in the state of Ceará in eastern Brazil. Long distance dispersal seems the only explanation.

The genus Steyermarkina consists of three species in southern and central Brazil, and a fourth species restricted to an area in Venezuela draining in to Lake Maracaibo. The specific differences are sufficient to rule out recent introduction, but are not sufficient to suggest long separation that might result from migration through suitable habitats to the west of the Amazon Basin. Long distance dispersal across the Amazon Basin seems most likely. Even though the Critoniinae, to which the genus belongs, are presumed to have started nearer Venezuela and to have migrated more recently to Brazil, the dispersal in Steyermarkina seems to have been from Brazil to Venezuela.

The genus Idiothamnus includes four species (King \& Robinson, 1975v), and relationships of three of the species have been recognized since the work of 
B. Robinson $(1919 a, 1930 c)$ in spite of the scattered distributions. None of the species seem common in collections, but a number of specimens have been seen of I. lilloi from the eastern slopes of the Argentine Andes from Salta and Tucuman. Two specimens have been seen of $I$. pseudorgyalis from near Rio de Janeiro in Brazil. Only the type is known of I. orgyaloides from near Tarapoto in northern Peru, and $I$. clavisetus is represented by a few specimens from the northern coastal range in Venezuela. The disjunction of the genus may be partly the result of inadequate collecting, but a severe habitat restriction might also play a role. The species all have a look commonly associated with shrubs of temperate forests, and the general range of the genus seems to be entirely within the distribution of the more temperate forest areas in South America.

A final notable feature of the Eupatorieae is the many species that have achieved wide distribution, many having become thoroughly weedy. Ageratum conyzoides has become a pantropical and pansubtropical weed, and two species of Ageratina, one species of Chromolaena, and an Austroeupatorium are adventive in the Eastern Hemisphere where they seem to be expanding their range. Fleischmannia microstemon has apparently become adventive in West Africa, and is a weedy annual in the Neotropical Region. Successful adventives and naturally occurring Eupatorieae in the Eastern Hemisphere include representatives of at least six of the subtribes, and at least four other subtribes have weedy representatives in the Western Hemisphere. Most major elements of the tribe seem capable of producing weedy species.

The basis for the successful distribution of individual species or groups of species may or may not be obvious. The sticky knobs of the Adenostemma achene can easily account for the pantropical distribution of the genus and the wide distribution of many species, but the slightly differently formed glandular knobs of the closely related Sciadocephala have apparently had no such beneficial effect. The species of the cordiformes group of Mikania have expanded their available habitat by their scandent habit, and they may also come in more contact with birds that could distribute their achenes. Many of the remaining weedy species of Eupatorieae are aided by removal of limitations imposed by dependence on pollinators. This is particularly true of the many apomictic forms such as Chromolaena odorata, C. ivaefolia, C. laevigata, Praxelis pauciflora, and others in the Praxelinae, Ageratina adenophora and the triploid $A$. riparia in the Oxylobinae, and various species of Stevia in the Ageratinae. To the same end result, such species as Fleischmannia microstemon and Brickellia diffusa have become selfpollinating annuals, in the former case with a simplified chromosome complement. In both these cases, the species are freed even from the need to correlate their time of flowering. There remain a few widely distributed species that seem to have little evident advantage over their less widely distributed relatives. Conocliniopsis prasiifolia is common in the Andes of Venezuela and adjacent Colombia, and occurs widely again in eastern Brazil, but its principal advantage over members of the closely related Gyptidinae of the genus Barrosoa seems to be a sometimes polyploid chromosome number. Hebeclinium macrophyllum, which occurs throughout most of the Neotropical Region, seems to differ from its closest relatives in Hebeclinium in Colombia, Ecuador, and Venezuela mostly in a greater density of glandular punctations.

Many additional phytogeographic patterns can be recognized in the Eupatorieae, and these are noted under the genera or generic groups where they are found. 


\section{Keys to The Genera of the Eupatorieae}

The following keys to the genera of the Eupatorieae attempt to use obvious rather than technical characters where possible, and in all cases when it can be done easily, the use of characters requiring the compound microscope is deferred to later points in the key. Where microscopic characters are used, an effort is made to correlate with other characters. Receptacle surface characters are also omitted as much as possible from initial stages in keys because of the possible need to destroy single heads on a specimen.

The most technical of the following keys is that to subtribes, where a number of exceptions are not accommodated because of the extensive parallelisms between the subtribes. Nevertheless, for those users able to determine the subtribe, the keys to genera within each subtribe are the most accurate in the treatment. In contrast, the overall key to genera is patterned broadly on the more workable characters in the artificial keys by B. Robinson (1913a) to genera of the Eupatorieae and to species groups of Eupatorium sensu lato in various countries. Our key to all the genera makes extensive use of multiple entries, and provides some indication, when compared with B. Robinson's keys, of the artificiality and present dispositions of the elements of the traditional genera. As a further aid to users of this treatment, four keys are provided to genera in major geographic areas, Mexico, the West Indies, Colombia, and Brazil. The latter keys provide some important additional character combinations. With the use of the keys and the illustrations, all genera of the tribe should be identifiable with a reasonable amount of effort.

\section{Keys to THE Genera of the Eupatorieae}

\section{ARTIFICIAL KEY TO THE GENERA OF THE EUPATORIEAE}

1. Involucral bracts herbaceous and non-articulated at base; receptacle unsclerified between the areoles, changing shape on drying 2

2. Pappus lacking

3. Gymnocoronis

2'. Pappus of 3 or 5 viscid-tipped knobs

3. Viscid tips of pappus elements spherical, not extending downward on outer surface of knob; pappus of 5 knobs; anther appendage as long as wide

2. Sciadocephala

3'. Viscid tips of pappus elements extending downward on outer surface of knobs; pappus usually of $3 \mathrm{knobs,} \mathrm{rarely} 5$; anther appendage about half as long as wide

1. Adenostemma

I'. Involucral bracts sclerified or articulated at base; receptacle sclerified or paleaceous between areoles

4. Peripheral flowers of head with greatly expanded ray-like limbs consisting only partly of lobes

64. Microspermum

4'. Peripheral flowers of head not ray-like, any asymmetry consisting exclusively of larger lobes

5. Minute plants with 4-lobed corollas and 4 stamens in flowers

6. Achenes with 4-5 ribs; style appendages pointed, tapering

6'. Achenes with 8-10 ribs; style appendages rounded at tip, not tapered

5'. Plants with 5-lobed corollas and 5 stamens per flower

7. Anther appendages half as long as wide or less, sometimes tolally lacking

8. Plants repent with a series of small rosettes, inflorescence of clustered heads scapose on peduncles that are shorter than the leaves; outer wall of achene sometimes expanded into a fluid-filled sac

48. Ascidiogyne

8'. Plants not repent with a series of rosettes, with inflorescence usually exceeding the leaves; outer surface of achene never forming a fluid-filled sac

9. Pappus lacking

10. Heads with paleae, at least among outer flowers

11'. Leaves opposite, at least below; receptacle paleaceous throughout

12. Leaves linear; style base with hairs

78. Parapiqueria

12'. Leaves ovate or elliptical; style base without hairs

$10^{\prime}$. Heads without paleae

54. Ferreyrella

13. Plants rosulate with a scapose inflorescence

10. Hartwrightia

13'. Plants not rosulate or scapose

14. Corolla lobes broadly triangular, smooth on inner surface; tips of style branches rather abruptly broadly clavate

15. Leaves strictly alternate; leaves and inflorescence covered with colored glandular punctations

164. Erythradenia

$15^{\prime}$. Leaves usually opposite or closely spirally inserted; leaves and inflorescence not covered with colored glandular punctations 
16. Involucral bracts eximbricate, subequal; anther appendage essentially lacking

146. Ophryosporus

16'. Involucral bracts weakly to strongly subimbricate, unequal; anther appendages distinct 122. Koanophyllon

14'. Corolla lobes oblong-triangular, papillose on inner surface; tips of style branches not clavate or gradually broadened from base of appendage

17. Heads with 3-5 involucral bracts and an equal number of flowers; filaments of anthers mamillose to pubescent in

lower part; walls of achenes with sparse internal micropunctations 57. Piqueria

17'. Heads with more than 5 involucral bracts, with number of flowers not equal to bracts; filaments of anthers smooth in lower part; walls of achenes with internal micropunctations densely spaced

18. Involucral bracts weakly overlapping, with acute tips; corolla tubes with gland-tipped hairs

19. Leaves repand-dentate to pinnatifid; throat of corolla gradually funnelform, with a few hairs inside near bases of filaments; achenes glabrous

51. Gardnerina

19'. Leaves crenate to serrate; throat of corolla broadly campanulate, without hairs inside; achenes with setulae on sides

45. Phalacraea

18'. Involucral bracts distinctly overlapping, with rounded or denticulate apices; corolla tubes without gland-tipped hairs

20. Achenes with $8-10$ ribs; corollas with 4 lobes

56. Piqueriopsis

20 . Achenes with 5 ribs; corollas with 5 lobes

21. Heads with 15-40 flowers; receptacle conical; corollas with basal tube bearing non-glandular hairs; base of plant decumbent

53. Guevaria

$21^{\prime}$. Heads with ca. 8 flowers; receptacle slightly convex; tubes of corollas glabrous; base of plant erect .

55. Piqueriella

9'. Pappus present

22. Peripheral flowers of head with greatly expanded outer lobes; anthers inserted high in corolla at bases of lobes

157. Praxeliopsis

$22^{\prime}$. Peripheral flowers of heads not asymmetrical; anthers inserted lower in corolla, not near bases of lobes 23. Heads solitary on erect peduncles from intermittently congested groups of leaves in pseudowhorls

23'. Heads in complex inflorescences, peduncles not arising from pseudowhorls

24. Pappus of 5 awns or squamellae

25. Pappus of short fimbriate squamellae, with sinuous cell walls

25 . Pappus with aristate squamellae, with cell walls not sinuous

23

178. Hofmeisteria

24'. Pappus of many usually capillary bristles

26. Pappus bristles plumose

86. Ageratella

26'. Pappus bristles not plumose

27. Plants rosulate

27'. Plants not rosulate

28. Heads with paleae, leaves opposite

28. Heads without paleae or with leaves alternate

29. Style base with hairs

30. Style appendages with enlarged tips; plants scandent

$30^{\prime}$. Style appendages not enlarged at tips; plants not scandent

29'. Style base glabrous

31. Involucre eximbricate, bracts subequal

24. Trichogoniopsis

118. Ciceronia 32. Pappus of many short awn-like bristles; inner surface of corolla lobes papillose;
inside of corolla with hairs at bases of filaments

$32^{\prime}$. Pappus of capillary bristles, nearly as long as corolla; inner surface of corolla lobes smooth; inside of corolla without hairs at bases of filaments

31'. Involucre weakly to strongly subimbricate, bracts unequal

33. Corolla with numerous hairs on inner surface; inflorescence with ascending, mostly subopposite to alternate branches

149. Neocabreria

33'. Corolla without numerous hairs in inner surface; inflorescence with straight, usually opposite branches

34. Pappus bristles slender, not contiguous, often fragile

35. Involucral bracts usually persistent, often whitish; veins of corolla ending at sinus, not extending into lobes; anther thecae reddish; receptacle glabrous; leaves opposite 120. Fleischmanniopsis

35'. Inner involucral bracts deciduous, bracts not whitish; veins of corolla extending into lobes; anther thecae pale; receptacle hirsute; leaves mostly alternate, opposite in one species 163. Decachaeta 
34'. Pappus bristles stout, contiguous, persistent

36. Corolla funnelform; leaves with few to many hairs; involucre often weakly subimbricate

122. Koanophyllon

36'. Corolla tubular; leaves without evident hairs on blade; involucre strongly subimbricate with deciduous inner bracts 37

37. Leaves with numerous glandular punctations on lower surface; involucral bracts in 7-8 series, 3-4 series of short bracts at base

116. Adenocritonia

37 . Leaves glabrous, without hairs or glands, sometimes with minute internal secretory cavities between veins; involucral bracts in 5-6 series

38. Filaments of anthers inserted near base of corolla; achenes and corollas glabrous

115. Urbananthus

$38^{\circ}$. Filaments of anther inserted well above base of corolla; achenes with sparse glands and setulae; corolla lobes glanduliferous on outer surface

114. Critoniadelphus

7 . Anther appendage nearly as long as wide or longer

39. Achenes with 7-10 ribs, sometimes closely ribbed and appearing terete

40. Heads with 4 subequal involucral bracts and 4 flowers

40 . Heads with more than 4 involucral bracts, usually more than 4 flowers

41. Pappus of aristate awns with squamellate bases; style branches with stigmatic lines on inner surface, extending near to the tapering tip

60. Carphochaete

$41^{\prime}$. Pappus of capillary or plumose bristles; stigmatic lines lateral on style branches, not reaching near tip (except in Brickellia diffusa)

42. Achenes obcompressed

82. Barroetea

$42^{\prime}$. Achenes prismatic or terete

43. Style base with hairs

44. Pappus with alternating larger and smaller bristles; heads with 4 flowers

44'. Pappus with bristles essentially equal; heads with 5 or more flowers

45. Pappus bristles not flattened on outer surface, not plumose; stems with densely spirally inserted filiform leaves 98. Pseudobrickellia

45'. Pappus bristles flattened on outer surface, sometimes plumose; leaves often opposite, not filiform

81. Brickellia

$43^{\prime}$. Style base glabrous

46. Style appendages longly clavate, with nearly smooth surface; corollas narrowly funnelform to tubular

47. Leaves sessile, alternate or opposite, linear or squamulose; involucral bracts in 4 or more series

$47^{\prime}$. Leaves petiolate, opposite or whorled; involucral bracts in 2-3 series 94. Steviopsis

$46^{\prime}$. Style appendages linear, papillose; corollas distinctly funnelform

48. Mature plants without basal rosettes, leaves not progressively smaller above base

49. Pappus of 2-3 series, shorter in outer series; achenes densely setiferous; involucre subimbricate

109. Garberia

49'. Pappus with 1-2 series of subequal bristles; achenes with numerous glands; involucre eximbricate

48'. Mature plants with basal rosettes, with progressively or abruptly smaller leaves above base 50

50. Pappus plumose or strongly barbellate; inflorescence usually spiciform or racemiform; heads without paleae; corolla often with hairs inside, lobes long-lanceolate to linearoblong

$50^{\prime}$. Pappus bristles scabrous or barbellate; inflorescence corymbose or thyrsoid; heads often with a few paleae; corolla glabrous inside, with lobes triangular to oblong _._.... 51 51. Pappus uniseriate; tip of anther appendage obtuse to rounded. 107. Trilisa

$51^{\prime}$. Pappus in ca. 2 series; tip of anther appendage distinctly retuse

52. Involucre with $15-40$ closely overlapping bracts in 3-4 series; achenes densely setuliferous; flowers $12-35$ in a head 108. Carphephorus

$52^{\prime}$. Involucre with 5-10 loosely overlapping bracts in 2-3 series; achenes with sparse short setulae and numerous glands; flowers 5-10 in a head _ 106. Litrisa

39'. Achenes with 2-5 ribs sparse short setulae and numerous glands, flowers $5-10$ in a head - 106. Litrisa

53. Pappus of squamellae, crowns, winged aristae, 1-2 long bristles, numerous short bristles less than one-half as long as the corolla, or lacking

54. Heads with 5-6 subequal involucral bracts in 1 series, with 4-6 flowers; corollas densely hirtellous on inner surface; anther appendages obovate or elliptical with crenulate distal margins 55. Achenes with bulging sides, all with no pappus; heads with 4-5 flowers

$55^{\prime}$. Achenes narrow with straight sides, some or all in each head with a pappus 58. Stevia 
54'. Heads with more or less than 4-6 involucral bracts or flowers; corollas not hirtellous on inner surface, usually glabrous; anther appendages oblong or ovate, not elliptical or obovate

56. Pappus completely lacking, achene with at most an upper callus rim

57. Heads with paleae

58. Achenes compressed; leaves alternate, with sinuously lobed margins

58'. Achenes prismatic; leaves mostly opposite, without sinuously lobed mar

179. Oaxacania

59. Receptacle conical or columnar.____........ 60

60. Heads becoming elongate with a columnar receptacle; style appendages widely diverging; style base usually enlarged

80. Isocarpha

$60^{\prime}$. Heads not becoming elongate; receptacle conical; style appendages erect or scarcely spreading, prominent; style base not enlarged

43. Ageralum

59'. Receptacle plane or low-convex

61. Corolla continuous with wall of achene, achene without apical callus ___ 50. Teixeiranthus

$61^{\prime}$. Corolla not structurally continuous with outer wall of achene, intervening apical callus present ........ 62

62. Stems with few to many holes; style base enlarged; inner surface of corolla lobes densely papillose

$62^{\prime}$. Stems without holes; style base not enlarged; inner surface of corolla lobes not papillose _.__ 63

63. Achenes with symmetrical carpopodium; leaves with a mixture of sessile and stipitate minute glands; cells of anther collar with weakly ornamented walls

46. Blakeanthus

$63^{\prime}$. Achenes with asymmetric contorted carpopodia; leaves with glands uniform, obscure, or

lacking; cells of anther collar with dense annulate thickenings on walls ....... 41. Acritopappus

$57^{\prime}$. Heads without paleae

64. Outer involucral bracts subfoliaceous; style base with a prominent hairy node

64 '. Outer involucral bracts not foliaceous; style base glabrous.

101. Planaltoa

65. Leaves alternate

66. Plants rosulate, with scapose inflorescence

66'. Plants with leafy stems, not rosulate; inflorescence not scapose

67. Lobes of corolla obscured by dense non-glandular pubescence; shaft of style glabrous; herbs

23. Trichogonia

67'. Lobes of corolla not obscured by non-glandular pubescence; shaft of style pubescent; shrubs

34. Stylotrichium

65'. Leaves mostly opposite

68. Aquatic plants, with broadly sessile leaves

67. Shinnersia

68'. Plants not aquatic, with petiolate leaves

69. Leaves fleshy or subcoriaceous; plants often epiphytes on mangroves

69'. Leaves herbaceous or membranaceous; plants not epiphytes

70. Achenes with blunt, peg-like setulae on sides

70'. Achenes glabrous or sparsely scabrid on ribs

71. Involucre subimbricate, with bracts strongly unequal; corolla with veins of tube and lower throat strongly thickened; style base with expanded node above nectary

152. Tuberostylis

70

90. Alomia

71

76. Alomiella

$71^{\prime}$. Involucral bracts eximbricate, equal or subequal; style base not enlarged

72. Involucral bracts with rounded apices; leaves distinctly acuminate; carpopodium symmetrical 49. Cavalcantia

$72^{\prime}$. Involucral bracts pointed; leaves not acuminate; carpopodium asymmetrical

43. Ageratum

56'. Pappus present

73. Style branches terete, with stigmatic lines toward inside surface; style base with distinct glabrous node

74. Involucral bracts strongly unequal in length; pappus with long awns; corollas glabrous on inner surface; stigmatic lines reaching near apex of style branch

60. Carphochaete

74'. Involucral bracts subequal; pappus without long awns; corolla pubescent inside; stigmatic lines ending near middle of style branch

62. Revealia

73'. Style branches usually flattened, at least on inner surface, with stigmatic lines along lower lateral margins; style base with or without node

75. Involucral bracts distinctly and regularly subimbrica te in many unequal series, with inner bracts often deciduous

76. Involucre with bracts all deciduous, rarely $1-2$ persistent at base, not spreading with age, remaining appressed until loss

77. Achenes obcompressed, with asymmetric carpopodia; receptacle columnar; leaf blades oblong-ovate with simple serrate margins 
77'. Achenes prismatic, with obsolete carpopodium; receptacle with floriferous portion flat; leaf blades often lobed to bipinnatifid

$76^{\prime}$. Involucre with at least lower bracts persistent

78. Involucral bracts with broad tips; pappus a series of short scales; leaves strictly opposite; South American plants

42. Radlkoferotoma

78'. Involucral bracts with narrow tips; pappus with bristles or awns; leaves usually alternate; Mexican plants

79. Leaves narrow and sessile

88. Malperia

$79^{\prime}$. Leaves petiolate with distinct blade

80. Heads with paleae

$80^{\prime}$. Heads without paleae

180. Carterothamnus

81. Achenes with setulae restricted to ribs, carpopodium with small subquadrate cells in many tiers; heads solitary on erect peduncles, usually arising from intermittent congested groups of leaves in pseudowhorls

178. Hofmeisteria

81'. Achenes with dense pubescence on lateral surfaces between ribs; carpopodium with elongate cells in radiating pattern; heads in branching inflorescence

89. Pleurocoronis

$75^{\circ}$. Involucral bracts eximbricate or weakly subimbricate, often subequal, persistent

68. Sclerolepis

82. Pappus an indurated crown, papillose with densely projecting cell ends; leaves linear, in whorls

82'. Pappus thin or smooth: leaves opposite or alternate

83. Plants with leaves in dense spirals, not decreascent above

84. Leaves large and fleshy, with veins not prominulous on surfac

$84^{\prime}$. Lcaves less than $3 \mathrm{~cm}$ long, with veins prominulous on surface; heads with less than 40 flowers

85. Leaves scale-like, erect-spreading or appressed; style shaft glabrous; heads sometimes with paleae

85'. Leaves not scale-like, spreading; style shaft pubescent; heads without paleae

31. Agrianthus 34. Stylotrichium

83'. Plants with leaves opposite or laxly alternate, often decreascent above

86. Receptacle conical

87. Base of achene not slender, with asymmetrical carpopodium; style appendages linear

43. Ageratum

$87^{\prime}$. Base of achene narrowed, stipitate, with symmetrical carpopodium; style appendages broad, often clavate 88

88. Involucral bracts glabrous externally; corolla glabrous; carpopodium minute; anther collar greatly broadened below

25. Platypodanthera

88'. Involucral bracts with hairs or glands externally; corolla lobes usually with hairs or glands; carpopodium much enlarged, short-cylindrical, much larger than scars on receptacle; anther collar cylindrical

$86^{\prime}$. Receptacle plane or slightly convex

36. Campuloclinium

89. Heads with paleae

90. Involucre eximbricate, with subequal bracts; inner surface of corolla lobes densely papillose; cells of anther collar without dense thickenings on walls

90'. Involucre weakly subimbricate, with some shorter outer bracts; inner surface of corolla lobes smooth or weakly mamillose; cells of anther collars with dense annular thickenings on walls

91. Style branches diverging, appendages tapering; leaves herbaceous; base of style enlarged above nectary

79. Lepidesmia

91'. Style branches erect or converging, linear; leaves firm to coriaceous; base of style not enlarged 92

92. Leaves densely inserted on stem, with longitudinal venation; tips of involucral bracts and paleae enlarged and ornate

92 . Leaves usually laxly inserted on stem, with pinnate or trinervate venation; tips of involucral bracts and paleae not enlarged or ornate

$89^{\prime}$. Heads without paleae

41. Acritopappus

93. Heads each single-flowered, grouped in spherical clusters

132. Mexianthus

93'. Heads with 3 or more flowers, not in spherical clusters

94. Plants rosulate or subrosulate, with branching scapose inflorescence _..._. 117. Antillia

94'. Plants not rosulate, with inflorescence not scapose

95. Achenes flattened, with 2 ribs and 2 bristles

95. Achenes prismatic

63. Macvaughiella

96. Plants weakly herbaceous; lobes of corolla smooth on inner surface; carpopodium with lowest tier of cells distinctly larger

97. Leaves simple, toothed; style base not enlarged; heads solitary on long erect peduncles

66. Trichocoronis

97'. Leaves dissected; style base enlarged above nectary; heads scattered in diffuse inflorescence 
96'. Plants shrubs or subshrubs; lobes of corolla densely papillose on inner surface; carpopodium without enlarged lower tier of cells

98. Corollas with ampliate throats and narrow basal tubes; base of style enlarged above nectary .

98'. Corollas narrowly funnelform in tube and throat; base of style not or slightly enlarged

99. Corolla lobes triangular, slightly longer than wide; roughened or papillose on outer surface; involucre weakly subimbricate

99'. Corolla lobes oblong, distinctly longer than wide, smooth on outer surface; involucre eximbricate 174. Spaniopappus

61. Cronquistia

53'. Pappus of 5 or more capillary bristles more than one-half as long as the corolla 100

100. Pappus with plumose bristles (see also members of Brickellia and Liatris with 8-10-ribbed achenes)

101. Corollas tubular

102. Pappus coalesced at base, falling as a unit; leaf blades with truncate bases; style branches not clavate; corollas with few or no glands

95. Carminatia

102'. Pappus bristles not coalesced at base, not falling as unit; leaf blades with tapering base; style branches long-clavate; corollas glanduliferous externally

103. Helogine

101'. Corollas funnelform

103. Corollas with upper throat and lobes obscured by dense pubescence; stems with distinct ribs

23. Trichogonia

103'. Corolla with only glandular punctations on lobes; stems without distinct ribs 24. Trichogoniopsis

$100^{\prime}$. Bristles of pappus not plumose 104

104. Achenes strongly obcompressed, with asymmetrical carpopodia 105

105. Leaves with prickles on tips of lobes; pappus bristles flattened on outer surface; style base with hirsute node; receptacle slightly convex

82. Barroetea

105'. Leaves without prickles on tips of lobes; pappus bristles not flattened on outer surface; style base glabrous, without node; receptacle high-conical or columnar 153. Praxelis 106. Achenes with 3-4 ribs; pappus of ca. 40 bristles nearly as long as the corolla 106'. Achenes usually with 2 ribs; pappus of less than 10 bristles or shorter bristles 107. Pappus of 5-8 stout bristles, sometimes with interspersed slender bristles 107'. Pappus of numerous short bristles

104'. Achenes prismatic, with 4-6 ribs

108. Pappus with bristles of two different sizes intermixed, often alternating 109. Heads with 6-8 flowers; leaves opposite; pappus with only 5 longer bristles

109'. Heads with 4 flowers; leaves mostly alternate; pappus with numerous alternate bristles

96. Dissothrix

99. Goyazianthus

108'. Pappus without two distinct sizes of bristles intermixed in one series, sometimes with shorter bristles in outer series

110. Individual pappus bristles easily deciduous, fragile (see also Decachaeta with short anther appendages)

111. Heads with paleae

112. Involucre eximbricate with $15-20$ bracts in ca. 2 series; heads with 11-25 flowers 172. Jaliscoa

112'. Involucre with more than $75-125$ bracts in many series, enclosed in many series of subinvolucral bracts; heads with ca. 200 flowers

166. Matudina

111'. Heads without paleae …..................

113. Base of style densely hirsute

114. Corolla tubular; style appendage long-clavate, nearly smooth _._. 100. Leptoclinium

$114^{\prime}$. Corolla with ampliate throat and narrow basal tube; style appendage not clavate or clavate only at tip, papillose

26. Neocuatrecasia

113'. Base of style glabrous

115. Involucre distinctly and regularly subimbricate with bracts of graduated lengths; cells on inner surface of corolla lobes mostly elongate

116. Pappus bristles with slightly but distinctly broadened tips _ 134. Peteravenia

$116^{\prime}$. Pappus bristles not broadened at tips

117. Style base with enlarged node above nectary; style branches with long-projecting papillae; carpopodium with lowest tier of cells much enlarged

117'. Style base not enlarged; style branches smooth or with short dense papillosity; carpopodium without larger cells in lowest row 
118. Lobes of corolla smooth; corolla not noticeably expanded at base of throat; style branches smooth; cells of anther collars without dense annular thickenings on walls 129. Lorentzianthus

118'. Lobes of corolla papillose by projecting upper ends of cells; corolla slightly but distinctly expanded at base of throat; style branches densely short-papillose; cells of anther collars with dense annulate ornamentation.

111. Fleischmannia

115'. Involucre eximbricate or weakly and irregularly subimbricate with a few shorter outer bracts; cells on inner surface of corolla lobes mostly isodiametric

119. Plants without leaves at anthesis, with thickened stems; corolla lobes roughened on outer surface by projecting ends of cells

173. Pachythamnus

119'. Plants with leaves at anthesis; corolla lobes smooth on outer surface

120. Style base with distinct enlarged node above nectary; style branches and usually inner surface of corolla lobes papillose

121. Achenes with carpopodium distinct

169. Ageratina

121'. Achenes without carpopodium or with obsolete carpopodium

171. Piptothrix

$120^{\prime}$. Style base without nodular enlargement; style appendages and inner surfaces of corolla lobes smooth to slightly mamillose or prolate

122. Stems and leaves with yellowish granular pubescence; throats of corollas strongly campanulate

$122^{\prime}$. Stems and leaves without yellowish granular pubescence; throats of corollas funnelform

177. Jaramilloa

176. Kaunia

110'. Pappus bristles persistent, not easily deciduous

123. Involucre with all bracts deciduous leaving a bare receptacle; bracts not spreading, remaining appressed until lost; heads often cylindrical when dry

124. Receptacle with floriferous portion conical; carpopodium asymmetrical, turned toward inside

124'. Receptacle with floriferous part flat; carpopodium symmetrical

125. Corolla lobes broadly triangular, as wide as long; style branches with broadened tips, mostly smooth

125'. Corolla lobes longer than wide; style branches not broadened at tip, usually densely papillose

159. Osmiopsis

154. Chromolaena

123'. Involucre with at least outer bracts persistent, some or all bracts spreading when aged or dried

126. Heads sessile in dense spherical clusters

127. Individual heads with 1 flower; leaves mostly alternate

127'. Individual heads with many flowers; leaves mostly opposite

126'. Heads not sessile in dense spherical clusters

128. Heads with paleae

129. Leaves scale-like, inserted in a dense spiral

129'. Leaves not scale-like, mostly opposite

130. Throat of corolla expanded from a narrow basal tube; in ner surface of corolla lobes slightly to strongly papillose; involucral bracts subequal in length

131. Heads with 50-80 flowers; base of style without enlarged node above nectary; cells of anther collar with dense annular thickenings on walls

15. Gyptidium

131'. Heads with 11-25 flowers; base of style with enlarged node above nectary; cells of anther collar without annular thickenings on walls

130'. Corolla funnelform without extremely narrowed basal tube, basal tube not closely investing shaft of style; inner surface of corolla lobes smooth; involucral bracts subimbricate

132. Heads with 10-20 flowers; leaves pinnately veined 131. Idiothamnus

$132^{\prime}$. Heads with 100-300 flowers; leaves trinervate

133. Involucre enclosed in many series of densely imbricated subinvolucral bracts; stems with solid pith; anther appendages longer than wide 166. Matudina

133'. Involucre without imbricated subinvolucral bracts; stems fistulose; anther appendages shorter than wide 123. Eupatoriastrum

128'. Heads without paleae 134. Heads with four subequal involucral bracts and four flowers, sometimes with distinct subinvolucral
bracts; plants often scandent

134'. Heads with more or less than four involucral bracts or flowers 168. Mikania

135. Pappus of 5-10 slender bristles

136. Heads solitary on erect peduncles, arising of leaves; leaves lobed or dissected 
136'. Heads in branching inflorescences, not arising from pseudowhorls of leaves; leaves toothed, not lobed or dissected

137. Involucre eximbricate; inner surfaces of corolla lobes densely papillose with isodiametric cells; cells of anther

137'. Involucre subimbricate; inner surfaces of corolla lobes with elongate cells; cells
. annular thickenings on walls; carpopodium with distinct upper rim 169. Ageratina

138. Style base

138'. Style base cell ends

135'. Pappus with more than 10 bristles 75. Gyminocondylus

139. Receptacle with hairs large or numerous

e, papillose on 111. Fleischmannia

140. Involucre eximbricate with subequal or scarcely overlapping bracts 139

141. Heads with 20-25 flowers

without strong annulate thickenings on walls; corolla with funnelform throat

141'. Heads with 50-150 flowers; pappus bristles with enlarged round-tipped apical cells; cells of anther collar closely investing shaft of style

142. Involucral bracts with densely pubescent caudate apical appendages; carpopodium large with large thin-walled cells; style appendages densely papillose with slender imbricated papillae __.. 16. Urolep

142'. Involucral bracts without pubescent caudate appendages; carpopodium obsolete; style appendages with short papillae 15. Gyptidium

$140^{\prime}$. Involucre distinctly subimbricate, with bracts of graduated lengths in 3 or more series

143. Leaves winged to base, often with auricles at stem; inner involucral bracts persistent; corollas narrowly tubular, scarcely broadened distally 71. Polyanthina

$143^{\prime}$. Leaves not winged to base, shortly to longly petiolate; inner involucral bracts usually deciduous; corollas distinctly funnelform

144. Plants epiphytic or growing in deep humus; leaves usually fleshy or coriaceous; style base with enlarged node

144'. Plants not epiphytic or growing in deep humus; leaves mostly herbaceous; style base not enlarged 145

145. Receptacle hemispherical, often sclerified throughout; style appendages filiform, terete 160. Hebeclinium

145'. Receptacle flat or shallowly convex, sclerified only in surface; style appendages linear, wider than thick

146. Corolla with hairs on inner surface; anther appendages shorter than wide, bilobed

149. Neocabreria

$146^{\prime}$. Corolla without hairs on inner surface; anther appendages as long as wide, not bilobed

139'. Receptacle glabrous or with few hairs, or hidden from view

162. Bartlettina

147. Style base with hairs or enlarged node above nectary

148. Style base glabrous, node without hairs

149. Corollas tubular, with throat not noticeably wider than basal tube; style branches slightly or broadly

long-clavate

150. Achenes densely glanduliferous; leaves small and densely inserted, subtrinervate

102. Crossothamnus

$150^{\prime}$. Achene with few or no glands, often with setulae; leaves large and pinnately veined

149'. Corollas narrowly to rather broadly funnelform

104. Condylopodium

151. Plants epiphytic or growing in deep humus; inner involucral bracts easily deciduous; corolla lobes with lax subquadrate cells

167. Neomirandea

151'. Plants terrestrial; inner involucral bracts persistent; corolla lobes with small or narrow cells 152

152. Involucre eximbricate or irregularly subimbricate; inner surface of corolla with isodiametric usually papillose cells; carpopodium without distinct upper rim _.......... 153

153. Carpopodium present, distinct

169. Ageratina

153'. Carpopodium obsolete, essentially absent

171. Piptothrix

152'. Involucre usually regularly subimbricate with bracts of graduated lengths; inner surface of corolla with elongate cells, smooth; carpopodium with distinct upper rim ___.. 154 154. Carpopodium without enlarged lower series of cells

73. Heterocondylus

154'. Carpopodium with lowest series of cells much enlarged 
155. Style appendages with long papillae 69. Ayapana

155'. Style appendages scarcely papillose or mamillose

156. Corollas slender with slight expansion in distal one-tenth; stamens small with staggered insertions; receptacle usually with short hairs

71. Polyanthina

156'. Corollas funnelform; anthers inserted at the same level; receptacle glabrous …__..........____._. 70. Ayapanopsis

148: Style base with hairs

157. Involucre eximbricate, with bracts subequal in length

158. Corolla with ampliate throat and narrow basal tube

158'. Corolla funnelform

26. Neocuatrecasia

159. Achenes with broad bases, without attenuate or stipitate bases; with carpopodium often procurrent along ribs of achene

160. Receptacle flat or slightly convex; anther appendage bilobed; plant of maritime habitats

160 '. Receptacle conical; anther appendage not bilobed

19. Diacranthera

18. Dasycondylus

159'. Achenes with slender attenuate bases; carpopodium not procurrent on ribs 161

161. Corolla lobes 2-3 times as long as wide; carpopodium not broader than stipitate portion of achene 37. Macropodina

I61'. Corolla lobes about as long as wide; carpopodium distinctly broader than the stipitate portion .... 162

162. Receptacle conical; base of style with hairs but without enlarged node; corolla lobes strongly mamillose to papillose

36. Campuloclinium

162'. Receptacle flat or slightly convex; base of style with distinctly enlarged node; corolla lobes smooth

73. Heterocondylus

157'. Involucre subimbricate, with bracts in regular series of graduated lengths

163. Plants with narrowly linear leaves inserted in a dense spiral

98. Pseudobrickellia

163'. Plants with leaves not narrowly linear, mostly opposite

164

164. Pappus bristles flat on outer surface, scabrae restricted to lateral margins

165. Achene with more than 5 ribs or costae

165. Achene with 4 or 5 ribs

81. Brickellia

166. Leaves with prickles on tips of lobes

$166^{\prime}$. Leaves without prickles on tips of lobes

82. Barroetea

167. Corollas funnelform; corolla lobes and style appendages densely covered with papillae

167'. Corollas tubular or constricted above; corolla lobes and style appendages smooth 97. Austrobrickellia

164'. Pappus bristles not flat on outer surface, scabrid outside and laterally

168. Carpopodium asymmetrical, with irregularly shaped cells

169. Corolla tubular; style branches distinctly clavate

169'. Corolla funnelform or campanulate; style branches linear to scarcely broadened above ....... 170

170. Corolla funnelform; involucral bracts not in regular ranks

73. Heterocondylus

$170^{\prime}$. Corolla with campanulate throat; involucre with 5 ranks of 3 bracts

168'. Carpopodium symmetrical or obsolete, with regularly shaped cells when present

74. Condylidium

172. Scandent plants; style branches with enlarged fusiform tips

172'. Plants not scandent; style branches linear, without enlarged tips

171'. Carpopodium without enlarged lower tier of cells, sometimes obsolete

72. Gongrostylus

70. Ayapanopsis

173. Corolla tubular; leaves distinctly pinnately veined

173'. Corolla funnelform or campanulate; lon. Condylopodium

with trinervate or pinnate venation …... 174 nulate thickenings on walls enings

174'. Achenes with numerous setulae

5. Austroeupatorium

176. Inflorescence corymbose paniculate; filaments of anthers long and flexuous

7. Hatschbachiella

176'. Inflorescence mostly pyramidally paniculate; filaments of anthers short and stout, straight 
147'. Style base without hairs and without distinct enlarged node, sometimes slightly papillose

177. Involucre eximbricate or weakly subimbricate, bracts not in regular series, often subequal in length, persistent

178. Corolla tubular, with numerous glands on surface

$178^{\prime}$. Corolla with funnelform or campanulate throat, with or without glands

179. Pappus with slender non-contiguous bristles; inner surface of corolla lobes with elongate cells projecting as papillae at upper ends; base of corolla 5-costate

111. Fleischmannia

179'. Pappus with contiguous bristles; corolla lobes with smooth or isodiametric cells on inner surface; base of corolla not costate

180. Corollas with slender basal tube closely investing shaft of style, with campanulate limb _....... 181

181. Apical cclls of pappus bristles with roundcd tips, often inflated; receptacle usually pubescent

182. Involucral bracts with slender densely pubescent apical appendages

182'. Involucral bracts without pubescent apical appendages

15. Gypridium

181'. Apical cells of pappus bristles pointed; receptacle glabrous

183. Stems and leaves with yellowish granular pubescence; corolla lobes papillose on inner surface

177. Jaramilloa

$183^{\prime}$. Stems and leaves without yellowish granular pubescence; corolla lobes smooth on inner surface 130. Chacoa

$180^{\prime}$. Corollas funnelform with basal tubes not closely enclosing shaft of style 184

184. Plants rosulate with a scapose inflorescence

35. Bishopiella

184'. Plants with elongate leafy stems

185. Shrubs with leaves inserted in dense spirals, leaves not decreasent upwardly

186. Leaves scale-like, imbricated, appressed or with recurving tips, scarcely rowed at base

186'. Leaves spreading from a narrow base, not or weakly imbricated

187. Leaves viscid, without hairs; receptacle flat or slightly convex; style branches filiform, not or scarcely broadened and flattened. 29. Bahianthus

187'. Leaves not viscid, pubescent

188. Leaves linear; receptacle high conical, with paleae on lower part; anther appendage shorter than wide; pappus bristles not noticeably fringed laterally at base 32. Arrojadocharis

188'. Leaves ovate to obovate; receptacle low conical, without paleae; anther appendage as long as wide or longer; pappus bristles fringed laterally at base

33. Lasiolaena

$185^{\prime}$. Herbs or shrubs with mostly opposite leaves, or with leaves becoming progressively smaller above, leaves not inserted in dense even spiral

189. Achenes with strong constriction under upper callus to one-third width of achene, pappus with callus casily detached 40. Lourteigia

189'. Achenes not strongly constricted under upper callus, pappus and callus not notably detachable

190. Corolla lobes smooth on inner surface, with texturc and cell form continuous with that of inside of throat

191. Achenes 5-7 mm long; receptacle with hairs 192

191'. Achenes less than $4 \mathrm{~mm}$ long: receptacle glabrous ......
192. Leaves trinervate from well above base or pinnately veined

193. Epiphytes; leaves fleshy or coriaceous; cells of corolla lobes often quadrate with straight walls

167. Neomirandea

193'. Terrestrial plants; leaves herbaceous; cells of corolla lobes usually elongate with sinuous walls

194. Style appendages slightly but distinctly enlarged at tip; heads often with 1 or more paleae; pappus bristles usually with broadened tips

131. Idiothammus

194'. Style appendages of even width to tip; heads without paleae; pappus bristles without broadened tips 
192'. Leaves trinervate from or near base

195. Peduncles enlarged and fistulose above; carpopodium a narrow rim not sharply delimited above

39. Tamaulipa

195'. Peduncles not enlarged or fistulose above; carpopodium stopper-shaped or short cylindrical, sharply delimited above

196. Corolla lobes slightly wider than long; plants without minute stipitate glands; leaves usually opposite 122. Koanophyllon

196'. Corolla lobes slightly longer than wide; plants often with minute stipitate glands on stems, leaves, or involucral bracts; leaves often alternate

197. Heads with 4-10 flowers; involucre weakly subimbricate with oblong or ovate bracts

197'. Heads with 30-60 flowers; involucre eximbricate with linear bracts

21. Bejaranoa

125. Bishovia

190'. Corolla lobes mamillose or papillose on inner surface with short or isodiametric cells; lobes with cells or texture often abruptly different from that on inside of throat

198. Anther collars elongate with many subquadrate cells filling lower half, without annulate thickenings on cell walls

199. Leave trifoliolate

199'. Leaf blade simple

175. Standleyanthus

200. Stems thickened with fleshy cortex, defoliated at anthesis

$200^{\prime}$. Stems not unusually thickened, not seasonally defoliated

201. Corolla lobes papillose on outer surface and margins

201'. Corolla lobes with smooth cushion on outer surface and margins

174. Spaniopappus 169. Ageratina

198'. Anther collars about 5 times as long as wide, with cellular structure obscured by dense annular thickenings on cell walls

202. Receptacle conical

203. Bases of achenes narrowly attenuate, with broad and short cylindrical carpopodium; scars on receptacle much smaller than carpopodium 36. Campuloclinium

203'. Bases of achenes short and broad, not stipitate or attenuate; carpopodium not broader than scars on the receptacle

204. Apical cells of pappus bristles with rounded tips, sometimes enlarged

204'. Apical cells of pappus bristles narrow with pointed tips

205. Achenes with glands, without setulae; carpopodium procurrent on ribs of achene

38. Conoclinium

205'. Achenes with setulae, without glands; carpopodium with upper rim even, bearing setulae

20. Conocliniopsis

202'. Receptacle plane or slightly convex. 206

206. Perennial herbs, usually with tuberous rootstock, leaves becoming progressively smaller above; achenes densely setuliferous

14. Gyptis

206'. Shrubs with leaves of uniform size except in inflorescences; achenes mostly or completely glabrous

207. Leaves oblanceolate, fleshy and viscid; heads with 50-100 flowers; plants not maritime

207'. Leaves 30. Morithamnus

207. Leaves ovate to elliptical, not fleshy and viscid; heads with 10-15 flowers; plants maritime 208. Leaves coriaceous, elliptical, entire, not punctate; tips of corolla lobes without ap-
pendages

208'. Leaves herbaceous, ovate, 28. Litothamnus with short papillose appendage extending glandular-punctate; tips of corolla lobes

177'. Involucre distinctly subimbricate, in graduated series, inner bracts of involucre often easily deciduous 22.0 Prolobus

209. Leaves viewed against light showing translucent or lens-like internal secretory easily deciduous

glandular-punctations; coarse shrubs or vines

209'. Leaves without translucent secretory pockets, with or without glandular-punctations

210. Corollas tubular, as wide 210 corolla; style branches distinctly clavate

211. Involucral bracts stramineous

212. Leaves densely glandular-punctate; involucre with 8 or more series of bracts, ca, 4 at base 
$212^{\prime}$. Leaves without glandular-punctations; involucre with 5-6 series of bracts

213. Filaments of anthers inserted near base of corolla; achene glabrous

115. Urbananthus

$213^{\prime}$. Filaments inserted well above base of corolla; achene with few to many setulae or glands

$211^{\prime}$. Involucral bracts greenish

114. Critoniadelphus

214. Achenes densely covered with long-stalked glands

91. Dyscritogyne

214'. Achenes with short-stalked glands or with non-glandular setulae

215. Leaf blades with tapering bases; corolla with numerous glands on much of outer surface

103. Helogyne

215'. Leaf blades with truncate or cordate bases; corollas with glands on only lobes or basal part of throat _ 216

216. Inflorescence with branches spreading at right angles; involucral bracts with attenuate tips; bases of petioles becoming thickened and embracing node …_._._._._._._._._._. Pseudokyrsteniopsis

216'. Inflorescence with ascending branches; involucral bracts with obtuse or rounded tips; bases of petioles not unusually enlarged

217. Heads with 25-30 flowers; pappus bristles flat on outer surface, with scabrae restricted to lateral margins; achenes scabrous or with short setulae

84. Brickelliastrum

217 . Heads with 10-16 flowers; pappus bristles with scabrae on outer and lateral surfaces; achenes

with prominent long setulae

92. Kyrsteniopsis

$210^{\prime}$. Corollas funnelform or with campanulate throats, usually with spreading lobes; style appendages of even width or shortly clavate at tips

218. Lobes of corolla papillose on inner surface

219. Cells on inner surface of corolla elongate with upper ends projecting as papillae 220. Achenes terete; shaft of style with hairs and stipitate glands

$220^{\prime}$. Achenes prismatic with 5 ribs; shaft of style glabrous

219'. Cells on inner surface of corolla isodiametric, forming dense papillosity

221. Corolla lobes roughened by projecting cells on outer surface

111. Fleischmannia

221 '. Corolla lobes with smooth cushion on outer surface

218'. Lobes of corolla not papillose on inner surface

222. Stems and leaves with granular yellow pubescence, pubescence often evanescent

223. Corolla with throat as narrow as the tube, only the long lobes spreading; yellowish hairs with cells multiseriate; leaves less than $3 \mathrm{~cm}$ wide

141. Corethamnium

223'. Corolla with throat campanulate above a narrow basal tube; yellowish hairs with cells uniseriate; leaves mostly over $5 \mathrm{~cm}$ wide

177. Jaramilloa and leaves glabrous or with hairs not yellowish and granular

224. Achenes constricted below pappus to one-third or less width of achene, pappus and upper callus easily detached as unit

40. Lourteigia

224'. Achenes not extremely constricted below pappus

225. Style branches distinctly papillose; heads always with 5 flowers

226. Inflorescence pyramidally paniculate

227. Leaves pinnately to bipinnately dissected, with long narrow lobes; style appendage fragile and hirsute with long narrow papillae; apical cells of pappus bristles sharply acute

8. Acanthostyles

$227^{\prime}$. Leaves narrowly ovate or elliptical to linear-lanceolate, serrulate; style branches shortpapillose; apical cells of pappus bristles enlarged with rounded tips

9. Raulinoreitzia

rescence corymbose paniculate, flattened or broadly rounded on top

228. Peduncles essentially glabrous, striated with prominent ridges; midveins of leaves prominent, exsculpate above; plants often having viscid appearance

$228^{\prime}$. Peduncles distinctly pubescent, not or scarcely ridged; midvein of leaves sometimes depressed or insculpate above

229. Plants with opposite, mostly ovate, usually distinctly petiolate leaves; involucre with long, narrow often reddish bracts in differentiated outer series; pappus not usually separating from achene as unit

12. Grazielia

$229^{\prime}$. Plants with alternate or rarely opposite leaves densely inserted on stems; involucre without distinct narrower bracts in outer series; pappus often separating from achene as a unit

230. Outer surface of involucral bracts glabrous: leaves alternate or opposite; achene with carpopodium distinct; anthers not hastate at base 
$230^{\prime}$. Outer surface of involucral bracts slightly to densely pubescent; leaves densely spirally inserted; carpopodium obsolete; anthers hastate at base 10. Disynaphia

225'. Style branches smooth to slightly mamillose; heads with 3 to many flowers, usually not consistently 5-flowered ............... 231

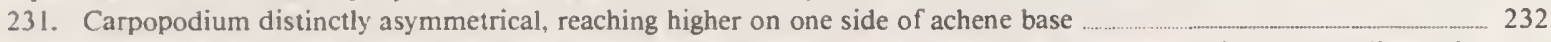

232. Leaves often tomentose on lower surface; style branches usually broadened, at least at tip; carpopodium with sinuous vascular trace; plants of Andes

147. Cronquistianthus

232'. Leaves not tomentose; style branches filiform; carpopodium opening to one side of achene base; plants of Amazonia and Guayana 165. Guayania

231'. Carpopodium essentially symmetrical on base of achene 233

233. Leaves bipinnately dissected into minute lobules

4. Eupatorina

233'. Leaves not dissected

234. Epiphytic plants, with fleshy or coriaceous pinnately veined leaves

167. Neomirandea

234'. Terrestrial or scandent plants without fleshy or coriaceous leaves that are pinnately veined

235. Heads sessile in axils of leaves

235'. Heads not sessile in axils of leaves

150. Uleophytum

236. Involucre weakly subimbricate in up to 3 series; inner bracts mostly persistent

237. Leaves with pinnate venation or with lower secondary veins parallel to lower margin

238. Style appendages slightly but distinctly clavate at tip

131. Idiothamnus

238'. Style appendages not clavate at tip 176. Kaunia

237'. Leaves trinervate at or near base 239

239. Basal tube of corolla very narrow, closely investing shaft of style _... 130. Chacoa

239'. Basal tube of corolla not very narrow, not closely investing shaft of style

240. Receptacle highly rounded or conical; heads with 50-70 fiowers

39. Tamaulipa

240'. Receptacle not highly rounded or conical; heads with less than 50 flowers, usually with less than 20 flowers

241. Lobes of corolla about twice as long as wide, with few or no glands on outer surface; plants scandent 127. Santosia

$241^{\prime}$. Lobes of corolla about as long as wide, densely glanduliferous on outer surface; plants rarely scandent

242. Leaves usually alternate; tip of style appendage not clavate; corolla lobes slightly longer than wide; lower leaf surface appearing thinly tomentose 21. Bejaranoa

242 '. Leaves usually opposite; tip of style appendage often clavate; corolla lobes usually slightly wider than long; lower leaf surface not tomentose 122. Koanophyllon

236'. Involucre strongly subimbricate with bracts in more than 3 series; inner bracts often easily deciduous

243. Style appendages broadly strap-shaped and fleshy, ca. 3 times as wide as thick, often folded longitudinally or wrinkled

244. Achenes with non-glandular setulae, without glands; inflorescence with mostly alternate ascending branches 136. Aristeguietia

244'. Achenes with numerous glands, without non-glandular setulae; inflorescence with mostly opposite widely spreading branches

245. Involucral bracts multicostate; carpopodium cylindrical with upward extensions along ribs of achene; pappus bristles flattened and smooth on outer surface, especially near base

140. Grosvenoria

$245^{\prime}$. Involucral bracts 2-4-costate; carpopodium annuliform or shortly stopper-shaped with a straight upper edge; pappus bristles not flattened on outer surface 139. Badilloa

243'. Style appendages not prominently broadened throughout, sometimes broadened only at tip, not longitudinally folded or wrinkled

246. Outer surfaces of involucral bracts and undersurfaces of leaves tomentose or densely villous 128. Grisebachianthus

246 . Outer surfaces of involucral bracts and undersurfaces of leaves not both tomentose or densely villous

247. Pappus bristles slender and smooth for most of length with greatly enlarged spinose tips 
247 . Pappus bristles not slender and smooth below with greatly enlarged tips

248. Plants with small alternately or spirally inserted leaves; branches of inflorescence spiciform

248'. Plants with mostly opposite leaves; branches of inflorescence rarely spiciform

249. Pappus bristles scabrid below, becoming smooth and tapered in distal half

249'. Pappus bristles not becoming smooth in distal half

138. Austrocritonia

250. Anther appendages usually shorter than wide, usually truncate or bilobed

251. Corollas with hairs on inner surface; leaf blades narrowly elliptical with ascending-pinnate venation

$251^{\prime}$. Corollas glabrous on inner surface; leaf blades various, without strongly ascending-pinnate venation

\section{Neocabreria}

250'. Anther appendages as long as wide or longer, not bilobed

122. Koanophyllon

253. Receptacle flat; involucral bracts persistent 135. Critoniella

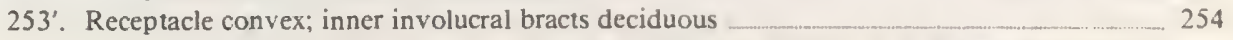

254. Receptacle broadly convex, with parenchymatous interior; style appendages slightly flattened, not terete; carpopodium often somewhat swollen _.... 162. Barlettina

254'. Receptacle hemispherical, often sclerified throughout; style appendages terete except sometimes at tips; carpopodium not swollen .......... 160. Hebeclinium

252'. Carpopodium not procurrent upward on ribs of achene, with sharp upper line of demarcation in cellular structure

255. Heads all with distinct peduncles which are sometimes elongate________ 256

256. Inner bracts of involucre persistent; pappus bristles rather fragile; inflorescence with prominent spreading opposite branching

257. Pappus bristles slightly but distinctly broadened at tips; heads with 18-35 flowers; corollas glabrous 134. Peteravenia

257'. Pappus bristles not broadened at tip; heads with 10-12 flowers; corolla lobes with glands on outer surface 129. Lorenzianthus

$256^{\prime}$. Inner bracts of involucre easily deciduous; pappus bristles persistent; inflorescence with ascending often alternate branching ___.....__

258. Leaf blades trinervate from base; most heads with large foliose bract at base 121. Verieckia

258'. Leaf blades pinnately veined with ascending veins; heads without foliose bracts at base

144. Malmeanthus

255'. Heads at least partly sessile or subsessile in clusters ___ 259

259. Leaves elliptical with widely spreading pinnate venation ____ 260

260. Leaves stiflly coriaceous, with glands and stout hairs on both surfaces; involucral bracts partly hirtellous; style appendages wider than thick 143. Imeria

$260^{\prime}$. Leaves thinly coriaceous, with glabrous upper surface and paler lower surface; involucral bracts subglabrous; style appendages narrowed above stigmatic area, becoming terete and filiform

142. Castenedia

$259^{\prime}$. Leaves mostly ovate with secondary veins strongly ascending or trinervate ............. 261

261. Corollas with lobes $2-4$ times as long as wide; throat with a thick mass of hairs inside; tips of pappus bristles distinctly broadened 148. Sieyermarkina

$26 \mathrm{l}^{\prime}$. Corolla lobes about as long as wide; throat of corolla glabrous on inner surface; tips of pappus bristles mostly not broadened

262. Inflorescence with thyrsoid paniculate branches; most involucral bracts easily deciduous: receptacle strongly convex, subhemispherical; plants scandent 145. Hughesia

$262^{\prime}$. Inflorescence with branches bearing dense glomerulate clusters of heads; most involucral bracts usually persistent; receptacle with flower-bearing surface flat; plants erect or arching herbs 137. Asplundianthus 


\section{KEY TO THE SUBTRIBES OF THE EUPATORIEAE}

1. Involucre eximbricate with bracts not articulated at base; receptacle epaleaceous, without sclerification, changing shape with maturity

I. Adenostem matinae

I'. Involucre eximbricate to imbricate with bracts sclerified or articulated at base; receptacle sclerified between areolae or paleaceous 2

2. Paleae present, bearing a flower in the axil when withdrawn; heads solitary on erect peduncles

2'. Paleae absent or superficial on receptacle; heads often in complex inflorescences

XVIII. Oaxacaninae

3. Heads solitary on erect peduncles from intermittently congested group of leaves in pseudowhorls; pollen grains appearing smooth under light microscope

XVII. Hofmeisteriinae

3'. Heads often in complex inflorescences, peduncles not arising from pseudowhorls of leaves; pollen spinulose under light microscope

4. Heads with 4 subequal bracts and 4 flowers, sometimes with fifth unequal subinvolucral bract; style branches never clavate at tips; pappus always present

4'. Heads without 4 subequal bracts and 4 flowers, or with clavate style branches, or with defective pappus . Mikaniinae

5. Involucral bracts all deciduous leaving a bare receptacle, remaining appressed until loss, not spreading with age

5'. Involucre with at least some persistent basal bracts, bracts usually spreading with age XII. Praxelinae

6. Aquatic or subaquatic plants with sessile or whorled leaves; plants from Mexico and

6'. Plants not aquatic or subaquatic, often with petiolate leaves

7. Alternate-leaved usually rosulate plants from the eastern United States

7'. Opposite-leaved plants or plants from places other than the United States

8. Cell walls of anther collars with weakly or reticulately ornamented walls

9. Plants epiphytes or growing in humus;
pappus of numerous capillary bristles

9'. Plants not epiphytic or growing in humus, or pappus defective

10. Style base with hairs

10'. Style base without hairs 11. Corolla lobes with mostly isodiametric often papillose cells on inner surface; invo-
lucral bracts eximbricate or weakly subimbricate XVI. Oxylobina 11 . Corolla lobes smooth on inner surface with elongate cells; involucral bracts often
strongly subimbricate, rarely eximbricate.

United States

VI. Trichocoroniinae

12. Anther collar usually less than 5 times as long as wide, with quadrate 12

12'. Anther collar usually more than 5 times as long as wide, with quadrate cells
filling lower half or more; receptacle often filling lower half or more; receptacle often with dense pubescence

$8^{\prime}$. Cell walls of anther collar with dense transverse annular thickenings XIII. Hebecliniinae

13. Cells of inner surface of corolla lobes elongate with upper ends projecting as papillae

13'. Cells of inner surface of corolla lobes either short and bulging on . Xleischmanniinae not projecting

14. Heads becoming elongate on an elongate strongly paleaceous receptacle

14'. Heads not becoming elongate with an elongate receptaci... VII. Ayapaninae (Isocarpha)

15. Inner surfaces of corolla lobes with

eximbricate to weakly subimbrith short bulging usually papillose cells; involucre lose, rarely with enlarged or

16. Pappus of capillary bristles, sometim

with densely spirally inserted leaves; with less than 6 flowers

16. Pappus of awns, scales, crowns, or lacking, never of IV. Gyptidinae awns bristle-like in some 5-flowered species; planer unwinged bristles; pappus inserted leaves

15'. Inner surface of corolla lobes usually $\mathrm{V}$. Ageratinae weakly to strongly subimbricate; receptacle

or expanded with clavate or broadly linear appendages

(hickness, few ex-

on achene 
17'. Style appendage not thickened or thickened only at tip, if long-clavate then flattened; achenes never 10-ribbed, never with plumose pappus, and never with peg-like non-glandular hairs on achenes

18. Base of style glabrous and not enlarged; inner involucral bracts often deciduous

19. Heads always with 5 flowers; style appendages papillose; pappus bristles sometimes with bulbous-tipped apical cells; achenes with internal micropunctations usually arranged in transverse bands; plants of eastern South America

19'. Heads with 1-300 flowers, rarely consistently 5-flowered; style appendages usually smooth, at least at tips; pappus bristles never with bulbous-tipped apical cells; achenes with micropunctations not arranged in transverse bands; plants throughout tropical and subtropical America

XI. Critoniinae

18'. Base of style inflated or pubescent or both

20. Style base inflated above nectary, with or without hairs; heads usually with more than 20 flowers, sometimes with paleae; apical cells of pappus bristles pointed

V11. Ayapaninae

$20^{\prime}$. Style base not inflated, with hairs; heads with less than 20 flowers, never with paleae; apical cells of pappus bristles usually with rounded tips

II. Eupatoriinae

\section{KEY TO THE GENERA OF THE EUPATORIEAE IN MEXICO}

1. Individual heads with 1 or rarely 2 flowers, heads in globose clusters

2. Pappus of broad scales; achenes constricted above

2'. Pappus capillary; achenes not strongly constricted above

Individual heads with 3 or more flowers

132. Mexianthus

133. Neohintonia

3. Heads solitary on simple long-pedunculate inflorescences arising from intermittent clusters of leaves in pseudowhorls

178. Hofmeisteria

3'. Simple or branched inflorescences, not arising from subverticillate clusters of leaves

4. Pappus of awns, short bristles, squamae, a crown, 1-2 long bristles, or lacking

5. Peripheral flowers of head with ray-like expanded limb

5'. Peripheral flowers of head with outer lobes not or slightly enlarged

6. Anther appendage half as long as wide or less

7. Pappus with awns or short bristles

8. Pappus of numerous short bristles; leaves with abruptly distinct narrow petioles

$8^{\prime}$. Pappus of 5 awns; leaves subsessile or gradually narrowed to base

'. Pappus with slight lobes or lacking

9. Heads with 3-5 equal involucral bracts and with equal number of flowers; filaments of anthers with papillae or hairs

$9^{\prime}$. Heads with more than 5 involucral bracts and flowers

10. Leaves alternate

64. Enthradenia

10'. Leaves opposite, at least below

64. Microspermum

11. Minute ephemeral herbs up to $4 \mathrm{~cm}$ tall; corollas with 4 lobes and 4 stamens; receptacle with sclerified surface

56. Piqueriopsis

11'. Large herbs of moist areas up to $1 \mathrm{~m}$ tall; corollas with 5 lobes and 5 stamens; receptacle with unsclerified surface between areoles

3. Gymnocoronis

6'. Anther appendage nearly as long as wide or longer

12. Achenes flattened

13. Heads with paleae. single on long peduncles, with ca. 100 flowers

13'. Heads without paleae, numerous in corymbose inflorescences, with 16-25 flowers _ 63. Macvaughiella

12'. Achenes prismatic

14. Corollas with strongly ampliate throats from a slender basal tube

14'. Corollas tubular or funnelform

15. Lobes of corolla oblong, twice or more times as long as wide; inner surface of lobes densely papillose

16. Corolla without hairs inside of throat; anther appendage cleft apically

17. Involucral bracts strongly unequal; style branches terete and tapering with stigmatic lines closely paired along inner surface; base of style distinctly enlarged

60. Carphochaete

17. Involucral bracts equal or subequal; style branches somewhat flattened with stigmatic lines widely separated along lateral margins; style base not enlarged

61. Cronquistia

16'. Corolla with hairs inside of throat; anther appendage not cleft apically

18. Heads with ca. 10 involucral bracts and flowers; anther appendages shortly ovate and obtuse: heads single on tips of leafy branches 
18'. Heads with 4-6 involucral bracts and flowers; anther appendages elliptical or obovate with crenulate upper margins; heads usually in groups

19. Pappus present on most or all achenes of head, sometimes shortly coroniform; achenes narrowly prismatic; heads always with 5 involucral bracts and 5 flowers

19'. Pappus totally lacking on all achenes; achenes widened in middle; heads with 4-6 bracts and flowers 58. Stevia 59. Metastevia

15'. Lobes of corolla triangular, not or only slightly longer than wide

20. Petioles lacking or indistinct _..._._._._. 21

21. Heads with columnar receptacles, with paleae _____ 80. Isocarpha

21 '. Heads with convex or plane receptacles, without paleae _.___. 22

22. Leaves mostly alternate, with narrow bases; pappus of alternating awns and squamellae _.____. 88. Malperia

22'. Leaves opposite, broadly sessile; pappus of short setulae or lacking

23. Pappus lacking; leaves trilobed

23'. Pappus of short setulae; leaves not lobed

67. Shinnersia

20. Leaves with distinct petioles

66. Trichocoronis

24. Receptacle conical; lower surfaces of leaves usually with large partially immersed glandular punctations .

43. Ageratum

24 . Receptacle plane or slightly convex; lower surfaces of leaves with glandular punctations exserted or lacking _- 25

25. Heads with paleae

26. Pappus absent; heads clustered in corymbose glomerules; leaf blades not lobed

26'. Pappus with a long bristle and numerous short setulae; heads solitary; leaf blades lobed

25'. Heads without paleae

180. Carterothamnus

27. Pappus of alternating awns and squamellae; lateral surfaces of achenes covered with numerous setulae

27'. Pappus lacking; achenes with short papilliform setulae

89. Pleurocoronis 90. Alomia

4'. Pappus with 5 or more capillary bristles half as long as the corolla or longer 28. Involucral bracts remaining appressed until loss, not spreading with age, all bracts eventually deciduous, leaving a bare
receptacle

28'. Involucral bracts spreading with age, at least some lower bracts persistent on aged receptacles 154. Chromolaena

29. Heads with paleae, leaves opposite

30. Heads with 11-25 flowers; style with basal node above nectary

30'. Heads with 50 or more flowers; style without basal node
31. Heads with numerous multiseriate subinvolucral bracts; stems not fistulose; anther appendage as long as
wide; central heads of inflorescence maturing distinctly before others

31'. Heads without multiseriate subinvolucral bracts; stems fistulose; anther appendage about half as long as
wide; central heads of inflorescence maturing not or slightly before others

29'. Heads without paleae or with leaves alternate

32. Style base with numerous hairs; shaft of style glabrous

33. Style branches broadly to narrowly linear not $\quad 33$

34. Receptacle conical; carpopodia en 34 30-100 flowers

34'. Receptacle plane to slightly convex; carpopodin... 36. Campuloclinium with broad scarious

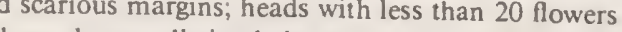

4. Eupatorium

33'. Style branches long-clavate, distinctly broadened; style bases usually distinctly enlarged as well as hirsute 35
35. Achenes with $8-10$ ribs

35'. Achenes usually with $3--5$ ribs

81. Brickellia 36. Pappus bristles not noticeably flattened on outer surface; carpopodium composed of rather thin-
walled cells 85. Flyriella 36'. Pappus bristles flattened on outer surface, with scabrae restricted to lateral margins; carpopodia
composed of thick-walled cells

37. Leaves with prickles on tips of lobes; corolla lobes and style appendages smooth, without papillae

37'. Leaves without prickles on tips of lobes; spreading corolla lobes and _... 82. Barroete covered with minute papillae

32'. Style base glabrous or slightly papillose, rarely with pubescence on shaft of style
38. Pappus bristles plumose dages den sely 83. Phanerostylis

38'. Pappus bristles barbellate, not plumose 95. Carminatia 
39. Individual heads with 4 flowers and 4 equal bracts, with or without fifth outer subinvolucral bract

$39^{\prime}$. Heads with 5 or more flowers and more than 5 involucral bracts

40. Corolla lobes with cells of inner surface distinctly projecting as mamillae or papillae

41. Papillae of corolla lobes formed by projecting upper ends of elongate papillae 4

involucre often strongly subimbricate 42

distinct blackened layer; shaft of style glabrous

111. Fleischmannia

1'.

112. Sartorina

$4 \mathrm{I}^{\prime}$. Inner surface of corolla lobes densely papillose with short isodiametric bulging cells; involucre eximbricate or weakly subimbricate

43. Receptacle conical; pappus bristles persistent

43'. Receptacle plane or slightly convex; pappus bristles often easily deciduous 44. Plants with thickened stems, defoliated at anthesis; outer surfaces of corolla lobes roughened; style base
not enlarged

44'. Plants without unusually thickened stems, not seasonally defoliated: outer surfaces of corolla lobes smooth; style base with distinct enlarged node

45. Carpopodium distinct

45'. Carpopodium obsolete, nearly or essentially lacking

169. Ageratina

171. Piptoihrix

$40^{\prime}$. Corolla lobes with cells of inner surface essentially smooth, usually elongate

46. Leaves when viewed against light showing translucent or lens-like internal secretory pockets along and between

veins, without glandular punctations; heads with many deciduous stramineous inner bracts

47. Corolla lobes about as long as wide, with numerous small glands on outer surface; anther appendage shorter than wide

114. Critoniadelphus

$47^{\prime}$. Corolla lobes ca. 2 times as long as wide, glabrous or nearly glabrous on outer surface; anther appendage longer than wide

113. Critonia

46'. Leaves without internal secretory pockets, often with glandular punctations; heads often with bracts not stramineous or not deciduous

48. Epiphytic plants with rather fleshy or coriaceous leaves; corolla limbs usually with large quadrate cells with non-sinuous walls

167. Neomirandea

48'. Plants not epiphytic; leaves herbaceous; corolla limbs with some elongate cells

49. Style branches with appendage clavate or much broadened distally

50. Corolla lobes equilaterally triangular; anther appendages often distinctly shorter than wide; heads with 5-20 flowers

51. Involucre strongly subimbricate, cylindrical, often whitish; pappus bristles slender, non-contiguous; reddish anthers visible through pale corollas; veins of corolla terminating at sinuses, not extending into lobes; corolla lobes without glands 120. Fleischmanniopsis

5I'. Involucre usually weakly subimbricate, campanulate; pappus bristles stout, contiguous; an thers not reddish; veins of corolla extending into lobes; corolla lobes with numerous glands on outer surface

$50^{\prime}$. Corolla lobes oblong-ovate or distinctly longer than wide; anther appendages as long as wide or longer; heads with 8-35 flowers

52. Achenes densely covered with long-stalked glands

52'. Achenes with short-stalked glands or non-glandular setulae

91. Dyscritogyne

53. Leaf blades with tapering bases; achenes with 6-10 ribs___

54. Leaves sessile, opposite, linear or squamulose; involucral bracts in 4 or more series

54'. Leaves petiolate, opposite or whorled; involucral bracts in 2-3 series

87. Asanthus

94. Steviopsis

53'. Leaf blades with truncate or cordate bases; achenes with 5 ribs

55. Inflorescence with branches spreading at right angles; involucral bracts with attenuate tips; bases of petioles becoming thickened and embracing node 93. Pseudokyrsteniopsis

55'. Inflorescence with ascending branches; involucral bracts with obtuse or rounded tips; bases of petioles not unusually enlarged

92. Kyrsteniopsis

49'. Style branches linear or filiform, not clavate

56. Style base much enlarged above nectary; receptacle often with spines ___... 171. Piptothrix

56. Style base not enlarged; receptacle never with spines

57. Receptacle with hairs

58. Anther appendage much shorter than wide; leaves usually alternate

163. Decachaeta 
58'. Anther appendage about as long as wide; leaves opposite ___ 59

59. Involucral bracts eximbricate; achenes $5-7 \mathrm{~mm}$ long

161. Amolinio

59'. Involucral bracts distinctly subimbricate; achenes less than $4 \mathrm{~mm}$ long

60. Receptacle hemispherical, composed of highly sclerified cells, central part easily broken off; style branches filiform

160. Hebeclinium

$60^{\prime}$. Receptacle slightly convex, with parenchymatous core and sclerified surface; style branches narrowly linear or slightly widened above

162. Bartlettina

$57^{\prime}$. Receptacle glabrous

61. Heads with 10-12 flowers, usually subtended by a large foliose subinvolucral bract

121. Verieckia

61 '. Heads with 18-70 flowers, without foliose subinvolucral bract

62. Involucre weakly subimbricate with narrow bracts rather irregularly arranged; receptacle distinctly convex to conical

62'. Involucre strongly subimbricate with bracts in many distinct series; receptacle plane to slightly convex

39. Tamaulipa

63. Pappus fragile, bristles with bases narrowly articulated, non-contiguous, tips slightly but distinctly enlarged; carpopodium sharply delimited above in cellular stucture; leaves cordate at base in all but one species

134. Peteravenia

63'. Pappus persistent, bristles not articulated at base, contiguous or nearly so, often tapering to tip; carpopodium intergrading upward along ribs of achene; leaf blades usually truncate or tapering at base

162. Bartlettine

\section{KEY TO THE GENERA OF THE EUPATORIEAE IN THE WEST INDIES}

1. Heads with 3-5 involucral bracts and an equal number of flowers

2. Pappus and anther appendage essentially lacking; filaments of the anthers papillose to puberulous

2'. Pappus and anther appendage prominent; flaments of anthers smooth

3. Heads with 5 flowers and 5 involucral bracts; anther appendage elliptical to obovate, with crenulate upper margin; inner surface of corolla hirtellous; pappus of narrow awns or scales

3'. Heads with 4 flowers and 4 principal involucral bracts; anther appendage ovate to oblong, with margin entire; inner surface of corolla without hairs except on lobe margins; pappus of many capillary bristles 168. Mikania

1'. Heads with more than 5 flowers or involucral bracts

4. Pappus of 3 viscid-tipped knobs; receptacle with soft areas between achene scars

4'. Pappus without viscid-tipped knobs; receptacle with sclerified areas between achene scars

5. Heads with flowers interspersed with bracts or paleae

6. Pappus present; receptacles not elongate

6'. Pappus absent; receptacles becoming columnar

5'. Heads without bracts or paleae among the flowers

7. Leaves viewed against light showing translucent or lens-like internal secretory pockets between veins; without glandular punctations

113. Critonia 7'. Leaves without distinct translucent secretory pockets between veins, sometimes present along veins, glandular
punctations often present

8. Styles with distinct clavate or broadened tips

9. Rosulate or subrosulate herbs with scapose inflorescences

10. Heads with 9-10 flowers; pappus bristles about as long as corolla; anther appendages vestigial

79. Lepidesmia

80. Isocarpha

10. Heads with 30-50 flowers; pappus with a low crown of deeply laciniate scales; an 118. Ciceronia nearly as long as wide

9'. Coarse herbs or shrubs with leafy stems

117. Antillia

11. Involucre and undersurfaces of leaves densely tomentose or villous

11'. Involucre and undersurfaces of leaves not densely tomentose or villous

12. Corollas narrowly tubular, not or scarcely broadened below the lobes

13. Leaves with numerous glandular punctations on lower surface; involucral bracts in 7-8 series, 3-4 series of short bracts at base; filaments of anthers inserted well above base of corolla

13'. Leaves glabrous, without glandular punctations; involuctal 1 of anthers inserted near base of corolla

116. Adenocriton

12'. Corollas funnelform

115. Urbananthus

14. Leaves greatly dissected, bipinnatifid

14'. Leaf blades simple, not dissected

119. Eupatorina

15. Involucral bracts all deciduous, leaving a bare receptact

15'. Involucral bracts partially to , 15'. Involucral bracts partially to completely persistent ____. 122. Koanophyllon 
$8^{\prime}$. Styles linear or filiform, without clavate or expanded tips

16. Pappus of simple awns or scales; receptacle conical

17. Pappus of scales with sinuous cell walls; anther appendages reduced, half or less as long as wide

17'. Pappus of awns or coroniform, without prominently sinuous cell walls; anther appendages as long as wid

16'. Pappus of capillary bristles, sometimes short

43. Ageratum

18. Involucre with at least inner bracts deciduous

19. Receptacle strongly convex, densely pubescent; outer involucral bracts persistent; lobes of corolla smooth on inner surface; carpopodium of thin-walled cells, procurrent on ribs of achene 160. Hebeclinium

19'. Receptacle with flower-bearing surface flat, with few or no hairs; often with all involucral bracts deciduous; lobes of corolla often densely papillose on inner surface; carpopodium with thick-walled cells, not procurrent along ribs of achene

18'. Involucral bracts persistent

20. Corolla lobes covered on inner surface with bulging, mamillose or papillose isodiametric cells; carpopodium with thin-walled cells

21. Involucre weakly subimbricate with graduated bracts; achenes nearly or completely glabrous; corolla lobes roughened on outer surface

174. Spaniopappus

21'. Involucre eximbricate without graduated bracts; achenes setuliferous or glanduliferous; corolla lobes smooth on outer surface, with or without hairs

169. Ageratina

20 . Corolla lobes with elongate usually smooth cells on inner surface; carpopodium with thick-walled cells or obsolete

22. Achenes glanduliferous, without setulae

22 '. Achenes setuliferous or spiculiferous, with few or no glands

4. Eupatorium

23. Corolla tubular; style base densely hirsute; achene with ca. 10 weak ribs

$23^{\prime}$. Corolla slightly to strongly funnelform or with campanulate throat; style base glabrous and unenlarged; achene with ca. 5 prominent ribs

24. Leaves without distinct and abruptly delimited petiole, sessile with tapering bases or subsessile; corolla without abrupt expansion at base of throat; carpopodium with enlarged basal row of cells

24'. Leaves with distinct petiolate or petioliform bases; corolla with abrupt expansion at base of throat; carpopodium without enlarged basal row of cells

25. Involucre with 15 bracts in 5 ranks of 3; corolla with basal tube about as long as throat; lobes smooth; base of style enlarged; carpopodium asymmetrical

74. Condylidium

25'. Involucral bracts not ranked; corolla with basal tube half or less as long as throat; lobes papillose by projecting upper ends of cells; carpopodium symmetrical __.. 111. Fleischmaninia

\section{KEY TO THE GENERA OF THE EUPATORIEAE IN COLOMBIA}

1. Pappus of knobs, scales, awns, less than 10 bristles or lacking

2. Pappus completely absent

3. Heads with paleae among flowers; receptacle columnar 80. Isocarpha

3'. Heads without bracts or paleae among the flowers

4. Anther appendages vestigial; leaves herbaceous; plants terrestrial

4'. Anther appendages as long as wide; leaves succulent or coriaceous; epiphytes on coastal mangroves

45. Phalacraea

present

152. Tuberosiyles

2'. Pappus present

5. Pappus of 3-5 viscid-tipped knobs; receptacle with unsclerified areas between areoles; corolla lobes smooth

6. Viscid tips of pappus knobs rounded, not extending downward on outer surface; pappus with 5 knobs; anther appendage as long as wide

2. Sciadocephala

6'. Viscid tips of pappus knobs extending downward on outer surface; pappus with 3 knobs, rarely 5 ; anther appendage about half as long as wide

1. Adenostemma

5'. Pappus without viscid-tipped knobs; receptacle with sclerified areas between areoles; corolla lobes papillose on inner surface

7. Heads with 5 involucral bracts and 5 flowers; corollas hirtellous on inner surface

7 '. Heads with more than 5 involucral bracts and 5 flowers; corollas without hairs on inner surface

8. Receptacle flat or slightly convex; corolla with ampliate throat and slender basal tube; corolla lobes smooth on margins and outer surface; carpopodium symmetrical; cells of anther collar without distinct annular thickenings on walls

170. Oxylobus

8'. Receptacle conical; corolla tube short, expanding into funnelform throat: corolla lobes papillose on both surfaces; carpopodium asymmetrical; cells of anther collar with distinct annular thickings 
1'. Pappus of more than 10 capillary or plumose bristles

9. Pappus bristles plumosc

9'. Pappus bristles capillary, scabrid

10. Leaves viewed against light showing translucent or lens-like internal secretory pockets appearing as spots between veins, without glandular punctations

113. Critonia

$10^{\prime}$. Leaves without distinct translucent sccretory pockets, often with glandular punctations

11. Style appendages broadencd, more than twicc as wide as thick or with apex clavate

12. Style base distinctly enlarged, forming a node, often hirsute

13. Scandent plants with trincrvate leaves; anther appendages half as long as wide; tips of style branches with abrupt enlargements

72. Gongrostylus

13'. Non-scandent plants with pinnately veined leaves; anther appendages as long as wide; tips of styles gradually enlarged 104. Condylopodium

$12^{\prime}$. Style base not enlarged or pubescent

14. Carpopodium asymmetrical, higher on one side, with distinct upper rim

14'. Carpopodium symmetrical, without distinct upper rim

147. Cronquistianthus

15. Style appendage broadened only at apex; involucre usually weakly subimbricate in up to 3 series; anther appendage often about half as long as wide

122. Koanophyllon

15'. Style appendages broadened throughout; involucre strongly subimbricate in 4 or more graduated series; anther appendage as long as wide

16. Achenes with non-glandular setulae, without glands; inner involucral bracts rather persistent

136. Aristeguietia

16. Achenes with numerous glands, without non-glandular setulae; inner involucral bracts often deciduous

11'. Style appendages not enlarged or clavate, less than twice as wide as thick

139. Badilloa

17. Involucral bracts all deciduous, leaving a bare receptacle, remaining appressed until loss, not spreading with age

18.

Receptacle with flow

flower-bearing part conical; carpopodium strongly asymmetrical; achene usually flat153. Praxelis 18. Rcceptacle with flower-bearing part flat; carpopodium symmetrical; achene prismatic with usually 5
ribs 17. Involuc 154. Chromolaena

flowers and 4 involucral bracts, often with fifth subinvolucral bract; plants usually scandent

19. Heads with more than 4 flowers or 4 involucral bracts; plants not scandent 168. Mikania

20. Leavcs and stems with yellowish granular pubescence; leaves with pinnate venation
21. Corolla throat narrow and forming continuation leaves subsessile, with bladcs less cells 21'. Corolla with throat ampliatc; leaves distinctly and abruptly petiolate, with blades $7-16 \mathrm{~cm}$
long; granular pubescence with thin-walled uniseriate cells

20 . Leaves and stems without yellowish granular pubescence; leaf blades trinervately or pinnately

22. Plants epiphytic or growing in deep humus; leaves rather fleshy or subcoriaceous; cells of corolla broad and quadrate with straight walls 167. Neomirandea 22 . Plants not epiphytic or in deep humus; leaves not fleshy; cells of corolla not broad and
quadrate.

23. Achenes with strong constriction under upper callus to one-third width of achene, pappus with callus easily detached 23'. Achenes not strongly constricted under upper callus, pappus and callus not notably

24. Inner surface of corolla lobes densely covered with bulging isodiametric cells; involucre eximbricate or irregularly subimbricate, with scarious margins narrow
or lacking

25. Lobes of corolla usually longer than wide, smooth on outer surface except for pubescence; style basc with enlarged node above nectary; anther collar with numerous quadrate cells, with weakly ornamented walls 169. Ageratina

25'. Lobes of corolla about as long as wide, with bulging cells on outer surface, at least near margins; style base not enlarged; only lower cells of anther collar quadrate, with dense annular thickenings on walls 
26. Achenes with glands, without non-glandular hairs; carpopodium procurrent on ribs of achene

17. Barrosoa 26 . Achenes with non-glandular hairs, without glands; carpopodium with straight upper margin, not procurrent on ribs of
achene

24'. Inner surface of corolla lobes with cells longer than wide, not significantly different from those inside of throat; involucre subim bricate with 3-5 series of graduated lengths, bracts usually with broadly scarious margins

27. Corolla narrowly tubular throughout or narrower above

28. Heads narrow with 8-14 flowers; leaves with distinct narrow petioles; achenes with 10 weak ribs; style base with hirsute node

81. Brickellia diffusa

28'. Heads broad with 150-300 flowers; leaves winged to base; achenes with 5 angles; node of style base glabrous

27'. Corolla distinctly funnelform

71. Polyanthina

29. Style base enlarged or pubescent above nectary

30. Style base without enlarged node; achenes with glands, without non-glandular hairs

30'. Style base with distinct node above nectary; achenes with non-glandular hair

31. Achene with carpopodium symmetrical, with basal tier of cells mus, with few or no glands 3 walls

32. Style appendage with long-projecting papillae, appendage often tapering or curled

$32^{\prime}$. Style appendage nearly smooth, linear

'. Achene with carpopodium asymmetrical, without distinctly larger basal tier of cells, with cell walls
irregularly thickened or porose

33. Involucre with bracts not in distinct ranks; heads with 20-80 flowers; corollas narrowly funnelform

73. Heterocondylus

33'. Involucre with 15 bracts in 5 ranks of 3; heads with 5-6 flowers; corollas with cylindrical basal tube and abruptly campanulate limb

$29^{\prime}$. Style base without enlargement or hairs above nectary

74. Condylidium

34. Corolla lobes papillose by projecting upper ends of elongate cells; carpopodium with distinct upper rim; involucral bracts persistent, spreading at maturity

111. Fleischmannia

34'. Corolla lobes essentially smooth on inner surface; carpopodium with little or no projecting upper margin; inner involucral bracts often deciduous

35. Style appendages usually slightly flattened and broadened, especially at tip

36. Carpopodium with thin-walled cells, procurrent on ribs of achene; receptacle sometimes with hairs

162. Bartletina

36'. Carpopodium without thin-walled cells, not procurrent on ribs of achene; receptacle glabrous

37. Heads mostly in sessile glomerulate clusters; achenes glabrous or nearly glabrous; anther appendage as long as wide 137. Asplundianthus

37'. Heads mostly short-pedunculate or in spicate clusters; achenes with numerous scabrae or glands; anther appendage less than half as long as wide to as wide as long

122. Koanophyllon

35'. Style appendages becoming terete and filiform above stigmatic lines

38. Leaves elliptical, with widely spreading pinnate venation; many-branched shrubs to $4 \mathrm{~m}$ tall

142. Castanedia

$38^{\prime}$. Leaves ovate to suborbicular and cordiform, usually trinervate or with ascending secondary veins; herbs or subshrubs

39. Receptacle hemispherical, often sclerified throughout, often pilose

160. Hebeclinium

39'. Receptacle flat or shallowly convex, sclerified only on surface, with parenchymatous core, glabrous

40. Carpopodium symmetrical

135. Critoniella

$40^{\prime}$. Carpopodium asymmetrical, opening to one side

165. Guayania

\section{KEY TO THE GENERA OF THE EUPATORIEAE IN BRAZIL}

1. Involucral bracts herbaceous and non-articulated at base; receptacle unsclerified except in achene scars, changing shape when drying

2. Pappus lacking

2'. Pappus of 3 viscid-tipped knobs

3. Gymnocoronis

$\therefore$ Involucral bracts sclerified or articulated at base; receptacle either sclerified or paleaceous between achene scars

3. Involucral bracts all deciduous leaving a bare receptacle, bracts remaining appressed until loss, not spreading with age

4. Receptacle with flower-bearing surface flat: achenes prismatic usually with 5 ribs; carpopodium essentially symmetrical or obsolete

\section{9} 30 31 32 . 
5. Outer lobes of peripheral flowers greatly expanded; anthers inserted near bases of corolla lobes; style base with enlarged node above nectary

5'. Peripheral flowers not asymmetrical with enlarged lobes; anthers inserted well below corolla lobes; style base not enlarged

6. Pappus short and irregular; carpopodium minute, poorly differentiated; leaves often dissected 6

6'. Pappus capillary with long bristles; carpopodium distinct, shortly cylindrical 156. Lomatozona 154. Chromolaena

4'. Receptacle conical to columnar; achenes flattened with 2-4 ribs; carpopodium strongly asymmetrical, born laterally on achene base

7. Pappus short and irregular; receptacle columnar; outer involucral bracts sometimes slightly persistent

155. Eupatoriopsis

7'. Pappus with long bristles; receptacle conical; in volucral bracts totally deciduous

8. Pappus with 5-8 stout bristles, with or without additional smaller bristles; achenes with 2 marginal ribs

8'. Pappus with 20-40 capillary bristles; achenes with 3-4 ribs

158. Eitenia 153. Praxelis

3'. At least outer involucral bracts persistent

9. Individual heads with 4 or 5 subequal involucral bracts and an equal number of flowers; style branches never enlarged at tips

10. Heads with 5 involucral bracts and 5 flowers; pappus with narrow awns or short scalcs; corollas hirtellous on inner surface; plants not scandent

$10^{\prime}$. Heads with 4 involucral bracts and 4 flowcrs; pappus of capillary bristles; corollas with few or no hairs on inner surface; plants sometimes scandent 168. Mikania

9'. Individual heads with more than 4 or 5 involucral bracts, often with more than 4 or 5 flowers, or style branches with enlarged tips

11. Heads becoming elongate on columnar receptacle, with numerous indurated paleae

11 '. Heads not becoming elongate on columnar receptacle, with palcae thin or lacking

12. Style shaft pubescent on upper part

$12^{\prime}$. Style shaft glabrous on upper part

80. Isocarpha

13. Style base enlarged or pubescent above nectary

14. Pappus absent

15. Heads with paleae; leaves linear; anther appendage absent

15'. Heads without paleae; leaves ovate to oblong; anther appendage present

16. Heads with 4-5 flowers; corolla throats tubular, without thickened veins; style appendages

thickened; style base pubescent

101. Planaltoa

16. Heads with ca. 40 flowers; corolla throats narrowly funnelform, with veins greatly thickened

14'. Pappus present

below; style appendages not broader distally; style base glabrous

17. Pappus of numerous bristles flattened on outer surface

17'. Pappus bristles not flattened on outer surface

76. Alomiella

18. Style branches long-clavate

19. Pappus easily deciduous, bristles usually completely detached from achene at maturity

19'. Pappus persistent

100. Leptoclinium

20. Pappus elements of two different sizes

21. Heads with 4 flowers; leaves alternate or opposite; with numerous longer pappus bristle alternating with shorter bristles 99. Goyazianthus

21'. Heads with 6-8 flowers; leaves opposite; pappus with only 5 longer bristles and with more numerous smaller bristles

20'. Pappus elements without two distinctly different sizes

22. Leaves narrowly linear, inserted in dense spiral

22 '. Leaves ovate, mostly opposite

18. Style branches linear or filiform or enlarged only at tip, not long-clavate 98. Pseudobrickellia 97. Austrobrickellia 23. Corolla with narrow basal tube closely investing shaft of style, with campanulate throat;
pappus bristles easily deciduous.....

169. Ageratina

23'. Corolla funnelform with basal tube not closely investing shaft of style; pappus rather
persistent

24. Achenes with long-stipitate or attenuate bases

25. Heads large with 30-100 flowers; receptacle conical with minute scars; carpopodium greatly enlarged, annuliform or short cylindrical; achene with prominent pale ribs; corolla lobes not longer than wide, often mamillose in
inner surface 
$25^{\prime}$. Heads usually with less than 30 flowers; receptacle flat; carpopodium only slightly broader than stipe; achene with concolorous ribs; corolla lobes 3 times as long as wide, smooth on inner surface

$24^{\prime}$. Achenes without long-stipitate or attenuate bases 37. Macropodina

26. Style base without enlargement, with only hairs

27. Surface of achene with only glands, without non-glandular hairs

27 . Surface of achene with numerous non-glandular setulae

28. Inflorescence corymbose; filaments of anthetulae _._........ 28

28'. Inflorescence pyramidal to thyrsoid; filaments of anthers short and stout

26'. Style base with distinct enlarged node above nectary, with or without hairs

29. Pappus with a single long bristle; leaves dissected into 3 or more parts

29'. Pappus with 5 or more bristles; leaves simple

30. Carpopodium with large thin-walled cells, procurrent along ribs of achene

31. Anther appendage bilobed, shorter than wide; receptacle flat

31 . Anther appendage as long as wide; receptacle conical

$30^{\prime}$. Carpopodium with thick-walled cells, not procurrent along ribs of achene

32. Carpopodium with lowest tier of cells distinctly larger, upper tiers of cells smaller, with walls of cells evenly thickened

33. Style appendage with elongate often imbricated papillae; basal node of style glabrous

7. Hatschbachiella

6. Stomatanthes

33'. Style anana 69. Ayana

33'. Style appendage nearly smooth to slightly mamillose; basal node of style often with hairs

77. Monogereion

70. Ayapanopsis

32'. Carpopodium with lowest tier of cells not distinctly larger than upper tiers, walls of cells with beaded thickenings

34. Pappus with 5-10 bristles; style appendage with elongate imbricated papillae; basal node of

34'. Pappus with 20-35 bristles; style appendage mamillose to nearly smooth; basal node of style often with hairs

73. Heterocondylus

13'. Style base not enlarged or pubescent

35. Pappus of scales, awns, or lacking; leaves opposite or alternate but not inserted in dense spiral

36. Anther appendage half as long as wide or less; heads with $8-12$ flowers

37. Involucral bracts weakly overlapping, with acute tips; corolla tubes with gland-tipped hairs; leaf blades repanddentate to pinnatifid

51. Gardnerina

37'. Involucral bracts distinctly overlapping, with rounded or denticulate apices; corolla tubes without gland-tipped hairs; leaf blades with dentate margins

36'. Anther appendage nearly as long as wide or longer

55. Piqueriella

38. Heads without paleae

39. Shrubs

39'. Herbs

40. Involucral bracts broadly rounded; achenes with carpopodium small and symmetrical; leaves acuminate, lobed

49. Cavalcantia

$40^{\prime}$. Involucral bracts pointed; achenes with large asymmetrical carpopodia; leaves not acuminate, not lobed

43. Ageratum

38'. Heads with paleae

41. Pappus and upper callus of achene absent, walls of achene continuing directly into corolla

50. Teixeiranthus

41'. Pappus or upper callus of achene present, corolla not continuous with apex of achene

42. Paleae of head with expanded and ornamented tips; leaves sessile and congested, with prominent parallel venation

47. Scherya

$42^{\prime}$. Paleae without expanded tips; leaves usually petiolate or narrowed at base, with pinnate or palmate venation

41. Acritopappus

35'. Pappus of bristles, sometimes short, rarely lacking in plants with closely spirally inserted leaves

43. Pappus of plumose or strongly barbellate bristles, or without pappus and bearing dense pubescence that hides distal part of corolla

44. Corolla densely pubescent on upper throat and lobes; stems with distinct ribs; anther appendages rounded to slightly retuse apically

23. Trichogonia

44'. Corolla with only small glands distally on outer surface; stems scarcely striate; anther appendages deeply cleft

43'. Pappus not plumose; corolla without mass of dense pubescence hiding distal part

24. Trichogoniopsis

45. Plants rosulate with a scapose inflorescence 
45'. Plants not rosulate or scapose

46. Shrubs with leaves inserted in close spiral, leaves not progressively decreasing in size upwardly

47. Leaves scale-like, imbricated, appressed or recurved, scarcely narrowed at base

$47^{\prime}$. Leaves spreading from a narrow base, not or weakly imbricate

48. Leaves viscid, without hairs; receptacle flat or slightly convex; style branches filiform, not or scarcely broadened and flattened

49. Leaves fleshy; veins of leaves and corolla with pairs of resin ducts; involucre strictly eximbricate, with slender-tipped bracts; pappus setae of uniform width

30. Morithamnus

49'. Leaves not fleshy, with prominent veins; resin ducts or pockets of leaves and corolla throat simple or single along veins; involucre weakly subimbricate, with blunt rather scarious-tipped bracts; pappus setae of various widths

29. Bahianthus

48'. Leaves not viscid, pubescent; receptacle conical; style branches distinctly broadened and flattened at tips _... 50

50. Leaves linear; receptacle highly conical, with paleae among the more peripheral flowers; anther appendage much shorter than wide; leaves not tomentose; pappus bristles not broadly fringed 32. Arrojadocharis

$50^{\prime}$. Leaves ovate to obovate; receptacle low conical, without paleae; anther appendage as long as wide or longer; leaves tomentose below; pappus bristles somewhat awn-like with narrowly winged bases

33. Lasiolaena

46'. Herbs or shrubs with mostly opposite or laxly alternate leaves, leaves often progressively decreasing in size upwardly on plant, not inserted in a dense even spiral

51. Achene with narrowly stipitate base; receptacle conical; pappus sometimes short

52. Pappus of short, lanceolate, densely fringed bristles; anther collar very broad below; achene ribs concolorous with sides

52'. Pappus usually of long bristles; anther collar cylindrical; achene with very prominent pale ribs

25. Platypodanthera

36. Campuloclinium

51'. Achene base not narrowly stipitate; receptacle conical or plane; pappus always of numerous long capillary bristles

53. Anther appendage distinctly shorter than wide

54. Involucre distinctly subimbricate in unequal series; corolla with hairs on inner surface; style appendages not distinctly broadened distally 149. Neocabreria

54'. Involucre eximbricate or weakly subimbricate, bracts mostly subequal; corolla glabrous inside; style appendages often broadened distally

55. Anther appendage essentially lacking, often in form of 2 separate minute lobes; involucre eximbricate

55'. Anther appendage distinct, one-third as long as wide or longer; involucre usually weakly subimbricate

53'. Anther appendage as long as wide or longer

122. Koanophyllon

56. Heads congested in dense spherical clusters

56'. Heads not in dense spherical clusters

124. Sphaereupatorium

57. In volucral bracts with slender densely pubescent apical appendages; receptacle bulbous and pubescent 16. Urolepis

57'. Involucral bracts without narrow apical appendages; receptacle not bulbous, with or without hairs

58. Involucral bracts subequal in length, all persistent

59. Achenes with 7-10 ribs; leaves broad and subsessile

59 '. Achenes with 4-6 ribs; leaves with narrow or petiolate bases

27. Vittetia

60. Coarse shrubs, with coriaceous or fleshy leaves

61. Leaves broadly elliptical, coriaceous, shiny; corolla lobes with simple tips; pappus bristles not flattened on outer surface; maritime plants 28. Litothamnus

61 '. Leaves obovate to oblanceolate, fleshy, viscid; corolla lobes with subapical crest on outer surface; pappus bristles flattened on outer surface; not maritime plants

30. Morithamnus

60 . Herbs or weak shrubs, with leaves herbaceous or subcoriaceous, not strongly coriaceous or fleshy

62. Achenes with numerous non-glandular setulae on surface

63. Carpopodium narrower than achene; receptacle flat; plants with leaves usually progressively decreasing in size above 14. Gyptis

63'. Carpopodium as broad as achene, with setulae on upper edge; receptacle conical; leaves not decreascent above

20. Conocliniopsis

62'. Achene without non-glandular setulae on sides, with or without glands

64. Achenes glabrous; receptacle flat; tips of corolla lobes with inner surface projecting as small papillose appendage

64'. Achenes with glands; receptacle conical; tips of corolla lobes simple 
65. Corollas with narrowly constricted basal tubes closely investing shaft of style; receptacles pubescent or paleaceous; apical cells of pappus bristles with rounded tips; carpopodium obsolete

15. Gyptidium

$65^{\prime}$. Corollas with broadly cylindrical basal tube, not closely investing shaft of style; receptacles glabrous; apical cells of pappus bristles pointed; carpopodium large with large thin-walled cells

$58^{\prime}$. Involucral bracts unequal in length, with inner bracts often deciduous

17. Barrosoa

66. Inner surface of corolla with dense pubescence; corolla lobes 2-4 times as long as wide

66 '. Inner surface of corolla glabrous; corolla lobes usually less than twice as long as wide

67. Heads always with 5 flowers

68. Inflorescence pyramidally paniculate

69. Leaves pinnately to bipinnately dissected, with long narrow lobes; style appendages fragile, hirtellous with long narrow papillae; apical cells of pappus bristles sharply acute

8. Acanthostyles

$69^{\prime}$. Leaves narrowly ovate to linear-lanceolate, serrulate; style branches short-papillose; apical cells of pappus bristles blunt and enlarged

68'. Inflorescence corymbose, with flattened or broadly rounded top

9. Raulinoreitzia

70. Peduncles essentially glabrous, striated with prominent ridges; midveins of leaves prominently exsculpate on upper surface; plants often having viscid appearance. $70^{\prime}$. Peduncles distinctly pubescent, not or scarcely ridged; midveins of lcaves sometimes depressed or in
sculpate on upper surface

71. With opposite, mostly ovate, usually distinctly petiolate leaves; involucre with long, narrow, often reddish bracts in differentiated outer series, pappus not usually separating from achene as unit .........

12. Grazielia

71'. With alternate or rarely opposite leaves, densely inserted on stems; involucre without distinct narrower bracts in outer series; pappus often separating from achene as unit

72. Outer surface of involucral bracts glabrous; leaves alternate or opposite; carpopodium small but distinct

11. Campovassouria

72'. Outer surface of involucral bracts pubescent; leaves densely spirally inserted; carpopodium obsolete

$67^{\prime}$. Heads usually with more than 5 flowers, rarely consistently 5 -flowered

10. Dișyaphia

73. Cells of corolla lobes elongate with upper ends projecting as papillae; style appendages densely long-papillose

111. Fleischmannia

73'. Cells of the corolla lobes not projecting at upper ends, style appendages mamillose to short-papillose

74. Leaves viewed against light with translucent or lens-like internal secretory pockets showing as spots between veins, without glandular punctations 113. Critonia

74'. Leaves without translucent internal secretory pockets, often with glandular punctations

75. Pappus bristles barbellate below and tapering to a smooth tip in distal half

75'. Pappus bristle without smooth tapering distal halves, scabrid to tips

76. Leaves with pinnate venation, secondary veins sometimes strongly ascending

77. Carpopodium asymmetrical on base of achene

77'. Carpopodium symmetrical on base of achene or obsolete

78. Heads with paleae; leaf blades elliptical

$78^{\prime}$. Heads without paleae; leaf blades ovate

$76^{\prime}$. Leaves strongly trinervate from base

79. Scandent plants; bases of leaf blades acute; corolla lobes twice as long as wide or longer

138. Austrocritonia

..._- 127. Santosia

79'. Erect herbs or shrubs; bases of leaf blades obtuse, truncate, or cordate; corolla lobes about as long as wide

80. Heads with 5-10 flowers; cells of anther collars with dense transverse annular thickenings on walls; shrubs

21. Bejaranoa

$80^{\prime}$. Heads with 20-80 flowers; cells of anther collars without obvious annulations on walls; coarse herbs

81. Leaf blades with cordate bases; receptacle hemispherical, sclerified throughout; style appendages filiform, terete

160. Hebeclinium

$81^{\prime}$. Leaf blades with obtuse or truncate bases; receptacle convex to low conical, with parenchymatous core; style appendages narrowly linear, somewhat flattened or channeled 
Treatment of the Subtribes and Genera of THE EUPATORIEAE

ACCEPTED SEQUENCE OF THE SUBTRIBES AND GENERA OF THE EUPATORIEAE

The 18 subtribes and 180 genera of the Eupatorieae are treated in this revision in the following sequence. The numbers before the genera are a rearrangement based on the series of numbers allotted to the tribe in the Dalla Torre and Harms (1900 1907) system.

I. Adenostemmatinae 8778 Adenostemma 8778a Sciadocephala 8778b Gymnocoronis

II. Eupatoriinae 8779 Eupatorium 8779a Austroeupatorium 8780 Stomatanthes 8780a Hatschbachiella

III. Disynaphiinae

8781 Acanthostyles

8781a Raulinoreitzia

8781 b Disynaphia

8781c Campovassouria

8781d Grazielia

8782 Symphyopappus

IV. Gyptidinae

8783 Gyptis

8783a Gyptidium

8783b Urolepis

8784 Barrosoa

8784a Dasycondylus

8784b Diacranthera

8784c Conocliniopsis

8784d Bejaranoa

8784e Prolobus

8785 Trichogonia

8785a Trichogoniopsis

8785b Platypodanthera

8785c Neocuatrecasia

8786 Vittetia

8786a Litothamnus

8787 Bahianthus

8787a Morithamnus

8788 Agrianthus

8788a Arrojadocharis

8788b Lasiolaena

8788c Stylotrichium

8788d Bishopiella

8789 Campuloclinium

8789a Macropodina

8790 Conoclinium 8790a Tamaulipa

8791 Lourteigia

V. Ageratinae

8792 Acritopappus

8793 Radlkoferotoma

8794 Ageratum

8794a Phania

8794b Phalacraea

8794c Blakeanthus

8794d Scherya

8794e Ascidiogyne

8794f Cavalcantia

8794g Teixeiranthus

8794h Gardnerina

8795 Ellenbergia

8795a Guevaria

8795b Ferreyrella

8795c Piqueriella

8795d Piqueriopsis

8796 Piqueria

8797 Stevia

8797a Metastevia

8798 Carphochaete

8798a Cronquistia

8798b Revealia

8799 Macvaughiella

8800 Microspermum

8800 a Iltisia

VI. Trichocoroninae

8801 Trichocoronis

8801a Shinnersia

8801 b Sclerolepis

VII. Ayapaninae

8802 Ayapana

8802a Ayapanopsis

8802b Polyanthina

8802c Gongrostylus

8802d Heterocondylus

8802e Condylidium

8802f Gymnocondylus

$8802 \mathrm{~g}$ Alomiella

8802h Monogereion

$8802 \mathrm{i}$ Parapiqueria

$8802 \mathrm{j}$ Lepidesmia

8803 Isocarpha

VIII. Alomiinae

8804 Brickellia

8804a Barroetea

8804b Phanerostylis

8804c Brickelliastrum 
8804d Flyriella

8805 Ageratella

8805a Asamthus

8806 Malperia

8806a Pleurocoronis

8807 Alomia

8808 Dyscritogyne

8808a Kyrsteniopsis

8808b Pseudokyrsteniopsis

8808 c Stcviopsis

8809 Carminatia

8810 Dissothrix

8810 a Austrobrickellia

8810 b Pseudobrickellia

8810 c Goyazianthus

8810 d Leptoclinium

8810 e Planalioa

8811 Crossothammus

8811 a Helogyne

8812 Condylopodium

IX. Liatrinae

8813 Liatris

8813a Litrisa

8813 b Trilisa

8813c Carphephorus

8813d Garberia

8814 Hartwrightia

$X$. Feischmanniinae

8815 Fleischmannia

$8815 a$ Sarlorina

XI. Critoniinae
8816 Crilonia
8816 a Critoniadelphus
$8816 \mathrm{~b}$ Urbananthus
8816 c Adenocritonia
8817 Antillia
8817a Ciceronia
8817 b Eupatorina
8817c Fleischmanniopsis
8817 d Verieckia
8818 Koanophyllon
8818a Eupatoriastrum
8818 b Sphacreupatorium
$8818 \mathrm{c}$ Bishovia
8818d Nothobaccharis
8818 e Santosia
$8818 \mathrm{f}$ Grisebachianthus
$8818 \mathrm{~g}$ Lorentzianthus
8818 h Chacoa
$8818 \mathrm{i}$ Idiothamnus
$8818 \mathrm{j}$ Mexianthus
8818k Neohintonia
88181 Peteraveria

8819 Critoniella

8819a Aristeguietia

8819b Asplundianthus

8819c Austrocritonia

8819d Badilloa

$8819 \mathrm{e}$ Grosvenoria

$8819 f$ Corethamnium

$8819 \mathrm{~g}$ Castenedia

8819 h Imeria

8819 i Malmeanthus

8819j Hughesia

8820 Ophryosporus

8820 a Cronquistianthus

8820 b Steyermarkina

8820 c Neocabreria

8820 d Uleophytum

8820e Amboroa

8821 Tuberostyles

XII. Praxelinae

8822 Praxelis

8822a Chromolaena

8822b Eupatoriopsis

8822c Lomatozona

8822d Praxeliopsis

8822 e Eitenia

8822f Osmiopsis

XIII. Hebecliniinae

8823 Hebeclinium

8823a Amolinia

8823b Bartlettina

8823c Decachaeta

8823d Erythradenia

8823 e Guayania

8823f Matudina

XIV. Neomirandeinae

8824 Neomirandea

XV. Mikaniinae

8825 Mikania

XVI. Oxylobinae

8826 Ageratina

8826a Oxylobus

8826b Piptothrix

8826c Jaliscoa

8826d Pachythamnus

8826e Spaniopappus

$8826 \mathrm{f}$ Standleyanthus

8826 g Kaunia

8826h Jaramilloa

XVII. Hofmeisteriinae

8827 Hofmeisteria

XVIII. Oaxacaniinae

8828 Oaxacania

8828a Carterothamnus 


\section{SubTribe I. Adenostemmatinae}

Adenostemmatinae B. Robinson, Contr. Gray Herb. n.s. 42: 435. 1913. TYPE: Adenostemma J. R. Forster \& G. Forster.

Annual or perennial herbs, often creeping or with decumbent bases; leaves opposite. Inflorescence terminal, unbranched or cymose. Heads pedicellate; involucral bracts eximbricate, herbaceous without articulated or sclerified bases; receptacle glabrous, without sclerified tissue between achene scars, shallowly convex, becoming more convex with age. Flowers 10-200 in a head; corollas mostly pale, lobes smooth on inner surface; cells of anther collar with annular thickenings on walls; style base without enlargement, glabrous; style branches weakly mamillose to smooth. Achenes 3-5-angled; carpopodium with thin-walled subquadrate cells; pappus often with 3 or 5 viscid-tipped knobs. Basic chromosome number $x=10$.

The subtribe is regarded as the most individually isolated element in the Eupatorieae, but it does show all essential features of the tribe. The most distinctive character is the receptacle, which is mostly soft tissue without fixed form, and which shows structural continuity with the involucral bracts. The two most obvious results are the change of shape in the receptacle as the plant ages, and the tendency for the involucral bracts in Adenostem$m a$ to be fused for a short distance at their bases.

The viscid-tipped knobs of the pappus are also a distinctive feature of the subtribe, although these are lacking in the genus Gymnocoronis. It is the combination of viscid-tipped knobs and the presentation on the more convex older receptacles that apparently accounts for the great distributional success in the pantropical genus Adenostemma (Yapp, 1906).

The Adenostemmatinae was the subtribe most nearly recognized as a natural unit prior to the present study. Even so, all previous treatments included some extraneous elements. Bentham and Hooker (1873) placed $A d$ enostemma and Gymnocoronis together, but as two of seven genera of the Piquerieae. B. Robinson (1913a) also placed the two genera together in the new subtribe Adenostemmatinae, but included Hartwrightia in the group. The latter is placed in the Liatrinae in this treatment. At the time of its description, Sciadocephala Mattfeld (1938) was recognized as a close relative of Adenostemma, although it did not have the anther appendage shortened as in the other two genera of the group.

Two of the genera, Gymnocoronis and Sciadocephala, are restricted to the Neotropical Region. Adenostemma is pantropical with apparently nearly equal amounts of diversity in each hemisphere.

\section{KEY TO THE GENERA OF THE SUBTRIBE ADENOSTEMMATINAE}

1. Pappus essentially absent

1'. Pappus of 3 or 5 elongate viscid-tipped knobs

3. Gymnocoronis 2. Glandular tips of pappus knobs rounded, not extending downward on outer surface of knob; pappus with 5 knobs; anther
appendage as long as wide... 2'. Glandular tips of pappus knobs extending downward on outer surface of knob; pappus usually with 3 knobs, rarely 5; anther appendage about one-half as long as wide

1. Adenostemma

\section{Adenostemma} Adenostemma J. R. Forster \& G. Forster, Char. Gen. PI. 89. 1776. TYPE: A. viscosum J. R. Forster \& G.
Forster.

Lavenia Sw., Prodr. Veg. Ind. Occ. 112. 1788. Lectotype: L. erecta Sw.

Perennial herbs, creeping or erect with usually procumbent bases, few or no branches. Stems terete to weakly ribbed, fistulose. Leaves opposite, short- to long-petiolate; blades narrowly elliptical to broadly ovate or hastate, base slightly to strongly cuneate, trinervate, margin crenate to strongly serrate, apex acute to slightly acuminate. Inflorescence very laxly cymose, branches elongate, heads pedicellate. Involucral bracts 10-30, eximbricate, in 2 slightly overlapping series, somewhat fused at base, equal to subequal, spreading when mature; receptacle convex, becoming more convex with age, covered with discrete oval deeply concave scars, with soft tissue between, glabrous. Florets 10-60 in a head; corolla usually pale, narrowly funnelform or with narrow basal tube and broadly campanulate limb, usually with hairs or glands on outer surface, hairs often moniliform; lobes triangular, ca. 1.5 times longer than wide, non-papillose; anther collar usually strongly expanded below, with few to many subquadrate cells, cell walls with transverse annular thickenings; anther appendage distinctly shorter than wide; style base not enlarged, glabrous, shaft of style with or without long 


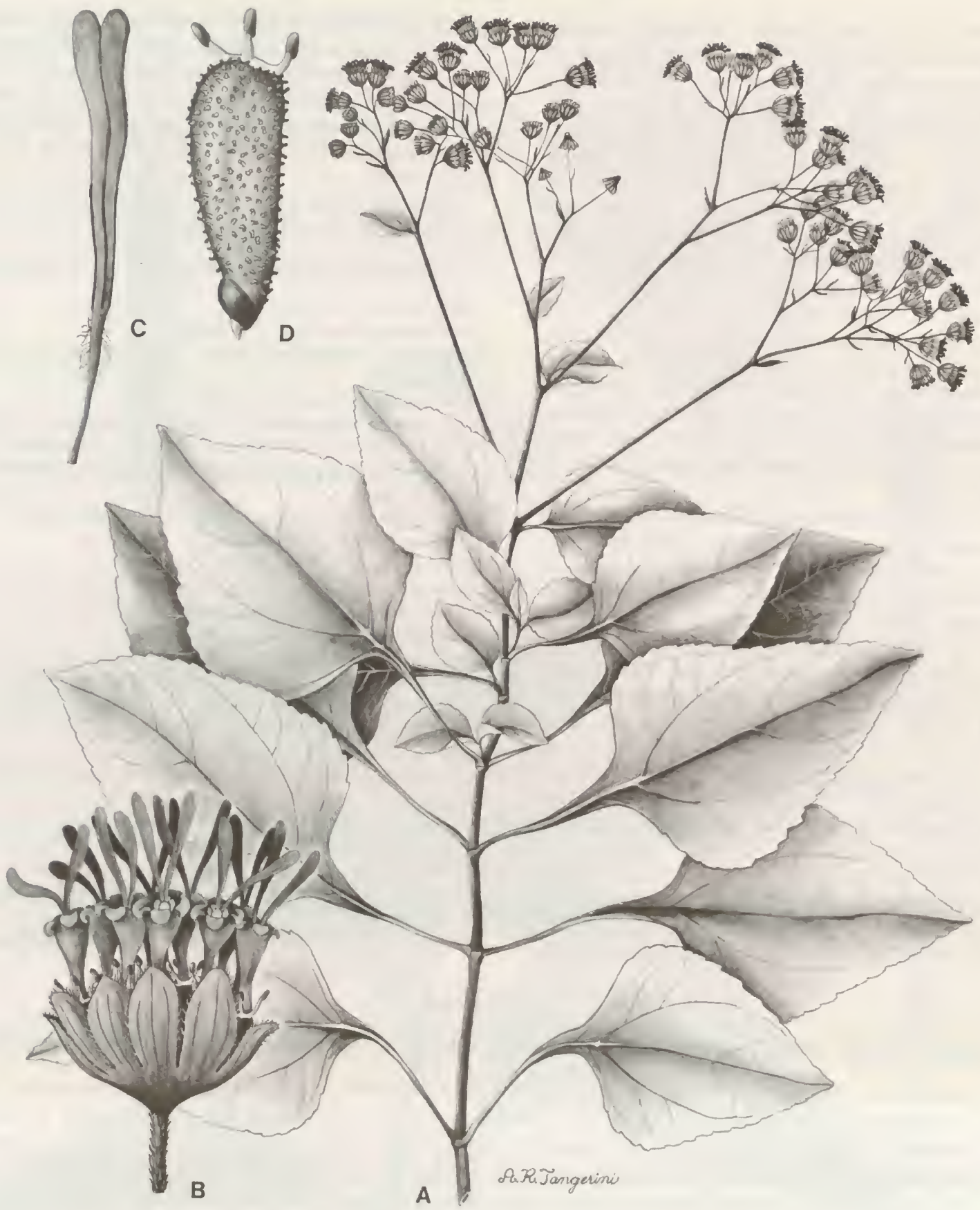

Plate 1. Adenostemma platyphyllum Cass. -A. Habit, $\times 1 / 2 .-$ B. Head, $\times 6 .-$ C. Style, $\times 15 .-$ D. Achene, $\times 15$.

hairs; style appendages slightly to strongly clavate, often forming most showy part of head, fleshy, rounded apically, scarcely mamillose below, becoming smooth above. Achenes slightly curved, usually 3-angled without distinct ribs ( 5 -angled in $A$. hirtiflora), often tuberculate; carpopodium forming a prominent asymmetrical knob with a stout vascular basal point, vascular trace usually sinuous (symmetrical in $A$. hirtiflora), cells subquadrate with firm thin walls; pappus of usually 3 terete clavate knobs ( 5 in $A$. hirtiflora), knobs with tips and upper outside surface covered with elongate mass of viscid glands. Pollen grains ca. 20-23 $\mu \mathrm{m}$ in diameter. Plate 1. 
Adenostemma is a genus of about 20 species occurring primarily at low elevations in Central America, the West Indies, South America, Africa, Asia, and the Pacific Islands. Species are almost equally divided between the Neotropical and Paleotropical Regions. The Neotropical species with the exception of $A$. flintii have hairs on the shaft of the style, but no such hairs occur in the Paleotropical members of the genus. The 5-angled and 5 -knobbed condition of the achene, which might be presumed more primitive, is found only in the Central American $A$. hirtiflora. In the Paleotropical Region, the Linnaean species, A. lavenia (L.) Kuntze, is notable for its near restriction to the type locality, Ceylon. This contrasts with the wide distribution of the Forster species, A. viscosum, which ranges from Africa to Hawaii. Among the Neotropical species, the $A$. platyphyllum group shows a series of parallel north-south distributions in the Andes that may be the result of distribution by birds (King \& Robinson, 1974l).

The distribution mechanism of Adenostemma is particularly highly developed. At anthesis, the knobs of the achenes are borne upright and buried under the mass of corollas. As the head ages, the corollas remain in a mass, held together by the entangled hairs on their surfaces, while the receptacle changes shape and pulls the achenes outward from under the corollas. In the fully mature achenes, the knobs are viscid and are presented in a subspherical cluster, while the mass of corollas has fallen away. The result is the wide distribution of the genus and many of the species. The pantropical distribution is reminiscent of that of the Helianthean subtribe Coreopsidinae, many members of which are also well-equipped for distribution by animals.

At the time that the present study was initiated, the most recent survey of Adenostemma was that of DeCandolle (1836). In the absence of any monograph, various floras tended to treat most members of the genus as part of one pantropical species, sometimes under the name A. viscosum and sometimes as A. lavenia. Grierson (1972) was the first to partially refine the species concepts in his review of the genus in Ceylon. Subsequently, the species that have been placed under the names $A$. viscosum and $A$. lavenia in America have been revised (King \& Robinson, 1974l).

The generic name is derived from the greek words adeno (= gland) and stemma (= crown).

The following 24 species are recognized in the genus:

Adenostemma angustifolium Arn., Ceylon, India.

Adenostemma berterii DC., W Indies.

Adenoslemma brasilianum Cass., Argentina, Bolivia, Brazil, Uruguay.

Adenostemma caffrum DC., S Africa.

Adenostemma cuatrecasasii R. King \& H. Robinson, Colombia. Adenostemma flintii R. King \& H. Robinson, Nicaragua.

Adenostemma fosbergii R. King \& H. Robinson, Colombia, Ecuador, Peru.

Adenostemma goyazense R. King \& H. Robinson, Brazil. Adenostemma hirsutum (Blume) DC., Indonesia.

Adenostemma hirtiflorum Benth., Nicaragua.

Adenostemma involucratum R. King \& H. Robinson, Brazil. Adenostemma lanceolatum Miq., Pacific.

Adenostemma lavenia (L.) Kuntze, Ceylon.

Adenosternma madurense DC. in Wight, India.

Adenostemma mauritianum DC., Ceylon, Indian Ocean. Adenostemma platyphyllum Cass., Venezuela, Colombia, Pana-

ma, Ecuador, Peru, Bolivia, Argentina.

Adenostemma renschii J. Koster, Indonesia.

Adenostemma schimperi Schultz-Bip. ex A. Rich., E Africa.

Adenostemma suffruticosum Gardner, Brazil.

Adenostemma tinctorium (Lour.) Cass., SE Asia.

Adenostemma vargasii $\mathrm{R}$. King \& $\mathrm{H}$. Robinson, Peru.

Adenostemma verbesina (L.) Kuntze, W Indies, Brazil.

Adenostemma viscosum J. R. Forster \& G. Forster, Africa, Cey-

Ion, India, Indonesia, Pacific.

Adenostemma vitiense $\mathrm{H}$. Robinson, Fiji.

\section{Sciadocephala}

\section{Sciadocephala Mattf., Notizbl. Bot. Gart. Berlin-Dahlem 14: 41. 1938. TYPE: S. schultze-rhonhofiae Mattf.}

Perennial herbs, with procumbent to erect bases, usually decumbent with few or no branches; stems terete, striated, puberulous. Leaves opposite, distinctly petiolate; blades narrowly ovate to elliptical or slightly obovate, margin entire to serrate, venation trinervate to pinnate. Inflorescence monocephalic to laxly subcymose, heads pedicellate. Involucral bracts ca. 6-14, persistent, eximbricate in 1-2 series, subequal to equal, ovate, separated to base, spreading when mature, with scarious margin; receptacle scarcely convex, becoming more convex with age, with discrete oval scars separated by soft tissue, glabrous. Florets ca. 9-15 in a head; corolla white, narrowly funnelform with sparse hairs on outer surface; lobes 5, triangular, slightly to distinctly longer than wide; anther collar stout, not or slightly broadened below, cell walls with prominent transverse annular thickenings; anther appendage ovate, as long as wide or slightly longer; nectary usually glabrous (bearing hairs in S. amazonica); style base not enlarged, glabrous; style branches long and narrow, rounded apically, scarcely mamillose below, smooth distally. Achenes narrowly prismatic, nearly terete, without distinct ribs; carpopodium only slightly asymmetrical, not enlarged, not sharply demarcated above, with cells subquadrate, cell walls thin; pappus of 5 terete clavate knobs, knobs with a short globular mass of glutiniferous glands apically. Pollen grains ca. 25-30 $\mu \mathrm{m}$ in diameter. Plate 2. 


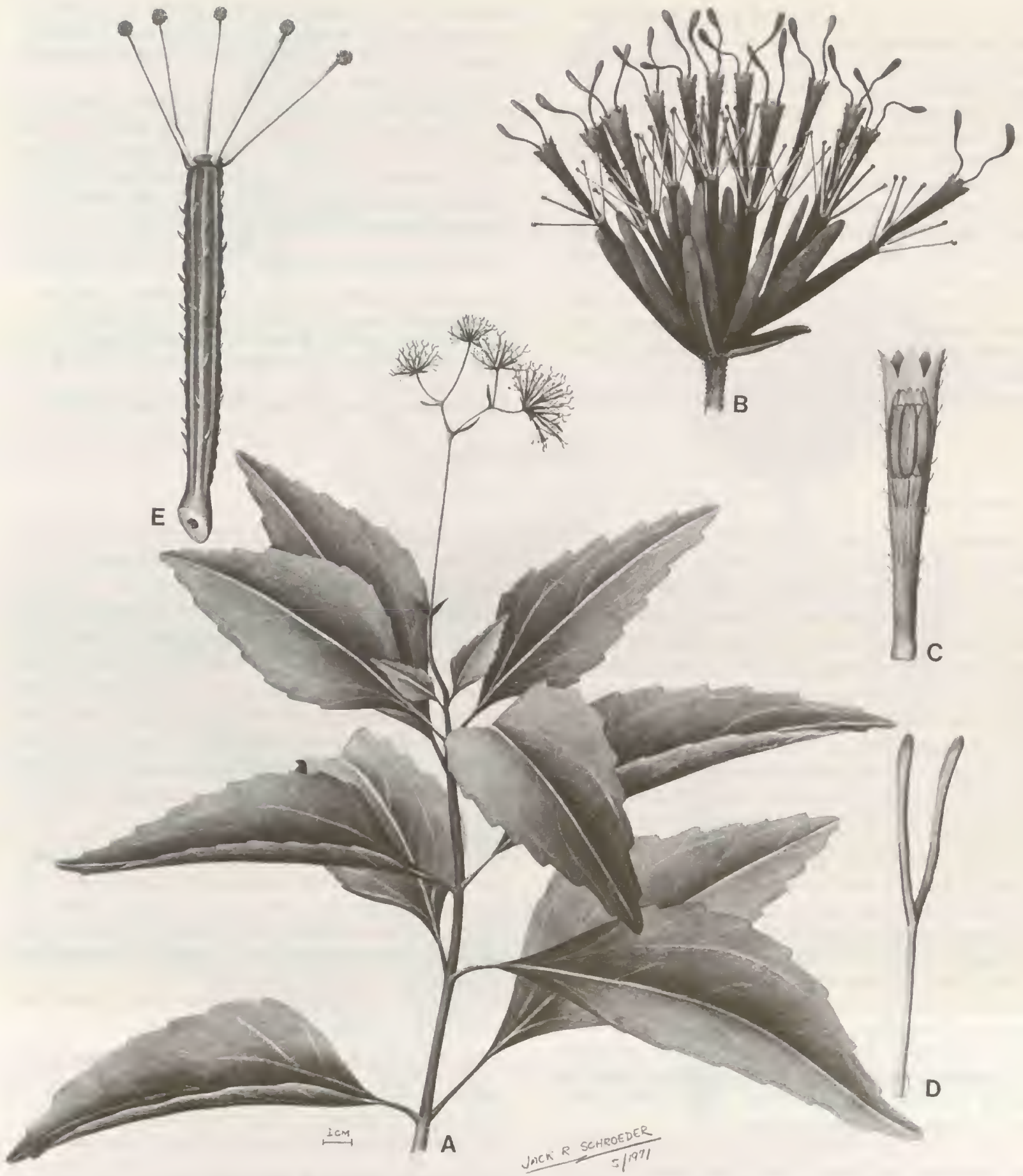

Plate 2. Sciadocephala schultze-rhonhofiae Mattf. - A. Habit, $\times 4 \%$ - B. Head, $\times 3 \frac{1}{2} .-$ C. Corolla showing anthers, $\times 7$. - D. Style with nectary, $\times 5 .-E$. Achene, $\times 9$.

The genus consists of five known species from northern South America and Panama. In contrast to Adenostemma. the species of Sciadocephala appear to have very limited distributions, and the species are represented by few col- lections (King \& Robinson, 1974l, 1975a, 1976d). The species do not seem to share the full adaptation to more effective animal vectors that is seen in Adenostemma.

In many of its characteristics, Sciadocephala seems to 
retain a state that would be regarded as primitive in comparison with the condition in Adenostemma. The achenes retain five angles and five knobs, the glanduliferous tips of the knobs are simple spheres, the style appendages are narrow and comparatively dense as in most members of the tribe, the anther collars are not broadened below, and the involucral bracts are separate to the base. Nevertheless, it does not seem likely that Sciadocephala is simply a relict of the primitive stock from which Adenostemma arose. It seems more likely that Sciadocephala is actually specialized in its own way, with adaptation toward a different reproductive strategy. Certainly, where mentioned, the habitat of mature forest floors is different. It is possible that the glandular tips of the pappus may function in a completely different manner from those in Adenostemma, perhaps being some form of elaiosome.

Sciadocephala amazonica is the only species in the tribe known to have pubescence on the nectary. Eremanthus mattogrossensis Kuntze of the Vernonieae is the only other species presently known in the family with a pubescent nectary (H. Robinson, 1980).

The generic name is formed from the Greek words skiados (= umbrella) and cephala (= head), apparently in reference to the spreading form of the head parts. Mattfeld (1938) commented that the head of his species of Sciadocephala superficially looked more like the umbel of a Hydrocotyle than the head of an Asteraceae.

The following five species are recognized in the genus:

Sciadocephala amazonia R. King \& H. Robinson, Colombia. Sciadocephala asplundii R. King \& H. Robinson, Ecuador. Sciadocephala dressleri R. King \& H. Robinson, Panama.

Sciadocephala pakaraimae (Maguire \& Wurd.) R. King \& H. Robinson, Gayana.

Sciadocephala schultze-rhonhofiae Mattf. in Diels, Ecuador.

\section{Gymnocoronis}

\section{Gymnocoronis DC., Prodr. 5: 106. 1836. LeCTOTYPE: G. attenuata DC.}

Annual to perennial herbs, erect, mostly unbranched; stems angled, fistulose. Leaves opposite, sessile or petiolate; blades lanceolate to ovate or deltoid, venation trinervate to subpinnate with ascending veins. Inflorescence strongly cymose, heads pedicellate. Involucral bracts ca. 20-50, eximbricate in ca. 2 series, equal to subequal, narrowly oblong; receptacle convex, becoming more convex with age, with discrete oval scars and with soft tissue between, glabrous. Florets 50-200 in a head; corolla white, narrowly funnelform, with short-stalked glands on outer surface; lobes triangular, as wide as long to wider than long; anther collar slightly enlarged, cells subquadrate, cell walls with transverse annular thickenings; anther appendage small, wider than long; style base not enlarged, glabrous; style branches very broadly oar-shaped, surface mamillose below, smooth above. Achenes slightly curved, prismatic (4-)5-ribbed, glanduliferous between ribs, ribs sometimes corky (projecting slightly above rim of upper callus in G. nutans); carpopodium short-cylindrical, with ca. 8 series of small, thin-walled, quadrate cells, with or without a sinuous vascular trace; pappus lacking. Pollen grains ca. $23 \mu \mathrm{m}$ in diameter. Plate 3.

The five species of the genus occur in marshy areas in tropical America. Four of the species form a closely related group in Mexico and Guatemala, while one species has a wide range in South America from Argentina and Uruguay northward to northern Bolivia and western Brazil. One of the species, G. nutans, has corky wings with slight upward extensions that were interpreted as rudiments of a pappus by Greenman, who placed the species in Adenostemma (Greenman, 1912). Actually, in this species as in all members of the genus, a true pappus is completely lacking. The expanded base of the corolla almost completely covers the top of the achene.

Gymnocoronis and Adenostemma apparently have been associated with each other in previous taxonomic treatments primarily because of the similar appearance of their heads, the short anther appendages, and the often glan- dularly papillose surfaces of their achenes. The association has been in spite of the difference in their pappus. The presence of a pappus of gland-tipped knobs in both $A d$ enostemma and Sciadocephala might indicate that the ancestor of Gymnocoronis had a pappus of a somewhat similar type.

The distinctions and distributions of the species are discussed by King and Robinson (1974l).

The following five species are recognized in the genus:

Gymnocoronis latifolia Hook. \& Arn., Mexico, Guatemala. Gymnocoronis matudae R. King \& H. Robinson, Mexico.

Gymnocoronis nutans (Greenman) R. King \& H. Robinson, Mexico.

Gymnocoronis sessilis S. F. Blake, Mexico.

Gymnocoronis spilanthoides DC., Argentina, Bolivia, Brazil, Paraguay, Peru, Uruguay. 

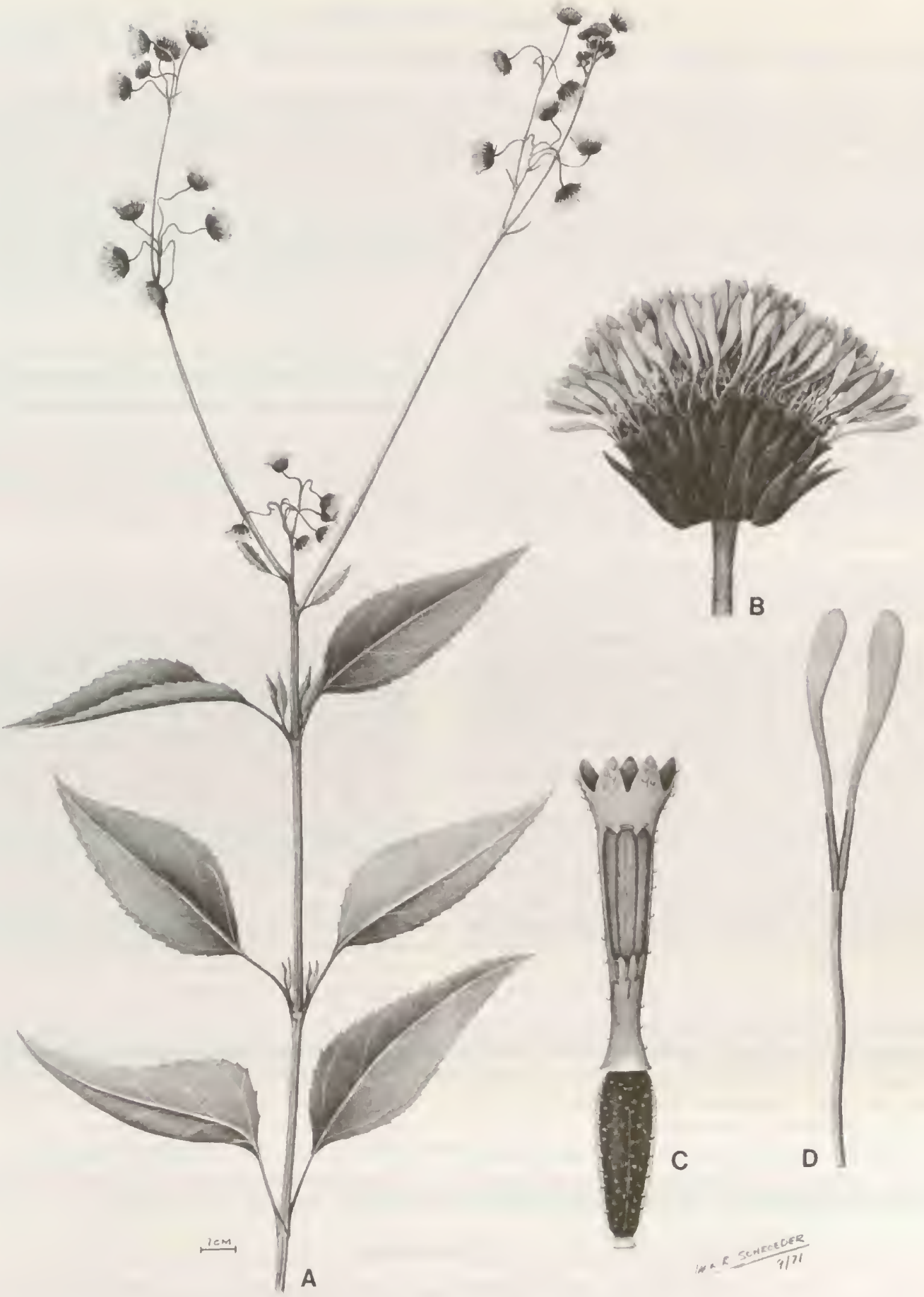

PlAte 3. Gymnocoronis spilanthoides (D. Don) DC. - A. Habit, $\times 5 \% .-$ B. Head, $\times 4 \frac{1}{2} .-$ C. Floret showing anthers, $\times 16 .-$ D. Style, $\times 16$. 


\section{Subtribe II. Eupatorinae}

\section{Eupatoriinae Dumort., Fl. Belg. 64. 1827. TYPE: Eupatorium L.}

Annual or perennial herbs and subshrubs, usually erect with clustered or branching stems; leaves mostly opposite or whorled, alternate above. Inflorescence terminal, usually corymbose or pyramidal. Heads short pedicellate or sessile; involucral bracts subimbricate, often broadly scarious or sclerified; receptacle scarcely convex, glabrous. Flowers 3-23 in a head; corollas white or reddish purple, lobes smooth on inner surface, sometimes with stomata on outer surface; cells of anther collar with or without annular thickenings on walls; style base with hairs, usually without enlargement, somewhat enlarged in 4 species of Eupatorium; style branches usually without apical enlargement, enlarged in some Stomatanthes, densely short papillose except on enlargements. Achenes 5-angled; carpopodium obsolete to enlarged, cells with thin to nodularly thickened walls; pappus of many capillary bristles. Basic chromosome number $x=10$.

The subtribe is most distinct in the comparatively fewflowered heads and the pubescent bases of the styles. Pubescence on the style is lacking in the subtribe only in some specimens of Eupatorium capillifolium. The subtribe is also notable for the only members of the tribe with stomata on the corolla lobes, such stomata being found in some species of both Eupatorium and Stomatanthes. The base of the style is usually without an enlarged node, but some enlargement occurs in the four American species of Eupatorium with verticillate leaves. The cells of the anther collar have dense annular thickenings on the walls in the basically South American genera, but these are lacking in the more northern genus Eupatorium. Many members of the group have apical cells of the pappus bristles with rounded tips, a character mostly restricted in the tribe to genera of the three related subtribes, Eupatoriinae, Disynaphiinae, and Gyptidinae.

Whorled leaves occur in two of the genera of the subtribe, but are of two different types. The whorled leaves in some species of Eupatorium seem to be sessile variations of the tripartite leaf type found in some European and Asian members of the genus. The whorled leaves of
Stomatanthes trigonus seem to be true verticils, varying in some specimens into subverticillate or alternate-leaved forms.

The Eupatoriinae shares with the Disynaphiinae and Gyptidinae, a distribution centered in the eastern parts of North and South America. The Eupatoriinae differs from the others by its wide natural occurrence in the Eastern Hemisphere. Eupatorium has extended its range into Asia, Europe, and as far as northern Africa, apparently through Alaska where it no longer occurs. Stomatanthes has reached Africa with three species, apparently across the South Atlantic. In addition to the natural occurrences, Austroeupatorium inulaefolium has become adventive in various areas such as Sumatra and Ceylon. The fourth genus, Hatschbachiella, is restricted to eastern South America.

All members of the Eupatoriinae have a capillary pappus, and have been included in the traditional concepts of the genus Eupatorium, but the members of the four genera included here in the subtribe were not recognized as having any special relationship to each other until the present study.

\section{KEY TO THE GENERA OF THE SUBTRIBE EUPATORIINAE}

1. Surface of achenes with only glands

2. Achenes without prominent carpopodium; cells of anther collars without dense annular thickening on walls 2

2'. Achenes with prominent elongate or broadened carpopodium; cells out dense annular thickenings on walls _- 4 . Eupatorium walls

1'. Surface of achenes with numerous setulae 5. Austroeupatorium

3. Inflorescence pyramidal or thyrsoid; filaments of anthers short and stout; tips of style branches often enlarged

3'. Inflorescence corymbose; filaments of anthers elongate, flexuous 6. Stomatanthes 7. Haischbachiella

\section{Eupatorium}

Eupatorium L., Sp. PI. 2: 836. 1753. TYPE: Eupatorium cannabinum L.

Traganthes Wallr., Sched. Crit. 1:456. 1822. TYPE: Artemisia tenuifolia Willd. [= Eupatorium capillifolium
(Lam.) Small].

Eutrochium Raf., New Fl. 4: 78. 1838. No species assigned.

Chone Dulac, Fl. Hautes-Pyrénées 512. 1867. TYPE: C. heterophylla Dulac (= Eupatorium cannabinum

Cunigunda Bubani, Fl. Pyren. 2: 273. 1900. TYPE: C. vulgaris Bubani (= Eupatorium cannabinum L.). 
Uncasia E. Greene, Leafl. Bot. Observ. 1: 13. 1903. TYPE: Eupatorium perfoliatum L.

Eupatoriadelphus R. King \& H. Robinson, Phytologia 19: 431. 1970. TYPE: Eupatorium purpureum L.

Annual to perennial herbs, erect, few- to many-branched. Stems terete, striated, pubescent or glabrous, fistulose or solid. Leaves opposite or verticillate, upper leaves subopposite to alternate, sessile or petiolate; blades linear to ovate, deltoid, or trilobed, margins serrate to subentire. Inflorescence a corymbose or pyramidal panicle; heads short pedicellate. Involucral bracts 10-22, weakly to strongly subimbricate, in $2-$ 5 series, usually persistent, inner bracts deciduous in some species; receptacle flat or weakly convex, glabrous. Florets 3-23 in a head; corollas white to purple, lavender, or pink, narrowly funnelform or with constricted basal tube and narrowly to broadly campanulate limb, outer surface with glands often concentrated at base of throat and on outer surfaces of lobes, rarely with a few hairs; lobes triangular to oblong-ovate, usually slightly longer than wide, smooth on inner surface, with or without stomata on outer surface; anther collar cylindrical, cells subquadrate to short-oblong, walls without or with beaded thickenings; anther appendage large, ovate-triangular, ca. 1.5 times as long as wide; style base puberulous (rarely glabrous in E. capillifolium), with or without enlargement; style branches filiform to slightly broadened or flattened distally, papillose with erect-spreading usually apiculate surface cells. Achenes prismatic, 5-ribbed, with few to many glands, sometimes with a few setulae; carpopodium not or slightly differentiated, sclerified cells when present subquadrate to broadly oblong in up to 8 series, with thin firm walls; pappus of $25-40$ scabrous persistent bristles, apical cells of bristles with rounded to short-acute tips. Pollen grains $16-25 \mu \mathrm{m}$ in diameter. Plate 4 .

As treated in traditional systems of classification, $E$ patorium has been a highly artificial concept, tending to include all members of the tribe with a pappus of numerous capillary bristles, 5 ribs on the achene, and an anther appendage as long as or longer than wide. Even from the time of the original validation of Tournefort's name by Linnaeus (1753), Eupatorium has been a somewhat artificial concept; still, nine of the original fourteen species were what is here recognized as Eupatorium, and the concept was no more artificial than many others at the time. This is likely a reflection of the primarily north temperate orientation of Linnaeus's work, since true Eupatorium is prominent in that area.

The limits and arcto-tertiary geography of the genus are discussed by King and Robinson $(1970 u)$. The present treatment differs from that of 1970 only by the re-inclusion of the verticillate American species (Eupatoriadelphus) in the concept.

Eupatorium is the typical genus of the tribe and the only genus of the tribe occurring naturally in Europe. The type species, E. cannabinum, the only species west of India, is regarded as a comparatively recent range extension. The diversity of species in eastern Asia, Taiwan, and the Philippines would indicate a longer residency of the genus in that area. Access to Asia was evidently across the Bering Strait.

The genus is concentrated in North America, where it is presently restricted to areas from the eastern slopes of the Rocky Mountains eastward. The overall geographical patterns of the tribe, and the present distribution of the genus, suggest that Eupatorium never occurred in the western United States. The link to Asia through Alaska was probably tenuous at best, and it did not survive the Pleistocene. Links between Eupatorium and related genera to the south have also disappeared. The southward extensions of Eupatorium into the West Indies, and the northward extensions of Austroeupatorium to Panama and Trinidad are recent.

The genus in eastern North America consists of three distinctive subunits. The verticillate-leaved species with enlarged style bases, stomata on the corolla lobes, and reddish-purple flowers have been recently segregated as Eupatoriadelphus and apparently represent the same group designated by Rafinesque as Eutrochium. The group is distinctive among the American species, but it is approached closely in leaf arrangement and head shape by some palearctic material, especially some variants of $E$. chinense. The majority of Eupatorium in eastern North America falls into what was called Uncasia by Greene (1903). The group widely overlaps the area of the verticillate-leaved species but does not reach as far to the northwest. It reaches farther south with one collection from just south of the Rio Grande in Mexico and one (adventive?) species in the Dominican Republic. The species are apparently completely reproductively isolated from those with verticillate leaves. Sullivan (1976) has extensively studied the distributions of diploid and polyploid populations of the Uncasia group. Uncasia, Eutrochium, and the palearctic Eupatorium seem to stand in relationship to each other as three points of a triangle. The remaining element of the genus in eastern North America involves three species, $E$. capillifolium. E. compositifolium, and $E$. leptophyllum, which are specialized for wind pollination and that are the group to which the name Traganthes can be applied. Typical Traganthes and typical Uncasia are well known to hybridize, forming the entity known as $E$. pinnatifidum Elliott, but Sullivan (1975) has shown that the hybrids are always sterile and that the two groups are totally isolated reproductively. The pollen of the windpollinated Traganthes group can be distinguished by its 


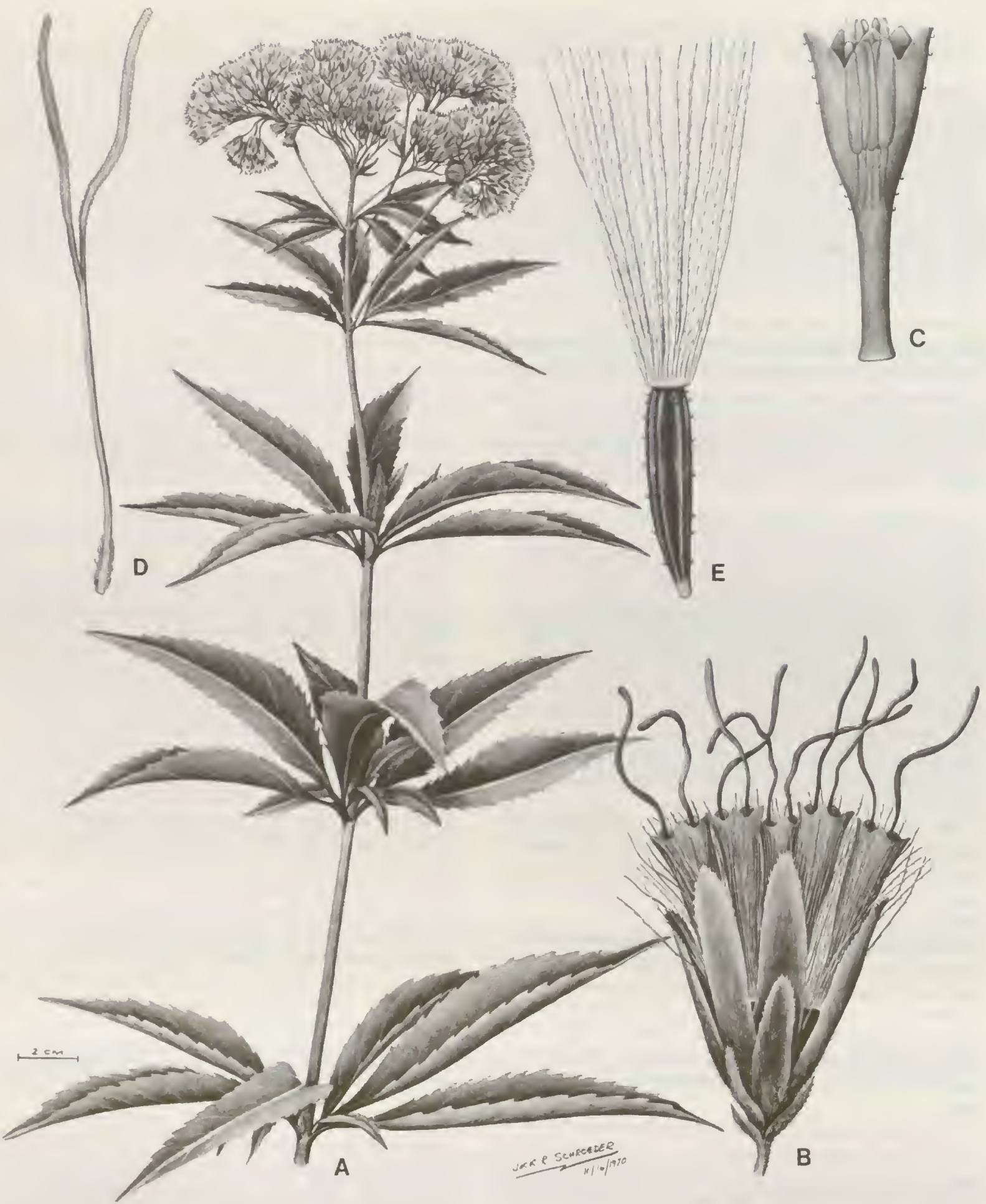

PLATE 4. Eupatorium cannabinum L. - A. Habit, $\times 1 / 2 .-$ B. Head, $\times 7 \frac{1}{2},-$ C. Corolla showing anthers, $\times 10 .-D$. Style, $\times 10 .-E$
chene, $\times 10$. 
shorter spines (Sullivan, 1975). The group ranges farther south than other members of the genus, reaching Cuba and the Bahamas. Eupatorium capillifolium has occasionally been found as a waif on Caribbean shores in Guatemala (Williams, 1976) and Venezuela.

Some common names are in use for members of the genus Eupatorium in eastern North America. The Eutrochium group is often known as Joe-Pye-Weed, Uncasia species are commonly called Bonesets or Throughworts, and members of the Traganthes group are known as DogFennels.

The occurrence of occasional setulae on the achenes in a few Asiatic species of Eupatorium and in some verticillate-leaved American species indicates that the genes for such setulae are not lost in the genus but simply suppressed.

The genus Eupatorium was dedicated to Mithridates Eupator, King of Pontus 132-63 BC, who is said to have used a species of the genus in medicine.

The following 45 species are recognized in the genus:

Eupatorium album L., E North America.

Eupatorium altissimum L., E North America.

Eupatorium amabile Kitam., Japan.

Eupatorium anomalum Nash, SE United States.

Eupatorium benguetense C. Robinson, Philippines.

Eupatorium camiguinense Merr., Philippines.

Eupatorium cannabinum L., Europe, N Africa, Asia Minor, India.

Eupatorium capillifolium (Lam.) Small, SE United States, Cuba, Bahamas.

Eupatorium chinense L., E Asia.

Eupatorium compositifolium Walter, SE United States.

Eupatorium cuneifolium Willd., E United States.
Eupatorium dubium Willd. ex Poir., E United States. Eupatorium fistulosum J. Barratt, E United States. Eupatorium formosanum Hayata, Taiwan, China. Eupatorium fortunei Turcz., E Asia.

Eupatorium godfreyanum Cronq., E United States. Eupatorium hyssopifolium L., E United States.

Eupatorium lancifolium (Torrey \& A. Gray) Small, SE United States.

Eupatorium leptophyllum DC., SE United States. Eupatorium leucolepis Torrey \& A. Gray, E United States. Eupatorium lindleyanum DC., E Asia, Philippines. Eupatorium luchuense Nakai, Ryukyu Islands. Eupatorium maculatum L., E \& central North America. Eupatorium mikanioides Chapman, Florida.

Eupatorium mohrii E. Greene, SE United States.

Eupatorium nodiflorum Wallich ex DC., India. Eupatorium perfoliatum L., E North America. Eupatorium pilosum Walter, E United States. Eupatorium pinnatifidum Elliott, SE United States. Eupatorium purpureum L., E United States.

Eupatorium quaternum DC., Indo-China.

Eupatorium quinqueflorum Urban \& Ekman, Dominican Republic, $=E$. mohrii?

Eupatorium resinosum Torrey \& A. Gray, E United States. Eupatorium rotundifolium L., E United States.

Eupatorium sambucifolium Elmer, Philippines.

Eupatorium semiserratum DC., E United States.

Eupatorium serotinum Michx., E United States, Mexico.

Eupatorium sessilifolium L., E North America.

Eupatorium shimadai Kitam., Taiwan.

Eupatorium squanosum D. Don, S Asia.

Eupatorium tashiroi Hayata, Taiwan.

Eupatorium $\times$ tawadae Kitam. ex Masam., Ryukyu Islands.

Eupatorium toppingianum Elmer, Philippines, SE Asia.

Eupatorium variabile Makino, Japan.

Eupatorium yakushimaense Masam. \& Kitam., Japan.

\section{Austroeupatorium}

Austroeupatorium R. King \& H. Robinson, Phytologia 19: 433. 1970. TYPE: Eupatorium inulaefolium H.B.K.

Erect herbs or subshrubs, with few branches. Stems terete, slightly striate. Leaves opposite below, often subopposite or alternate above, petiolate; blades ovate to narrowly oblong, margin usually crenulate to serrulate. Inflorescence a flattened corymbose panicle; heads short-pedicellate. Involucral bracts 12-18, subimbricate, in 2-3 series, persistent, spreading at maturity, mostly unequal, ovate to oblong; receptacle flat or slightly convex, glabrous. Florets $9-23$ in a head; corolla white (lilac in 1 species), narrowly funnelform with rather narrow tube, glands on outer surface, cells narrow with sinuous lateral walls; lobes triangular, ca. 1.5 times as long as wide, smooth on inner surface, without stomata; lower part of filaments slender and flexuous; anther collar narrowly cylindrical, with mostly subquadrate or short-oblong cells, cell walls with obvious transverse annular thickenings; anther appendage ovate-oblong, longer than wide; style base not enlarged, densely puberulous; style branches filiform, covered with short papillae. Achenes prismatic, 5-ribbed, usually glanduliferous, without setulae; carpopodium distinct, sometimes elongate, cells enlarged with thin walls; pappus of 30-40 slender scabrous bristles, persistent, apical cells often enlarged, with rounded tips. Pollen grains ca. $17 \mu \mathrm{m}$ in diameter. Plate 5 .

In the presence of glands and lack of setulae on the achene, Austroeupatorium is the closest to Eupatorium of the three South American genera of the subtribe. Nevertheless, Austroeupatorium differs from Eupatorium by the large carpopodium with large thin-walled cells and the strongly ornamented walls of the anther collar, in addition to being different in geography.

The geographical ranges of Austroeupatorium and Eu- 

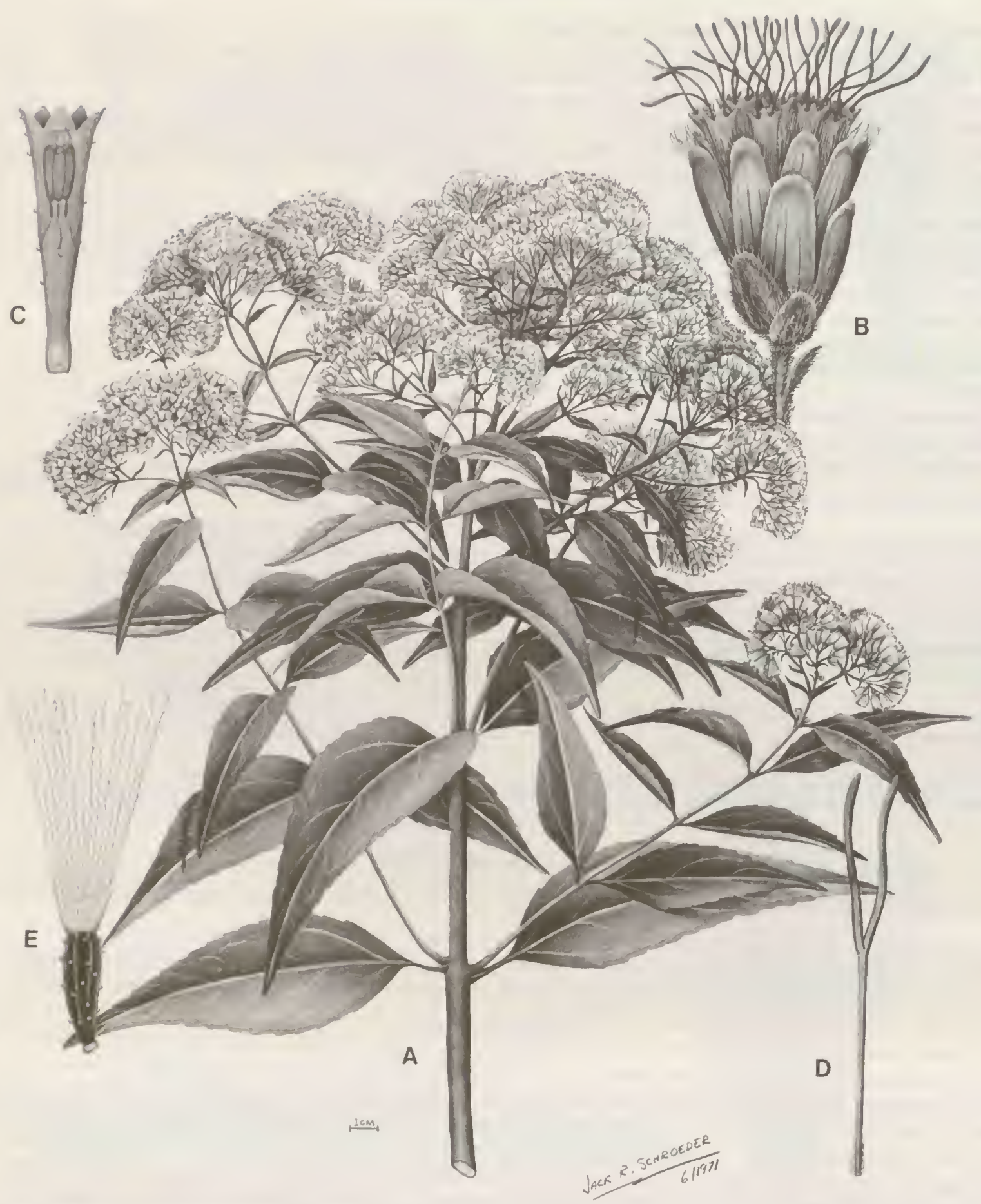
PLATE 5. Austroeupalorium inulaefolium (H.B.K.) R. King \& H. Robinson. - A. Habit, $\times 1 / 2 .-$ B. Head, $\times 6$. - C. Corolla showing
anthers, $\times 13$. D. Style, $\times 13$. E. Achene, $\times 13$. 
patorium do not overlap, but the separation is greater than recent distributions would suggest. The center of diversity of Austroeupatorium is in eastern South America westward to Bolivia, and the distribution in Andean South America northward to Panama and Trinidad is of comparatively recent origin. The difference in range may be to some extent physiological rather than strictly historical, since the genera do not overlap, even in the Paleotropics, where Austroeupatorium has been introduced.

The genus is characterized by enlarged carpopodia with large thin-walled cells, but two different elements of the genus have carpopodia of different shapes. The typical element of the genus, including most of the species, has a carpopodium about as broad as long, but one group of species, including $A$. chaparense, A. laetevirens, $A$. paulinum, $A$. petrophilum, and $A$. rosmarinaceum, has a carpopodium narrowly cylindrical and distinctly longer than wide.

Since the original delimitation of Austroeupatorium (King \& Robinson, 1970n), there have been a few older names found for some species and two species added to the genus (King \& Robinson, 1980e, 1982a, 1982d). No keys have been provided to the species.

The following 13 species are recognized in the genus:
Austroeupatorium apense (Chodat) R. King \& H. Robinson, Brazil, Paraguay.

Austroeupatorium chaparense (B. Robinson) R. King \& H. Robinson, Bolivia.

Austroeupatorium decemflorum (DC.) R. King \& H. Robinson, Ecuador, Peru, Bolivia.

Austroeupatorium entreriense (Hieron.) R. King \& H. Robinson, Uruguay.

Austroeupatorium inulaefolium (H.B.K.) R. King \& H. Robinson, Panama, Colombia, Venezuela, Ecuador, Peru, Bolivia, Brazil, Uruguay, Argentina, adventive in Indonesia, Ceylon.

Austroeupatorium laeterirens (Hook. \& Am.) R. King \& H. Robinson, Argentina, Brazil, Paraguay.

Austroeupatorium morii $\mathrm{R}$. King \& H. Robinson, Brazil.

Austroeupatorium neglectum (B. Robinson) R. King \& H. Robinson, Brazil.

Austroeupatorium paulinum (DC.) R. King \& H. Robinson, Brazil.

Austroeupatorium petrophilum (B. Robinson) R. King \& H. Robinson, Brazil.

Austroeupatorium picturatum (Malme) R. King \& H. Robinson, Brazil, Argentina.

Austroeupatorium rosmarinaceum (Cabrera \& Vittet) R. King \& H. Robinson, Brazil.

Austroeupatorium silphiifolium (Martius) R. King \& H. Robinson, Brazil.

\section{Stomatanthes}

Stomatanthes R. King \& H. Robinson, Phytologia 19: 430. 1970. TYPE: Eupatorium africanum Oliver \& Hiern.

Perennial herbs or subshrubs, sparsely to densely branched. Stems terete, striated. Leaves alternate, opposite, or ternate, short-petiolate; blades elliptical or oblanceolate to ovate or orbicular, margin entire to grossly dentate. Inflorescence usually pyramidal to thyrsoid paniculate (corymbose in subgenus Verticifolium); heads very short-pedicellate or sessile. Involucral bracts 4-12, eximbricate to weakly subimbricate, in 2-3 series, unequal to subequal, narrowly oblong or lanceolate, obtuse to acute; receptacle scarcely convex, glabrous. Florets 4-11 in a head; corolla white, funnelform or nearly tubular, glabrous or glanduliferous with few to many hairs outside; lobes triangular, as long as wide to nearly 1.5 times as long as wide, inner surface smooth, outer surface sometimes with stomata, cells of limb narrow with sinuous lateral walls; lower parts of filaments short, thick, straight; anther collars cylindrical, with two layers of transversely or irregularly banded cells; anther appendages ovate or slightly shorter than wide; style base not enlarged, covered with numerous hairs; style branches linear to filiform or with clavate tips, papillose at least below, tips when greatly enlarged with smooth surfaces. Achenes prismatic, 5-8-ribbed, densely setuliferous and sometimes glanduliferous; carpopodium usually distinct, with cells rather small and subquadrate, cells with rather thin nodulose walls; pappus of numerous scabrous bristles, persistent, apical cells with obtuse or acute tips. Pollen grains ca. $22-27 \mu \mathrm{m}$ in diameter. Plate 6.

The genus was originally named to accommodate a single African species (King \& Robinson, 1970/). Subsequently, twelve species have been added to the genus from South America (H. Robinson, 1970), and a total of three species has been recognized from Africa (King \& Robinson, 1975x). All members of the genus share the characteristic stout filaments of the anthers, and species with stomata on the corolla lobes occur in both Africa and Brazil.

The African species are presumed to have resulted from a single past introduction of the genus from South America, but one of the three species is sufficiently distinct to warrant separate subgeneric status. The subgenus Verticifolium is distinguished by the more corymbose inflo- 

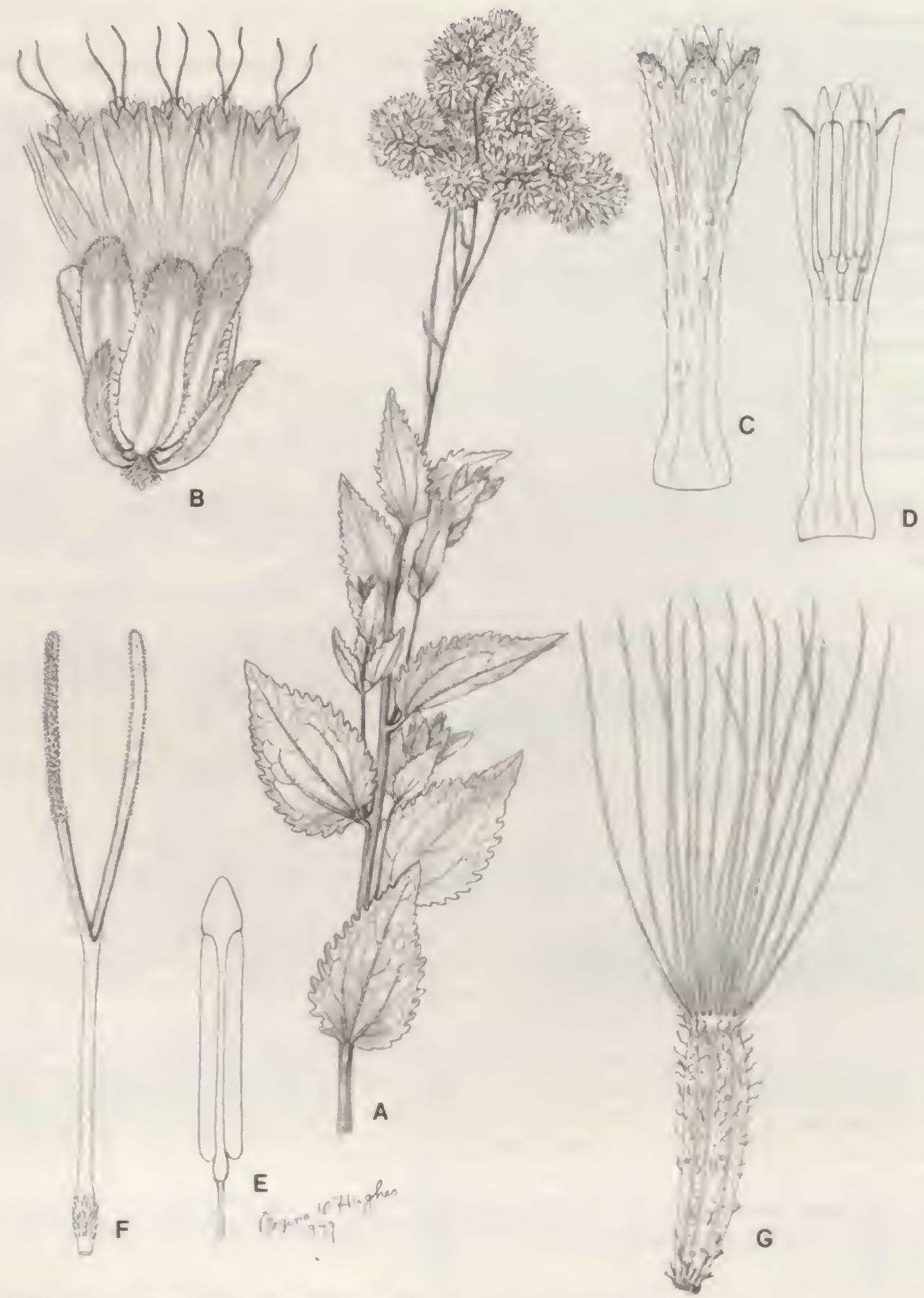

Plate 6. Stomatanthes africanus (Oliver \& Hiern) R. King \& H. Robinson. - A. Habit, $\times 1 / 2 .-$ B. Head, $\times 7 .-$ C. Corolla, outer surface, $\times 14,-$ D. Corolla, inner surface with anthers, $\times 14 .-$ E. Anther, $\times 25 .-$ F. Style, $\times 14 .-$ G. Achene, $\times 11$.

rescence, the lack of a prominent close reticulation of the veins on the lower leaf surface, and the achenes with few or no setulae. As indicated by the name, the leaves are ternate, but the latter condition is also found in some specimens of $S$. trigonus of Brazil.
A number of South American species of Stomatanthes have style branches with strongly clavate tips, a character not seen elsewhere in the subtribe. It is to one of these species, $S$. subcapitatus, that we have scen inscribed the unpublished generic name Microconia Dusén. Such 
clubbed style branches are found also in $S$. corumbensis, $S$. dentatus, S. hirsutus, S. loefgrenii, S. pinnatipartitus, and $S$. trigonus.

While widely distributed in the genus, stomata on the corolla lobes seem somewhat erratic in distribution. Stomata have been seen in the corollas of $S$. dyctiophyllus, $S$. loefgrenii, S. oblongifolius, S. subcapitatus, and $S$. trigonus in South America. In spite of repeated efforts, however, no such stomata have been found in any of the closely related group, including $S$. corumbensis, $S$. dentatus, $S$. hirsutus, or $S$. pinnatipartitus. Examination of the African type species, $S$. africanus, indicates that stomata may be completely lacking in corollas of some specimens of that species.

The following 15 species are recognized in the genus:

Stomatanthes africanus (Oliver \& Hiern) R. King \& H. Robinson, central \& S Africa.
Stomatanthes corumbensis (B. Robinson) H. Robinson, Brazil. Stomatanthes dentatus (Gardner) H. Robinson, Brazil. Stomatanthes dyctiophyllus (DC.) H. Robinson, Brazil. Stomatanthes hirsutus H. Robinson, Brazil.

Stomatanthes loefgrenii (B. Robinson) H. Robinson, Brazil. Stomatanthes meyeri R. King \& H. Robinson, E Africa.

Stomalamthes oblongifolius (Sprengel) H. Robinson, Brazil, Uruguay.

Stomatanthes pernambucensis (B. Robinson) H. Robinson, Brazil.

Stomatanthes pinnatipartitus (Schultz-Bip. ex Baker) H. Robinson, Brazil.

Stomatanthes polycephalus (Schultz-Bip. ex B. Robinson) H. Robinson, Brazil.

Stomatanthes subcapitatus (Malme) H. Robinson, Brazil.

Stomatanthes trigonus (Gardner) H. Robinson, Brazil.

Stomatanthes warmingii (Baker) H. Robinson, Brazil.

Stomatanthes zambiensis R. King \& H. Robinson, Malawi, Zambia.

\section{Hatsch bachiella}

\section{Hatschbachiella R. King \& H. Robinson, Phytologia 23: 393. 1972. TYPE: Eupatorium tweedieanum Hook.} \& Arn.

Erect herbs or subshrubs, few- to many-branched. Stems terete, striated, puberulous. Leaves opposite or alternate, subsessile to short-petiolate; blades elliptical to narrowly elliptical, margin entire to remotely serrulate. Inflorescence diffuse, with corymbose panicles at tips of leafy branches; heads short-pedicellate. Involucral bracts 12-15, weakly subimbricate, in 2-3 series, unequal, oblong to ovate, hirsute and glanduliferous; receptacle flat, glabrous. Florets $10-12$ in a head; corolla white, narrowly funnelform with a narrow basal tube, glanduliferous on outer surface, cells of limb narrow with sinuous lateral walls; lobes triangular, ca. 1.5 times as long as wide, smooth on inner surface, with or without hairs on outer surface; filaments in lower part slender and flexuous; anther collar cylindrical, with few to many subquadrate cells, cell walls with prominent transverse annular thickenings; anther appendage ovate, as long as or longer than wide; style base not or slightly enlarged, with a few hairs; style branches linear to narrowly clavate, distinctly papillose. Achenes prismatic, 5-ribbed, setuliferous and glanduliferous, sometimes stipitate below; carpopodium distinct, short, with cells subquadrate and not inflated; pappus of ca. 30-40 scabrous bristles, persistent, with slender tips, with apical cells acute. Pollen grains ca. $20 \mu \mathrm{m}$ in diameter. Plate 7.

The genus is the most geographically restricted of the four in the subtribe, being found only in eastern South America. In the form of the achenes, the genus is closest to Stomatanthes, but it differs in the more corymbose branches of the inflorescence and the slender flexuous filaments of the anthers.

The type species, $H$. tweedieana, has been commonly confused in herbaria with Austroeupatorium laetevirens. The two species were described in the same paper by $W$. Hooker and Arnott (1835) and are indistinguishable from their original descriptions. The types of both species have been borrowed through the courtesy of the Royal Botanic Gardens, Kew. In spite of very similar aspect, the two species are completely distinct, and they can be separated generically on the basis of the differences in pubescence of their achenes and form of their carpopodia. The Austroeupatorium completely lacks setulae on the sides of the achene and has an achene base consisting entirely of a carpopodium of large, pale, thin-walled cells.

The genus is named for Dr. Gerdt Hatschbach, Museu Botânico Municipal, Curitiba, Brazil.

The following two species are recognized in the genus:

Hatschbachiella polyclada (Dusén ex Malme) R. King \& H. Robinson, Brazil.

Hatschbachiella tweedieana (Hook. \& Arn.) R. King \& H. Robinson, Argentina, Brazil, Paraguay, Uruguay. 


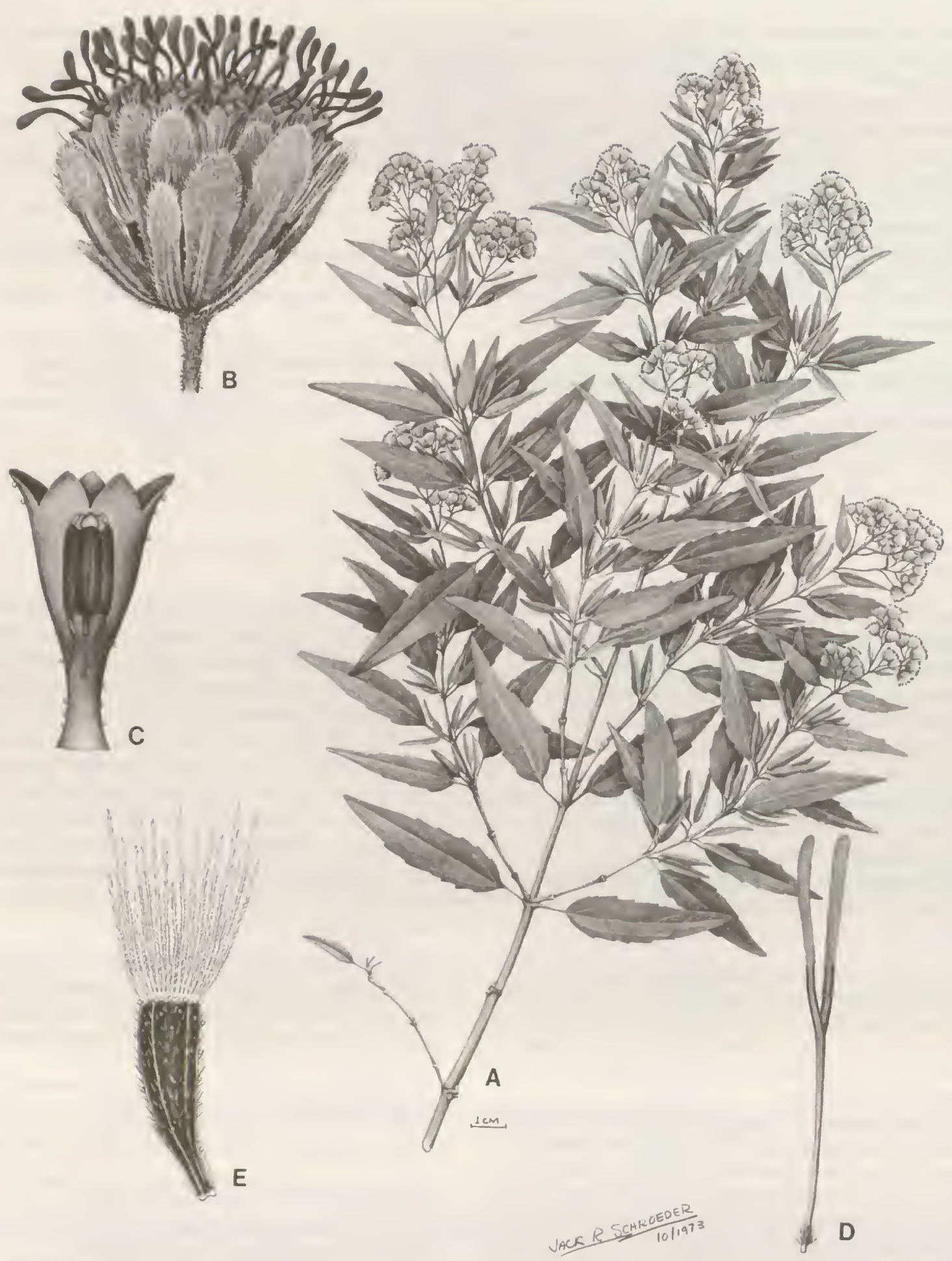

Plate 7. Hatschbachiella tweediana (Hook. \& Arn.) R. King \& H. Robinson. - A. Habit, $\times \%$. B. Head, $\times 8 .-$ C. Corolla showing
nthers, $\times 21$. D. Style, $\times 21$. E. Achene, $\times 16$. 


\section{SubTRIBE III. DisynaphinaE}

\section{Disynaphiinae R. King \& H. Robinson, Phytologia 39: 133. 1978. TYPE: Disynaphia Hook. \& Arn.}

Perennial herbs, shrubs, or small trees, erect with few to many branches; leaves opposite or spirally inserted. Inflorescence terminal, corymbose or pyramidal. Heads mostly short-pedicellate; involucral bracts subimbricate, most or all usually persistent; receptacle scarcely convex, glabrous. Flowers 5 in a head; corollas purple, lavender, or white; lobes smooth or nearly smooth on inner surface, without stomata on outer surface; cells of anther collar with dense annular thickenings on walls; style base without hairs, not enlarged; style branches linear, distinctly and usually densely papillose. Achenes 5-angled, with micropunctations mostly aligned in dense transverse bands; carpopodium obsolete to annuliform or short-cylindrical, cells with thin to slightly thickened walls; pappus of many capillary bristles, sometimes with enlarged round-tipped apical cells. Basic chromosome number $x=10$.

The most notable feature of the subtribe is the consistent presence of five flowers in a head in all members of the six genera. Indications of variation in this number (King \& Robinson, 1974n) have proven erroneous, being based on unrelated elements included in the genus $S y m$ phyopappus.

The dense annular thickenings on the cell walls in the anther collar, the transverse banding of micropunctations in the achene wall, the papillose style appendages, the sometimes enlarged and round-tipped apical cells of the pappus bristles, and the geographical restriction of the Disynaphiinae to eastern South America, all indicate closest relationship to two other subtribes concentrated in the same geographical area, the Eupatoriinae and Gyptidinae. The Disynaphiinae differ from the Eupatoriinae most obviously by the lack of hairs on the style base, and differ from the Gyptidinae mostly by the fewer flowers in the head and the more subimbricate involucre. The Disynaphiinae are also more generally shrubby or subarborescent than the Eupatoriinae or many Gyptidinae.

The capillary pappus and fully developed anther ap- pendages of the members of the Disynaphiinae have resulted in their inclusion at various times in the broad concept of Eupatorium. Nevertheless, many distinctive forms are present in the group, the densely spiralled leaves in Disynaphia, the often viscid opposite leaves of Symphyopappus, and the almost grass-like aspect of the inflorescences in Acanthostyles and Raulinoreitzia. The distinctive aspect of Disynaphia led to recognition at the generic level during part of the last rentury, and the genus Symphyopappus was maintained by both Bentham and Hooker (1873) and B. Robinson (1913a) because of the described dehiscence of the pappus as a unit. Grazielia was recognized by Barroso (1950) as a section Dimorpholepis of Eupatorium because of its differentiated outer involucral bracts. While there has been some inclination to recognize individual genera of the subtribe as distinct in the past, the first recognition of the series as a group was by King and Robinson (1971s). It is notable that Campovassouria and Grazielia to some extent form a connecting series between the extremes of Disynaphia and Symphyopappus.

\section{KEY TO THE GENERA OF THE SUBTRIBE DISYNAPHIINAE}

1. Inflorescence pyramidally paniculate

2. Leaves pinnately to bipinnately dissected, with long narrow lobes; style appendage fragile, hirsute with long narrow papillae;

apical cells of pappus bristles sharply acute

8. Acanthostyles

2'. Leaves narrowly ovate or elliptical to linear-lanceolate, serrulate; style branches short-papillose; apical cells of pappus bristles blunt and inflated

9. Raulinoreitzia

$1^{\prime}$. Inflorescence corymbose, flattened or broadly rounded on top

3. Midveins of leaves prominent or exsculpate above

4. Leaves opposite; pedicels essentially glabrous, striated with prominent ridges; plants often having viscid appearance

13. Symphyopappus

4'. Leaves alternate, usually in dense spiral; pedicels pubescent, not or scarcely ridged; plants mostly densely pubescent

3'. Midveins of leaves depressed or insculpate above

10. Disynaphia

5. Plants with opposite, mostly ovate, usually distinctly petiolate leaves; involucre with long, narrow, often reddish involucral bracts in differentiated outer series; bases of anther thecae pointed 12. Grazielia

5'. Plants with opposite or alternate, short-petiolate or subsessile leaves, usually densely inserted on stem; involucre without distinct narrower bracts in outer series; bases of anther thecae rounded 11. Campovassouria 


\section{Acanthostyles}

Acanthostyles R. King \& H. Robinson, Phytologia 22: 111. 1971. TYPE: Eupatorium buniifolium Hook. \& Arn.

Erect shrubs, with many lax branches. Stems hexagonal, becoming terete, slightly striated. Leaves opposite, distinctly petiolate; blades narrowly lobed to pinnately dissected, surface with glandular punctations. Inflorescence a long pyramidal panicle; heads pedicellate. Involucral bracts ca. 25 , subimbricate, in ca. 4 series, with glands on outer bracts, otherwise glabrous; receptacle slightly convex, glabrous. Florets 5 in a head; corolla narrowly funnelform, purple-lilac; lobes ovate-triangular, ca. 1.5 times as long as wide, with inner surface smooth, outer surface glanduliferous; cells of limb elongate, often with closely sinuous lateral walls; anther collar elongate, cylindrical, with subquadrate cells below, cell walls with annular to intricately ornate thickenings; anther appendage oblong to triangular, longer than wide; style base not enlarged, glabrous; style branches long-linear, with stigmatic papillae elongate and forming a brush, flagelliform appendages with many large non-septate hairs scattered along surface. Achenes prismatic, 4-5-ribbed, with short setulae on ribs and clustered at base and apex, micropunctations in transverse bands; carpopodium indistinct or minutely annuliform with a series of minute subquadrate cells; pappus of ca. 30-40 bristles, persistent, in one series, densely divaricately barbellate on margins and outer surface, not enlarged at apex, apical cells acute. Pollen grains ca. $20-23 \mu \mathrm{m}$ in diameter. Plate 8 .

The genus is named for its most distinctive feature, the flagelliform style appendage, which is laxly hirtellous with large acicular papillae. The appendage structure is unique in the tribe, furnishing instant recognition of the genus. Unfortunately, the style appendages are often broken off in dried specimens. The genus is also distinct by its dissected leaves with narrowly linear lobes, but in many specimens the upper leaves are linear, without lobes. It is notable that on the style branches the stigmatic papillae are also elongate, forming a dense brush along each side in the lower part.

The type species, $A$. buniifolius, shows considerable uniformity throughout its range. The second species, $A$. saucechicoensis, is distinguished by Cabrera and Vittet (1954)

as having shorter leaves and narrower leaf segments and is credited to the provinces of Buenos Aires and Río Negro in Argentina. Lorentz material, agreeing closely with the type photograph, shows much more profusely divided leaves, more robust heads with more glanduliferous involucral bracts, and more hispid pubescence on the lateral surfaces of the achenes. The latter material is labelled as from Sierras Pampeanas, Sauce chico, which is evidently in northwestern Argentina near Tucumán.

The following two species are recognized in the genus:

Acanthostyles buniifolius (Hook. \& Arn.) R. King \& H. Robinson, Argentina, Brazil, Bolivia, Paraguay, Uruguay.

Acanthostyles saucechicoensis (Hieron.) R. King \& H. Robinson, Argentina.

\section{Raulinoreitzia}

Raulinoreitzia R. King \& H. Robinson, Phytologia 22: 113. 1971. TYPE: Baccharis crenulata Sprengel.

Erect shrubs, laxly branched. Stems terete, faintly striated, glabrous. Leaves opposite, distinctly petiolate; blades elliptical to linear, with cuneate base, margin serrulate. Inflorescence a pyramidal panicle; heads pedicellate. Involucral bracts ca. 15-20, subimbricate, in ca. 4 series, strongly unequal, glabrous; receptacle slightly convex, glabrous. Florets 5 in a head; corolla white, narrowly funnelform; cells of limb elongate, often with closely sinuous walls; lobes ovate-triangular, about as long as wide to longer than wide, smooth on inner surface; anther collar narrowly cylindrical, with cells subquadrate below, elongate above, cell walls glabrous; style branches linear, anther appendage triangular, slightly longer than wide; style base not enlarged, glabrous, internal micropunctation with a few small cells at base, with in transverse bands; carpopodium short-cylindrical to stopper-shaped, bristles, persistent, in 1 series, with larger projecting cells or setulae above, in ca. 5 series; pappus of ca. 30 cells. Pollen grains ca. $18-21 \mu \mathrm{m}$ in diameter. Plate 9.

The genus can be distinguished from all others in the tribe Eupatorieae by the combination of the large blunt apical cells on the pappus bristles, the five-flowered heads, and the lack of hairs on the style base. Raulinoreitzia is similar to Acanthostyles in aspect, having a pyramidal, rather grass-like inflorescence, which seems specialized for 


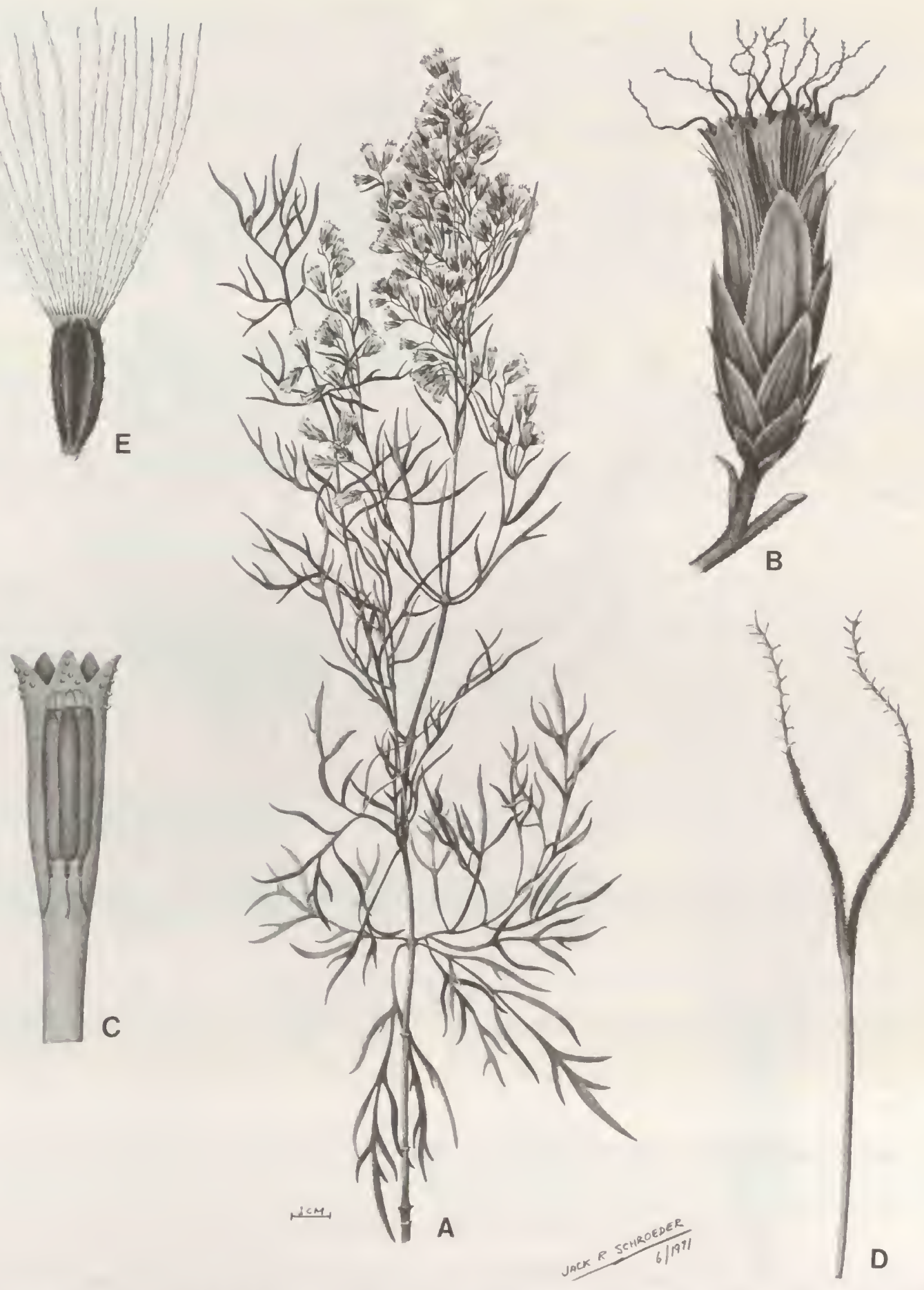

Plate 8. Acanthostyles buniifolius (Hook. \& Arn.) R. King \& H. Robinson. - A. Habit, $\times 3 / 5 .-$ B. Head, $\times 7 .-$ C. Corolla showing anthers, $\times 12 .-D$. Style, $\times 12 .-$ E. Achene, $\times 10$. 


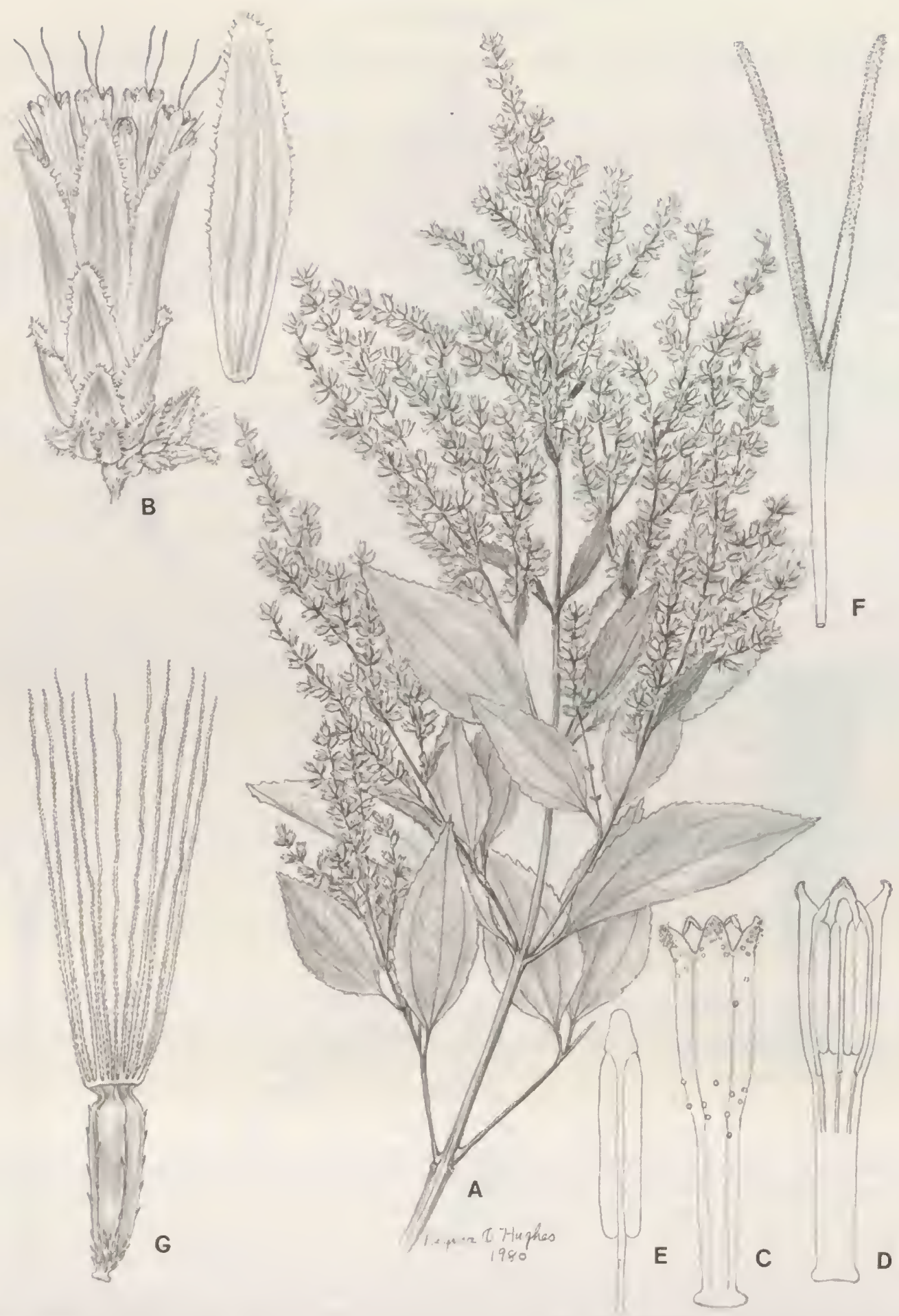

PlATE 9. Raulinoreitzia crenulata (Sprengel) R. King \& H. Robinson. - A. Habit, $\times 1 / 2 .-$ B. Head with representative inner involucral bract, $\times 7 .-$ C. Corolla outer surface, $\times 11 .-D$. Corolla inner surface with anthers, $\times 11 .-$ E. Anther, $\times 18 .-F$. Style, $\times 11 .-G$. Achene,
$\times 11$. 
wind-pollination. The aspect is reflected by the original placement of the type species in the genus Baccharis. Raulinoreitzia lacks the specialized style branches and dissected leaves that are characteristic of Acanthostyles, and it also differs by having enlarged apical cells on the pappus bristles and a more highly developed carpopodium.

The three species are distinguished by the shape of their leaf blades, elliptical in $R$. crenulata, lanceolate in $R$. leptophlebia, and linear in $R$. tremula. According to B. Robinson $(1919 b), R$. crenulata occurs in the Department of Cuzco in Peru, the farthest west reached by any member of the Disynaphiinae.
The genus is named after Padre Raulino Reitz of the Herbario "Barbosa Rodrigues" in Itajai, Santa Catarina, Brazil. Dr. Reitz has served as editor of Sellowia and of the Flora Ilustrada Catarinense.

The following three species are recognized in the genus:

Raulinoreitzia crenulata (Sprengel) R. King \& H. Robinson, Argentina, Brazil, Bolivia, Paraguay, Peru.

Raulinoreitzia leptophlebia (B. Robinson) R. King \& H. Robinson, Brazil.

Raulinoreitzia tremula (Hook. \& Arn.) R. King \& H. Robinson, Argentina, Brazil, Uruguay.

\section{Disynaphia}

Disynaphia Hook. \& Arn. ex DC., Prodr. 7: 267. 1838. TyPE: Disynaphia monteridensis DC. [= D. calyculata (Hook. \& Arn.) R. King \& H. Robinson].

Erect shrubs or subshrubs, many-branched. Stems terete, faintly to regularly striated, pubescent. Leaves alternate, usually densely spirally inserted, sessile to subsessile; blades linear to oblong or oblanceolate, margins entire to minutely serrulate, midvein prominent above and below. Inflorescence corymbose-paniculate; heads short pedicellate, pedicels covered with prominent pubescence. Involucral bracts ca. 11-15, subimbricate, in $2-3(-4)$ series, unequal, pubescent on outer surface (sparsely pubescent in $D$. praeficta) receptacle slightly convex or flat, glabrous to slightly pubescent. Florets 5 in a head; corolla broadly tubular below, slightly broadening above, purple, pink, or white; cells of limb mostly oblong to subquadrate, with non-sinuous to weakly sinuous walls; lobes triangular, as long as wide or longer, smooth to slightly mamillose on inner surface; anther collar short, cells mostly subquadrate, cell walls with annular thickenings; anther base hastate, in a few species with bases as long as collar; anther appendage large, as long as wide, often notched at tip; style base not enlarged, glabrous. Achenes prismatic, 4-5-ribbed, glabrous to slightly glanduliferous, a few species setuliferous; micropunctations often in transverse bands; carpopodium indistinct, with or without a few minute quadrate cells in 1-3 series; pappus of ca. 35 bristles, persistent on callus, often falling as unit with callus, apical cells of bristles acute. Pollen grains ca. 19-25 $\mu \mathrm{m}$ in diameter, type B sometimes present. Plate 10.

According to DeCandolle (1838) the genus is named after dis- (= duo), and synapheia (= series), in reference to the double series of involucral bracts and pappus bristles. Neither of these features is significant in the present distinction of the genus.

The genus is most notable for the densely spirally inserted, often linear leaves, resulting in a "bottle brush" aspect of the branches. The habit is common among plants in eastern Brazil in similar habitats, including many Asteraceae. In the Eupatorieae, such a habit is approached in some genera of the Gyptidinae but is equaled in the tribe in only the genus Pseudobrickellia of the Alomiinae. The latter differs from Disynaphia by its expanded style branches and hirsute nodular style base, among other characteristics.

The pappus of Disynaphia often separates from the achene as a unit with the upper callus, in the same manner as seen in the related genus Symphyopappus. The separation is caused by a breakdown of cellular structure at the base of the callus in both genera. The character occurs to a lesser extent in the related genera Campovassouria and Grazielia.
A number of the species of Disynaphia are distinguished in the treatment of the Eupatorieae of Santa Catarina (Cabrera \& Vittet, 1963), and distinctions are provided for some additional species by King and Robinson (1977d, 1980 ).

One species, $D$. praeficta, is placed in the genus on the basis of its habit and five-flowered heads, but it differs by being nearly glabrous and lacking hastate bases on the anther thecae. The disposition of the species is considered in no way final.

The genus reaches its northern limits in Brazil, in the states of Goyaz and Minas Gerais, and reaches its southern limit in Uruguay. Some species range westward through part of Argentina to Paraguay.

The following 16 species are recognized in the genus:

Disynaphia achillea (Chodat) R. King \& H. Robinson, Paraguay. Disynaphia albissima (Hassler) R. King \& H. Robinson, Paraguay.

Disynaphia calyculata (Hook. \& Am.) R. King \& H. Robinson, Argentina, Brazil, Uruguay.

Disynaphia ericoides (DC.) R. King \& H. Robinson, Brazil. 

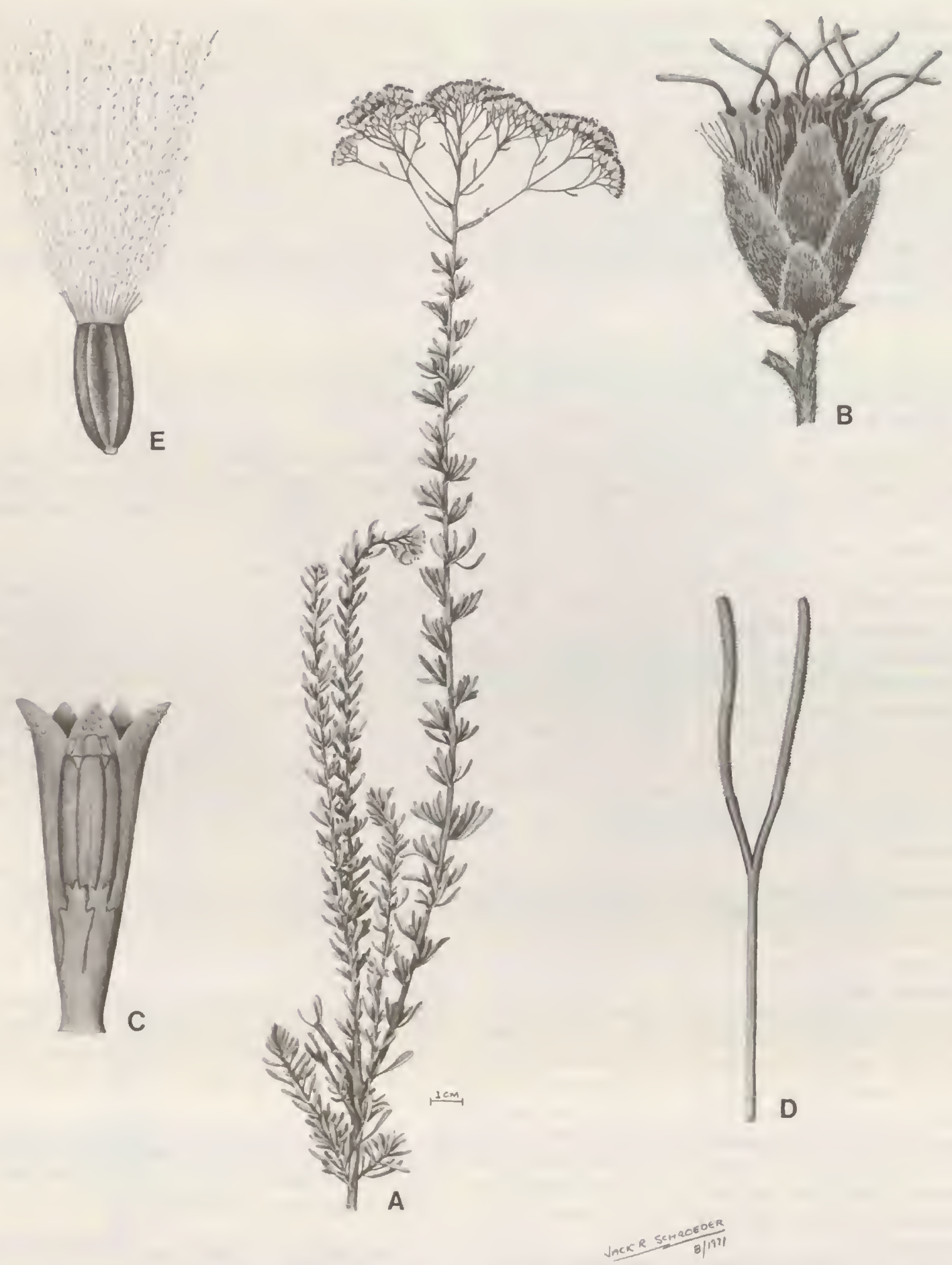

PLATE 10. Disynaphia littoralis (Cabrera) R. King \& H. Robinson. - A. Habit, $\times 1 / 2,-$ B. Head, $\times 7 .-$ C. Corolla showing anthers,
$\times 17$. D. Style, $\times 17 .-$ E. Achene, $\times 17$. 
Disynaphia filifolia (Hassler) R. King \& H. Robinson, Paraguay. Disynaphia halimifolia (DC.) R. King \& H. Robinson, Brazil.

Disynaphia ligulaefolia (Hook. \& Arn.) R. King \& H. Robinson, Brazil.

Disynaphia littoralis (Cabrera) R. King \& H. Robinson, Brazil. Disynaphia minutiflora $\mathrm{R}$. King \& H. Robinson, Brazil.

Disynaphia multicrenulata (Schultz-Bip. ex Baker) R. King \& H. Robinson, Brazil.

Disynaphia praeficta (B. Robinson) R. King \& H. Robinson, Brazil.
Disynaphia radula (Chodat) R. King \& H. Robinson, Brazil, Paraguay.

Disynaphia senecionidea (Baker) R. King \& H. Robinson, Brazil. Disynaphia spathulata (Hook. \& Arn.) R. King \& H. Robinson, Brazil.

Disynaphia tacuarembensis (Hieron. \& Arech.) R. King \& H. Robinson, Uruguay.

Disynaphia variolata (B. Robinson) R. King \& H. Robinson, Brazil.

\section{Campovassouria}

Campovassouria R. King \& H. Robinson, Phytologia 22: 121. 1971. TYPE: Eupatorium bupleurifolium DC.

Erect shrubs or subshrubs, with few branches. Stems terete, faintly striated, subglabrous. Leaves opposite to alternate, usually closely spaced, short-petiolate to subsessile; blades narrowly lanceolate to narrowly oblong or linear, margins entire to serrulate, midvein depressed above. Inflorescence terminal, densely corymbose-paniculate; heads short-pedicellate. Involucre cylindrical, bracts ca. 12, subimbricate, in 3-4 series, unequal and graduated in length, outer surface glabrous, mostly persistent, inner bracts tardily deciduous; receptacle flat, glabrous. Florets 5 in a head; corolla narrowly funnelform, lavender to purple; cells of throat elongate with sinuous lateral walls; lobes triangular, as long as wide, smooth on inner surface, apical cells of outer surface somewhat papillose; anther collar cylindrical with lower cells mostly subquadrate, cell walls with transverse annular thickenings; anther thecae with short rounded bases; anther appendage broadly ovate to oblong; style base not enlarged, glabrous; style branches narrowly linear, with dense, short, acute papillae. Achenes prismatic, 5-ribbed, slightly glanduliferous, internal micropunctations in transverse bands; carpopodium distinct, cylindrical, with inflated, subquadrate to oblong cells in ca. 5 series; pappus of ca. 30-35 bristles, congested, persistent on callus, sometimes falling as unit with callus, apical cells of bristles acute. Pollen grains ca. $20 \mu \mathrm{m}$ in diameter. Plate 11 .

The genus seems closely related to Disynaphia, having similar terminal corymbose-paniculate inflorescences and often having slender alternate leaves. However, a number of characters indicate that a significant discontinuity exists between the two genera. Campovassouria has more cylindrical, almost Chromolaena-like heads, with glabrous bracts, has a number of populations with opposite leaves, lacks the hastate bases on the anther thecae, and has a distinct short cylindrical carpopodium. In addition, the midveins of the leaves are depressed on the upper surface in Campovassouria but are exsculpate in Disynaphia. Campovassouria has no trace of narrower outer involucral bracts of the type found in many species of Disynaphia, and most of Grazielia and Symphyopappus.
The single species credited to the genus has considerable variation in its leaves, and a number of synonyms exist. The widely used epithet, bupleurifolia, of DeCandolle was based on material with comparatively narrow, alternately inserted leaves. The recently resurrected Vellozo specific epithet, cruciata, is based on material with shorter, oblong, opposite leaves.

The generic name is taken from the common name of the plant as given in Cabrera and Vittet (1963) "vassoura do campo" (broom of the campo).

The following single species is recognized in the genus:

Campovassouria cruciata (Vell.) R. King \& H. Robinson, Argentina, Brazil, Bolivia, Paraguay, Uruguay.

\section{Grazielia}

Grazielia R. King \& H. Robinson, Phytologia 23: 305. 1972. TYPE: Eupatorium dimorpholepis Baker. Eupatorium section Dimorpholepis G. Barroso, Arq. Jard. Bot. Rio de Janeiro 10: 97. 1950.

Dimorpholepis (G. Barroso) R. King \& H. Robinson, Phytologia 22: 118. 1971, non Dimorpholepis A. Gray.

Coarse, mostly erect, herbs, subshrubs, or shrubs, with few to many branches. Stems terete, striated, usually densely puberulous to hirtellous or sparsely hirsute. Leaves opposite, short petiolate; blades ovate to lanceolate, sometimes pinnately to bipinnately dissected into narrow segments, margins often serrate, midveins depressed or insculpate on upper surface. Inflorescence densely corymbose; heads mostly short-pedicellate. 


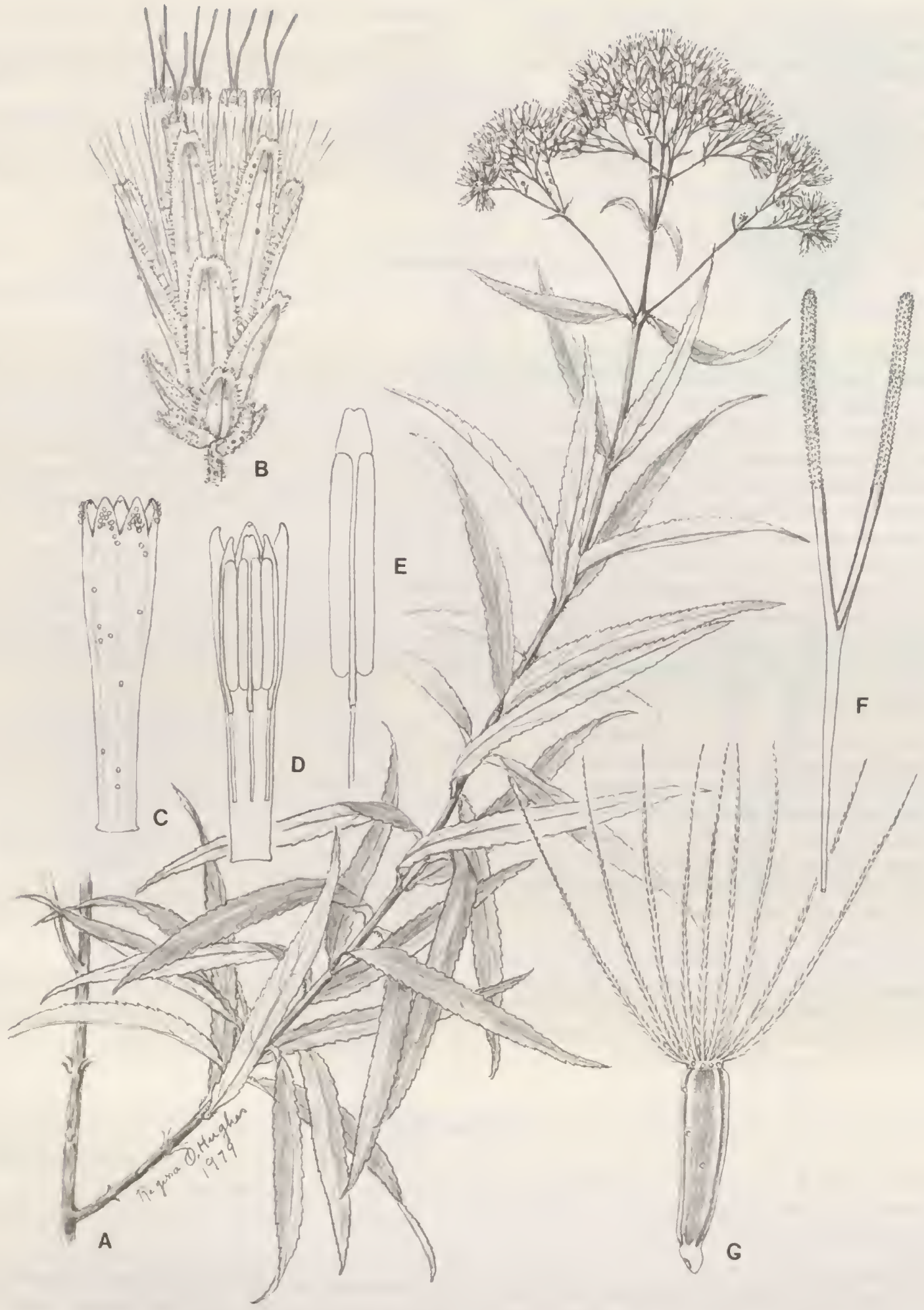
Plate 11. Campovassouria cruciata (Vell.) R. King \& H. Robinson. - A. Habit, $\times 1 / 2 .-$ B. Head, $\times 5$. - C. Corolla outer surface,
$\times 10 .-$ D. Corolla inner surface with anthers, $\times 10 .-$ E. Anther, $\times 18 .-$ F. Style, $\times 10 .-$. Achene, $\times 10$. 
Involucral bracts ca. 15, subimbricate, in 3-4 series, unequal, with strongly differentiated, darker, linear basal bracts in distinct outer series; receptacle flat or slightly convex, glabrous. Florets 5 in a head; corollas with broadly tubular bases, slightly broadening above, white, rose, lilac, or purple; cells of throat and lower part of lobes elongate with slightly to distinctly sinuous lateral walls; lobes triangular, longer than wide, mostly smooth on inner surface; anther collars short, cylindrical, with cells subquadrate or oblong, cell walls with transverse, oblique, or vertical annular thickenings; anther thecae with short-pointed bases; anther appendage longer than wide; style base not enlarged, glabrous; style branches linear, not or scarcely broadened distally, densely short-papillose. Achenes prismatic, 4-5-ribbed, often with a few short-stalked glands and short setulae, micropunctations mostly in transverse bands; carpopodium obsolete or short-cylindrical, composed of numerous, moderate-sized or enlarged, thin-walled cells, procurrent upward on lower part of achene ribs; pappus of ca. 20-30, congested, scabridulous, persistent bristles tapering to a sharp point, apical cells acute. Pollen grains ca. 20-22 $\mu \mathrm{m}$ in diameter. Plate. 12.

The present name of the genus honors Dr. Graziela Maciel Barroso of the Jardim Botânico in Rio de Janeiro, Brazil, and is one of two genera in the Eupatorieae named for this leading authority on Brazilian Asteraceae.

The name originally chosen for the genus, Dimorpholepis, refers to the distinctive outer bracts of the involucre which are prolonged and narrowly linear, often reddish or blackish, in marked contrast to the inner bracts. Such bracts also occur in Symphyopappus and to some extent in Disynaphia, confirming the relationships between the genera. In spite of the similarity in involucre, the present genus, Grazielia, does not closely resemble either of the related genera. Disynaphia differs by its usually densely spirally inserted leaves, and Symphyopappus differs by the glabrous, strongly ridged branches of its inflorescences and its often viscid aspect. Both related genera differ by the midveins of their leaves which are exsculpate on the upper surface. Grazielia does not seem to have the upper callus separating from the achene to the extent that is seen in the two related genera.

Two names that have been used on herbarium specimens of Grazielia, and that have been transferred to the genus during the present series of studies, prove not to belong to the genus. Matzenbacher (1978) has shown that true Eupatorium anethifolium is a Mikania, and material of Grazielia in herbaria under the name seems to belong to $G$. multifida. More recent studies have shown that the original description of Eupatorium coriaceum of Scheele is probably Symphyopappus reticulatus. The Scheele name was also flawed in being a later homonym. Material in herbaria under the Scheele name has been renamed $G$. schultzii (King \& Robinson, 1981h).

There appears to be a tendency for dissected leaves in the genus. Such leaves are characteristic of G. multifida, but there is considerable variation in $G$. gaudichaudeana as noted by Malme (1933). Characteristics of some other species are mentioned by King and Robinson (1971w, 1981h).

The following nine species are recognized in the genus:

Grazielia dimorpholepis (Baker) R. King \& H. Robinson, Brazil. Grazielia gaudichaudiana (DC.) R. King \& H. Robinson, Brazil. Grazielia intermedia (DC.) R. King \& H. Robinson, Brazil.

Grazielia mollicoma (B. Robinson) R. King \& H. Robinson, Brazil.

Grazielia mollissima (Schultz-Bip. ex Baker) R. King \& H. Robinson, Brazil.

Grazielia multifida (DC.) R. King \& H. Robinson, Brazil.

Grazielia nummularia (Hook. \& Am.) R. King \& H. Robinson, Brazil.

Grazielia schultzii R. King \& H. Robinson, Brazil.

Grazielia serrata (Sprengel) R. King \& H. Robinson, Argentina, Brazil, Uruguay.

\section{Symphyopappus}

Symphyopappus Turcz. Bull. Soc. Imp. Naturalistes Moscou 21: 583. 1848. TYPE: Symphyopappus decussatus Turcz.

Kallophyllon Pohl ex Baker in C. Martius, Fl. Bras. 6(2): 365. 1876, nom. nud. including K. crenatum Pohl and $K$. ovatum Pohl, nom. nud., both $=$ Symphyopappus reticulatus Baker.

Erect shrubs or small trees, moderately branched, often viscid. Stems terete, striated, minutely puberulous. Leaves opposite, becoming alternate near inflorescence in some species, subsessile to short-petiolate; blades ovate-lanceolate, margins serrate, midvein prominent or exsculpate on both upper and lower surfaces. Inflorescence rather densely corymbose; heads short-pedicellate, pedicels glabrous with prominent decurrent ridges. Involucral bracts ca. 15, subimbricate, in 3-4(-5) series, inner unequal and graduated in length, substramineous, usually mostly persistent (totally deciduous in some specimens of $S$. decussatus), often with one or more long, narrow, thickened, reddish or blackish bracts in outer series; receptacle flat or slightly convex, glabrous or with numerous stiff hairs. Florets 5 in a head; corolla with broadly tubular base, slightly 

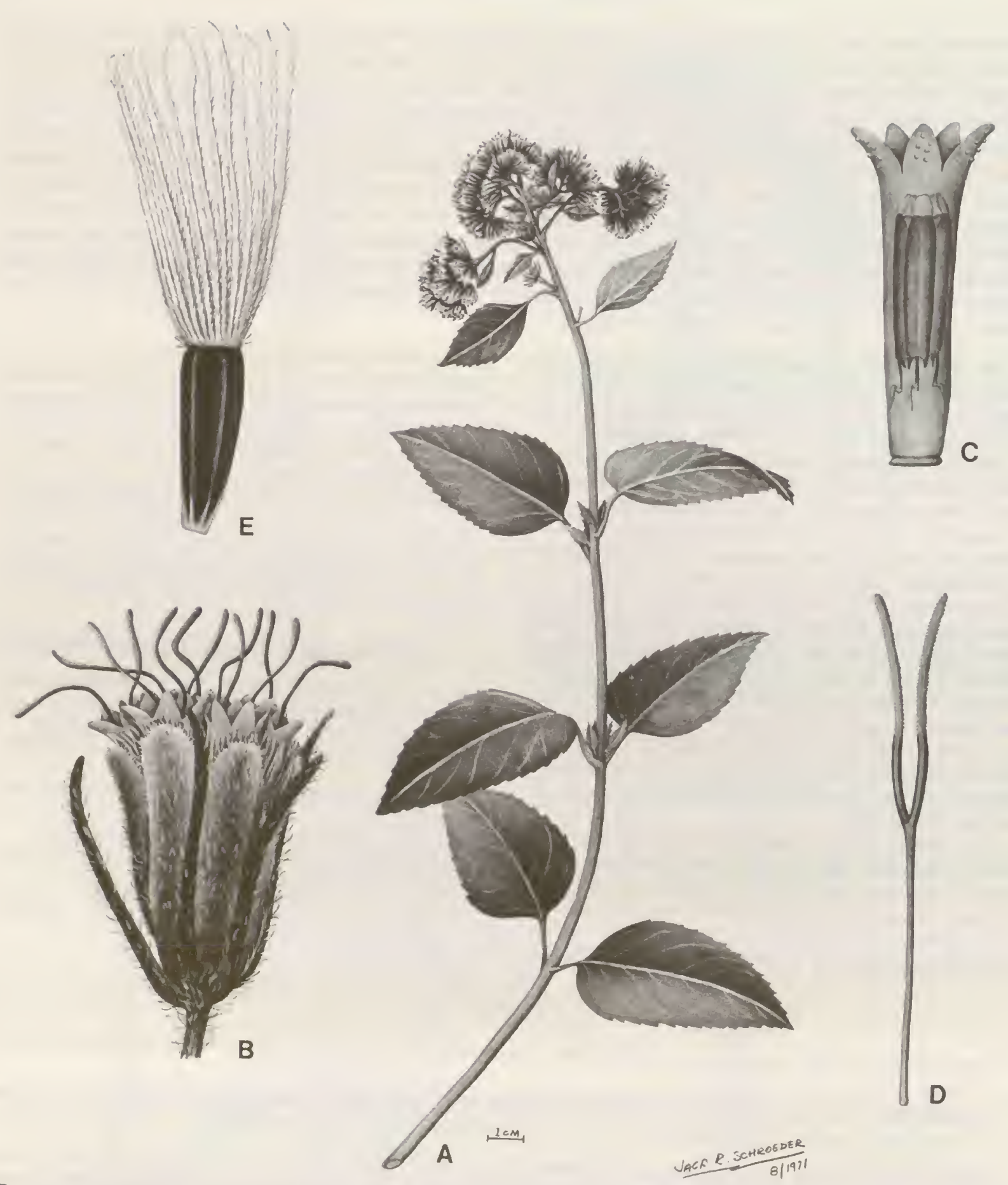

PLATE 12. Grazielia dimorpholepis (Baker) R. King \& H. Robinson. - A. Habit, $\times 3 / s-B$. Head, $\times 10 .-$ C. Corolla showing anthers,
18. -D. Style, $\times 18$. E. Achene, $\times 18$. broadening above, rarely narrowly funnelform throughout, white, rose, or purple-pink; cells of limb mostly tips, outer surface otherwise glabrous; anther collar short, cylindrical, with subquadrate or oblong cells, cell 


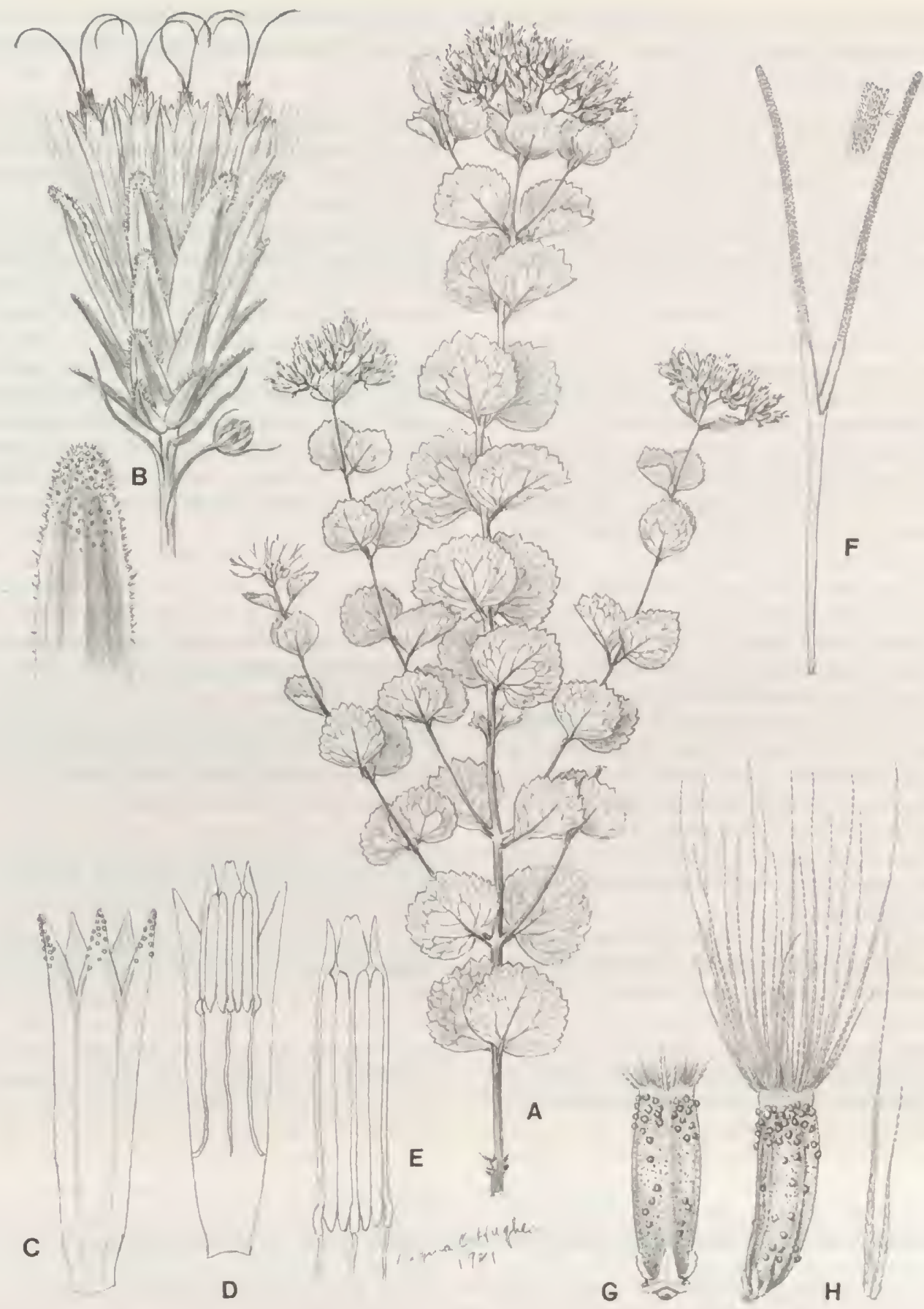

Plate 13. Symphyopappus decussatus Turcz. - A. Habit, $\times 1 / 2 .-$ B. Head, $\times 5$, with separate enlarged tip of involucral bract. - C. Corolla outer surface, $\times 12 .-$ D. Corolla inner surface with anthers, $\times 12 .-E$. Anther, $\times 25 .-F$. Style, $\times 12 .-G$. Achenes, inner and lateral views, $\times 8 .-\mathrm{H}$. Segments of pappus, $\times 9$.

walls with transverse to vertical annular thickenings; bases of anther thecae pointed; anther appendage large, triangular, twice as long as wide; style base not enlarged, glabrous; style branches linear, covered with crowded, short, erect papillae. Achenes short-prismatic, 4-5-ribbed, glabrous or with a few short-stalked glands, internal micropunctations often in transverse bands; carpopodium short-cylindrical, with small thin-walled cells in 
ca. 5 series, procurrent on lower part of ribs; pappus of ca. 40 congested bristles, often in 2 series, persistent on callus, often falling as unit with callus, bristles tapering to sharp points, apical cells acute to obtuse. Pollen grains ca. $23 \mu \mathrm{m}$ in diameter. Plate 13.

The Turczaninow name for the genus is in reference to the pappus that is strongly fused to the callus and falls as a unit with the callus in most of the species.

The genus has been maintained as distinct during most of the 130 years since its description. It was recognized by Bentham and Hooker (1873), and B. Robinson added new species to it. In the B. Robinson key to genera (1913a) the genus is distinguished by the pappus bristles being coalesced into a thickened annulus at the base and by the leaves being coriaceous. The genus was ultimately reduced to the synonymy of Eupatorium by Steyermark in 1953, and has been treated as a part of the latter genus by Cabrera and Vittet (1963). In retrospect, B. Robinson was correct in maintaining the genus, but admittedly, the characters given by him were not entirely reliable, and there was no way to adequately separate Symphyopappus from Eupatorium as the latter was then conceived.

In spite of the great differences in the habits of the plants, the closest relationships of Symphyopappus are clearly to Disynaphia and Grazielia. Many of the species of Symphyopappus have long narrow outer phyllaries as in most of Grazielia and some Disynaphia, and the anatomy of the floret is like that of Disynaphia in all respects except the larger carpopodium. The pappus, which has been used as a key character, is matched in many specimens of Disynaphia, and the two genera share the exsculpate upper surface of the midvein of the leaf. Symphyopappus is most readily distinguished from its relatives by the glabrous, ascending, strongly and decurrently ridged branches of the inflorescence.

In some specimens of Symphyopappus decussatus, the involucre has all the bracts deciduous. It is the only example in the tribe of this trait outside of the subtribe Praxelinae. Smooth corolla lobes, the organization of micropunctations in the achene wall, and cellular details of the anther collar and carpopodium all indicate that there is no close relationship between the Praxelinae and this or any other member of the Disynaphiinae.
Of the various species included in the genus, the position of Symphyopappus itatiayensis seems most questionable. The latter species has narrower corollas and achenes, and the pappus less congested in one series.

Three of the species placed in the genus by B. Robinson $(1923,1931 b, 1934 a)$, and retained in the genus in the initial review by King and Robinson (1971v), prove to belong to other genera. Symphyopappus leptophlebia has been transferred to Raulinoreitzia, S. tetrastichus is the basis of the genus Goyazianthus, and S. pennivenius is a member of the genus Neocabreria. Goyazianthus of the Alomiinae can be distinguished by the alternating pappus bristles of two different sizes, and the pubescent node at the base of the style. Neocabreria of the Critoniinae is distinguished most easily by the hairs on the inner surface of the corolla.

The genus Symphyopappus appears to be restricted in Brazil, reaching farthest south in Rio Grande do Sul, farthest west in Goyaz, and farthest north in Bahia. The limits of the genus have been discussed in three previous studies in the present series (King \& Robinson, 1971s, $1971 v, 1978 g$ ).

The following 11 species are recognized in the genus:

Symphyopappus angustifolius Cabrera, Brazil.

Symphyopappus brasiliensis (Gardner) R. King \& H. Robinson, Brazil.

Symphyopappus casarettoi B. Robinson, Brazil.

Symphyopappus compressus (Gardner) B. Robinson, Brazil.

Symphyopappus cuneatus (DC.) Schultz-Bip. ex Baker, Brazil.

Symphyopappus decussatus Turcz., Brazil.

Symphyopappus itatiayensis (Hieron.) R. King \& H. Robinson, Brazil.

Symphyopappus lymansmithii B. Robinson, Brazil.

Symphyopappus myricifolius B. Robinson, Brazil.

Symphyopappus reitzii (Cabrera) R. King \& H. Robinson, Brazil. Symphyopappus reticulatus Baker, Brazil.

\section{SubTRIBE IV. GyPTIDINAE}

\section{Gyptidinae R. King \& H. Robinson, Phytologia 46: 446. 1980. TYPE: Gyptis (Cass.) Cass.}

Erect perennial herbs, subshrubs, or shrubs, unbranched to many-branched; leaves opposite to spirally inserted (rosulate in Bishopiella). Inflorescence terminal on leafy branches or rarely scapose. Heads clustered, usually short-pedicellate or sessile; involucral bracts eximbricate to weakly subimbricate, persistent; receptacle scarcely convex to strongly conical, with or without paleae or hairs. Flowers usually numerous, rarely less than 10 in a head; corollas blue to purple or white; lobes often with papillose or isodiametric cells on inner surface, without stomata on outer surface; cells of anther collar with dense annular thickenings on walls; and glabrous, sometimes with enlarged node or pubescent or both; style brant style base often not enlarged greatly broadening toward tips, usually densely mamillose or papillose. branches usually linear, sometimes 
ribs in Vittetia), with micropunctations often aligned in transverse bands, base of achene sometimes prolonged to form narrow stipe; carpopodium with cells of variable size but usually subquadrate or shortly oblong, cells with thin to slightly thickened walls; pappus usually of many capillary bristles, sometimes very short, rarely lacking, sometimes with enlarged round-tipped apical cells. Basic chromosome number $x=10$.

The large and diverse subtribe is notable for the eximbricate to weakly subimbricate involucral bracts, the heads almost always with ten or more flowers, and the pappus usually of many capillary or sometimes plumose bristles. The pappus may be short in species of Stylotrichium, Morithamnus, Arrojadocharis, and Platypodanthera, or totally lacking in some species of Stylotrichium and Trichogonia. The anther collar characteristically has prominent annular thickenings on the cell walls, the corolla lobes often have rounded or projecting cells on the inner surface, and, with a few marked exceptions, the style bases are unenlarged and glabrous. Many of the genera have a characteristically conical receptacle of a type seen elsewhere in the tribe mostly in the closely related Ageratinae and Trichocoroninae. Such a receptacle also occurs in one species of Aristeguietia in the comparatively distant subtribe Critoniinae.

The Gyptidinae seem most closely related to the subtribes Eupatoriinae, Disynaphiinae, and Ageratinae. The Eupatoriinae differ primarily by the characteristic pubescence on the style base, by the more subimbricate involucre, and by the generally fewer flowers in the head. The Disynaphiinae differ by the consistent five flowers in each head, the distinctly subimbricate involucre, and the generally shrubby habit. The Ageratinae seem most closely related, but have a pappus of various forms or lacking, but never capillary. The Ageratinae also tend to have a center of distribution more in the Andes and Central America, outside of the range of most members of the Gyptidinae. Two genera of the Gyptidinae, Gyptis and Bejaranoa, are unusual in the subtribe by sometimes having as few as four flowers in a head, and Gyptis has a habit resembling that of some Eupatoriinae, but neither genus has pubescence on the style base. The various members of the Gyptidinae with defective forms of pappus resemble the Ageratinae, but each shows details relating them directly to forms with a capillary pappus, and none shows any squamellae or other structures that cannot be interpreted simply as reduction forms from capillary bristles.

As presently defined, the Gyptidinae represents one of the largest and most variable complexes in the Eupatorieae, and it might be regarded as something of a residuum after the more precisely defined Eupatoriinae and Disynaphiinae have been removed. The Gyptidinae give the impression, nevertheless, of a natural group with only minor infusions from and to other subtribes through hybridization. Much of the integrity of the subtribe probably derives from the comparative geographical isolation from many of the other subtribes of the Eupatorieae, and pos- sibly habitat isolation as well. The Gyptidinae achieve their greatest diversity in the savanna type habitats in Brazil where Critoniinae are rare. It is probably because of the habitat preferences of members of the Gyptidinae that the subtribe appears to show its most phyletically extreme forms in that part of the available habitat that is the most remote in eastern Brazil.

The drier habitats preferred by members of the Gyptidinae are probably a factor in the relative wealth of secondary metabolites that have been reported from some of the genera. Numerous compounds have recently been reported from Trichogonia, Lasiolaena, Stylotrichium, Bahianthus, Agrianthus, Conocliniopsis, and Bejaranoa (Bohlmann et al., 1980e, 1980f, 198Ia, 198Ig, 1981k, 1981l, $1981 n, 1982 c$ ).

Of the 27 genera included in the Gyptidinae, 23 are concentrated in the eastern part of South America. Two additional genera, Conoclinium and Tamaulipa are concentrated in the eastern United States and Mexico. Lourteigia occurs at comparatively high elevations in the northern Andes, and Neocuatrecasia is endemic to the eastern edge of the Andes in Peru and Bolivia. A few individual species have distributions of note. Trichogonia and Barrosoa, genera that are concentrated in Brazil, have one or two species in the area of Colombia and Venezuela. Conocliniopsis prasiifolia ranges from southern Brazil and Bolivia north to Colombia and Venezuela. Campuloclinium macrocephalum is most common in Brazil and Paraguay, but it also occurs in Central America as far north as Mexico.

A few elements of the Gyptidinae have been treated as separate genera in previous treatments of the tribe. Trichogonia was simply interpreted to include members with a plumose pappus. Arrojadocharis was regarded as a relative of Piqueria because of the reduced anther appendage and defective pappus. Agrianthus was recognized mostly on the basis of a short pappus, but the presence of paleae was noted in some species. Stylotrichium was recognized because of the combination of a short pappus and the presence of pubescence on the shaft of the style. At various times, those species with a conical receptacle were placed in the genus or subgenus Conoclinium, and those species with large multi-flowered heads were placed in the genus or subgenus Campuloclinium. In spite of the great variety of types, the majority of the subtribe having a capillary pappus was placed in traditional systems in the genus Eupatorium. The close resemblance of some members of the Gyptidinae to the genus Ageratum, in many features other than pappus, was often noted. 


\section{KEY TO THE GENERA OF THE SUBTRIBE GYPTIDINAE}

1. Achene with constriction below the pappus and upper callus to less than one-third width of achene, pappus and callus easily broken from achene; plants of high elevations in northern Andes 40. Lourteigia

1'. Achene without extreme constriction below pappus

2. Pappus of plumose or strongly barbellate long bristles or without pappus and bearing dense pubescence on corolla that hides lobes

3. Corolla densely pubescent on upper throat and lobes; stem with distinct ribs; anther appendages rounded to slightly retuse apically

3'. Corolla with only glands distally on outer surface; stems scarcely striate; anther appendages deeply cleft

23. Trichogonia

2'. Pappus not plumose; corolla without mass of dense pubescence distally hiding lobes

24. Trichogoniopsis

4. Plants rosulate with scapose inflorescence

$4^{\prime}$. Plants not rosulate or scapose

35. Bishopiella

5. Shrubs with leaves inserted in dense spiral, leaves not progressively smaller upwardly

6. Leaves scale-like, imbricated, appressed or recurved, scarcely narrowed at base

6'. Leaves spreading from a narrow base, not or weakly imbricated

7. Leaves viscid, without hairs; receptacle flat or slightly convex; style branches filiform, not or scarcely broadened and flattened

8. Leaves fleshy, without prominent veins; veins of leaves and corolla throat with paired resin ducts; involucre strictly eximbricate, with slender-tipped bracts; achenes with setulae on upper ribs; pappus bristles of uniform widths

30. Morithamnus

8'. Leaves not fleshy, with prominent veins; resin ducts or pockets of leaves and corolla throat simple or single along veins; involucre weakly subimbricate, bracts with blunt rather scarious tips; achenes completely glabrous; pappus bristles of irregular widths

29. Bahianthus

7 . Leaves not viscid, pubescent; receptacle conical; style branches distinctly broadened and flattened at tips

9. Leaves linear; receptacle highly conical, with paleae among peripheral flowers; anther appendage shorter than wide

9'. Leaves ovate to obovate; receptacle low-conical, without paleae 32. Arrojadocharis

10. Shaft of style pubescent; pappus of short bristles or lacking; corolla whitish, densely glanduliferous on outer surface; under surface of leaves with erect or glandular pubescence; anther appendage shorter than wide

34. Stylotrichium

10 . Shaft of style glabrous; pappus of rather awn-like bristles with narrowly winged bases; corolla lavender, sparsely glandular-punctate distally; undersurface of leaf densely tomentose; anther appendage as long as wide or longer

33. Lasiolaena

5'. Herbs or shrubs with mostly opposite leaves, or with leaves becoming alternate or decreascent above, leaves not inserted in dense even spiral

11. Coarse shrubs with glabrous, shiny or viscid, coriaceous or succulent, elliptical to oblanceolate leaves

12. Leaves elliptical to obovate, coriaceous, shiny; pappus bristles not flattened on outer surface; maritime plants

12'. Leaves oblanceolate, somewhat fleshy, viscid; pappus bristles flattened on outer surface; not maritime plants

11'. Herbs or weak shrubs with pubescent or herbaceous, ovate to lanceolate or linear leaves

30. Morithamnus

13. Base of achene narrowly attenuate or stipitate

14. Pappus of short, lanceolate, densely fringed segments; anther collar very broad below; style base glabrous 25. Platypodanthera

14'. Pappus usually of long bristles; anther collar cylindrical; style base usually pubescent

15. Heads large with 30-100 flowers; receptacle conical with minute scars; carpopodium much enlarged, annuliform to short cylindrical; achene with prominent pale ribs ... 36. Campuloclinium

$15^{\circ}$. Heads usually with less than 50 flowers; receptacle flat or slightly convex; carpopodium only slightly enlarged, often rounded; achene with concolorous ribs

16. Corolla narrowly funnelform, with lobes 3 times as long as wide, not papillose on inner surface, with glands on outer surface; style base hirsute without enlarged node

16'. Corolla with slender basal tube closely investing shaft of style, lobes 1-2 times as long as idide, limb broadly campanulate, style base hirsute with enlarged node

13'. Base of achene not narrowly attenuate or stipitate 26. Neocuatrecasia

17. Pappus with tips of apical cells obviously rounded, sometimes inflated

18. Basal tube of corolla not or scarcely narrowed above nectary; North America, northern Mexico 
18'. Basal tube of corolla very narrow, closely investing shaft of style, limb campanulate; South America

19. Involucral bracts ending in a slender densely pubescent appendage; receptacle greatly expanded at maturity, bearing 100-150 flowers; corolla lobes essentially smooth on inner surface; style appendage with long, imbricated papillae 16. Urolepis

19'. Involucral bracts without slender pubescent apical appendage; receptacle short-conical, bearing 50-80 flowers; corolla lobes slightly to strongly papillose on inner surface; style appendage with short papillae

17'. Pappus with tips of apical cells pointed 15. Gyptidium

20. Base of style enlarged and hirsute above nectary

21. Anther appendage slightly longer than wide, 21

21 . Anther appendage slightly longer than wide, not cleft; receptacle conical _ 18. Dasycondy/us
. Anther appendage shorter than wide, deeply cleft; receptacle shallowly convex

20'. Base of style not enlarged, glabrous

19. Diacranthera

22. Plants with broad subsessile leaves; achenes with 7-10 ribs

$22^{\prime}$. Leaves with narrow or petiolate bases; achenes with 4-6 ribs 27. Vittetia

23. Achene completely glabrous; corolla lobes with small papillose apical appendage from inner surface

22. Prolobus

23'. Achene with glands or setulae; corolla lobes with outer surface not exceeded by apical appendage from inner layer

24. Achene with glands, without non-glandular setulae; carpopodium enlarged and procurrent on ribs of achene

17. Barrosoa

24'. Achenes with non-glandular setulae, with or without glands; carpopodium small or narrowly annuliform, not procurrent on ribs of achene

25. Receptacle highly conical; involucre eximbricate with subequal bracts; achenes without glands 20. Conocliniopsis

$25^{\prime}$. Receptacle plane to slightly conical; involucre weakly subimbricate; achenes with few to many glands

26. Herbs; bases of leaf blades acute to acuminate; lobes of corolla papillose on both surfaces 14. Gyptis

$26^{\prime}$. Shrubs; bases of leaf blades abrupt, truncate; lobes of corolla smooth on both surfaces

27. Heads with 4-10 flowers; peduncles not enlarged or fistulose distally; carpopodium sharply delimited above_ 21. Bejaranoa

27'. Heads with 40-70 flowers; peduncles enlarged and fistulose distally; carpopodium not sharply delimited above _. 39. Tamaulipa

\section{Gyptis}

Gyptis (Cass.) Cass., Dict. Sci. Nat. 16: 10. 1820. TYPE: Gyptis pinnatifida Cass.

Eupatorium subgenus Gyptis Cass., Bull. Sci. Soc. Philom. Paris 1818: 139. 1818. Clearly referred to as a subgenus of Eupatorium in this publication by Cassini, not as genus or subgenus as in many others of his proposed names. Nevertheless, the subgenus was credited with the species "Gyptis pinnatifida" at this time, a combination that cannot be considered valid as of that date.

Perennial herbs usually with stout or tuberous tap roots or stolons, not or sparingly branched above base. Stems terete, striated, puberulous to hirtellous. Leaves opposite, often becoming alternate above, petiolate; blades ovate to bipinnatifid, margin serrulate to deeply dissected. Inflorescence subscapose, usually densely corymbose or cymose above; heads mostly short-pedicellate or subsessile. Involucral bracts 16-25, weakly subimbricate, in 2-3 series, subequal, lanceolate to linear, usually appearing truncate at tip because of dense apical pubescence; receptacle flat, glabrous. Florets 4-26 in a head; corollas narrowly funnelform, white, pink, or violet; cells of throat narrow with sinuous lateral walls; lobes triangular, about as long as wide or slightly longer, strongly papillose on both surfaces, with hairs and often glands on outer surface, margin often with bicellular teeth; anther collars short-cylindrical, only slightly expanded below, with cells subquadrate or short-oblong, cells with transverse or oblique annular thickenings; anther appendage ovate, twice as long as wide; style base not enlarged, glabrous (slightly papillose in $G$. artemisifolia); style branches narrowly linear to filiform, densely papillose. Achenes prismatic, 5-ribbed, broad, narrowed below to short base, costae and lateral surfaces densely setuliferous, internal micropunctations in rather regular transverse bands; car- 


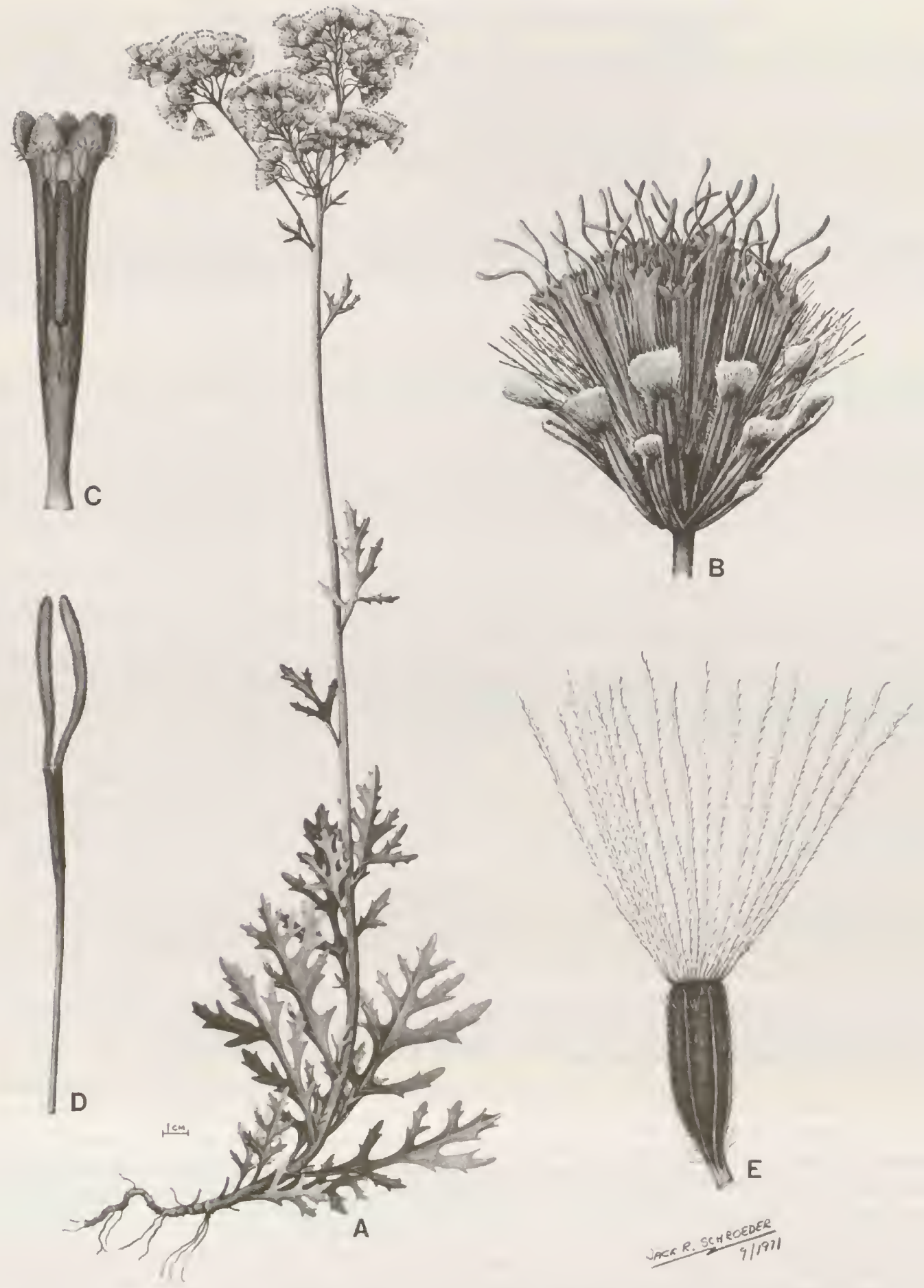

Plate 14. Gyptis pinnatifida Cass. - A. Habit, $\times 2 / 5 .-$ B. Head, $\times 6 .-$ C. Corolla showing anthers, $\times 13 .-$ D. Style, $\times 13 .-$ E. Achene,
13. popodium very short or vestigial, with cells small, subquadrate, in up to 4 series, with densely beaded walls;
pappus of ca. $20-30$ persistent bristles in one series, pappus of ca. $20-30$ persistent bristles in one series, apical cells of bristles subacute or acute. Pollen grains
ca. $15-20 \mu \mathrm{m}$ in diameter. Plate. 14 . 
Gyptis is unusual in the Gyptidinae in a few respects. The number of flowers in a head can be as few as four, while most members of the subtribe have ten or more. Also, Gyptis lacks the conical receptacle that marks many genera of the Gyptidinae. Gyptis does have a habit resembling members of the subtribe Eupatoriinae, and one species, Eupatorium oblongifolium, which has been associated with members of the genus Gyptis in the past, belongs to the genus Stomatanthes in the Eupatoriinae. The present genus is placed with others in the present concept of the Gyptidinae on the basis of its glabrous style base. The closest approach to pubescence on the style base in Gyptis is the few papillae sometimes seen in $G$. artemisifolia.
Gyptis occurs in northern Argentina, Paraguay, Uruguay, and southern Brazil. A key to the species is provided by King and Robinson (1971a).

The following seven species are recognized in the genus:

Gyptis artemisifolia (Griseb.) R. King \& H. Robinson, Argentina. Gyptis commersonii Cass., Argentina, Brazil, Uruguay.

Gyptis crassipes (Hieron.) R. King \& H. Robinson, Argentina, Brazil, Paraguay.

Gyptis inornata R. King \& H. Robinson, Brazil.

Gyptis lanigera (Hook. \& Am.) R. King \& H. Robinson, Argentina, Brazil, Paraguay.

Gyptis pinnatifida Cass., Argentina, Brazil, Uruguay.

Gyptis vernoniopsis (Schultz-Bip. ex Baker) R. King \& H. Robinson, Argentina, Brazil, Paraguay, Uruguay.

\section{Gyptidium}

\section{Gyptidium R. King \& H. Robinson, Phytologia 23: 310. 1972. TYPE: Eupatorium militare B. Robinson.}

Erect annual herbs, rarely branched above base. Stems terete, striated. Leaves opposite, sometimes alternate above, distinctly petiolate; blades ovate to lanceolate, bases truncate, margin crenulate. Inflorescence cymose to subcymose; heads sessile to long-pedicellate. Involucral bracts ca. 25 , eximbricate to weakly subimbricate, in 2-3 series, subequal, persistent; receptacle conical, hirsute or covered with narrow paleae. Florets 50-80 in a head; corollas white or pale lilac, with very narrow basal tube; throat narrowly campanulate, smooth on both surfaces, cells elongate with sinuous lateral walls; lobes triangular, not or only slightly longer than wide, with outer surface mostly smooth, inner surface slightly to strongly papillose, cells of inner surface without sinuous walls; anther collars elongate, narrow, cells mostly oblong with dense annular thickenings on walls; anther appendage ovate, longer than wide; style base not enlarged, glabrous; style branches linear, densely papillose with papillae 1-2 times as long as wide. Achenes prismatic, 4-5-ribbed, glanduliferous; carpopodium obsolete, with few small thin-walled cells; pappus of ca. 28 bristles, persistent, in one series, apical cells of bristles with rounded and sometimes dilated tips. Pollen grains ca. 20-22 $\mu \mathrm{m}$ in diameter. Plate 15.

The name Gyptidium is a diminutive of Gyptis, and was intended to reflect the general relationship and geographical coincidence. Closest relationship seems to be with Urolepis which also has very narrow basal tubes on the corollas, conical pubescent receptacles, and blunt apical cells on the pappus bristles. The two genera both have well-defined slender petioles, a feature lacking in some Gyptidinae such as Gyptis. Gyptidium lacks two features that are prominent in Urolepis, however, the extremely long papillae on the style appendage, and the large carpopodium with large thin-walled cells. The corolla lobes of Urolepis differ from those in Gyptidium by being essentially smooth, and the receptacle is greatly enlarged.
The two species of Gyptidium differ by a number of significant characters such as the density of the inflorescence and the indument of the receptacle. The presence of paleae in G. militare is considered to be a prime example of a secondary development of this character from non-paleaceous ancestors.

The genus is restricted to southern Brazil and adjacent Argentina.

The following two species are recognized in the genus:

Gyptidium militare (B. Robinson) R. King \& H. Robinson, Argentina.

Gyptidium trichobasis (Baker) R. King \& H. Robinson, Brazil.

\section{Urolepis}

Urolepis (DC.) R. King \& H. Robinson, Phytologia 21: 304. 1971.

Hebeclinium section Urolepis DC., Prodr. 5: 136. 1836. TYPE: Hebeclinium hecatanthum DC.

Eupatorium section Urolepis (DC.) Benth. ex Baker in C. Martius, Fl. Bras, 6(2): 364. 1876.

Coarse, erect annual herbs or subshrubs, sparingly branched. Stems terete, striated, densely covered with minute stipitate glands. Leaves opposite, distinctly long-petiolate; blades broadly deltoid, usually cordate at base, trinervate from or near base, margin dentate or denticulate. Inflorescence a corymbose or subcymose 

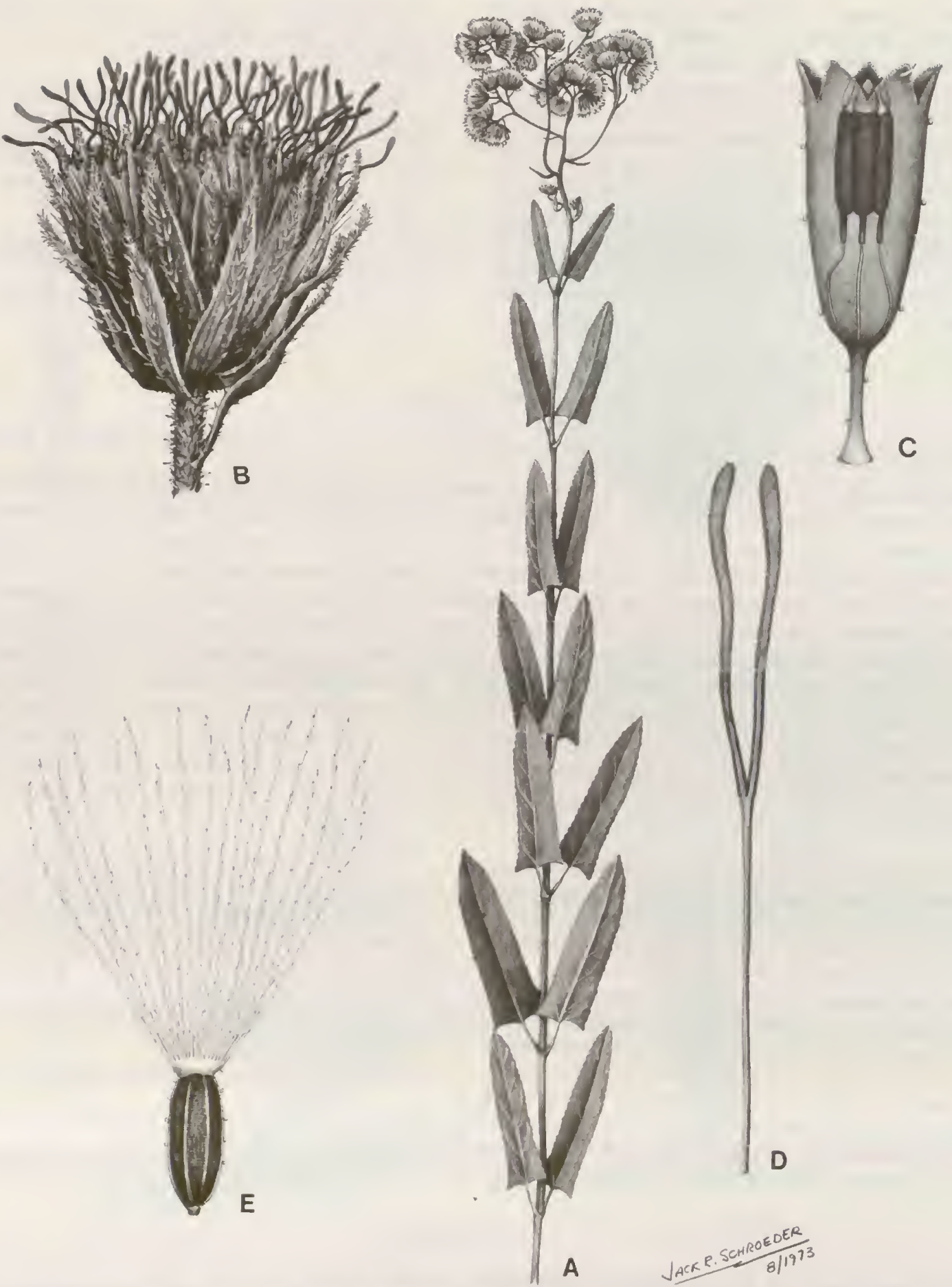
PLATE 15. Gyptidium militare (B. Robinson) R. King \& H. Robinson. - A. Habit, $\times 3 \%$. B. Head, $\times 6 .-$ C. Corolla showing anthers,
$\times 17 .-$ D. Style, $\times 17 .-$ E. Achene, $\times 17$.

panicle; heads mostly with short often slender pedicels. Involucral bracts ca. 50, weakly subimbricate, in 34 series, equal or subequal, inner bracts attenuate into long densely pubescent appendage; receptacle subglobose, densely short-pubescent. Florets 100-150 in a head; corollas pink, with long narrow basal tube; 

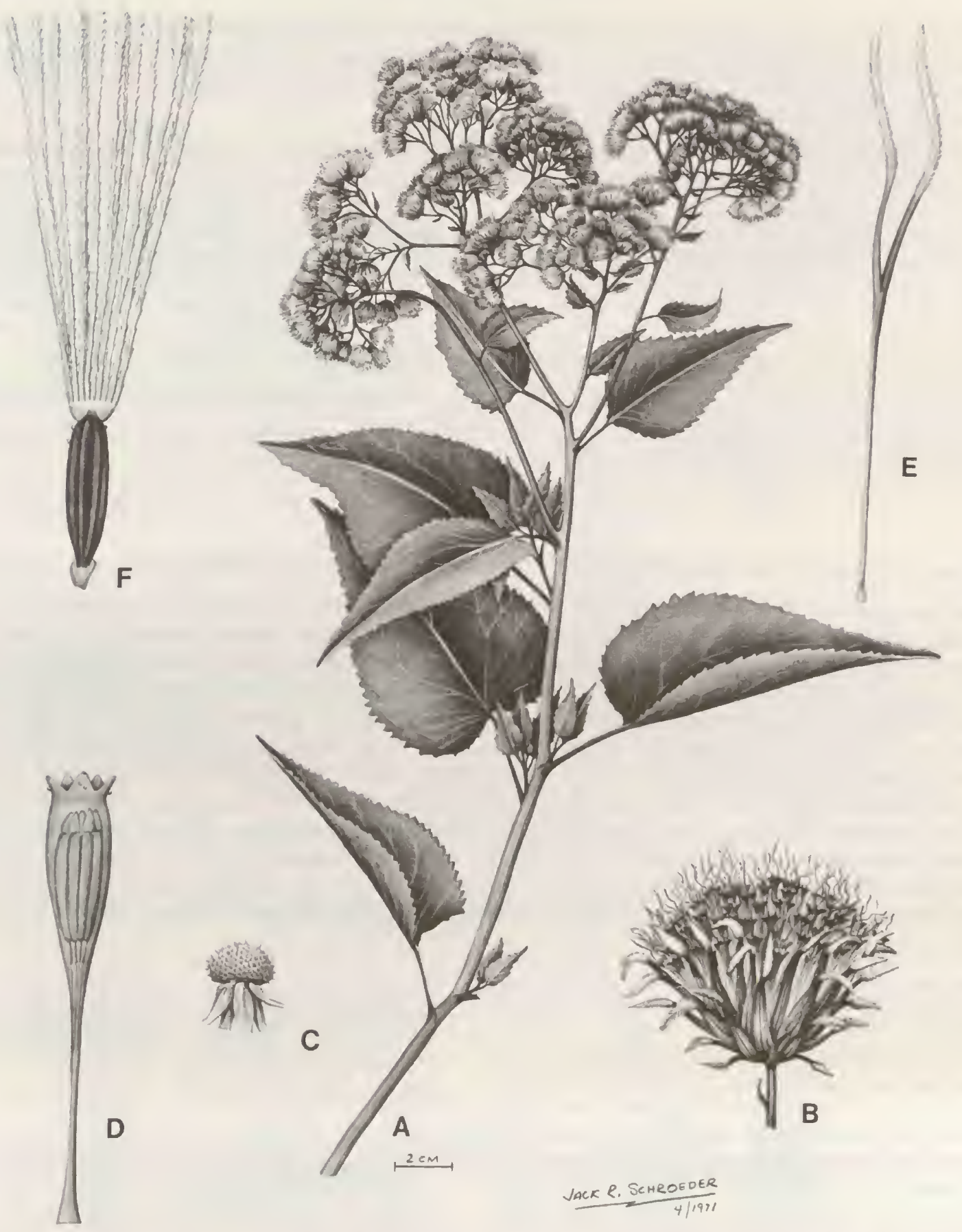

Plate 16. Urolepis hecatantha (DC.) R. King \& H. Robinson, -A. Habit, $\times 4 / \% .-$ B. Head, $\times 4,-$ C. Receptacle, $\times 4,-D$. Corolla showing anthers, $\times 20 .-E$. Style, $\times 20 .-F$. Achene, $\times 20$.

throat funnelform below, becoming cylindrical above, with outer surface of tube and throat glabrous, cells of throat and lower lobes narrow with sinuous lateral walls; lobes triangular, slightly longer than wide, with a few short-stalked glands externally, smooth on inner and outer surface, extreme tips of lobes papillose; anther collars slender, with mostly rectangular cells, cell walls with numerous transverse annular thickenings; anther appendage ovate-triangular, longer than wide; style base not enlarged, glabrous; style branches linear, 
densely papillose with very long antrorsely imbricated papillae. Achenes prismatic, 4-5-ribbed with occasional short-stalked glands; carpopodium large, somewhat stopper-shaped with slight upper rim, cells elongate in ca. 3 series, with slightly thickened walls; pappus of ca. 20 scabrid bristles, persistent, enlarged distally, apical cells with rounded tips. Pollen grains ca. 16-20 $\mu \mathrm{m}$. Plate 16.

Urolepis is named after the densely pubescent tails or appendages on the tips of the involucral bracts. The character provides immediate recognition for the single distinctive species, but would not alone be a basis for separate generic status. The more significant features on which the genus is based include the greatly expanded subglobose receptacle bearing 100-150 flowers, the very long imbricated papillae of the style appendages, and the large carpopodia of the achenes. Closest relationship is to the preceding genus, Gyptidium, which also has narrow basal tubes on the corollas, round-tipped apical cells on the pappus bristles, and an annual habit.

The species on which Urolepis is based has usually been placed in the genus or section Hebeclinium because of the pubescence on the receptacle. Actual relationship is extremely remote as indicated by the placement in separate subtribes. The fine puberulence on the receptacle of Urolepis is not even of the same aspect as the pilosity found on the receptacles in many members of the Hebecliniinae.

Urolepis ranges from central Argentina northward to Uruguay and southern Brazil and westward to Paraguay and Bolivia.

The following single species is recognized in the genus:

Urolepis hecatantha (DC.) R. King \& H. Robinson, Argentina, Bolivia, Brazil, Paraguay, Uruguay.

\section{Barrosoa}

\section{Barrosoa R. King \& H. Robinson, Phytologia 21: 26. 1971. TYPE: Eupatorium candolleanum Hook. \& Arn.}

Erect perennial herbs, with few branches above base. Stems terete, striated, densely pubescent. Leaves opposite, sometimes alternate above, distinctly sessile to long-petiolate; blades lanceolate to broadly ovate, margin serrate to crenulate, trinervate. Inflorescence densely corymbose; heads short-pedicellate. Involucral bracts ca. 15-25, eximbricate, usually in 2 series, subequal; receptacle conical, glabrous, strongly foveolate. Florets 20-55 in a head; corollas funnelform, white, pink, blue, or purple; throat smooth with elongate sinuous-walled cells; lobes triangular, slightly longer than wide, papillose on both surfaces, cells of inner surface abruptly shorter than those of throat, outer surface with hairs and glands; anther collars short, cells with annular thickenings on walls; anther appendage subquadrate to oblong, about as long as wide; style base not enlarged, glabrous; style branches linear, densely short-papillose. Achenes prismatic, 5-ribbed, sparsely glanduliferous, scarcely constricted above and below; carpopodium distinct, with large thin-walled subquadrate cells in 5-10 series, procurrent on lower part of achene ribs; pappus of 25-30 persistent, slender, scabrid, bristles, apical cells acute or subacute. Pollen grains ca. $18-23 \mu \mathrm{m}$ in diameter. Plate 17.

The name Barrosoa is one of two given to genera of the Eupatorieae by the present authors to honor Dr. Graziela Maciel Barroso of the Jardim Botânico in Rio de Janeiro, Brazil.

The genus is central to a group containing most of the species that have been referred to the genus or section Conoclinium in South America. The closest of the related genera is Dasycondylus which differs by having a pubescent node on the base of the style. Somewhat more distantly related is Conocliniopsis which differs by a more shrubby habit, by setulae on the sides of the achene, and by details of the receptacle and carpopodium.

Among the nine species presently recognized in the genus, six occur in the area of southern Brazil and Uruguay (King \& Robinson, 1971b, 1972ee), and one occurs in Bolivia (King \& Robinson, 1981e). The two remaining species form a disjunct group in northern South America in the llanos and other low elevation habitats of Colombia and Venezuela. In its entirety, the range of Barrosoa approaches but does not equal that of the single widely distributed species of the related genus Conocliniopsis.
One species with a more subimbricate involucre, $E u$ patorium viridiflorum, has been placed in Barrosoa in previous studies of this series (King \& Robinson, $1971 b$, $1972 e e$ ), but the species is now placed in the synonymy of Bartlettina hemisphaerica.

The following nine species are recognized in the genus:

Barrosoa apiculata (Gardner) R. King \& H. Robinson, Brazil.

Barrosoa betonicaeformis (DC.) R. King \& H. Robinson, Argentina, Bolivia, Brazil, Uruguay.

Barrosoa cabrerae (B. Robinson) R. King \& H. Robinson, Argentina, Uruguay?

Barrosoa candolleana (Hook. \& Am.) R. King \& H. Robinson, Argentina, Bolivia, Brazil, Paraguay, Uruguay.

Barrosoa confluentis (B. Robinson) R. King \& H. Robinson, Bolivia.

Barrosoa metensis (B. Robinson) R. King \& H. Robinson, Colombia, Venezuela.

Barrosoa organensis (Gardiner) R. King \& H. Robinson, Brazil. Barrosoa ramboi (Cabrera) R. King \& H. Robinson, Brazil. Barrosoa trianae (B. Robinson) R. King \& H. Robinson, Colom- 


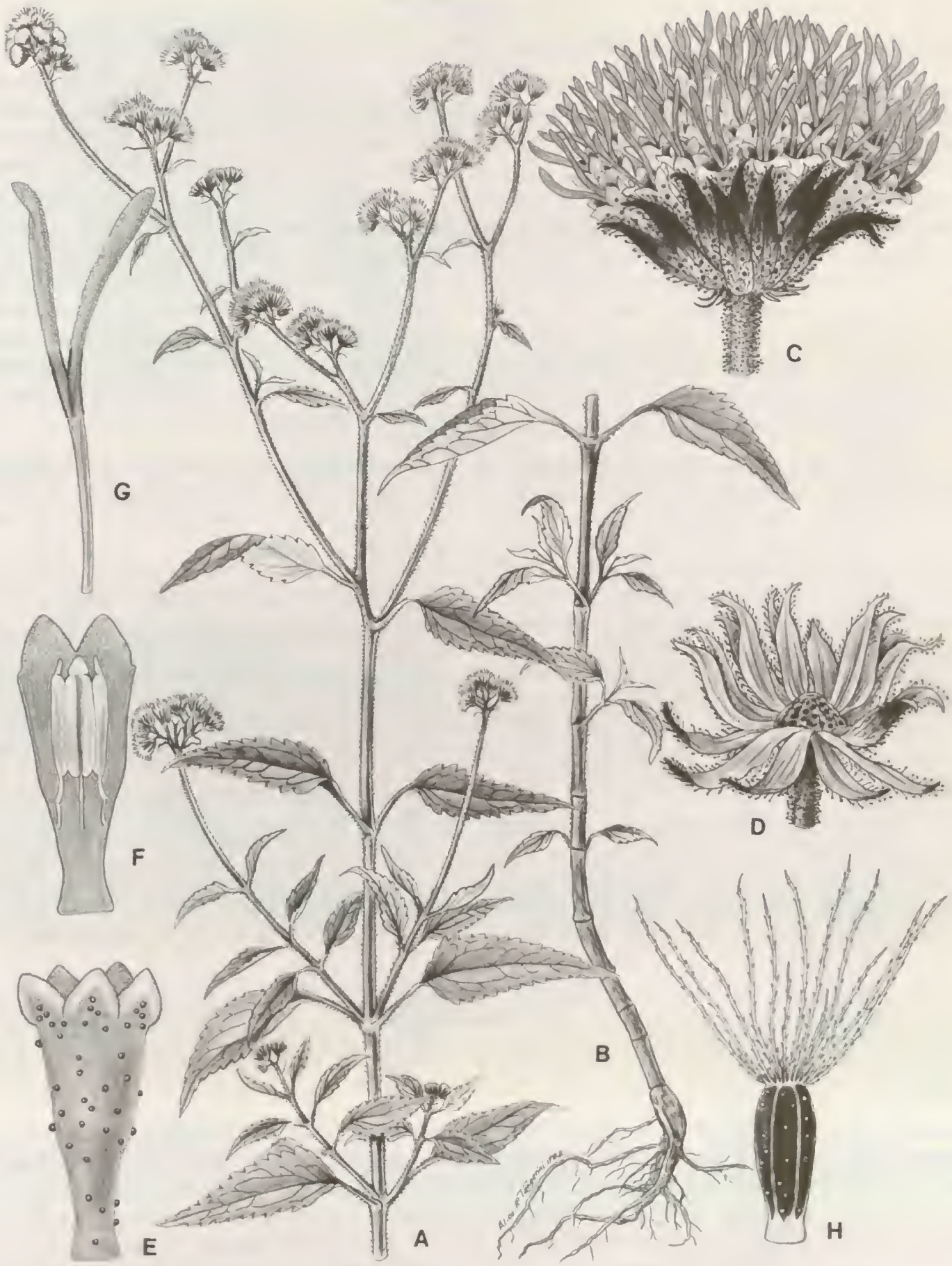

Plate 17. Barrosoa candolleana (Hook. \& Am.) R. King \& H. Robinson. - A. Habit, x1/2. - B. Base of plant, $\times 1 / 2,-$ C. Head, $\times 7 .-$ D. Older head showing receptacle, $\times 7,-$ E. Corolla outer surface, $\times 18 .-$ F. Corolla inner surface with anthers, $\times 18 .-$ G. Style, $\times 18 .-$ H. Achene, $\times 18$. 


\section{Dasycondylus}

\section{Dasycondylus R. King \& H. Robinson, Phytologia 24: 188. 1972. TYPE: Eupatorium lobbii Klatt.}

Erect or spreading subshrubs or shrubs, sometimes subscandent, moderately branched. Stems terete, striated, hirsute to hirtellous. Leaves opposite, distinctly petiolate; blades ovate to oblong, base cuneate to cordate, margin entire to serrate. Inflorescence a corymbose panicle; heads sessile to short-pedicellate. Involucral bracts ca. 15-25, subimbricate in 3-4 series, unequal, inner bracts somewhat deciduous, outer bracts often broad; receptacle conical, glabrous to sparsely pilose, strongly foveolate. Florets 20-60 in a head; corollas white, narrowly funnelform; cells of throat elongate with sinuous lateral walls; lobes triangular, about as long to twice as long as wide, inner surface smooth with cells more quadrate than in throat, outer surface slightly papillose, glanduliferous, and setiferous; anther collars short, slightly swollen, cells with annular thickenings on walls; anther appendage ovate, longer than wide; style base enlarged, densely hirsute; style branches linear, slightly clavate distally, slightly mamillose. Achenes prismatic, 5-ribbed, sparsely setuliferous above; carpopodium distinct, broad, cells usually large with walls not thickened, in ca. 5-10 series, procurrent onto lower part of achene ribs; pappus of ca. 30-40 persistent, scabrid bristles in one series, apical cells of bristles narrowly obtuse to acute. Pollen grains ca. 20-25 $\mu \mathrm{m}$ in diameter. Plate 18.

The carpopodia and receptacles of Dasycondylus indicate close relationship to Barrosoa, but there are a number of significant differences. Dasycondylus contains less herbaceous and more branching plants with subimbricate rather than eximbricate involucres. The corolla lobes are smooth on the inner surface, and the style base has a large hirsute node. It is the hairy stylar node after which Das$y$ condylus is named. The distributions of the two genera are also somewhat different, Dasycondylus being concentrated in Brazil in Minas Gerais and Bahia (King \& Robinson, $1972 \mathrm{gg}, 1980 \mathrm{f}$ ) to the north of the Brazilian center of distribution of Barrosoa. One of the species of Dasycondylus extends its range westward from Brazil to Bolivia and Peru.

The genus Diacranthera of eastern Brazil, in Bahia and Ceará, has an aspect very similar to Dasycondylus, and members of both genera have been misidentified with the species now known as Dasycondylus resinosus and Diacranthera crenata. Both genera have hirsute nodes at the base of the style, and the two are undoubtedly related. Diacranthera differs from Dasycondylus by the slightly convex rather than conical receptacles, and by the shorter cleft anther appendages.

A key to most of the species of Dasycondylus has been provided by King and Robinson (1972 gg).

The following eight species are recognized in the genus:

Dasycondylus debeauxii (B. Robinson) R. King \& H. Robinson, Brazil.

Dasycondylus dusenii R. King \& H. Robinson, Brazil.

Dasycondylus hirsutissimus (Baker) R. King \& H. Robinson, Brazil.

Dasycondylus lobbii (Klatt) R. King \& H. Robinson, Bolivia, Brazil, Peru.

Dasycondylus platylepis (Baker) R. King \& H. Robinson, Brazil. Dasycondylus regnellii R. King \& H. Robinson, Brazil.

Dasycondylus resinosus (Sprengel) R. King \& H. Robinson, Brazil.

Dasycondylus riedelii $\mathrm{R}$. King \& H. Robinson, Brazil.

\section{Diacranthera}

\section{Diacranthera R. King \& H. Robinson, Phytologia 24: 192. 1972. TYPE: Diacranthera ulei R. King \& H.
Robinson.}

Perennial herbs or subshrubs, with few branches, slightly fleshy, in maritime habitats. Stems terete, striated, puberulous. Leaves opposite, short-petiolate; blades ovate to elliptical with narrowly acuminate base, margin crenulate to serrulate, venation pinnate with 2-3 pairs of ascending veins, pair near basal third somewhat pedicellate. Inve ascending. Inflorescence slightly to strongly cymose with many branches; heads shortFlorets 50-65 incral bracts ca. 25, eximbricate, in 2 series, subequal; receptacle broadly convex, glabrous. subquadrate, with a head; corolla rosaceous, narrowly funnelform; cells of limb mostly short-oblong or surface smooth to non-sinuous or scarcely sinuous walls; lobes triangular, slightly longer than wide, inner short, narrowly cylindrical, cells subquadrate with with a few glands, with or without hairs; anther collars appendage bilobed, shorter than wide; style base slighe transverse annular thickenings on walls; anther slightly clavate, scarcely mamillose. Achenes prismatic, 5-riblarged, densely hirsute; style branches linear to 


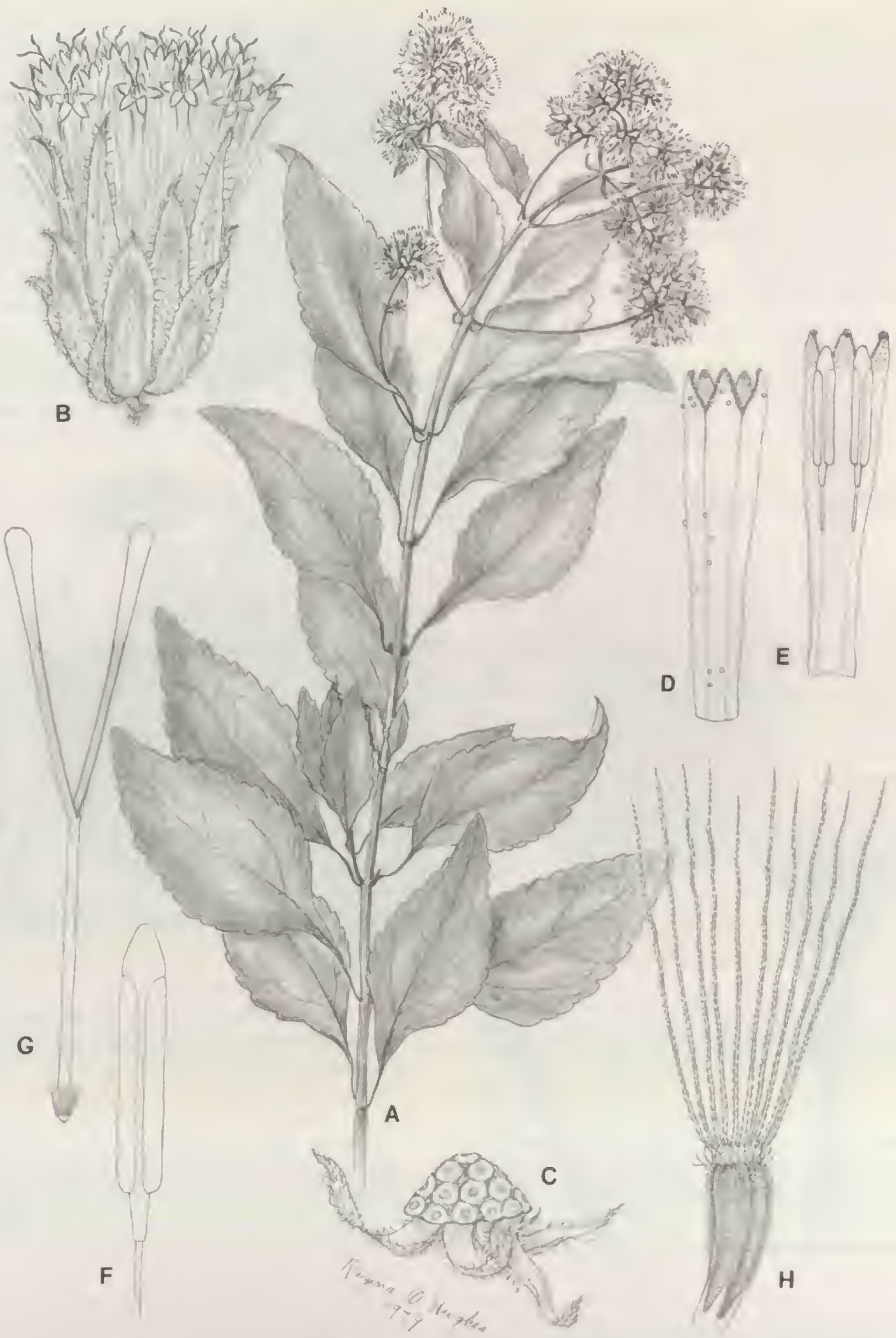

Plate 18. Dasycondylus resinosus (Sprengel) R. King \& H. Robinson. - A. Habit, $\times 1 / 2 .-$ B. Head, $\times 71 / 2 .-$ C. Receptacle, $\times 14 .-$ D. Corolla outer surface, $\times 10 .-$ E. Corolla inner surface with anthers, $\times 10 .-F$. Anther, $\times 22 .-$ G. Style, $\times 10 .-H$. Achene, $\times 14$. 


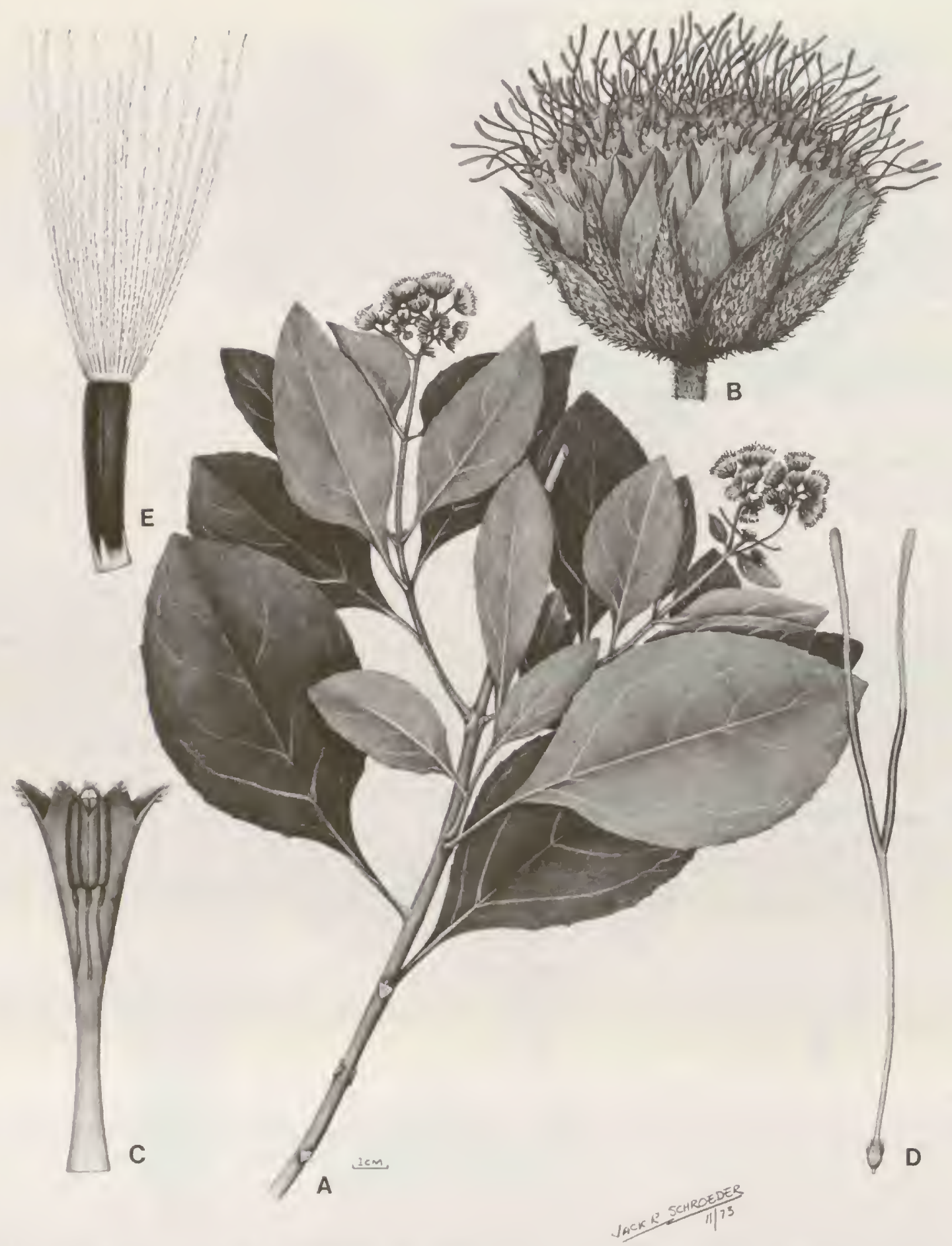
Plate 19. Diacranthera ulei R. King \& H. Robinson. - A. Habit, $\times 5 \% .-$ B. Head, $\times 6 .-$ C. Corolla showing anthers, $\times 20 .-$ D. Style,
$\times 20 .-$ E. Achene, $\times 20$.

and shortly procurrent on ribs of achene, cells large, oblong, with thin walls, in ca. 5 series; pappus of ca. 35 persistent bristles in one series, not enlarged at tips, apical cells of bristles acute. Pollen grains ca. $23 \mu \mathrm{m}$
in diameter. Plate 19 . 
The generic name refers to the bilobed appendage on the apex of the anther. It is the short bilobed appendage and the shallowly convex receptacle that distinguish the genus from the closely related Dasycondylus. The two genera, Diacranthera and Dasycondylus, have large carpopodia with large thin-walled cells that are procurrent on the achene ribs, a feature by which they are related to the genus Barrosoa. The two differ from the latter by the enlarged and hirsute base of the style. Diacranthera seems distinct from both Dasycondylus and Barrosoa by its maritime habitat, said to be in reach of salt spray.

The two species occur along the coast of eastern Brazil in southern Bahia and in Ceará. The oldest name for the most common species, Campuloclinium crenatum, is the basis for the accepted combination of Diacranthera. A prior combination in Eupatorium, however, made it nec- essary for B. Robinson (1928) to provide a new name, $E$. carnosifolium, for use in that genus. Some confusion has resulted from the inclusion of specimens of three different species among the specimens cited by B. Robinson, both species of Diacranthera and one species of Dasycondylus. More confusion has resulted from the recent use of the name $E$. carnosifolium for the more remotely related shrub from the coast of Bahia, Litothamnus ellipticus.

A key to the two species is provided by King and Robinson $(1972 h h)$.

The following two species are recognized in the genus:

Diacranthera crenata (Schldl. in C. Martius) R. King \& H. Robinson, Brazil.

Diacranthera ulei R. King \& H. Robinson, Brazil.

\section{Conocliniopsis}

\section{Conocliniopsis R. King \& H. Robinson, Phytologia 23: 308. 1972. TYPE: Conoclinium prasiifolium DC.}

Erect subshrubs or shrubs, with few to many branches. Stems terete, striated, hirtellous and minutely stipitate-glanduliferous. Leaves opposite, with few alternate above, distinctly petiolate; blades ovate, base often truncate, margin strongly crenate, trinervate from or near base. Inflorescence a dense corymbose panicle or cyme; heads short-pedicellate, pedicels sometimes slender. Involucral bracts 12-16, eximbricate, subequal, in ca. 3 series, persistent; receptacle high-conical, glabrous, strongly foveolate. Florets 20-30 in a head; corollas blue or lavender, narrowly funnelform, with outer surface glanduliferous, inside glabrous; cells of throat elongate with sinuous lateral walls; veins thickened below; lobes triangular, twice as long as wide, inner surface mamillose with broad cells, outer surface somewhat papillose distally; anther collars elongate, narrow, cells oblong with dense annular thickenings on walls; anther appendage ovate, longer than wide; style base not enlarged, glabrous; style branches filiform, scarcely broader distally, densely papillose. Achenes prismatic, 4-5-ribbed, setuliferous on ribs and lateral surfaces, without glands; carpopodium very prominent, annuliform with projecting setuliferous upper rim, cells rather large with firm walls, in 5-6 series; pappus of 30-35 persistent scabrid bristles in one series, apical cells of bristles acute to subacute. Pollen grains ca. 16-20 $\mu \mathrm{m}$ in diameter. Plate. 20.

Conocliniopsis is named after the genus Conoclinium in which the type species was originally included, and indirectly is named for the conical form of receptacle that is characteristic of both genera. The receptacles in $\mathrm{Co}$ noclinium and Conocliniopsis are the most highly conical in the Gyptidinae, usually having the flower-bearing portion as high as wide or higher. The two genera are not regarded as close relatives, however, since Conoclinium is a genus of rhizomatous herbs with obsolete carpopodia, geographically restricted to the United States and Mexico.

The closest relationships of Conocliniopsis seem to be with the South American genera, Barrosoa and Bejaranoa. The former of these has a distinct though shallow conical receptacle and large cells in the carpopodium, but lacks setulae on the achene and has the carpopodium procurrent on the achene ribs. Barrosoa is also a more herbaceous genus. Bejaranoa is most similar in habit, but has the receptacle not or minutely conical, the achene with both glands and setulae, the carpopodium somewhat smaller with much smaller cells, and the involucre weakly subimbricate.
The carpopodium of Conocliniopsis seems rather unique in the tribe by the manner that setulae are borne on its upper edge. The form of the carpopodium is particularly distinct from that in Barrosoa which lacks a rim and is procurrent on the ribs. In this respect, Bejaranoa seems the nearest relative.

The single widely distributed species of Conocliniopsis has been represented in most botanical literature of the last 100 years under the wrong name. The name Eupatorium ballotaefolium that has been applied to the species, proves to belong instead to a Colombian species of similar superficial appearance, but with detailed characters of the genus Lourteigia. Conocliniopsis also occurs in Colombia, but is more common in Venezuela and south of the Amazon in eastern Brazil (Bahia, Ceará, Pernambuco). The original locality of the type species, Conoclinium prasiifolium, was Venezuela.

The following single species is recognized in the genus:

Conocliniopsis prasiifolia (DC.) R. King \& H. Robinson, Brazil, Colombia, Venezuela. 

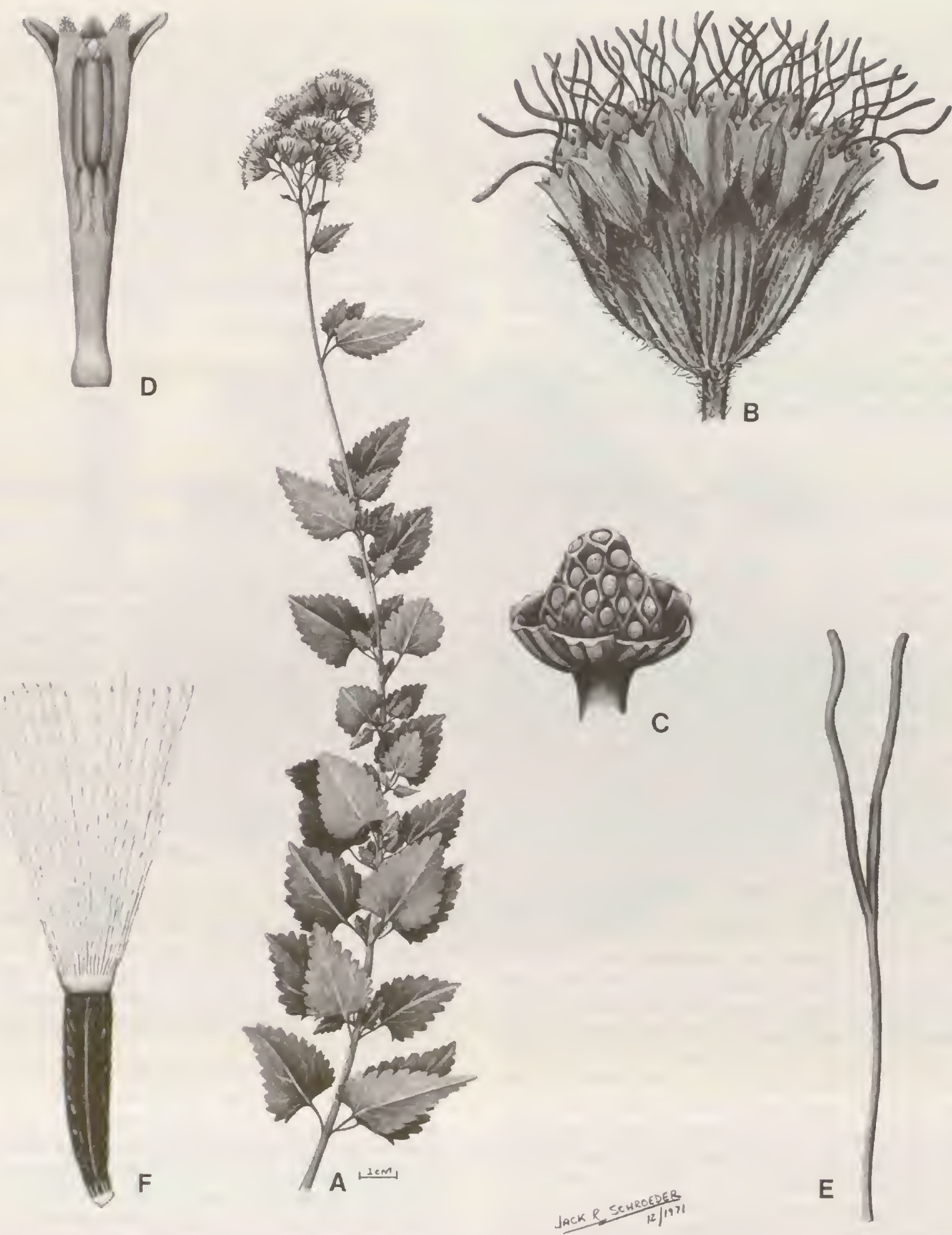
PLATE 20. Conocliniopsis prasiifolia (DC.) R. King \& H. Robinson. - A. Habit, $\times 3 / 3 .-$ B. Head, $\times 7 .-$ Receptacle, $\times 17 .-$ D. Corolla
showing anthers, $\times 17 .-$ E. Style, $\times 17,-$ F. Achene, $\times 17$. 


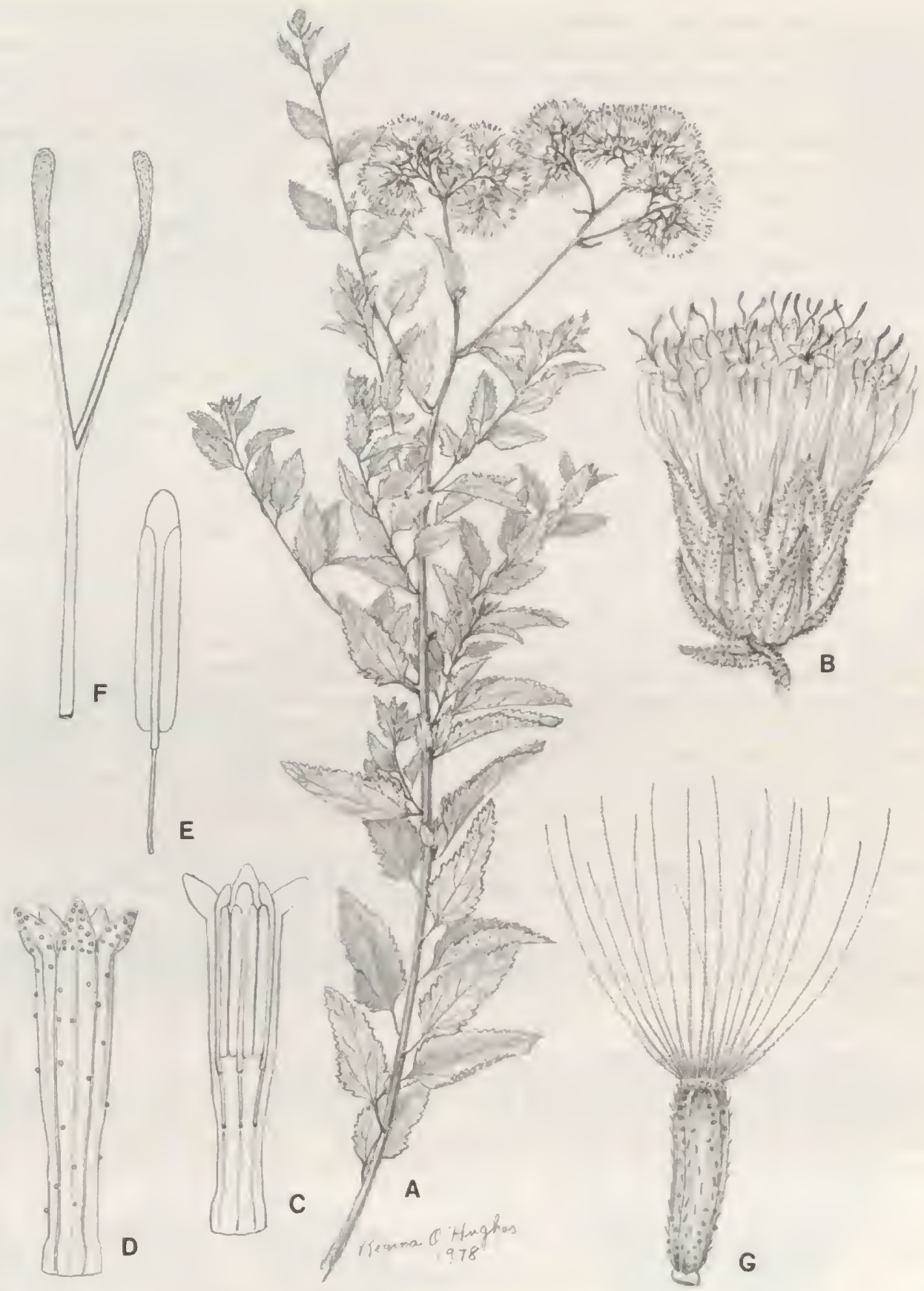

Plate 21. Bejaranoa balansae (Hieron.) R. King \& H. Robinson. - A. Habit, $\times 1 / 2 .-$ B. Head, $\times 5 .-$ C. Corolla outer surface, $\times 9 .-$ D. Corolla inner surface with anthers, $\times 9 .-$ E. Anther, $\times 12 .-$ F. Style, $\times 9 .-G$. Achene. $\times 12$.

\section{Bejaranoa}

Bejaranoa R. King \& H. Robinson, Phytologia 40: 52. 1978. TYPE: Eupatorium balansae Hieron.

Erect subshrubs or shrubs, moderately to rather densely branched. Stems terete, striated, densely hirtellous and glanduliferous. Leaves alternate or sometimes opposite, distinctly short-petiolate; blades ovate or ovate- 
lanceolate, base obtuse and trinervate, margin serrate to doubly serrate. Inflorescence terminal on leafy stems, with densely corymbose branches; heads sessile or short-pedicellate. Involucral bracts 8-15, subimbricate, in ca. 4 series, unequal and somewhat graduated, persistent; receptacle flat to minutely conical, glabrous or subglabrous. Florets 4-10 in a head; corollas white to pale lavender, narrowly funnelform, glabrous inside, outside with glands above; cells of throat oblong with laxly sinuous walls; lobes ovate-triangular, scarcely longer than wide, inner surface smooth with cell scarcely shorter than in throat, outer surface densely glanduliferous and minutely papillose near tip, lateral margins somewhat thickened; anther collars shortcylindrical, cells short-oblong with dense annular thickenings on walls; anther appendage oblong, longer than wide; style base not enlarged, glabrous; style branches linear, slightly minutely mamillose, slightly broadened distally. Achenes prismatic, 5-ribbed, with setulae and glands on sides, narrowed below; carpopodium shortly and broadly stopper-shaped, with distinct upper rim, cells rather small, quadrate to short-oblong, in 4-8 series, with walls slightly thickened; pappus with ca. 30-55 persistent scabrid bristles in one series, apical cells of bristles acute or sometimes truncated. Pollen grains ca. 23-25 $\mu \mathrm{m}$ in diameter. Plate 21.

The genus is named after Prof. Gaston Bejarano of the Ministry for Forestry, National Parks, Hunting, and Fishing in Bolivia.

The most notable aspect of Bejaranoa is the extent to which its characters are Critonioid and the fact that it could not theoretically be distinguished from some of the relatives of Koanophyllon. The style base is not enlarged or pubescent, the involucre is subimbricate, the corolla lobes are smooth without notably shorter cells on the inner surface, and the style branches are not papillose. Nevertheless, detailed comparison of the structures with their equivalents in the Critoniinae show the many subtle differences that would be expected of the products of parallelism. In spite of the approximation in described features, the involucre and corolla lobes of Bejaranoa do not look like those of any members of the Critoniinae. Furthermore, the annular thickenings in the cells of the anther collar in Bejaranoa are like those of the Gyptidinae and denser than in the Critoniinae. Though useless as a key character, the fact that the receptacle in Bejaranoa is sometimes minutely conical confirms the position of the genus in the Gyptidinae.

The problem of relationship of Bejaranoa is also resolvable by the recognition of the overall similarity and apparent close relationship to the genus Conocliniopsis in the Gyptidinae. The two genera are sufficiently close so as to be confused in the field and in the herbarium. Some setulae of the achene are actually on the upper rim of the carpopodium in Bejaranoa as in Conocliniopsis. The two

genera are amply distinct in details, Conocliniopsis having an eximbricate involucre, a highly conical receptacle, mamillose inner surfaces of the corolla lobes, setulae but no glands on the achene, and large cells in the carpopodium. At the time Bejaranoa was described, the leaves were believed to be characteristically alternate, but the leaves in $B$. semistriata prove to sometimes be opposite. Still, completely or partially alternate leaves of Bejaranoa remain a distinction from Conocliniopsis.

Bejaranoa also differs from Conocliniopsis by the smaller number of flowers in the head, the smallest number of flowers in a head of any member of the Gyptidinae except Gyptis. The low flower number in B. semistriata can be difficult to interpret, however, because of the manner in which two or three heads can form complexes in that species.

The two species of Bejaranoa are distinctly separated geographically, the type species in Paraguay and Bolivia, and $B$. semistriata in eastern Brazil. Until recently, the latter species was known only from the original collection, but recent field work indicates that the species forms vast populations in parts of eastern Bahia. Distinctions of the species are given by King and Robinson (1978k).

The following two species are recognized in the genus:

Bejaranoa balansae (Hieron.) R. King \& H. Robinson, Bolivia, Paraguay.

Bejaranoa semistriata (Baker) R. King \& H. Robinson, Brazil.

\section{Prolobus}

\section{Prolobus R. King \& H. Robinson, Phytologia 50: 386. 1982. TYPE: Eupatorium nitidulum Baker.}

Erect shrubs, moderately branched. Stems terete, striated, puberulous. Leaves mostly opposite, becoming alternate above, narrowly petiolate; blades ovate, with acute base, margins coarsely serrate, surfaces somewhat shiny, venation pinnate, more prominent below. Inflorescence cymose with ascending branches, often extraaxillary, pedicels rather short. Involucral bracts ca. 12-15, slightly subimbricate, in ca. 2 series, subequal, glanduliferous above on outer surface; convex, glabrous. Florets ca. 12-14 in a head; corollas pale violet, with sinuous lateral walls; lobes triangular, slightly cylindrical; throat narrowly funnelform, cells elongate 


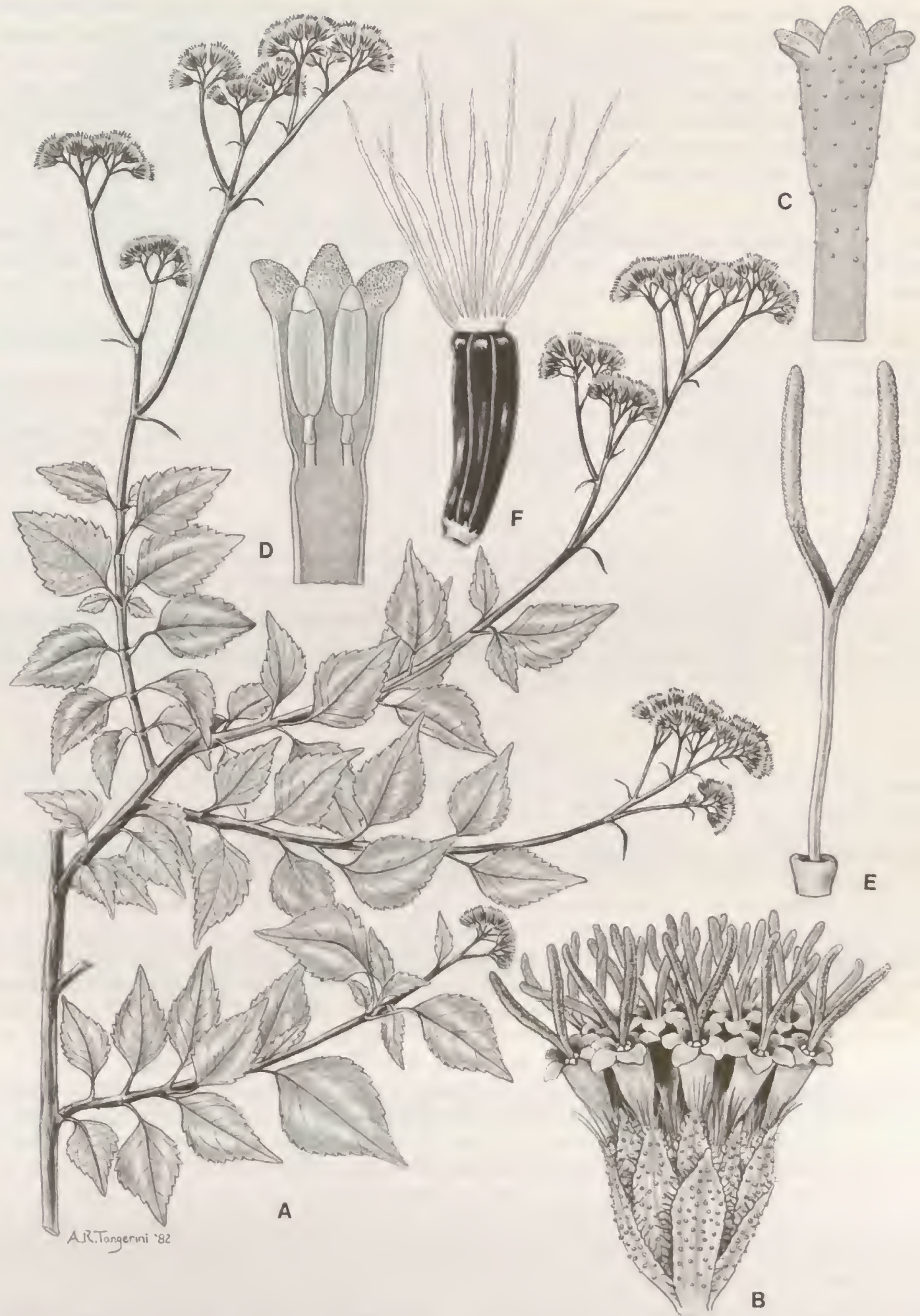

Plate 22. Prolobus nitidulus (Baker) R. King \& H. Robinson. -A. Habit, $\times 1 / 2,-$ B. Head, $\times 7$. - C. Corolla outer surface, $\times 15 .-$ D. Corolla inner surface with anthers, $\times 15 .-E$. Style, $\times 15 .-F$. Achene, $\times 15$. 
extension of inner layer, inner surface mamillose below, anatomical apex of outer surface forming prominent hump; anther collar cylindrical, cells mostly short-oblong with dense transverse annular thickenings on walls; anther appendage oblong, scarcely longer than wide; style base not enlarged, glabrous; style appendage narrowly linear, short-mamillose. Achenes prismatic, 5-ribbed, slightly narrowed below, glabrous or with 1 2 setulae above; carpopodium short-cylindrical, with distinct crenulate upper margin, cells oblong with thickened porose walls, in 2-3 series; pappus with 25-30 irregularly elongate persistent bristles in one series, outer surfaces not flattened and smooth, apical cells of bristles narrow, subacute. Pollen grains ca. $20 \mu \mathrm{m}$ in diameter. Plate 22.

Prolobus, like Litothamnus and Diacranthera, is a member of the Gyptidinae apparently restricted to maritime habitats. Like Litothamnus, it appears to be without close relatives in the subtribe.

The genus is deceptively ordinary in its appearance, and seems superficially similar to Barrosoa on the basis of limited material. Recent collections from the type area near Salvador in Bahia, Brazil, confirm many small but significant differences. Prolobus is more of a shrub than Barrosoa, but this is not always evident in dried plants. It is the non-conical receptacle that initially calls relationship to Barrosoa into question, and the carpopodium with a marked upper rim and thick-walled cells is totally inconsistent with any of the generic complex to which Barrosoa belongs. Further indication of an isolated position in the subtribe is the unique structure of the corolla lobe after which Prolobus is named. The cells of the anatomical inner surface form a papillose projection that extends well beyond the swollen tip of the anatomical outer surface. The inner projection tends to be somewhat sharper than in the illustration, and the papillosity of the inner surface tends to grade into larger mamillose cells in the middle of the base than is shown in the illustration. Nevertheless, the impression of a protruding tongue in the illustration is fairly accurate.

At the time of the description of Prolobus (King \& Robinson, 1982b), the genus was thought to be related to Morithamnus, but reexamination of the corolla lobes in that genus has shown no approximation of the structure seen in Prolobus. No other candidates for close relationship can be offered at this time. In overall shape the carpopodium might suggest relation to Conocliniopsis or Bejaranoa, but the thick-walled cells of the carpopodium in Prolobus seem unique in the subtribe.

The following single species is recognized in the genus: Prolobus nitidulus (Baker) R. King \& H. Robinson, Brazil.

\section{Trichogonia}

\section{Trichogonia (DC.) Gardner, London J. Bot. 5: 459. 1846.}

Kuhnia section Trichogonia DC., Prodr. 5: 126. 1836. LeCTOTYPE: Kuhnia arguta H.B.K.

Erect perennial herbs or subshrubs, sparingly branched above base. Stems terete, with prominent longitudinal ridges, shortly pubescent, often with gland-tipped hairs. Leaves usually alternate, opposite in some crenate. Inflorescence a lax to dense cymose or corymbose panicle; heads on short to margin usually crenulate to Involucral bracts 10-25, eximbricate, in ca. 2 series, subequal to heads on short to moderately long pedicels. glabrous. Florets 10-60 in a head; corolla pink, purple, or equal to equal; receptacle flat to slightly convex, narrow and elongate, limb appearing more campanulate white, narrowly funnelform, basal tube sometimes lobes; throat with cells elongate below and shorter above, with sine dense pubescence on upper throat and than long to slightly longer than wide, inner walls, outer surface densely hirtellous and with smooth with oblong or subquadrate cells with sinuous narrowly cylindrical, cells with prominent annular glands, hairs often septate; anther collars usually rather to distinctly longer than wide, with rounded or retuse tip; linear or clubbed at tip, densely papillose or mamillose except on clubbed tips. Achenes prism; style branches short- to long-stipitate at base, setuliferous at least on ribs; carpopodium a schenes prismatic, 5-ribbed, 1-3 series, with rather thin somewhat beaded walls or with walls modium a small rim, cells subquadrate in ca. 14-30 plumose or strongly barbellate persistent bristles in one series, in some species, pappus usually of epappose, apical cells of bristles acute. Pollen grains ca. 18-23 $\mu \mathrm{m}$ in diameter. Plate 23 .

The name Trichogonia refers to the characteristic setulae on the angles of the achene. The name originally stood in contrast to Kuhnia section Leiogonia which included among other things a species now placed in Trichogo- 


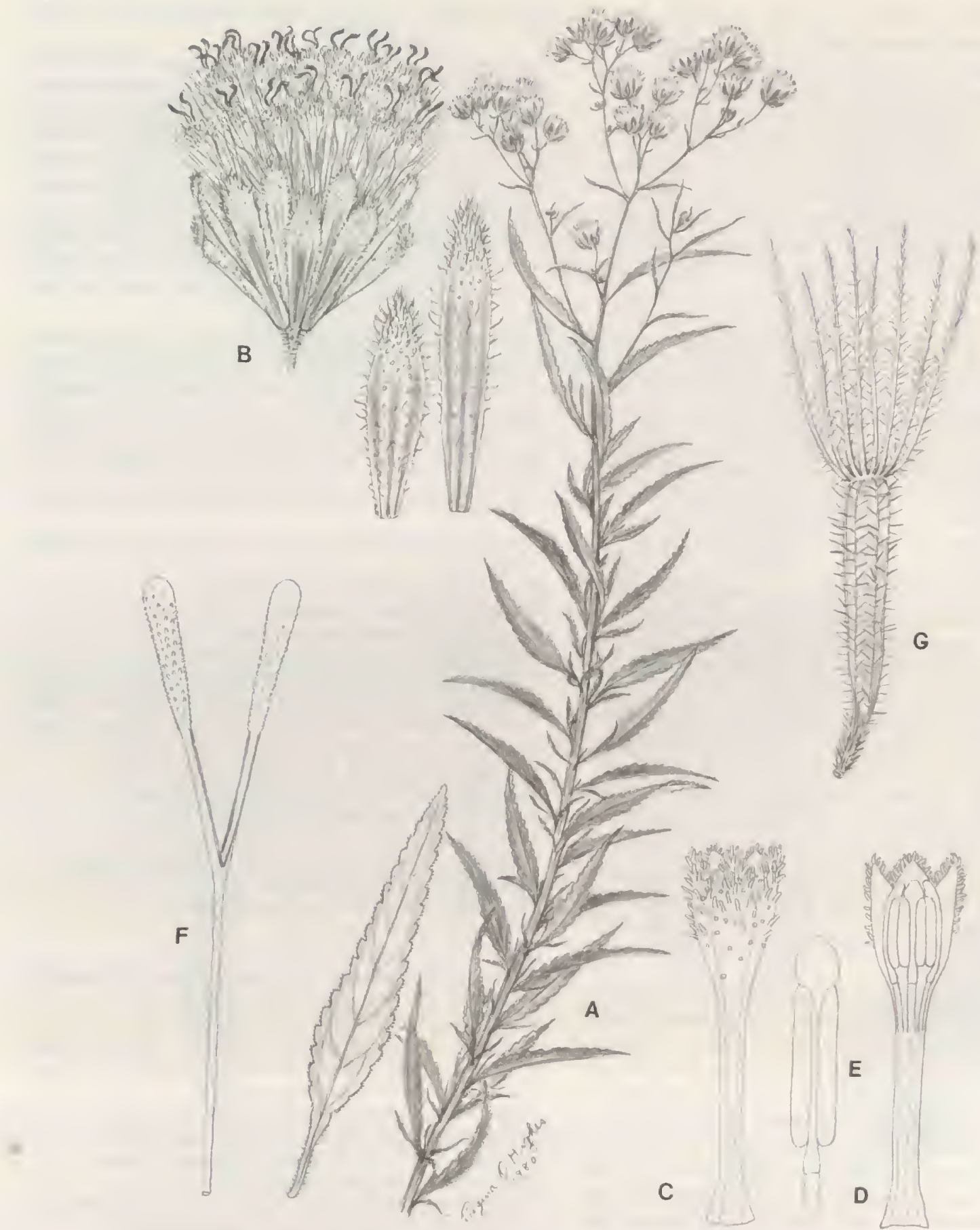

Plate 23. Trichogonia arguta (H.B.K.) Benth. - A. Habit, $\times 1 / 2$, with one separate enlarged leaf. - B. Head, $\times 5$, with two separate enlarged involucral bracts. - C. Corolla outer surface, $\times 10 .-$ D. Corolla inner surface with anthers, $\times 10 .-E$. Anther, $\times 22 .-F$, Style, $\times 10 .-\mathrm{G}$. Achene, $\times 10$. 
niopsis which lacks strong setulae on the achene ribs. Achene pubescence does not seem to have been a factor in any subsequent evaluations of the genus Trichogonia.

The principal factor in the wide acceptance of Trichogonia as a genus has bcen the plumose pappus that is found in most of the species. Traditionally, Trichogonia and Helogyne of the Alomiinae were the two genera with a plumose pappus in South America. Recent study has shown that the traditional concept excluded some species that should have been included, and included some that should be placed in other genera.

The redefined Trichogonia is characterized by the dense pubescence on the upper part of the corolla. The recharacterization results in inclusion of some species without a plumose pappus, but has the benefit of excluding all species with a conical receptacle. The species added include $T$. chodatii and $T$. phlebodes which have a capillary pappus and were previously placed in Eupatorium. Other additions are $T$. cinerea and $T$. dubia which are totally epappose, and which were placed in Alomia. B. Robinson (1906) commented on the relationship of the latter two species to Trichogonia even as he retained them in the artificial concept of Alomia.

The excluded species fall into three genera which share various aspects of Trichogonia. Trichogoniopsis has a plumose pappus, essentially flat receptacle, and a stipitate achene base as in Trichogonia, but differs by the corolla pubescence, the nearly smooth stems, and the deeply cleft anther appendages. Platypodanthera has a slender base on most achenes as in Trichogonia, but has a short, fimbriate rather than plumose pappus, has a conical receptacle, smooth stems, glabrous corollas, and a distinctively broadened anther collar. Campuloclinium has a habit similar to some Trichogonia and a slender base on the achene, but has a conical receptacle, a very broad annuliform carpopodium, prominent pale ribs on the achene, and lacks the distinctive corolla pubescence. Of the three, only Trichogoniopsis seems to have an immediate relationship to Trichogonia.

Within Trichogonia a few distinctions are notable. The two Bolivian species, T. bishopii (King \& Robinson, 1978i) and $T$. capitata are mostly opposite-leaved, a condition that is unusual in the genus. Opposite lower leaves are found in some other species, most notably $T$. rhodotricha of Brazil, and a subopposite condition is common in $T$. rhadinocarpa of the northern Andes.

Among the Brazilian species, a natural group can be distinguished by the presence of numerous glands on the tube of the corolla. The same group has a tendency for some or all achenes to be epappose. Included are $T$. $c i$ - nerea, $T$. dubia, $T$. martii, $T$. menthaefolia, and $T$. zehntneri.

One species, T. harleyi, was originally credited with 10 flowered heads, the only such low number reported in the genus. More recent material, which apparently represents the same Bahian species, has approximately 20 flowers per head as in many other species. The species remains distinguishable by its densely spirally inserted minute leaves. Five other Brazilian species, T. hirtiflora, T. grazielae, $T$. laxa, $T$. santosii, and $T$. villosa, can be distinguished from most others by the higher number (30-60) of flowers in the heads, but the five species do not form a natural group.

The genus is common in Brazil with a few species in Paraguay, Bolivia, and the northern Andes. The two species in Colombia and Venezuela can be keyed in Aristeguieta (1964). A key to the Brazilian species has been provided by Barroso (1950) and distinctions of many Brazilian species are given by King and Robinson (1980b).

The following 30 species are recognized in the genus:

Trichogonia arguta (H.B.K.) Benth. \& Hook. ex Klatt, Colombia, Venezuela.

Trichogonia attenuata G. Barroso, Brazil.

Trichogonia bishopii R. King \& H. Robinson, Bolivia.

Trichogonia campestris Gardner, Brazil.

Trichogonia capitata (Rusby) B. Robinson, Bolivia.

Trichogonia chodatii (Hassler) R. King \& H. Robinson, Paraguay. Trichogonia cinerea (Gardner) R. King \& H. Robinson, Brazil. Trichogonia dubia (B. Robinson) R. King \& H. Robinson, Brazil. Trichogonia fiebrigii Mattf. in Pilger, Brazil, Paraguay. Trichogonia grazielae R. King \& H. Robinson, Brazil. Trichogonia harleyi R. King \& H. Robinson, Brazil. Trichogonia hassleri Mattf. in Pilger, Paraguay.

Trichogonia heringeri R. King \& H. Robinson, Brazil. Trichogonia hirtiflora (DC.) Schultz-Bip. ex Baker, Brazil. Trichogonia laxa Gardner, Brazil.

Trichogonia margarethi Soares Nunes, Brazil.

Trichogonia martii Baker, Brazil.

Trichogonia menthaefolia Gardner, Brazil.

Trichogonia phlebodes (B. Robinson) R. King \& H. Robinson, Paraguay.

Trichogonia prancii G. Barroso, Brazil.

Trichogonia pseudocampesiris R. King \& H. Robinson, Brazil. Trichogonia rhadinocarpa B. Robinson, Colombia, Venezuela.

Trichogonia rhodotricha Malme, Brazil.

Trichogonia salviaefolia Gardner, Brazil, Paraguay.

Trichogonia santosii R. King \& H. Robinson, Brazil.

Trichogonia scottmorii R. King \& H. Robinson, Brazil.

Trichogonia spathulaefolia Mattf. in Pilger, Brazil.

Trichogonia tombadorensis R. King \& H. Robinson, Brazil.

Trichogonia villosa Schultz-Bip. ex Baker, Brazil.

Trichogonia zehntneri Mattf. in Pilger, Brazil.

\section{Trichogoniopsis}

Trichogoniopsis R. King \& H. Robinson, Phytologia 24: 180. 1972. TYPE: Eupatorium adenanthum DC. Kuhnia section Leiogonia DC., Prodr. 5: 127. 1836. LeCTOTYPE: Kuhnia podocarpa DC.

Erect perennial herbs or subshrubs, with few branches. Stems terete, scarcely or not striate, hirsute. Leaves alternate or opposite, distinctly petiolate; blades ovate, base cuneate to cordate, margin serrate. Inflorescence 


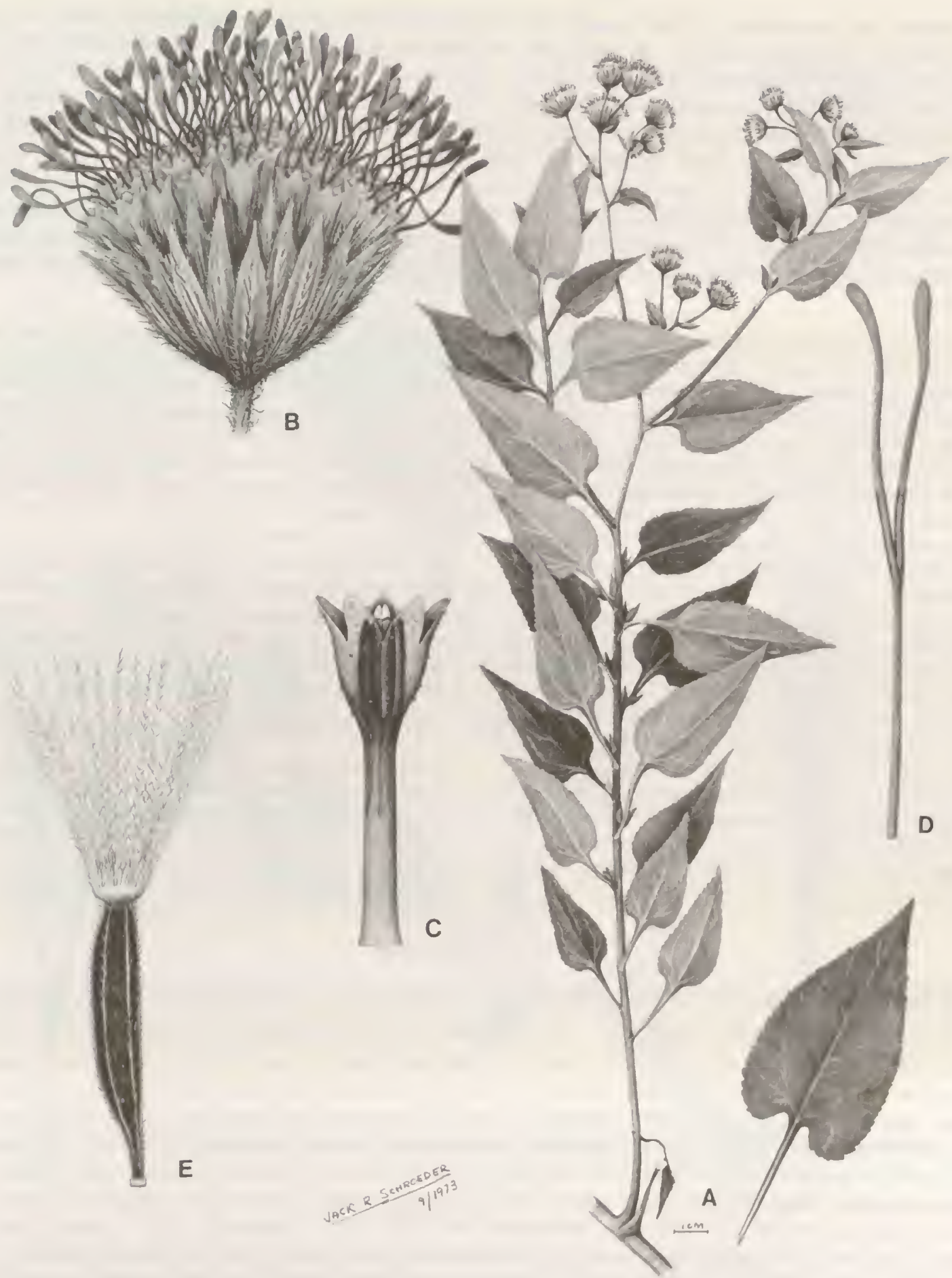

Plate 24. Trichogoniopsis adenantha (DC.) R. King \& H. Robinson, - A. Habit with separate lower leaf, $\times 1 / 2 .-B, H e a d, \times 5,-$ C. Corolla showing anthers, $\times 12$. - D. Style, $\times 12 .-$ E. Achene, $\times 12$. 
a lax cymose or corymbose panicle; heads with moderately long pedicels. Involucral bracts ca. 18-20, eximbricate, in 2 series, subequal; receptacle flat or shallowly convex, glabrous. Florets $25-50$ in a head; corollas white, narrowly funnelform, outer surface with few or no hairs above; cells of limb oblong with slightly sinuous walls; lobes broadly triangular, ca. 1.5 times as long as wide, inner surface smooth, outer surface smooth and glanduliferous; anther collars narrow, cells usually oblong with strong annular thickenings on walls; anther appendage ovate, shorter than wide, strongly retuse to bilobed; style base not enlarged, glabrous; style branches long-clavate, slightly mamillose. Achenes prismatic, 5-ribbed, with a narrow stipitate base, hispidulous with setulae not restricted to ribs; carpopodium small, short-cylindrical, cells subquadrate with moderately thickened walls, in 3-5 series; pappus of ca. 30 plumose persistent bristles in one series, mostly smooth on outer surface, apical cells of bristles slenderly acute. Pollen grains ca. $23 \mu \mathrm{m}$ in diameter. Plate 24.

The genus is named after the related genus Trichogonia with which it shares a number characteristics including a plumose pappus, an essentially flat receptacle, and narrow bases on the achenes. Trichogoniopsis differs by the lack of a dense covering of hairs on the upper part of the corolla, the lack of distinct ridges on the stem, and the deeply to completely cleft anther appendage. The achenes have setulae, contrary to the statement of DeCandolle (1836) under his section Leiogonia, but such setulae are not restricted to the angles of the achene as in many species of Trichogonia.

Trichogoniopsis was not included in Trichogonia either by DeCandolle, or when the latter was raised to generic level by Gardner (1846). The first to include species lacking hairs on the corollas was apparently Asa Gray (1851). The species continued to be treated as part of Trichogonia until their removal by King and Robinson (1972cc).

The species of Trichogoniopsis seem to have been particularly subject to misinterpretation. Asa Gray concluded incorrectly that Eupatorium adenanthum of DeCandolle was the species now known as Macropodina bradei and provided a new name, Trichogonia gardneri for the
DeCandolle species. The error remained uncorrected until the study of King and Robinson (1972cc), and most material in herbaria under the name $E$. adenanthum is $M a c$ ropodina. More recently, King and Robinson (1980b) have shown that the Kuhnia podocarpa of DeCandolle has been misinterpreted by various authors (J. Baker, 1876) as a true Trichogonia, but that it is actually the proper name for the species of Trichogoniopsis commonly known as Trichogonia macrolepis Baker.

Trichogoniopsis is restricted to Brazil, ranging near the coast from Sao Paulo in the south to Pernambuco in the north. Trichogoniopsis podocarpa seems to be most common in restinga habitats. A key to three of the species is provided by Soares Nunes (1981), and other distinctions are given by King and Robinson $(1980 b)$.

The following four species are recognized in the genus:

Trichogoniopsis adenantha (DC.) R. King \& H. Robinson, Brazil. Trichogoniopsis grazielae Soares Nunes, Brazil.

Trichogoniopsis morii R. King \& H. Robinson, Brazil.

Trichogoniopsis podocarpa (DC.) R. King \& H. Robinson, Brazil.

\section{Platypodanthera}

\section{Platypodanthera R. King \& H. Robinson, Phytologia 24: 182. 1972. TYPE: Ageratum melissaefolium DC.}

Erect perennial herbs, with few branches. Stems terete or slightly hexagonal, faintly striated, glabrous to sparsely pilose. Leaves usually alternate, distinctly petiolate; blades ovate to lanceolate, base cuneate to subtruncate or rarely cordate, margin serrate. Inflorescence a lax cymose or subcorymbose panicle with elongate basal internodes; heads with moderately long pedicels, pedicels fistulose above. Involucral bracts ca. 35 , eximbricate, in 2 series, mostly subequal; receptacle low-conical, glabrous. Florets ca. 100 in a head; corollas pink or lavender, narrowly funnelform, glabrous; cells oblong with sinuous lateral walls; lobes broadly triangular, slightly longer than wide, smooth on both surfaces; anther collars short, greatly expanded below, cells subquadrate with strongly annulate thickenings on walls; anther appendage slightly shorter than wide, truncate; style base not enlarged, glabrous; style branches longly and rather broadly clavate, smooth. Achenes prismatic, 5-ribbed, with narrow usually stipitate base, setuliferous on ribs and upper surfaces; carpopodium narrowly annuliform, cells small, subquadrate, in 2-3 series, with moderately thickened walls; pappus of 15-20 rather broad, subplumosely fimbriate bristles of various lengths, mostly half to two-thirds as long as corolla, in one congested series, smooth on outer surface, apical cells of bristles acute. Pollen grains ca. 18 $\mu \mathrm{m}$ in diameter. Plate 25. 


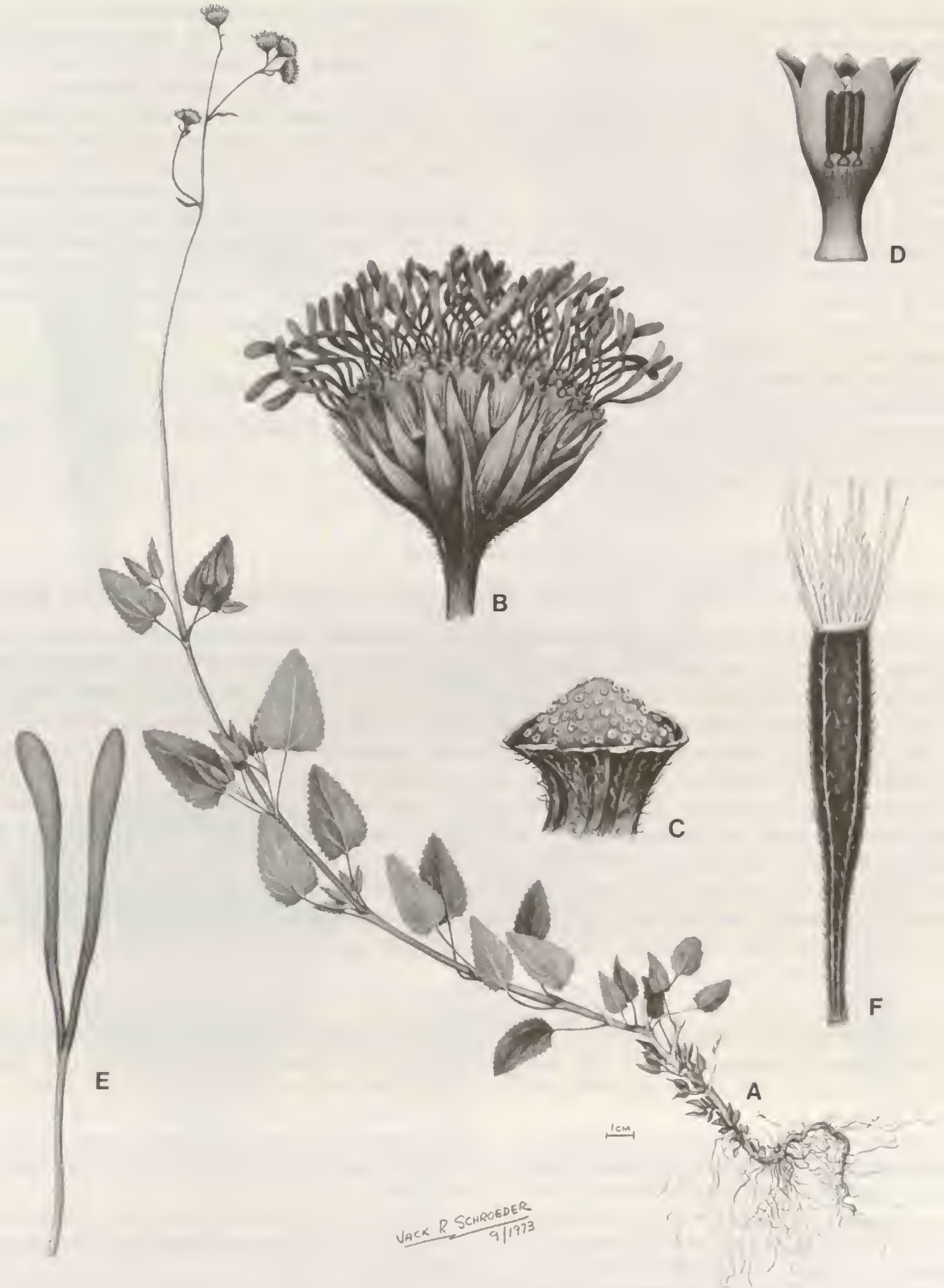

Plate 25. Platypodanthera melissaefolia (DC.) R. King \& H. Robinson, - A. Habit, $\times 2 / 5 .-$ B. Head, $\times 5 .-$ C. Receptacle, $\times 5 .-$ D. Corolla showing anthers, $\times 15,-$ E. Style, $\times 15 .-F$. Achene, $\times 15$. 
The genus contains a single species which was originally described as an Ageratum by DeCandolle (1836) and was later transferred to Trichogonia by Mattfeld (1923). Even by traditional standards, the species did not fit comfortably in either genus in which it had been placed. Platypodanthera differs from Ageratum by the numerous broad fimbriate bristles of the pappus, by the slender base on the achene, and by the lack of sunken glandular punctations on the leaves. The Brazilian species is also geographically remote from the center of diversity of Ageralum in Mexico and Central America, and the two genera are presently regarded as members of two different subtribes. Platypodanthera is more like Trichogonia in the multisegmented pappus and the slender achene bases, but differs by the tendency of the receptacle to be conical, by the broader fimbriate rather than plumose pappus bristles, by the essentially smooth stems, and by the glabrous corollas. One additional feature distinguishes the genus from both Ageratum and Trichogonia, the short and basally broad- ened anther collar. It is after the unique form of collar, which is often as broad as long, that the genus Platypodanthera is named. The pedicels, slightly broadened and fistulose above, are also somewhat distinctive.

The genus is known only from Bahia and Pernambuco in Brazil. The typical variant has the broader sometimes cordate leaves from which the species derives its name. The other variant, from the Rio Contas area, has narrowly 'anceolate leaves and more glabrous sometimes slightly hexagonal stems. Both variants have been grown from achenes and maintain their differences, but they hybridize with the broad-leaved form showing incomplete dominance. There are no obvious differences in the structure of the inflorescences.

The following single species is recognized in the genus: Platypodanthera melissaefolia (DC.) R. King \& H. Robinson, Brazil.

\section{Neocuatrecasia}

\section{Neocuatrecasia R. King \& H. Robinson, Phytologia 20: 332. 1970. TYPE: Eupatorium lobatum B. Robinson.}

Erect to procumbent perennial herbs, unbranched to densely branched. Stems terete, faintly striated. Leaves usually opposite, sessile to distinctly petiolate; blades ovate to deltoid or narrowly oblong, margin entire or dentate to deeply lobed. Inflorescence a lax to rather dense corymbose or cymose panicle; heads pedicellate. Involucral bracts ca. 10, eximbricate, in ca. 2 series, subequal; receptacle convex, glabrous. Florets 17-50 in a head; corolla white, with narrow basal tube, with abruptly expanded usually elongate and campanulate throat; cells of limb oblong with sinuous lateral walls; lobes triangular, longer than wide, inner surface densely papillose, outer surface smooth with a few hairs; anther collars short, cells subquadrate with dense transverse annular thickenings on walls; anther appendage ovate, longer than wide; style base enlarged, covered with hairs; style branches longly clavate, densely papillose. Achenes prismatic, 5-ribbed, with narrowly stipitate base, densely setuliferous; carpopodium short-cylindrical to annuliform, cells small, subquadrate, in ca. 35 series, with thin somewhat beaded walls; pappus of ca. 20-30 usually persistent and contiguous bristles in one series (rather deciduous and not contiguous in $N$. sessilifolia), apical cells of bristles acute. Pollen grains ca. 19-23 $\mu \mathrm{m}$ in diameter. Plate 26.

The genus is named for Dr. Jose Cuatrecasas of the Smithsonian Institution, in Washington D.C., who has extensively studied the flora of the Andes, especially the Asteraceae.

The genus consists of eight species that are distributed along the eastern slopes of the Andes in southeastern Peru and northcentral Bolivia. The distribution is west of and at higher elevation than most members of the Gyptidinae. The distribution, corolla shape, and cellular structure of the carpopodium are actually reminiscent of the genus Ageratina of the Oxylobinae, but Neocuatrecasia has hairs on the style base and dense annular thickenings on the cells of the anther collar, characters never seen in the Oxylobinae. The anther collars and the stipitate bases of the achenes are indicative of a rela tionship closer to Trichogonia, and pubescent style bases, while rather rare, are known in the Gyptidinae.
Some members of the genus are notable for their dissected leaves. One species, $N$. sessilifolia, is distinct in both the sessile leaves and the fragile non-contiguous pappus bristles. In $N$. mancoana and $N$. hirtella the pubescence or papillosity of the style base continues upward on the lower part of the shaft, while in other species it is restricted to a tuft at the base.

A key to species has been provided by King and Robinson (1972v) with two species added subsequently (King \& Robinson, 1974c).

The following eight species are recognized in the genus: Neocuatrecasia cuzcoensis R. King \& H. Robinson, Peru. Neocuatrecasia dispar (B. Robinson) R. King \& H. Robinson,
Peru.

Neocuatrecasia hirtella R. King \& H. Robinson, Peru. 


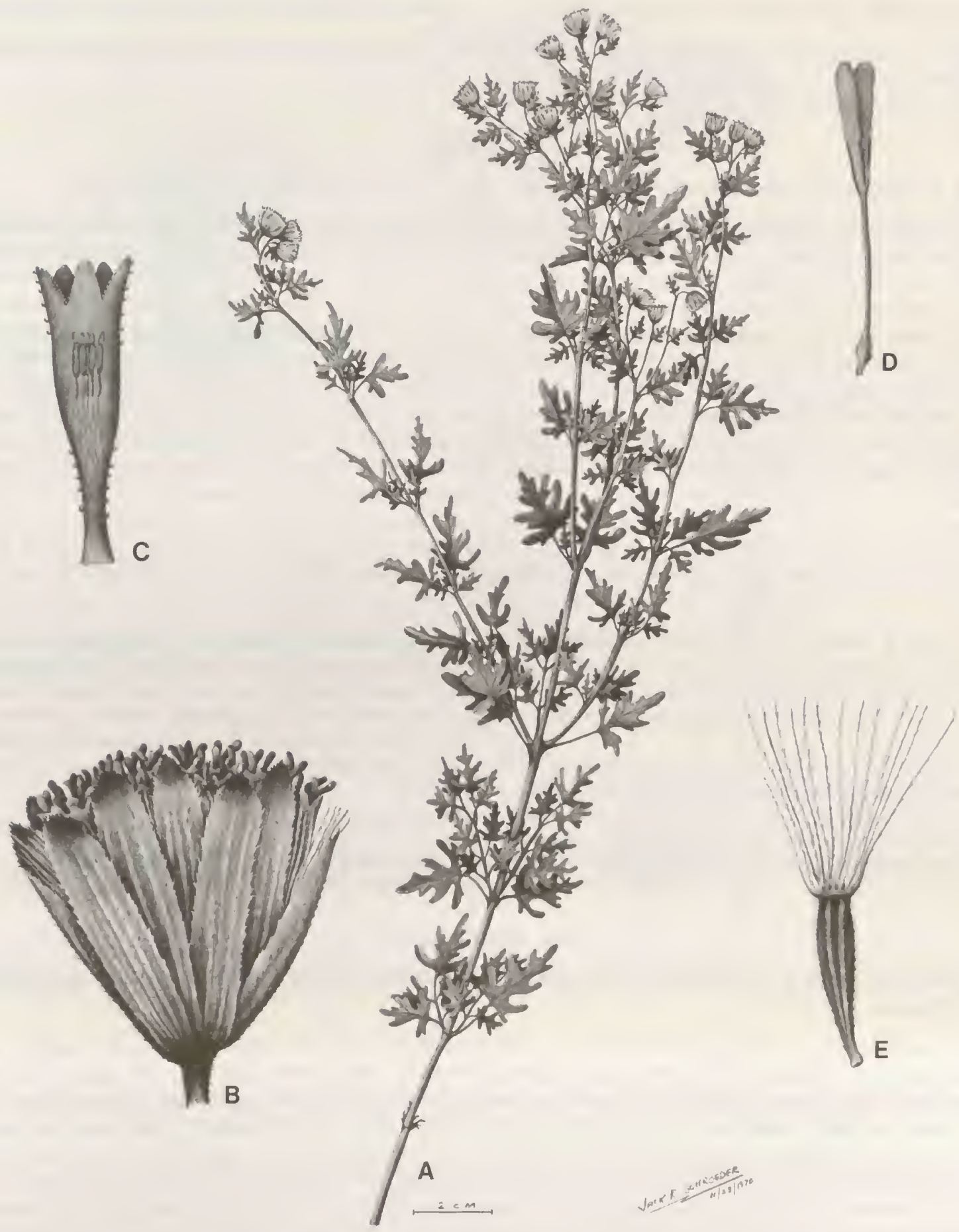

Plate 26. Neocuatrecasia lobata (B. Robinson) R. King \& H. Robinson. - A. Habit, $\times 3 / 5 .-B$. Head, $\times 7$. C. Corolla showing anthers, $\times 12,-D$. Style, $\times 12,-$ E. Achene, $\times 12$. 
Neocuatrecasia lobala (B. Robinson) R. King \& H. Robinson, Bolivia.

Neocuatrecasia mancoana (B. Robinson) R. King \& H. Robinson, Peru.

Neocuatrecasia sessilifolia R. King \& H. Robinson, Peru.
Neocuatrecasia thymifolia (Britton) R. King \& H. Robinson, Bolivia.

Neocuatrecasia weddellii (B. Robinson) R. King \& H. Robinson, Peru.

\section{Vittetia}

\section{Vittetia R. King \& H. Robinson, Phytologia 29: 122. 1974. TYPE: Eupatorium orbiculatum DC.}

Erect shrubs or subshrubs, woody at least at base, with few to many branches. Stems terete, minutely hirtellous. Leaves opposite or alternate, very short-petioled, subsessile; blades orbicular to broadly ovate or oblong, base broadly rounded, margin entire to crenate-serrate, distinctly trinervate from base. Inflorescence an ascending multi-branched corymbose panicle; heads rather slenderly pedicellate. Involucral bracts ca. 1015 , eximbricate, in ca. 2 series, subequal; receptacle flat, glabrous to minutely puberulous. Florets $10-12$ in a head; corollas white to pink, narrowly funnelform or with narrow basal tube and rather campanulate limb; cells of limb elongate, often with closely sinuous lateral walls; lobes ovate-triangular, slightly longer than wide, smooth on both surfaces, with glands on outer surface; anther collar short-cylindrical, cells mostly subquadrate below, with dense transverse annular thickenings on walls; anther appendage ovate, as long as or slightly longer than wide; style base not enlarged, glabrous; style branches narrowly to broadly linear or narrowly clavate, densely sharply papillose, papillae sometimes very long. Achenes prismatic, 7-10-ribbed, glanduliferous, with few to many uniseriate non-glandular hairs; carpopodium small, annuliform to shortcylindrical, with minute subquadrate cells in 2-4 series, walls thin to slightly thickened; pappus of 30-65 persistent bristles in one series, apical cells of bristles sharply acute. Pollen grains ca. 20-27 $\mu \mathrm{m}$ in diameter. Plate 27.

The genus is named for Nelly Vittet, coauthor with Cabrera on the studies of the Vernonieae and Eupatorieae of Santa Catarina in Brazil $(1961,1963)$. The genus is the only member of the Gyptidinae with seven or more ribs on the achenes.

The genus consists of two species restricted to southeastern Brazil, the type species in Santa Catarina, Paraná, and Sao Paulo, and $V$. bishopii from the Serro do Cipó area of Minas Gerais. The two species are not similar in superficial aspect, and are very different in the general shape of the corolla, but ribbing of the achene, the pres- ence of uniseriate hairs and lack of twin-hairs on the achene, the broad subsessile leaves, the strongly ascending branches of the inflorescence, the detailed structure of the corolla lobes, and the dense sharp papillosity of the style branches, all indicate relationship. The similarities and differences of the two species are discussed by King and Robinson (1981g).

The following two species are recognized in the genus: Viltetia bishopii R. King \& H. Robinson, Brazil. Vittetia orbiculata (DC.) R. King \& H. Robinson, Brazil.

\section{Litothamnus}

\section{Litothamnus R. King \& H. Robinson, Phytologia 44: 80. 1979. TYPE: Litothamnus ellipticus R. King \& H.
Robinson.}

Erect moderately branching, glabrous shrubs with subcarnose stems and leaves. Stems 4-6-angled, more strongly grooved when dry; internodes short to moderate in length. Leaves opposite, with short often stout shiny, lower surface somewhat dulled, trinervate from above base with secondary veins nearly parallel to lower margin. Inflorescence corymbose, with opposite branches; heads short to moderately long-pedicellate. Involucral bracts 12-15, eximbricate, in ca. 2 series, subequal, often with reddish tips, outer bracts broad with prominulous irregular venation; receptacle flat, glabrous. Florets ca. 15 in a head; corollas white, narrowly funnelform, sparsely glandular-puberulous on outer surface; cells of throat elongate with sinuous lateral walls; lobes ovate-triangular, slightly longer than wide, inner surface with short-oblong to subquadrate cells, mamillose, outer surface papillose; anther collar short-cylindrical, cells short-oblong to subquadrate with dense mostly transverse annular thickenings on walls; anther appendage oblong, slightly longer than wide; style glabrous or with few minute gland-tipped hairs above; carpopotently papillose. Achenes prismatic, 5-ribbed, 

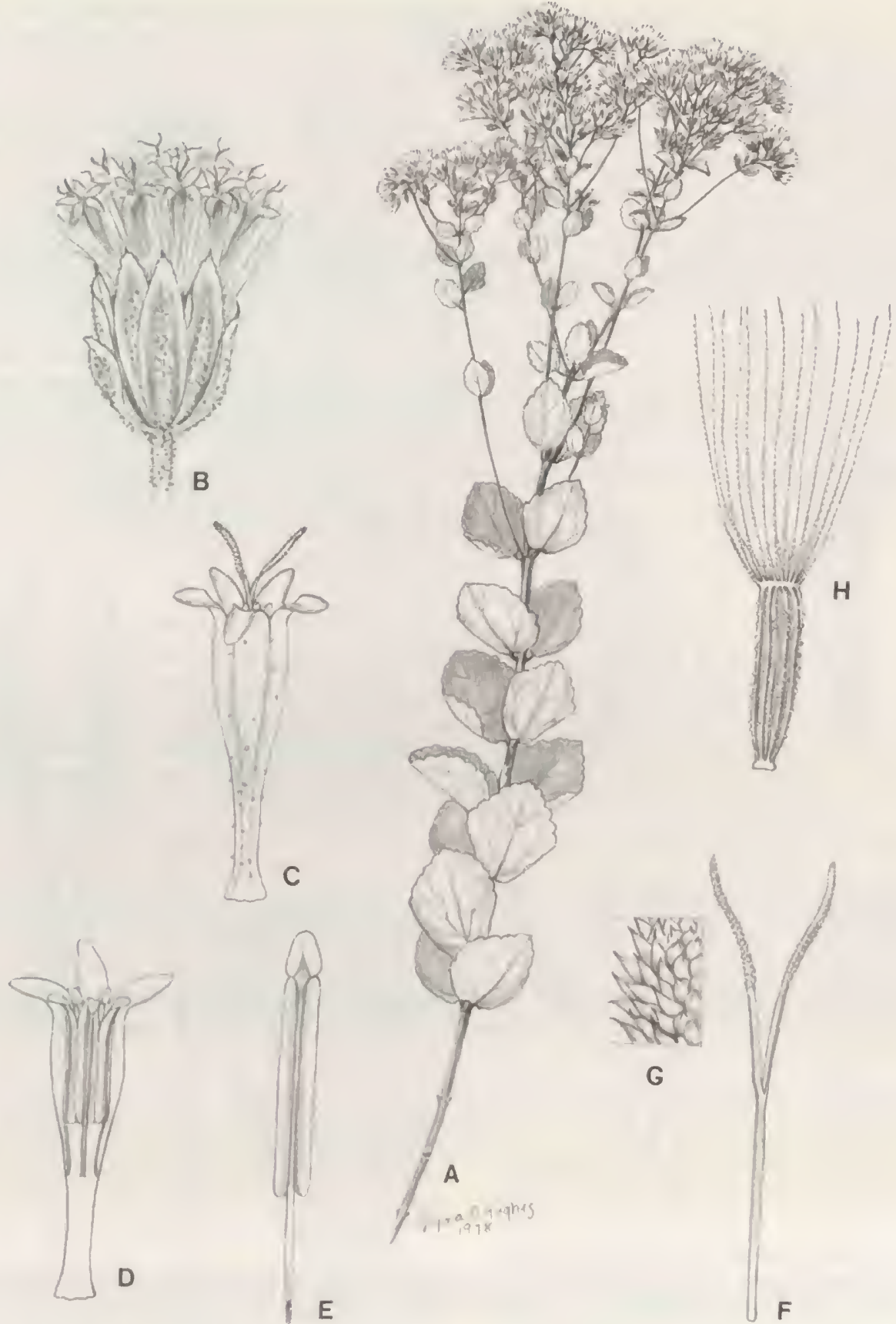

Plate 27. Vitteria orbiculala (DC.) R. King \& H. Robinson. - A. Habit, $\times 1 / 2 .-$ B. Head, $\times 5 .-$ C. Corolla outer surface, $\times 10 .-D$. Corolla inner surface with anthers, $\times 10 .-$ E. Anther, $\times 20 .-F$. Style, $\times 10$, with separate enlarged segment of papillae on appendage. G. Achene, $\times 10$.

series, with thin or slightly thickened walls; pappus with ca. 30 persistent densely scabrid bristles, congested, subbiseriate, apical cells of bristles sharply acute. Pollen grains ca. 20-22 $\mu \mathrm{m}$ in diameter. Plate 28.

The coriaceous to subcarnose, glabrous, elliptical to obovate, opposite leaves distinguish Litohamnus from all other members of the Gyptidinae, and closest relationship is difficult to determine. The shrubby habit is reminiscent 


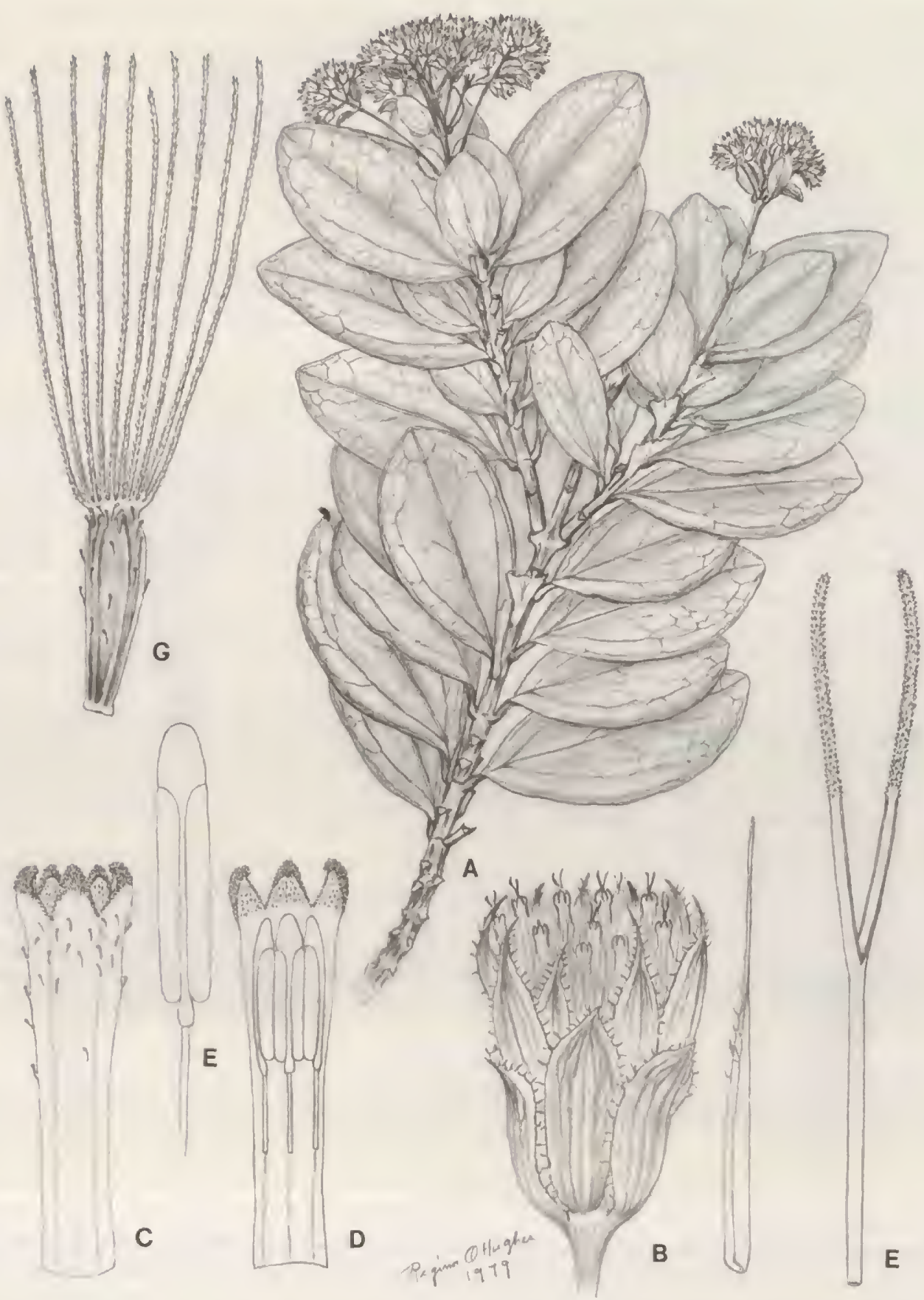

PlATE 28. Litothamnus ellipticus R. King \& H. Robinson. - A. Habit, $\times 1 / 2 .-$ B. Head with separate inner involucral bract, $\times 5$. C. Corolla outer surface, $\times 14 .-$ D. Corolla inner surface with anthers, $\times 14 .-$ E. Anther, $\times 28 .-F$. Style, $\times 14 .-$ G. Achene, $\times 14$.

of Prolobus, also along the coast of Bahia, but the latter has an anomalous expansion of the inner surface of the corolla lobes and an expanded carpopodium with thickwalled cells, unlike anything in Litothamnus. Two other shrubby genera from south-central Bahia, Bahianthus and
Morithamnus, have obovate, viscid leaves, have wellformed resin ducts in the throats of their corollas, and also have essentially glabrous outer surfaces on their pappus segments. Other genera of the subtribe differ even more by various characters including sometimes herba- 
ceous habits, conical receptacles, pubescent bases or shafts of their styles, or reduced forms of anther appendages. At present, Litothamnus is regarded as clearly a member of the Gyptidinae, but rather isolated within that subtribe.

Litothamnus is not totally without resemblance to any other member of the Eupatorieae. Some of the collections seen have been named as Kanimia nitida, a species now placed in Mikania that has a remarkable similarity to Litothamnus vegetatively. Both species occur in the shrubby zone along the coast of Bahia, the Mikania in the central part of the state in the area of Salvador south to the Rio Contas, and Litothamnus farther south in the Itabuna area southward to Porto Seguro. The two species are almost indistinguishable when sterile, the Mikania differing only by having leaves that tend to be slightly smaller and more pointed. Flowering plants of the two species differ by all the features that characterize the two different subtribes Gyptidinae and Mikaniinae, and there is no evidence of close relationship.

In some cases, previous identifiers have noted that specimens of Litothammus have more than four flowers in a head, and have distinguished the specimens from Mikania nitida. On those occasions, unfortunately, the name $E u$ patorium carnosifolium has been applied. The latter name is appropriate for Litothamnus in its meaning, but it belongs to a totally different species that is presently recognized as Diacranthera crenata. The misidentifications of material of Litothamnus have contributed to the fact that the species remained undescribed until 1979.

The name of the genus derives from the Greek words litos (= plain or simple), and thamnos (= shrub).

The following single species is recognized in the genus:

Litothamnus ellipticus R. King \& H. Robinson, Brazil.

\section{Bahianthus}

\section{Bahianthus R. King \& H. Robinson, Phytologia 23: 312. 1972. TYPE: Mikania viscosa Sprengel.}

Erect shrubs, moderately branching, with stems, leaves, and involucres viscid. Stems terete, striated. Leaves densely spirally inserted, with distinct narrow petioles; blades obovate with narrowly cuneate acuminate base, distal margin serrate across an obtuse or truncate apex, with strongly ascending closely pinnate venation, veins and close reticulum of veinlets prominulous on both surfaces; resin cavities in leaves irregular, not forming continuous ducts. Inflorescence a corymbose panicle, branching strongly ascending and mostly extraaxillary, pedicels glabrous and striated; heads hemispherical. Involucral bracts 18-20, weakly subimbricate, in ca. 3 series, somewhat unequal to subequal, linear to lanceolate; receptacle flat to slightly convex, glabrous. Florets 15-22 in a head; corollas pink or white, narrowly funnelform to subcylindrical, tubes scarcely narrower than throat, resin ducts narrow and solitary along veins of throat; cells of throat elongate with slightly sinuous lateral walls; lobes triangular, as long as wide or slightly longer, bearing glands outside, papillose toward tip, mamillose with isodiametric cells on inner surface; collars with subquadrate to short oblong cells with strongly annulate or intricate thickenings on walls; anther appendage oblong-ovate, about as long as wide; style base not enlarged, glabrous; style branches filiform with slightly clavate tips, densely patently papillose. Achenes prismatic, 4-5-ribbed, with few glands; carpopodium enlarged, procurrent on lower part of achene ribs, cells irregular to oblong, large, with firm thin walls; pappus with ca. 30 persistent shortly ciliate-dentate bristles in one series, flattened on outer surface, apical cells of bristles narrowly rounded. Pollen grains ca. $25 \mu \mathrm{m}$ in diameter. Plate 29.

The genus Bahianthus is endemic to south-central Bahia, the state of Brazil after which the genus is named. The single species seems rather common in some localities.

The nomenclatural history of the genus is representative of the confusion that has existed in the past regarding generic concepts in the Eupatorieae. The single species has been placed at various times in Mikania, Kuhnia, Gyptis, and Symphyopappus, and was only recently placed in Eupatorium by Steyermark (1953) on his reduction of the genus Symphyopappus. It is notable that previous authors have had such a disinclination to place a plant with the distinctive appearance of Bahianthus in the genus $E u$ patorium.

At the time Bahianthus was described (King \& Robinson, $1972 f$ ), little was understood of the various related members of the Gyptidinae in the area of Bahia. It was clear, however, that the species could not be accommodated under any generic name available at that time. Symphyopappus, which Bahianthus resembled in leaf surface and inflorescence form, was a genus with opposite leaves, strongly subimbricate involucres, and five flowers in a head, belonging to the subtribe Disynaphiinae. Agrianthus, which is similar in its spirally inserted leaves and prominulous leaf veins, is undoubtedly closely related, but has the leaves subsessile and ascending at the base, the receptacles more conical, and the heads subsessile in a terminal cluster. Agrianthus also has pubescent stems and often paleaceous receptacles.

The probable closest relative of Bahianthus is the genus Morithamnus, described as a genus only seven years ago (R. King et al., 1979). Both genera have viscid leaves and 

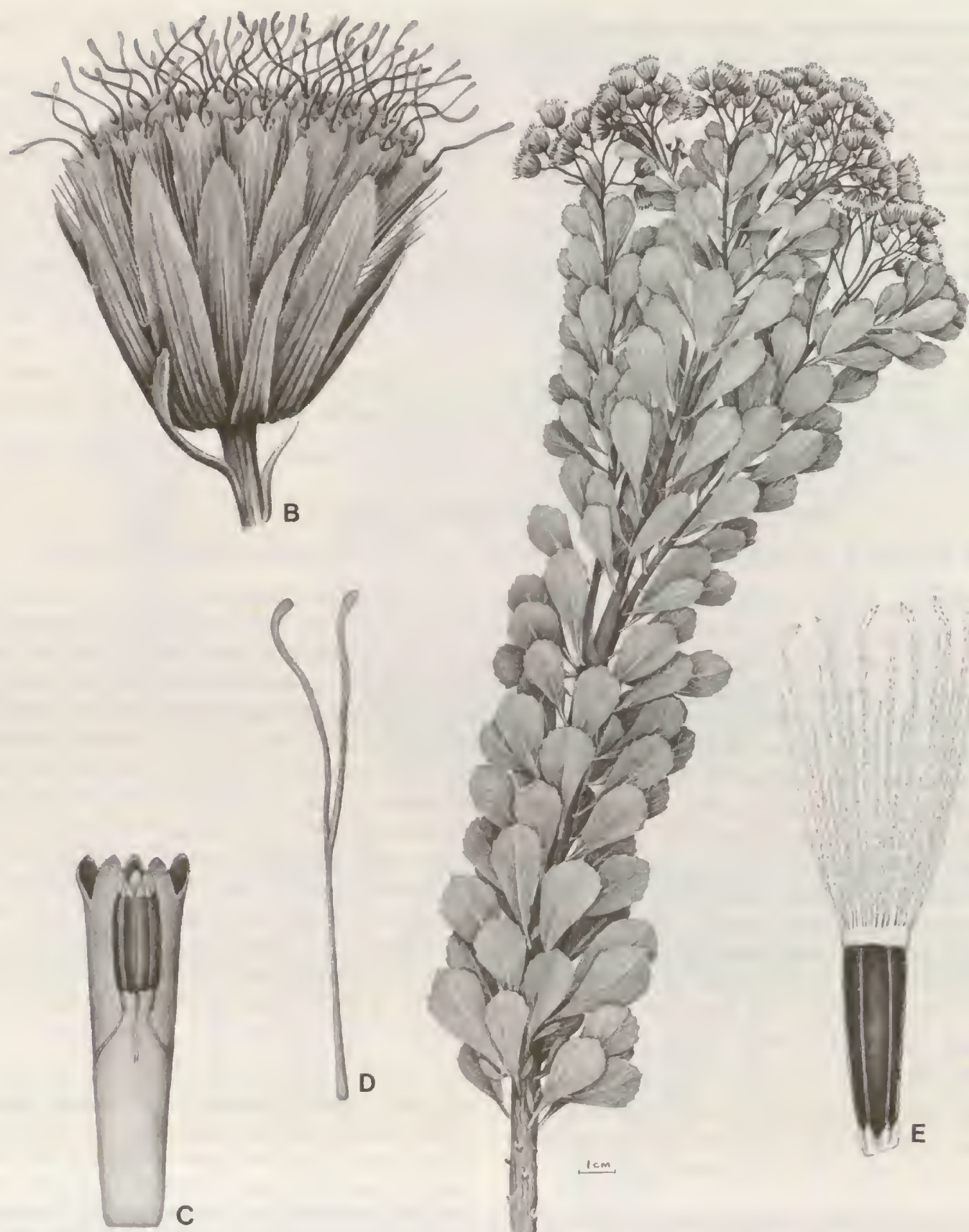
stems, cuneate leaf bases, resin ducts in the corollas, shoulders on the achene below the callus, and smooth outer surfaces on the pappus segments. Morithamnus differs from Bahianthus most obviously in the larger and more succulent stems and leaves, the strictly eximbricate involucral bracts with firm slender tips, the general greater size of the heads with ca. 25-100 flowers, the distinct paired resin ducts along the veins in the leaves and in the throats of the corollas, the setulae on the ribs near the apex of the achene, and the more regular width of the segments of the pappus.

The following single species is recognized in the genus: Bahianthus viscosus (Sprengel) R. King \& H. Robinson, Brazil.

\section{Morithamnus}

\section{Morithamnus R. King, H. Robinson \& G. Barroso, Phytologia 44: 452. 1979. TYPE: Morithamnus crassus} R. King, H. Robinson \& G. Barroso.

Erect shrubs or small trees, with candelabra-form branching, with stems, leaves and involucre viscid. Stems thick and fleshy, terete, subtly broadly striated, without hairs, with glandular punctations. Leaves opposite or alternate, long-petiolate; blades obovate to oblanceolate, to $15 \mathrm{~cm}$ long, base narrowly cuneate, margins entire, apex obtuse or acute; secondary veins somewhat irregular, subpinnate, strongly ascending, veinlets not prominulous, secondary veins with distinct resin ducts above and below. Inflorescence abruptly terminal on branches, withering with age and becoming overtopped by subfloral innovation, branches strongly ascending and mostly extra-axillary; pedicels moderately to very long; heads hemispherical. Involucral bracts ca. 35 , eximbricate, in 2 series, herbaceous, linear to narrowly lanceolate, with narrow tips, inner bracts persistent; receptacle flat to slightly convex, glabrous. Florets ca. 25-100 in a head; corollas pink or white, narrowly funnelform; tubes broad, gradually broadened into cylindrical throat; resin ducts of throat paired along veins; cells oblong with walls not or weakly sinuous in throat, gradually shorter in lobes; lobes ovateoblong, smooth inside, outside with glands and sometimes minutely crested; anther collar short-cylindrical, cells mostly oblong with dense transverse annular thickenings on walls; anther appendage oblong-ovate; style base not enlarged, glabrous; style branches filiform, densely papillose. Achene prismatic, 5-ribbed, with or without shoulders above, base shortly constricted, mostly glabrous, densely setuliferous on upper part of ribs; carpopodium short-cylindrical, cells subquadrate, rather large with firm scarcely thickened walls, in ca. 5 series; pappus with 20-25 capillary or irregularly shortened persistent segments, with outer surfaces flattened and essentially smooth, densely scabrid or sub-barbellate on margins, apical cells of segments sharply acute. Pollen grains $27-30 \mu \mathrm{m}$ in diameter. Plate 30 .

The genus is thoroughly distinct in the tribe by its robust, often candelabra-form, fleshy, viscid nature. Microscopically, the paired resin ducts along the veins in the leaves and corollas are unique in the Eupatorieae. The closest relative seems to be Bahianthus, from the same area of south-central Bahia, which has smaller, coriaceous, obovate to oblanceolate, viscid leaves, with prominulous venation; a similar form of inflorescence and receptacle, and a more subimbricate involucre and blunter involucral bracts. Bahianthus also has resin ducts in the corolla, but single along each vein, and has pappus bristles flattened and smooth on the outer surface, but more irregular in width and toothing. The fact that the generic differences are consistent between the two quite different species of Morithamnus, tends to reinforce the generic separation.

The two species of Morithamnus show some differences that are of interest in assessing the relationships of the genus. The type species has shoulders below the upper callus of the achene, similar to the achenes of Bahianthus, but the Mattfeld species seems to have nearly straight sides. The type species also has a short pappus, that was a partial factor in the initial establishment of the genus, but the Mattfeld species has bristles of more normal length. Such reductions of pappus length seem common in some members of the Gyptidinae, where they seem to be of very minor phyletic significance. Finally, the two species of Morithamnus differ in the insertion of their leaves. Phyllotaxy is unquestionably a character of erratic reliability in the Asteraceae, but the opposite-leaved condition of the Mattfeld species seems to intrude into a group of genera with spirally inserted leaves that has seemed, perhaps mistakenly, to be rather natural.

The genus honors Dr. Scott A. Mori, who was at the time of its description, Curator of the Herbarium at CEPEC in Itabuna in Bahia.

The following two species are recognized in the genus:

Morithamnus crassus R. King, H. Robinson \& G. Barroso, Brazil. Morithamnus ganophyllus (Mattf.) R. King \& H. Robinson, Brazil. 


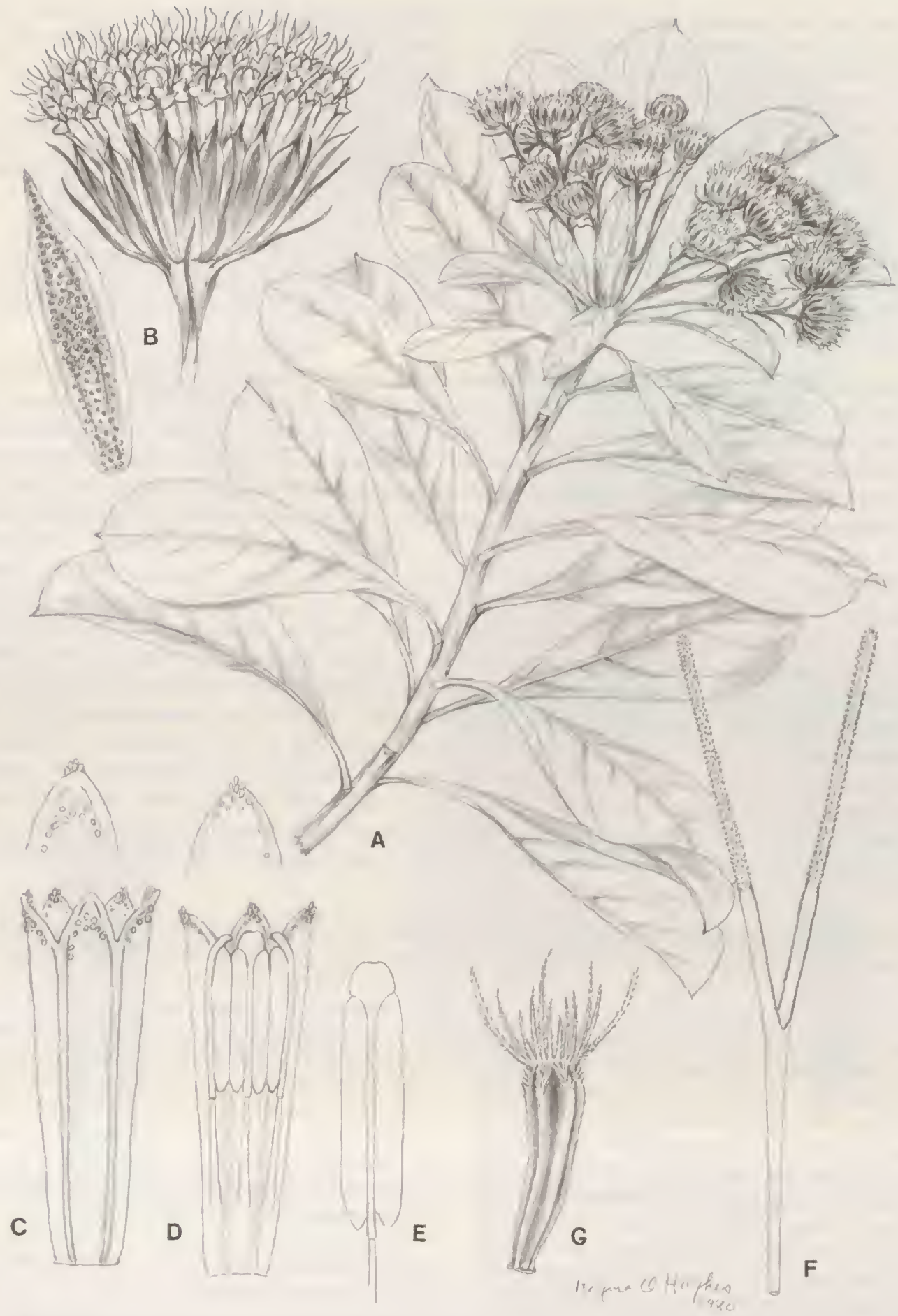

PLATE 30. Morithamnus crassus R. King, H. Robinson \& G. Barroso. - A. Habit, $\times 1 / 2 .-B$. Head, $\times 4$, with separate enlarged involucral bract. - C. Corolla outer surface, $\times 10$, with enlargement of lobe. $-D$. Corolla inner surface with anthers, $\times 10$, with enlargement
of lobe. - E. Anther, $\times 15$. - F. Style, $\times 10 .-$ G. Achene, $\times 10$. 


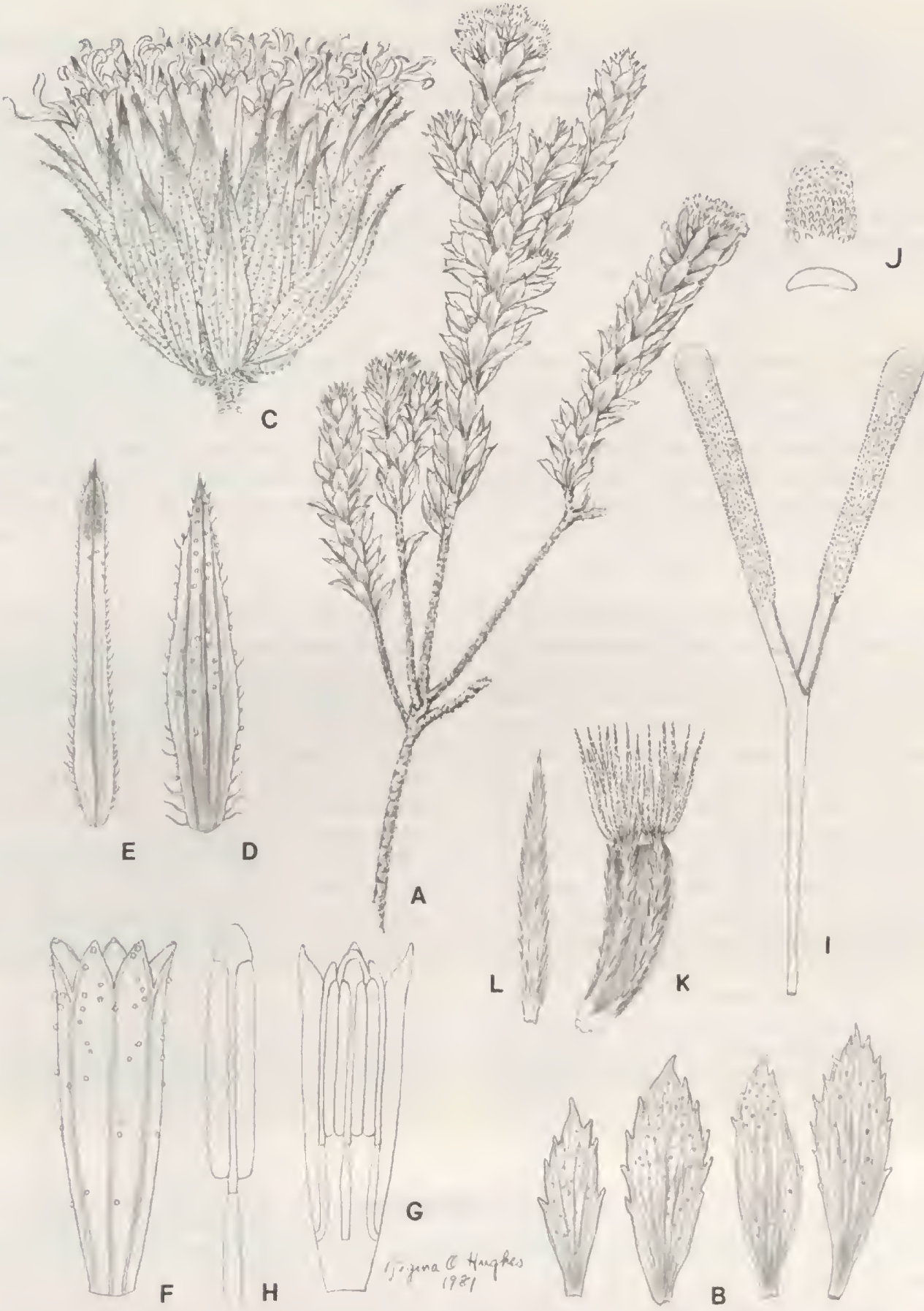

Plate 31. Agrianthus pungens Mattf. - A. Habit, $\times 1 \frac{1}{2}$. - B. Leaves, $\times 21 / 2 .-$ C. Head, $\times 5 .-$ D. Involucral bract, $\times 7 .-$ E. Palea, $\times 7 .-$ F. Corolla outer surface, $\times 10 .-$ G. Corolla inner surface with anthers, $\times 10 .-H$. Anther, $\times 15 .-$ I. Style, $\times$ I0. - J. Tip of style appendage in face view and section, $\times 15 .-\mathrm{K}$. Achene, $\times 10 .-\mathrm{L}$. Pappus bristle, $\times 25$. 


\section{Agrianthus}

Agrianthus C. Martius ex DC., Prodr. 5: 125. 1836. TYPE: Agrianthus campestris C. Martius ex DC.

Erect many-branched shrubs, with glabrous appearance. Stems terete, striated. Leaves densely spirally inserted, ascending from broadly sessile bases and usually imbricated, with tips often recurving, glabrous; blades elliptical to oblong-lanceolate or subulate, with venation subparallel, with large internal resin ducts in one layer. Inflorescence terminal on normal leafy branches, abrupt, a dense cluster of sessile or subsessile heads. Involucral bracts ca. 18-40, eximbricate to weakly subimbricate, in ca. 3 series, subequal, lanceolate; receptacle convex to conical, often with scattered narrow paleae, without hairs. Florets $20-45$ in a head; corollas usually purplish (white in $A$. campestris), narrowly funnelform, with single distinct resin ducts along veins in throat, cells of throat oblong with not or weakly sinuous lateral walls; lobes triangular, slightly longer than wide, mamillose to slightly papillose on inner surface, with slightly to strongly papillose apical cap on outer surface, with glands externally; anther collars cylindrical, cells subquadrate to short-oblong, becoming longer above, with dense annular or intricate thickenings on walls; anther appendages longer than wide; style base not enlarged, glabrous, shaft glabrous; style branches narrowly clavate, strongly mamillose. Achenes prismatic, 5-ribbed, stout, somewhat curved, slightly narrowed below, bearing setulae and occasional glands on surface; carpopodium annuliform, cells large, quadrate, rather thin-walled, in several series; pappus with 20-40 narrow sometimes subplumose segments in one series, as long as corolla in some species, less than one-third length of corolla in three species, flattened on outer surface, apical cells of segments mostly acute. Pollen grains ca. 27-30 $\mu \mathrm{m}$ in diameter. Plate 31.

The genus Agrianthus is one of the most distinctive in habit of any in the Eupatorieae, being distinguished appropriately by $\mathrm{B}$. Robinson in his key $(1913 a)$ on the basis of the sessile inflorescence and the squamiform imbricated leaves. The traditional acceptance of the genus, however, owes less to the distinctive aspect than to the short pappus found in a number of the species including the type. In Agrianthus, as in a number of other genera in the Gyptidinae, the length of the pappus is variable, some species having pappus bristles of normal length.

As a result of the distinctive aspect of the genus, the original concept, based on two species, was a natural one, and most subsequent additions have maintained the integrity of the group. The one striking exception was Agrianthus corymbosus, described by DeCandolle in his supplement to the Compositae in the Prodromus (1838). The latter species was recognized as at least sectionally distinct by DeCandolle on the basis of its pedicellate heads. On the basis of the different inflorescence form, the petiolate spreading leaves, and the pubescent shaft of the style, the latter species has subsequently been segregated into the genus Stylotrichium by Mattfeld (1923).

Agrianthus was originally described as having a glabrous receptacle, but paleae have been described from a number of the more recently described species, and the character has been used to distinguish between species by Mattfeld (1923). Paleae have been found in some material of $A$. empetrifolius, however, and occurrence of the character seems somewhat unreliable.

The genus is restricted to northern Minas Gerais and south-central Bahia in Brazil. The treatment by Mattfeld (1923) remains the only complete review of the species.

The following six species are recognized in the genus:

Agrianthus campestris C. Martius ex DC., Brazil. Agrianthus empetrifolius C. Martius ex DC., Brazil. Agrianthus leutzelburgii Mattf. in Pilger, Brazil. Agrianthus microlicioides Mattf. in Pilger, Brazil. Agrianthus myrtoides Mattf. in Pilger, Brazil. Agrianthus pungens Mattf. in Pilger, Brazil.

\section{Arrojadocharis} Arrojadocharis Mattf., Notizbl. Bot. Gart. Berlin-Dahlem 10: 1053. 1930. TYPE: Arrojadoa praxeloides Mattf.
in Pilger.

Arrojadoa Mattf. in Pilger, Notizbl. Bot. Gart. Berlin-Dahlem 8: 434. 1923. TYPE: Arrojadoa praxeloides Mattf. in Pilger, non Arrojadoa Britton \& Rose.

Annual or short-lived perennial herbs, with few branches, with intermixed biseriate glandular hairs and uniseriate non-glandular hairs on stems and leaves. Stems terete, striated. Leaves spirally inserted, sessile; blades linear, with parallel venation. Inflorescence of single heads or lax corymbs terminating leafy branches, heads short- to long-pedicellate. Involucral bracts ca. 20, eximbricate, in 2-3 series, subequal, narrowly lanceolate; receptacle highly conical, paleaceous in lower part. Florets ca. 50-60 in a head; corollas pink, 


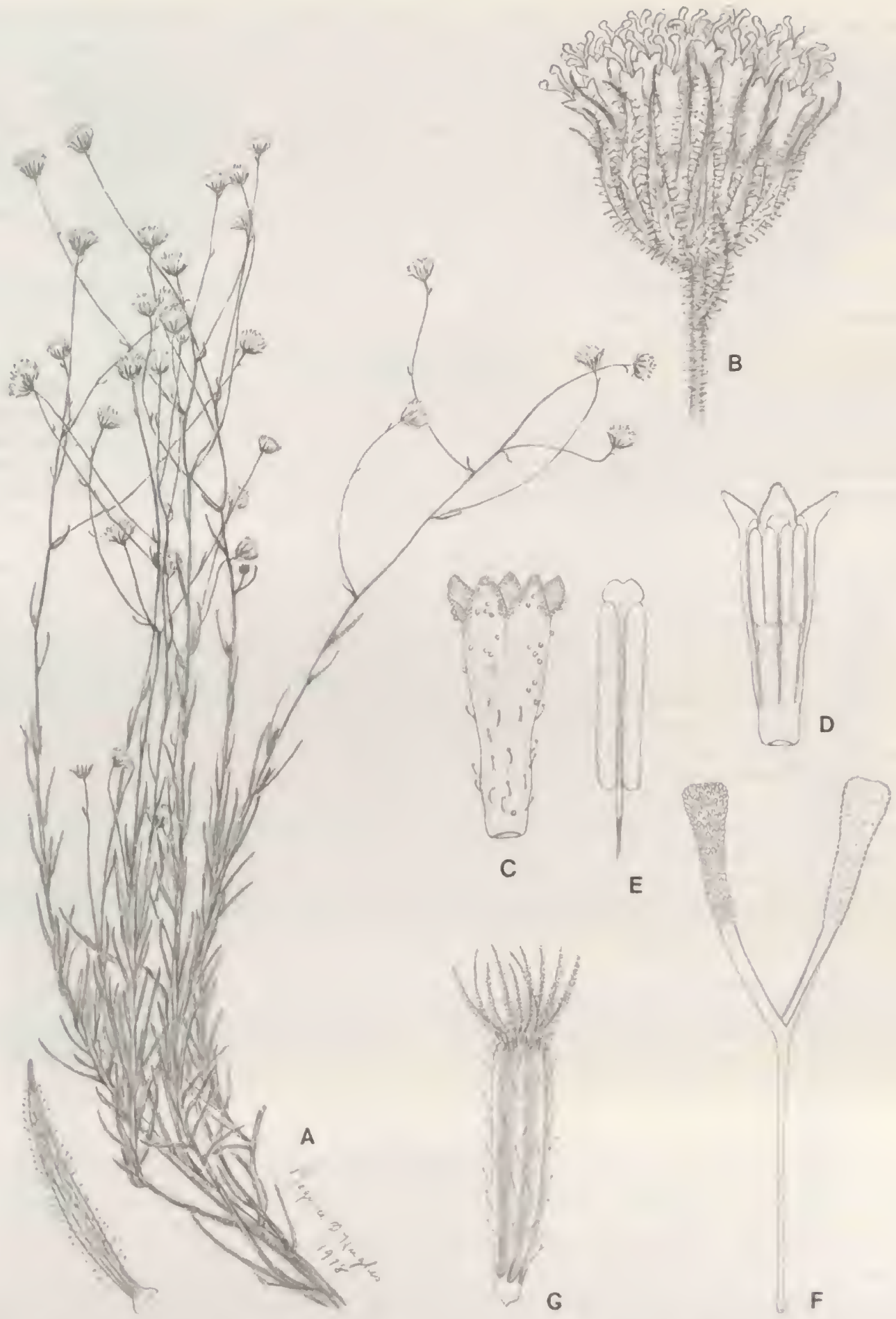

PLAte 32. Arrojadocharis praxeloides (Matt.) Mattf. - A. Habit, $\times 1 / 2$, with separate enlarged leaf. - B. Head, $\times 5 .-C$. Corolla outer surface, $\times 15 .-D$. Corolla inner surface with anther. $\times 15 .-$ E. Anther, $\times 30 .-F$. Siyle, $\times 15 .-$ G. Achene, $\times 15$. 
funnelform, with small glands on outer surface; cells of throat elongate with sinuous lateral walls; lobes triangular, slightly longer than wide, mamillose on inner surface, papillose on most of outer surface; anther collars cylindrical, cells mostly elongate, a few short-oblong cells below, densely ornamented with annular thickenings on walls; anther appendages mostly half to two-thirds as long as wide; style base not enlarged, glabrous, shaft of style glabrous; style branches clavate, mamillose. Achenes prismatic, 5-ribbed, stout, somewhat curved, slightly narrowed below, with setulae and occasional glands on sides; carpopodium cylindrical or annuliform, cells large, quadrate, with rather thin walls, in many series; pappus variable, lacking or with ca. 25 short or long bristles, apical cells of bristles acute. Pollen grains ca. $23 \mu \mathrm{m}$ in diameter. Plate 32.

The genus Arrojadocharis is most distinct in the highly conical receptacle with paleae on the lower part. The genus is also distinct among the Gyptidinae by the spirally inserted linear leaves.

In his original description of the genus, Mattfeld (1930) placed Arrojadoa in the typical element of the tribe, the Ageratinae as designated at that time, and mentioned various similarities to Eupatorium section Praxelis. The short pappus was apparently regarded as a primary distinguishing character. The short anther appendages were mentioned only in the description. By the time of the tribal survey of H. Robinson and King (1977), it was the short appendage of the anther that was given prime consideration, and the genus Arrojadocharis was placed in the Piqueria group with other genera such as Ageratum or Phania having a reduced anther appendage or reduced pappus or both. The genus was geographically somewhat anomalous in that primarily Central American and Andean group, however, and was without evident close relatives. Proper placement in the subtribe Gyptidinae was firmly established by King and Robinson (1979e) along with the description of a second species having a normal capillary pappus and a somewhat longer anther appendage. Except for the paleae on the receptacle, the latter species would have fallen into the broad traditional concept of Eupatorium, and was obviously not a member of the Ageratinae as presently conceived.

In the Gyptidinae, Arrojadocharis can be placed in a series of genera characterized by densely spirally inserted leaves. The genus is somewhat unusual but not unique in the subtribe by the very short anther appendage of the type species. Arrojadocharis is only the most extreme ex- ample of a number of genera in the Gyptidinae sometimes having a shortened pappus. The pappus variation includes some plants of Mattfeld type series which have no pappus whatsoever.

A point of interest involves the superficially similarlooking fine whitish spreading pubescence of the stems and leaves. The obvious hairs in the type species are biseriate and gland-tipped, while the hairs of similar size in A. santosii are uniseriate and non-glandular. Such structurally different hairs cannot be considered developmentally equivalent. Detailed examination shows that in each species minute examples of the contrasting type of hairs are intermixed. The actual difference proves to be in the relative prominence of the two differing hair types.

Both species of Arrojadocharis are known from single collections from the Bom Jesus and Pico das Almas areas in south-central Bahia, Brazil. The distinctions are discussed by King and Robinson (1979e).

The Asteraceous genus of Mattfeld and the Cactaceous genus of Britton and Rose were both named in honor of Dr. Miguel Arrojado Lisbõa, at one time superintendent of Estrada de Ferro Central de Brazil, who made extensive botanical explorations of the semiarid regions of Brazil in the early part of the twentieth century. The Cactaceous genus had priority by three years, and a variation of the name was provided as a replacement for the Asteraceous genus by Mattfeld (1930).

The following two species are recognized in the genus: Arrojadocharis praxeloides (Mattf.) Mattf., Brazil. Arrojadocharis santosii R. King \& H. Robinson, Brazil.

\section{Lasiolaena}

\section{Lasiolaena R. King \& H. Robinson, Phytologia 24: 185. 1972. TYPE: Eupatorium blanchetii Schultz-Bip.}

Erect shrubs, with few to many branches, with stems, leaves, and outer surfaces of involucre tomentose. Stems terete, striated. Leaves inserted in a dense spiral, short-petiolate; blades narrowly to broadly obovate, serrulate above, apex obtuse or shortly acute. Inflorescence densely corymbose on tips of leafy branches, heads short-pedicellate. Involucral bracts ca. 20, weakly subimbricate, in 2-3 series, mostly subequal, oblonglanceolate; receptacle distinctly conical, pilose with a few hairs. Florets 18-45 in a head; corollas narrowly funnelform, with scattered small glands on outer surface; cells of throat oblong with weakly sinuous or nonsinuous lateral walls; lobes triangular, slightly to distinctly papillose on both surfaces, with or without hairs on outer surface; anther collars cylindrical, with few to many subquadrate cells below, with longer cells 

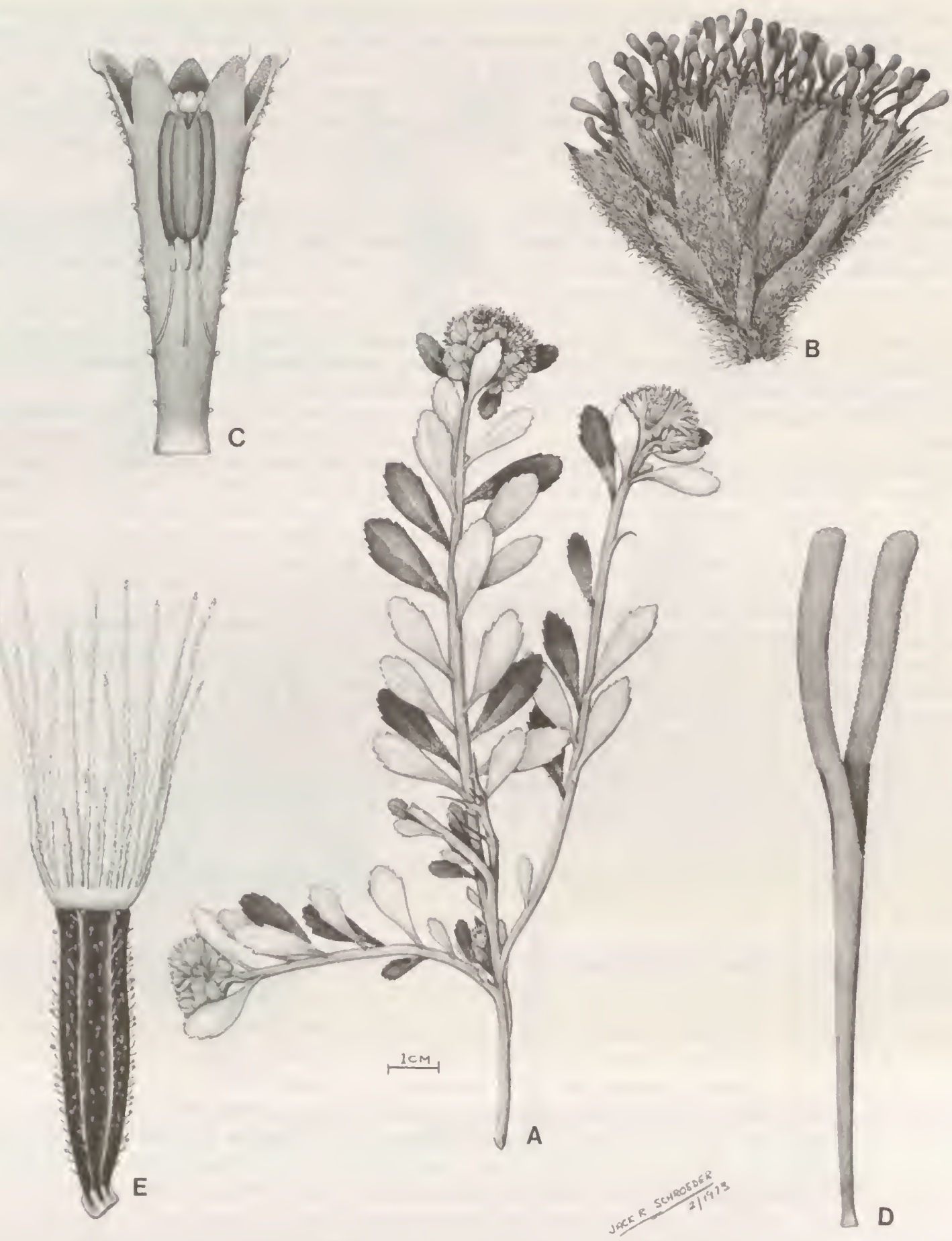

PLATE 33. Lasiolaena blanchetii (Schultz-Bip. ex Baker) R. King \& H. Robinson. - A. Habit, $\times 3 / 4 .-B$. Head, $\times 6 .-$ C. Corolla showing anthers, $\times 20 .-D$. Style, $\times 20 .-E$. Achene, $\times 20$. 
above, with dense annular thickenings on walls; anther appendages two-thirds as long as wide to slightly longer than wide; style base not enlarged, glabrous; style shaft glabrous; style branches linear, slightly mamillose to short-papillose. Achenes prismatic, 5-ribbed, slightly narrowed below, bearing setulae and glands; carpopodium annuliform with rather distinct upper rim, cells large and quadrate, in many series, with walls scarcely thickened; pappus with 20-40 persistent bristles in one congested series, bristles with scabrae fused into slight wing along lower margins, with outer surface flattened and nearly smooth, apical cells of bristles sometimes with rounded tips. Pollen grains ca. 20-25 $\mu \mathrm{m}$ in diameter. Plate 33.

The most distinctive features of Lasiolaena are the spirally arranged leaves, the tomentum on the stems, leaves, and involucres after which the genus is named, and the winged bristles of the pappus. The broadened pappus bristles approach or even exceed the limits of what should be called capillary. The conical receptacle of the genus was originally thought to indicate relationship to Barrosoa and Conocliniopsis (King \& Robinson, 1972ff), but the character occurs widely among various groups of genera in the Gyptidinae.

Closest relationship of Lasiolaena evidently lies with a series of genera having spirally inserted leaves and somewhat winged or broadened pappus segments, including Agrianthus, Stylotrichium, and Bahianthus. The latter genera have neither the tomentum nor the regularly elongate pappus segments of Lasiolaena. Also, each differs further by its own peculiarities, the sessile ascending imbricated leaves with parallel venation in Agrianthus, the densely glanduliferous white corollas, the more subumbellate inflorescence, the more eximbricate involucre, and the pubescent style shaft in Stylotrichium, and the glabrous viscid leaves, the subfasciate inflorescence, the corollas with distinct resin ducts, the glabrous achenes, and the flattened receptacle in Bahianthus. Of the genera mentioned, Bahianthus is considered the most remote, being itself more closely related to Morithamnus.
The anther appendages of most species of Lasiolaena are about as long as wide or slightly longer, but those of $L$. morii are only about two-thirds as long as wide in immature material seen. The appendages in mature material of the latter species seem unique in the tribe in being deciduous. Remnants of some mature appendages indicate a belated elongation and formation of a weak unsclerified intercalary zone at the base.

The genus Lasiolaena contains five known species, all from central and south-central Bahia in Brazil. Four of the species have been described during the present series of studies. Only one species is known from collections other than its type series, and discovery of additional species seems likely. A key is provided by King and Robinson $(1979 f)$ to four of the species, with one species added subsequently (King \& Robinson, 1980f).

The following five species are recognized in the genus:

Lasiolaena blanchetii (Schultz-Bip. ex Baker) R. King \& H. Robinson, Brazil.

Lasiolaena duartei R. King \& H. Robinson, Brazil.

Lasiolaena morii R. King \& H. Robinson, Brazil.

Lasiolaena pereirae $\mathrm{R}$. King \& H. Robinson, Brazil.

Lasiolaena santosii $\mathrm{R}$. King \& H. Robinson, Brazil.

\section{Stylotrichium}

Stylotrichium Mattf. in Pilger, Notizbl. Bot. Gart. Berlin-Dahlem 8: 436. 1923. TYPE: Agrianthus corymbosus DC.

Erect shrubs, with few to many branches, with stems, peduncles, and corollas bearing short Hieraceumtype hairs. Stems terete, striated. Leaves densely spirally inserted, narrowly sessile to short-petiolate; blades narrowly obovate to orbicular, undersurface with prominent reticulate venation. Inflorescence abruptly corymbose to subumbellate on tips of leafy branches; peduncles distinct, sometimes rather long. Involucral bracts ca. 25 , eximbricate, in ca. 2 series, subequal, oblanceolate, bicostate on outer surface; receptacle distinctly conical, glabrous. Florets ca. 25-50 in a head; corollas white, short-funnelform, with stalked glands below lobes, with sessile glands on outer surfaces of lobes; cells of throat oblong, with scarcely to distinctly sinuous lateral walls; lobes triangular, about as long as wide, mamillose on inner surface, papillose on most of outer surface; anther collars cylindrical, with few to many subquadrate cells below, cells becoming longer above, densely ornamented with annular or intricate thickenings; thecae reddish in most species (pale in $S$. corymbosum); anther appendages about half as long as wide, truncate or emarginate at apex; style base not enlarged, glabrous; style shaft and bases of style branches on outer surface densely pubescent with hairs and glands; style appendages with clavate tips, densely papillose below tips. Achenes prismatic, 5-ribbed, stout, somewhat curved, slightly narrowed below, bearing setulae and occasional glands on sides; carpopodium 


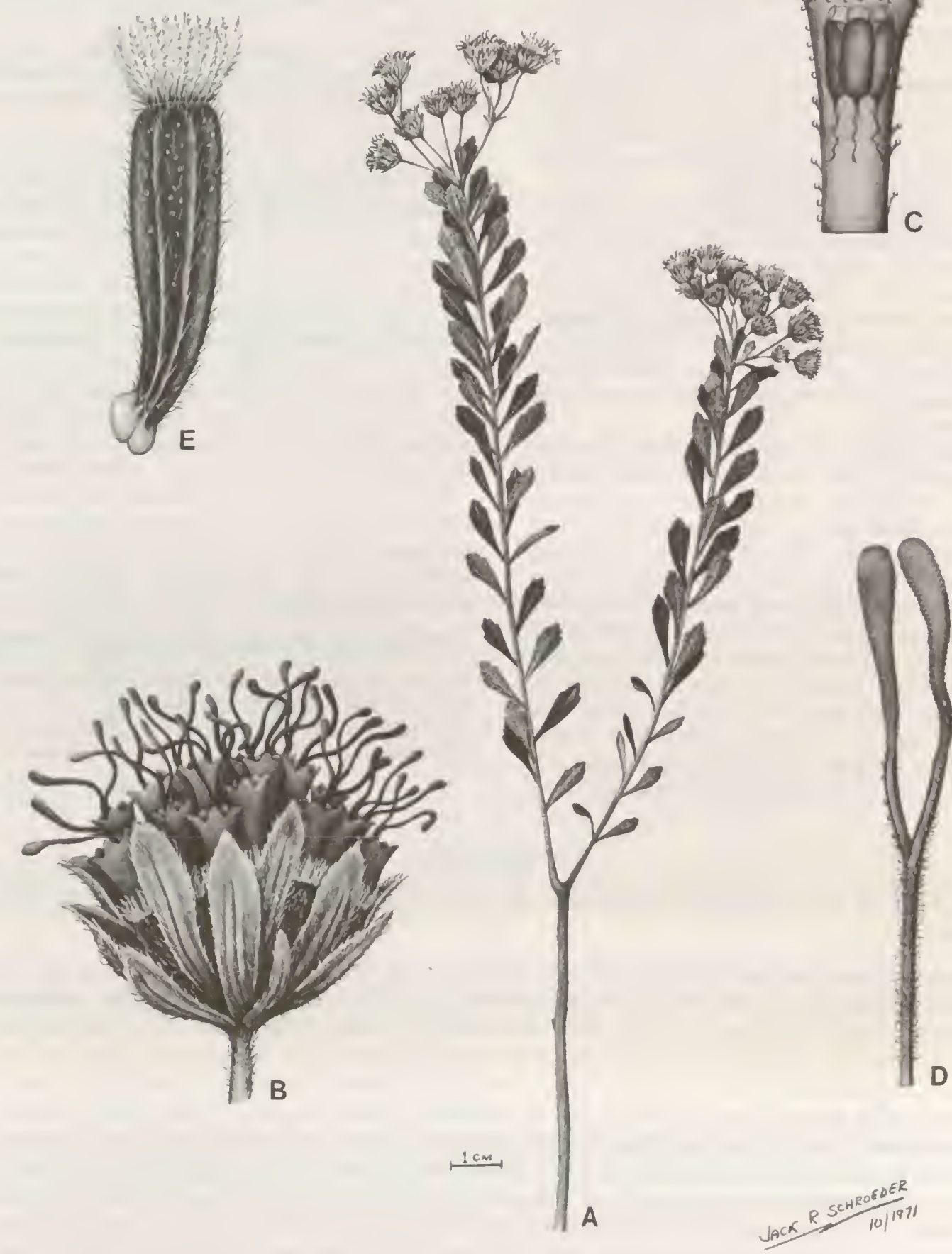

Plate 34. Stylotrichium corymbosum (DC.) Mattf. - A. Habil, $\times 3 / 4,-$ B. Head, $\times 6 .-$ C. Corolla showing anthers, $\times 20 .-D$. Style, $\times 20$. - E. Achene, $\times 20$.

cylindrical or annuliform, cells large, quadrate, in many series, with walls not thickened; pappus short or lacking, when present with 20-25 short, laterally densely fringed, persistent bristles in one series, apical cells of bristles often blunt. Pollen grains ca. 23-25 $\mu \mathrm{m}$ in diameter. Plate 34. 
Mattfeld (1923) named the genus Stylotrichium after its most distinctive feature, the dense pubescence on the shaft and lower part of the branches of the style. The character appears in all four of the known species, varying only by the lack of intermixed glands in S. edmundoi. Pubescence occurs on the style shaft in only one other genus of the Eupatorieae, the distantly related Sartorina of the subtribe Fleischmanninae. Closely related genera all have glabrous style shafts.

The species of Stylotrichium also all share a rather distinctive form of pubescence on the stems, peduncles, and corollas, unlike that in related genera. The majority of the hairs are a small form of what might be generally termed the Hieraceum-type, being biseriate with a triangular shape, and tapering to a tip which often bears a minute gland. The outer walls of the hair are somewhat thickened while the walls between the two rows of cells are thin and form a variably zigzag line.

Unlike many of the related genera, Stylotrichium has been spared inclusion in the broad concept of Eupatorium because of the consistently reduced form of the pappus. The type species was initially placed in Agrianthus, a genus to which it was related, but from which it differs strikingly in its foliation and style structure. The species was transferred at one point to Ageratum (J. Baker, 1876), a genus from which it differs most notably by the Gyptidine form of pappus with 20 or more segments. Originally, Mattfeld (1923) placed Stylotrichium in the then broadly defined typical subtribe of the Eupatorieae, but a close comparison was made with Agrianthus. The probable closest relative of Stylotrichium is Lasiolaena, which was known until recently from only one species placed in Eupatorium. Styl- otrichium differs from the latter by its unique pubescence features as well as some other characters mentioned under Lasiolaena.

In spite of one suggestion to the contrary, the corollas of Stylotrichium are apparently all white. The pink-flowered specimen cited as $S$. corymbosum by Barroso (1957) has proven to be a Lasiolaena.

Stylotrichium sucrei demonstrates that the genus is capable of significant diversity. The hairs of its stems, leaves, and peduncles have glandular tips while the hairs of the other species do not. The upper surfaces of its leaves are densely pubescent while the leaves of the other species have only a few hairs on the main veins. The corollas are longer and more funnelform, while in the other species the corollas are scarcely narrower below. The achene, which is the most distinctive part, has no pappus, has a short and very broad annuliform carpopodium, and a unique type of peg-like setulae with rounded tips, all different from the other species. Nevertheless, in all essential features of the genus, the species is a Stylotrichium.

The genus is endemic to central and south-central Bahia in Brazil. A treatment of the genus with a key to three of the species has been provided by Barroso (1957). Distinctions of the four known species, with some corrections of concepts, are given by King and Robinson (1980a).

The following four species are recognized in the genus:

Stylotrichium corymbosum (DC.) Mattf, in Pilger, Brazil.

Stylotrichium edmundoi G. Barroso, Brazil.

Stylotrichium rotundifolium Mattf. in Pilger, Brazil.

Stylotrichium sucrei R. King \& H. Robinson, Brazil.

\section{Bishopiella}

Bishopiella R. King \& H. Robinson, Phytologia 48: 418. 1981. TYPE: Bishopiella elegans R. King \& H. Robinson.

Acaulescent, scapose, annual or short-lived perennial herbs, without evident branching. Leaves forming a rosette, short-petiolate or sessile; blades fleshy, oblanceolate with narrowly cuneate base, margins entire, apex narrowly obtuse; secondary veins strongly ascending in trinervate form, obscure. Inflorescence with long scape, terminating in a small few-branched cyme; pedicels short; heads broadly campanulate. Involucral bracts ca. 20, eximbricate, in ca. 2 series, equal or subequal, linear-lanceolate; receptacle highly conical, glabrous, with large maculae and narrow recessed interstices. Florets ca. 40-50 in a head; corollas white, shortly funnelform from a broad, tapering, scarcely narrowed base, outer surface with a few short-stalked glands; cells of throat oblong with scarcely sinuous lateral walls; lobes ovate-triangular to triangular, as long as wide, strongly mamillose on inner surface, outer surface papillose near margins and apex; anther collar short-cylindrical, cells subquadrate to short-oblong, with strong transverse annular thickenings on walls; anther appendage about half as long as wide, broadly rounded to truncate at tip; style base not enlarged, glabrous; style branches broadly linear to strap-shaped, slightly broader distally, mamillose, essentially smooth at tip. Achenes short-prismatic, 5-ribbed, slightly narrowing below, with many long setulae on sides; carpopodium narrowly annuliform on broad achene base, somewhat indistinct, cells subquadrate, in 2-3 tiers, with walls usually thin; pappus of ca. 35 persistent bristles in one series, with dense fringes or wings of confluent scabrae on lateral margins, with flat and smooth outer surfaces, apical cells of bristles sharply acute. Pollen grains ca. 25-28 $\mu \mathrm{m}$ in diameter. Plate 35. 


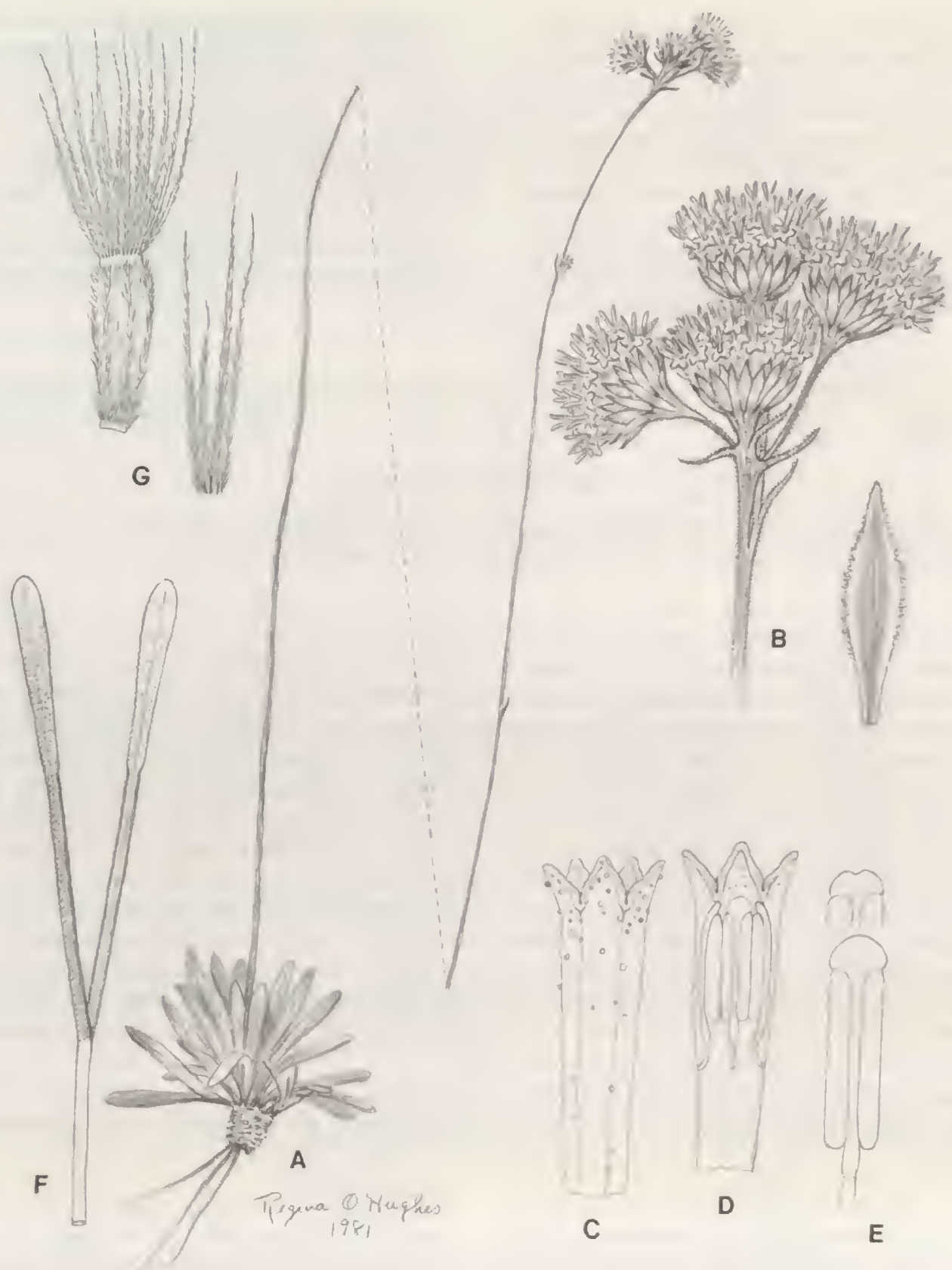

Plate 35. Bishopiella elegans R. King \& H. Robinson. - A. Habit, $\times 1 / 2 .-B$. Cluster of heads, $\times 1 \frac{1}{2}$, with separate enlarged representative involucral bract. - C. Corolla outer surface, $\times 12 .-$ D. Corolla inner surface with anthers, $\times 12 .-E$. Anthers showing appendage variation, $\times 22$. - F. Style, $\times 12 .-$ G. Achene, $\times 12$, with group of representative pappus bristles.

The genus Bishopiella is totally distinct within the Gyptidinae by the rosulate scapose habit. The habit is most closely approached elsewhere in the tribe in the remotely related West Indian genera Ciceronia and Antillia of the Critoniinae. Other Eupatorieae with rosulate leaves are restricted to the subtribe Liatrinae of the southeastern
United States. It is notable that of the members of the tribe having such habits, only Antillia was ever included within the broad concept of Eupatorium.

The characters of Bishopiella thoroughly distinguish the genus from any possible relatives, but detection of possible relatives within the Gyptidinae is made difficult. The con- 
ical receptacle with large maculae resembles those of $B a r$ rosoa, Dasycondylis, and Conocliniopsis, but Bishopiella differs from the first two of these by the small carpopodium and the dense setulae on the achene, and from the second by the simple base of the style. Neither does Bishopiella seem particularly reminiscent of the more shrubby Conocliniopsis. It is assumed in this treatment that the rosulate habit would be more easily derived from plants with spirally inserted leaves such as those of the Agrianthus relationship. Such plants are common in the area of south-central Bahia in Brazil where Bishopiella is found, and many show similarly fringed lateral margins on the pappus bristles. Such genera are mostly shrubs, however, and all have distinctive features of their own. The rela- tionships of Bishopiella within the Gyptidinae cannot be considered resolved, and the distinct impression remains of an isolated genus having the general characteristics of the subtribe, but having none of the peculiarities of any of the smaller generic complexes.

The genus is known from only the type-collection series of the single species. The habitat was a boggy marsh on the slope of the Pico das Almas.

The genus is one of two in the Eupatorieae named after the co-collector of the type specimens, Dr. Luther Earl Bishop.

The following single species is recognized in the genus: Bishopiella elegans R. King \& H. Robinson, Brazil.

\section{Campuloclinium}

\section{Campuloclinium DC., Prodr. 5: 136. 1836. TYPE: Eupatorium macrocephalum Less.}

Eupatorium section Campuloclinium (DC.) Benth. ex Baker in C. Martius, Fl. Bras. 6(2): 354. 1876.

Erect coarse herbs or subshrubs, with few to many branches. Stems terete, striated, usually hirsute. Leaves opposite or alternate, sessile or on narrowly winged petioles; blades ovate to narrowly oblong. Inflorescence corymbose, with few to many heads, with ultimate branches often long; heads moderate-sized or often large. Involucral bracts ca. 15-30, eximbricate to weakly subimbricate, in 2-3 series, subequal, often rather broad (fleshy at base in C. irwinii); receptacle highly rounded to conical, with small scars raised on protuberances, glabrous. Florets 30-100 in a head; corollas pink, lavender, or purple, narrowly funnelform, basal tube somewhat constricted above nectary; cells of throat elongate with sinuous lateral walls; lobes broadly triangular, usually slightly wider than long, with isodiametric usually mamillose or papillose cells on inner surface, slightly to strongly papillose with projecting cells on most of outer surface, with glands and often hairs outside; anther collar shortly cylindrical, cells subquadrate below, becoming longer above, with dense horizontal, oblique, or vertical thickenings on walls; anther appendage oblong, about as long as wide to ca. 1.5 times wider than long; style base not to distinctly enlarged, with few to many hairs (glabrous in C. irwinii); style branches broadly linear, flat, slightly mamillose to papillose. Achenes elongate, 4-7 mm long, prismatic, with narrowly stipitate base, with 5 prominent, pale, strongly setuliferous ribs, with few to many glands; carpopodium greatly enlarged, annuliform to very short-cylindrical, completely enclosing protuberances of receptacle when attached, with large cells subquadrate or wider, in ca. 6-8 series, walls slightly thickened; pappus of ca. 25-40 persistent scabrellous bristles in one series, usually elongate (short in C. alternifolium and $C$. campuloclinioides), apical cells of bristles subacute to acute. Pollen grains ca. 21-25 $\mu \mathrm{m}$ in diameter. Plate 36.

The genus Campuloclinium is named after the hemispherical to conical receptacle that was emphasized in the original description. Also apparently important in the original delimitation (DeCandolle, 1936) were the lack of hairs on the receptacle and the rather broad subequal bracts of the involucre. The value of the concept of DeCandolle can be judged by the fact that only one of the originally included species remains in the genus, others proving to be members of Praxelis, Barrosoa, and Dasycondylus.

Most authors since DeCandolle have treated Campuloclinium as a section of Eupatorium, and the definition of the group has been altered to emphasize heads of moderate to large size. The redelimited section of J. Baker
(1876) was a nearly natural group, flawed primarily by the exclusion of species with a short pappus. The two species excluded by Baker and placed in Ageratum, included one that had been described originally as Campuloclinium alternifolium by Gardner (1847) and one that Baker himself named campuloclinioides.

The redefinition of Campuloclinium with consideration of head size generally improved the naturalness of the concept, but some species with smaller heads such as $C$. parvulum could be excluded, and some totally unrelated species such as Ageratina zinniifolia of Colombia and Heterocondylus leptolepis of Brazil could be included. At the time of the restoration of generic status of Campuloclinium (King \& Robinson, 1972z), the distinctions empha- 


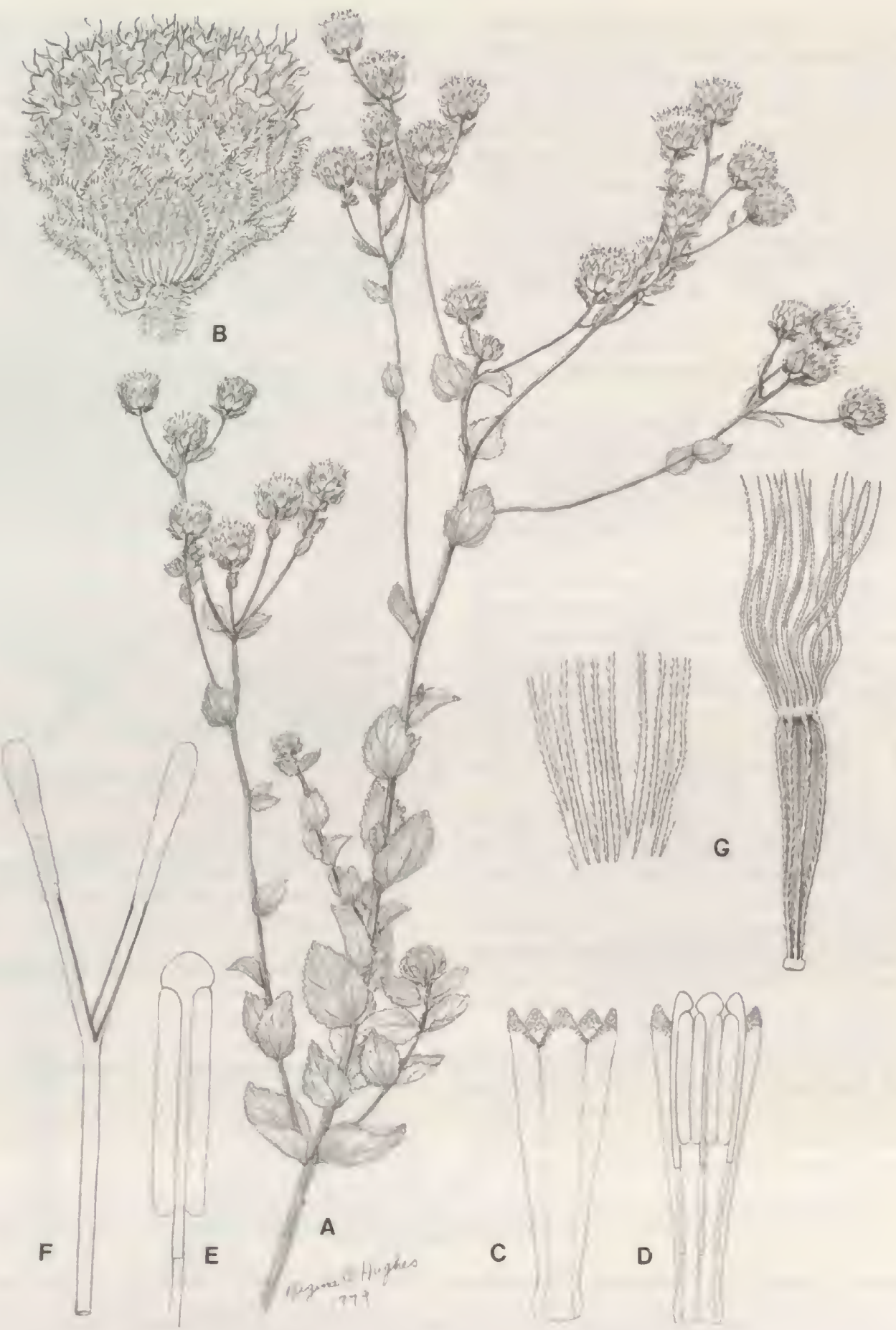

Plate 36. Campuloclinium megacephalum (C. Martius) R. King \& H. Robinson. - A. Habit, $\times 1 / 2 .$, B. Head, $\times 3 .-$ C. Corolla outer surface, $\times 10 .-$ D. Corolla inner surface with anthers, $\times 10 .-$ E. Anther, $\times 17 .-F$. Style, $\times 10 .-$ G. Achene, $\times 10$, with separate enlarged basal pappus segment. 
sized were again the receptacle, and in addition, the functionally interacting carpopodium of the achene. The small scars on the receptacle are unique in the tribe, and contrast particularly with the conical receptacles of many Gyptidinae such as Barrosoa and Conocliniopsis which have large maculae. In most genera of the tribe, the carpopodium tends to fit into a recess in the surface of the receptacle, but in Campuloclinium it is the small protuberance of the receptacle that tends to fit into the recess in the large carpopodium. It is notable that species showing the distinctive receptacle structure, also share a number of other distinctive features such as the elongate achenes with stipitate bases and prominent, pale, setuliferous ribs, usually pubescent style bases, and broad rather strap-shaped style branches.

During the early phases of the present series of studies, the pubescent and often enlarged style bases combined with the tendency for sessile or basally winged leaves, led to the belief that Campuloclinium was related to the Ayapana group (King \& Robinson, 1970r). The Ayapaninae have predominantly smooth corolla lobes, however, and involucres with graduated bracts in more series. Furthermore, enlarged and pubescent style bases are now known for a number of other genera that are unmistakably members of the Gyptidinae. Some species of Heterocondylus in the Ayapaninae are superficially similar to some members of Campuloclinium in habit, and might be mistaken for members of the genus by casual observers, but examination of details indicates that there is no close relationship.

Within the Gyptidinae, the habit and stipitate achene bases of Campuloclinium resemble those of some species of Trichogonia, and synonyms of two species of Campuloclinium have been named in Trichogonia. The two genera are readily distinguished by the form of the receptacles and carpopodia and by the pubescence of the corollas. Because of the unique details of the receptacle in Campuloclinium, the genus is not regarded as particularly close to Trichogonia in this treatment.

Species of Campuloclinium show considerable variation in habit, especially regarding a few large heads as opposed to many smaller heads. Such variations, however, are accompanied by a nearly total uniformity of essential details. The most basically distinctive species of the genus, $C$. irwinii, is unexceptional in appearance, being nearly identical in habit to $C$. burchellii. The species has an extremely high conical almost cylindrical receptacle that has caused specimens to be compared with the distantly related Eupatoriopsis hoffmanniana of the subtribe Praxelinae. The species also has a glabrous style base, rather short pappus bristles, and fleshy bases on the involucral bracts. In spite of the lack of superficial differences, the species seems isolated in the genus, and is a likely candidate for subgeneric distinction.

Campuloclinium is mostly restricted to Brazil with a few extensions into Paraguay and northern Argentina. One species, C. macrocephalum has a wider distribution from Brazil and northern Argentina to Colombia, Central America, and Mexico. No keys exist to the species of Campuloclinium as a group, but some of the distinctions are given in older treatments dealing with Eupatorium sensu lato in Brazil (J. Baker, 1876; Barroso, 1950; Cabrera \& Vittet, 1963). Distinctions of a few additional species are given by King and Robinson (1972tt, 1980f).

The following 14 species are recognized in the genus:

Campuloclinium alternifolium Gardner, Brazil.

Campuloclinium burchellii (Baker) R. King \& H. Robinson, Argentina, Brazil.

Campuloclinium campuloclinioides (Baker) R. King \& H. Robinson, Brazil.

Campuloclinium chlorolepis (Baker) R. King \& H. Robinson, Brazil.

Campuloclinium eiteniorum $\mathrm{R}$. King \& H. Robinson, Brazil.

Campuloclinium hickenii (Cabrera \& Vittet) R. King \& H. Robinson, Argentina.

Campuloclinium hirsutum Gardner, Brazil.

Campuloclinium irwinii R. King \& H. Robinson, Brazil.

Campuloclinium macrocephalum (Less.) DC., Mexico, Guatemala, Honduras, Colombia, Bolivia, Brazil, Paraguay, Argentina.

Campuloclinium megacephalum (C. Martius ex Baker) R. King \& H. Robinson, Brazil.

Campuloclinium parvulum (Glaz. ex B. Robinson) R. King \& H. Robinson, Brazil.

Campuloclinium purpurascens (Schultz-Bip. ex Baker) R. King \& H. Robinson, Brazil.

Campuloclinium riedelii (Baker) R. King \& H. Robinson, Brazil.

Campuloclinium tubaraoense (Hieron.) R. King \& H. Robinson, Brazil.

\section{Macropodina}

\section{Macropodina R. King \& H. Robinson, Phytologia 24: 173. 1972. TYPE: Eupatorium blumenavii Hieron.}

Erect subshrubs or shrubs, with moderate lax branching. Stems terete, faintly striated, puberulous to glanduliferous. Leaves usually opposite, becoming alternate above, distinctly petiolate; blades ovate, serrulate, trinervate from near base. Inflorescence a lax cyme; heads long-pedicellate. Involucral bracts 18 40, weakly subimbricate, in 3-4 series, narrowly elliptical to linear, with outer bracts distinctly shorter; receptacle flat to slightly convex, glabrous, with small scars. Florets 20-45 in a head, usually 25-30; corollas pale blue, narrowly funnelform, basal tubes elongate; cells of limb elongate with sinuous lateral walls; lobes oblongtriangular, ca. 3 times as long as wide, smooth on both surfaces, outer surface with small glands; anther 


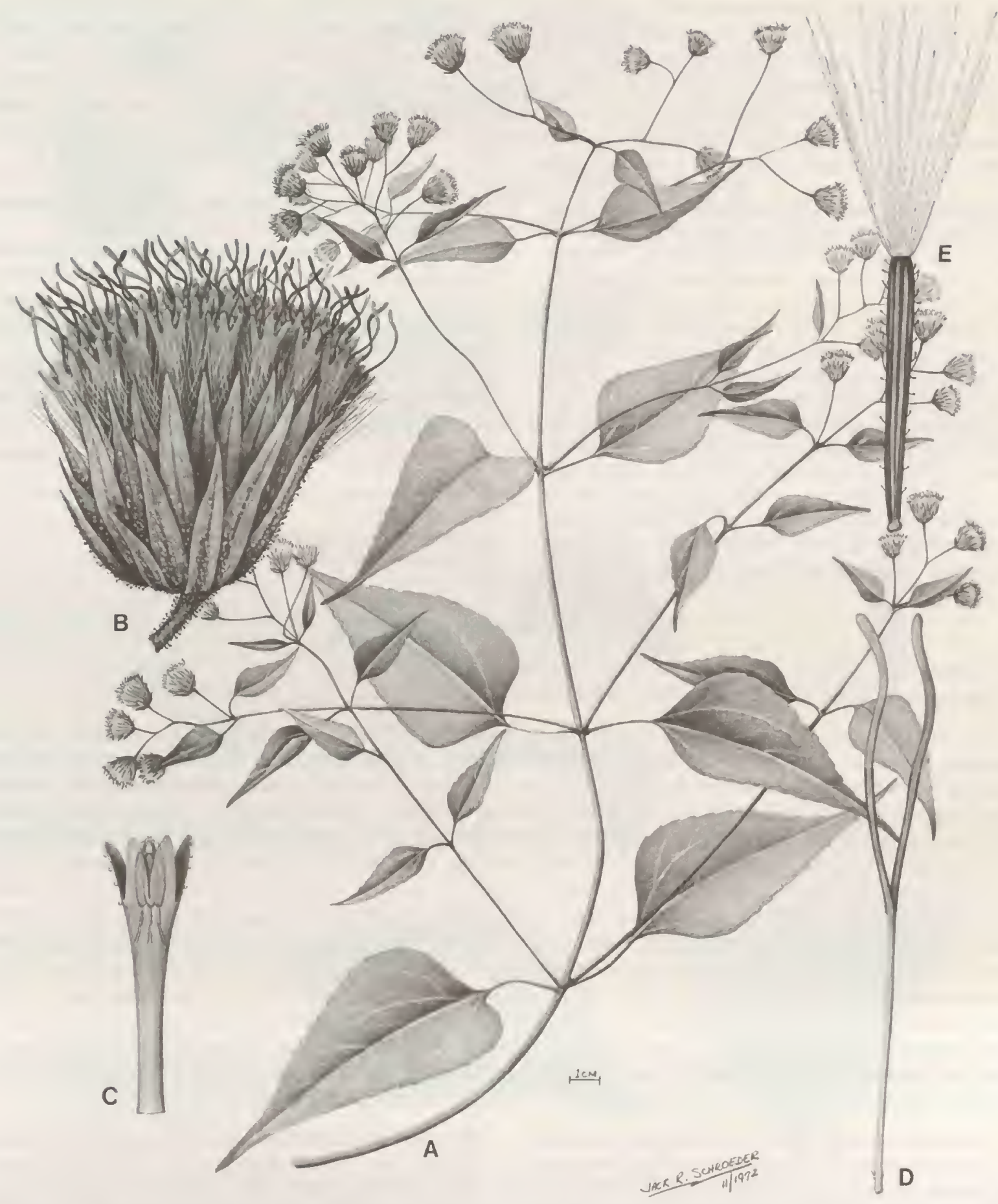

PLATE 37. Macropodina blumenavii (Hieron.) R. King \& H. Robinson. - A. Habit, $\times 1 / 2$. - B. Head, $\times 5 .-$ C. Corolla showing anthers, $\times 9 .-$ D. Style, $\times 9$. E. Achene, $\times 9$. 
collar cylindrical, cells subquadrate below, oblong above, with dense annular or intricate thickenings transversely, obliquely, or vertically on walls; anther appendage subquadrate, slightly longer than wide; style base not or only very slightly enlarged, sparsely to densely hirsute; style branches linear, smooth to slightly mamillose. Achenes prismatic, 5-6 $\mathrm{mm}$ long, with long basal stipe, 5-ribbed, sometimes minutely spiculiferous on ribs; carpopodium annuliform to very short-cylindrical, somewhat broader than stipe of achene, cells subquadrate in ca. 6-8 series, with walls slightly thickened; pappus of ca. 25-30 scabrellous persistent bristles in one series, apical cells of bristles subacute to acute. Pollen grains ca. 18-20 $\mu \mathrm{m}$ in diameter. Plate 37.

Macropodina is named for the narrow elongate bases of the achenes, a type of stipitate base found in various genera of the Trichogonia relationship and in Campuloclinium in the Gyptidinae. The length of the stipe, the slightly but distinctly broadened carpopodium with the rather large cells, the complex thickenings on the cells of the anther collar, and the pubescence on the base of the style all suggest that Macropodina is best placed near Campuloclinium. Actual relationship remains in question since Macropodina differs significantly from Campuloclinium in its flat receptacle, elongate smooth corolla lobes, narrow style branches, narrow concolorous achene ribs, and narrowly petiolate leaves. The long smooth corolla lobes of Macropodina are unique in the Gyptidinae, being more reminiscent of some Critoniinae, but the strong thickenings in the cells of the anther collar and the pu- bescence on the base of the style preclude any close relationship to members of the latter subtribe.

For more than 100 years, the most common species of the genus, Macropodina bradei, was known under the name Eupatorium adenanthum. The latter name is now known to apply to a species of Trichogoniopsis which has a habit somewhat similar to Macropodina.

Macropodina is restricted to the area of southern Brazil westward into Paraguay. Distinctions of the three species are discussed by King and Robinson (1972aa).

The following three species are recognized in the genus:

Macropodina blumenavii (Hieron.) R. King \& H. Robinson, Brazil, Paraguay.

Macropodina bradei R. King \& H. Robinson, Brazil. Macropodina reitzii $\mathrm{R}$. King \& H. Robinson, Brazil.

\section{Conoclinium}

Conoclinium DC., Prodr. 5: 135. 1836. TYPE: Eupatorium coelestinum L.

Eupatorium section Conoclinium (DC.) Benth. ex Baker in C. Martius, Fl. Bras. 6(2): 360. 1876.

Erect, rhizomatous, perennial herbs, not or sparingly branched above base. Stems terete, striated. Leaves opposite, petiolate; blades ovate to deltoid-ovate in outline, margin crenate to bipinnatifid, trinervate to tripartite from near base. Inflorescence laxly cymose below, with densely cymose branches; heads usually short-pedicellate. Involucral bracts ca. 25, eximbricate, in 2-3 series, mostly subequal, lanceolate; receptacle highly conical, glabrous, with depressed maculae of intermediate size. Florets 50-70 in a head; corollas blue or white, narrowly funnelform, with glands on outer surface; basal tube not constricted above nectary; cells of throat elongate with sinuous lateral walls; lobes triangular, slightly longer than wide, inner surface with short bulging cells, mamillose to short-papillose, outer surface papillose in distal half; anther collars cylindrical, often narrow, cells short-oblong below, longer above, with dense transverse annular thickenings on walls; anther appendage ovate to subquadrate, about as long as wide; style base not enlarged, glabrous; style branches narrowly linear to filiform, slightly broadened distally, densely papillose. Achenes prismatic, with a short narrowed base, 5-ribbed, glabrous or with a few scattered glands (with setulae above in C. greggii); carpopodium usually obsolete, with very few sclerified cells (distinct and asymmetrical in C. greggii); pappus of ca. 30 scabrid persistent bristles in one series, often with slightly to distinctly enlarged tips, apical cells of bristles obtuse to rounded. Pollen grains ca. 18-23 $\mu \mathrm{m}$ in diameter. Plate 38.

Conoclinium was established by DeCandolle for a series of Eupatorian species having glabrous conical receptacles and narrow eximbricate involucral bracts, the conical receptacle being the basis of the name. Of the five original species, the two from the United States and Mexico remain in the genus as delimited in the present treatment. The others of the original species and a number of other South American species, that have been placed in the genus or section Conoclinium, have much larger carpo- podia with large cells, and prove to belong to other genera such as Barrosoa, Conocliniopsis, or Lourteigia. Among the excluded elements, only Conocliniopsis tends to have receptacles as high as Conoclinium, and the Lourteigia has a receptacle that is at most convex.

Only one species has been added to the concept of $\mathrm{Co}$ noclinium since the time of DeCandolle. The added species, C. greggii, differs in a number of features such as the dissected leaves, the setulae on the achenes, and the small 


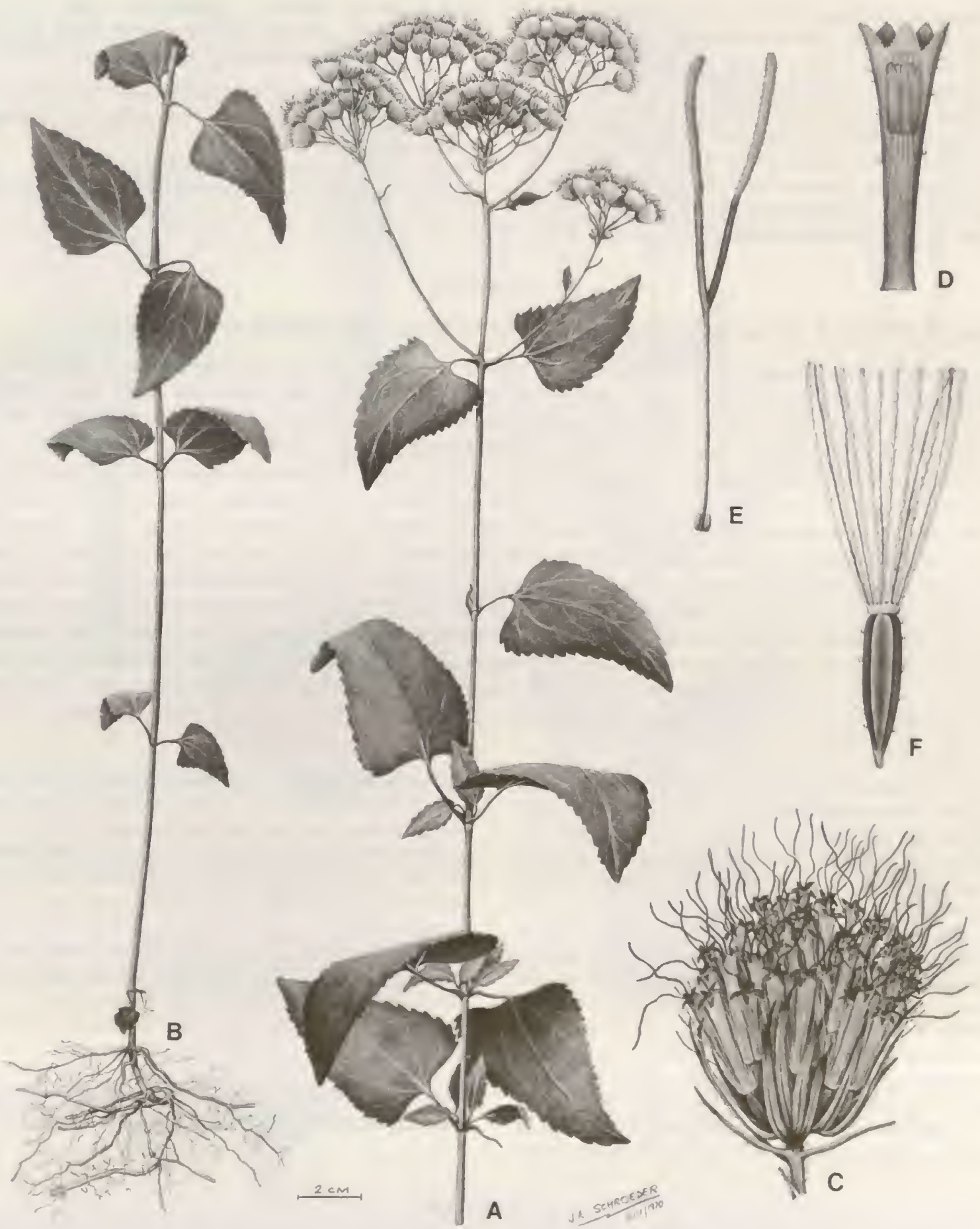

Plate 38. Conoclinium coelestinum (L.) DC. - A, B. Habit, $\times 1 / 2 .-$ C. Head, $\times 7 .-$ D. Corolla showing anthers, $\times 16 .-$ E. Style with nectary, $\times 16 .-F$. Achene, $\times 16$. 
but distinct carpopodium, but is clearly congeneric with the other species of DeCandolle from North America and Mexico. A subgeneric status might be justified.

The genus Conoclinium is notable for the blue flowers from which the name coelestinum is derived. It is a combination of the flower-color and habit that has caused the type species to often be called Ageratum or false-Ageratum. The similarity between Conoclinium and Ageratum extends to the conical receptacles, but Ageratum is characterized by a reduced non-capillary pappus. The com- mon cultivated species of Ageratum can also be distinguished by the marked pilosity of the stems and the prominent scarious lateral margins on the involucral bracts.

The following three species are recognized in the genus: Conoclinium betonicifolium (Miller) R. King \& H. Robinson, Mexico, Texas.

Conoclinium coelestinum (L.) DC., E United States. Conoclinium greggii (A. Gray) Small, SW United States, Mexico.

\section{Tamaulipa}

Tamaulipa R. King \& H. Robinson, Phytologia 22: 154. 1971. TYPE: Eupatorium azureum DC.

Erect woody shrubs, moderately branched. Stems terete, slightly striated, becoming smooth and glabrous below. Leaves opposite, distinctly and narrowly petiolate; blades deltoid, trinervate from base, margin subserrate to dentate. Inflorescence terminal on branches, corymbose; peduncles usually short, slightly broadened and fistulose distally. Involucral bracts 30-35, eximbricate to slightly subimbricate, in 2-3 series, outer series unequal, inner series subequal; receptacle convex to low-conical, glabrous, with depressed maculae of intermediate size. Florets 40-70 in a head; corollas pale blue, narrowly funnelform, mostly glabrous on outer surface; cells of limb elongate with sinuous lateral walls; lobes triangular, about as long as wide, smooth on both surfaces, with glands on outer surface; anther collar narrowly cylindrical, cells subquadrate below, longer above, with weak but distinct mostly annular thickenings on walls; anther appendage oblong to ovate, slightly longer than wide; style base not enlarged, glabrous; style branches broadly linear, rather strap-shaped, smooth to slightly mamillose. Achenes prismatic, not narrowed below, 5-6-ribbed, setuliferous on sides; carpopodium sometimes indistinct, very narrow, without distinct upper margin, somewhat confluent with broadened bases of ribs, cells small and subquadrate, in 3-4 series, with slightly thickened walls; pappus of ca. 35 scabrid, persistent, capillary bristles in one series, apical cells of bristles acute to subacute. Pollen grains ca. 18-22 $\mu \mathrm{m}$ in diameter. Plate 39.

Tamaulipa has an eximbricate to scarcely subimbricate involucre, a sometimes slightly conical receptacle, and bluish flowers that indicate a placement of the genus in the subtribe Gyptidinae. The placement is in spite of some discrepancies such as the smooth corolla lobes and style branches, the perhaps weakest thickenings in the cells of the anther collar in any member of the subtribe, and a geographical distribution remote from most of the genera of the Gyptidinae. The placement is reinforced by the presence in the geographical area of one other genus undoubtedly belonging to the Gyptidinae, and by the comparative lack of detailed evidence of relationship between Tamaulipa and members of any other subtribes from its area.

The geographical distribution of Tamaulipa would tend to indicate closest relationship within the subtribe to the only other genus of the Gyptidinae found in North America, Conoclinium. The exact relationship to Conoclinium is not certain, however, because that genus differs by its more herbaceous habit, its more strictly eximbricate involucre with narrower bracts, its papillose corolla lobes and style branches, its narrower style branches, the more rounded apical cells of its pappus bristles, and its totally different narrowed achene base with a less developed carpopodium. In no case is the conical receptacle of $\mathrm{Ta}$ maulipa as prominent as that of Conoclinium.

Tamaulipa is restricted to the Tamaulipan Desert region from which the generic name is derived.

The following single species is recognized in the genus: Tamaulipa azurea (DC.) R. King \& H. Robinson, Mexico, Texas.

\section{Lourteigia}

Lourteigia R. King \& H. Robinson, Phytologia 21: 28. 1971. TYPE: Eupatorium stoechadifolium L. f.

Small to medium-sized subshrubs or shrubs, sometimes procumbent, with few to many branches. Stems terete, striated, puberulous or densely tomentose with white hairs. Leaves opposite, petiolate, sometimes indistinctly short-petiolate; blades ovate to narrowly elliptical, margins crenulate to serrate, undersurface 

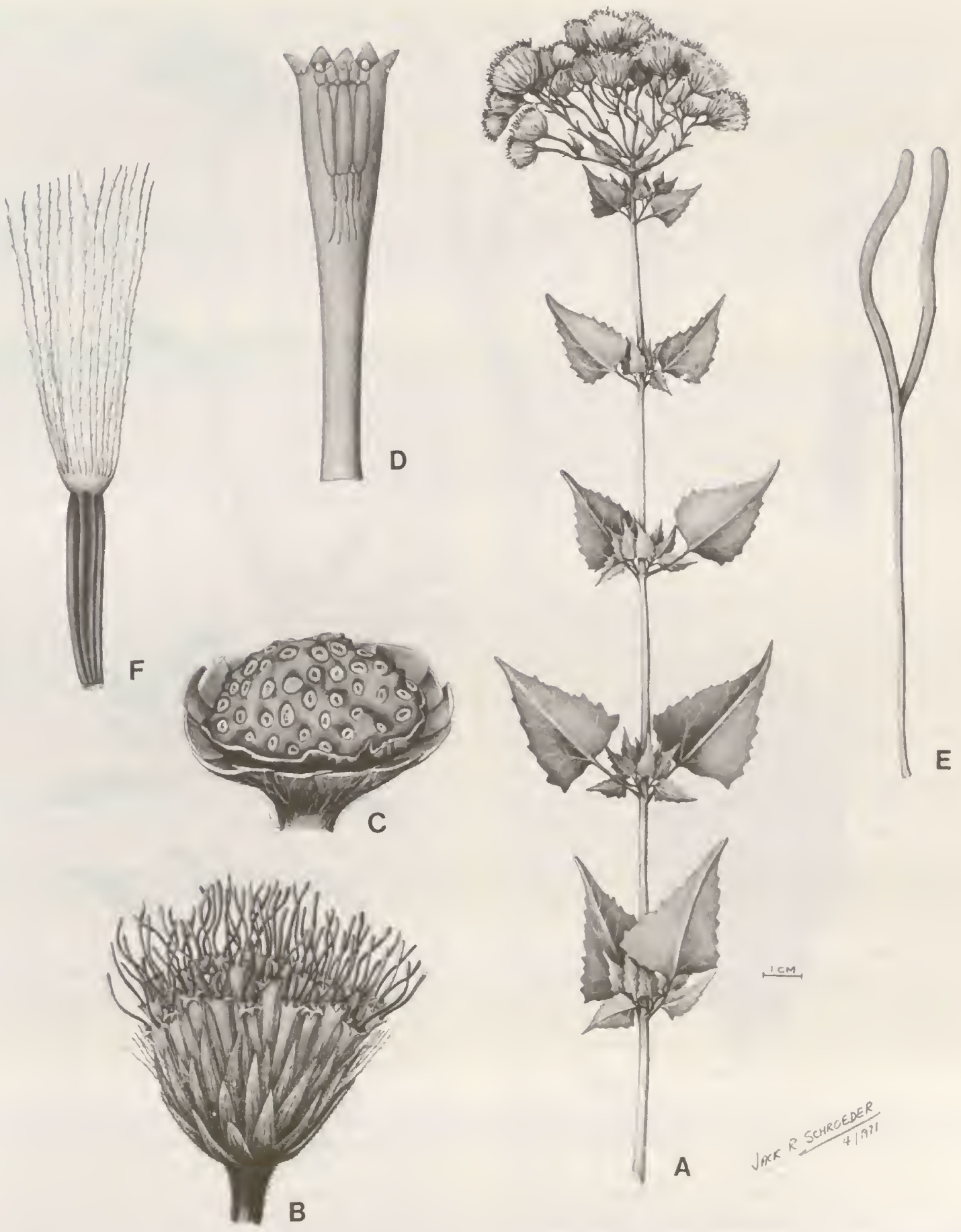

PlATE 39. Tamaulipa azurea (DC.) R. King \& H. Robinson. - A. Habit, $\times 3 / 3 .-B$. Head, $\times 4 .-$ C. Receptacle, $\times 12 .-D$. Corolla showing anthers, $\times 12 .-$ E. Style, $\times 12 .-F$. Achene, $\times 12$. 


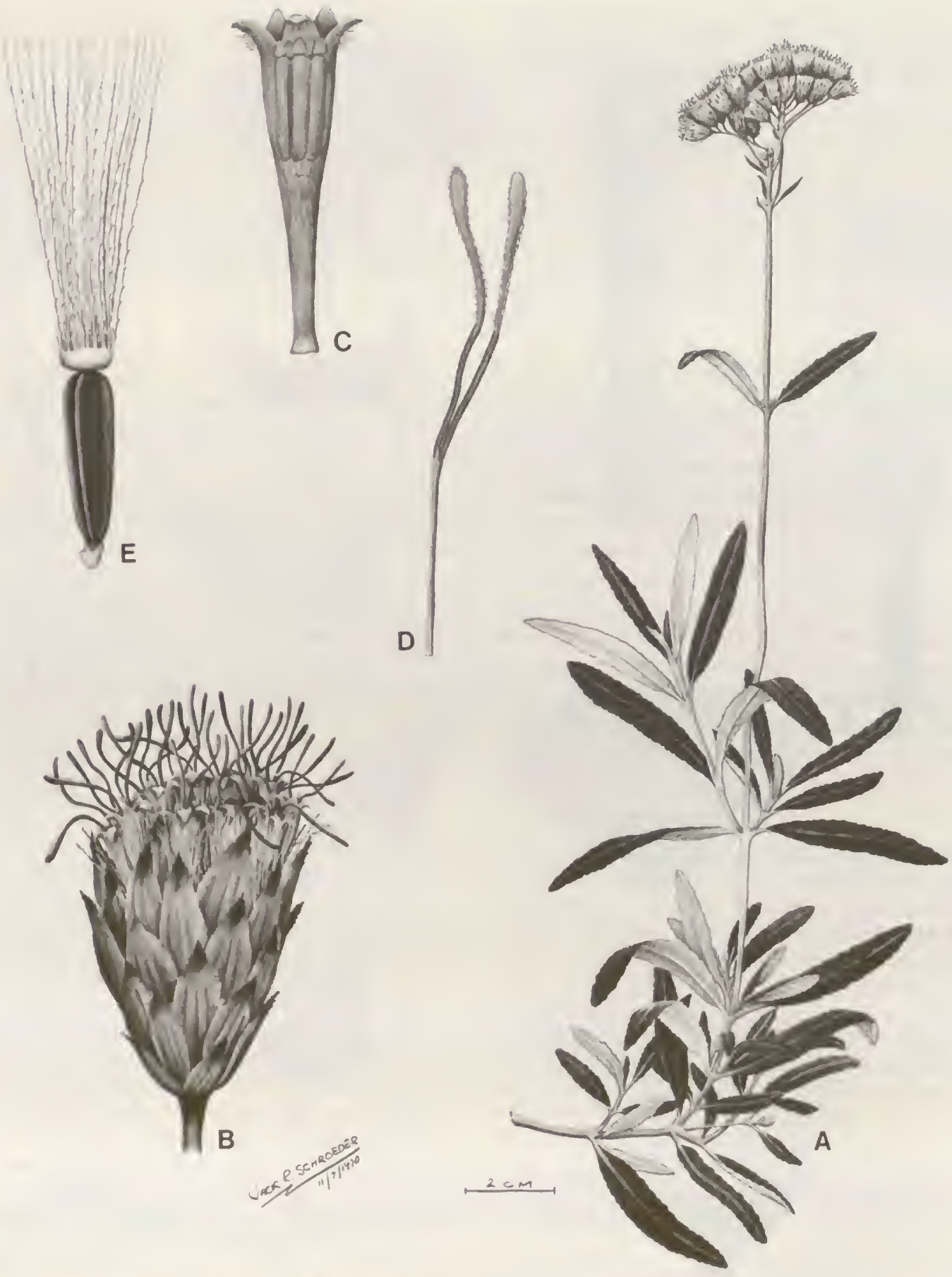

Plate 40. Lourtiegia stoechadifolia (L. f.) R. King \& H. Robinson. - A. Habit, $\times 2 / 3 .-$ B. Head, $\times 7$. C. Corolla showing anthers, $\times 17 .-D$. Style, $\times 17 .-$ E. Achene, $\times 17$.

often white-tomentose. Inflorescence terminal, densely corymbose; pedicels short. Involucral bracts ca. 2025 , weakly to moderately subimbricate, in 3-4 series, unequal; receptacle convex, rarely slightly conical, glabrous or with minute hairs. Florets usually 20 in a head (to 40 in L. ballotaefolia); corollas lilac, blue, purple, or greenish white, funnelform, basal tube narrowed above nectary; cells of throat and bases of lobes 
elongate with sinuous lateral walls; lobes triangular, slightly longer than wide, smooth on most of both surfaces, papillose near margins, outer surface densely puberulous and with few to many glandular-punctations, hairs sometimes moniliform; anther collar narrowly cylindrical, lower cells subquadrate to short oblong, longer above, with dense annular or intricate thickenings on walls; anther appendage ovate to oblong, slightly longer than wide; style base not enlarged, glabrous; style branches longly subclavate, slightly broadening to near tip, flat, densely papillose. Achenes prismatic, 5-ribbed, strongly constricted above at base of upper callus to one-third or less width of achene, narrowed below, scarcely setuliferous to subglabrous on sides; carpopodium prominent, with distinct upper rim, stopper-shaped, usually asymmetrical, cells mostly subquadrate, small below, becoming somewhat larger above, in ca. 7-10 series, with walls moderately thickened; pappus mounted on an easily detached callus, of ca. 30 slender scabrid bristles in one series, persistent on callus, apical cells of bristles acute. Pollen grains ca. 18-20 $\mu \mathrm{m}$ in diameter. Plate 40.

Lourteigia occurs in the northern Andes in an area remote from most Gyptidinae, and in close proximity to a number of genera of the Critoniinae. There is a particularly strong superficial resemblance and a similar form of carpopodium to Cronquistianthus of the Critoniinae. The involucre of some species of Lourteigia is more regularly subimbricate than in any other Gyptidinae, and the cells of the inside surface of the corolla lobes are mostly elongate though somewhat bulging. Nevertheless, Lourteigia has an involucre that is rather weakly subimbricate with persistent bracts, unlike most Critoniinae, and it has densely papillose style branches and strongly ornamented cell walls in the anther collar that indicate a position in the Gyptidinae. The placement of Lonrteigia species in the genus or section Conoclinium by DeCandolle (1836) and B. Robinson (1918b) might be considered supporting evidence for a position in the Gyptidinae, but the latter authors seemed to have relied on comparatively superficial features for their placement, since the receptacle in Lourteigia is not or is scarcely conical.

The resemblance between some species of Lourteigia and Fleischmannia has been noted (King \& Robinson, 1971 c), but Lourteigia differs in the two features that are most significant in the subtribe Fleischmanniinae. The corolla lobes are not papillose by the projecting upper ends of the elongate cells as in Fleischmannia, and the lower cells of the anther collars are obviously short with some vertical and oblique patterns of thickenings. In Fleischinannia the anther collars are narrower without evident shorter cells, and all annular thickenings are transverse.

Lourteigia is unique in the Gyptidinae and in the entire tribe Eupatorieae by the extreme constriction of the achene under the pappus. The achene is narrowed to a third or less of its median width, and the upper callus with the pappus is easily broken off. The separated callus has a flat or even concave undersurface with the small central scar from the narrow point of attachment. The narrowed base of the callus is not as obvious as constrictions under the pappus in some Mutisieae and Lactuceae because there is no elongation. The character differs basically from that seen in the often deciduous upper callus of Symphyopappus where there is no constriction but only a break-down of connecting tissue.
An unusual feature of the genus Lourteigia is the relative consistency of the number of flowers in the head. All of the species originally placed in the genus had been shown to have heads with 20 flowers. Consistency of flowernumber is known for many other Eupatorieae, but always at comparatively lower numbers of flowers. The two more robust species that have been recognized as members of Lourteigia subsequent to its description, $L$. ballotaefolia and $L$. fimbriata, have a larger number of flowers, up to 40.

The dense pubescence on the corolla lobes in Lourteigia is characteristic of the genus, and approaches in its density the condition seen in another Gyptidine genus, Trichogonia. The latter genus does occur in Colombia, but is primarily Brazilian, and differs in sufficient characters such as the plumose pappus to be rejected as a possible close relative of Lonrteigia. The lobe pubescence in Lourteigia shows interesting differences in detailed structure between species. The hairs are very short in $L$. stoechadifolia, strongly moniliform in $L$. ornatiloba, and slender with long apical cells in $L$. ballotaefolia.

The name of one species of Lourteigia, that of $L$. ballotaefolia, has been widely misapplied to the species that is now known as Conocliniopsis prasiifolia, ranging from Colombia to Venezuela and occurring widely in Brazil. True L. ballotaefolia seems to be endemic to a few areas in Colombia near Bogota.

Lourteigia is rather ecologically distinct in addition to its structural distinctions. Lourteigia and Ageratina are the two genera of the Eupatorieae that occur widely in the paramos of the northern Andes. The genus Lontreigia is more restricted to higher elevations, being unknown or nearly unknown from elevations below $2,500 \mathrm{~m}$. The altitudinal restriction is in sharp contrast to the low elevation restriction seen in another Gyptidine genus found in Colombia and Venezuela, Barrosoa.

The genus is named in honor of Dr. Alicia Lourteig of the Laboratoire de Phanerogamie, Museum National d'Histoire Naturelle in Paris.

There is no key to the species of Lourteigia as a group. The smaller species of the genus can be distinguished using the key to Eupatorium section Conoclinium in Colombia by B. Robinson $(1918 b)$. 
The following nine species are recognized in the genus:

Lourteigia ballotaefolia (H.B.K.) R. King \& H. Robinson, Colombia.

Lourteigia dichroa (B. Robinson) R. King \& H. Robinson, Colombia.

Lourteigia fimbriata V. Badillo, Venezuela.

Lourteigia humilis (Benth.) R. King \& H. Robinson, Colombia.
Lourteigia lanulata (B. Robinson) R. King \& H. Robinson, Colombia.

Lourteigia microphylla (L. f.) R. King \& H. Robinson, Colombia.

Lourteigia ornatiloba (B. Robinson) R. King \& H. Robinson, Colombia.

Lourteigia scandens Badillo, Venezuela.

Lourteigia stoechadifolia (L. f.) R. King \& H. Robinson, Colombia, Venezuela.

\section{Subtribe V. Ageratinae}

Ageratinae Less., Syn. Gen. Compos. 154. 1832. TyPE: Ageratum L.

Piqueriinae Benth. \& Hook., Gen. Pl. 2: 172. 1873. TYPE: Piqueria Cav.

Erect to procumbent annual or perennial herbs or shrubs, unbranched to many-branched; leaves opposite, sometimes alternate above, rarely alternate throughout. Inflorescence terminal on leafy or elongated branches, sometimes diffuse. Heads clustered, sessile to long-pedicellate; involucral bracts eximbricate to weakly subimbricate (subimbricate in Radlkoferotoma), persistent; receptacle scarcely convex to distinctly conical, with or without paleae. Flowers 3-125 in a head, lower numbers often equaling number of involucral bracts; corollas blue to purple or white; lobes usually with papillose or isodiametric cells on inner surface, without stomata on outer surface; cells of anther collar with dense annular thickenings on walls; anther appendage short or absent to longer than wide, sometimes cleft apically or crenulate; style base not or rarely enlarged, usually glabrous (pubescent in some Stevia); style branches usually linear, sometimes longly clavate, not abruptly short clavate at tips, usually densely papillose or mamillose. Achenes usually prismatic with 5 ribs (compressed with 2 ribs in Macvaughiella), with micropunctations not strongly aligned in transverse bands, base of achene sometimes contorted but not long-stipitate; carpopodium with cells variable in size and shape, cells usually with thin to slightly thickened walls; pappus reduced, sometimes totally lacking, when present, coroniform, or with awns or scales, rarely with more than 5 primary elements (multi-aristate in some Stevia; many scales in Ellenbergia). Basic chromosome numbers $x=9,10,11,12$.

The Ageratinae appear to be closely related to the Gyptidinae, sharing with them the mostly eximbricate involucre, the sometimes conical receptacle, the papillose corolla lobes and style appendages, the lack of an abruptly broadened short tip on the style branch, the dense annular thickenings on the cell walls of the anther collars, and the mostly unenlarged and glabrous style bases. The subtribe differs from the Gyptidinae primarily by the strong tendencies for reduction in both the pappus and the anther appendage. Although reduced forms of pappus are scattered throughout the Eupatorieae, the majority are concentrated in the Ageratinae, including the most extreme form in Teixeiranthus in which the entire upper callus of the achene is lacking and the corolla is fused directly to the achene. The only reduced pappus forms treated in the Gyptidinae in the present survey are those with many shortened capillary bristles or those proving directly related to forms with capillary bristles. The capillary bristle is the one pappus form consistently absent in the Ageratinae, and almost all the Ageratinae with more than five basic segments are in the Stevia relationship.

Reduction is a major trend in many aspects of the Ageratinae besides the pappus. With the exception of Parapiqueria of the Ayapaninae and Ophryosporus of the Critoniinae, all Eupatorieae with extreme reduction of the anther appendage are in the Ageratinae. Again with the exception of Parapiqueria, the most minute and ephemeral Eupatorieae, including Piqueriopsis and Ferreyrella, are members of the Ageratinae.

It is possible to view the Ageratinae as Gyptidinae with a reduced pappus. As such, it is possible to suspect that the Ageratinae might have originated from the Gyptidinae many times, and that the subtribe is artificial. The naturalness of the subtribe is reinforced, however, by the geography. Most Ageratinae occur or are concentrated in those areas of the Neotropics where the Gyptidinae are few or lacking. With the exceptions of Acritopappus and Radlkoferotoma, the only Ageratinae in eastern Brazil are clearly related to or derived from the Ageratum, Ferryerella, and Stevia groups with centers of distribution to the west. The Ageratinae are primarily a subtribe of Mexico, Central America, and Andean South America where the only Gyptidinae seem to be elements related to or derived from elements farther to the east. Any artificiality of the Ageratinae would seem to be on a broader basis of large generic complexes, of which there seem to be three. The three subgroups of the subtribe show some significant differences including differences in chromosome number $(R$. King et al., 1976). Further work may show a basis for recognition of at least one additional subtribe, perhaps using the available subtribal name Piqueriinae.

The first significant subgroup of the Ageratinae, con- 
sisting of Acritopappus and Radlkoferotoma, was recognized as a separate group of potential subtribal level in the summary of the Eupatorieae by H. Robinson and King (1977). Prime factors were the geographical limitation of the genera to eastern South America, mostly in Brazil, and the shrubby habit of the plants. Also important was the reduced basic chromosome number of $x=9$ in $A C$ ritopappus. Some doubts of the value of the group arise from the growing suspicion that the two genera involved are not closely related. One character mentioned in the previous summary of the tribe, the subimbricate involucral bracts, proves not to be a unifying character between the genera. Subimbricate bracts of graduated lengths are well developed in Radlkoferotoma, but the bracts of $\mathrm{AC}$ ritopappus are actually eximbricate. As regards possible separate subtribal status, the two genera should be treated separately.

The typical element of the Ageratinae, with a basic chromosome number of $x=10$, contains most of the genera in the subtribe. The group, itself, may be somewhat artificial, containing two generic complexes, one centered around Ageratum, and the other centered around Ferreyrella. There is no sharp line of demarcation between the two generic complexes, however, and they overlap geographically in the Andes and to a slight extent in Mexico. It is the generic complex containing Ageratum that most closely resembles the Gyptidinae in habit, number of flowers in a head, and in the sometimes blue corollas.

The third major element of the Ageratinae has basic chromosome numbers of $x=11$ and 12 , and is geographically mostly restricted to Mexico and Central America. Of the group, only Stevia extends its range in South Amer- ica. The genera of the group tend to have moderate to low numbers of flowers in the heads, and are most unlike the typical Ageratinae and the Gyptidinae in this respect. A few of the genera such as Microspermum and Iltisia resemble some of the Ferreyrella group superficially, but they are clearly members of the present group and different from the Ferreyrella group in geography and cytology. The present group of genera includes Piqueria, and would take the name Piqueriinae if recognized at the subtribal level.

Because of the characteristically reduced pappus, the Ageratinae contains genera that have consistently been excluded from the broad concept of Eupatorium in the past. It is notable that a high proportion of the genera of the subtribe have been recognized and maintained in traditional systems, reflecting a tendency in the past to treat the Eupatorieae with a defective pappus more realistically than those with a capillary pappus. A number of unnatural concepts have prevailed, however. The worst example has been Piqueria which has been interpreted much too broadly, even including parts of Ophryosporus of the Critoniinae. Also, a number of Ageratinae, including parts of Ageratum, have been included in the past in the genus Alomia, whose typical element is related to the genus Brickellia in the subtribe Alomiinae.

A number of members of the Ageratinae have been examined chemically, and a number of chemicals widely distributed in the tribe have been demonstrated. Two genera are of particular interest chemically, Stevia with its ambrosanolide (Rios et al., 1967) and its glycoside (Vis \& Fletcher, 1957), and Acritopappus with its kolavane and labdane derivatives (Bohlmann et al., 1980g).

\section{KEY TO THE GENERA OF THE SUBTRIBE AGERATINAE}

1. Peripheral flowers of head with greatly expanded, asymmetrical, ray-like limbs

1'. Peripheral flowers of head without greatly expanded ray-like limbs, rarely with somewhat longer outer lobes 64. Microspermum

2. Anther appendage half as long as wide or less; style branches often broadened distally

3. Small repent plants with leaves in a series of rosettes; inflorescence of clustered scapose heads on peduncles that are shorter than the leaves; lobes of corolla nearly smooth on inner surface; outer wall of achene often expanded at maturity
to form fluid-filled sac 48. Ascidiogyne

3'. Erect or decumbent plants, not rosulate; inflorescence usually exceeding leaves; lobes of corolla usually papillose on inner surface; achene wall not expanded to form fluid-filled sac

4. Pappus present

5. Pappus of many short bristles; achenes with many scabrae on ribs; filaments of anthers very short below collar, with cluster of hairs at base; leaves without distinct glandular punctations 52. Ellenbergio

5'. Pappus with a few scales with strongly sinuous cell walls; achenes glabrous or nearly glabrous; anther filaments elongate, without hairs at base; leaves with large recessed glandular punctations on lower surface 44. Phania

4'. Pappus absent

6. Heads with 3-5 subequal involucral bracts and an equal number of flowers; filaments mamillose to pubescent in lower part; walls of achenes with sparse internal micropunctations 57. Piqueria

6'. Heads with more than 5 involucral bracts, with number of flowers not equal; filaments smooth on lower part; walls of achenes with internal punctations of normal density, not over $12 \mu \mathrm{m}$ apart in vertical series

7. Heads with paleae

7'. Heads without paleae 54. Ferreyrella

8. Involucral bracts weakly overlapping, with acute tips; basal tube of corolla with gland-tipped hairs

9. Leaves repand-dentate to pinnatifid; throat of corolla gradually funnelform, with a few hairs inside near bases of anther filaments; achenes glabrous 
9'. Leaves crenate to serrate; throat of corolla broadly campanulate, without hairs inside; achenes with setulae on sides 45. Phalacraea

8'. Involucral bracts distinctly overlapping, with rounded or denticulate apices; basal tube of corolla without gland-tipped hairs

10. Achenes with $8-10$ ribs; corollas with 4 lobes

$10^{\prime}$. Achenes with 5 ribs; corollas with 5 lobes

11. Heads with 15-40 flowers; receptacle conical; corolla with basal tube bearing non-glandular hairs; base of plant decumbent

11'. Heads with ca. 8 flowers; receptacle slightly convex; basal tube of corolla glabrous; base of plant erect

2'. Anther appendage nearly as long as wide or longer; style branches usually with cylindrical or linear appendages

12. Heads with paleae; achenes nearly or completely glabrous

13. Tips of paleae expanded or ornamented; leaves sessile

14. Pappus and upper callus of achene absent, walls of achene continuing directly in to corolla; leaves without numerous longitudinal veins 50. Teixeiranthus

14'. Pappus present as laciniate tubular crown, corolla not continuous with apex of achene; leaves with prominent parallel venation

13'. Tips of paleae not expanded or ornamented; leaves mostly petiolate

15. Receptacle conical; leaves with large partially immersed glandular punctations on lower surface _... 43. Ageratum

15'. Receptacle flat; lower surfaces of leaves without large partially immersed glandular punctations

16. Achenes with symmetrical carpopodium; leaves with a mixture of sessile and stipitate minute glands; anther collars with cell walls weakly ornamented 46. Blakeanthus

16'. Achenes with an asymmetrical contorted carpopodium; leaves with glands uniform, obscure or lacking; cells of anther collars with dense transverse annular thickenings on walls 41. Acrilopappus

$12^{\prime}$. Heads without paleae; achenes often with setulae 65. Iltisia

17. Minute plants to $10 \mathrm{~cm}$ tall; corollas with 4 lobes

17'. Plants more than $10 \mathrm{~cm}$ tall; corollas with 5 lobes

18. Achenes compressed, with 2 ribs

18'. Achenes prismatic, with 5 ribs

18

19. Corolla lobes triangular, about as long as wide

20. Shrubs; involucral bracts subimbricate in 4-5 series, unequal to subequal in length

$20^{\prime}$. Herbs; involucral bracts eximbricate in 2-3 series, equal to subequal in length

63. Macvaughiella

21. Involucral bracts broadly rounded apically; achenes with carpopodium small and symmetrical; leaf blades acuminate, lobed

49. Cavalcantia

$21^{\prime}$. Involucral bracts pointed; achenes with large asymmetrical carpopodia; leaf blades not acuminate, not lobed

19'. Corolla lobes oblong, longer than wide 43. Ageratum

22. Corollas glabrous on inner surface; anther appendages cleft apically, not crenulate

23. Style branches obcompressed with stigmatic lines widely separated along lower lateral margins; base of style without node above nectary; involucral bracts subequal in length

61. Cronquistia

23'. Style branches terete to compressed with stigmatic lines closely paired along inner surface, lines reaching near to tip of branch; base of style with large node above nectary; involucral bracts unequal in length 60. Carphochaete

$22^{\prime}$. Corolla pubescent on inner surface; anther appendages not cleft apically, sometimes crenulate -24

24. Heads with ca. 10 involucral bracts and with 7-12 flowers, solitary on tips of leafy branches; anther appendages shortly ovate with entire margins 62. Revealia

24'. Heads with 4-6 involucral bracts and 4-6 flowers, forming distinct inflorescences; anther appendages elliptical to obovate with crenulate margins

25. Pappus present in most or all achenes of head, sometimes shortly coroniform; achenes narrowly prismatic; heads always with 5 involucral bracts and 5 flowers 58. Stevia

25 . Pappus totally lacking on all achenes, only upper callus present; achenes widened in middle; heads with 4-6 involucral bracts and 4-6 flowers 59. Metastevia

\section{Acritopappus}

Acritopappus R. King \& H. Robinson, Phytologia 24: 401. 1972. TYPE: Decachaeta longifolia Gardner.

Erect shrubs, moderately branched. Stems terete to 6-angled, glabrous. Leaves opposite, usually short- to long-petiolate (sessile in $A$. morii, sessile and connecting across node in $A$. connatifolius); blades ovate, ovate- 
elliptical, lanceolate, or linear, base usually acute (truncate in $A$. santosii), apex short-acute to long-acuminate, margin serrate to subserrulate or nearly entire, secondary veins pinnate (subtrinervate at base in $A$. santosii); tertiary veins forming prominulous reticulum. Inflorescence terminal on leafy sometimes attenuated branches, branches densely subcymose; pedicels usually short, hirtellous. Involucral bracts 5-25, eximbricate, in 2-3 series, somewhat unequal to subequal; receptacle flat to convex, with linear paleae. Florets 5-30 in a head; corollas usually pale lavender, narrowly funnelform, with small glands on outer surface; cells of throat elongate with sinuous lateral walls; lobes triangular, slightly longer than wide, inner surface with short cells usually bulging as short papillae, sometimes smooth; anther collar cylindrical, lower cells often subquadrate, cells with distinct transverse annular thickenings on walls; anther appendage oblong-triangular, slightly longer than wide; style base not enlarged, glabrous; style branches linear, densely short-papillose. Achenes prismatic, 5-ribbed, glabrous; carpopodium distinct, short, contorted with sinuous trace, cells short-oblong, with thin walls; pappus vestigial, with a short crown, or with a few awns. Pollen grains ca. 20-23 $\mu \mathrm{m}$ in diameter. Plate 41.

The name Acritopappus refers to the irregularity of pappus form that is found in the genus, an irregularity that has resulted in erratic placement of some of the species in the traditional classifications of the tribe. Certainly, the original placement of the first two species described, $A$. longifolius and $A$. confertus, in Decachaeta by Gardner (1846) seems inexplicable. The placement of various species in Ageratum by J. Baker (1876) was more realistic, but to some extent violated even the artificial concept of Ageratum prevalent at that time. The treatment of B. Robinson $(1913 b)$ ultimately separated the two original species of Gardner from Ageratum, placing one in Alomia with which it did not agree in its pappus structure, and leaving the other generically unassigned. It was against this background that the genus Acritopappus was established (King \& Robinson, 1972ss).

Since the redefinition of other genera with which species of Acritopappus have been associated, only Ageratum remains to provide a useful basis for comparison. Detailed examination shows that the two genera are not closely related. Acritopappus has coriaceous or subcoriaceous leaves without large glandular punctations, has a flat to slightly convex receptacle, has pale lavender flowers with the color concentrated in the anthers, has the pappus segments totally indurated and unwinged, and has a chromosome number of $x=9$, all different from Ageratum and its close relatives. The chromosome number difference is based on three counts (Coleman, 1970; R. King et al., 1976) representing two species. The receptacle of Acritopappus is not only not conical as in Ageratum, but is one of the most consistently paleaceous of any genus of such size in the Eupatorieae, having paleae in all cases where flowers are sufficiently numerous. Paleae occur in only some Central American and Mexican species of Ageratum. Geographically, Acritopappus is restricted to eastern Brazil, an area on the extreme fringe of the natural range of Ageratum.
The genus Acritopappus shows considerable uniformity in floral structure associated with striking diversity of foliar structure. The original definition of the genus included only those species with narrow, glabrous, pinnately veined, viscid leaves, including the two species described by Gardner (1846). The genus was subsequently expanded to include species that had been placed in Ageratum or that were undescribed having broader sometimes pubescent or non-viscid leaves (King \& Robinson, 1977h, 1980d). A key to the species was provided by King and Robinson $(1980 d)$, with one species being described since (Soares Nunes, 1981). The species with viscid leaves have a rich diterpene chemistry with kolavane and labdane derivatives that is apparently lacking in the species with nonviscid leaves (Bohlmann et al., 1980g, 1982b).

The genus is concentrated primarily in the state of $\mathrm{Ba}$ hia, Brazil, with two species to the south in Minas Gerais and $A$. confertus extending northward to Ceará.

The following 13 species are recognized in the genus:

Acritopappus confertus (Gardner) R. King \& H. Robinson, Brazil. Acritopappus connatifolius (Soares Nunes) R. King \& H. Robinson, Brazil.

Acritopappus hagei R. King \& H. Robinson, Brazil. Acritopappus harleyi R. King \& H. Robinson, Brazil. Acritopappus heterolepis (Baker) R. King \& H. Robinson, Brazil. Acritopappus irwinii R. King \& H. Robinson, Brazil. Acritopappus longifolius (Gardner) R. King \& H. Robinson, Brazil.

Acritopappus micropappus (Baker) R. King \& H. Robinson, Brazil.

Acritopappus morii R. King \& H. Robinson, Brazil. Acritopappus prunifolius R. King \& H. Robinson, Brazil. Acritopappus santosii R. King \& H. Robinson, Brazil. Acritopappus subtomentosus R. King \& H. Robinson, Brazil. Acritopappus teixeirae R. King \& H. Robinson, Brazil. 


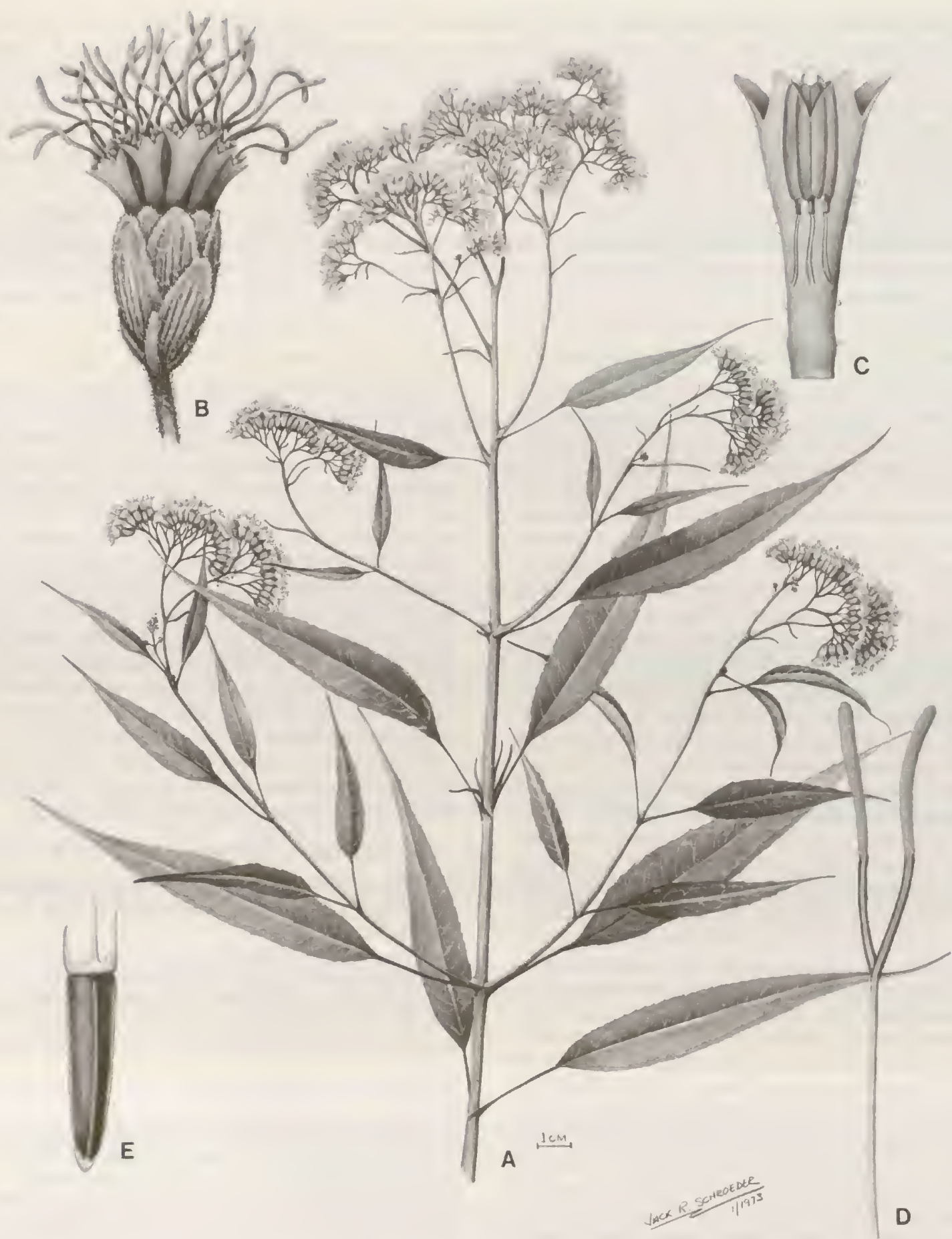

PLATE 41. Acritopappus longifolius (Gardner) R. King \& H. Robinson. - A. Habit, $\times 1 / 2,-$ B. Head, $\times 7 .-$ C. Corolla showing anthers, $\times 15$. D. Style, $\times 15-$ E. Achene, $\times 15$. 


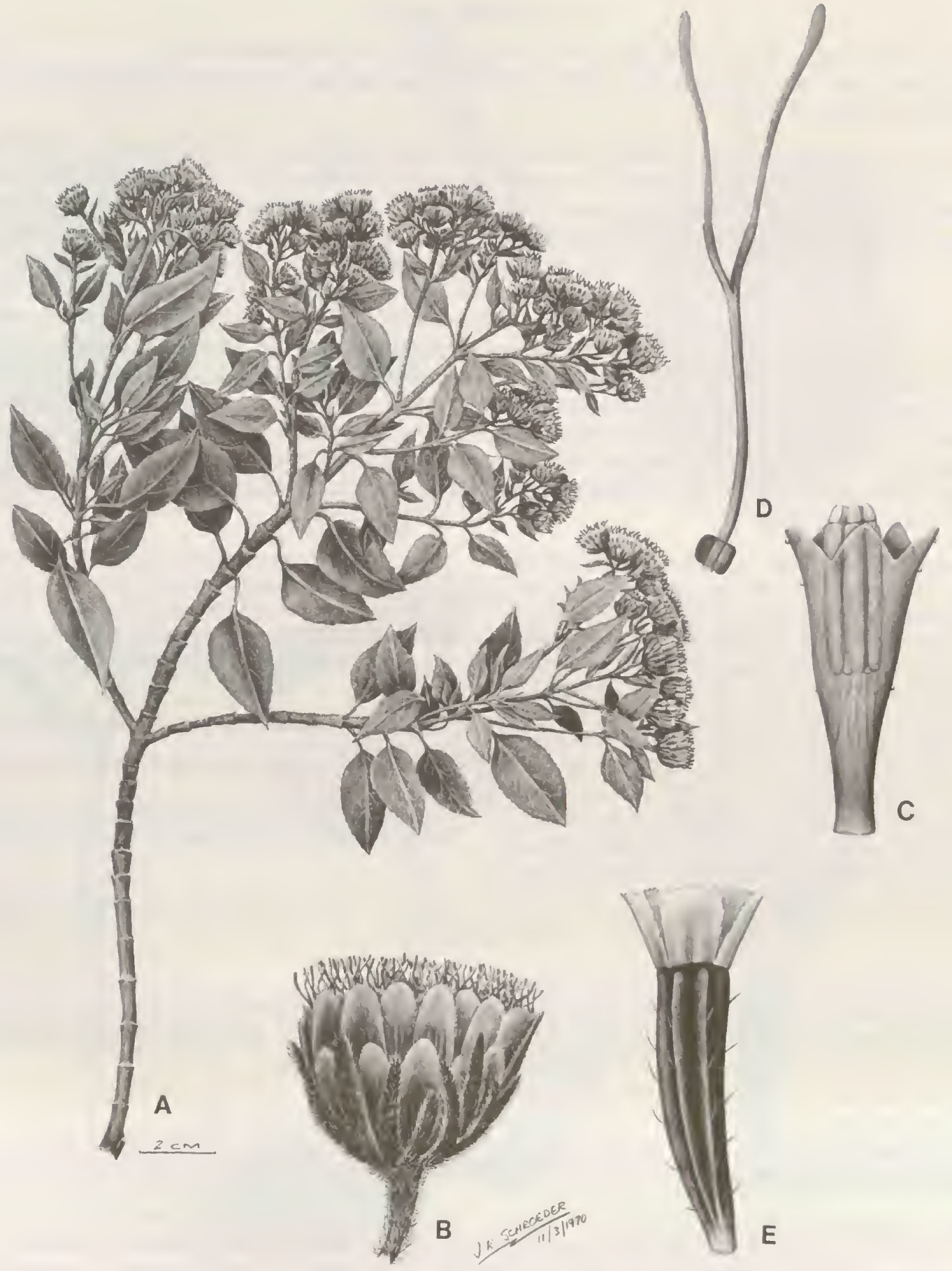

Plate 42. Radlkoferotoma cistifolia (Less.) Kuntze. - A. Habit, $\times \% \frac{1}{2}-$ B. Head, $\times 3 \frac{1}{2} .-$ C. Corolla showing anthers, $\times 12 .-$ D. Style with nectary, $\times 12 .-E$. Achene, $\times 12$. 


\section{Radlkoferotoma}

Radlkoferotoma Kuntze, Revis. Gen. P1. 1: 358. 1891. TYPE: Carelia cistifolia Less.

Carelia Less., Syn. Gen. Compos. 156. 1832. TyPE: Carelia cistifolia Less., non Carelia Ponted. ex Fabr., non Carelia Juss. ex Cav.

Erect shrubs or small trees, moderately branched. Stems terete, striated. Leaves opposite, long-petiolate; blades ovate to lanceolate, margin serrate, trinervate from or near base, with strongly ascending secondary veins. Inflorescence corymbose, pedicels mostly of moderate length. Involucral bracts ca. 35, strongly subimbricate, in ca. 4-5 series, of graduated lengths, inner bracts somewhat deciduous; receptacle flat, glabrous. Florets ca. 35-70 in a head; corollas white or rosaceous, funnelform, with only minute glands on outer surface; cells of throat and lower lobes laxly oblong with sinuous lateral walls; lobes triangular, about twice as long as wide, smooth on both surfaces; anther collar broadly cylindrical (shorter and constricted above in $R$. cistifolia), with many subquadrate cells in lower half or more, with distinct transverse, oblique or vertical ornamentation on walls; anther appendage ovate, about as long as wide, slightly to strongly bifid at apex; style base not enlarged, glabrous; style branches linear, scarcely or not broadened distally, densely papillose. Achenes prismatic, 4-5-ribbed, sparsely setuliferous; carpopodium cylindrical, forming ca. onefifth of achene, cells elongate and enlarged, with rather thin firm walls, lowermost 2-3 series of cells subquadrate, upper cells procurrent on base of achene ribs; pappus of 5 short broad squamae. Pollen grains ca. 23 $\mu \mathrm{m}$ in diameter. Plate 42.

In its pappus, anther collar, and style branches, Radlkoferotoma conforms best with the subtribe Ageratinae, but the strongly subimbricate involucre and the southern Brazilian and Uruguayan distribution are anomalous in that subtribe. The genus was associated with Acritopappus in a separate subgroup in the summary paper on the Eupatorieae by H. Robinson and King (1977) on the basis of the shrubby habits and Brazilian centers of distribution shared by the two genera. The basic differences in involucre, paleae, and achenes are part of the reason that close relationship between the two genera is now doubted.

A key to the species of Radlkoferotoma has been provided by Cabrera (1957) treating the genus under the older name Carelia. The genus was briefly redescribed and the nomenclature updated by King and Robinson (1971l).

The genus is named in honor of Ludwig A. T. Radlkofer of Munich who was credited with being a proponent of the use of anatomical approaches in systematics by Kuntze (1891).

The following three species are recognized in the genus:

Radlkoferotoma berroi (Hutch.) R. King \& H. Robinson, Brazil, Uruguay.

Radlkoferotoma cistifolia (Less.) Kuntze, Brazil, Uruguay.

Radlkoferotoma ramboi (Cabrera) R. King \& H. Robinson, Brazil.

\section{Ageratum}

Ageratum L., Sp. Pl. 2: 839. 1753. TYPE: Ageratum conyzoides L.

Carelia Ponted. ex Fabr., Enum. 85. 1959. LectotyPE: Ageratum conyzoides L.

Coelestina Cass., Bull. Soc. Philom. Paris 1817: 10. 1817. LeCTOTYPE: Ageratum corymbosum Zuccagni.

Isocarpha Less., Linnaea 5: 141. 1830. TYPE: Isocarpha echioides Less.

Ageratum subgenus Coelestina (Cass.) Baker in C. Martius, Fl. Bras. 6(2): 197. 1876.

Ageratum section Coelestina (Cass.) A. Gray, Syn. Fl. N. Amer. I(2): 93. 1884.

Ageratum section Stachyofolium M. Johnson, Ann. Missouri Bot. Gard. 58: 79. 1971. TYPE: Ageratum stachyofolium B. Robinson.

Annual to perennial herbs or subshrubs, few- to many-branched, base often decumbent with numerous adventitious roots. Stems terete, striated, sparsely puberulous to sparsely hirsute. Leaves opposite or sometimes alternate, short- to long-petiolate; blades elliptical or lanceolate to deltoid or ovate, margins entire to dentate, apex not or scarcely acuminate, undersurface usually with large sessile or partially sunken glandular punctations (lacking in some cultivated $A$. houstonianum), usually trinervate from or near base. Inflorescence cymose to subcymose, sometimes subumbellate, pedicels short to moderately long. Involucral bracts 30-40, eximbricate, in 2-3 series, equal or subequal, lanceolate, strongly indurated and often with scarious lateral margins; receptacle conical, glabrous or paleaceous. Florets $20-125$ in a head; corollas white, blue, or lavender, funnelform or with distinct basal tube; cells of throat elongate with sinuous lateral walls; lobes triangular, 

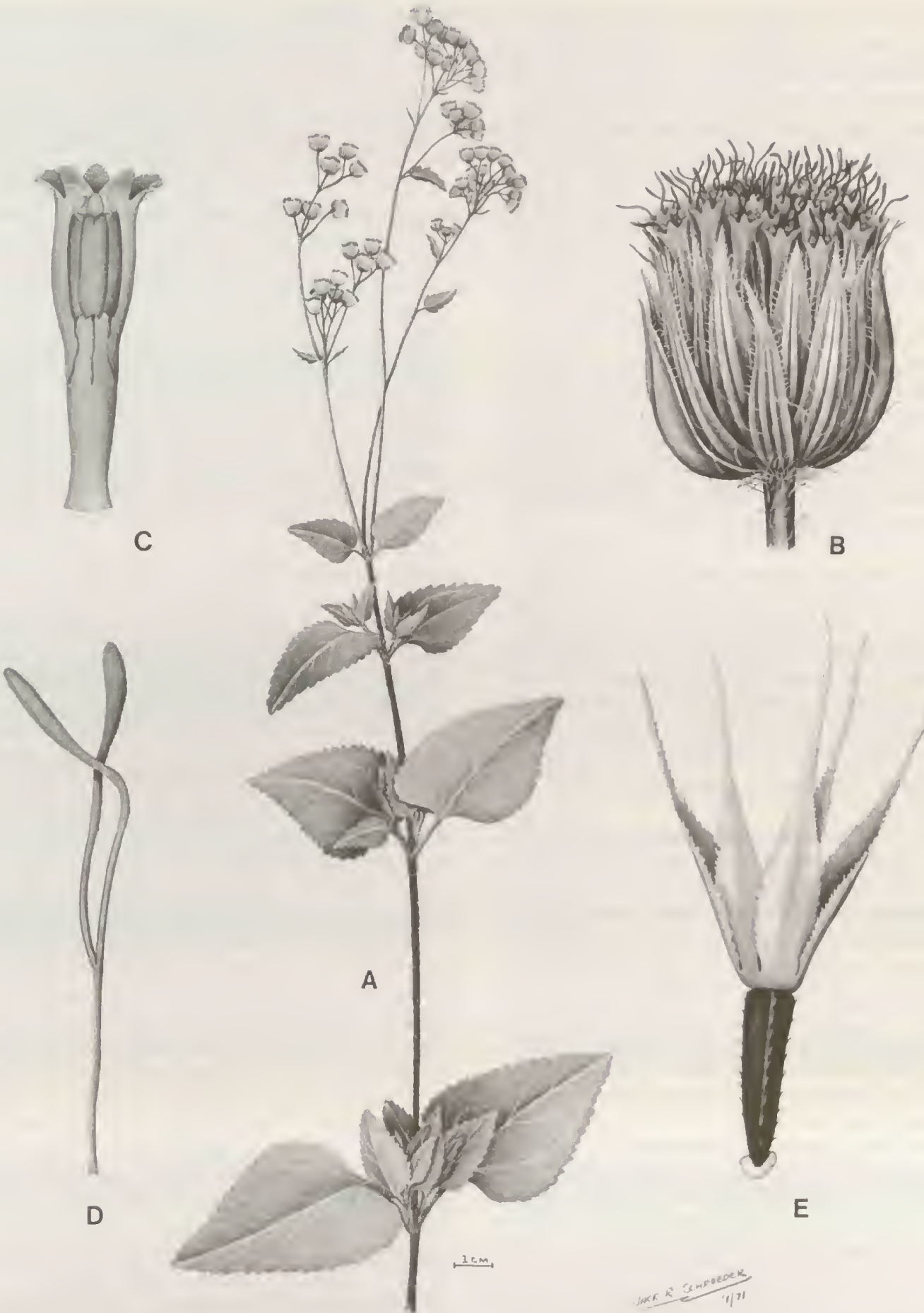

Plate 43. Ageratum houstonianum Miller. - A. Habit, $\times 3 / 3 .-$ B. Head, $\times 5 .-$ C. Corolla showing anthers, $\times 15 .-$ D. Style, $\times 15 .-$ E. Achene, $\times 13$. 
about as long as wide, papillose on inner surface, partially papillose and sometimes hispidulous on outer surface; anther collar cylindrical, cells subquadrate to short-oblong below, more elongate above, with dense transverse annular thickenings on walls; anther appendage large, somewhat longer than wide; style base not enlarged, glabrous; style branches linear, usually strongly and densely papillose (slightly papillose in $A$. ballotaefolium). Achenes prismatic, 4-5-ribbed, glabrous or with short setulae on ribs; carpopodium distinct, usually large and asymmetrical (nearly vestigial in $A$. stachyofolium), cells in spreading pattern, with subquadrate outer faces, with rather firm thin walls, in ca. 2-5 series, without zone of soft thin-walled cells above; pappus lacking, or coroniform, or of 5-6 free, flattened, sometimes awn-like scales. Pollen grains ca. $20 \mu \mathrm{m}$ in diameter. Plate 43.

Ageratum is undoubtedly the most widely known generic name in the Eupatorieae, both in scientific and common usage. The familiarity is based primarily on the two closely related, usually blue-flowered species, $A$. conyzoides and $A$. houstonianum, that are widely cultivated and even more widely adventive. Unfortunately, understanding of what additional species should be included in the genus has varied greatly in the past, and has resulted in concepts that were all at least partially artificial up until the time of the present series of studies.

The name Ageratum apparently derives from the ancient Greek $a(=$ not) and geras (= old age), and is generally acknowledged to refer to the long-lasting nature of the flowers (Johnson, 1971a). The name was used in antiquity for some other Asteraceous plant native to Europe, but was transferred to the present genus by Linnaeus (1753), where it is nomenclaturally fixed. The thusly established scientific name has also become widely accepted as a common name for the members of the genus, but some other common and native names for many of the species are given by Johnson (1971a).

Linnaeus (1753) placed Ageratum in his treatment next to Eupatorium, obviously in recognition of the general similarity of the plants. Ageratum differed principally by the pappus having five awns rather than many capillary bristles. Inclusion of Ageratum altissimum L., having a capillary pappus and now placed in Ageratina, was evidently an error by Linnaeus resulting from inadequate observation.

Subsequent concepts of Ageratum have been erratic in their allowance for variation in the pappus. Cassini $(1817 c)$ followed by DeCandolle (1836) placed species with a coroniform rather than awned pappus in a separate genus Caelestina, but the Ageratum of DeCandolle was still artificial, containing species belonging to Phania and Platypodanthera. By the time of J. Baker's treatment (1876), Ageratum properly included Caelestina, but also included Brazilian species belonging in Platypodanthera, Acritopappus, and Campuloclinium, and was on the way to becoming as artificial as the then prevalent concept of $E u$ patorium. Hemsley (1882), dealing with Mexican species, included in Ageratum some belonging to Trichocoronis of the Trichocoroninae and Oxylobus of the Oxylobinae. Additional examples of the artificially broad concept of the genus can be seen by referring to the nomenclator accompanying this treatment.
The definition of Ageratum was greatly improved by B. Robinson (1913b) with the removal of many of the unrelated elements, and the Robinson concept was followed closely in the most recent monograph of the genus by Johnson (1971a). An important element of artificiality remained, however. Even in the broadest interpretations of the genus by J. Baker (1876) and Hemsley (1882), the epappose species of Ageratum were excluded from the genus and placed in an artificial concept of Alomia. It was not until the studies by King and Robinson (1972w, 1972x), that the genus Alomia was properly redelimited, and the epappose species belonging to Ageratum were correctly placed.

At the present time, Ageratum is recognized by the conical receptacle, the leaves with large glandular punctations on their undersurfaces, the large anther appendages, and the achenes almost always having distinct and contorted carpopodia. As such, the genus is seen to have rather erratic variations in paleaceous versus non-paleaceous receptacles, and a range of variation of pappus from awnlike to coroniform or totally lacking. Correlation of pappus and palea variations with natural elements of the genus are somewhat limited, but it is notable that the species totally lacking a pappus that were previously placed in Alomia seem to be dispersed throughout the genus.

Some of the five sections of Ageratum recognized in the monograph of the genus by Johnson (1971a) seem to represent natural groups, and should be maintained. Typical Ageratum has the pappus when present divided into distinct units, and has scabrid angles on the achenes. The group is basically Mexican and Central American, but is widely adventive. The species include $A$. conyzoides, $A$. houstonianum, A. microcarpum, A. gaumeri, A. peckii, and a few others. The section Coelestina contrasts by its fused, usually coroniform pappus, and its glabrous achenes. It contains all the paleaceous members of the genus as well as many that are epaleaceous. It is essentially Mexican and Central American, and is the largest section in the genus. Included are such species as $A$. albidum, A. echioides, A. corymbosum, A. maritimum, A. paleaceum, A. rugosum, and A. petiolatum. Section Stachyofolium of Johnson contains only the Mexican species after which it is named, and is rather distinct in the poorly developed carpopodium and the alternate leaves. Still, the latter is mostly like section Coelestina. The South American members of the genus such as $A$. fastigiatum with its alternate leaves, 
A. scorpioideum with its diffuse inflorescence, and A. ballotaefolium with its nearly smooth style branches, are comparatively few in number, but represent considerable diversity, and should be recognized in additional sections. Two sections of Johnson (1971a) that must be eliminated are the West Indian Pectinellum which belongs to Phania and the Bolivian Perplexans which belongs to Galinsoga of the Heliantheae.

The most nearly complete keys to species of Ageratum are those of B. Robinson (1913b) and Johnson (1971a), but these exclude many epappose species, include one species of Acritopappus, and fail to properly distinguish between $A$. conyzoides and $A$. houstonianum. Distinctions of $A$. conyzoides and a number of other species are provided in the treatment of the genus in Panama by King and Robinson (1975y). The first to emphasize the distinctive small flowers and comparative lack of prominence of the style branches in A. conyzoides seems to have been Koster (1935). Some further additions and notes on other species have been provided by King and Robinson (1977d, 1978l).

Many uses of Ageratum conyzoides in folk medicine are listed by Johnson $(1971 a)$. The uses are of great variety, and many seem of comparatively recent origin such as for malaria in Guatemala, or for the many ailments in the Paleotropics where the plant is not native. The plant seemingly acts through alkaloids which have a vaso-constrictor action similar to that of ergot (Chevalier, 1910; Johnson, 1971a).

The chromosome numbers of Ageratum have been reviewed by Johnson (1971a) and R. King et al. (1976), showing a nearly consistent base of $x=10$.

The following 40 species are recognized in the genus:

Ageratum albidum (DC.) Hemsley, Mexico.

Ageratum ballotaefolium (Maguire, Steyerm. \& Wurd.) R. King

\& H. Robinson, Venezuela.

Ageratum candidum G. Barroso, Brazil.

Agerafum chiriquense (B. Robinson) R. King \& H. Robinson,

Panama.

Ageratum chortianum Standley \& Steyerm., Guatemala, Honduras.
Ageratum conyzoides L., Mexico, Central America, West Indies, South America, widely adventive.

Ageratum corymbosum Zuccagni, Mexico, Guatemala, El Salvador, Honduras.

Ageratum echioides (Less.) Hemsley, Mexico, Guatemala.

Ageratum elassocarpum S. F. Blake, Mexico.

Ageratum ellipticum B. Robinson, Belize, Guatemala.

Ageratum fastigiatum (Gardner) R. King \& H. Robinson, Brazil.

Ageratum gaumeri B. Robinson, Guatemala, Mexico.

Ageratum guatemalense M. Johnson, Guatemala.

Ageratum houstonianum Miller, Mexico, Central America, West

Indies, South America, widely cultivated and adventive.

Ageratum iltisii R. King \& H. Robinson, Ecuador.

Ageratum isocarphoides (DC.) Hemsley, Mexico.

Ageratum littorale A. Gray, Florida, West Indies, Belize.

Ageratum lucidum B. Robinson, Mexico.

Ageratum lundelii R. King \& H. Robinson, Guatemala, Mexico.

Ageratum maritimum H.B.K., Greater Antilles, Mexico (Quintana Roo).

Ageratum microcarpum (Benth. ex Oersted) Hemsley, Costa Rica,

Panama, Nicaragua, Honduras.

Ageratum microcephalum Hemsley, Mexico.

Ageratum myriadenum (Schultz-Bip. ex Baker) R. King \& H. Robinson, Brazil.

Ageratum nelsonii (B. Robinson) M. Johnson, Mexico, Guatemala.

Ageratum oerstedii B. Robinson, Costa Rica.

Ageratum oliveri R. King \& H. Robinson, Panama.

Ageratum paleaceum (DC.) Hemsley, Mexico.

Ageratum panamense B. Robinson, Panama.

Ageratum peckii B. Robinson, Belize, Guatemala.

Ageratum petiolatum (Hook. \& Arn.) Hemsley, Costa Rica, Nicaragua.

Ageratum platylepis (B. Robinson) R. King \& H. Robinson, Guatemala.

Ageratum platypodum B. Robinson, Mexico.

Ageratum radicans B. Robinson, Belize.

Ageratum riparium B. Robinson, Costa Rica.

Ageratum rugosum Coulter ex J. D. Smith, Mexico, Central America.

Ageratum salicifolium Hemsley, Mexico.

Ageratum scorpioideum Baker, Guayana.

Ageratum stachyofolium B. Robinson, Mexico.

Ageratum standleyi B. Robinson, Honduras.

Ageratum tomentosum (Benth. ex Oersted) Hemsley, Mexico.

\section{Phania}

Phania DC., Prodr. 5: 114. 1836. TYPE: Phania multicaulis DC.

Ageratum section Pectinellum DC., Prodr. 5: 109. 1836. LECTOTYPE: Ageratum domingense Sprengel.

Erect to repent, annual or perennial herbs or small shrubs, with few to many branches. Stems terete, striated, puberulous. Leaves opposite, petiolate; blades ovate or deltoid to palmate, margins crenate-dentate to shallowly lobed, undersurface with obvious sessile or partially sunken glandular punctations, trinervation from or near base. Inflorescence of small cymes terminal on leafy branches or with a single slenderly pedicellate head; pedicels usually short to moderately long. Involucral bracts ca. 10-20, eximbricate, in ca. 2 series, equal or subequal, broadly lanceolate to narrowly oblanceolate; receptacle conical, epaleaceous, glabrous. Florets ca. $12-25$ in a head; corollas pale lavender to white, with short constricted basal tube abruptly expanding into short-campanulate limb, with scattered glandular punctations on outer surface; cells of throat short-oblong with sinuous lateral walls; lobes mostly broadly triangular, about as long as wide or slightly 

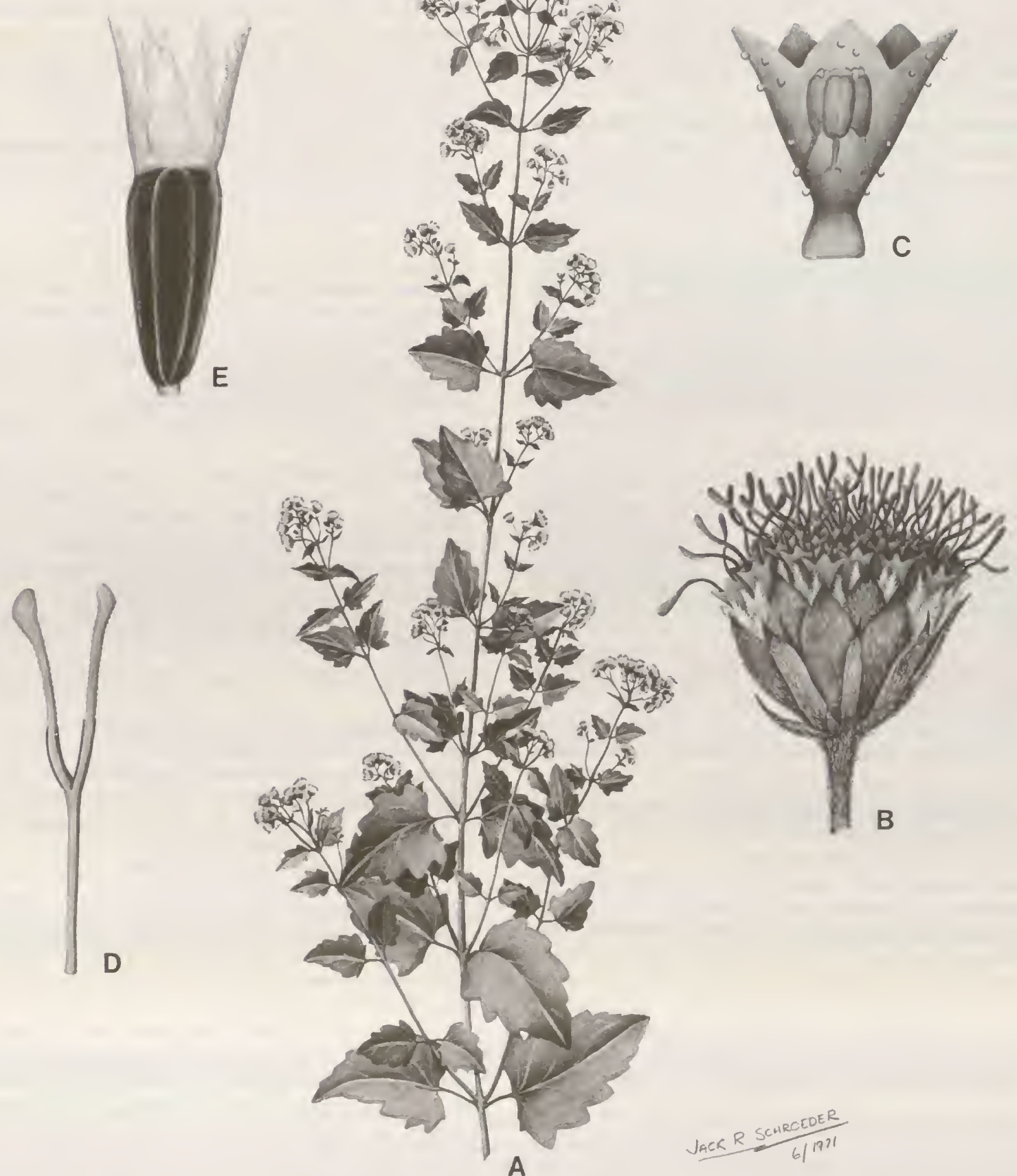

Plate 44. Phania matricarioides (Less.) Griseb. - A. Habit, $\times 3 / 5 .-$ B. Head, $\times 9 .-$ C. Corolla showing anthers, $\times 30 .-D$. Style, $\times 30 .-$ E. Achene, $\times 30$. 
wider, with large strongly mamillose cells on inner surface; lower filament very short; anther collar rather long, cells mostly oblong with distinct transverse annular thickenings on walls; anther appendages small, very short (to half as long as wide in $P$. domingensis); style base not enlarged, glabrous; style branches somewhat to strongly clavate distally, short-papillose or mamillose. Achenes prismatic, 4-5-ribbed, glabrous or with few glands or setulae; carpopodia distinct, moderately large, cylindrical, cells oblong with firm walls, in ca. 4 series, somewhat procurrent on lower ribs of achene; pappus of 5 squamellae, cells elongate with distinctly sinuous lateral walls. Pollen grains ca. 16-18 $\mu \mathrm{m}$ in diameter. Plate 44.

Phania is a small genus of the West Indies distinguished by its reduced anther appendages and pappus squamellae with sinuous-walled elongate cells. The reduced floral parts and corollas with campanulate limbs are reminiscent of species that have been placed in Piqueria, and the genus was placed in the subtribe Piqueriinae by $\mathrm{B}$. Robinson $(1913 a)$. The glandular punctations of the leaves and conical receptacles, nevertheless, indicate close relationship to Ageratum, and one of the species, $P$. domingensis, has been placed in the latter genus as recently as 1971 (Johnson, 1971 a). The two Mexican species that were included in the original concept of Phania by DeCandolle (1836), belong to the genus Oxylobus of the subtribe Oxylobinae.

Phania domingensis was excluded from Phania and placed in Ageratum by DeCandolle (1836) and Johnson $(1971 a)$ on the basis of the appearance more closely resembling members of the latter genus. The annual repent plants with solitary heads on longer pedicels, and the palmate blades of the leaves, clearly distinguish the species from others in the genus Phania, but they still furnish no more than a superficial resemblance to species of Ageratum. The reduced anther appendages and the pappus squamellae with elongate sinuous-walled cells, combined with the West Indian distribution, indicate proper placement is in Phania.

Regarding the name, DeCandolle (1836) says, "Nomen à Phanio vetustissimo botanico Theophrasti coaevo."

The following five species are recognized in the genus:

Phania cajalbanica Borh. \& Muniz, Cuba. Phania curtissii B. Robinson, Cuba.

Phania domingensis (Sprengel) Griseb., West Indies.

Phania matricarioides (Sprengel) Griseb., Cuba.

Phania multicaulis DC., West Indies.

\section{Phalacraea}

\section{Phalacraea DC., Prodr. 5: 105. 1836. TYPE: Phalacraea latifolia DC.}

\section{Steleocodon Gilli, Feddes Repert. 94: 311. 1983. TYPE: Steleocodon gracilis Gilli.}

Perennial herbs, procumbent or erect from decumbent bases, with few to many branches. Stems terete, striated. Leaves opposite, with slender petioles; blades ovate to broadly triangular, margin crenate to serrate, with distinct glandular punctations below, trinervate from base. Inflorescence rather laxly cymose, with denser ultimate branching, pedicels rather short. Involucral bracts 10-18, eximbricate, in 2-3 series, subequal, broad with short-acute non-scarious tips, with few to many hairs and glandular punctations on outer surface; receptacle flat to slightly convex, glabrous. Florets $10-18$ in a head; corollas white, with constricted basal tube and abruptly expanding campanulate limb, many scattered minutely gland-tipped hairs on tube, more sparse on limb; cells of throat short-oblong with sinuous lateral walls, usually slightly bulging on inner surface; lobes triangular, slightly longer than wide, papillose on inner surface; anther collar often rather stout, cells mostly subquadrate to short-oblong, with dense transverse annular thickenings on walls; anther appendage vestigial, bilobed, usually consisting of two separated minute lobes; style base not enlarged, glabrous; style branches broad, becoming slightly broader toward the broadly rounded tips, densely papillose. Achenes prismatic, 4-5-ribbed, covered with numerous setulae on sides and base, sometimes with distinct narrow and twisted base; carpopodium small, short-cylindrical or rounded, cells small- to medium-sized, mostly subquadrate with rather thin firm walls, in ca. 6-8 series; pappus lacking. Pollen grains ca. 23-25 $\mu \mathrm{m}$ in diameter. Plate 45.

Phalacraea is named for the Greek phalacro- (= bald), which is in reference to the lack of a pappus on the achene. It is because of the lack of pappus and the vestigial anther appendages that the genus has resided in the traditional treatments of the tribe in the synonymy of the genus $P i$ queria. The two genera cannot be considered closer than members of the same subtribe, however, since Piqueria is now recognized to be Mexican, Central American, and West Indian, with 3-5 involucral bracts and an equal number of flowers, papillose lower filaments of the anthers, very sparse minute internal punctations of the achene wall, and a basic chromosome number of $x=11-$ 12. Phalacraea has a greater number of bracts and flowers, smooth filaments, denser punctations, and on the basis of 


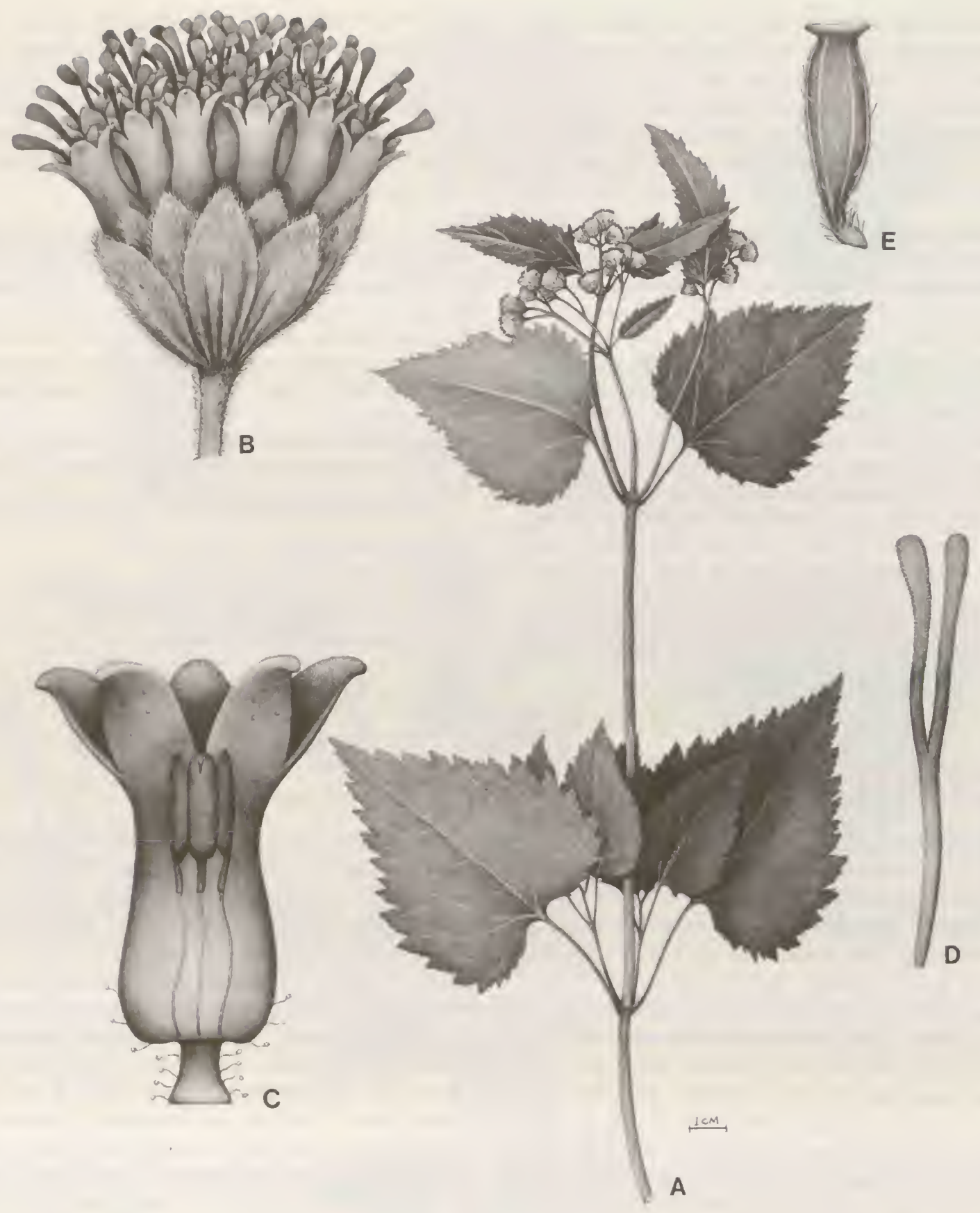

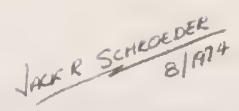

Plate 45. Phalacraea latifolia DC. - A. Habit, $\times 5 / 9 .-$ B. Head, $\times 7 .-$ C. Corolla showing anthers, $\times 17 .-$ D. Style, $\times 17 .-$ E. Achene, $\times 17$. 
a single report (R. King et al., 1976), a chromosome number of $n=20$.

The closest relationship of Phalacraea is possibly with other Andean genera in the Ferreyrella-Guevaria group. From these, Phalacraea seems to differ by the non-conical receptacle, the acute rather than rounded tips on the involucral bracts, the almost exclusively glandular hairs on the corolla, and the numerous setulae on the achenes. Phalacraea has a superficial resemblance to Ageratum but differs in the non-conical receptacle, broader involucral bracts, reduced anther appendages, and more setuliferous achenes. Phania, which has a reduced anther appendage as in Phalacraea, differs by its distinctive consistently present pappus, and by other characters which it shares with Ageratum.
Within the genus Phalacraea there is some variation in the shape of the achene base. Three of the species have attenuate bases, while $P$. callitrich $a$ has a short broad base. In both variations, the carpopodium is reduced to a narrow basal rim consisting of a few series of small cells. The slender form of achene base has no equivalent in the related genera.

The following four species are recognized in the genus:

Phalacraea callitricha (B. Robinson) R. King \& H. Robinson, Colombia.

Phalacraea ecuadorensis R. King \& H. Robinson, Ecuador.

Phalacraea latifolia DC., Peru.

Phalacraea longipetiolata (B. Robinson) R. King \& H. Robinson, Colombia, Ecuador.

\section{Blakeanthus}

\section{Blakeanthus R. King \& H. Robinson, Phytologia 24: 118. 1972. TYPE: Alomia cordata S. F. Blake.}

Erect shrubs, with moderate branching. Stems terete, unstriated, hirsute. Leaves opposite, with slender petioles; blades ovate, base truncate to cordate, trinervate, margin crenate to serrulate, upper surface densely puberulous, lower surface with various intermixed glandular punctations, stalked glands, and longer nonglandular hairs. Inflorescence a compact corymbose panicle, branches with heads subglomerulous, pedicels very short. Involucral bracts ca. 20, eximbricate, in 2-3 series, subequal, lanceolate; receptacle flat to slightly convex, paleaceous, paleae like involucral bracts in form. Florets ca. 25 in a head; corollas white, narrowly funnelform; cells of throat elongate with sinuous lateral walls; lobes triangular, slightly longer than wide, with glandular punctations on outer surface, smooth with oblong cells on inner surface; anther collar slender, cells subquadrate to oblong, inornate or upper cells with slight annular thickenings on walls; anther appendage slightly longer than wide; style base not enlarged, glabrous, style branches linear, not or scarcely broader at tips, mamillose to subpapillose. Achenes prismatic, 5-ribbed, mostly glabrous, with few minute spicules on ribs and some glands on upper callus; carpopodium symmetrical, short, subcylindrical with rounded base, cells rounded to subquadrate, in ca. 8 series, with thin walls; pappus completely lacking. Pollen grains ca. $20 \mu \mathrm{m}$ in diameter. Plate 46.

Blakeanthus has a geographical distribution in Central America, no pappus, indurated eximbricate involucral bracts, and paleae, all of which might suggest relationship to the genus Ageratum. The genus is placed in this relationship with considerable reservation, however. Detailed examination shows essentially flat rather than conical receptacles, symmetrical carpopodia, numerous small glands rather than less numerous large glandular punctations on the leaves, rather smooth inner surfaces of the corolla lobes, and very weak ornamentation of the cell walls of the anther collars. The latter two characters, combined with the weak papillosity of the style branches and the size and shape of the cells in the carpopodium, might indicate a more proper placement far from Ageratum in the subtribe Critoniinae. The genus was tentatively placed in the Critonioid series at the time of its original description. In that subtribe, the genus would be rather unusual in its paleaceous heads, and would be unique in the combination of paleaceous heads and epappose achenes. It is because the latter combination of characters is common in the Ageratinae and otherwise unknown in the Crito- niinae that Blakeanthus is placed in the Ageratinae in this treatment. The redefinition of Alomia by King and Robinson (1972w), the genus in which the species of Blakeanthus was originally described, indicates that it is a relative of Brickellia and remote from either the Ageratinae or the Critoniinae.

The leaf pubescence of Blakeanthus is of particular interest for the variety of hairs and glands. In some specimens, a small area of leaf undersurface may have intermixed small glandular punctations, distinctly stalked glands of a slightly different color, and longer non-glandular hairs. In no case are the glandular punctations as large or as sunken into the surface as in Ageratum.

The genus Blakeanthus is named in honor of Sidney Fay Blake, one of the leading synantherologists of the twentieth century, and author of the type species.

The following single species is recognized in the genus: Blakeanthus cordatus (S. F. Blake) R. King \& H. Robinson, Guatemala, Honduras. 

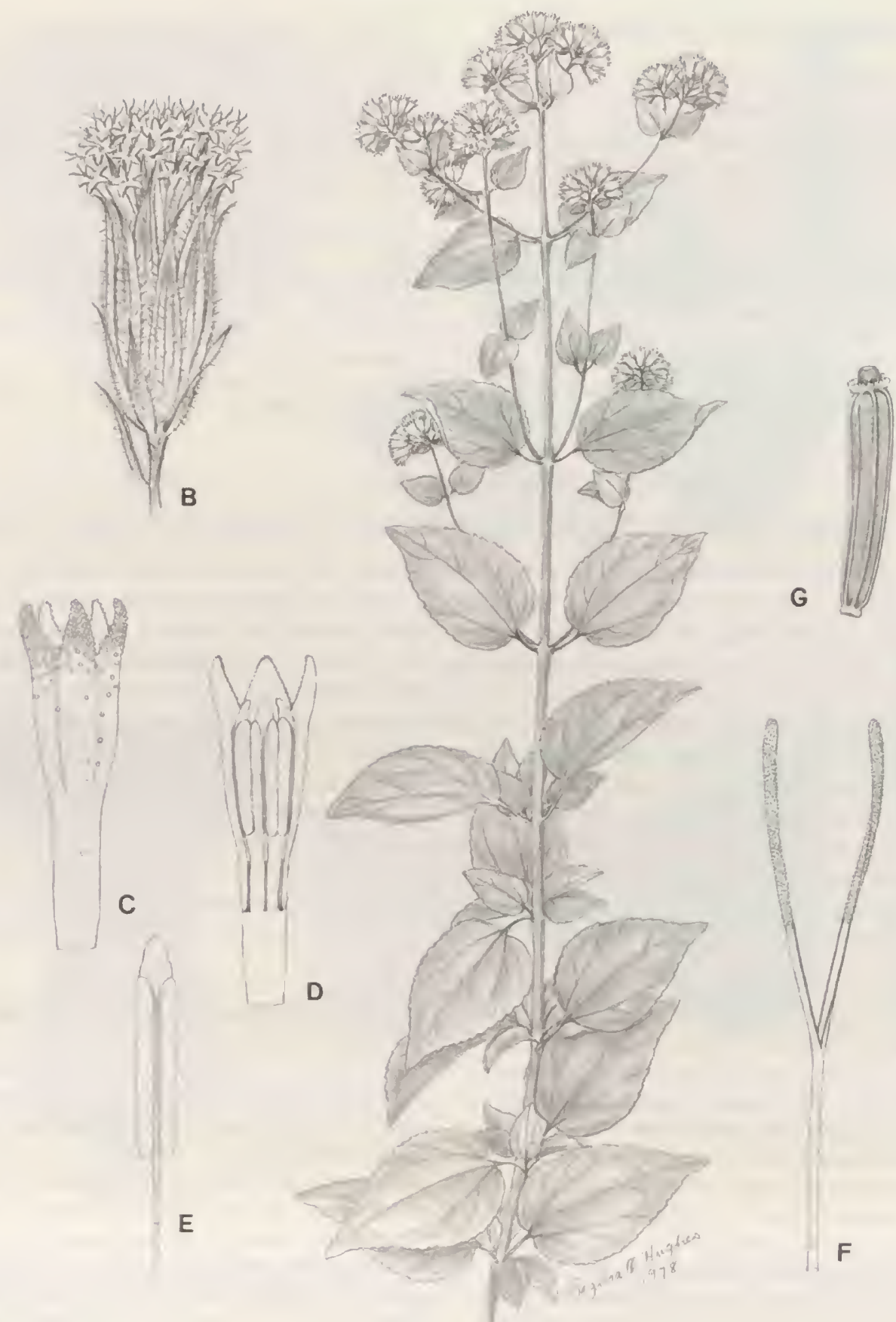

A

Plate 46. Blakeanthus cordatus (S. F. Blake) R. King \& H. Robinson. - A. Habit, $\times 1 / 2 .-$ B. Head, $\times 7$. - C. Corolla outer surface, $\times 15 .-D$. Corolla inner surface with anthers, $\times 15 .-$ E. Anther, $\times 24 .-F$. Style, $\times 15 .-$ G. Achene, $\times 15$.

\section{Scherya}

Scherya R. King \& H. Robinson, Phytologia 38: 101. 1977. TYPE: Scherya bahiensis R. King \& H. Robinson.

Erect perennial herbs, with few or no branches. Stems terete to subhexagonal, covered with densely hirtellous pubescence and sessile glands. Leaves opposite, crowded, sessile; blades linear, trinervate with longitudinal 


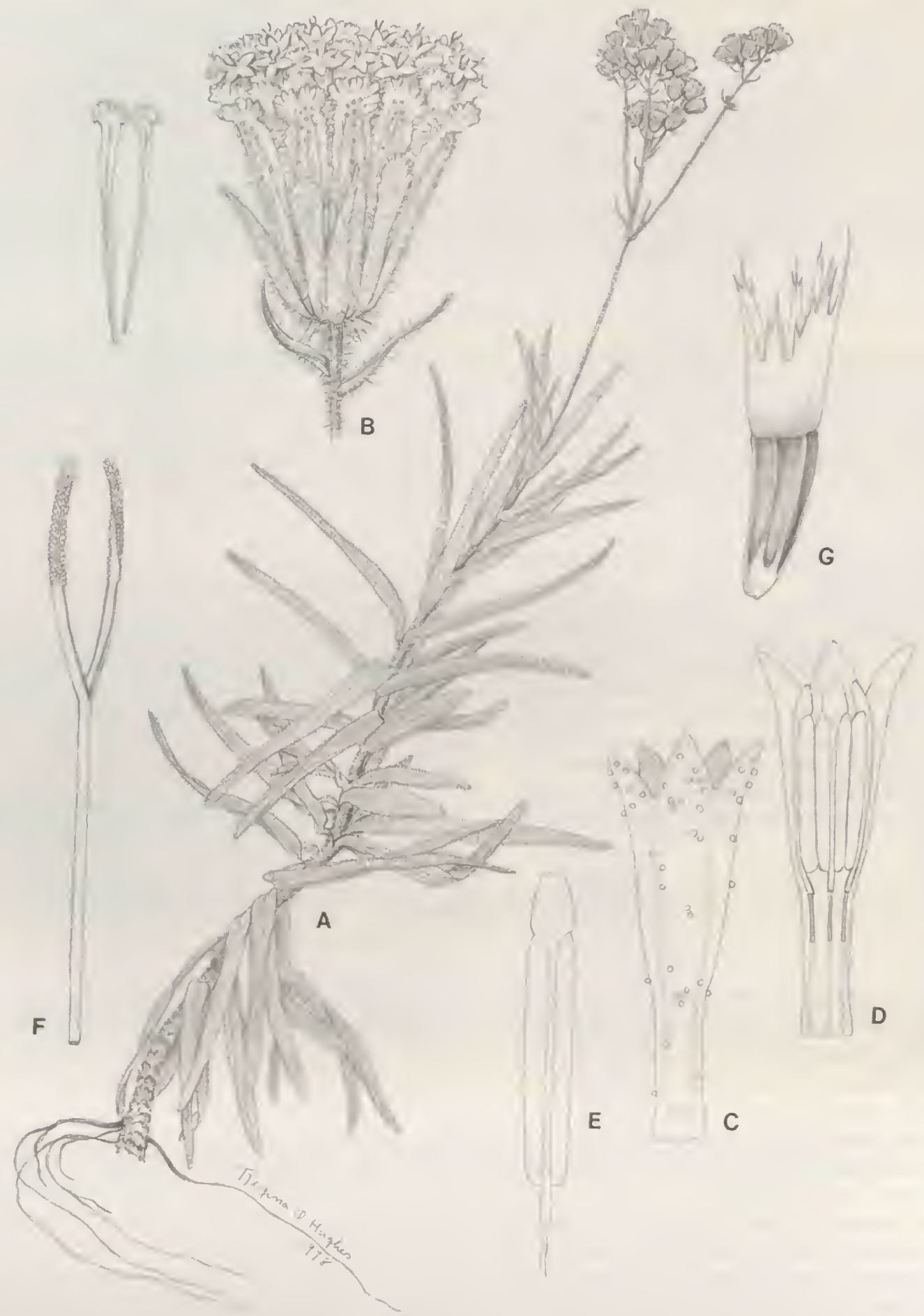

Plate 47. Scherya bahiensis R. King \& H. Robinson. - A. Habit, $\times 1 / 2 .-$ B. Head, $\times 7$, with separate pair of paleae. - C. Corolla outer surface, $\times 20,-D$. Corolla inner surface with anthers, $\times 20 .-$ E. Anther, $\times 30 .-$ F. Style, $\times 20 .-G$. Achene, $\times 14$. 
secondary veins, apex short acute, margin entire. Inflorescence terminal, subscapose, cymose to subcymose, branches erect, usually alternate, pedicels short. Involucral bracts ca. 20, eximbricate, in ca. 2 series, subequal, with broad, rounded, chartaceous, colored tips bearing a cluster of glands on their outer surface; receptacle flat to slightly convex, paleaceous; paleae linear. Florets ca. 25 in a head; corollas pale, funnelform, with glands on outer surface; cells of throat elongate with sinuous lateral walls, lobes triangular, slightly longer than wide, nearly smooth and glanduliferous on outer surface, densely papillose in inner surface; anther collar rather short, cells usually short-oblong to oblong, with strong annular thickenings on walls; anther appendage about as long as wide; style base not enlarged, glabrous; style branches filiform, densely papillose. Achenes prismatic, 5-ribbed, glabrous, bands of carbonization very narrow between greatly thickened longitudinal cell-walls; carpopodium symmetrical, short-cylindrical, cells usually longer than wide, usually in 6-8 series, with slightly thickened walls, with similar cells extending upward along ribs of achene; pappus a laciniate crown with 5 long primary teeth, rather indurate. Pollen grains ca. $22 \mu \mathrm{m}$ in diameter. Plate 47.

The genus Scherya can be immediately distinguished from all other Eupatorieae by the superficial appearance of the plant with its densely inserted linear leaves. The strap-shaped leaves with subparallel non-prominulous venation seem to be unique in the tribe. Some details of the achene are also unique, including the narrow bands of carbonization in the wall and the firm somewhat ornamented walls of the carpopodial cells. Further distinctions are evident in comparisons with other individual genera that might be related.

Scherya seems unquestionably a member of the Ageratinae, and the herbaceous habit and strongly cymose inflorescence suggest a position near Ageratum. The genus is distinct by the characters cited above, and also by the non-conical receptacle, the glands of the leaf not being partially immersed in the surface, and the involucral bracts having an ornate apical appendage which is glabrous except for the cluster of glands borne externally at the base. The pappus also differs in being more indurated than those in Ageratum.
In the form of the pappus, Scherya is more like Acritopappus which occurs in the same geographical area in Bahia, Brazil. The manner in which some of the characters of Ageratum and Acritopappus are combined in Scherya provides the most significant support available for assuming any close relationship between those two genera. Nevertheless, Scherya differs significantly from Acritopappus by its unique characters as well as its herbaceous habit, cymose instead of corymbose inflorescence, and ornate appendages on the involucral bracts.

The ornate appendages of the in volucral bracts actually distinguish Scherya from all other members of the subtribe except Teixeiranthus, and the latter genus is totally distinct in its unique fusion of the corolla to the achene.

Scherya is named for the collector of the single specimen on which the genus is based, Robert W. Schery, a coauthor on the Flora of Panama project.

The following single species is recognized in the genus: Scherya bahiensis R. King \& H. Robinson, Brazil.

\section{Ascidiogyne}

\section{Ascidiogyne Cuatrec., Ann. Missouri Bot. Gard. 53: 310. 1965. TYPE: Ascidiogyne wurdackii Cuatrec.}

Prostrate, somewhat carnose, stoloniferous herbs with a series of erect rosulate branches. Stems terete. Leaves of prostrate stems opposite, congested on erect stems, distinctly to indistinctly petiolate, petioles hirsute; blades ovate or obovate to narrowly elliptical, margin entire. Inflorescence of clustered separate short scapes, each bearing a single head, not longer than leaves. Involucral bracts 4-7, eximbricate, in 2 series, equal, broadly oblong to ovate, with rounded tips; receptacle flat, glabrous, foveolate. Florets 5-7 in a head; corollas white, tube strongly constricted and pilose in upper part, limb broadly campanulate and glabrous; cells of limb oblong with walls not or scarcely sinuous; lobes triangular, up to twice as long as wide, smooth on most of inner surface; anther collar rather short, enlarged, cells subquadrate to oblong, with dense annular thickenings on walls; anther appendage totally absent, tip of anther somewhat emarginate; style base not enlarged, glabrous; style branches short, clavate, with short papillae denser toward tip. Achenes prismatic, 5-ribbed, glabrous, with internal micropunctations dense, outer wall of $A$. wurdackii thin and slightly to widely separated from body of achene to form fluid-filled sac; carpopodium slightly asymmetrical, cells broadly oblong, in 2-4 series, with thin usually firm walls; pappus lacking or with rim of callus forming a high 5-lobed crown. Pollen grains ca. $25 \mu \mathrm{m}$ in diameter. Plate 48.

Ascidiogyne shows all the types of reduction that are common in the subtribe Ageratinae, and is one of the few members of the tribe with an anther appendage totally lacking. Still, there is no evidence of an ephemeral nature 

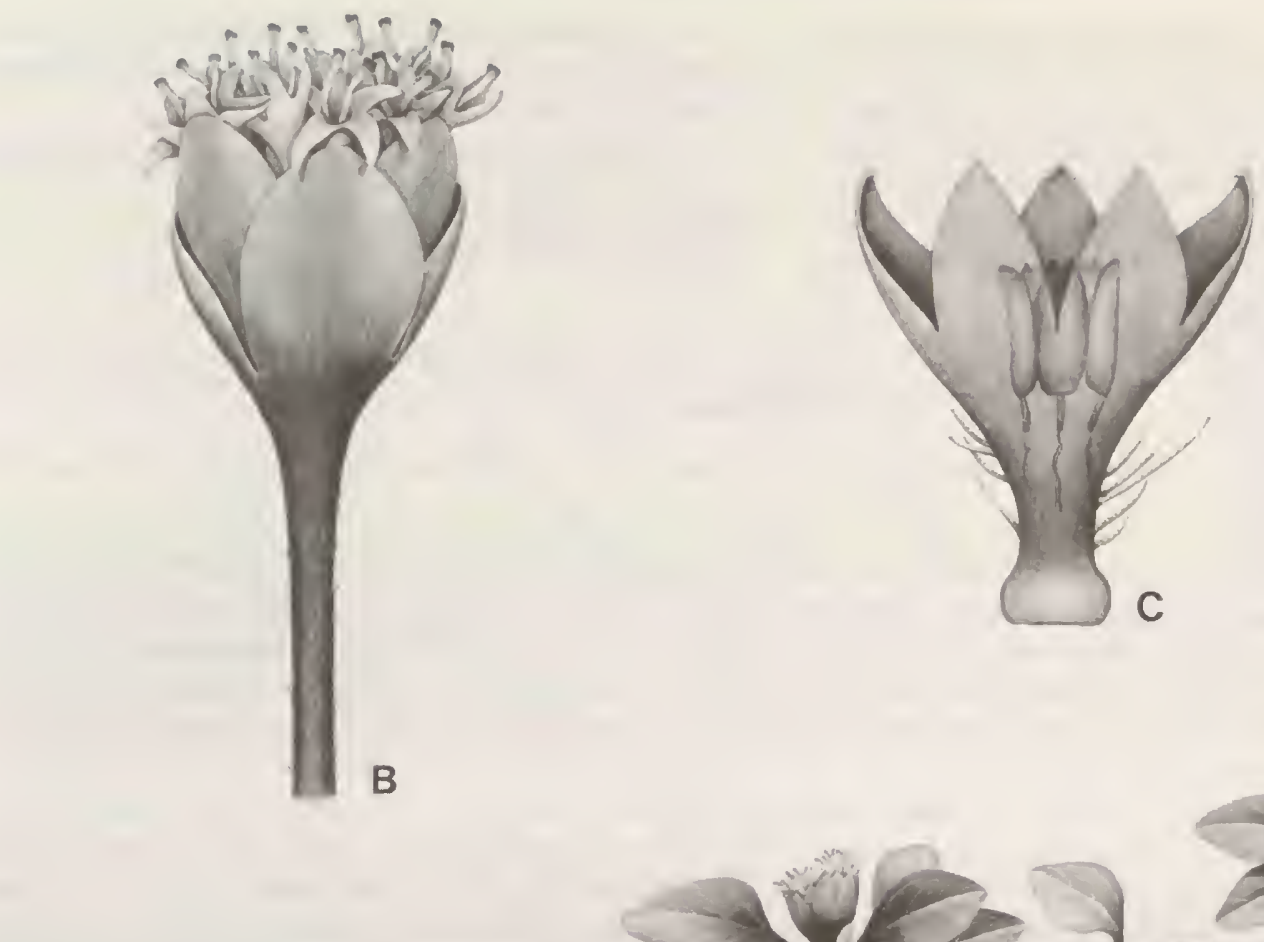

A
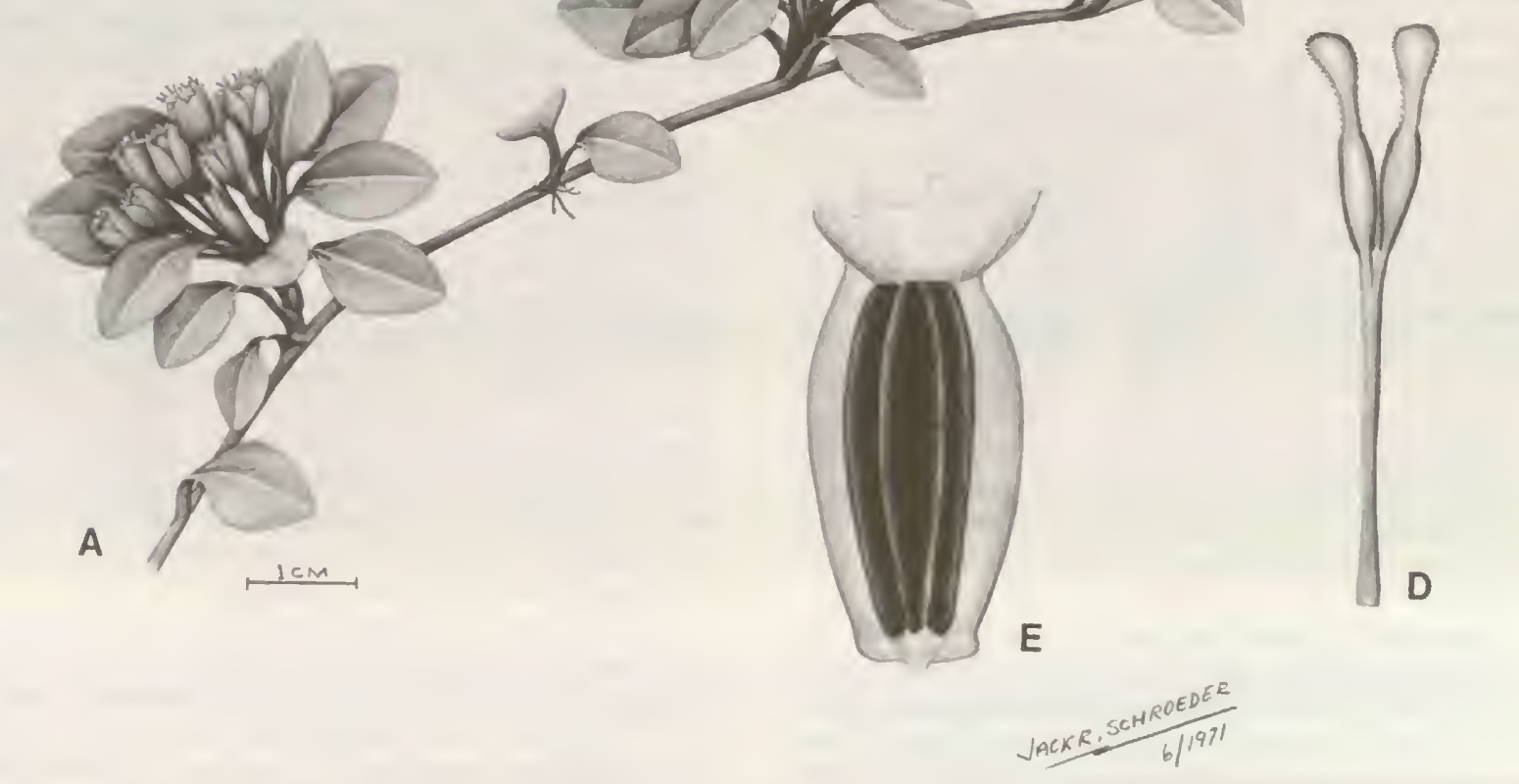

Plate 48. Ascidiogyne nurdackii Cuatrec. - A. Habit, $\times 1 \frac{114}{4}-$ B. Head, $\times 9 .-$ C. Corolla showing anthers, $\times 20 .-$ D. Style, $\times 20 .-$ E. Achene, $\times 20$.

of the kind seen in other reduced genera of the subtribe, and the genus seems quite isolated in its relationship.

The genus Ascidiogyne is most distinct from all other genera of the Eupatorieae by the prostrate stoloniferous habit with its series of small rosettes, and clusters of heads each solitary on a short peduncle. These features are shared by both of the known species, while other characters that initially seemed more significant have proven to be variable.

The type species has a striking character, after which 
the genus is named, an inflated outer achene wall that evidently forms a fluid-filled sac in the living material. Such a structure is not evident in A. sanchezvegae. Also, the type species has a distinct coroniforme pappus, while A. sanchezvegae has none. For further information on species distinctions, the papers of Cuatrecasas (1965) and Cabrera (1976) should be consulted, where illustrations of each of the species are available.
The two known members of the genus are endemic to restricted areas in the states of Amazonas and Cajamarca in northern Peru.

The following two species are recognized in the genus: Ascidiogyne sanchezvegae Cabrera, Peru. Ascidiogyne wurdackii Cuatrec., Peru.

\section{Cavalcantia}

\section{Cavalcantia R. King \& H. Robinson, Phytologia 47: 113. 1980. TYPE: Ageratum glomeratum G. Barroso \& R. King.}

Erect annual or short-lived perennial herbs, with few branches. Stems terete, striated, puberulous. Lower leaves opposite, becoming alternate above, narrowly petiolate; blades ovate to deltoid, margin distinctly shallowly lobed, tip strongly acuminate. Inflorescence strongly divaricately cymose or aggregated in glomerules; heads short-pedicellate or sessile. Involucral bracts 8-10, eximbricate, in 2 series, subequal to equal, persistent, narrowly obovate to ovate with rounded fimbriate apices; receptacle flat or conical, glabrous. Florets ca. 6-30 in a head; corollas white; basal tube short, broad below and constricted above, densely pubescent; limb funnelform, with few to many sclerids along veins of throat, cells of throat elongate with sinuous lateral walls; lobes triangular, as long as wide, papillose on inner surface, without sclerified shield distally on outer surface; lower part of filament short, somewhat replicate; anther collar slightly enlarged below, cells with distinct transverse annular thickenings on walls which obscure cell limits; anther appendage bluntly triangular, as long as wide; style base not enlarged, glabrous; style branches filiform, densely papillose. Achenes prismatic, 5-ribbed, glabrous; carpopodium small, annuliform to very shortly cylindrical, cells small, subquadrate, in ca. 3-4 series, with walls thickened, with zone of small, soft, thin-walled cells above carpopodium sometimes protruding; pappus lacking. Pollen grains ca. $18 \mu \mathrm{m}$ in diameter. Plate 49.

Cavalcantia is one of three genera described during the present series of studies that is endemic to the isolated savanna areas in the interior of Brazil in southern Pará, along the southern fringe of the Amazon Basin, the other genera being Monogereion and Parapiqueria of the Ayapaninae. Cavalcantia is the only one of the three known from more than a single species and known from more than one such area. The two areas, the Serra dos Carajás and the Serra do Cachimbo are separated from each other by nearly 500 kilometers. The genus is known from only two collections, one of each of the two species. Neither of the specimens is well preserved, and only one has leaves present.

Cavalcantia is evidently related to Ageratum, and the type species was originally described as an Ageratum (Barroso \& King, 1971) on the basis of a broader interpretation of that genus. The most superficially useful distinction of Cavalcantia, the broad round-tipped somewhat Piquerian involucral bract, was noted by the original authors of the type species. The bracts of Ageratum are always lanceolate and narrowly pointed. Additional distinctions of Cavalcantia are the small symmetrical carpopodia with small quadrate, thick-walled cells, the dense pubescence on the basal tube of the corolla, the lack of any apical shield of thicker-walled cells on the outer surface of the corolla lobes, and a tendency for internal sclereids along the veins and in the lobes of the corollas. In both species of $\mathrm{Ca}$ valcantia, there is a zone of small, somewhat colored, thinner-walled cells above the carpopodium that appear expanded in one observed achene. This zone is possibly elaiosomal in nature. Such a zone is not present in Ageratum. In the species of Cavalcantia in which leaves are present, there is a shallow lobing and an abrupt acuminate tip unlike anything seen in Ageratum. It is significant that one of the species of Cavalcantia does not have a conical receptacle, perhaps only a reflection of the few flowers in its heads. Nevertheless, a conical receptacle is present consistently in all species of Ageratum.

The two species of Cavalcantia differ by a number of significant features including the number of flowers in the heads and the correlated shape of the receptacle. Elongate bare internodes in the inflorescence are evident in both species, but the branching in C. percymosa is divaricately cymose with a subracemose capitular arrangement, while the type species has more erect branching with extremely dense glomerules of heads. The two species differ in the form of bracts on the inflorescence and subtending the heads. The hairs on the basal tubes of the corollas are biseriate and gland-tipped in C. percymosa, but uniseriate and non-glandular in C. glomerata. One feature of $C$. 


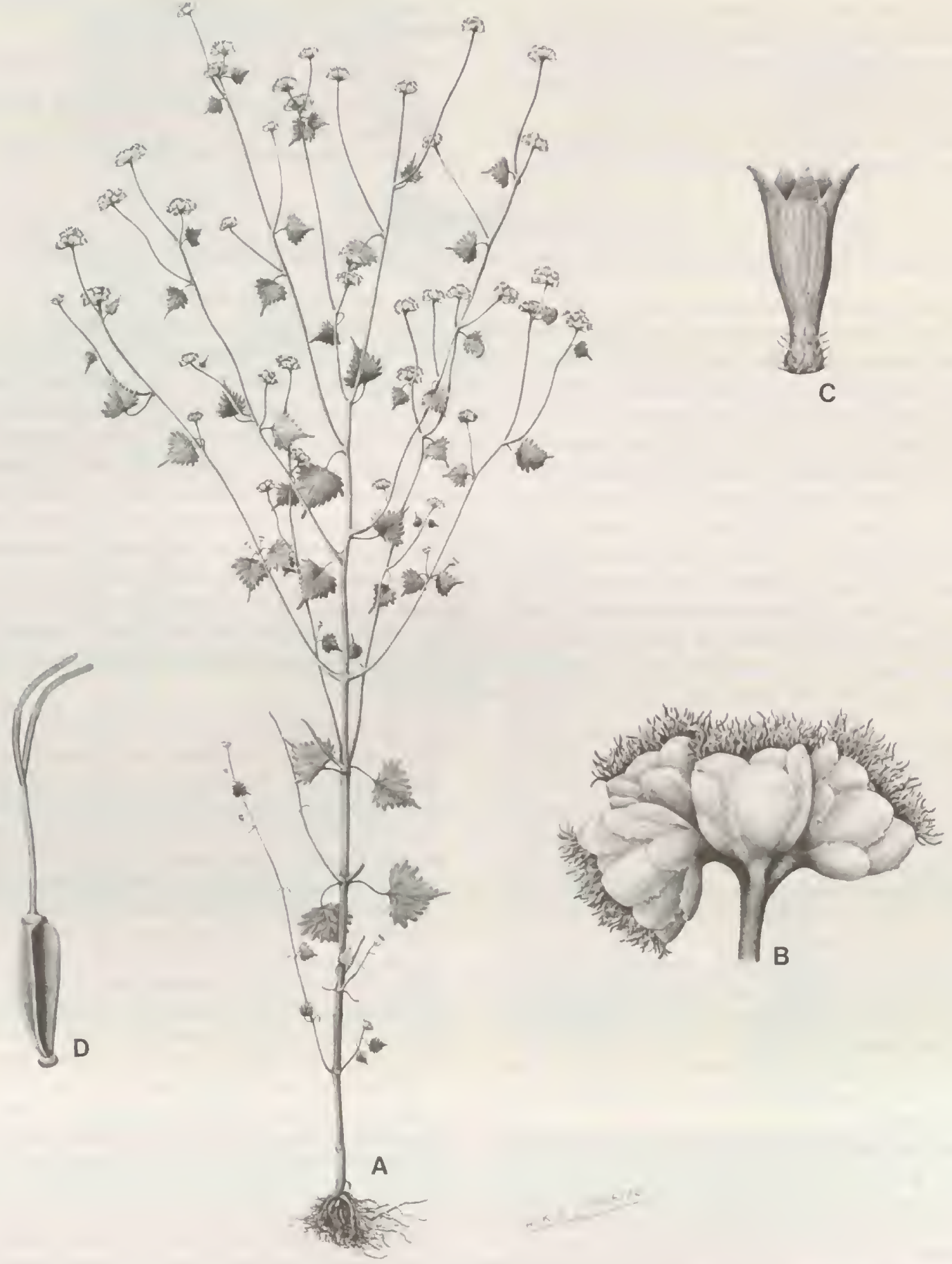

Plate 49. Cavalcantia glomerata (G. Barroso \& R. King) R. King \& H. Robinson. - A. Habit, $\times 1 / 2 .-$ B. Cluster of heads, $\times 5 .-$ C. Corolla, $\times 15 .-D$. Achene with style, $\times 15$. 
percymosa of unknown consistency is the short basal internode and immediate rebranching of the basal branches which gives the initial impression of a verticil of four branches. The distinctions are reviewed in more detail by King and Robinson (1980 j).

The genus is named in honor of Paulo Cavalcante of the Museu Paraense Emilio Goeldi in Belem, Brazil, the collector of the type species of Cavalcantia and of other endemic Eupatorieae of southern Pará.

The following two species are recognized in the genus: Cavalcantia glomerata (G. Barroso \& R. King) R. King \& H. Robinson, Brazil.

Cavalcantia percymosa R. King \& H. Robinson, Brazil.

\section{Teixeiranthus}

\section{Teixeiranthus R. King \& H. Robinson, Phytologia 47: 108. 1980. TYPE: Isocarpha foliosa Gardner.}

Erect or decumbent, annual or short-lived perennial herbs, with few branches. Stems terete, hirsute to glabrescent. Leaves opposite, sessile; blades elliptical to linear, with glandular punctations beneath. Inflorescence a corymbose cyme, pedicels rather short. Involucral bracts ca. 10, eximbricate, in ca. 2 series, equal, persistent, elliptical to narrowly obovate, irregularly 3-4-costate, with expanded, violet, scarious, rounded, densely hirsute-fimbriate tips; receptacle conical, paleaceous; paleae oblanceolate with expanded, densely hirsute-fimbriate tips. Florets ca. 30 in a head; corollas pale reddish, cylindrical with extreme base campanulate, base fused directly to top of achene; cells of throat elongate with sinuous lateral walls; lobes ovatetriangular, slightly longer than wide, densely papillose on inner surface, smooth on outer surface; filaments inserted near base of corolla; anther collar with cells short-oblong below, longer above, with distinct transverse annular thickenings on walls; anther appendage broadly oblong, as wide as long to slightly wider than long; style base not enlarged, glabrous; style branches filiform, becoming slightly wider distally, densely and strongly papillose. Achenes prismatic to subfusiform, usually 5-ribbed, internal micropunctations distinctly in transverse bands, achene base narrow, slightly flexuous; carpopodium lacking or obsolete; apex of achene without pappus or upper callus, constricted and directly confluent into corolla base, sometimes with poorly developed abscission zone. Pollen grains ca. 20-22 $\mu \mathrm{m}$ in diameter. Plate 50.

Teixeiranthus can be immediately distinguished by the fusion of the bases of the corollas to the tops of the achenes. The apices of the achenes lack not only a pappus, but they lack any trace of a callus on which a pappus could be borne. Older achenes of the type species show traces of abraded corollas still attached, while the corolla bases in $T$. pohlii appear to have a slight line of dehiscence. Such confluence of the achene apex and corolla base is otherwise unknown in the Eupatorieae, but is seen in some other tribes such as some Ecliptinae of the Heliantheae (H. Robinson, 1981). In its details, the corolla base of Teixeiranthus is further distinguished by the constriction and campanulate shape at the point of fusion, and by the insertion of the anther filaments almost at the base. These characters are not approached in any of the other genera of the Ageratinae.

Actual relationship of Teixeiranthus is almost certainly with such genera as Ageratum and Scherya, both of which have species with paleae. In the latter, the involucral bracts have ornate tips as in Teixeiranthus, but receptacles are not conical, a pappus is well developed, and the tips of the involucral bracts and paleae are glabrous or partially glanduliferous rather than fimbriate. Ageratum has no ornamentation of the tips of the involucral bracts, and has no paleaceous species native in South America. Both of the genera mentioned have well-developed carpopodia on the achenes.

Previous placement of the species of Teixeiranthus in
Alomia (J. Baker, 1876) reflects the traditional definition of the latter genus to include most Eupatorieae with an anther appendage but lacking a pappus. Alomia is now more narrowly defined and placed in the Alomiinae with Brickellia (King \& Robinson, 1972w). The genus Isocarpha, in which the type species was originally placed, is a member of the Ayapaninae distinguished easily by its elongate receptacle. Isocarpha megacephala of Brazil does actually resemble Teixeiranthus in the form of the corolla and the presence of paleae, but it lacks the ornamentation of the bracts seen in Teixeiranthus. It should be noted that I. megacephala is anomalous in Isocarpha in the form of its corolla, and in the base of its style (Keil \& Stuessy, 1981), and its position in that genus needs further study.

The two species of Teixeiranthus were collected from what seem to have been moist habitats or stream banks in northern Minas Gerais and southern Bahia in Brazil. There have been only a few collections seen, dating from the last century. There seem to have been no recent collections of either species. The distinctions of the species are briefly given by King and Robinson (1982a).

The genus is named in honor of Alcides Ribeiro Teixeira, who at the time of the study was Coordenador do Programa Flora CNPq in Brasilia.

The following two species are recognized in the genus: Teixeiranthus foliosus (Gardner) R. King \& H. Robinson, Brazil. Teixeiranthus pohlii (Baker) R. King \& H. Robinson, Brazil. 


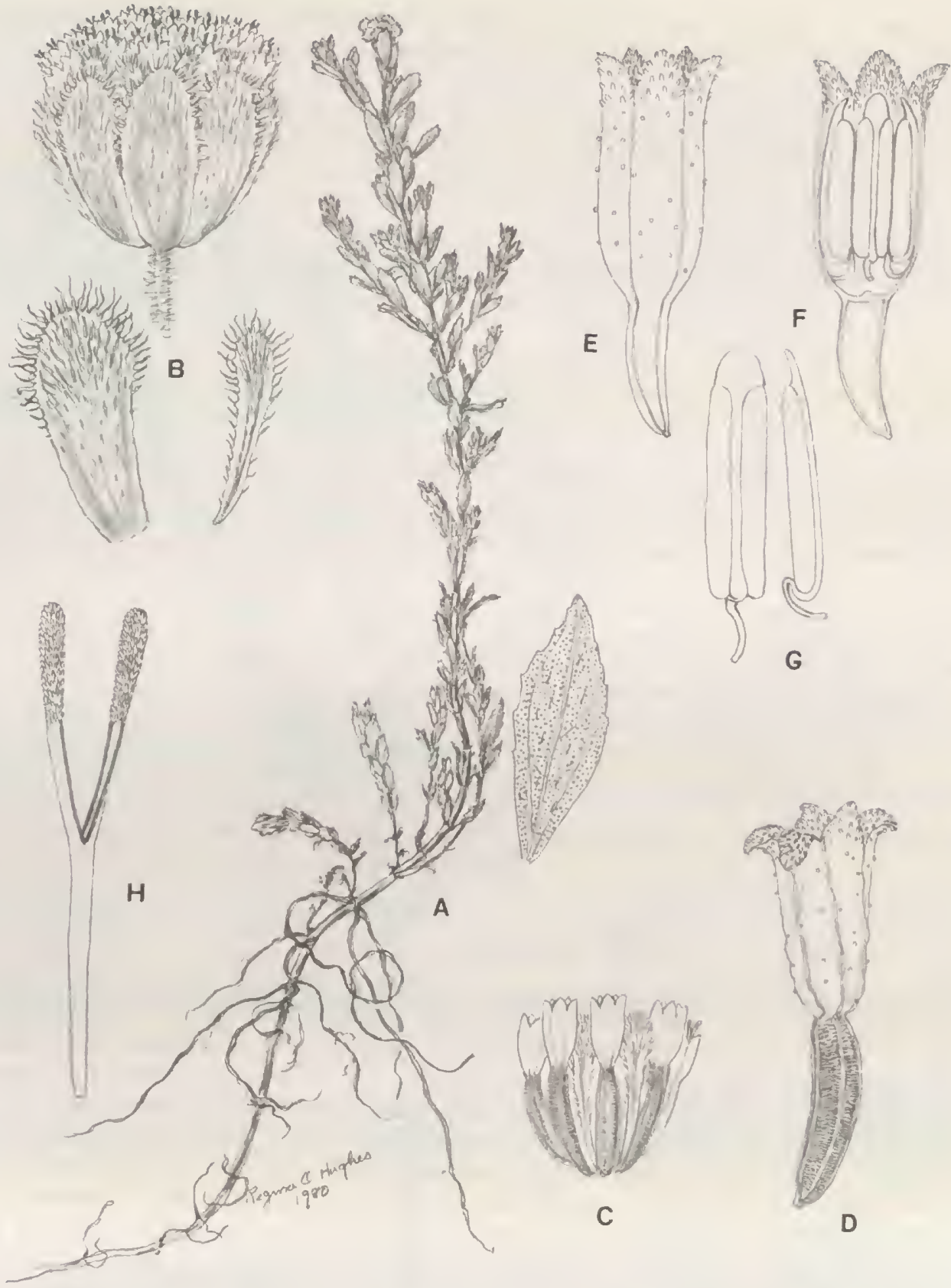

Plate 50. Teixeiranthus foliosus (Gardner) R. King \& H. Robinson. - A. Habit, $\times 1 / 2$, with separate enlarged leaf, - B. Head, $\times 7$, with separate involucral bract and palea.-C. Head without involucre showing peripheral flowers and paleae, $\times 7 .-D$. Floret with achene, $\times 15 .-$ E. Floret with immature achene, outer surface, $\times 20 .-$ F. Floret in section showing anthers, $\times 20 .-G$. Anther, $\times 30$. H. Style, $\times 20$.

\section{Gardnerina}

Gardnerina R. King \& H. Robinson, Phytologia 49: 2. 1981. TYPE: Piqueria angustata Gardner.

Annual or short-lived perennial herbs, erect from decumbent bases, moderately branched, with stems, leaves, pedicels, and involucral bracts bearing minute stipitate glands. Stems terete, striated. Leaves opposite 


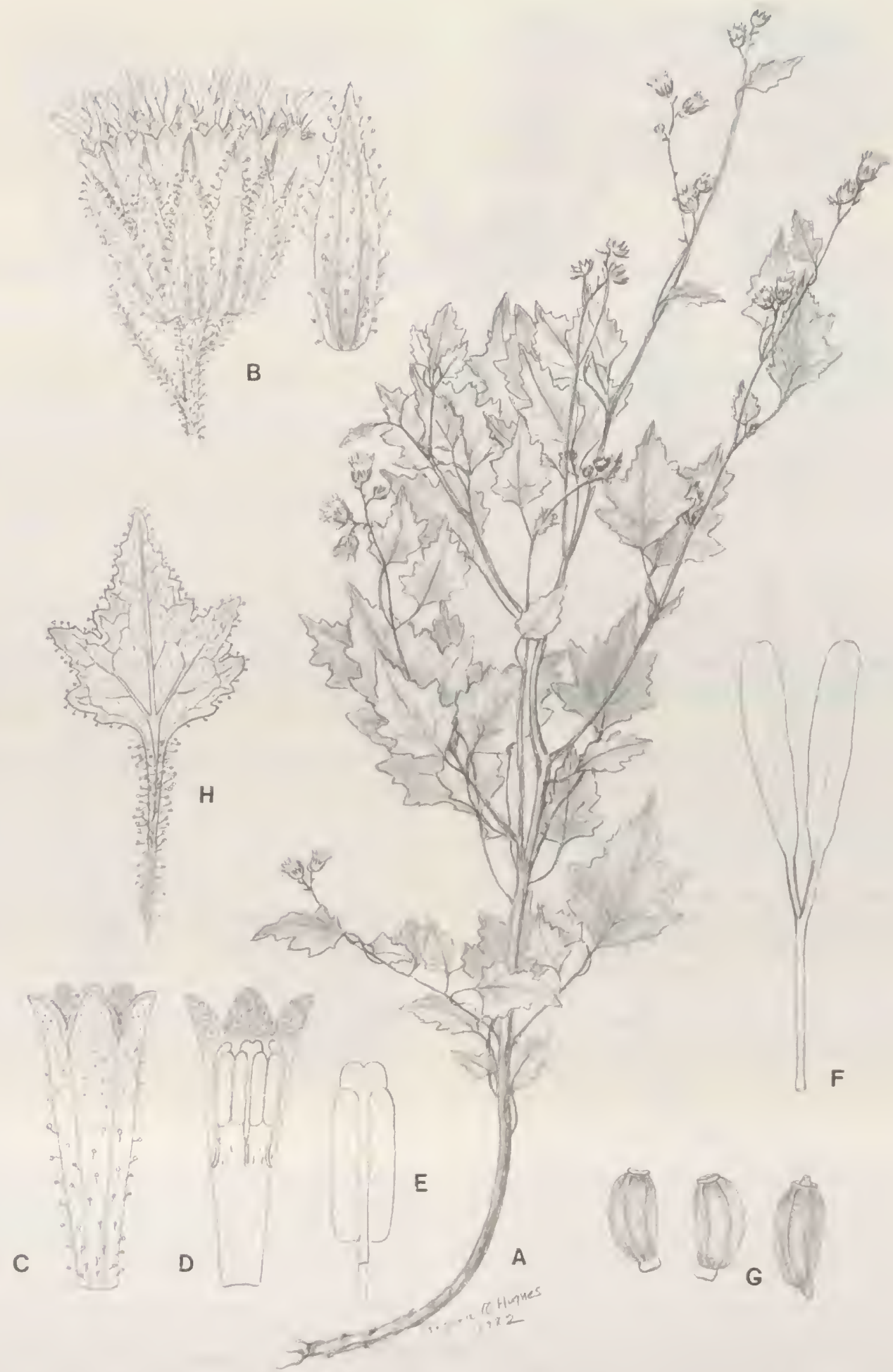

Plate 51. Gardnerina angustata (Gardner) R. King \& H. Robinson. - A. Habit, $\times 1 / 2,-$ B. Head, $\times 5$. - C. Corolla outer surface, $\times 12 .-$ D. Corolla inner surface with anthers, $\times 12 .-$ E. Anther, $\times 25 .-$ F. Style, $\times 12 .-$ G. Achenes, $\times 9 .-H$. Leaf, $\times 3 / 4$. 
below, becoming alternate above, non-petiolate; blades membranaceous, ovate to rhomboid in general outline, margin repand-dentate to pinnatifid, base broadly cuneate, shortly and narrowly acuminate, trinervate from near base. Inflorescence a few-headed cyme, pedicels slender. Involucral bracts ca. 10-12, eximbricate, in ca. 2 series, equal to subequal, persistent, lanceolate, bicostate, apex narrowly acute; receptacle flat, glabrous. Florets 12-15 in a head; corollas white?, funnelform, with stipitate glands outside in lower part; cells of throat oblong with sinuous lateral walls, throat with short non-glandular hairs inside on and near bases of filaments; lobes shortly oblong to triangular, ca. 1.25-1.5 times as long as wide, inner surface densely papillose, outer surface smooth; anther collar cylindrical, composed of subquadrate to short-oblong cells with dense annular thickenings on walls; anther appendage short, ca. twice as wide as long, slightly bilobed; style base not or scarcely enlarged, glabrous; style branches broadly clavate or strap-shaped, flattened, rather fleshy, surface densely short-papillose, mamillose distally. Achenes subprismatic, 5-ribbed, glabrous; carpopodium distinct, symmetrical, subinflated, sometimes easily broken from achene, composed of subquadrate to rotund moderately sized cells mostly $25-35 \mu \mathrm{m}$ in diameter, in ca. 8 tiers, walls mostly rather moderately and evenly thickened; pappus lacking. Pollen grains ca. 21-23 $\mu \mathrm{m}$ in diameter. Plate 51 .

The single known species of Gardnerina is immediately distinguishable by the repand-dentate to pinnatifid leaves. Also distinctive are the greatly expanded style branches and the cover of minute stipitate glands on the leaves, stems, and inflorescence. Difficult to observe but generically significant are the non-glandular hairs on the inner surface of the corollas near the bases of the anther filaments.

Relationships of Gardnerina to other genera are nebulous. The two genera in which the type species has been placed in the past, Piqueria and Alomia, have both been redefined and are now recognized as small and discrete genera geographically restricted to areas outside of South America. Gardnerina does not seem particularly related to Ageratum or any of its close relatives having conical receptacles. The appearance of the plant is no help in determining its relationship, since superficial resemblance is to members of the subtribe Adenostemmatinae rather than to any other genera of the Ageratinae.

Gardnerina is apparently known only from the type material which was collected from among limestone rocks in Goias, Brazil, near the Villa de Arrayas. The genus is named in honor of the collector of the type specimens, George Gardner, who collected and published extensively on the Asteraceae of Brazil during a period of a few years during the middle of the last century.

The following single species is recognized in the genus: Gardnerina angustata (Gardner) R. King \& H. Robinson, Brazil.

\section{Ellenbergia}

\section{Ellenbergia Cuatrec., Proc. Biol. Soc. Wash. 77: 142. 1964. TYPE: Ellenbergia glandulata Cuatrec.}

Erect annual herbs, unbranched. Stems terete, striated, puberulous. Leaves opposite, a few alternate above, short-petiolate; blades ovate to ovate-elliptical, membranaceous, base obtusely cuneate to subtruncate, margin crenate-dentate, apex acute. Inflorescence a lax panicle with subcymose branches; pedicels slender, bearing stipitate glands. Involucral bracts 8, eximbricate, in 2 series, subequal, persistent, oblong-elliptical to obovateelliptical, with rounded tips; receptacle flat, foveolate, glabrous. Florets 10-12 in a head; corollas white?, with distinct constricted basal tube, bearing glandular punctations outside; throat broadly campanulate, with short-oblong cells on inner surface projecting as papillae, with somewhat sinuous lateral walls; lobes triangular-ovate, about as long as wide, densely papillose on inner surface and margin; lower part of filament short, densely pubescent; anther collar slender, cells mostly short-oblong, obscured by strong transverse annular thickenings on walls; anther appendage reduced to a small vestigial lobe on each theca; style base not enlarged, hirtellous; style branches shortly clavate, densely papillose. Achenes prismatic, 5-ribbed, setuliferous on ribs, narrowed and densely setuliferous above carpopodium, internal micropunctations rather dense; carpopodium distinct, nearly symmetrical, shortly cylindrical, cells mostly oblong, in 5-6 series, with slightly thickened densely porose walls; pappus of ca. 20 short, lanceolate squamellae, densely scabrid on margins, nearly smooth on outer surface. Pollen grains ca. $18 \mu \mathrm{m}$ in diameter. Plate 52.

The reduced habit, the shape of the corolla, and the vestigial anther appendage all indicate that Ellenbergia is closely related to a series of genera including Ferreyrella.
Guevaria, Piqueriopsis, and Piqueriella. The generic group is evidently centered in the Andes of South America, with only the latter two genera outside of that area. Ellenbergia 

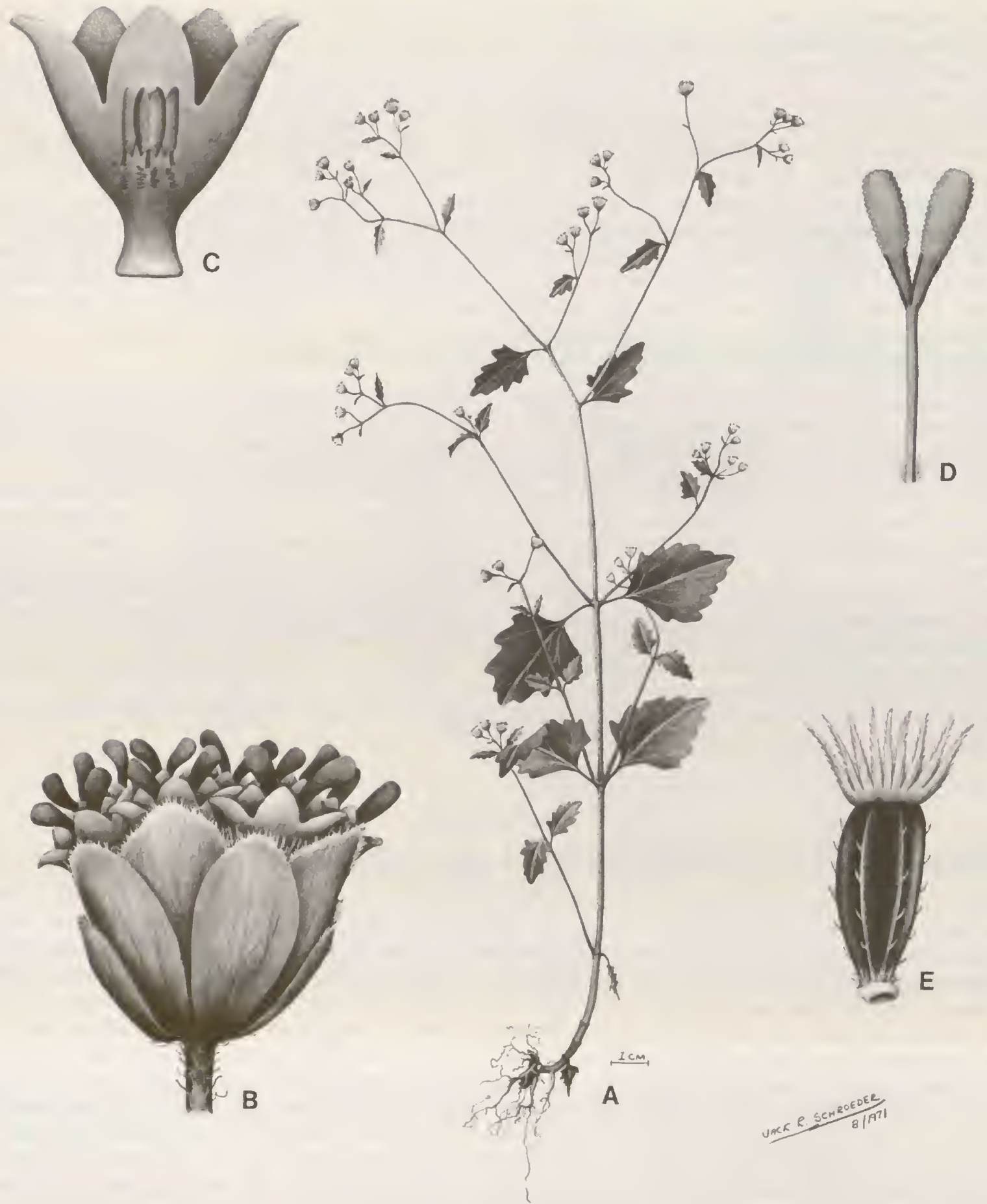

Plate 52. Ellenbergia glandulata Cuatrec. - A. Habit, $\times 3 / 5 .-$ B. Head, $\times 16 .-$ C. Corolla showing anthers, $\times 23 .-$ D. Style, $\times 23 .-$ E. Achene, $\times 23$. 
is distinct from all other members of the group by having a pappus, by having hairs on the base of the style, and by having the lower part of the anther filaments densely pubescent. Each of the three characters is of considerable significance.

Ellenbergia, as the only pappose member of a group of genera, provides the only insight into the form of pappus that is potential within the group. It is notable that the one example has approximately twenty segments. Such a form is rather anomalous in the subtribe, being found otherwise only in the Stevia relationship. Most other genera of the subtribe show a pappus reduced to five or less segments or totally fused. It is not believed that such reduced forms could have given rise to the type of pappus seen in Ellenbergia, which might indicate that the whole group of genera belongs to a separate reduction series.

Pubescent style bases are very rare in the Ageratinae, being found elsewhere in only some Stevia species. The only other member of the Eupatorieae as small as Ellenbergia having an ornate style base is Parapiqueria of Brazil, but that genus shows unmistakable evidence of membership in the subtribe Ayapaninae.

The hairs on the lower part of the anther filament in
Ellenbergia might suggest close relationship to Gardnerina of Brazil in which some hairs occur. The hairs would be the only basis for assuming such a relationship, however, and the possibility is rejected by the present authors. The genera are placed together in the treatment for other reasons.

Cuatrecasas (1964) mentions in his description that the segments of the pappus are united at the base into a cupular piece easily separable from the achene. Examination of material indicates that the degree of separation from the achene is not significant. The fact that Chung (1967) redescribed the single species as a member of the genus Piqueria is inexplicable since he acknowledged the presence of a pappus.

Both known collections of Ellenbergia are from Machupicchu, in the Province of Urubamba in the Department of Cuzco, Peru. The genus is named in honor of the collector of the Cuatrecasas type material, Heinz Ellenberg of Utrecht, an ecologist who has collected extensively in the Andes.

The following single species is recognized in the genus: Ellenbergia glandulata Cuatrec., Peru.

\section{Guevaria}

Guevaria R. King \& H. Robinson, Phytologia 29: 259. 1974. TYPE: Piqueria sodiroi Hieron. in Sodiro.

Small perennial herbs, decumbent or erect with decumbent bases, with few to many branches. Stems terete, striated, puberulous to hirtellous. Leaves opposite, mostly to completely alternate in $G$. vargasii, with narrow petioles; blades ovate, trinervate, margin crenulate to serrulate, surfaces pilosulous, often glandular-punctate below. Inflorescence laxly paniculate with cymose branches; pedicels slender. Involucral bracts 10-20, eximbricate, in 2-3 series, subequal, persistent, oblong with rounded tips; receptacle conical, glabrous. Florets 15-40 in a head; corollas white, with distinct constricted basal tube bearing many hairs; throat shortly and broadly campanulate, cells short-oblong with sinuous lateral walls, produced at upper ends as mamillae; lobes triangular-ovate, 1-2 times as long as wide, densely papillose on inner surface and margins, with short hairs and glands on outer surface; anther collar only slightly expanded, cells mostly subquadrate, with prominent transverse annular thickenings on walls; anther appendage vestigial; style base not enlarged, glabrous; style branches broadly linear, densely long-papillose. Achenes prismatic, obovate, 5-ribbed, glabrous; carpopodium cylindrical, asymmetrical above with a sinuous vascular trace, cells elongate, in $2-5$ series, with firm scarcely thickened walls; pappus lacking. Pollen grains ca. 16-18 $\mu \mathrm{m}$ in diameter. Plate 53.

Guevaria has the reduced habit, lack of pappus, vestigial anther appendage, and corolla structure that indicate relationship to Ferreyrella, Ellenbergia, Piqueriopsis, and Piqueriella. Guevaria differs from the others most obviously by the decumbent perenniating habit, and it appears to occupy habitats not available to the related mostly annual genera. The conical receptacle is also rather distinctive. The only other genus of the immediate group with the receptacle conical is the paleaceous Ferreyrella. The numerous, mostly non-glandular hairs on the basal tube of the corolla further distinguish Guevaria from $P i$ queriella of eastern Brazil.

The type species of Guevaria was one of the South
American elements, along with Phalacraea and Ophryosporus, that was treated as Piqueria by B. Robinson (1906). The present concept of Piqueria is restricted to species with 3-5 involucral bracts and an equal number of flowers, occurring in Mexico, Central America, and the West Indies. Ophryosporus belongs to another subtribe, the Critoniinae, and Phalacraea has flat receptacles, a generally larger size, and pointed involucral bracts.

Guevaria is the only member of its immediate group that has been examined cytologically. Ten populations representing two species, indicate a consistent $x=10(\mathrm{R}$. King et al., 1976).

The three species from southern Ecuador and northern 


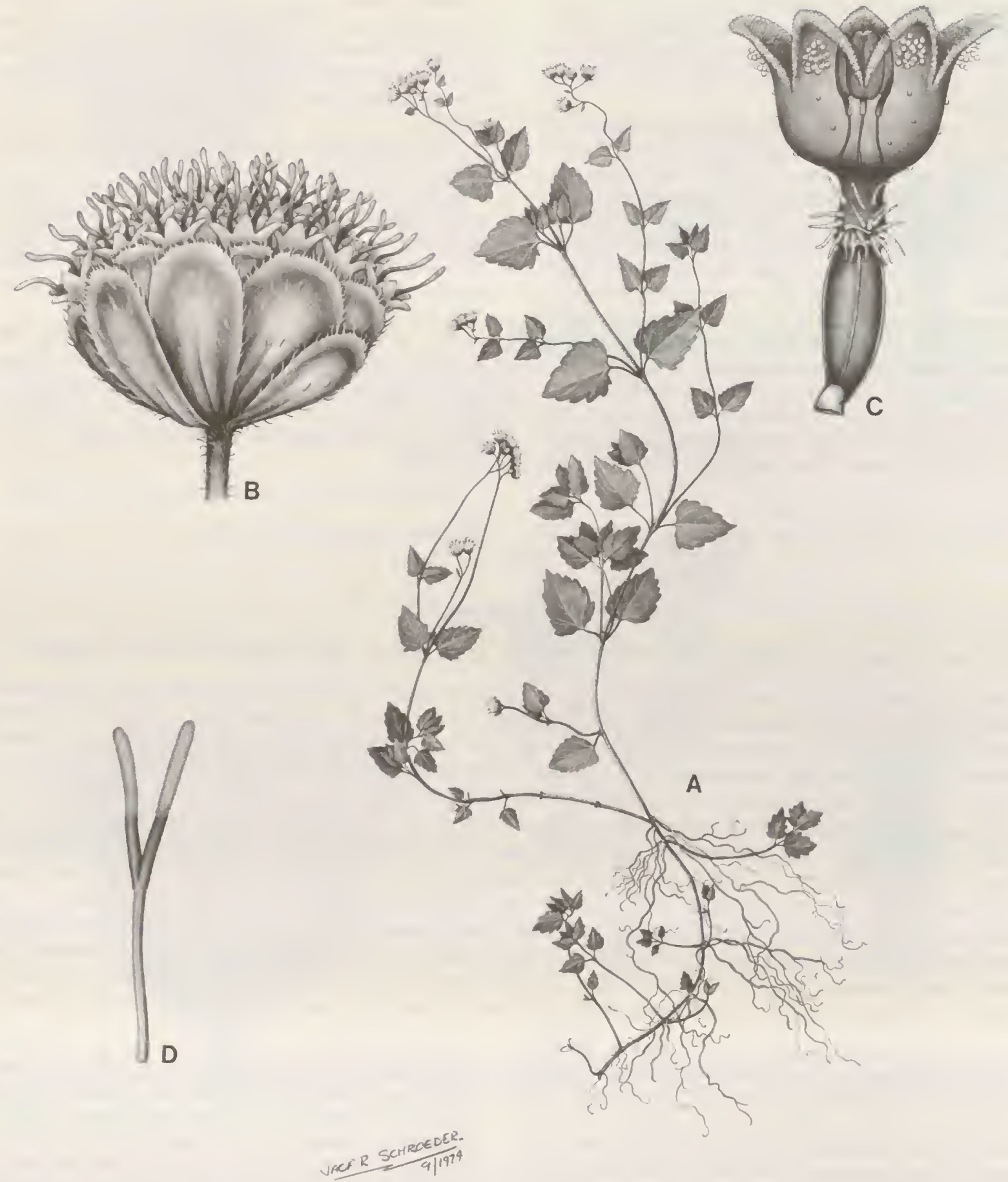
Plate 53. Guevaria sodiroi (Hieron. in Sodiro) R. King \& H. Robinson. - A. Habit, $\times 3 / 5 .-$ B. Head, $\times 15 .-$ C. Floret showing anthers,
$\times 30 .-$ D. Style, $\times 30$. 
Peru form a closely related group distinguished by minor variations of habit and pubescence. The fourth species, $G$. vargasii, from the Department of Apurimac in southern Peru, is known from only the type which lacks a base. The distinctions of the species are discussed by King and Robinson (1974p).

The genus is named for Alvaro E. Guevara of Austin, Texas, a participant in trips to collect Asteraceae in Ecuador, Colombia, Costa Rica, and Guatemala.
The following four species are recognized in the genus:

Guevaria alvaroi R. King \& H. Robinson, Ecuador.

Guevaria loxensis (S. F. Blake \& Steyerm.) R. King \& H. Robinson, Ecuador.

Guevaria sodiroi (Hieron. in Sodiro) R. King \& H. Robinson, Ecuador.

Guevaria vargasii (Chung) R. King \& H. Robinson, Peru.

\section{Ferreyrella}

\section{Ferreyrella S. F. Blake, J. Wash. Acad. Sci. 47: 407. 1958. TyPE: Ferreyrella peruviana S. F. Blake.}

Small, erect, annual herbs, unbranched below the inflorescence. Stems terete, striated. Leaves opposite below, alternate above, short-petiolate or sessile; blades ovate to broadly elliptical, usually cuneate at base, margins coarsely to finely serrate. Inflorescence a diffuse corymbose cyme; pedicels slender. Involucral bracts ca. 15-25, eximbricate, in 2 series, subequal to equal, persistent, ovate to broadly oblanceolate, with rounded tips, pubescent; receptacle conical, paleaceous; paleae ovate to oblong. Florets ca. 30 in a head; corollas white, with short constricted basal tube bearing glandular or non-glandular hairs; throat shortly and broadly campanulate, cells broadly oblong with somewhat sinuous lateral walls, with upper ends slightly to distinctly bulging as mamillae; lobes triangular-ovate, usually as long as wide (outer lobes of peripheral flowers more enlarged in F. peruviana), densely short-papillose on inner surface and margin; lower part of filament glabrous; anther collar rather short, few cells subquadrate below, more oblong above, with dense annular thickenings on walls; anther appendage very small and broader than long, or lacking; style base not enlarged, glabrous; style branches rather short-clavate at tips, densely short-papillose, papillae larger and less dense below clavate tip. Achenes prismatic, 5-ribbed, glabrous, with dense minute internal punctations; carpopodium distinct, rather symmetrical, short-cylindrical, cells oblong in 3-4 series, thick-walled; pappus lacking. Pollen grains ca. $18 \mu \mathrm{m}$ in diameter. Plate 54 .

Ferreyrella was one of the first to be described of the considerable number of genera of extremely reduced form in the Eupatorieae, and was the first described of a small related group including Ellenbergia, Piqueriopsis, Piqueriella, and Guevaria in the Ageratinae. All genera of the group have a pappus reduced or lacking, an anther collar small or absent, and corollas with broadly campanulate throats. Ferreyrella of Peru and Piqueriopsis of Mexico are of such reduced nature as to suggest an ephemeral habit, while only Guevaria in the series seems to be perennial. Ferreyrella is unique in the series by its paleaceous receptacle, and differs from all but Guevaria by having the receptacle conical. The genus is also the only one of the immediate group showing any asymmetry of the corolla lobes.

The presence of paleae in Ferreyrella is considered an elaboration in what is in most other ways a greatly reduced plant. Such paleae closely resemble the involucral bracts, and seem to relate to them developmentally more than to paleae in other genera of the Ageratinae such as Ageratum and Acritopappus. Another of the extremely reduced Eupatorieac, Parapiqueria, shows similar paleae, but the latter genus is not closely related, being a member of the Ayapaninae.

The enlargement of the outer lobes of the peripheral corollas in the type species of Ferreyrella were noted by Blake (1958), and considered as suggestive of those of Microspermum. Blake was correct in rejecting an immediate relationship between the two genera which belong to groups in the Ageratinae with different basic chromosome numbers, but he was incorrect in considering the two genera tribally distinct. Actually, irregular corollas occur in yet other members of the Eupatorieae, especially in the Praxelinae.

Two species are presently known in Ferreyrella occurring in the closely adjacent Departments of La Libertad, and Cajamarca in northern Peru. The distinctions of the species are discussed by King and Robinson. (1973a). In spite of great superficial similarity between the species, there are significant differences in corolla symmetry and anther appendage development.

The genus was named by Blake in honor of Ramon Alejandro Ferreyra Huerta, Peruvian botanist at the Herbario San Marcos of the Museo de Historia Natural in Lima.

The following two species are recognized in the genus:

Ferreyrella cuatrecasasii R. King \& H. Robinson, Peru. Ferreyrella peruviana S. F. Blake, Peru. 

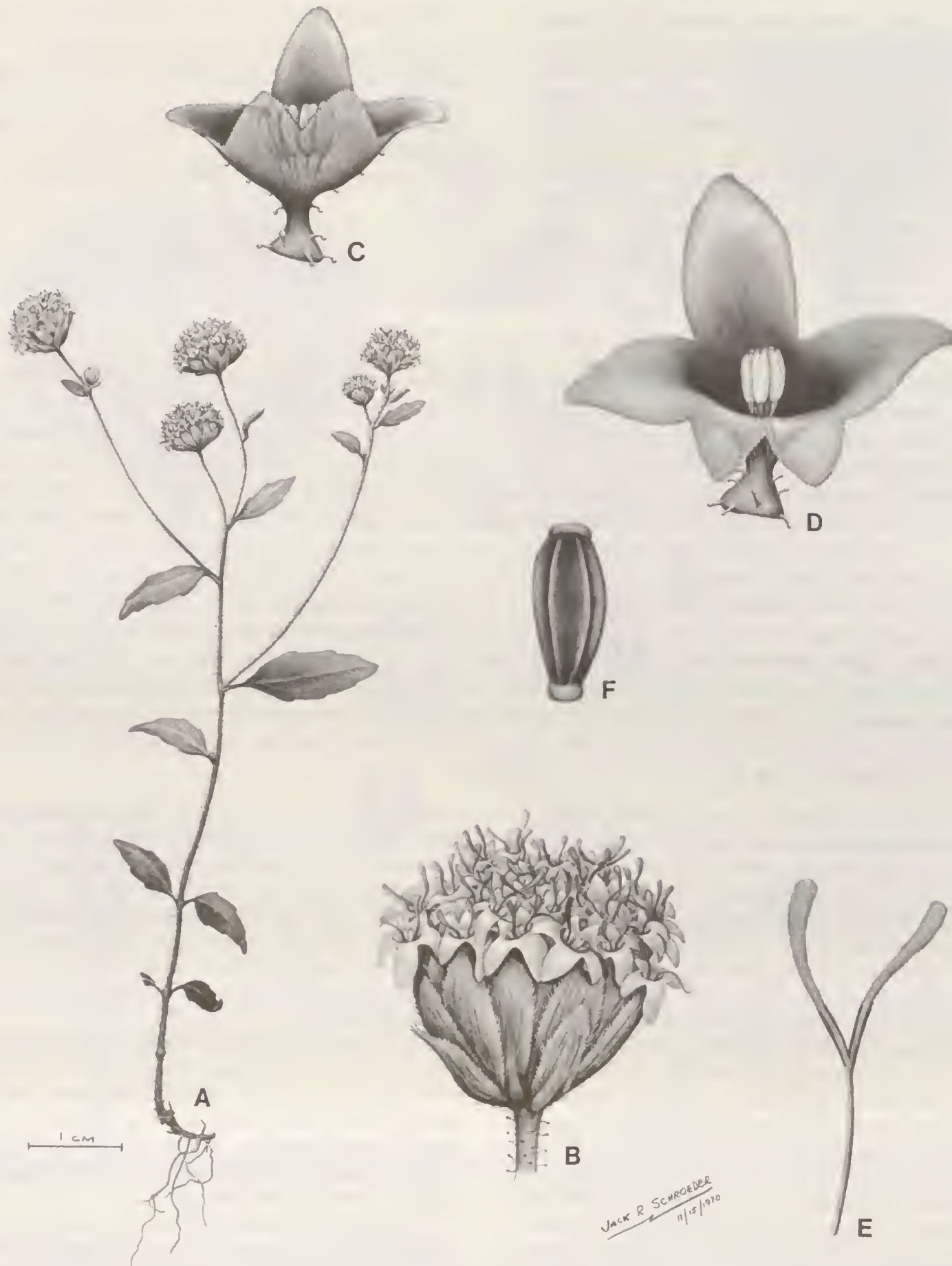

Plate 54. Ferreyrella peruviana S. F. Blake. - A. Habit, $\times 11 / 3 .-$ B. Head, $\times 6 .-$ C, D. Corollas showing anthers, $\times 20 .-E$. Style, $\times 20,-F$. Achene, $\times 20$. 

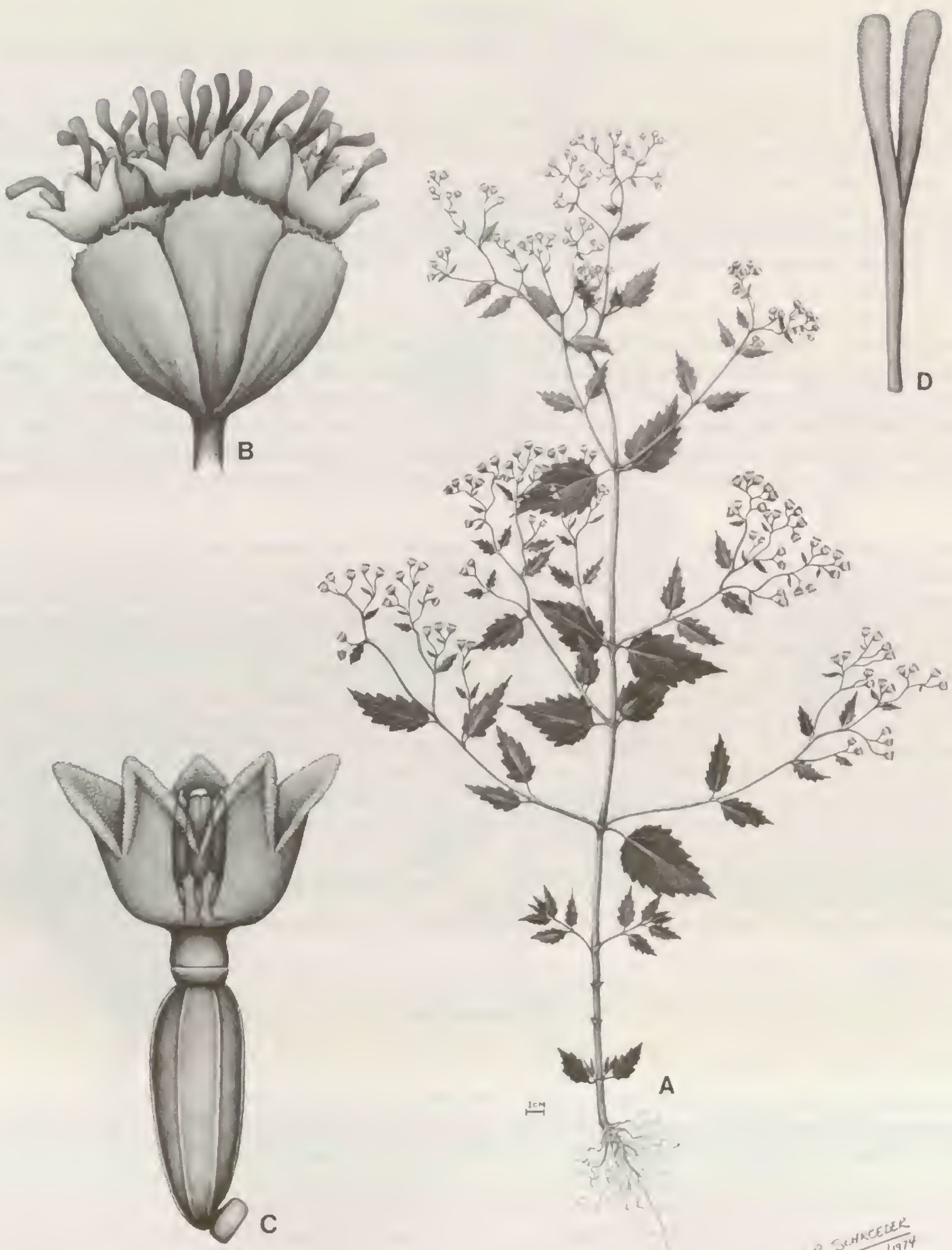

$$
\text { . }
$$
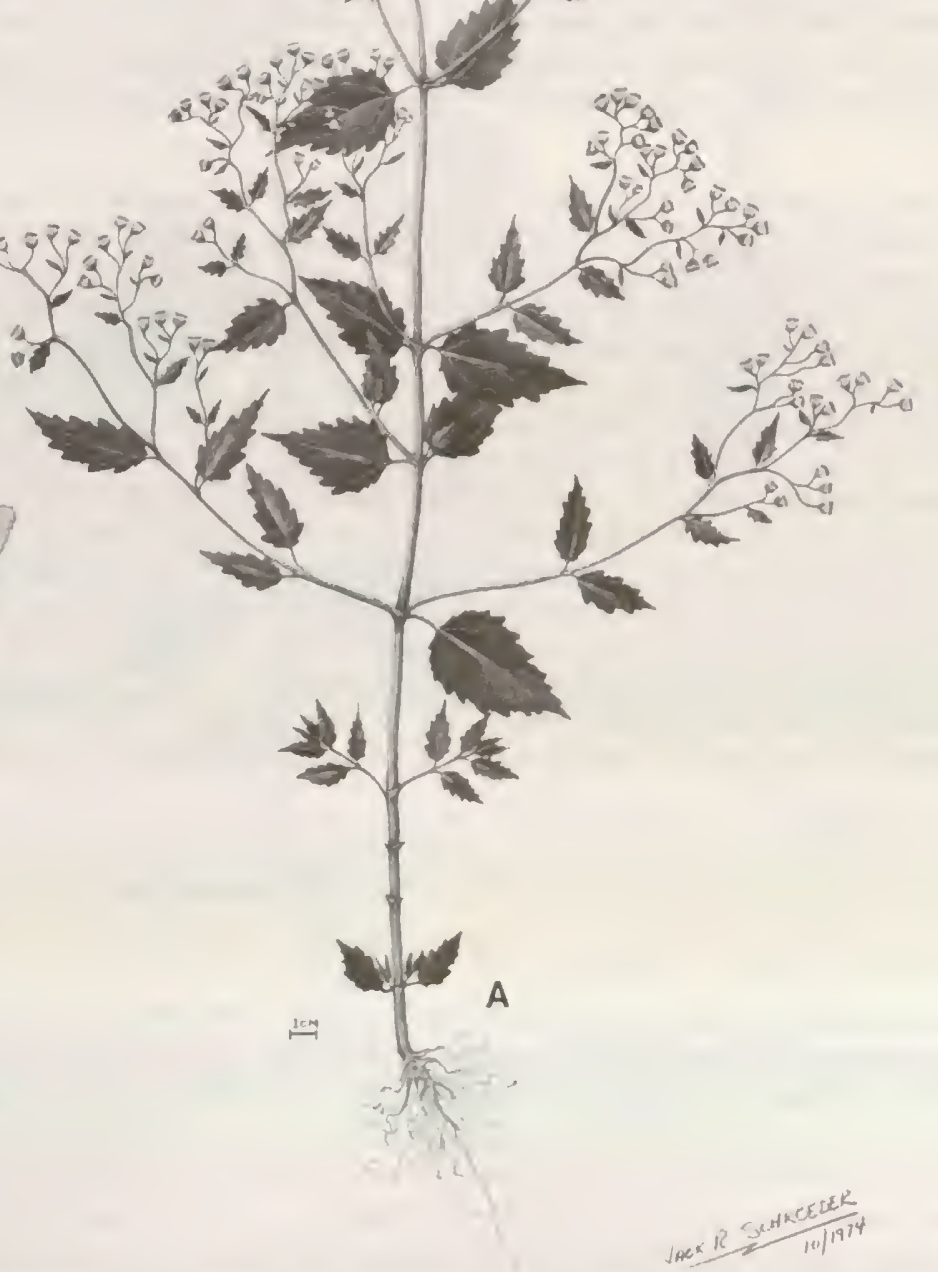

PLAte 55. Piqueriella brasiliensis R. King \& H. Robinson. - A. Habit, $\times 1 / 2,-$ B. Head, $\times 15$. C. Floret showing anthers, $\times 30 .-D$. Style, $\times 30$. 


\section{Piqueriella}

Piqueriella R. King \& H. Robinson, Phytologia 29: 264. 1974. TyPE: Piqueriella brasiliensis R. King \& H. Robinson.

Small, annual or short-lived perennial herbs from erect bases, with few branches. Stems terete, striated. Leaves usually opposite, narrowly petiolate; blades ovate, thin, trinervate from or near base, base broadly cuneate, margin with many large teeth, apex shortly and narrowly acuminate, sparsely glanduliferous below. Inflorescence a lax cyme, branches with stipitate glands; pedicels slender, moderately long, puberulous. Involucral bracts ca. 6, eximbricate, in 2 series, equal, persistent, broadly oblong, subtruncate, 3-5-denticulate; receptacle slightly convex, glabrous. Florets ca. 8 in a head; corollas white?, with distinct constricted basal tube, glabrous on outer surface; throat broadly and shortly campanulate, cells short-oblong with sinuous lateral walls, with upper ends projecting slightly on inner surface as mamillae; lobes triangular-ovate, longer than wide, densely papillose in inner surface and margins; anther collar rather short, stout, cells usually short, with strong transverse annular thickenings on walls; anther appendage small but distinct, very short and broad, with slightly recurved apical margin; style base not enlarged, glabrous; style branches short and subclavate, with dense long papillae. Achenes prismatic, 5-ribbed, glabrous; carpopodium strongly asymmetric in placement, with very narrow constriction at attachment to achene, rather annuliform, cells usually elongate, in 2-3 series, with slightly thickened walls; pappus lacking. Pollen grains ca. 16-18 $\mu \mathrm{m}$ in diameter. Plate 55.

The name Piqueriella is a diminutive of Piqueria after which the former is named. The latter genus, Piqueria, is also a member of the subtribe Ageratinae, and was once interpreted widely to include all Eupatorieae such as $P i$ queriella that lack a pappus and have a vestigial anther appendage. At present, Piqueria is interpreted narrowly to include Mexican, Central American, and West Indian species with 3-5 involucral bracts and an equal number of flowers, papillose anther filaments, and chromosome base numbers of $x=11-12$. Piqueriella lacks these and other specialized characters of Piqueria, and the details of its corolla indicate actual relationship is to the series of genera, Ellenbergia, Ferreyrella, Guevaria, and Piqueriopsis. On the basis of Guevaria, the series seems to have a chromosome base number of $x=10$.

Piqueriella is unique in its immediate group of related genera by the glabrous basal tube of its corolla. It also differs from the other fully epappose members of the group in South America by the non-conical non-paleaceous receptacles. The asymmetrically placed, narrowly attached carpopodium is distinctive, but is similar to Ferreyrella in the shape of its cells.

Within the immediate related group of genera, Piqueriella is actually most notable for its geographical distribution. Most of the generic group is centered in the Andes with one other genus, Piqueriopsis, in Mexico. The location of Piqueriella in Ceará, in eastern Brazil, is actually farther from the Andean center of the group than the area in Mexico where Piqueriopsis occurs.

The following single species is recognized in the genus: Piqueriella brasiliensis R. King \& H. Robinson, Brazil.

\section{Piqueriopsis}

\section{Piqueriopsis R. King, Brittonia 17: 352. 1965. TYPE: Piqueriopsis michoacana R. King.}

Small, ephemeral, erect herbs, forming sparingly branched inflorescence above, unbranched below. Stems terete, striated. Leaves opposite, narrowly petiolate; blades ovate to elliptic-rhomboid, margin crenulate to undulate. Inflorescence a small panicle with few-headed cymose branches; pedicels slender, of moderate length. Involucral bracts (4-)5-6, eximbricate, in ca. 2 series, equal to subequal, persistent; obovate to oblanceolate, with mostly obtuse apices; receptacle convex, glabrous. Florets 3-7 in a head; corollas white, with distinct constricted short basal tube, bearing numerous stout non-glandular hairs near base; throat short and widely funnelform from subcampanulate base, cells broadly oblong with slightly sinuous lateral walls, upper ends of cells sometimes slightly bulging on inner surface as mamillae; lobes four, triangular-ovate, ca. 1.5 times as long as wide, strongly mamillose on inner surface, glabrous on outer surface; anther collar stout, cells obscured by dense transverse annular thickenings on walls; apex of anther retuse with appendage completely absent; style base slightly enlarged with rather large firm-walled cells, glabrous; style appendage short, not or slightly clavate, with mamillose surface. Achenes prismatic, 8-10-ribbed, glabrous, wall with 

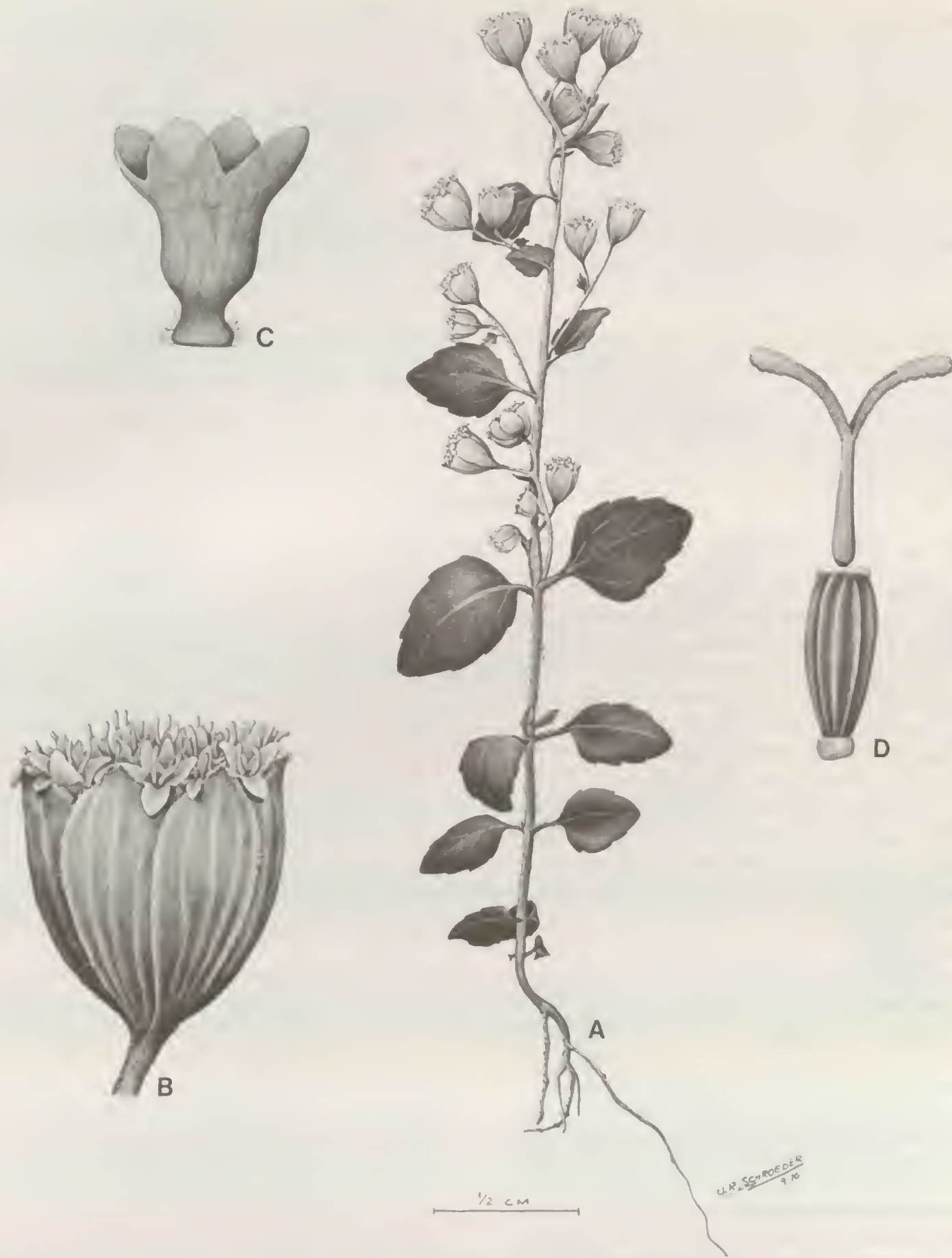

Plate 56. Piqueriopsis michoacana R. King. - A. Habit, $\times 4 \frac{1}{2},-$ B. Head, $\times 28 .-$ C. Corolla showing anthers, $\times 45 .-D$. Achene with style, $\times 45$.

dense minute internal punctations: carpopodium rather symmetrical, forming a somewhat flaring annulus, cells elongate, in 2-3 series, with outer walls greatly thickened: pappus lacking. Pollen grains ca. $16 \mu \mathrm{m}$ in diameter. Plate 56. 
The genus Piqueriopsis of Mexico is named after the genus Piqueria of Mexico, Central America, and the West Indies, which it resembles in the lack of a pappus and the reduction of its anther appendage. Piqueriopsis is extremely reduced in size, and has details of the corolla indicating closest relationship to Ferreyrella, Ellenbergia, Guevaria, and Piqueriella, all of South America. Piqueriopsis is distinct from all its immediate relatives, and from Piqueria as well, by its 8-10-ribbed achenes and 4lobed-4-anthered corollas. The minute size and evident ephemeral habit of Piqueriopsis are most closely matched among its relatives by Ferreyrella, but the latter differs in its conical and paleaceous receptacle.

The original description of Piqueriopsis was previous to the refinement of the concept of Piqueria, but was necessitated by the anomalous combination of characters used at that time to artificially distinguish the traditional subtribes. The reduced anther appendages were supposed to be characteristic of the Piqueriinae, while the manyribbed achenes were a key character of the Kuhniinae (B. Robinson, 1913a). A position near Piqueria was nevertheless assumed by R. King (1965). The subsequent refinement in the concept of Piqueria has led to the present view that the two genera belong to two basically different generic groups within the subtribe Ageratinae.

The single species of Piqueriopsis is known only from the type series from the state of Michoacan in Mexico. It represents an isolated occurrence in Mexico of what seems to be mostly a South American group. Explanation of such an occurrence may eventually be clarified if further relatives of these rarely collected minute and ephemeral plants are found elsewhere in tropical America.

The following single species is recognized in the genus: Piqueriopsis michoacana R. King, Mexico.

\section{Piqueria}

\section{Piqueria Cav., Icon. 3: 18. 1794. TYPE: Piqueria trinervia Cav.}

Erect, annual to perennial herbs or subshrubs, sparsely branched. Stems terete to slightly quadrangular, sometimes with decurrent lines of pubescence. Leaves mostly opposite, short-petiolate to sessile; blades ovate to lanceolate, trinervate from base, margins serrulate to serrate. Inflorescence laxly paniculate with laxly to densely subcymose branches; pedicels short to moderately long. Involucral bracts 3-5, eximbricate, in one series, equal, persistent, with obtuse to apiculate apices; receptacle flat, glabrous. Florets $3-5$ in a head, same number as involucral bracts; corollas white to slightly lavender, with short, narrow, densely pubescent basal tube; throat short-campanulate, cells oblong with somewhat to strongly sinuous lateral walls, nearly smooth on inner surface or projecting as hair-like papillae, especially in lower part of throat; lobes triangular to oblong, 1.5-3 times as long as wide, densely papillose on inner surface, slightly papillose on margins and tip outside; filaments of anthers with small to large papillae on lower part; anther collar broad, cells subquadrate below, longer above, with strong transverse annular thickenings on walls; anther appendages vestigial or lacking; style base not enlarged, glabrous; style branches with slightly to strongly clavate tip, with dense long papillosity on narrower parts, becoming nearly smooth on tips. Achenes prismatic, 5-ribbed, glabrous, with sparse minute internal punctations in carbonized layer between ribs, densely punctate on ribs; carpopodium usually asymmetrical and large, with strongly sinuous vascular trace and large oblong cells, in ca. 8 series on more expanded surface (carpopodium symmetrical forming small ring with 3-5 rows of small quadrate cells in P. serrata and P. hintonii); pappus lacking. Pollen grains ca. $18 \mu \mathrm{m}$ in diameter. Plate 57.

The traditional delimitation of Piqueria included most members of the Eupatorieae in which both the pappus and the anther appendage are essentially lacking. As such the genus was highly artificial, taking in various elements such as Phalacraea and Guevaria from South America which are now placed elsewhere in the Ageratinae, part of Ophryosporus also of South America, now placed in the Critoniinae, and Erythradenia of Mexico, which belongs in the Hebecliniinae. Many additional species that have been misplaced in Piqueria for various reasons in the past can be found in the nomenclator that accompanies this generic review. Piqueria was, furthermore, the type genus of a subtribe Piqueriinae, defined by the reduced anther appendage, a character even more erratically dis- tributed in the tribe. Nevertheless, both the generic and subtribal names find actual or potential application for natural elements of the tribe as presently defined.

The limits of Piqueria as defined here, conform closely to the subgenus Eupiqueria as delimited by B. Robinson (1906). The heads have three to five equal eximbricate involucral bracts and an equal number of flowers. In addition, the lower part of the anther filament is papillose or pubescent in all species, and the walls of the achene have the internal minute punctations in a unique sparse pattern. The chromosome number has been reported as usually $x=12$ (R. King et al., 1976).

Both the organization of the head in Piqueria, with its few bracts and matching number of flowers, and the ten- 


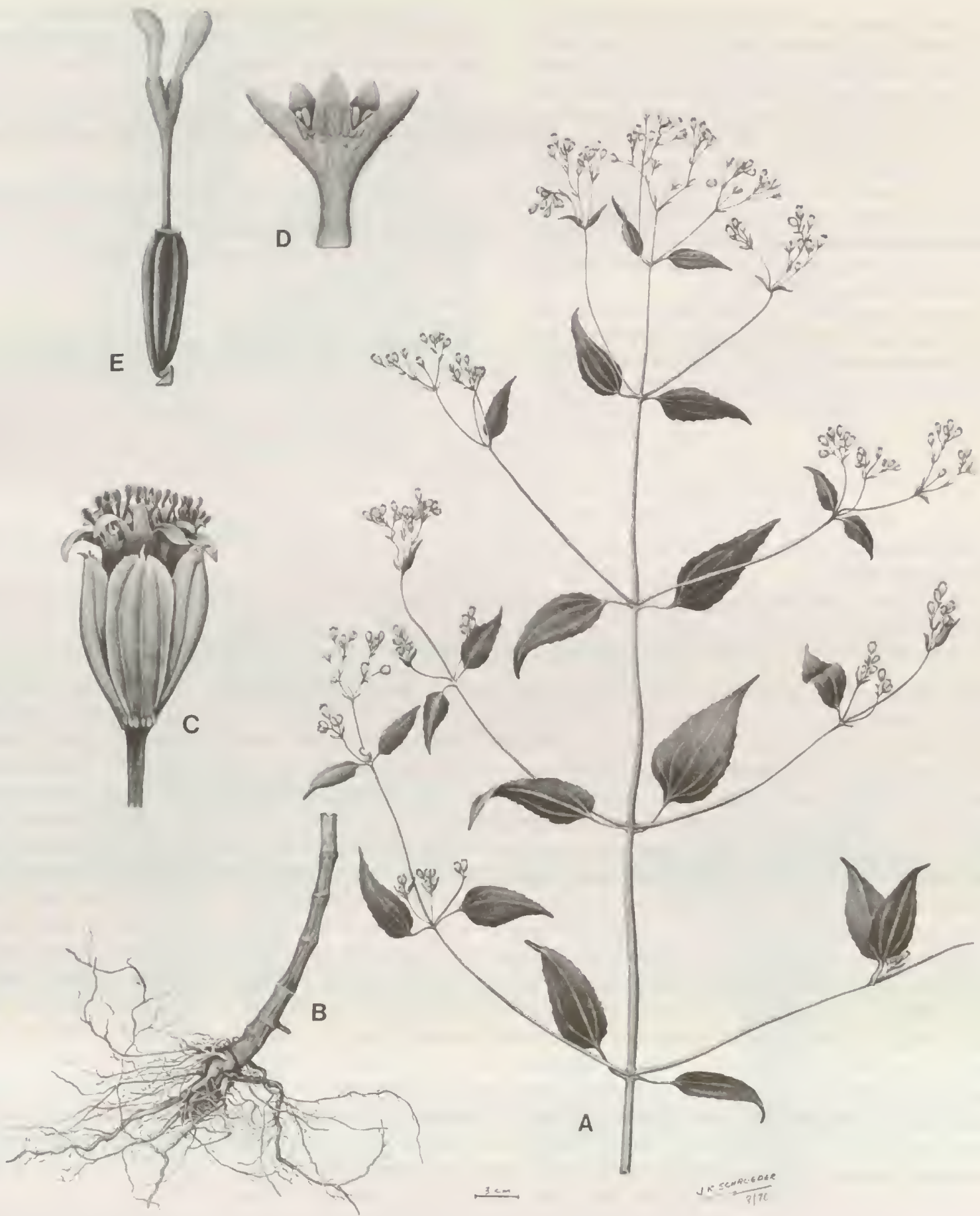

Plate 57. Piqueria trinervia Cav.-A. Habit, $\times 1 / 4,-$ B. Base of plant, $\times 1 / 4,-$ C. Head, $\times 5 .-D$. Corolla showing anthers, $\times 13 .-$ E. Achene with style, $\times 13$. 
dency for hair-like papillae inside the throat of the corolla, suggest relationship to genera such as Stevia, and some early literature did place material of Piqueria in the latter genus. Stevia is, in turn, related to a series of genera, all of which where known have basic chromosome numbers of $x=11$ or 12 . This group, which includes Piqueria, Stevia, and all those members of the Ageratinae that follow in this treatment, seems natural, and could be recognized as a separate subtribe Piqueriinae. Piqueria remains thoroughly distinct in the generic group by its lack of an anther appendage and by its unique sparse pattern of punctations in the achene wall.

As presently recognized, Piqueria contains seven species mostly confined to Mexico. One species, $P$. trinervia, extends its range through Central America and into the West Indies. A key to most species is provided by $\mathrm{B}$. Robinson
(1906) under his subgenus Eupiqueria. Distinctions of $P$. serrata and $P$. hintonii, the two species with small symmetrical rather than strongly asymmetrical carpopodia, are given by $\mathrm{R}$. King (1967b).

Piqueria was named by Cavanilles in honor of Andrés Piquer of Spain, known for work in both medicine and philosophy.

The following seven species are recognized in the genus:

Piqueria hintonii R. King, Mexico.

Piqueria laxiflora B. Robinson \& Seaton, Mexico. Piqueria pilosa H.B.K., Mexico.

Piqueria pringlei B. Robinson \& Seaton, Mexico.

Piqueria serrata A. Gray, Mexico.

Piqueria triflora Hemsley in Godman \& Salvin, Mexico.

Piqueria trinervia Cav., Mexico, Central America, West Indies.

\section{Stevia}

Stevia Cav., Icon. 4: 32. 1797. LeCtOTYPE: Stevia serrata Cav.

Mustelia Sprengel, Bot. Gart. Halle 1: 28. 1801. TYPE: Mustelia eupatoria Sprengel [= Stevia eupatoria (Sprengel) Willd.].

Nothites Cass., Dict. Sci. Nat. 35: 163. 1825. TYPE: Nothites latifolia Cass. [= Stevia melissaefolia (Lam.) Schultz-Bip.].

Xetoligus Raf., New Fl. 4: 74. 1838. TYPE: Stevia salicifolia Cav.

Mostly erect, annual or perennial herbs or shrubs, sparingly to densely branched. Stems terete to slightly hexagonal, slightly striated, glabrous to variously pubescent. Leaves opposite or in some species alternate, sessile to distinctly petiolate; blades linear to orbicular, margins entire to serrate or dentate, rarely deeply lobed, surface usually puberulous, sometimes stipitate-glandular, usually glandular-punctate. Inflorescence diffuse with few long-pedicellate heads, or dense in corymbose clusters on tips of branches. Involucre cylindrical, rarely funnelform, narrow at base; involucral bracts 5, eximbricate, in 1 series, equal to subequal, linear to elliptical, easily torn from receptacle; receptacle flat to slightly convex, glabrous. Florets 5 in a head; corollas white or lavender to purple, basal and distal parts sometimes of different color, narrowly funnelform below lobes or with somewhat expanded throat, usually with hairs or glands on outer surface; with erect hairs on inner surface of throat, cells of throat elongate with sinuous lateral walls; lobes usually less than 2 $\mathrm{mm}$ long, unequal and zygomorphic in series Podocephalae, radially symmetrical in others, longest lobes shorter than throat and tube, lobes triangular or oblong-ovate, densely papillose on inner surface, smooth on outer surface; anther collar cylindrical or broadened below, cells subquadrate to short-oblong below, with variable annular thickenings on walls; anther appendage mostly obovate, with a prominently crenulate distal margin; style base often slightly enlarged, glabrous or in a few species papillose; style branches filiform, densely long-papillose. Achenes narrowly fusiform to narrowly prismatic, with mostly straight sides, strongly 5-ribbed, faces concave, with few to many glands or setulae; carpopodium distinct, short, slightly asymmetrical, cells small, subquadrate to short-oblong, in 2-5 series, with scarcely projecting upper rim; pappus with at least a crown of free or united scales, often with 1-30 bristle-like awns, 1 or 2 achenes in each head often with more reduced pappus. Pollen grains ca. 18-27 $\mu \mathrm{m}$ in diameter. Plate 58.

The recognition of Stevia serrata as lectotype of the genus was established by King and Robinson (1969c). The typification is considered to have been accomplished when Rafinesque removed the other available species named by Cavanilles, $S$. salicifolia, to his new genus Xetoligus. Cabrera and Vittet (1963) cite $S$. salicifolia as type of the genus, but their action is considerably antedated by that of Rafinesque (1838).

Stevia is one of the most distinctive genera of the Eupatorieae, and has been segregated with considerable precision in most systems of classification since the time of its original description. Only one unnatural element, 


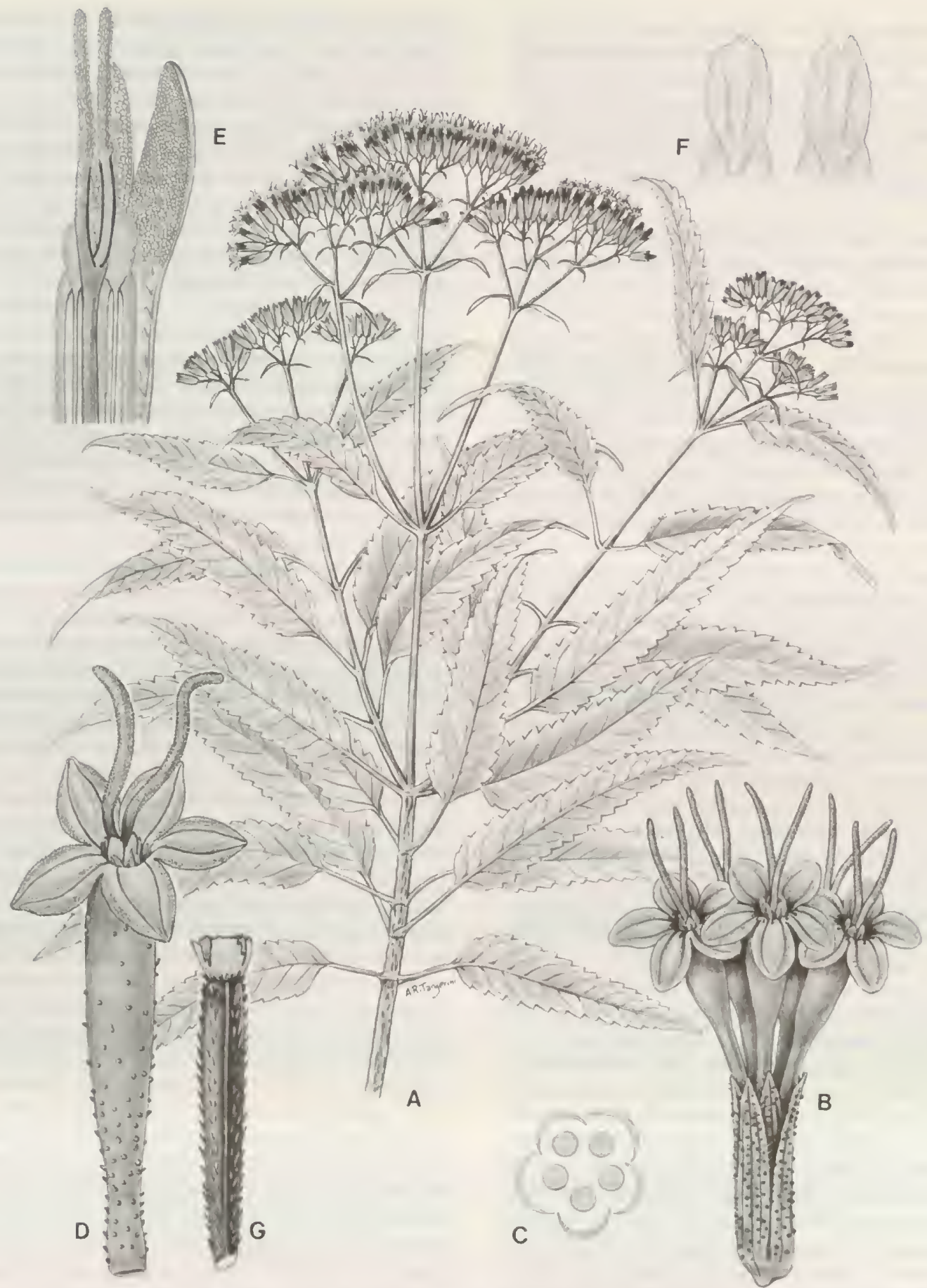

Plate 58. Stevia lucida Lag. - A. Habit, $\times 1 / 2 .-$ B. Head, $\times 7 .-$ C. Schematic cross-section of head, $\times 14 .-D$. Corolla, $\times 12 .-$ E. Upper section of floret, inside view, $\times 30 .-F$. Anther appendages, $\times 50 .-G$. Achene, $\times 12$.

Cronquistia, has required removal from the genus during the present series of studies. Only one genus, Metastevia, shows intimate relationship with Stevia, and presents any question of delimitation between the genera. The distinc- tions of Cronquistia and Metastevia are reviewed under those genera, but it is significant that neither shows the stable number of five flowers in a head seen in Stevia.

All species of Stevia have heads with five flowers. Sug- 
gestions of exceptions in the literature were shown to be erroneous by B. Robinson ( $1930 d)$. All species of Stevia also have dense pubescence on the inner surface of the corolla throat, and a distinctive obovate to elliptical anther appendage with a crenulate distal margin. The distinctive anther appendage and pubescence inside the corolla were both noted by Cassini $(1820 c)$ in his description of the tribe.

The genus shows a remarkable uniformity of basic floral structure considering the large number of species. It seems significant that many of the species seem to show similar characters repeated in different combinations, and a reticulating evolution seems likely. Hybridization is cited between various species in the thesis by Grashoff (1972), and apomixis is found in many species in association with modified forms of pollen. Four different pollen states have been demonstrated by King and Robinson (1967) in two species, and different chromosome races seem to be present in these and other species. Some fertile populations seem to occur in most if not all of the species that are commonly apomictic.

Though the variations in the pollen are not taxonomically useful, the modified pollen forms seem to be restricted to the Mexican and Central American species and some populations of those species that occur in South America. Modified pollen forms have not been noticed in strictly South American elements of the genus.

Variations of pappus between awn-like and squamose segments have long been regarded as taxonomically useful in Stevia. However, further significant variations of pappus form within each head have been studied by B. Robinson $(1930 d)$, and often prove stable within a species. One or two of the achenes may have a comparatively vestigial pappus and these have been termed idiocarps, while the remaining achenes have been termed adelphocarps. In their positions, the idiocarps follow a two-fifths phyllotactic sequence in the head like that of the subtending involucral bracts. Only in a few species of Stevia do idiocarps completely lack a pappus. In Stevia, at least some achenes of each head have a distinct pappus.

Some taxonomic subgroups have been recognized in Stevia. The North American subdivisions are summarized by B. Robinson $(1930 \mathrm{~g})$ with two sections, Podocephalae Schultz-Bip., with laxly disposed long-pedicellate heads, and Corymbosae Schultz-Bip., with heads in dense corymbose clusters. The Corymbosae were divided into subseries Fruticosae and Herbaceae on the basis of woodiness. In his unpublished thesis on the species of Mexico and Central America, Grashoff (1972) recognized the three groups all at sectional level, Podocephalae, Corymbosae, and Fruticosae. The Corymbosae with the herbaceous species, contained the type of the genus, Stevia serrata. Among the members of the genus occurring in Peru and southward, there is a tendency for achenes to have a pappus with ten or more awns. For such species, J. Baker (1876) in his Brazilian treatment established a group Mul- tiaristatae which was recognized by B. Robinson (1932b) in his Peruvian treatment at sectional level. Baker also recognized two other more artificial categories that were not perpetuated, Paleaceo-aristatae having $0-4$ awns in the pappus, and Pauci-aristatae having 4-10 awns in the pappus. The division of the non-multiaristate species in Peru by B. Robinson was scarcely less artificial. The section Eustevia had the pappus of the adelphocarps with short subequal squamellae or with some awns nearly as long as the corolla. The section Breviaristatae had the pappus unequal with the longest segments only up to half the corolla length. Though it seems significant because of its geographical restriction, the multiaristate condition seems erratically distributed among species within the area where it occurs. Multiaristate achenes are found in species with lax and diffuse inflorescences as well as those with heads in dense corymbs, and even in a Bolivian species, $S$. samaipatensis, that is habitally very similar to the generic type, $S$. serrata.

Stevia has been studied extensively cytologically and according to Grashoff (Grashoff et al., 1972), the shrubby species all have a gametic chromosome number of $n=$ 12 ; herbaceous species with laxly paniculate arrangements of heads have $n=11$ with no aneuploidy; and herbaceous species with compact-corymbose arrangements of heads mostly have $2 n=34$ univalents with considerable aneuploidy. As indicated in the cytological review of the tribe (R. King et al., 1976), the great variation and widespread apomixis in Stevia allows for interpretation of $2 n=33$ and $2 n=34$ as triploid derivatives of $n=11$. There has been a tendency, however, to interpret the $2 n=34_{\text {I }}$ found in Stevia as a potential $n=17$ partly because of the common occurrence of $n=17$ elsewhere in the tribe. Grashoff et al. report $S$. jorullensis as having $2 n=17_{\mathrm{II}}$ and $34_{\mathrm{I}}$ and S. plummerae variety durangensis as having $2 n=\mathrm{ca} .17_{\mathrm{ll}}$, and he suggests that among the compact-corymbose herbaceous species the alternate-leaved species "may have numbers based on 11,12 , or 17 within the same species," while "the opposite-leaved species appear to be based on $x=17$ alone." Nevertheless, Grashoff does report the opposite-leaved species $S$. origanoides as having both 34 univalents and $43 \pm 1$ univalents, and Keil and Stuessy (1975) have since reported $S$. origanoïdes as having $n=$ 11 and another opposite-leaved species $S$. plummerae variety durangensis as having $n=44$. Such evidence, and the lack of a close relationship of Stevia to any of the genera with $n=17$, indicates that the counts for the genus should be interpreted on the basis of the known $n=11$ and $n=12$ numbers that are common in the genus and in related genera.

Stevia is widely distributed from the southwestern United States southward through Mexico and Central America. It occurs in non-Amazonian South America southward to central Argentina. No species are native in the West Indies. The genus has been treated extensively in a series of separate papers by B. Robinson, with intro- 
ductory material (1930d), the species of North America south to Panama (1930g), Colombia $(1931 c)$, Venezuela (1931d), Ecuador (1931e), Peru (1932b), Bolivia (1932c), Paraguay (1930 $f$ ), and Argentina (1930e). The species north of South America have been reviewed more recently by Grashoff (1972) in an unpublished thesis, and a number of new species have been validated by Grashoff (1974). Cabrera (1978) has provided a useful treatment of the species in northern Argentina. There has been no significant survey of the Brazilian species since the inadequate treatment by J. Baker (1876).

The chemistry of Stevia is of more interest than that of most Eupatorieae. Stevia rebaudiana has been studied extensively as a source of a strong sweetener and possible sugar substitute, stevioside. The compound is a glycoside yielding on hydrolysis the kaurene diterpene steviol, glucose, and sophorose (Vis \& Fletcher, 1957; Dominguez, 1977). Stevioside more recently has been studied as a potential contraceptive (Mazzei \& Kuć, 1968).

An ambrosanolide has been reported from Stevia rhombifolia (= S. ovata) (Rios et al., 1967). Ambrosanolides are not otherwise known in the Eupatorieae, being restricted to more advanced tribes of the subfamily Asteroideae.

Reports of Stevia-type chemistry in the genus Palafoxia (Bohlmann \& Zdero, 1975) has led to some speculation of a Eupatorian relationship for the latter genus (Turner and Powell, 1977). A sample achene from the material that was analyzed has been seen and proves to be a Stevia (Bohlmann et al., 1979b). There is not now any known structural or chemical basis for relating Palafoxia to Stevia, and the genus is presently regarded as a member of the subtribe Chaenactidinae in the Heliantheae $(H$. Robinson, 1981).

A review of the ethnobotany of many species of Stevia is provided by Soejarto et al. (1983).

Cavanilles dedicated his genus to the memory of "Petri Iacobi Stevii (vulgo Steve aut Esteve)," a noted medical practitioner and botany professor of Valencia, Spain.

The following 230 species are recognized in the genus:

Stevia achalensis Hieron., Argentina.

Stevia adenophora Lagasca, Chile.

Stevia alatipes B. Robinson, Mexico.

Stevia alpina Griseb., Argentina.

Stevia alternifolia Hieron., Brazil.

Stevia amambayensis B. Robinson, Paraguay.

Stevia amblyolepis (B. Robinson) B. Robinson, Mexico.

Stevia ammotropha B. Robinson, Paraguay.

Stevia amplexicaulis Hassler, Paraguay.

Stevia andina B. Robinson, Ecuador, Peru.

Stevia anisostemma Turcz., Peru.

Stevia apensis B. Robinson, Paraguay.

Stevia aristata D. Don ex Hook. \& Arn., Argentina, Paraguay,

Uruguay.

Stevia aschenborniana Schultz-Bip. ex Klotzsch, Mexico.

Stevia balansae Hieron., Paraguay.
Stevia bangii Rusby, Bolivia.

Stevia beckii R. King \& H. Robinson, Bolivia.

Stevia benderi Perkins, Bolivia.

Stevia berlandieri A. Gray, Mexico.

Stevia bermejensis Hieron. in Urban, Bolivia.

Stevia bertholdii B. Robinson, Ecuador.

Stevia boliviensis Schultz-Bip. ex Rusby, Bolivia.

Stevia breviaristata Hook. \& Arn., Argentina, Bolivia.

Stevia breviflora (Cass.) Schultz-Bip., Brazil.

Stevia bridgesii Rusby, Bolivia.

Stevia brunetii Hieron., Brazil.

Stevia burkartii B. Robinson, Argentina.

Stevia cajabambensis Hieron. in Urban, Peru.

Stevia calderillensis Hieron. in Urban, Bolivia.

Stevia camachensis Hieron. in Urban, Bolivia.

Stevia camporum Baker, Brazil.

Stevia caracasana DC., Mexico, Central America, Colombia, Venezuela.

Stevia carapariensis Cabrera \& Vittet, Argentina.

Stevia cardiatica Perkins, Bolivia.

Stevia catharinensis Cabrera in Cabrera \& Vittet, Brazil.

Stevia cathartica Poeppig \& Endl., Peru.

Stevia centinelae Cabrera, Argentina.

Stevia chacoensis R. E. Fries, Bolivia.

Stevia chamaedrys Griseb., Argentina, Bolivia.

Stevia chiapensis Grashoff, Mexico.

Stevia cinerascens Schultz-Bip. ex Baker, Brazil.

Stevia clausseni Schultz-Bip. ex Baker, Brazil.

Stevia clinopodioides Greenman, Mexico.

Stevia clivicola B. Robinson, Bolivia.

Stevia cochabambensis Hieron., Bolivia.

Stevia collina Gardner, Brazil.

Stevia commixta B. Robinson, Brazil.

Stevia connata Lagasca, Mexico.

Stevia copiosa J. Koster, Bolivia.

Stevia cordifolia Benth., Mexico.

Stevia crassicephala Cabrera, Argentina.

Stevia crenata Benth., Mexico.

Stevia crenulata Baker, Brazil.

Stevia cruziana Malme, Brazil.

Stevia cruzii Grashoff, Mexico.

Stevia cryptantha Baker, Brazil.

Stevia cuneata Hassler, Paraguay.

Stevia cuzcoensis Hieron. in Urban, Peru.

Stevia decumbens (B. Robinson \& Greenman) E. Greene, Mexico.

Stevia decussata Baker, Brazil.

Stevia deltoidea E. Greene, Mexico.

Stevia dianthoidea Hieron. in Sodiro, Ecuador.

Stevia dictyophylla B. Robinson, Mexico.

Stevia discolor B. Robinson, Bolivia.

Stevia divaricata DC., South America?

Stevia dubia B. Robinson, Brazil.

Stevia eclipes B. Robinson, Bolivia.

Stevia effusa Hieron., Argentina.

Stevia elatior H.B.K., Mexico, Central America, Colombia, Venezuela, Ecuador.

Stevia entreriensis Hieron., Argentina, Paraguay, Uruguay.

Stevia ephemera Grashoff, Mexico.

Stevia estrellensis Hassler ex B. Robinson, Paraguay.

Stevia eupatoria (Sprengel) Willd., Mexico.

Stevia fiebrigii Hieron, in Urban, Argentina, Bolivia. 
Stevia flipes Rusby, Bolivia.

Stevia fruticosa Griseb., Argentina.

Stevia galeopsidifolia Hieron., Bolivia.

Stevia gardneriana Baker, Brazil.

Stevia gilliesii Hook. \& Am., Argentina, Brazil.

Stevia glandulosa Hook. \& Am., Mexico.

Stevia glanduloso-pubescens Hieron. in Urban, Bolivia.

Stevia glomerata Hieron. in Urban, Bolivia.

Stevia grisebachiana Hieron., Argentina.

Sievia haenkeana DC., South America?

Stevia heptachaeta DC., Brazil.

Stevia herrerae B. Robinson, Peru.

Stevia hilarii B. Robinson, Brazil.

Stevia hispidula DC., South America?

Stevia hoppii B. Robinson, Peru.

Stevia hypericifolia Hieron., Brazil.

Stevia hypomalaca B. Robinson, Mexico.

Stevia hyptifolia Gardner, Brazil.

Stevia iltisiana Grashoff, Mexico.

Stevia incognita Grashoff, Mexico, Guatemala, Honduras, Colombia, Venezucla.

Stevia involucrata Schultz-Bip. ex Baker, Brazil.

Stevia isomeca Grashoff, Mexico.

Stevia jaliscensis B. Robinson, Mexico.

Stevia jorullensis H.B.K., Mexico.

Stevia jujuyensis Cabrera, Argentina.

Stevia karwinskyana Steudel, Mexico.

Stevia kuhnioides Rusby ex B. Robinson, Bolivia.

Stevia kuntzei Hieron., Bolivia.

Stevia lasioclada Grashoff, Mexico.

Stevia latifolia Benth., Mexico.

Stevia lechleri Hieron., Peru.

Stevia lehmannii Hieron., Mexico, Guatemala, Honduras, Colombia, Venezuela.

Stevia lemmonii A. Gray, Arizona, Mexico.

Stevia leptophylla Schultz-Bip. ex Baker, Brazil.

Stevia leucosticta B. Robinson, Peru.

Stevia liebmannii Schultz-Bip. ex Klatt, Mexico.

Stevia lilloi B. Robinson, Argentina.

Stevia lita Grashoff, Mexico.

Stevia lucida Lagasca, Mexico, Central America, Colombia, Venezuela.

Stevia lundiana DC., Brazil.

Stevia macbridei B. Robinson, Peru, Bolivia, Argentina.

Stevia macvaughii Grashoff, Mexico.

Stevia maimarensis (Hieron.) Cabrera, Argentina.

Stevia mandonii Schultz-Bip., Peru, Bolivia.

Stevia melancholica B. Robinson, Bolivia.

Stevia menthaefolia Schultz-Bip., Brazil.

Stevia mercedensis Hieron., Argentina, Bolivia.

Stevia micradenia B. Robinson, Mexico.

Stesia micrantha Lagasca, Mexico.

Stevia microchaeta Schultz-Bip., Mexico, Guatemala.

Stevia minor Griseb., Argentina.

Stevia mitopoda B. Robinson, Mexico.

Stevia monardaefolia H.B.K., Mexico.

Stevia morii R. King \& H. Robinson, Brazil.

Stevia multiaristata Sprengel, Argentina, Brazil, Uruguay.

Stevia myriadenia Schultz-Bip. ex Baker, Brazil.

Stevia myricoides McVaugh, Mexico.

Stevia neglecta Rusby, Bolivia.

Stevia nelsonii B. Robinson, Mexico.
Stevia neurophylla B. Robinson \& Greenman in B. Robinson, Mexico.

Stevia obovata Rusby, Bolivia.

Stevia okadae Cabrera, Argentina.

Stevia oligocephala DC., Brazil.

Stevia ophiomaches B. Robinson, Colombia.

Stevia ophryodonta B. Robinson, Uruguay.

Stevia ophryophylla B. Robinson, Brazil.

Stevia organensis Gardner, Brazil.

Stevia origanoides H.B.K., Mexico.

Stevia orizabensis B. Robinson, Mexico.

Slevia ovalis (B. Robinson) B. Robinson, Mexico.

Stevia pabloensis Hieron. in Urban, Peru.

Stevia palmeri A. Gray, Mexico.

Stevia parvifolia Hassler, Paraguay.

Stevia pauciflora J. Koster, Bolivia.

Stevia pearcei $\mathrm{B}$. Robinson, Peru.

Stevia pelophila S. F. Blake, Mexico.

Stevia pennellii B. Robinson, Peru.

Stevia pereyrae (B. Robinson) Cabrera, Argentina.

Stevia perfoliata Cronq., Mexico.

Stevia petiolata (Cass.) Schultz-Bip., Peru.

Stevia philippiana Hieron. in Urban, Chile.

Stevia phlebophylla A. Gray in S. Watson, Mexico.

Stevia pilosa Lagasca, Mexico.

Stevia plummerae A. Gray, SW United States, Mexico.

Stevia pohliana Baker, Brazil.

Stevia polycephala Bertol., Mexico, Guatemala.

Stevia polyphylla DC., Peru?

Stevia potosiensis R. King \& H. Robinson, Bolivia.

Stevia potrerensis Hieron., Argentina.

Stevia procumbens Hieron., Argentina.

Stevia puberula Hook., Peru.

Stevia punensis B. Robinson, Peru.

Stevia purdiei B. Robinson, Colombia.

Stevia purpusii B. Robinson, Mexico.

Stevia pyrolaefolia Schlechtdl., Mexico.

Stevia rebaudiana (Bertoni) Bertoni, Paraguay.

Stevia reclinata Rusby, Bolivia.

Stevia resinosa Gardner, Brazil.

Stevia reticulata Grashoff, Mexico.

Stevia revoluta $\mathrm{B}$. Robinson, Mexico.

Stevia riedelii Schultz-Bip. ex Baker, Brazil.

Stevia rojasii Hassler, Paraguay.

Stevia rosei B. Robinson, Mexico.

Stevia rzedowskii McVaugh, Mexico.

Stevia sabulonis B. Robinson, Uruguay.

Stevia salicifolia Cav., Mexico, New Mexico.

Stevia samaipatensis B. Robinson, Bolivia.

Stevia sanguinea Hieron., Argentina.

Stevia santacruzensis Hieron., Bolivia.

Stevia sarensis B. Robinson, Bolivia.

Stevia satureifolia Lam., Argentina, Brazil, Uruguay.

Stevia scabrella Benth., Mexico.

Stevia schickendantzii Hieron., Argentina.

Stevia schreiteri B. Robinson, Argentina, Bolivia.

Stevia seemanioides Grashoff, Mexico.

Stevia seemannii Schultz-Bip. in Seemann, Mexico, Guatemala. Stevia seleriana B. Robinson, Mexico.

Stevia selloi (Sprengel) B. Robinson, Brazil, Paraguay, Uruguay. Stevia serrata Cav., SW United States, Mexico, Guatcmala, Honduras, Colombia, Venezuela, Ecuador. 
Stevia setifera Rusby ex B. Robinson, Bolivia.

Stevia soratensis Hieron., Peru, Bolivia.

Stevia stricta Hornem., Mexico.

Stevia stuebelii Hieron., Bolivia.

Stevia suaveolens Lagasca, Mexico, Guatemala, Costa Rica, Colombia, Ecuador.

Stevia subpubescens Lagasca, Mexico.

Stevia talpensis Grashoff, Mexico.

Stevia tarijensis Hieron. in Urban, Argentina, Bolivia.

Stevia tenuis Hook. \& Am., Brazil.

Stevia tephra B. Robinson, Mexico.

Stevia tephrophylla S. F. Blake, Mexico, Honduras.

Stevia tomentosa H.B.K., Mexico.

Stevia totorensis B. Robinson, Bolivia.

Stevia triangularis Grashoff, Mexico.

Stevia triaristata Hieron. in Urban, Bolivia.

Stevia trifida Lagasca, Mexico.

Stevia triflora DC., Mexico, Central America, to Ecuador.

Stevia tunariensis Hieron., Bolivia.
Stevia tunguraguensis Hieron., Ecuador.

Stevia urceolata Grashoff, Mexico.

Stevia urticacfolia Billb. in Thunb., Brazil, Bolivia, Peru.

Stevia vaccinioides J. Koster, Bolivia.

Stevia vaga Griseb., Argentina.

Stevia velutinella Grashoff, Mexico.

Stevia venosa A. Gray, Mexico.

Stevia vernicosa Greenman, Mexico.

Stevia verticillala Schlechtdl., Brazil.

Stevia villaregalis McVaugh, Mexico.

Stevia villaricensis (B. Robinson) Cabrera \& Vittet, Argentina.

Stevia viscida H.B.K., SW United States, Mexico, Guatemala.

Stevia wagneri Hieron., Colombia, Venezuela.

Stevia weberbaueri B. Robinson, Peru.

Stevia westonii R. King \& H. Robinson, Costa Rica.

Stevia yaconensis Hieron., Argentina.

Stevia yalae Cabrera, Argentina.

Stevia zacatecana McVaugh, Mexico.

Stevia zephyrantha Grashoff, Mexico.

\section{Metastevia}

\section{Metastevia Grashoff, Brittonia 27: 69. 1975. TYPE: Metastevia hintonii Grashoff.}

Erect perennial herbs, unbranched. Stems terete, slightly striated, puberulous and hirsute, hairs often glandular-tipped. Leaves opposite, distinctly petiolate, basal pairs very small; blades ovate, margins crenate to serrate, apex acute to obtuse, base cuneate. Inflorescence a lax panicle; pedicels moderately long. Involucre narrowly campanulate, broad at base; involucral bracts 4-6, eximbricate, in ca. 2 series, equal to subequal, ovate-oblong, firmly attached to receptacle; receptacle slightly convex, alveolate. Florets 4-6 in a head; corollas white, with narrow basal tube, expanding into narrowly campanulate throat, pilosulous in inner surface of throat; cells of throat elongate with sinuous lateral walls; lobes oblong, more than 2.5 times longer than wide, 2-2.5 mm long, longest equal to throat and tube, sometimes zygomorphic with outer lobes longer, inner surface densely papillose, outer surface mostly glabrous, with a few papillae at tips; anther collar rather short, cells mostly oblong, with distinct annular thickenings on walls; anther appendage large, longer than wide, ovate with rather truncate or retuse tip, margins crenulate; style base enlarged, glabrous; style branches filiform, densely long-papillose. Achenes obconical, 5-ribbed, glabrous, faces convex at maturity; carpopodium distinct, short, symmetrical, cells small and subquadrate, in 3-6 series, with thickened walls; pappus lacking. Pollen grains ca. $21 \mu \mathrm{m}$ in diameter. Plate 59.

The generic name was formed by the addition of the prefix meta (= altered or beyond) to the name Stevia. It was intended by Grashoff (1975) to reflect the close relationship of Metastevia to Stevia, and derivation from the latter genus. Metastevia shows the form of anther appendage with crenulate margins and the form of pubescence inside the throat of the corolla that is otherwise unique to the genus Stevia. Furthermore, Metastevia shows the rather lax inflorescence and somewhat zygomorphic corolla that is characteristic of the Mexican and Central Amercian section Podocephalae of Stevia, and relationship seems to be to that section.

Metastevia must be regarded as having immediate relationship to Stevia, but the comparative instability of number of involucral bracts and flowers in the heads makes exclusion from Stevia desirable. Fortunately, a number of additional distinctions are available, as indicated by Grashoff (1975). The achenes are obconical with sides convex at maturity rather than fusiform with concave sides. The pappus is totally lacking, while some pappus is present in at least the adelphocarps in all the heads of Stevia. Involucral bracts are not easily torn from the receptacle as in Stevia. The throat and tube portion of the corolla is comparatively short, being equaled in length by the longest lobes. The involucres are narrowly campanulate rather than cylindrical to funnelform or urceolate as in Stevia. The receptacle is alveolate, rather than rough to lacerate-reticulate as in Stevia. Finally, scale-like leaves are present at the bases of the stems, but are lacking or only present on stolons in Stevia. Grashoff suggests that the broader heads would be the most useful distinction of the genus in the field.

The genus is known only from two collections from closely adjacent areas in the states of Mexico and Guerrero in Mexico. Both specimens were collected by George Hinton, after whom the species is named.

The following single species is recognized in the genus: Metastevia hintonii Grashoff, Mexico. 


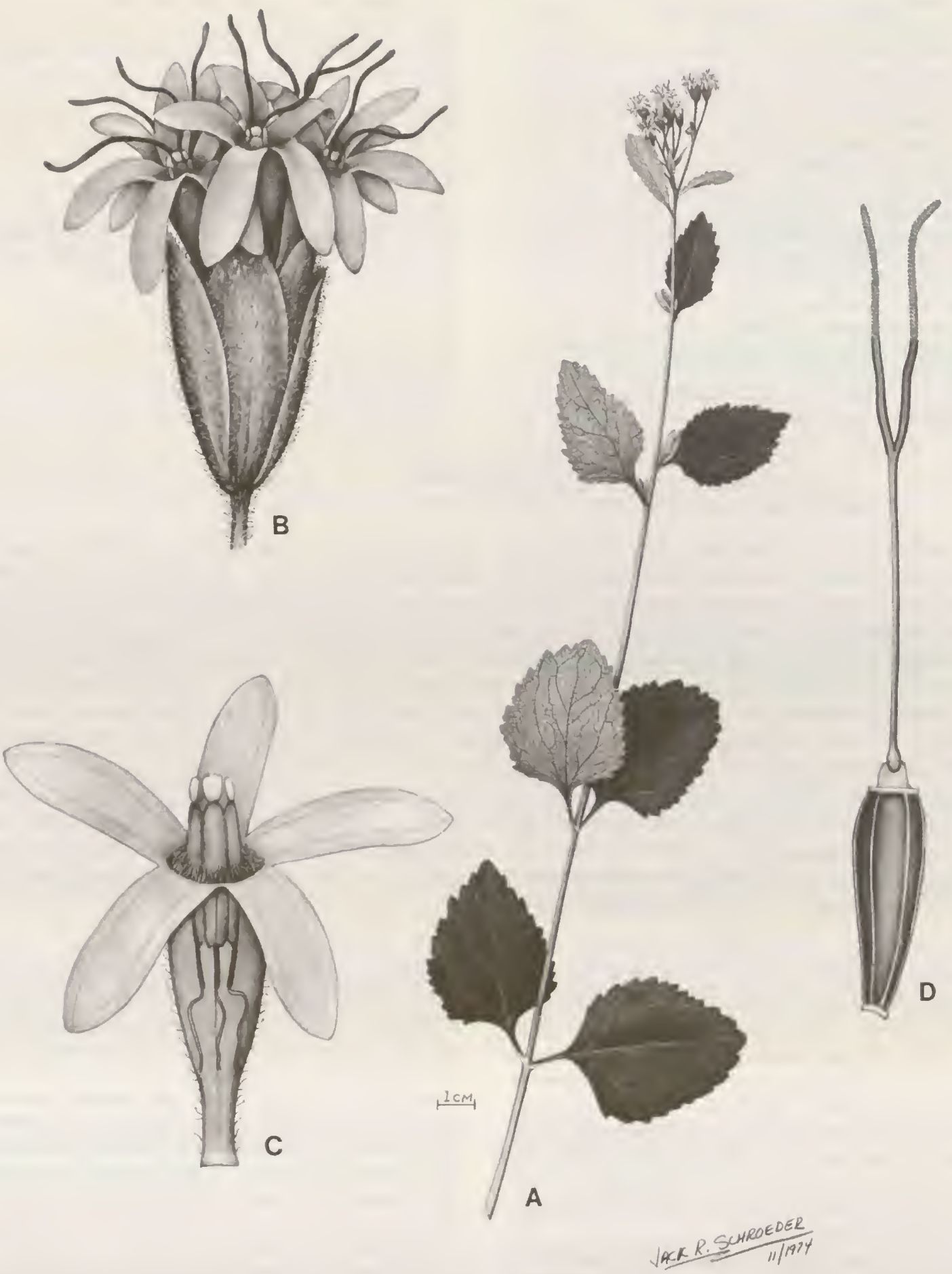

PLATE 59. Metastevia hintonii Grashoff. - A. Habit, $\times 3 / 3 .-$ B. Head, $\times 8 .-$ C. Corolla showing anthers, $\times 10 .-D$. Achene with style, $\times 10$. 

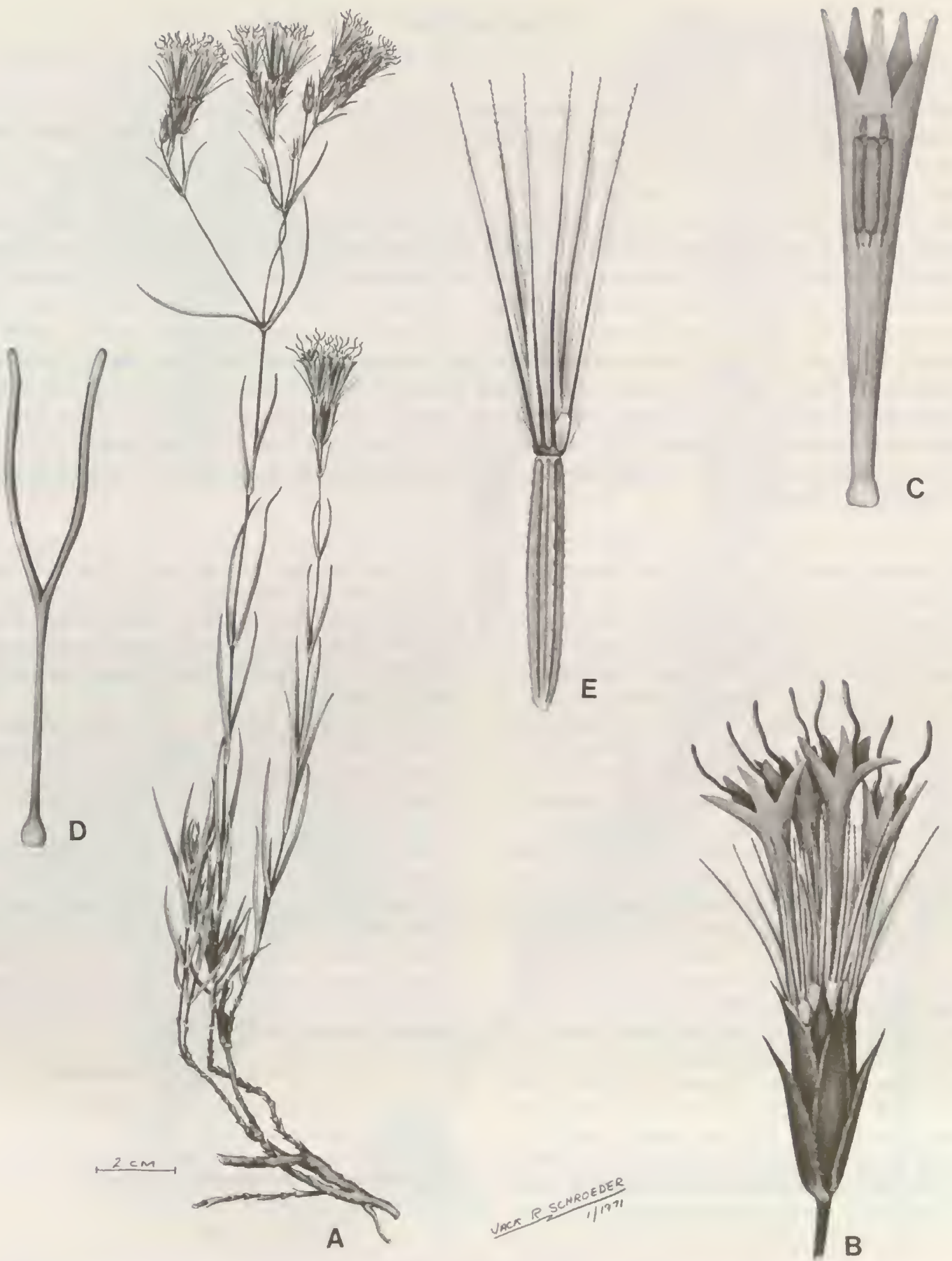

PLATE 60. Carphochaete wislizenii A. Gray. - A. Habit, $\times 3 / 35,-$ B. Head, $\times 3 \frac{1}{2},-$ C. Corolla showing anthers, $\times 6 .-$ D. Style, $\times 6$. E. Achene, $\times 6$. 


\section{Carphochaete}

\section{Carphochaete A. Gray, Mem. Amer. Acad. n.s. 4: 65. 1849. TYPE: Carphochaete wislizeni A. Gray.}

Erect perennial herbs or small shrubs, with many branches, especially from the base. Stems terete, slightly striated. Leaves opposite, sessile; blades linear to elliptical-spathulate. Inflorescence monocephalic or a loose corymbose cyme; heads pedicellate. Involucral bracts ca. 6, eximbricate to subimbricate, in 2-4 series, unequal to subequal, persistent, elliptical to oblong-lanceolate; receptacle flat to slightly convex, glabrous. Florets 46 in a head; corollas white, pink, or purple, tubular below with narrowly funnelform throat, glabrous; cells of throat elongate with somewhat sinuous lateral walls; lobes oblong to linear, ca. 2-3 times as long as wide, densely papillose on inner surface, smooth or nearly smooth on outer surface; anther collar expanded below, cells subquadrate, with annular thickenings on walls; endothecial cells often oblong, sometimes without thickenings on some transverse walls; anther appendage large, oblong to slightly broader above middle; style base bulbously enlarged, glabrous; style branches filiform, densely papillose, terete to slightly compressed, with stigmatic lines close together on inner surface and running somewhat irregularly to near tip of branch. Achenes narrowly prismatic, 5-10-ribbed, ribs setulose; carpopodium distinct, without upper rim, nearly symmetrical to asymmetrical, forming a cap of small, thick-walled, quadrate to oblong cells in 5-10 series; pappus of 5-10 awns, longer than corolla, sometimes with a few shorter squamellae. Pollen grains ca. 25$35 \mu \mathrm{m}$ in diameter. Plate 60.

Carphochaete has been recognized as a distinct genus consistently since the time of its original description. The principal characters by which the genus has been distinguished appear to be the prominent winged awns of the pappus after which it is named, and the mostly ten-ribbed achenes. Because of the ten-ribbed achenes, the genus has been associated in previous systems of Bentham and Hooker (1873) and B. Robinson (1913a) with the artificial subtribe variously called the Adenostylinae or the Kuhniinae. The Eupatorian genera with which Carphochaete has previously been associated are now placed in the separate subtribes Alomiinae, Liatrinae, and Mikaniinae.

Actual relationship of Carphochaete is found among those genera that most resemble it in the form of their pappus. Similar forms of winged awns are found in both Stevia and Cronquistia. Carphochaete is distinct within the generic group by the more numerous ribs on the achenes, the details of the stigmatic lines, and the tendency toward large pollen. The subimbricate involucral bracts found in most of the species are also unique in the group. The pollen is, on the average, the largest in the tribe, and the stigmatic lines furnish an absolute distinction from the probably most closely related genus, Cronquistia. In Carphochaete, the stigmatic lines are scarcely separated, and run along the inner surface to near the apex of the branch. In Cronquistia, the stigmatic lines are as in most members of the tribe, widely separated along the lower lateral margins of the style branch, and the base of the style is not enlarged. In the details of its style branches, Carphochaete is actually approached most closely by the genus Revealia, which differs by the more spreading habit, the coroniform pappus, the presence of pubescence inside the corolla throat, and the lack of an apical notch in the anther appendage.

A chromosome number of $n=11$ has been determined in two of the species of Carphochaete. The number furnishes further confirmation of the relationship of Carphochaete to the genera Stevia and Cronquistia having $x=$ 11 and 12.

Carphochaete occurs mostly in the drier parts of Mexico south to the Central Plateau, with only $C$. bigelovii extending northward into the southwestern United States. Carphochaete wislizenii is rather distinctive within the genus by its more subequal and rather eximbricate involucral bracts. McVaugh (1972) mentions a rather prominent gummy exudate in C. gummifera that is sparing or lacking in related species.

The following five species are recognized in the genus:

Carphochaete bigelovii A. Gray, Sw United States, Mexico.

Carphochaete grahamii A. Gray, Mexico.

Carphochaete gummifera McVaugh, Mexico.

Carphochaete schaffneri Greenman, Mexico.

Carphochaete wislizenii A. Gray, Mexico.

\section{Cronquistia}

\section{Cronquistia R. King, Brittonia 20: 11. 1968. TYPE: Stevia pringlei S. Watson.}

Erect perennial herbs, sparingly branched. Stems terete, slightly striated, puberulous. Leaves mostly opposite, often becoming alternate above, sessile or very shortly petiolate; blades linear to oblong, margins entire, with 3 longitudinal veins. Inflorescence laxly corymbose; heads pedicellate. Involucral bracts 10-15, eximbricate, in 1-2 series, equal or subequal, persistent, elliptical; receptacles flat to slightly convex, glabrous. 

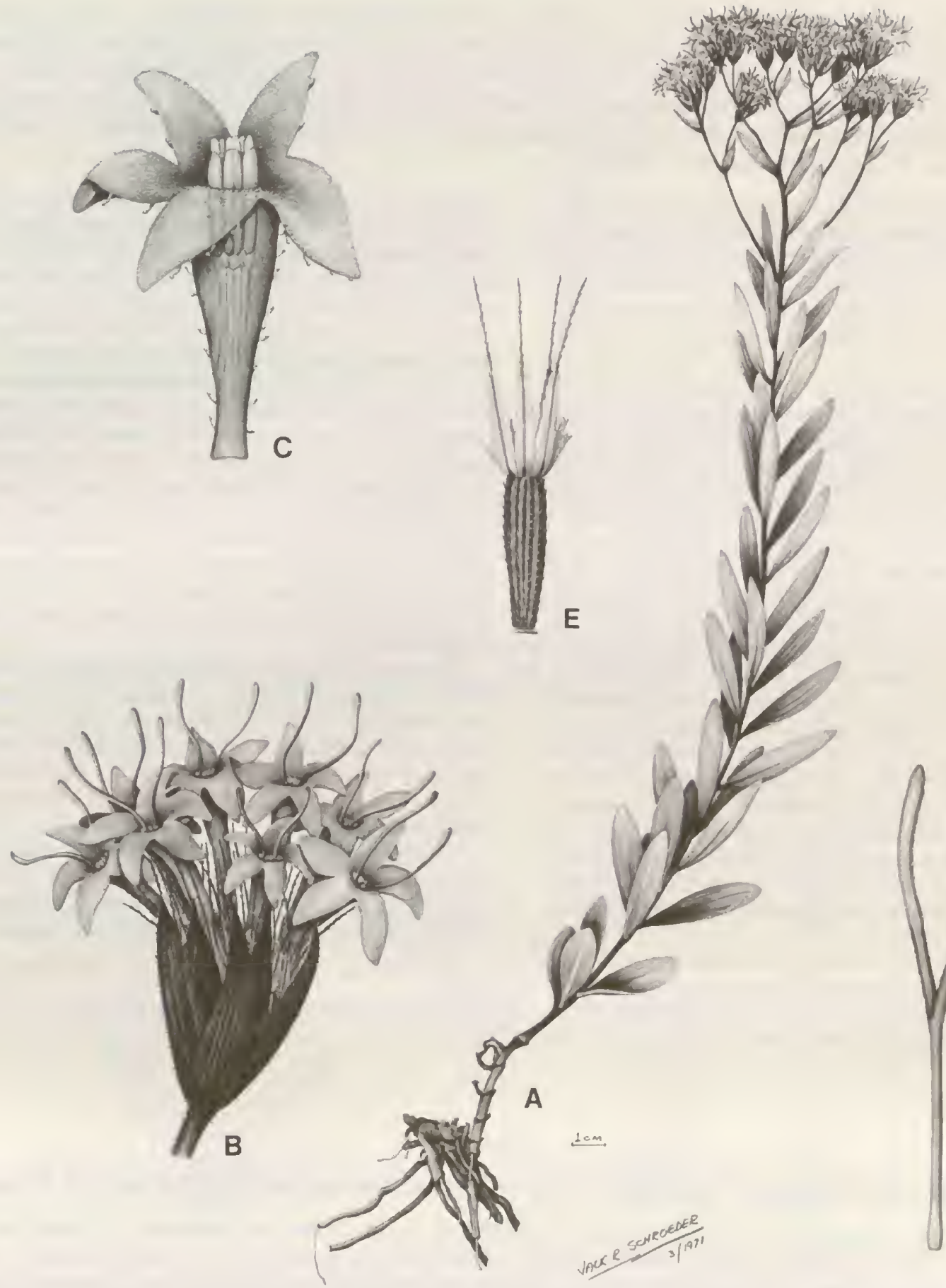
smooth; anther collar short, cells mostly short-oblong, with weak annular thickenings on walls; anther appendage short-oblong, with apical notch; style base not enlarged, glabrous; style branches distinctly flattened and somewhat long-clavate distally, densely short-papillose, with stigmatic lines widely separated along lower lateral margins. Achenes prismatic, 8-10-ribbed, ribs setuliferous; carpopodium forming a narrow basal rim of small, quadrate, thick-walled cells in 2-4 series; pappus of a few winged awns or squamellae, or lacking. Pollen grains ca. 23-25 $\mu \mathrm{m}$ in diameter. Plate 61.

Cronquistia shows the structure and chromosome number of $x=12$ that clearly indicate relationship to the series of genera including Stevia and Carphochaete, and it is with the latter two genera that Cronquistia has been primarily compared. It is these three genera that commonly show similar and rather distinctive winged awns in their pappus.

Of the two related genera, Stevia is closest to Cronquistia in comparatively superficial aspects such as size of heads and eximbricate form of involucres, and material of Cronquistia was originally described in Stevia where it remained for seventy years. B. Robinson $(1930 d, 1930 \mathrm{~g})$ did note the anomalous high number of flowers in the heads of Cronquistia material, but the full extent of the anomaly was evidently not noticed. It was many years later that Arthur Cronquist noted on herbarium specimens of his that the species was "not truly a Stevia." At the time of the original description of Cronquistia (R. King, 1968), the usually seven to eight rather than five flowers in the head, the lack of non-glandular pubescence on the corollas, and the oblong anther appendages that are not broadest at or above the middle, were all cited as distinctions from Stevia. The greater number of ribs on the achene and the lack of pubescence inside the corolla are additional distinctions that were not cited. The tricolporate pollen grains of Cronquistia were seen to a verage somewhat larger than grains of similar form in Stevia, although the size now seems less than the $30 \mu \mathrm{m}$ originally given.

At the time of the original description, the very close relationship of Cronquistia to Carphochaete was not recognized. It was Grashoff who in various places including his thesis (1972) indicated an intention to place Cron- quistia in the synonymy of Carphochaete, but none of these was ever published. The two genera are alike in the corolla pubescence, anther appendage, and ribbing of the achene by which they differ from Stevia, but there remain many significant differences that mandate the continued separation of Cronquistia. The style base in Cronquistia is not enlarged, and the style branches are distinctly flattened with widely separated stigmatic lines along the lower lateral margins. In Carphochaete the style base is greatly enlarged, and the style branches are terete with uniquely positioned and extended stigmatic lines close together on the inner surface. Lesser differences include the greater size of the floral parts and the pollen in Carphochaete, and the apparent slight difference in chromosome number, $x=12$ in Cronquistia versus $x=11$ in Carphochaete. Cronquistia can also be distinguished from most species of Carphochaete by its eximbricate rather than subimbricate involucre.

As a result of the variation between awned and awnless forms of pappus in material of Cronquistia, two species were recognized in Stevia (B. Robinson, 1930g). The two species were combined at the time of the original description of Cronquistia by R. King (1968). The species is known from the states of Chihuahua and Durango in northwestern Mexico.

The genus is one of two in the Eupatorieae named in honor of Arthur Cronquist of the New York Botanical Garden. The other genus is Cronquistianthus, a member of the Critoniinae from the Andes of South America.

The following single species is recognized in the genus: Cronquistia pringlei (S. Watson) R. King, Mexico.

\section{Revealia}

\section{Revealia R. King \& H. Robinson, Phytologia 33: 277. 1976. TYPE: Revealia stevioides R. King \& H. Robinson.}

Spreading and often procumbent shrubs, densely branched. Stems terete to subangular, striated, slightly puberulous. Leaves opposite, sessile; blades narrowly oblong, entire to obscurely crenulate-serrate, rather fleshy with only midvein obvious. Inflorescence usually of single heads on short leafy branches; heads pedicellate. Involucral bracts ca. 10, eximbricate, in 2 series, equal to subequal, persistent; receptacle flat to slightly convex, glabrous. Florets ca. 10 in a head; corollas purple, narrowly funnelform, with numerous small short-stalked glands on outer surface, upper throat pilosulous with numerous often septate hairs; cells of throat laxly oblong with not or weakly sinuous walls; lobes oblong, showing zygomorphy with outer three lobes longer, densely papillose on inner surface, nearly smooth on outer surface; anther collar very short, cells subquadrate, with weak annulations on walls; endothecial cells with transverse walls sometimes lacking nodular thickenings; anther appendage short-ovate, obtuse; style base with distinct enlargement, glabrous; 

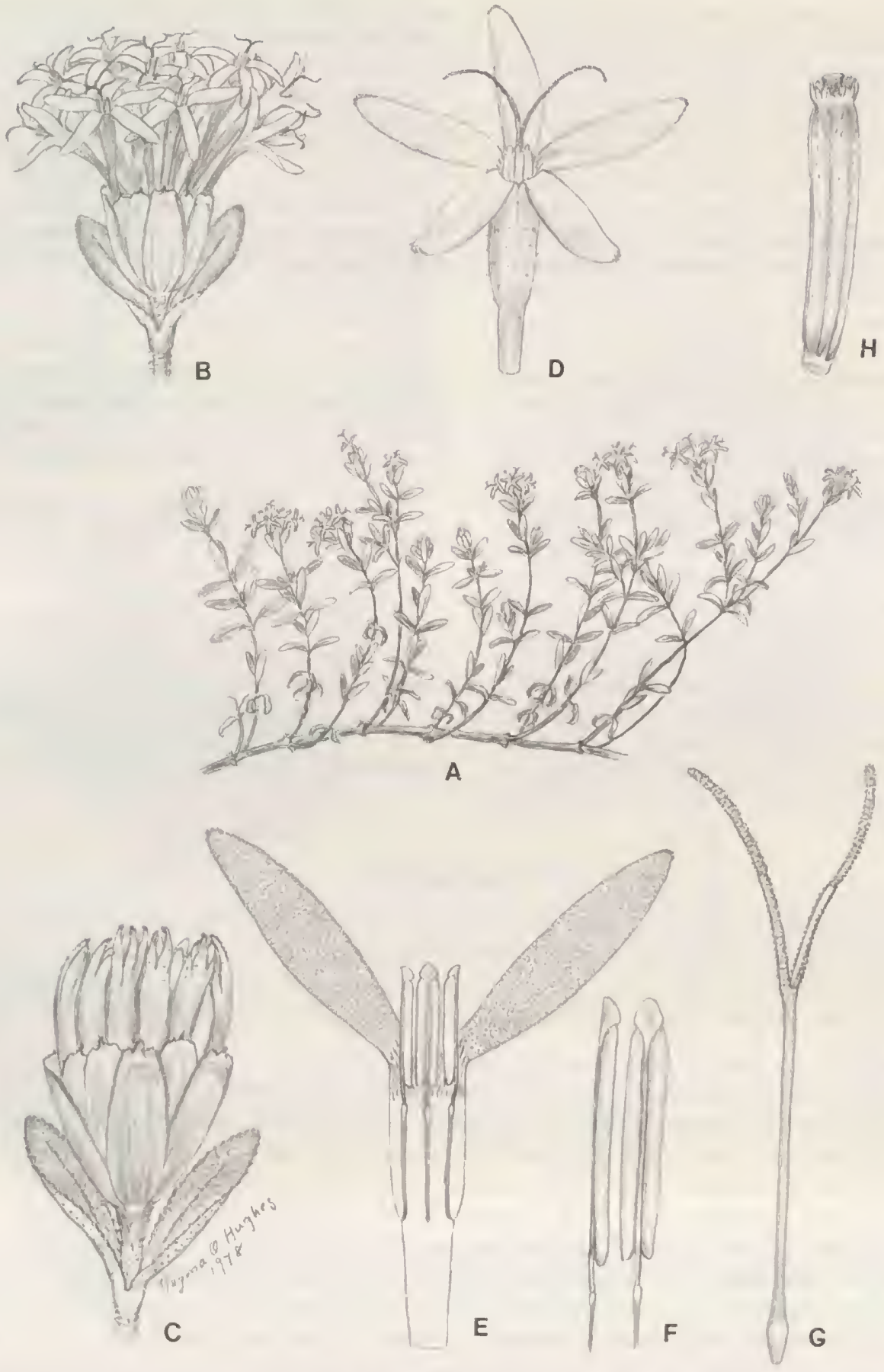

Plate 62. Revealia macrocephala (Paray) R. King \& H. Robinson. - A. Habit, $\times 1 / 2 .-$ B. Head, $\times 2 .-$ C. Young head with unopened asymmetric corollas, $\times 3 .-\mathrm{D}$. Corolla with tips of anthers and style, $\times 5 .-E$. Corolla in section showing inner surface with anthers, $\times 7 \frac{1}{2}$. - F. Anthers, $\times 15$. - G. Style, $\times 71 / 2 .-$ H. Achene, $\times 6$.

style branches filiform, terete, densely papillose, with stigmatic lines positioned close to each other along lower part of inner surface. Achenes prismatic, 5-6-ribbed, ribs with minute setulae; carpopodium distinct, forming a narrow symmetrical basal rim, cells small, in ca. 5-6 series, with thick walls; pappus short, rather coroniform with many short squamellae. Pollen grains ca. $30-33 \mu \mathrm{m}$ in diameter. Plate 62 . 
The rather distinctive habit of Revealia and the short form of its pappus, seem to predispose the genus to comparison with the superficially similar Oxylobus that has the center of its distribution in Mexico. At the time of the original description of Revealia, the spreading shrubby habit with small elliptical leaves and heads borne on short leafy branches were seen as particularly reminiscent of Oxylobus arbutifolius. Unknown at that time was the previous description of the species of Revealia by Paray (1958) as an Oxylobus. In spite of the similar aspects of the plants, however, the two genera prove to have no close relationship. Oxylobus differs notably by its broadly ampliate corollas with shorter triangular lobes, and by the elongate anther collars without obvious ornamentation on the cell walls. Oxylobus is treated in the present work as a member of a separate subtribe, Oxylobinae, which is characterized by chromosome numbers of $n=16$ and 17 , numbers not seen among the relatives of Revealia.

Revealia is actually unquestionably related to a totally different element of the Eupatorieae, the Piquerian series of the subtribe Ageratinae. Among the genera in the series, Stevia, Cronquistia, and Carphochaete seem to share the most characters with Revealia, but the manner in which those characters are combined in Revealia is somewhat confusing. The asymmetry of the corolla lobes, the presence of hairs inside the corolla, the lack of an apical notch in the anther appendage, and the basically five-ribbed achenes seem to suggest relationship to Stevia, and Revealia might be placed closest to the latter in spite of the greater number of flowers in the head and the shorter less crenulate anther appendages. However, the style branches in Revealia are of the terete form with stigmatic lines on the inner surface that is otherwise unique in the Eupatorieae to the genus Carphochaete. The style branches differ from those of Carphochaete only by the stigmatic lines not reaching as near to the tips. The pollen grains are also of the size found in Carphochaete. It is a mixture of characters that indicates relationship of Revealia to both Stevia and Carphochaete, but that precludes its inclusion in either.

The distinctive habit of Revealia seems to distinguish the genus from all of its close relatives. The style base differs from that of Cronquistia by being enlarged, but it is not as enlarged as that of Carphochaete. Revealia seems to completely lack the winged awns of the pappus that are common in all three of the related genera, Stevia, Cronquistia, and Carphochaete.

Revealia is endemic to the Sierra Madre del Sur in the area of Guerrero in Mexico. It is an area of Mexico noted for its numerous endemics, including such genera as the closely related Metastevia.

The genus is named in honor of James Reveal of the University of Maryland, the principal collector of the material on which the genus was originally based.

The following single species is recognized in the genus: Revealia macrocephala (Paray) R. King \& H. Robinson, Mexico.

\section{Macvaughiella}

\section{Macvaughiella R. King \& H. Robinson, Sida 3: 282. 1968. TYPE: Schaetzellia mexicana Schultz-Bip. Schaetzellia Schultz-Bip., Flora 33: 419. 1850. TYPE: Schaetzellia mexicana Schultz-Bip., non Schaetzellia Klotz. \\ Dichaeta Schultz-Bip., Flora 33: 419. 1850, nom. nud., non Dichaeta Nutt.}

Erect perennial herbs or small shrubs, sparingly branched. Stems terete, striated, densely pubescent with small spreading hairs. Leaves opposite, short- to long-petiolate; blades deltoid to rhomboid, margins serrate to dentate, tips short-acute to narrowly acuminate, lower surface densely glandular-punctate. Inflorescence densely corymbose, with or without elongate lower internodes; heads subsessile or with distinct short pedicels. Involucral bracts ca. 10, eximbricate, in ca. 2 series, equal to subequal, persistent; receptacle convex, glabrous. Florets 16-25 in a head; corollas white, with a narrow basal tube expanding into a narrowly campanulate throat, with numerous reddish glandular punctations on outer surface; cells of throat broadly oblong with sinuous lateral walls, with upper ends bulging as papillae; lobes oblong-triangular, slightly longer than wide, inner surface densely papillose, outer surface only slightly roughened, with many uniseriate non-glandular hairs; anther collar elongate, cells mostly elongate, obscure in narrower basal part, with weak annular thickenings on walls; anther appendages ovate, about as long as wide; style base not enlarged, glabrous; style branches filiform, densely papillose, bearing numerous reddish glandular-punctations. Achenes compressed, with 2 angles, setuliferous; carpopodium distinct, slightly asymmetrical, cells quadrate in 4-8 series, with firm thin walls; pappus of 2 , rarely 1 or 3-4 bristles, apical cells of bristles acute. Pollen grains ca. $18 \mu \mathrm{m}$ in diameter. Plate 63.

Macvaughiella is one of two genera in the Eupatorieae having compressed achenes, the other genus being $\mathrm{Oa}$ - xacania of the subtribe Oaxacaniinae. Achenes of other members of the tribe are mostly prismatic, while a few 


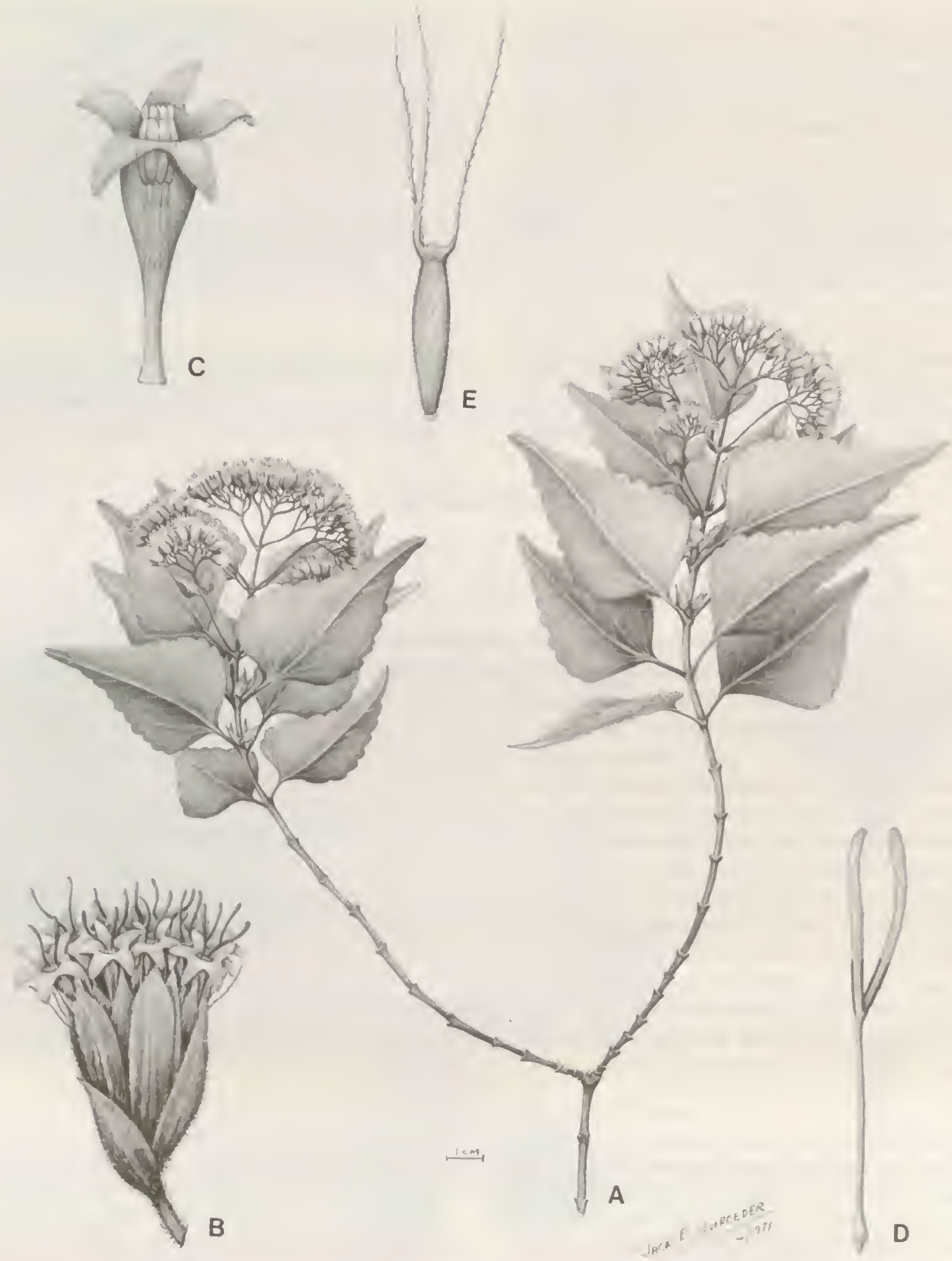

Plate 63. Macvaughiella mexicana (Schultz-Bip.) R. King \& H. Robinson. - A. Habit, $\times \%$. B. Head, $\times 7 .-$ C. Corolla showing anthers, $\times 17 .-$ D. Siyle, $\times 17 .-$ E. Achene, $\times 17$.

are obcompressed. The two-ribbed nature of the achene is reflected in the two bristles of the pappus, one bristle over each rib.

In early studies in the present series (King \& Robinson, 1970b), Macvaughiella was regarded as a relative of Ageratina and Oxylobus in the Oxylobinac on the basis of the corolla shape and pubescence, the papillosity of the corolla lobes and style branches, and the eximbricate involucral 
bracts. All the mentioned characters are subject to duplication in the Ageratinae, however, and the anther collar with few subquadrate cells and with weak annulations on the cell walls indicates that actual relationship is to the latter group (H. Robinson \& King, 1977). The one approximate chromosome count of $n=$ ca. 13 by Jackson (R. King et al., 1976) is also more indicative of the Ageratinae than the Oxylobinae. The bristle form of pappus is unusual in the Ageratinae, but similar bristles also occur in some species of Microspermum.

The genus Macvaughiella ranges from the state of Veracruz in Mexico southeastward through Guatemala to El Salvador and Honduras. Plants vary greatly in robustness of the leaves and exsertion of the inflorescences, but the only taxonomically useful distinction seems to be in the pubescence of the involucral bracts. Two separate species have been recognized in the past (King \& Robinson,
$1968 b$ ), but more recently these have been given only varietal status (King \& Robinson, 1970h).

The first name for the genus was, according to its author, an intentional reuse of the name Schaetzellia of Klotzsch which had proven a synonym of Isotypus (= Onoseris H.B.K.). The Klotzsch genus was named in honor of the wife of Herrn Geheimen Oberhofbuchdrucker Decker whose name was Pauline v. Schätzell. Since present rules of nomenclature do not allow such reuse of names, King \& Robinson (1968b) provided a new name, Macvaughiella, in honor of Rogers McVaugh of the University of Michigan, who has worked extensively with the Mexican flora.

The following single species is recognized in the genus:

Macvaughiella mexicana (Schultz-Bip.) R. King \& Robinson, Mexico, Guatemala, El Salvador, Honduras.

\section{Microspermum}

\section{Microspermum Lagasca, Gen. Sp. Pl. 25. 1816. TYPE: Microspermum nummulariifolium Lagasca.}

Miradoria Schultz-Bip. ex Benth. in Benth. \& Hook., Gen. Pl. 2: 407. 1873, nom. nud. TyPE: Miradoria sartorii Schultz-Bip. ex Benth., nom. nud. (= Microspermum nummulariifolium Lagasca).

Annual and perennial herbs, erect or decumbent, unbranched or in a few species sparingly branched. Stems terete, striated. Leaves opposite, petiolate; blades lanceolate to rhomboid-ovate, margins serrate, apices obtuse to rounded. Inflorescence with heads single or in lax cymose to corymbose panicles, heads long-pedicellate. Involucral bracts 6-18, eximbricate, in ca. 2 series, subequal, persistent, receptacle convex to low-conical, glabrous. Florets 8-85 in a head; corollas white; with narrow basal tube expanding rather abruptly into campanulate throat, with glandular punctations on outer surface; cells of throat broadly oblong with sinuous lateral walls, upper inside surface often bulging as mamillae or papillae; lobes 5 , in regular form triangular, in peripheral zygomorphic corollas with outer 3 lobes greatly expanded and oblong, partly fused at base, rather ray-like, densely papillose on inner surface, nearly smooth on outer surface; anther collar cylindrical, cells mostly short-oblong, with distinct transverse annular thickenings on walls; anther appendage often ovate and about as wide as long, sometimes shorter and minutely trilobed with strongly crenulate margin, cell walls of appendage often thickly collenchymatous; style base not enlarged, glabrous; style branches rather short, linear, densely papillose. Achenes prismatic (4-)5(-7)-ribbed, setuliferous and glanduliferous; carpopodium distinct, slightly asymmetrical, cells slightly inflated, subquadrate, in ca. 8-10 series, with walls slightly thickened, especially on outer surface; pappus with 0-4 scabrid bristles, apical cells acute. Pollen grains ca. 18-20 $\mu \mathrm{m}$ in diameter. Plate 64.

Microspermum is notable for the rather ray-like, bilabiate peripheral flowers in the head with greatly expanded outer lobes. The ray-like flowers possess functional anthers, and are the most extreme examples of such zygomorphy in the Eupatorieae. They are not the only example in the tribe, however, being closely approached in form by fiowers in the distantly related Praxeliopsis of the Praxelinae.

In spite of the technically Eupatorian nature of the raylike flowers of Microspermum, the superficially heterogamous appearance of the heads has caused confusion in tribal placement of the genus. Various early authors, including Lagasca y Segura (1816) and DeCandolle (1838) did place the genus in proximity to some members of the
Eupatorieae, but Microspermum came to rest near the Tagetinae or near other elements in the tribe Helenieae in the classical treatments of the family (Bentham \& Hooker, 1873; Hoffmann, 1890-1894; Rydberg, 1914). More recently, Turner (1966) and Turner and Flyr (1966) have suggested that the genus is related to the subtribe Galinsoginae of the tribe Heliantheae, in spite of the lack of paleae on the receptacles.

The present knowledge of Microspermum has been mostly summarized in two papers by Rzedowski (1970, 1972), the first a monograph of the genus, and the second a supplemental paper with two additional species and a revised key. It was in the first of these papers that Rzedowski recognized the unmistakable Eupatorian relation- 

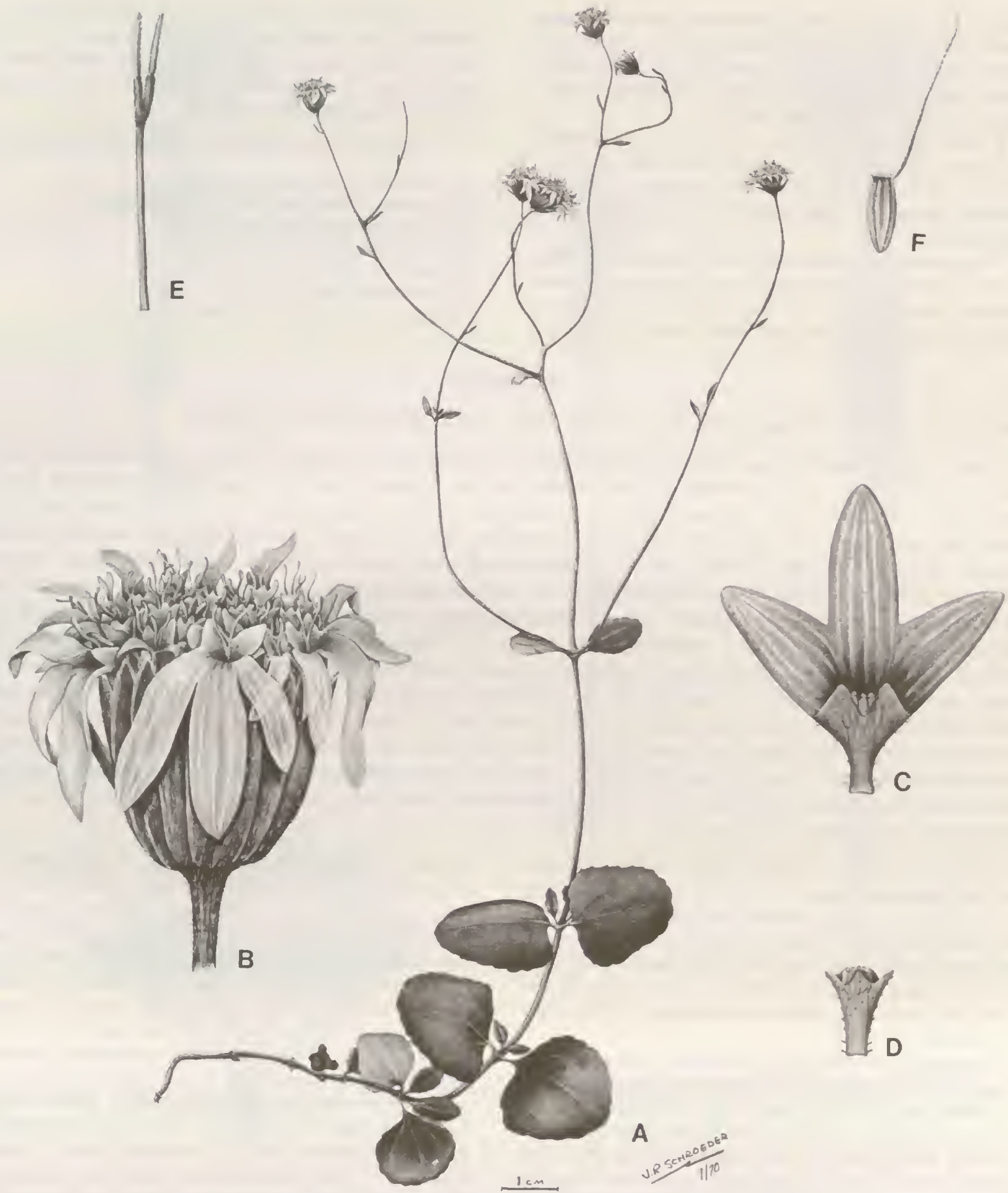

PLATE 64. Microspermum nummulariffolium Lag. - A. Habit, $\times 8 / 8 .-$ B. Head, $\times 9 .-$ C. Corolla of peripheral fower showing anthers, $\times 9 .-$ D. Corolla of central flower showing anthers, $\times 9 .-$ E. Style, $\times 15 .-$ F. Achene, $\times 9$. 
ship of the genus. It has only remained necessary to point out in the present series of studies that Microspermum represents a specialized element within the Eupatorieae, rather than a basal offshoot retaining Helianthian characters as suggested by Rzedowski.

A chromosome number of $x=12$ has been determined for Microspermum on the basis of three species (Rzedowski, 1970). The number tends to reinforce the placement of the genus in the Piqueria-Stevia series of the Ageratinae.

The species of Microspermum are all endemic to Mexico in a central area extending from Jalisco eastward to Oaxaca. Keys and other details regarding the species are available in the papers by Rzedowski (1970, 1972).
The name Microspermum was undoubtedly given in reference to the small achenes of the genus. The name seems to have no particular significance other than to suggest that the genus is among the many in the Eupatorieae having generally small size.

The following seven species are recognized in the genus:

Microspermum debile Benth., Mexico.
Microspermum flaccidum Paul G. Wilson, Mexico.
Microspermum gonzalezii Rzed., Mexico.
Microspermum gracillimum Rzed., Mexico.
Microspermum hintonii Rzed., Mexico.
Microspermum nummulariaefolium Lagasca, Mexico.
Microspermum tenue Paul G. Wilson, Mexico.

Microspermum debile Benth., Mexico. Microspermum flaccidum Paul G. Wilson, Mexico. Microspermum nummulariaefolium Lagasca, Mexico. Microspermum tenue Paul G. Wilson, Mexico.

\section{Iltisia}

Iltisia S. F. Blake, J. Wash. Acad. Sci. 47: 409. 1958. TYPE: Iltisia repens S. F. Blake.

Decumbent, annual or short-lived perennial herbs, unbranched in vegetative part. Stems subterete, only slightly striated, pilosulous, rooting at lower nodes. Leaves opposite, very short-petiolate; subsessile blades orbicular to broadly ovate, base subabruptly constricted, margins crenate-serrate with 1-2 coarse teeth on each side, apex obtuse to rounded. Inflorescence cymose, with 3-7 heads, pedicellate, with ascending often slender branches. Involucral bracts 8-10, eximbricate, in 2 series, equal, persistent; receptacle slightly convex, glabrous. Florets ca. 30 in a head; corollas white, with narrow basal tube, expanding into broadly campanulate throat, with a few glands externally; cells of throat broadly oblong with slightly sinuous lateral walls, on upper inside surface bulging as mamillae; lobes (3-)4(-5), triangular, slightly wider than long, sometimes with 2 outer lobes of marginal flowers enlarged, densely papillose on inner surface, scarcely mamillose on outer surface near tip; anther collar cylindrical, cells short with dense transverse annular thickenings on walls that obscure cell limits; anther appendage short, about twice as wide as long, often discolored, with slightly crenulate margin; style base not enlarged, glabrous; style branches short, appendages lanceolate, densely short-papillose, apex acute. Achenes prismatic, usually 4-ribbed, glabrous; carpopodium distinct, forming a narrow projecting rim, symmetrical but sometimes inserted at an angle, cells oblong in mostly 1 series, with thickened walls; pappus lacking. Pollen grains ca. $17 \mu \mathrm{m}$ in diameter. Plate 65.

Iltisia is a minute procumbent herb of high elevations in the Talamanca Range of Costa Rica. It is one of the two members of the Eupatorieae with the number of lobes of the corolla and correlated number of anthers mostly being reduced to four. The other such genus in the tribe is Piqueriopsis of Mexico which has erect bases on the plants, has broader style branches, and totally lacks anther appendages.

The genus has most of the characters commonly associated with the tribe Eupatorieae, and was described in the same paper with the equally minute Eupatorian genus Ferreyrella (Blake, 1958). Nevertheless, Blake rejected a possible position in the Eupatorieae because of the tapering tips of the minute style branches, and he ultimately placed the genus in the tribe Helenieae. Blake seemed to be at least partially aware of the relationship of Itisia to Microspermum of Mexico, from which he said it differed by its discoid heads and relatively short epappose achenes. It was Williams (1961) who actually placed Iltisia in the synonymy of Microspermum, but Rzedowski (1970), in his monograph of the latter genus, listed as distinctions, the lack of bilabiate flowers, the lack of submarginal zygomorphic corollas, the narrowly triangular rather than linear to subulate style appendages, and the ectexine of the pollen being two times as thick as the endexine rather than the same thickness. The inflorescence of Iltisia also seems more cymose than that of Microspermum, with more ascending branches and more densely clustered heads. A second species of Iltisia has zygomorphic marginal flowers, but these have only 2 completely separated expanded outer lobes.

The name of the genus was intended by Blake to honor both Hugh Hellmut Iltis of the University of Wisconsin, one of the collectors of the type material, and his father, Hugo Iltis, educator, botanist, and geneticist, formerly of Brünn (Brno) in Czechoslovakia, where he founded the Mendel Museum.

The following two species are recognized in the genus: Iltisia echandiensis $\mathrm{R}$. King \& H. Robinson, Costa Rica, Panama. Iltisia repens $\mathbf{S}$. F. Blake, Costa Rica. 

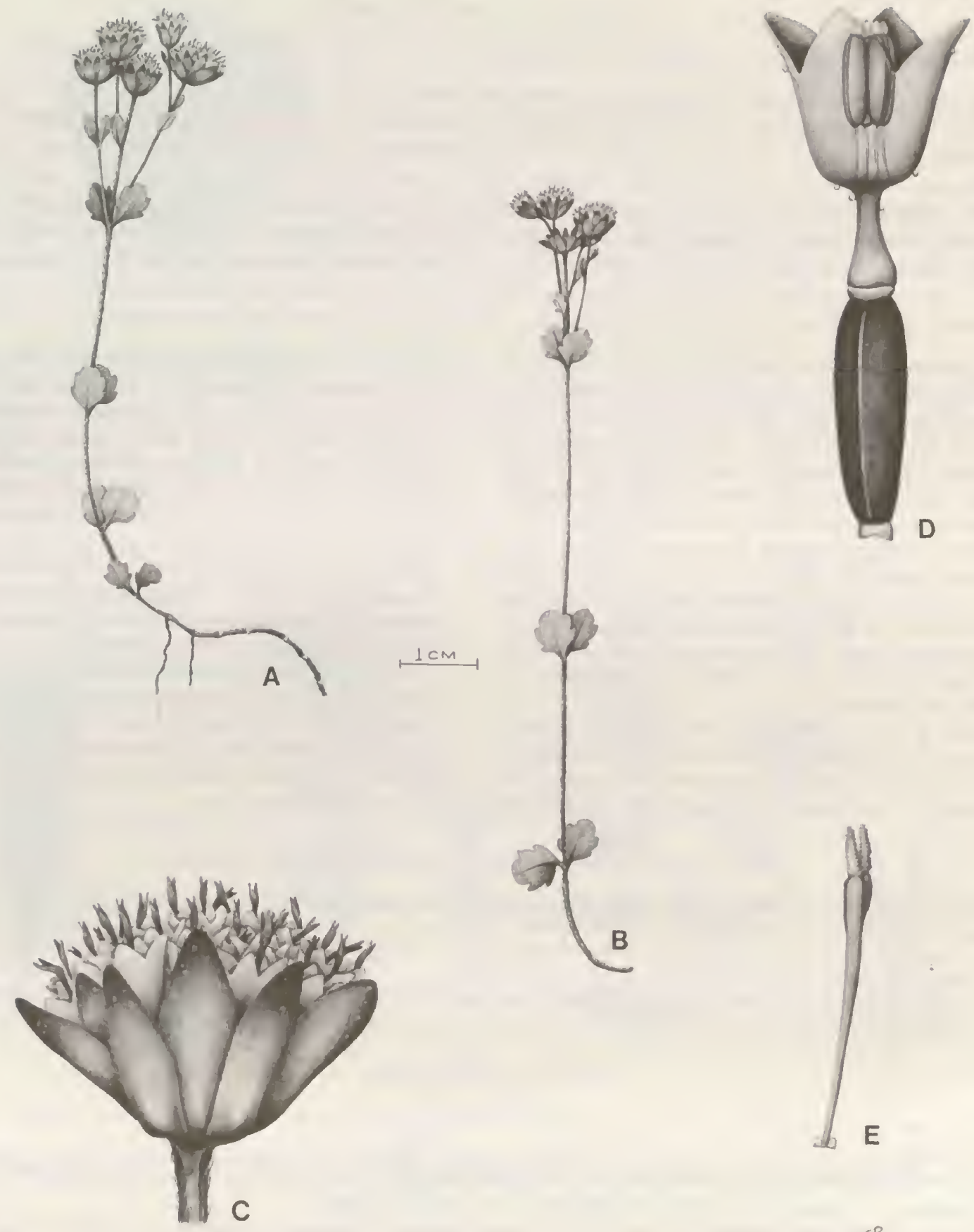

PLAte 65. Iltisia repens S. F. Blake. - A, B. Habit, $\times 11 / 5 .-$ C. Head, $\times 10 .-D$. Floret, $\times 27,-$ E. Style, $\times 27$. 


\section{SubTRIBE VI. TRICHOCORONINAE}

Trichocoroninae R. King \& H. Robinson, Phytologia 46: 446. 1980. TYPE: Trichocoronis A. Gray.

Erect to ascending, aquatic or subaquatic, perennial herbs, not or sparingly branched above base; leaves opposite, sessile, sometimes verticillate. Inflorescence terminal or axillary. Heads often solitary on long peduncles, not or laxly clustered; involucral bracts eximbricate, persistent; receptacle convex to conical, epaleaceous. Flowers 50-125 in a head; corollas white to pale pink; lobes papillose inside and at tip and margins outside, without stomata on outer surface; cells of anther collar not or weakly ornamented on walls; anther appendage about as long as wide; style base not enlarged, glabrous; style branches narrowly linear to broadly filiform or slightly clavate, flattened at least at tip, densely long-papillose. Achenes prismatic with 5 ribs, with micropunctations not strongly aligned in transverse bands; carpopodium distinct, sometimes with upper rim; pappus of short bristles, a crown, or lacking. Basic chromosome numbers $x=15,30$.

The Trichocoroninae contains three genera that share a number of the basic characters of the subtribe Ageratinae to which it seems related. The characters include the eximbricate persistent involucre, the reduced pappus, the somewhat conical receptacle, and the papillose corolla lobes and style branches. The genera of the Trichocoroninae share a series of additional characters, however, that distinguish them as a group from the Ageratinae, the aquatic or subaquatic habit, the sessile leaves, the often solitary heads of the inflorescences, and the lack of strong ornamentation on the cell walls of the anther collars. It seems further notable that the three genera are all North American in distribution, extending farthest south in southwestern Mexico.

Because of the reduced form of the pappus, the members of the Trichocoroninae, like those of the Ageratinae, have escaped inclusion in the broad artificial concepts of Eupatorium. Unfortunately, concepts of relationships among the members of the subtribe have been rather erratic. Shinnersia was included within the genus Trichocoronis until the present series of studies, in spite of many basic differences, probably partly because of their geographical correlation in Texas and adjacent areas. At the same time, relationship to Sclerolepis of the eastern United States seems to have gone completely unrecognized. The relationship of Trichocoronis to Eupatoriopsis of Brazil, suggested by B. Robinson (1906), is totally rejected here. The latter genus, with its "broad obovate quasi two-winged achenes," has proven to be a member of the utterly distinct and remotely related subtribe Praxelinae.

There are at least circa chromosome counts for all three genera of the Trichocoroninae, and the evidence indicates a unique series in the Eupatorieae on a base of $x=15$. The chromosome counts, if verified by further work, would provide additional evidence of a unified subtribe, distinct from the Ageratinae.

\section{KEY TO THE GENERA OF THE SUBTRIBE TRICHOCORONINAE}

1. Leaves narrow and verticillate at nodes; pappus a thickened, irregular, indurated crown 68. Sclerolepis

1'. Leaves sessile in pairs; pappus of short setulae or lacking

2. Pappus present, of short setulae; corolla throat funnelform; achenes with firm sharply pointed setulae on sides; carpopodium stopper-shaped, with thick-walled cells which are larger below 66. Trichocoronis

2'. Pappus absent; corolla throat broadly campanulate; achenes with thin-walled blunt-tipped setulae on sides; carpopodium cylindrical, with large thin-walled cells 67. Shinnersia

\section{Trichocoronis}

Trichocoronis A. Gray, Mem. Amer. Acad. Arts n.s. 4: 65. 1849. LeCTOTYPE: Ageratum wrightii Torrey \& A. Gray.

Margacola Buckley, Proc. Acad. Nat. Sci. Philadelphia 1861 [v. 13]: 457. 1862. TYPE: Margacola parvula Buckley [= Trichocoronis wrightii (Torrey \& A. Gray) A. Gray].

Biolettia E. Greene, Pittonia 2: 216. 1891. TYPE: Biolettia riparia E. Greene [= Trichocoronis wrightii (Torrey \& A. Gray) A. Gray].

Erect, subaquatic, annual or perennial herbs, with erect to decumbent bases. Stems terete, faintly striated, with non-glandular hairs. Leaves opposite, sometimes becoming alternate above, sessile and somewhat clasping; blades membraneous, oblong, with few strongly ascending secondary veins, margins serrate, apex acute. Inflorescences monocephalic to laxly branched; heads pedicellate. Involucral bracts ca. 30 , eximbricate, in 2-3 series, subequal, broadly lanceolate, with 3-4 striae and glabrous on outer surface; receptacle convex to conical, rather warty, glabrous. Florets $75-125$ in a head; corollas white to pale pink, with a constricted 

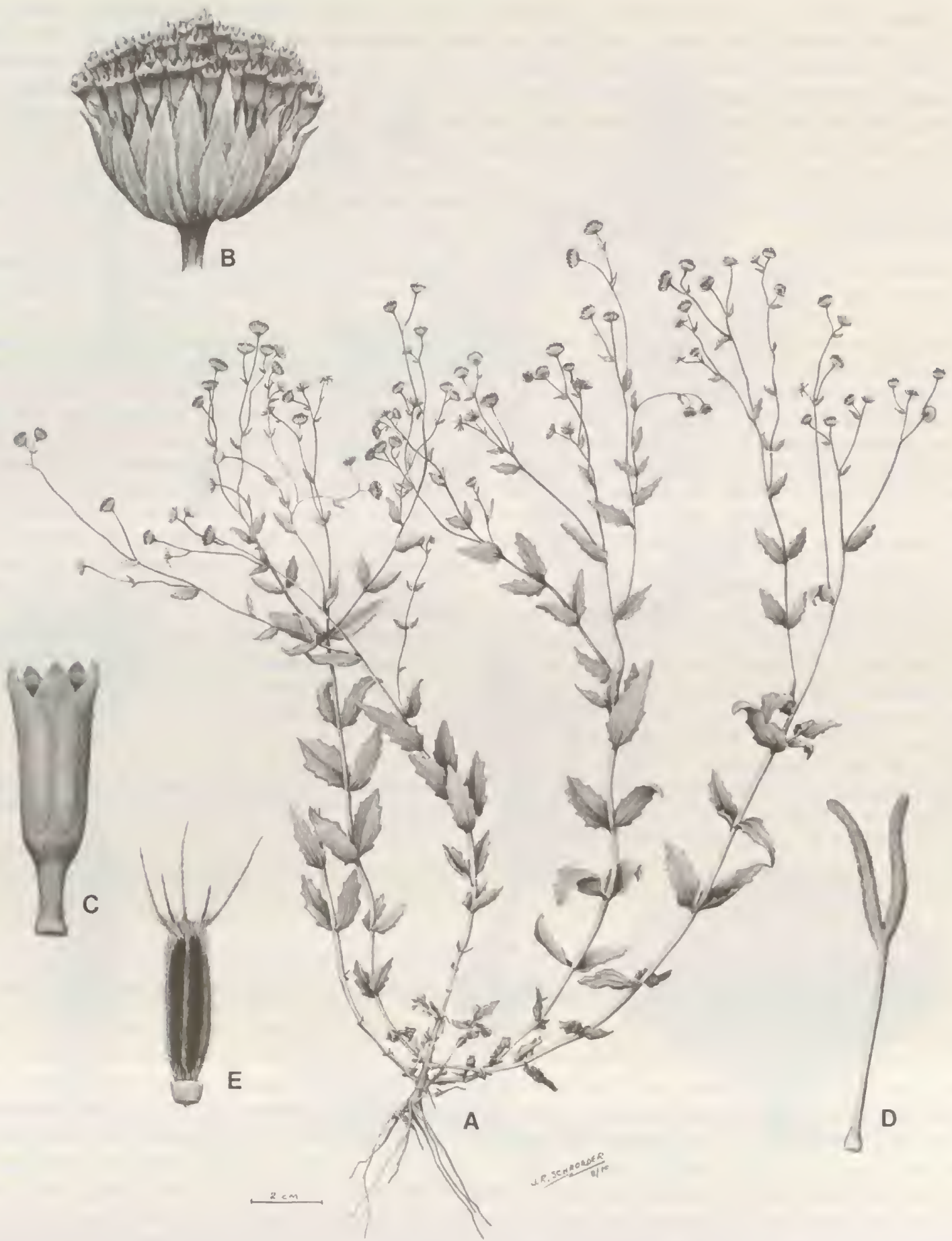

PLATE 66. Trichocoronis wrightii A. Gray. - A. Habit, $\times 5 / \% .-$ B. Head, $\times 8 .-$ C. Corolla showing anthers, $\times 27 .-$ D. Style, $\times 27 .-E$. Achene, $\times 27$. 
rather elongate basal tube, limb narrowly campanulate; cells of throat elongate with sinuous lateral walls; lobes triangular, about as long as wide, papillose on inner surface and on tip and margins of outer surface; anther collar cylindrical, with numerous subquadrate cells, a few more oblong above, walls with beaded thickenings; anther appendage subquadrate, slightly longer than wide; style base not enlarged, glabrous; style branches broadly filiform, densely long-papillose. Achenes prismatic to somewhat fusiform, 4-5-ribbed, ribs setuliferous with sharp-pointed setulae; carpopodium well developed, stopper-shaped, with distinct upper rim, upper cells small, nearly subquadrate, in ca. 5 series, basal row of cells very large; pappus of 2-6 short rather setiform squamellae, persistent, apical cells of pappus squamellae acute. Pollen grains ca. $17 \mu \mathrm{m}$ in diameter. Plate 66.

Trichocoronis was originally established by Asa Gray (1849) for the three species that are now placed in Trichocoronis and Shinnersia. Distinction from the broad concept of Ageratum was apparently based on the irregular short pappus after which the genus is named. The separate narrow segments match neither the coroniform structure nor the five-awned form seen in Ageratum. Subsequent study has shown differences in the habit, inflorescence form, basically sessile leaves, achene structure, and chromosome number that all indicate that Trichocoronis and Ageratum are not closely related. The lack of close relationship is reflected in the present placement of the two genera in separate subtribes.

The present study has confirmed the general relationship within the group segregated as Trichocoronis by Gray (1849). The only change during the present studies has been the removal of one species to the distinct but related genus Shinnersia (King \& Robinson, 1970c). The general reasons for the separation are given under the latter genus, but it is most notable that the Shinnersia, contrary to the comments by Gray, lacks a pappus.

The carpopodium of Trichocoronis is rather distinctive, being stopper-shaped with an enlarged lower row of cells. Such a carpopodium is not found in related genera, but there are similar forms elsewhere in the Eupatorieae in some genera of the subtribe Ayapaninae. The latter subtribe is not very closely related to Trichocoronis, being a mostly South American group with distinctly subimbricate involucral bracts and enlarged bases on the style.

The type species of Trichocoronis, $T$. wrightii, is the only member of the subtribe showing branched inflorescences. The species shows a clinal variation in the character, with the most branched forms in the north in Texas, and the least branched forms in Tamaulipas in northern Mexico. The material adventive in California is like that from Texas, while the Tamaulipan material seems to approach, both structurally and geographically, $T$. sessilifolia of southwestern Mexico, having solitary monocephalic inflorescences.

A chromosome number of $n=15$ has been reported for the genus (Turner et al., 1962; R. King et al., 1976).

The genus has been reviewed and a key provided to the species by King and Robinson (1970o).

The following two species are recognized in the genus:

Trichocoronis sessilifolia (S. Schauer) B. Robinson, Mexico.

Trichocoronis wrightii (Torrey \& A. Gray) A. Gray, SW United States, Mexico.

\section{Shinnersia}

\section{Shinnersia R. King \& H. Robinson, Phytologia 19: 297. 1970. TYPE: Trichocoronis rivularis A. Gray.}

Ascending aquatic herbs, usually unbranched or very sparingly branched. Stems terete, striated, initially pilose, becoming glabrous. Leaves opposite, sessile, somewhat clasping; blades obovate-spathulate, margin sinuate-incised, grossly dentate to partly dissected, with auriculate wings basally. Inflorescence usually monocephalic, in a few cases borne contiguously; heads long pedicellate. Involucral bracts ca. 25-30, eximbricate, in 2-3 series, essentially equal, persistent, oblong, with 3-4 striae, glabrous on outer surface, obtuse at apex; receptacle convex to conical, warty, glabrous. Florets $90-100$ in a head; corollas white; with narrow basal tube as long as limb, throat broadly and rather abruptly rounded-campanulate, with glands on tube, with numerous hairs on upper throat and outer surface of lobes; cells of throat broadly oblong, with sinuous lateral walls; lobes short-triangular, broader than long, papillose on inner surface and on tip and margins of outer surface; anther collar short-cylindrical, cells subquadrate below, with beaded thickenings on walls; anther appendage ovate to subquadrate, about as long as wide; style base not enlarged, glabrous; style branches broadly linear, flat, densely long-papillose. Achenes prismatic, 4-5-ribbed, with a few glands, ribs with larger thin-walled apically branched setulae; carpopodium distinct, short-cylindrical, cells rather large, mostly isodiametric, rather thin-walled, in ca. 5 series; pappus lacking. Pollen grains ca. $21 \mu \mathrm{m}$ in diameter. Plate 67. 


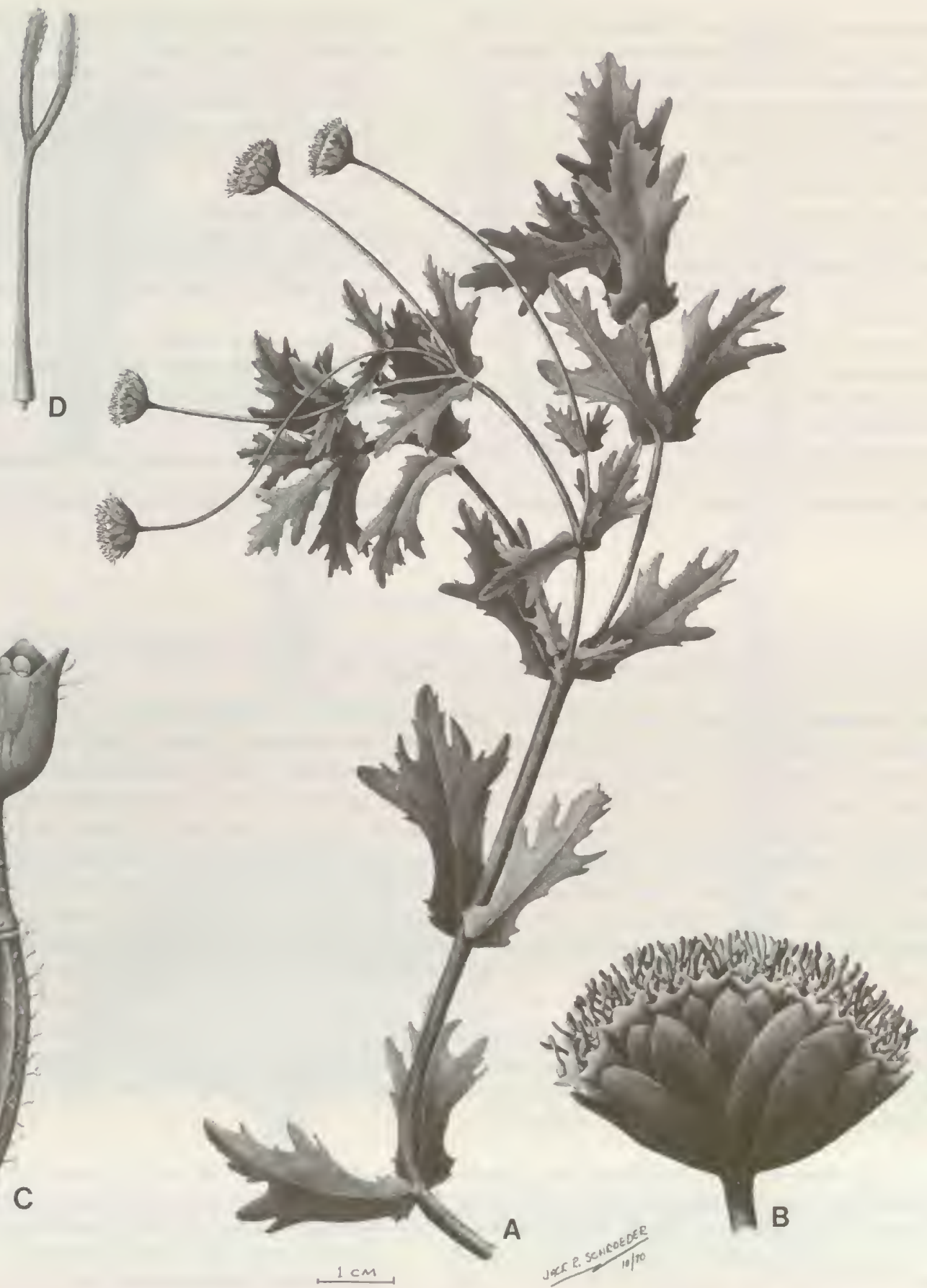

Plate 67. Shinnersia rivularis (A. Gray) R. King \& H. Robinson. - A. Habit, $\times 1 .-$ B. Head, $\times 7 .-$ C. Floret showing anthers, $\times 20 .-$ D. Style, $\times 20$.

The single species of Shinnersia was originally described as a Trichocoronis, and the two genera are closely related. Nevertheless, the two genera differ greatly in details of leaves, corolla shape and pubescence, achene shape and pubescence, carpopodium structure, and development of pappus. Many of the differences involve the structures consisting of larger and thinner-walled cells, and this might be a reflection of Shinnersia being a more aquatic plant 
than Trichocoronis. Such a trend cannot, however, fully explain the unique form of trichomes on the achenes of Shinnersia having lax cells and blunt tips as in glands, but having organization with non-glandular forked tips as in ordinary setulae or twin-hairs.

Asa Gray (1849) in his original description of the species of Shinnersia, commented on the pappus consisting of numerous minute setae rather than squamellae without a trace of stouter bristles or awns. A position next to Phalacraea of DeCandolle was suggested. It is of interest that the structures that have been mistaken for such a pappus in both Shinnersia and Phalacraea prove to be setulae of the achene surface borne around the apical callus. No true pappus is present in either genus.

The clasping leaf bases that remain separate but essentially surround the stem node, are similar to those in Trichocoronis, but the leaf blades are more lobed. Such a tendency, in the extreme, could lead to a verticillate type leaf condition such as is found in the related genus Sclerolepis.
Asa Gray (1849) indicates that the flowers were said to be yellow by one collector, Dr. Gregg, but were pronounced as purple by another collector, Mr. Wright. The yellow color seemed to be doubted by Gray.

A chromosome number of $n=$ ca. 30 has been determined by Chambers (King \& Robinson, 1970c; R. King et al., 1976).

The single species of Shinnersia occurs in the area of the Edwards Plateau in central Texas, and in a small area in Coahuila in northern Mexico. A full citation of specimens is given in the treatment by King and Robinson (1970c).

The genus was named in honor of Lloyd $\mathrm{H}$. Shinners (1918-1971), for many years on the staff of Southern Methodist University in Dallas, Texas, and founder of the journal SIDA.

The following single species is recognized in the genus:

Shinnersia rivularis (A. Gray) R. King \& H. Robinson, Texas, Mexico.

\section{Sclerolepis}

Sclerolepis Cass., Bull. Soc. Philom. Paris 1816: 198. 1816. TYPE: Sparganophorus verticillatus Michaux [= Sclerolepis uniflora (Walter) Britton, Sterns \& Pogg.].

Erect, subaquatic to aquatic perennial herbs, with decumbent or creeping bases, rhizomatous, unbranched or belatedly producing branches above base. Stems terete, not or scarcely striated, glabrous. Leaves verticillate, 4-6 at a node; blades linear, margin entire. Inflorescences terminal, usually monocephalic; heads pedicellate. Involucral bracts 22-25, eximbricate, in 2 series, subequal, persistent, broadly lanceolate, glabrous; receptacle highly convex to conical, rather warty, glabrous. Florets $\mathrm{ca}$. 50 in a head; corollas pink, narrowly funnelform from slightly narrowed base, with glands on tube and base of throat; cells of throat broadly oblong with sinuous lateral walls; lobes short-triangular, wider than long, papillose on inner surface and on tip and margins of outer surface, with short thick hairs on outer surface; anther collar narrowly cylindrical, with numerous subquadrate cells below, with beaded thickenings on walls; anther appendage scarcely wider than long; style base not enlarged, glabrous; style branches narrowly linear to slightly clavate, rather flattened distally, densely long-papillose. Achenes prismatic, 5-ribbed, serrulate to slightly crested on ribs with series of large thin-walled cells, with few glands near upper end; carpopodium subcylindrical, with sinuous vascular trace, with large thin-walled cells that are continuous onto lower ribs of achene; pappus of usually 5 , thick, broadly oblong, blunt, indurated scales, with margins densely crenulate-denticulate, with cells in many layers. Pollen grains ca. $17 \mu \mathrm{m}$ in diameter. Plate 68.

Sclerolepis is thoroughly distinct in the tribe by its subaquatic nature, its narrow verticillate leaves, and its pappus structure. The indurated, oblong pappus segments with multistratose cells, is the feature after which the genus is named.

The genus has been consistently recognized as distinct since its original description by Cassini $(1816 b)$, and has been placed in various systems of classification in the broad relationship that includes both Ageratum and Trichocoronis along with many other genera. A more accurate disposition for the genus was not provided until the survey of the tribe by H. Robinson and King (1977), who noted that Sclerolepis, Trichocoronis, and Shinnersia resemble each other and differ from Ageratum by the less strongly ornamented cell walls of the anther collars, the subaquatic to aquatic habit, and the generally North American distribution. Sclerolepis remains more distinct from Trichocoronis and Shinnersia than the latter two are from each other. It should be noted that the verticillate leaves, that help distinguish Sclerolepis, actually seem similar to the leaf pairs of Trichocoronis and Shinnersia in the way that they surround the nodes of the stem. Also, the rather distinctive crests of the cells on the ribs of the achenes in Sclerolepis are probably structurally related to the pappus.

The single species of Sclerolepis is distributed in eastern North America in the coastal plain and adjacent areas 

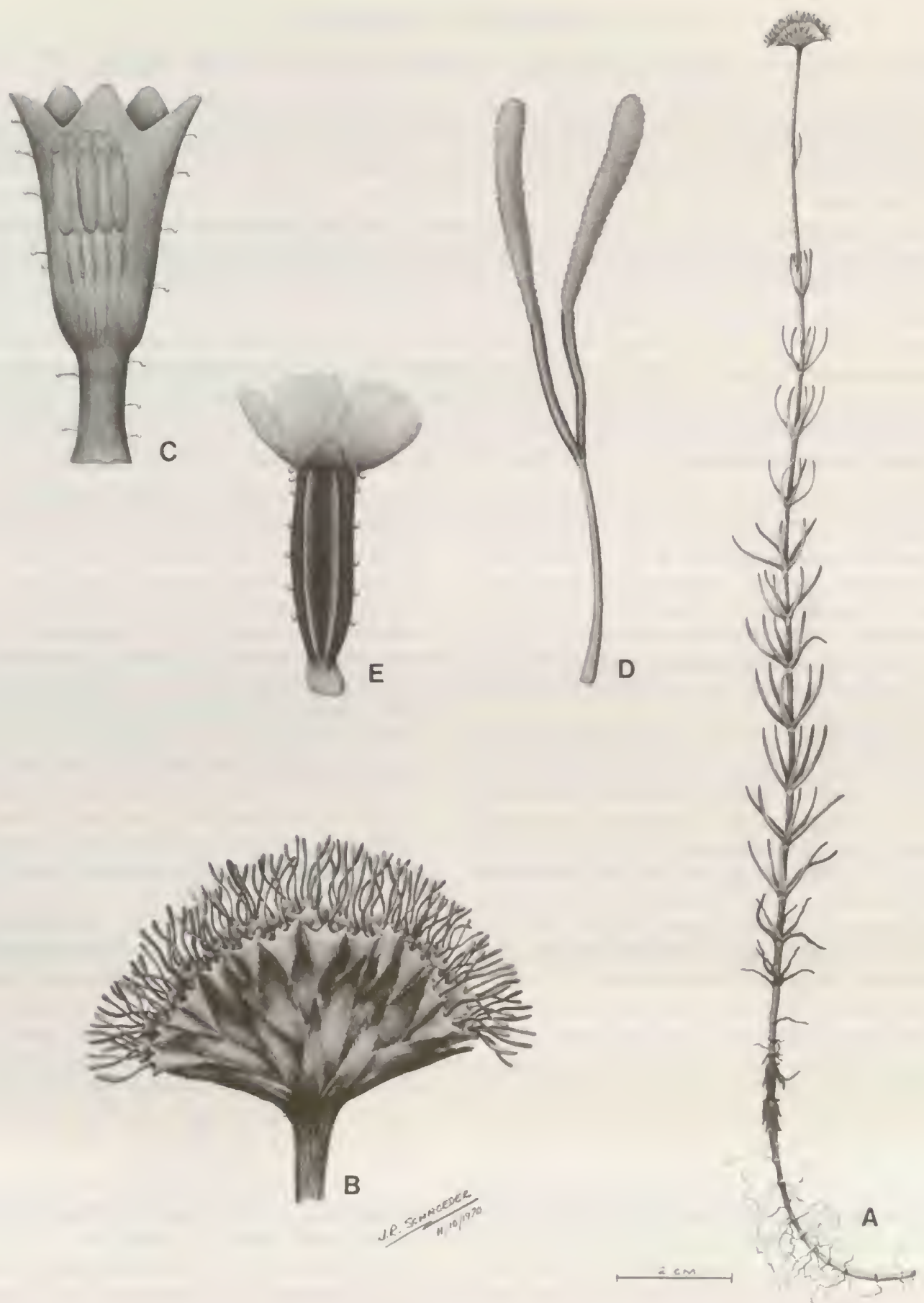

PLATE 68. Sclerolepis uniflora (Walter) Porter. -A. Habit, $\times 7 / 8 .-$ B. Head, $\times 4$. - C. Corolla showing anthers, $\times 21 .-D$. Style, $\times 21 .-$ E. Achene, $\times 21$.

from New Hampshire in the north southward through New Jersey and Delaware to Florida and Alabama.

Chromosome numbers of $n=15$ and ca. 30 have been reported by $\mathrm{R}$. King et al. (1976).
The following single species is recognized in the genus:

Sclerolepis uniflora (Walter) Britton, Sterns \& Pogg., E United States. 


\section{Subtribe VII. Ayapaninae}

\section{Ayapaninae R. King \& H. Robinson, Phytologia 46: 446. 1980. TYPE Ayapana Spach.}

Erect annual or perennial herbs or subshrubs, rarely vines, sparingly to moderately branched; leaves opposite, sometimes becoming alternate above, usually sessile or short-petiolate. Inflorescence terminal on leafy branches, sometimes diffuse. Heads clustered, usually short-pedicellate; involucral bracts usually distinctly subimbricate with bracts of graduated lengths, persistent; receptacle slightly convex, rarely columnar, usually glabrous, more rarely paleaceous or with hairs. Flowers 3-300 in a head; corollas white to pink or reddish purple; lobes usually smooth with rather elongate cells on inner surface, without stomata on outer surface; cells of anther collar with dense annular thickenings on walls; anther appendage usually as long as wide, rarely reduced (lacking in Parapiqueria); style base with enlarged node, with or without hairs; style branches linear to tapering (greatly broadened apically in Gongrostylus), smooth to strongly papillose. Achenes prismatic with 5 ribs, micropunctations of walls not strongly aligned in transverse bands; carpopodium distinct, strongly demarcated, contorted with sinuous vascular trace or stopper-shaped with greatly enlarged basal row of cells, walls of cells strongly thickened or beaded; pappus usually of many capillary bristles, sometimes of reduced number, rarely short or lacking, with pointed apical cells. Basic chromosome number $x=10$.

The Ayapaninae represents a considerable break from the preceding series of related subtribes. All share the densely annulated walls of the cells in the anther collar, but the Ayapaninae differ by the distinctly subimbricate rather than eximbricate involucral bracts, the corolla lobes with smooth elongate cells on the inner surface rather than short or bulging cells, and the characteristically enlarged style base. The latter character is of only erratic occurrence in the preceding subtribes.

Closest relationship of the Ayapaninae is actually to the following subtribe Alomiinae with which it shares the basic form of involucre, corolla lobes, and to some extent style base. The Ayapaninae differs primarily by the lack of the long-clavate style appendage that is characteristic of most Alomiinae. It seems notable that the one example of an enlarged style tip in the Ayapaninae, in Gongrostylus, has the enlargement in both width and thickness, the same as in the Alomiinae. The enlarged style bases of the Ayapaninae and many Alomiinae have resulted in members of both subtribes being placed in the past in the genus Bulbostylis of DeCandolle, which is a synonym of Brickellia.

During early phases of the present series of studies, the combination of sessile or basally winged leaves and the pubescent and often enlarged style bases led to the belief that Campuloclinium of the Gyptidinae was related to Ayapana, and the present subtribal group was initially referred to as Campuloclinioid (King \& Robinson, 1970r, Barroso \& King, 1971). There remain some close superficial similarities between Campuloclinium and some species of Heterocondylus of the Ayapaninae, but examination of details shows that there is no close relationship.

Among the genera presently placed in the Ayapaninae, only the position of Isocarpha seems to be in any question.
Leaf bases and bases of styles as well as the reduced form of style branches seen in Isocarpha, Lepidesmia, and Ayapana were factors in the original placement of Isocarpha in the present group of genera. The reduced style branches and the defective forms of pappus of Isocarpha and Lepidesmia have caused these two genera to be placed in the tribe Heliantheae in traditional systems of classification (Bentham \& Hooker, 1873; Hoffmann, 1890-1894). In early phases of the present series of studies, the characteristic Ayapana-type carpopodium was noted in Lepidesmia, and both that genus and Isocarpha were treated as close relatives of Ayapana (King \& Robinson, 1970r). The close relationship of Isocarpha has since been reconsidered, as indicated under that genus, but relationship to the Ayapaninae is still regarded as most likely (Keil \& Stuessy, 1981).

A few other elements of the Ayapaninae besides Isocarpha and Lepidesmia have a reduced pappus. Of these, Alomiella is based on a species that was originally included in the broad concept of Alomia, Parapiqueria has some of the characters of the traditional genus Piqueria, and Monogereion is individually distinctive with a single long pappus bristle. The majority of the Ayapaninae, however, possess a pappus of numerous capillary bristles, and were placed in the broad concept of Eupatorium in the traditional systems of classification.

The elements of the subtribe with paleae, Isocarpha, Lepidesmia, and Parapiqueria do not seem to form a related group within the subtribe.

The Ayapaninae are mostly restricted to South America with a few species extending their natural range into Central America. Members of the Ayapaninae tend to occur at lower elevations than members of some other subtribes such as the Oxylobinae or Critoniinae. 
KEY TO THE GENERA OF THE SUBTRIBE AYAPANINAE

1. Heads with paleae or coalesced with bracts among the flowers

2. Heads congested; pappus present, short; carpopodium with basal tier of cells much enlarged

2'. Heads separate on distinct peduncles; pappus absent

3. Receptacle highly conical to columnar, with indurate bracts; anther appendage present; sparingly branched plants with narrowly elliptical to ovate leaves

3'. Receptacle low-conical, with broadly scarious bracts; anther appendage absent; small densely branched plants with linear leaves

78. Parapiqueria

1'. Heads without paleae, without bracts among flowers

4. Pappus with single long bristle or with bristles short or lacking

5. Pappus lacking or of short deciduous bristles; veins of corolla greatly thickened in lower part; corolla glabrous inside; leaves simple

76. Alomiella

5'. Pappus present, with a single long and persistent bristle; veins of corolla not greatly thickened in lower part; corolla with a few hairs inside; leaves tripartite

77. Monogereion

4'. Pappus with 5 or more symmetrically arranged long and persistent bristles

6. Style appendage with elongate often imbricated papillae; base node of style glabrous

7. Pappus of 5-10 bristles; style branches slightly thickened; basal tier of carpopodial cells scarcely enlarged

75. Gymnocondylus

7'. Pappus of 18-30 bristles; style branches narrowly linear to tapering at tip; carpopodium with basal tier of cells distinctly enlarged 69. Ayapana

6'. Style appendage mamillose to nearly smooth; style node often with hairs

8. Carpopodium contorted, with cells of lowest row not more enlarged

9. Branches of inflorescence with regular widely dichotomous branching; involucre with 15 bracts in 5 regular ranks of 3; corolla with abruptly broadly campanulate throat

74. Condylidium

9'. Inflorescence without regular widely dichotomous branching; involucral bracts not in regular ranks; corolla funnelform

73. Heterocondy/us

$8^{\prime}$. Carpopodium cylindrical, with the lowest row of cells distinctly enlarged

10. Epiphytes; tips of style branches with prominent fusiform enlargements

72. Gongrostylus

$10^{\prime}$. Terrestrial plants; style branches linear to filiform

11. Heads with 150-300 flowers; corollas extremely slender with anthers inserted at staggered levels

71. Polyanthina

11'. Heads with 25-150 flowers; corollas funnelform with anthers inserted at the same level _. 70. Ayapanopsis

\section{Ayapana}

Ayapana Spach, Hist. Nat. Vég. Phan. 10: 290. 1841. TYPE: Ayapana officinalis Spach [= A. triplinervis (Vahl) R. King \& H. Robinson].

Erect perennial herbs, unbranched in vegetative parts or basally branched. Stems terete or somewhat hexagonal. Leaves mostly opposite, sessile or winged to base; blades narrowly ovate to elliptical, margin entire to serrulate, pinnately to trinervately veined. Inflorescence laxly paniculate, with laxly or densely corymbose to subcymose branches; heads pedicellate to sometimes sessile. Involucral bracts 15-35, subimbricate, in 4-5 graduated series, persistent, lanceolate, spreading at maturity; receptacle convex, glabrous. Florets 5-40 in a head; corollas white or pink, narrowly funnelform to nearly tubular, glabrous on inner surface, with glands on outer surface of lobes; cells of limb elongate with sinuous walls; lobes short- to longtriangular, smooth on inner surface; anther collar slender, cells mostly elongate, with transverse annular thickenings on walls; anther appendage triangular to oblong, slightly longer than wide; style base enlarged, glabrous; style branches filiform or with short tapering recurved appendages, densely long-papillose. Achenes prismatic, 5-ribbed, with few to many setulae mostly on ribs; carpopodium stopper-shaped, with distinct upper rim, slightly asymmetrical, cells of basal row greatly enlarged, other cells small, in many series, with evenly thickened walls; pappus of ca. 20-40 slender, scabrous, persistent bristles, apical cells of bristles sharply pointed. Pollen grains ca. 17-22 $\mu \mathrm{m}$ in diameter. Plate 69.

Ayapana was first established at generic rank in 1841 by Spach on the basis of a single species native to the Amazon and widely introduced into other parts of the tropics as a medicinal plant. The species had been variously known under the names Eupatorium aya-pana Vent. and E. triplinerve Vahl, with the epithat aya-pana being ultimately derived from the Tupi Indian name for the plant. The Spach generic concept was neither adequately explained nor extended to related plants, and the concept passed from notice for more than a century. 


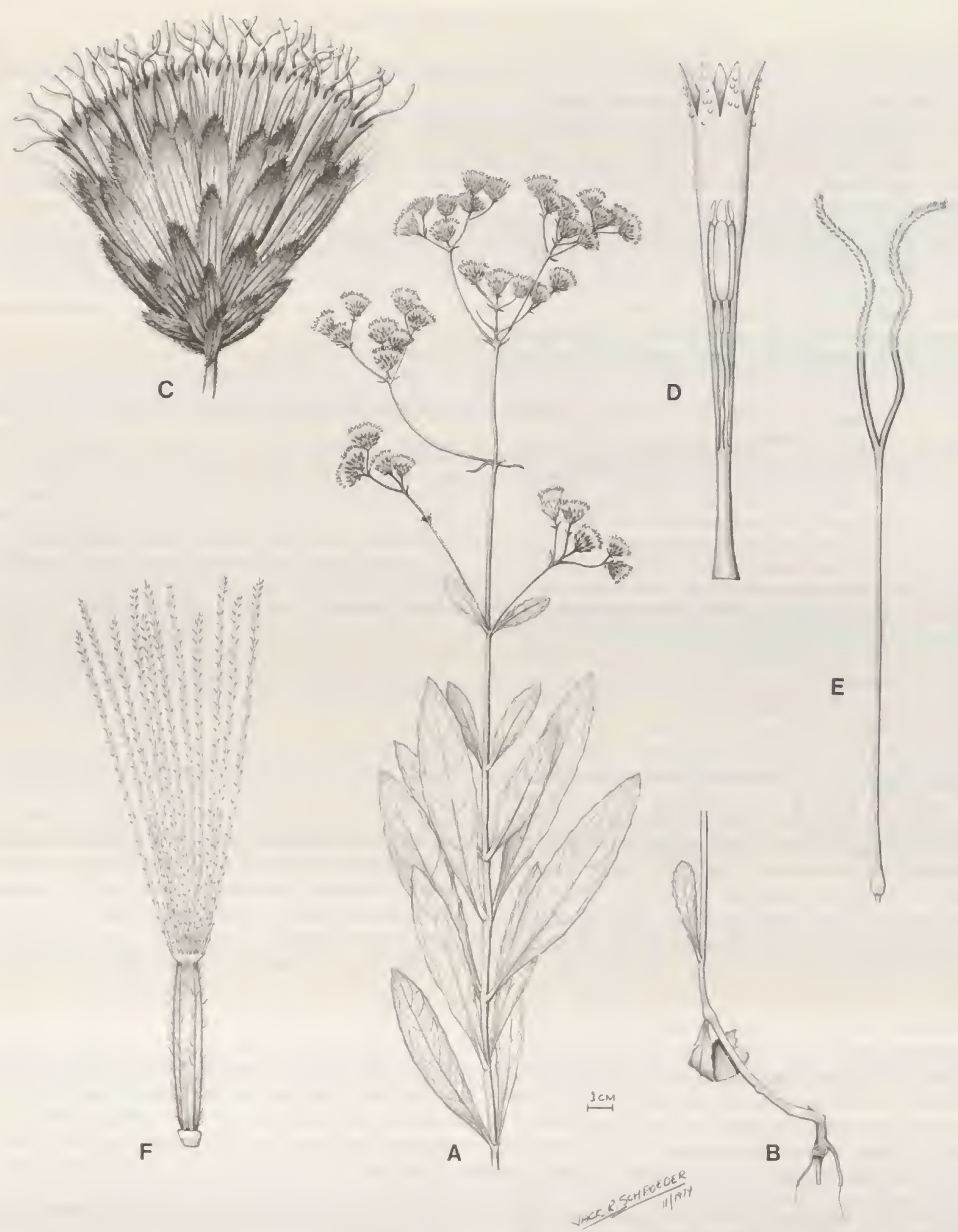

PLATE 69. Ayapana amygdalina (Lam.) R. King \& H. Robinson. - A. Habit, $\times 2 / 5 .-$ B. Base of plant, $\times 2 / 5 .-$ C. Head, $\times 5 .-$ D. Corolla showing anthers, $\times 15 .-$ E. Style, $\times 15 .-F$. Achene, $\times 15$. 
It has been during the present series of studies that the name Ayapana has been found to be applicable to a natural group of species, previously placed in Eupatorium, that differ from their nearest relatives by the long papillae of their style appendages and by the enlarged basal row of cells in their carpopodia. The members of the genus also happen to have expanded style bases that are glabrous, lacking the hairs that are present in some members of related genera. The genus remains one of the most distinct and most commonly collected of the related series placed in the subtribe Ayapaninae.

A number of the related genera share with Ayapana the distinctive type of carpopodium with an enlarged basal row of cells. Such carpopodia are found in no other subtribe, being approached in form only in Trichocoronis of the Trichocoroninae. Among the genera with such carpopodia is only one, Lepidesmia, that also has short and papillose style appendages, a correlation that led to its placement in Ayapana in earlier studies of the present series. Lepidesmia is resegregated here on the basis of its defective pappus and its small partially paleaceous heads in complex clusters. It is notable that many species of Ayapana show the same type of style appendages that have been considered Helianthean in Lepidesmia by various authors including B. Robinson (1913a).

Ayapana as presently delimited, consists of two rather distinctive groups. The typical group with reddish flowers and filiform style branches contains in addition to the type, the widely distributed $A$. amygdalina of Central and South America. The non-typical group of the genus has whitish flowers with comparatively short corolla lobes, and has short reflexed appendages. The latter group contains most of the species of the genus, but is almost completely restricted to the northern Andes.

Most species of Ayapana, like most Asteraceae, seem to prefer open habitats. Even the rather recently described A. ecuadorensis has apparently become rather weedy along certain roadsides in Cañar in Ecuador. The habitat preference of Ayapana seems significant when compared to that of the related genus Ayapanopsis.

In spite of some variation in reported numbers, a constant chromosome base of $x=10$ is suspected for the genus (R. King et al., 1976).

A key to the species of Ayapana, including Lepidesmia, is provided by King and Robinson (1976c).

The following 14 species are recognized in the genus:

Ayapana amygdalina (Lam.) R. King \& H. Robinson, Guatemala, Honduras, Nicaragua, Costa Rica, Panama, Colombia, Venezuela, Trinidad, Guayana, Ecuador, Peru, Bolivia, Paraguay, Brazil.

Ayapana ecuadorensis R. King \& H. Robinson, Ecuador.

Ayapana elata (Steetz) R. King \& H. Robinson, Costa Rica, Panama, Peru.

Ayapana haughtii R. King \& H. Robinson, Colombia.

Ayapana hylophila (B. Robinson) R. King \& H. Robinson, Colombia.

Ayapana jaramillii R. King \& H. Robinson, Colombia.

Ayapana lanceolata R. King \& H. Robinson, Peru, Bolivia.

Ayapana ornithophora (B. Robinson) R. King \& H. Robinson, Colombia.

Ayapana pilluanensis (Hieron.) R. King \& H. Robinson, Peru.

Ayapana stenolepis (Steetz) R. King \& H. Robinson, Panama, Bolivia.

Ayapana tovarensis (B. Robinson) R. King \& H. Robinson, Venezuela.

Ayapana trinitensis (Kuntze) R. King \& H. Robinson, Colombia. Venezuela, Trinidad.

Ayapana triplinervis (M. Vahl) R. King \& H. Robinson, Brazil, Ecuador, introduced in West Indies \& East Indies.

Ayapana turbacensis (Hieron.) R. King \& H. Robinson, Colombia.

\section{Ayapanopsis}

Ayapanopsis R. King \& H. Robinson, Phytologia 24: 382. 1972. TYPE: Eupatorium latipaniculatum Rusby.

Erect perennial herbs or subshrubs, with few branches. Stems terete, striated, pubescent to subglabrous. Leaves opposite, distinctly to indistinctly petiolate, petioles with or without wings; blades elliptical or ovate to deltoid, pinnately to weakly trinervately veined, base cuneate to cordate, apex acute to acuminate, margin serrate to nearly entire. Inflorescence a corymbose panicle with corymbose to weakly cymose branches; heads pedicellate. Involucral bracts 30-50, subimbricate, in 3-4 strongly graduated series, persistent, narrowly oblong to lanceolate; receptacle slightly convex, glabrous to minutely pilulose. Florets $35-150$ in a head; corollas pink to violet, narrowly funnelform; cells of limb elongate with sinuous lateral walls; lobes triangular, as long as wide or longer, outer surface usually glanduliferous, sometimes with non-glandular hairs, inner surface smooth; anther collar cylindrical, cells subquadrate to longer than wide, with transverse annular thickenings on walls; anther appendage ovate 0.6-1.5 times as long as wide; style base distinctly enlarged, glabrous to densely hirtellous; style branches linear, almost smooth to slightly mamillose. Achenes prismatic to fusiform, 5-ribbed, with few to many setulae, glanduliferous; carpopodium large, with distinct upper rim, short-cylindrical, with enlarged basal row of cells, upper cells small, with evenly thickened walls; pappus of ca. 15-40 scabrous, persistent bristles, apical cells of pappus bristles acute to subacute. Pollen grains ca. 17$25 \mu \mathrm{m}$ in diameter. Plate 70 . 


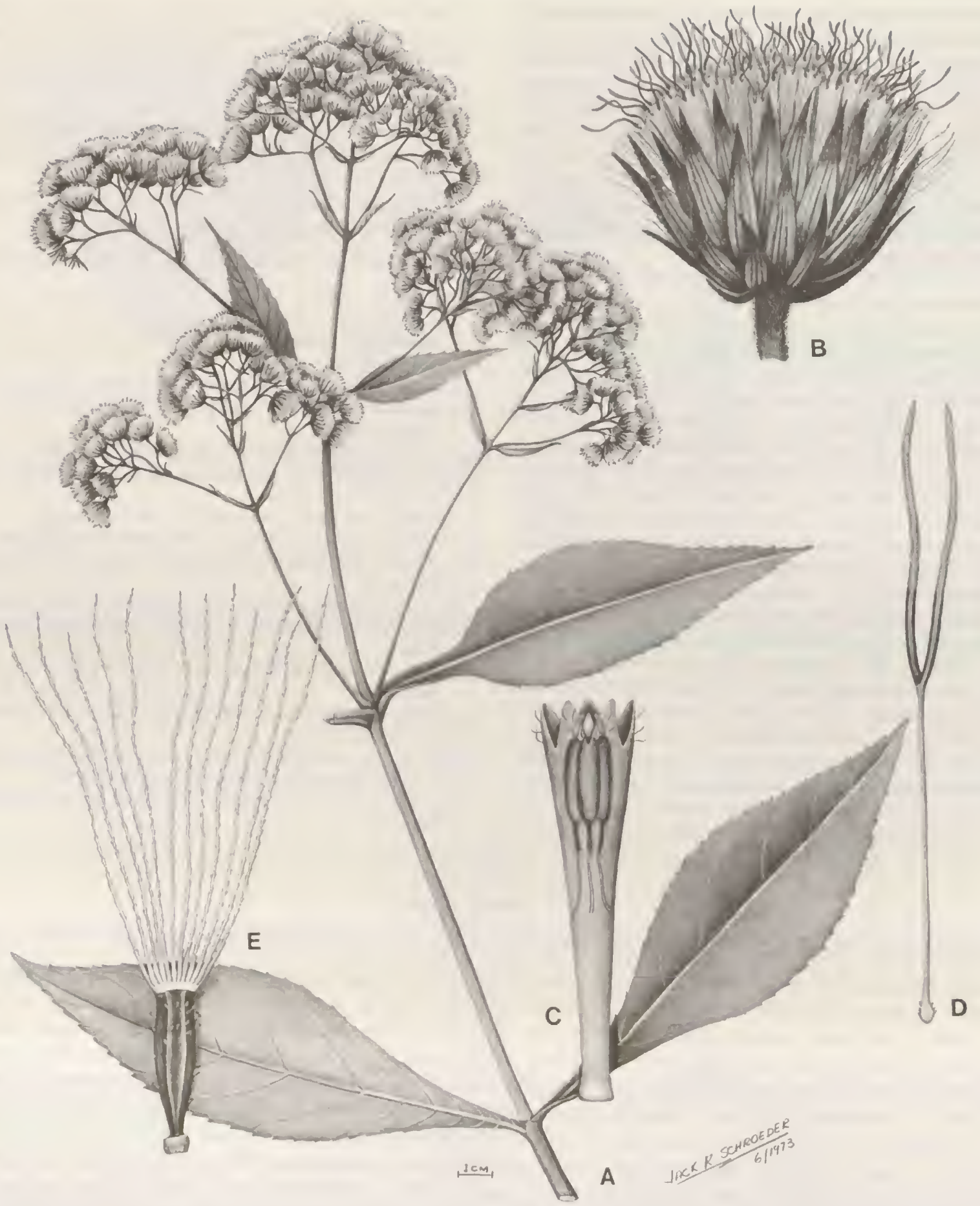
PLATE 70, Ayapanopsis latipaniculala (Rusby) R. King \& H. Robinson. - A. Habit, $\times \%$. B. Head, $\times 51 / 2 .-$ C. Corolla showing
anthers, $\times 13 .-$ D. Style, $\times 13 .-$ E. Achene, $\times 13$. 
Ayapanopsis is closely related to the genus Ayapana after which it is named, and it possesses the same type of carpopodium with an enlarged basal row of cells. Ayapanopsis is distinct in having linear non-papillose style branches rather than strongly papillose branches as in Ayapana. The genus is also different in its potential for producing hairs on the style bases in many species, a capacity not seen in Ayapana. A much more subtle difference between the genera seems to be ecological, with most of the species of Ayapanopsis prefering forested habitats often at medium elevations.

Ayapanopsis is also closely related to Polyanthina which has the same type of carpopodium and style branches. Also, the present genus often has hairs on the receptacle as in Polyanthina. The extremely narrow flowers of the latter genus are distinct, however, and it has a preference for open habitats.

The genus Ayapanopsis ranges from southern Colombia southward in the Andes to Argentina. The only exceptions to the general geographic pattern are A. oblongifolia of Minas Gerais in eastern Brazil, and $A$. esperanzae with its broad rather cordate leaves from west-central Paraguay. The majority of the species seem to be concentrated in Peru and Bolivia. Apparently because of the ecological preference of the genus, most of the species are very localized, and are poorly represented in collections. The genus may never be properly known since the habitat involved is particularly subject to destruction by human activity.

No key exists to the species of Ayapanopsis except the general treatments of Eupatorium sensu lato provided by
B. Robinson for various Andean countries such as Peru $(1919 b)$ and Bolivia (1920b). A list of species was given by King and Robinson $(1972 \mathrm{~mm})$, but many of the species have since been found to have older names. It would seem that future attempts to distinguish species of Ayapanopsis should rely not only on habit, but also on pubescence of corollas, achenes, and style bases.

The following 14 species are recognized in the genus:

Ayapanopsis adenophora R. King \& H. Robinson, Bolivia. Ayapanopsis andina (B. Robinson) R. King \& H. Robinson, Peru. Ayapanopsis cuchabensis (B. Robinson) R. King \& H. Robinson, Colombia, Ecuador.

Ayapanopsis didyma (Klatt) R. King \& H. Robinson, Bolivia.

Ayapanopsis esperanzae (Hassler) R. King \& H. Robinson, Paraguay.

Ayapanopsis euphyes (B. Robinson) R. King \& H. Robinson, Bolivia.

Ayapanopsis ferreyrii R. King \& H. Robinson, Peru.

Ayapanopsis latipaniculata (Rusby) R. King \& H. Robinson, Bolivia.

Ayapanopsis mathewsii (B. Robinson) R. King \& H. Robinson. Peru.

Ayapanopsis oblongifolia (Gardner) R. King \& H. Robinson, Brazil.

Ayapanopsis tarapotensis (B. Robinson) R. King \& H. Robinson, Peru.

Ayapanopsis triosteifolia (Rusby) R. King \& H. Robinson, Bolivia.

Ayapanopsis tucumanensis (Lillo \& B. Robinson) R. King \& H. Robinson, Argentina.

Ayapanopsis vargasii R. King \& H. Robinson, Peru.

\section{Polyanthina}

\section{Polyanthina R. King \& H. Robinson, Phytologia 20: 213. 1970. TYPE: Eupatorium nemorosum Klatt.}

Erect perennial herbs, unbranched or sparingly branched in vegetative part. Stems terete, striated, with both non-glandular and glandular hairs. Leaves opposite, sometimes alternate above, with petioles that are winged to base; blades ovate, margins serrate, with pinnate venation. Inflorescence a lax thyrsoid or pyramidal panicle with denser cymose branches; heads pedicellate. Involucral bracts ca. 40-50, subimbricate, in 2-3 strongly graduated series, persistent, lanceolate; receptacle slightly convex, shortly puberulous. Florets ca. 200-300 in a head; corollas white, very narrowly tubular, glabrous on inner and outer surface; cells of limb elongate with sinuous lateral walls; lobes triangular, longer than wide; filaments inserted at staggered levels on corolla tube; anther collar slender, with transverse annular thickenings on cell walls; anther appendage triangular to ovate, slightly longer than wide; style base distinctly enlarged, glabrous; style branches filiform, not tapered, shortly mamillose. Achenes prismatic, 5-ribbed, glabrous except for a few setulae near the top; carpopodium stopper-form or cylindrical, with distinct upper rim, slightly asymmetrical, basal row of cells very large, numerous upper rows of cells small with isodiametric outer faces, cell walls evenly thickened; pappus of ca. 25 scabrid persistent bristles, apical cells of bristles acute. Pollen grains ca. 18-22 $\mu \mathrm{m}$ in diameter. Plate 71.

The genus Polyanthina is unique in the Eupatorieae in the form of the numerous slender flowers after which it is named. The corollas are sufficiently narrow to resemble the female flowers of various non-Eupatorian genera such as Baccharis and Pluchea, and Polyanthina was described once as Baccharis oppositifolia. The small thecae of the anthers cause the only significant bulge in the corollas. The staggered insertions of the filaments eliminate the 


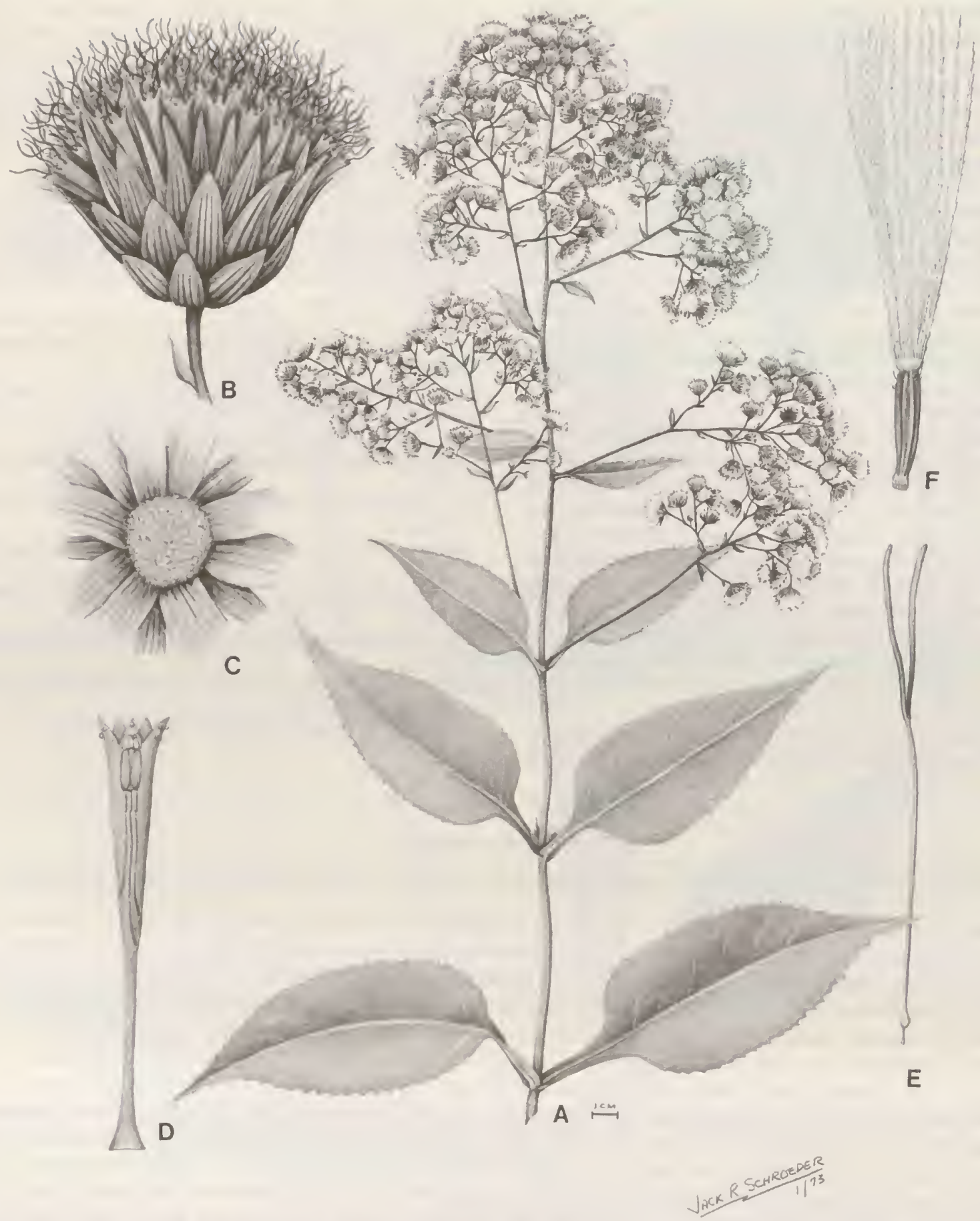

Plate 71. Polyanthina nemorosa (Klatt) R. King \& H. Robinson. - A. Habit, $\times 2 / 5 .-$ B. Head, $\times 5 .-$ C. Receptacle, $\times 5 .-$ D. Corolla showing anthers, $\times 12 .-$ E. Style, $\times 12 .-F$. Achene, $\times 12$.

slight bulge of the type that occurs in anther-bearing corollas of most other Asteraceae at the base of the throat.

The single species presently placed in Polyanthina is also notable for the numerous minute hairs on the surface of the receptacle. The hairs have caused the species to be included in Eupatorium section Hebeclinium in the treatments of Eupatorium sensu lato by B. Robinson (1918b, $1918 c, 1919 b, 1920 b)$. Polyanthina is subtribally distinct 
from any of the other elements that have been placed in the section Hebeclinium.

Polyanthina has the same form of carpopodium with an enlarged basal row of cells, and the same type of enlarged glabrous style base as in the genus Ayapana, and a close relationship is assumed. Polyanthina differs by the non-papillose style branches, the number of flowers in the head, the narrow form of the corolla, and the hairs on the receptacle. The genus also seems close to Ayapanopsis which has the same type of carpopodium and non-papillose style branches, but the style appendages in the latter genus are wider, the corollas are not specialized, the hairs that sometimes occur on the receptacle are not as small or as numerous, and the style base often has hairs.
The single species of Polyanthina is common in open areas at median elevations in Costa Rica and in the Andes from Colombia south to Bolivia. The species is commonly collected, and seems to thrive in areas frequented by botanists during the last century. The rather late initial description of the species, however, seems to indicate that the species has not always been so accessible to plant collectors.

In spite of a few uncertain reports, the chromosome number of Polyanthina is apparently $n=10$.

The following single species is recognized in the genus:

Polyanthina nemorosa (Klatt) R. King \& H. Robinson, Costa Rica, Panama, Colombia, Venezuela, Ecuador, Peru, Bolivia.

\section{Gongrostylus}

\section{Gongrostylus R. King \& H. Robinson, Phytologia 24: 387. 1972. TYPE: Eupatorium costaricense Kuntze.}

Slender epiphytic vines, sparingly branched. Stems terete, striated, sparsely to coarsely hirsute. Leaves opposite, distinctly short-petiolate; blades ovate, bases rounded, margins with remote serrations, veins trinervate from near base. Inflorescences mostly in axils of normal leaves, corymbose with cymose branches; pedicels slender, usually moderately long. Involucral bracts ca. 25 , subimbricate, in ca. 3 graduated unequal series, persistent, ovate to lanceolate or linear-lanceolate; receptacle slightly convex, glabrous. Florets ca. 20 in a head; corollas white, very narrowly funnelform, mostly glabrous with glands on outer surface of lobes; cells of limb elongate with sinuous lateral walls; lobes triangular, slightly longer than wide, smooth on both surfaces; anther collar elongate, with short-oblong to elongate cells, cell walls with transverse annular thickenings; anther appendage short, only half as long as wide; style base enlarged, densely hirsute; style branches narrow and slightly mamillose below, greatly enlarged and smooth distally in broadened and thickened fusiform tip. Achenes prismatic, 5-ribbed, glabrous; carpopodium large, forming a distinct short cylinder with a prominent upper rim, basal row of cells greatly enlarged, numerous upper rows of cells small and subquadrate, cell walls evenly thickened; pappus of ca. 30 scabrid, persistent bristles, scarcely narrowed toward tips, apical cells of bristles subacute. Pollen grains ca. $20 \mu \mathrm{m}$ in diameter. Plate 72 .

The genus Gongrostylus consists of a single scandent epiphytic species occurring at rather low elevations in moist forests along the Atlantic slopes of Costa Rica and Panama and along Pacific slopes in Colombia and Ecuador. The genus is related to Ayapana and Ayapanopsis in the form of its carpopodium with the basal row of distinct enlarged cells. The habitat in moist forests and the hairs on the style base would indicate that relationship might be closest to Ayapanopsis. The scandent form of the plants and the structure of the style branches are the features that distinguish the genus from Ayapanopsis and all other members of the Ayapaniinae.

Gongrostylus is named after the most distinctive feature of the genus, the greatly enlarged tips of the style branches. The tips are rather fusiform, being both thickened and broadened as in the style branches of most Alomiinae. The enlargements are not flattened as the enlargements are in members of the Critoniinae and most other Eupatorieae. The enlargements in Gongrostylus are accentuated by the narrowness of the rest of the style appendage, and the style branch resembles a Lepidopteran antenna.
In addition to the habit and the style appendage, the short anther appendage in Gongrostylus distinguishes the genus from all others in the subtribe having a pappus of many capillary bristles. Reduction of the anther appendage is rather common in some other subtribes of the Eupatorieae, but is uncommon in the Ayapaniinae.

Though both Gongrostylus and Ayapanopsis seem to prefer moist forested areas, the very different distributions would indicate their habitats are not identical. It is notable that the species of Gongrostylus is not localized as are most Ayapanopsis species. Actually, the species of Gongrosty/us was until recently known only from the extremes of its range, and the more continuous distribution was not demonstrated until collecting efforts were extended into the more uncomfortable, warm, moist areas of Colombia and Panama. The species is treated in more detail in the Flora of Panama (King \& Robinson, 1975y).

The following single species is recognized in the genus:

Gongrostylus costaricensis (Kuntze) R. King \& H. Robinson, Costa Rica, Panama, Colombia, Ecuador. 


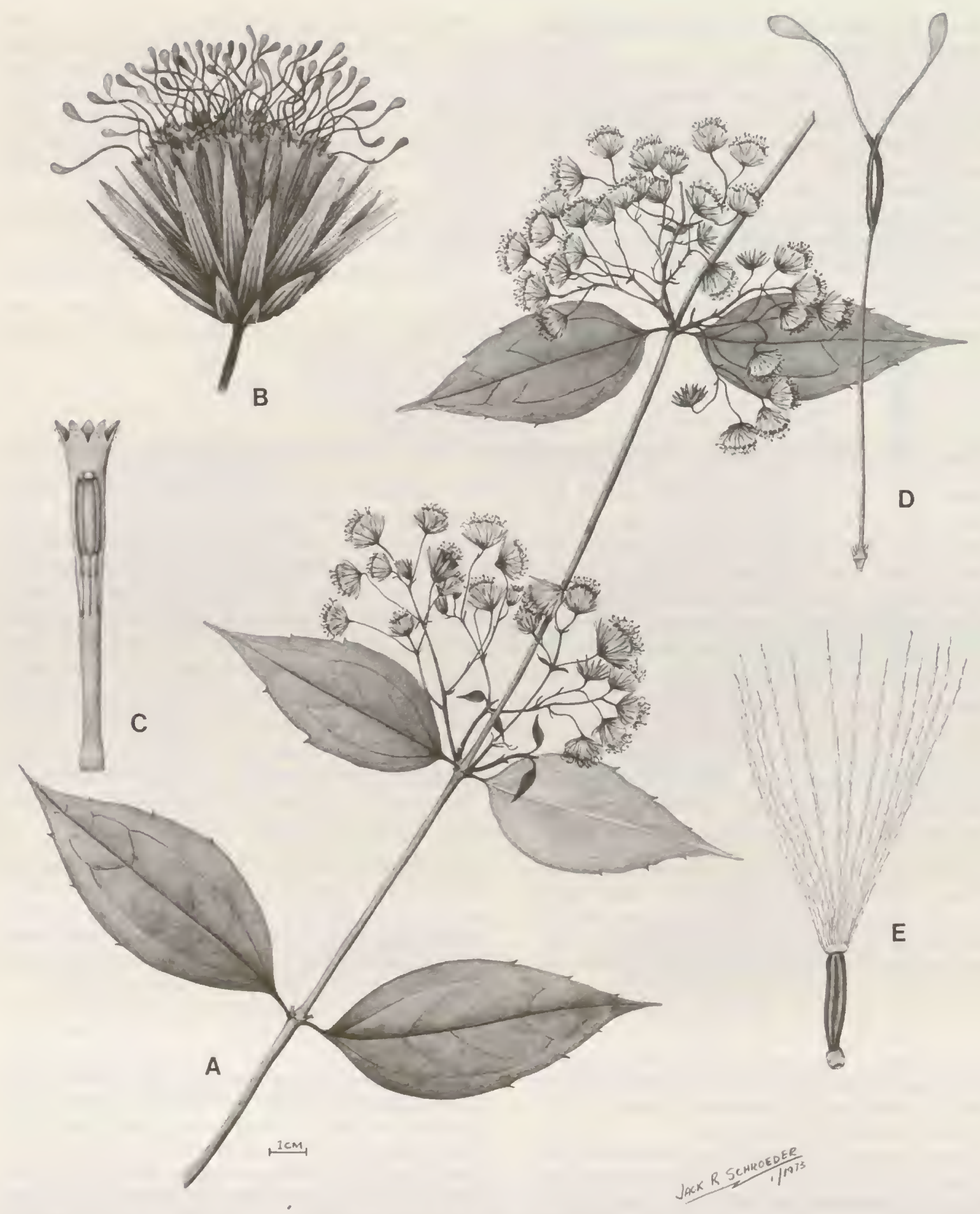

PLATE 72. Gongrostylus costaricensis (Kuntze) R. King \& H. Robinson. - A. Habit, $\times 3 / s .-B$. Head, $\times 4$. - C. Corolla showing anthers, $\times 9 .-D$. Style, $\times 9 .-$ E. Achene, $\times 9$. 


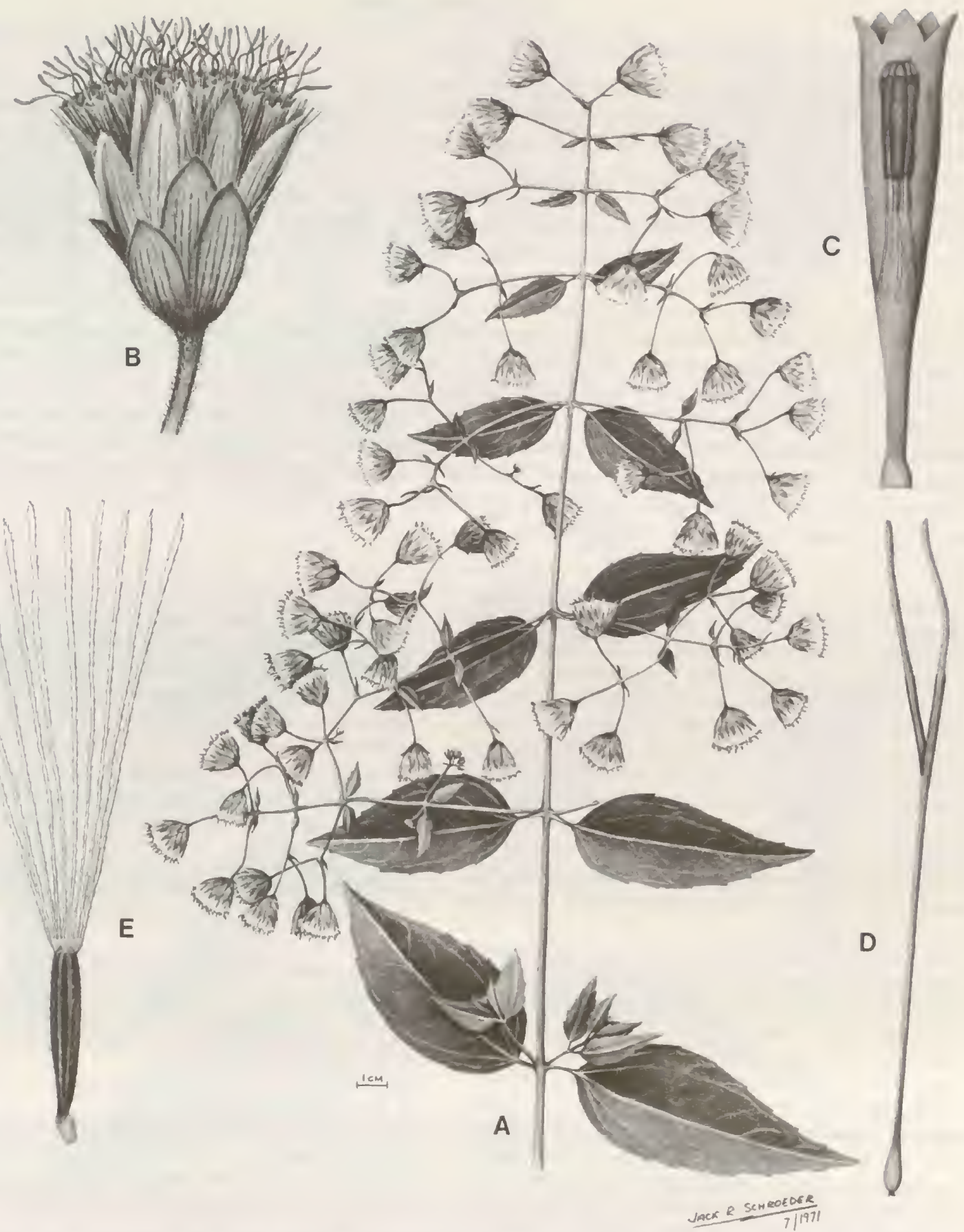

Plate 73. Heterocondylus vitalbae (DC.) R. King \& H. Robinson. - A. Habit, $\times 1 / 2 .-$ B. Head, $\times 4$. - C. Corolla showing anthers, $\times 9,-D$. Style, $\times 9,-$ E. Achene, $\times 9$ 


\section{Heterocondylus}

\section{Heterocondylus R. King \& H. Robinson, Phytologia 24: 389. 1972. TYPE: Eupatorium vitalbae DC.}

Erect to subscandent perennial herbs or subshrubs, with few to many branches. Stems terete, striated, with non-glanduliferous or glanduliferous pubescence. At least lower leaves opposite, upper leaves alternate in some species, bases sessile or short-petiolate; blades ovate to narrowly oblong or panduriform, margin entire to serrate, with pinnate to trinervate venation. Inflorescence with few to many branches, pyramidal to distinctly cymose; pedicels short to moderately long; heads large, sometimes noding. Involucral bracts ca. 15-30, subimbricate, in 3-5 often strongly graduated series, persistent, oblong to lanceolate; receptacle flat, glabrous. Florets 20-80 in a head; corollas white to pink or reddish-purple, narrowly funnelform; cells of limb elongate with mostly sinuous lateral walls; lobes triangular, usually distinctly longer than wide, smooth on both surfaces, glabrous to sparsely glanduliferous on outer surface; anther collar often thickened above, lower cells subquadrate or wider than long, upper cells oblong to narrowly oblong, with annular thickenings on walls; anther appendage ovate to oblong, slightly longer than wide; style base distinctly enlarged, glabrous or hirtellous; style branches linear to broadly linear, smooth to short-mamillose. Achenes prismatic or fusiform, 4-5-ribbed, with short setulae or glands on sides, lower part of achene long-tapering; carpopodium distinct, somewhat asymmetrical with sinuous vascular trace, stopper-shaped with distinct upper rim, cells subquadrate to short-oblong, in many series, with distinctly thickened rather porose walls; pappus of ca. 2030 scabrid persistent bristles, apices of bristles not enlarged or only gradually dilated, apical cells of bristles acute. Pollen grains ca. $19-26 \mu \mathrm{m}$ in diameter. Plate 73.

The genus Heterocondylus includes a remarkably diverse group of species that is distinguished within the Ayapaninae by a carpopodial structure strikingly unlike the specialized type seen in the typical element of the subtribe. The carpopodium in Heterocondylus differs by the lack of a different-sized basal row of cells, by the porosity of the cell walls, and by the more pronounced asymmetry especially in the vascular trace. Since the carpopodium in the genus shows comparative uniformity, some uniformity in other characters might be expected, but the genus as a group is otherwise notable only for the tendency toward large heads that has caused some of its species to be placed in the remotely related Gyptidine genus Campuloclinium.

The variations within Heterocondylus are so marked that unity of the group is not initially obvious. The variation between hirtellous and glabrous basal nodes of the style is the basis of the generic name. Other variations involve the habit, where there are such extremes as the slender, nearly monocephalic, microphyllous $H$. lysimachioides, the small rather scapose forms like $H$. amphidictyus, $H$. pumilus, and $H$. pandurifolius, and comparatively shrubby forms such as $H$. vitalbae. Most species have distinctly alternate leaves and branching above and in the inflorescence, but the leaves and branches of the inflorescences are opposite in two species, $H$. alatus and $H$. vitalbae. The involucral bracts of $H$. vitalbae and $H$. grandis are comparatively broad and comparatively subequal, unlike those of other species.

In more carefully assessing variations in Heterocondylus, it seems probable that the closest relationships are among those species restricted to the area of Brazil and Paraguay. Only $H$. alatus of the Brazilian species seems particularly distinctive. It is the type species, $H$. vitalbae, with its mostly Andean and Central American distribution, that seems the most distinct element of the genus. The type species has no evident close relationship to $H$. grandis which it approaches in the form of its involucre. There does not seem to be any immediate relationship between the two species with opposite branching in the inflorescence, either, although some non-Brazilian material of $H$. vitalbae has been misidentified as Eupatorium vautherianum ( $=H$. alatus), as reported by $\mathrm{B}$. Robinson $(1919 b)$.

The following 12 species are recognized in the genus:

Heterocondylus alatus (Vell. Conc.) R. King \& H. Robinson, Brazil.

Heterocondylus amphidictyus (DC.) R. King \& H. Robinson, Brazil.

Heterocondylus decipiens (Baker) R. King \& H. Robinson, Brazil.

Heterocondylus grandis (Schultz-Bip. ex Baker) R. King \& H. Robinson, Brazil.

Heterocondylus itacolumiensis (Schultz-Bip. ex Baker) R. King \& H. Robinson, Brazil.

Heterocondylus jaraguensis (B. Robinson) R. King \& H. Robinson, Brazil.

Heterocondylus leptolepis (Baker) R. King \& H. Robinson, Brazil.

Heterocondylus lysimachioides (Chodat) R. King \& H. Robinson, Paraguay.

Heterocondylus pandurifolius (Baker) R. King \& H. Robinson, Brazil.

Heterocondylus pumilus (Gardner) R. King \& H. Robinson, Brazil.

Heterocondylus reitzii R. King \& H. Robinson, Brazil.

Heterocondylus vitalbae (DC.) R. King \& H. Robinson, Honduras, Nicaragua, Costa Rica, Panama, Colombia, Venezuela, Surinam, Ecuador, Peru, Bolivia, Paraguay, Brazil. 


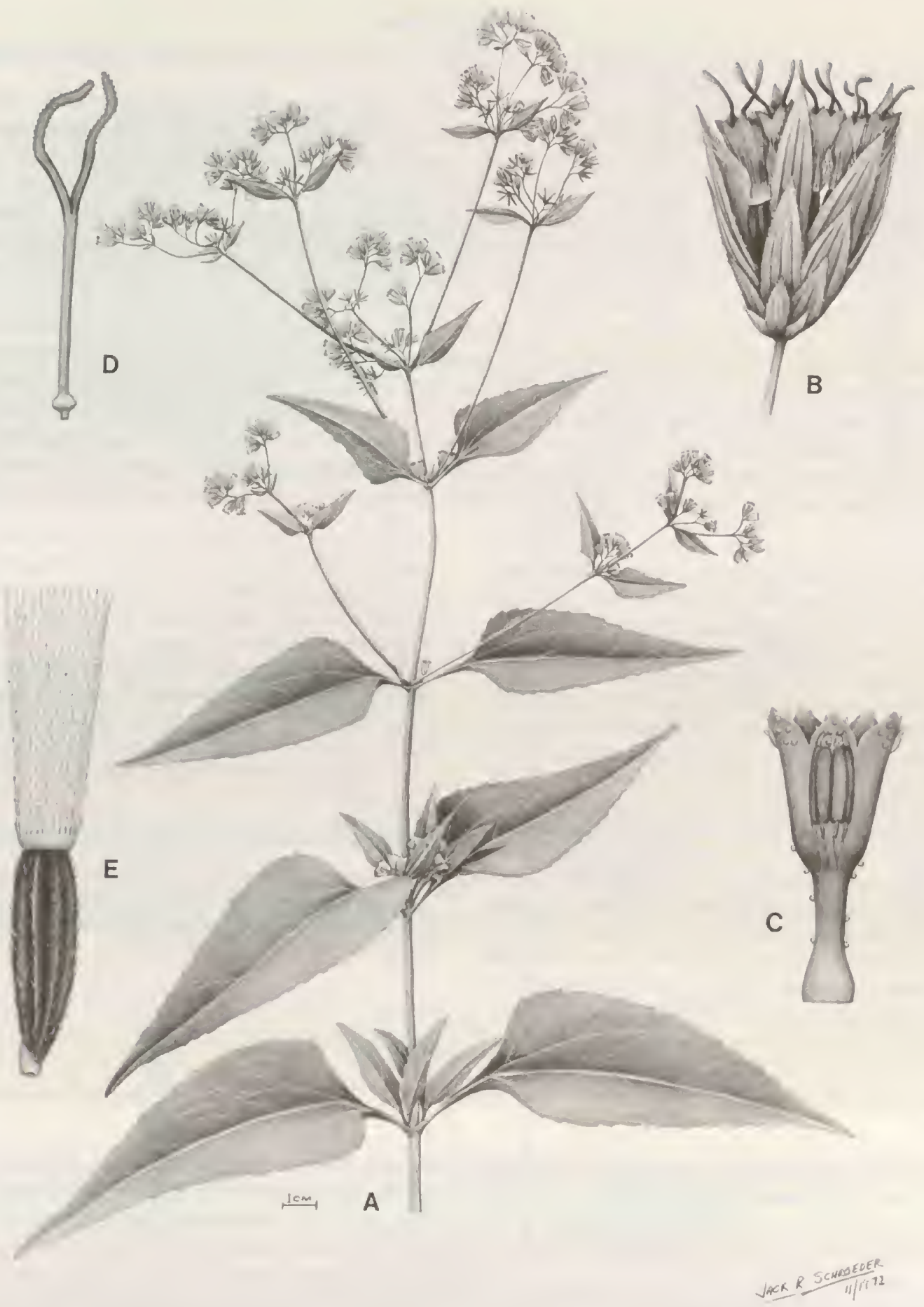

Plate 74. Condylidium iresinoides (H.B.K.) R. King \& H. Robinson. - A. Habit, $\times 1 / 2 .-$ B. Head, $\times 8 .-$ C. Corolla showing anthers, $\times 25$. - D. Style, $\times 25,-$ E. Achene, $\times 25$. 


\section{Condylidium}

Condylidium R. King \& H. Robinson, Phytologia 24: 380. 1972. TyPE: Eupatorium iresinoïdes H.B.K.

Erect to decumbent perennial herbs or subshrubs, laxly branching. Stems terete, striated, puberulous. Leaves opposite, short-petiolate with petioles winged to near base; blades ovate to ovate-lanceolate, margin bluntly serrate to subentire, a pex short-acuminate, base rounded to truncate, abruptly and narrowly decurrent into petiole wing, trinervate from near base of blade. Inflorescence thyrsoid-paniculate, with laxly and divaricately cymose branches; pedicels mostly short. Involucral bracts 15, subimbricate, in 5 ranks and 3 series, unequal and graduated, persistent, suborbicular to narrowly lanceolate, tips acute; receptacle flat to slightly convex, glabrous. Florets $5-6$ in a head; corollas white, with a short constricted basal tube, with abruptly and rather narrowly campanulate limb; cells of limb elongate with sinuous lateral walls; lobes triangular, slightly longer than wide, smooth on both surfaces; lower filament rather short, collar almost as long, cylindrical, collar cells subquadrate below, more elongate above, with weak annular or otherwise ornate thickenings on walls; anther appendage slightly longer than wide; style base enlarged, densely short-hirsute; style branches linear, densely long-papillose. Achenes prismatic, 5-ribbed, ribs with numerous short setulae; carpopodium asymmetrical, very prominent on one side, contorted and slightly tapering, with sigmoid vascular trace, lower cells subquadrate, thick-walled, upper cells more elongate; pappus of ca. 30-40 slender, scabrid, persistent bristles, apical cells of bristles acute. Pollen grains ca. 18-20 $\mu \mathrm{m}$ in diameter. Plate 74.

The genus Condylidium, as a number of others in the Ayapaninae, has a name referring to the knob-like base of the style that is characteristic of the subtribe. The node at the base of the style, however, is not particularly unusual in the subtribe, being one of many in the group bearing dense pubescence. The position of the genus in the subtribe is actually somewhat peripheral and somewhat transitional to the Alomiinae where the carpopodium finds a rather close match in some species of $F l y$ riella. Condylidium is placed in the Ayapaninae on the basis of the narrowly linear and densely papillose style branches, unlike the long-clavate form found in most Alomiinae.

A number of characteristics serve to distinguish Condylidium from other genera of the Ayapaninae. The wellformed inflorescence with widely divaricate cymose branches is rather unique in the tribe. Also, the corolla with its constricted basal tube and campanulate throat is distinct from other Ayapaninae. The most unique feature of Condylidium is the well-ordered involucre with bracts in five ranks and three rows. The latter character is most obvious in older heads where the bracts are completely spread in a five-rayed pattern.

The type species of Condylidium has a wide range, probably aided by the intervention of man. The center of distribution of the genus, however, seems to be northern South America where a second closely related species is found. The species differences are given by King and Robinson (1972ll).

The following two species are recognized in the genus:

Condylidium cuatrecasasii R. King \& H. Robinson, Colombia. Condylidium iresinoïdes (H.B.K.) R. King \& H. Robinson, Guatemala, Honduras, Nicaragua, Panama, Cuba, Lesser Antilles, Colombia, Venezuela, Peru, Bolivia.

\section{Gymnocondylus}

Gymnocondylus R. King \& H. Robinson, Phytologia 24: 393. 1972. TYPE: Eupatorium galeopsifolium Gardner.

Erect perennial herbs, few-branched. Stems terete, striated, hirsute. Leaves opposite, distinctly petiolate; blades ovate, base abruptly short-cuneate, margin crenulate, apex scarcely acuminate, venation trinervate. Inflorescence a laxly corymbose cyme, with few branches; pedicels moderately long. Involucral bracts ca. 50 , eximbricate, in 2-3 unequal graduated series, persistent, narrowly lanceolate to linear; receptacle slightly convex, glabrous. Florets $60-80$ in a head; corollas white or red?, narrowly funnelform, basal tube very narrow below; cells of limb elongate with sinuous lateral walls; lobes triangular, about twice as long as wide, smooth on inner and outer surface, outer surface densely hirsute; anther collar slender, cells short-oblong, with transverse annular thickenings on walls; anther appendage triangular, 1.5 times as long as wide; style bases greatly enlarged, glabrous; style branches very narrowly clavate, densely papillose. Achenes fusiform, 5-ribbed, setuliferous in upper part, setulae with sharp points; carpopodium distinct, stopper-shaped, with 


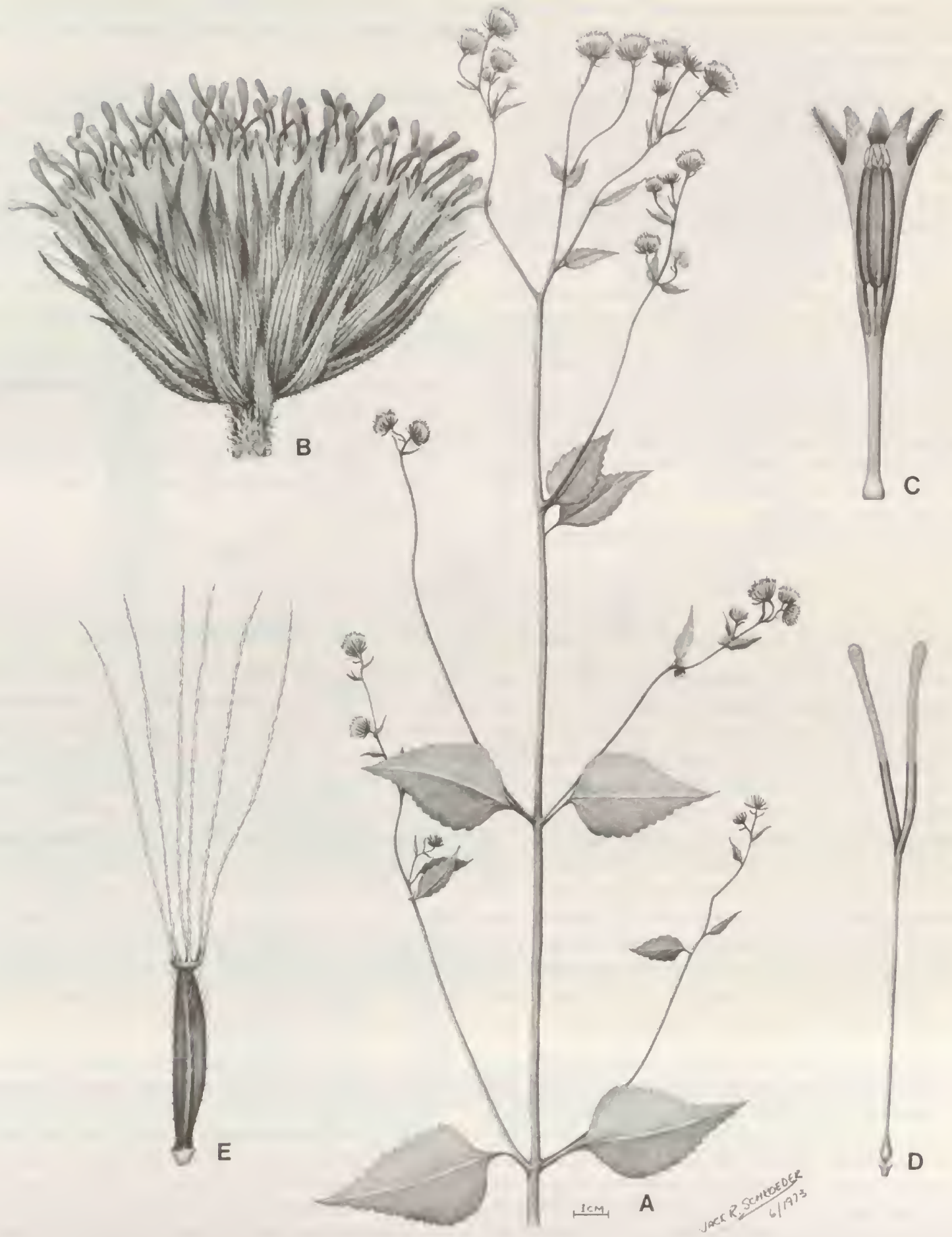

Plate 75. Gymnocondylus galeopsifolius (Gardner) R. King \& H. Robinson. -A. Habil, x3/\%. - B. Head, ×6. - C. Corolla showing anthers, $\times 18 .-D$. Style with nectary, $\times 18 .-$ E. Achene, $\times 18$. 
distinct upper rim, cells subquadrate to short-oblong, with walls greatly thickened and multiporose, lowest cell row not enlarged; pappus of ca. 5-10 scabrid persistent bristles, enlarged distally, apical cells of bristles acute. Pollen grains ca. $16 \mu \mathrm{m}$ in diameter. Plate 75 .

The genus Gymnocondylus, by the combination of its characters, must be considered closely related to, but clearly distinct from, Heterocondylus. The carpopodium has an external symmetry similar to that of Ayapana, and the distortion of the vascular trace is not evident from all sides, but the gradual progression to larger basal cells, and the porosity of the cell walls is like that of Heterocondylus. Gymnocondylus is distinct from other genera of the Ayapaninae by the presence of five to ten bristles in the pappus, and by the somewhat expanded but densely papillose appendages of the style. The genus is also somewhat distinct in the hairs of the corolla lobes, differing from Heterocondylus which has only glands. Though the involucral bracts of Gymnocondylus are subimbricate and graduated in length as in most members of related genera, the bracts are so narrow that the condition is not immediately obvious. The genus has a glabrous basal stylar node, as indicated in the generic name.

The type and only presently recognized species in the genus was collected in eastern Goias in Brazil. In view of the few bristles in the pappus, the original placement in Eupatorium might have seemed questionable even by traditional systems of classification. Still, the pappus bristles may not always be so few. J. Baker (1876) placed the type species in the synonymy of Eupatorium rupestre Gardner, a species from nearby western Minas Gerais which has been credited with a pappus of 15 to 20 bristles. Material of the Minas Gerais species has not been seen, and its conspecific or even congeneric status remains to be determined.

The type species of Gymnocondylus was originally described as having purple flowers, but isotype material seen shows no trace of such intense coloration.

The following single species is recognized in the genus:

Gymnocondylus galeopsifolius (Gardner) R. King \& H. Robinson, Brazil.

\section{Alomiella}

\section{Alomiella R. King \& H. Robinson, Phytologia 24: 395. 1972. TYPE: Alomia regnellii Malme.}

Erect to decumbent perennial herbs, with few branches. Stems terete, slightly striated, covered with long non-glandular hairs and stipitate glands. Leaves opposite to subopposite, distinctly petiolate; blades broadly ovate, margin serrate, apex acute, venation trinervate from near base of blade, surface not glandular-punctate. Inflorescence laxly cymose; pedicels slender, usually of moderate length. Involucral bracts 20-30, subimbricate, in 3 unequal graduated series, persistent, elliptical to oblong, short-acute; receptacle flat, glabrous. Florets ca. 40 in a head; corollas white, narrowly funnelform, glabrous below on both surfaces, veins of corolla greatly thickened in tube and throat; cells of limb elongate with sinuous lateral walls; lobes triangular, about as long as wide, smooth on inner and outer surfaces, outer surface with a few small biseriate hairs; anther collar cylindrical, slightly enlarged, lower cells usually subquadrate, upper cells longer than wide, with transverse annular thickenings on walls; anther appendage ovate, slightly longer than wide; style base greatly enlarged, glabrous; style branches linear, densely papillose with narrow spreading papillae. Achenes prismatic, 5-ribbed, with or without setulae; carpopodium distinct, shortly stopper-shaped, with slight upper rim, basal cells oblong, upper cells shorter, with interior walls of cells more thickened and with porose inclusions; pappus lacking or of short deciduous bristles. Pollen grains ca. $17 \mu \mathrm{m}$ in diameter. Plate 76.

The genus Alomiella is one of the numerous elements of the Eupatorieae that was once placed in the broad and artificial traditional concept of the genus Alomia because of the combination of no pappus and a well-developed anther appendage. The true Alomia, as now recognized, is a Mexican genus with distinctive peg-like setulae on the achene and belongs to the distinct subtribe Alomiinae. Alomiella, in contrast, clearly belongs to the Ayapaninae, with a glabrous basal node on the style, slender papillose style branches, and symmetrical stopper-shaped carpopodia. As a Brazilian genus, Alomiella appears to find many close relatives among the genera of Ayapaninae that are found in that country.
The carpopodium in Alomiella is symmetrical as in the widely distributed genus Ayapana, without even an evident distortion in the vascular trace. The basal row of cells is also rather enlarged as in Ayapana, but not as abruptly so. The strong porosity of the cell wall is one reason for suggesting relationship to some of the more Brazilian genera of the Ayapaninae such as Heterocondylus and Gymnocondylus, and closest relationship may be to the genus Monogereion of Pará in Brazil, a genus with the pappus reduced to a single bristle. Alomiella and Monogereion both show greatly thickened veins in the corolla that seem to compensate for the lack or near lack of a pappus, but Monogereion differs by a number of characters including 


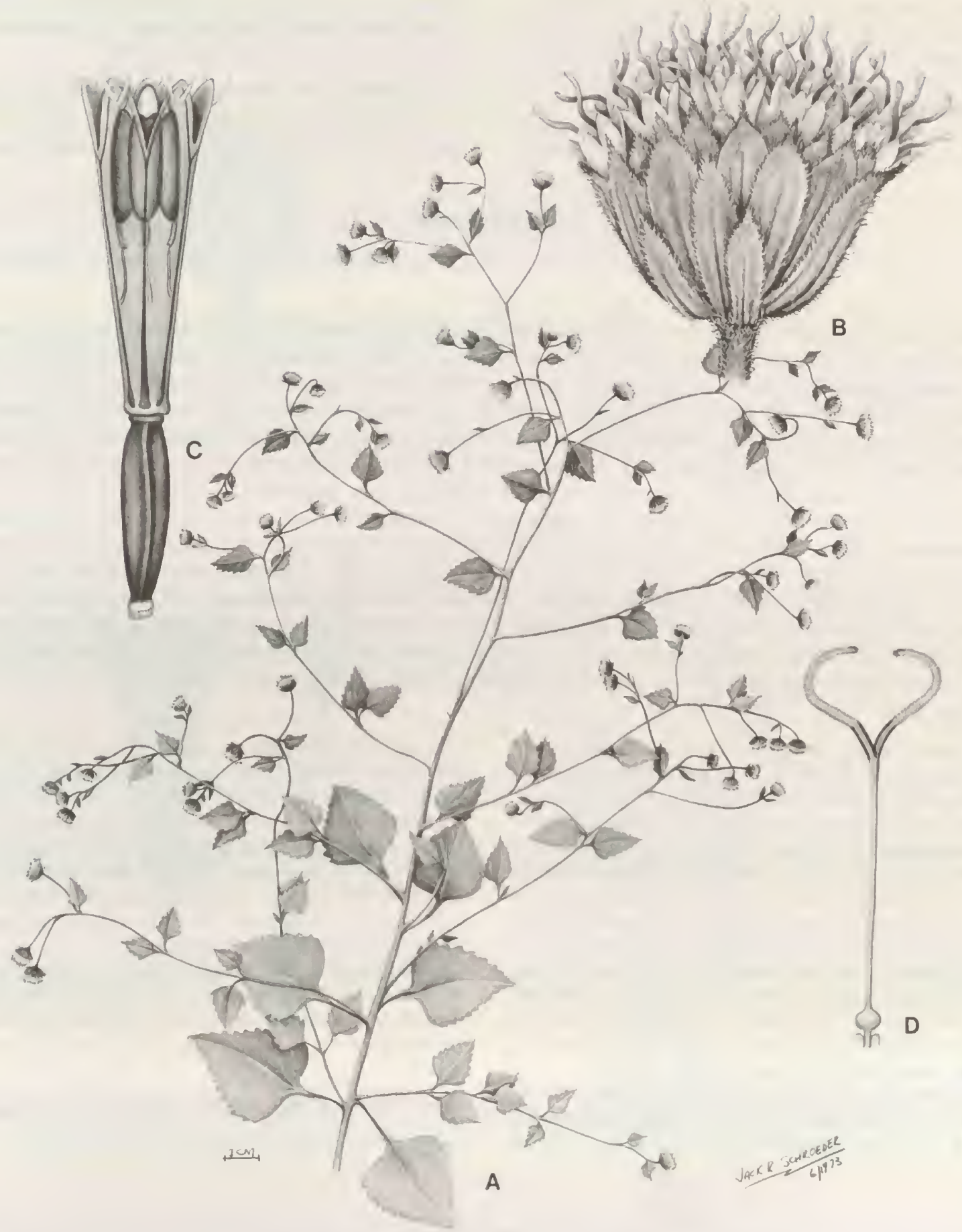

Plate 76. Alomiella regnellii (Malme) R. King \& H. Robinson. - A. Habit, $\times 1 / 2,-$ B. Head, $\times 7 .-$ C. Floret showing anthers, $\times 18 .-$ D. Style with nectary and node, $\times 18$. 
the form of the pappus, the hairs on the inner surface of the corolla, and the tripartite leaves. None of the related genera seem to have the small group of somewhat thickwalled papillae on the ends of the style branches as seen in Alomiella.

Both the original collections and recent collections of the two species of Alomiella indicate a rather restricted distribution in the crevices of sandstone ledges in central Mato Grosso, Brazil. The type species is rather well described and illustrated by Malme (1899).

The following two species are recognized in the genus: Alomiella hatschbachii R. King \& H. Robinson, Brazil. Alomiella regnellii (Malme) R. King \& H. Robinson, Brazil.

\section{Monogereion}

\section{Monogereion G. Barroso \& R. King, Brittonia 23: 118. 1971. TYPE: Monogereion carajensis G. Barroso \& R. King.}

Erect, short-lived perennial herbs or subshrubs, with few to many branches. Stems terete, striated, densely stipitate-glandular. Leaves mostly alternate, basal leaves opposite, long-petiolate; blades ovate in over-all shape, usually deeply lobed to tripartite. Inflorescence diffuse, with heads laxly cymosely disposed on ends of leafy branches, pedicels slender. Involucral bracts ca. 15, weakly subimbricate, in 2-3 series, somewhat unequal to subequal, persistent, lanceolate; receptacle slightly convex, glabrous. Florets ca. 25-30 in a head; corollas white, narrowly funnelform, with hairs near base of tube and near tips of lobes, with hairs on entire upper two-thirds of inner surface of lobes, veins of corolla greatly thickened in basal tube; cells of limb elongate with sinuous lateral walls; lobes triangular, ca. 1.5 times as long as wide, smooth on both surfaces; anther collar slender, cells subquadrate to oblong, with transverse annular thickenings on walls; anther appendage ovate, about as long as wide; style base with enlarged node, glabrous; style branches with linear densely papillose appendages. Achenes somewhat fusiform, 5-ribbed, setuliferous on sides; carpopodium distinct, with slight upper rim, very shortly stopper-shaped, cells in 3-4 series, basal row distinctly larger, walls greatly thickened and porose; pappus with a single long scabrid persistent bristle and a fringe of numerous short narrow squamellae, apical cells of bristle and squamellae sharply acute. Pollen grains ca. $20 \mu \mathrm{m}$ in diameter. Plate 77.

The genus Monogereion was described in the transitional period at the beginning of the present series of studies, being distinguished more on the basis of traditional generic concepts, but with an advanced understanding of the relationships. The genus was originally distinguished and remains most readily recognizable by its dissected leaves, by the pappus with a single bristle, and by the hairs on the inner surface of the corolla lobes. It was the pappus after which the genus was named (Barroso \& King, 1971). The dissected leaves were seen to resemble those of one other Eupatorian genus of Brazil, Lomatozona, but the latter was correctly recognized as a member of the remotely related group now known as the Praxelinae having strongly imbricate deciduous involucral bracts.

The genus Monogereion was initially correctly recognized as a member of the Ayapana relationship on the basis of the carpopodium with an enlarged basal row of cells, the enlarged glabrous basal node of the style, and the slender densely papillose style branches. More recently, the probable closest relative of Monogereion has been treated as the genus Alomiella from Mato Grosso in Brazil, having somewhat similar but more extensive enlarged veins in the corolla (King \& Robinson, 1972qq). Alomiella differs by the non-dissected leaves, the total lack of a persistent pappus, and the glabrous inner surfaces of the corolla lobes, among other details.

Monogereion is known only from the Marabá area of Pará in Brazil. It is one of the two genera of the Ayapaninae found on the outlying savanna areas along the southern fringe of the Amazon Basin, the other being Parapiqueria.

The following single species is recognized in the genus: Monogereion carajensis G. Barroso \& R. King, Brazil.

\section{Parapiqueria}

Parapiqueria R. King \& H. Robinson, Phytologia 47: 111. 1980. TYPE: Parapiqueria cavalcantei R. King \&
H. Robinson.

Small, erect, annual or short-lived perennial herbs, multi-branched above a single base. Stems subterete, striated, glabrous. Leaves opposite, upper leaves subopposite to alternate, narrowly but rather indistinctly 

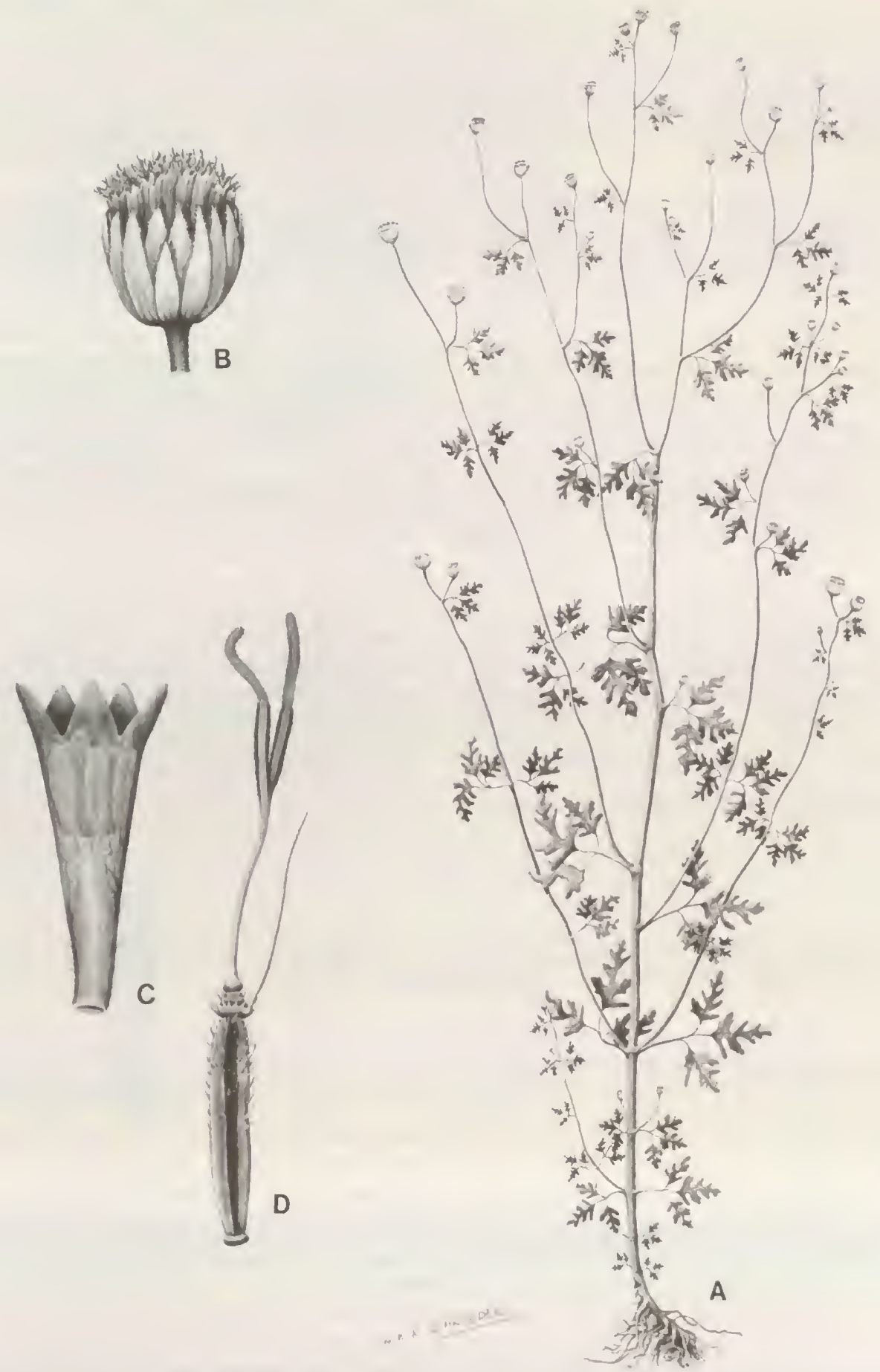

Plate 77. Monogereion carajensis G. Barroso \& R. King. - A. Habit, $\times 1 / 2,-B$. Head, $\times 5 .-$ C. Corolla showing anthers, $\times 15 .-D$. Achene with style, $\times 15$. 

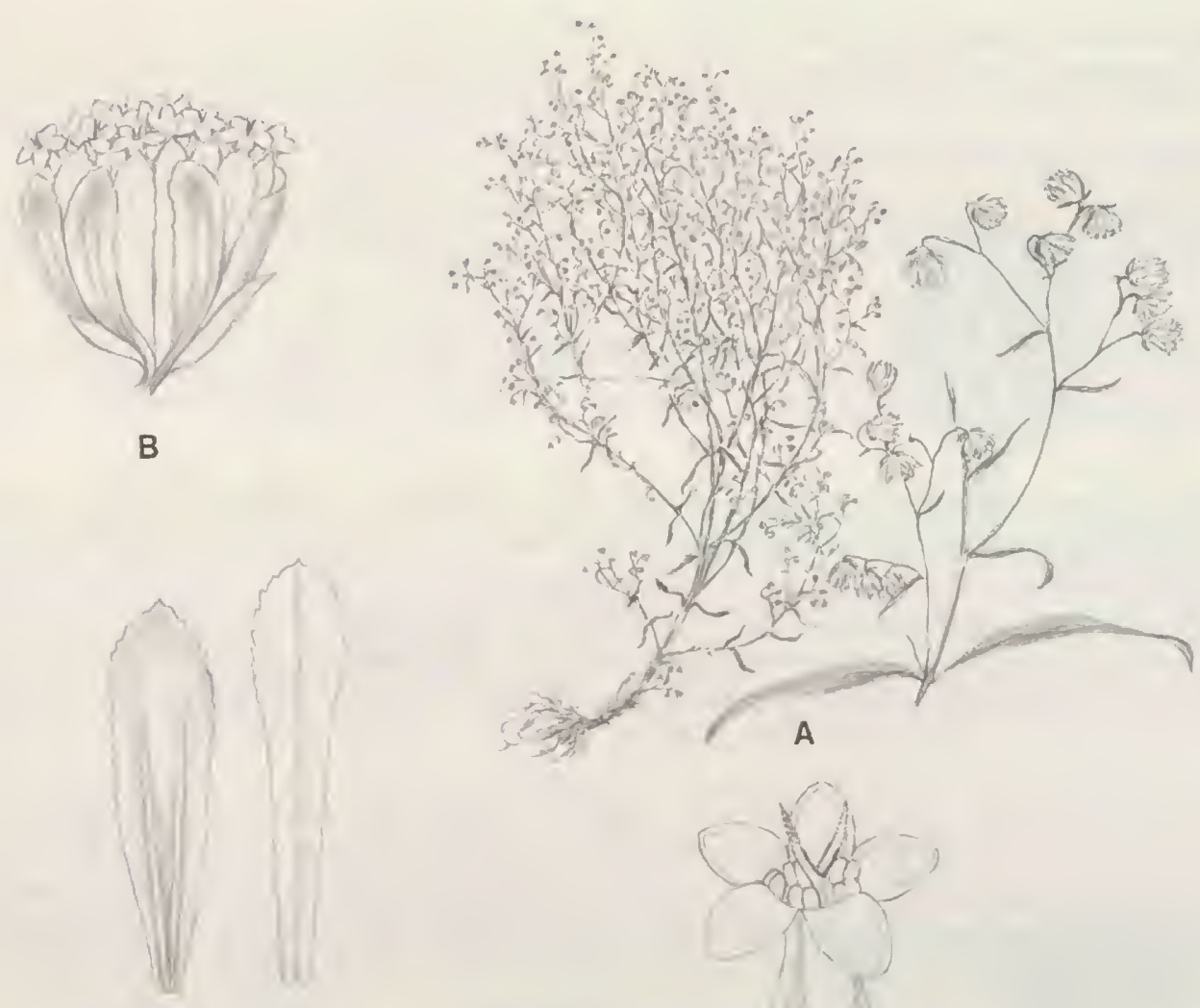

C

D

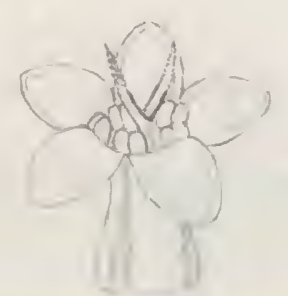

E
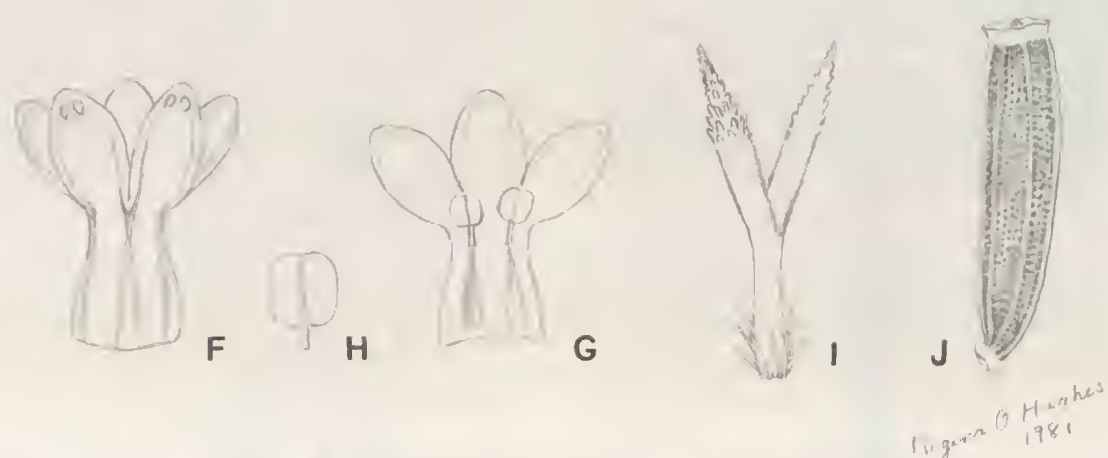

Plate 78. Parapiqueria cavalcantei R. King \& H. Robinson. -A. Habit, $\times 1 / 2$, with separate enlarged portion of branch. - B. Head, $\times 15$. C. Involucral bract, $\times 22 .-$ D. Palea, $\times 22$. - E. Floret without achene, $\times 40 .-F$. Corolla outer surface, $\times 40 .-G$. Corolla inner surface with anthers, $\times 40 .-$ H. Anther, $\times 80 .-1$. Style, $\times 40 .-J$. Achene, $\times 30$.

petiolate; blades membranous, linear. Inflorescence very diffuse with many heads, individual branches rather thyrsoid-paniculate; pedicels slender. Involucral bracts ca. 10, eximbricate, in ca. 2 series, subequal, persistent, oblong, narrowly bicostate; receptacle conical, paleaceous with paleae similar to involucral bracts. Florets ca. 12 in a head; corollas white, with a short glabrous basal tube, limb broadly campanulate, with a short throat; cells of limb elongate with sinuous lateral walls; lobes $4-5$, oblong-ovate, ca. 1.5 times as long as wide, smooth on inner surface, outer surface with 1-2 short, ovate, basally uniseriate glands; anther collar 
narrowly cylindrical, cells usually elongate, with distinct transverse annular thickenings on walls; anther thecae each with only 8-10 pollen grains; anther appendage lacking; style base scarcely enlarged, distinctly pilosulous; style branches short, tapering, short-papillose. Achenes subfusiform, 5-ribbed, glabrous on sides; carpopodium distinct, asymmetrical, shortly stopper-shaped with distinct upper rim, cells in ca. 4 series, mostly subquadrate, with lower row slightly larger, with evenly thickened walls; pappus absent. Pollen grains ca. $18-20 \mu \mathrm{m}$ in diameter. Plate 78 .

Parapiqueria is a genus of very small plants that are evidently annuals and possibly rather ephemeral. As such, it is most like the series of genera related to Ferreyrella and Piqueriopsis in the subtribe Ageratinae. Certainly, the total reduction of the anther appendage seen in Parapiqueria is matched elsewhere in the tribe in only such genera as Piqueriopsis and Ascidiogyne in the Ageratinae. In the case of Parapiqueria, however, the structural reduction of the plant does not indicate relationship to other such reduced Eupatorieae but only complicates the recognition of the true relationships.

The smooth lobes of the corolla with rather elongate cells and the broadened carpopodium with a distinct upper rim strongly indicate that Parapiqueria is not a member of the Ageratinae, and essentially preclude relationship to the immediate Ferreyrella-Piqueriopsis group. A pubescent base of the style is also rare in the Ageratinae, being found in only a few genera such as Ellenbergia. Actually, the combination of smooth lobes, well-developed carpopodium, and style base are indicative of the subtribe Ayapaninae, a subtribe well represented by less extremely reduced forms in the interior of Brazil. The tapering style appendages are unusual for the tribe, but tapering forms occur also in Ayapana of the Ayapaninae and Iltisia of the Ageratinae.

Parapiqueria is more reduced than any other genus in the Ayapaninae, but the nearest approach is in Monogereion which is from the same area of Para in Brazil. The two genera differ in leaf form, corolla shape, anther form, style base, and pappus, and they are not regarded here as immediate relatives. The position of Parapiqueria may be found with the other paleaceous members of the Ayapaninae, Lepidesmia and Isocarpha. In no case does the relationship to other genera seem close.

The small glands on the corolla lobes of Parapiqueria are rather distinctive in having uniseriate stalks. Most such glands in the family are biseriate throughout. The only other example of uniseriate glands known in the family at this time is in another genus of the Eupatorieae, Lomatozona of the Praxelinae.

The generic name derives from Piqueria, a genus name previously applied to all such reduced forms in the tribe, and from the name of the state of Pará in Brazil that happens to be the same as the common Greek prefix meaning near or beside.

The following single species is recognized in the genus: Parapiqueria cavalcantei R. King \& H. Robinson, Brazil.

\section{Lepidesmia}

Lepidesmia Klatt, Bull. Herb. Boissier 4: 479. 1896. TYPE: Lepidesmia squarrosa Klatt.

Tamayoa V. Badillo, Bol. Soc. Venez. Ci. Nat. 9: 139. 1944. TYPE: Tamayoa paraguanensis V. Badillo (= Lepidesmia squarrosa Klatt).

Erect perennial herbs, with few to many branches. Stems terete, striated, pilose. Leaves opposite, sessile; blades rather fleshy, lanceolate to linear-lanceolate, margins entire to subentire, apices blunt, venation trinervate from well above base, strongly ascending. Inflorescence terminal, with elongate lower internodes, ending in dense cymes; pedicels short. Involucral bracts ca. 15, subimbricate, in ca. 2-3 series, unequal, persistent, lanceolate with pale chartaceous central ribs and sharply differentiated broad transparent scarious margins; receptacle slightly convex to flat, paleaceous, paleae lanceolate, similar to involucral bracts but more scarious and more acute. Florets 3-7 in a head; corollas white, narrowly funnelform, glabrous below, with a few glands on lobes; cells of limb elongate with sinuous lateral walls; lobes triangular, ca. 1.5 times as long as wide, smooth on inner surface; anther collar slender, cells with transverse annular thickenings on walls; anther appendage oblong-ovate, slightly longer than wide; style base enlarged, glabrous; style branches narrowly tapering, densely long-papillose, often spreading. Achenes prismatic, 4-5-ribbed, with few to many setulae mostly on ribs; carpopodium cylindrical, with distinct upper rim, cells in 4-5 series, basal row greatly enlarged, cell walls strongly and evenly thickened; pappus consisting of a corona of short bristles, apical cells of bristles sharply pointed. Pollen grains ca. $18-20 \mu \mathrm{m}$ in diameter. Plate 79. 


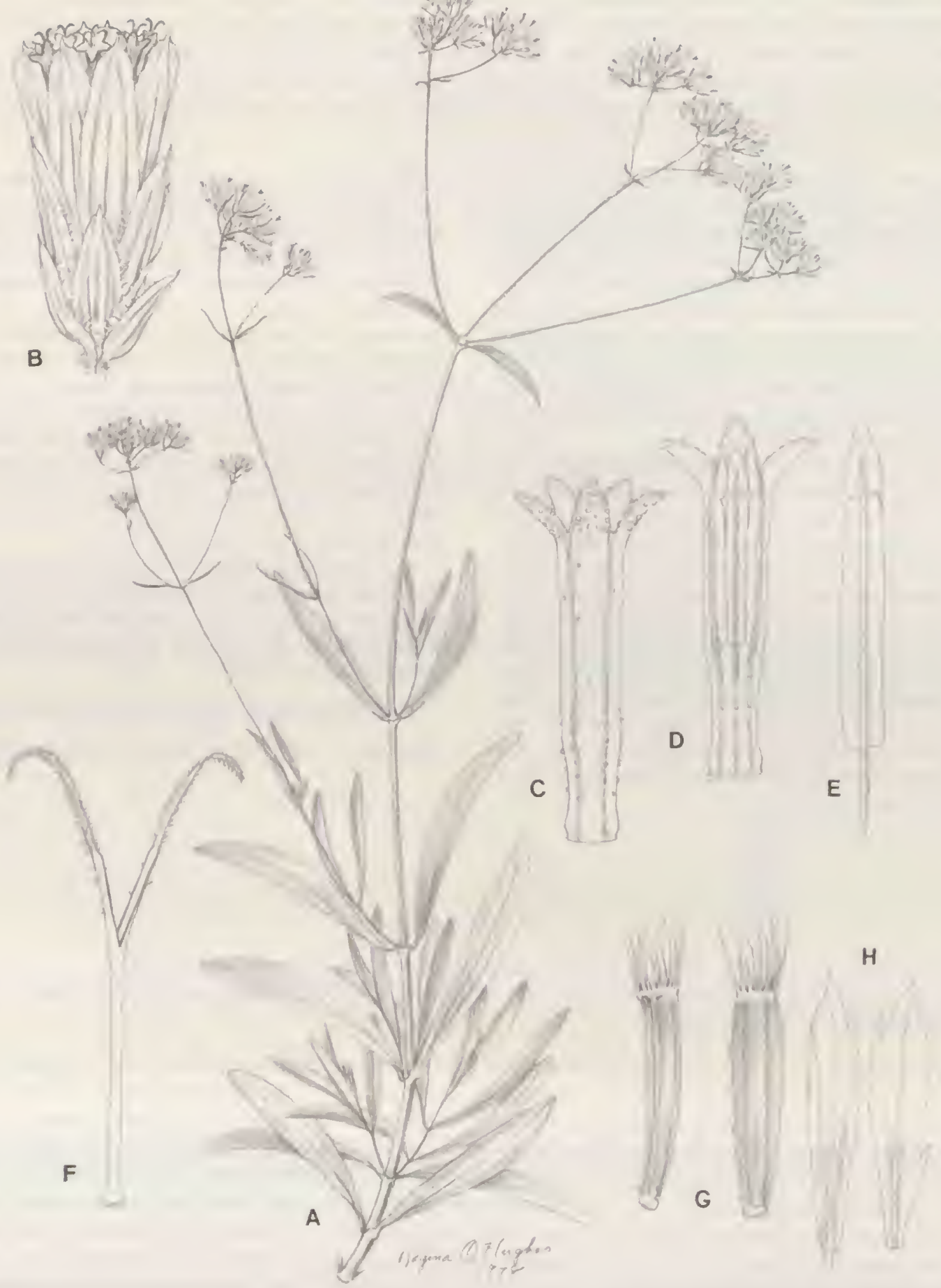

Plate 79. Lepidesmia squarrosa Klatt. - A. Habit, $\times 1 / 2,-B$. Head, $\times 7,-$ C. Corolla outer surface, $\times 17$. - D. Corolla inner surface with anthers, $\times 17 .-$ E. Anther, $\times 30 .-F$. Style, $\times 17 .-G$. Achenes, $\times 17 .-H$. Paleae, $\times 17$. 
Lepidesmia is readily distinguished from other Eupatorieae by the combination of paleaceous heads, tapering style appendages, and a short fimbriate pappus. In fact, because of this combination of characters, the problem with Lepidesmia has not been its distinction in the tribe, but its recognition as a member of the tribe. Klatt (1896) placed the genus close to Aschenbornia Schauer, a genus that has been placed in the Eupatorieae, but which is a synonym of Calea in the Heliantheae. B. Robinson (1913a), after careful consideration, concluded that Lepidesmia belonged in the Heliantheae with the related genus Isocarpha. Finally, Badillo (1944b), mistakenly treating the genus as new under the name Tamayoa, placed it in the Heliantheae. The misplacement of Lepidesmia, as well as that of Isocarpha, derived entirely from the inadequacy of the traditional tribal concepts in the Asteraceae, and was in spite of the fact that all the features involved can be found independently in various other members of the Eupatorieae.

Refined tribal concepts now allow for a more accurate placement of the genera of the Eupatorieae and Heliantheae (H. Robinson, 1981), and some of these are mentioned in the discussion of the following genus, Isocarpha. The case of Lepidesmia is comparatively eased by the fact that the genus has immediate relatives in the Eupatorieae. The tapering style appendage, which seems to have been the primary factor for placement of the genus in the Heliantheae, can be matched in the genus Ayapana, which has a normal Eupatorian pappus of numerous capillary bristles. The carpopodium of Lepidesmia can also be matched in Ayapana, being of the distinctive form having a greatly enlarged basal row of cells. These two characters led to our own earlier inclusion of Lepidesmia in the genus Ayapana (King \& Robinson, 1970r, 1976c). The combination of paleae on the receptacle and a reduced pappus in Lepidesmia are now regarded as sufficient basis for generic separation from Ayapana, although the two are still regarded as closely related. It seems significant that both of the characters by which Lepidesmia is distinguished from Ayapana are found in other genera of the Ayapaninae; paleae in Isocarpha and Parapiqueria, and a reduced pappus in Alomiella, Isocarpha. Monogereion, and Parapiqueria.

The single species has been collected from maritime habitats or areas of saline soil in Cuba and coastal northern South America. The fleshy aspect of the leaves seems to reflect the rather saline environments.

The name Lepidesmia seems to be a contraction of words meaning a "bundle of scales." This is apparently in reference to the prominent whitish involucral bracts and included reddish paleae mentioned by Klatt (1896). The Badillo name apparently honors the Venezuelan collector of his type specimen, Francisco Tamayo.

The following single species is recognized in the genus: Lepidesmia squarrosa Klatt, Cuba, Colombia, Venezuela.

\section{Isocarpha}

Isocarpha R. Br., Trans. Linn. Soc. London 12: 110. 1817. TYPE: Calea oppositifolia L. [= Isocarpha oppositifolia (L.) Cass.].

\section{Dunantia DC., Prodr. 5: 627. 1836. TYPE: Dunantia achyranthes DC. [=Isocarpha oppositifolia (L.) Cass.]}

Erect annual or perennial herbs, branching mostly from base, bases sometimes creeping. Stems terete to slightly hexagonal, striated, puberulous. Leaves opposite or alternate, sessile or with narrowly winged petioles, with or without basal auricles; blades narrowly elliptical, slightly to strongly trinervate, margins entire to serrulate, apices narrowly acute. Inflorescence a lax panicle, sometimes leafy, branches with heads single or in small clusters; pedicels short to elongate. Involucral bracts ca. 10-15, eximbricate, in ca. 2 series, subequal to equal, persistent, elliptical to lanceolate, mostly strongly costate; receptacle highly conical to columnar, paleaceous, paleae similar to involucral bracts. Florets more than 100 in a head; corollas white to pink, usually narrowly funnelform with a distinct short basal tube, cylindrical without distinct basal tube in $L$. megacephala, glands on outer surface mostly on tube and lobes; cells of limb usually elongate with sinuous lateral walls; lobes triangular, somewhat longer than wide, mostly smooth on inner surface, papillose distally and marginally on inner surface in I. megacephala; filaments usually inserted well above base, inserted near base in I. megacephala; anther collar cylindrical, cells mostly short-oblong, with prominent annular thickenings on walls; anther appendage triangular to oblong. slightly longer than wide; nectary disciform and deciduous with style in $I$. megacephala; style base distinctly enlarged, glabrous or papillose, not enlarged in I. megacephala; style branches rather short, sometimes slightly tapering, often spreading or strongly curled, densely long-papillose. Achenes prismatic, 5-ribbed, glabrous or setuliferous on sides, base narrowed; carpopodium short, stopper-shaped, symmetrical without a distinct upper rim or asymmetrical and strongly stipitate, with small subquadrate or transversely oblong cells in 8-18 rows, basal row not enlarged, walls moderately thickened; pappus lacking. Pollen grains $18-20 \mu \mathrm{m}$ in diameter. Plate 80. 

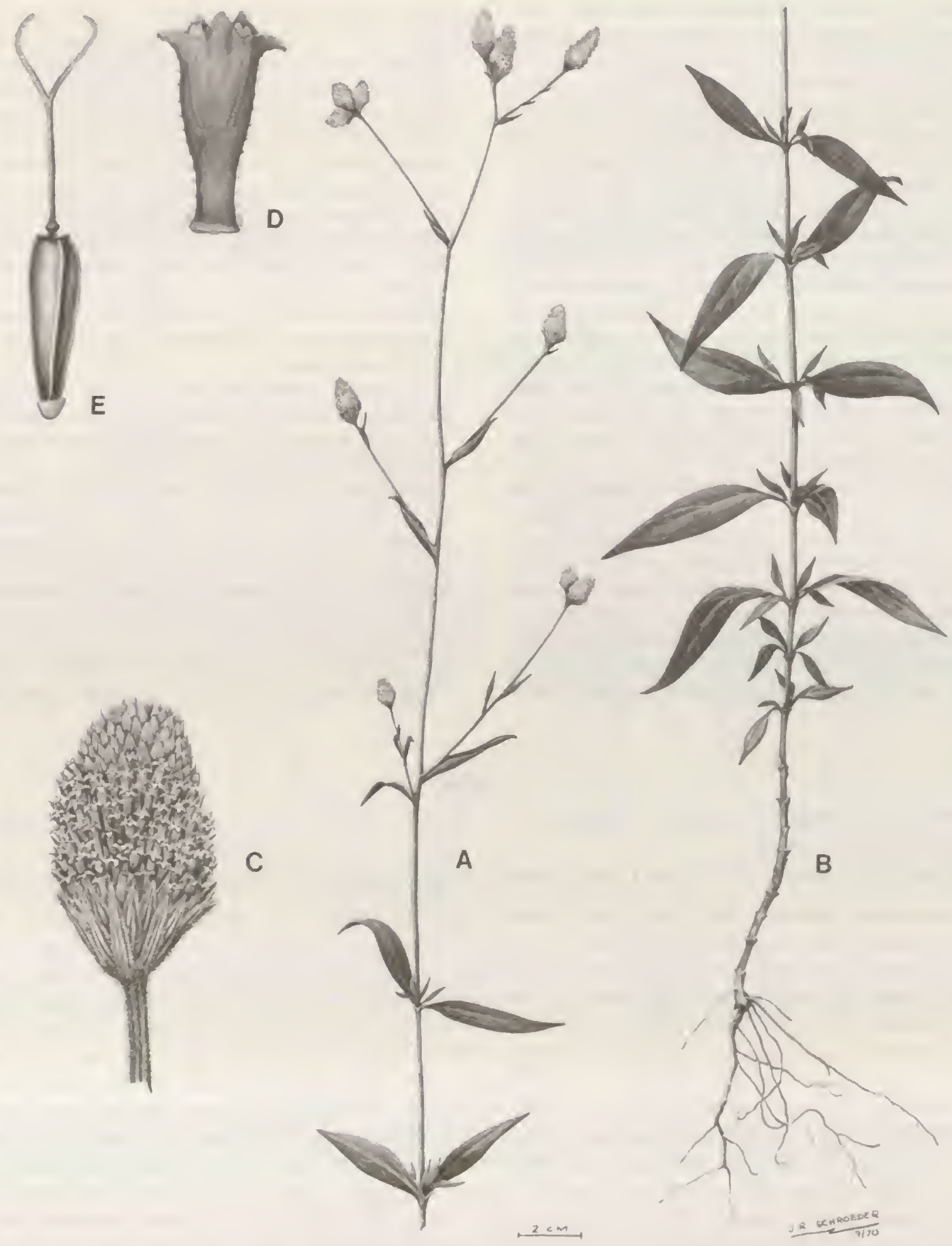

PLATE 80. Isocarpha oppositifolia (L.) Cass. - A. Habit, $\times 1 / 2 .-$ B. Base of plant, $\times 1 \frac{1}{2},-$ C. Head, $\times 3 \frac{1}{2} 2-$ D. Corolla showing anthers, $\times 17 .-E$. Achene with style, $\times 17$. 
Isocarpha is the most Helianthian in its characters of any of the Eupatorieae. The highly conical to columnar strongly paleaceous receptacle, rather short spreading style branches, and epappose achenes are a combination of features found in no other Eupatorieae but in a number of Heliantheae. It is, therefore, not surprising that the type species of Isocarpha was first described as a member of the Helianthian genus Calea, or that Isocarpha was placed in the Heliantheae by many authors including Cassini (1822a), Bentham in Bentham and Hooker (1873), Hoffmann (1890-1894), and B. Robinson (1911a, 1913a). Stuessy (1977) briefly regarded the genus as a member of the Heliantheae primarily on the basis of the remarkably close similarity in appearance between Isocarpha and the Helianthian genera Acmella Rich. ex Pers. and Spilanthes Jacq. Lessing (1832) seems to have been the first to treat Isocarpha as a member of the Eupatorieae, and he was followed by DeCandolle (1836). It was Lessing who first noted that, in its details, the style branch of Isocarpha is Eupatorioid.

King and Robinson (1970r, 1975y) and H. Robinson and King (1977) ultimately recognized Isocarpha as a member of the Eupatorieae near the genus Ayapana on the basis of many technical characters not previously used in the distinction of the tribes. In the anthers of Isocarpha, the collars have strong transverse annular thickenings on the walls, the endothecial cells have thickenings radially disposed, the anther appendage is flat with only two cell layers, and the basic chromosome number is $x=10$. All these features are rare in the Heliantheae. The pollen of Isocarpha is $18-20 \mu \mathrm{m}$ in diameter, while that of the Heliantheae is $23 \mu \mathrm{m}$ or more in diameter with only one apomictic exception (H. Robinson, 1981). The style base bears papillae or hairs in two species of Isocarpha, while hairs are present on the style base in only three genera of the Chaenactidinae in the Heliantheae (H. Robinson, 1981). Isocarpha also lacks raphids which are present in various floral parts in most Heliantheae, and the achenes lack the striations in the carbonized walls such as occur in many Heliantheae. These characters, in addition to the texture of the corollas, and the details of the style branches, provide overwhelming evidence of the Eupatorian nature of the genus. A position in the Eupatorieae has also been accepted by Keil and Stuessy (1981) in their recent revision of Isocarpha.

The contrasting view expressed by Seaman (1982) is based on the presence of heliangolides in Isocarpha, especially atripliciolides, which he suggests are found otherwise in the family only in the Heliantheae. The tables in the Seaman paper do not agree with the text, however, citing such an atripliciolide in one genus of the Eupatorieae, Disynaphia.
In the earlier studies of the present series (King \& Robinson, 1970r, 1975y), Isocarpha was regarded as a rather immediate relative of Ayapana and unquestionably a member of the Ayapana group. The view was partially based on the belief that the style branches of Isocarpha were more narrow and tapering as in Ayapana. The present view indicates that Isocarpha is not as close to Ayapana or Lepidesmia, but that it remains best placed in the Ayapaninae. Isocarpha shows, in the typical section, the smooth corolla lobes, ornate style bases, tendency for sessile leaves, carpopodia with distinct upper margins, and a preference for lower elevations that would suggest a position in the Ayapaninae. Part of the apparent marked distinction of Isocarpha from other genera of the subtribe might be explained by a mechanism proposed by Keil and Stuessy (1981). The latter authors noted that all bracts of the head in the genus have flowers in their axils, and suggested that the head was altered developmentally to produce flowers in the axils of the involucral bracts. It would seem, in any case, that an alternation has occurred that eliminates the zonation found in most Asteraceous receptacles between a bracteiferous lower part and a floriferous upper part.

The genus has been monographed by Keil and Stuessy (1981) with the recognition of two sections. The typical group with four species is found from southern Texas and the West Indies south to northern South America, with some occurrences as far east as Brazil. The remaining section Cylindriflorae of Keil and Stuessy consists of the single species $I$. megacephala of eastern Brazil. As is evident from the above description of the genus, the latter species is strikingly distinct. The corolla of the species differs in addition by having greatly thickened veins in the throat. It is possible that the section Cylindriflorae is not actually closely related to typical Isocarpha. In its geography, the papillose inner surfaces of the corolla lobes, and the cylindrical corollas with basally inserted filaments, the section resembles Teixeiranthus of the subtribe Gyptidinae.

The name Isocarpha comes from Greek words meaning "same" and "chaff or scale," and is evidently in reference to the sameness of all the bracts in the head.

The following five species are recognized in the genus:

Isocarpha atriplicifolia (L.) R. Br. ex DC., Mexico, Guatemala, Nicaragua, Costa Rica, Cuba, Dominican Republic, Colombia, Venezuela.

Isocarpha fistulosa Keil \& Stuessy, Ecuador, Peru. Isocarpha megacephala Mattf., Brazil.

Isocarpha microcephala (DC.) S. F. Blake, Ecuador, Peru. Isocarpha oppositifolia (L.) Cass., Texas, Mexico, Guatemala, El Salvador, Honduras, Nicaragua, Costa Rica, Panama, Bahamas, Cuba, Jamaica, Colombia, Venezuela, Trinidad. 


\section{Subtribe ViII. Alominae}

Alomiinae Less., Syn. Gen. Compos. 154. 1832. TYPE: Alomia H.B.K.

Kuhniinae B. Robinson, Proc. Amer. Acad. Arts 49: 437. 1913. TYPE: Kuhnia L.

Erect annual or perennial herbs or shrubs, sparingly to densely branched; leaves opposite or alternate, sometimes densely spiralled, usually petiolate. Inflorescence terminal on leafy branches, sometimes diffuse. Heads usually clustered, rarely solitary, usually pedicellate; involucral bracts usually distinctly subimbricate with bracts of graduated lengths, persistent; receptacle flat or slightly convex, epaleaceous, usually glabrous. Flowers 2-100 in a head; corollas usually whitish, rarely purplish, usually tubular; lobes usually smooth with rather elongate cells on inner surface, without stomata on outer surface; cells of anther collar usually with dense annular thickenings on walls; anther appendage usually as long as wide, short in Ageratella; style base with or without enlarged node, node when present usually with hairs; style branches usually appearing yellowish from yellowish pollen, longly clavate, both thickened and broadened distally, rarely narrow (Carminatia, Brickellia diffusa), usually smooth, papillose in Phanerostylis. Achenes prismatic to obcompressed, 4-10-ribbed, micropunctations of walls not strongly aligned in transverse bands; carpopodium distinct, with little or no projecting upper rim, often asymmetrical with distorted vascular trace, cells usually in many rows, with walls strongly thickened or beaded; pappus usually of many capillary bristles, sometimes flattened on outer surface, sometimes plumose, rarely few, winged, or lacking. Basic chromosome numbers $x=9,10$.

The Alomiinae are related to the preceding subtribe Ayapaninae, and the subtribes share the tendency for subimbricate, graduated, persistent involucral bracts, annular thickenings on the walls of the anther collars, and enlarged stylar nodes. Within this more generalized group, the Alomiinae are characterized by the usually tubular, often upwardly narrowed corollas and the broadened as well as thickened style branches. The clavate branches frequently appear broader than the opening of the corolla. There are a few exceptions in the subtribe, including two rather unlikely, the type species of the type genus, Alomia, and the most widely distributed species of Brickellia, B. diffusa. The style branches in most of the subtribe often have a yellowish color which is apparently the result of adherent pollen, and which has resulted in a number of members being credited by collectors with yellowish flowers. Flowers of the subtribe are actually mostly whitish with colored flowers unusually rare compared to other subtribes of the Eupatorieae. Many but not all members of the Alomiinae have an enlarged basal node on the style, and the node when present is almost always pubescent.

There is a long history of attempts to segregate various usually artificial elements of the Alomiinae. Two such examples are the groups originally recognized under the two established subtribal names. The name Alomiinae was first established by Lessing (1832) for Eupatorieae totally lacking a pappus. The name takes priority for the subtribe, but only the typical genus of the original concept remains in the present concept. Even Alomia has been reduced to a small remnant of the traditional concept of the genus (King \& Robinson, 1972w).

The name Kuhniinae was established for the Eupatorian part of the so-called Adenostyleae of some earlier authors. As delimited by B. Robinson (1913a), the Kuhniinae contained members of the tribe with ten-ribbed achenes plus some of their obvious relatives with less ribs. Included were diverse elements such as Carphochaete now placed in the Ageratinae, Liatris and its relatives now placed in the Liatrinae, Kanimia now synonymized with Mikania of the Mikaniinae, and Kuhnia, Brickellia, and Barroetea of the Alomiinae. The artificiality of the concept was at least partially recognized from the start, but was not documented until publication of the various biosystematic studies of members of the Kuhniinae by Gaiser (1949, $1950 a, 1950 b, 1953,1954)$.

During the last century, a brief effort was made to recognize members of the subtribe with an enlarged basal node on the style as a genus Bulbostylis DeCandolle. The genus was initially mostly restricted to species now placed in Brickellia, but was subsequently expanded to include many species belonging to the subtribe Ayapaninae. The genus was ultimately both nomenclaturally and systematically flawed, and passed from use. Unfortunately, all use of the style base in the Eupatorieae ceased at that time, and was not resumed until the present series of studies.

A more recent effort to define a related group including Brickellia has been based on the common chromosome number of $x=9$ reported for many members of the group (Gaiser, 1953, 1954; R. King et al., 1976). The base number occurs in a number of genera of the Alomiinae as now defined, and represents a significant departure in a tribe based mostly on $x=10$. The only other notable occurrence of the number in the tribe is in Acritopappus of the subtribe Ageratinae. The recent attempts to define Brickellia or its relatives on the basis of the chromosome number (Harcombe \& Beaman, 1967; Turner, 1978) suffer from an unfortunate lack of correlation with structural features. The present system rejects generic concepts that cannot be recognized without knowing the chromosome number.

The present subtribal concept based on floral characters is a product of the present series of studies. The concept 
includes numerous genera from the area of the western United States and Mexico where the genus Brickellia and its close relatives have long been known to occur. However, the present concept also includes numerous genera from South America beyond the range of most of the previously recognized relatives of Brickellia. The South American genera occur mostly in Brazil and west to the eastern slopes of the Andes. The most extreme element on the subtribe, Helogyne, is also notable as the only genus common on the Pacific side of the Andes.

Three distinct elements in the subtribe, the Kuhnia group in Brickellia, part of Helogyne, and the genus Carminatia have a well-developed plumose pappus. The character is found elsewhere in the Eupatorieae primarily in Trichogonia and Trichogoniopsis of the Gyptidinae and in Liatris of the Liatrinae.

A number of genera of the subtribe have been investigated chemically as indicated in the introductory chapter. The chemistry of Brickellia is of particular interest because of a unique type of acyclic sesquiterpenes found in the genus (H. Robinson et al., 1979).

\section{KEY TO THE GENERA OF THE SUBTRIBE ALOMIINAE}

1. Pappus lacking

2. Heads with 40-50 flowers; corollas glabrous or with glands; achenes with small papilliform setulac; Mexico

2'. Heads with 4-5 flowers; corollas with numerous hairs and glands; achenes glabrous; Brazil

1'. Pappus present, sometimes deciduous

3. Base of style without distinct enlarged node above nectary

4. Pappus with basally winged awns or with squamellae

5. Pappus of 5 awns; anther appendages much shorter than wide

5'. Pappus of alternating awns and squamellae; anther appendages as long as wide or longer

6. Leaves mostly opposite, petiolate with distinct blade; lateral surfaces of achene covered with dense pubescence: cells of carpopodium elongate in radiating pattern

89. Pleurocoronis

6'. Leaves mostly alternate, narrow and sessile; achenes with setulae restricted to ribs; cells of carpopodium subquadrate

4'. Pappus of strictly capillary bristles

88. Malperia

7. Achenes densely covered with long-stalked glands

7'. Achenes with short-stalked glands or setulae

8. Leaf blades with tapering bases

9. Corollas with glands externally, with lobes rather oblong; achenes with 5-6 ribs; South America

91. Dyscritogyne

9. Corollas with gands externally, with lobes rather oblong; achenes with 5-6 ribs, South America 103. Helogyne

9'. Corollas without glands externally, with lobes mostly triangular; achenes usually with 7-10 ribs; North America, Mexico

10. Leaves sessile, opposite, linear or squamulose; involucral bracts in 4 or more series

$10^{\prime}$. Leaves petiolate, opposite or whorled; involucral bracts in 2-3 series

$8^{\prime}$. Leaf blades with truncate or cordate bases

11. Style appendages not enlarged distally; pappus of plumose bristles coalesced at bases 95. Carminatia

11'. Style appendages enlarged distally; pappus bristles not plumose, not coalesced above callus of achene - 12

12. Inflorescence with branches spreading at right angles; involucral bracts with attenuate tips; bases of petioles becoming thickened and embracing node 93. Pseudokyrsteniopsis

12'. Inflorescence with ascending branches; involucral bracts with obtuse or rounded tips; bases of petioles not unusually enlarged

13. Heads with $25-30$ flowers; corollas funnelform; achenes scabrous or with short setulae

13'. Heads with 10-16 flowers; corollas tubular; achenes with prominent long setulae 84. Brickelliastrum

92. Kyrsteniopsis

3'. Base of style with distinct and abrupt enlarged node above nectary

14. Pappus easily deciduous, usually completely detached from achene at maturity

14'. Pappus persistent 100. Leptoclinium

15. Pappus bristles with two different sizes in one series

16. Heads with 4 flowers; leaves mostly alternate; pappus with numerous longer bristles alternating with shorter bristles

99. Goyazianthus

16. Heads with 6-8 flowers; leaves opposite; pappus with only 5 longer bristles positioned above ribs of achene

15'. Pappus bristles without two distinctly different sizes

96. Dissothrix

17. Leaves narrowly linear, inserted in dense spirals

17'. Leaves usually ovate or oblong, opposite or whorled on main stems

18. Achenes with $8-10$ ribs

$18^{\prime}$. Achenes usually with 5 ribs

98. Pseudobrickellia

19. Shrubs; leaves with pin

81. Brickellia 
tips, densely pubescent on outer surface with non-glandular hairs; basal node of style glabrous or with hairs

20. Leaves abruptly short-petiolate, blades oblong-ovate, $\mathrm{ca} .1 \mathrm{~cm}$ wide; inflorescence with ascending branches; achenes densely glanduliferous 102. Crossothamnus

20 . Leaves tapering to a stout petiole, leaf blades elliptical, $4 \mathrm{~cm}$ or more wide; inflorescence with widely spreading branches; achenes with few or no glands 104. Condylopodium

19'. Herbs or flexuous subshrubs; leaves usually trinervate from at or near base of blade; involucral bracts mostly acute, not densely pubescent on outer surface with non-glandular hairs; basal node of style covered with hairs

21. Leaves with prickles on tips of lobes 82. Barroetea

21 '. Leaves without prickles on tips of lobes

22. Corollas flaring, corolla lobes and style branches covered with prominent dense papillosity 82. Phanerostylis

22 . Corollas tubular or very narrowly funnelform, corolla lobes and style branches essentially smooth

23. Carpopodia enlarged and contorted, with irregularly shaped cells; inflorescence with laxly ascending branches; pappus bristles not smooth on outer surface; petioles often narrowly winged; Texas, Mexico 85. Flyriella

23'. Carpopodia small, short-cylindrical, with small regularly shaped cells; inflorescence with stiffly spreading branches; pappus bristles smooth on outer surface, scabrae mostly restricted to lateral margins of bristles; South America __ 97. Austrobrickellia

\section{Brickellia}

Brickellia Elliott, Sketch Bot. S. Carolina 2: 290. 1824. TYPE: Brickellia cordifolia Elliott, nom. cons.

Kuhnia L., Sp. Pl. ed. 2. 1662. 1763. TYPE: Kuhnia eupatorioides L. [= Brickellia eupatorioides (L.) Shinn.]. Coleosanthus Cass., Bull. Soc. Philom. Paris 1817: 67. 1817. TYPE: Coleosanthus cavanillesii Cass. [= Brickellia cavanillesii (Cass.) A. Gray].

Rosalesia Llave in Llave \& Lex., Nov. Veg. Descr. 1: 14. 1824. TYPE: Rosalesia glandulosa Llave in Llave \& Lex. [= Brickellia cavanillesii (Cass.) A. Gray].

Clavigera DC., Prodr. 5: 127. 1836. TYPE: Clavigera corymbosa DC. [= Brickellia corymbosa (DC.) A. Gray].

Bulbostylis DC., Prodr. 5: 138. 1836. TYPE: Coleosanthus cavanillesii Cass. [= Brickellia cavanillesii (Cass.) A. Gray], non Bulbostylis Kunth, nom. cons. Cyperaceae.

Ismaria Raf., Sylva Tellur. 117. 1838. TyPE: Rosalesia glandulosa Llave in Llave \& Lex. [= Brickellia cavanillesii (Cass.) A. Gray].

Erect annual or perennial herbs, subshrubs, or shrubs, unbranched or branched. Stems terete, striated, glabrous or pubescent. Leaves opposite or alternate, sessile or petiolate; blades linear, lanceolate, ovate, deltoid, or lobate, bases cuneate to cordate, margins usually dentate, veins usually trinervate. Inflorescence usually with heads clustered in leafy thyrsoid panicle, sometimes corymbose or cymose, rarely solitary and noding on long peduncles; heads sessile to long-pedicellate. Involucral bracts 14-45, subimbricate, in 5-6 usually graduated unequal series, persistent, spreading with age, lanceolate to oblanceolate, usually 6-8ribbed, rarely with expanded herbaceous tips; receptacle flat to slightly convex. Florets ca. 4-100 in a head; corollas usually white to cream-colored, sometimes purplish, tubular (narrowly funnelform in B. monocephala); cells of throat elongate with sinuous lateral walls; lobes as long as wide to twice as long as wide, ovate-oblong to triangular, smooth on both surfaces, cells mostly oblong to quadrate with slightly sinuous walls; anther collars slender to slightly thickened, cells subquadrate to oblong, with transverse beaded thickenings on walls; anther appendages slightly longer than wide; style base with distinct enlarged node, covered with dense contorted hairs; style branches long-clavate (tapering with stigmatic lines reaching near tip in $B$. diffusa). Achenes prismatic, 10-ribbed, with setulae on sides; carpopodium distinct, with slightly projecting upper rim, slightly to greatly longer on outer surface, cells small, subquadrate to short-oblong, in 6-20 series, with thickened walls; pappus of 10-80 persistent bristles in 1 series, flattened on outer surfaces, scabrid to densely plumosely fringed on lateral margins, apical cells of bristles acute. Pollen grains ca. $20-25 \mu \mathrm{m}$ in diameter. Basic chromosome number $x=9$. Plate 81 . 


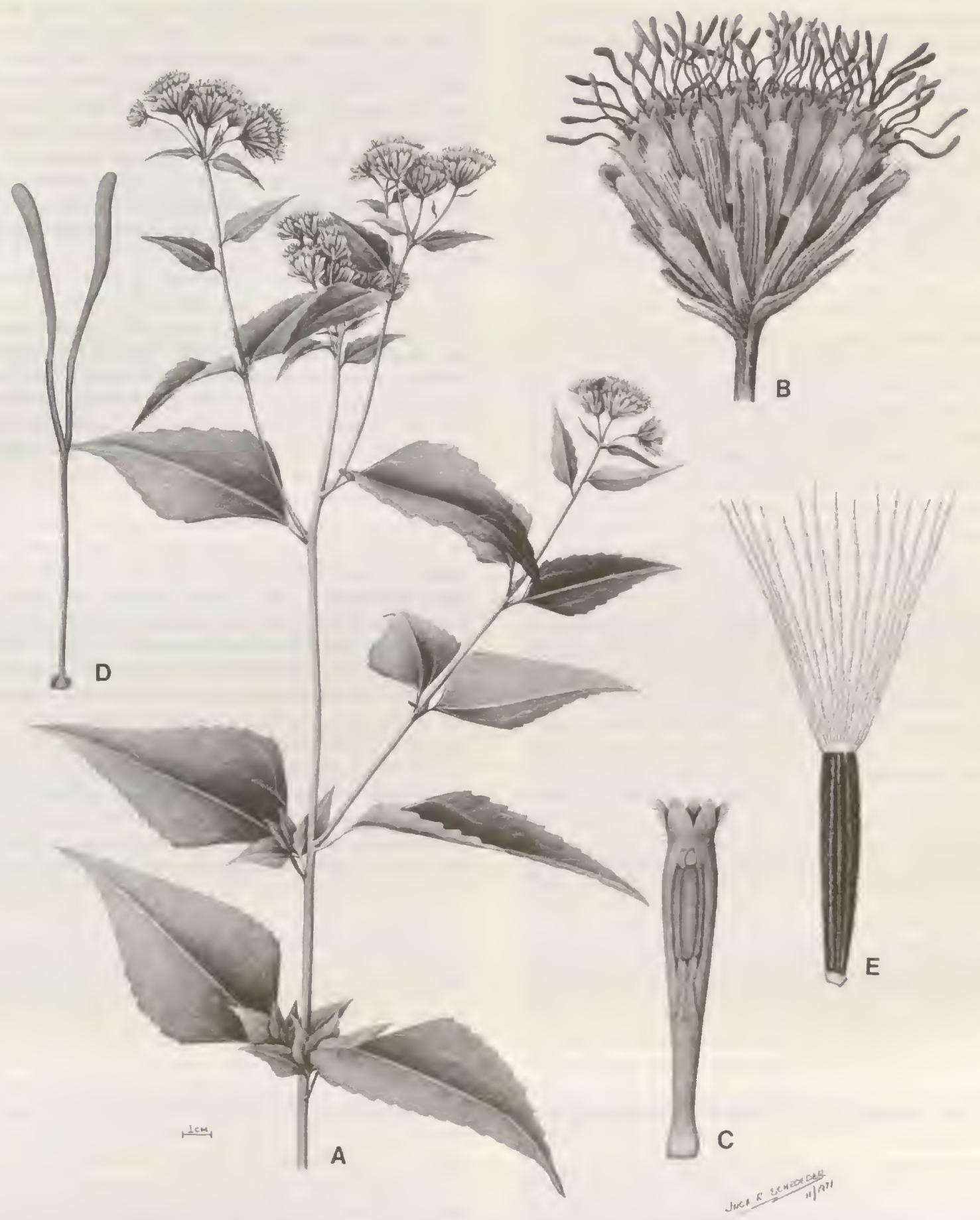

Plate 81. Brickellia cordifolia Elliott. - A. Habit, $\times 4 \% .-$ B. Head, $\times 3 .-$ C. Corolla showing anthers, $\times 9 .-D$. Style, $\times 9 .-E$. Achene, $\times 9$. 
The present concept of Brickellia seems totally monophyletic in spite of considerable diversity in habit. All the species show the ten-ribbed achenes by which they can be distinguished from related genera. The species also all have flattened outer surfaces on the pappus bristles, and a densely pubescent nodular base on the style. The flattened pappus surface occurs also in some closely related genera, and similar but usually not identical forms of pubescent style bases can be found in many other genera of the Alomiinae.

The genus has been provided with a number of generic names. The two names based on eastern North American material are Brickellia itself, honoring John Brickell of Savanna, Georgia, and Kuhnia, honoring Adam Kuhn of Pennsylvania. The names based on Mexican material include Coleosanthus, from the Greek words coleos (= sheath) and anthos (= flower), in reference to the sheathing involucre, Bulbostylis, named after the bulbous base of the style and including Coleosanthus at the time it was named, and Clavigera, honoring Francis Xavier Clavigero of Mexico. The only one of the names accompanied by a significant character difference was Kuhnia, based on a species having a plumose pappus. The name Brickellia was actually third by order of date of publication, but it is conserved.

The present concept of Brickellia contains a majority of the species placed in the genus in the classic monograph by B. Robinson (1917), but one element, Kuhnia, has been added, and some species have been transferred to other genera named during the present series of studies.

Kuhnia has usually been excluded from Brickellia, and was not synonymized until the paper by Shinners (1971). The species once placed in Kuhnia include $B$. schaffneri, $B$. leptophylla, $B$. chlorolepis, $B$. oreithales, $B$. mosieri, $B$. eupatorioides, and $B$. adenolepis, and seem to form a monophyletic group. Still, they are distinguished from typical Brickellia by a single character, the length of the lateral projections on the margins of the pappus bristles. Also, the species of Kuhnia seem to represent only part of a larger group of comparatively herbaceous species in Brickellia that Gaiser (1953) found to have only mediumlength and short chromosomes. For these reasons, we have chosen to deemphasize the pappus character, and treat all the species having ten-ribbed achenes as a single unified genus.

The species included in Brickellia by B. Robinson (1917), but excluded here, have been transferred to the related genera Asanthus, Brickelliastrum, Kyrsteniopsis, Pseudobrickellia, and Steviopsis which have been named during the present series of studies. The latter genera, many of which also contain elements from the broad traditional concept of Eupatorium, are distinguished from Brickellia by various characters such as the lack of a basal stylar node, the presence of only five ribs on the achenes, or the lack of flattened outer surfaces on the pappus bristles, and various combinations of these. Many also have the dif- ferent chromosome base number of $x=10$ and other distinctions detailed under the individual genera.

Also excluded in the present concept of Brickellia is a group of species with five-ribbed achenes and erect unbranched inflorescences that have been included in Brickellia by Harcombe and Beaman (1967) and Turner (1978). The latter species, with one other described originally in Barroetea, show a unique form of papillosity of the corolla lobes and style branches, and they are regarded here as a distinct genus, Phanerostylus, closely related to but collateral with Brickellia.

Barroetea, which has never been included in the synonymy of Brickellia, is actually more closely related, showing the same type of style base with dense contorted hairs seen in the species of Brickellia. Barroetea differs from Brickellia by the obcompressed achenes with fewer ribs, but it may represent a reversal in the latter character. As a derived element, Barroetea would impair the monophyly of Brickellia in the cladistic sense by its exclusion, but it would impair the definability of Brickellia even more by its inclusion.

In his monograph of Brickellia, B. Robinson (1917) established a number of sections, many of which have proven artificial. The section Steviastrum consists of elements of Steviopsis and Asanthus, while Gemmipedium is partly Asanthus. The sections Pityophyllum and Pseudocarphephorus are Brazilian, and are in the genus Pseudobrickellia or, in the latter case, a close relative. The genus Brickelliastrum was treated as a single species in the section Eubrickellia, and one species of Kyrsteniopsis was placed in the large section Bulbostylis. It would have seemed that $B$. Robinson could have avoided some of the confusion by a more judicious use of the form of the style base, which was shown in the included illustrations. However, careful reading shows that the stylar node and nectary were evidently not adequately distinguished, and pubescence on the node was not always properly represented.

Of the B. Robinson (1917) sections remaining in Brickellia, section Leptanthodium seems to be of most interest, containing the widely distributed annual weed, $B$. diffusa, which has a slender style form unique in the genus. It is unfortunate that the most common member of the genus in the Neotropical Region is so atypical of the genus and the subtribe. The habitally similar $B$. filipes of southwestern Mexico, that B. Robinson placed in the same section, has a more conventional Brickellia-type style branch. Gaiser (1954) has shown the two species of the section to differ from the rest of Brickellia by the tristichously rather than distichously arranged barbules on the pappus bristles. Section Macrobrickellia is rather distinctive in its one species, $B$. monocephala, having large solitary noding heads on long erect peduncles. The other sections and subsections of Brickellia established by $\mathrm{B}$. Robinson are mostly distinguished by less significant characters such as the number of flowers in the head, the presence of glands on the pedicels, or the xerophytic form 
of the plants. None of the latter characters seem to be phyletically reliable.

The genus Brickellia has a distribution concentrated in the western United States, Mexico, and Central America, with one species, $B$. diffusa, extending throughout most of the Neotropical Region. For identification of the species, the monograph by B. Robinson (1917) offers nearly complete coverage. A few species have been combined since, as indicated by King and Robinson (1977f) for P. paniculat $a$ and $B$. argyrolepis in Central America. The manner in which B. Robinson chose to have the heads of the Brickellia species illustrated in their natural moist cylindrical condition might cause some problems in comparing with dried material.

A number of species of Brickellia have been analyzed chemically. Flavonoids have been reported by Mues et al. (1979), Roberts et al. (1980), Timmermann et al. (1979), and Ulubelen et al. (1980). Brickellia contains the only significantly distinctive form of acyclic sesquiterpene lactone in the tribe, having the esterification with angelic acid at the C-5 position (H. Robinson et al., 1979).

The chromosomes of Brickellia have been studied extensively by Gaiser (1953). The number proves to be $x=$ 9 throughout the genus, but some variation in form was cited. In some species, including those of Kuhnia, there were only medium-length and short chromosomes as in Barroetea, but in most species which are shrubs or longerlived perennials, the complements include longer chromosomes.

The following 98 species are recognized in the genus:

Brickellia adenolepis (B. Robinson) Shinn., Mexico. Brickellia amplexicaulis B. Robinson, Arizona, Mexico. Brickellia arguta B. Robinson, California, Baja California. Brickellia argyrolepis B. Robinson, Mexico, Guatemala, Costa Rica.

Brickellia atractyloides A. Gray, W United States. Brickellia baccharidea A. Gray, SW United States. Brickellia betonicaefolia A. Gray, SW United States, Mexico. Brickellia botterii B. Robinson, Mexico.

Brickellia brachiata A. Gray, Mexico.

Brickellia brachyphylla A. Gray, SW United States.

Brickellia brandegei B. Robinson, Baja California.

Brickellia californica A. Gray, W United States, NW Mexico.

Brickellia cardiophylla B. Robinson, Central Mexico.

Brickellia cavanillesii (Cass.) A. Gray, Mexico.

Brickellia chenopodina (E. Greene ex Wooton \& Standley) B.

Robinson, New Mexico.

Brickellia chlorolepis (Wooten \& Standley) Shinn., W United States, Mexico.

Brickellia conduplicata B. Robinson, Mexico.

Brickellia cordifolia Elliott, SE United States.

Brickellia corymbosa (DC.) A. Gray, central Mexico.

Brickellia coulteri A. Gray, SW United States, Mexico.

Brickellia cuspidata S. Watson in A. Gray, central Mexico.

Brickellia cylindracea A. Gray \& Engelm., Texas, Mexico.

Brickellia dentata (DC.) Schultz-Bip., Mexico.

Brickellia desertorum Cov., SW United States.
Brickellia diffusa (M. Vahl) A. Gray, Mexico, Central America, Greater Antilles, Colombia, Venezuela, Ecuador, Galapagos, Peru, Bolivia, Brazil, Argentina.

Brickellia eupatorioides (L.) Shinn., E \& central United States. Brickellia extranea McVaugh, Mexico.

Brickellia flipes B. Robinson, Mexico.

Brickellia floribunda A. Gray, SW United States, Mexico.

Brickellia frutescens A. Gray, W United States, Baja California. Brickellia glabrata (Rose) B. Robinson, Baja California.

Brickellia glandulosa (Llave in Llave \& Lex.) McVaugh, Mexico, Guatemala, El Salvador, Honduras, Nicaragua.

Brickellia glomerata Fern., Mexico.

Brickellia glutinosa A. Gray, Mexico.

Brickellia grandiflora (Hook.) Nutt., central \& W United States, Baja California.

Brickellia greenei A. Gray, W United States.

Brickellia hastata Benth., Baja California.

Brickellia hebecarpa A. Gray, Mexico.

Brickellia hymenochlaena A. Gray, Mexico.

Brickellia incana A. Gray, W United States.

Brickellia jaliscensis McVaugh, Mexico.

Brickellia kellermanii Greenman, Guatemala, Honduras.

Brickellia knappiana E. C. Drew in E. Greene, California.

Brickellia laccata Flyr, Mexico.

Brickellia laciniata A. Gray, SW United States, Mexico.

Brickellia lanata (DC.) A. Gray, Mexico.

Brickellia lancifolia B. Robinson \& Greenman, Mexico.

Brickellia lemmonii A. Gray, SW United States, Mexico.

Brickellia leptophylla (Scheele) Shinn., Texas, Mexico.

Brickellia lewisii B. Turner, NW Mexico.

Brickellia longifolia S. Watson, W United States.

Brickellia macromera B. Robinson, Baja California.

Brickellia magnifica McVaugh, Mexico.

Brickellia mcdonaldii B. Turner, NE Mexico.

Brickellia megaphylla M. E. Jones ex B. Robinson in S. F. Blake, Baja California.

Brickellia microphylla (Nutt.) A. Gray, W United States.

Brickellia monocephala B. Robinson, Mexico.

Brickellia mosieri (Small) Shinn., Florida.

Brickellia multiflora V. Kellogg, W United States.

Brickellia nelsonii B. Robinson, Mexico.

Brickellia nevinii A. Gray, California.

Brickellia nutanticeps S. F. Blake, Mexico.

Brickellia oblongifolia Nutt., W United States, British Columbia.

Brickellia odontophylla A. Gray, Mexico.

Brickellia oliganthes (Less.) A. Gray, Mexico.

Brickellia oreithales (B. Robinson) Shinn., Mexico.

Brickellia orizabaensis Klatt, Mexico.

Brickellia palmeri A. Gray, Mexico.

Brickellia paniculata (Miller) B. Robinson, Mexico, Guatemala,

Nicaragua, Costa Rica.

Brickellia parryi A. Gray, Mexico.

Brickellia parvula A. Gray, Texas.

Brickellia pendula (Schrader) A. Gray, Mexico.

Brickellia peninsularis Brandegee, Baja California.

Brickellia pringlei A. Gray, Arizona, Mexico.

Brickellia reticulata (DC.) A. Gray, Mexico.

Brickellia rhomboidea E. Greene, Mexico.

Brickellia robinsoniana S. F. Blake, Mexico.

Brickellia rusbyi A. Gray, SW United States, Mexico.

Brickellia saltillensis B. Robinson, Mexico. 
Brickellia scabra (A. Gray) Nelson in J. Coulter \& Nelson, W United States.

Brickellia schaffneri (A. Gray) Shinn., Mexico.

Brickellia scoparia (DC.) A. Gray, Mexico.

Brickellia secundiflora (Lagasca) A. Gray, Mexico.

Brickellia seemannii A. Gray, Mexico.

Brickellia simplex A. Gray, Arizona, Mexico.

Brickellia spinulosa A. Gray, Mexico.

Brickellia stolonifera B. Tumer, Mexico.

Brickellia subsessilis B. Robinson, Baja California.

Brickellia tomentella A. Gray, Mexico.
Brickellia urolepis S. F. Blake, Mexico.

Brickellia venosa (Wooton \& Standley) B. Robinson, SW United States, Mexico.

Brickellia verbenacea (E. Greene) B. Robinson, Mexico.

Brickellia vernicosa B. Robinson, Mexico.

Brickellia veronicaefolia (H.B.K.) A. Gray, Texas, Mexico.

Brickellia viejensis Flyr, Texas.

Brickellia vollmeri Wiggins, Mexico.

Brickellia watsonii B. Robinson, W United States.

Brickellia wislizenii A. Gray, Mexico.

\section{Barroetea}

Barroetea A. Gray, Proc. Amer. Acad. Arts 15: 29. 1880. Type: Barroetea setosa A. Gray.

Annual or short-lived perennial herbs, with or without a woody taproot, usually unbranched below, branched in inflorescence. Stems faintly striate, slightly puberulous. Leaves opposite, sessile or short-petiolate; blades deltoid, margins serrate to dentate, with prickles on tip and on teeth. Inflorescence a loose panicle; pedicels slender, usually of moderate length. Involucral bracts ca. 20-25, subimbricate, in ca. 4 series, unequal in graduated series, spreading with age, persistent, lanceolate, mostly 4-costate; receptacle flat to convex, glabrous. Florets ca. 15-35 in a head; corollas white, tubular; cells of limb linear with straight or slightly sinuous lateral walls; lobes oblong-ovate, more than twice as long as wide, smooth on both surfaces; anther collars very slender, elongate, a few subquadrate cells below, with distinct annular thickenings on walls; anther appendages oblong, blunt, slightly longer than wide; style base enlarged, covered with contorted hairs; style branches longly clavate, surface smooth to slightly mamillose. Achenes slightly to strongly obcompressed, constricted below pappus, 4-6-ribbed, setuliferous on sides; carpopodium distinct, broad, strongly asymmetrical, with a slight but distinct upper margin, cells mostly subquadrate in 6-12 series, with walls thickened; pappus of ca. 16-30 persistent bristles, in one series, flattened on outer surface, densely pectinately fringed on lateral margins; apical cells of bristles acute. Pollen grains ca. 20-22 $\mu \mathrm{m}$ in diameter. Chromosome number $x=9$. Plate 82 .

The genus Barroetea was named by Asa Gray in honor of Gregorio Barroeta, a medical doctor and professor in San Luis Potosí, Mexico. Barroeta was a friend of the well-known collectors Parry and Palmer.

The genus is unique in the Alomiinae by the distinctly obcompressed achenes which have only four to six ribs. In other characters including the pappus, carpopodium, shape of the corolla, style base with contorted hairs, and chromosome number, the gen us is very close to Brickellia. The stylar node seems to be of the precise form seen in Brickellia, a form shared in its details by no other genus. The character of prickles or spines on the tips and teeth of the leaves in Barroetea is approached but not matched in some species of Brickellia such as B. cuspidata, $B$. atractyloides, and $B$. arguta. but the latter are shrubby or subshrubby plants sufficiently different in many details to preclude close relationship. It is possible, but by no means certain, that the unique achene form of Barroetea is derived from the cylindrical ten-ribbed form in Brickellia, but even if this could be demonstrated, it would seem unwise to lessen the definability of Brickellia by the inclusion of species with such strikingly different achenes. Gaiser (1954) has shown that in addition to the achene, Barroetea differs from Brickellia by the tetrastichously rather than distichously arranged barbules of the pappus bristles. The outer surface is flattened in both genera.
One species originally described in Barroetea, B. glutinosa, has been transferred by King and Robinson (1972q) to the genus Phanerostylis. This was, perhaps, without adequate explanation, since the species was returned to Barroetea by Turner (1978). The species, nevertheless, has precisely those characters that were given by King and Robinson for Phanerostylis, distichous pappus barbulae, flaring corollas, rather long sinuous hairs on the basal stylar node, comparatively triangular and papillose corolla lobes, and densely papillose style branches. The characters are all foreign to the genus Barroetea, especially the form of the corolla. The removal of $B$. glutinosa has the additional effect of removing the only species that had been credited to Barroetea that lacks prickles on the leaves.

The genus Barroetea is distributed in the drier parts of Mexico from Sonora and Coahuila in the north to Oaxaca in the south. A key to the species, including B. glutinosa, has been provided by B. Robinson (1911b).

The following six species are recognized in the genus:

Barroetea brevipes B. Robinson, Mexico. Barroetea laxiflora Brandegee, Mexico. Barroetea pavonii A. Gray, Mexico. Barroetea sessilifolia Greenman, Mexico. Barroetea setosa A. Gray, Mexico. Barroetea subuligera (S. Schauer) A. Gray, Mexico. 

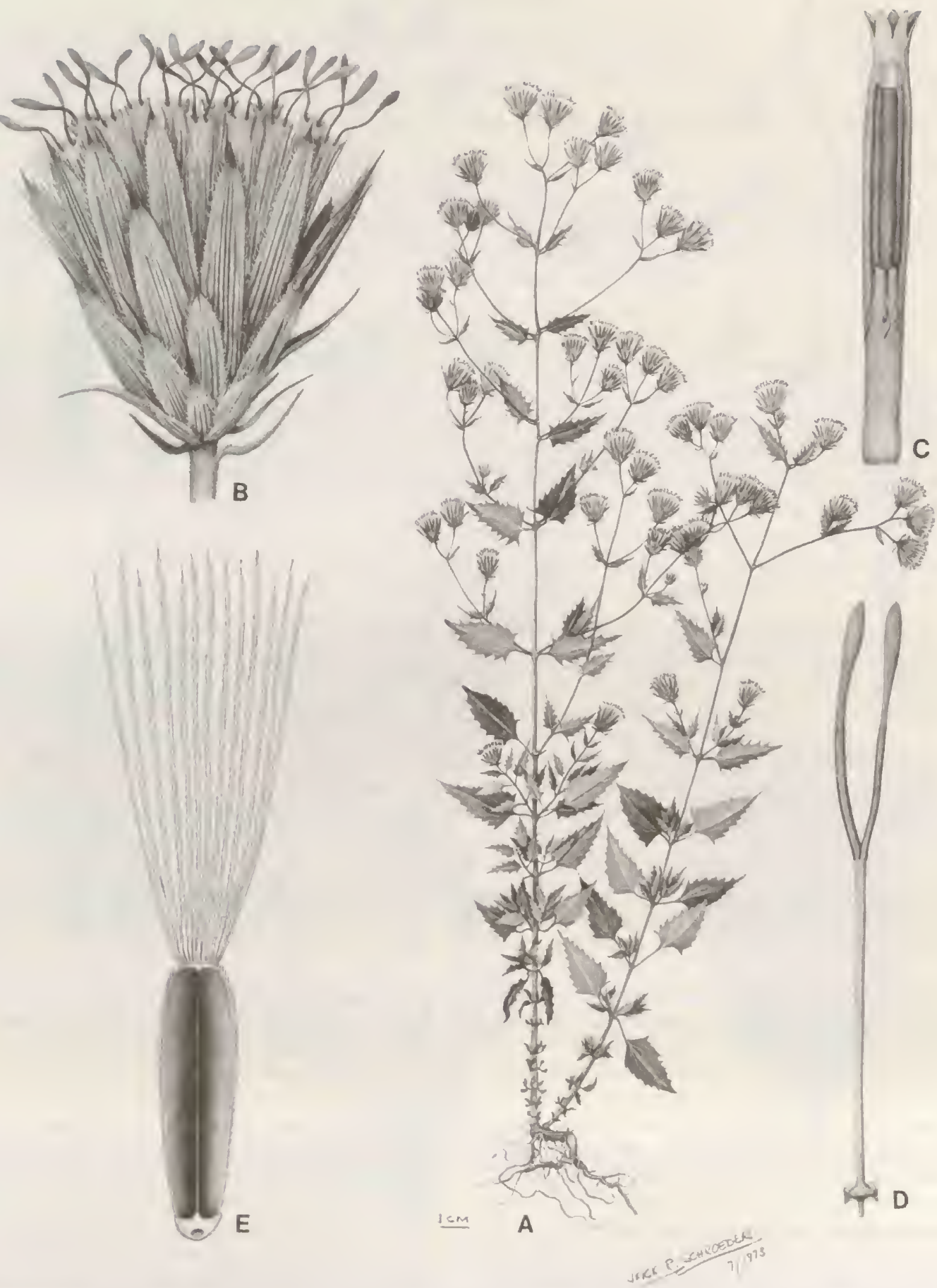

Plate 82. Barroetea setosa A. Gray. - A. Habit, $\times 4 \% .-$ B. Head, $\times 6 .-$ C. Corolla showing anthers, $\times 14 .-$ D. Style, $\times 14 .-$ E. Achene, $\times 14$. 


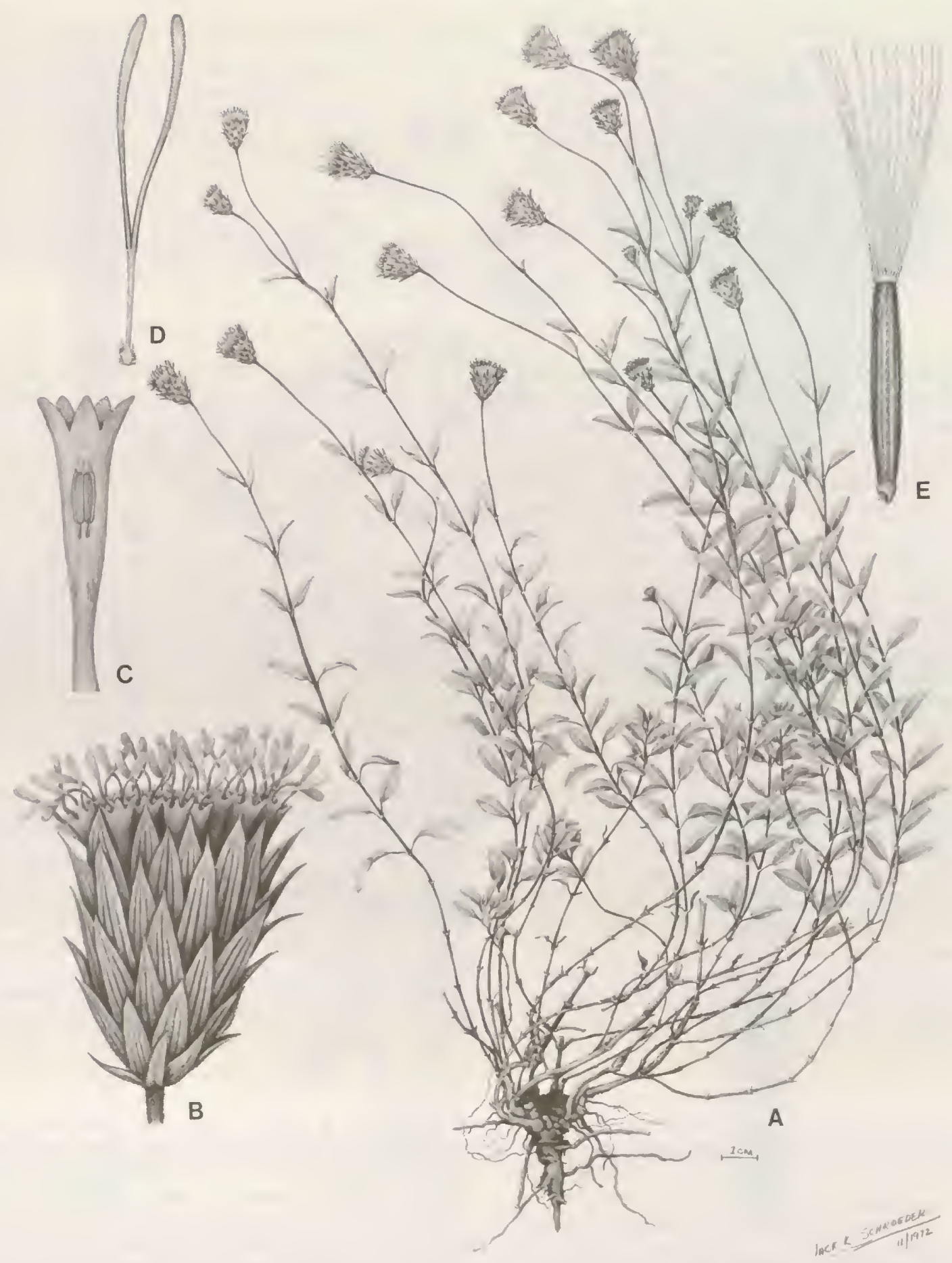

PLATE 83. Phanerostylus pedunculosus (DC.) R. King \& H. Robinson. -A. Habit, $\times 1 / 2,-$ B. Head, $\times 3 .-$ C. Corolla showing anthers, $\times 7$. D. Style with nectary, $\times 7 .-E$. Achene, $\times 6$. 


\section{Phanerostylis}

Phanerostylis (A. Gray) R. King \& H. Robinson, Phytologia 24: 70. 1972.

Eupatorium subgenus Phanerostylis A. Gray, Proc. Amer. Acad. Arts 17: 205. 1882. TYPE: Eupatorium coahuilense A. Gray.

Brickellia subgenus Phanerostylis (A. Gray) B. Turner, Brittonia 30: 343. 1978.

Erect to decumbent or rhizomatous, annual or perennial herbs, with few to many branches; stems, leaves, and involucral bracts puberulous or with small stipitate glands. Stems terete with faint striations. Leaves opposite, with distinct slender petiole; blades ovate to narrowly oblong. Inflorescence sparsely branched or with heads solitary on long erect peduncles. Involucral bracts ca. 30-50, subimbricate, in 3-7 graduated unequal series, spreading with age, persistent, oblong to lanceolate, strongly 2-4-costate; receptacle flat or slightly convex, glabrous. Florets $25-50$ in a head; corollas white or pale pink, with slender basal tube, throat funnelform; cells of throat elongate with sinuous lateral walls; lobes triangular to oblong-triangular, scarcely longer than wide to half again as long as wide, papillose on both surfaces by projecting upper ends of oblong cells; anther collars short to rather elongate, many subquadrate cells below, with distinct annular to irregular thickenings on walls; anther appendages slightly shorter to distinctly longer than wide; style base enlarged, covered with rather long and rather straight hairs; style branches longly clavate, fleshy, enlarged part densely covered with small high papillae. Achenes prismatic, 4-5-ribbed, scabrid with minute setulae on sides; carpopodium distinct, nearly symmetrical to asymmetrical, cells mostly short-oblong, in 6-20 series, walls greatly thickened; pappus of ca. 25 persistent bristles in one series, essentially smooth on outer surface, apical cells very slender; narrowly acute. Pollen grains ca. 20-22 $\mu \mathrm{m}$ in diameter. Chromosome number $x=9$. Plate 83.

Phanerostylis was originally recognized as a subgenus of Eupatorium by Asa Gray (1882), being distinguishable from Brickellia by the achenes with five rather than ten ribs. Gray named the genus after the large showy style branches. Such styles are distinct from those of most other species that have been placed in Eupatorium, but are of the shape common in Brickellia and its related genera. Still, the style branches do remain one of the most distinctive features of the genus because of the unique dense papillosity on the surface, a detail not known to Gray. Phanerostylis has the only papillose style branches in the subtribe. In living plants, it is quite possible that the papillose surfaces of the branches would provide a visible sheen lacking in other genera.

The genus Phanerostylis is evidently closely related to Brickellia, and has been placed in the latter genus in part by some recent authors (Harcombe \& Beaman, 1967; Turner, 1978) because of the chromosome number of $x=$ 9 found in both genera. The genera also share the longclavate style branches, the flattened outer surfaces and distichous barbulae of the pappus bristles, pubescent style bases of different types, and details of carpopodial structure. It is also true, as Harcombe and Beaman (1967) point out, that solitary heads on erect peduncles occur in both typical Phanerostylis and Brickellia monocephala, however, these are obviously isolated and separate specializations in their respective groups.

Phanerostylis differs from Brickellia in a number of significant features including the five-ribbed achenes that initially caused the typical species to be placed in Eupatorium, the densely papillose style branches, the prorulose papillosity of the corolla lobes, the funnelform rather than tubular throats of the corollas, and the more erect nearly straight hairs on the basal node of the style. The details of the corolla and style place the genus distinctly outside of the immediate group formed by the genera Brickellia and Barroetea.

The unique form of papillosity in the flowers of Phanerostylis is considered a particularly significant specialized character that unites the two elements of the genus, the elements previously placed in Eupatorium and Barroetea. In reversing the unification of these two elements by King and Robinson (1972q), Turner (1978) ignored the unique papillosity and emphasized instead the slightly obcompressed achenes, and the erect, annual, polycephalic nature of $P$. glutinosa, formerly placed in Barroetea, versus the rhizomatous perennial habit, totally prismatic achenes, and unbranched inflorescences of typical Phanerostylis. As is shown above, typical Phanerostylis differs fundamentally from Brickellia where it was placed by Turner (1978). The placement of $P$. glutinosa in Barroetea is also unacceptable, since the latter has more strongly obcompressed achenes, non-glanduliferous leaves and stems, prickle-tipped teeth on the leaves, tubular and non-papillose flowers, and contorted hairs on the basal stylar node. The removal of the various Phanerostylis species from the other genera in which they have been placed has the beneficial secondary effect of greatly improving the homogeneity of those genera. The resulting diversity of habit emphasized by Turner (1978), that is seen in the present concept of Phanerostylis does nothing to disprove the basic unity evident in the floral details, but does indicate some internal complexity in the evolution of the genus. 
Phanerostylis is restricted geographically to northern and central Mexico. Two of the species occur in San Luis Potosi or to the west and south, while $P$. coahuilensis occurs in northern Mexico. The distinctive $P$. glutinosa occurs to the east in Puebla.

A key to the species with unbranched inflorescences has been provided by Turner (1985).

The following five species are recognized in the genus:
Phanerostylis coahuilensis (A. Gray) R. King \& H. Robinson, Mexico.

Phanerostylis glutinosa (Brandegee) R. King \& H. Robinson, Mexico.

Phanerostylis hintoniorum (B. Turner) R. King \& H. Robinson, NE Mexico.

Phanerostylis nesomii (B. Turner) R. King \& H. Robinson, Mexico.

Phanerostylis pedunculosa (DC.) R. King \& H. Robinson, Mexico.

\section{Brickelliastrum}

\section{Brickelliastrum R. King \& H. Robinson, Phytologia 24: 63. 1972. TYPE: Brickellia fendleri A. Gray.}

Erect to decumbent subshrubs, much branched from base. Stems terete, pubescent. Lower leaves opposite, upper leaves often alternate, with distinct slender petiole; blades ovate to triangular, base subtruncate to slightly cordate, margins crenate-serrate. Inflorescence corymbose to pyramidally paniculate, with many branches; pedicels slender, usually rather short. Involucral bracts ca. 25 , subimbricate, in ca. 4 unequal graduated series, persistent, spreading with age, broadly lanceolate, strongly 2- or 4-costate; receptacle slightly convex, glabrous. Florets $25-35$ in a head; corollas white, narrowly and evenly funnelform from base; cells of limb laxly oblong with slightly sinuous lateral walls; lobes triangular-ovate, slightly longer than wide, smooth on both surfaces; anther collars rather short, slender, cells mostly elongate, with distinct annular thickenings on walls; anther appendages oblong, slightly longer than wide; style base not enlarged, glabrous; style branches very narrowly and longly clavate, slightly mamillose, nearly smooth. Achenes prismatic, mostly 5-7-ribbed, scabrous with short setulae; carpopodium distinct, shortly rounded, mostly symmetrical, cells oblong, in 3-4 series, walls thickened; pappus of ca. 25 rather deciduous scabrid bristles, slightly flattened on outer surface, with apical cells sharply acute. Pollen grains ca. 20-22 $\mu \mathrm{m}$ in diameter. Chromosome number $x=10$. Plate 84 .

The single species of Brickelliastrum, from New Mexico and western Texas; was originally described in Brickellia by Gray (1849) and was retained in that genus within the section Eubrickellia by B. Robinson (1917). In spite of this, Robinson was able to say regarding the species, “... affinitate generico dubia locum inter Brickellia et Eupatorium quasi intermedium tenens." This was in reference to the five- to seven-ribbed rather than ten-ribbed achenes. The species was one of two with primarily five- to sixribbed achenes included in Brickellia by B. Robinson, the other being the inadequately known Kyrsteniopsis cymulifera.

The habit of Brickelliastrum, the longly clavate style branches, and the cell form in the carpopodia all tend to confirm a relationship to Brickellia, but the number of differences is impressive. In addition to the ribbing of the achene, Brickelliastrum differs by the unenlarged and glabrous base of the style, the corolla that is funnelform from the base with more triangular lobes, the symmetrical carpopodium with few rows of cells, and the deciduous pappus bristles with rather irregularly scabrid outer surfaces.
According to a count by Watson (1973), the chromosome number also differs, being $n=10$.

The actual relationship of Brickelliastrum within the Alomiinae seems to be closer to Kyrsteniopsis of central Mexico. The latter is also one of the genera in the subtribe lacking any node or pubescence at the base of the style. The differences from Kyrsteniopsis include the 25-30 rather than 10-16 flowers in a head, the less tubular corollas, the more fragile pappus that is slightly more flattened on the outer surface, the anther collars having fewer distinct short cells below and having distinct transverse annular thickenings on the cell walls, the achene having only short setulae, having a strong tendency for six ribs rather than the usual five, and the shorter non-attenuate achene base with rectangular carpopodial cells in fewer rows.

The generic name is derived from the name Brickellia plus the Latin suffix -astrum indicating inferiority or an incomplete resemblance.

The following single species is recognized in the genus: Brickelliastrum fendleri (A. Gray) R. King \& H. Robinson. 


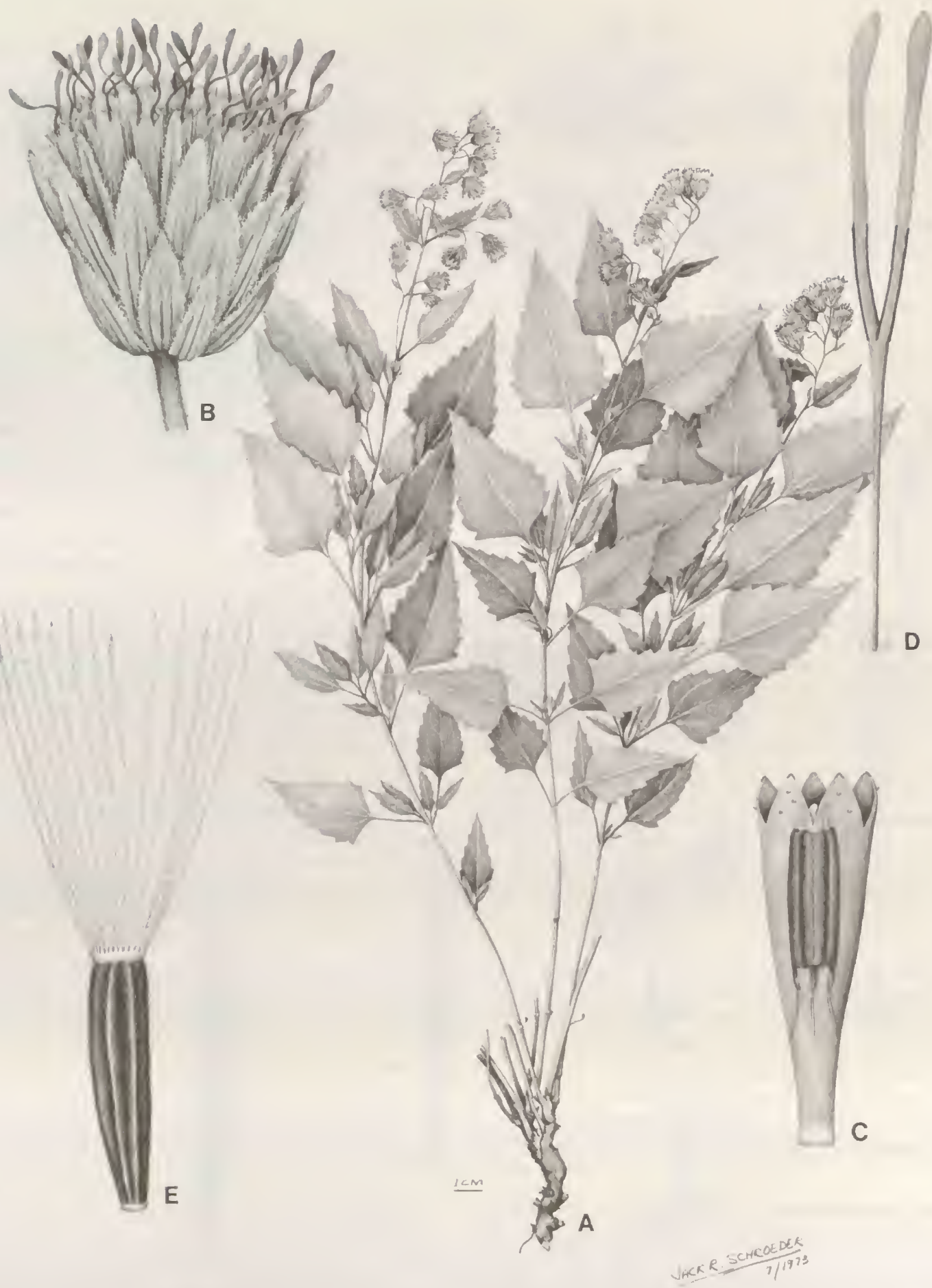

Plate 84. Brickelliastrum fendleri (A. Gray) R. King \& H. Robinson. - A. Habit, $\times 2 / 3 .-B$. Head, $\times 5$. C. Corolla showing anthers, $\times 12,-D$. Style with nectary, $\times 12 .-$ E. Achene, $\times 12$. 


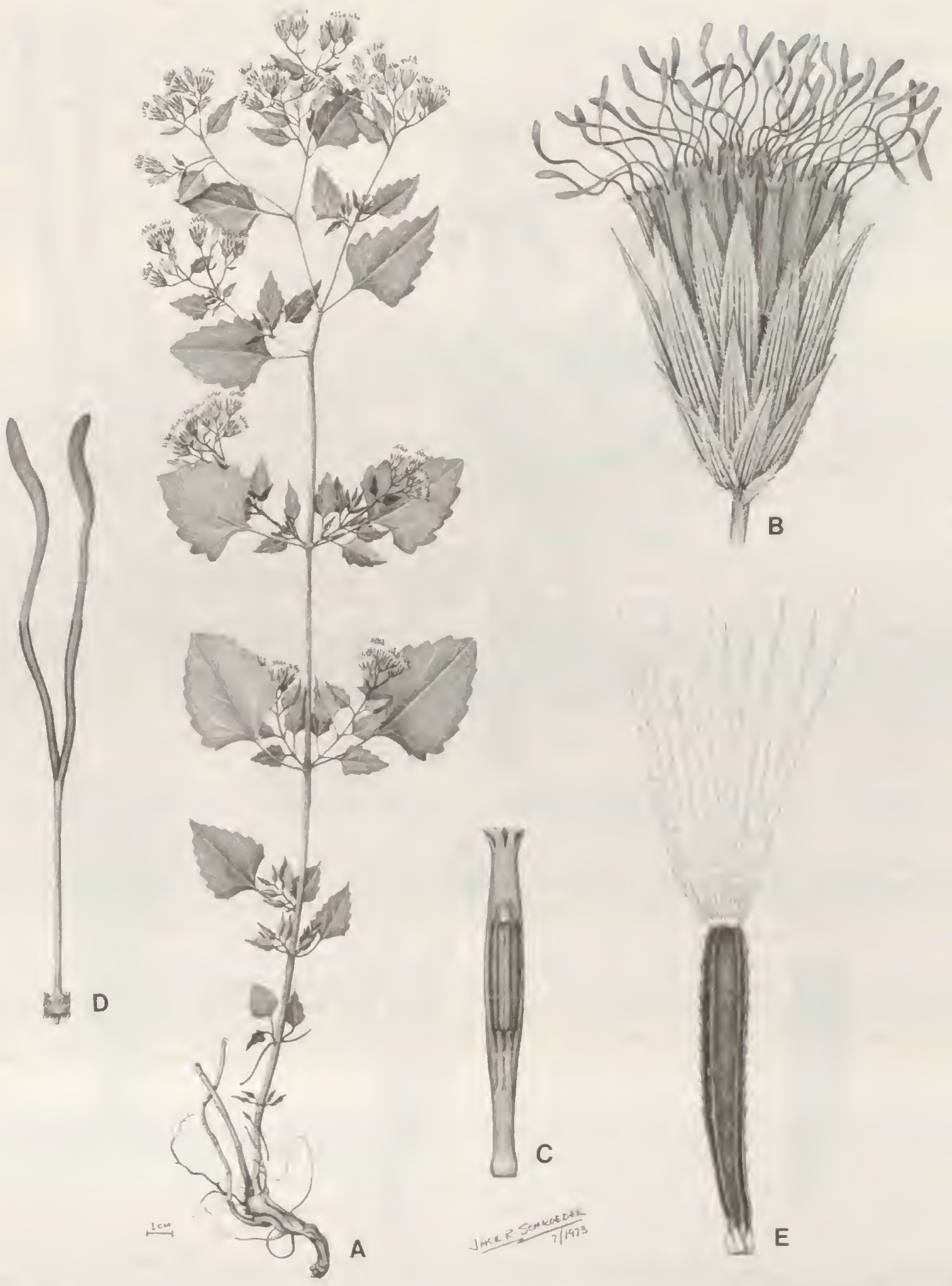

PLATE 85. Flyriella parryi (A. Gray) R. King \& H. Robinson. - A. Habit, $\times 2 / 5,-$ B. Head, $\times 5 .-$ C. Corolla showing anthers, $\times 11$, D. Style, $\times 11$. - E. Achene, $\times 11$. 


\section{Flyriella}

\section{Flyriella R. King \& H. Robinson, Phytologia 24: 67. 1972. TYPE: Eupatorium parryi A. Gray.}

Perennial herbs to subshrubs, erect or decumbent, many-branched from base, densely hirsute or stipitate glandular. Stems terete, slightly striated, sometimes fistulose (in F. harrimanii). Leaves usually opposite, sometimes alternate above, with distinct petioles, petioles sometimes winged; blades ovate to deltoid, base truncate to subcordate, margins serrate. Inflorescence a laxly branched panicle, branches laxly to densely cymose; pedicels short to moderately long. Involucral bracts ca. 30, subimbricate, in ca. 3 unequal graduated series, persistent, spreading with age, usually lanceolate (ca. 40 with enlarged foliaceous-tipped outer bracts in $F$. harrimanii); receptacle flat, glabrous. Florets usually 10-30 in a head (ca. 75 in $F$. harrimanii); corollas white, tubular to scarcely funnelform, mostly glabrous; cells of limb mostly elongate with sinuous lateral walls; lobes rather oblong-triangular, scarcely to distinctly longer than wide, smooth on both surfaces, outer surface with few glands, sometimes with short hairs; anther collars narrow, with many poorly defined subquadrate cells below, most cells with weak transverse annulations on walls; anther appendages oblongovate, slightly longer than wide; style base enlarged, densely hirsute, with hairs erect or somewhat curved, not strongly contorted; style branches longly clavate, smooth. Achenes prismatic, 5-ribbed, with setulae on sides, sometimes glabrous below; carpopodium distinct, shortly to longly cylindrical or asymmetrical with a sigmoid vascular trace; cells variously contorted, in many series, with moderately and porosely thickened walls; pappus of 20-40 capillary scabrous bristles, in one series, narrowed distally, slightly flattened and scabrid on outer surface, persistent, apical cells obtuse to acute. Pollen grains ca. $20 \mu \mathrm{m}$ in diameter. Chromosome number $x=10$. Plate 85 .

The species of Flyriella have achenes with five angles, and the four species known before 1972 were described as members of the genus Eupatorium. It was Flyr (1968) who first noted the relationship to Brickellia, and who included the type species in that genus. The genus does show the greenish, subimbricate, striated involucral bracts, and the narrow corolla with short erect lobes as in Brickellia. The genera are also alike in the longly clavate style branches and the enlarged pubescent basal node of the style, characters not mentioned by Flyr. The relationship of the type, Eupatorium parryi to other species now placed in Flyriella was apparently not recognized by Flyr.

At the time of the Flyr paper (1968), a few other species without ten-ribbed achenes had been placed in Brickellia, including species now placed in Brickelliastrum, Kyrsteniopsis, and Phanerostylis, only the first of which was noted by Flyr. The series of studies by King and Robinson (1972l, $1972 n, 1972 p, 1972 q$ ), however, has shown that all these species differ from Brickellia by combinations of characters, and often show close relationship to other species not placed in that genus. In the present case, Flyriella differs from Brickellia by the fewer ribs on the achene, the variously shaped cells of the carpopodia with thinner porose walls, the less flattened outer surfaces and irregularly scabrid margins of the pappus bristles, and by the less contorted hairs on the basal node of the style. The genus also differs in its chromosome number of $n=10$ as cited by Mabry et al. (1981) on the basis of the Turner collection of $F$. leonensis. M. Baker and Turner (1986) have noted that Flyriella, like Alomia, is mostly spring flowering, while Brickellia and its closer relatives are mostly fall flowering.

The flavonoid pattern has been studied in Flyriella par- ryi (Mabry et al., 1981) and proves to consist of four glycosides of quercetin and its $4^{\prime}$ - and 7,4'-methyl ethers. The pattern is stated to be unrelated to that observed among any of the numerous tested species of Brickellia. Limited testing of other species of Flyriella showed one or more of the same flavonoids found in $F$. parryi.

Flyriella has a distribution mostly in northern Mexico, reaching into southern Texas and west into Chihuahua. The most distinctive species, $F$. harrimanii, occurs at the southern known limit of the generic range in southern Tamaulipas. The distribution of the genus seems rather truncated in the north and may have extended farther north during warmer periods in the past.

A key has been provided for all but one of the species of Flyriella by King and Robinson (1972p). The more recently described $F$. harrimanii is a larger plant with enlarged foliaceous outer involucral bracts and about 75 flowers in a head (King \& Robinson, 1982a). M. Baker and Turner (1986) have monographed the genus, recognizing only $F$. leonensis of the several B. Robinson species.

The genus is named in honor of the late David Flyr, who first recognized the relationship of the type species to Brickellia.

The following six species are recognized in the genus: Flyriella chrysostyla (B. Robinson) R. King \& H. Robinson, Mexico.

Flyriella harrimanii R. King \& H. Robinson, Mexico.

Flyriella leonensis (B. Robinson) R. King \& H. Robinson, Mexico.

Flyriella parryi (A. Gray) R. King \& H. Robinson, Texas, Mexico. Flyriella sphenopoda (B. Robinson) R. King \& H. Robinson, Mexico.

Flyriella stanfordii R. King \& H. Robinson, Mexico. 


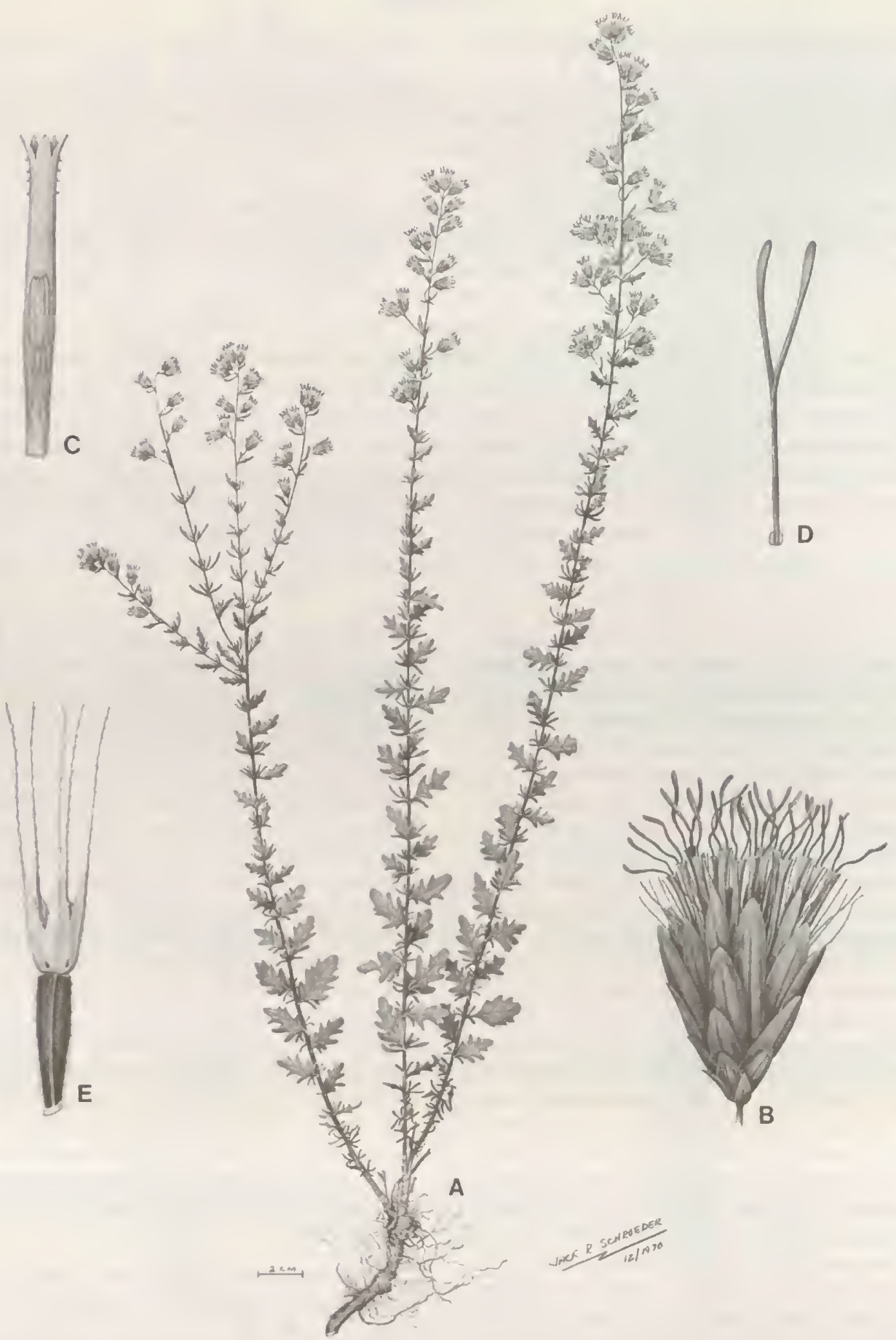

Plate 86. Ageratella palmeri (A. Gray) B. Robinson. - A. Habit, $\times 1 / 3,-B$. Head, $\times 6 \frac{1}{2},-$ C. Corolla showing anthers, $\times 15$. D. Style, $\times 5 .-$ E. Achene, $\times 15$. 


\section{Ageratella}

Ageratella A. Gray ex S. Watson, Proc. Amer. Acad. Arts 22: 419. 1887. TYPE: Ageratum microphyllum Schultz-Bip.

Erect subshrub or shrub, usually with many ascending branches. Stems terete to slightly striated, reddish brown, densely puberulous. Leaves alternate or sometimes opposite below, shortly petiolate or sessile, gradually broadened into blade; blades ovate, obovate, linear, or linear-oblanceolate, margins entire to lobed. Inflorescence a loose racemose or narrowly thyrsoid panicle; pedicels slender, usually rather short. Involucral bracts ca. 18-20, subimbricate, in 4-5 unequal graduated series, somewhat ranked, persistent, spreading with age, short-ovate to lanceolate; receptacle slightly convex, glabrous. Florets 15 in a head; corollas whitish, tubular, somewhat constricted above, with glands on outer surface on tube and lobes and especially on base of throat; cells of limb narrowly elongate with sinuous lateral walls; lobes narrowly oblong, more than twice as long as wide, smooth on both surfaces; anther collars slender, with cells mostly elongate, walls of most cells with numerous transverse annular thickenings; anther appendages about twice as wide as long; style base not enlarged, glabrous; style branches longly and narrowly clavate, with surface mamillose on lower part of appendage, becoming smoother above. Achenes prismatic, 5-ribbed, with short setulae on sides; carpopodium shortly stopper-shaped, cells minutely subquadrate in ca. 5 series, walls moderately thickened, foramen large; pappus of 4-5 persistent scabrid awns, winged below, apical cells acute. Pollen grains ca. 18$20 \mu \mathrm{m}$ in diameter. Plate 86 .

Ageratella is the only genus in the Alomiinae having a shortened anther appendage, one that is half or less as long as wide. The genus is also one of the few in the subtribe with winged awns rather than capillary bristles in the pappus. Nevertheless, in other respects, such as the greenish subimbricate involucral bracts, the tubular or upwardly narrowed corollas with small erect lobes, and the longly clavate style branches, the genus is like most other members of the subtribe. The genus is among those in the subtribe lacking a node or pubescence at the base of the style.

Material of Ageratella has at times been referred to the genera Ageratum and Stevia, apparently because of the awned pappus. Ageratella differs from both of the latter by its short anther appendages, and its tubular corollas with non-papillose short erect lobes. Ageratella differs further from Ageratum by the lack of a conical receptacle, and from Stevia by the greater number of flowers in the head and the lack of hairs inside the corolla.

Ageratella is restricted to western Mexico from Jalisco northward to Sonora. The genus is reviewed by B. Robinson (1906).

The name Ageratella is a Latin diminutive of Ageratum.

The following two species are recognized in the genus:

Ageratella microphylla (Schultz-Bip.) A. Gray ex S. Watson, Mexico.

Ageratella palmeri (A. Gray) B. Robinson, Mexico.

\section{Asanthus}

\section{Asanthus R. King \& H. Robinson, Phytologia 24: 66. 1972. TYPE: Brickellia squamulosa A. Gray.}

Erect subshrubs, with many branches. Stems terete to slightly angled, puberulous or glanduliferous, sometimes glabrescent. Lower leaves opposite, upper leaves sometimes alternate, all sessile to indistinctly shortpetiolate; blades narrowly lanceolate to linear, upper leaves sometimes reduced and scale-like, sometimes in densely imbricated axillary clusters. Inflorescence thyrsoid-paniculate with branches densely corymbose; pedicels short. Involucral bracts ca. 20-25, sometimes immediately subtended by numerous scale-like leaves, subimbricate in 4 or more strongly unequal graduated series, persistent, spreading with age, oblong; receptacle flat, glabrous. Florets $8-14$ in a head; corollas whitish, tubular and slightly constricted above to minimally funnelform, with sparse minute glands externally; cells of limb elongate with sinuous lateral walls; lobes oblong to narrowly oblong-triangular, 2-3 times as long as wide, smooth on both surfaces; anther collars cylindrical, cells short-oblong to more elongate, with dense transverse annular thickenings on walls; anther appendages oblong, slightly longer than wide or longer; style bases not enlarged, glabrous; style branches longly and narrowly clavate, slightly mamillose below, usually becoming smooth above. Achenes longprismatic, ca. 10-ribbed, ribs narrow and bearing short setulae; carpopodium shortly stopper-shaped, sym- 

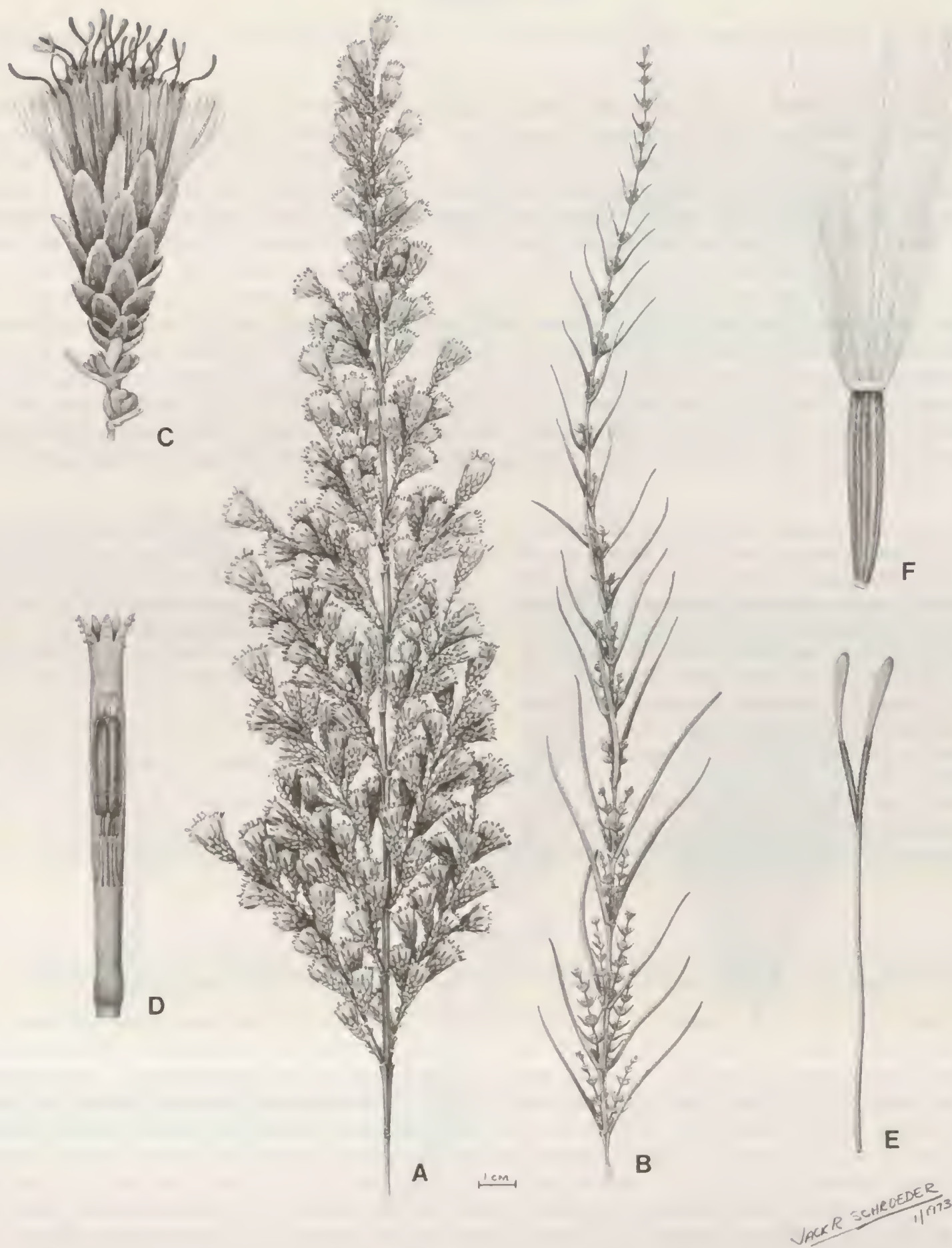

Plate 87. Asanthus squamulosus (A. Gray) R. King \& H. Robinson. - A. Habit, $\times \% \% .-B$. Habit showing primary leaves and young branches, $\times 3 \%$ - - C. Head, $\times 3 .-$ D. Corolla showing anthers, $\times 9 .-$ E. Style, $\times 9 .-$ F. Achene, $\times 9$. 
metrical, with slight upper rim, cells subquadrate to short-oblong, with moderately thickened walls; pappus of 20-100 persistent bristles in 1-3 series, scabrid on margins and outer surface, often barbellate distally, apical cells sharply acute. Pollen grains ca. $20 \mu \mathrm{m}$ in diameter. Plate 87.

The genus Asanthus has numerous features such as the greenish subimbricate involucral bracts, narrow corollas with erect or slightly spreading lobes, and longly clavate style branches that would indicate a position in the subtribe Alomiinae, possibly near the genus Brickellia with which it is sympatric. The fact that Asanthus has tenribbed achenes would initially seem to confirm such a close relationship, and it has been the reason for inclusion of the species in the genus Brickellia by Gray, B. Robinson (1917), and others. Still, Asanthus differs from Brickellia by the unenlarged and glabrous bases of the styles, the pappus bristles without flattened outer surfaces, and the carpopodia shortly stopper-shaped with small subquadrate cells. Also, the ribs are more irregularly disposed than those of Brickellia and very narrowly raised. It is the present view that Asanthus is a member of the Alomiinae, but well outside of the immediate relationship of Brickellia. It also seems probable that the ten-ribbed condition of the achenes is of separate origin from the ten-ribbed condition in Brickellia.

In relationship, Asanthus may be closest to Steviopsis, but it can be distinguished by the sessile or subsessile leaves, the presence of glands on the outer surface of the corolla lobes, the presence of four or more series of involucral bracts, the lack of glands on the achenes, the very narrow raised ribs on the achenes, and the distinct carpopodia of small moderately thick-walled cells. Asanthus also lacks the mottled reddish coloration of the stem that occurs in Steviopsis.

Asanthus is regarded as a natural group of three species, but nevertheless, is composed of two very distinctive elements.

The type species, Asanthus squamulosus, is the most distinctive member of the genus, but has a remarkable superficial resemblance to Brickellia spinulosa in the form of its scale-like leaves that has caused the two species to be placed together by B. Robinson (1917) in his section Gemmipedium of Brickellia. Both species have strobiluslike clusters of reduced leaves in the leaf axils and below the involucres. In reality, $A$. squamulosus is totally distinct in the lack of the hirsute node on the style base, the more reduced carpopodium, the narrower costae on the sparsely setuliferous achene, and the great number of $75-$ 100 fine pappus bristles in about three series without flattened outer surfaces. In all of these features except the number of pappus bristles, the type species is like the other members of Asanthus.

The remaining two species of Asanthus form a closely related pair that was placed by B. Robinson (1917) in his Brickellia section Steviastrum. The species were placed in the section with the species now known as Steviopsis vigintiseta, and the two species do resemble the members of the latter genus. The two species differ from typical Asanthus in both their lack of reduced scale-like leaves and in their lack of an extreme number of pappus bristles in two or three series. The two species are worthy of at least subgeneric distinction.

The species of Asanthus occur in northern Mexico as far south as San Luis Potosí, and the type species ranges northward into Arizona and New Mexico. The species can be distinguished by the keys in B. Robinson's (1917) monograph of Brickellia.

The genus Asanthus is named in honor of Asa Gray who was the original author of all three of the presently recognized species.

The following three species are recognized in the genus: Asanthus solidaginifolius (A. Gray) R. King \& H. Robinson, Mexico.

Asanthus squamulosus (A. Gray) R. King \& H. Robinson, SW United States, Mexico.

Asanthus thyrsiflorus (A. Gray) R. King \& H. Robinson, Mexico.

\section{Malperia}

\section{Malperia S. Watson, Proc. Amer. Acad. Arts 24: 54. 1889. TyPE: Malperia tenuis S. Watson.}

Erect annual herbs, usually many-branched from a thick tap-root. Stems terete, mostly smooth, slightly puberulous to nearly glabrous. Leaves opposite below, becoming alternate above, sessile to subsessile; blades linear, entire. Inflorescence a loose cymose panicle; pedicels slender, sometimes rather short. Involucral bracts $20-25$, subimbricate, in ca. 3 strongly unequal series, persistent, spreading with age, lanceolate; receptacle flat, glabrous. Florets ca. $20-30$ in a head; corollas white, narrowly tubular, with scattered small glands on outer surface; cells elongate with sinuous lateral walls; lobes scarcely spreading, oblong-ovate, ca 1.5 times as long as wide, smooth on both surfaces; anther collars with cells mostly elongate, with strong transverse annular thickenings on walls; anther appendages oblong-ovate, slightly longer than wide; style base not enlarged, glabrous; style branches narrowly and longly clavate, scarcely mamillose. Achenes somewhat fusiform, 5-ribbed, with spreading setulae on ribs; carpopodium somewhat asymmetrical, cells small and 
KING \& ROBINSON

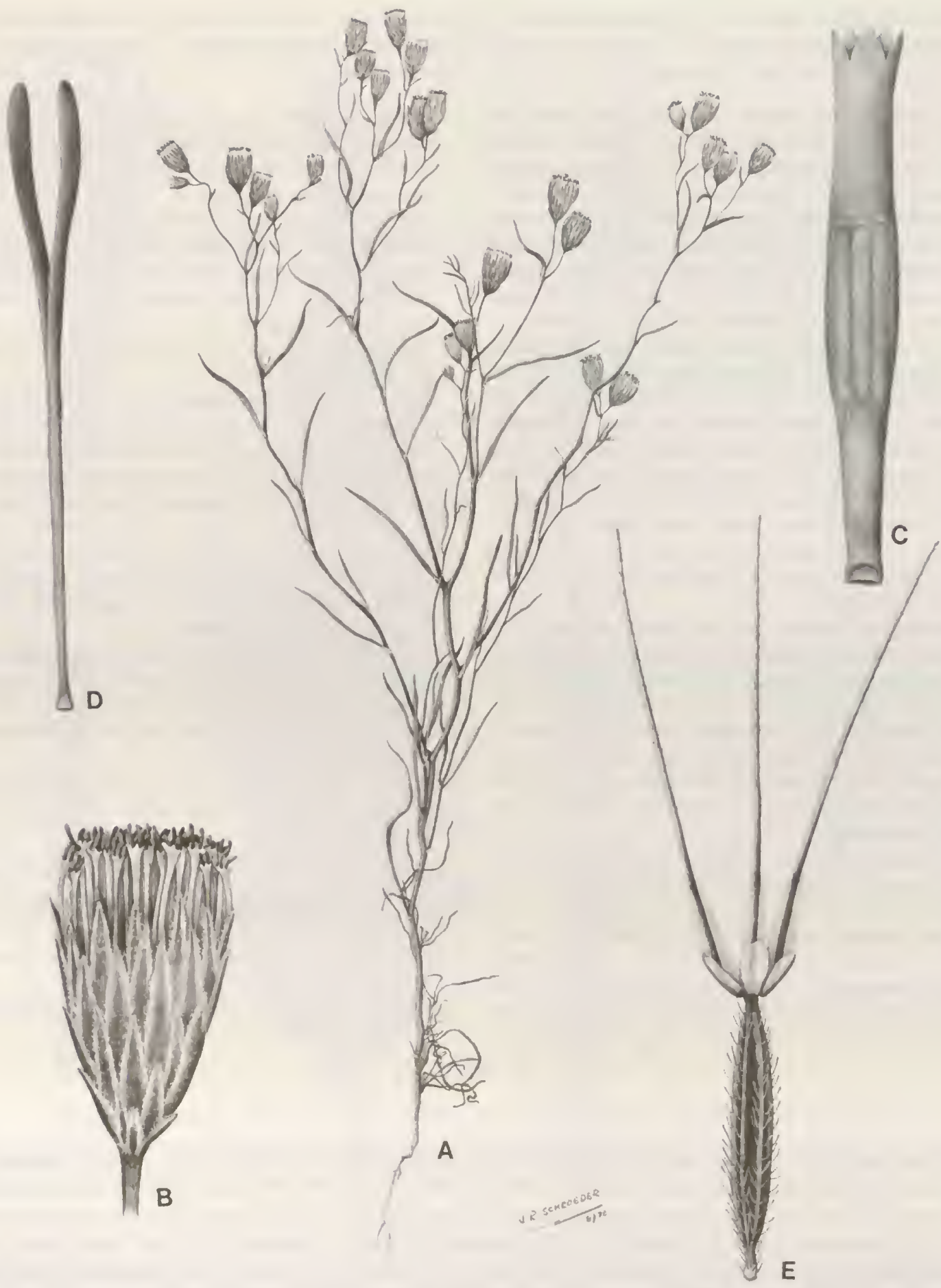

PLAtE 88. Malperia tenuis S. Watson. -A. Habit, $\times 3 \%$. B. Head, $\times 3 \frac{344}{-}-$ C. Corolla showing anthers, $\times 15 .-D$. Style, $\times 15 .-$ E. Achene, $\times 15$. 
subquadrate, with moderately thickened walls; pappus of ca. 3 long awns with minutely winged bases and intervening short squamellae, in one series, persistent, awns scabrid, becoming barbellate distally, with apical cells sharply acute. Pollen grains ca. $25 \mu \mathrm{m}$ in diameter. Chromosome number $n=10$. Plate 88 .

The genus Malperia was named by Watson to accommodate a single annual species occurring in rather dry areas in northern Baja California and in southernmost California. The generic name is an anagram formed from the name of the collector of the type material, Edward Palmer. The genus has usually been recognized as distinct, following the well-established tendency for narrower delimitation of genera of the Eupatorieae that have various non-capillary types of pappus (B. Robinson, 1913a). Nevertheless, Malperia was transferred by I. M. Johnston (1924) into an artificial concept of the genus Hofmeisteria based on a pappus with awns or bristles alternating with squamellae. The artificiality of the latter concept, and the distinction of Malperia has been discussed by King and Robinson (1966).

The actual relationship of Malperia is far from the Hoffmeisteriinae and is unquestionably in the Alomiinae. The corollas are narrowly tubular, and the style branches are longly though narrowly clavate. Also, the involucre is subimbricate and persistent, and the cells of the anther collar have weak annular thickenings on the walls. Malperia is one of the members of the subtribe having no node or pubescence on the base of the style. The pappus of alternating bristles and squamellae seems to place Malperia close to the genus Pleurocoronis, but this is called into question by the numerous differences in detail. Malperia has a rather fusiform achene with spreading setulae restricted to the ribs, while the achenes of Pleurocoronis are prismatic with more numerous less spreading setulae mostly between the ribs. The carpopodium of Pleurocoronis is of a distinctive form seen in no other genus, and the awns or bristles of the pappus are winged at the base in Malperia, unlike those of Pleurocoronis. Malperia is also distinct in the characters emphasized by B. Robinson $(1913 a)$, the sessile or subsessile linear leaves and the annual habit. The chromosome number also differs.

The genus has been reviewed by R. King (1967a).

The following single species is recognized in the genus:

Malperia tenuis S. Watson, SW United States, Mexico.

\section{Pleurocoronis}

\section{Pleurocoronis R. King \& H. Robinson, Phytologia 12: 468. 1966. TYPE: Hofmeisteria pluriseta A. Gray.}

Erect, small, usually spreading shrubs, with few to many branches. Stems terete and puberulous or often glanduliferous when young, becoming thinly corticated and whitish when older. Leaves opposite in lower portions, becoming alternate above, distinctly and narrowly petiolate; blades minutely rhomboid to broadly deltoid or cordiform in outline, slightly to deeply toothed or incised to bipinnatifid. Inflorescence with heads solitary or in lax to rather dense corymbose or subcymose panicles; pedicels slender, rather short to very long. Involucral bracts 30-35, subimbricate, in 3-4 unequal graduated series, persistent, spreading with age, outer bracts short-ovate, inner lanceolate, sharply pointed, outer bracts with small herbaceous tips; receptacle flat or slightly convex, epaleaceous, glabrous. Florets 25-30 in a head; corollas white, tubular, with scattered minute glands on outer surface; cells of limb elongate with sinuous lateral walls; lobes scarcely spreading, short-oblong, 1.5 times as long as wide, smooth on both surfaces; anther collars cylindrical, cells most elongate, with beaded or weakly annular thickenings on lateral walls; anther appendages ovate to oblong, ca. 1.5 times as long as wide; style base not enlarged, glabrous; style branches longly and sometimes rather broadly clavate, slightly mamillose. Achenes prismatic, 4-5-ribbed, with setulae on ribs and intercostal surfaces; carpopodium slightly asymmetrical, with basal foramen indistinct, cells spreading with outer surfaces ascending and elongate toward slightly projecting upper rim, with slightly thickened walls; pappus of 3-6 long scabrid to barbellate persistent bristles, with intervening short erosely dentate squamellae, apical cells of bristles sharply acute. Pollen grains ca. 16-18 $\mu \mathrm{m}$ in diameter. Chromosome number $n=9$. Plate 89 .

During the period preceding the present series of studies, when the artificiality of generic concepts in the Eupatorieae was at its maximum, there was a tendency to treat the comparatively few members of the tribe with a pappus of alternating bristles and squamellae as members of a single genus, Hofmeisteria. The concept often included the genus Malperia for which a separate generic name had already been provided, but it also included three species similarly unrelated to Hofmeisteria for which there was no name. The genus Pleurocoronis, named to include the three species, was the first of those proposed jointly by the present authors (King \& Robinson, 1966) in the initial stages of the study of the tribe. The genus was subsequently monographed by R. King (1967a). It seems ironic that the pappus form, which was once thought of as characteristic of Hofmeisteria, is a type consistently 


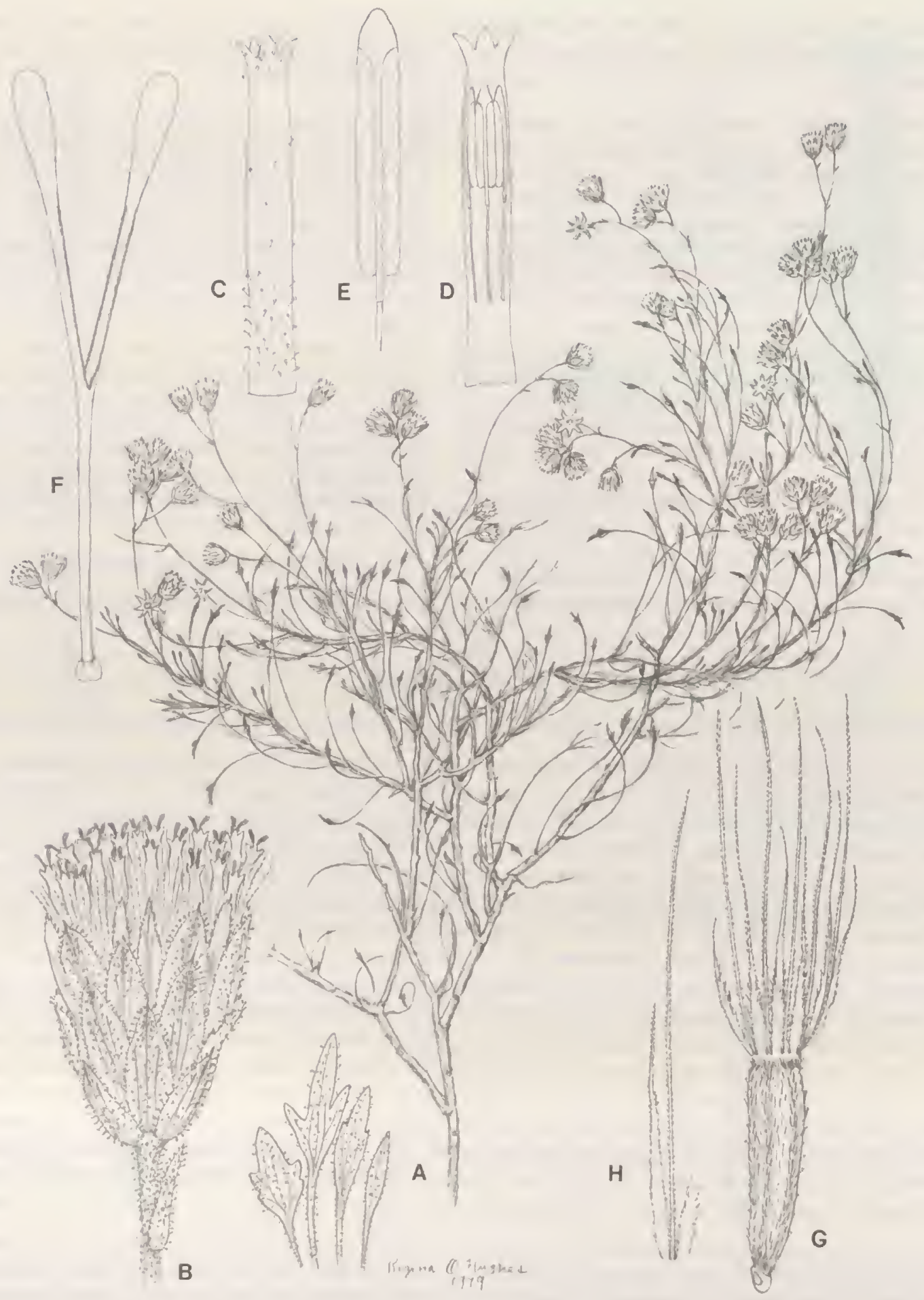

Plate 89. Pleurocoronis pluriseta (A. Gray) R. King \& H. Robinson. - A. Habit, $\times 1 / 2$, with group of separate enlarged leaf tips. B. Head, $\times 5$. - C. Corolla outer surface, $\times 12 .-$ D. Corolla inner surface with anthers, $\times 12 .-E$. Anther, $\times 30 .-F$. Style, $\times 12 .-G$. Achene, $\times 12,-H$. Segments of pappus, $\times 15$. 
present in Pleurocoronis, while the pappus of Hofmeisteria as presently understood is highly variable.

Neither Pleurocoronis nor Malperia have proven to be closely related to Hofmeisteria, in spite of the resemblance in pappus and the close geographical correlation in western Mexico and the southwestern United States. Hofmeisteria is presently placed in a distinct subtribe Hofmeisteriinae, with a chromosome base number of $x=18$ or 19. Both Pleurocoronis and Malperia show the narrowly tubular corollas and longly clavate style branches that mark them as members of the subtribe Alomiinae where they are the only two genera with squamellae in the pappus. Further details of Pleurocoronis and Malperia, however, indicate that the genera are not immediate relatives. Pleurocoronis has a prismatic rather than fusiform achene, with setulae on the sides rather than restricted to the ribs. The bases of the pappus bristles are not winged as in Malperia, and the leaves are distinctly petiolate. The carpopodium of Pleurocoronis is unique in the tribe, with no distinct foramen at the base, only a small central scar, and with the lateral cells ascending and elongate in a distinctive spreading pattern. The plants of Pleurocoronis are shrubs, while those of Malperia are evidently annuals. According to the few counts available (R. King, 1967a; R. King et al., 1976), the chromosome numbers of the two genera also differ. The position of Pleurocoronis in the subtribe is sufficiently far from the immediate rela- tionship of Brickellia to indicate that the chromosome number of $n=9$ is separately derived. Pleurocoronis does not appear to be particularly close to any other genus in the subtribe, being placeable only in the general series lacking any node or pubescence at the base of the style.

The three species of Pleurocoronis are distributed in a series, with the type species in northern Baja California northward into the United States as far as Nevada. The rather weakly differentiated $P$. laphamioides is restricted mostly to central Baja California. The most distinctive species, $P$. gentryi, with the dissected leaf blades, is restricted to the area of southern Baja California north of La Paz. A key is provided by R. King (1967a).

The name of the genus is from the Greek word pleuro (= side), and the Latinized corona (= crown), in reference to the series of squamellae in the pappus that appears to form a crown subtending the bristles of the pappus. The squamellae are actually positioned in the gaps between the bristles, and in spite of their slightly lower position, are evidently part of the same pappus series.

The following three species are recognized in the genus: Pleurocoronis gentryi (Wiggins) R. King \& H. Robinson, Baja California.

Pleurocoronis laphamioides (Rose) R. King \& H. Robinson, W Mexico.

Pleurocoronis pluriseta (A. Gray) A. King \& H. Robinson, SW United States, W Mexico.

\section{Alomia}

Alomia H.B.K., Nov. Gen. Sp., Folio ed. 4: 119. 1818. TyPE: Alomia ageratoides H.B.K.

Erect to decumbent short-lived perennial herbs, sparingly branched. Stems terete to 6-angled, puberulous to pilose, sometimes stipitate-glandular. Leaves opposite, long-petiolate, petioles sometimes narrowly winged; blades usually ovate, in upper leaves sometimes elliptical or lanceolate, with shortly cuneate to cordate bases, margins usually serrate or dentate, trinervate from near base, without immersed glandular punctations on lower surface. Inflorescence rather lax, weakly to strongly cymose paniculate; pedicels slender, short to moderately long. Involucral bracts 25-30, subimbricate, in 2-4 unequal to subequal series, persistent, spreading with age; receptacle broadly convex, without paleae, glabrous. Florets 40-50 in a head; corollas white, tubular or with narrowly campanulate throat, with minute scattered glands on outer surface; cells of throat and sometimes lobes laxly to narrowly oblong with sinuous lateral walls; lobes triangular or oblong, longer than wide, sometimes with rather short-oblong cells, smooth or nearly smooth on both surfaces; anther collars cylindrical, cells mostly elongate, with weak annular thickenings on walls; anther appendages ovate, about as long as wide; style base not enlarged, glabrous; style branches scarcely thickened to longly and narrowly clavate, slightly mamillose to densely short-papillose. Achenes prismatic, 5-ribbed, with short blunt twin-hairs shaped like glands; carpopodium appearing rather cylindrical but with sigmoid vascular trace and excentric connection to achene, cells elongate with thickened lateral walls; pappus completely absent, apical callus unarmed. Pollen grains ca. 15-20 $\mu \mathrm{m}$ in diameter. Plate 90.

The name Alomia is derived from the Greek $a$ - meaning without and loma meaning margin, referring to the lack of a pappus. The genus is also the basis for the subtribal name Alomiinae, the earliest name available for the present series of Brickellioid Eupatorieae. The present application of the names, however, has little similarity with the traditional usage. Actually, for its size, Alomia may have been the most abused concept in the Eupatorieae in the traditional systems of classification.

The genus Alomia previous to the present series of studies had come to include most Eupatorieae that possessed the combination of no pappus and a well-developed an- 


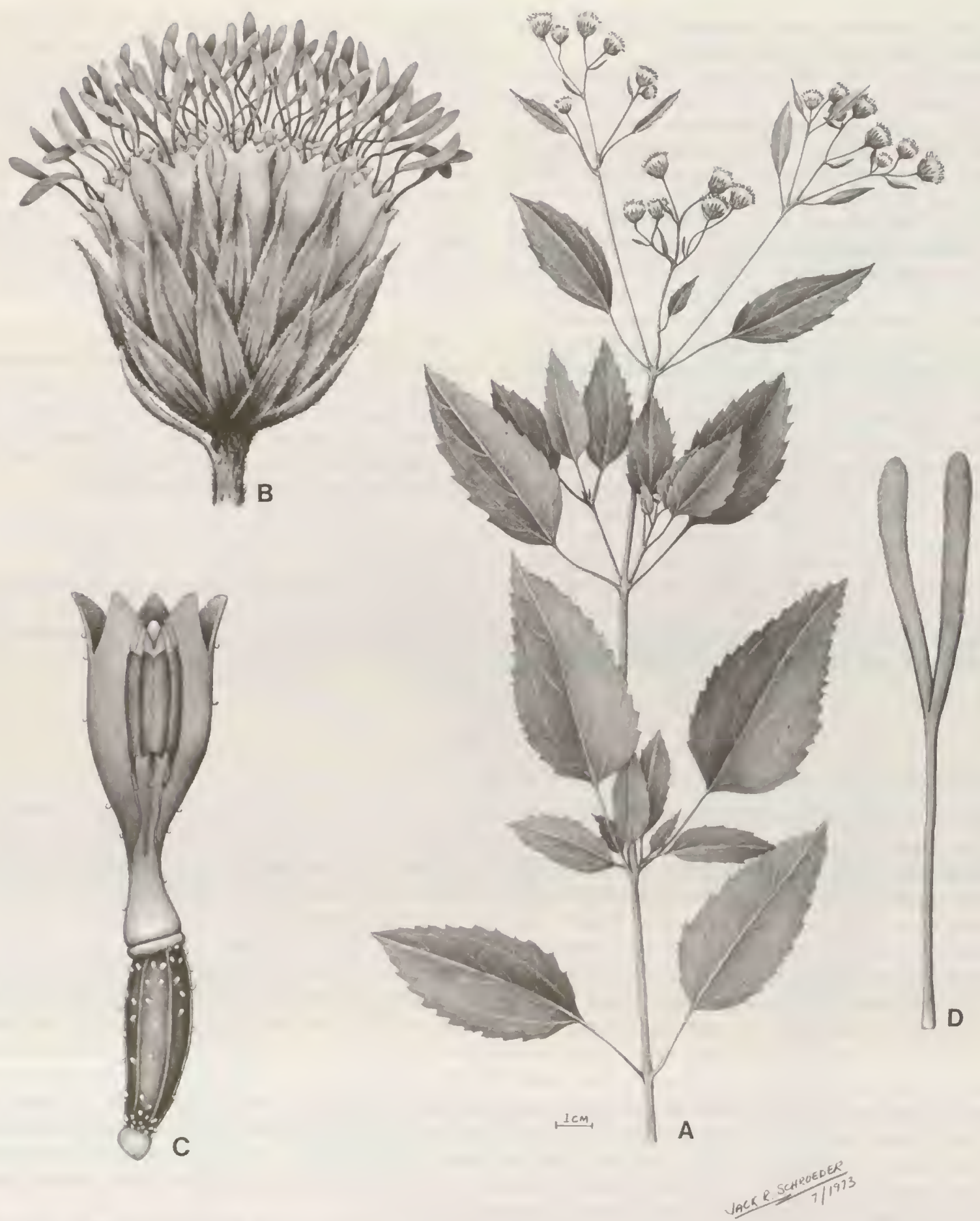

Plate 90. Alomia ageraloides H.B.K. - A. Habit, $\times 3 \% .-$ B. Head, $\times 9 .-$ C. Floret showing anthers, $\times 25 .-$ D. Style, $\times 25$.

ther appendage. At least eight distinct elements were included, none of which except the typical element are now regarded as members of the Alomiinae. The furthest departure was undoubtedly the species of Lycapsus from
San Ambrosio and San Felix Islands off the coast of Chile. The species, treated as a separate subgenus by $\mathrm{B}$. Robinson $(1913 b)$ who did not have the benefit of material, proves to be a member of the tribe Heliantheae (H. Robinson, 
1981). One large part of what was called Alomia has conical and sometimes paleaceous receptacles and large partially immersed glandular punctations on the undersides of the leaves. The latter are actually members of the genus Ageratum and are the reason why the two genera are often associated with each other in various classifications. A single Central American species has been placed in a separate genus, Blakeanthus, with a flat paleaceous receptacle and complexly pubescent leaves. Both Blakeanthus and Ageratum show firm eximbricate involucres and are placed in this treatment in the subtribe Ageratinae, although not as immediate relatives of each other. Yet another element was included in Alomia by B. Robinson (1913b) that he himself acknowledged as being epappose representatives of Trichogonia of the subtribe Gyptidinae. Other Brazilian species have proven to be the basis for segregate genera such as Teixeiranthus with its unique form of corolla fused to the top of the achene without an intervening callus, Gardnerina with short anther appendages and shallowly pinnatifid leaves, Acritopappus with a shrubby habit, paleaceous receptacles, and a chromosome base number of $x=9$, and Alomiella with a distinct basal node on the style and thickened veins in the corolla. The first three of these are presently regarded as members of the subtribe Ageratinae, while Alomiella has the unique form of carpopodium that places it in the Ayapaninae. For a more complete review of the abuses of the name Alomia, see the listing in the nomenclator accompanying the present treatment.

The present concept of Alomia is admittedly derived without direct examination of the type. Nevertheless, two Hinton collections, numbers 308 and 3509 , seem to conform in every possible detail with the illustration in the publication of Humboldt, Bonpland, and Kunth (1818) and the microfiche of the type in the herbarium in Paris. The five species included in the genus have very similar herbaceous habits, identical scarcely convex recaptacles bearing 40 to 50 flowers, and essentially identical epap- pose achenes with small peg-like twin-hairs on the surface. In spite of the uniformity, two distinctive subgroups can be detected in the genus. The typical element, including $A$. ageratoides and $A$. hintonii, from the area of northern Guerrero, Morelos, and the state of Mexico, has campanulate throats of the corollas, narrower papillose style branches, and more subequal involucral bracts. The atypical element was designated by B. Robinson $(1913 b)$ as the subgenus Geissanthodium, meaning "protected flowers" in reference to the subimbricated involucre. The group shows more tubular flowers with broader style branches. The atypical group includes $A$. alata from the same area as the typical element, $A$. callosa from Jalisco, and $A$. stenolepis from southern Sonora. It is the latter group that betrays the relationship to other members of the Brickellia series. The typical element, but for its clear relationship in achene and receptacle structure, would not be recognized as a part of the Brickellia group. It is, nevertheless, this element that typifies the subtribal name that now applies to the entire group.

The genus Alomia, as presently delimited, is restricted to central and western Mexico in the Sierra Madre Occidental and western parts of the Sierra Madre de Sur. The monograph by B. Robinson $(1913 b)$ provides keys and descriptions to the genus in its broad and artificial concept. The monograph, as such, includes many presently excluded species, and also excludes two species described more recently. A key to the five presently recognized species has been provided by King and Robinson $(1972 w)$.

The following five species are recognized in the genus:

Alomia ageratoides H.B.K., Mexico.

Alomia alata Hemsl., Mexico.

Alomia callosa (S. Watson) B. Robinson, Mexico.

Alomia hintonii R. King \& H. Robinson, Mexico.

Alomia stenolepis S. F. Blake, Mexico.

\section{Dyscritogyne}

Dyscritogyne R. King \& H. Robinson, Phytologia 22: 158. 1971. TYPE: Eupatorium adenospermum SchultzBip.

Erect perennial herbs, sparingly branched. Stems terete, striated, puberulous. Leaves opposite to alternate, with very short petioles; blades broadly to narrowly ovate, base broadly acute to subtruncate, margins subserrulate to serrate, apices acute, trinervate from or near base, with minute glandular dots mostly on undersurface. Inflorescence a loose pyramidal or corymbose panicle; pedicels usually slender, short to moderately long. Involucral bracts ca. 33-40, subimbricate, in ca. 4-6 strongly unequal graduated series, mostly persistent, spreading when dry, with rounded tips, mostly greenish with 4 costae on outer surface, mostly glabrous; receptacle flat to slightly convex, glabrous. Florets 11-16 in a head; corollas white or pink, tubular, with scattered minute glands on outer surface, with sparse hairs inside near base of throat in $D$. adenosperma; cells of limb laxly oblong with somewhat sinuous lateral walls; lobes ovate-triangular, scarcely longer than wide, smooth on both surfaces; anther collars cylindrical or narrow below, with many subquadrate or shorter cells in basal part, walls with transverse or vertical intricate thickenings; anther appendages oblong to ovate, 


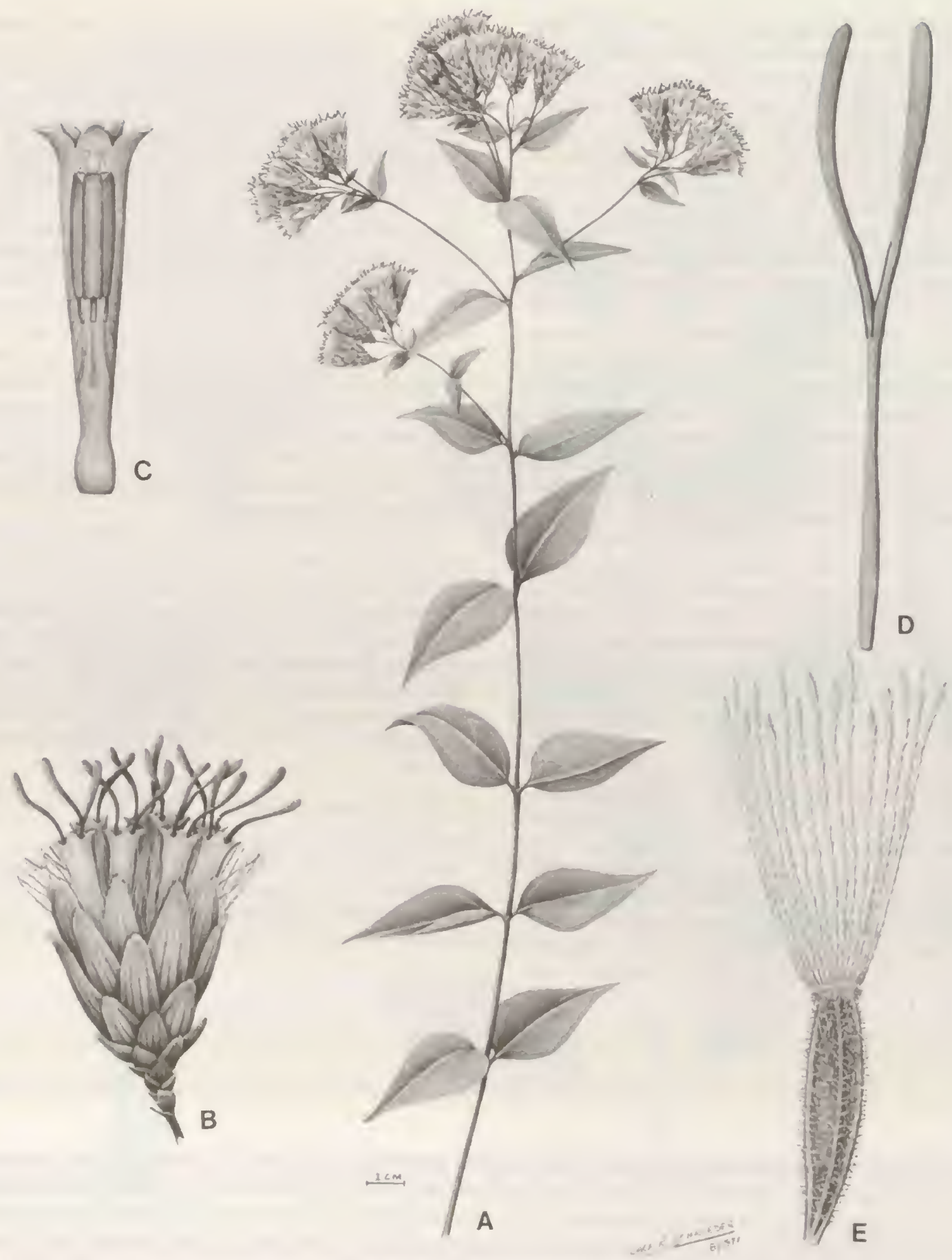

Plate 91. Dy'scritogyne adenospermum (Schultz-Bip.) R. King \& H. Robinson. - A. Habit, $\times 5 \%$. - B. Head, $\times 31 / 2 .-C$. Corolla showing anthers, $\times 15 .-D$. Style, $\times 15 .-$ E. Achene, $\times 15$.

about as long as wide; style base not enlarged, glabrous or with a few minute papillae; style branches longly clavate or strap-shaped, fleshy, nearly smooth. Achenes prismatic to rather fusiform, 4-5-ribbed, densely punctate- or stipitate-glandular on sides, stipes of stipitate glands with somewhat thickened walls; carpopodium indistinct, at most a few rows of small cells with unthickened walls; pappus of ca. 35-40 persistent 
bristles in 1-2 series, irregularly scabrid on margins and outer surface, apex not or slightly broadened, apical cells acute. Pollen grains ca. $25 \mu \mathrm{m}$ in diameter. Plate 91 .

The genus Dyscritogyne was named after the distinctive or discrete form of its gynoecial parts, the achenes and style branches. The achenes are notable for the extremely dense glandular pubescence, and the style branches are perhaps the broadest of any member of the Eupatorieae in Mexico.

At the time the genus was first described by King and Robinson (1971ee), a proper understanding of the Brickellia relationship had not yet been achieved. Dyscritogyne with Steviopsis was thought to represent an extreme element within the Mexican Critoniinae, distinguished by the broad style branches. It was later that the tubular corollas and broad style branches of Dyscritogyne and some other seemingly isolated genera in Mexico were recognized as indicative of the broad subtribal group including both Brickellia and Alomia. Even so, Dyscritogyne is somewhat unusual in the group by its broader corollas and more triangular corolla lobes, the partially deciduous inner involucral bracts, the more strap-shaped and blunt style branches with a thickened vein near the tip, and the numerous short cells in the base of the anther collar with often vertical thickenings on the walls. The genus is distinct from its closest potential relative, Steviopsis, by the densely glanduliferous achenes and by the multiseriate involucre with round-tipped bracts, among other characters. The carpopodium of Dyscritogyne seems to be characteristically poorly differentiated.

The genus is distributed in oakwoods in the Sierra Madre de Sur of Mexico from the states of Guerrero and Mexico in the east to Jalisco in the west. The two species are sufficiently similar in aspect to have been misidentified with each other on a few occasions. Still, the species are clearly distinguished by a number of characters. Dyscritogyne adenosperma to the east has more narrowly ovate leaves, more fusiform achenes with stipitate glands, and corollas with hairs on the inner surface near the insertions of the filaments. The more western species, $D$. dryophila. has more prismatic achenes with essentially sessile glands, broadly ovate leaves with rather truncate bases, and corollas without hairs inside. Label data indicates that $A$. dryophila also differs by having pink or lavender flowers.

The following two species are recognized in the genus:

Dyscritogyne adenosperma (Schultz-Bip.) R. King \& H. Robinson, Mexico.

Dyscritogyne dryophila (B. Robinson) R. King \& H. Robinson, Mexico.

\section{Kyrsteniopsis}

\section{Kyrsteniopsis R. King \& H. Robinson, Phytologia 22: 146. 1971. TYPE: Eupatorium nelsonii B. Robinson.}

Erect subshrubs or shrubs, moderately branched. Stems terete, puberulous to tomentellous, becoming glabrous. Leaves opposite, with slender petioles; blades ovate to deltoid, with cordate or subcordate bases, margins entire to dentate, trinervate from base, with numerous glandular punctations on lower surface. Inflorescence a lax leafy thyrsoid panicle, with laxly to densely corymbose branches; pedicels usually short, puberulous to tomentellous. Involucral bracts green, sometimes tinged with red, 20-25, subimbricate, in ca. 4 strongly unequal graduated series, persistent, spreading when dry, chartaceous, oblong, obtuse to shortacute, 3-4-striate on outer surface; receptacle slightly convex, glabrous. Florets 9-16 in a head; corollas greenish white, narrowly tubular to minimally funnelform, with glands on outer surface of tube and lobes; cells of limb elongate, mostly with sinuous lateral walls; lobes ovate-triangular, slightly longer than wide, slightly spreading, smooth on both surfaces; anther collars narrowly cylindrical, with few subquadrate cells below, longer cells above, cell walls not ornamented; anther appendages oblong to ovate, slightly longer than wide; style base not enlarged, glabrous; style branches linear to scarcely longly clavate, rounded on outer surface, scarcely or not mamillose. Achenes prismatic, 5-ribbed, with setulae mostly on ribs, often with stipitate glands on and between ribs, stipes of stipitate glands with somewhat thickened cell walls; carpopodium distinct, without projecting upper edge, cells short-oblong to subquadrate in $3-5$ series, with partially thickened rather collenchymatous walls; pappus of 25-45 scabrid persistent bristles in 1 series, apical cells acute. Pollen grains 20-25 $\mu \mathrm{m}$ in diameter. Plate 92.

Kyrsteniopsis was described by King and Robinson $(1971 a a)$ on the basis of numerous technical differences, especially in the achenes, but with an incomplete understanding of the relationships. Primary comparisons were made to the genera Koanophyllon of the Critoninae and
Steviopsis which was then also regarded as a possible member of the Critonia relationship. Less than a year later (King \& Robinson, 1972l), both Kyrsteniopsis and Steviopsis were recognized as relatives of Alomia and Brickellia, and both genera were shown to contain some 


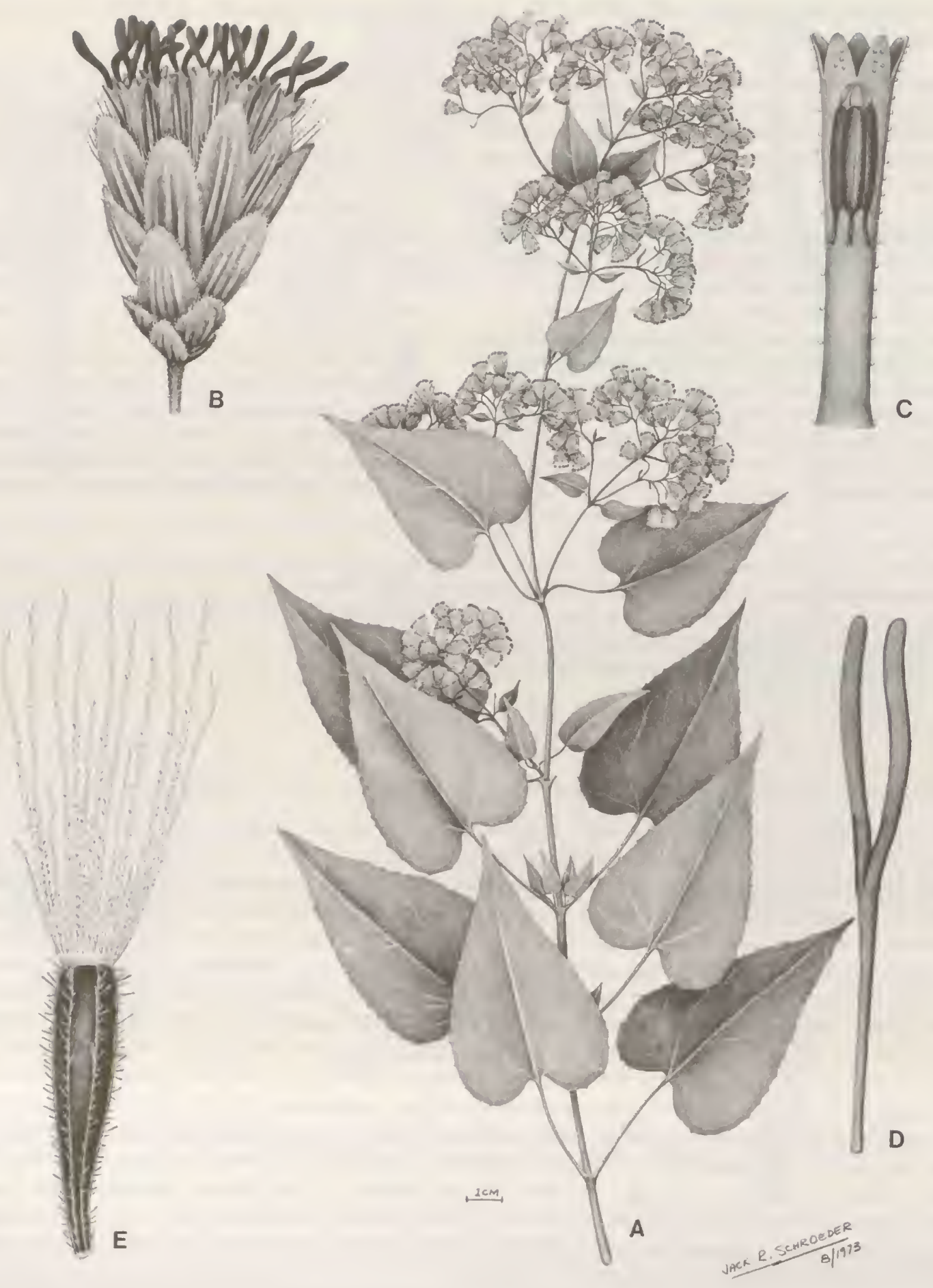

Plate 92. Kyrsteniopsis nelsonii (B. Robinson) R. King \& H. Robinson. - A. Habit, $\times \%$. B. Head, $\times 6 .-$ C. Corolla showing anthers, $\times 17 .-D$. Style, $\times 17 .-E$. Achene, $\times 17$. 
species that had been described in Eupatorium and others described in Brickellia. Kyrsteniopsis does resemble Koanophyllon of the Critoniinae in the shape of its leaves and in the slightly deciduous nature of some of its inner involucral bracts. Also, the corollas have more spreading lobes and the style branches are narrower than in most Alomiinae, but the tubular corollas are thoroughly distinct from the characteristically flaring and broadly lobed type seen in Koanophyllon.

Within the Alomiinae, Kyrsteniopsis does not seem to be immediately related to Steviopsis which differs by its eximbricate to weakly subimbricate pointed involucral bracts and glabrous more narrowly lobed corollas. In habit, Kyrsteniopsis is closer to Brickelliastrum of the southwestern United States and Pseudokyrsteniopsis of Guatemala and Chiapas, but differs from both in the more prominent corolla lobes and narrower style branches. The present genus also tends to have fewer flowers in the head, especially in comparison with Brickelliastrum. The achenes of Kyrsteniopsis seem to be rather unique in the large often thin-walled epidermal cells in which the more sclerotized bases of the setulae and glands are imbedded.

Kyrsteniopsis is one of the genera of the Alomiinae that has been credited with yellowish flowers in label data. The corollas actually seem to be rather greenish, with the yel- lowish appearance being from pollen on the style branches.

The four species of Kyrsteniopsis occur in the area of central Mexico extending from the states of Veracruz and San Luis Potosí in the north to Guerrero and Oaxaca in the south. A key to the species has been provided by King and Robinson (1972l). The two more northern species, $K$. cymulifera and $K$. dibollii, seem to differ from the others by having achenes with many stipitate glands and having a pappus with more bristles.

The name Kyrsteniopsis is derived from the earlier name Kyrstenia which is a synonym of Ageratina. The name was used for the present genus mostly because the authors wished to reclaim something for modern usage from the older Necker name. There is some habital resemblance between Kyrsteniopsis and some species of Ageratina of the subtribe Oxylobinae, but there is no close relationship.

The following four species are recognized in the genus:

Kyrsteniopsis congesta R. King \& H. Robinson, Mexico. Kyrsteniopsis cymulifera (B. Robinson) R. King \& H. Robinson, Mexico.

Kyrsteniopsis dibollii R. King \& H. Robinson, Mexico. Kyrsteniopsis nelsonii (B. Robinson) R. King \& H. Robinson, Mexico.

\section{Pseudokyrsteniopsis}

Pseudokyrsteniopsis R. King \& H. Robinson, Phytologia 27: 241. 1973. TYPE: Pseudokyrsteniopsis perpetiolata R. King \& H. Robinson.

Erect or arching subshrubs or shrubs, moderately branched. Stems terete, scarcely striated, sparsely hirsute and minutely stipitate-glandular. Leaves opposite, petioles long, inflated at base and encircling node; blades broadly deltoid, strongly hastate, usually with recessed trinervate base, margins denticulate, with minute mostly stipitate glands on surfaces. Inflorescence a lax pyramidal panicle with usually densely corymbose branchlets; branches spreading at wide angles or right angles; pedicels slender, usually short. Involucral bracts green, sometime reddish tinged, ca. 20, subimbricate, in ca. 3-4 strongly unequal graduated series, persistent, spreading or reflexed with age or drying, lanceolate to linear, narrowly acute to slightly acuminate; receptacle flat, glabrous. Florets $13-18$ in a head; corollas cream-white, tubular, constricted above, mostly glabrous on outer surface, a few minute glands on lobes; cells of limb elongate with mostly sinuous lateral walls; lobes small, suboblong, 1.5 times as long as wide, erect to scarcely spreading, smooth on both surfaces; anther collars with a few subquadrate cells below, longer cells above, cell walls with weak annular thickenings; anther appendages oblong-ovate, ca. 1.5 times as long as wide; style base not enlarged, glabrous; style branches longly and narrowly clavate, scarcely mamillose, smooth distally, rounded on outer surface. Achenes prismatic, 5-ribbed, base sometimes attenuate, with numerous setulae on sides; carpopodium short and rounded, cells subquadrate in 5-6 series, with strongly thickened walls; pappus of ca. 30 scabrid subpersistent bristles in 1 series, not or scarcely contiguous at base, slightly broadened distally, apical cells sharply acute. Pollen grains ca. $20 \mu \mathrm{m}$ in diameter. Plate 93.

The genus Pseudokyrsteniopsis contains a single known species occurring in Guatemala and the adjacent Mexican state of Chiapas. The genus has a greenish subimbricate involucre, tubular corollas, somewhat broadened style branches, and a yellowish appearance from pollen on the style branches, which are characteristics of the subtribe
Alomiinae. The genus is among the members of that subtribe having an unenlarged and glabrous style base.

Pseudokyrsteniopsis is named after the genus Kyrsteniopsis of central Mexico, also a member of the Alomiinae. The two genera are somewhat similar in habit, and both have distinctly petiolate leaves with somewhat cordate 


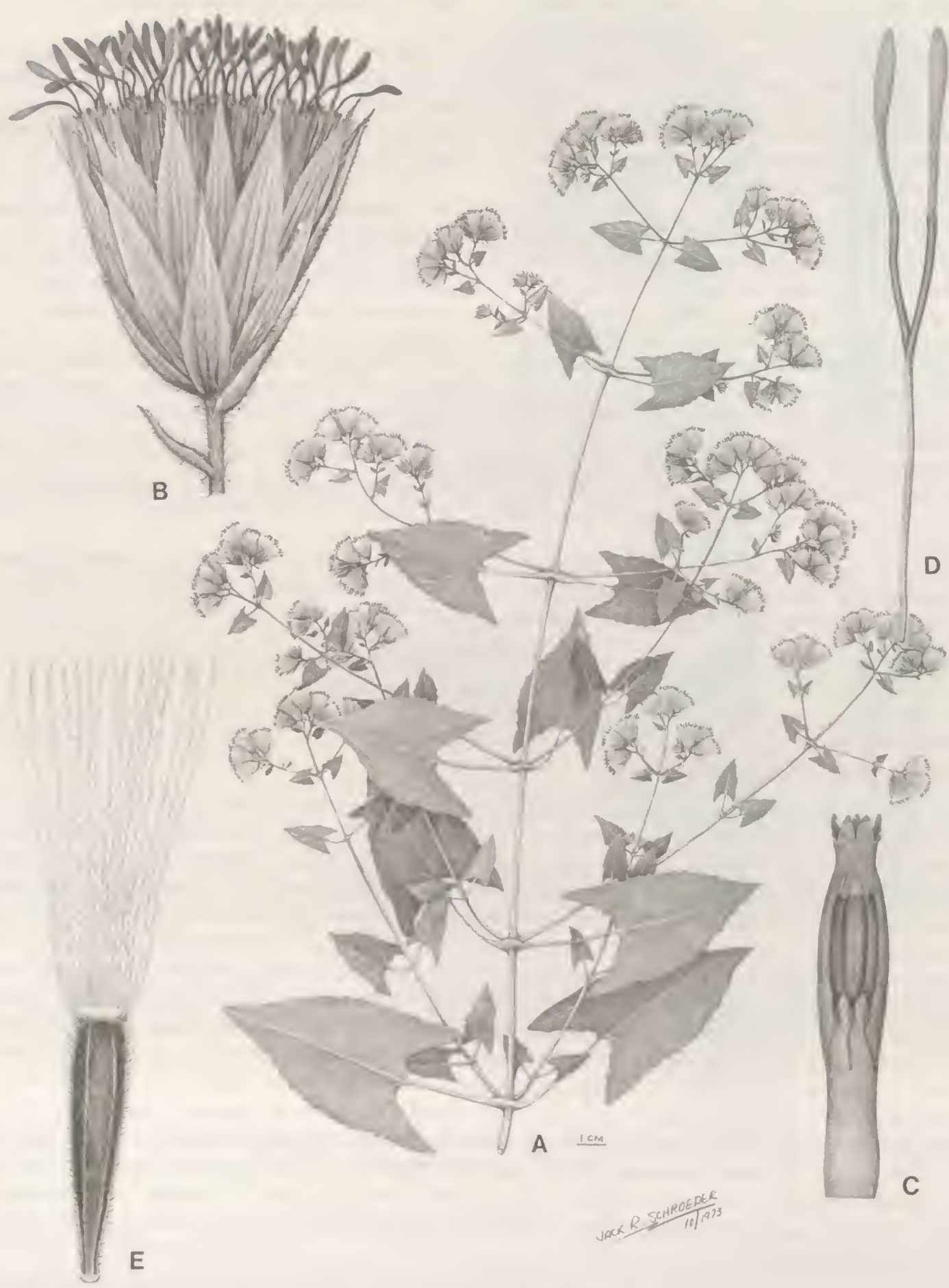

Plate 93. Pseudokyrsteniopsis perpetiolata R. King \& H. Robinson. - A. Habit, $\times 2 / 5 .-$ B. Head, $\times 6$. - C. Corolla showing anthers, $\times 15 .-D$. Siyle, $\times 15,-$ E. Achene, $\times 15$. 
bases on the blades. The closeness of relationship is questionable, however, because of some of the more Critonioid features of Kyrsteniopsis, the broader corollas which vary toward funnelform, the larger and slightly spreading corolla lobes, the linear style branches, and the blunt-tipped involucral bracts with some inner bracts somewhat deciduous. In addition, the pappus bristles are narrower and carpopodia different. Kyrsteniopsis also has more ascending branches in the inflorescence, while the branches of the inflorescence in Pseudokyrsteniopsis spread at very wide angles, sometimes at right angles.

The unique feature of Pseudokyrsteniopsis after which the species is named is the enlargement of the petiole base.
The bases of the adjacent petioles surround the stem. The character is not matched in any other mem ber of the tribe, and when well-developed is an immediate means for identifying the genus.

Subsequent to its description, the species of Pseudokyrsteniopsis has been transferred to Eupatorium by Williams (1975), in a study considered as anachronistic by the present authors.

The following single species is recognized in the genus:

Pseudokyrsteniopsis perpetiolata R. King \& H. Robinson, Mexico, Guatemala.

\section{Steviopsis}

\section{Steviopsis R. King \& H. Robinson, Phytologia 22: 156. 1971. TYPE: Stevia rapunculoïdes DC.}

Erect coarse herbs, sparingly branched or with numerous axillary fascicles. Stems often with mottled reddish color, terete, striated when dry, becoming glabrous below. Leaves usually opposite or verticillate, alternate above, shortly petiolate; blades ovate to narrowly lanceolate, bases acute, margins serrulate, apices narrowly acute to acuminate, trinervate from near base or in narrower leaves essentially pinnate, surfaces scabridulous and without glandular punctations in three species, pilosulous and with glands below in $S$. vigintiseta. Inflorescence a loose often leafy pyramidal or corymbose panicle, branches ascending; pedicels usually short. Involucral bracts green, 20-30, eximbricate to weakly subimbricate, in ca. 2-3 series, persistent, spreading with age, with some shorter exterior bracts, apices obtuse to acute, faintly costate on outer surface; receptacle slightly convex, glabrous. Florets $15-20$ in a head; corollas greyish pink to purplish, tubular to narrowly funnelform, glabrous on outer surface; cells of limb elongate, often with sinuous lateral walls; lobes longly triangular, 1.2-2 times longer than wide, spreading, smooth on both surfaces; anther collars broadly cylindrical, with subquadrate cells near base, longer cells above, cell walls ornamented with dense annular or intricate thickenings; an ther appendages oblong, slightly longer than wide; style base not enlarged, glabrous; style branches longly and narrowly clavate, fleshy, somewhat flattened, slightly mamillose to smooth. Achenes prismatic, 5-10-ribbed, densely to sparsely setuliferous on sides, with few to many short-stalked glands; carpopodium indistinct, cells small and subquadrate, in many series, with walls not or slightly sclerified; pappus of ca. 25-30 often coarse scabrid persistent bristles in 1 series, not flattened or smooth on outer surface, apices not broadened, apical cells acute. Pollen grains ca. 23-25 $\mu \mathrm{m}$ in diameter. Plate 94.

The three genera, Steviopsis, Dyscritogyne, and Kyrsteniopsis, were described in an early stage of the present series of studies (King \& Robinson, 1971aa, 1971dd. 1971 ee) before the development of a proper concept of the Brickellia relationship that is now treated as the subtribe Alomiinae. The genera did not have either the traditional features of Brickellia or the pubescent node at the base of the style that the present authors associated at that time with Brickellia and its immediate relatives (King \& Robinson, 1966). The three genera were dimly perceived as related to each other, but as an element on the fringe of the group now treated as the subtribe Critoniinae. Only one species was placed in Steviopsis. Almost simultaneously, McVaugh (1972) transferred the same species from Eupatorium to the genus Brickellia, pointing out the similarity to at least one species, $B . a m$ blyolepis, that had been placed in the latter genus by $B$. Robinson $(1901,1917)$. Later in the same year the genus
Steviopsis was revised by King and Robinson (1972m), proving, as in the case of Kyrsteniopsis, to include species that had been described in both Eupatorium and Brick. ellia. The relationship was recognized as being in the Brickellia group at that time.

In spite of the various precedents, including comments by Asa Gray dating back to 1887 (McVaugh, 1972), the relationship of Steviopsis to Brickellia is rather remote within the subtribe. The broader and often narrowly funnelform corollas and the reddish flowers are both unusual in the Alomiinae, and the weakly subimbricate to eximbricate involucres found in three of the species are totally uncharacteristic of the group. Even the broadened style branches of Steviopsis are unlike most members of the subtribe in their details, being most like those of Dyscritogyne. Some of the problems, however, seem to be the result of specializations within the genus, such as the less imbricated involucre. There also may be results of some 


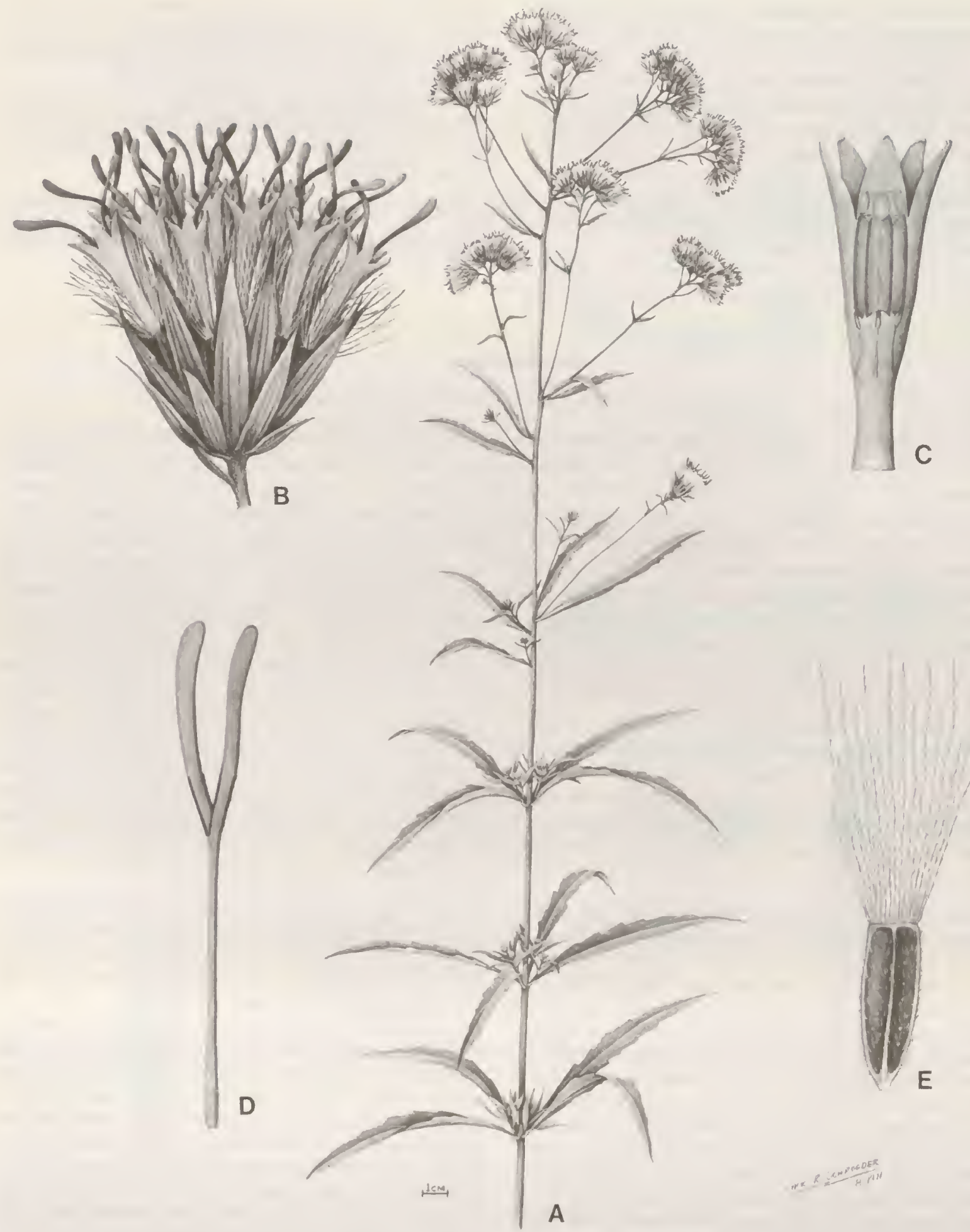

PLATE 94. Steviopsis rapunculoides (DC.) R. King \& H. Robinson, - A. Habit, $\times 2 / s .-$ B. Head, $\times 4 .-$ C. Corolla showing anthers,
$\times 10 .-$ D. Style, $\times 10 .-$ E. Achene, $\times 10$. 
intersubtribal hybridization of the type that is believed to rarely but significantly affect the overall evolution of the Eupatorieae (see introduction) and other Asteraceous tribes such as the Heliantheae (H. Robinson, 1981). The sum of all characters of Steviopsis continues to indicate a position in the Alomiinae close to Dyscritogyne and possibly Asanthus.

A factor in the description of members of Steviopsis in both Eupatorium and Brickellia is a variation in the number of ribs on the achene in different species. The higher number of $S$. amblyolepis and $S$. vigintiseta might reflect a closer relationship within the subtribe to the genus $A S$ anthus. In this respect, it is of interest that $S$. vigintiseta was included by B. Robinson (1917) in his Brickellia section Steviastrum with the two species now placed in the atypical element of Asanthus. As in the case of Asanthus, the higher number of achene ribs does not seem to indicate close relationship to Brickellia.

Steviopsis is rather distinctive in the Alomiinae by the above mentioned eximbricate or weakly subimbricate involucral bracts. A more significant unifying character, however, seems to be the often funnelform glabrous corollas with rather long triangular somewhat spreading lobes.
There is a tendency in the genus for whorled leaves on the main stems, but the character is not as significant as thought before the expansion of the generic concept.

The genus Steviopsis occurs in Mexico in the Sierra Madre de Sur, ranging from Jalisco in the west to Oaxaca in the east. A key to the species is provided by King and Robinson (1972m).

The generic name is derived from that of Stevia which the species somewhat resemble habitally. There is no close relationship between the two genera, Stevia being a member of the subtribe Ageratinae close to Piqueria. Nevertheless, the habital resemblance seems to have been sufficient to inspire independently both the names Steviopsis and Brickellia section Steviastrum which have been applied to members of the genus.

The following four species are recognized in the genus: Steviopsis amblyolepis (B. Robinson) R. King \& H. Robinson, Mexico.

Steviopsis arsenei R. King \& H. Robinson, Mexico.

Steviopsis rapunculoides (DC.) R. King \& H. Robinson, Mexico. Steviopsis vigintiseta (DC.) R. King \& H. Robinson, Mexico.

\section{Carminatia}

\section{Carminatia Mociño ex DC., Prodr. 7: 267. 1838. TyPE: Carminatia tenuiflora DC.}

Erect annual herbs, unbranched or sparingly branched from base. Stems terete to subquadrangular, striated, puberulence often in lines, sometimes pilose. Leaves opposite, petioles long and slender; blades deltoid to broadly ovate, base truncate or cordate, margins dentate, trinervate from base, without glands on surface. Inflorescence spiciform in aspect, with heads single or clustered at nodes along spike, sessile or on short lateral branchlets, rarely on longer lateral branch. Involucral bracts greenish or tinged with red, ca. 20, subimbricate in ca. 3 strongly unequal series, persistent, spreading with age, lanceolate to linear, sharply acute; receptacle flat, glabrous. Florets ca. $10-11$ in a head; corollas white, rather tubular, either slightly broader or slightly narrower above, glabrous on outer surface or with a few minute glands above, veins greatly thickened toward base; cells of limb short-oblong, those of throat with distinctly sinuous lateral walls; lobes triangular-ovate to oblong-ovate, slightly shorter or slightly longer than wide, smooth on both surfaces; anther collars slender, cells subquadrate below, oblong above, with weak annular thickenings on walls; anther appendages slightly longer than wide; style base not enlarged, glabrous; style branches narrowly linear to scarcely long-clavate, surface slightly mamillose. Achenes prismatic, 5-ribbed, minutely spiculiferous, spicules consisting of 4 small cells in 2 series, more minute apical pair of cells often somewhat sclerified; carpopodium strongly differentiated, of many greatly enlarged narrow cells in 1 series, cell walls thickened; pappus of ca. 9-13 bristles, often deciduous in groups with narrowly fused bases, flattened on outer surface, plumose by extremely long hairs on lateral margins, apical cells cute. Pollen grains ca. 20-25 $\mu \mathrm{m}$ in diameter. Chromosome number $x=10$. Plate 95 .

The genus Carminatia was introduced by DeCandolle (1838) and stated to have affinity to Liatris and Kuhnia. undoubtedly on the basis of the plumose bristles of the pappus. The genus was distinguished by the rather racemose inflorescence with narrow few-flowered heads, resulting in a habital resemblance to the Mutisian genus Ainsliaea. The genus also differed from Liatris and typical Kuhnia $(=$ Brickellia $)$ by the achenes with five angles.
With one recent exception, the genus Carminatia has been consistently recognized by all subsequent authors.

Carminatia has the involucral form and narrow corollas with smooth lobes that are regarded as characteristic of the subtribe Alomiinae. The narrow style branches do seem anomalous in the subtribe, but in some specimens the branches are slightly long-clavate. Although plumose pappus bristles were the basis of DeCandolle's original 

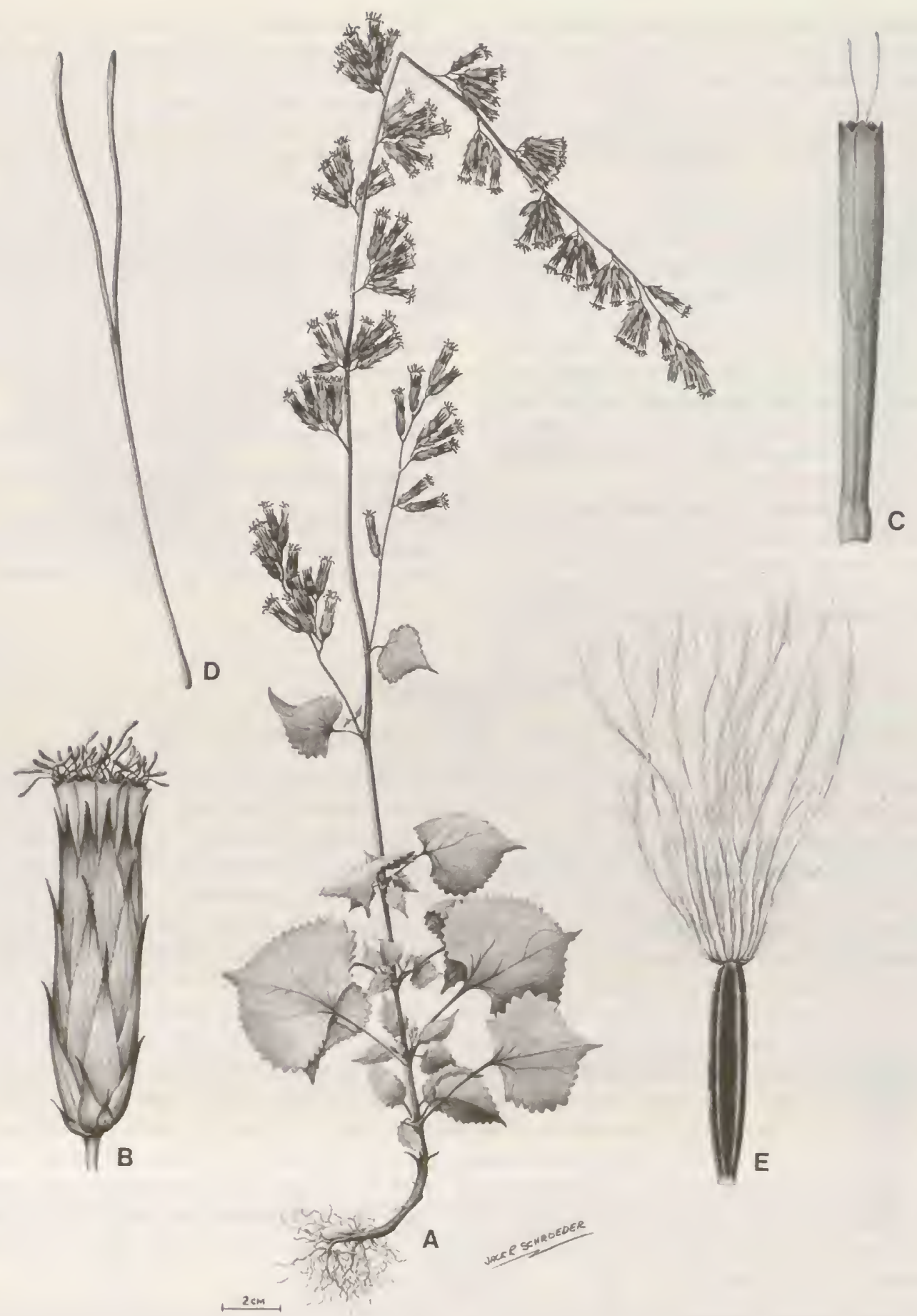

Plate 95. Carminatia tenuiflora DC. - A. Habit, $\times 2 / 3 .-$ B. Head, $\times 3 .-$ C. Corolla showing anthers and style branches, $\times 7 .-$ D. Style, $\times 7 .-$ E. Achene, $\times 7$.

comparison with the Kuhnia element of Brickellia, the detailed structure of the pappus does not support close relationship between the two. The pappus in Carminatia has a more tapering central axis with broader bases often narrowly fused to each other. The bristles, which differ by being rather deciduous, are often shed in groups or as a unit because of the narrow basal fusion. The lateral hairs of the bristles are also longer than those of any of the other 
genera with a plumose pappus, resulting in the soft appearance first mentioned by DeCandolle (1838). The genus is also distinct by many other characters including the abruptly differentiated row of carpopodial cells, the thickened veins of the corolla, and the shorter more regularly oblong cells of the corolla. From Brickellia, the genus is distinct by the unornamented style base and the fewer ribs on the achene.

It seems of interest that Carminatia is placed next to another genus of the Alomiinae, Helogyne, in the generic key by $\mathrm{B}$. Robinson (1913a). The latter genus also sometimes has a plumose pappus. Both genera are notable for the frequent presence of a vascular strand in the pappus bristles. Helogyne is not closely related to Carminatia, however, being a South American genus with a shrubby rather than annual habit, and lacking many details such as the highly differentiated single cell row of the carpopodium and the thickened veins of the corolla.

The only exception to the recognition of Carminatia as a distinct genus was the treatment by Keil and Pinkava (1976). The latter authors placed Carminatia in Brickellia, citing a chromosome number of $n=9$ in both genera, and noting that various concepts of Brickellia allowed for a plumose pappus, simple style bases, and a five-angled achene. Many of the structural features were inadequately examined, and various generic refinements were rejected. Keil and Pinkava (1977) reversed their opinion on the status of Carminatia after reviewing the characters and after their chromosome report was shown to be in error.

The genus Carminatia contains two known species, the second being described by McVaugh (1972) who provided a key. The type species occurs primarily in the interior uplands of western Mexico, ranging from southern Arizona south to the cape of Baja California and Jalisco and east to Hidalgo and Guerrero. Carminatia recondita is apparently a plant of the Pacific slope of western Mexico mostly at elevations between 400 and $1,500 \mathrm{~m}$ from southern Nayarit to Michoacán. The latter seems to occur as a disjunct in Oaxaca and Chiapas (McVaugh, 1972).

The genus is said by DeCandolle (1838) to be named in honor of "cl. Carminati qui de materia medica bene meruit."

The following two species are recognized in the genus:

Carminatia recondila $\mathrm{McV}$ augh, Mexico.

Carminatia tenuiflora DC., Arizona, Mexico.

\section{Dissothrix}

\section{Dissothrix A. Gray, Hooker's J. Bot. Kew Gard. Misc. 3: 223. 1851. TYPE: Dissothrix gardneri [= Dissothrix imbricata (Gardner) B. Robinson].}

Erect annual herbs, branching only in inflorescence. Stems terete, striated, puberulous. Leaves opposite, short-petiolate; blades ovate-lanceolate, bases cuneate, margins serrate, weakly trinervate from above base, without glandular punctations. Inflorescence a loose leafy thyrsoid panicle with cymose branches; pedicels slender, rather short. Involucral bracts ca. 15, subimbricate, in ca. 3 unequal graduated series, persistent, spreading with age, short-ovate to lanceolate, apices acute; receptacle flat, glabrous. Florets 6-8 in a head; corollas whitish, tubular, somewhat constricted above, glands dense at tips of lobes, very sparse elsewhere on outer surface, veins distinctly thickened below; cells of limb elongate, often with sinuous lateral walls; lobes narrowly oblong, about twice as long as wide, smooth on both surfaces; anther collars slender, with cells mostly elongate, a few subquadrate cells basally, cell walls with numerous transverse annular thickenings; anther appendages longer than wide; style base enlarged, with numerous thin-walled hairs; style branches with long narrow mamillose bases on appendages, with broad elongate clavate smooth tips. Achenes prismatic, 5-ribbed, with short setulae on and between ribs; carpopodium stopper-shaped with slight but distinct upper rim, cells oblong, moderate-sized, in ca. 5 series, with thickened walls; pappus of persistent scabrid bristles in 1 series with two distinct types, ca. 5 longer thicker bristles above ribs of achene, ca. 18 shorter narrower unequal bristles distributed above areas between ribs, apical cells of longer bristles obtuse, apical cells of others mostly short-acute. Pollen grains ca. $23 \mu \mathrm{m}$ in diameter. Plate 96.

The genus Dissothrix was established by Asa Gray (1851) to include the single species previously described as Stevia imbricata by Gardner (1846). In noting the obvious fact that the species was not a Stevia, Gray emphasized the truly setose pappus, the minutely five-toothed and connivent limb of the corolla, and the biserial, imbricated involucre. In passing, Gray also noted that the involucral bracts were thin, smooth, and strongly two-nerved "in the manner of Brickellia, \&c." Whether intended to imply close relationship or not, the latter comparison proved accurate, as evidenced by the broadened style branches and the enlarged pubescent style base shown in the illustration in the Flora Brasiliensis (J. Baker, 1876). Dissothrix proves to be one of many genera of the Alomiinae in South America, most of whose species have not previously been recognized as relatives of the primarily North American and Mexican genus Brickellia.

Dissothrix does not fall into the immediate relationship 


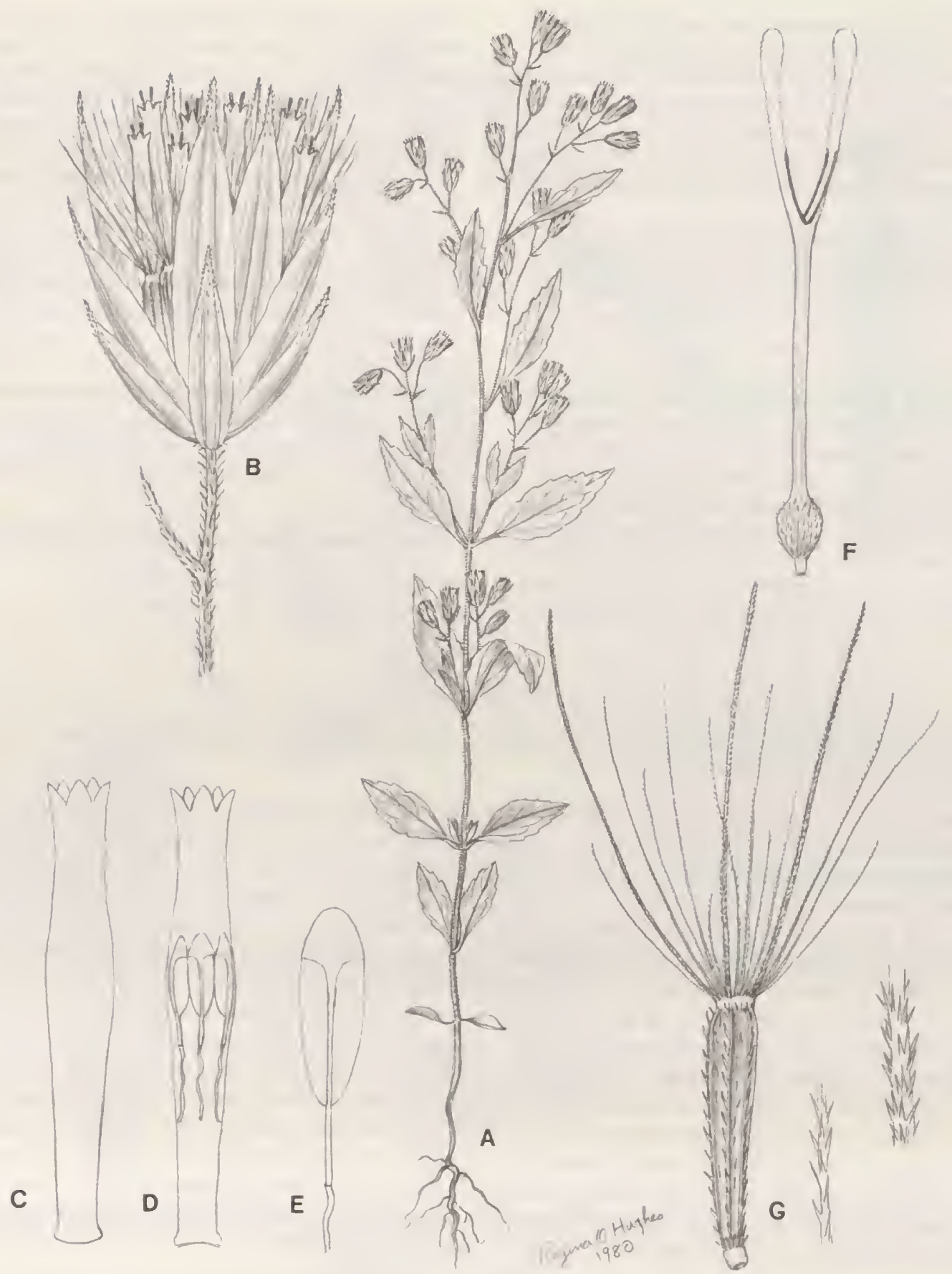

Plate 96. Dissothrix imbricata (Gardner) B. Robinson. - A. Habit, $\times 1 / 2,-$ B. Head, $\times 5 .-$ C. Corolla outer surface, $\times 19 .,-$ D. Corolla outline with anthers, $\times 19 .-$ E. Anther, $\times 45 .-$ F. Style, $\times 19 .-G$. Achene, $\times 12$, with separate enlarged representative segments of smaller and larger pappus bristles. Partly after J. Baker (1876).

of Brickellia, lacking as it does the flattened outer surfaces and densely fringed lateral margins of the pappus bristles. Actually, within the Alomiinae, Dissothrix is unique and easily distinguished by the pappus with two types of bris- tles, after which it is named. The pappus is arranged with the smaller bristles in groups between the few more widely spaced larger bristles. Such a pappus is matched in Brazilian Eupatorieae in one species of Eitenia, but the latter 
is a member of the distant subtribe Praxelinae. Another member of the Alomiinae from Brazil, Goyazianthus, has two types of bristles in the pappus, but in an essentially regularly alternating pattern. The latter genus is a perennial differing in many additional characters and is evidently not close to Dissothrix.

Dissothrix remains a monotypic genus as presently known. A second species credited to the genus, $D$. hassleriana of Paraguay, proves to be Stevia aristata. The original species is known from a few localities in the states of Ceará and Piauhy in northeastern Brazil. No collections have been reported since the first half of the last century.

Asa Gray (1851) mentioned that the corollas have purpurascent apices. Such coloration is not evident in the sparing material seen.

The following single species is recognized in the genus:

Dissothrix imbricata (Gardner) B. Robinson, Brazil.

\section{Austrobrickellia}

Austrobrickellia R. King \& H. Robinson, Phytologia 24: 72. 1972. TYPE: Eupatorium patens Don ex Hook. \& Arn.

Erect or spreading to arching subshrubs or shrubs; moderately branched, branching at approximately rightangles. Stems terete, pilosulous to tomentellous. Leaves opposite, with distinct slender petioles; blades ovate, bases obtuse to truncate, margins entire to sharply dentate, trinervate from at or near base, with or without glandular punctations. Inflorescence a lax leafy thyrsoid panicle, branches densely corymbose at tips; pedicels slender, short. Involucral bracts ca. 6-20, subimbricate, in 2-4 unequal graduated series, persistent, spreading when aged or dried, ovate to lanceolate, obtuse to acute, weakly to strongly bicostate on outer surface; receptacle flat to slightly convex, glabrous. Florets 3-12 in a head; corolla greenish white to purple, tubular, sometimes with slight constrictions above and near base, glabrous on outer surface or with few minute glands on lobes; cells of limb elongate, with scarcely sinuous lateral walls; lobes narrowly oblong, about twice as long as wide, erect, smooth on both surfaces; anther collars cylindrical, sometimes short, with few subquadrate cells below, longer above, with numerous annular thickenings on walls; anther appendages oblong, $1.25-1.5$ times as long as wide; style base enlarged, with numerous scarcely distorted ascending hairs; style branches longly clavate, mostly smooth. Achenes prismatic, 5-ribbed, with setulae often nearly restricted to ribs, with or without glands on sides; carpopodium distinct, shortly stopper-shaped with projecting upper rim; cells small, subquadrate, in ca. 5-15 series, with slightly to densely beaded walls; pappus of 30-35 persistent scabrid bristles in one series, with flattened mostly uninterrupted band along middle of outer surface, margins rather densely scabrid, apical cells mostly obtuse, sometimes narrowly rounded. Pollen grains ca. $20 \mu \mathrm{m}$ in diameter. Chromosome number $x=10$. Plate 97.

Austrobrickellia is named after the fact that it is the most southern member of the Brickellia relationship, reaching as far south in Argentina as the Province of Chubut. The species were placed in traditional treatments in the genus Eupatorium because of the capillary pappus and the five-angled achenes. Previous to the present series of studies, there seems to have been no mention of the resemblance to Brickellia, although the genus showed most of the important characters of that relationship, the subimbricate involucre, the tubular corollas, the longly clavate style branches, and the pubescent node at the base of the style. The outer surfaces of the pappus bristles actually have a somewhat flattened surface, approaching the form seen in Brickellia and its immediate relatives, though the margins of the bristles are not as densely and regularly scabrid. The primary distinctions of Austrobrickellia from Brickellia are the five-angled achenes, the smaller stoppershaped carpopodia, and the regular pattern of branching at right angles. Still, Austrobrickellia may be the closest relative in South America of the primarily North American Brickellia.

The genus Austrobrickellia consists of three recognized species. The type, A. patens, is widely distributed from central Bolivia south to southern Argentina, while the other two have more restricted ranges, A. arnottii in northwestern Argentina and A. bakeriana in the state of Minas Gerais in Brazil. The two Argentinian species are distinguished by Cabrera (1978) in his treatment of the Flora of Jujuy. Austrobrickellia arnottii is credited in the key with 6-10 involucral bracts in 2-3 series compared to $12-$ 18 bracts in 3-4 series in $A$. patens. The former species, on observation, proves to differ further by the 3-5 rather than 7-12 flowers in the heads, and the lack of numerous prominent glands on the achenes and undersurfaces of the leaves. The Brazilian species is most like A. patens in its characters, but has less glanduliferous achenes and more enlarged tips on the pappus bristles.

The following three species are recognized in the genus:

Austrobrickellia arnotii (Baker) R. King \& H. Robinson, Argentina.

Austrobrickellia bakerianum (B. Robinson) R. King \& H. Robinson, Brazil.

Austrobrickellia patens (Don ex Hook. \& Arn.) R. King \& H. Robinson, Argentina, Bolivia, Brazil, Paraguay. 


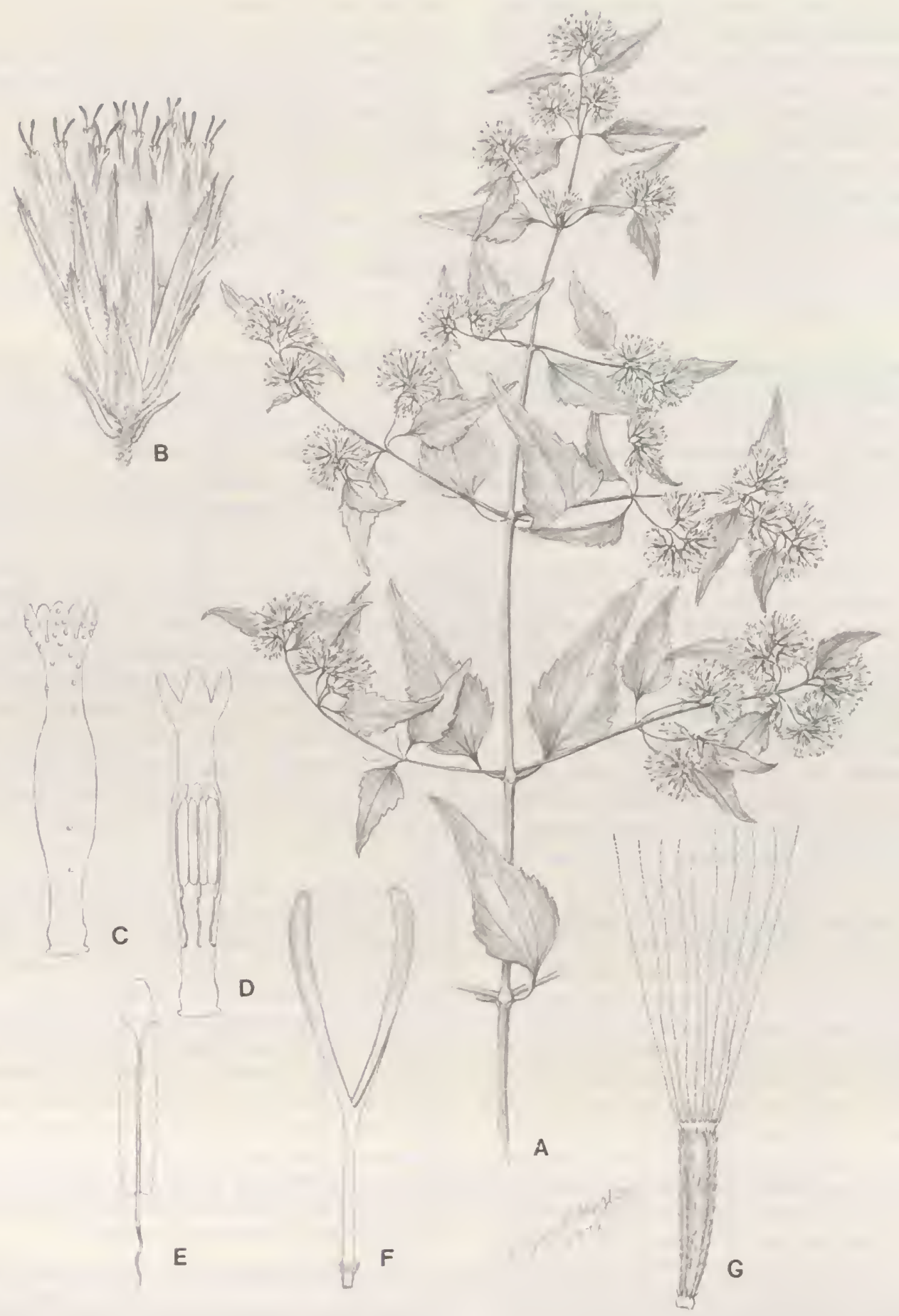

Plate 97. Austrobrickellia patens (Don ex Hook. \& Am.) R. King \& H. Robinson. - A. Habit, $\times 1 / 2 .-$ B. Head, $\times 4 .-$ C. Corolla outer surface, $\times 10,-D$. Corolla inner surface with anthers, $\times 10 .-$ E. Anthers, $\times 20 .-F$. Style, $\times 10 .-G$. Achene, $\times 12$ 


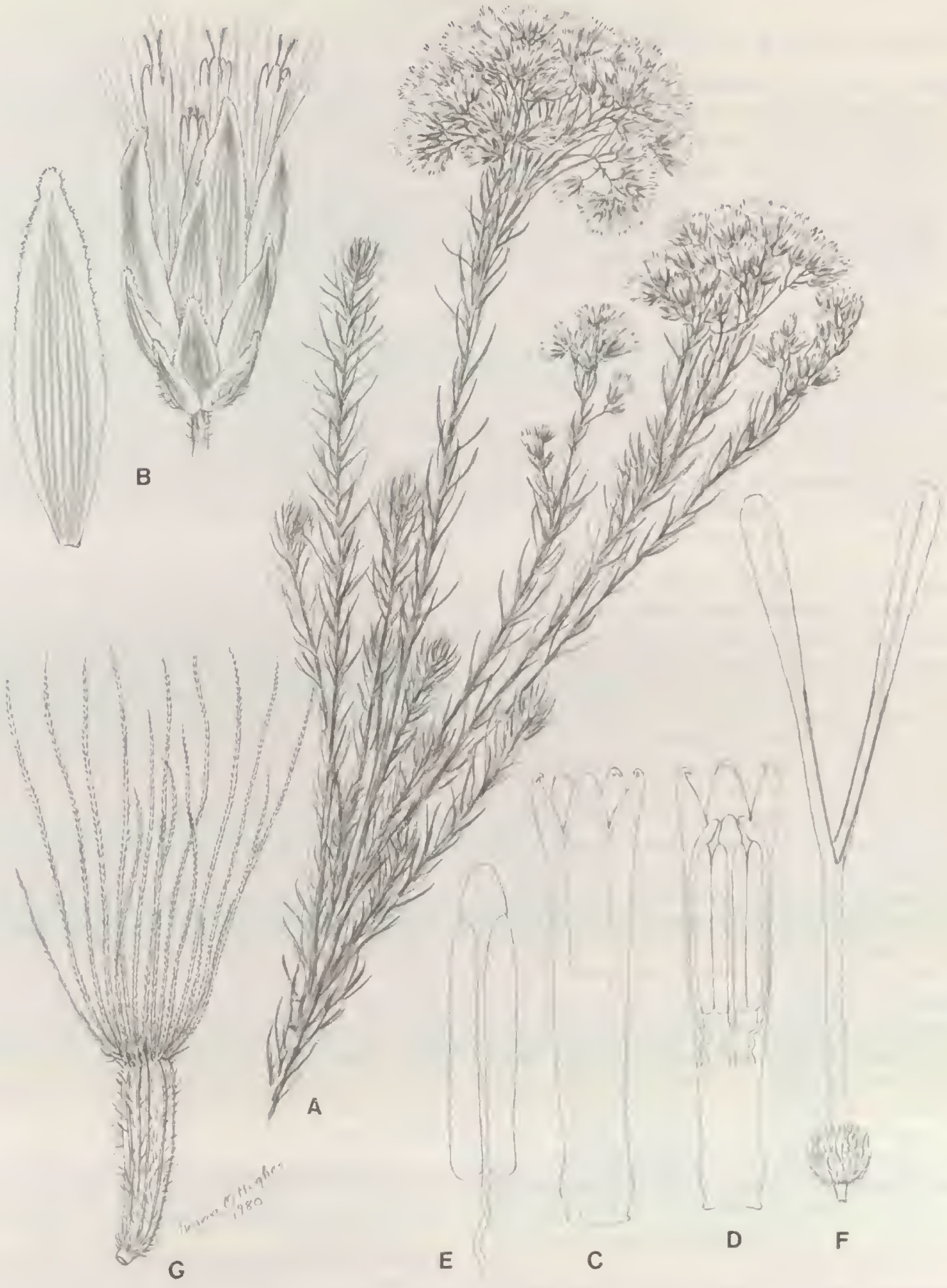

Plate 98. Pseudobrickellia brasiliensis (Sprengel) R. King \& H. Robinson. - A. Habit, $\times 1 / 2 .-$ B. Head, $\times 5$, with separate enlarged inner involucral bract, - C. Corolla outer surface, $\times 12$. D. Corolla inner surface with anthers, $\times 12,-$ E. Anther, $\times 20 .-$ F. Style $\times 12$. G. Achene, $\times 8$. 


\section{Pseudobrickellia}

\section{Pseudobrickellia R. King \& H. Robinson, Phytologia 24: 74. 1972. TYPE: Eupatorium brasiliense Sprengel.}

Erect often somewhat fasciculately branching shrubs. Stems essentially terete, marked with short ridges or scars from leaf insertions, puberulous. Leaves densely spirally inserted, sessile or indistinctly shortpetiolate; blades narrowly linear, without evident lateral veins, glabrous. Inflorescence terminal on leafy branches, densely corymbose to somewhat pyramidal; pedicels usually rather short, glabrous or short-puberulous. Involucral bracts 12-18, subimbricate, in 3-4 strongly unequal graduated series, persistent, spreading when aged or dried, oblong to lanceolate, usually stramineous or reddish brown on outer surface, weakly striated; receptacle flat, epaleaceous (with a few marginal paleae?), glabrous. Florets 2-4(-8?) in a head; corollas greenish white, tubular or minimally funnelform, glabrous on outer surface; cells of limb elongate, with sinuous lateral walls; lobes oblong, ca. twice as long as wide, erect, smooth on both surfaces; anther collars broadly cylindrical, with few subquadrate cells basally, cells longer above, with numerous annular or beaded thickenings on walls; anther appendages broadly ovate, about as long as wide; style base enlarged, hirsute with short, contorted, blunt-tipped hairs; style branches longly clavate, flattened only on inner surface, scarcely mamillose below, smooth apically. Achenes prismatic, 5-10-ribbed, distinctly setuliferous on sides; carpopodium distinct, narrowly annuliform to shortly stopper-shaped, with little or no projecting upper rim, cells small, subquadrate, in 2-5 series, with moderately thickened walls; pappus of ca. 35 sharply scabrid persistent bristles in ca. 2 series, some outer bristles shorter, outer surfaces with median glabrous band. Pollen grains ca. $25 \mu \mathrm{m}$ in diameter. Plate 98.

The genus Pseudobrickellia is notable for the shrubby habit with branches bearing linear leaves in a densely spiralled insertion. The habit is one found in a number of Asteraceae in southern Brazil, including the Eupatorian genus Disynaphia, but is unique to Pseudobrickellia within the subtribe Alomiinae. It is possible to distinguish the genus from genera such as Disynaphia by the Brickellioid features of the tubular corollas, broadened style branches, and enlarged pubescent style bases, and no close relationship is seen to any of the other groups with similar habit.

Within the Alomiinae, Pseudobrickellia seems rather close to Brickellia on the basis of character comparison, and part of the genus has been included in Brickellia by various authors including B. Robinson (1917) because of the presence of ten-ribbed achenes. One species from $E u$ patorium, having five-ribbed achenes, however, is also unquestionably a member of Pseudobrickellia, kept unnaturally separated in past treatments because of the one character difference. Actually, the flattened outer surface of the pappus bristles is close to that of Austrobrickellia, and differs from Brickellia by the less restricted dense fringe of marginal teeth. Pseudobrickellia differs from Brickellia, Austrobrickellia, and others, by the habit, the congestion of the pappus bristles resulting in essentially two rows, and the short but strongly contorted form of the hairs on the style base. It is perhaps closest to Goyazianthus and Leptoclinium.

The recognized species of the genus are characterized by having only two to four flowers in the head and having epaleaceous receptacles. As such, the genus includes Brickellia section Pityophyllum of B. Robinson (1917) based on the same type species with its ten-ribbed achenes. Nevertheless, Carphephorus coridifolius DeCandolle, recognized as Brickellia section Pseudocarphephorus by B. Robinson (1917) has a similar habit, and similar basic characters, and may belong in the genus. The latter differs primarily by having heads with up to eight flowers with a few intermixed paleae.

All of the species involved are restricted to the Planalto region of Brazil in the states of Minas Gerais and Goiás. They must be at least partially distinguishable in the field, from others of similar habit, by the greenish white or creamy white flowers of a type common in the Aloniinae. Label data indicates that some plants have yellowish flowers, and the flowers of some dried specimens seem slightly yellowish, but such coloration in live plants is assumed to be primarily due to pollen on the style branches, as in other members of the subtribe.

The name of the genus translates as "False Brickellia," in reference to the misplacement of the type species in the latter genus.

The following two species are recognized in the genus:

Pseudobrickellia angustissima (Sprengel ex Baker) R. King \& H. Robinson, Brazil.

Pseudobrickellia brasiliensis (Sprengel) R. King \& H. Robinson, Brazil. 


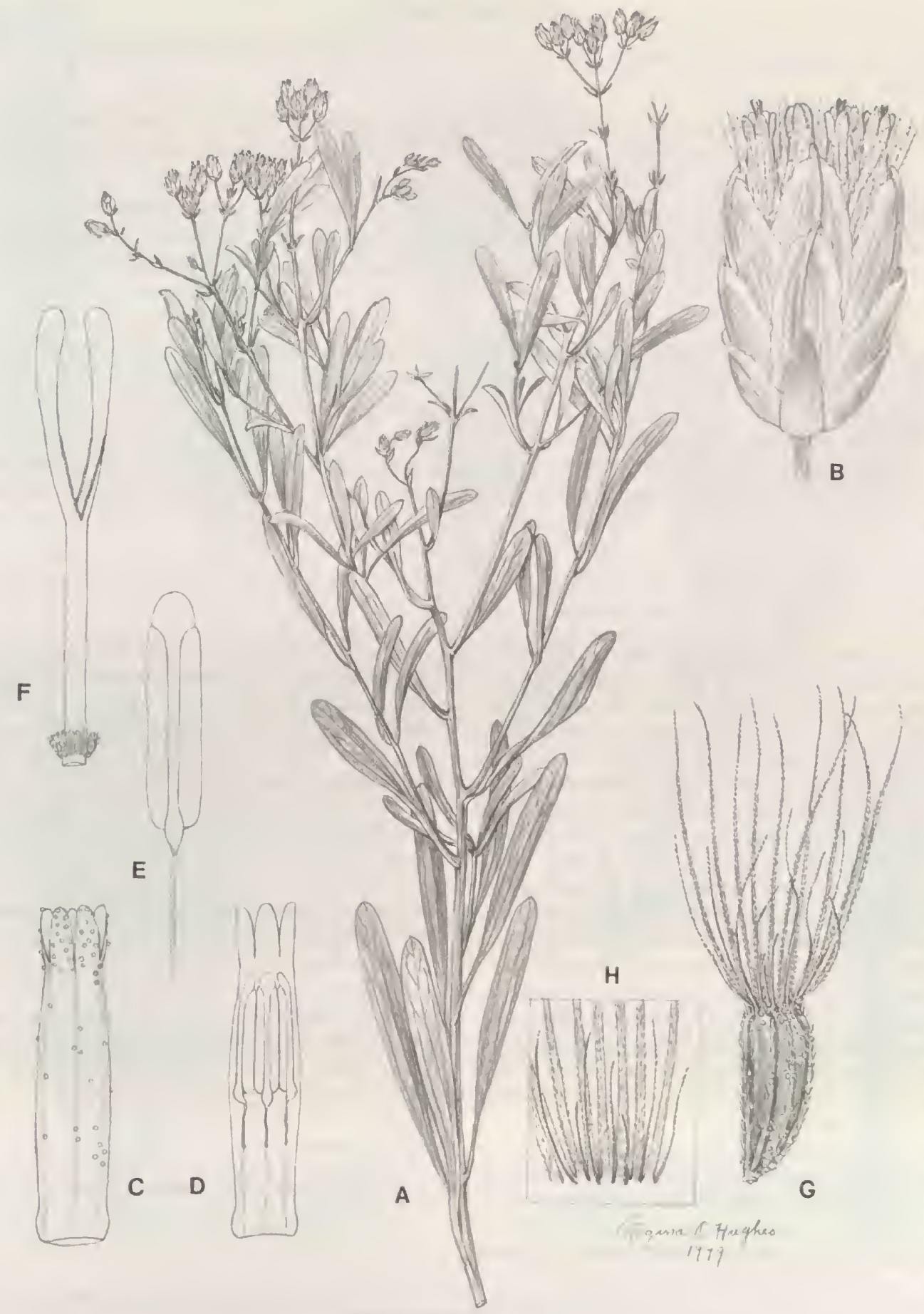

Plate 99. Goyazianthus tetrastichus (B. Robinson) R. King \& H. Robinson. - A. Habit, $\times 1 / 2,-$ B. Head, $\times 5 .-$ C. Corolla outer surface, $\times 10 .-D$. Corolla inner surface with anthers, $\times 10 .-$ E. Anther, $\times 20 .-$ F. Style, $\times 10 .-$ G. Achene, $\times 8 .-H$. Enlargement of pappus base, $\times 16$. 


\section{Goyazianthus}

Goyazianthus R. King \& H. Robinson, Phytologia 37: 461. 1977. TYPE: Symphyopappus tetrastichus B. Robinson.

Erect subshrubs, branching above, with stems, leaves, and exposed surfaces of involucral bracts cinereopuberulous and glandular-punctate, older leaves and stems somewhat glabrescent. Stems terete, striated when dry. Primary leaves usually alternate and with alternate vegetative branches in upper axils, branch leaves and bracts of inflorescence usually opposite; blades of leaves narrowly oblong-oblanceolate, entire, with rounded and apiculate tips, trinervate from near base with weak veins parallel to margin, lower surface sometimes thinly arachnoid tomentellous. Inflorescence thyrsoid-paniculate, with subcymose mostly opposite branches; pedicels short. Involucral bracts 15-16, subimbricate, in ca. 4 unequal graduated series, mostly in 4 distinct ranks, persistent, spreading with age, oblong, often somewhat keeled; receptacle flat, glabrous. Florets 4 in a head; corollas creamy white, tubular, narrower above, with numerous glands on outer surface; cells of limb elongate, with walls not or weakly sinuous; lobes oblong, about twice as long as wide, smooth on both surfaces; filaments inserted near basal fourth of corolla, lower part of filament short; anther collars slightly thickened, cells oblong, with distinct annular thickenings on walls; appendages oblong-ovate, about as long as wide; style base enlarged, densely pubescent with short contorted hairs; style branches longly clavate, fleshy, mamillose below, becoming smooth above. Achenes prismatic, ca. 7-ribbed, densely setuliferous and glanduliferous on sides; carpopodium shortly stopper-shaped, slightly asymmetrical, cells small, subquadrate, in 4-8 series; pappus of ca. 50 persistent bristles, dimorphic, with outer smaller series at most gaps between larger inner bristles, densely scabrid on margins, with few small scabrae on outer surface, apical cells acute. Pollen grains ca. $25 \mu \mathrm{m}$ in diameter. Plate 99.

The genus Goyazianthus is based on a species originally placed by B. Robinson (1934a) in the genus Symphyopappus because of the slight tendency of the upper callus with the pappus to separate from the body of the achene, a character that is somewhat characteristic of the latter genus. Goyazianthus and some species of Symphyopappus also share an involucral form with ranked bracts. These are the only characters, however, by which Goyazianthus particularly resembles Symphyopappus or any other members of the subtribe Disynaphiinae to which Symphyopappus belongs. The latter subtribe has consistently five-flowered heads, while Goyazianthus has four flowers. Goyazianthus differs further by the tubular upwardly narrowed corollas, the broadly long-clavate style branches, and the densely pubescent node on the style base, characters that place the genus in the subtribe Alomiinae. The graduated subimbricate persistent involucral bracts and the creamy white corollas also conform with the common condition in the latter subtribe.

Within the Alomiinae, Goyazianthus is most closely related to Pseudobrickellia, both sharing heads with few flowers and somewhat ranked involucral bracts, setuliferous achenes, and a somewhat biseriate pappus with the outer bristles somewhat smaller. Nevertheless, Goyazian- thus differs in the outer bristles of the pappus being considerably shorter and more regularly alternating, in the involucral bracts being more regularly ranked, and in the achenes and the corollas bearing numerous glands. Goyazianthus differs from Pseudobrickellia more obviously in vegetative appearance, having more widely spaced mostly oblanceolate leaves that are opposite on most of the branches and in the inflorescence. The progression from alternate primary phyllotaxy to lateral and distal opposite phyllotaxy is in significant contrast to the trends in most of the advanced families of dicots, but is present in all specimens of Goyazianthus observed.

Goyazianthus and Pseudobrickellia appear to differ considerably in their chemistry. Goyazianthus seems particularly notable for numerous diterpenes, including kolavenol derivatives (Bohlmann et al., 1982i), none of which have been isolated from Pseudobrickellia brasiliensis (Bohlmann et al., 1984).

The name Goyazianthus refers to the state of Goiás in Brazil where the single known species occurs.

The following single species is recognized in the genus:

Goyazianthus tetrastichus (B. Robinson) R. King \& H. Robinson, Brazil.

\section{Leptoclinium}

\section{Leptoclinium Benth. in Benth. \& Hook., Gen. Pl. 2: 244. 1873. TYPE: Liatris trichotoma Gardner.}

Erect shrubs, with many branches above. Stems terete, slightly puberulous. Leaves alternate, imbricated, sessile or subsessile; blades broadly lanceolate, margins entire, weakly trinervate from near base with veins parallel to margin, surfaces sparsely puberulous, non-glanduliferous. Inflorescence of small terminal cor- 

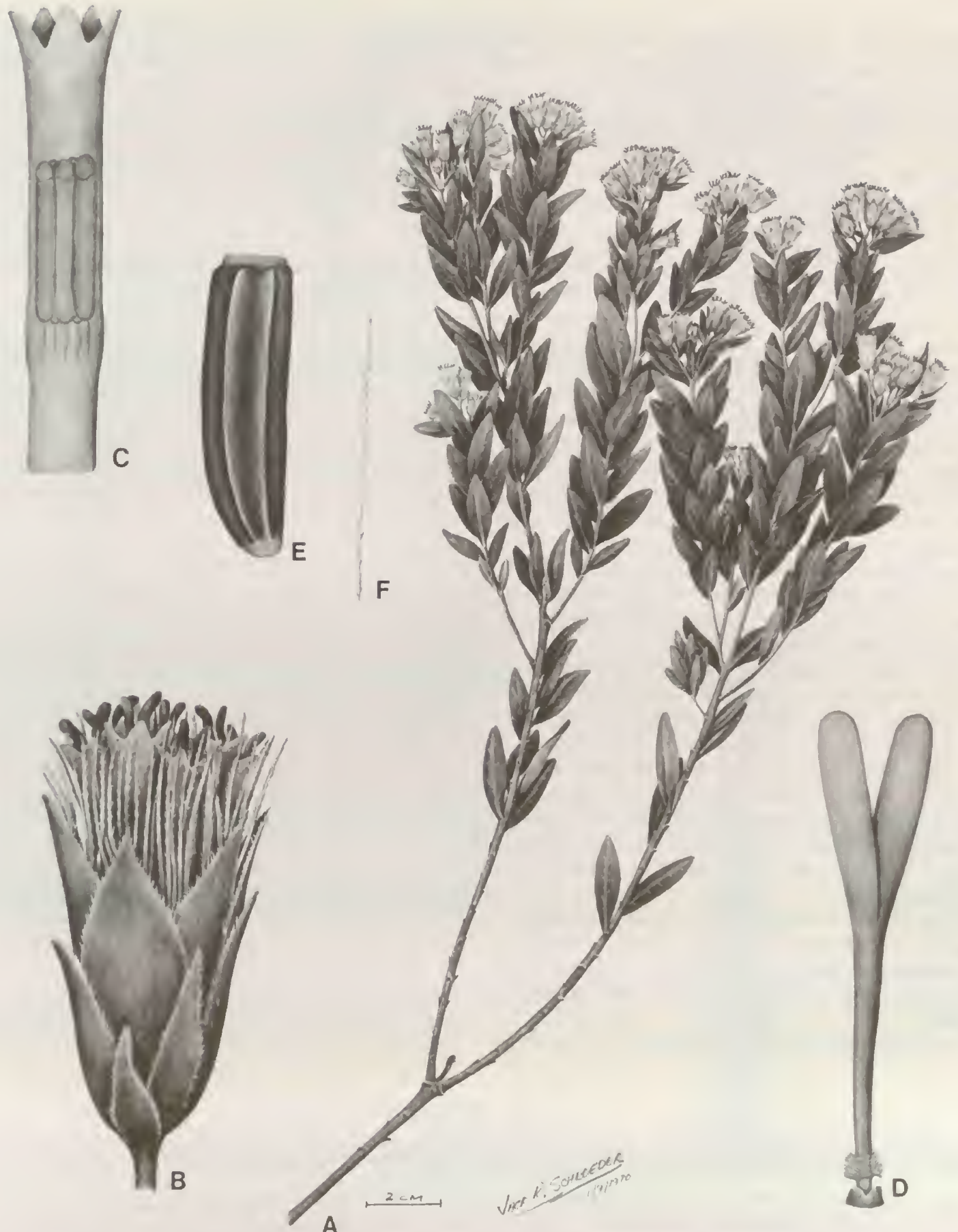

Plate 100. Leptoclinium trichotomum Benth. ex Baker. -A. Habit, $\times 3 / 5 .-B$. Head, $\times 7 .-$ C. Corolla showing anthers, $\times 14 .-D$. Style, $\times 14 .-$ E. Achene, $\times 14,-F$. Pappus bristle, $\times 14$.

ymbose panicles; pedicels short. Involucral bracts ca. 12, subimbricate, in ca. 3 unequal series, persistent, spreading with age, narrowly ovate to oblong-ovate, acute, weakly costate in basal half; receptacle flat to slightly convex, glabrous. Florets 5 in a head; corollas creamy white, tubular, glabrous; cells of limb elongate with sinuous lateral walls; lobes oblong, over twice as long as wide, smooth on both surfaces; anther collars 
short-cylindrical, cells subquadrate below, oblong above, with numerous distinct complex thickenings on walls; anther appendage about as long as wide; style base enlarged, with dense cluster of short contorted hairs; style branches broadly and longly clavate, with inner surface flattened, mamillose below, smooth on broadest parts, stigmatic lines on inside surface at or slightly in from edges. Achenes prismatic, 5-ribbed, glabrous; carpopodium distinct, symmetrical, stopper-shaped, without projecting upper margin, cells small, subquadrate, in ca. 10 series, with thickened walls; pappus of numerous easily deciduous bristles, apparently in 1 series, detached before maturity, apical cells of bristles short-acute. Pollen grains ca. $25 \mu \mathrm{m}$ in diameter. Plate 100.

The genus Leptoclinium includes one of the many shrubby members of the Eupatorieae from the Brazilian planalto showing the essential features of the subtribe Alomiinae. The involucre is subimbricate and persistent, the corollas are tubular with smooth surfaces on the lobes, the style branches are longly clavate, and the style base has a densely pubescent node. The genus is similar in general habit to Pseudobrickellia, Goyazianthus, and Planaltoa, related members of the Alomiinae from the Planalto region. Leptoclinium is distinguished from the related genera by the deciduous bristles of the pappus. The pappus is evident in mature heads only in the form of loose bristles among the flowers. The genus also differs by the broader sparsely pubescent leaves, broader than those of Pseudobrickellia or Goyazianthus and less pubescent than those of Planaltoa.

In establishing the genus, Bentham (Bentham \& Hooker, 1873) mentioned the broad style branches of the flowers which are very noticeable projecting from the openings of the tubular corollas. The branches in Leptoclinium actually seem to be the broadest of any in the subtribe Alomiinae, and the broadening extends downward to the base of the branches where the stigmatic lines are displaced on to the inside surface. The position of the stigmatic lines is unique in the tribe, but observable only with dissection and magnification.

Gardner (1847) described the corollas as pale yellowish, a description common for members of the Alomiinae. Nevertheless, any truly yellow coloration is presumed to be restricted to the pollen in the anthers and on the style branches.

The single species of the genus is apparently known only from the type which was cited from dry grassy hills, near Villa de Arrayas in Goiás, Brazil.

The name of the genus derives from the Greek words leptos (= small or thin) and kline (= bed), the latter word being used by synantherologists in the sense of a receptacle. The name came to the Brazilian species through a series of errors. The name was established originally by Nuttall (1822), as a subunit of Liatris, based on a plant from Florida presently known as Garberia heterophylla. It was Gardner who extended the use of the name to two Brazilian species, first Liatris (Leptoclinium) brasiliensis (1846), and second $L$. (Leptoclinium) trichotoma (1847). There was no intent by Gardner to establish a new concept, only a mistaken but honest belief that the Brazilian species were related to the one from Florida. Actually, not even the two Brazilian species prove to be closely related, Liatris brasiliensis proving to be a Symphyopappus in the subtribe Disynaphiinae.

Contrary to the citation in the paper on the typification of the Eupatorian genera (King \& Robinson, 1969c), the Bentham use of the name Leptoclinium at the generic level was only inspired by the earlier name, but not based upon it nomenclaturally. The Bentham description fits only the second of the Brazilian species of Gardner, Liatris trichotoma, and it was only that species that was transferred into the Bentham genus by J. Baker (1876). Leptoclinium of Bentham has priority at the generic level, even over the later attempt by Asa Gray $(1879 a)$ to raise the original Leptoclinium of Nuttall to a genus.

The following single species is recognized in the genus:

Leptoclinium trichotomum (Gardner) Benth. ex Baker, Brazil.

\section{Planaltoa}

\section{Planaltoa Taubert, Bot. Jahrb. Syst. 21: 454. 1896. TYPE: Planaltoa salvifolia Taubert.}

Erect subshrubs or shrubs, with few to many branches above, with stems, leaves, and involucres densely hirtellous. Stems terete. Leaves alternate, imbricated, sessile; blades lanceolate to oblong-elliptical, minutely serrulate, margins sometimes reflexed, venation with strongly ascending secondaries or weakly trinervate from base, undersurface with strongly exsculpate reticulum, with or without glandular punctations. Inflorescence terminal, densely corymbose or thyrsoid with densely corymbose branches; heads sessile in small bracteolate clusters. Involucral bracts 5-7, weakly subimbricate, in ca. 2 subequal series, persistent, spreading with age, herbaceous at least at tips, lanceolate to broadly lanceolate, acute; receptacle flat, glabrous. Florets 3-5 in a head, corollas pink, tubular or minimally funnelform, outer surface densely pubescent with nonglandular hairs, stipitate glandular hairs, or short-stalked glands; cells of throat elongate, with somewhat 


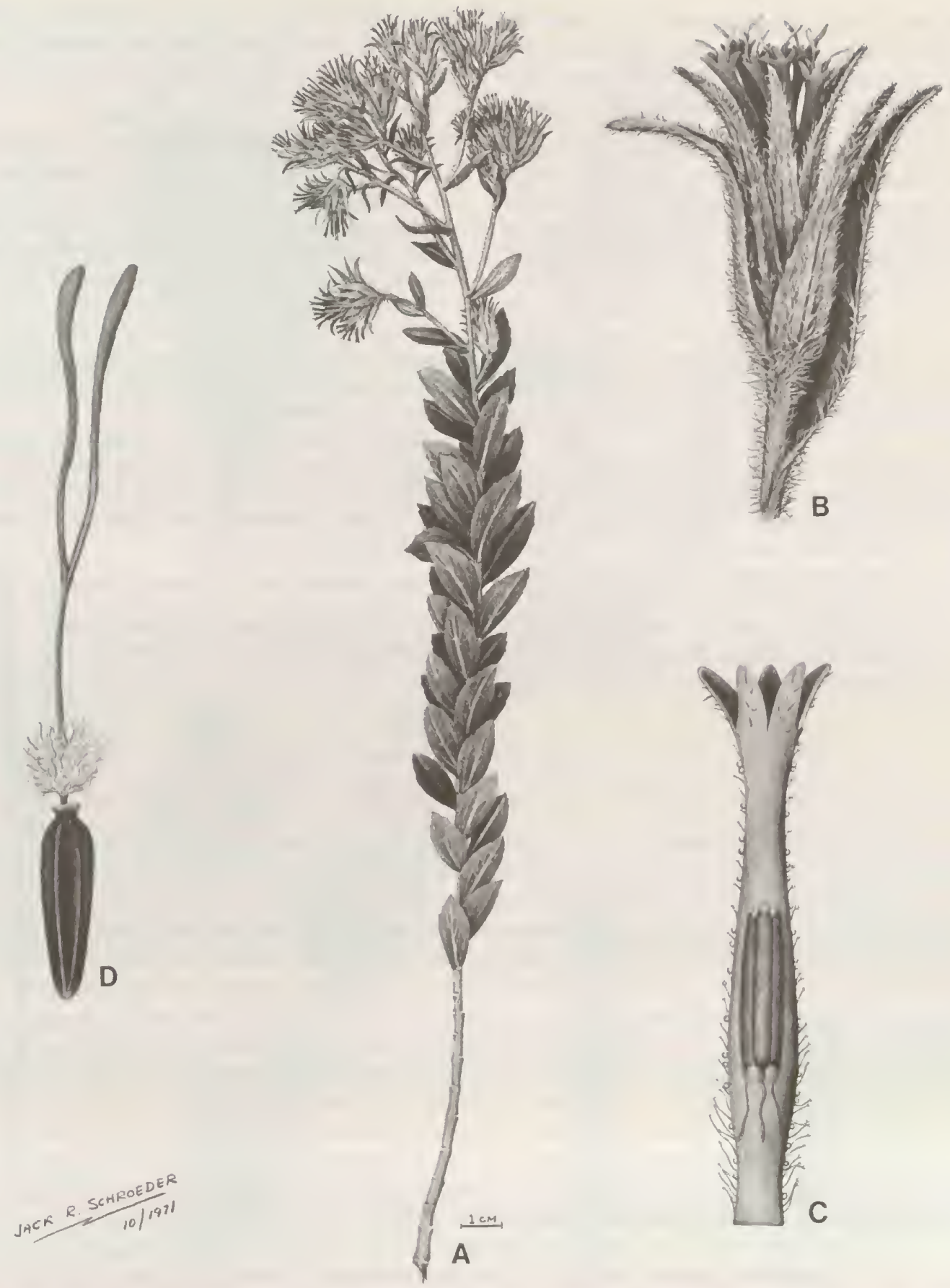

Plate 101. Planaltoa salviifolia Taubert. - A. Habit, $\times 3 / 5 .-$ B. Head, $\times 4 .-$ C. Corolla showing anthers, $\times 9 .-$ D. Achene with style, $\times 9$.

sinuous lateral walls; lobes narrowly triangular, nearly twice as long as wide or longer, with cells of inner surface short-oblong to isodiametric and somewhat mamillose, with or without hairs on inner surface; anther collar short, cells subquadrate below, cell walls with dense transverse annular thickenings; anther appendages slightly wider than long to longer than wide; style base scarcely enlarged, densely pubescent with long scarcely 
contorted hairs; style branches longly and narrowly clavate with papillae below, becoming mamillose to smooth above, or linear and densely papillose. Achenes prismatic, 5-6-ribbed, glabrous, abruptly constricted at base; carpopodium indistinct, rarely with a few small subquadrate cells with slightly thickened walls; pappus lacking. Pollen grains $23-27 \mu \mathrm{m}$ in diameter. Plate 101.

The genus Planaltoa consists of two presently known epappose pubescent species of superficially Vernonian appearance from the Planalto area of Brazil. The genus is evidently a member of the subtribe Alomiinae on the basis of the tubular and upwardly somewhat constricted corolla of the type species and on the basis of the densely pubescent style bases in both species. Planaltoa is one of only two genera of the subtribe without a pappus, and is the only such member in South America. The epappose Alomia of Mexico is a totally different extreme in the subtribe with many-flowered heads and mostly opposite leaves.

The two known species of Planaltoa are alike in many characteristics and are evidently each other's closest relatives. Both have erect habits with branching above, somewhat crowded sessile leaves, crowded few-flowered heads with very weakly subimbricate subequal involucral bracts with at least the tips herbaceous, glabrous epappose achenes without distinct carpopodia, and corollas with densely pubescent outer surfaces. However, the Barroso species, $P$. lychnophoroides, is sufficiently different, that by itself, its placement in the subtribe might have been questioned. The corollas are slightly funnelform, and have uniseriate and biseriate non-glandular hairs with intermixed glandular punctations, and there are hairs on the inner surfaces of the lobes. Also, the style branches are narrow and densely papillose throughout. There are none of the glandular tips on the longer hairs of the corolla nor the distal broadening of the style branches seen in the type species. The leaves also differ by the slightly auriculate bases, narrower tips, reflexed margins, and large abaxial glandular punctations.

The two known species of Planaltoa occur only in the state of Goiás in the interior of eastern Brazil.

Various compounds, including ent-labdane derivatives, have been reported from Planaltoa lychnophoroides (Bohlmann et al., 1982g).

The following two species are recognized in the genus: Planaltoa lychnophoroides G. Barroso, Brazil. Planaltoa salviifolia Taubert, Brazil.

\section{Crossothamnus}

\section{Crossothamnus R. King \& H. Robinson, Phytologia 24: 77. 1972. TYPE: Eupatorium weberbaueri Hieron.}

Erect shrubs, with many branches. Stems terete, densely puberulous and glandular-punctate; internodes short. Leaves opposite to alternate, short-petiolate; blades ovate, bases rounded to subtruncate, margins serrulate to subserrulate, narrowly reflexed, upper surface glabrous, lower surface densely glandular-punctate and tomentellous, venation pinnate or with more ascending secondaries near base. Inflorescence thyrsoidpaniculate, with branches rather densely corymbose; pedicels rather slender and drooping, densely shortpubescent. Involucral bracts ca. 20, strongly subimbricate, in 3-4 strongly unequal graduated series, persistent, spreading when aged or dried, oblong, obtuse to rounded at tip, densely puberulous and glanduliferous on outer surface. Florets ca. 10 in a head; corollas white, minimally funnelform, slightly narrowed above, glanduliferous on outer surface; cells of limb laxly oblong, with lateral walls not or scarcely sinuous; lobes oblong, erect, slightly longer than wide, smooth on both surfaces; anther collars broadly cylindrical, cells mostly or totally elongate, with numerous transverse annular thickenings on walls; anther appendages oblong, 1.25 times as long as wide; style base enlarged, smooth to papillose; style branches longly clavate, slightly mamillose below, smooth above, flattened only on inner surface. Achenes prismatic, 5-7-ribbed, densely glanduliferous on sides with short-stipitate glands, rarely with setulae; carpopodium short-cylindrical, without distinctly projecting upper rim, cells small, subquadrate, in ca. 6 series, with moderately thickened walls; pappus of ca. 35 persistent scabrid bristles in 1 series, without flattened outer surfaces, tips somewhat broadened, apical cells obtuse. Pollen grains ca. $26 \mu \mathrm{m}$ in diameter, with minute spines. Chromosome number $x=10$. Plate 102 .

The genus Crossothammus is based upon a single species of rather distinctive appearance from Peru. The species has been placed in the broad concept of Eupatorium and has not been regarded as a possible relative of Brickellia previous to the present series of studies. Still, the presence of rather narrow somewhat constricted corollas, broad style branches, a basal node on the style, and a tendency for more than five angles on the achene indicate a relationship to the latter genus. Though Crossothamnus seems to have adopted some traits more common in higher el- 


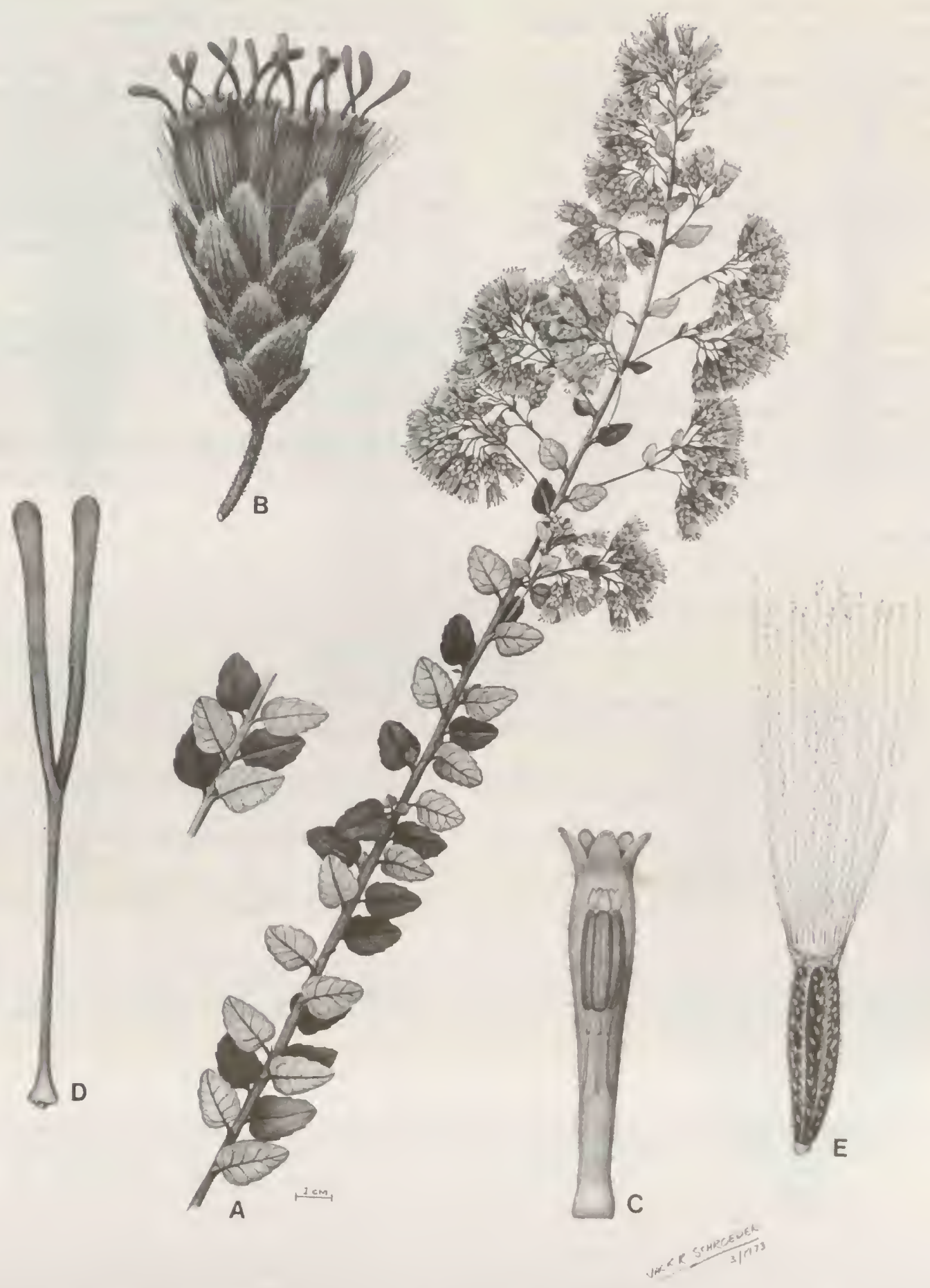

Plate 102. Crossothamnus weberbaueri (Hieron.) R. King \& H. Robinson. - A. Habit with separate stem segment, $\times 5 / \% .-$ B. Head, $\times 5$. C. Corolla showing anthers, $\times 12 .-$ D. Style, $\times 12,-$ E. Achene, $\times 12$. 
evation plants of other tribes and subtribes, there is no structural detail indicating relationship to any subtribe other than the Alomiinae.

In the Alomiinae, Crossothammus actually has little in common with Brickellia except the subimbricate involucre, narrow corollas, broadened style branches, and similarly shaped stylar node. The differences include the essentially glabrous nature of the stylar node, the dense glandular covering of the corollas and achenes, the carpopodia being small and symmetrical with small subquadrate cells, the achenes having less than ten ribs, and the pappus setae lacking the distinctly flattened outer surface and densely fringed lateral margins. The chromosome number as reported by Turner et al. (1967) is also different.

Crossothamnus is closer to Helogyne in general aspect and in the numerous glands on the florets, and is in a geographical area in the mountains of Peru transitional between the more numerous genera of the Alomiinae in the east and Helogyne to the west. Helogyne differs in the not or only slightly enlarged base of the style, the narrower leaves that are not noticeably pubescent below, the sharper tips of the pappus bristles, and the narrow pointed rather than broadly tipped involucral bracts.
All presently known specimens of Crossothamnus are from a restricted area near Chachapoyas in the Department of Amazonas in northern Peru, and are cited from elevations between 2,000 and $2,400 \mathrm{~m}$, above the elevations attained by other members of the subtribe. The more pubescent leaf undersurfaces are apparently a specialization correlated with the higher elevation, being more like those of members of other subtribes of the Eupatorieae from the same area, but unlike other members of the Alomiinae. The large inflorescences with nodding heads and less strongly spinulose pollen would indicate specialization toward wind pollination, another probable specialization correlated with the higher elevations.

The name Crossothamnus is based on the Greek words krossos (= tassel) and thamnos (= shrub or bush), in reference to the distinctive habit of the plants with their nodding tassel-like heads.

The following single species is recognized in the genus:

Crossothamnus weberbaueri (Hieron.) R. King \& H. Robinson, Peru.

\section{Helogyne}

Helogyne Nutt., Trans. Amer. Philos. Soc. n.s. 7: 449. 1841. TYPE: Helogyne apaloidea Nutt.

Brachyandra Philippi, Fl. Atacam. 34. 1860. TYPE: Brachyandra macrogyne Philippi [= Helogyne macrogyne (Philippi) B. Robinson].

Leto Philippi, Ann. Mus. Nac. Chile, Sect. 2, Bot. 8: 33. 1891. TYPE: Leto tenuifolia Philippi (= Helogyne apaloidea Nutt.).

Addisonia Rusby, Bull. Torrey Bot. Club 20: 432. 1893. TYPE: Addisonia virgata Rusby [= Helogyne virgata (Rusby) B. Robinson].

Erect subshrubs or shrubs, with many branches. Stems with young portions terete, striated, often pubescent. Leaves alternate, short-petiolate; blades small, elliptical to lanceolate, entire, uninervate or trinervate from near base, surfaces with punctate or short-stipitate glands. Inflorescence a dense rather pyramidal or thyrsoid panicle or sometimes diffuse and leafy; heads sessile or short-pedicellate. Involucral bracts ca. 10-30, usually subimbricate in 2-5 unequal series (eximbricate and subequal in type species), persistent, spreading with age, oblong to obovate, with rounded to sharply acute tips; receptacle slightly convex, glabrous. Florets 518 in a head; corollas white, pink, purple, or according to some descriptions, yellow, tubular and somewhat constricted above or funnelform, with many minute glands on outer surface, at least on lobes; cells of limb elongate with rather sinuous lateral walls, short oblong with non-sinuous walls in $\mathrm{H}$. calocephala; lobes oblong-ovate to long-triangular, broadly triangular in $H$. calocephala, erect to somewhat spreading, smooth on both surfaces; anther collars cylindrical, with cells mostly or totally oblong, with numerous annular thickenings on walls, with numerous subquadrate cells and beaded thickenings in $\mathrm{H}$. virgata; anther appendage slightly longer than wide; style base not enlarged, scarcely broadened in $I$. calocephala, glabrous; style branches longly clavate, flattened on inner surface, minutely mamillose to slightly papillose to tip, smooth above in $H$. calocephala. Achenes prismatic, 5-6-ribbed, usually with both setulae and numerous minute glands on sides; carpopodium distinct, stopper-shaped to short-cylindrical, with or without distinct projecting upper edge, cells small, subquadrate, in 5-10 series, walls somewhat thickened; pappus of ca. 20-30 persistent bristles in 1 series, often vascularized, barbellate to plumose on margins, scabrae reduced or lacking along middle of outer surface, apical cells acute. Pollen grains ca. $23 \mu \mathrm{m}$ in diameter. Plate 103. 

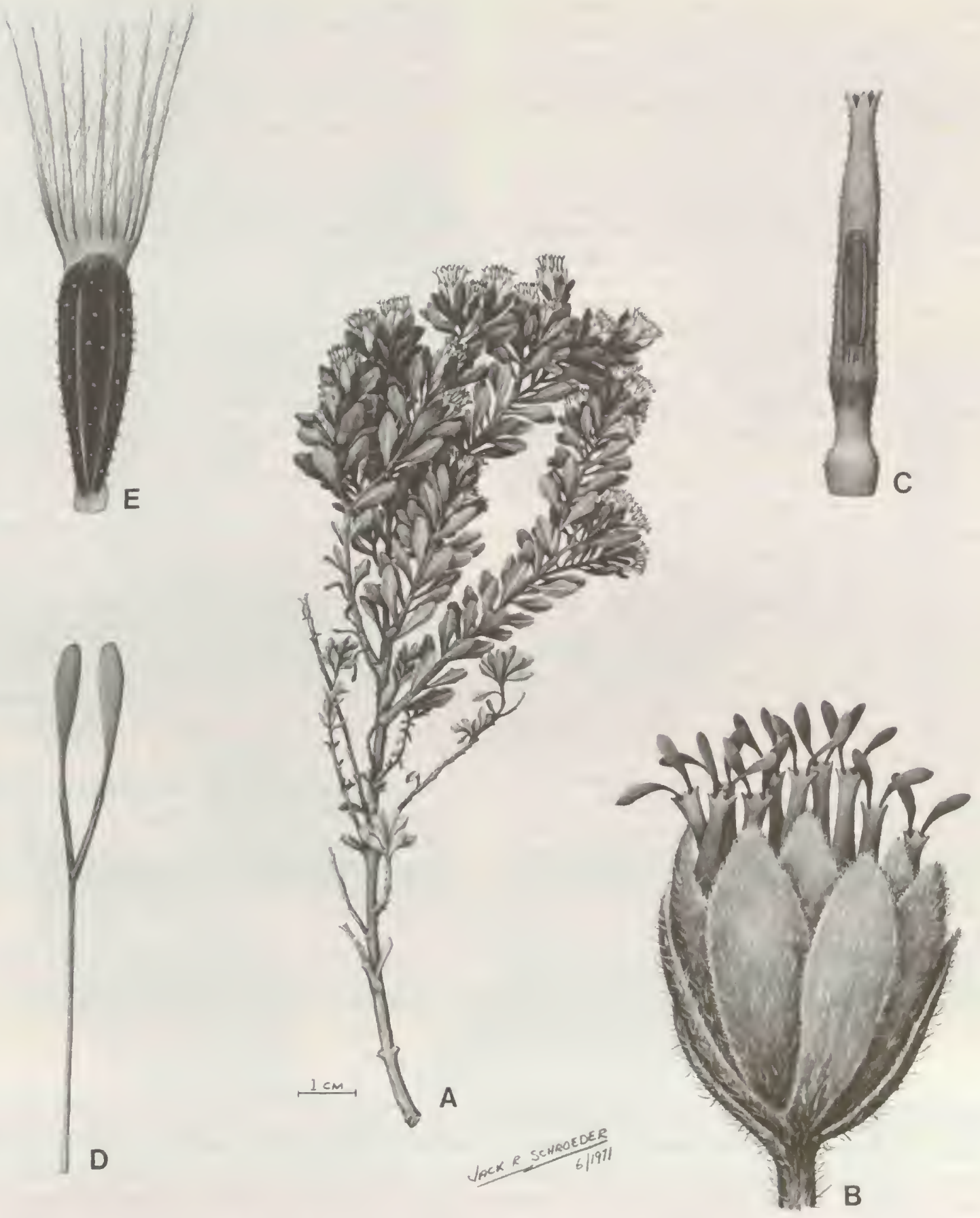

Plate 103. Helogyne hutchisonii R. King \& H. Robinson. -A. Habit, $\times \frac{8 \%}{9} .-$ B. Head, $\times 7 .-$ C. Corolla showing anthers, $\times 14 .-$ D. Style, $\times 14 .-E$. Achene, $\times 14$.

The name Helogyne is derived from the Greek words helos (= nail or clavus), and gyne (= female), and is in reference to the Brickellioid type of style branch that occurs in the genus. The style branches, the tubular corollas with a constriction above, and various observations of yellowish flowers in the typical element of the genus, all represent characters of the subtribe Alomiinae to which Helogyne belongs. The type species departs from the re- 
mainder of the subtribe in the eximbricate form of its involucre, but the latter character is variable within the genus. As presently recognized, the genus contains the only members of the subtribe in the drier areas of western South America from northern Peru southward to northern Argentina and Chile.

In spite of considerable variation in the number of characters, Helogyne appears to form a natural group in the Alomiinae having no distinct enlarged node at the base of the style, having mostly mamillose or papillose surfaces on even the broadened part of the style branch, and having numerous glands on both the corollas and achenes. The genus contains the only South American members of the subtribe with a plumose pappus, but the latter character is restricted to only a few of the species. The pappus in all the species is partially flattened on the outer surface, and the bristles in many of the species show a central vascular trace not seen in the majority of Eupatorian genera.

The position and limits of Helogyne have not always been so certain. As discussed by B. Robinson (1906), the original material was sparing and inadequately described, leading to various errors. Bentham and Hooker (1873) placed the genus in their Piquerinae on the mistaken impression that it lacked an anther appendage. Also Philippi $(1860,1891)$ named two genera and Rusby (1893) named another genus, all of which have proved to be synonyms, sometimes with misleading descriptions of their own. In spite of his earlier resolution of many problems in the generic concept, B. Robinson (1930c) encountered problems on the discovery that his Eupatorium dejectum was the same species as Helogyne tacaquirensis of Hieronymus. B. Robinson indicated that Helogyne, ". . . if it is to be maintained as a separate group, will probably have to be restricted to a few Andean species of xerophytic habit with very small alternate leaves, small few-flowered heads and narrowly tubular corollas. In the past some emphasis has been laid on the enlarged style-branches and the plumose pappus, but these characters prove too vague and variable within the little group itself to furnish distinctions for its recognition." It is notable that, in treating his species as a Eupatorium, B. Robinson (1926a) considered it closely related to E. patagonicum and E. patens, species now also recognized as Brickellioid in the genus Austrobrickellia. It seems of interest that $E$. huambutiense of Cabrera (1945) is a subopposite- to opposite-leaved variant of the same species described by Hieronymus and B. Robinson, or a very close relative.

B. Robinson (1906) treated the genus Helogyne and its synonyms, with the recognition of four species and three sections. Of the synonymized genera, he found Leto to be conspecific with the type species, and characterized the typical selection by the subequal biseriate involucral bracts. Brachyandra was reduced to sectional level and distinguished by the unequal bracts in 3-4 series. Addisonia was also reduced to a section with unequal involucral bracts erect in 4-5 series. Though not mentioned as such, the species of the first two sections had plumose to subplumose pappus bristles, unlike the barbellate bristles of $A d$ disonia.

The more recent studies in the present series have shown no reason to resurrect any of the elements synonymized under Helogyne by B. Robinson (1906). The primary departure is to include a few species with atypically funnelform corollas such as $H$. tacaquirensis and $H$. calocephala. In fact, only the latter Mattfeld species seems in any way questionable in the genus, differing by the short-oblong cells, the shorter triangular lobes, and the slightly mamillose inner surfaces of the lobes in the corolla, the smooth surface of the style branches, and the slight broadening of the style base. Separate subgeneric status for the latter species seems justified.

The following eight species are recognized in the genus:

Helogyne apaloidea Nutt., Chile, Peru.

Helogyne calocephala Mattf., Peru.

Helogyne ferreyrii $\mathbf{R}$. King \& $\mathrm{H}$. Robinson, Peru.

Helogyne hutchisonii R. King \& H. Robinson, Peru.

Helogyne macrogyne (Philippi) B. Robinson, Chile.

Helogyne straminea (DC.) B. Robinson, Peru, Bolivia.

Helogyne tacaquirensis Hieron. in Urban, Peru, Bolivia, Argentina.

Helogyne virgata (Rusby) B. Robinson, Peru, Bolivia.

\section{Condylopodium}

\section{Condylopodium R. King \& H. Robinson, Phytologia 24: 397. 1972. TYPE: Eupatorium fuliginosum H.B.K.}

Erect to subscandent shrubs, moderately branching with widely spreading branches. Stems terete, densely pubescent with coarse sometimes long non-glandular hairs. Leaves opposite, petioles distinct, short; blades broadly elliptical, base cuneate or rounded, margins entire to remotely serrulate, venation pinnate, undersurface with glandular punctations and hairs. Inflorescence broadly pyramidally paniculate, with branches spreading at right angles, terminating in denser panicles; pedicels short. Involucral bracts 20-30, subimbricate, in ca. 4-5 unequal graduated series, inner bracts deciduous, ovate to narrowly oblong, densely pubescent on outer surface; receptacle slightly convex, puberulous. Florets ca. 10-12 in a head; corollas greenish white, minimally narrowly funnelform, with glands above on outer surface; cells of limb oblong, often with sinuous lateral walls; lobes oblong-ovate, ca. 1.5 times as long as wide, erect, smooth on both surfaces; anther collars cylindrical, poorly demarcated at base, cells oblong, with weak annular thickenings on walls; anther appendage 


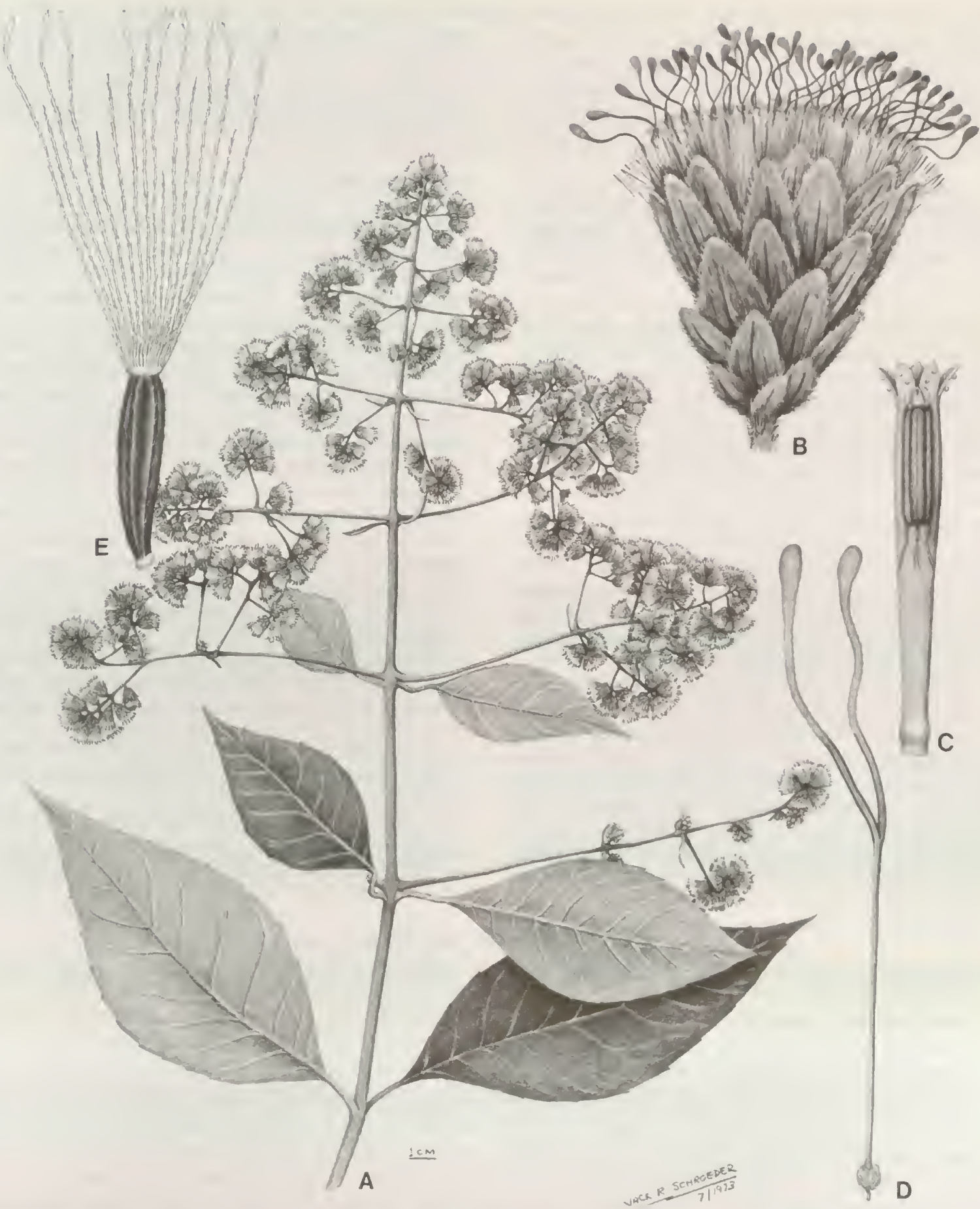

Plate 104. Condylopodium fuliginosum (H.B.K.) R. King \& H. Robinson. - A. Habit, $\times 4 \%$. - B. Head, $\times 8 .-$ C. Corolla showing anthers, $\times 16 .-D$. Style, $\times 16 .-$ E. Achene, $\times 16$. 
oblong-ovate, slightly longer than wide; style base enlarged, with or without somewhat contorted hairs; style branches scarcely to distinctly long-clavate, mamillose below, in broader forms becoming smooth at tip. Achenes prismatic, 5-ribbed, with sparse setulae or minute glands on sides; carpopodium shortly stoppershaped, without projecting upper rim, cells small and subquadrate in about 5 series, with thickened walls; pappus of 30-40 scabrid persistent contiguous bristles in 1 series, with broadened apices, apical cells obtuse. Pollen grains ca. 20-25 $\mu \mathrm{m}$ in diameter, with very short spinules. Plate 104.

A number of genera included in the present concept of the subtribe Alomiinae, such as Dyscritogyne and Steviopsis, show significant departures in one or more characters from the form found in most members of the subtribe, nevertheless, the genera betray in various ways a real relationship to the group. In contrast, Condylopodium is a genus included in the Alomiinae more because of the presence of certain technical characters than out of any strong conviction that it belongs. The lax shrubs with large pinnately veined leaves, and the involucres with distinctly deciduous inner bracts, give a strong impression of the subtribe Critoniinae. Even the rather Brickellioid narrow greenish white corollas and somewhat longly clavate style branches of Condylopodium are features duplicated or very closely approached in some members of the Critoniinae. It is the basal node of the style, alone, that immediately distinguishes the genus from all members of the Critoniinae, however, and indicates the need for placement in the Alomiinae. The degree of thickening of the style branches in the typical element of Condylopodium does tend to reinforce the latter placement.

The combination of Critonioid and Brickellioid characteristics in Condylopodium distinguishes the genus from any other genera in the tribe. The densely pubescent stems are also unlike those of other members of the Alomiinae. It seems of interest that Condylopodium is geographically restricted to Colombia, a part of South America where the subtribe Alomiinae is almost completely unrepresented. The latter fact would seem to decrease the possibility that the genus is a product of one of the inter- subtribal hybridizations that seem to occur in the Asteraceae.

The distinctive combination of characters seen in Condylopodium is shared by species that show some significant differences. The typical element of three species, distributed in central and western Colombia, has leaves with cuneate bases and pubescent basal nodes on the styles. The leaves of the group are densely sericeous to villous. The other species, C. killipii, differs by the broader leaves with abruptly rounded bases, by the puberulous to pilosulous leaf surfaces, and by the glabrous basal node on the style. The style branches of the latter species are also distinct in being scarcely clavate. No other genus of the Alomiinae shows variation in pubescence on the base of the style, and only one other member of the subtribe, Crossothamnus of Peru, shows a basal stylar node that is glabrous. Even in Crossothamnus, the stylar node is papillose with what might be regarded as incipient hairs.

A key to the genus has been provided by King and Robinson (1972rr).

The name Condylopodium is derived from the Greek words kondylos ( $=\mathrm{knob}$ ), and podion (= diminutive of foot), in reference to the enlarged basal node of the style.

The following four species are recognized in the genus: Condylopodium cuatrecasasii R. King \& H. Robinson, Colombia.

Condylopodium fuliginosum (H.B.K.) R. King \& H. Robinson, Colombia.

Condylopodium killipii R. King \& H. Robinson, Colombia. Condylopodium pennellii R. King \& H. Robinson, Colombia.

\section{Subtribe IX. LiatrinaE}

\section{Liatrinae R. King \& H. Robinson, Phytologia 46: 447. 1980. TYPE: Liatris Gaertner ex Schreber.}

Erect perennial herbs or small shrubs, often unbranched above base, with rosulate basal leaves at least in early stages. Leaves alternate, often decrescent upwardly, mostly sessile or subsessile, petioles when present not sharply delimited above. Inflorescence terminal on stems or branches, thyrsoid or corymbose to pseudospicate, heads clustered, not solitary, sessile or pedicellate; involucral bracts usually distinctly subimbricate with bracts of graduated lengths, persistent; receptacle flat or slightly convex, epaleaceous or with a few paleae, otherwise glabrous. Flowers 4-80 in a head; corollas mostly lavender or purple, funnelform; lobes shortly triangular to linear-oblong, mamillose or papillose inside, without stomata on outer surface; cells of anther collar with numerous subquadrate cells, ornamented with beaded or reticulate thickenings; anther appendage slightly wider than long to longer than wide, often truncate or retuse at tip; style base not enlarged, glabrous; style branches filiform or linear, not or scarcely broadened above, densely mamillose or shortpapillose. Achenes prismatic, mostly 8-10-ribbed, 5-ribbed in Hartwrightia, usually setuliferous on sides with setulae divided nearly to base, with only glands in Hartwrightia, micropunctations of walls not strongly aligned in transverse bands; carpopodium indistinct; pappus of many capillary, scabrid to plumose bristles in 1-3 series, with pointed apical cells, epappose in Hartwrightia. Basic chromosome number $x=10$. 
The subtribe Liatrinae is unique in the Eupatorieae by its geographical restriction to the United States in North America, being concentrated in the southeastern part of the country. The occurrence close to centers of taxonomic study has resulted in a more complete understanding of the subtribe prior to the present series of studies. The various detailed studies of Gaiser (1946, 1949, 1950a, $1950 b, 1954)$ are particularly significant. The changes that have bcen necessary during the present study have been minor comparcd to other subtribes, and precedent exists for most of the changes.

The Liatrinae show the subimbricate involucre with persistent bracts that might suggest relationship to such subtribes as the Ayapaninae, Alomiinae, or Fleischmanniinae. The Liatrinae, however, differs from the related pair of the Ayapaninae and Alomiinae by the mamillose or papillose inner surfaces of the corolla lobes, and by the lack of any enlargement or pubescence on the stylc base of the type common in those two subtribes. The Liatrinae also lack the many details of corolla lobe papillosity, carpopodial structure, and corolla venation and shape that are characteristic of the Fleischmanniinae. In papillosity of the corolla lobes, the Liatrinae seems more like subtribes that have basically eximbricate involucral bracts. The subtribe remains distinct from almost all other Eupatorieae by the characteristic basal rosette of leaves in all of the genera in at least the early stages.

The genera of the Liatrinae have been mostly recognized as a related group in previous literature, but have been included in a larger subtribe variously known as the Adenostylinae or Kuhniinae, characterized by mostly tenribbed achenes. The presence of plumose pappus bristles in both Liatris and the Kuhnia group of Brickellia undoubtedly impressed some authors as further evidence of relationship between the Brickellia and Liatris groups. However, in spite of the inclusion of some subgroups of related gcnera, the earlier subtribal concept was, in its overall dclimitation, highly artificial. Adenostyles Cassini, itsclf, proves to belong to the Senecioneae, as suggested by B. Robinson (1913a). Still, the remnant, placed by B. Robinson in his subtribe Kuhniinae, proves to contain four thoroughly distinct elements. as shown by Gaiser (1954). The four elements all show distinctive basic chromosome numbcrs, along with other differences. Kanimia was recognized by Gaiser as a relative of Mikania, the latter now known to have base numbers of $x=18,19$, or 20. Carphochaete, a relative of Stevia, having an awned pappus, shows a base of $x=11$. Kuhnia of the Alomiinae, was shown by Gaiser to have a base number of $x=9$, like the rest of the genus Brickellia with which it is now synonymized. Only the genera related to Liatris, among the members of the Kuhniinae of B. Robinson, show the common Eupatorian base number of $x=10$ (Gaiser, 1954).

In a kcy to the genera of the Kuhniinae, Gaiser (1954) distinguishes the Liatris rclationship as Group I, with the key characters being phyllaries not conspicuously striate, the leaves alternate, thc young plants with rosettes, thc corolla rose-colored, rarely white, the barbules of the pappus indefinitely arranged along thc axis, and the chromosome number $n=10$. The Brickellia group, in contrast, was defined by the phyllaries thin, striate, scarcely herbaceous, the leaves alternate or opposite, the young plants without rosettes, the corolla ochroleucous to yellow, rarely rose-colored, the barbules of the pappus tending to be in linear arrangcment along the axis, and the chromosome number $n=9$. The distinctive tubular corollas and longly clavate style branches of the Brickellia group were not mentioned. It can be secn that even the superficially similar plumose bristles of the pappus of $\mathrm{Li}_{\mathrm{i}}$ atris and the Kuhnia element of Brickellia are basically different in the alignment of the barbules along the axis.

King and Robinson (1970i) noted a distinctive form of setula or twin-hair on the achenes of Liatris that is now known also in Carphephorus, Trilisa, and Litrisa. Biseriate setulae or twin-hairs are found in most Asteraccae, and are characteristic of the family, but the two cells in most members of the family remain joined to near the tip. The setulae of the Liatris group differ by having the two cells separate near the base or having sctulae occasionally totally uniseriate. A few additional micro-characters that seem to distinguish the Liatris group are the lack of a carpopodium on the achene, and the laxly subquadrate to short-oblong cells usually without sinuous walls in the corollas of all the genera except Litrisa.

In spite of the well-established distinctions dating from the work of Gaiser (1954), it remained for King and Robinson $(1980 \mathrm{~g})$ to provide the formal scparatc subtribal status for the Liatris group. The delimitation of the subtribe followed mostly the traditionally recognized relatives of Liatris, but $\mathrm{H}$. Robinson and King (1977) included the genus Hartwrightia of the southeastern United States in the group, in spite of its lack of a pappus, its five-ribbed achenes, and its lack of setulae on the achenes. The correlation in geographical distribution, rosulate. habit, lack of a carpopodium, and lax subquadrate cells in the corolla seem to indicate that the latter genus was close to Liatris.

The various studies by Gaiser have provided detailed knowledge of the karyotypes of many members of the subtribe Liatrinae. The variations observed by Gaiser $(1949,1950 a, 1950 b)$ in Liatris are reviewed under that genus. A distinctive karyotype was noted by Giaser (1954) in the monotypic genus Garberia, having one of the two short pairs of chromosomes heterobrachial. Carphephorus and Trilisa had karyotypes that were alike, but different from Garberia in the closer approach of the shortest heterobrachial chromosome pair to the medium class. As such, the genera of the Liatrinae studicd by Gaiser could be placed in three groups on the basis of details in their chromosome structure.

Regarding generic limits, the primary area of disagreement in the Liatrinae involves the genera Carphephorus, Trilisa, and Litrisa. which the study by Gaiser (1954) indicated as indistinguishable on the basis of chromosome 
karyotype. Both Hebert (1968) and Correa and Wilbur (1969) opted for a broad generic concept, as indicated in detail under the respective genera. Such a broad concept is not regarded as unnatural, but is considered as less definable. Narrower generic concepts are restored in the present treatment.

The chemistry has been investigated in a number of members of the Liatrinae. Heliangolides are evidently present in both Liatris and Hartwrightia, as well as benzofurans and diterpenes (Bohlmann \& Dutta, 1979; Bohlmann et al., 1981b, 1981k). Reports of an Anthem- idian-type thiophen polyacetylene in Liatris pycnostachya (Atkinson \& Curtis, 1971), however, seems to be in error. The flavonoids in ten species of Liatris have been reported by Wagner et al. (1973), including kaempferitrin which is apparently rare in the Asteraceae (Dominguez, 1977). There are also reports of lignans and other compounds in Trilisa odoratissimus (Wahlberg et al., 1972; Karlsson et al., 1972a). Oleoresin obtained from the latter plant is used as a fixative in perfumery and the dried leaves are used as an additive to flavor tobacco (Dominguez, 1977).

\section{KEY TO THE GENERA OF THE SUBTRIBE LIATRINAE}

1. Pappus absent; achenes with 5 ribs, glanduliferous, without setulae

1'. Pappus present, of capillary bristles; achenes with 8-10 ribs, with few to many setulae

10. Hartwrightia

2. Shrubs; leaves of mature stems not or scarcely reduced in size on more distal parts of stems; pappus of 60-70 barbellate setae, shorter and more slender in outer series

2'. Erect perennial herbs with basal rosettes and decrescent upper leaves; pappus of 12-40 bristles 109. Garberia

3. Pappus bristles plumose or strongly barbellate; inflorescence usually spiciform or racemiform; heads without paleae; corolla often with hairs inside. with lobes narrowly lanceolate to linear-oblong; plants with corm-like or deeply penetrating root systems

3'. Pappus bristles scabrous or barbellate; inflorescence corymbose or thyrsoid; heads often with a few paleae; corolla glabrous inside, with lobes usually triangular to oblong; plants with fibrous roots

4. Pappus uniseriate; tip of anther appendage obtuse to rounded

4'. Pappus in ca. 2 series; tip of anther appendage distinctly retuse 107. Trilisa

5. Involucre with 15-40 closely overlapping bracts in 3-4 series; achenes densely setuliferous; heads with $12-35$ flowers 108. Carphephorus

5'. Involucre with 5-10 loosely overlapping bracts in 2-3 series; achenes with sparse short setulae and numerous glands; heads with 5-10 flowers 106. Litrisa

\section{Liatris}

Liatris Gaertner ex Schreber, Gen. Pl. 2: 542. 1791, nom. cons. TYPE: Serratula squarrosa L. [= Liatris squarrosa (L.) Michaux].

Lacinaria Hill, Veg. Syst. 4, ed. 2: 49. 1772. LeCtOTYPE: Serratula squarrosa L. [= Liatris squarrosa (L.) Michaux].

Psilosanthus Necker, Elem. Bot. 1: 69. 1790, nom. inval.

Suprago Gaertner, Fruct. Sem. P1. 2(3): 402. 1791 . LeCTOTYPE: Serratula spicata L. [= Liatris spicata (L.) Willd.].

Calostelma D. Don in Sweet, Brit. Flow. Gard. Ser. 2, 2: 184. 1833. TYPE: Staehelina elegans Walter [= Liatris elegans (Walter) Michaux].

Liatris section Suprago (Gaertner) DC., Prodr. 5: 129. 1836.

Ammopursus Small, Bull. Torrey Bot. Club 51: 392. 1924. TyPE: Lacinaria ohlingerae S. F. Blake [= Liatris ohlingerae (S. F. Blake) B. Robinson].

Erect perennial herbs, with a thickened, usually corm-like, penetrating rootstock, unbranched except at base and rarely in inflorescence. Stems terete, striated. Leaves alternate, initially in basal rosette, decrescent upwardly, sessile or narrowed into petiole; blades linear, elliptic, or oblanceolate, margins entire, venation uninervate or with strongly ascending to subparallel secondaries, surfaces with glandular punctations. Inflorescence always cymose in order of maturation, usually spicate or racemose in shape, corymbiform in $L$. cymosa and L. ohlingerae; with or without distinct pedicels. Involucral bracts ca. 20-25, subimbricate, in 3-5 unequal graduated series, mostly persistent, broadly rounded to oblong-lanceolate, petaloid with colored or whitish tips in L. elegans; receptacle nearly flat, epaleaceous, glabrous. Florets 3-80 in a head; corollas usually purple, sometimes lavender or white, broadly to narrowly funnelform, usually with glandular punctations on outer surface, rarely with uniseriate hairs outside, inner surface often with hairs near insertion of 


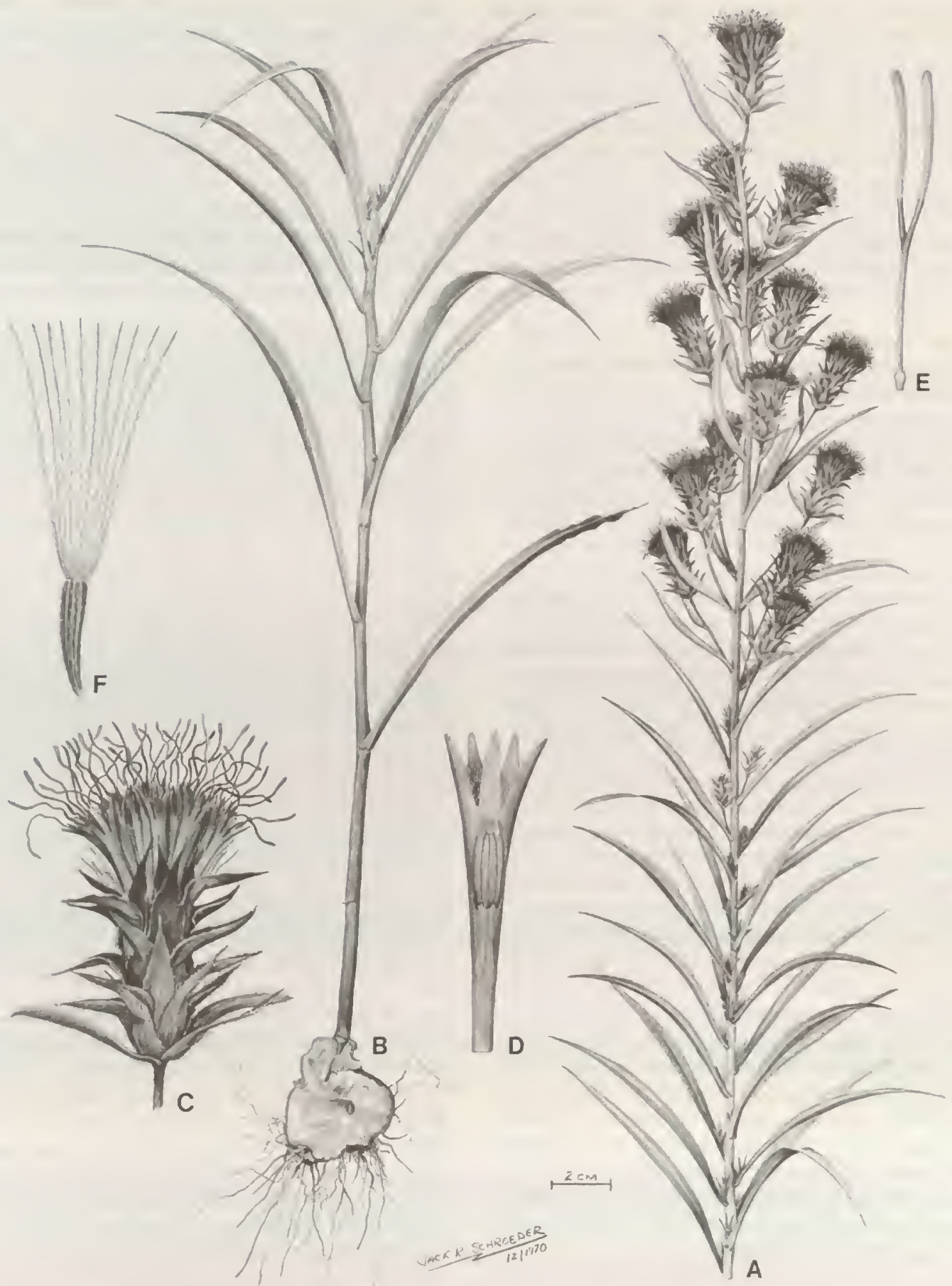

Plate 105. - Liatris squarrosa (L.) Michaux. - A. Habit, $\times 4 / \% .-$ B. Base of plant, $\times \%$. - C. Head, $\times 1 \frac{1}{2},-$ D. Corolla showing anthers and internal hairs, $\times 2 \frac{1}{2}$. - E. Style, $\times 2 .-F$. Achene, $\times 2 \frac{1}{2}$. 
filaments or on lobes; cells of limb laxly subquadrate to short-oblong, without sinuous walls; lobes linearlanceolate to linear oblong, ca. 3-4 times as long as wide, densely mamillose or short-papillose on at least distal part of inner surface, smooth on outer surface; anther collars broadly cylindrical or slightly broadened below, cells subquadrate below, longer above, with beaded or intricate thickenings on walls; anther appendage usually oblong-ovate and as long as wide, short and obsolete in L. cymosa, L. elegans, and L. ohlingerae; style base not enlarged, glabrous; style branches narrowly linear to scarcely broadened distally, flattened, densely mamillose, often with glands on inner surface, with septate hairs on upper shaft and abaxially on lower half of branches in $L$. cylindracea and $L$. squarrosa. Achenes prismatic, with ca. 10 ribs, densely setuliferous on sides, setulae with two cells usually diverging from near base; carpopodium lacking; pappus of ca. 12-40 plumose or strongly barbellate bristles in 1-2 series, persistent, scabrae and fimbrae on both lateral and outer surfaces, apical cells acute. Pollen grains ca. 21-36 $\mu \mathrm{m}$ in diameter. Plate 105.

The genus Liatris consists of many species of striking appearance, native to eastern North America, where it is the largest and most widely distributed genus in the subtribe. The range extends north to Canada and west to Colorado and New Mexico. As such, the genus came early to the attention of botanists, and has continued to receive considerable and often careful attention. On the basis of the monographic (1946) and cytological (1949, 1950a, $1950 \mathrm{~b}$ ) studies of Gaiser, the genus remains one of the most intensively studied in the Eupatorieae.

The earliest treatments of species of Liatris tend to confuse the genus with members of other tribes, particularly members of the subfamily Cichorioideae. The genera Serratula and Staehelina, in which Linneaus and Walter placed some of the species, are members of the tribes Cardueae and Carlineae. A second species placed by Gaertner (1791) in his genus Suprago, was a Vernonia of the tribe Vernonieae. Nevertheless, comments by Gaertner (1791) under Suprago indicate that he recognized at least part of what is now called Liatris as being close to Eupatorium. Confusion at the tribal level continued to a limited degree, as the name Liatris, itself, was applied to some members of the Cichorioideae. Liatris baicalensis Adams of Siberia, proves to be a Saussurea in the tribe Cardueae, the Himalayan species of Liatris validated by C. B. Clarke (1876) prove to be species of Ainsliaea in the Mutisieae, and L. umbellata Bertol. is a Vernonia.

The name Liatris has had comparatively limited abuse within the Eupatorieae. Gardner did place in Liatris two Brazilian species now placed in the genera Leptoclinium of the subtribe Alomiinae, and Symphyopappus of the Disynaphiinae. The remaining extensions of the use of the name Liatris included one for a species of Chromolaena of the subtribe Praxelinae, but are mostly restricted to the closely related genera Carphephorus, Garberia, and Trilisa in the subtribe Liatrinae.

Within the Liatrinae, Liatris is distinctive by its cormlike or penetrating rootstock, the sometimes plumose pappus, the sometimes pubescent inner surface of the corolla, and the usually spicate to racemose shape of the inflorescence. The elongate lobes of the corollas distinguish $\mathrm{Li}$ atris from all except the distinctive shrubby Garberia. Though clearly related to Carphephorus, and showing a number of convergent features in some species, the genus
Liatris stands unmistakably outside of the complex including Carphephorus, Litrisa, and Trilisa. Though regarded as collateral phyletically to the Carphephorus complex as presently represented in the fora, it should be noted that Liatris is comparatively specialized in its characters, and possesses comparatively less basic diversity among its many species.

The various generic names that have been provided for Liatris are of interest. The first two names chronologically, Lacinaria Hill and Psilosanthus Necker, have been rejected nomenclaturally, the former through conservation of the name Liatris, and the latter through the blanket rejection of all Necker names. Still, the name Lacinaria or Laciniaria was used in a number of foristic treatments. The remaining generic names all represent distinctive species or species groups of some significance. The name Suprago continues to be used at the sectional level for the large element of the genus having only barbellate pappus bristles, and presumably represents a natural group. The section contains most of the species of the genus, but has a comparatively uniform habit similar to that of the type of Liatris. Greater superficial diversity is seen in the section Liatris containing approximately ten species having plumose pappus bristles. The section Liatris shows some diversity of interest, including species that have been the basis for two segregate genera. The genus Calostelma seemed to be rather casually described to accommodate the horticulturally interesting $L$. elegans with its showy petaloid involucral bracts, but little noticed until recently (King \& Robinson, 1970i) was the obsolete anther appendage of the species. Ammopursus was described for $L$. ohlingerae, a Florida species with an unusual broadly cymose inflorescence, an almost rotate corolla, and a somewhat segmented or lobed root. As indicated by Gaiser (1946), a second species, L. cymosa of Texas, has a similar inflorescence, and both species have obsolete anther appendages.

In her monograph of Liatris, Gaiser (1946) recognized ten series, four in section Liatris and six in section Suprago. Gaiser $(1949,1950 a)$ studied four of the series in section Suprago cytologically and found them prevailingly diploid with some distinction in karyotypes. The Spicatae and Pycnostachyae exhibited variation in chromosome length, with some medium and long chromosomes with 
subterminal constrictions. The Graminifoliae and Pauciflorae had more uniform karyotypes. Gasier $(1950 b)$ also studied the series Punctatae in the section Liatris which proved to be the only prevailingly polyploid series in the genus.

Most of the series of Gaiser seem to represent related groups, although there are, as stated by Cronquist (1980), numerous hybrids, some of them between species that are not closely related. There is certainly no reason to alter two of the series in the section Liatris, the Elegantes containing only $L$. elegans with its petaloid involucral bracts and its reduced anther appendage, and the Punctatae with its polyploidy. In the same section, however, $L$. ohlingerae and $L$. cymosa, with cymose inflorescences and reduced anther appendages, seem out of place with $L$. cylindracea in the Cylindraceae. The latter species with its racemose inflorescence, large anther appendages, corolla lobes with hairs inside, and styles with septate hairs, would seem best placed with $L$. squarrosa in the series Squarrosae.

The striking inflorescences of Liatris have resulted in the plants being grown horticulturally. Fragrance, apparently, has been reported from only one variety of Liatris scariosa and from L. tenuifolia (Gaiser, 1946). As noted by Gaiser, the seemingly spicate and racemose inflorescences of the genus are all strictly cymose in the order of maturation of the heads. Gaiser notes that the first maturing apical head is often larger than the others, and that depauperate specimens of many species have only one such larger head.

The origins of the names Liatris and Suprago seem to be unknown. The name Lacinaria would seem to refer to the small divisions of the pappus bristles. Calostelma seems to be derived from the Greek words kalos (= beautiful), and stele (= pillar or column), in reference to the inflorescence. According to Small (1924), the name Ammopursus means "sand-torch," in reference to the habitat and the blazing rose-purple flower heads of the type species. Common names given for Liatris by Cronquist (1980) are Blazing star, Gay feather, and Button Snakeroot.

The following 42 species and hybrids are recognized in the genus:
Liatris acidota Engelm. \& A. Gray, SE United States. Liatris angustifolia (Bush) Gaiser, central United States, Liatris aspera Michaux, E United States.

Liatris borealis Nutt. ex Macnab, NE United States. Liatris boykinii $\times$ Torrey \& A. Gray, SE United States. Liatris bracteata Gaiser, Texas.

Liatris chapmanii Torrey \& A. Gray, SE United States. Liatris creditonensis $\times$ Gasier, cultivated.

Liatris cylindracea Michaux, E United States, Ontario. Liatris cymosa (Nessel) Schumann, Texas.

Liatris densispicata (Bush) Gaiser, Minnesota.

Liatris earlei (E. Greene) Schumann, E United States. Liatris elegans (Walt.) Michaux, SE United States.

Liatris fallacior $\times$ (Lunell) Rydb., North Dakota.

Liatris frostii $\times$ Gaiser, Minnesota.

Liatris garberi A. Gray. Florida, Bahama.

Liatris gladewitzii $\times$ (Farw.) Farw. in Shinn., Wisconsin, Michigan, Ontario.

Liatris gracilis Pursh, SE United States.

Liatris graminifolia (Walt.) Willd., E United States.

Liatris helleri (Porter) Porter, North Carolina.

Liatris laevigata Nutt., Florida.

Liatris lancifolia (E. Greene) Kittell in Tidstrom \& Kittell, central \& SW United States.

Liatris ligulistylis (A. Nelson) Schumann, N central United States. Liatris microcephala (Small) Schumann, SE United States.

Liatris mucronata DC., Texas, central United States.

Liatris ohlingerae (S. F. Blake) B. Robinson, Florida.

Liatris pauciflora Pursh, SE United States.

Liatris pilosa (Aiton) Willd., E United States.

Liatris provincialis Godfrey, Florida.

Liatris punctata Hook., E \& SW United States, N Mexico.

Liatris pycnostachya Michaux, central United States, Texas.

Liatris regimontis (Small) Schumann, SE United States.

Liatris ridgwayi $\times$ Standley, Illinois.

Liatris scariosa Willd., E United States.

Liatris spheroidea $\times$ Michaux, Ontario, central United States.

Liatris spicata (L.) Willd., E United States to Wyoming.

Liatris squarrosa (L.) Willd., E United States.

Liatris squarrulosa Michaux, E United States.

Liatris stellei $\times$ Gaiser, Indiana.

Liatris tenuifolia Nutt., SE United States.

Liatris tenuis Shinn., Texas.

Liatris turgida Gaiser, SE United States.

Liatris weaveri $\times$ Shinn., Nebraska, cultivated.

\section{Litrisa}

\section{Litrisa Small, Bull. Torrey Bot. Club 51: 392. 1924. TYPE: Litrisa carnosa Small.}

Erect, scapose, perennial herbs, with depressed basal rosette; with freely branching rootstock. Stems from stout basal caudices, flowering stems terete, striated, unbranched, densely pubescent. Leaves alternate, mostly in basal rosette, abruptly reduced and decrescent on scape, mostly subsessile; blades somewhat carnose, oblanceolate, margins entire, apices narrowly acute to acuminate, secondary veins subparallel, surfaces with numerous minute glandular punctations. Inflorescence a flat-topped corymbose cyme; pedicels short. Involucral bracts 5-10, weakly subimbricate in 2-3 somewhat unequal series, mostly persistent, with hairs and glands on outer surface; receptacle slightly convex, usually glabrous or with 1-2 paleae. Florets 5-10 in a head; corollas purple, narrowly funnelform, with a few glands on outer surface, glabrous inside; cells of throat oblong, with somewhat sinuous lateral walls; lobes triangular, ca. 1.5 times as long as wide, inner surface 

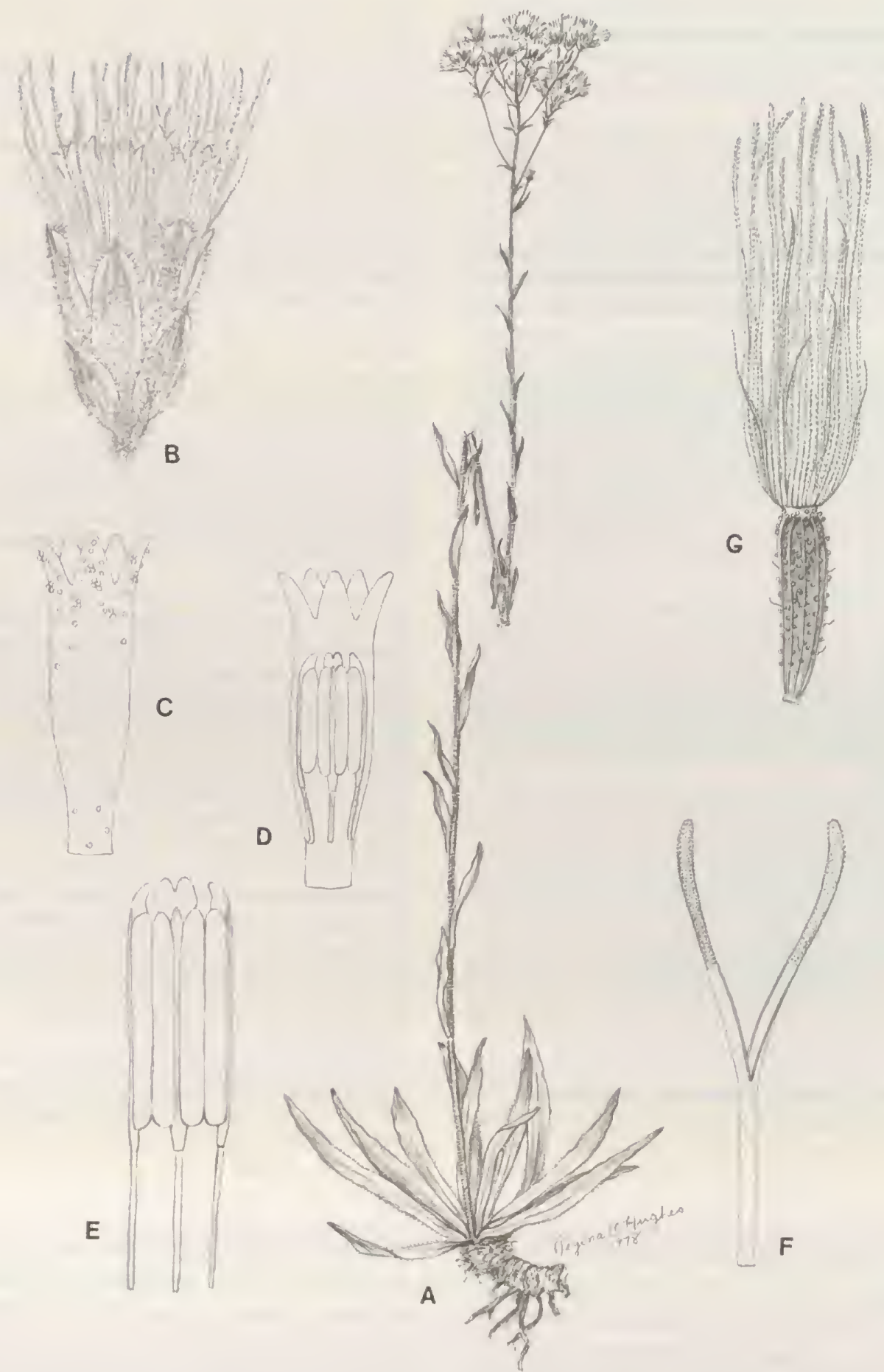

PLATE 106. Litrisa carnosa Small. - A. Habit, $\times 1 / 2,-$ B. Head, $\times 7$, - C. Corolla outer surface, $\times 12 .-D$. Corolla outline with anthers, $\times 12 .-$ E. Group of anthers, $\times 20 .-F$. Style, $\times 12 .-$ G. Achene, $\times 10$. 
mamillose with isodiametric bulging cells, outer surface with numerous glands and some hairs; anther collar short-cylindrical somewhat narrowed above, with many subquadrate to transversely oblong cells below, longer cells above, with beaded thickenings on walls; anther appendage large, ovate, as long as wide, retuse at tip; style base not enlarged, glabrous; style branches narrowly linear, densely short-papillose, without glands or hairs. Achenes prismatic, 8-10-ribbed, with glands and setulae on sides, setulae sometimes sparse, contorted, usually forking well below tip; carpopodium lacking: pappus of ca. 35 scabrid persistent bristles in ca. 2 series, apical cells acute. Pollen grains ca. $25 \mu \mathrm{m}$ in diameter. Plate 106.

Litrisa contains a single species endemic to the prairie areas of peninsular Florida. The genus was one of many described or resegregated by J. K. Small (1924) in his study of the flora of the southeastern United States, and it has seemed to suffer from the general lack of credibility of Small's generic concepts. Litrisa is unquestionably closely related to the genus Carphephorus, with which it is sympatric, and it has been reduced to synonymy under that genus by most recent authors (James, 1958; Hebert, 1968; Correa \& Wilbur 1969; Cronquist, 1980). Litrisa was placed in the synonymy of another closely related genus, Trilisa, by B. Robinson (1934a) and Gaiser (1954).

Litrisa is most similar to Carphephorus, and distinct from Trilisa, in the multiseriate pappus, the distinctly retuse tip of the anther appendage, and the glandularpunctate leaf surfaces. There is also a greater degree of imbrication in the involucre, although not much more than in Trilisa, and not as much as in Carphephorus. The weakly subimbricate involucre and the tendency for few or no paleae on the receptacle, are the only points of particular similarity between Litrisa and Trilisa, and both characters seem to be correlated with general size of the heads. As indicated in the discussion under Carphephorus, the smaller head size of Litrisa and Trilisa is not considered here as evidence of close relationship between them.

In restoring Litrisa to generic status, the smaller heads with much less imbricated involucral bracts are recognized as the best key character. However, more important is the very different form of inflorescence with strongly ascending densely cymose branches. The pedicels are short with few or no subinvolucral bracts, while in Carphephorus the pedicels are mostly long and bear numerous small bracts. The achene in Litrisa also differs, having comparatively few setulae, especially in the upper half, and having the setulae very contorted with anomalous septations. The cells of the corolla of Litrisa tend to be narrower than those of Carphephorus, and the cells of the inner layer seem to consistently have sinuous lateral walls, a feature very rare in Carphephorus which usually has straight walls on all the corolla cells.

The name of the resurrected genus Litrisa was originally derived by Small (1924) as an anagram of Liatris.

The following single species is recognized in the genus: Litrisa carnosa Small, Florida.

\section{Trilisa}

Trilisa (Cass.) Cass., Dict. Sci. Nat. 26: 228. 1823.

Anonymos Walt., Fl. Carol. 196. 1788, pro parte, nom. illeg.

Liatris subgenus Trilisa Cass., Bull. Soc. Philom. Paris 1818: 140. 1818. TYPE: Liatris odoratissima (J. Gmelin) Michaux [= Trilisa odoratissima (J. Gmelin) Cass.].

Liatris section Trilisa (Cass.) DC., Prodr. 5: 131. 1836.

Liatris subgenus Euthyrsis Raf., New Fl. 4: 75. 1838. LeCTOTYPE: Liatris paniculata (J. Gmelin) Michaux [= Trilisa paniculata $(\mathrm{J}$. Gmelin) Cass.].

Liatris subgenus Osmilis Raf., New Fl. 4: 75. 1838. TYPE: Liatris odoratissima (J. Gmelin) Michaux [= Trilisa odoratissima (J. Gmelin) Cass.].

Erect, scapose, perennial herbs, with basal rosette, with short rootstock and thickened fibrous roots. Flowering stems terete, striated, unbranched. Leaves alternate, in rosette with narrow bases, on scape rapidly decrescent and sessile; blades oblanceolate to obovate or rather narrowly elliptic, somewhat succulent, margins entire or coarsely few-dentate, apices obtuse to short-acute, 2-3 pairs of strongly ascending nearly longitudinal secondary veins, surfaces without obvious glandular punctations. Inflorescence corymbose or thyrsoid in form, slightly cymose in order of maturation; pedicels mostly short. Involucral bracts ca. 6-12, eximbricate to weakly subimbricate in ca. 2 series, slightly unequal to subequal, inner bracts not deciduous, with numerous glands and sometimes hairs on outer surface; receptacle slightly convex, usually epaleaceous, or with $1-2$ paleae. Florets 4-10(-15) in a head; corollas pink to purplish, narrowly funnelform, with numerous glands on outer surface, glabrous inside; cells of throat short-oblong to subquadrate, with non-sinuous or scarcely 


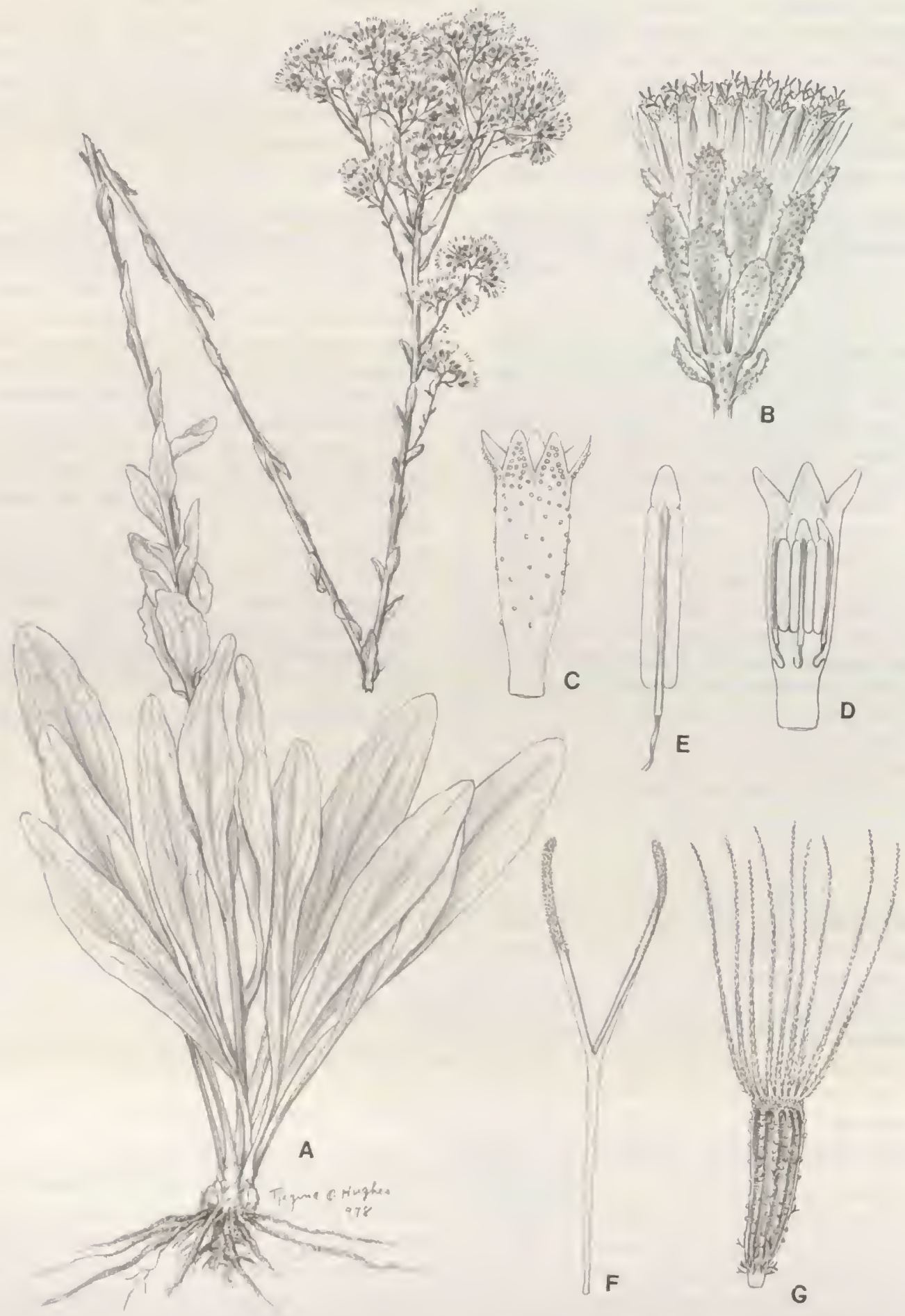

PLATE 107. Trilisa odoratissima (Willd.) Cass. - A. Habit, $\times 1 / 2,-$ B. Head, $\times 6 .-$ C. Corolla outer surface, $\times 9 .-$ D. Corolla inner surface with anthers, $\times 9 .-$ E. Anther, $\times 18 .-F$. Style, $\times 9 .-G$. Achene, $\times 9$. 
sinuous walls; lobes triangular, ca. 1.25-1.5 times as long as wide, densely short-papillose on inner surface; anther collar cylindrical, with many subquadrate or shorter cells below, oblong cells above, with beaded thickenings on walls; anther appendage large, slightly longer than wide, rounded to scarcely retuse at tip; style base not enlarged, glabrous; style branches filiform, densely short-papillose. Achenes prismatic, ca. 8-ribbed, with glands and setulae on sides, setulae mostly straight, usually forked or becoming uniseriate well before tip; carpopodium lacking; pappus of ca. 35 persistent scabrid bristles, mostly in 1 series, with narrower bristles sometimes between and slightly outside of larger bristles, apical cells acute. Pollen grains ca. $25 \mu \mathrm{m}$ in diameter. Plate 107.

Trilisa was described by Cassini $(1818 d)$ with the realization that it was related to Carphephorus, but it was placed as a subugenus of Liatris because of the lack or near lack of paleae on the receptacle. Trilisa was subsequently recognized at generic rank by Cassini (1823a, $1828 b$ ) with the inclusion of two species from the southeastern United States. The genus was maintained as distinct by authors up to the time of B. Robinson (1913a), Gaiser (1954), and James (1958), but was reduced to synonymy under Carphephorus by Hebert (1968), Correa and Wilbur (1969), and Cronquist (1980). Briefly, Trilisa was expanded to include three species with the addition of the monotypic Litrisa of J. K. Small (B. Robinson, 1934a), although the latter is generally recognized as being closer to Carphephorus (James, 1958; Correa and Wilbur, 1969). The present treatment restores separate generic status for both Trilisa and Litrisa.

The authors that reduce Trilisa to synonymy under Carphephorus emphasize the fact that paleae can be present on the receptacles in all three genera of the complex. The other commonly cited character of Trilisa, the eximbricate involucre, is also questioned by such authors, with reference to the intermediate form of weakly subimbricate involucre in Litrisa. The very different forms of inflorescence in the two species of Trilisa may have caused some doubt regarding the naturalness of the genus, further complicating the concept. Ultimately, it must be acknowledged that the broad concept combining Trilisa, Litrisa, and Carphephorus is not phyletically wrong.

The present acceptance of Trilisa as a separate genus rests on the conviction that the two species form a natural group, and on the presence of a number of distinguishing characters, some of which have not been noted previously. Correa and Wilbur (1969) did notice the mostly nonretuse tips of the anther appendages, but the leaves also lack glandular punctations on the surfaces, there is ap- parently no penetrating or elongate rootstock, and the pappus bristles are mostly in one series with narrower bristles inserted slightly outside at some of the gaps. The rootstock mentioned shows none of the elongation seen in most specimens of Litrisa and Carphephorus. The lack of glandular punctations was analyzed by Gaiser (1954) showing the presence of rosette-like cell arrangements around single non-depressed surface cells, and showing a complete lack of depressed biseriate glands of the type seen in Carphephorus and Litrisa. The phyletic gap between Trilisa and Carphephorus becomes more obvious when the eximbricate involucre of the former is compared directly with the strongly subimbricate involucre of the latter, without consideration of the seemingly intermediate Litrisa. It is the present view that Litrisa is not particularly close to Trilisa, and that it should not be viewed as intermediate. The involucre, flower number, and reduced incidence of paleae, by which Litrisa resembles Trilisa, are all simply facets of trends toward reduction in the size of the heads, and other evidence would indicate the two genera are not in the same line of reduction.

The two species of Trilisa have rather wide and greatly overlapping distributions in the southeastern United States from North Carolina south into peninsular Florida and west along the Gulf Coast. This suggests a somewhat different biology from the species of Carphephorus which mostly have more restricted and non-overlapping distributions. The habitats of the Trilisa species are summarized by Correa and Wilbur (1969) as savannahs and open pinelands or piney flatwoods in the Coastal Plain.

The name Trilisa is an anagram of Liatris.

The following two species are recognized in the genus:

Trilisa odoratissima (Willd.) Cass., SE United States. Trilisa paniculata (Willd.) Cass., SE United States.

\section{Carphephorus}

Carphephorus Cass., Bull. Soc. Philom. Paris 1816: 198. 1816. TyPE: Carphephorus pseudoliatris Cass. Liatris subgenus Corymbilis Raf., New Fl. 4: 75. 1838.

Erect, scapose, perennial herbs, with a basal rosette, with short or narrow rootstock, with thickened fibrous roots. Flowering stems terete, striated, unbranched. Leaves alternate, decrescent upwardly, sessile to subsessile or with winged bases; blades linear to linear-lanceolate or oblanceolate, margins entire, secondary veins obscure or strongly ascending to nearly longitudinal, surfaces with distinct glandular punctations. Inflorescence 


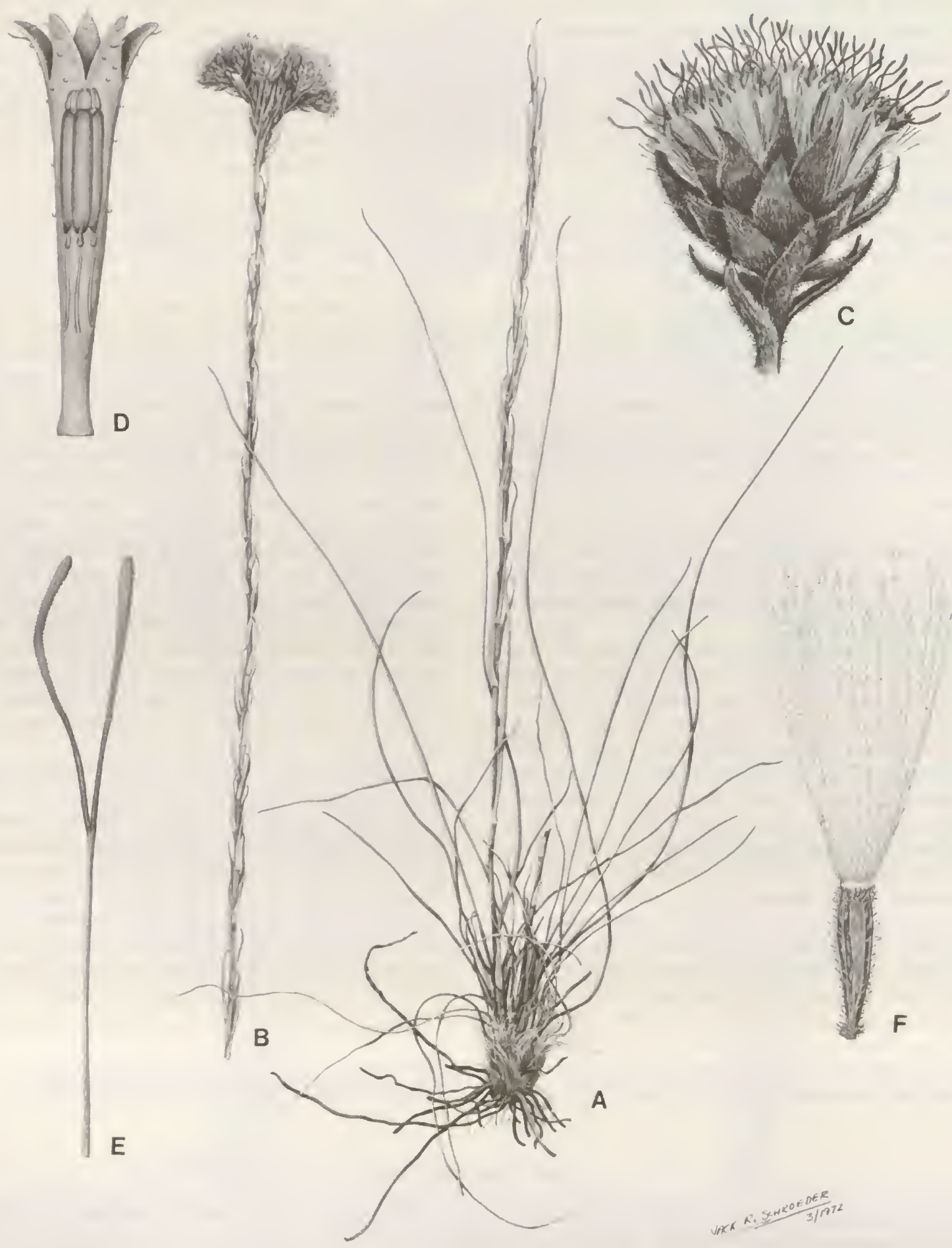

Plate 108. Carphephorus pseudoliatris Cass. - A. Habit, base, $\times 5 / \% .-B$. Inflorescence, $\times 5 / 9 .-$ C. Head, $\times 4 .-$ D. Corolla showing anthers, $\times 11 .-$ E. Style, $\times 11 .-$ F. Achene, $\times 8$. 
an open flat-topped corymbose cyme; pedicels usually moderately long, with many squamulose bracts. Involucral bracts ca. 15-40, distinctly subimbricate in ca. 3-5 strongly unequal graduated series, mostly or totally persistent, with rounded or acute tips, with or without obvious hairs on margins and outer surface; receptacle slightly convex, usually with a few paleae, sometimes glabrous. Florets ca. $12-35$ in a head; corollas lavender to purple, funnelform or with narrowly campanulate throat, usually with glands on outer surface, glabrous in C. bellidifolius, glabrous on inner surface; cells of throat short-oblong or sometimes subquadrate, with lateral walls not or weakly sinuous; lobes triangular to triangular-oblong, ca. 1.5-2.5 times as long as wide, densely short-papillose on inner surface, smooth on outer surface; anther collar short-cylindrical, slightly constricted above, with numerous subquadrate cells below, oblong cells above, walls with beaded thickenings; anther appendage medium-sized to large, ovate-oblong, as long as wide, distinctly retuse at tip; style base not enlarged, glabrous; style branches narrowly linear, rather densely high-mamillose or shortpapillose. Achenes prismatic, ca. 10-ribbed, with numerous setulae and often with glands on sides, setulae rather straight and becoming forked or uniseriate well before tip; carpopodium lacking; pappus of ca. 3540 scabrid or barbellate somewhat unequal bristles, congested in $2-3$ series, apical cells acute. Pollen grains ca. $25 \mu \mathrm{m}$ in diameter. Plate 108.

The genus Carphephorus is generally recognized as forming a related group with Trilisa and Litrisa, within the larger gro up recognized here as the subtribe Liatrinae. The three genera of the Carphephorus complex, in spite of some past confusion on the point, are now known to share a tendency for paleaceous receptacles (James 1958), and the available information indicates that all show the same chromosome karyotype (Gaiser, 1954). The three genera also show reasonable uniformity in their habit compared to the other pappose genera of the subtribe, having neither the shrubby habit of Garberia or the spicate to racemose inflorescences of Liatris. All evidence seems to confirm that Carphephorus. Trilisa, and Litrisa together form a natural group.

The obvious relationship between Carphephorus, Trili$s a$, and Litrisa has led numerous recent authors to partially or completely reduce the genera to synonymy, $\mathrm{Li}$ trisa into Trilisa (B. Robinson 1934a; Gaiser, 1954), Litrisa into Carphephorus with Trilisa separate (James, 1958). and all three together under Carphephorus (Hebert, 1968; Correa \& Wilbur, 1969; Cronquist, 1980). Only one of these, the combination of Litrisa with Trilisa, is regarded here as phyletically untenable, nevertheless, all the various reductions to synonymy are rejected here for two reasons. First, the broader concept of Carphephorus, though natural, is difficult to define in contrast to Liatris. Secondly, the actual differences between Carphephorus, Trilisa, and Litrisa have been underestimated by the various authors favoring synonymy.

Although the Carphephorus group and Liatris are clearly distinct, and are widely recognized as such, the key characters all fail at one or more points. The spicate or racemose form of inflorescence in Liatris is closely approached in some plants of Trilisa paniculata, and two species of Liatris, L. cymosa and L. ohlingerae, have inflorescences that are corymbose cymes. The plumose pappus often cited for Liatris is found in only the typical section that was recognized as Liatris by Cassini $(1816 b)$. The barbellate pappus form of species in the section $S_{l l-}$ prago is often equalled in species of Carphephorus. All of Liatris does not have a corm-like rootstock, and members of Carphephorus and Litrisa seem to have elongate rootstocks. The paleae of the receptacle in the Carphephorus complex are not always present, especially in Trilisa and Litrisa. Even the elongate corolla lobes of Liatris are essentially equalled in Carphephorus bellidifolius. It can be seen that the reduction of Trilisa and Litrisa to synonymy simplifies the generic concepts within the Carphephorus complex at the cost of complications at a higher level.

Actually, detailed examination shows that the differences between Trilisa, Litrisa, and Carphephorus are greater than previously thought. Hebert (1968) contended that the broad concept of Carphephorus was justified by the fact that equivalent variation in Liatris was not recognized at the generic level. We acknowledge the variation in Liatris, but do not agree that it is equivalent. The genus Liatris appears to be a comparatively uniform genus in the process of active diversification, while the Carphephorus group is unquestionably more relictual in nature. Correa and Wilbur (1969) commented on the remarkably distinct nature of all seven species in the Carphephorus complex.

In combining the genera of the Carphephorus complex. the various authors overlooked a number of characters. and perhaps for that reason, they made certain erroneous basic assumptions about the evolution of the group. In one example, Correa and Wilbur (1969) over-emphasize the importance of the thyrsoid inflorescence of Trilisa paniculata, and their evolutionary diagram relegates the two species of Trilisa to separate origins from the base of the complex. The unity of Trilisa as a derived group is not recognized, and the unifying characters of the uniseriate pappus, the lack of normal glandular punctations on the leaves, the short rootstock, the non-retuse tips on the anther appendages, and the non-imbricated involucral bracts are only partially appreciated.

The most consistent and serious flaw in previous studies, however, seems to be the inattention given Litrisa, 
and the tendency to regard it as intermediate between Carphephorus and Trilisa. The involucre and palea reductions, by which Litrisa resembles Trilisa, are only facets of a simple and scarcely unique process of reduction of head size and structure. In all other characters, Litrisa is remote from Trilisa and nearest Carphephorus. The other characters by which Litrisa differs from Carphephorus, the distinctive inflorescence with short non-squamuliferous pedicels and the contorted comparatively sparse setulae of the achene, both suggest evolution in Litrisa completely divergent from that in Trilisa.

The present view of the Carphephorus complex accepts an ancestor with larger heads having well-developed paleae on the receptacle, derived from more remote ancestors with epaleaceous receptacles. Still. Carphephorus, itself, is not considered ancestral in the complex, being specialized in its rather elongate pedicels with numerous squamulose bracts. Carphephorus, although specialized within the complex, nevertheless, is sufficiently old to produce four totally distinctive species that show no intergradation.
The species of Carphephorus have distributions that are all narrow compared to those of the two species of Trilisa, and the ranges of the Carphephorus species do not overlap except in the cases of $C$. bellidifolius and $C$. tomentosus in the Carolinas. The first of these seems distinctive in the generic complex by its often clustered stems (Correa $\&$ Wilbur, 1969). The most distinctive species in the genus is the narrow-leaved type species of the genus, C. pseudoliatris, from the Gulf Coast. Keys to all the species of the complex have been provided by James (1958), Correa and Wilbur (1969), and Cronquist (1980).

The name Carphephorus comes from the Greek karphos (= chaff), and phoras (= bearing), in reference to the paleae on the receptacle.

The following four species are recognized in the genus: Carphephorus bellidifolius Torrey \& A. Gray, SE United States. Carphephorus corymbosus (Nutt.) Torrey \& A. Gray, Florida, Georgia.

Carphephorus pseudoliatris Cass., SE United States.

Carphephorus tomentosus (Michaux) Torrey \& A. Gray, SE United States.

\section{Garberia}

Garberia A. Gray, Proc. Acad. Nat. Sci. Philadelphia 1879: 379. 1879. TYPE: Liatris fruticosa Nutt.

Liatris section Leptoclinium Nutt., Amer. J. Sci. Arts 5: 299. 1822. TYPE: Liatris fruticosa Nutt.

Leptoclinium (Nutt.) A. Gray, Proc. Amer. Acad. Arts 15: 48. 1879, non Leptoclinium Benth. in Benth. \& J. D. Hook.

Small erect shrubs, with moderate branching, seedlings with basal rosettes; stems, leaves, pedicels, and more exposed surfaces of involucral bracts with numerous glandular punctations. Stems terete, striated when dry. Leaves alternate, initially rosulate at base, usually distinctly short-petiolate; blades viscid when fresh, spathulate to spathulate-obovate or rounded-obovate, often slightly retuse at tip, base acuminate, margins entire. Inflorescence a corymbose panicle; peduncles mostly short, sometimes longer and slender, with few or no bractlets. Involucral bracts ca. 15, subimbricate in ca. 3 strongly unequal series, persistent, spreading with age; receptacle slightly convex, epaleaceous, glabrous. Florets 5 in a head; corollas pink to purplish, narrowly funnelform with slightly campanulate throat, glabrous on both surfaces; cells of throat rather oblong on outer surface, more subquadrate and often slightly bulging inside; lobes 4-5 times as long as wide, longer than throat, inner surface densely and rather antrorsely short-papillose, outer surface smooth; anther collar short-cylindrical, cells mostly short-oblong, some below middle subquadrate, with intricate rather multipitted thickenings on walls; anther appendage large, slightly longer than wide, somewhat retuse at tip; style base not enlarged, glabrous; style branches longly linear, densely short-papillose. Achenes prismatic, ca. 10-ribbed, densely setuliferous, setulae with paired cells usually separating well below tip, often from near base; carpopodium lacking; pappus of ca. 60-70 basally barbellate and distally scabrid persistent bristles in 2-3 series, outer bristles somewhat shorter and narrower, apical cells acute. Pollen grains ca. 27-30 $\mu \mathrm{m}$ in diameter. Plate 109.

The single species of Garberia is a small shrub with fragrant rose-colored to purplish flowers and somewhat viscid leaves when fresh. The species is endemic to sandy areas of peninsular Florida. The genus shows the geography, ten-ribbed achenes, deeply divided setulae on the achenes, and the lack of a carpopodium that seem to confirm its position in the subtribe Liatrinae. Gaiser (1954) has shown that the species also produces a basal rosette in its seedling stage, a character occurring in all members of the Liatrinae.

The genus Garberia is distinct in the subtribe Liatrinae by the shrubby habit and has been shown by Gaiser (1954) to have one of the distinct karyotypes within the Liatris relationship, having a heterobrachial short chromosome. The genus also has the longest corolla lobes in the subtribe, longer than those in Liatris, and much firmer in texture 


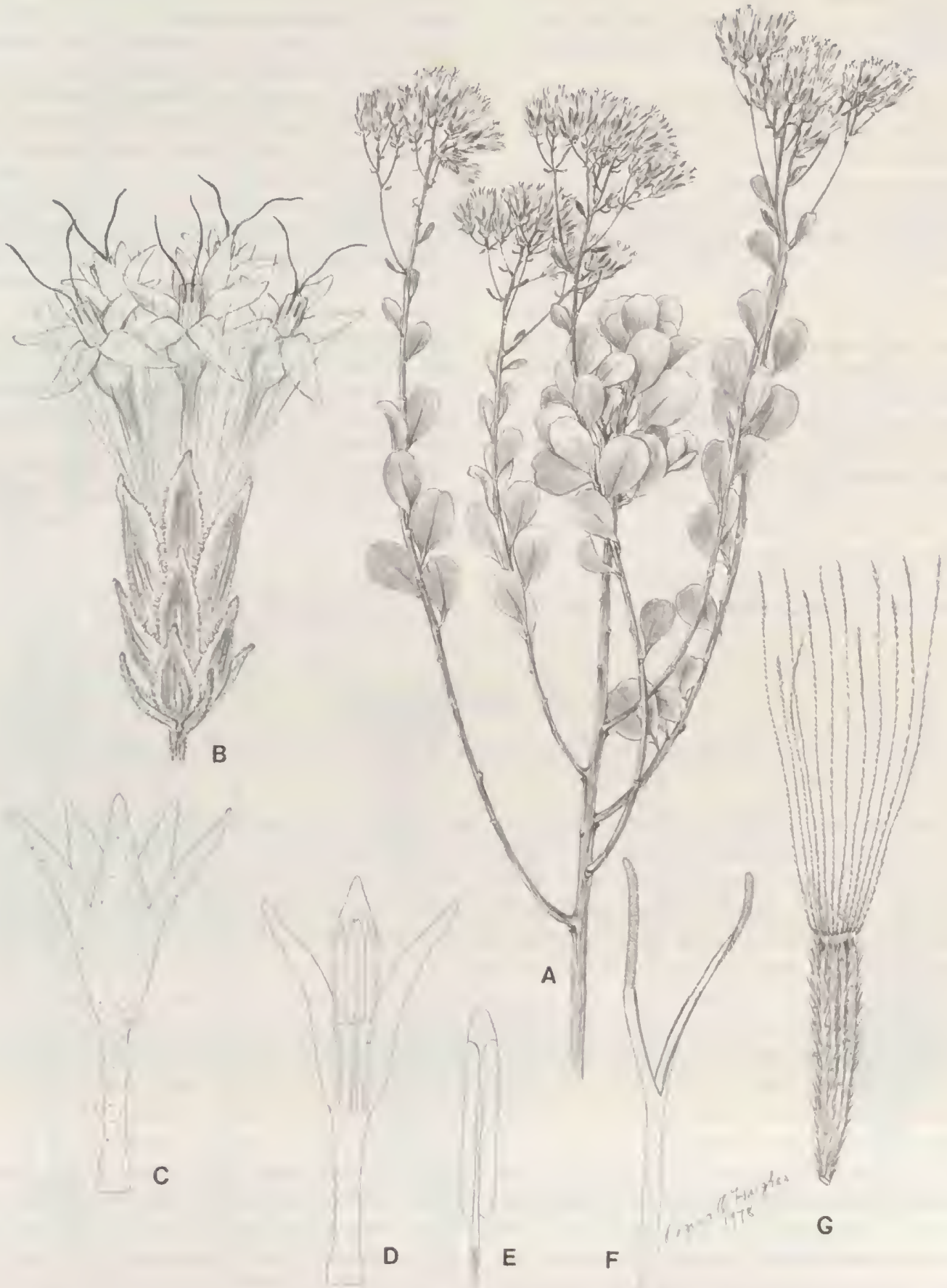

PlATE 109. Garberia heterophylla (Bartr.) Merr. \& Harper. - A. Habit, $\times 1 / 2,-$ B. Head, $\times 5 .-$ C. Corolla outer surface, $\times 7 .-$ D. Corolla inner surface with anthers, $\times 7$. E. Anther, $\times 14 .-F$. Style, $\times 7 .-$ G. Achene, $\times 7$. 
without the large regularly subquadrate cells. Both the separate generic status and the relationship to Liatris appear to have been accepted by all authors since Asa Gray (1879a).

The shrubby habit that distinguishes Garberia in the Liatrinae, presents a problem of interpretation. The shrubby habit has come to be regarded as a comparatively primitive condition in the Asteraceae (Cronquist, 1977) and is regarded as the probable primitive condition in the tribe Eupatorieae by the present authors. However, the condition in Garberia is anomalous in the Liatrinae which throughout its diversity is otherwise herbaceous and unbranched in the erect vegetative stems. The presence of a basal rosette in the young stages of Garberia suggests that the herbaceous condition was basic to this genus as well, and that the shrubby habit is derived.

The nomenclatural history of the genus is of some interest. The first description of the species in the Senecionian genus Cacalia by Bartram (1791) reflects a period of early abuse of that generic name to include, among other things, members of the Eupatorieae such as Mikania cordifolia. The validity of the names in Bartram's Travels through North and South Carolina (1791) has been questioned by some (Cronquist, 1980), because of slight in- consistency in the use of the binomial system, but the validity is adequately defended by Merrill (1945).

The second description of the species of Garberia as a Liatris was by Nuttall (1822), who interpreted the latter genus broadly to include Carphephorus and Trilisa. The description by Nuttall did recognize some distinction with a sectional name Leptoclinium for the species. Extension of the Nuttall sectional concept by Gardner $(1846,1847)$ to two Brazilian species, led to the use of the name Leptoclinium at the generic level by Bentham (1873) for one of the latter species. The Leptoclinium of Bentham is a member of the subtribe Alomiinae, and has no significant similarity to Garberia. The Bentham use of the name was unquestionably inspired by the Nuttall sectional name, as used by Gardner, but was not based upon it nomenclaturally. The Bentham use of the name preempted that of Asa Gray (1879a) for the Nuttall species and made the substitute name Garberia necessary.

The name Garberia, provided by Asa Gray $(1879 b)$, was to honor Dr. A. P. Garber of Columbia, Pennsylvania, noted by Gray for his contributions to the development of the botany of subtropical Florida.

The following single species is recognized in the genus: Garberia heterophylla (Bartram) Merr. \& F. Harper, Florida.

\section{Hartwrightia}

Hartwrightia A. Gray ex S. Watson, Proc. Amer. Acad. Arts 23: 264. 1888. TYPE: Hartwrightia floridana A. Gray ex S. Watson.

Erect perennial herbs, from a slender penetrating rootstock, with basal rosette of leaves. Stems terete, slightly striated. Leaves alternate, in rosette at base, decreasing greatly in size and density upwardly, with long slender petioles not sharply demarcated distally; blades elliptic-oblanceolate to elliptical, narrowly cuneate at base, margins usually entire, rarely with a large tooth or small lobe, with 2-3 pairs of usually strongly ascending secondary veins, surfaces densely glandular punctate. Inflorescences scapose, terminating in an open corymbose often flat-topped cyme; peduncles rather short to moderate in length, distinct, with few or no bractlets. Involucral bracts ca. 12-15, essentially eximbricate, mostly subequal with a few shorter ones outside, herbaceous, persistent, narrowly oblong-elliptical; receptacle slightly convex, often with a few bracts inside outermost florets, otherwise glabrous. Florets 7-10 in a head; corollas pink, blue, or white, broadly funnelform, with short and rather indistinct basal tube, with broad and slightly campanulate throat, with numerous glandular punctations on outer surface; cells of throat rather subquadrate, with not or scarcely sinuous lateral walls; lobes triangular, about as long as wide or slightly longer, densely short-papillose on inner surface, with slight mamillosity outside near margins; anther collar short-cylindrical, composed of short-oblong cells, with densely reticulate thickenings on walls; anther appendage transversely oblong, slightly wider than long, truncate or retuse apically, with median groove adaxially; style base not enlarged, glabrous; style branches short, linear, densely short-papillose. Achenes prismatic to obpyramidal, 5-ribbed, glanduliferous, without setulae; carpopodium lacking; pappus usually lacking, rarely with a single hair-like glanduliferous seta. Pollen grains ca. $25 \mu \mathrm{m}$ in diameter. Plate 110.

The monotypic genus Hartwrightia occurs in moist areas and at edges of marshes in pine lands in peninsular Florida as far south as Highlands County and as far north as southeastern Georgia. The genus is the only member of the Eupatorieae in the southeastern United States having an essentially epappose achene. The plants are notable otherwise for the dense glandular punctation on the stems, leaves, involucre, corollas, and achenes. The corollas are also unusually short and broad with a scarcely distinct basal tube. The corollas are apparently usually pink or 


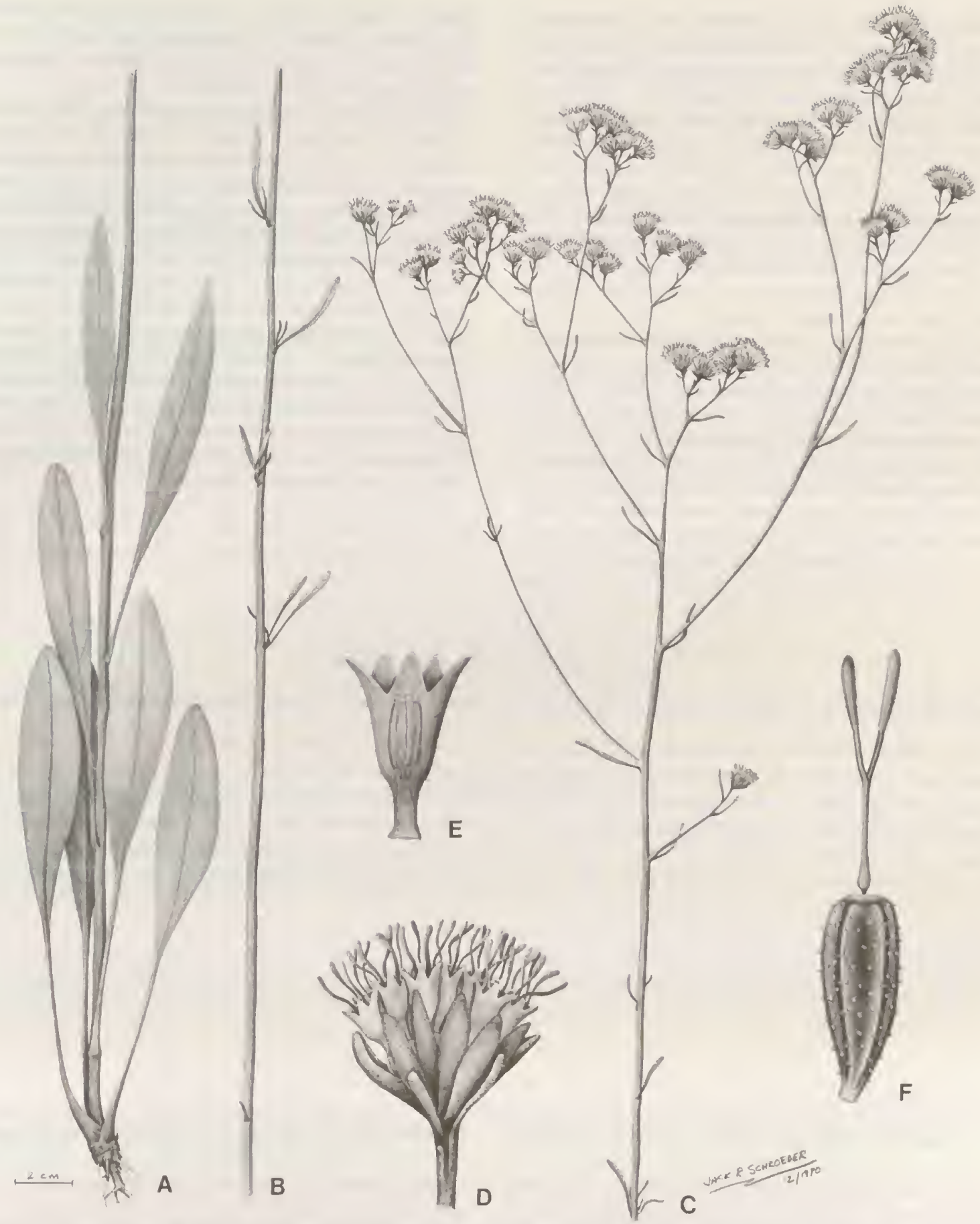

Plate 110. Hartwrightia floridana A. Gray.-A-C. Habit, base, upper stem, and inflorescence, $\times 4 \% .-D$. Head, $\times 4 .-E$. Corolla showing anthers, $\times 8 .-F$. Achene with style, $\times 8$.

white but were referred to on one label, perhaps erroneously, as pale blue.

The essentially epappose condition of the achene in Hartwrightia is evidently the basis for the consistent ac- ceptance as a separate genus since the time of the initial description. The epappose condition, however, is also the source of much confusion regarding the proper relationship of the genus, since variations in the pappus were 
automatically treated in artificial groups in the traditional systems of classification of the Eupatorieae. The original placement of the genus was in the subtribe "Piquerieae" in the sense of Bentham and Hooker (1873). The actual suggested relationship was to the genera Gymnocoronis and Adenostemma in that group. The relationship was the same as suggested by B. Robinson (1913a) under his more narrowly circumscribed subtribe Adenostemmatinae. During the interim, Holzinger (1893) had noted the fact that typical Piqueriinae lacked an anther appendage, and that Hartwrightia had a distinct anther appendage. On that basis, Holzinger suggested a position for Hartwrightia in the "Agerateae" nearest Alomia.

It was not until 1977 that H. Robinson and King suggested a relationship for Hartwrightia in the Liatris group, on the basis of its geography and rosulate habit. The relationship seems to be supported by the form of the achene base with its lack of a carpopodium and by the cellular detail of the corolla. Chemistry is somewhat supportive, since heliangolides, benzofurans, and diterpenes have been found in both Hartwrightia and Liatris (Bohlmann et al., $1981 \mathrm{~b}$ ). The lack of setulae on the achene prevents confirmation of the relationship on the basis of the distinctive form of setulae found in other Liatrinae. The only char- acters in direct conflict with the other Liatrinae are the lack of pappus and the five-angled achenes. Neither of these is seen as sufficient reason to reject the placement of Hartwrightia in the subtribe.

Actually, the achenes of a few specimens of Hartwrightia are not completely epappose, although the structure involved is scarcely recognizable as being a pappus. A few specimens have occasional narrow filaments originating from the positions where a pappus bristle might be. The filaments are hair-like and flexuous with a few capitate glands born along their length. It is not known whether such structures were seen by the authors who placed Hartwrightia in the relationship of Adenostemma which has pappus knobs bearing glands on their tips. It is certain, however, that the anomalous structures in Hartwrightia are totally unlike the knobs in Adenostemma, and are not evidence of any special relationship between the genera.

The generic name Hartwrightia honors Dr. S. Hart Wright, the collector of the Florida specimens from which the genus was originally described.

The following single species is recognized in the genus: Hartwrightia floridana A. Gray ex S. Watson, Florida, Georgia.

\section{Subtribe X. Fleischmannitnae}

Fleischmanniinae R. King \& H. Robinson, Phytologia 46: 447. 1980. TYPE: Fleischmannia Schultz-Bip.

Erect annual or mostly perennial herbs, moderately branched, without rosulate basal leaves. Leaves opposite, rarely alternate, distinctly narrowly petiolate; blades serrate to rarely dissected. Inflorescence terminal on stems or branches, with corymbose or cymose branches, heads clustered, usually pedicellate; involucral bracts usually distinctly subimbricate with bracts of graduated lengths, persistent; receptacle flat to slightly conical, epaleaceous. Flowers (10-)20-50 in a head; corollas lavender or bluish to white, with short basal tube, throat narrowly campanulate, with veins thickened below; lobes shortly triangular, cells prorulose on inner and outer surfaces, without stomata on outer surface; anther collar slender, with cells elongate or indistinct, ornamented with dense transverse annular thickenings; anther appendage about as long as wide; style base usually not enlarged, glabrous below, with scattered glands or hairs on shaft in Sartorina; style branches filiform, not or scarcely broadened distally, densely papillose. Achenes prismatic, 5-ribbed, terete in Sartorina, micropunctations of achene walls not strongly aligned in transverse bands; carpopodium distinct with slight projecting upper rim, with mostly subquadrate thick-walled cells, carpopodium indistinct in Sartorina; pappus of 5 to many scabrid capillary bristles in 1 series, with pointed apical cells. Basic chromosome numbers $x=4,10$.

The subtribe Fleischmanniinae has various individual characters that suggest comparison with many other subtribes of the Eupatorieae, but the combination of characters precludes inclusion of the present group in any of the others. The subtribe resembles the Gyptidinae in the general presence of papillose corolla lobes and strongly annulated anther collars, but differs in details of these as well as its basically subimbricate involucre and thickwalled carpopodial cells. The involucre is more like the Ayapaninae, but the corolla lobes of the latter are basically smooth and the style base is enlarged and sometimes pu- bescent. The Critoniinae have deciduous inner involucral bracts and smooth corolla lobes. Of all of these, none, except some of the Ayapaninae, have any particular strong superficial resemblance to the Fleischmanniinae.

A subtribe to which the Fleischmanniinae shows a strong superficial resemblance, and with which its species have often been confused in herbaria, is the Oxylobinae. However, the subtribe Oxylobinae is not closely related, differing in its basically eximbricate involucre, its corolla lobes with densely papillose inner surfaces and smooth outer surfaces, its anther collars with many subquadrate 
cells and no distinct annulations, its unrimmed carpopodium with thin-walled cells, its usually enlarged style base, and its basic chromosome number of mostly $x=$ 17. The members of the Oxylobinae that vary from the above standard are not convergent with the Fleischmanniinae.

The Fleischmanniinae are actually unique in the tribe in the details of their narrow strongly annulated anther collars and in the prorulosity of the corolla lobes. The prorulosity is approached, but in no way equalled, in only one other genus of the tribe, Phanerostylis, which is a specialized member of the Alomiinae. The combination of characters in the Fleischmanniinae not only prevents inclusion in other subtribes, but leaves the closest relationship of the subtribe in doubt.

The subtribe Fleischmanniinae consists almost entirely of the single large and distinctive genus Fleischmannia, and the discussion under that genus should be consulted for many significant details of the group. The only other member of the subtribe is the monotypic, and in some ways rather freakish, Sartorina, which has a unique pubescence of scattered glands and hairs on the shaft of the style and a unique form of terete non-carbonized achene.
Because of the characteristic capillary pappus, the members of the Fleischmanniinae have been mostly included in the genus Eupatorium in traditional systems of classification. An exception is the type species of Fleischmannia which was distinguished by its pappus of five bristles. Complications resulting from that generic concept are noted under Fleischmannia.

The Fleischmanniinae has a distribution concentrated in Mexico, Central America, and the western parts of South America, Only two species reach eastern Brazil and there is one species in the eastern United States. The distribution pattern is rather closely aligned with that of the Oxylobinae to which the subtribe is not closely related. The pattern is in particularly strong contrast to the three subtribes, Eupatoriinae, Disynaphiinae, and Gyptidinae, which are mostly or completely restricted to the eastern halves of the continents.

The only particularly well-known member of the subtribe is the wide-spread weedy annual. Fleischmannia microstemon, which has been of interest cytologically because of its anomalous chromosome number of $n=4$.

The chemistry of a few species of Fleischmannia has been studied by Bohlmann et al. (1981i).

\section{KEY TO THE GENERA OF THE SUBTRIBE FLEISCHMANNIINAE}

1. Achenes prismatic with 5 ribs, with blackened layer internally; shaft of style glabrous

1'. Achenes terete, without blackened layer; shaft of style bearing hairs and glands

111. Fleischmannia 112. Sartorina

\section{Fleischmannia}

\section{Fleischmannia Schultz-Bip., Flora 33: 417. 1850. TYPE: Fleischmannia rhodostyla Schultz-Bip. [= Fleisch- mannia arguta (H.B.K.) B. Robinson].}

Erect annual or perennial herbs or subshrubs, usually sparingly branched. Stems terete, striated. Leaves usually opposite, rarely subopposite or alternate, usually with slender petioles, often elongate: blades elliptical to rhomboidal or broadly cordate-ovate, upper margin serrate or crenulate, blades dissected into long narrow segments in $F$. carletonii, venation pinnate to trinervate, with or without glandular punctations below. Inflorescence laxly branching, with laxly cymose to densely corymbose branches: pedicels short to moderately long. Involucral bracts 20-30, subimbricate, rarely eximbricate, in 2-4 series, usually unequal and graduated in length, rarely subequal, persistent, spreading with age, rounded to acute at tip; receptacle flat to slightly convex, rarely minutely conical, glabrous or with minute scattered hairs. Florets (10-)20-50 in a head; corollas white, lavender, bluish, or purple, with rather short basal tube, limb narrowly funnelform with subcampanulate base, with outer surface above or on the lobes often with short hairs or glands, veins greatly thickenend in tube or throat; cells of limb mostly narrow with sinuous walls, mostly with upper ends projecting as papillae on inner surface of upper throat and on both surfaces of lobes; lobes short, broadly triangular, moderately spreading; anther collars slender, with mostly oblong cells, cell walls with dense transverse annulations throughout; anther appendage broadly ovate or oblong, about as long as wide; style base not enlarged, glabrous; style branches linear, not or scarcely broadened distally, densely long-papillose. Achenes prismatic, 5-ribbed, usually with setulae or scabrae on ribs or upper parts, usually without glands, ribs often pale; carpopodium distinct with prominent upper rim, stopper-shaped with rounded edges, cells subquadrate to short-oblong, with greatly thickened walls. Pappus of 5-40 slender scabrid sometimes slightly fragile bristles in one series, apical cells of bristles acute. Pollen grains ca. 15-20 $\mu \mathrm{m}$ in diameter. Plate 111 . 


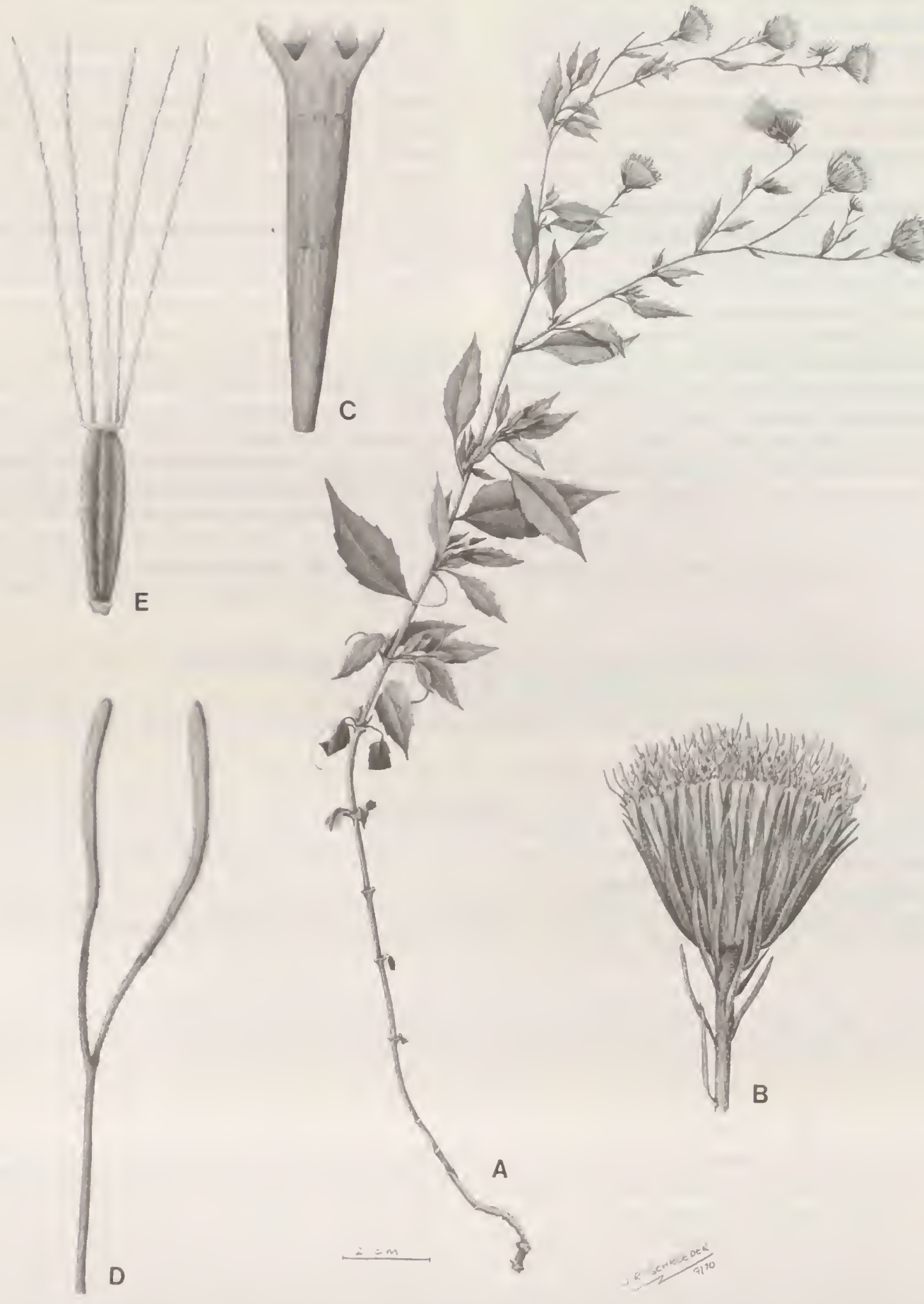

PLATE 111. Fleischmannia arguta (H.B.K.) B. Robinson. - A. Habit, $\times 2 / 3 .-$ B. Head, $\times 5 .-$ C. Corolla showing anthers, $\times 19 .-$ D. Style,
$\times 19 .-$ E. Achene, $\times 19$. 
The genus Fleischmannia was originally described for a single species from Mexico having a pappus with five widely spaced bristles, and the genus continued to be defined by that form of pappus for the next hundred years. The species added to the genus under the traditional concept, however, proved to form a highly artificial group. Three of the added species are now known to be Hofmeisteriae (King \& Robinson, 1966) and one is an Ageratina (King \& Robinson, 1970b).

Even as the traditional concept of Fleischmannia prevailed, some authors seemed aware of more natural relationships. In the original description of Eupatorium trinervium Schultz-Bip. (Seemann, 1852-1857) there was the comment "Eupatorio arguto H.B.K. . . a affinis esse videtur," and B. Robinson (1926a) remarks in his description of Eupatorium rivolurum "This species in habit, habitat, foliage, and in some details of pubescence recalls Fleischmannia arguta (H.B.K.) Robinson,.... The species, if referred to Fleischmannia would by its indefinite (though not very numerous) pappus-bristles, break down the slight distinction between that genus and Eupatorium. If, on the other hand it is referred to Eupatorium (from which on technical grounds it cannot be readily separated) its close similarity to Fleischmannia must render the further separation of that genus rather artificial. Neither disposition is entirely satisfactory."

The natural limits of Fleischmannia were determined by King and Robinson (1970a) with removal of all the previously included species except the type. At that time 52 species were added to the genus that had previously been placed in Eupatorium. Subsequent papers have added more species (King \& Robinson, 1974b, 1974e, 1975m, $1977 b, 1978 b$ ), with the genus ultimately proving to be the seventh largest in the tribe. Regarding the traditional character of the genus, there are some species, including $F$. pycnocephala, with the pappus bristles slightly separated from each other, and one species, $F$. capillipes, has only ten bristles. The type remains the only species with only five bristles.

All specimens seen of Fleischmannia multinervis, the single collection of $F$. guatemalensis, many specimens of $F$. bohlmanniana, and a few specimens of $F$. pycnocephala (King \& Robinson, 1975m, 1978) have the outermost four achenes of each head lacking setulae and pappus. The presence of such calvous achenes does not seem to be necessarily species constant, but it seems to be restricted geographically, being presently known only from Guatemalan and Mexican specimens. A similar condition of peripheral calvous achenes was cited by B. Robinson $(1913 b)$ for some species of Trichogonia in the subtribe Gyptidinae.

Although not a primary character of the genus, the involucre of Fleischmannia is basically subimbricate, and the genus can generally be distinguished from members of the Oxylobinae by the character. Williams (1975) men- tions the "intermediate" nature of the involucre in $F$. imitans, an involucral form also seen in the type species, $F$. arguta, and in $F$. capillipes. The involucral form is eximbricate in the sense of having narrow seemingly weakly overlapping bracts, but is not eximbricate in the sense of subequal lengths of the bracts. As in other species of the genus, the involucre has bracts of graduated lengths, although the shorter bracts are comparatively less numerous.

The distinct nature of the genus Fleischmannia is evident in the distinctive overall aspect of the individual florets, involving both the corollas and the achenes. Still, most of the definitive characters such as the prorulosity of the corolla lobes and the narrow annulated anther collars are too small to be seen under a binocular microscope or be used in a workable key. One microcharacter that can be seen, however, is the ribbing of the basal tube of the dried corolla caused by the greatly thickened veins in that part.

The number of flowers in the heads of Fleischmannia is almost always 20 or more. Counts of ten flowers are known for $F$. matudae, based on one collection number, and have been reported in Eupatorium valerianum ( $=F$. hymenophylla), where it has not been confirmed by examination of the type or any other specimens.

There are two examples in Fleischmannia of significant variations in chromosome numbers. H. Baker (1967) studied the two annual species, $F$. microstemon and $F$. sinclairit, the former a common weedy species. $\mathrm{H}$. Baker reported the anomalous $n=4$ in both species, but reexamination of specimens and accurate delimitation of the species shows that the $n=4$ is restricted to and characteristic of $F$. microstemon (King \& Robinson, 1975z; R. King et al., 1976). A count of $n=4$ has also been reported by Grashoffet al. (1972) from the comparatively unrelated perennial herb, $F$. hymenophyllum from Costa Rica, but the count has not been duplicated.

In Central America, a series of species seems to form a rather classical polyploid complex. The two widely distributed species, $F$. pycnocephala and $F$. pratensis, are among a number of comparatively variable species in the area that are polyploid, with numbers of $n=20$ or 30 . In the same area, a number of more localized and less variable species such as $F$. seleriana and $F$. bohlmanniana prove to be diploids with $n=10$ (R. King et al., 1976; King \& Robinson, 1978b). The latter species, which seem comparatively insignificant, are actually the basic elements in the polyploid complex.

The chemistry of five species has been studied, with reports of a number of rather widely distributed compounds and one new caryophyllene derivative (Bohlmann et al., 1981 $i$ ). Sesamin-like lignans have been isolated from three of the species. Such lignans occur in various other members of the Asteraceae, including a few Eupatorieae, but seem unusually common in Fleischmannia. 
The genus Fleischmannia is widely distributed from the southern United States southward through Mexico and Central America to Argentina in South America. The vast majority of the species are concentrated in Mexico, Central America, and the Andes. Members of the genus are rare in Brazil and mostly adventive in the West Indies. Members of the genus are included in many early treatments of tropical Eupatorieae such as that of B. Robinson $(1926 b)$ in the Trees and Shrubs of Mexico, but the species treated under the broad concept of Eupatorium are not necessarily grouped together or particularly accurately delimited. The only treatment along modern lines is that provided by King and Robinson (1975y) for the eleven species in Panama, with a key and some discussion of extraterritorial relatives.

The limited description of Caradesia pauciflora Rafinesque (1838) of the eastern United States is somewhat suggestive of Fleischmannia incarnata of that area. The Rafinesque name, however, is provisional and invalid, having no priority as either a genus or species.

The genus Fleischmannia was named by Schultz-Bipontinus in honor of his teacher at Erlangen, Hon. Prof. Dr. Gottfried Fleischmann.

The following 79 species are recognized in the genus:

Fleischmannia aequinoctialis (B. Robinson) R. King \& H. Robinson, Ecuador.

Fleischmannia allenii $\mathrm{R}$. King \& H. Robinson, Panama.

Fleischmannia anisopoda (B. Robinson) R. King \& H. Robinson, Guatemala.

Fleischmannia antiquorım (Standley \& Steyerm.) R. King \& H. Robinson, Guatemala.

Fleischmannia arguta (H.B.K.) B. Robinson, Mexico, Guatemala, Honduras, Nicaragua, Costa Rica?

Fleischmannia bergantinensis (V. Badillo) R. King \& H. Robinson, Venezuela.

Fleischmannia blakei (B. Robinson) R. King \& H. Robinson, Honduras.

Fleischmannia bohlmanniana R. King \& H. Robinson, Guatemala.

Fleischmannia bridgesii (B. Robinson) R. King \& H. Robinson, Bolivia.

Fleischmannia capillipes (Benth. ex Oersted) R. King \& H. Robinson, Mexico, Guatemala, El Salvador, Nicaragua.

Fleischmannia carletonii (B. Robinson) R. King \& H. Robinson, Honduras.

Fleischmannia chiriquensis R. King \& H. Robinson, Panama.

Fleischmannia ciliolifera R. King \& H. Robinson, Honduras.

Fleischinannia cookii (B. Robinson) R. King \& H. Robinson, Peru.

Fleischmannia croatii R. King \& H. Robinson, Panama.

Fleischmannia crocodilia (Standley \& Steyerm.) R. King \& H. Robinson, Guatemala.

Fleischmannia cllatrecasasii R. King \& H. Robinson, Colombia. Fleischmannia deborabellae R. King \& H. Robinson, Guatemala. Fleischmannia dissolvens (Baker) R. King \& H. Robinson, Brazil.

Fleischmannia ejidensis (V. Badillo) R. King \& H. Robinson, Venezuela.

Fleischmannia ferreyrii R. King \& H. Robinson, Peru.
Fleischmannia fragilis (B. Robinson) R. King \& H. Robinson, Peru.

Fleischmannia gentryi R. King \& H. Robinson, Costa Rica.

Fleischmannia gonzalezii (B. Robinson) R. King \& H. Robinson, Mexico.

Fleischınannia granatensis R. King \& H. Robinson, Colombia.

Fleischmannia guatemalensis R. King \& H. Robinson, Guatemala.

Fleischmannia harlingii R. King \& H. Robinson, Ecuador.

Fleischmannia haughtii R. King \& H. Robinson, Colombia.

Fleischmannia holwayana (B. Robinson) R. King \& H. Robinson, Mexico.

Fleischınannia hymenophylla (Klatt) R. King \& H. Robinson, Costa Rica, Panama.

Fleischmannia ignota (V. Badillo) R. King \& H. Robinson, Venezuela.

Fleischmannia imitans (B. Robinson) R. King \& H. Robinson, Guatemala, El Salvador, Honduras, Nicaragua, Costa Rica.

Fleischmannia incarnata (Walter) R. King \& H. Robinson, E United States, Mexico.

Fleischmannia klattiana (Hieron.) R. King \& H. Robinson, Colombia.

Fleischmannia laxa (Gardner) R. King \& H. Robinson, Brazil.

Fleischmannia laxicephala (Cabrera) R. King \& H. Robinson, Brazil.

Fleischmannia lellingeri R. King \& H. Robinson, Colombia.

Fleischmannia lithophila (B. Robinson) R. King \& H. Robinson, Peru.

Fleischmannia lloensis (Hieron.) R. King \& H. Robinson, Ecuador.

Fleischmannia magdalenensis (B. Robinson) R. King \& H. Robinson, Colombia.

Fleischmannia marginata (Poeppig \& Endl.) R. King \& H. Robinson, Peru.

Fleischmannia matudae R. King \& H. Robinson, Mexico.

Fleischmannia mayorii (B. Robinson) R. King \& H. Robinson, Colombia.

Fleischmannia mercedensis (B. Robinson) R. King \& H. Robinson, Peru.

Fleischmannia microstemon (Cass.) R. King \& H. Robinson, Mexico, Central America, West Indies, South America, adventive in Africa.

Fleischmannia misera (B. Robinson) R. King \& H. Robinson, Colombia, Panama.

Fleischmannia monagasensis (V. Badillo) R. King \& H. Robinson, Venezuela.

Fleischmannia multinervis (Benth.) R. King \& H. Robinson, Guatemala, El Salvador.

Fleischmannia nix R. King \& H. Robinson, Honduras.

Fleischmannia obscurifolia (Hieron.) R. King \& H. Robinson, Ecuador.

Fleischmannia panamensis R. King \& H. Robinson, Panama.

Fleischmannia pastazae (B. Robinson) R. King \& H. Robinson, Ecuador.

Fleischmannia pennellii (B. Robinson) R. King \& H. Robinson, Colombia.

Fleischmannia plectranthifolia (Benth. ex Oersted) R. King \& H. Robinson, Costa Rica.

Fleischmannia polopolensis (B. Robinson) R. King \& H. Robinson, Bolivia.

Fleischmannia porphyranthema (A. Gray) R. King \& H. Robinson, Mexico. 
Fleischmannia prasiifolia (Griseb.) R. King \& H. Robinson, Argentina, Brazil, Paraguay.

Fleischmannia pratensis (Klatt) R. King \& H. Robinson, Mexico, Central America, N South America.

Fleischmannia purpusii R. King \& H. Robinson, Mexico.

Fleischmannia pycnocephala (Less.) R. King \& H. Robinson, Mexico, Guatemala, El Salvador, Belize, Honduras.

Fleischmannia pycnocephaloides (B. Robinson) R. King \& H. Robinson, Guatemala, El Salvador, Honduras, Nicaragua.

Fleischmannia remotifolia (DC.) R. King \& H. Robinson, Brazil.

Fleischmannia rhodotephra (B. Robinson) R. King \& H. Robinson, Peru.

Fleischmannia rivulorum (B. Robinson) R. King \& H. Robinson, Mexico.

Fleischmannia saxorum (Standley \& Steyerm.) R. King \& H. Robinson, Guatemala.

Fleischmannia schickendantzii (Hieron.) R. King \& H. Robinson, Argentina, Bolivia.

Fleischmannia seleriana (B. Robinson) R. King \& H. Robinson, Mexico.
Fleischmannia sideritides (Benth. ex Oersted) R. King \& H. Robinson, Costa Rica, Panama, Ecuador.

Fleischmannia sinaloensis (B. Robinson) R. King \& H. Robinson, Mexico.

Fleischmannia sinclairii (Benth. ex Oersted) R. King \& H. Robinson, Mexico, Central America to Panama.

Fleischmannia sonorae (A. Gray) R. King \& H. Robinson, Arizona, W Mexico.

Fleischmannia soratae (Schultz-Bip. ex B. Robinson) R. King \& H. Robinson, Bolivia.

Fleischmannia splendens R. King \& H. Robinson, Guatemala.

Fleischmannia steyermarkii R. King \& H. Robinson, Venezuela.

Fleischmannia tamboensis (Hieron.) R. King \& H. Robinson, Bolivia.

Fleischmannia trinervia (Schultz-Bip.) R. King \& H. Robinson, Mexico.

Fleischmannia tysonii R. King \& H. Robinson, Panama.

Fleischmannia viscidipes (B. Robinson) R. King \& H. Robinson, Guatemala.

Fleischmannia yungasensis (B. Robinson) R. King \& H. Robinson, Bolivia.

\section{Sartorina}

Sartorina R. King \& H. Robinson, Phytologia 28: 98. 1974. TYPE: Sartorina schultzii R. King \& H. Robinson.

Erect to partially decumbent perennial herbs, with many branches. Stems terete to subquadrangular, slightly striated, densely puberulous. Leaves opposite, with long narrow petioles; blades broadly ovate to deltoid, base truncate, margins crenulate to obtusely serrulate, apex short-acute, distinctly trinervate from base. Inflorescence terminal on branches, subthyrsoid with subcorymbose branches, pedicels slender, moderately long. Involucral bracts ca. 20, subimbricate, in ca. 3 unequal graduated series, persistent, spreading with age, outer bracts ovate, inner bracts oblong; receptacle flat, glabrous. Florets ca. 15-22 in a head; corollas white or lavender?, with short, narrowly cylindrical basal tube, limb narrowly funnelform with subcampanulate base, glabrous outside below lobes, veins greatly thickened in tube and throat; cells of limb mostly narrow with sinuous lateral walls, with upper ends projecting as papillae on upper inside surface of throat and on both surfaces of lobes; lobes broadly triangular, with glands on outer surface; anther collar very narrow, cells mostly oblong, with dense transverse annular thickenings on walls; anther appendage shortly oblong. slightly longer than wide; style base slightly enlarged, glabrous; style shaft sparsely pilosulous and stipitate-glanduliferous; style branches linear, densely long-papillose. Achenes terete, narrowed below to a point, glabrous, with 5 narrow veins, without black deposits in walls, with large cells forming rather spongiose tissue between veins; carpopodium undifferentiated; upper callus slightly swollen and rather spongiose; pappus of ca. 15 slender somewhat non-contiguous scabrid persistent bristles, apical cells of bristles sharply acute. Pollen grains ca. $18 \mu \mathrm{m}$ in diameter. Plate 112.

The genus Sartorina is unquestionably related to Fleischmannia, having the same form of corolla with prorulose lobe surfaces, and the same type of anther collar, but is too different in the form of its achene and style shaft to be included in that genus. The sparse hairs and long-stalked glands on the shaft of the style are not equalled in any other member of the Asteraceae and are not present in Fleischmannia. The achene lacks both the carbonization and carpopodium that are characteristic of Fleischmannia. The lack of carbonization is nearly unique in the tribe. Fleischmannia never has even the slight enlargement of the style base seen in Sartorina, and has larger denser papillae on the style branches.
In the features that Sartorina shares with Fleischmannia, the isolation of the subtribe seems to be further accentuated. Unfortunately, the distinct characters of Sartorina are not instructive. Both the style shaft and the achene are too unique to suggest convergence or hybridization with any other group in the tribe. The two characters are actually rather freakish in their nature, and the achene is reduced to the point of probable sterility. It is possible that the type of Sartorina is the product of a single anomalous event.

It is certainly true that Sartorina is known from only a single specimen of somewhat questionable nature. The specimen is from the Schultz-Bipontinus herbarium in 


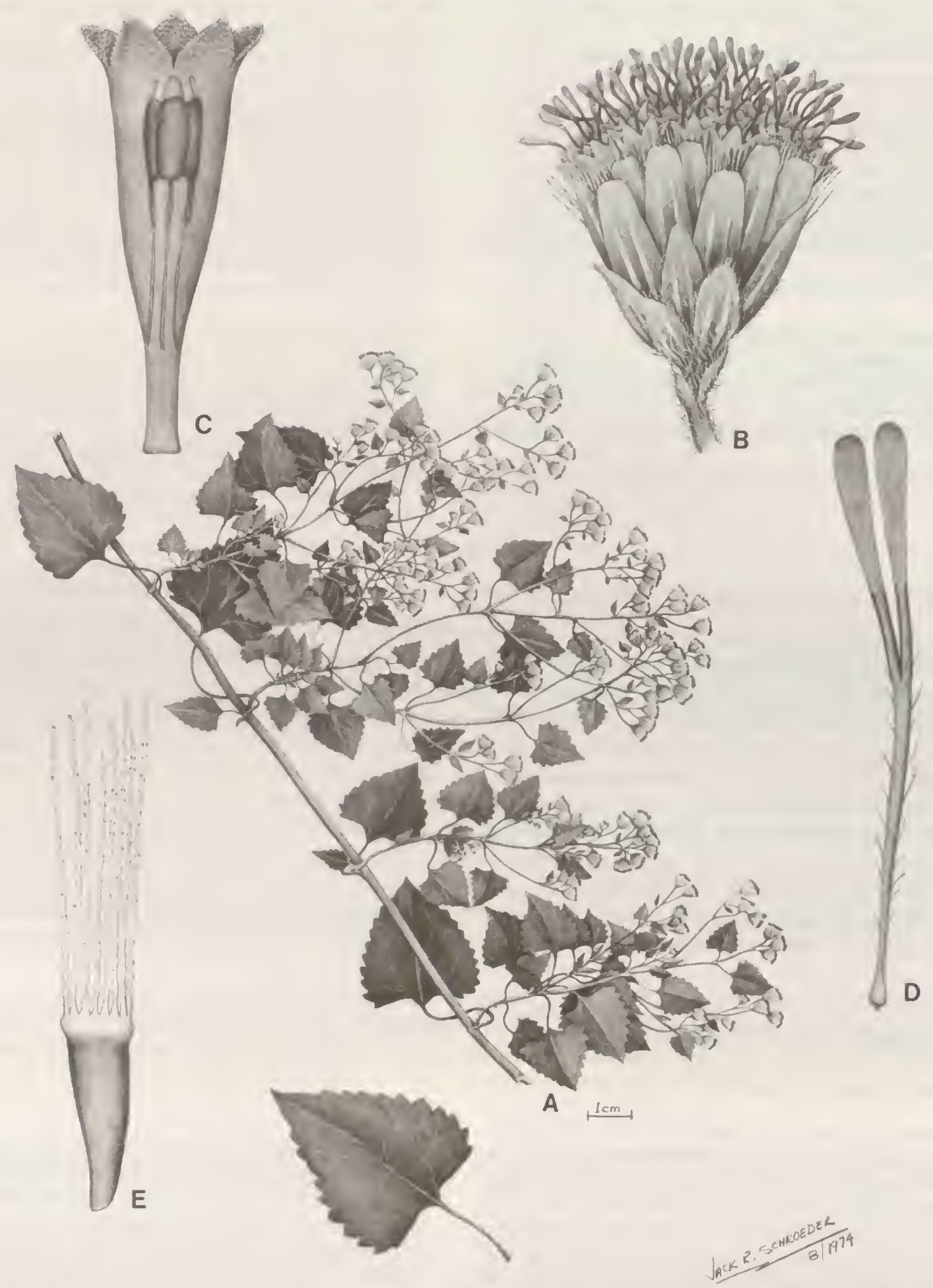

PLATE 112. Sartorina schultzii R. King \& H. Robinson, - A. Habit, $\times 2 / 3$, with separate lower leaf. - B. Head, $\times 12 .-$ C. Corolla showing anthers, $\times 27 .-D$. Style, $\times 27 .-$ E. Achene, $\times 27$. 
the Paris Museum where it was annotated as Sartoria eupatorioides, apparently by Schultz-Bipontinus. The genus, as annotated, was never published, and the name Sartoria is not now available, being used for a genus of the Fabaceae from the Middle East. The Paris material is obviously a duplicate specimen, with a part of an inflorescence and one lower leaf from an original that must have been destroyed at Berlin. The Paris specimen has a penciled note that we read as follows: "nov. Eupat. genus ob ach \& pappus connata," and "Sartoria n. g., ach. teretia (non striate) oblonga glabra albida apice in cupulam brevem spongiosam expansa e qua pappas oritur 1 ser pilosa, cap. 22 flora, rec. plana."
Among all the notes on the Paris specimen, there is none giving any collection data, even the country of origin. The relationship of the plant does not allow localization of the plant closer than Tropical America. The only probable clue on the specimen regarding place of origin seems to be the name given to the plant by Schultz-Bipontinus. It seems likely that "Sartoria" was intended to honor Carlos Sartorius 1796-1872 who lived at Mirador in Veracruz, Mexico, for most of his life following 1820 .

The following single species is recognized in the genus: Sartorina schultzii R. King \& H. Robinson, Mexico?

\section{Subtribe Xi. Critoninae}

\section{Critoniinae R. King \& H. Robinson, Phytologia 46: 447. 1980. TyPE: Critonia P. Browne.}

Perennial herbs, erect or scandent shrubs, or small trees, unbranched to densely branched, rarely with rosulate or congested basal leaves. Leaves mostly opposite, sometimes alternate, usually petiolate with rather short to moderately long petioles, infrequently long-petiolate or sessile; blades entire or serrate to rarely dissected. Inflorescence terminal on stems or branches, or lateral, to rarely axillary, usually with corymbose branches, heads clustered, pedicellate or sessile; involucral bracts weakly to strongly subimbricate or imbricate, bracts usually graduated in length, inner bracts usually deciduous, at least outermost bracts persistent; receptacle flat to slightly convex, rarely conical, with or without paleae. Flowers $1-300$ in a head; corollas white to lavender, reddish, or purple, rarely bluish, usually funnelform, sometimes tubular or with campanulate throat, glabrous or sometimes with hairs on inner surface; cells of limb mostly elongate; lobes shortly to longly triangular or oblong, shorter than wide to three times as long as wide, smooth on both surfaces, without stomata on outer surface; anther collar cylindrical, less than 5 times as long as wide, rarely very short, subquadrate cells usually present, at most filling less than lower half, without or with weak annular ornamentation on cell walls; anther appendage often as long as wide or longer, less often half as long as wide or less, rarely essentially lacking (Ophryosporus); style base not enlarged, glabrous; style branches filiform or linear to distinctly clavate, mamillose or distally smooth, rarely distinctly short-papillose. Achenes prismatic to fusiform, 5-ribbed, micropunctations of achene walls not strongly aligned in transverse bands; carpopodium usually distinct, usually without projecting upper rim, sometimes procurrent along ribs of achene, cells small to large, with rather thick to thin walls; pappus usually of many capillary scabrid bristles in one series, with tips not to greatly expanded, apical cells obtuse to sharply acute, pappus infrequently squamiform or lacking. Basic chromosome number $x=10$.

The subtribe Critoniinae is most notable for its lack of three types of structural specialization, lack of papillosity or otherwise shortened cells on the inner surface of the corolla lobes, lack of any enlargement or pubescence at the base of the style, and lack, with minimal exception, of distinct papillosity on the style branches. Also, in the Critoniinae, any annular thickenings in the cells of the anther collar are weak compared to those of most Gyptidinae or Ageratinae. The Critoniinae, as such, might seem to some to be a residuum after the other subtribes have been removed, reminiscent of the broad concept of genus Eupatorium in the traditional systems of classification of the tribe. There seem to be some trends through most members of the Critoniinae such as deciduous involucral bracts, however, and many of the genera that seem superficially very different can be linked by intermediates. At present, the subtribe is viewed as being generally natural, with some important but related subgroups.

The Critoniinae seem thoroughly distinct from the previously discussed subtribes of the Eupatorieae which tend to have persistent and sometimes eximbricate involucres, and which usually have strongly annulate thickenings on the walls of the anther collars. The style branches of the Critoniinae are usually broadened and clavate apically, in a manner reminiscent of the Alomiinae, but the broadened parts in the Critoniinae are more restricted to the tip and flattened, without any significant thickening or rounding on the back.

Actual relationships of the Critoniinae seem to be to the subtribes that follow in this treatment, Praxelinae, 
Hebecliniinae, and Neomirandeinae. The three related subtribes are comparatively small and are not necessarily more phyletically significant than some of the individual subgroups of the Critoniinae, nevertheless, each shows distinctive characteristics and internal integrity that make segregation at the subtribal level advantageous. The Praxelinae differ most significantly by the totally deciduous involucre, usually starting with the outermost bracts, and by usually having papillose inner surfaces of the corolla lobes. The Hebecliniinae have more elongate anther collars with more subquadrate cells, a strong tendency for pubescent receptacles, and many members with a chromosome base number of $x=16$. The Neomirandeinae grow as epiphytes or in humus, and also have longer anther collars and high chromosome base numbers. The epiphytism of the Neomirandeinae does not seem to be related to that of the one distinctly epiphytic genus of the Critoniinae, Tuberostyles. The distinctions of the related subtribes are discussed more fully under their individual treatments.

Some subgroups of the Critoniinae show extreme specializations that might themselves seem to justify subtribal status, but these are linked by intergrading forms. The Critonia subgroup, itself, includes Critonia, Critoniadelphus, Urbananthus, and Adenocritonia, with various tendencies toward glabrous leaves with internal secretory pockets, tubular corollas, and stramineous involucral bracts, but none of the tendencies are consistent throughout the group, and only the secretory pockets are restricted to it. The large Koanophyllon group includes segregate genera such as Bishovia, Lorentzianthus, Idiothamnus, and Chacoa of temperate South America, Nothobaccharis of Peru, Ophryosporus of the Andes, Sphaereupatoritum and Santosia of Brazil, Grisebachianthus of Cuba, and the strongly paleaccous Eupatoriastrum of Mexico and Central America, with variations toward short anther appendages and eximbricate involucres, but both characters vary, even within Koanophyllon. Fleischmanniopsis of Mexico and Central America seems rather intermediate between the Koanophyllon and Critoria groups. Two genera, Mexianthus and Neohintonia of Mexico, with singleflowered heads in a cluster, are unquestionably closely related to Koanophyllon. The Andean group of the Critoniinae, with broadened strap-shaped style branches, reaches its extreme form in Aristeguietia which has mostly persistent involucral bracts and one species with a conical receptacle, but the genus seems linked to more typical elements of the subtribe through such genera as Badilloa, Asplundianthus, Cronquistianthus, and Ophryosporus. The group of Critoniinae including Malmeanthus, Austrocritonia, Steyermarkina, and Neocabreria seems notable as a group only because of their geography, being mostly isolated in the moist areas in and near southern Brazil. The two endemic West Indian genera, Antillia of Cuba, and Eupatorina of Hispaniola, seem distinctive in their reduced somewhat rosulate or congested basal leaves, but otherwise relate to other members of the subtribe. Even Uleophytum, with its sessile axillary heads, is not discordant in the Critoniinae. If there are unnaturally associated elements in the present concept of the subtribe, they would be small and isolated genera such as Amboroa of Peru and Bolivia, with the uniquely greatly expanded tips on their otherwise smooth pappus bristles, Corethamnium of Colombia with its narrow corolla throat forming an apparent continuation of the basal tube and its strongly papillose style branches, or the epappose Tuberostyles, a specialized epiphyte on Mangroves along the Pacific Coast from Panama to northern Ecuador.

Most members of the Critoniinae have a pappus of many capillary bristles, and were included in the broad concept of Eupatorium in older classifications. Some elements with variation in pappus or anther appendages, however, were recognized as distinct. Mexianthus, one of two members of the subtribe with broadly squamellose pappus elements, was recognized as distinct, with mention of its single-flowered heads, but Neohintonia with similar heads and a capillary pappus, was left in Eupatorium. Amboroa, with extremely large tips on the pappus bristles, was distinguished, while Antillia, with a short fimbriate pappus was described in Eupatoriuın. The distinctive axillary sessile heads allowed distinction of Uleophytum, while Eupatoriastrum and Sphaereupatorium with paleaceous receptacles were sometimes recognized and sometimes not. Completely epappose elements of the subtribe were segregated either in Tuberostyles or Piqueria, depending on the development of the anther appendages. Those placed in Piqueria have proven to be members of the genera Koanophyllon and Ophryosporus where the pappus form is capillary in other members of the same genera. The pappose forms of Ophryosporus were also distinguished in texts, because of their obsolete anther appendages, but were often misidentified as Eupatorium in herbaria.

In the course of the present study, more difficulties have been encountered with the Critoniinae than with any other subtribe. Initially, it was hoped that a broad concept of Critonia could be applied to include most of the members that had been previously placed in Eupatorium. However, as in the case of Eupatorium, the prospective recipient of the rest of the subtribe, Critonia, proved to be a wellmarked and highly natural restricted group itself, unsuitable for expansion. A broader concept failed in other ways as well, since many other elements proved too distinctive to be included, and too artificial in the aggregate. The impression remains of a subtribe with too many segregates for the variation that is seen, and some of the genera were admittedly originally technical in their distinctions for purposes of definability. Still, subsequent reviews of some of these genera, such as Fleischmantiopsis (King \& Robinson, 1977c) and Neocabreria (King \& Robinson, 1978c), have shown evidence of strong generic delimitation and confirmed the presence of significant internal variation. 
In any case, the impression of over-segregation is a natural result of the size and complexity of the group which lacks variations in more obvious characters. A few species of the subtribe remain unplaced at present, such as Eupatorium clibadioides of Brazil, which seems near to but distinct from either of the probable relatives, Austrocritonia and Malmeanthus. Also, Critoniella leucolithogena seems out of place in its genus. Further study might show need for still a few more genera.

The subtribe Critoniinae is widely distributed in the Neotropical Region, but is concentrated in the more moist areas of the range, excluding the Amazon Basin. The members of the subtribe form the predominant element of the tribe in the West Indies, Central America, and the Andes. Most of the Brazilian members of the subtribe are in the moist areas to the south. Only a few members of the Koanophyllon group are found in the drier areas in the interior of Brazil where members of the subtribes Gyptidinae, Eupatoriinae, Ageratinae, Ayapaninae, Alomiinae, and Praxelinae are rather common. The Critoniinae are also rather scarce in the drier parts of Mexico where the Alomiinae seem most common.

The cytology of the Critoniinae seems very uniform as far as is known (R. King et al., 1976). All genera counted have a base of $x=10$, and there seems to be little polyploidy.

Chemistry has been reported for a few genera of the Critoniinae, Critonia (Bohlmann et al., $1977 b$; Fischer et al., 1979), Bishovia (Bohlmann et al., 1979d), Aristeguietia (Bohlmann et al., 1980c), and Koanophyllon (Bohlmann et al., 1981p). It seems interesting that labdane derivatives have been reported from all but the first of the four genera tested, but such compounds are found in many other Eupatorieae. The chemistry of the subtribe does not seem particularly rich. It is a personal opinion that such a subtribe, mostly in more moist areas, will not show the concentrations of secondary metabolites that are found in members of such subtribes as the Gyptidinae or Praxelinae occurring in drier areas with higher water-stress.

\section{KEY TO THE GENERA OF THE SUBTRIBE CRITONIINAE}

1. Plants rosulate or subrosulate with scapose inflorescences

2. Heads with 9-10 flowers; pappus bristles about as long as the corolla: anther appendage vestigial 118. Ciceronia

2. Heads with 30-50 flowers; pappus a low crown of deeply laciniate scales; anther appendage large, nearly as long as wide

1'. Plants coarse herbs to small trees, with leafy stems

117. Antillia

3. Individual heads with ! flower, aggregated into spherical clusters; leaves mostly alternate

4. Pappus of squamellae

4'. Pappus of capillary bristles

132. Mexianthus

133. Neohintonia

3'. Individual heads with 3 or more flowers; leaves opposite or alternate

5. Pappus totally lacking; maritime epiphyte

152. Tuberostylis

5'. Pappus usually present

6. Leaves distinctly alternate except sometimes at base (see also some specimens of Koanophy:lon myrilloides and

K. tatei)

7. Leaves densely spirally inserted, short-petiolate; involucre strongly subimbricate, bracts with strongly scarious margins; stems and leaves without stalked glands; heads sessile in spiciform inflorescences, with 6-8 flowers

126. Nothobaccharis

7'. Leaves rather renote, with slender petioles; involucre eximbricate, herbaceous; stems and leaves with numerous stalked glands; heads pedicellate in corymbose inflorescences, with 30-60 flowers _............... 125. Bishovia

6'. Leaves mostly opposite or subopposite

8. Heads sessile in axils of leaves

150. Uleophytum

$8^{\prime}$. Heads not sessile in axils of leaves

9. Heads with many paleae, with 75-300 flowers

9'. Heads with few or no paleae, usually with 4-70 flowers (to 100 in Aristeguietia)

10. Leaves bipinnately dissected

9

123. Eupatoriastrum

10 . Leaves not dissected, rarely pinnately lobed

119. Eupatorina

11. Involucral bracts eximbricate or weakly subimbricate in up to 3 rather irregularly disposed series

12. Anther appendage essentially absent, often in form of two separate minute lobes; involucre eximbricate

146. Ophryosporus

12'. Anther appendage distinct, one-third as long as wide or longer; involucre weakly subimbricate

13. Corolla lobes twice as long as wide, glabrous or subglabrous on outer surface; plants scandent 
13'. Corolla lobcs not distinctly longer than wide, with a dense clustcr of glands on outer surface; plants erect or subscandent herbs or shrubs

14. Basal tube of corolla constricted, closely investing shaft of style, with throat distinctly expandcd near base

130. Chacoa

14'. Basal tube of corolla broadly cylindrical, not closely investing shaft of style, expanding gradually into funnelform throat

15. Heads scssile in dense spherical clusters

124. Sphaereupatorium

15'. Heads not sessile in dense spherical clusters

16. Receptacle usually with some paleae; shrubs with strongly pinnately veined elliptical leaves

16'. Receptacle without paleae; herbs or shrubs with pinnately or trinervately veined leaves of various shapes 122. Koanophyllon

II'. Involucral bracts subimbricate or imbricate in 4 or more graduated series, inner bracts sometimes easily deciduous 17

17. Undersurfaces of leaves and involucral bracts both covered with dense tomentum or densely villous; plants of eastern Cuba

128. Grisebachianthus

17'. Undersurfaces of leaves and involucral bracts not both densely tomentose or villous

18. Anther appcndages shorter than wide, truncate to bilobed; style branches often with abruptly enlarged tips

19. Corolla with hairs on inner surface; inflorescence with strongly ascending, mostly subopposite to alternate branches; anther appendages bilobed; style branchcs not clavate at tip

149. Ncocabreria

19'. Corolla usually without hairs on inncr surfacc; inflorescence with numerous spreading opposite branches; anther appendages usually truncate

20. Pappus bristles slender, mostly non-contiguous; veins of corolla ending at sinus, not reaching into lobes; anther thecae reddish; inner involucral bracts usually persistent, bracts often whitish

20. Pappus bristles stout, contiguous; veins of corolla extending into lobes; anther thecae not reddish; inner involucral bracts often easily deciduous, bracts never whitish

21. Corollas funnelform; leaf blades with few to many hairs

$21^{\prime}$. Corollas tubular, not wider at lobes than at base; leaf blades without evident hairs

22. Leaves with numerous glandular punctations on lower surface; involucral bracts

$22^{\prime}$. Leaves glabrous, without hairs or glands, sometimes with minute intcrnal secretory cavities

$$
\text { 3-4 series of short bracts at base }
$$
showing as translucent spots along or between veins; involucral bracts in 5-6 series 23. Filaments of anthers inserted near base of corolla; achenes and corollas glabrous

115. Urbananthus

23'. Filaments of anthers inserted well above base of corolla; achenes with sparse glands and setulae; corolla lobes glanduliferous on outer surface

114. Critoniadelphus

18'. Anther appcndages about as long as wide or longer, with apices usually rounded, rarely retuse; style branches with abruptly cnlarged tips only in some Critonia and Cronquistianthus

24. Leaves vicwed against light with translucent or lens-like internal secretory pockets showing as spots between veins, without glandular punctation; coarse shrubs and vincs

24'. Leaves without transluccnt secretory pockets, often with glandular punctations

25. Style appendages broad and flcshy, $0.25 \mathrm{~mm}$ widc or wider at least near tip, often rather strap-shaped and wrinkled when dry; Andean plants

26. Achenes glabrous or with non-glandular setulae, without glands

27. Inflorescence with mostly alternate asccnding branches; involucral bracts pointed; carpopodium symmetrical, with little or no upper rim

27'. Inflorcscence with many spreading opposite branches; involucral bracts rounded apically; carpopodium asymmetrical, with distinct upper rim 147. Cronquistianthus

26'. Achcnes with numerous glands, without non-glandular setulae

28. Involucral bracts multicostate; carpopodium cylindrical with upward extensions along ribs of achene; pappus bristles flattened and smooth on outer surface, especially near base

140. Grosvenoria

28'. Involucral bracts 2-4-costate; carpopodium annuliform or shortly stopper-shaped with a straight upper cdge; pappus bristles not flattened on outer surface 139. Badilloa

25 . Style appendages not prominently broadened, Icss than $0.25 \mathrm{~mm}$ wide

29. Pappus bristles with greatly enlarged spinose tips; hcads with 50-70 flowers

$29^{\prime}$. Pappus bristles without or with only slightly enlarged tips; heads with only 4-35 flowers

30. Leaves with numcrous yellowish vermiform hairs when young, cclls of hairs thick-walled and often multiseriate; corolla with large lobes spreading from the apcx of a narrowly cylindrical combined basal tubc and throat 
30 . Leaves without yellowish vermiform hairs; corolla with lobes not appearing to spread directly from tube

31. Heads all with distinct peduncles which are sometimes elongate branches America

33'. Pappus bristics not broadened at tip;

Sous bristles not broadened at tip; heads with 10-12 flowers; corolla lobes with glands on outer surface; 32'. Inner bracts of involucre easily deciduous; pappus bristles persistent; inflorescence with ascending often alternate
branches

34. Leaf blades trinervate from base; most heads with large foliose bract at base; Mexico

121. Verieckia

34'. Leaf blades pinnately veined with ascending veins; heads without foliose bract at base; Brazil and Uruguay

31'. Heads at least partly sessile or subsessile in clusters 144. Malmeanthus

35. Pappus bristles barbellate below and tapering to a smooth point in distal half

35'. Pappus bristles without smooth tapering distal halves

36. Leaves elliptical with widely spreading pinnate venation

37. Leaves stiffly coriaceous, with glands and stout hairs on both surfaces; involucral bracts partly hirtellous: corolla lobes with sclerified caps distally on outer surface; heads with ca. 10 flowers; style appendage wider than thick

37'. Leaves thinly coriaceous, with glabrous upper surface and paler lower surface: involucral bracts subglabrous; corolla lobes without sclerified caps; heads with 6-7 flowers: style appendage narrowed above stigmatic area, becoming terete and filiform

$36^{\prime}$. Leaves mostly ovate with secondary veins ascending or trinervate

38. Corolla with lobes $2-4$ times as long as wide, throat with thick mass of hairs inside; tips of pappus bristles distinctly enlarged

148. Steyermarkina

$38^{\prime}$. Corolla lobes about as long as wide, throat glabrous on inner surface; tips of pappus bristles mostly unenlarged

39. Carpopodium with thin-walled cells, extending upward along ribs of achene: petioles more than onethird as long as leaf blade; style branches slender and terete above stigmatic area 135. Critoniello

39'. Carpopodium with numerous small thick-walled cells below; petioles usually less than one-fourth as long as leaf blade; style branches usually slightly flattened and broadened, at least at tip _.. 40

40. Inflorescence with thyrsoid-paniculate branches; most involucral bracts easily deciduous: receptacle strongly convex, subhemispherical; plants scandent

145. Hughesia

40 '. Inflorescence with branches bearing dense glomerulate clusters of heads; most involucral bracts usually persistent; receptacle with flower-bearing surface flat; erect or arching herbs

137. Asplundiamthus

\section{Critonia}

Critonia P. Browne, Civ. Nat. Hist. Jamaica, Ed. 1. 490. 1756. TYPE: Eupatorium dalea L.

Dalea P. Browne, Civ. Nat. Hist. Jamaica, Ed. 1. 314. 1756. TYPE: Eupatorium dalea L., non Dalea L. (Leguminosae).

Wikstroemia Sprengel, Kongl. Vetensk. Akad. Handl. 167. 1821. TYPE: Wikstroemia glandulosa Sprengel (= Eupatorium dalea L.), nec. Wikstroemia Schrader, 1821, nom. rej. (Theaceae), non Wikstroemia Endl., 1833, nom. cons. (Thymelaeaceae).

Coarse subshrubs to small trees or woody vines, sparingly branched. Stems terete to quadrangular or hexagonal, striate, often fistulose, glabrous to densely villous. Leaves opposite, distinctly petiolate, petioles sometimes broadly winged; blades elliptical to broadly ovate, base acute to subtruncate or hastate, margins entire to serrate, venation pinnate or trinervate from distinctly above base, surfaces without glandular punctations, internally with distinct translucent secretory pockets or dots in areoles between veinlets, sometimes appearing lens-like. Inflorescences usually thyrsoid-paniculate, with branches opposite and usually spreading at $90^{\circ}$ angles; heads either pedicellate or sessile in often dense clusters; heads usually cylindrical to fusiform. Involucral bracts ca. 20-25, subimbricate to weakly imbricate, in 4-6 unequal graduated series, all but outer series easily deciduous, stramineous, ovate to oblong-lanceolate; receptacle flat to slightly convex, 


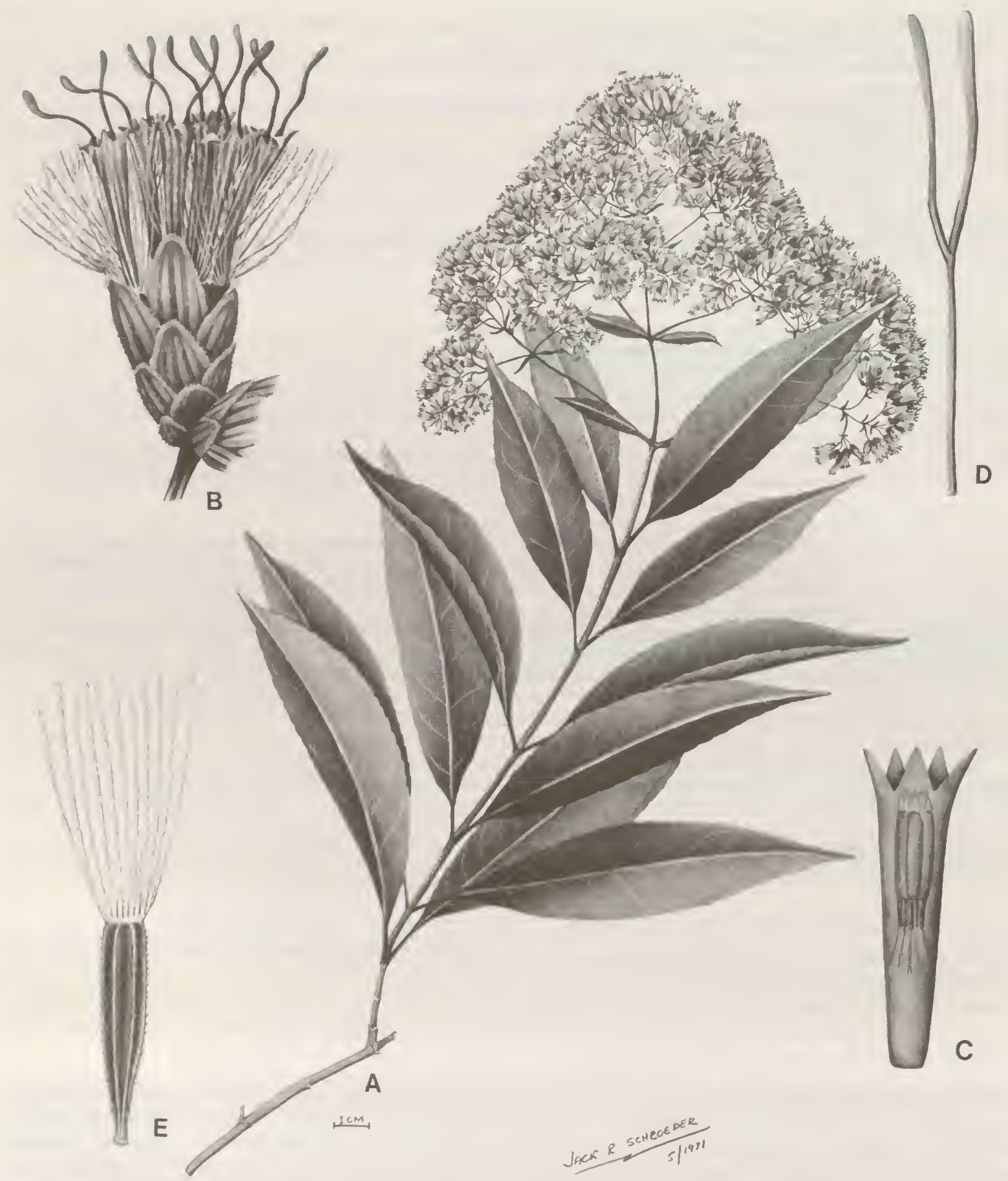

Plate 113. Critonia dalea (L.) DC. - A. Habit, $\times 3 / 9 .-$ B. Head, $\times 7 .-$ C. Corolla showing anthers, $\times 13 .-$ D. Style, $\times 13 .-$ E. Achene, $\times 13$.

glabrous. Florets 4-12 in a head; corollas whitish, tubular or narrowly funnelform, glabrous outside or rarely a few glands on lobes; cells of limb elongate with slightly sinuous lateral walls; lobes oblong to long-triangular, erect to slightly spreading, smooth on inner surface, sometimes roughened at tip outside; filament inserted well above base and below middle of corolla; anther collar moderately narrow, with many subquadrate cells 
below, oblong cells above, walls inornate or with slight annular thickenings; anther appendages large, scarcely to distinctly longer than wide; style base not enlarged, glabrous; style branches filiform to slightly spathulate, smooth to slightly mamillose. Achenes prismatic, 5-ribbed, with or without setulae; carpopodium a narrow rim or short cylinder, cells small, subquadrate to rounded, cell walls with confluent thickenings; pappus of 25-35 persistent, scabrid, congested bristles in 1 series, tips slightly enlarged and more densely scabrid, apical cells usually acute. Pollen grains ca. $18-23 \mu \mathrm{m}$ in diameter. Plate 113.

The genus Critonia was one of the earliest proposed in the tribe Eupatorieae, dating from only three years after Linnaeus' Species Plantarum. The genus is one of the many usually placed in the synonymy of Eupatorium because of the presence of a pappus of many capillary bristles, but Critonia was recognized as distinct by some authors during the first century after its description, especially by DeCandolle (1836). DeCandolle seemed to understand the genus rather well, citing the tendency for smooth opposite leaves, shrubby habit, unenlarged style bases, 3-5 flowers in the head, imbricate involucres, and even the pellucid punctations caused by the internal secretory pockets in the leaves. The present concept differs from that of DeCandolle in no significant way except being broadened to include such species as Eupatorium morifolium of Miller, having less smooth leaves and up to twelve flowers in the heads.

There was some confusion in the early application of the name Critonia. The name was initially a substitute in the errata of Patrick Browne's work (1756) for the name Dalea used in the text. Browne aiso provided an illustration that was misleading, seeming to show such features as branched pappus bristles. Lacking knowledge of true Eupatorium dalea of Linneaus, on which the genus was based, Gaertner (1791) interpreted Critonia as an older name for Kuhnia, and Cassini (1819b), on the basis of some misidentified material, suggested it might be Vernonieae. The latter speculations have all proven needless with proper knowledge of the type.

Within the Critoniinae, Critonia is most distinctive in the translucent pellucid internal secretory pockets in the areoles of the leaves. Such pockets are found only in $\mathrm{Cri}$ tonia and in a more minute scarcely visible form in the two closely related genera, Urbananthus and Critoniadelphus. It is notable that the three genera with the pockets lack glandular punctations on the leaves. Most of the remaining Critoniinae, including the habitally similar $A d$ enocritonia of Jamaica, have glandular punctations on the surfaces of the leaves, and none have internal secretory pockets in the areoles. The two structures appear to be mutually exclusive and presumably serve similar purposes in the plants where they occur. The lack of glands on the leaves does not mean that they are absent from the entire plant. Glandular punctations occur on the backs of the corolla lobes in a few species of Critonia such as $C$. conzattii, and they are characteristically numerous on the corolla lobes in Critoniadelphus. For this reason, the presence of numerous glands on Adenocritonia is a basis for distinction, but does not preclude close relationship.
The translucent pockets remain a character useful in a key only for Critonia. In the genus they are visible with a hand-lens when holding a leaf against the light. In some like $C$. morifolia the spots are small and numerous, but in the typical subgroup the spots can be seen without a hand-lens. In C. stigmatica of Hispaniola, the spots themselves look like small lenses in the center of each areole of the leaf. The pockets were the basis for the name of the latter species. Only in the small $C$. billbergiana-C. eggersii group of smaller-leaved vines are the pockets not evident. The secretory pockets, in contrast, are not sufficiently obvious in either Urbananthus or Critoniadelphus to use as a key character, only as a phyletic one.

The two most closely related genera can both be distinguished from Critonia by their short anther appendages. Each also has other distinctions. Urbananthus has glabrous achenes, anther filaments inserted near the base of the corolla, and shorter more abrupt broadened tips on the style branches. Critoniadelphus has slender-tipped pappus bristles, shorter corolla lobes, and a number of glands on the backs of the corolla lobes.

We have not established subgeneric divisions in $\mathrm{Cr}$ tonia, but some rather well-defined groups occur in the genus. Most evident is the typical element with very narrow bases on the achenes with small carpopodia, and larger secretory pockets in the leaves. The other large group includes the lianas such as C. billbergiana and coarse or scandent subshrubs or shrubs such as $C$. quadrangularis and $C$. morifolia having larger carpopodia and smaller secretory pockets. Two species with distinctive hastate leaves have many individually distinctive features. $\mathrm{Cr}$ tonia peninsularis of Baja California has a distinctive oblong anther appendage with many thickenings on the walls of the cells. Critonia spiniciaefolia has unusually long pedicellate heads, and the nodes of the inflorescence usually have numerous extra branches arising from the axils of the leaves, sometimes forming a fan of up to seven branches at a node.

Critonia occurs throughout most of the range of the subtribe from Mexico and the Greater Antilles south to Argentina in South America. The broader distribution is shown by the $C$. morifolia group, while the typical element is limited to the West Indies and Central America. The closely related genera, Critoniadelphus and Urbananthus both occur within the range of the typical element of Critonia, but in different areas from each other. The first is resticted to Central America, while the latter occurs in restricted localities in Jamaica and southcentral Cuba. 
The following 40 species are recognized in the genus:

Critonia arachnoidea (Legn.) R. King \& H. Robinson, Argentina. Critonia aromatisans (DC.) R. King \& H. Robinson, Cuba, Dominican Republic.

Critonia bartlettii (B. Robinson) R. King \& H. Robinson, Belize, Guatemala.

Critonia billbergiana (Beurl.) R. King \& H. Robinson, Costa Rica, Panama.

Critonia breedlovei R. King \& H. Robinson, Mexico.

Critonia campechensis (B. Robinson) R. King \& H. Robinson, Belize, Mexico (Yucatan).

Critonia conzattii (Greenman) R. King \& H. Robinson, Mexico.

Critonia dalea (L.) DC., Jamaica.

Critonia daleoides DC., Mexico, Central America to Panama.

Critonia dominicensis R. King \& H. Robinson, Lesser Antilles.

Critonia eggersii (Hieron.) R. King \& H. Robinson, Ecuador.

Critonia eriocarpa (B. Robinson \& Greenman) R. King \& H. Robinson, Mexico.

Critonia hebebotrya DC., Mexico, Guatemala, El Salvador, Costa Rica.

Critonia hemipteropoda (B. Robinson) R. King \& H. Robinson, Mexico (Yucatan).

Critonia heteroneura Ernst, Colombia, Venezuela.

Critonia hospitalis (B. Robinson) R. King \& H. Robinson, Mexico.

Critonia iltisii R. King \& H. Robinson, Mexico, Guatemala.

Critonia imbricata Griseb., Cuba.

Critonia inaequidens (Urban) R. King \& H. Robinson, Dominican Republic, Haiti.

Critonia lanicaulis (B. Robinson) R. King \& H. Robinson, Guatemala, Belize.

Critonia laurifolia (B. Robinson) R. King \& H. Robinson, Costa Rica.
Critonia lozanoana (B. Robinson) R. King \& H. Robinson, Mexico.

Critonia macropoda DC., Trinidad.

Critonia magistri (L. O. Williams) R. King \& H. Robinson, Guatemala, Belize.

Critonia megaphylla (Baker) R. King \& H. Robinson, Argentina, Brazil, Paraguay.

Critonia morifolia (Miller) R. King \& H. Robinson, Mexico, Guatemala, Belize, El Salvador, Honduras, Nicaragua, Costa Rica, Panama, Colombia, Venezuela, Ecuador, Peru, Bolivia, Brazil.

Critonia naiguatensis (V. Badillo) R. King \& H. Robinson, Venezuela.

Critonia nicaraguensis (B. Robinson) R. King \& H. Robinson, Nicaragua.

Critonia parviflora DC., Jamaica.

Critonia peninsularis (Brandegee) R. King \& H. Robinson, Mexico.

Critonia platychaeta (Urban) R. King \& H. Robinson, Jamaica. Critonia portoricensis (Urban) Britton \& P. Wilson, Puerto Rico.

Critonia pseudo-dalea DC., Cuba.

Critonia quadrangularis (DC.) R. King \& H. Robinson, Mexico, Guatemala, El Salvador, Nicaragua.

Critonia sexangularis (Klatt) R. King \& H. Robinson, Guatemala, Honduras, Nicaragua, Costa Rica.

Critonia spinaciaefolia (DC.) R. King \& H. Robinson, Mexico.

Critonia stigmatica (Urban \& E. Ekman) R. King \& H. Robinson, Haiti.

Critonia thyrsigera (Hieron.) R. King \& H. Robinson, Colombia. Critonia thyrsoidea (Mociño ex DC.) R. King \& H. Robinson, Mexico, Honduras, Nicaragua.

Critonia tuxtlae R. King \& H. Robinson, Mexico.

\section{Critoniadelphus}

\section{Critoniadelphus R. King \& H. Robinson, Phytologia 22: 52. 1971. TYPE: Eupatorium nubigenum Benth.}

Erect shrubs to small trees, moderately and laxly branched. Stems terete to subhexagonal, not to scarcely striated, glabrous to minutely puberulous. Leaves opposite, with short distinct petioles; blades elliptical to broadly lanceolate, margin entire to serrulate, pinnately veined, without glandular punctations, with obscure internal translucent secretory pockets in areoles between veinlets. Inflorescences pyramidally paniculate; heads short pedicellate or in sessile groups of 2-5; heads cylindrical to narrowly campanulate. Involucral bracts $25-30$, strongly subimbricate to imbricate in 5-6 unequal graduated series, stramineous, orbicular to oblong, 2-4-costate, glabrous, inner bracts deciduous; receptacle flat, glabrous. Florets 3-8 in a head; corollas white, tubular to minimally funnelform, glabrous below lobes; cells of limb mostly elongate with sinuous lateral walls; lobes equilaterally triangular, smooth on inner surface, with glandular punctations clustered on outer surface; filaments inserted well above base and below middle of corolla; anther collar rather longcylindrical, cells mostly subquadrate below, oblong above, cell walls with little or no ornate thickenings; anther appendage rather short-oblong, slightly but distinctly shorter than wide; style base not enlarged, glabrous; style branches distinctly broadened in distal fourth, flattened, mostly mamillose, becoming smooth apically. Achenes prismatic, 5-ribbed, sparsely setuliferous and glanduliferous; carpopodium symmetrical, short-cylindrical, with slight upper margin when dried, cells minutely subquadrate, in 10-12 series, with thickened walls; pappus of ca. 30-35 scabrid contiguous persistent bristles in 1 series, not broadened distally, apical cells acute. Pollen grains ca. $22 \mu \mathrm{m}$ in diameter. Plate 114. 


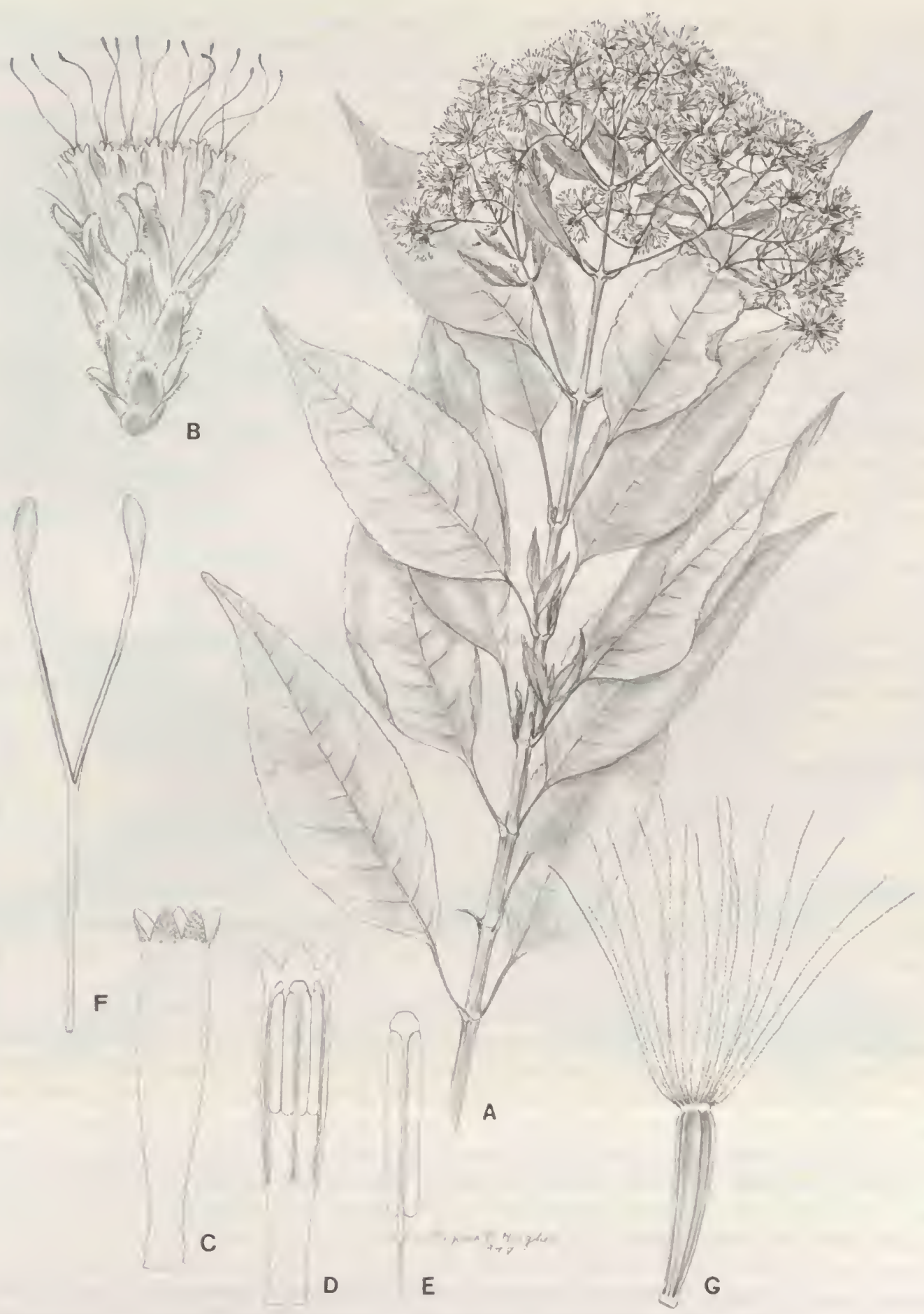

PLATE 114. Critoniadelphus nubigenus (Benth.) R. King \& H. Robinson. - A. Habit, $\times 1 / 2,-$ B. Head, $\times 5 .-$ C. Corolla outer surface, $\times 10 .-D$. Corolla inner surface with anthers, $\times 10 .-$ E. Anther, $\times 16,-F$. Style, $\times 10,-\mathrm{G}$. Achene, $\times 10$. 
Critoniadelphus is part of the small closely related group containing Critonia, Urbananthus, and apparently $A d$ enocritonia. All share a shrubby broad-leaved habit, stramineous involucres with numerous deciduous inner bracts, and narrow corollas. The first three have internal translucent secretory pockets in the areoles of the leaves, though these are prominent only in Critonia. Critoniadelphus differs from Critonia in its more obscure secretory pockets, the slender tips on the pappus bristles, the glands on the backs of the corolla lobes and on the achenes, and the anther appendages which are slightly shorter than wide. The genus differs from Urbananthus by the presence of any glands and by having the anther filaments inserted well above the base of the corolla. Adenocritonia differs by the densely glanduliferous leaves and fowers and by the much shorter anther appendages.

In a number of its characters, Critoniadelphus appears to be rather transitional between the Critonia group and some of the other genera of the Critoniinae such as Fleischmanniopsis, and one species of the latter genus was named Eupatorium nubigenoides by B. Robinson for its resemblance to the type species of Critoniadelphus. Fleischmanniopsis does not seem very closely related, however. The latter differs in the trinervate to subtrinervate venation of the leaves, the usually persistent inner involucral bracts, the pollen grains only $18-20 \mu \mathrm{m}$ in diameter, the slight but distinct annulation of the anther collar cell walls, the nearly glabrous corolla lobes, the veins of the corollas not reaching into the lobes, the anthers being pinkish with much shorter apical appendages, the carpopodium being pale and tapering with a sharp upper rim, the ribs of the achene being narrower without evident cortication, and the pappus bristles being slender and somewhat non-contiguous.

The two species of Critoniadelphus both have obvious enlarged tips on the style branches, more than in any species of Critonia except $C$. hospitalis. In spite of the similarity in style branches, $C$. hospitalis is a member of the typical group in Critonia and is not closely related to Critoniadelphus. The fact that the latter species and the two species of Critoniadelphus were all reduced to synonymy under Eupatorium nubigenum by Williams (1975) does not seem particularly significant, since type material had not been seen, and since Williams in the same paper redescribes material of Critoniadelphus microdon as a separate species, Eupatorium lucentifolium.

The genus Critoniadelphus is native to northern Central America and southern Mexico. A key to the species has been provided by King and Robinson (1971q). Of the two species, $C$. nubigena seems rather common, while $C$. $m i$ crodon is known from only about three collections.

The name Critoniadelphus, with the Greek suffix adelphus (= brother), indicates the close relationship to the genus Critonia.

The following two species are recognized in the genus:

Critoniadelphus microdon (B. Robinson) R. King \& H. Robinson, Mexico, Guatemala.

Critoniadelphus nubigenus (Benth.) R. King \& H. Robinson, Mexico, Guatemala, Honduras, El Salvador.

\section{Urbananthus}

\section{Urbananthus R. King \& H. Robinson, Phytologia 22: 55. 1971. TYPE: Eupatorium critoniforme Urban.}

Erect shrubs or small trees, moderately and laxly branched, glabrous except sometimes in branches of inflorescence and margins of involucral bracts. Stems terete, slightly striated. Leaves opposite, petiolate; blades elliptical, acute to acuminate at base, margins entire to subserrulate, apices shortly to longly acuminate, venation with moderately to rather strongly ascending secondaries, sometimes subtrinervate from well above base, areoles with obscure internal translucent secretory pockets. Inflorescence pyramidally paniculate; heads short-pedicellate or in sessile groups of 2-6; heads cylindrical to narrowly campanulate. Involucral bracts ca. 20-30, in 5-6 unequal graduated series, stramineous, orbicular to oblong, inner bracts deciduous; receptacle usually slightly convex, glabrous. Florets 4-10 in a head; corollas white, tubular, glabrous; cells of limb elongate with sinuous lateral walls; lobes oblong to oblong-ovate, mostly erect, smooth on inner surface; filaments inserted near base of corolla; anther collars cylindrical, cells mostly subquadrate, short-oblong above, walls with little or no ornate thickening; anther appendages short, slightly but distinctly shorter than wide, rounded; style base not enlarged, glabrous; style branches with minutely spathulate tips, mamillose except at tips. Achenes prismatic, 5-ribbed with somewhat thickened ribs, glabrous; carpopodium distinct, without distinct upper margin, symmetrical, short-cylindrical to stopper-shaped, cells minutely subquadrate to short-oblong, in 7-8 series, with moderately thickened walls; pappus of ca. 30 scabrid persistent contiguous bristles in 1 series, not broadened at tips, apical cells acute. Pollen grains ca. $19 \mu \mathrm{m}$ in diameter. Plate 115.

Urbananthus seems to represent the extreme element in the related group containing Critonia, Critoniadelphus, and Adenocritonia. Urbananthus is almost totally gla- brous, and definitely lacks glandular punctations on any part. The genus has internal translucent secretory pockets in the areoles of the leaves, as in Critonia, but the pockets 


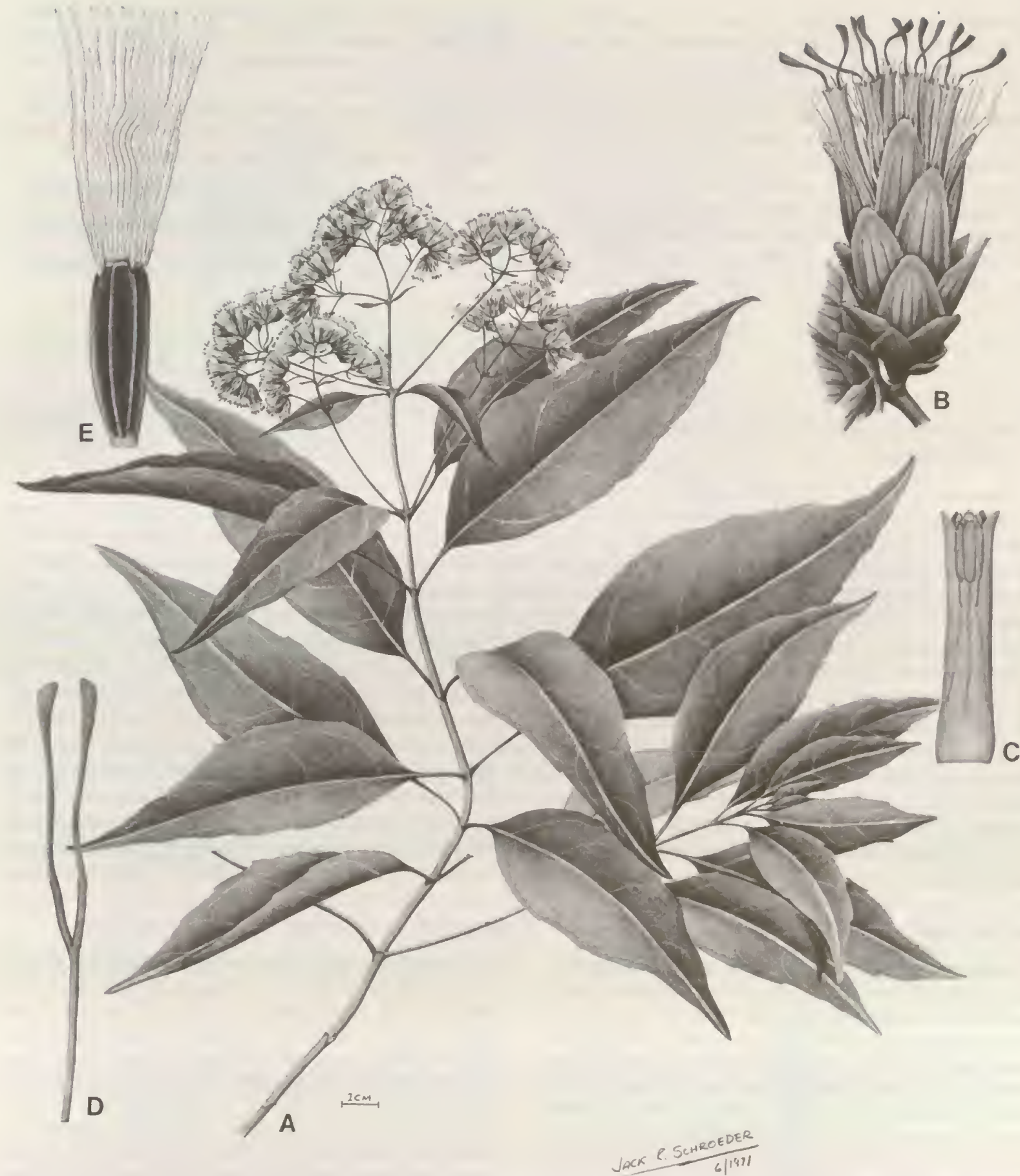

PLATE 115. Urbananthus critoniformis (Urban) R. King \& H. Robinson. - A. Habit, $\times 3 / 5 .-$ B. Head, $\times 7 .-$ C. Corolla showing anthers, $\times 12$. - D. Style, $\times 12$. - E. Achene, $\times 12$.

are small and obscure, not being useful as a key character. Urbananthus differs from Critonia, and is like Critoniadelphus, in the pappus bristles without broadened tips and the anther appendages slightly but distinctly shorter than wide, but the genus is unique in the subtribe and nearly unique in the tribe by the insertion of the anther filaments near the base of the corolla.

In spite of the clear distinction in detail, the species of 
Urbananthus closely resemble Critonia. The type species of Urbananthus is sympatric in Jamaica with the type species of Critonia, and was not distinguished from it until Urban (1900) noted the comparative lack of pellucid or translucent dots in the leaves. More recently, a plant described by Adams (1971) as a variety of the type species of Urbanamthus has proven to be the very distinct $A d$ enocritonia having densely glanduliferous leaves and anther filaments inserted well above the base of the corolla.

The genus Urbananthus is known only from the Greater Antilles. Though the two species occur on different islands, the Trinidad Mountains in southcentral Cuba are the closest part of that island to the island of Jamaica.
The two species are quite different in superficial appearance, with $U$. pluriseriatus of Cuba having much stronger more ascending lower secondary veins and a longer acuminate tip on the leaves.

The name Urbananthus is in honor of Ignatz Urban, author of the type species and noted worker in the West Indian flora in the early part of this century.

The following two species are recognized in the genus:

Urbananthus critoniformis (Urban) R. King \& H. Robinson, Jamaica.

Urbananthus pluriseriatus (B. Robinson) R. King \& H. Robinson, Cuba.

\section{Adenocritonia}

Adenocritonia R. King \& H. Robinson, Phytologia 33: 281. 1976. TYPE: Adenocritonia adamsii R. King \& H. Robinson.

Erect shrubs, with moderate branching. Stems terete, becoming striate when dry, sparsely puberulous. Leaves opposite, with slender petioles; blades ovate, subtrinervate from well above base, with a few other equally ascending secondary veins, base and apex narrowly acuminate and entire, intervening margin serrulate to serrate, undersurface densely glandular-punctate. Inflorescence a broad corymbose cyme with densely corymbose branches; heads shortly pedicellate or sessile in fascicles of 2-3. Involucral bracts strongly subimbricate in 6-7 strongly unequal series, lower bracts densely congested in 3-4 slightly spreading series, persistent, broadly ovate, inner bracts $12-15$ in 3-4 series, erect-spreading and somewhat deciduous, narrowly oblong, exposed surfaces of all bracts usually with glandular punctations; receptacle slightly convex, glabrous. Florets 5 in a head; corollas white?, tubular, base slightly inflated, glabrous outside below lobes; cells of throat elongate with sinuous lateral walls; lobes ovate-triangular, about as long as wide, inner surface smooth with short-oblong cells, outer surface with numerous glands; anther filament inserted well above base and below middle of corolla; anther collars cylindrical, cells subquadrate below, without ornate thickenings on walls, cells short-oblong above, with some weak annular thickenings on walls; anther appendages short, half as long as wide, truncate; style base not enlarged, glabrous; style branches distinctly and shortly spathulate at tip. Achenes prismatic, 5-ribbed, with ribs slightly corticated, sides glabrous or sparsely glanduliferous; carpopodium short-cylindrical, without distinct upper margin, cells minutely subquadrate to short-oblong, in 7-8 series, with thickened walls; pappus of ca. 30-35 persistent contiguous scabrid bristles in 1 series, not noticeably broadened at tips, apical cells acute. Pollen grains ca. $20 \mu \mathrm{m}$ in diameter. Plate 116.

Adenocritonia generally resembles members of the genera Critonia, Urbananihus, and Critoniadelphus, and it has tubular corollas similar to those seen in many species of the latter genera. Adenocritonia is also an endemic of Jamaica, where members of both Critonia and Urban. anthus are common. The similarity is sufficient to have caused Adams (1971) to treat material of Adenocritonia as only a variety of the type species of Urbananthus which is also from Jamaica. The combined species concept of Adams was defined by its long-acuminate leaves with translucent lines accompanying the veins only, and by the cylindrical corolla with very short lobes. The only cited difference of the variety was the pubescence of the inflorescence. Neither the literature nor any superficial examination would have suggested that the plant was necessarily even specifically distinct.
Detailed examination of material has resulted in a completely different impression of the plant, and led to the establishment of the genus Adenocritonia (King \& Robinson, 1976b). The genus continues to be regarded at present as a rather close relative of Critonia and Urbananthus, but the distinctions are sufficient to place even that in some doubt.

It is the numerous glandular punctations on the leaves, after which Adenocritonia is named, that are most significant. Such glands are totally lacking on the leaves in the related group of Critonia. Urbananthus, and Critoniadelphus, where there are internal translucent secretory pockets between or along the leaf veins. In spite of the suggestion of identical structure by Adams (1971), the leaves of true Urbananthus have such pockets while those of Adenocritonia lack them. The two structures seem to be 


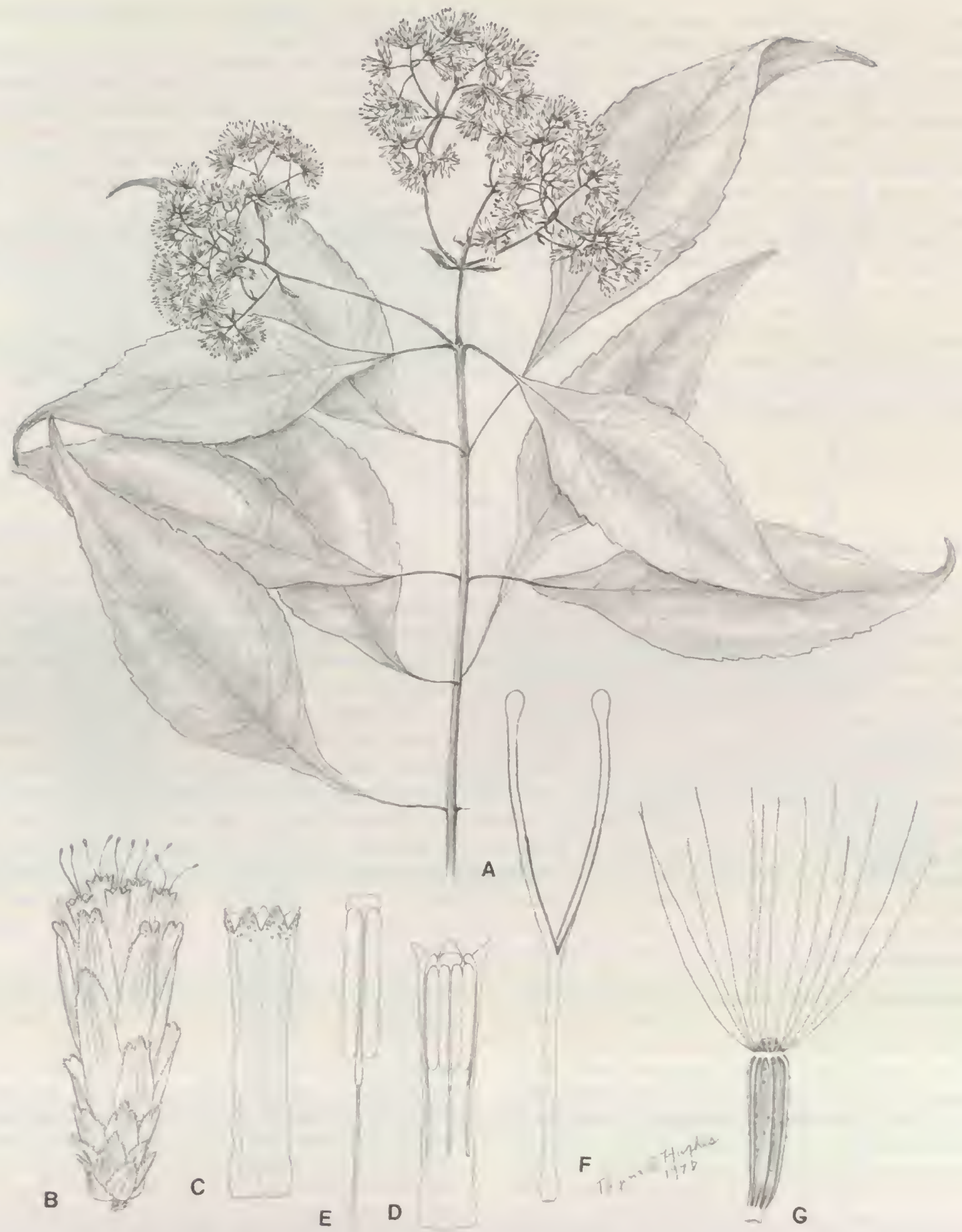

Plate 116. Adenocritonia adamsii R. King \& H. Robinson. - A. Habit, $\times 1 / 2,-B$. Head, $\times 6 .-C$. Corolla outer surface, $\times 12 .-D$. Corolla inner surface with anthers, $\times 12 .-$ E. Anther, $\times 18 .-$ F. Style, $\times 12 .-G$. Achene, $\times 12$. 
mutually exclusive, and probably represent alternative mechanisms, and are a sufficiently significant basis for exclusion of Adenocritonia from the immediate relationship of Critonia or Urbananthus.

Some other differences cause further doubt regarding the placement of Adenocritonia. The anther appendages are much shorter than those in any members of the immediate Critonia group, and more like those in such Critoniinae as Fleischmanniopsis and more typical members of Koanophyllon which have their closest occurrence in Central America. The inner involucral bracts of Adenocritonia are also more persistent than those of the immediate Critonia group, and more like those of Fleischmanniopsis. On the basis of limited material, Adenocritonia also seems to differ from Critonia, Urbananthus, and Critoniadelphus by not having a pyramidally paniculate inflorescence. The ribs of the achenes furnish a final differ- ence, not being thickened by any cortication as in the immediate Critonia group.

A distinct but not necessarily phyletically significant feature of Adenocritonia is the many series of short involucral bracts at the base of the head. From Urbananthus, the genus differs in particular by its anther filaments inserted well above the base of the corolla, by the glands on its achenes and corolla lobes, and by the more strongly trinervate leaves.

Adenocritonia is known from the type series and from one older collection. The genus seems to have a restricted distribution in the gorge of the Stony River near Nanny Town in the Portland district of Jamaica.

The following single species is recognized in the genus: Adenocritonia adamsii R. King \& H. Robinson, Jamaica.

\section{Antillia}

Antillia R. King \& H. Robinson, Phytologia 21: 398. 1971. TYPE: Eupatorium brachychaetum B. Robinson.

Erect subrosulate perennial herbs, subscapose, unbranched or with occasional short branches. Stems terete, weakly striated. Leaves mostly opposite, indistinctly short-petiolate; blades oblanceolate with tapering base, margins crenate-lobate, minutely glandular-punctate below, with ascending pinnate venation, veins and veinlets whitish and sparsely pilosulous on lower surface. Inflorescence scapose, with few ascending mostly elongate branches above; heads broadly campanulate. Involucral bracts ca. 25 , eximbricate to very weakly subimbricate, in 2-3 mostly subequal series, a few shorter outer bracts, persistent, bracts oblong-lanceolate; receptacle slightly convex, glabrous. Florets ca. 40-50 in a head; corollas white?, funnelform, with scattered minute glands and short rather pointed hairs on outer surface of throat and lobes; cells of limb oblong with slightly to strongly sinuous lateral walls; lobes triangular, slightly longer than wide, smooth on both surfaces; anther collar cylindrical, with many subquadrate cells below, oblong cells above, cell walls with slight annular thickenings; anther appendage large, oblong, blunt, as long as wide; style base not enlarged, glabrous; style branches narrowly linear, slightly broader at tip, mamillose except at tip. Achenes prismatic, 7-8-ribbed, setuliferous mostly on ribs; carpopodium distinct, symmetrical, short-cylindrical or annuliform, with 2-3 series of rather small subquadrate cells, cell walls slightly thickened; pappus a short crown of deeply laciniate scales, marginal cells of scales acute. Pollen grains ca. $19 \mu \mathrm{m}$ in diameter. Plate 117.

Three monotypic West Indian genera of the Critoniinae, Antillia, Ciceronia, and Eupatorina, are among the comparatively few members of the Eupatorieae having congested or rosulate leaves basally or intermittently along the stems. In the two genera, Antillia and Eupatorina, where the leaves are sufficiently separated, they prove to be further distinct by being opposite, those of other rosulate members of the Eupatorieae being spirally inserted. The leaves in Ciceronia are too densely inserted to see any tendency toward opposite positions, but the present placement of the genus would suggest such a tendency is present.

The reduced habits with congested leaves, and the distribution in the Greater Antilles furthers the impression that Antillia, Ciceronia, and Eupatorina are closely related to each other. This is not very certain, however, since each genus has distinctive features and each is separated geographically within the islands where they occur. $E u$ patorina of Hispaniola, with its dissected leaves, seems particularly remote. It is the two Cuban genera, Antillia and Ciceronia, that seem most alike, with oblanceolate leaves furnishing an almost Chaptalian appearance, achenes with more than five ribs, and involucres that are only weakly subimbricate or eximbricate. Antillia of central Cuba differs from Ciceronia of eastern Cuba by the more reduced pappus, the longer anther appendages, the more funnelform corollas, the presence of a carbonized layer in the achene wall, and the less condensed insertion of the leaves. In Antillia, the clusters of leaves are occasionally separated by quite long internodes.

In view of the structure of the pappus in Antillia, the placement of the species in Eupatorium by B. Robinson 


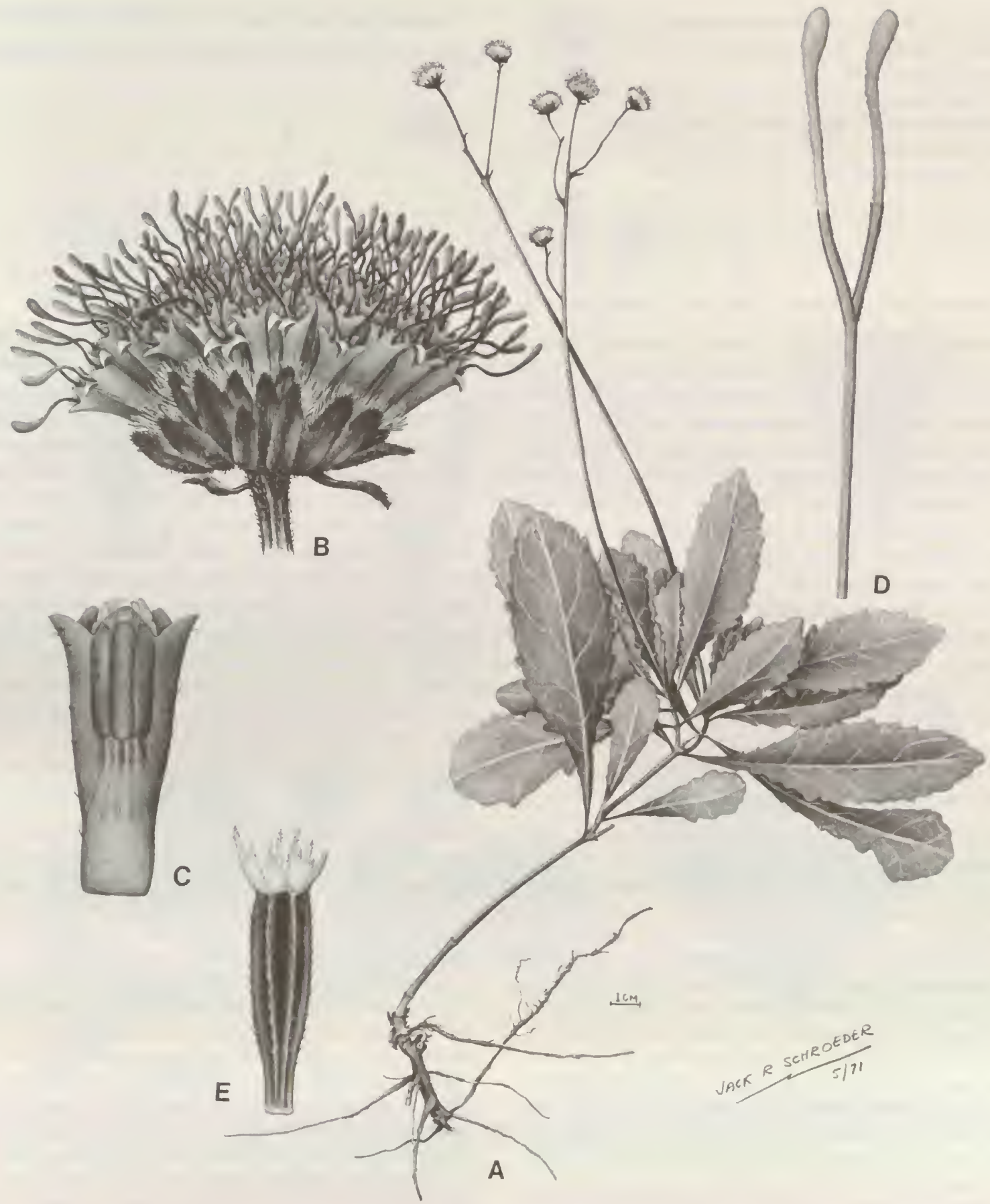

PLATE 117. Antillia brachychaeta (B. Robinson) R. King \& H. Robinson. - A. Habit, $\times 1 / 2 .-$ B. Head, $\times 6$. C. Corolla showing anthers, $\times 18 .-$ D. Style, $\times 18 .-$ E. Achene, $\times 18$. 
(1916) is inexplicable. The seven to eight ribs on the achene are also in conflict with the traditional broad concept of the genus Eupatorium.

Antillia is known only from the Trinidad Mountain area in southern Santa Clara Province of central Cuba.

The generic name Ant illia derives from the geographical name Antilles that refers to the West Indies.
The following single species is recognized in the genus: Antillia brachychaeta (B. Robinson) R. King \& H. Robinson, Cuba.

\section{Ciceronia}

\section{Ciceronia Urban, Repert. Spec. Nov. Regni Veg. 21: 324. 1925. TYPE: Ciceronia chaptalioides Urban.}

Perennial rosulate herbs, with or without some branching in basal rosette. Stems extremely short, not obvious. Leaves densely inserted, spiralled or perhaps partially opposite; blades oblanceolate, narrowed below to a slender narrowly winged base, margins lobate-crenate, venation pinnate, upper surface dark green, appressed pilosulous, white-tomentose below. Inflorescence longly and abruptly scapose, with few slender branches distally, pedicels slender and rather elongate. Involucral bracts ca. 10, weakly subimbricate, in ca. 3 subequal series, persistent, oblanceolate to elliptical, obtuse; receptacle flat, glabrous. Florets 9-10 in a head; corollas lavender, with short broad basal tube shortly constricted above, throat broadly and shortly funnelform with slightly campanulate base, with scattered glandular punctations on outer surface, dense on outer surfaces of lobes; cells of limb short-oblong with firm non-sinuous walls; lobes triangular, about as long as wide, smooth on both surfaces; anther collar cylindrical, with mostly short-oblong cells, cell walls not or scarcely ornamented; anther appendage small, blunt, half as long as wide; style base not enlarged, glabrous; style branches with stigmatic portion slightly broadened, style appendages slightly narrowed and mamillose above stigmatic portion, slightly broadened distally and becoming smooth at tip. Achenes prismatic, with ca. 8 ribs and 5 major angles, densely setuliferous mostly on ribs, glandular-punctate mostly between ribs, carbonization and minute internal punctations of achene wall apparently absent; carpopodium distinct, with slight upper rim, symmetrical, short cylindrical, cells short-oblong in 3-5 series, with evenly thickened porose walls; pappus of ca. 45 persistent bristles, with tips of teeth and apical cells blunt. Pollen grains ca. $23 \mu \mathrm{m}$ in diameter. Plate 118 .

Unlike most members of the subtribe Critoniinae, including those considered here as most closely related, Ciceronia has been spared inclusion in the broad concept of the genus Eupatorium. However, this may have been because of the comparatively limited attention given to this monotypic genus endemic to eastern Cuba. Certainly, the short anther appendage that caused Urban (1925) to place the genus in the Piqueriinae is not short enough to be unusual among species once placed in Eupatorium, being half as long as wide. The appendage in Ciceronia does not approach the degree of reduction seen in Ophryosporus with which Urban compared his genus, and though the two genera prove to belong to the same subtribe, they do not seem particularly closely related within the Critoniinae.

Urban (1925) also compared Ciceronia with Trilisa with which it shares a rosulate habit and 8-10 ribs on the achenes, and the habit may have been the most significant character cited by Urban. The basal rosette of Ciceronia is definitely one of the most highly developed in the tribe, being equalled in its abruptly scapose inflorescence only by Litrisa of the Liatrinae and Bishopiella of the Gypti- dinae. Ciceronia differs from such rosulate genera by its smooth corolla lobes and simple distally broadened style branches, traits of the Critoniinae. The rosulate habit of Ciceronia seems to be related more to the subrosulate forms of Antillia and Eupatorina in the Critoniinae which are marked by opposite leaves.

Ciceronia seems most closely related to Antillia, also of Cuba, and Eupatorina of Hispaniola. Of these, Eupatorina seems least close, being easily distinguished by its dissected leaves, its less well-defined rosette, and its more subimbricate involucre. Antillia, with oblanceolate leaves, seems closer to Ciceronia, but the differences are still sufficient to cause some doubt. Ciceronia has a sharply distinct rosette unlike Antillia, and has tomentum on the leaf undersurfaces, broader blunt involucral bracts, shorter flaring corolla limbs, a distinctly capillary pappus, and shorter anther appendages. Although the two genera share a higher number of ribs on the achene, the achenes of Ciceronia are amply distinct in other features. The setulae are blunt-tipped, there are numerous glands born between the ribs, and the carpopodium is longer with thicker-walled cells. Most interestingly, the limited material examined 


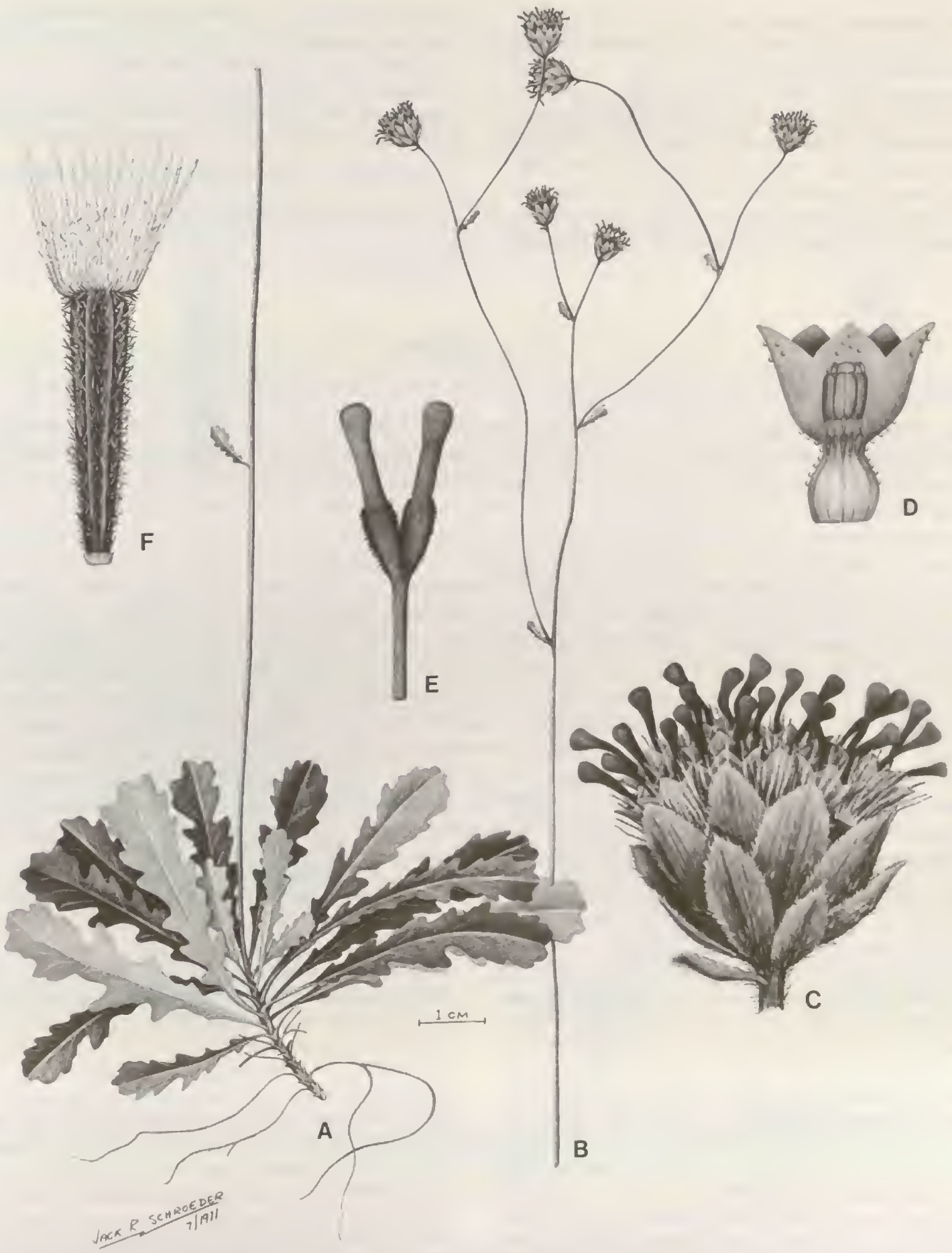

Plate 118. Ciceronia chaptalioides Urban. - A. Habit, base, $\times 1 .-$ B. Habit, inflorescence, $\times \%$. - C. Head, $\times 4 .-$ D. Corolla showing anthers, $\times 16 .-$ E. Style, $\times 16 .-F$. Achene, $\times 16$. 
seems to indicate that the achenes of Ciceronia are among the few in the Eupatorieae having no carbonized deposits or minute internal punctations in the walls.

The material examined of Ciceronia shows a rather unusual form of anther filament with the lower part comparatively thick and free standing. The filament becomes abruptly narrower and more tenuous in the collar. Filaments of most Asteraceae have the lower part of the filament thinner or more subject to collapse than the collar.

The genus Ciceronia is known only from the Sierra de
Nipe, Rio Piloto area in Oriente Province of eastern Cuba. Only the members of the type series collected by Ekman have been seen during the present study.

As indicated by Urban (1925), the genus was named in memory of "M Tullii Cicero, oratoris romani praestantissimi et auctoris latinitatis optimae celeberrimi."

The following single species is recognized in the genus: Ciceronia chaptalioides Urban, Cuba.

\section{Eupatorina}

\section{Eupatorina R. King \& H. Robinson, Phytologia 21: 396. 1971. TYPE: Eupatorium sophiaefolium L.}

Erect perennial calcicolous herbs, occasionally branched from base. Stems terete, striated, grayish puberulous. Leaves opposite, larger leaves congested at base, often lacking in older plants, leaves decrescent and increasingly remote above, with narrow petioles; blades deeply bipinnatifid with small rounded to oblong ultimate segments, fern-like, with glandular punctations on undersurface. Inflorescence a lax thyrsoid panicle, with branches ending in lax cymes; pedicels slender. Involucral bracts ca. 12, moderately subimbricate, in 2-3 unequal graduated series, persistent or with a few deciduous inner bracts, mostly oblong, bicostate, puberulous and glandular-punctate on outer surface; receptacle flat to slightly convex, glabrous. Florets 1320 in a head; corollas blue, lavender, or pale purple, narrowly funnelform, outer surface with numerous glandular punctations mostly on lobes and at slightly constricted top of basal tube; veins of throat ending in sinuses between lobes, not extending into lobes; cells of limb oblong with sinuous lateral walls; lobes triangular, about as long as wide, smooth on both surfaces; anther collar narrow, with subquadrate cells below, elongate cells above, cell walls with slightly beaded thickenings; anther appendage large, slightly wider than long, truncate or rounded apically; style base not enlarged, glabrous; style branches only slightly broadened at tips, mamillose except at tips. Achenes prismatic, 4-5-ribbed, setuliferous on sides; carpopodium distinct, with slight upper rim, symmetrical, annuliform or shortly stopper-shaped, cells subquadrate in 35 series, walls slightly thickened; pappus of ca. 40 scabrid persistent contiguous bristles in 1 series, apical cells short-acute. Pollen grains ca. $18 \mu \mathrm{m}$ in diameter. Plate 119.

Eupatorina of Hispaniola has the general characters that caused its species to be placed early in the genus Eupatorium and to be retained there in all the traditional classifications of the tribe. The pappus is of many capillary bristles, the achene has five ribs, and the anther appendage is nearly as long as wide. It was not until the present series of studies that Eupatorina, like many other members of the Critoniinae, was first raised to a separate generic status. Still, the genus is strikingly distinctive in characters that are not usually thought of as generic in value, the dissected fern-like leaves and the affinity for calciferous habitats. Closer examination shows other details that support the separation of the genus.

Geography and the subrosulate basal leaves seem to indicate that Eupatorina is most closely related to two other monotypic genera of the Critoniinae, Antillia and Ciceronia, from Cuba. Of the three genera, Eupatorina seems to be the most distant, and shows more characters of the typical Critoniinae such as the definitely subimbricate involucre. Viewed alone, a head of Eupatorina looks superficially like that of a small Koanophyllon, with the dense glands on the corolla lobes and with slightly enlarged tips on the style branches. Of course, Koanophyllon and its close relatives do not have the subrosulate basal leaves or the finely dissected leaf blades like those seen in Eupatorina. Corollas with veins ending short of the lobes as in Eupatorina are seen in only one other member of the Critoniinae, Fleischmanniopsis, of Central America. The latter genus, which follows next in this treatment, differs in details of involucre, pappus, and lack of glands, and is not considered here as closely related.

Eupatorina appears to be one of the few calciphiles in the Critoniinae. Certainly, such a habitat preference has not been obvious to us in any other member of the subtribe. Label data indicates that Eupatorina often grows at bases of limestone bluffs, often in moist clay. Some labels indicate that plants are sometimes collected from crevices in the rock.

Most collections of the genus seem to be from northern Haiti and the adjacent part of the Dominican Republic. 


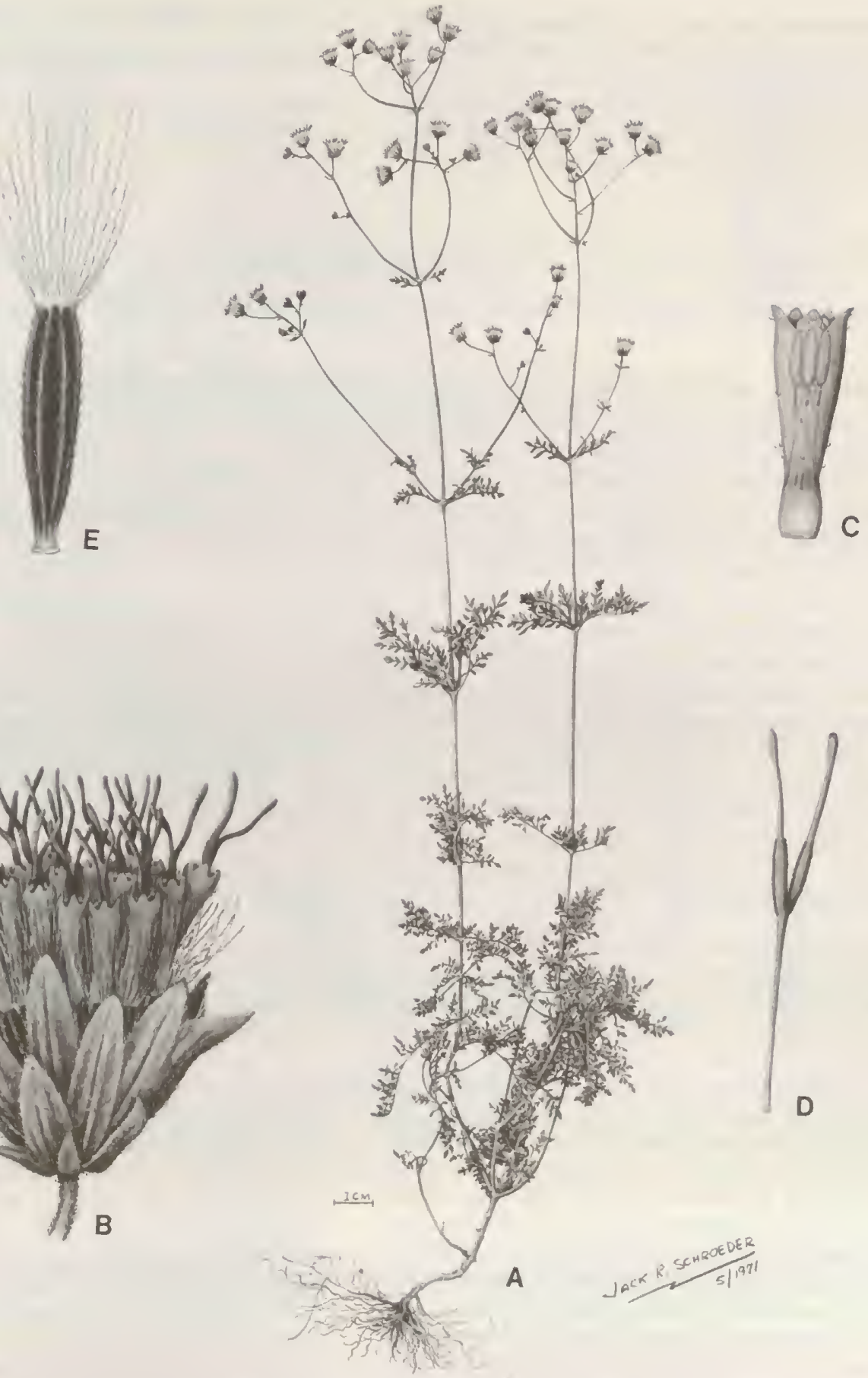

PLATE 119. Eupatorina sophiaefolia (DC.) R. King \& H. Robinson. - A. Habit, $\times \% .-$ B. Head, $\times 12 .-$ C. Corolla showing anthers, $\times 24$. - D. Style, $\times 24 .-$ E. Achene, $\times 24$. 
A few specimens are from southern Haiti and immediately adjacent Barahona Province. One specimen collected by Liogier, farther east in Puerto Plata Province in the northern part of the Dominican Republic, has somewhat less dissected leaves with larger segments, and has few or no glands on the undersurfaces of the leaves.
The name Eupatorina is a diminutive of Eupatorium.

The following single species is recognized in the genus:

Eupatorina sophiaefolia (L.) R. King \& H. Robinson, Haiti, Dominican Republic.

\section{Fleischmanniopsis}

\section{Fleischmanniopsis R. King \& H. Robinson, Phytologia 21: 402. 1971. TYPE: Eupatorium leucocephalum} Benth.

Erect perennial herbs, with few to many branches. Stems terete to subhexagonal, slightly striated. Leaves opposite, with distinct slender petioles; blades ovate-lanceolate, bases acute, margins usually serrate, trinervate from base or subtrinervate with strongly ascending lower secondary veins, without glandular punctations. Inflorescence a rather diffuse corymbose to thyrsoid panicle with densely corymbose branchlets; pedicels short. Involucral bracts ca. 15-20, strongly subimbricate, in 3-5 strongly unequal graduated series, ovate-lanceolate, often whitish, inner bracts usually persistent; receptacle flat or slightly convex, glabrous. Florets 5-10 in a head; corollas white, narrowly funnelform without distinct constriction at top of basal tube, nearly glabrous outside, with few hairs inside near bases of filaments in $F$. langmaniae; cells of limb oblong to linear with sinuous lateral walls; veins reaching only to sinuses between lobes, not extending into lobes; lobes triangular, about as long as wide, smooth on both surfaces, with short papillae only at tips; anther collar slender, with subquadrate cells below, rectangular cells above, cell walls with usually distinct annular thickenings; anther thecae often reddish; anther appendage small, half as long as wide, sometimes retuse at tip; style base not enlarged, glabrous; style branches rather abruptly spathulate at tips, slender bases of appendages short-papillose, becoming mamillose near tips. Achenes prismatic, 4-5-ribbed, ribs with few scabrae or many setulae; carpopodium distinct, with distinct upper rim, symmetrical, stopper-shaped, cells small and subquadrate in ca. 8 rows, with thick walls; pappus of ca. $30-40$ scabrid, persistent, contiguous to somewhat separated bristles in 1 series, apical cells acute, sometimes distorted. Pollen grains ca. 17-20 $\mu \mathrm{m}$ in diameter. Plate 120.

The genus Fleischmanniopsis is one of the many segregated from the broad concept of Eupatorium during the present series of studies. It includes a small group of Central American species belonging to the Critoniinae, but nevertheless shows a number of details of the florets reminiscent of Fleischmannia of the Fleischmanniinae. The initial inclination was to relate the genus closely to the genus Critonia, and to regard the group in the Critoniinae as a possible point of departure for the distinctive Fleischmannia (King \& Robinson, $1971 \mathrm{~m}$ ). The shape of the involucres and the expanded tips of the style branches approach the forms seen in Critoniadelphus, also of Central America, and the carpopodia, pappus, general shape of the corolla, and annular thickenings of the anther collar are like Fleischmannia. Although containing some diversity, the genus was originally regarded as somewhat technical in nature, distinguished mostly by a combination of characters. Only the veins of the corolla ending below the lobes seemed particularly unique, occurring elsewhere in the subtribe in only the monotypic Eupatorina of Hispaniola. It remained for a later study (King \& Robinson, 1977c) to show that Fleischmanniopsis was more distinct and more diverse than first suspected.
As presently understood, Fleischinanniopsis has absolutely no close relationship to Fleischmannia. The corollas lack the prorulose cells on the lobes, the externally visible demarcation between the basal tube and the throat, the thickened veins of the corolla throat, and the extension of the veins into the lobes. The style branches are greatly expanded at the tips and very slender below. The anthers are reddish and usually visible through the corolla, and the appendages are short. The heads contain less flowers, and the involucres are more cylindrical and imbricated. Even the anther collars differ in detail, having a few subquadrate cells evident at the base. It seems more logical, on the basis of its characters, to seek the relationships of the Fleischmanniinae elsewhere, perhaps with such subtribes as the Ayapaninae.

The relationship between Fleischmanniopsis and the Critonia group represented by Critoniadelphus is now also considered more remote. This is in spite of the fact that one species of Fleischmanniopsis is named $F$. nubigenoides because of its resemblance to the type species of Critoniadelphus. Fleischmanniopsis does not have the internal secretory pockets in the leaves, its inner involucral bracts are persistent, the cell walls of the anther collars 


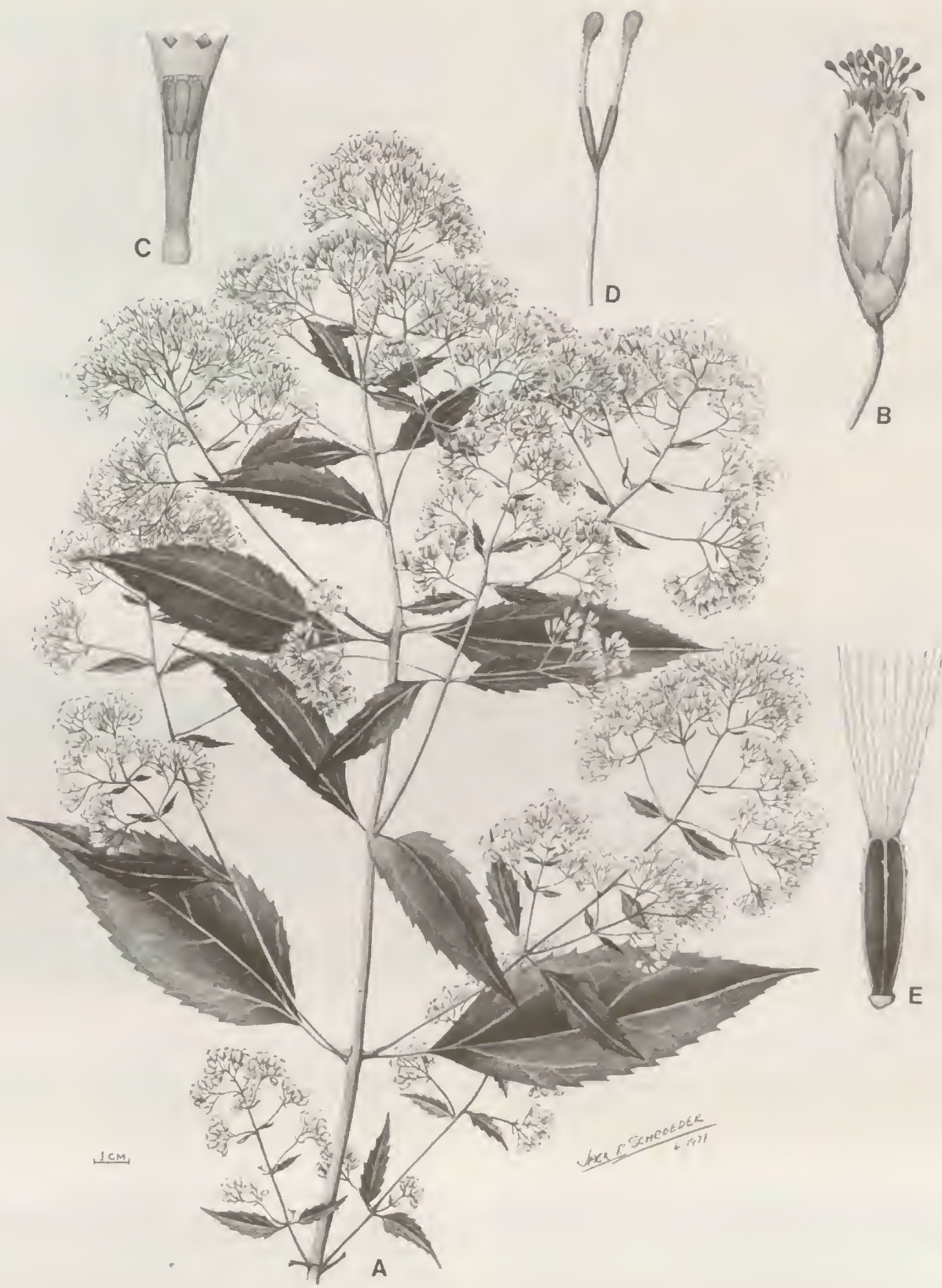

Plate 120. Fleischmanniopsis leucocephala (Benth.) R. King \& H. Robinson. - A. Habit, $\times 1 / 2,-$ B. Head, $\times 6 .-$ C. Corolla showing anthers, $\times 13 .-D$. Style, $\times 13 .-$ E. Achene, $\times 13$.

are distinctly annulated, the corolla lobes have no glands, the pappus bristles are in a single uncongested series, the ribs of the achene are not broadened by cortication, the carpopodium is pale and tapering with a distinct upper rim, the anther appendage is only half as long as wide, the pollen grains are only $18-20 \mu \mathrm{m}$ inm diameter, the corolla veins end below the lobes, and the leaves have trinervate or subtrinervate rather than pinnate venation.

Fleischmanniopsis is presently regarded as rather close to the genus Koanophyllon within the Critoniinae. The 
lack of glands on the corolla, the reddish anther thecae, the narrower pappus bristles, the slender rather papillose stalks of the style appendages, and the shorter veins of the corolla are among the distinguishing characters of Fleischmanniopsis.

The genus Fleischmanniopsis would be most notable to the casual observer for the showy white involucres of three of the species. The white inflorescences are very ornamental, and plants are apparently used by natives as decoration on various special days. The whitish involucres are obvious very early in the development of the plants and have caused many specimens to be collected immature. The involucral bracts are greenish rather than white in $F$. mendax, and brownish in $F$. nubigenoides.

The genus is distributed from Mexico southeastward to
El Salvador with the greatest diversity in Guatemala. The key to the species has been provided by King and Robinson $(1977 c)$.

The following five species are recognized in the genus:

Fleischmanniopsis anomalochaeta R. King \& H. Robinson, Guatemala, El Saivador.

Fleischmanniopsis langmaniae R. King \& H. Robinson, Mexico. Fleischmanniopsis leucocephala (Benth.) R. King \& H. Robinson, Mexico, Guatemala.

Fleischmanniopsis mendax (Standley \& Steyerm.) R. King \& H. Robinson, Guatemala.

Fleischmanniopsis nubigenoides (B. Robinson) R. King \& H. Robinson, Guatemala.

\section{Viereckia}

Viereckia R. King \& H. Robinson, Phytologia 31: 118. 1975. TYPE: Viereckia tamaulipasensis R. King \& H. Robinson.

Erect moderately branched shrubs. Stems slender and flexuose, terete, scarcely striated, puberulous. Leaves opposite, with distinct short petioles; blades deltoid, base truncate or subtruncate, margin serrulate, apex sharply acute, strongly trinervate from base, minutely glanduliferous on both surfaces. Inflorescence terminal on branches, with small rather corymbose clusters; heads few, shortly pedicellate, usually with 1-2 distinct spreading foliose bracts immediately below involucre. Involucral bracts ca. 20 , subimbricate, in 4-5 unequal graduated series, ovate-lanceolate to linear, 2-4-costate, inner series easily deciduous; receptacle slightly convex, glabrous to scarcely puberulous. Florets 10-12 in a head; corollas whitish?, narrowly funnelform, glabrous; cells of limb oblong with sinuous lateral walls; lobes long-triangular, about twice as long as wide, smooth on both surfaces; anther collar narrowly cylindrical, cells oblong, with weak but distinct annular thickenings on walls; anther appendages large, oblong-ovate, twice as long as wide; style base not enlarged, glabrous; style branches linear, not broadened distally, mamillose or shortly papillose. Achenes prismatic, 5-ribbed, setulae mostly on ribs, a few minute glands at upper end; carpopodium distinct, with distinct upper rim, symmetrical, short-cylindrical, with cells small and subquadrate in 3-5 rows, with distinctly and evenly thickened walls; pappus of ca. 30-35 scabrid slender persistent bristles, slightly broadened distally, apical cells acute. Pollen grains ca. 23-25 $\mu \mathrm{m}$ in diameter. Plate 121.

Viereckia is one of a number of small genera of the Eupatorieae restricted to limited areas in northern Mexico. Most of the other such genera are members of the Alomiinae, a subtribe that is predominant in the area. Another such genus is the superficially similar Tamaulipa, of the Gyptidinae, a subtribe that is mostly in eastern South America. The two subtribes to which Viereckia shows any possible relationship, however, the Critoniinae and the Praxelinae, are represented in the area by only fringe elements of larger genera.

Geography and superficial appearance might initially lead one to place Viereckia close to Tamaulipa, and there has been one unpublished suggestion that Viereckia is a hybrid with Tamaulipa as one of the parents. Tamaulipa differs, however, in its stouter straighter pale stems, its more irregular weakly subimbricate and totally persistent involucral bracts, its $40-75$ flowers in a head, its highly convex to conical receptacle, the shorter externally glanduliferous corolla lobes, and the detailed differences of the achene and carpopodium. Present evidence seems to preclude close relationship.

The imbrication of the involucre with some deciduousness of bracts in Viereckia indicates relationship to the subtribal group containing the Critoniinae and Praxelinae. The carpopodium, long anther appendages, and style are like those of Chromolaena in the Praxelinae, but Viereckia does not have the totally deciduous involucre that is characteristic of that subtribe. In the latter feature, the genus falls technically within the Critoniinae, where closest relationships are not clear.

The suggestion of a hybrid origin for Viereckia is not altogether unreasonable. The genus is known from a single 

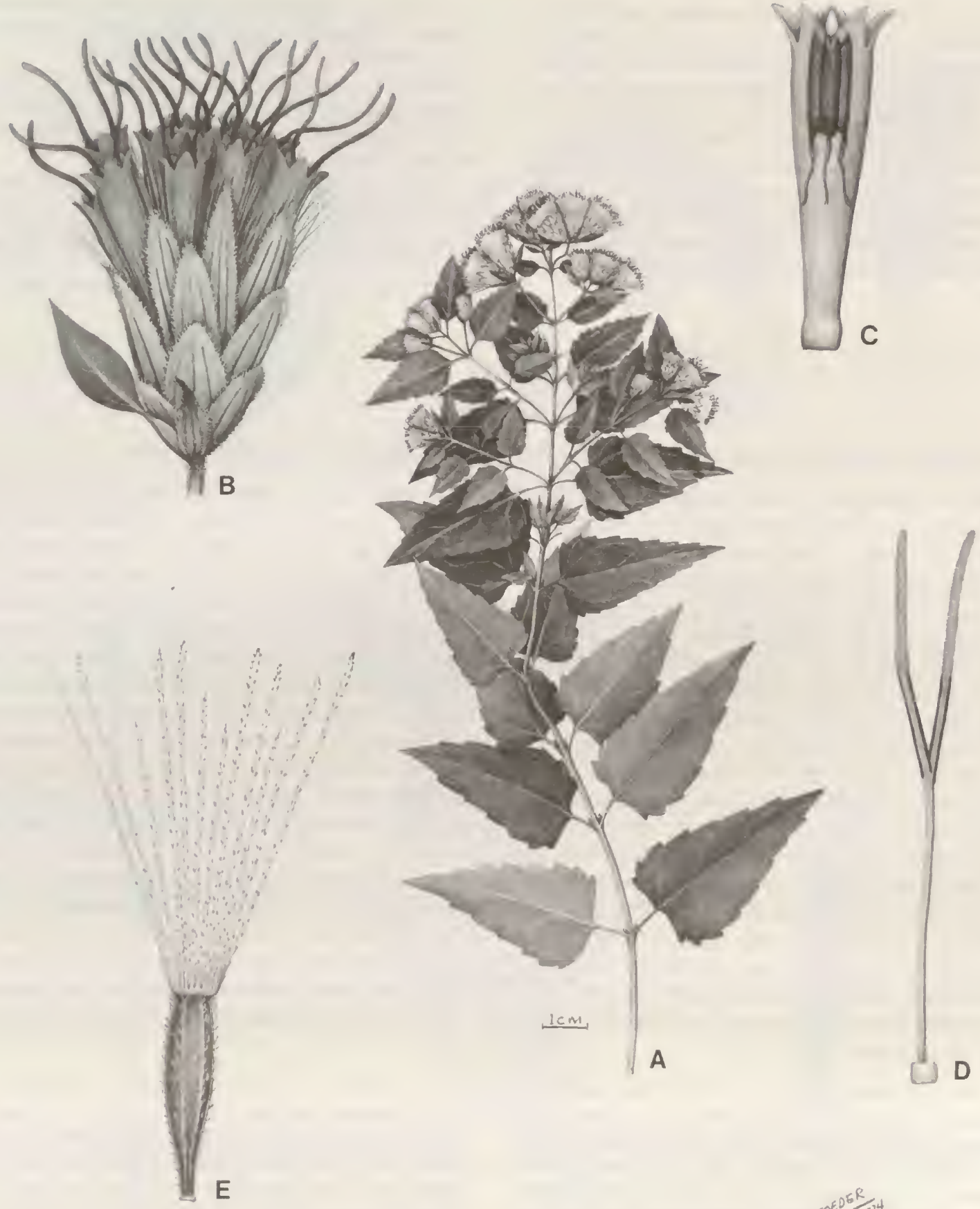

PLATE 121. Viereckia tamaulipensis R. King \& H. Robinson. - A. Habit, $\times 2 / 3,-B$. Head, $\times 6 .-$ C. Corolla showing anthers, $\times 10 .-$ D. Style with nectary, $\times 10 .-$ E. Achene, $\times 10$. 
collection in a comparatively well-collected area, which might indicate a single hybrid event. Also, a number of apparent hybrids seem to exist between Chromolaena and such Critoniinae as Koanophyllon in Mexico and the West Indies. Still, potential parents for such a hybrid are not common in northern Mexico, and Viereckia does not have abnormal pollen or other features that might accompany some solitary hybridization events. In the present view, Viereckia undoubtedly has some intergeneric hybridization in its past, as do many other if not all elements in the Asteraceae, but the hybridization does not seem very recent.
The few sprigs of Viereckia that are available indicate a rather distinctively flexuous shrub with characteristic foliose bracts at the bases of the heads.

The genus is presently known from only the type collection from Jaumave in Tamaulipas, Mexico, at an elevation of $620 \mathrm{~m}$ above sea level. Recent efforts to recollect the genus seem to have been unsuccessful.

The name of the genus honors H. W. Viereck, the collector of the type specimen.

The following single species is recognized in the genus: Viereckia tamaulipasensis R. King \& H. Robinson, Mexico.

\section{Koanophyllon}

\section{Koanophyllon Arruda, Diss. Pl. Brazil, 38? 1810. TYPE: Koanophyllon tinctorium Arruda.}

Shrubs or small trees, rarely vines, with few to many branches. Stems terete, striated. Leaves opposite, rarely alternate, distinctly petiolate, petioles usually short; blades broadly lanceolate to elliptical, base acute, truncate, or cordate, margins entire to serrate (irregularly lobed in $K$. lobatifolium), venation pinnate to trinervate, surfaces usually with few or no short hairs, rarely densely pubescent, with glandular punctations very sparse to numerous, without internal secretory pockets in areoles. Inflorescences pyramidally paniculate to corymbose, pedicels usually short. Involucral bracts 7-16, eximbricate to strongly subimbricate, usually weakly subimbricate, in 2-4 unequal to subequal series, mostly spreading at maturity, inner bracts sometimes deciduous; receptacle flat to slightly convex, glabrous, epaleaceous. Florets 5 to ca. 20 in a head; corollas usually whitish to greenish yellow, rarely violet, funnelform with broadly cylindrical basal tube; cells of limb narrow with rather sinuous walls; lobes broadly triangular, as wide as long to 1.5 times as long as wide, smooth on both surfaces, with numerous clustered short-capitate glands and sometimes a few hairs on outer surface; anther collar cylindrical, usually with numerous subquadrate cells below, longer cells above, cell walls usually without ornate thickenings, sometimes with annular thickenings, base of collar unsclerotized in $K$. albicaule; anther appendages often wider than long, sometimes very short, apical margin flat to strongly recurved, sometimes longitudinally grooved on middle of inner surface and notched apically; style base not enlarged, glabrous; style branches usually distinctly broadened and becoming smooth apically, without glands. Achenes prismatic, 5-ribbed, ribs and upper lateral surfaces bearing setulae, with few or no glands; carpopodium distinct, short, stopper-shaped or cylindrical, with slight but distinct upper rim, with small subquadrate cells in 5-10 series, walls slightly thickened; pappus of ca. 30-35 long persistent scabrid bristles, in 1 series, usually rather stout, short in $K$. ravenii, lacking in $K$. standleyi, apical cells of bristles acute. Pollen grains ca. 16$22 \mu \mathrm{m}$ in diameter. Plate 122.

As presently conceived, Koanophyllon is the largest genus of the subtribe Critoniinae, and is the center of a complex of additional genera. The group tends to include those members of the subtribe with more weakly subimbricate or eximbricate involucres, and those with much shortened anther appendages, though these features are subject to variation even within Koanophyllon. The Koanophyllon group, in spite of distinctive trends, does relate to the typical element of the subtribe.

In spite of great variation in many features including habit, Koanophyllon is delimited within its related group by the corolla with its broadly cylindrical tube and its short triangular lobes bearing numerous glands on the outer surface. The pappus bristles are also rather stout and persistent, and the plants are all at least partially opposite-leaved. Most of the segregate genera differ by two or more characters, such as Eupatoriastrum with its paleae and very numerous flowers in the heads, and Fleischmanniopsis with its short corolla veins and narrower style appendage bases. Three of the related genera have their heads in spherical clusters, Sphaereupalorium having paleae intermixed with the flowers, Neohintonia having single-flowered heads, and Mexianthus having both single-flowered heads and a squamulose pappus. Nothobaccharis has spirally inserted leaves and longer scarcely glanduliferous corolla lobes, and Bishovia has laxly alter- 

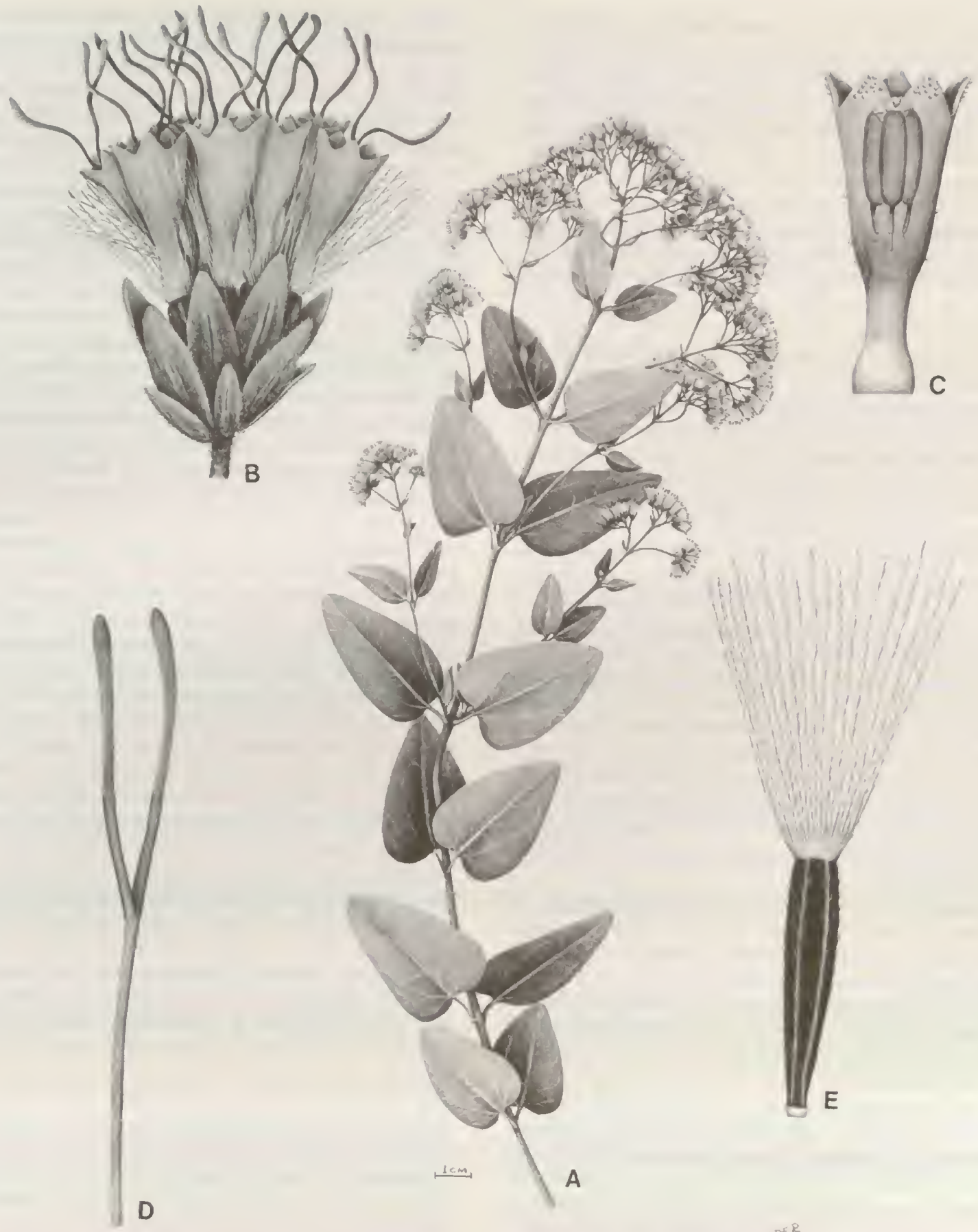

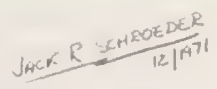

Plate 122. Koanophyllon villosum (Sw.) R. King \& H. Robinson. - A. Habit, $\times \%$. B. Head, $\times 10 .-$ C. Corolla showing anthers, $\times 17 .-D$. Style, $\times 17 .-E$. Achene, $\times 17$. 
nate leaves and densely stipitate-glandular pubescence. Other genera differ primarily by single characters that fall outside the definition of Koanophyllon. Grisebachianthus is densely tomentose or villous on leaf-undersurfaces and involucres; Lorentzianthus has slender rather fragile pappus bristles; Chacoa has a narrow basal tube on the corolla; and Idiothamnus has scattered paleae in the heads. Some of the seemingly weaker segregates are strengthened by possession of characteristics that are rare in Koanophyllon; Santosia having longer non-glanduliferous corolla lobes and also being a vine; Grisebachianthus having strongly subimbricate acute-tipped involucral bracts; Idiothamnus having strictly pinnately veined leaves; Ophryosporus having almost totally obsolete anther appendages, narrower corolla bases, and eximbricate involucres with comparatively few bracts; and Lorentzianthus having strongly subimbricate involucres and long slender petioles. Any impression of untidiness in achieving a definable Koanophyllon is largely dispelled by the evidence of sharp distinction and sometimes significant internal variation for most of the segregates.

As delimited, Koanophyllon shows great variation in a number of characters. In the present series of studies, the genus was initially limited to a typical element with a short usually somewhat reflexed anther appendage with a distinct median groove running up the inner surface (King \& Robinson, $1971 b b$ ). In some species the appendage is divided almost into two separate parts. Most of the species in the early concept have pyramidally paniculate inflorescences. A later study expanded the genus to include a large complex in the West Indies having usually short ungrooved anther appendages and more corymbose inflorescences, and species in South America with longer ungrooved appendages and various forms of inflorescences (King \& Robinson, 1975q).

Among the species included in the earlier treatment of the genus, $K$. simillimum has an anther appendage almost as long as wide, and $K$. albicaule is distinctive in having larger heads in a rather corymbose inflorescence and having anther collars with clear annular thickenings on the cell walls. Among the more recently added species are $K$. thysanolepis with its large coarse heads and partially dentate involucral bracts, and $K$. mytilloides with subopposite, opposite, and ternate leaves. Most members of the genus have short-petiolate leaves, but $K$. consanguineum sometimes has petioles approaching those of Lorentzianthus and many Hebecliniinae in length. Leaves of $\mathrm{KO}$ anophyllon are characteristically glandular-punctate, and only $K$. prionoides shows no glands on the leaf surfaces under a dissecting microscope. The flowers in Koanophyllon are usually whitish but are recorded as pale pink or violet in $K$. mesoreopolum of Colombia. There are unusually large pinnately veined leaves in $K$. jugipaniculatum.

The involucre in the Eupatorieae has been used extensively in distinguishing groups, and various subtribes tend to have characteristic forms. The extreme variation in Koanophyllon, therefore, is quite remarkable. The great majority of the species have involucres weakly subimbricate, and a few such as $K$. adamantium and $K$. andersonii of Brazil are strictly eximbricate. The characteristic involucral form of the Critoniinae, with strong subimbrication and deciduous inner bracts, occurs in some species of the typical group from Central America with pinnately veined leaves such as $K$. pittieri and $K$. galeottii, and in one scandent member of the atypical group from Jamaica, K. tetranthum.

The most striking variation in the genus is found in a group of three species in southern Mexico and northern Central America. The common $K$. solidaginoides has a conventional pappus of capillary bristles, but a closely related species in Guatemala and El Salvador has no pappus and was described originally as Piqueria standleyi by B. Robinson (1934a). A third species in southern Mexico, $K$. ravenii, has a pappus of very short bristles.

In the West Indies and Mexico there are a number of species showing a mixture of characters of Koanophyllon and Chromolaena, and hybridization between the two genera has apparently occurred. The effects seem more obvious in elements placed in this treatment in Chromolaena and Osmiopsis of the subtribe Praxelinae. Two species in Koanophyllon showing some effects are $K$. selleanum and $K$. phanioides of Haiti which differ from $O s$ miopsis by little other than the persistent outer involucral bracts by which the subtribes are technically distinguished. In spite of such evidence, the genera Koanophyllon and Chromolaena do not seem very closely related, the former having its center of origin probably in Central America, and the latter belonging to a basically Brazilian group.

Grashoff and Beaman (1970) have noted the elongate many-headed inflorescences, the reduced anther appendages, the less spinose pollen, and the probability of wind pollination in various species of the Eupatorieae that are now placed in the genera Koanophyllon, Decachaeta, Neohintonia, and Critonia. The pollination in Koanophyllon and the other genera is undoubtedly rather facultative. The pollen in one group of species, $K$. solidaginoides, $K$. standleyi, and $K$. ravenii seems to have longer spines than seen in other members of the genus. Koanophyllon palmeri and $K$. solidaginifolium have only low papillae on their pollen. Pollen matching what we have called Type II in the genus Stevia (King \& Robinson, 1967) has been observed in $K$. coulteri indicating irregular meiosis and apomixis.

The base of the corolla in Koanophyllon is characteristically broadly tubular and scarcely distinguishable externally from the limb. The nectary in the genus is usually quite large, extending upward partly into the broadly tubular corolla base.

The genus Koanophyllon was described over one hundred and sixty years ago in a publication of Arruda 
da Camara (1810) of very limited distribution. As yet we have not seen a copy of the original publication, but we have seen a partial translation by Koster (1816), and the review of and comments on Arruda's names by Britten (1896) based on Koster's translation and pagination. It is the Koster translation that is cited in the Index Kewensis, although the original 1810 publication of Arruda da Camara seems perfectly valid. The type species, Koanophyllon tinctorium, was described as a dye plant with the common name, Anil de Pernambuco. This is apparently the same plant called Eupatorium tinctorum by Pohl (unpubl. data) and identified by J. Baker (1876) and Oliver (1892) as Eupatorium laeve DC. The Arruda da Camara and DeCandolle species have been recently lectotypified with the same type by King and Robinson (1972h).

Oliver (1892) reviews some of the history of attempts to use Koanophyllon tinctorium commercially as a source of indigo. It seems of interest that another species of the genus, $K$. albicaule is credited on herbarium labels as a source of a green dye used on cloth and cord locally in Honduras.

The genus Koanophyllon ranges from Paraguay and Brazil in the south, northward along the Andes, reaching the West Indies, Central America, and Mexico. One species reaches the southwestern United States and another reaches southernmost Florida. The typical element of the genus extends through most of the range, being rare or absent only in the West Indies. The only key within the present concept treats the four species in Panama (King \& Robinson, 1975y). Older keys do not directly compare nor adequately distinguish the species.

The source of the name Koanophyllon is not known, but possibly refers in some way to the use of the leaves of the type species as a source of indigo.

The following 114 species are recognized in the genus.

Koanophyllon adamantium (Gardner) R. King \& H. Robinson, Brazil.

Koanophyllon albicaule (Schultz-Bip. ex Klatt) R. King \& H. Robinson, Mexico, Guatemala, Belize, Honduras.

Koanophyllon andersonii R. King \& H. Robinson, Brazil.

Koanophyllon atroglandulosum (Alain) R. King \& H. Robinson, Cuba.

Koanophyllon ayapanoides (Griseb.) R. King \& H. Robinson, Cuba.

Koanophyllon baccharifolium (Gardner) R. King \& H. Robinson, Brazil.

Koanophyllon barahonense (Urban) R. King \& H. Robinson, Hispaniola.

Koanophyllon brevifolium (Alain) R. King \& H. Robinson, Cuba.

Koanophyllon bullescens (B. Robinson) R. King and H. Robinson, Cuba.

Koanophyllon cabaionum (Urban \& E. Ekman) R. King and H. Robinson, Haiti.

Koanophyllon calcicola (Urban) R. King \& H. Robinson, Hispaniola.

Koanophyllon celtidifolia (Lam.) R. King \& H. Robinson, Jamaica, Lesser Antilles, Colombia, Venezuela, Ecuador.
Koanophyllon chabrense (Urban \& E. Ekman) R. King \& H. Robinson, Haiti.

Koanophyllon chalceorithales (B. Robinson) R. King \& H. Robinson, Cuba.

Koanophyllon clementis (Alain) R. King \& H. Robinson, Cuba.

Koanophyllon conglobatum (DC.) R. King \& H. Robinson, Brazil.

Koanophyllon consanguineum (DC.) R. King \& H. Robinson, Brazil.

Koanophyllon correlliorum (Plettman) R. King \& H. Robinson, Bahamas.

Koanophyllon coulteri (B. Robinson) R. King \& H. Robinson, Guatemala, El Salvador, Honduras.

Koanophyllon delpechianum (Urban \& E. Ekman) R. King \& H. Robinson, Haiti.

Koanophyllon dolicholepis (Urban) R. King \& H. Robinson, Puerto Rico.

Koanophyllon dolphinii (Urban) R. King \& H. Robinson, Jamaica.

Koanophyllon droserolepis (B. Robinson) R. King \& H. Robinson, Puerto Rico.

Koanophyllon dukei R. King \& H. Robinson, Panama.

Koanophyllon eitenii R. King \& H. Robinson, Brazil.

Koanophyllon ekmanii (B. Robinson) R. King \& H. Robinson, Cuba.

Koanophyllon flavidulum (Urban \& E. Ekman) R. King \& H. Robinson, Haiti.

Koanophyllon flexile (B. Robinson) R. King \& H. Robinson, Peru.

Koanophyllon fuscum (N. E. Br.) R. King \& H. Robinson, Venezuela.

Koanophyllon gabbii (Urban) R. King \& H. Robinson, Hispaniola.

Koanophyllon galeotiii (B. Robinson) R. King \& H. Robinson, Mexico, Guatemala, Belize.

Koanophyllon gibbosum (Urban) R. King \& H. Robinson, Hispaniola.

Koanophyllon gracilicaule (Schultz-Bip. ex B. Robinson) R. King \& H. Robinson, Mexico.

Koanophyllon gracilipes (Urban) R. King \& H. Robinson, Jamaica.

Koanophyllon grandiceps (E. Wright) R. King \& H. Robinson, Cuba.

Koanophyllon grisebachianum (Alain) R. King \& H. Robinson, Dominican Republic.

Koanophyllon gundlachii (Urban) R. King \& H. Robinson, Cuba.

Koanophyllon hammatocladum (B. Robinson \& Britton) R. King \& H. Robinson, Jamaica.

Koanophyllon hardwarense (Proctor \& C. Adams) R. King \& H. Robinson, Jamaica.

Koanophyllon helianthemoides (B. Robinson) R. King \& H. Robinson, Cuba.

Koanophyllon heptaneurum (Urban) R. King \& H. Robinson, Dominican Republic.

Koanophyllon hidrodes (B. Robinson) R. King \& H. Robinson, Cuba.

Koanophyllon hondurensis (B. Robinson \& Standley) R. King \& H. Robinson, Honduras.

Koanophyllon hotteanum (Urban \& E. Ekman) R. King \& H. Robinson, Haiti.

Koanophyllon huantae (B. Robinson) R. King \& H. Robinson, Peru. 
Koanophyllon hylonoma (B. Robinson) R. King \& H. Robinson, Costa Rica.

Koanophyllon hypomalaca (B. Robinson ex J. D. Smith) R. King \& H. Robinson, Guatemala.

Koanophyllon isillumense (B. Robinson) R. King \& H. Robinson, Peru.

Koanophyllon iteophyllum (Urban \& E. Ekman) R. King \& H. Robinson, Haiti.

Koanophyllon jaegerianum (Urban) R. King \& H. Robinson, Haiti.

Koanophyllon jenssenii (Urban) R. King \& H. Robinson, Haiti.

Koanophyllon jugipaniculatum (Rusby) R. King \& H. Robinson, Bolivia.

Koanophyllon juninense (B. Robinson) R. King \& H. Robinson, Peru.

Koanophyllon kavanayense (V. Badillo) R. King \& H. Robinson, Venezuela.

Koanophyllon littorale R. King \& H. Robinson, Cuba.

Koanophyllon lobatifolium (Cabrera in Cabrera \& Vittet) R. King \& H. Robinson, Brazil.

Koanophyllon longifolium (B. Robinson) R. King \& H. Robinson, Mexico.

Koanophyllon maestrense (Urban) R. King \& H. Robinson, Cuba.

Koanophyllon mesoreopolum (B. Robinson) R. King \& H. Robinson, Colombia.

Koanophyllon microchaetum (Urban \& E. Ekman) R. King \& H. Robinson, Hispaniola.

Koanophyllon mimicum (Standley \& Steyerm.) R. King \& H. Robinson, Guatemala.

Koanophyllon minutifolium (Alain) R. King \& H. Robinson, Cuba.

Koanophyllon miragoanae (Urban) R. King \& H. Robinson, Haiti.

Koanophyllon ınontanum (Sw.) R. King \& H. Robinson, Jamaica.

Koanophyllon mornicola (Urban \& E. Ekman) R. King \& H. Robinson, Haiti.

Koanophyllon muricatum (Alain) R. King \& H. Robinson, Cuba.

Koanophyllon myrtilloides (DC.) R. King \& H. Robinson, Brazil.

Koanophyllon nervosum (Sw.) R. King \& H. Robinson, Hispaniola.

Koanophyllon nudiflorum (A. Rich.) R. King \& H. Robinson, Cuba.

Koanophyllon obtusissimum (DC.) R. King \& H. Robinson, Dominican Republic.

Koanophyllon oligadenium (Alain) R. King \& H. Robinson, Cuba.

Koanophyllon pachyneurum (Urban) R. King \& H. Robinson, Hispaniola.

Koanophyllon palmeri (A. Gray) R. King \& H. Robinson, Mexico.

Koanophyllon panamensis R. King \& H. Robinson, Panama.

Koanophyllon paucicrenatum (Urban \& E. Ekman) R. King \& H. Robinson, Hispaniola.

Koanophyllon phanioides (Ưrban \& E. Ekman) R. King \& H. Robinson, Haiti.

Koanophyllon picardae (Urban) R. King \& H. Robinson, Haiti. Koanophyllon pitonianum (Urban \& E. Ekman) R. King \& H. Robinson, Haiti.

Koanophyllon pittieri (Klatt) R. King \& H. Robinson, Costa Rica. Koanophyllon polyodon (Urban) R. King \& H. Robinson, Puerto Rico.

Koanophyllon polystictum (Urban) R. King \& H. Robinson, Cuba,
Koanophyllon porphyrocladum (Urban \& E. Ekman) R. King \& H. Robinson, Haiti.

Koanophyllon prinodes (B. Robinson) R. King \& H. Robinson, Cuba.

Koanophyllon pseudoperfoliatum (Schultz-Bip. ex Klatt) R. King \& H. Robinson, Mexico.

Koanophyllon puberulum (DC.) R. King \& H. Robinson, Hispaniola.

Koanophyllon quisqueyanum (Alain) R. King \& H. Robinson, Dominican Republic.

Koanophyllon ravenii $\mathrm{R}$. King \& H. Robinson, Mexico.

Koanophyllon reversum (Urban) R. King \& H. Robinson, Haiti.

Koanophyllon rhexioides (B. Robinson) R. King \& H. Robinson, Cuba.

Koanophyllon rubroviolaceum (UTban \& E. Ekman) R. King \& H. Robinson, Haiti.

Koanophyllon sagasteguii R. King \& H. Robinson, Peru.

Koanophyllon scabriusculum (Urban \& E. Ekman) R. King \& H. Robinson, Haiti.

Koanophyllon sciatraphes (B. Robinson) R. King \& H. Robinson, Hispaniola. Venezuela.

Koanophyllon selleanum (Urban) R. King \& H. Robinson, Haiti.

Koanophyllon semicrenatum (Urban) R. King \& H. Robinson, Hispaniola.

Koanophyllon silvaticum (B. Robinson) R. King \& H. Robinson, Cuba.

Koanophyllon simile (Proctor) R. King \& H. Robinson, Jamaica.

Koanophyllon simillimum (B. Robinson) R. King \& H. Robinson, Argentina, Paraguay.

Koanophyllon solidaginifolium (A. Gray) R. King \& H. Robinson, SW United States, Mexico.

Koanophyllon solidaginoides (H.B.K.) R. King \& H. Robinson, Mexico, Central America, Colombia, Venezuela, Ecuador, Galapagos, Peru, Brazil.

Koanophyllon sorensenii R. King \& H. Robinson, Belize.

Koanophyllon standleyi (B. Robinson) R. King \& H. Robinson, Guatemala, El Salvador.

Koanophyllon stipuliferum (Rusby) R. King \& H. Robinson, Argentina, Bolivia.

Koanophyllon subpurpureum (Urban \& E. Ekman) R. King \& H. Robinson, Dominican Republic.

Koanophyllon tapeinanthum (Urban) R. King \& H. Robinson, Haiti.

Koanophyllon tatei (B. Robinson) R. King \& H. Robinson, Venezuela.

Koanophyllon teiranthum (Griseb.) R. King \& H. Robinson, Jamaica.

Koanophyllon thysanolepis (B. Robinson) R. King \& H. Robinson, Brazil.

Koanophyllon tinctorium Arruda, Brazil.

Koanophyllon tricephalotes (Schultz-Bip. ex Baker) R. King \& H. Robinson, Brazil.

Koanophyllon triradiatum (Urban) R. King \& H. Robinson, Haiti.

Koanophyllon turquinense (Alain) Borh., Cuba.

Koanophyllon villosum (Sw.) R. King \& H. Robinson, S Florida, Greater Antilles.

Koanophyllon wetmorei (B. Robinson) R. King \& H. Robinson, Panama. 


\section{Eupatoriastrum}

Eupatoriastrum Greenman, Proc. Amer. Acad. Arts 39: 93. 1903. TYPE: Eupatoriastrum nelsonii Greenman.

Erect perennial herbs or subshrubs, moderately branched above. Roots fibrous or forming a crown. Stems often solitary, fistulose, terete, striated, puberulous. Leaves opposite, with distinct narrow abruptly demarcated petioles; blades deltoid or broadly ovate, basal leaves sometimes deeply lobed, bases cordate to broadly rounded, margins serrate, trinervate to palmately veined at or near base, with punctate or short-stipitate glands on lower surface. Inflorescence a very lax thyrsoid panicle, with terminal or central heads not distinctly maturing first; pedicels usually moderately long. Involucral bracts ca. 50, weakly to moderately subimbricate in 3-5 unequal to subequal series, ovate-lanceolate, rather persistent; receptacle strongly convex, paleaceous with 100-300 paleae in a head; paleae interspersed throughout head, filiform with broader tips. Florets $100-$ 300 in a head; corollas pink, purple, red, or whitish, narrowly funnelform, inner and outer surfaces of throat glabrous; cells of limb oblong with sinuous lateral walls; lobes broadly triangular, about as long as wide, smooth on both surfaces, with clustered short-stalked capitate glands on outer surface, with or without hairs outside; anther collar narrowly cylindrical, with many subquadrate cells below, oblong cells above, with weak transverse thickenings on walls; anther appendage short, about half as long as wide, often with vertical median groove; style base not enlarged, glabrous; style branches filiform with scarcely to distinctly broadened tips, weakly mamillose except at expanded tips. Achenes prismatic, 4-5-ribbed, with numerous setulae on sides; carpopodium distinct, with distinct upper rim, symmetrical, shortly stopper-shaped, with small subquadrate cells in 5-6 series, cell walls thin to slightly thickened; pappus of 15-35 slender scabrid persistent to slightly deciduous bristles in 1 series, with non-contiguous bases, not or scarcely broadened distally, apical cells acute. Pollen grains ca. $18 \mu \mathrm{m}$ in diameter. Plate 123.

The genus Eupatoriastrum was originally established for a coarse herbaceous species having paleaceous heads with many flowers and large broad leaves with often cordate bases. A second somewhat similar species, Eupatorium triangulare $\mathrm{DC}$., was transferred into the genus by B. Robinson (1924). The two species have been widely and accurately recognized as close relatives of each other. The definition of the genus by its paleaceous receptacles, however, has led to erosion of the natural concept and the addition of a number of unrelated species. The abuse of the concept ultimately led to the reduction of Eupatoriastrum to synonymy under Eupatorium by McVaugh (1972). The revised Eupatoriastrum of the present treatment proves to be a natural group having no close relationship to true Eupatorium.

In recognizing Eupatoriastrum in the present series of studies, three unrelated species have been excluded from the genus. Two of the excluded species are placed in this treatment in other subtribes.

Eupatoriastrum opadocladium of S. F. Blake from Central America is clearly a Chromolaena of the subtribe Praxelinae. The species differs from close relatives in the area by little other than the presence of paleae in the head, and may equal C. glaberrima (Williams, 1976). The presence of paleae is not common in Chromolaena, but it is significant that they are present in the type species and some of its close relatives in Brazil.

Eupatoriastrum clavisetum of Badillo from Venezuela is a species overlooked in most discussions of the genus, but it is the only one of the excluded species that is particularly closely related. The species has heads with com- paratively few flowers and paleae, and has elliptical leaves with pinnate venation. The species is placed here in the genus Idiothamnus which, like Eupatoriastrum, is a close relative of Koanophyllon.

The most severe test of Eupatoriastrum was the species that McVaugh (1972) placed with species of Eupatoriastrum in his broadened concept of Eupatorium. The $E$. corvi of McVaugh has large paleaceous heads and broad leaves with cordate bases as in typical Eupatoriastrum. The species was originally distinguished from others in the group by the numerous foliaceous bracts subtending the heads, the more deciduous pappus bristles, and the anther appendages as long as wide or longer. The species proved to differ in a number of additional significant characters as well, including the non-fistulose stems, the cymose inflorescences with the central heads distinctly maturing first, and the fleshy roots. The elongate anther appendage, in particular, seems to place the species outside of the Eupatoriastrum-Koanophyllon relationship where the appendages are usually short. The species was placed in the separate genus Matudina by King and Robinson (1973b). A further distinction of Matudina is the chromosome number of $n=16$, a number unlikely in the still uncounted Eupatoriastrum, but a number common in the subtribe Hebecliniinae where the genus is placed in this treatment (R. King et al., 1976).

In spite of much attention to the genus Eupatoriastrum, it was not until the treatment by King and Robinson $(1971 h)$ that the small Guatemalan species, $E$. angulifolinm was recognized as a member of the genus. The third species seems to differ from the other two in no significant 


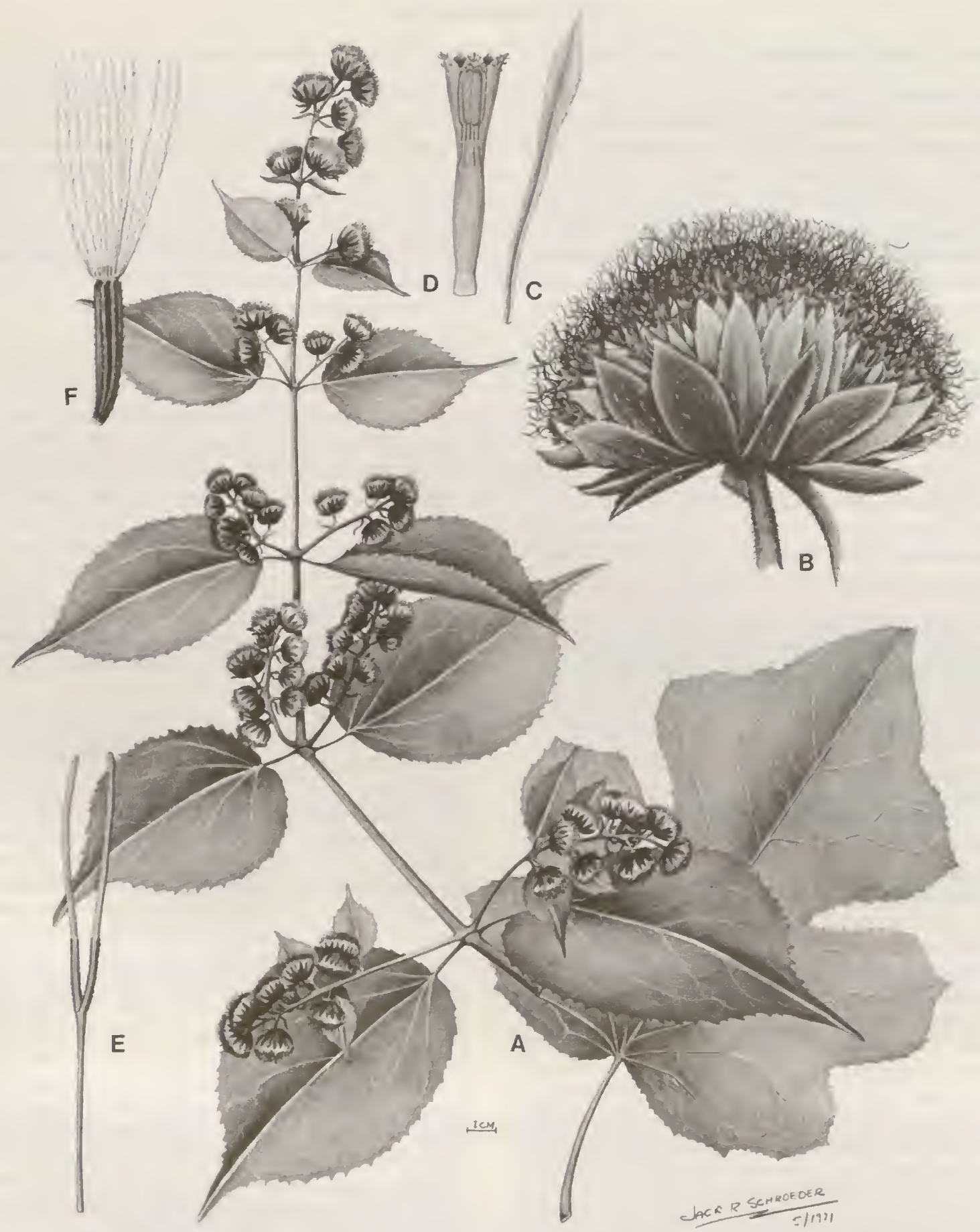

PLATE 123. Eupatoriastrum nelsonii Greenman,-A. Habit, $\times 4 / \%$. B. Head, $\times 3 \frac{1}{2}$. - C. Palea, $\times 9 .-$ D. Corolla showing anthers,
$\times 9 .-$ E. Style, $\times 9 .-$ F. Achene, $\times 9$. 
way except its smaller size and its anther appendages lacking a vertical median groove.

Notes attached to a specimen of Eupatoriastrum nelsonii from El Salvador, collected by S. Calderón, indicate that the plant is highly esteemed there as a depurative, being pungent and aromatic with the leaves slightly bitter. The plants are described as dying down to the crown of roots during the dry season.

The name of the genus is derived from the generic name Eupatorium combined with the Latin substantival suffix -astrum indicating inferiority or incomplete resemblance.
The following four species are recognized in the genus:

Eupatoriastrum angulifolium (B. Robinson) R. King \& H. Robinson, Mexico, Guatemala.

Eupatoriastrum chlorostylum B. Turner, Mexico.

Eupatoriastrum nelsonii Greenman, Mexico, Guatemala, El Salvador, Costa Rica.

Eupatoriastrum triangulare (DC.) B. Robinson, Mexico.

\section{Sphaereupatorium}

Sphaereupatorium (O. Hoffm.) Kuntze ex B. Robinson, Contr. Gray Herb. n.s. 61: 24. 1920.

Eupatorium section Sphaereupatorium O. Hoffm. in Engl. \& Prantl, Nat. Pflanzenfam. Nachtr. 1: 322. 1897. TYPE: Eupatorium hoffmannii Kuntze.

Erect perennial herbs or shrubs, with moderate branching. Stems terete, striated. Leaves opposite, with short distinct petioles; blades broadly ovate, bases rounded to subcordate, margins shallowly mucronatedentate, apex acuminate, trinervate from base, densely minutely glandular-punctate below. Inflorescence laxly thyrsoid-paniculate, with branches and branchlets at right angles; heads sessile in globose clusters at ends of branchlets. Involucral bracts ca. 12-20, eximbricate, in 3-4 slightly unequal series, ovate-lanceolate, partially deciduous; receptacle complex, with convex lobes, paleaceous or with interspersed bracts from incompletely separated heads. Florets ca. 11 in a head; corollas white, narrowly funnelform, with broadly cylindrical basal tube, outer surface with few glandular punctations, inner surface glabrous; cells of limb oblong with somewhat sinuous lateral walls; lobes triangular, about as long as wide, smooth on both surfaces, with small cluster of glands in middle of outer surface; anther collar narrowly cylindrical, with numerous subquadrate cells below, with beaded thickenings on cell walls; anther appendage slightly shorter than wide, retuse; style base not enlarged, glabrous; style branches spathulate distally, mamillose except at tips. Achenes prismatic, 5-ribbed, with a few setulae on ribs; carpopodium without distinct upper rim, symmetrical, with small subquadrate cells in 3-6 rows, cell walls slightly thickened; pappus of ca. 20 scabrid scarcely flexuous persistent bristles in 1 series, not broadened distally, apical cells acute. Pollen grains ca. $18 \mu \mathrm{m}$ in diameter. Plate 124.

The South American genus Sphaereupatorium is closely related to Koanophyllon, having similar involucral bracts, flower number, anther appendages shorter than wide, corolla form, style branches, and achenes. The genus is held distinct in this treatment on the basis of the spherical clusters of heads after which it is named, and the tendency to produce paleae or interspersed bracts in the heads. The paleaceous condition was given primary significance by B. Robinson (1920a), who made a number of interesting comments with his validation of the genus. Nevertheless, the spherical clusters of heads are regarded here as a more reliable basis for a natural generic limit.

Two other genera in the Koanophyllon group from Mexico, Mexianthus and Neohintonia, have heads borne in dense spherical clusters, but in both genera the individual heads have only one flower. Mexianthus differs further in its squamellose pappus and its more fusiform achene. The two Mexican genera are regarded as closely related to each other, but not directly related to the South American Sphaereupatorium.

The full extent of Sphaereupatcrium is not certain. The type species from eastern Bolivia is described by B. Robinson $(1920 a)$ as having paleae throughout the heads. The common species occurring from Minas Gerais westward to Mato Grosso in Brazil is apparently the same, but has few or no paleae. The only interspersed bracts in the Brazilian species are the result of incompletely formed heads in the clusters. An additional epaleaceous specimen from Bolivia, with the same habit, represents an additional apparently undescribed species.

The following one species is recognized in the genus:

Sphacreupatorium scandens (Gardner) R. King \& H. Robinson, Bolivia, Brazil. 


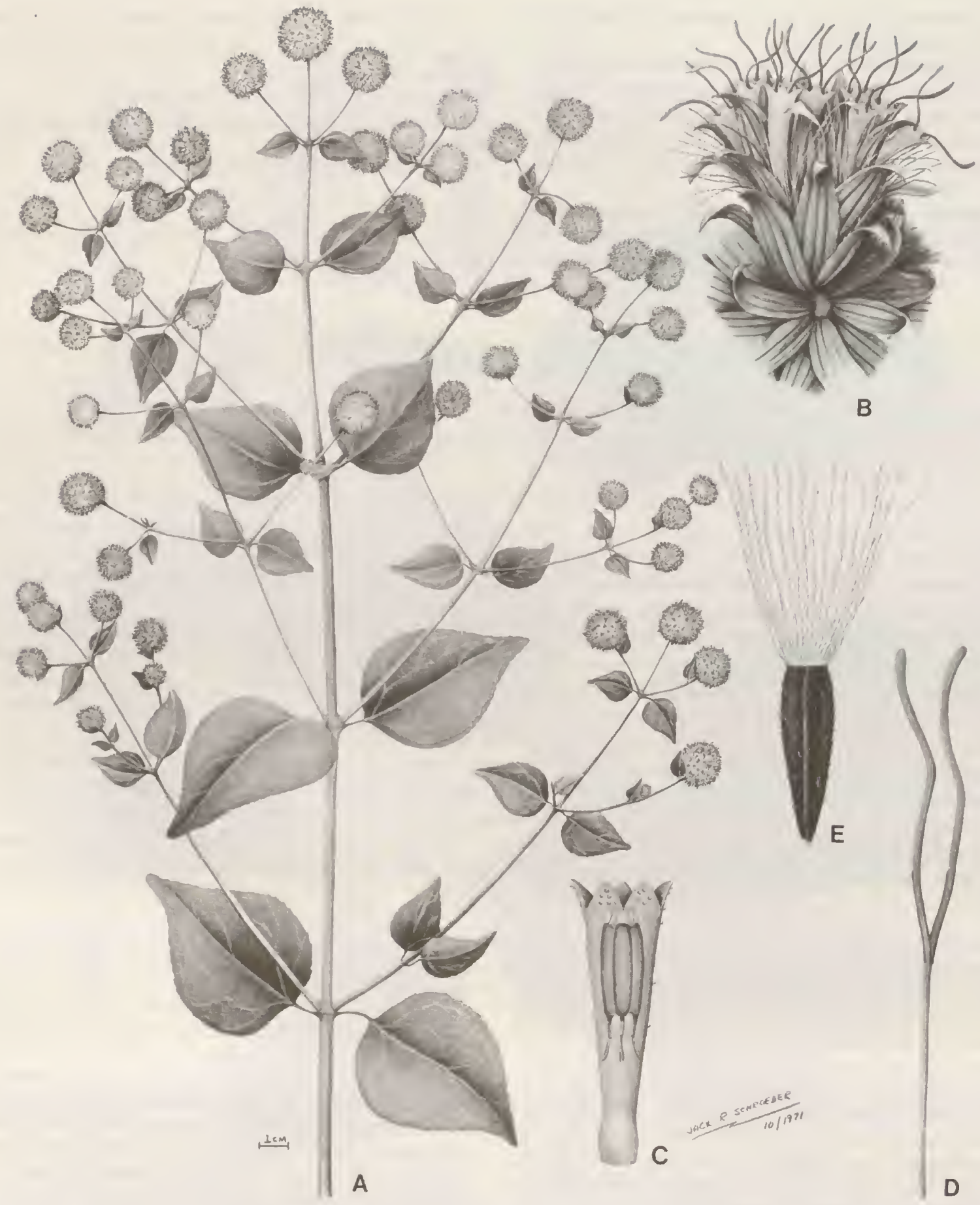
PLATE 124. Sphaereupatorium scandens (Gardner) R. King \& H. Robinson. - A. Habit, $\times 1 / 2 .-$ B. Head in cluster, $\times 61 / 2 .-$ C. Corolla
showing anthers, $\times 15$. D. Style, $\times 15$. E. Achene, $\times 15$. 


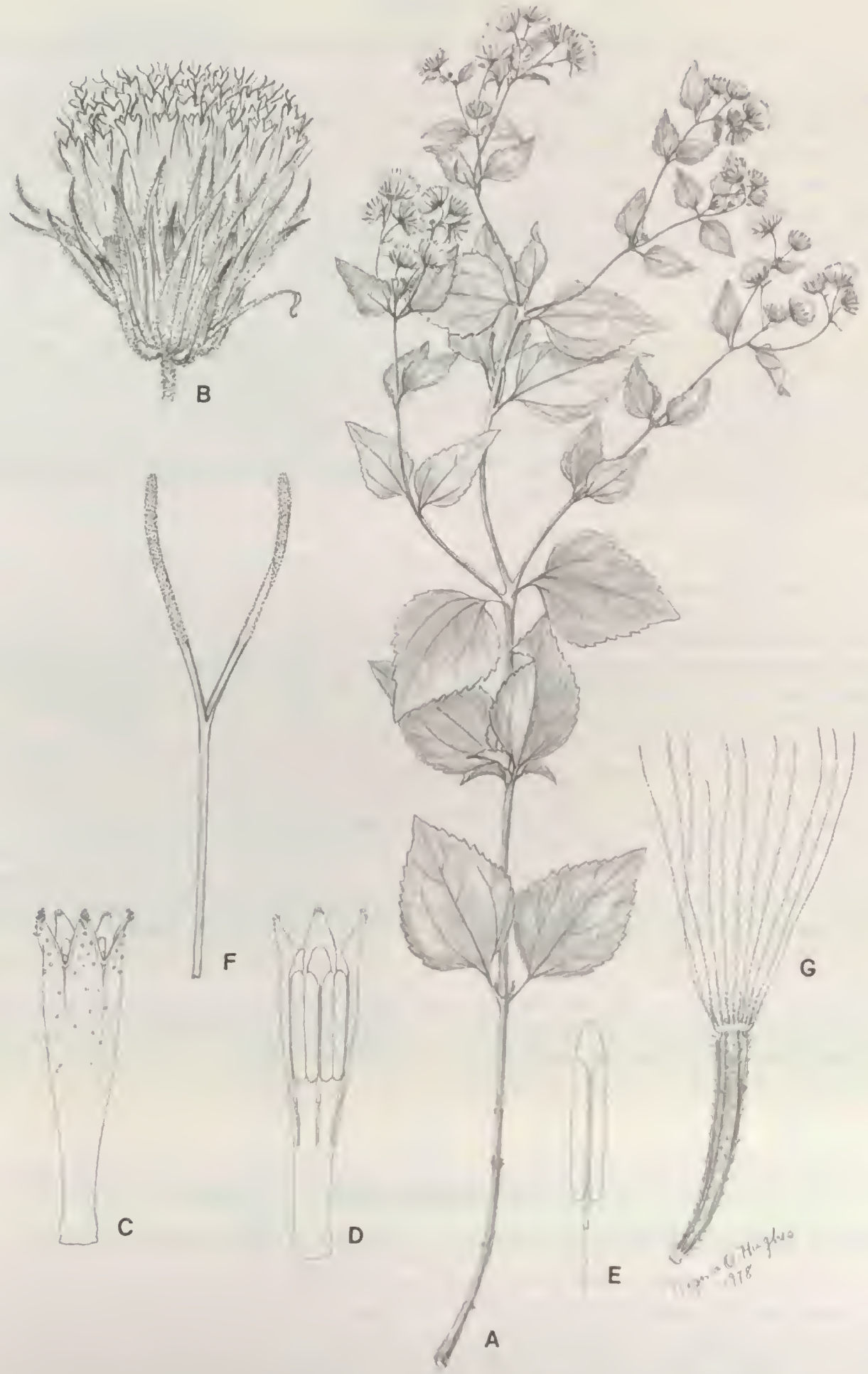

PLATE 125. Bishovia boliviensis R. King \& H. Robinson. - A. Habit, $\times 1 / 2,-$ B. Head, $\times 5 .-$ C. Corolla outer surface, $\times 12 .-$ D. Corolla inner surface with anthers, $\times 12 .-$ E. Anther, $\times 16 .-F$. Style, $\times 12 .-G$. Achene, $\times 12$. 


\section{Bishovia}

Bishovia R. King \& H. Robinson, Phytologia 39: 339. 1978. TYPE: Bishovia boliviensis R. King \& H. Robinson.

Erect perennial herbs and subshrubs, moderately branched, with stems, leaves, and involucral bracts covered with minute stipitate glands. Stems terete, substriate. Leaves alternate above, opposite near base, with rather short slender sharply delimited petioles; blades ovate to broadly ovate, obtuse to rounded at base, margins serrate to sublobate, apex acute, strongly trinervate from base. Inflorescence a diffuse somewhat leafy cyme; pedicels slender, short to moderately long. Involucral bracts ca. 25 , eximbricate to scarcely subimbricate, in ca. 2 subequal series, linear-lanceolate, distinctly bicostate on outer surface, persistent; receptacle flat to slightly convex, glabrous. Florets $30-60$ in a head; corolla lavender, narrowly funnelform, with cylindrical basal tube; cells of limb oblong with sinuous lateral walls; lobes triangular, longer than wide, smooth on both surfaces, glabrous or with minute hairs or glands; anther collar narrowly cylindrical, cells shortly oblong, with beaded thickenings on walls; anther appendage large, distinctly longer than wide, oblong to ovateoblong; style base not enlarged, glabrous; style branches linear, only slightly enlarged distally, densely mamillose. Achenes prismatic, 5-ribbed, with setulae and small glands on sides; carpopodium distinct, symmetrical, short-cylindrical, cells rather small, subquadrate, in 3-7 series, cell walls slightly thickened; pappus of ca. 30-40 slender scabrid persistent contiguous bristles in 1 series, scarcely broadened distally, apical cells acute. Pollen grains ca. 20-22 $\mu \mathrm{m}$ in diameter. Plate 125.

The genus Bishovia presents a distinctive aspect with its mostly alternate leaves, diffusely cymose inflorescence, dense stipitate-glandular pubescence, and its eximbricate involucre of narrow slender-tipped bicostate bracts. Bishovia seems close to Koanophyllon, having similar floral structures, but the latter genus has almost completely opposite leaves, rarely has stipitate glands, and usually has at least weakly subimbricate involucres. The somewhat longer corolla lobes, half again as long as wide, and the larger cells in the carpopodium, further tend to distinguish Bishovia from Koanophyllon.

During the present series of studies, B. mikaniifolium was initially transferred from Eupatorium to Chacoa (King \& Robinson, 1975v), before the genus Bishovia was recognized. The type and presently only recognized species of Chacoa is not stipitate-glandular, has opposite leaves, has a pyramidal inflorescence, broader less costate involucral bracts, and distinctly narrowed bases on the corollas, all of which are unlike Bishovia. Still, the involucre of Chacoa is very weakly subimbricate and the Bishovia species occurs in the same geographical area, and the two species seemed closely related on the basis of the incom- plete knowledge of the complex in South America. The subsequent discovery of the type species of Bishovia, sharing many of the characters of $B$. mikaniifolia, shows the earlier concept to be too simplistic. Also, the earlier observations of narrow corolla bases in B. mikaniifolia prove to be erroneous, being the result of distortion. At present, Bishovia and Chacoa are not regarded as immediate relatives.

The genus Bishovia occurs in two areas along the eastern side of the Andes. The type species is known from near Santa Cruz in Bolivia, and B. mikaniifolia is from the Chaco region in northern Argentina.

Bishovia is one of two genera in the Eupatorieae named in honor of Luther Earl Bishop, one of the collectors of the type species. The other genus is Bishopiella of the Gyptidinae from Bahia, Brazil.

The following two species are recognized in the genus:

Bishovia boliviensis R. King \& H. Robinson, Bolivia.

Bishovia mikaniifolia (B. Robinson) R. King \& H. Robinson, Argentina.

\section{Nothobaccharis}

\section{Nothobaccharis R. King \& H. Robinson, Phytologia 41: 397. 1979. TYPE: Baccharis candolleana Steudel.}

Erect shrubs, usually densely branched. Stems terete, slightly striated, with glandular punctations, minutely puberulous. Leaves densely spirally inserted, with short narrow petioles; blades small, suborbicular to elliptical, margins dentate to crenate, with ascending rather pinnate to subtrinervate secondary veins, surfaces glandular-punctate. Inflorescence a dense thyrsoid panicle, with branches usually spiciform; heads crowded and sessile or with very short pedicels. Involucral bracts ca. 15, distinctly subimbricate, in 3-4 strongly unequal graduated series, oblong to elliptical with distinct scarious margins, rather persistent but whole heads often falling in dried specimens; receptacle flat to slightly convex, glabrous. Florets $6-8$ in a head; corollas 


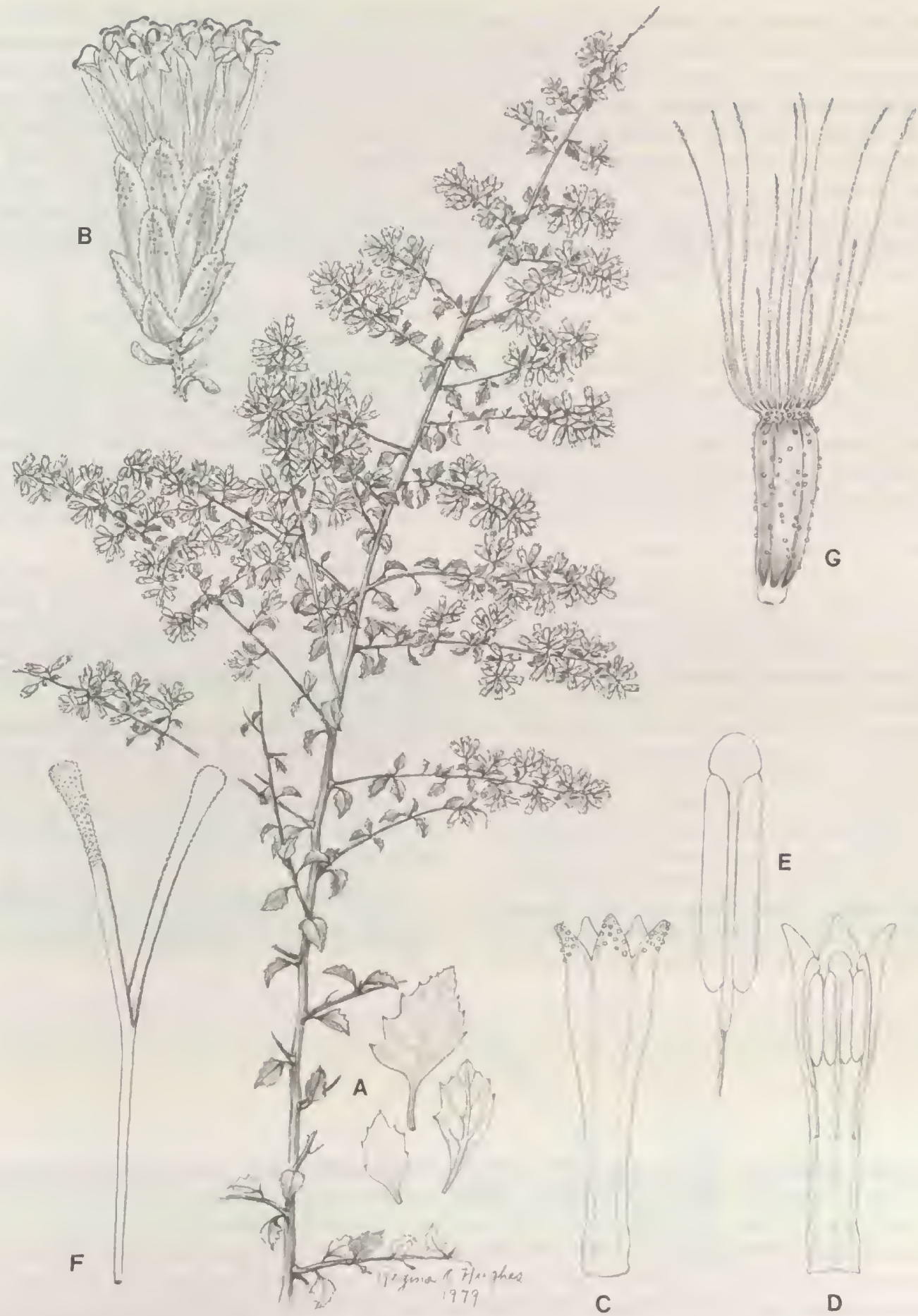

PLATE 126. Nothobaccharis candolleana (Steudel) R. King \& H. Robinson. - A. Habit, $\times 1 / 2$, with three separate enlarged leaves. B. Head, $\times 8 .-$ C. Corolla outer surface, $\times 15 .-$ D. Corolla inner surface with anthers, $\times 15 .-$ E. Anther, $\times 35 .-$ F. Style, $\times 15 .-$ G. Achene, $\times 15$. 
whitish, narrowly funnelform, glabrous on inner and most of outer surfaces; cells of limb narrowly oblong with sinuous lateral walls; lobes triangular to oblong, ca. 1.5 times as long as wide, smooth on both surfaces, outer surface with cluster of short capitate glands in upper half; anther collar narrowly cylindrical, with subquadrate cells below, rectangular cells above, cell walls with beaded thickenings; anther appendage ovate to short-oblong, about as long as wide; style base not enlarged, glabrous; style branches slightly enlarged distally, mamillose, becoming smooth at tips. Achenes prismatic, 5-ribbed, glanduliferous and sparsely setuliferous on sides; carpopodium distinct, usually symmetrical, shortly stopper-shaped, with slight but distinct upper rim, cells small in 6-7 rows, with thickened walls; pappus of ca. 30-35 scabrid contiguous persistent bristles in 1 series, slightly broadened and distinctly more barbellate distally, apical cells acute. Pollen grains ca. $20-23 \mu \mathrm{m}$ in diameter. Plate 126.

The single species of Nothobaccharis was initially described by DeCandolle (1836) as a Baccharis on the basis of a single specimen from an unspecified locality in Peru. The species seems not to have been recollected for over a hundred years, and has remained poorly known. The original species name $B$. microphyllum was a later homonym, but continued to be the name by which the species was best known until well into the present century. The species was not recognized as a member of the Eupatorieae until it was transferred into the genus Brickellia by Hieronymus (1901), and it was not placed in the broad concept of Eupatorium until the genus Brickellia was monographed by B. Robinson (1917). The nomenclatural history of the two substitute species names and the various combinations is reviewed by King and Robinson (1979a).

Neither of the two Eupatorian genera in which the species of Nothobaccharis was previously placed represents any particular insight on the part of the authors. The actual position of Nothobaccharis is unquestionably in the Critoniinae, and seems close to Koanophyllon. The Peruvian plant is technically excluded from the latter genus by elongate corolla lobes and the small consistently spirally inserted leaves. The rather spicate appearance of the densely thyrsoid inflorescence branches is approached by some of the more typical members of the genus Koanophyllon, but there is no direct relationship between the two groups.
The distinctly subimbricate scarious-margined and somewhat laciniate-tipped involucral bracts are not descriptively beyond the range of variation in Koanophyllon, but differ sufficiently in combined details to call any immediate relationship to the latter genus into question. Nothobaccharis also seems close to Ophryosporus but differs by its well-developed anther appendage, the less enlarged tips of its style branches, and the lack of any lateral heads of the inflorescence arising from axils of the lower involucral bracts of primary heads.

Nothobaccharis is now known from a number of collections from the area of Lima in Peru. A number of specimens are from the immediate area of Chosica, slightly inland from Lima, at elevations of ca. $900 \mathrm{~m}$. One specimen from Chilca is stated to be from a sandy plain near the seashore.

The name Nothobaccharis is derived from the name of the Asterian genus with the Greek prefix notho (= false). In spite of the fact that Baccharis is in a different tribe, the appearance of Nothobaccharis is such that confusion in the field is much more likely with that than with $\mathrm{Ko}$ anophyllon.

The following single species is recognized in the genus: Nothobaccharis candolleana (Steudel) R. King \& H. Robinson, Peru.

\section{Santosia}

\section{Santosia R. King \& H. Robinson, Phytologia 45: 463. 1980. TYPE: Santosia talmonii R. King \& H. Robinson.}

Woody vines, moderately branched. Stems terete, faintly striated when dry, minutely evanescently puberulous. Leaves opposite, narrowly petiolate; blades ovate to ovate-elliptical, base obtuse to rounded, margins subentire, strongly trinervate from base, surfaces essentially glabrous. Inflorescence terminal on branches, an elongate thyrsoid panicle with branches rather densely corymbose to pyramidal; pedicels rather short. Involucral bracts ca. 13, subimbricate in ca. 3 unequal series, ovate-lanceolate, with outer surfaces faintly multistriated, inner bracts rather easily deciduous; receptacle flat to slightly convex, glabrous. Florets 8-10 in a head; corollas white, narrowly funnelform, with broadly cylindrical base, essentially glabrous on outer surface; cells of limb oblong with sinuous lateral walls; lobes oblong-triangular, more than twice as long as wide, smooth on both surfaces, with only an occasional gland on outer surface; anther collar shortcylindrical, cells subquadrate below, oblong above, without ornate thickenings on walls; anther appendage large, longer than wide, ovate to ovate-oblong; style base not enlarged, glabrous; style branches linear to 


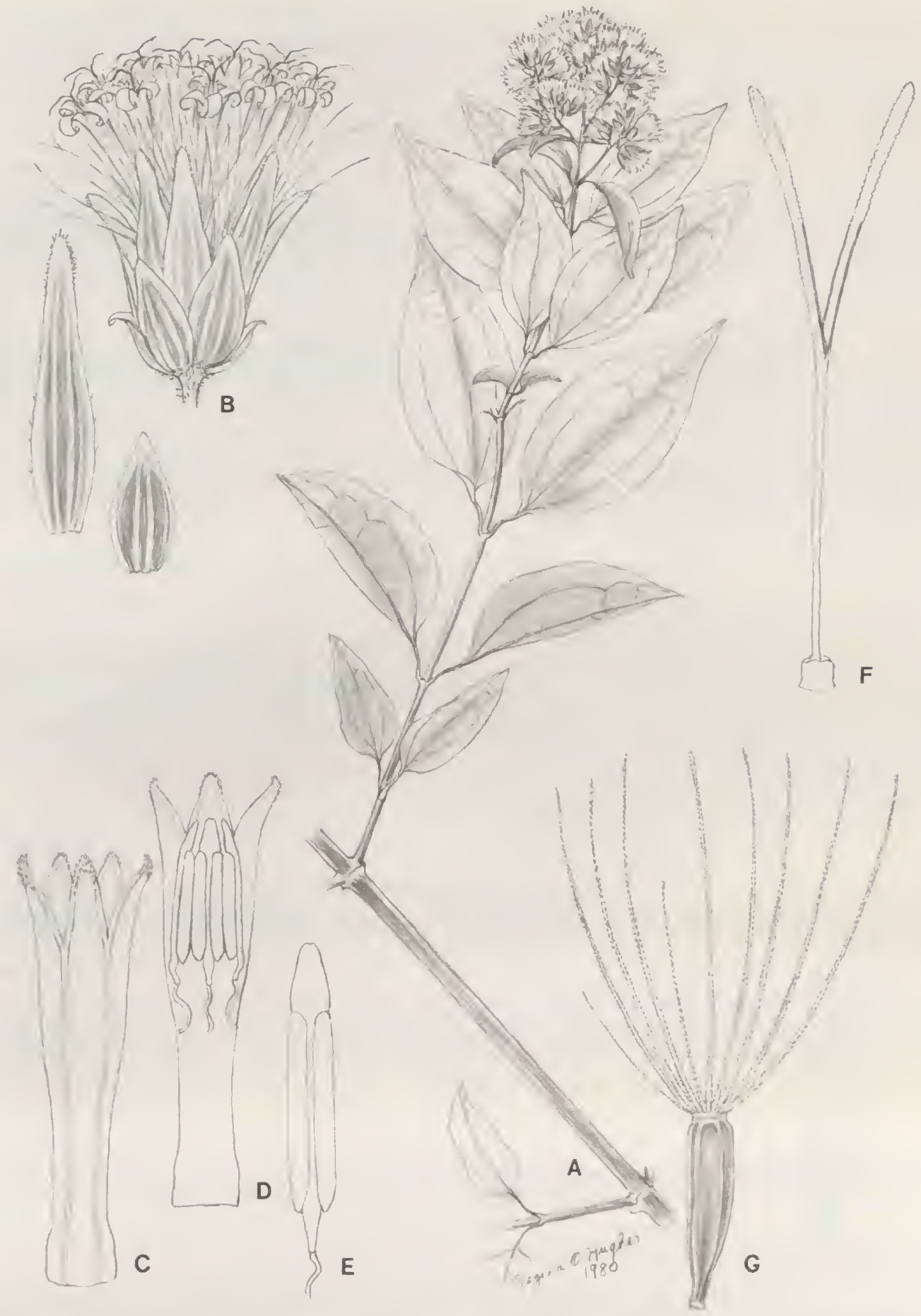

Plate 127. Santosia talmonii R. King \& H. Robinson. - A. Habit, $\times 1 / 2,-B$. Head with separate representative involucral bracts, $\times 7$. C. Corolla outer surface, $\times 14 .-$ D. Corolla inner surface with anthers, $\times 14 .-$ E. Anther, $\times 25 .-$ F. Style with nectary, $\times 14 .-G$. Achene, $\times 14$. 
subfiliform, mamillose to short-papillose below, essentially smooth at slightly broadened tips. Achenes prismatic, 5-ribbed, sparsely setuliferous mostly on ribs; carpopodium distinctly symmetrical, very short, forming a basal ring, cells small and subquadrate in 3-4 rows, with somewhat thickened walls; pappus of ca. 20 scabrid persistent bristles in 1 series, broadened and somewhat flattened externally near base, sometimes slightly broadened distally, apical cells acute. Pollen grains ca. $22 \mu \mathrm{m}$ in diameter. Plate 127.

The genus Santosia contains a single scandent species that is apparently locally endemic to the coastal region of southern Bahia in Brazil. Evidently because of the restricted distribution, the plant remained uncollected until 1961 and undescribed until 1980. Nevertheless, two descriptions have recently been provided for the species, almost simultaneously, both based on different specimens of the same 1961 Duarte Collection. The first description was by King and Robinson (1980e) as a Santosia, and the second was by Soares Nunes (1981) as a Eupatorium.

Santosia is interpretable as a Eupatorium only in the broad unnatural traditional sense of that genus, and is not close in relationship or similar in aspect to true Eupatorium. The genus Santosia does show resemblance to two other genera of the Eupatorieae, Mikania, with which it is most similar in habit, and Koanophyllon, to which it seems related.

Santosia is noted by collectors as a vine, sometimes being abundant in trees. As such, the plant closely approaches the form of some species of Mikania, and one of the specimens bore a preliminary determination as that genus. Still, Santosia lacks the involucre of four subequal bracts and the four-flowered heads that are characteristic of the Mikaniinae and does not show any other details suggesting relationship to that subtribe.
The significant resemblance of Santosia is that to the genus Koanophyllon. The resemblance to typical Koanophyllon is particularly strong in segments of plants on herbarium sheets, as suggested by the name Eupatorium pseudolaeve chosen for the plant by Soares Nunes (1981). The latter author compared the plant with Eupatorium laeve (= Koanophyllon tinctorium), the type species of Koanophyllon, citing differences in habit, leaf venation, and potentially sectional differences in the involucre. The character by which Santosia differs technically from all of Koanophyllon is the long essentially glabrous corolla lobes. The involucre is also distinct from any in Koanophyllon by the combination of subimbrication and the broad multistriated bracts. The outer bracts seem to strongly invest the head in a way not seen in Koanophyllon. The scandent habit is very rare in Koanophyllon, and the character therefore is most useful in the distinction of the genus.

The genus Santosia is named in honor of Sr. Talmon S. dos Santos, a collector at the Centro de Pesquisas do Cacau at Itabuna, Bahia, Brazil.

The following single species is recognized in the genus: Santosia talmonii R. King \& H. Robinson, Brazil.

\section{Grisebachianthus}

Grisebachianthus R. King \& H. Robinson, Phytologia 32: 268. 1975. TYPE: Eupatorium plucheoides Griseb.

Erect to spreading shrubs, little to moderately branched, with stems, undersurfaces of leaves, branches of inflorescence, and involucres densely tomentose to villous. Stems terete, slightly striated. Leaves opposite, petioles usually very short, longer in $G$. carsticola; blades broadly elliptical or oblong to broadly ovate, subcoriaceous, glabrous and somewhat roughened above, margins entire to remotely subserrulate, apex rounded to shortly acute, venation trinervate at or near base or pinnate with strongly ascending secondaries. Inflorescence terminal on branches or branchlets, cymose to somewhat pyramidal, with densely corymbose branches; heads sessile or subsessile in irregular congested glomerules. Involucral bracts ca. 15-25, strongly subimbricate, in 4-5 congested unequal graduated series, inner bracts deciduous; receptacle flat, glabrous. Florets 12-60 in a head; corollas white to pink or purple, narrowly funnelform, glands on outer surface often restricted to lobes, glabrous on inner surface; cells of limb elongate with sinuous lateral walls; lobes triangular, distinctly longer than wide, smooth on both surfaces; anther collar narrowly cylindrical, with many subquadrate cells below, cell walls slightly ornamented with beaded thickenings; anther appendage ovate to oblong, longer than wide; style base not enlarged, glabrous; style branches linear, slightly but distinctly spathulate distally, mamillose to short-papillose except at tip. Achenes prismatic, 5-ribbed, sparsely setuliferous and glanduliferous on sides; carpopodium distinct, symmetrical, short-cylindrical, cells small and subquadrate, in 5-10 rows, with walls only slightly thickened; pappus of ca. 20-30 rather stout scabrid persistent contiguous bristles in 1 series, not to scarcely broadened distally, apical cells obtuse to short acute. Pollen grains ca. $18-20 \mu \mathrm{m}$ in diameter. Plate 128. 


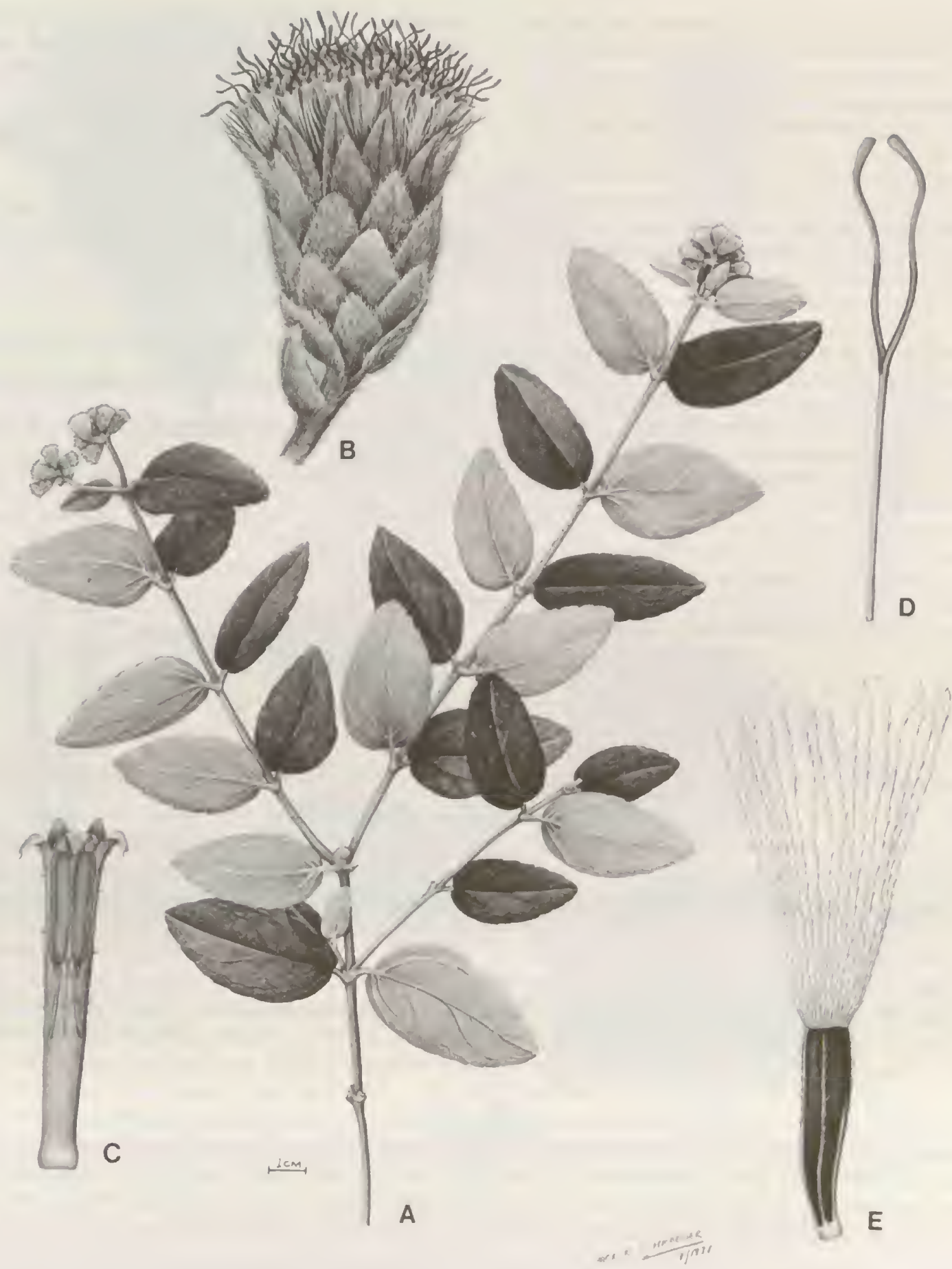

Plate 128. Grisebachianthus lantanaefolius (Griseb.) R. King \& H. Robinson. - A. Habit, ×3/s. - B. Head, $\times 7 .-$ C. Corolla showing anthers, $\times 13 .-D$. Style, $\times 13 .-$ E. Achene, $\times 13$. 
Grisebachianthus has a habit and distribution that falls completely within that of the West Indian members of the genus Koanophyllon with which it seems to be related. Nevertheless, the genus is easily distinguished by its dense pubescence, and is technically distinct in the form of its involucre and corolla lobes. As a result of the characters cited, Grisebachianthus is regarded here as more of a collateral group to Koanophyllon than as a subset within it.

The undersurfaces of the leaves, stems, and involucres of Grisebachianthus are immediately distinguishable from those of Koanophyllon by the dense pale or fulvous pubescence. The pubescence on the leaves is rather evenly spread over the surface, unlike that of the most densely pubescent species of Koanophyllon, $K$. thysanolepis of Brazil, where the pubescence is concentrated on the veins. The combination of pubescence and density of imbrication of the involucres in Grisebachianthus gives the heads a strongly Vernonian appearance, and the plants would probably be confused with that tribe in the field except for the regularly opposite condition of the leaves. A final technical difference from Koanophyllon is the corolla lobes that are distinctly longer than wide in Grisebachianthus.

Most members of the genus Grisebachianthus seem to be restricted to northern Oriente Province in Cuba where they occur on or near serpentine areas. One species, $G$. carsticola, is cited from a calcareous area in the Sierra Maestra of southern Oriente Province (Borhidi \& Muñiz, 1973). A key to the species has been provided by King and Robinson (1975r) and by Borhidi (1983).

The genus name honors August H. R. Grisebach (18141879), a German botanist well known for his work on the flora of the West Indies and Argentina.

The following eight species are recognized in the genus:

Grisebachianthus carsticola (Borh. \& Muñiz) R. King \& H. Robinson, Cuba.

Grisebachianthus holquinensis (B. Robinson) R. King \& H. Robinson, Cuba.

Grisebachianthus hypoleucus (Griseb.) R. King \& H. Robinson, Cuba.

Grisebachianthus lantanifolius (Griseb.) R. King \& H. Robinson, Cuba.

Grisebachianthus libanotica (Schultz-Bip.) R. King \& H. Robinson, Cuba.

Grisebachianthus mayarensis (Alain) R. King \& H. Robinson, Cuba.

Grisebachianthus nipensis (B. Robinson) R. King \& H. Robinson, Cuba.

Grisebachianthus plucheoides (Griseb.) R. King \& H. Robinson, Cuba.

\section{Lorentzianthus}

Lorentzianthus R. King \& H. Robinson, Phytologia 32: 273. 1975. TYPE: Eupatorium viscidum Hook. \& Arn.

Erect shrubs, with moderate branching. Stems terete to obscurely 6-angled, puberulous. Leaves opposite, distinctly narrowly petiolate; blades ovate, often rather large, somewhat to distinctly acuminate at base, margins serrate, apex narrowly acuminate, trinervate from near base, minutely and darkly reticulately veined below, with minute immersed glandular punctations. Inflorescence a pyramidal panicle, pedicels short, slender. Involucral bracts ca. 20, subimbricate, in ca. 5 unequal graduated series, stramineous, oblong to ovate-elliptical, 4-costate on outer surface; receptacle slightly convex, glabrous. Florets ca. 10-12 in a head; corollas whitish to purple, narrowly funnelform, with narrowly cylindrical basal tube, mostly glabrous outside below lobes, glabrous on inner surface; cells of limb oblong with somewhat sinuous lateral walls; lobes broadly triangular, smooth on both surfaces, with clustered short capitate glands on outer surface; anther collar narrowly cylindrical, with numerous subquadrate cells below, with thin non-ornamented walls; anther appendage large, ovate-oblong, slightly longer than wide; style base not enlarged, glabrous; style branches linear, not or scarcely broadened at tips, mamillose, becoming smooth at tip. Achenes prismatic with broad base, 5-ribbed, setuliferous on ribs; carpopodium distinct, symmetrical, very short, annuliform, with moderatesized subquadrate cells in 2-3 rows, walls scarcely thickened; pappus of 35-40 slender scabridulous rather fragile bristles in 1 series, tips not broadened, apical cells sharply acute. Pollen grains ca. $22 \mu \mathrm{m}$ in diameter. Plate 129.

The genus Lorentzianthus contains a single South American species that has a corolla and general achene structure similar to Koanophyllon, and the two genera are considered closely related. Lorentzianthus differs most significantly by the easily deciduous pappus bristles, the bristles of Koanophyllon being characteristically rather stout and persistent. The present genus also differs from Koanophyllon and superficially resembles Critonia in the strongly subimbricate stramineous involucres. In the few species of Koanophyllon where the involucres are distinct- 


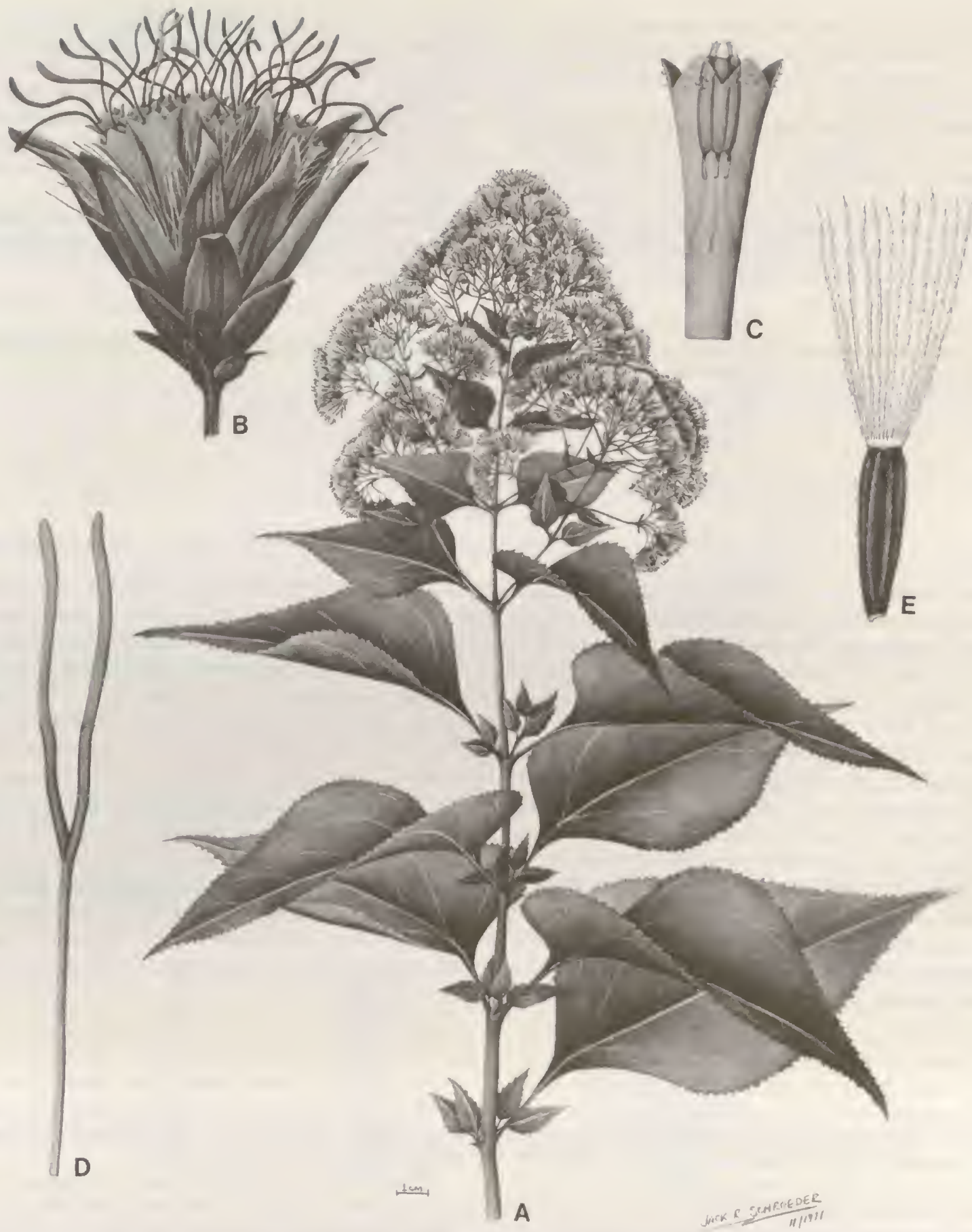

Plate 129. Lorentzianthus viscidus (Hook. \& Arn.) R. King \& H. Robinson. - A. Habit, x1/2. - B. Head, $\times 7 .-$ C. Corolla showing anthers, $\times 12,-D$. Style, $\times 12 .-$ E. Achene, $\times 12$. 
ly subimbricate, the heads and bracts are not so narrow and the bracts are less numerous, being usually less than sixteen. There are up to 25 bracts in the involucre of Lorentzianthus.

The distinctive appearance of Lorentzianthus extends to its leaves. The broadly ovate outline with acuminate bases and tips seems unique in the area of occurrence. The minute dark reticulum of veins on the undersurface also distinguishes the genus from close relatives. The petioles in Lorentzianthus tend to be longer than those in most Critoniinae, approaching the longer form most common in the Hebecliniinae.

The single species of Lorentzianthus has an essentially continuous distribution from Santa Cruz in Bolivia southward through Jujuy, Salta, and Tucuman to Cordoba in Argentina. Previous to the present series of studies, the
Bolivian material of the species, which sometimes has narrower and more nearly entire leaves, was placed in a separate species, Eupatorium santacruzense. Comments with the species give no evidence that the relationship to the Argentinian material was recognized. Two unvalidated names, $E$. nemorense Schultz-Bip. and $E$. erythrolepis Schultz-Bip., have also entered the literature on the basis of Bolivian material of the species.

The name Lorentzianthus honors Paul Günther Lorentz 1835-1881, a German botanist noted for his collections of Argentinian and Uruguayan plants.

The following single species is recognized in the genus:

Lorentzianthus viscidus (Hook. \& Arn.) R. King \& H. Robinson, Argentina, Bolivia.

\section{Chacoa}

Chacoa R. King \& H. Robinson, Phytologia 32: 275. 1975. TYPE: Eupatorium pseudoprasifolium Hassler.

Erect flexuous shrubs, with moderate branching. Stems slender, terete to obscurely 6-angled, puberulous to hispidulous. Leaves opposite, distinctly narrowly petiolate; blades ovate to deltoid, broadly acute to truncate at base, margins serrate, trinervate from base, with scattered minute glandular punctations below. Inflorescence terminal on branches, a lax pyramidal panicle with rather densely corymbose branches; pedicels rather short, slender. Involucral bracts ca. 15, very weakly subimbricate, appearing eximbricate, in ca. 2 subequal series, with a few very short at base, lanceolate to linear, rather persistent; receptacle flat to slightly convex, glabrous. Florets ca. 20 in a head; corollas white, with slender basal tubes and narrowly campanulate limbs, glanduliferous on outer surface; cells of limb oblong with rather sinuous lateral walls; lobes triangular to broadly triangular, not longer than wide, smooth on both surfaces, numerous glands on outer surface; anther collar narrowly cylindrical, with numerous subquadrate cells below, cell walls thin, not ornamented; anther appendage large, ovate-oblong, longer than wide; style base not enlarged, glabrous; style branches filiform, only slightly broadened near tips, short-papillose. Achenes prismatic, with somewhat narrowed bases, setuliferous and glanduliferous on sides; carpopodium small, shortly stopper-shaped with slight upper rim, with small subquadrate cells in 6-8 rows, walls somewhat thickened; pappus of ca. 30 persistent slender contiguous scabrid bristles in 1 series, not broadened distally, apical cells sharply acute. Pollen grains ca. 22 $\mu \mathrm{m}$ in diameter. Plate 130.

The South American genus Chacoa is closely related to Koanophyllon, differing primarily by the narrow basal tube of the corolla. The pappus bristles are also slenderer than those characteristic of Koanophyllon, but are not deciduous as in Lorentzianthus. The petioles are longer than most members of the Critoniinae, but are matched in Lorentzianthus and a few species of Koanophyllon. In other characters such as habit, the involucre with very few shorter outer bracts, and the style branches without significantly broadened tips, Chacoa is within the range of variation of Koanophyllon, and Chacoa must be considered only a technical segregate of that genus.

The genus Chacoa was originally described on the basis of two species (King \& Robinson, 1975u). Subsequent study has shown, however, that the alternate-leaved and stipitate-glandular Eupatorium mikaniifolium was observed incorrectly, and does not have a narrow basal tube on the corolla. The latter species does show a close correlation of characters with a recently discovered species from Bolivia with which it is now placed in the genus Bishovia (King \& Robinson, 1978j).

Chacoa is restricted geographically to Paraguay and the closely adjacent areas of Formosa and Missiones in Argentina. It is the Chaco region of these two countries after which the genus is named.

The following single species is recognized in the genus:

Chacoa pseudoprasiifolia (Hassler) R. King \& H. Robinson, Argentina, Paraguay. 


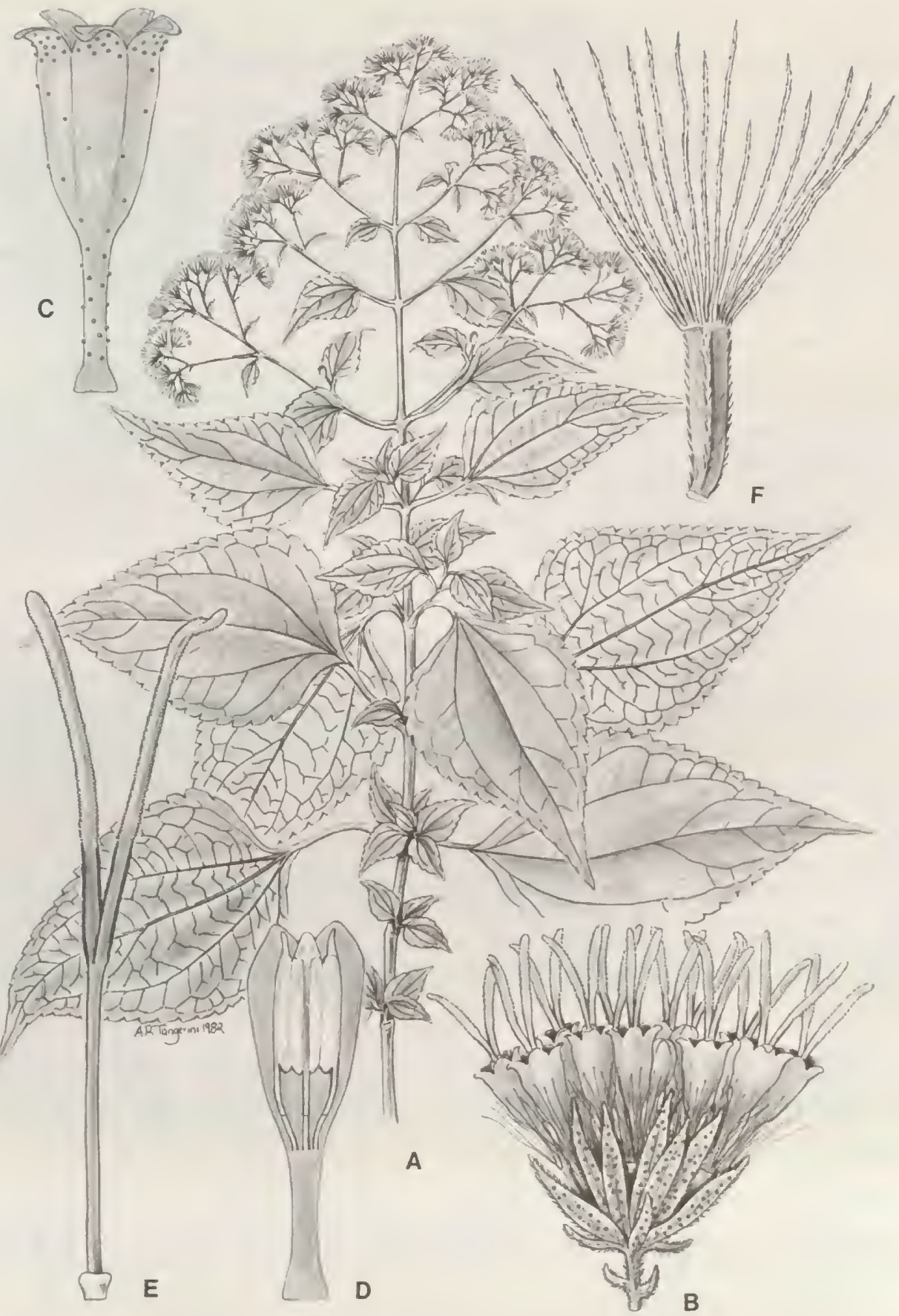

Plate 130. Chacoa pseudoprasiifolia (Hassler) R. King \& H. Robinson. - A. Habit, x1/2. - B. Head, $\times 7$. C. Corolla outer surface, $\times 15,-D$. Corolla inner surface with anthers, $\times 15,-$ E. Style, $\times 15,-F$. Achene, $\times 15$. 


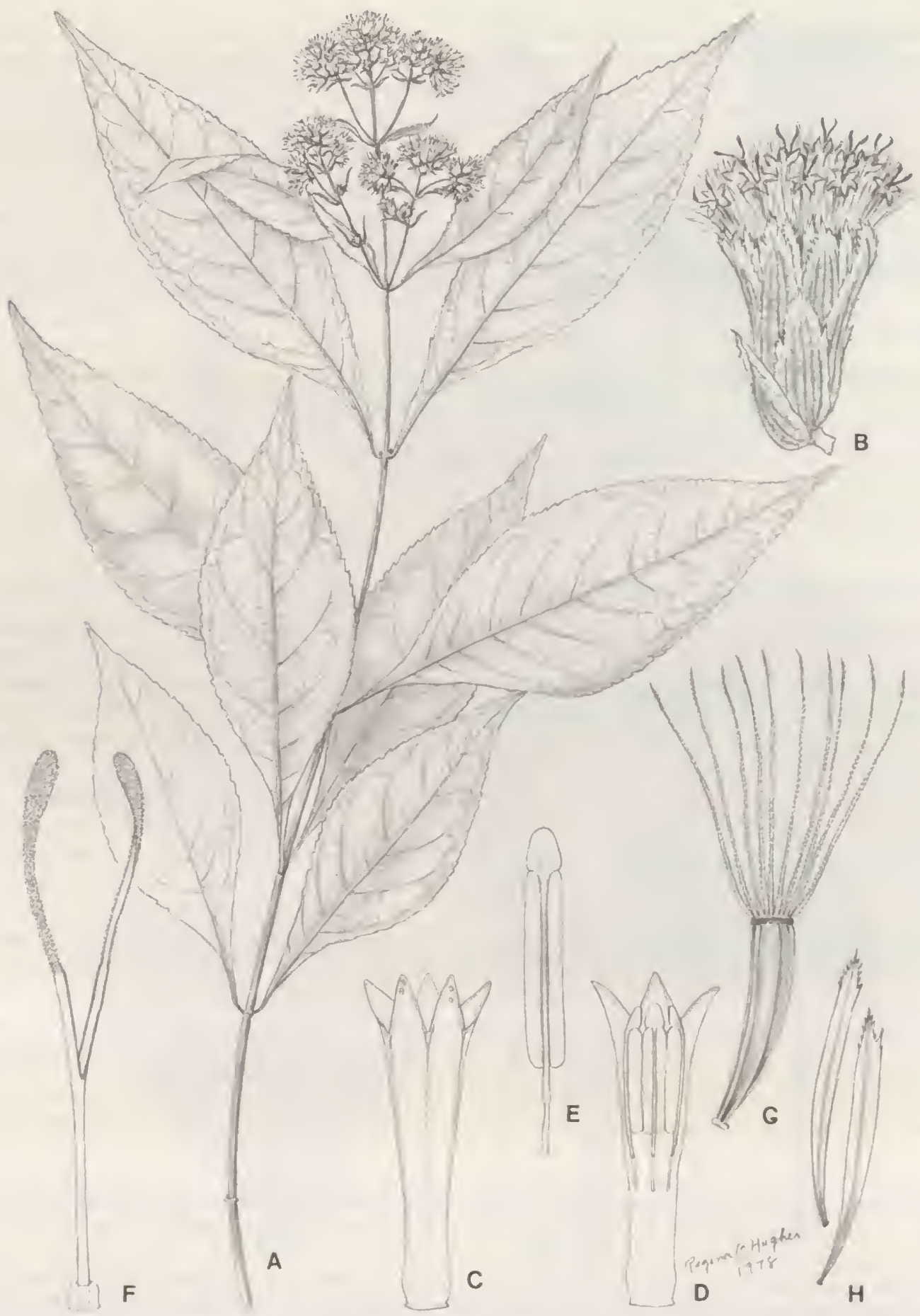

Plate 131. Idiothamnus pseudorgyalis R. King \& H. Robinson. - A. Habit, $\times 1 / 2 .-$ B. Head, $\times 7$. - C. Corolla outer surface, $\times 15 .-$ D. Corolla inner surface with anthers, $\times 15 .-$ E. Anther, $\times 28 .-$ F. Style, $\times 15 .-$ G. Achene, $\times 15 .-$ H. Paleae, $\times 15$. 


\section{Idiothamnus}

Idiothamnus R. King \& H. Robinson, Phytologia 32: 277. 1975. TYPE: Eupatoriastrum clavisetum V. Badillo.

Erect spreading shrubs or small trees. with moderate branching. Stems rather pale, terete, faintly striated, minutely puberulous. Leaves opposite, with short petioles; blades elliptical to ovate, with narrowly acuminate bases and tips, margins serrate to remotely subserrulate, venation pinnate with erect-spreading secondary veins, densely glandular-punctate below. Inflorescence terminal on branches, corymbose; pedicels short. Involucral bracts ca. 14-21, subimbricate in ca. 2-3 unequal to subequal series, persistent, ovate to oblonglanceolate; receptacle convex, with a few paleae, paleae similar to inner involucral bracts. Florets ca. 12-20 in a head; corollas whitish to lavender, narrowly funnelform, with broadly cylindrical basal tube, glabrous on outer surface below lobes; cells of limb oblong with rather sinuous lateral walls; lobes triangular, about 1-2 times as long as wide, smooth on both surfaces, with few to many short-capitate glands on outer surface; anther collar narrowly cylindrical, with few subquadrate cells below, cell walls with few or no beaded thickenings; anther appendage large, triangular, about as long as wide; style base not enlarged, glabrous; style branches filiform, scarcely broadened distally, slightly mamillose to smooth. Achenes prismatic, 5-ribbed, sparsely setuliferous; carpopodium distinct without or with slight upper rim, symmetrical, short-cylindrical to stopper-shaped, with small subquadrate cells in 6-7 rows, cell walls slightly thickened; pappus of 20-30 slender scabrid contiguous mostly persistent bristles in 1 series, sometimes slightly broadened distally, apical cells acute. Pollen grains ca. 18-22 $\mu \mathrm{m}$ in diameter. Plate 131.

The South American genus Idiothamnus is one of the two in the Koanophyllon relationship distinguished by the presence of paleae on the receptacle. The other genus, Eupatoriastrum from Mexico and Guatemala, has much larger heads with 100-300 flowers in the head, short anther appendages, fistulose stems, and trinervately to palmately veined leaves. As such, the two genera are not regarded as closely related to each other, but separately derived from epaleaceous ancestors.

The closeness of relationship of Idiothamnus to Koanophyllon remains in question. The paleaceous receptacles are basic to Idiothamnus but are not always obvious. Still, the genus also differs by a number of other minor characters such as the pale regularly foliated stems, the rather elliptical pinnately veined leaves, and the comparatively narrow, sometimes weakly glanduliferous corolla lobes. In the latter characters, Idiot hamnus partly overlaps with Koanophyllon and partly exceeds the known limits of that genus. It is further notable that the shared characters of the two genera are rather generalized, and that Idiothamnus shows none of the characters such as short anther appendages and broadened tips on the style branch. es that would tend to confirm close relationship to Koanophyllon. The present view is that the genera are not immediate relatives.
The remarkable insight of $\mathrm{B}$. Robinson is apparent in Idiothamnus. In spite of the very different geographical distributions involved, he $(1919 a, 1930 c)$ noted that the three paleaceous species then known were similar. The fourth species from Venezuela was subsequently described as Eupatiorastrum clavisetum by Badillo.

The phytogeography of Idiothamnus is anomalous. The four species are from four entirely different areas, Venezuela, Tarapoto in Peru, eastern Brazil, and northwestern Argentina. Only the Argentinian species seems particularly common. Habits and collection data would suggest that all the species of Idiothamnus share similar habitats in or bordering rather temperate woodlands.

The name of the genus is derived from the Greek idios (= distinct or peculiar) and thamnos (= shrub).

The following four species are recognized in the genus:

Idiothamnus clavisetus (V. Badillo) R. King \& H. Robinson, Venezuela.

Idiothamnus lilloi (B. Robinson) R. King \& H. Robinson, Argentina.

Idiothamnnus orgyaloides (B. Robinson) R. King \& H. Robinson, Peru.

Idiothamnus pseudorgyalis R. King \& H. Robinson, Brazil.

\section{Mexianthus}

Mexianthus B. Robinson, Contr. Gray Herb. n.s. 80: 5. 1928. TyPE: Mexianthus mexicanus B. Robinson.

Erect subshrub, with moderate branching. Stems terete, striated, puberulous. Leaves alternate, with narrowly winged petioliform base; blades ovate, acuminate at base and tip, margins serrate, venation subtrinervate with more strongly ascending secondaries from near basal fourth, lower surface with scattered minute glandular punctations. Inflorescence a laxly thyrsoid leafy panicle with laxly thyrsoid branches; heads sessile 


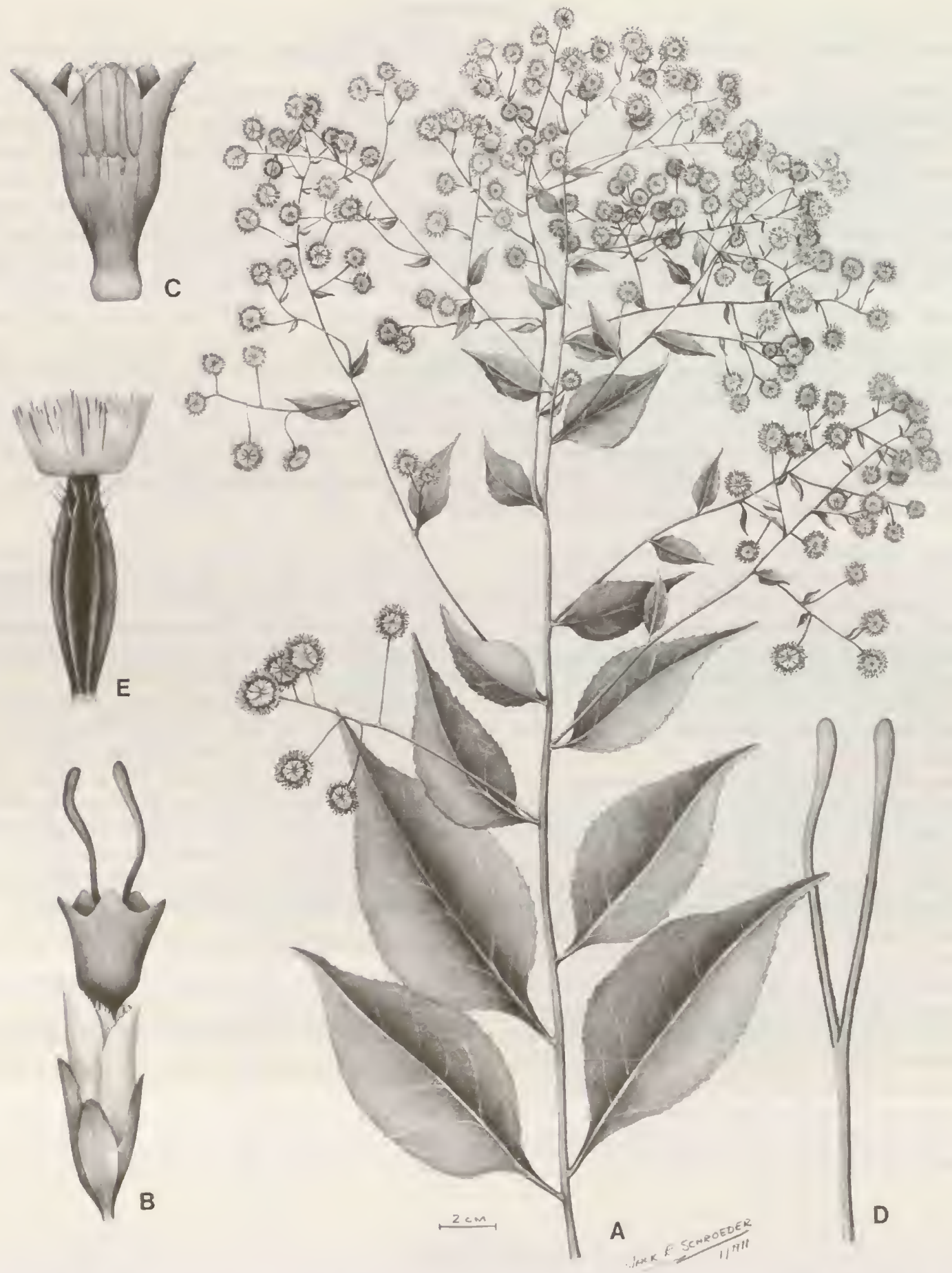

Plate 132. Mexianthus mexicanus B. Robinson. - A. Habit, $\times 4 / \% .-$ B. Head, $\times 16 .-$ C. Corolla showing anthers, $\times 25 .-$ D. Style, $\times 25$. - E. Achene, $\times 25$. 
in dense spherical glomerules at tips of branchlets. Involucral bracts 3(-5), eximbricate and subequal or with 1-2 short outer bracts, in 1-2 series, forming thin sheath around flower, mostly oblong with truncate to rounded tips, glanduliferous; receptacle minute, glabrous. Florets 1 in a head; corollas white, with short cylindrical basal tube and broadly funnelform to slightly campanulate limb, glabrous on outer surface below lobes; cells of limb oblong with sinuous lateral walls; lobes triangular, about as long as wide, slightly mamillose on inner surface, smooth with clustered short-stalked capitate glands on outer surface; anther collar narrowly cylindrical, with subquadrate cells below, oblong cells above, without obvious ornate thickenings on walls; anther appendage minute, wider than long; style base not enlarged, glabrous; style appendages with minutely but distinctly spathulate tips, slightly mamillose below tips. Achenes rather fusiform, 5-ribbed, glabrous below, with a few setulae above; carpopodium indistinct, occasionally with a few small subquadrate cells in 2-3 series; pappus of 5-7 laciniate squamellae. Pollen grains ca. $18 \mu \mathrm{m}$ in diameter. Plate 132.

The Mexican genus Mexianthus was originally distingiushed by B. Robinson (1928) on the basis of its singleflowered heads born in spherical clusters, its pappus of squamellae, and its seemingly exappendiculate anthers. The genus was compared by $\mathrm{B}$. Robinson with the only other member of the tribe with such single-flowered heads. the Mexican species treated here as the genus Neohintonia, but the latter was considered generically distinct because of its capillary pappus and evident anther appendages. Though not noted by B. Robinson (1928), Mexianthus is also distinct from most other members of the tribe, including Neohintonia, by the rather fusiform achenes which become quite narrow below the pappus.

In spite of the similarity of Mexianthus to Neohintonia, B. Robinson (1928) did not regard the species involved as closely related. Because of the nearly complete reduction of the anther appendage, B. Robinson placed Mexianthus in a very artificial subtribe Piqueriinae with diverse genera recognized here as members of the Ageratinae, the Alomiinae, and in the case of Trychinolepis (=Ophryosporus), the Critoniinae. Only the latter South American element, of those mentioned by B. Robinson, is considered here to belong to the same subtribe as Mexianthus.
In the present view, Mexianthus and Neohintonia are closely related, sharing a number of features in addition to their single-flowered heads. Both have mostly alternate leaves, broad and blunt involucral bracts forming a sheath around the flower, and considerable reduction of the anther appendages. The anther appendages, enlarged tips on the style branches, and corollas with broadly cylindrical bases and broadly triangular glanduliferous lobes indicate a relationship to the large Koanophyllon group. There is a similarity to the South American genus of the group, Sphaereupatorium, which has ca. 10-11-flowered heads in spherical clusters, but the genus does not seem to be directly related.

Mexianthus appears to have a restricted distribution near Puerto Vallarta, in Jalisco, on the Pacific coast of Mexico. Only the type series has been seen.

The genus Mexianthus was named by B. Robinson in honor of the original discoverer of the plant and wellknown collector of Neotropical plants, Ynes Mexia.

The following single species is recognized in the genus: Mexianthus mexicanus B. Robinson, Mexico.

\section{Neohintonia}

Neohintonia R. King \& H. Robinson, Phytologia 22: 143. 1971. TYPE: Eupatorium monanthum SchultzBip.

Scandent subshrubs or shrubs, with moderate branching. Stems terete, slightly striated, puberulous. Leaves alternate to subopposite or opposite, with distinct narrow petioles; blades ovate, bases obtuse to broadly rounded, margins serrulate, apices short-acuminate, trinervate from or near base, surfaces subglabrous, with glandular punctations on lower surface. Inflorescence a lax narrowly thyrsoid leafy panicle; heads sessile in spherical glomerules. Involucral bracts 4-5, weakly subimbricate, in 2 subequal series, oblong, persistent; receptacle minute, glabrous. Florets 1 or rarely 2 in a head; corollas white, with broadly cylindrical base and funnelform throat, scattered glands on outer surface, more numerous on lobes; cells of limb elongate with sinuous lateral walls; lobes triangular, as long as wide, smooth on both surfaces; anther collar narrowly cylindrical, with short-oblong cells, longer above, without evident ornate thickenings on walls; anther appendage small, very short, 3 times as wide as long, truncate; style base not enlarged, glabrous; style branches with minutely but distinctly spathulate tips, slightly mamillose below tips, with glands along inner surface. Achenes prismatic, 5-ribbed, with setulae and a few glands on sides; carpopodium distinct, shortly stopper- 

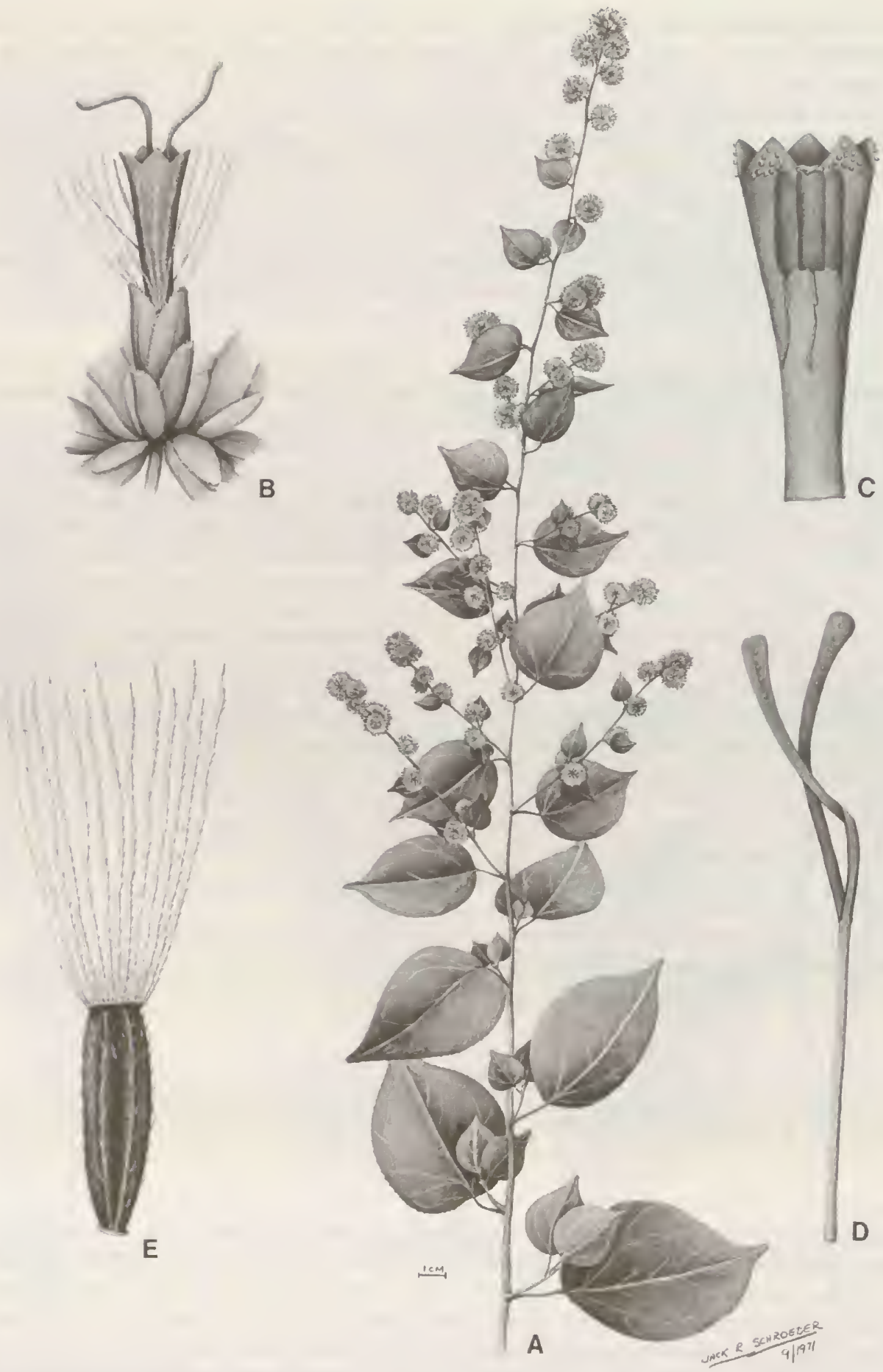

Plate 133. Neohintonia monantha (Schultz-Bip.) R. King \& H. Robinson. - A. Habit, $\times 1 / 3 .-$ B. Head in cluster, $\times 9 .-$ C. Corolla showing anthers, $\times 18,-D$. Style, $\times 18 .-E$. Achene, $\times 18$. 
shaped, with slight upper rim, with small subquadrate cells in 7-8 rows, cell walls slightly thickened; pappus of ca. 25 slender scabrid slightly deciduous scarcely contiguous bristles in 1 series, not broadened at tips, apical cells acute. Pollen grains ca. 16-18 $\mu \mathrm{m}$ in diameter. Plate 133.

The Mexican genera Neohintonia and Mexianthus are distinguishable from all other members of the Eupatorieae by their single-flowered heads born in spherical clusters. Unlike Mexianthus, however, Neohintonia has a pappus of numerous capillary bristles, and was originally included in the broad traditional concept of Eupatorium. The similarity between Mexianthus and the type species of Neohintonia, Eupatorium monanthum, was noted by B. Robinson (1928) when he described the former, but he considered his genus to be basically distinct in its scalepappus and its seemingly exappendiculate anthers. B. Robinson treated the two as not only generically, but subtribally distinct, placing Mexianthus in his highly artificial Piqueriinae.

The present treatment accepts the conclusion of $\mathrm{B}$. Robinson (1928) that the species involved in Neohintonia and Mexianthus are generically distinct. The two genera are closely related, however, and have corollas with broadly cylindrical bases, broadly triangular gianduliferous corolla lobes, slightly spathulate tips on the style branches, and variously reduced anther appendages that indicate a relationship in the Critoniinae close to Koanophyllon. Although the anther appendages of Neohintonia are larger than the minute bilobed structure in Mexianthus, they are sufficiently short to have, in their own right, called the placement of the species in traditional Eupatorium into question. The appendages are distinctly shorter than the short form found in the typical element of the related genus Koanophyllon that was also included in the traditional concept of Eupatorium. The non-fusiform achenes and the capillary pappus are more like Koanophyllon than Mexianthus, but the slender somewhat deciduous nature of the pappus bristles further distinguishes Neohintonia from Koanophyllon.

Neohintonia seems to have a wide distribution in central Mexico from Jalisco in the west to Oaxaca in the east. The range overlaps that of the local endemic Mexianthus in Jalisco.

The name of the genus honors another well-known plant collector, George B. Hinton, known for his extensive efforts in Sierra Madre del Sur in Mexico during the early part of the twentieth century (J. Hinton \& Rzedowski, 1972).

The following single species is recognized in the genus:

Neohintonia monantha (Shultz-Bip.) R. King \& H. Robinson, Mexico.

\section{Peteravenia}

\section{Peteravenia R. King \& H. Robinson, Phytologia 21: 394. 1971. TyPE: Eupatorium schultzii Schnittsp.}

Erect coarse herbs or subshrubs, few to moderately branched. Stems terete, weakly striated to somewhat 6-angled, densely hispid to lanate with glandular or non-glandular hairs. Leaves opposite, petioles narrow, sharply delimited, often long; blades broadly ovate to deltoid with cordate bases (oblong-elliptical with obtuse to rounded bases in $P$. cyrili-nelsonii) margins usually serrulate to serrate, apices short-acuminate, trinervate from base (venation pinnate in $P$. cyrili-nelsonii), undersurface usually with minute often stipitate glands (without glands in $P$. cyrili-nelsonii). Inflorescence pyramidally paniculate, sometimes laxly branched; pedicels slender, often elongate. Involucre often pale or brightly colored, broadly campanulate; involucral bracts ca. 25 , strongly subimbricate in 3-4 unequal graduated series, short-oblong to oblong-lanceolate, inner bracts mostly persistent; receptacle broadly convex, glabrous. Florets $18-75$ in a head; corollas white, lavender, or purple, narrowly funnelform, with outer and inner surfaces glabrous; cells elongate with sinuous lateral walls; lobes triangular, as long as wide or longer, smooth on both surfaces; anther collar usually narrowly cylindrical, with numerous subquadrate cells, cell walls thin with beaded thickenings; anther appendage large, oblongovate, longer than wide; style base not enlarged, glabrous; style branches linear, sometimes slightly spathulate at tip, short-papillose below, mamillose distally. Achenes prismatic, 4-5-ribbed, narrowed and sometimes long stipitate below, setuliferous mostly on ribs; carpopodium distinct, sharply delimited above, not procurrent on ribs of achene, shortly stopper-shaped, mostly with 3-7 tiers of thin-walled cells; pappus of ca. 30 rather scabrous deciduous bristles, uniform in size and spacing, slender and non-contiguous below, broadened distally, apical cells acute. Pollen grains ca. $20 \mu \mathrm{m}$ in diameter. Plate 134.

Peteravenia is a genus from Mexico and Central America notable for its often whitish or reddish involucral bracts, its usually cordate leaf bases, and its consistently slender based distally enlarged deciduous pappus bristles. The 


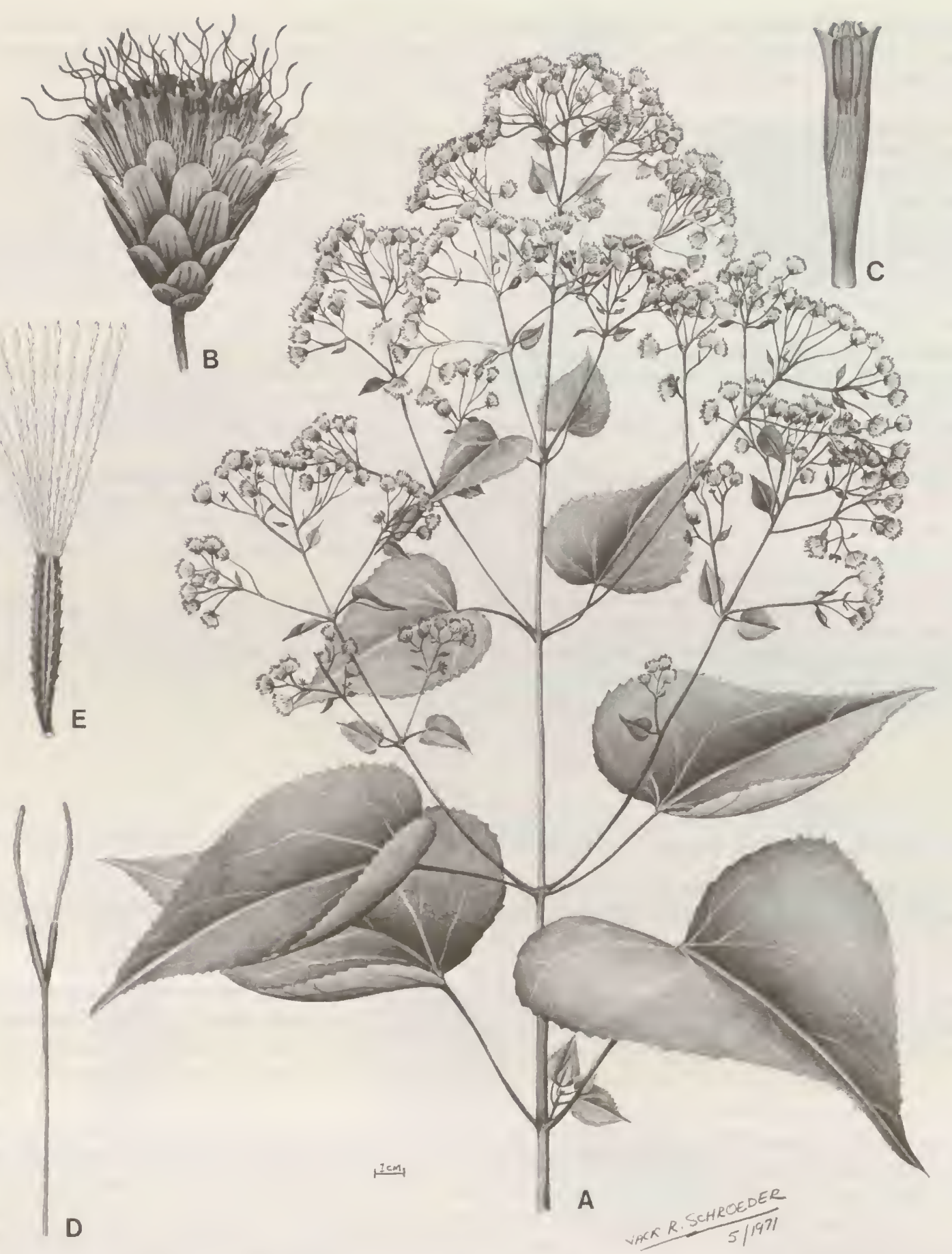

Plate 134. Peteravenia schultzii (Schnittsp.) R. King \& H. Robinson. -A. Habit, 4\%. - B. Head, $\times 4 \frac{1}{3} .-$ C. Corolla showing anthers, $\times 9 .-D$. Style, $\times 9 .-$ E. Achene, $\times 9$.

genus has all the characteristic features of the Critoniinae, the strongly subimbricate involucre, the smooth corolla lobes, the unenlarged glabrous style bases, and the weakly ornamented cells of the anther collar. The genus seems atypical, but in no way unique in the subtribe, only in the persistent nature of the inner involucral bracts.

In spite of the Critonioid nature of Peteravenia, the habit of the plant and the broad multi-flowered heads give 
the genus a strong resemblance to Bartlettina, of the Hebecliniinae, that occurs commonly in the same area. The resemblance caused Peteravenia to be placed in the $\mathrm{He}$ beclinium group in the recent review of the tribe $(H$. Robinson \& King, 1977). Nevertheless, when first proposed, Peteravenia (King \& Robinson, 1971 $i$ ) was not considered an immediate relative of Bartlettina (King \& Robinson, $1971 d, 1971 f f)$. The cordate leaf base of the then known species was a convenient distinction cited in the original reference, but was of tertiary importance. The character fails in both genera, some species of Bartlettina from northern South America having cordate leaf bases, and one more recently recognized species of Peteravenia lacking such bases. More important distinctions are the detailed structure of the pappus and the structure of the carpopodium.

The pappus of Peteravenia is fragile with the narrow articulated bases of the bristles well separated from each other. In all species, the tips of the bristles are slightly but distinctly enlarged. Only Decachaeta, among the undoubted members of the Hebecliniinae, has the pappus fragile, and none of the members of the latter subtribe has the bristles so uniform in size and spacing.

The carpopodium of Peteravenia is sharply delimited in cellular structure, while that of Bartlettina intergrades with the longer cells of the achene wall, especially along the ribs. In the mature achene of Bartlettina, the carpopodium extends upward along the bases of the ribs, and in all undoubted members of the Hebecliniinae, the ribs of the achene intergrade below with the carpopodium, although they are not always included in the callus formation.

It is notable that the receptacle in Peteravenia is glabrous, having none of the hairs that are common in many members of the Hebecliniinae.

Within the Critoniinae, Peteravenia shows some resemblance to Fleischmanniopsis in its showy and persistent involucral bracts and in its slender pappus bristles. How- ever, Fleischmanniopsis has comparatively few flowers in the heads, much more prominent enlargement on the tips of the style branches, short anther appendages, narrower and highly annulated anther collars, and a strikingly different corolla shape and venation.

As originally delimited, Peteravenia was regarded as rather isolated, with great internal uniformity. The more recent addition of $P$. cyrili-nelsonii considerably increases the diversity of the genus, and confirms the significance of the basic characters by which the genus is distinguished from others.

Chromosome reports for Peteravenia include two of $n=$ 10 and one of $n=$ ca. 17, all from $P$. phoenicolepis ( $R$. King et al., 1976). More recently, an additional voucher for the $n=17$ report has been seen (Breedlove 14148, CAS), and it is Ageratina subinclusa (Klatt) R. King \& H. Robinson, a member of a genus with a base number of $x=17$. Thus, only counts of $n=10$ can now be attributed to Peteravenia. Correction of this error removes any remaining question regarding the Critoniine rather than $\mathrm{He}-$ becliniine nature of the genus.

Peteravenia has its center of diversity in northern Central America, but ranges from Costa Rica in the south to northcentral Mexico in Nuevo Leon and Tamaulipas.

The generic name honors Peter $\mathrm{H}$. Raven, formerly of Stanford University, presently Director of the Missouri Botanical Garden in St. Louis.

The following five species are recognized in the genus:

Peteravenia cyrili-nelsonii (A. Molina) R. King \& H. Robinson, Honduras.

Peteravenia grisea (J. Coulter) R. King \& H. Robinson, Guatemala, Honduras, Nicaragua.

Peteravenia malvaefolia (DC.) R. King \& H. Robinson, Mexico. Peteravenia phoenicolepis (B. Robinson) R. King \& H. Robinson, Mexico, Guatemala, Honduras.

Peteravenia schultzii (Schnittsp.) R. King \& H. Robinson, Mexico, Guatemala, El Salvador, Honduras, Nicaragua, Costa Rica.

\section{Critoniella}

\section{Critoniella R. King \& H. Robinson, Phytologia 30: 284. 1975. TYPE: Eupatorium acuminatum H.B.K.}

Erect herbs or shrubs, with few branches. Stems terete or rather hexagonal, weakly striated. Leaves opposite petioles slender, more than one-third as long as blade, sharply delimited; blades ovate to broadly ovate, base obtuse to cordate, margins serrulate to serrate, apex acute to acuminate, trinervate from or near base, with or without glandular punctations below, with only veins or glandular punctations translucent. Inflorescence a broadly corymbose to cymose panicle with densely corymbose branches; heads sessile on congested glomerulate branchlets. Involucres narrowly cylindrical; involucral bracts ca. 18-32, strongly subimbricate to imbricate in 4-6(-7) strongly unequal graduated series, oblong to linear-lanceolate, 4-costate on outer surface, inner bracts usually rather persistent; receptacle flat; glabrous. Florets 6-25 in a head; corollas white, lavender, bluish, or purple, narrowly funnelform, glabrous on inner surface and outside below lobes; cells of limb narrow with sinuous lateral walls; lobes triangular, as long as wide, smooth on both surfaces, with few glands on outer surface; anther collar narrowly cylindrical, with many subquadrate cells below, short-oblong above, 


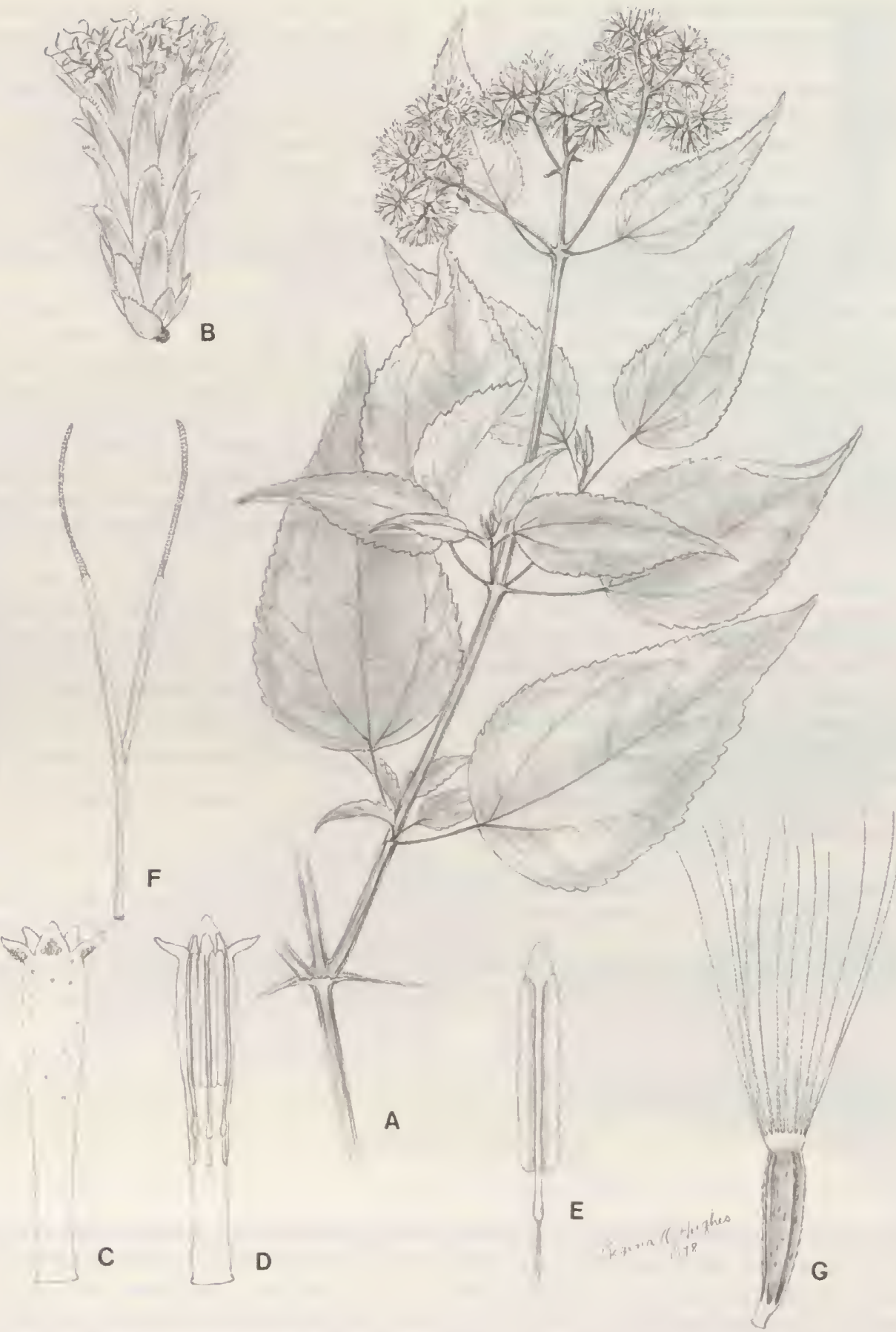

Pl.ATE 135. Critoniella acuminata (H.B.K.) R. King \& H. Robinson. - A. Habit, $\times 1 / 2 .-$ B. Head, $\times 7$. - C. Corolla outer surface, $\times 14 .-$ D. Corolla inner surface with anthers, $\times 14,-$ E. Anther, $\times 20$. - F. Style, $\times 14 .-G$. Achene, $\times 14$.

cell walls with distinct but weak annular thickenings; anther appendage large, ovate-oblong, longer than wide; style base not enlarged, glabrous; style branches with appendages terete and filiform, densely short-papillose. Achenes subfusiform, 5-ribbed, with few to many setulae on sides; carpopodium stopper-shaped, not sharply delimited above, longer cells extending upward on lower parts of achene ribs, with subquadrate cells below 
in many tiers, cell walls moderately thickened; pappus of ca. 40 persistent slender scabrid bristles in 1 series, narrowly tapering to tip, apical cells acute. Pollen grains ca. $19 \mu \mathrm{m}$ in diameter. Plate 135

The name Critoniella was given to the present genus because of the strong superficial resemblance, especially in the type species, to members of the genus Critonia. The resemblance is aided by the narrow and strongly subimbricate involucres with pale or stramineous bracts, and the presence of pellucid lines in the leaves of some species. Nevertheless, relationship to Critonia does not appear to be close. The pellucid lines, when examined carefully, prove to be all associated with veinlets. Also, the leaves of some species have glandular punctations, a feature never seen in Critonia. Critoniella differs from Critonia in numerous technical details as well, having shorter spreading rather than erect corolla lobes, slender pappus bristles tapering to the tip, narrower achenes rather fusiform from a distinct constriction below the pappus, more persistent involucral bracts, and narrower style branches.

The narrow style branches and the structure of the carpopodium prove to be characters of particular interest in Critoniella. The style appendages are very narrow and terete with papillosity evenly distributed on all sides. Such terete appendages occur elsewhere in the tribe in Hebeclinium, with a superficially similar but obviously different terete form in Castenedia. The procurrent cells of the carpopodium along the bases of the achene ribs are also similar to the type found in the subtribe Hebecliniinae to which Hebeclinium belongs, and a relationship of Critoniella to the latter subtribe seems possible. The narrow heads and the narrow flat receptacles of Critoniella, however, are completely foreign to the latter subtribe, and the ornamentation on the cell walls of the anther collar is not matched in undoubted members of the Hebecliniinae.

At the time of its original description, Critoniella was believed to contain four species (King \& Robinson, 1975i). One species that was added later, C. leucolithogena (King \& Robinson, 1975w), had been placed first in Hebeclinium (King \& Robinson, 1975n), where it proved anomalous by its flat receptacle. However, further examination has shown that the species is also rather anomalous in Critoniella, having lax inflorescences with pedicellate heads, sometimes distinctly broadened tips on the pappus bristles, and broader less terete weakly mamillose style branches. Although the species is retained in the genus here, its anomalous features have not been accounted for in the generic description.

Critoniella is known only from Colombia, Peru, and Venezuela, where it occurs mostly at medium elevations. It is the two rarer species, $C$. albertosmithii and $C$. lebrijensis that seem to be restricted to lower elevations of 150-700 $\mathrm{m}$ in the Department of Santander in Colombia. A survey of herbarium specimens seems to indicate the presence of at least one additional undescribed species in Colombia.

The following six species are recognized in the genus:

Critoniella acuminala (H.B.K.) R. King \& H. Robinson, Colombia, Venezuela, Peru.

Critoniella albertosmithii (B. Robinson) R. King \& H. Robinson, Colombia.

Critoniella lebrijensis (B. Robinson) R. King \& H. Robinson, Colombia.

Critoniella leucolithogena (B. Robinson) R. King \& H. Robinson, Colombia.

Critoniella temuifolia (H.B.K.) R. King \& H. Robinson, Venezuela.

Critoniella vargasiana (DC.) R. King \& H. Robinson, Venezuela.

\section{Aristeguietia}

Aristeguietia R. King \& H. Robinson, Phytologia 30: 218. 1975. TYPE: Eupatorium salvia Colla.

Erect to procumbent shrubs to small trees, moderately branched. Stems terete or 4-6-angled. Leaves opposite, petioles mostly short, usually sharply delimited; blades broadly ovate to linear, often oblong or elliptical, base cordate to cuneate, margins usually densely crenulate to dentate, venation pinnate or trinervate from base, upper surface often bullate or roughened, rarely with small glandular punctations, lower surface without evident glandular punctations, sometimes with small stipitate glands, often with tomentum. Inflorescence with few to many heads, corymbose with usually ascending branches, lower branches usually opposite; heads pedicellate. Involucral bracts ca. 25-70, strongly subimbricate, in 4-6 unequal graduated series, mostly persistent, a few innermost sometimes deciduous, ovate to lanceolate, outer surface striated; receptacle flat to slightly convex, conical in $A$. lamiifolia, glabrous. Florets 13-100 in a head; corollas bluish, lavender, purple, or pink, narrowly funnelform, inner and usually outer surfaces glabrous, some species with few hairs or few to many small glands on lobes; cells of limb oblong, usually with sinuous lateral walls; lobes triangular, slightly longer than wide, smooth on both surfaces; anther collar narrowly cylindrical, with mostly oblong cells, cell walls with weak but distinct annular thickenings; anther appendage large, longer than wide; style base not enlarged, glabrous; style appendage broadly strap-shaped, often longitudinally folded, mam- 


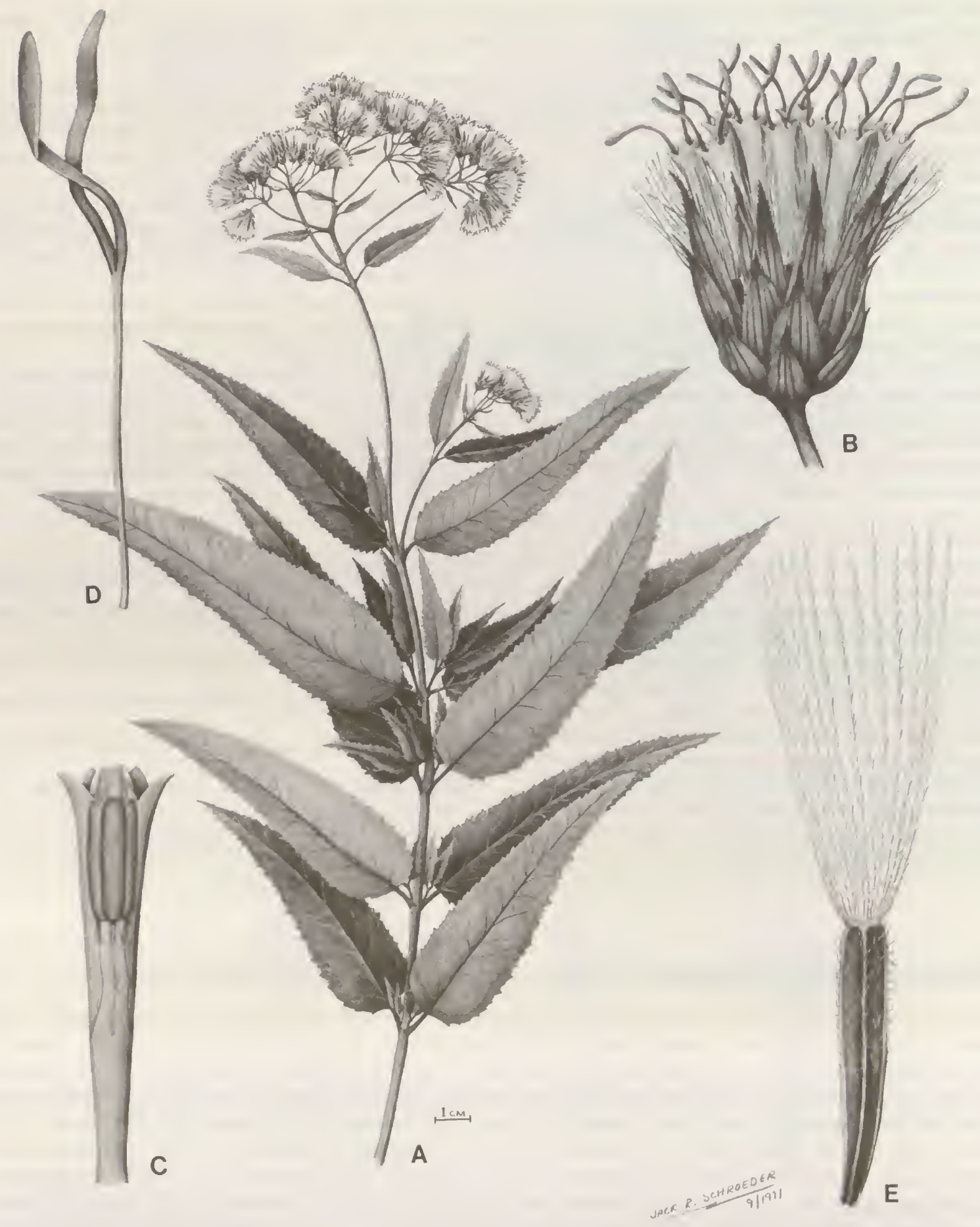

Plate 136. Aristeguietia salvia (Colla) R. King \& H. Robinson. - A. Habit, $\times 3 / 5 .-B$. Head, $\times 6 .-$ C. Corolla showing anthers, $\times 13$. D. Style, $\times 13,-$ E. Achene, $\times 13$. 
illose. Achenes prismatic, 5-ribbed, usually with setulae, without glands; carpopodium indistinct, without upper rim, composed of subquadrate to oblong cells in a few tiers, walls moderately thickened; pappus of ca. 30-45 scabrid persistent bristles congested in 1-2 series, scarcely spreading at maturity, not broadened distally, apical cells acute. Pollen grains ca. 22-25 $\mu \mathrm{m}$ in diameter. Plate 136.

Aristeguietia is the most Gyptoid of the genera of the Critoniinae, but this is seen only in its persistent involucral bracts, the conical receptacle of one species, the sometimes bluish flowers, and the distinctly ornamented cell walls of the anther collar. Of these characters, only the conical receptacle is unique in the Critoniinae to $\mathrm{Ar}$ isteguietia. In other essential characters, the subimbricate involucre, the smooth corolla lobes, the simple style base, and the mamillose rather than papillose style branches, the genus is clearly a member of the Critoniinae, with no variations toward other subtribes.

The broad strap-shaped appendages of the style branches seem to relate Aristeguietia to other genera of the Critoniinae with which it occurs in the northern Andes, $\mathrm{Ba}$ dilloa and Grosvenoria. Both of the latter genera differ by their glanduliferous achenes, the more spreading branches of their inflorescences, and the spreading pappus bristles. There is also possibly a close relationship to the genus Asplundianthus of the northern Andes, but the latter has narrower style branches, deciduous inner involucral bracts, and spreading pappus bristles. Cronquistianthus seems less closely related, having the style branches usually thickened only near the tips, the tips of the involucral bracts rounded, the branches of the inflorescence spreading, and the carpopodium distinctly asymmetrical.

Aristeguietia is widely distributed and sometimes common in the northern Andes from Colombia south to Peru, with most species in or near Ecuador. The type species in Chile seems a single disjunct member of the most common Ecuadorian element, being more like the latter than the otherwise southernmost species in central Peru.

The genus has some variation in the leaves, but most forms have slightly to strongly bullate upper surfaces, and the margins are usually densely crenate to dentate with scarcely any tendency toward serrate. The species from central Peru, $A$. ballii and $A$. cursonii, have only crenulate margins or margins incurved and essentially entire. The last species is more unusual in having small but distinct glandular punctations on the upper surface of the leaves. The leaves in the genus appear to have two basic shapes, one with cordate bases and usually trinervate venation, the other usually without cordate bases and with closely pinnate venation.

In most species of Aristeguietia, the corolla lobes are glabrous, rarely showing a hair or gland. Only A. chimboracensis of the more typical species seems to regularly have a few hairs or glands on the lobes. Pubescent lobes occur in some more peripheral members of the genus. The two species in central Peru, with more nearly entire leaf margins, have numerous small glands on the lobes. The species with the conical receptacle, A. lamiifolia of Colombia and Ecuador, has prominent hairs and some glands on the lobes.

One species originally placed in Aristeguietia by King and Robinson (1975e), A. perezioides of Colombia, was regarded as the one exception in the genus having narrower style branches. Subsequent study has shown that the species is not in the Critoniinae, being a member of a rather distinctive subgroup of Bartlettina in northern South America, often having cordate leaf bases (King \& Robinson, 1980/).

The generic name honors Dr. Leandro Aristeguieta of the Instituto Botanico in Caracas, Venezuela, author of the treatment of the Asteraceae in the Flora de Venezuela. In spite of the choice of name, the genus does not seem to occur in Venezuela.

The following 21 species are recognized in the genus:

Aristeguietia amelhystina (B. Robinson) R. King \& H. Robinson, Ecuador, Peru.

Aristeguietia anisodonta (B. Robinson) R. King \& H. Robinson, Peru.

Aristeguietia arborea (H.B.K.) R. King \& H. Robinson, Ecuador. Arisleguielia ballii (Oliver) R. King \& H. Robinson, Peru.

Arisleguietia buddleaefolia (Benth.) R. King \& H. Robinson, Ecuador.

Arisleguietia cacalioides (H.B.K.) R. King \& H. Robinson, Ecuador.

Aristeguietia chimborazensis (Hieron.) R. King \& H. Robinson, Ecuador.

Arisleguietia cursonii (B. Robinson) R. King \& H. Robinson, Peru.

Arisleguietia dielsii (B. Robinson) R. King \& H. Robinson, Ecuador.

Arisleguietia diplodictyon (B. Robinson) R. King \& H. Robinson, Peru.

Aristeguietia discolor (DC.) R. King \& H. Robinson, Peru. Aristeguietia gascae (B. Robinson) R. King \& H. Robinson, Peru. Aristeguietia gayana (Wedd.) R. King \& H. Robinson, Peru. Aristeguietia glutinosa (Lam.) R. King \& H. Robinson, Ecuador, Aristeguietia lamiifolia (H.B.K.) R. King \& H. Robinson, Colombia, Ecuador.

Arisleguietia persicifolia (H.B.K.) R. King \& H. Robinson, Ecuador.

Aristeguietia pseudarborea (Hieron.) R. King \& H. Robinson, Peru.

Aristeguietia salvia (Colla) R. King \& H. Robinson, Chile. Aristeguietia tahonensis (Hieron.) R. King \& H. Robinson, Peru. Arisleguietia tatamensis (B. Robinson) R. King \& H. Robinson, Colombia.

Aristeguietia uribei R. King \& H. Robinson, Colombia. 


\section{Asplundianthus}

\section{Asplundianthus R. King \& H. Robinson, Phytologia 30: 224. 1975. TYPE: Eupatorium pseudoglomeratum} Hieron.

Erect to scandent shrubs or trees, moderately to densely branched. Stems terete to slightly angled, weakly striated, fistulose to solid, puberulous. Leaves opposite, petioles usually short, sharply delimited distally; blades ovate to lanceolate, base acute to truncate, margins subserrate to serrate, usually trinervate from or near base, sometimes pinnate with ascending secondary veins, with or without glandular punctations on undersurface. Inflorescence usually corymbose-paniculate, primary branches usually opposite; heads sessile in glomerules. Involucral bracts ca. 15-20, subimbricate in ca. 3-5 strongly unequal graduated series, ovatelanceolate, often stramineous, inner bracts deciduous; receptacle flat, glabrous. Florets 6-10 in a head; corollas lilac, lavender, or purple, narrowly funnelform, usually with glands on outer surface; cells of throat narrow with sinuous lateral walls; lobes broadly triangular, as long as wide, smooth on both surfaces; anther collar narrowly cylindrical, lower cells subquadrate, oblong above, with weak transverse annular thickenings on walls; anther appendage large, ovate-triangular, up to twice as long as wide; style base not enlarged, glabrous; style branches narrowly linear, mamillose. Achenes prismatic, 5-ribbed, glabrous or with a few setulae, rarely with a few glands; carpopodium distinct, not abruptly demarcated above, stopper-shaped, composed of many tiers of subquadrate cells with moderately thickened walls; pappus of ca. 30-40 slender scabrid persistent bristles, spreading with age, slender and tapering distally, apical cells acute. Pollen grains ca. 20-23 $\mu \mathrm{m}$ in diameter. Plate 137.

The genus Asplundianthus occurs almost entirely between the elevations of 2,500 and $3,000 \mathrm{~m}$ in the northern Andes from Colombia southward to Peru. It is one of a series of distinctive genera of the Critoniinae common in the area, including Aristeguietia, Badilloa, Grosvenoria, and Critoniella, but is the only one of the series with neither unusually broad style appendages as in the first three genera nor unusually narrow style appendages as in the last genus. Asplundianthus is further distinguished from the associated genera with broader style branches by having glabrous or nearly glabrous achenes, and to some extent by the spreading pappus bristles with slender tips. Critoniella, which may be the most closely related genus, differs by its extremely narrow terete style appendages, by the exclusively large thin-walled cells in the carpopodium, and by the long petioles on its leaves. Asplundianthus also resembles the more widespread genus Critonia of lower elevations, but can be distinguished by the lack of internal secretory pockets in the areoles of the leaves and by the slender bristles of the pappus.

The pollen size in Asplundianthus is of some interest. In most species, grains are of ca. $20 \mu \mathrm{m}$ in diameter as measured in recently prepared slides with Hoyer's solution. This is the general size also found in the probably closely related Critoniella, and in many other genera of the Eupatorieae. Among the other genera of the Critoniinae from the same elevation in the northern Andes, however, pollen sizes near $25 \mu \mathrm{m}$ are most common. One species of Asplundianthus, A. arcuans, has a tendency for pollen grains up to $23 \mu \mathrm{m}$ in diameter. One other case of larger pollen in a specimen of $A$. stuebelii has proven to involve Type II pollen intermixed with some normalsized Type I grains.

Within Asplundianthus, it is A. arcuans that seems par- ticularly distinctive in a number of characters, and it is probably worthy of a separate subgenus. Its corollas are unusual in their long narrow bases, the style appendages have more enlarged tips and are more papillose below, and the leaves lack glands on their undersurfaces.

Asplundianthus has variation in a number of other features besides those seen in $A$. arcuans. The leaves are usually trinervate, but are pinnately veined in $A$. densus, $A$. scabrifolius, and $A$. toroi. The inflorescences vary from pyramidal to densely corymbose. The general pubescence ranges from nearly glabrous to tomentellous. There is a strong tendency toward glabrous achenes in the genus, but some species, especially $A$. scabrifolius and $A$. stuebelii, have sparsely scabrid to setuliferous or even glanduliferous upper surfaces on the achene. In one species, $A$. sagasteguii, the undersides of the leaves have a minute dense almost hyphal blackish tomentum that may be unique in the family.

The distinctions of the species of Asplundianthus are discussed in the two papers by King and Robinson (1975g, $1978 h$ ). There is no key to the species of the genus.

The generic name honors Erik Asplund, Swedish botanist well known for his collections of Ecuadorian plants.

The following ten species are recognized in the genus:

Asplundianthus arcuans (B. Robinson) R. King \& H. Robinson, Colombia.

Asplundianthus densus (Benth.) R. King \& H. Robinson, Colombia.

Asplundianthus pseudoglomeratus (Hieron. in Sodiro) R. King \&

H. Robinson, Ecuador.

Asplundianthus pseudostuebelii R. King \& H. Robinson, Colombia.

Asplundianthus sagasteguii R. King \& H. Robinson, Peru. 


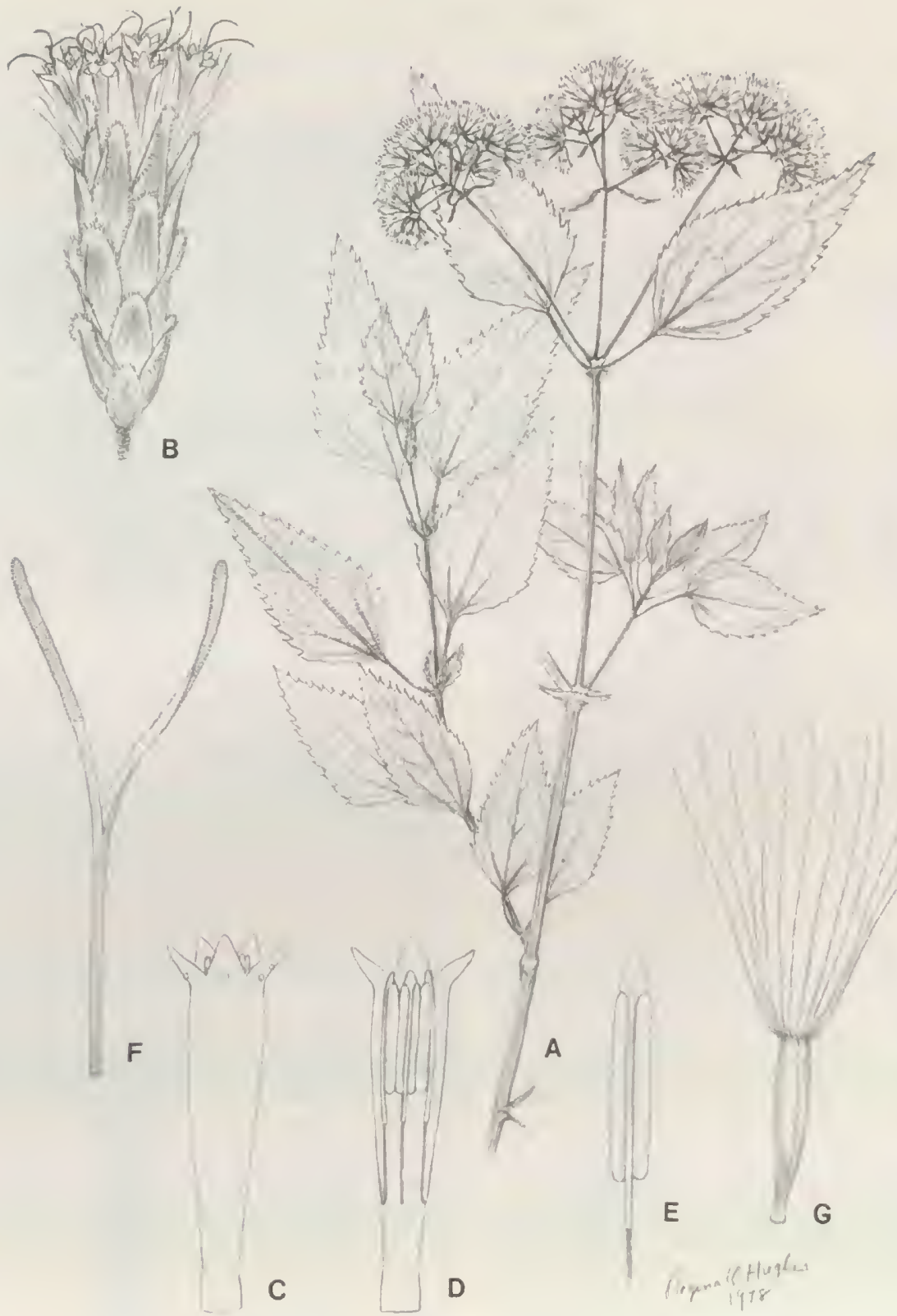

Plate 137.-Asplundianthus pseudoglomeratus (Hieron, in Sodiro) R. King \& H. Robinson. - A. Habit, $\times 1 / 2 .-$ B. Head, $\times 7 .-$ C. Corolla outer surface, $\times 14 .-D$. Corolla inner surface with anthers, $\times 14 .-E$. Anther, $\times 25 .-F$. Style, $\times 14 .-$ G. Achene, $\times 10$.

Asplundianthus scabrifolius (B. Robinson) R. King \& H. Robinson, Peru.

Asplundianthus smilacinus (H.B.K.) R. King \& H. Robinson, Colombia.

Asplundianthus stuebelii (Hieron.) R. King \& H. Robinson, Ecuador.
Asplundianthus toroi (B. Robinson) R. King \& H. Robinson, Colombia.

Asplundianthus trachyphyllus (Hieron.) R. King \& H. Robinson, Peru. 


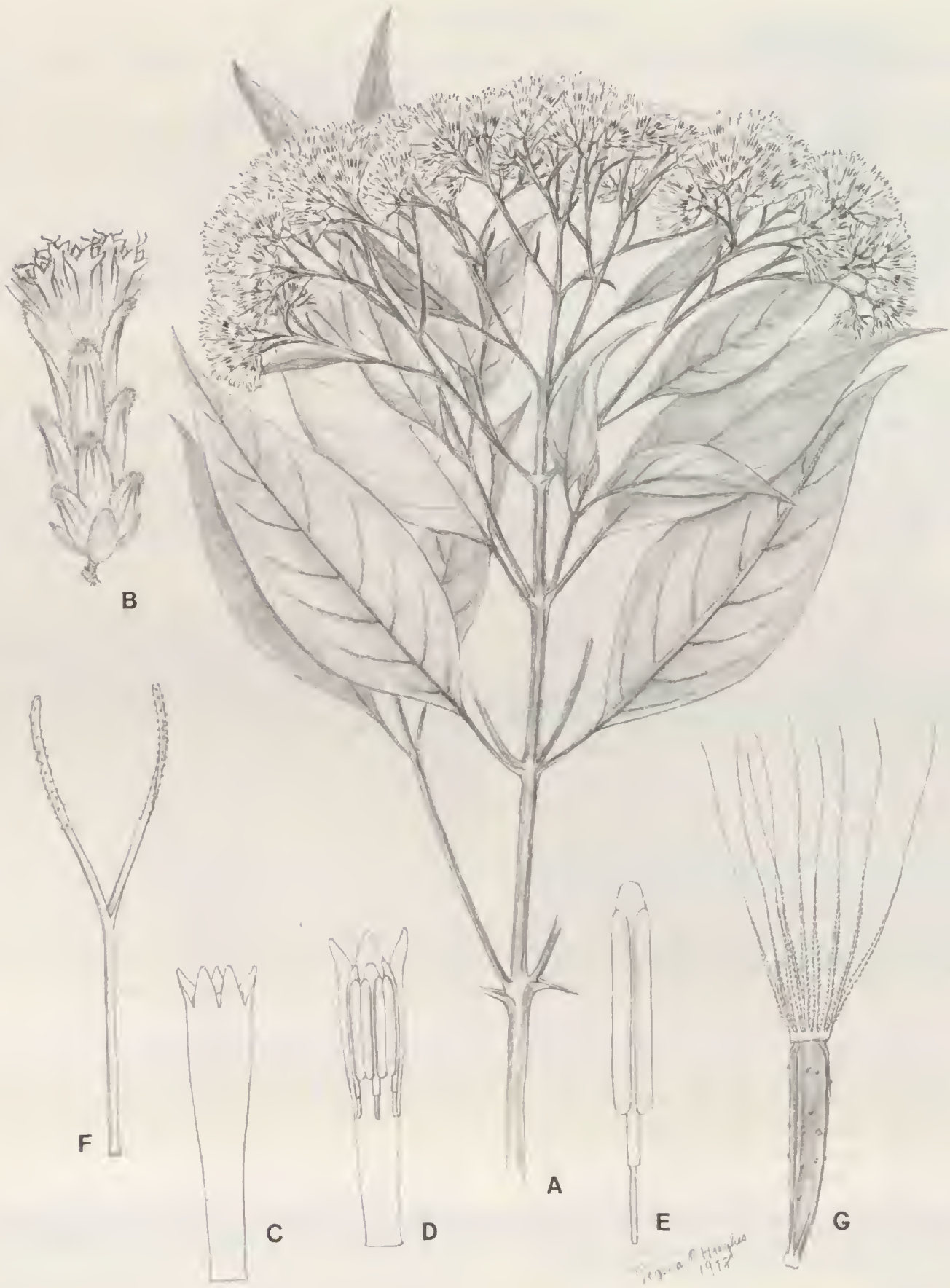

Plate 138. Austrocritonia velutina (Gardner) R. King \& H. Robinson. - A. Habit, $\times 1 / 2 .-B$. Head, $\times 4$. - C. Corolla outer surface, $\times 8 .-$ D. Corolla inner surface with anthers, $\times 8 .-$ E. Anther, $\times 16 .-F$. Style, $\times 8 .-$ G. Achene, $\times 8$. 


\section{Austrocritonia}

Austrocritonia R. King \& H. Robinson, Phytologia 31: 115. 1975. TYPE: Eupatorium velutinum Gardner.

Erect shrubs or small trees, with few to many branches. Stems angled to terete, subglabrous to velutinous. Leaves opposite, petioles very short or medium length; blades ovate to elliptical, bases acute to acuminate, obtuse in $A$. rosea, margins entire or remotely serrulate to closely serrate, venation usually pinnate, strongly trinervate or quinquenervate from above base in $A$. taunayana, glandular-punctate on both surfaces, without internal secretory pockets in areoles. Inflorescence broadly corymbose with ascending branches; heads sessile in clusters. Involucral bracts 12-25, strongly subimbricate in ca. 3-5 strongly unequal graduated series, oblong to elliptical-ovate, inner bracts easily deciduous; receptacle flat to slightly convex, glabrous. Florets 5 and ca. 10 in a head; corollas white, narrowly funnelform, glabrous on inner and outer surfaces; cells of throat narrow with sinuous lateral walls; lobes longly ovate-oblong, ca. twice as long as wide, smooth on both surfaces, glabrous; anther collar cylindrical, with subquadrate cells in lower part, oblong cells above, cell walls with distinct weak transverse annular thickenings; anther appendage large, oblong-triangular, ca. twice as long as wide; style base not enlarged, glabrous; style branches linear, mamillose. Achenes prismatic, 5-ribbed, glanduliferous to glabrous on sides; carpopodium distinct, long-cylindrical, not or weakly delimited above, composed of oblong cells in numerous tiers, with subquadrate cells at base, cell walls slightly thickened; pappus of ca. 40-50 persistent congested bristles mostly in 1 series, strongly scabrid below, narrowed and becoming essentially smooth distally, apical cells acute. Pollen grains ca. 22-24 $\mu \mathrm{m}$ in diameter. Plate 138.

As is reflected in its name, Austrocritonia is a member of the Critoniinae, having the simple style bases, smooth corolla lobes, and subimbricate involucres that mark that subtribe. Within the subtribe, the genus generally resembles the type genus, Critonia, and differs from the large Koanophyllon group, by the narrow heads with rather stramineous strongly imbricated involucral bracts that are mostly deciduous. The genus is not closely related to $\mathrm{Cri}$ tonia, however, having glanduliferous leaf surfaces and lacking internal secretory cavities in the areoles of the leaves. The genus is further distinct from Critonia, as well as other members of the subtribe, in the narrow tips of its pappus bristles.

From the remaining complexity of the Critoniinae, the most convenient distinction of Austrocritonia is geographical. As is reflected in its name, Austrocritonia is a southern member of the group, being one of a small series of genera in the subtribe that is restricted or nearly restricted in distribution to the southeastern part of Brazil. From the few other genera of the area with strongly subimbricate involucres, Austrocritonia is easily distinguished, lacking the hairs inside the corolla seen in Neocabreria and Steyermarkina, and having the narrow tips of the pappus bristles and large carpopodia unlike Malmeanthus.

The structure of the pappus bristles in Austrocritonia is the most unique and most significant unifying character of the genus. In all four species, the bristles are strongly scabrid or even barbellate at the base and become progressively smoother toward the tip. It is not simply the essentially smooth tips of the bristles that are significant, but the great contrast between the bases and tips. Such pappus bristles are not found in any other members of the subtribe.

As presently recognized, Austrocritonia has some di- versity of leaf form, even among the three pinnately veined species originally placed in the genus. A key to the latter has been provided by King and Robinson (1975k). The more recently added $A$. taunayana increases further the diversity evident in the genus by its strongly trinervate and closely serrate leaves. The latter species, with its leaves and its mostly five-flowered heads. resembles the genus Symphyopappus of the Disynaphiinae which is common in Brazil. From the latter, the Austrocritonia species can be distinguished by the depressed and hirtellous rather than exsulcate and glabrous upper surface of the midvein of the leaf, by the lack of ridges on the branches of the inflorescence, by the large carpopodium, and by the smooth tips on the pappus bristles.

The species of Austrocritonia occur in Brazil in the area of Rio de Janeiro and in the states of São Paulo and Minas Gerais. One specimen of the common A. velutina has been seen from the new Federal District.

Although Austrocritonia is a member of the Critoniinae occurring in an area where the subtribe Gyptidinae is predominant, there is no evidence that it shares any of the specialization toward savannah habitats that is common in the latter subtribe. More moist habitats are characteristic of the subtribe Critoniinae, and habitats cited for Austrocritonia include edges of forests and forested mountain tops.

The following four species are recognized in the genus: Austrocritonia angulicaulis (Schultz-Bip. ex Baker) R. King \& H. Robinson, Brazil.

Austrocritonia rosea (Gardner) R. King \& H. Robinson, Brazil. Austrocritonia taunayana (Glaz. ex B. Robinson) R. King \& H. Robinson, Brazil.

Austrocritonia velutina (Gardner) R. King \& H. Robinson, Brazil. 


\section{Badilloa}

\section{Badilloa R. King \& H. Robinson, Phytologia 30: 230. 1975. TYPE: Eupatorium salicinum Lam.}

Erect shrubs, moderately to densely branched. Stems terete, striated, pubescent. Leaves opposite, petioles short; blades oblong to lanceolate, base acute to rounded, margins serrate to remotely subserrulate, upper surface usually slightly insculpate, with glandular punctations usually on both surfaces, often dense below, venation usually pinnate, trinervate or subtrinervate from near or above base in $B$. steetzii. Inflorescence corymbose, with broadly spreading densely corymbose branches; heads shortly pedicellate or subsessile. Involucral bracts ca. 16-25, strongly subimbricate in 4-5 strongly unequal graduated series, oblong or ovate to linear, 2-4-costate, inner bracts rather deciduous; receptacle flat to slightly convex, glabrous. Florets usually $4-10$ in a head, up to 23 in a head in $B$. steetzii; corollas white, lavender, pink, or violet, narrowly funnelform, glabrous on inner surface and on outer surface of throat; cells of throat elongate with sinuous lateral walls; lobes triangular, ca. 1.5 times as long as wide, smooth on both surfaces, with glands or a few small hairs on outer surface near tips; anther collar usually broadly cylindrical, with subquadrate cells below, oblong cells above, cell walls with weak but distinct annular thickenings; anther appendages large, ovate, ca. 1.25 times as long as wide; style base not enlarged, glabrous; style branches broadly linear or strap-shaped, slightly mamillose. Achenes prismatic, 5-ribbed, densely glanduliferous on sides, without non-glandular setulae; carpopodium distinct, without projecting upper rim, short-cylindrical to annuliform, composed of small- to medium-sized subquadrate cells in ca. 2-9 tiers, with moderately thickened walls; pappus of ca. 30-35 scabrid persistent contiguous bristles in 1 series, spreading with age, not distinctly broadened and flattened on outer surface at base, not or slightly broadened distally, apical cells acute. Pollen grains ca. 25 $\mu \mathrm{m}$ in diameter. Plate 139.

The genus Badilloa is one of a group in the subtribe Critoniinae in the northern Andes notable for broadened strap-shaped style branches. The other two genera of the group, Aristeguietia and Grosvenoria, share similar shrubby habits and often occur in the same habitats. They are the genera most likely to be confused with Badilloa, although the relationship between the genera is not necessarily close. Badilloa is easily distinguished from Aristeguietia by the spreading opposite branches of its inflorescences, the distinctly deciduous nature of its inner involucral bracts, the densely glanduliferous rather than strictly non-glanduliferous achenes, the more cellularly differentiated carpopodia, the more spreading mature pappus, and the heads with usually about ten flowers. The relationship to Grosvenoria seems closer, but the latter has multistriate rather than 4-costate involucral bracts, more prominent but less cellularly differentiated carpopodia, and more flattened outer surfaces and sporadically enlarged tips on the pappus bristles.

The resulting concept of Badilloa shows considerable uniformity for a group of species ranging from Venezuela and Colombia in the north to Peru in the south. The species occur mostly at elevations between 2,500 and 4,000 $\mathrm{m}$. Nevertheless, the concept has been extended to include one particularly anomalous species. The Venezuelan $B$. steetzii differs from other members of the genus by its more prominently trinervate leaf blades, the greater number of flowers in the heads (15-23), and its occurrence at elevations as low as $1,000 \mathrm{~m}$. The species shows some resemblance to Asplundianthus pseudostuebelii of Colombia, which is anomalous in its genus by the presence of some glands on the achene. In $B$. steetzii, however, the pointed involucral bracts, the larger number of flowers in the heads, the densely glanduliferous achenes, the more sharply demarcated carpopodia, the broader style branches, and the larger pollen indicate that the species is remote from Asplundianthus and comparatively closely related to the other species of Badilloa.

The genus Badilloa was originally credited with nine species (King \& Robinson, 1975h). The more recently added $B$. atrescens (King \& Robinson, 1981f) was originally excluded because of certain features such as the long-stipitate glands of the achenes. The Ecuadorian species, represented by a single specimen, seemed to represent an intergeneric hybrid between Badilloa and Aristeguietia and was cited as a probable example of such hybridization in the survey of the tribe $(\mathrm{H}$. Robinson \& King, 1977). Still, the species did have the essential characters of Badilloa, and a second specimen from a slightly different location has demonstrated the validity of the species. Hybridization with Aristeguietia is not now considered probable.

The genus Badilloa was named in honor of Dr. Victor M. Badillo, author of numerous papers dealing with the Asteraceae of Venezuela.

The following ten species are recognized in the genus:

Badilloa atrescens (B. Robinson) R. King \& H. Robinson, Ecuador.

Badilloa drepanoides (B. Robinson) R. King \& H. Robinson, Peru.

Badilloa helianthifolia (H.B.K.) R. King \& H. Robinson, Peru. Badilloa herrerae (B. Robinson) R. King \& H. Robinson, Peru. Badilloa procera (B. Robinson) R. King \& H. Robinson, Peru. 

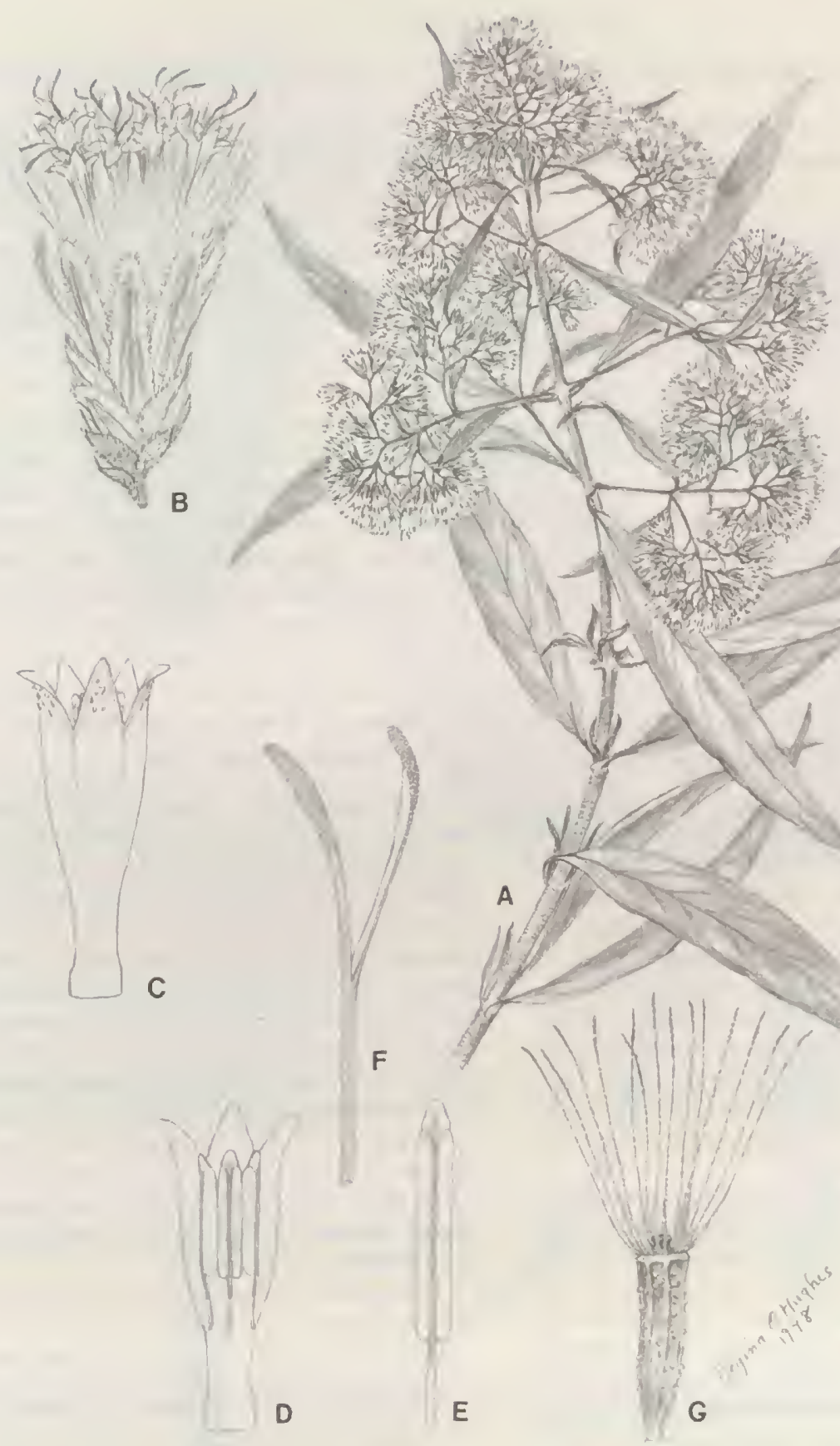

Plate 139. Badilloa salicina (Lam.) R. King \& H. Robinson. -A. Habit, $\times 1 / 2 .-$ B. Head, $\times 5 .-$ C. Corolla outer surface, $\times 9 .-D$. Corolla inner surface with anthers, $\times 9 .-$ E. Anther, $\times 17 .-F$. Style, $\times 9 .-G$. Achene, $\times 9$.

Badilloa salicina (Lam.) R. King \& H. Robinson, Colombia, Ecuador.

Badilloa sonsonensis R. King \& H. Robinson, Colombia. Badilloa sphagnophila (B. Robinson) R. King \& H. Robinson, Peru.
Badilloa steetzii (B. Robinson) R. King \& H. Robinson, Venezuela.

Badilloa venezuelensis (V. Badillo) R. King \& $\mathrm{H}$. Robinson, Venezuela. 


\section{Grosvenoria}

Grosvenoria R. King \& H. Robinson, Phytologia 30: 221. 1975. TYPE: Eupatorium rimbachii B. Robinson.

Erect shrubs or small trees, with many flexuous branches. Stems terete, striated, solid or partially fistulose, mostly fistulose in $G$. coelocaulis. Leaves opposite, petioles medium length to short, slender, rather sharply delimited above; blades ovate to narrowly elliptical, base narrowly to broadly acute, sometimes slightly acuminate, margins entire to remotely serrate, sharply acute to short-acuminate at apex, venation pinnate or trinervate with strongly ascending secondary veins parallel to lower margins, glandular punctate on lower surface, with or without tomentum of thin-walled flattened hairs below. Inflorescence broadly corymbose paniculate, with opposite densely corymbose branches spreading at $45^{\circ}$ or sometimes more; heads sessile or short-pedicellate in small clusters. Involucral bracts 12-15, strongly subimbricate in 3-5 strongly unequal graduated series, ovate to ovate-lanceolate, mostly stramineous and multistriate on outer surface, inner bracts easily deciduous; receptacle flat to slightly convex, glabrous. Florets 5-10 in a head; corollas pink to white, narrowly funnelform, with tube glabrous, without hairs on inner surface; cells of throat oblong with sinuous lateral walls; lobes triangular, ca. 1.5 times as long as wide, smooth on both surfaces; anther collar narrowly cylindrical, composed of subquadrate cells below, oblong cells above, cell walls moderately ornamented with weak but distinct transverse annular thickenings; anther appendage large, ovate, longer than wide; style base not enlarged, glabrous; style branches very elongate, broadly linear, somewhat broader near tip, rounded to obtusely mamillose. Achenes prismatic, 5-ribbed, glanduliferous on sides; carpopodium with slight upper rim, broadly stopper-shaped to cylindrical, procurrent on bases of ribs, composed of medium-sized shortoblong to subquadrate cells in 5-8 tiers, cell walls moderately thickened; pappus of ca. 30-40 scabrid persistent congested bristles mostly in 1 series, bases broadened and flattened, longer bristles distinctly broadened distally, apical cells acute to obtuse. Pollen grains ca. $25 \mu \mathrm{m}$ in diameter. Plate 140.

The genus Grosvenoria has a restricted distribution in the northern Andes from central Ecuador southward into northern Peru. The elevations listed at which the plants occur are between 2,700 and 3,700 m. Most specimens are recorded as tree-like, in one case up to $10 \mathrm{~m}$ high. As such the genus has an impressive appearance.

Grosvenoria is one of three genera of the Critoniinae from the area of the northern Andes showing broadly linear or strap-shaped style appendages. The appendages of the genus may be the most extreme in the group, with the appendages appearing to droop from their length in a photograph of one species. The appendages are over 0.25 $\mathrm{mm}$ wide throughout their length.

Of the other two genera with broad style appendages, Aristeguietia differs by its setuliferous but non-glanduliferous achenes, its persistent inner involucral bracts, less numerously striated bracts, and its pappus bristles not notably broadened at the bases or tips. The relationship of Grosvenoria is evidently closer to the genus Badilloa which has similarly glanduliferous achenes. Badilloa differs, however, in its narrower unflattened pappus bristles, its 2-4-costate rather than multicostate involucral bracts, and its smaller carpopodium with smaller cells. The pappus and carpopodium seem to be the most important distinctions.

The few species of Grosvenoria show considerable diversity. The Peruvian species differs from the others by the distinctly fistulose stems after which it is named, and by the more elliptical trinervate more serrate leaves with glabrous undersurfaces. Two of the Ecuadorian species have solid stems, and essentially entire pinnate leaves with distinctive matted thin-walled hairs below. The remaining species, G. campii, has stems mostly solid with some hollow areas near the nodes, and has serrulate leaves with pinnate venation and sparse hairs below. The latter species does not have the clearly multistriate involucral bracts seen in the other species. Two of the species have pink to purplish flowers, but the corollas in $G$. rimbachii are characteristically white. It should be noted that in spite of the different designations of trinervate and pinnate venation in the genus, the lower veins involved are all from above the base and run parallel to the margin. The trinervate veins of $G$. coelocaulis differ by the sharpness of their ascent, especially in contrast to the weaker secondaries in the remainder of the leaf.

The generic name honors the Grosvenor family, a family well known for its generations of leadership in the National Geographic Society in Washington, D.C.

The following four species are recognized in the genus:

Grosvenoria campii R. King \& H. Robinson, Ecuador.

Grosvenoria coelocaulis (B. Robinson) R. King \& H. Robinson, Peru.

Grosvenoria hypargyra (B. Robinson) R. King \& H. Robinson, Ecuador.

Grosvenoria rimbachii (B. Robinson) R. King \& H. Robinson, Ecuador. 

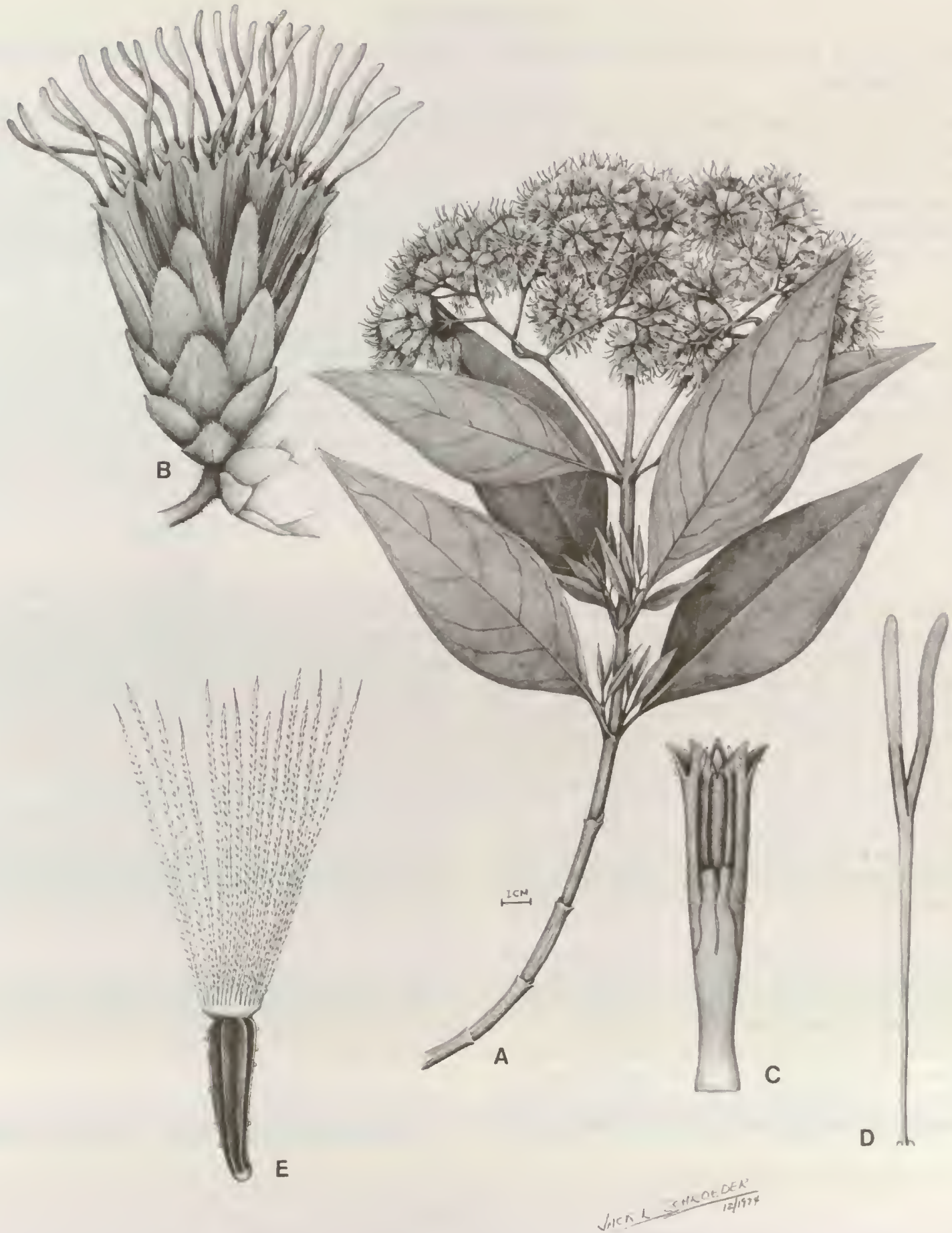

PLATE 140 Grosvenoria rimbachii (B. Robinson) R. King \& H. Robinson. - A. Habit, ×1/2. - B. Head, ×6. - C. Corolla showing anthers, $\times 10 .-D$. Style with nectary, $\times 10 .-E$. Achene, $\times 10$ 


\section{Corethamnium}

Corethamnium R. King \& H. Robinson, Phytologia 39: 55. 1978. TYPE: Corethamnium chocoensis R. King \& H. Robinson.

Erect shrubs, with many branches, with stems, surfaces of young leaves, and pedicels pilose with incrassate moniliform hairs. Stems terete, striated. Leaves opposite, petioles short and stout; blades ovate to suborbicular, base obtuse, apex short-obtuse to rounded, margins crenate-serrulate, venation pinnate, with numerous glandular punctations below initially partially hidden by hairs, deciduous hairs partly biseriate, with thickened cell walls. Inflorescence of dense small corymbose panicles on leafy branches; heads sessile or short-pedicellate. Involucral bracts ca. 16-18, subimbricate in ca. 4-5 strongly unequal graduated series, broadly ovate to oblong, mostly persistent; receptacle flat, glabrous. Florets ca. 6 in a head; corollas white, with narrowly cylindrical tube and throat without external differentiation, with only lobes spreading, outer surface very sparsely glanduliferous, inner surface glabrous; cells of limb short-oblong, without sinuous walls; lobes narrowly oblong, 3 times as long as wide, smooth on both surfaces; anther collar cylindrical, composed almost entirely of subquadrate cells, without ornate thickenings on walls; anther appendage large, triangularovate, about as long as wide or longer; style base incrassate without a node, glabrous; style branches narrowly linear to filiform, becoming terete distally, distinctly papillose on all sides. Achenes prismatic, 5-ribbed, glabrous or with very few small glands; carpopodium in form of short cylindrical ring without a distinct upper rim, with short-oblong cells in 3-5 tiers, cell walls thickened; pappus of ca. 45 scabrid coarse congested persistent bristles in 1-2 series, less scabrid and narrowed distally, apical cells subacute. Pollen grains ca. $25 \mu \mathrm{m}$ in diameter. Plate 141 .

The genus Corethamnium is known from a single specimen collected by Earl L. Core in a distinctive area of Colombia on the Pacific slope of the Andes, in the interior of the Choco region adjacent to the Department of Antioquia. The genus has a deceptively close resemblance to species of Ageratina subgenus Andinia which are common in the northern Andes. Nevertheless, Corethamnium is not even a member of the subtribe Oxylobinae to which Ageratina belongs. The genus is actually one of the more distinctive members of the subtribe Critoniinae.

The subtribal position of Corethamnium is fixed primarily by the strongly subimbricate bracts of the involucre. The essentially smooth corolla lobes and the glabrous unenlarged style base further indicate a position in the Critoniinae. The only character in conflict is the distinctly papillose stylar appendage, but such appendages are present in a few other Critoniinae. A feature that precludes relationship to the Oxylobinae is the poorly delimited carpopodium with small thick-walled cells.

Corethamnium has two particularly distinctive features, the form of the corolla, and the pubescence of the stem and leaves. The long lobes of the corolla seem to arise directly from the tube, and the throat can be distinguished from the tube only by observing the point of insertion of the filaments. The combined narrow throat and tube is remarkably thick and firm. The hairs of the stems and leaves are unique in their vermiform nature with various parts 1-3-seriate. Other hairs in the Eupatorieae having such short cells do not have such thick walls. The hairs of Corethamnium have thin-walled cells at the base which seem to be responsible for the ease of dehiscence. Older leaves of the genus become nearly glabrous.

The genus seems rather isolated in the Critoniinae, with possible closest relationships to the similarly monotypic or oligotypic genera Castenedia and Imeria of Colombia and Venezuela respectively. All three genera share distinctly pinnate leaf venation, but neither of the others has the distinctive hair or corolla types seen in Corethamnium.

The generic name honors the collector, Earl L. Core (1902-1984), a participant in the Cinchona Expedition in 1944. Dr. Core is best known for his work on the flora of West Virginia.

The following single species is recognized in the genus: Corethamnium chocoensis $\mathrm{R}$. King \& H. Robinson, Colombia.

\section{Castanedia}

Castanedia R. King \& H. Robinson, Phytologia 39: 58. 1978, "Castenedia." TYPE: Castanedia santamartensis R. King \& H. Robinson.

Erect shrubs, with many spreading branches. Stems subterete or angled, striated, glabrous, most internodes elongate but with frequent extremely short internodes. Leaves opposite, petioles of moderate length, rather sharply delimited; blades elliptical or elliptical-oblong to slightly obovate, base shortly and abruptly acute, 


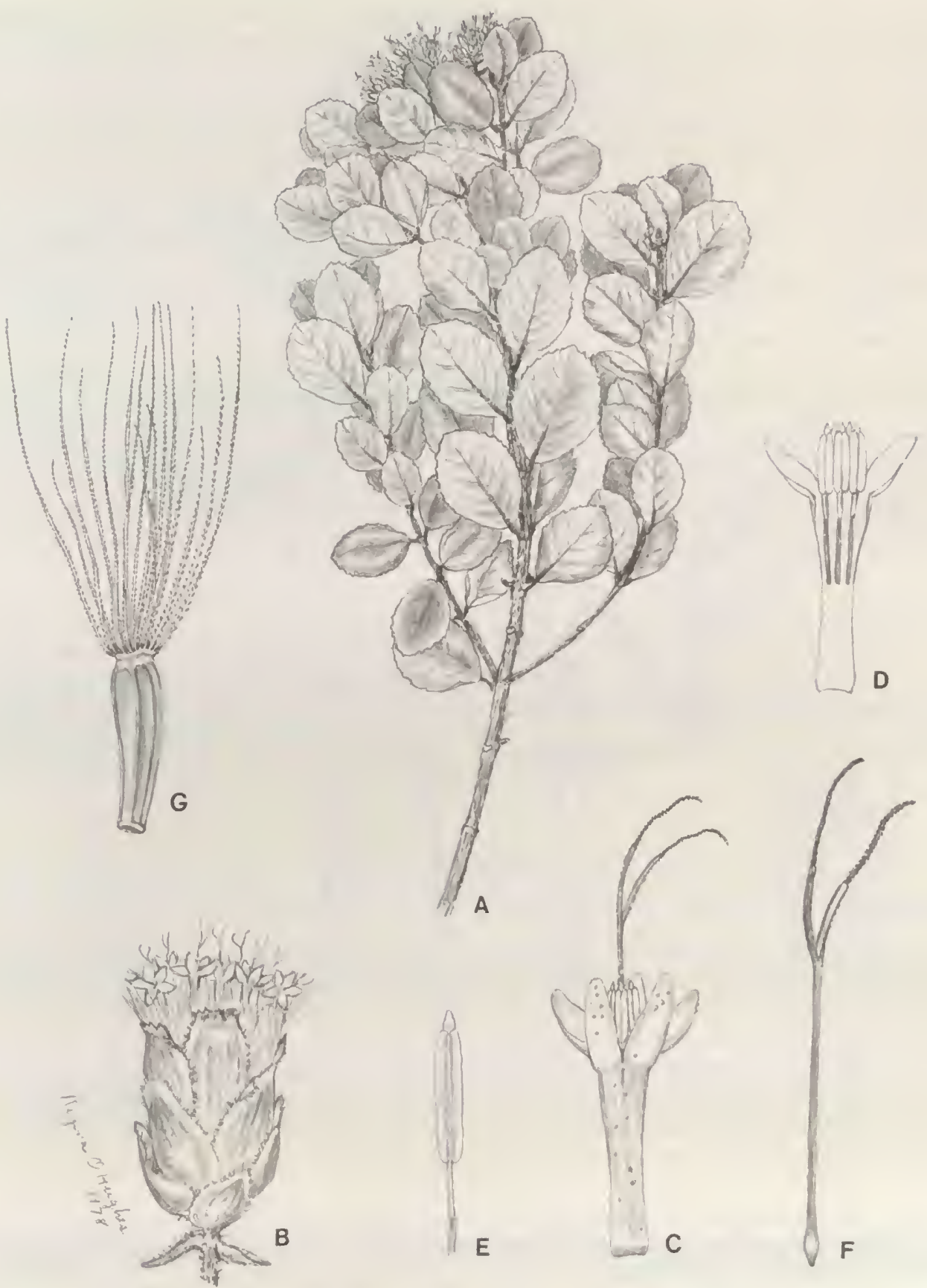

Plate 141. Corethamnium chocoensis $R$. King \& H. Robinson. - A. Habit, $\times 1 / 2 .-$ B. Head, $\times 5 .-$ C. Corolla outer surface, $\times 10 .-$ D. Corolla inner surface with anthers, $\times 10 .-$ E. Anther, $\times 15 .-F$. Style, $\times 12 .-G$. Achene, $\times 10$

margins remotely serrulate, apex short-acute to obtuse, venation pinnate, obscurely glandular-punctate below. Inflorescence a dense corymbose panicle; heads sessile to subsessile in smaller clusters of 2-3. Involucre cylindrical; involucral bracts ca. 25 , subimbricate, in ca. 4 strongly unequal graduated series, broadly ovate to linear-oblong, inner bracts easily deciduous; receptacle flat, glabrous. Florets $6-7$ in a head; corollas white, narrowly funnelform, sparsely glanduliferous on narrow tube and on throat, more glands on lobes; cells of 


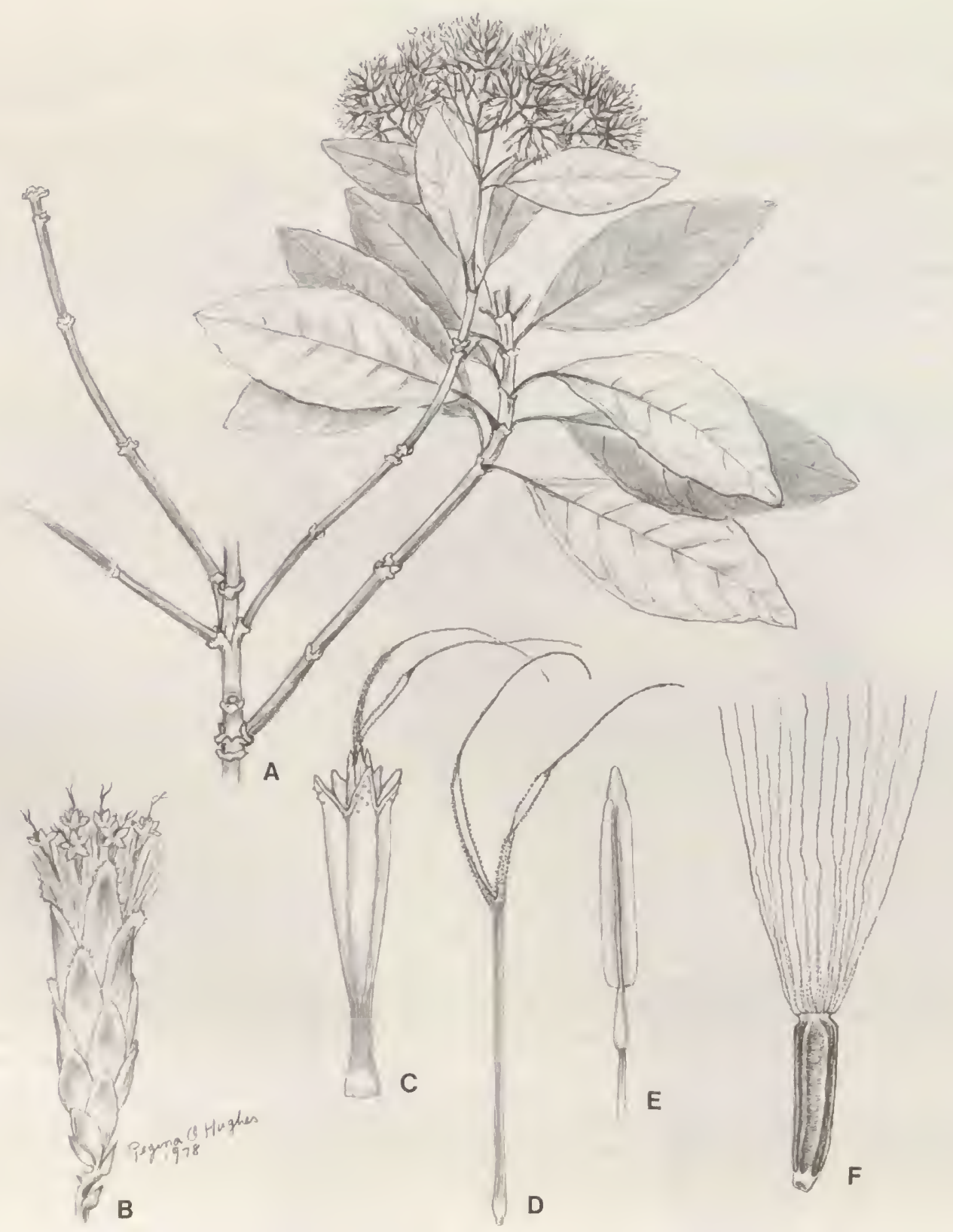

Plate 142. Castenedia santamartensis R. King \& H. Robinson. - A. Habit, $\times 1 / 2,-$ B. Head, $\times 5 .-$ C. Corolla with anthers and style, $\times 9 .-D$. Style, $\times 9 .-$ E. Anther, $\times 18 .-$ F. Achene, $\times 9$.

limb oblong, with walls not or scarcely sinuous; lobes triangular, slightly longer than wide, smooth on both surfaces; anther collar cylindrical, composed of subquadrate cells, cell walls distinctly and evenly thickened without ornate lines; anther appendage large, triangular-ovate, ca. twice as long as wide; style base not enlarged, glabrous; style branches with broader stigmatic part, in appendage becoming filiform and terete with short papillae on all sides. Achenes prismatic, 5-ribbed, glabrous; carpopodium shortly stopper-shaped, with slight projecting upper rim, with rather small usually oblong cells in 10-12 tiers, cell walls thickened; pappus of ca. 60 congested scabrid persistent bristles in ca. 2 series, narrowed distally, apical cells sharply acute. Pollen grains ca. 25-27 $\mu \mathrm{m}$ in diameter. Plate 142. 
The monotypic genus Castanedia has the unmistakable subimbricate involucre with deciduous inner bracts, simple style base, and smooth corolla lobes of the subtribe Critoniinae, and has a general resemblance to various other genera of the subtribe in the northern Andes. Castanedia, however, seems both structurally and geographically isolated from the other potential relatives in the Andes, and may represent part of an older relict group that presently has only limited representatives in northern South America.

Castanedia resembles the Andean genera Badilloa and Grosvenoria in habit and the form of the involucre. The large size of the shrubs or perhaps small trees, up to eight meters tall, is particularly reminiscent of Grosvenoria. The other two genera are nevertheless basically different in their unusually broad strap-shaped style appendages and their densely glanduliferous achenes. The style branches of Castanedia are also unusual in the tribe, but they are unusual in the way they taper from the broad stigmatic portion to a terete filiform tip. The terete filiform style appendages that occur in such genera as Hebeclinium and Critoniella are of a finer texture, and do not seem closely related. It also seems significant that none of the genera mentioned in comparison have slenderly cylindrical basal tubes on the corolla or distinctly bi-tri-seriate pappus bristles of the type seen in Castanedia.

The actual relationship of Castanedia in the Critoniinae is not certain, but the narrow papillose style appendages and strictly pinnate venation of the leaves recall another monotypic genus in Colombia, Corethamnium. The latter is thoroughly distinct in its unique vermiform hairs and peculiar corollas, as well as in details of the carpopodium and leaves, and would not itself be a very close relative. There is a possibility that the oligotypic pinnately veined Imeria of the Guayana Highlands is also related, but the differences in habit, pubescence, corolla form, and style branches only further the impression of isolation in Castanedia.

The specimens of Castanedia show a peculiarity in the lengths of the internodes of the stem. Sporadically, a pair of nodes is very close, sometimes resulting in very congested branching. The feature seems rather obvious in spite of considerable variation in the length of other internodes.

The distinct nature of Castanedia is partly explained by its endemism to the isolated Sierra de Santa Marta in northern Colombia. The area has a geological history distinct from that of the adjacent Andes, and is noted for many endemics. The area was actually elevated somewhat before the surrounding Andes.

The generic name honors the Colombian botanist and collector of the type of the single species, R. Romero Castañeda.

The following single species is recognized in the genus: Castanedia santamartensis R. King \& H. Robinson, Colombia.

\section{Imeria}

\section{Imeria R. King \& H. Robinson, Phytologia 32: 271. 1975. TYPE: Eupatorium memorabile Maguire \& Wurd.}

Erect slender shrub, with moderate branching. Stems rather thick, terete, densely villous, hairs with enlarged bases. Leaves opposite, petioles rather short, distinct, stout; blades thickly coriaceous to subcoriaceous, ovate to elliptical, obtuse to acuminate at base, margins entire or serrate, a pices shortly acute to acuminate, venation pinnate with spreading secondaries, strongly scabrid on upper surface, densely punctate below with large immersed glands, densely villous below on veins, sparsely pilosulous between. Inflorescences terminal on branches, corymbose, heads sessile in dense clusters on branchlets. Involucral bracts ca. 20-25, strongly subimbricate in 4-5 unequal graduated series, oblong-ovate to oblong-lanceolate, outer bracts persistent with densely puberulous tips, inner bracts deciduous; receptacle slightly convex, sparsely hirsute. Florets 8-10 in a head; corollas rose-colored or pink, narrowly funnelform, glabrous on inner and outer surfaces; cells of throat oblong with sinuous lateral walls; lobes triangular, slightly longer than wide, smooth on inner surface, densely mamillose to papillose outside on the tips, forming sclerified cap; anther collar shortly cylindrical, cells oblong, with thin to slightly thickened walls and with weak but distinct annular thickenings; anther appendage large, triangular, more than twice as long as wide; style base not enlarged, glabrous; style branches linear, slightly mamillose. Achenes prismatic, 7-9-ribbed, glabrous, with internal carbonization of wall often weakly developed; carpopodium without distinct upper limit, very shortly cylindrical, with subquadrate cells in 5-6 rows, cell walls strongly thickened; pappus of ca. 50 congested scabrid subpersistent bristles in 1-2 series, longer bristles broadened at tips, apical cells subacute to obtuse. Pollen grains ca. 27-30 $\mu \mathrm{m}$ in diameter. Plate 143.

The genus Imeria is one of the few members of the tribe Eupatorieae on the tepuis in the Guayana Highland region of northern South America. The other members of the tribe in the Guayana region, a few species of Koanophyllon 


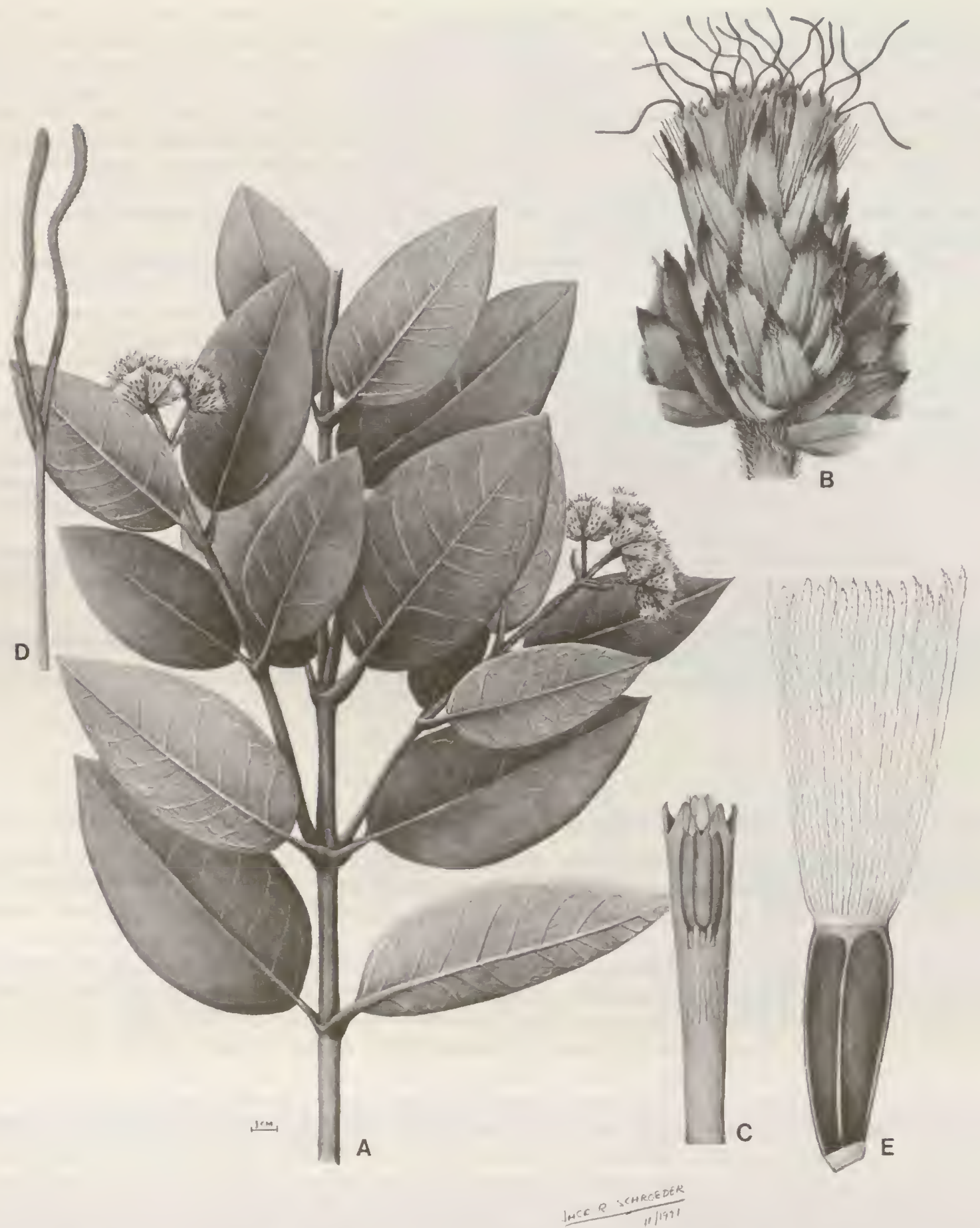

Plate 143. Imeria memorabilis (Maguire \& Wurd.) R. King \& H. Robinson. - A. Habit, $\times 4 / 9 .-$ B. Head, $\times 6 .-$ C. Corolla showing anthers, $\times 13 .-D$. Style, $\times 13 .-E$. Achene, $\times 13$. 
of the subtribe Critoniinae, some species of Chromolaena of the Praxelinae, and the genus Guayania of the Hebecliniinae differ in having rather obvious relationships to elements outside of the area, while Imeria seems rather remote from all other genera in the Critoniinae.

Imeria is unlike most members of the tribe, but similar to many other plants of the tepuis in the rigidly branched habit and coriaceous leaves. The hairs of the stems and leaves have prominent enlarged bases, with the crowded and somewhat persistent bases forming a rather papillose cover on the young stems. Cross sections of the leaves show large thick-walled epidermal cells, and vascular strands sheathed in sclerids. The glands are apparently a part of a small fascicle at the base of a pit with one to three small uniseriate hairs scarcely evident in the pit beside the large biseriate glands. The involucres are narrow and strongly subimbricate as in the Critoniinae and Praxelinae, but differ from the latter by having the outer bracts persistent. The receptacle is prominently hirsute as in many Hebecliniinae, but the anther collars and carpopodium are totally unlike members of that subtribe. The sclerified cap on the tips of the corolla lobes is slightly reminiscent of Chromolaena, but is interpreted here as of independent origin, being only part of a general trend in Imeria toward sclerification of parts. The achene walls are somewhat distinctive in the weak development of car- bonization, but not as distinctive as thought at the time when the genus was described (King \& Robinson, 1975s). The number of ribs on the achene distinguishes the genus from many others in the tribe. The combination of characters prevents any suggestion regarding inmmediate relatives, but the comparatively superficial character of spreading pinnate venation in the leaves encourages placement of Imeria in the system close to the equally isolated monotypic genera Corethamnium and Castanedia of Colombia.

The genus Imeria occurs in the southernmost part of Venezuela on the mountain known as Neblina. The name of the genus was chosen to honor the original name given to Neblina by Richard Spruce. The name Imeri has been used by some for the mountains to the south of NeblinaImeri, but there can be no doubt as to which mountain Spruce originally applied the name. Recently the type species has also been reponed from the adjacent Cerro Avispa, and a second species with serrate leaves has been described from the nearby Macizo Aracamuni (Badillo. 1985).

The following two species are recognized in the genus:

Imeria memorabilis (Maguire \& Wurd.) R. King \& H. Robinson. Venezuela.

Imeria serratifolia V. Badillo. Venezuela.

\section{Malmeanthus}

\section{Malmeanthus R. King \& H. Robinson, Phytologia 47: 225. 1980. TYPE: Eupatorium subintegerrimum Malme.}

Erect shrubs, moderately branched. Stems subterete, distinctly striated, densely puberulous or pilosulous. Leaves opposite, petioles rather short to medium length; blades ovate, base short-acute to short-acuminate, margins serrulate to subentire, apex scarcely acuminate, venation ascending pinnate, glandular-punctate on both surfaces, puberulous to tomentellous below. Inflorescences terminal on branches, corymbose paniculate, with ascending mostly alternate branching; heads with short narrow pedicels. Involucres campanulate; involucral bracts ca. 20 , strongly subimbricate in ca. 4 strongly unequal graduated series, stramineous, mostly oblong with rounded tips, glabrous and 2-4-costate on outer surface, inner bracts easily deciduous; receptacle slightly convex, glabrous. Florets 5-22 in a head; corollas whitish, narrowly funnelform, with broad basal tube, glabrous inside and on outer surface below lobes; cells of limb elongate with lateral walls straight or in inner layer sinuous; lobes triangular, about as long as wide to twice as long as wide, smooth on both surfaces, with or without sparse glands on outer surface; anther collar cylindrical, with mostly oblong cells, few to many subquadrate cells near base, cell walls with slight but distinct reticulate thickenings; anther appendage large, oblong, slightly longer than wide; base of style not enlarged, glabrous; style appendages narrowly linear, slightly to distinctly mamillose. Achenes prismatic, narrowed at base, 5-costate, with hairs, setulae, or glands on sides; carpopodium nearly to completely obsolete, with few differentiated cells; pappus of ca. 30-35 scabrid slender persistent bristles in mostly 1 series, not or scarcely broader and not more scabrid distally, apical cells acute. Pollen grains ca. $25 \mu \mathrm{m}$ in diameter. Plate 144.

The genus Malmeanthus is one of five genera of the Critoniinae in southeastern Brazil having strongly subimbricate involucres with the inner bracts deciduous. Within the small group, Malmeanthus is the smallest ge- nus and the least frequently collected, being known from little other than the type collections of its three known species. The genus also suffers from the rather ordinary nature of the combined characters by which it is distin- 

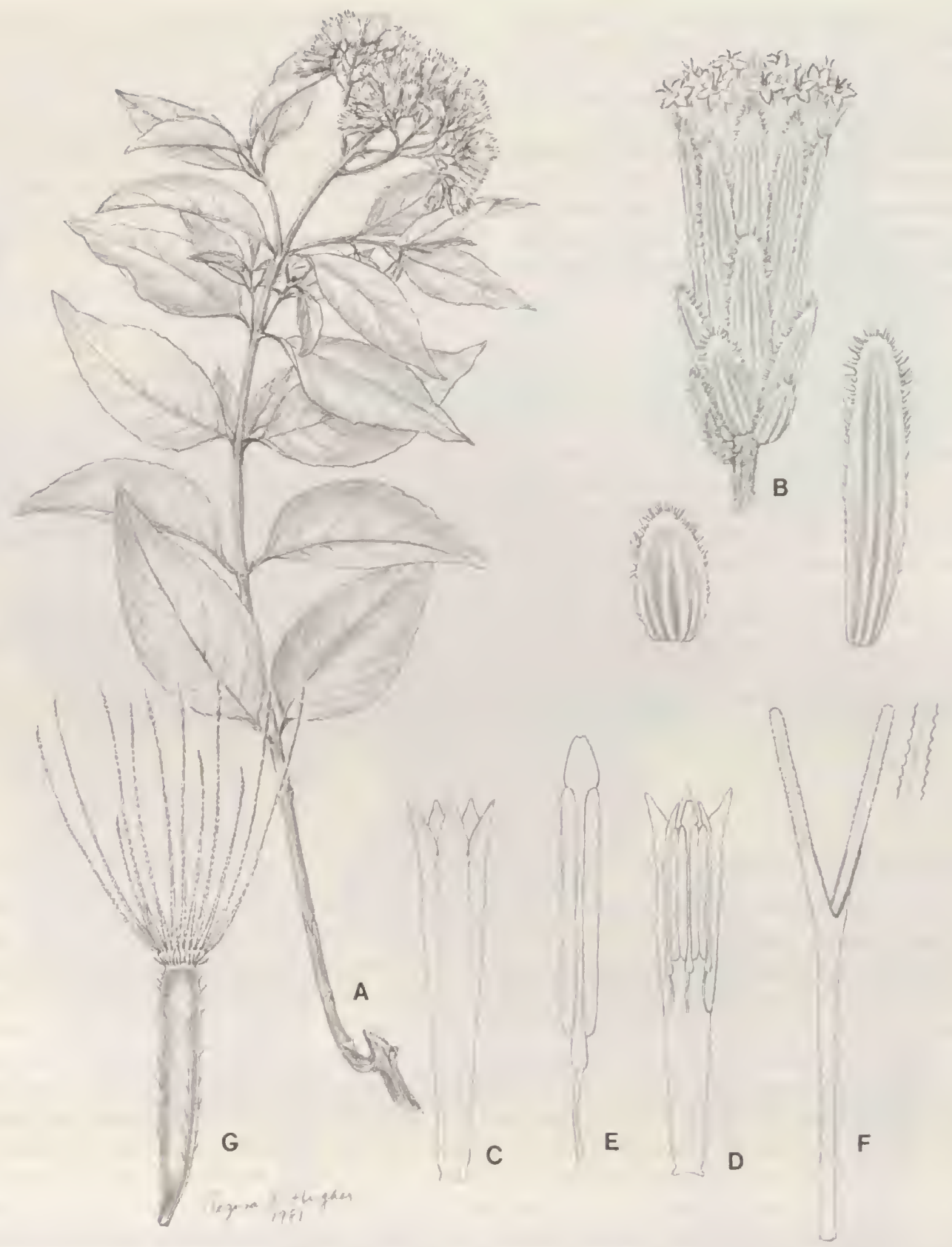

PLATE 144. Malmeanthus subintegerrimus (Malme) R. King \& H. Robinson, - A. Habit, $\times 1 / 2,-B$. Head with separate representative involucral bracts, $\times 6 .-$ C. Corolla outer surface, $\times 10 .-$ D. Corolla inner surface with anthers, $\times 10 .-E$. Anther, $\times 18 .-F$. Style, $\times 10 .-$ G. Achene, $\times 10$.

guished in the subtribe. Still, Malmeanthus is thoroughly distinct within the Brazilian group by the lack of the specialized characters seen in the other genera.

Malmeanthus differs from the most widely distributed genus in the group, Critonia, by the presence of glandular punctations on the leaves and by the lack of internal se- cretory cavities in the areoles of the leaves. The achenes and bristles of the pappus are also slenderer in Malmeanthus.

Of the remaining genera which are restricted or nearly restricted to the area of southeastern Brazil. Neocabreria and Steyermarkina are immediately distinct in the pu- 
bescent inner surfaces of their corollas. The two genera are further distinct in a number of details such as short anther appendages or pyramidally paniculate inflorescences that are indicated under those genera. The two genera, in spite of their geographical proximity, are not considered closely related to Malmeanthus.

Among the Brazilian genera, the only one potentially close to Malmeanthus in relationship is Austrocritonia. The latter has a similar habit, including the general form of the inftorescence, but it differs in significant details. Austrocritonia has the heads sessile in clusters, has the pappus bristles tapering to essentially smooth tips, and has a broad achene base with a distinct carpopodium, all features lacking in Malmeanthus.

In spite of the seeming negative nature of the distinctions of Malmeanthus, the genus shows considerable integrity of characters and is regarded as a natural group. It has been impossible to extend the generic characterization to include the homeless Brazilian species Eupatorium clibadioides Baker. The latter has most of the technical characters of Malmeanthus, but differs by being essentially glabrous with nearly sessile strongly acuminate leaves trinervate from above the base, by having only minute sparse glandular punctations restricted to the lower leaf surface, by having long-pedicellate heads, and by having usually a few extra ribs on the achenes.

Malmeanthus seems to be a rather temperate genus compared to Austrocritonia, being known mostly from Santa Catarina in Brazil southward into Uruguay and westward into Misiones in Argentina. Only M. hilarii occurs to the north in Minas Gerais. A key to the species of Malmeanthus has been provided by King and Robinson (1980n).

The generic name honors Gustaf Malme, the Swedish botanist, noted for his studies on Brazilian Asteraceae.

The following three species are recognized in the genus:

Malmeanthus calharinensis R. King \& $\mathrm{H}$. Robinson, Brazil.

Malmeanthus hilarii (B. Robinson) R. King \& H. Robinson, Brazil.

Malmeanthus subintegerrimus (Malme) R. King \& H. Robinson, Argentina, Brazil, Uruguay.

\section{Hughesia}

\section{Hughesia R. King \& H. Robinson, Phytologia 47: 252. 1980. TYPE: Hughesia reginae R. King \& H. Robinson.}

Woody vines. Stems terete, solid, glabrous, partly reddish brown. Leaves opposite, petioles moderately long, sharply delimited; blades ovate, base broadly rounded, margins subentire, remotely and minutely serrulate, apex shortly acute, minutely acuminate, trinervate with strongly ascending veins from near base, upper and lower surfaces essentially glabrous, without glandular punctations, with prominulous veinlets. Inflorescences terminal on lateral branches, distinctly thyrsoid-paniculate with spreading branches; heads sessile or subsessile in small clusters at ends of branchlets, broadly campanulate. Involucral bracts ca. 18, strongly subimbricate, in ca. 4 strongly unequal graduated series, broadly ovate to oblong or linear-oblong, tips rounded, outer surface glabrous, 2-4-costate, inner bracts easily deciduous; receptacle convex or hemispherical, glabrous. Florets ca. 9 in a head; corollas dried appearing as purple in distal half, narrowly funnelform with broadly cylindrical basal tubes, glabrous on inner and outer surfaces; cells of limb oblong with lateral walls not or scarcely sinuous, cells often filled with oil; lobes triangular, about as long as wide, smooth on both surfaces; anther collars cylindrical, with numerous subquadrate or shorter cells below, cell walls with weak but distinct annular thickenings; anther appendages large, oblong, 1.5 times as long as wide; style base not enlarged, glabrous; style branches linear, densely mamillose or short-papillose. Achenes prismatic, 5-ribbed, with short setulae above, glabrous below; carpopodium distinct, sharply delimited, with slight rim above, short-cylindrical, slightly procurrent on ribs, composed of small subquadrate cells in ca. 7 tiers, cell walls with densely beaded thickenings; pappus of ca. 30 slender scabrid persistent bristles in 1 series, not or scarcely broadened at tips, apical cells acute. Pollen grains ca. 18-20 $\mu \mathrm{m}$ in diameter. Plate 145.

The genus Hughesia has the strongly subimbricate involucre with deciduous inner bracts, the simple style bases, and the smooth corolla lobes that are characteristic of the subtribe Critoniinae, and membership in the subtribe is not in doubt. Nevertheless, Hughesia has some features reminiscent of members of other subtribes. The scandent habit caused the material of the genus to be labelled and distributed at one time as Mikania aff. lawrancei, in a genus that is mostly scandent and often has thyrsoid inflorescences. Still, the strongly subimbricate involucres and the circa nine flowers in the heads preclude a relationship between Hughesia and the Mikaniinae. The small rounded receptacles of Hughesia resemble those of $\mathrm{He}$ beclinium in the Hebecliniinae, but the inflorescence lacks the arcuate-cymose branching, the filiform style branches, the elongate anther collars, and the thin-walled carpo- 

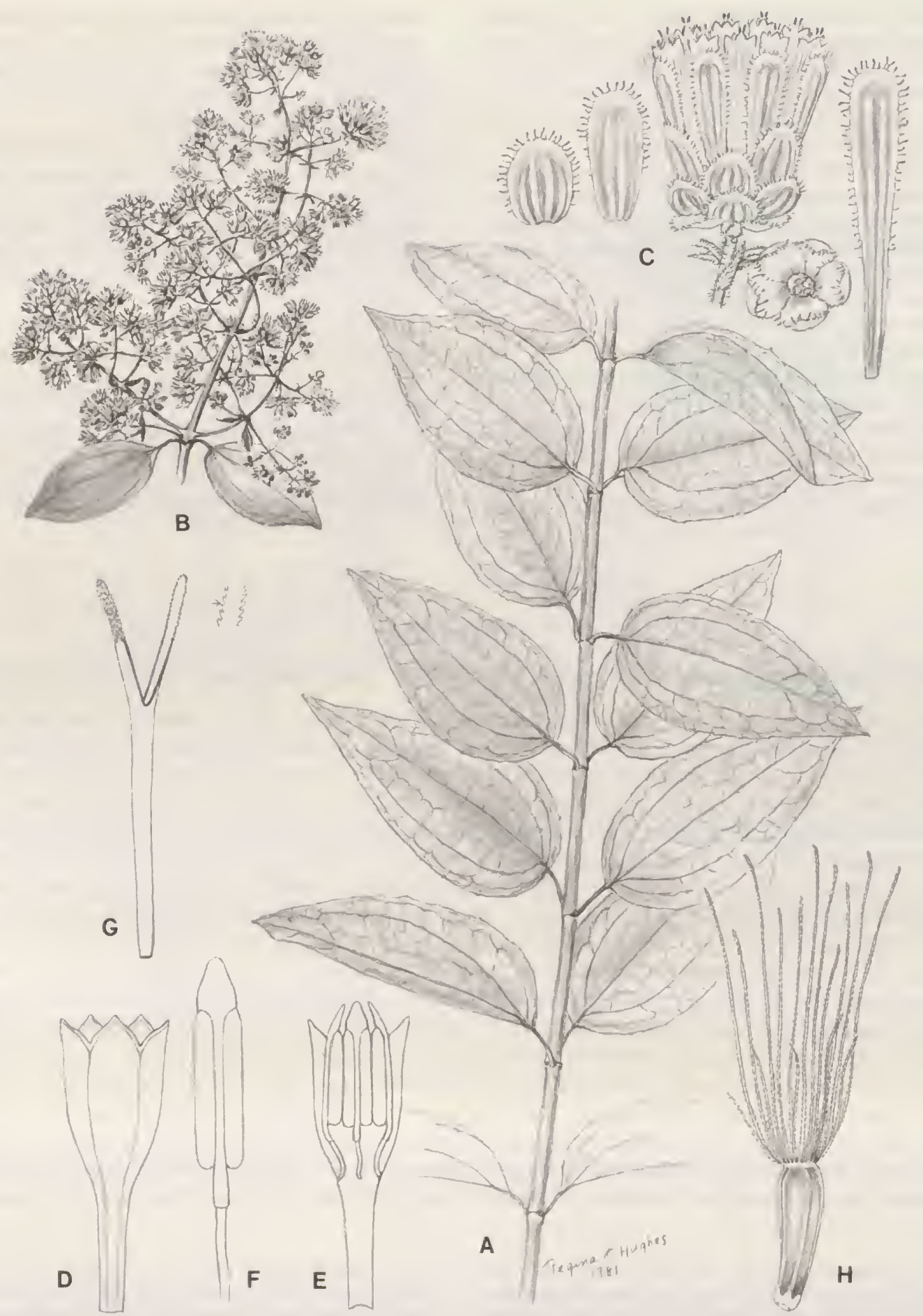

PLATE 145. Hughesia reginae R. King \& H. Robinson. - A. Habit, vegetative stem, $\times 1 / 2 .-$ B. Flowering branch, $\times 1 / 2 .-C$. Head, $\times 6$, with separate view of receptacle and representative involucral bracts. $-D$. Corolla outer surface, $\times 15$. - E. Corolla inner surface with anthers, $\times 15 .-F$. Anther, $\times 20 .-$ G. Style, $\times 15 .-$ H. Achene, $\times 15$. 
podial cells procurrent on the achene ribs as in the latter genus.

Within the Critoniinae, Hughesia is one of the most scandent genera and is also rather distinctive in the strictly thyrsoid inflorescence, the slender pappus bristles, and the glabrous corollas. The equally scandent Uleophytum from Peru differs by having its inflorescences sessile in the axils of normal leaves. Hughesia resembles the more scandent members of Critonia but differs in the strictly thyrsoid inflorescence branching, the convex receptacles, and the lack of internal secretory pockets in the areoles of the leaves. The combination of all characters suggests that Hughesia is actually closest to the somewhat more shrubby genus Steyermarkina which occurs mostly in southeastern Brazil. Hughesia is thoroughly distinct from the latter, however, by the more trinervate leaves, the more numerous flowers in the heads, the glabrous corollas with short lobes, the sparsely setuliferous achenes, and the contiguous rather than congested bristles of the pappus with scarcely broadened tips.

The leaves of Hughesia seem to have unusually prominent ducts along the larger veins. In both cross sections and cleared material, the ducts are seen to rest in a concavity along the upper surfaces of the veins.

The genus is named in honor of the well-known botanical illustrator, Dr. Regina Hughes, whose work appears in the present treatment as well as many other publications.

The following single species is recognized in the genus: Hughesia reginae R. King \& H. Robinson, Peru.

\section{Ophryosporus}

Ophryosporus Meyen, Reise Erde I: 402. 1834. TYPE: Ophryosporus triangularis Meyen.

Piqueria section Artemisioides DC., Prodr. 5: 105. 1836. TYPE: Piqueria artemisioides H.B.K.

Trychinolepis B. Robinson, Contr. Gray Herb. n.s. 80: 6. 1928. TYPE: Trychinolepis hoppii B. Robinson.

Erect herbs or subshrubs with woody stems or bases, 2 species scandent, sparsely to densely branched, often with prominent axillary fascicles. Stems terete, striated, puberulous. Leaves usually opposite, rarely alternate, spirally inserted in $O$. triangularis, petioles short to moderately long; blades minute to large, broadly lanceolate to elliptical, base cuneate to truncate, margins coarsely to scarcely serrate, apex acute to short-acuminate, venation strongly to scarcely trinervate, with or without glandular punctations, minutely stipitate-glandular in $O$. triangularis. Inflorescence corymbose or broadly to narrowly thrysoid, with corymbose branches; heads shortly pedicellate or sessile, lateral heads sometimes from axils of lower involucral bracts of central heads. Involucral bracts 4-8, eximbricate, in 1-2 mostly subequal series, ovate-lanceolate to oblong, persistent; receptacle slightly convex, glabrous. Florets $3-12$ in a head; corollas white, with constricted basal tube and narrowly funnelform or campanulate limb, usually glanduliferous outside, glabrous or rarely puberulous inside; cells of limb oblong with somewhat sinuous lateral walls; lobes triangular, $1-2$ times as long as wide, smooth on both surfaces; anther collar cylindrical, with short cells below, with distinct but weak annular thickenings on walls; anther appendages obsolete, divided into 2 minute lobes; style base not enlarged, glabrous; style branches with strongly knob-like smooth tips, mamillose below. Achenes prismatic, 5-ribbed, with minutely gland-tipped hairs, or setulae, or both on sides, base narrowed and sometimes striated, usually twisted with prominent wedge-shaped groups of cells; carpopodium distinct, slightly stoppershaped with projecting upper rim, composed of small subquadrate cells in 2-7 tiers, with slightly thickened walls; pappus of bristles, broad laciniate scales, vestigial squamellae, or lacking, bristles scabrid to subplumose, persistent, not broadened distally, apical cells acute. Pollen grains ca. 17-22 $\mu \mathrm{m}$ in diameter. Plate 146.

The genus Ophryosporus is one of many genera of the Critoniinae with shortened anther appendages but is thoroughly distinct in the extent of the reduction. The anthers superficially appear to be totally exappendiculate. The genus is also distinct in the subtribe by the totally eximbricate nature of the involucre and is somewhat distinct in the clearly knob-like tips of the style branches of all the species. The present genus, on this basis, would not be expected to present any problems of definition to taxonomists. Unfortunately, the opposite has proven to be true, as a result of a variable pappus and inaccurate observations.

To the extent that they have been properly observed, the species now placed in Ophryosporus have been placed in the traditional systems of classification in the subtribe Piqueriinae, because of the reduced anther appendage. Nevertheless, because of the variations in pappus, the species have been placed in three different genera. Traditional Ophryosporus included those members of the Eupatorieae having an obsolete anther appendage combined 

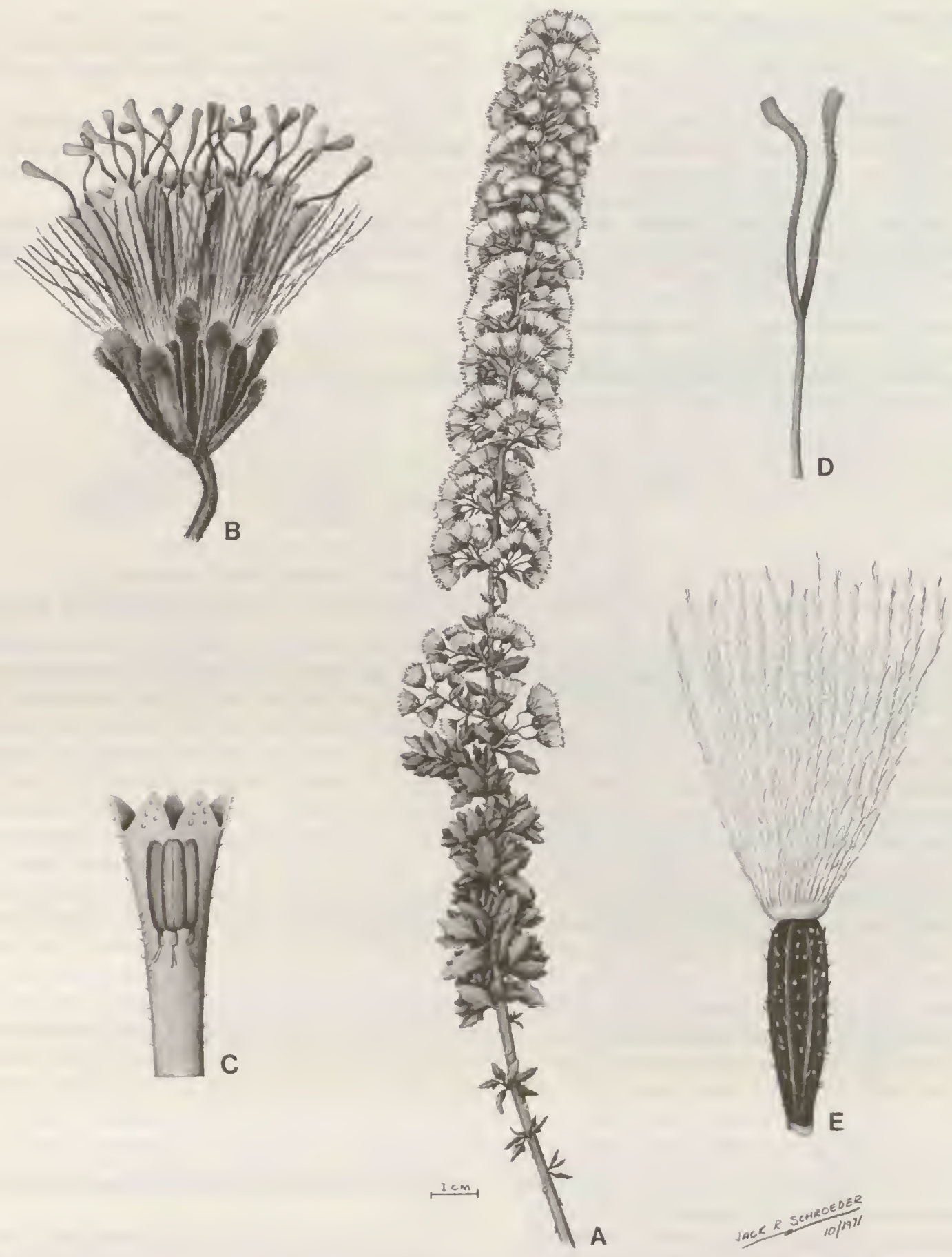

PLATE 146. Ophryosporus triangularis Meyen. - A. Habit, $\times 3 / 4 .-$ B. Head, $\times 7 .-$ C. Corolla showing anthers, $\times 10 .-D$. Style, $\times 10 .-$ E. Achene, $\times 10$.

with an ordinary capillary pappus. One species with a pappus of laciniate scales was the basis of a genus Trychinolepis, and the remaining species, lacking a pappus, were placed in Piqueria. In spite of the anther appendage, the eximbricate involucre, and the sometimes absent pappus, Ophryosporus is not closely related to the Ageratinae to which Piqueria belongs. It has the essentially smooth corolla lobes, weak annulations of the anther collar, and 
enlarged tips of the style branches that indicate a proper position in the Critoniinae. The species of Ophryosporus are definitely not closely related to the true Piqueria of Mexico, Central America, and the West Indies, which has longer corolla lobes densely papillose on the inner surface, densely papillose linear style branches without knob-like tips, papillose to puberulous lower parts of the anther filaments, strongly annulated cell walls of the anther collars, and sparse minute internal punctations in the achene walls.

Additional generic problems have been noted among species with a capillary pappus. Failure to note the lack of an anther appendage has resulted in some specimens and species being placed in the broad concept of Eupatorium, a placement unacceptable even before the redefinition of the latter genus. Since a number of species of Ophryosporus have four involucral bracts and four flowers in the heads, they have been placed in Mikania. Also, one species of Mikania, M. pachychaeta, was placed in Ophryosporus. Mikania is readily distinguished by the consistent presence of large anther appendages and by the total lack of knob-like tips on the style branches.

Three Mexican species of Decachaeta of the subtribe Hebecliniinae were placed at one time in Ophryosporus by B. Robinson (1925), because of their short anther appendages. The species can be distinguished from true Ophryosporus easily by their large alternate leaves, the larger number of flowers in their heads, the distinct tuft of hairs on their receptacles, by the anther appendages being reflexed and undivided instead of inflexed and divided, and by the cells of the anther collar lacking annular thickenings. Decachaeta, like true Piqueria, is outside of the geographical range of Ophryosporus.

The actual relationship of Ophryosporus in the Critoniinae seems closest to Koanophyllon, where many species have rather short anther appendages and enlarged tips on the style branches. Some species of Koanophyllon also show eximbricate involucres. The extreme reduction of the anther appendage in Ophryosporis distinguishes the genus. There is a habital resemblance and considerable geographical overlap with the Andean genus Cronquistianthus, and both show similar asymmetry in the achene base and carpopodium. The latter genus differs, however, in its well-developed anther appendage, its strongly subimbricate involucre, and the rounded tips of the involucral bracts.

Although Ophryosporus is a discrete and basically unified genus within the Critoniinae, there is significant internal variation. The variation in the pappus is most obvious, but seems to represent a general tendency for reduction in the genus rather than a natural subgroup within it. The species that were once placed in Piqueria section Artemisioides have variations in other characters that seem in part to parallel those among the species with a capillary pappus. For this reason, the section is not recognized in this treatment. The common habit is also seen in $O$. cumingii, which has a vestigial squamellose pappus and rather strongly mamillose cells on the corolla lobes. The other species with a squamellose pappus, $O$. (Trychinolepis) hoppii, has a different habit and smoother lobes, suggesting that the two are not close.

The type species, $O$. triangularis, along with two related Chilean species, presents a rather distinctive appearance with small short-petiolate leaves inserted in dense spirals and a more spike-like inflorescence. The type species also has hairs inside the corolla in some specimens. This more xeromorphic typical group might be worthy of subgeneric distinction.

Most species of Ophryosporis lack glandular punctations on the leaves, but punctations are present in a few such as $O$. pubescens.

The inflorescence in Ophryosporus varies in shape from spike-like to pyramidally thyrsoid or corymbose, and differs greatly in the density of branching. In all species, however, the heads are closely borne in the ultimate subunits. This reaches its extreme in some species where the lateral heads apparently arise from the axils of involucral bracts of the primary heads.

The genus Ophryosporus is restricted entirely to South America. The majority of the species fall within the Andean region from southern Ecuador south through Peru and Bolivia to Argentina. A small group of species in southeastern Brazil are generally similar to those of the Andes. Three Chilean species have a geographical isolation that somewhat reinforces their structural distinction. The closest approach to the latter, geographically, is the rather anomalous $O$. (Trychinolepis) hoppii of southern Peru. Only the problematical $O$. serratifolius has been cited from Colombia (B. Robinson, 1930c), but no material has been seen.

The limits of the genus have been discussed by King and Robinson (1972i, 1972uu), but the only keys to species are those of B. Robinson (1906) to Ophryosporus sensu stricto and to Piqueria section Artemisioides.

The name of the genus is derived from the Greek words ophrys (= brow or eyebrow) and spora (= seed). The name is said by B. Robinson to refer to the often ciliated costae of the achenes. The name Trychinolepis is from the Greek trychinos (= lacerated) and lepis (= scale), in reference to the squamellose pappus of the one species.

The following 37 species are recognized in the genus:

Ophryosporus angustifolius B. Robinson, Bolivia.

Ophryosporus anomalus R. King \& H. Robinson, Chile, Peru. Ophryosporus apricus B. Robinson, Peru.

Ophryosporus axilliflorus (Griseb.) Hieron., Argentina, Bolivia. Ophryosporus bipinnatifidus B. Robinson, Peru.

Ophryosporus burkartii Cabrera, Argentina.

Ophryosporus charua (Griseb.) Hieron., Argentina.

Ophryosporus chilca (H.B.K.) Hieron., Peru.

Ophryosporus cumingii Benth. ex Baker, Bolivia.

Ophryosporus densiflorus (Benth.) R. King \& H. Robinson, Ecuador.

Ophryosporus eleutherantherus (Rusby) B. Robinson, Peru, Bolivia. 
Ophryosporus floribundus (DC.) R. King \& H. Robinson, Peru. Ophryosporus freyreysii (Thunb.) Baker, Brazil.

Ophryosporus galioides (DC.) R. King \& H. Robinson, Peru.

Ophryosporus harlwegii (B. Robinson) R. King \& H. Robinson, Peru.

Ophryosporus heptanthus (Schultz-Bip. ex Wedd.) R. King \& H. Robinson, Ecuador, Peru, Bolivia.

Ophryosporus hoppii (B. Robinson) R. King \& H. Robinson, Peru.

Ophryosporus johnstonii B. Robinson, Chile.

Ophryosporus kuntzei Hieron., Bolivia.

Ophryosporus laxiflorus Baker, Brazil.

Ophryosporus lorentzii Hieron., Argentina.

Ophryosporus macbridei B. Robinson, Peru.

Ophryosporus macrodon Griseb., Argentina, Bolivia.

Ophryosporus mathewsii (B. Robinson) R. King \& H. Robinson, Peru.
Ophryosporus organensis Cabrera, Brazil.

Ophryosporus ovatus B. Robinson, Peru.

Ophryosporus paradoxus (Hook. \& Arn.) Benth. \& Hook. f. ex Hook. f. \& B. D. Jackson, Chile.

Ophryosporus peruvianus (J. Gmelin) R. King \& H. Robinson, Ecuador, Peru.

Ophryosporus pinifolius (F. Philippi) R. King \& H. Robinson, Chile.

Ophryosporus piquerioides (DC.) Benth. ex Baker, Argentina, Bolivia, Peru.

Ophryosporus pubescens (Smith) R. King \& H. Robinson, Peru. Ophryosporus regnellii Baker, Brazil.

Ophryosporus serratifolius (H.B.K.) B. Robinson, Colombia.

Ophryosporus sodiroi Hieron. in Sodiro, Ecuador.

Ophryosporus steinbachii $\mathrm{B}$. Robinson, Bolivia.

Ophryosporus triangularis Meyen, Chile.

Ophryosporus venosissimus (Rusby) B. Robinson, Bolivia.

\section{Cronquistianthus}

\section{Cronquistianthus R. King \& H. Robinson, Phytologia 23: 410. 1972. TYPE: Eupatorium niveum H.B.K.}

Erect or flexuous shrubs, few to moderately branched. Stems terete, striated, with evanescent tomentum or dense cover of stipitate glands. Leaves opposite, petioles short or medium length; blades ovate or lanceolate to linear, base cordate or truncate to narrowly cuneate, margins entire to serrate, apex mostly acute, not acuminate, venation usually trinervate from or near base, few species pinnate, with or without glandular punctations, sometimes with white tomentum below. Inflorescence terminal on branches, a dense corymbose panicle; heads usually sessile or subsessile in congested glomerules, with laxer branching and distinct short pedicels in $C$. chachapoyensis. Involucral bracts 12-25, strongly subimbricate, in 3-5 strongly unequal graduated series, broadly ovate to oblong, with rounded tips, inner bracts easily deciduous; receptacle flat, glabrous. Florets 8-18 in a head; corollas white, lavender, or bluish, narrowly funnelform with broadly cylindrical basal tube, outer surface glabrous or with few glands or scattered hairs, inner surface usually glabrous, rarely with small hairs (C. trianae) or small crests (C. kalenbornianus) near insertion of anther filaments; cells of limb elongate with sinuous lateral walls; lobes triangular, as long as wide or slightly longer, smooth on both surfaces; anther collar narrowly cylindrical, composed of subquadrate cells below, longer cells above, with slight but distinct transverse annular thickenings on walls; anther appendage large, ovate, slightly longer than wide; style base not enlarged, glabrous; style branches broadly linear or narrowly linear with slightly dilated tips, short-papillose. Achenes prismatic, usually 5-ribbed, with few to many setulae or scabrae mostly on ribs, without or rarely with glands; carpopodium distinct, asymmetrical, stopper-shaped, with sinuous vascular trace, composed of mostly subquadrate cells in few to many tiers, cell walls usually thickened; pappus of ca. 30-35 persistent contiguous bristles in 1 series, more scabrid below, narrowed and sometimes nearly smooth at tips, apical cells acute, bristles usually nearly as long as corolla, shorter in $C$. infantesii and C. lopez-mirandae. Pollen grains ca. 19-25 $\mu \mathrm{m}$ in diameter. Plate 147.

The Andean genus Cronquistianthus has the unmistakable involucre, corolla lobes, and style structure of the subtribe Critoniinae, and has some details that might indicate relationships to both the high elevation generic group of the subtribe in the Andes and the large Ophryosporus-Koanophyllon group within the subtribe. Cronquistianthus is thoroughly isolated from all other genera, however, and is easily distinguished by its strongly subimbricate involucres with round-tipped bracts and its asymmetrical carpopodia.

The actual relationships of Cronquistianthus within the
Critoniinae are not definite. The occurrence mostly between 2,000 and 4,000 m elevation in the Andes, and the sometimes broadly linear style appendages suggest a position near Aristeguietia or Badilloa which share these characters. The genus differs, however, in some basic features such as the rounded tips of the involucral bracts, the asymmetrical bases of the achenes, and the commonly smaller pollen grains. The style appendage is not even consistently broadly linear, sometimes being narrow with a minutely spathulate tip. The latter feature is more like Ophryosporus, a genus also common in the Andes in which 


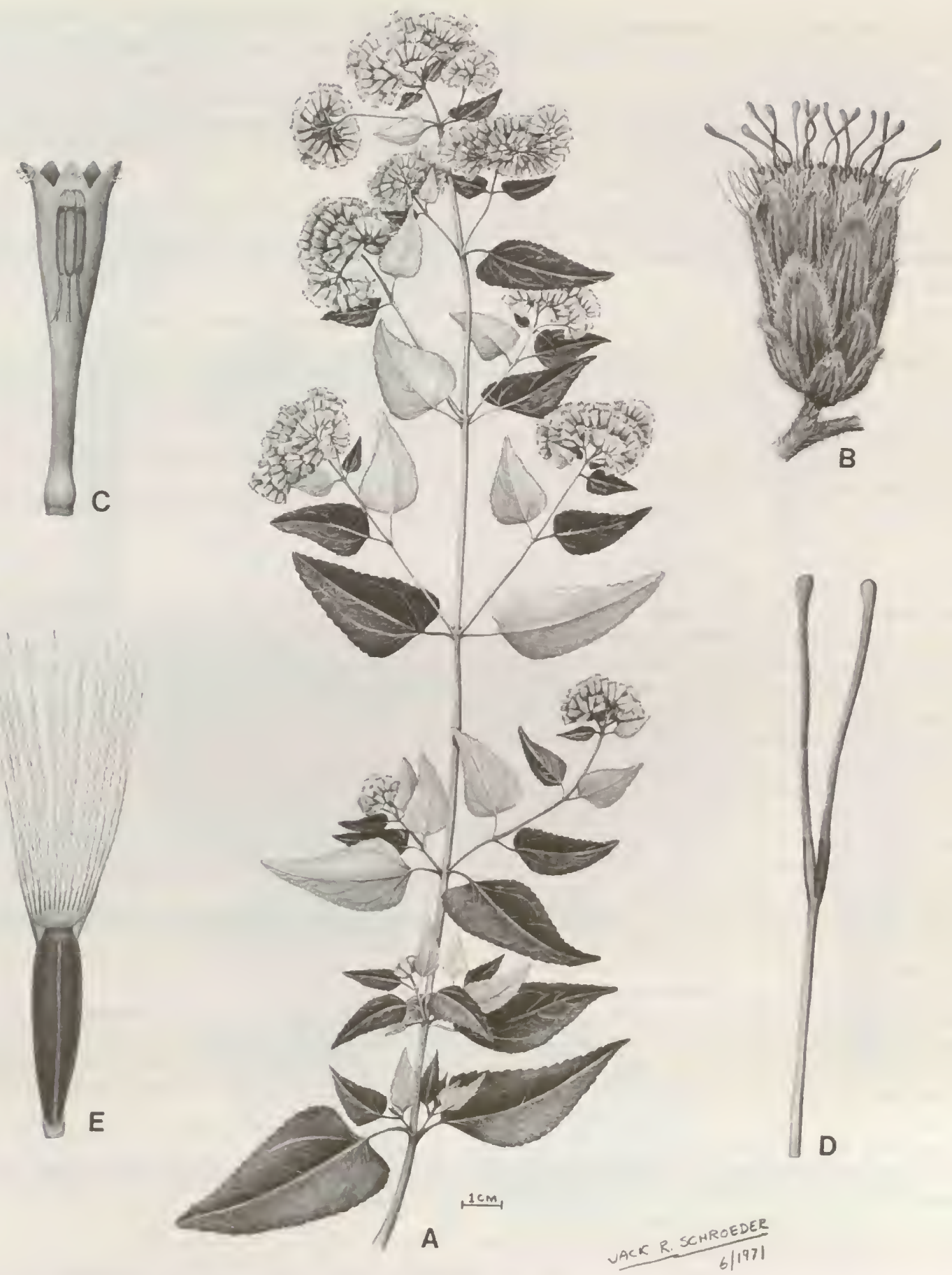

Plate 147. Cronquistianthus niveus (H.B.K.) R. King \& H. Robinson. - A. Habit, $\times 3 / 5 .-$ B. Head, $\times 7 .-$ C. Corolla showing anthers, $\times 20 .-$ D. Style, $\times 20 .-$ E. Achene, $\times 20$.

are found asymmetrical achene bases, corolla glands with small apical cells, and one species with some hairs on the inner surface of the corolla. From the latter, Cronquistianthus is immediately distingushed by its shrubby habit, its consistently well-developed anther appendages, and its strongly subimbricate involucre. A more distant relationship to the wide-spread genus Koanophyllon is probable, but the latter genus has symmetrical bases on the achenes, 
a tendency for shortened anther appendages, and glands on the corollas with expanded apical cells of the type most common in the tribe and family.

The asymmetrical base of the achene is a small feature of prime significance in delimiting the genus. The stoppershaped carpopodium is set off by numerous thin-walled easily collapsing wedge-shaped cells, leaving a distinct projecting edge. Internally, there is a sinuous vascular trace. Externally, the asymmetry is clearly evident in the much greater height of the carpopodium on one side of the achene than the other.

Variations within the genus include the scattered hairs inside the corolla in C. trianae, a condition not seen elsewhere in the genus, even in the closely related $C$. niveus. Also, there are small flaps inside the corolla near the insertions of the anthers in $C$. kalenbornianus. The three species, $C$. niveus, $C$. trianae, and $C$. origanoides, are notable for the white tomentum on the undersurfaces of their leaves, and the two species, $C$. determinatus and $C$. infantesii are notable for the dense stipitate-glandular pubescence on the stems. In other species, the characteristically dense pubescence of the leaves ranges from scabridulous to velutinous. Only in $C$. celendinensis are the areas between the veins on the upper leaf surface glabrous. The two Ecuadorian species, $C$. rosei and $C$. bulliferus (Eupatorium rugosum H.B.K. non Houtt.) tend to have more sordid tenuous-tipped pappus bristles.

One species, $C$. chachapoyensis, seems to have a rather isolated position in the genus. It is most distinct in the cymose rather than glomerulate ultimate units of the inflorescence, but the oblong entire leaves are also rather distinctive, and it is the only species in the genus with glanduliferous achenes.

A species from northern Peru, Eupatorium lopez-mirandae, has small ovate leaves with dense white tomentum below and was considered a close relative of $C$. origanoides by Cabrera (1962). The species, as seen in a second collection, Pennell 15486 (PH) from Cajamarca, represents a much shorter-pappused element of the genus than even $C$. infantesii which occurs in the same area. Still, the relationship is not certain, since Cabrera described the anther appendages as short and illustrated the involucral bracts as rather acute.

The genus is known from Peru northward into Colombia. The genus was delimited by King and Robinson $(1972 k)$ on the basis of 13 species and was expanded with discussion of some species distinctions ten years later (King \& Robinson, 1982d). There are no adequate keys to the species of Cronquistianthus, since many concepts have been refined and many species have been described subsequent to the treatments of Eupatorium sensu lato in Ecuador and Peru by B. Robinson (1918c, 1919b).

Cronquistianthus is one of two genera in the Eupatorieae honoring Arthur Cronquist of the New York Botanical Garden. The other is Cronquistia of the subtribe Ageratinae.

The following 25 species are recognized in the genus:

Cronquistianthus bishopii R. King \& H. Robinson, Peru.

Cronquistianthus bulliferus (S. F. Blake) R. King \& H. Robinson, Ecuador.

Cronquistianthus callacatensis (Hieron.) R. King \& H. Robinson, Peru.

Cronquistianthus celendinensis R. King \& H. Robinson, Peru. Cronquistianthus chachapoyensis R. King \& H. Robinson, Peru. Cronquistianthus chamaedrifolius (H.B.K.) R. King \& H. Robinson, Ecuador.

Cronquistianthus chotensis (Hieron.) R. King \& H. Robinson, Peru.

Cronquistianthus desmophyllus (B. Robinson) R. King \& H. Robinson, Peru.

Cronquistianthus determinatus (B. Robinson) R. King \& H. Robinson, Peru.

Cronquistianthus ferreyrii R. King \& H. Robinson, Peru.

Cronquistianthus glomeratus (DC.) R. King \& H. Robinson, Peru.

Cronquistianthus infantesii R. King \& H. Robinson, Peru.

Cronquistianthus kalenbornianus (B. Robinson) R. King \& H. Robinson, Peru.

Cronquistianthus lavandulaefolius (DC.) R. King \& H. Robinson, Peru.

Cronquistianthus leucophyllus (H.B.K.) R. King \& H. Robinson, Peru.

Cronquistianthus lopez-mirandae (Cabrera) R. King \& H. Robinson, Peru.

Cronquistianthus macbridei $\mathrm{R}$. King \& H. Robinson, Peru.

Cronquistianthus marrubiifolius (Hieron.) R. King \& H. Robinson, Peru.

Cronquistianthus niveus (H.B.K.) R. King \& H. Robinson, Ecuador.

Cronquistianthus origanoides (H.B.K.) R. King \& H. Robinson, Ecuador.

Cronquistianthus pseudoriganoides (Hieron.) R. King \& H. Robinson, Ecuador.

Cronquistianthus rosei R. King \& H. Robinson, Ecuador.

Cronquistianthus trianae R. King \& H. Robinson, Colombia, Ecuador.

Cronquistianthus urubambensis (B. Robinson) R. King \& H. Robinson, Peru.

Cronquistianlhus volkensii (Hieron.) R. King \& H. Robinson, Peru.

\section{Steyermarkina}

Steyermarkina R. King \& H. Robinson, Phytologia 22: 43. 1971. TYPE: Eupatorium pyrifolium DC.

Vines or flexuous shrubs, few to moderately branched mostly at right angles. Stems terete to rather hexagonal, striated. Leaves opposite, shortly but distinctly petiolate; blades herbaceous to subcoriaceous, 


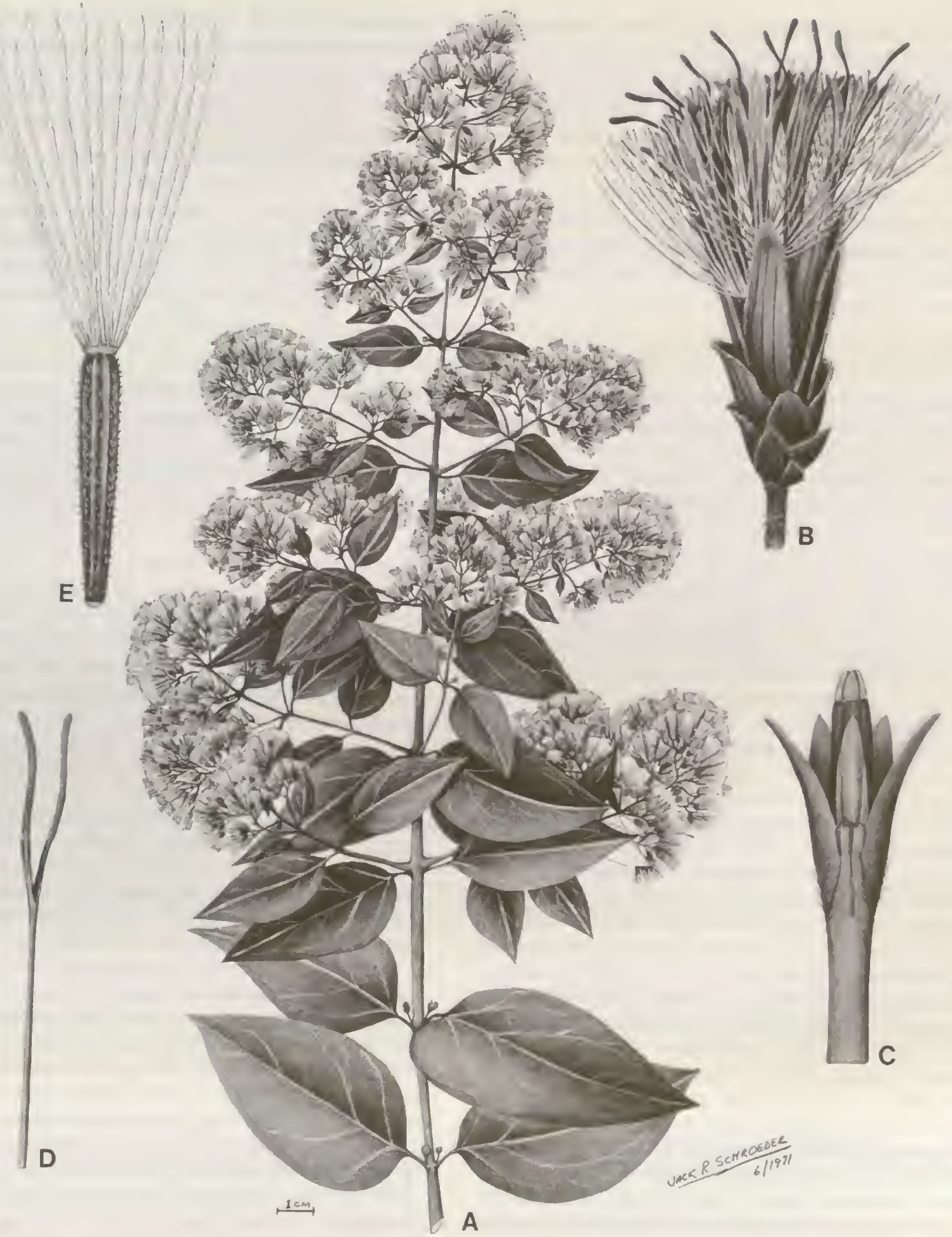

PlATE 148. Steyermarkina pyrifolia (DC.) R. King \& H. Robinson. - A. Habit, $\times 5 \% .,-$ B. Head, $\times 7 .-$ C. Corolla showing anthers and internal hairs, $\times 12 .-D$. Style, $\times 12 .-$ E. Achene, $\times 12$.

ovate, base obtuse to rounded, margins entire, apex obtuse to acute, venation pinnate, sometimes with lower pair stronger and subtrinervate, with or without hairs or glandular punctations below, without distinct internal resin pockets in areoles. Inflorescence a lax thyrsoid panicle, some nodes with extra axillary branches, branches at mostly right angles; heads subsessile in small clusters or distinctly pedicellate, cylindrical. Involucral bracts 
ca. 15-20, strongly subimbricate, in 4-5 strongly unequal graduated series, broadly ovate to oblong, with rounded or obtuse tips, 4-8-costate on outer surface, brownish with restricted pubescence; receptacle convex to slightly conical, usually glabrous. Florets $3-5$ in a head; corollas white, narrowly funnelform, outer surface glabrous or with minute glands or large hairs on base of throat and lobes, inner surface of throat densely pilose; cells of limb narrowly oblong with lateral walls not or slightly sinuous; lobes oblong with triangular tips, ca. 2-4 times as long as wide, cut to below bases of anther sacs, often exposing interior pilosity, smooth on both surfaces; anther collar narrowly cylindrical, composed mostly of rectangular cells, with weak but distinct annular thickenings on walls; anther appendages large, triangular, ca. twice as long as wide; style base not enlarged, glabrous; style branches linear, mamillose. Achenes prismatic, 5-6-ribbed, densely shortsetuliferous; carpopodium distinct, short, composed of small subquadrate cells in many tiers, with slightly thickened walls; pappus of ca. 30 scabrid slender congested persistent bristles mostly in 1 series, slightly flattened on outer surface, longer bristles distinctly broadened at tips, apical cells shortly to sharply acute. Pollen grains ca. $23 \mu \mathrm{m}$ in diameter. Plate 148 .

The genus Steyermarkina has the cylindrical heads with strongly subimbricate involucres and easily deciduous inner bracts of a type common in the Critoniinae, but in other features the genus is one of the most distinctive in the subtribe. The scandent to subscandent habit with widely spreading branches, the often deeply cut corolla lobes, the dense short pubescence of the achenes, and the rounded receptacle are unusual in the subtribe, and the dense pubescence on the inner surface of the corolla is in its detail unique. The only close relationship seems to be with the genus Hughesia, a scandent genus from Peru having a similar general habit, and similar rounded receptacles, but the latter has broader corollas with short lobes, and lacks hairs on the inner surface of the corollas.

The most distinctive feature of Steyermarkina is the thick mass of uniseriate, septate, non-glandular hairs on the inside of the corolla below the bases of the lobes. The hairs are sometimes visible from outside in species with more deeply cut lobes. The genus is one of two in the Critoniinae consistently pubescent inside of the corolla, and is the only one with such dense pubescence. Neocabreria, also consistently pubescent inside the corolla, and the isolated species in Ophryosporus, Cronquistianthus, and Fleischmanniopsis have comparatively few mostly appressed hairs. It seems coincidental that three of the four genera with hairs inside the corolla differ from Steyermarkina by having short anther appendages. Only Cronquistianthus, of the series, has longer non-bilobed appendages.

The combination of hairs inside the corolla and deeply cut lobes in Steyermarkina is reminiscent of some species of Neomirandea. There seems to be no close relationship, however, the latter being a primarily Central American genus of epiphytes with longer less ornamented anther collars. Chromosome numbers, when discovered for Steyermarkina, will undoubtedly also prove different from Neomirandea which has counts of $n=17$ and ca. 20 .

The receptacles of Steyermarkina are sometimes puberulous and are rather rounded. Such pubescence on the receptacle often seems to accompany hairs on the inner surface of the corolla. The same combination is seen in
Neocabreria, part of Neomirandea, and some species of Hebeclinium. Such pubescence on the receptacle does not indicate any relationship to members of the subtribe $\mathrm{He}-$ becliniinae where pubescence on the receptacle is common. The members of the latter subtribe differ by many characters including the more numerous flowers in the heads and the poorly differentiated carpopodia that are procurrent on the ribs of the achene.

Steyermarkina has a strong superficial resemblance to the genus Critonia in the shape and bearing of its leaves and heads, but the lack of internal secretory cavities in the leaves, the presence of hairs inside the corolla, and the dense short pubescence on the achenes dictate against any close relationship. Still, the similarity in habit and fungal hyphae on the corolla incorrectly interpreted as hairs have led Badillo (1976) to originally describe Critonia naiguatensis of Venezuela as a Steyermarkina.

What Steyermarkina lacks in problems of definition, it makes up for in its anomalous distribution. Three of the species are endemic to southeastern Brazil, and the genus undoubtedly centers in that area. Still, the fourth species is native to western Venezuela, in the mountains east of Lake Maracaibo. The species represents a nearly two thousand mile extension of the range, and follows none of the well-known phytogeographic patterns in higher plants. The inhospitable habitat in the intervening Amazon Basin further accentuates the disjunction. The Venezuelan species is sufficiently distinct in its fewer flowers in the head, the glabrous outer surfaces of its corollas, and the narrower less costate bracts of its involucre to preclude thought of recent introduction, but long-range dispersal at some time in the past is undoubtedly involved.

No accurate key exists for all members of the genus. The three Brazilian species are included as a group in the key to Eupatorium sensu lato in Cabrera and Vittet (1963), but it is the more pinnately veined $S$. displata that seems to have glabrous leaves rather than $S$. pyrifolium. The seemingly subtrinervate venation of $S$. pyrifolia and $S$. triflora is the result of stronger lower secondary veins, but does not involve any divergence from the basal margin of the leaf. 
The generic name honors Julian A. Steyermark, presently of Venezuela, collector of the type specimen of the Venezuelan species and of vast numbers of other Neotropical plants, and author of numerous works on the Rubiaceae and other plant families.

The following four species are recognized in the genus:
Steyermarkina dispalaı (Malme) R. King \& H. Robinson, Brazil.

Steyermarkina dusenii (Malme) R. King \& H. Robinson, Brazil. Sieyermarkina pyrifolia (DC.) R. King \& H. Robinson, Brazil. Steyermarkina triflora R. King \& H. Robinson, Venezuela.

\section{Neocabreria}

\section{Neocabreria R. King \& H. Robinson, Phytologia 23: 151. 1972. TYPE: Eupatorium serrulatum DC.}

Erect subshrubs, with few branches. Stems terete, striated, sparsely to densely pubescent. Leaves opposite, rather closely inserted, petioles short; blades narrowly elliptical, base cuneate, margins closely serrulate to crenate-serrulate, venation pinnate, upper surface sparsely pubescent, lower surface essentially glabrous to villous, with or without glandular punctations below. Inflorescence a corymbose panicle, with ascending alternate branches and decurrent ridges; pedicels rather short. Involucral bracts 25-30, strongly subimbricate, in 3-4 strongly unequal graduated series, oblong to linear-oblong, with rounded to short-acute tips, brownish or yellowish, mostly 4-costate on outer surface, inner bracts easily deciduous; receptacle flat to slightly convex, glabrous to densely hirsute. Florets 6-25 in a head; corollas white to rose-purple, narrowly funnelform, glabrous on outer surface, with numerous hairs on inner surface; cells of throat elongate with sinuous lateral walls; lobes triangular, as long as wide or longer, smooth on both surfaces, glabrous or with sparse glands on outer surface; anther collar cylindrical, composed of numerous subquadrate cells below, with weak but distinct transverse annular thickenings on walls; anther appendage strongly bilobed, with rather triangular halves, distinctly shorter than wide to slightly longer than wide; style base not enlarged, glabrous; style branches broadly linear, almost smooth or distinctly mamillose. Achenes prismatic, 4-5-ribbed, with narrow base, setuliferous or glanduliferous above; carpopodium indistinct, not or scarcely differentiated; pappus of 30-40 scabrid slender contiguous persistent bristles in 1 series, not broadened distally, apical cells acute. Pollen grains ca. $22 \mu \mathrm{m}$ in diameter. Plate 149.

The genus Neocabreria is one of the few genera of the Critoniinae mostly restricted to southeastern Brazil, and is one of only two genera of the subtribe showing consistently pubescent inner surfaces of the corollas. The members of the genus are further distinguishable by their narrowly elliptical pinnately veined leaves and their distinctly bilobed anther appendages. As such, the genus is distinctive and easily recognizable, with considerable uniformity of characters.

In spite of the great integrity of the genus Neocabreria, none of the species seem to have been recognized as close relatives of each other in the past. Because of the differences in their pubescence and flower number, even the two common species, $N$. malachophylla and $N$. serrulata, were not keyed together or associated in lists. The form of inflorescence with ascending alternate and ribbed branches seems to have been responsible for the original description of $N$. pennivenia in the genus Symphyopappus (B. Robinson, 1923), and the original comparison (Cabrera \& Vittet, 1963) and later transfer (King \& Robinson, $1974 n$ ) of $N$. catharinensis to that genus. This is in spite of the usual presence of more flowers per head than the five that are characteristic of the subtribe Disynaphiinae to which Symphyopappus belongs. The association of the two species with Symphyopappus was the closest authors came to placing two of the species of Neocabreria together prior to the establishment of the genus.

The other genus of the Critoniinae having the corollas consistently pubescent inside, Steyermarkina, is also primarily Brazilian. Steyermarkina differs from Neocabreria by numerous features, including the more cylindrical involucres with more appressed bracts, the more spreading opposite branches in the inflorescence, the more deeply cut corolla lobes, the unlobed anther appendages, and the nearly entire leaves. The two genera, in spite of their similar corolla pubescence and geography, do not seem particularly closely related.

The genus Neocabreria ranges from northern Argentina northward into southern Brazil. The northernmost species occurs in the state of Minas Gerais. Three of the species are treated in the key to Eupatorium sensu lato in the state of Santa Catarina by Cabrera and Vittet (1963). A key to all five known species of Neocabreria has more recently been provided by King and Robinson (1978c). The latter key errs only in the use of the name $N$. mexiae for the species properly known as $N$. pennivenia.

The name Neocabreria honors Angel L. Cabrera, a leading Argentinian botanist, author of innumerable studies 

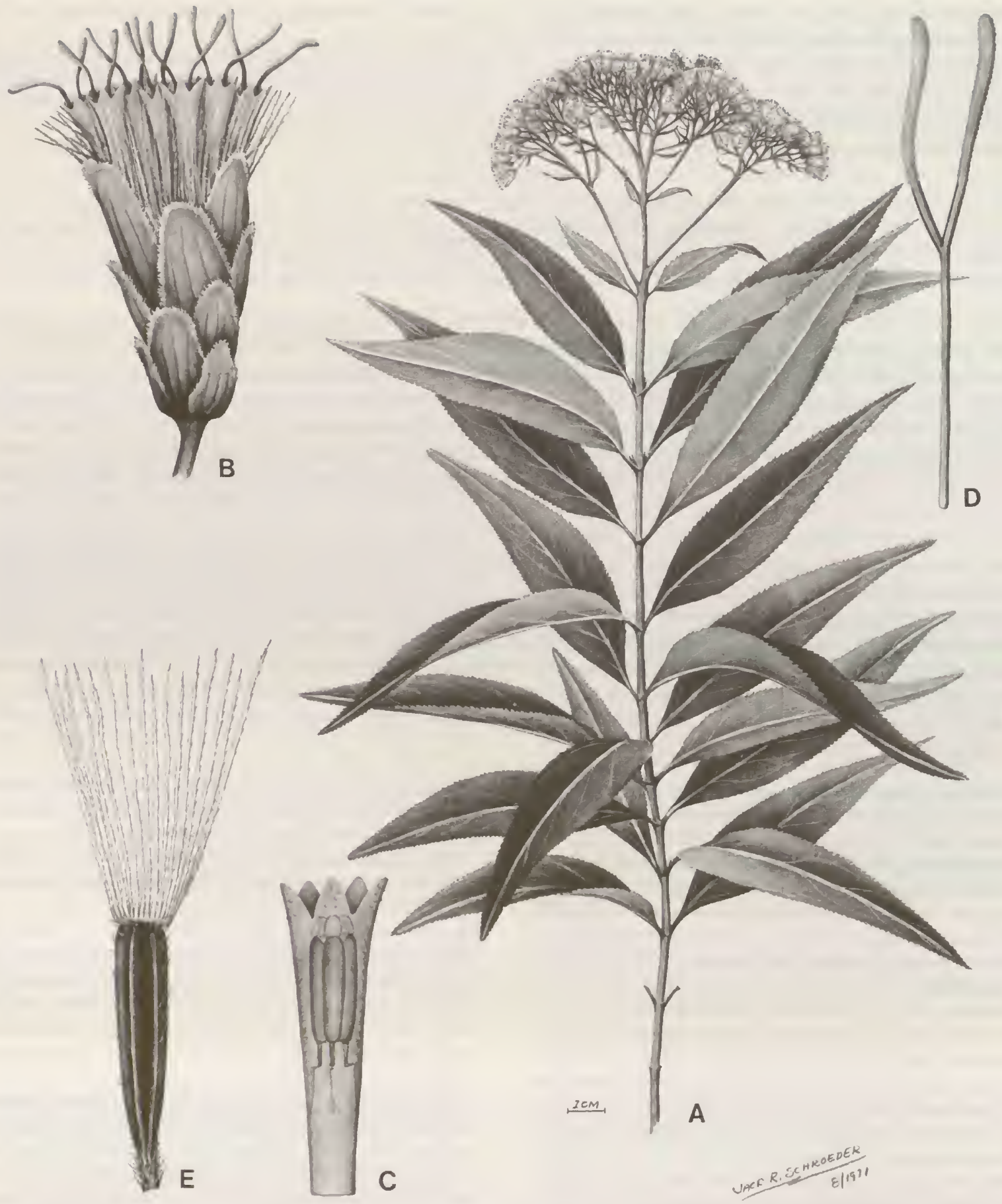

Plate 149. Neocabreria pennivenia (B. Robinson) R. King \& H. Robinson. - A. Habit, $\times 3 \%,-B$. Head, $\times 6 .-$ C. Corolla showing anthers and internal hairs, $\times 11 .-$ D. Style, $\times 11 .-$ E. Achene, $\times 11$. 
on the Asteraceae, and recently retired as Director of the Instituto de Botanica Darwinion.

The following five species are recognized in the genus:

Neocabreria catharinensis (Cabrera in Cabrera \& Vittet) R. King \& H. Robinson, Brazil.
Neocabreria concinna R. King \& H. Robinson, Brazil.

Neocabreria malachophylla (Klatt) R. King \& H. Robinson, Argentina, Brazil.

Neocabreria pennivenia (B. Robinson) R. King \& H. Robinson, Brazil.

Neocabreria serrulata (DC.) R. King \& H. Robinson, Brazil.

\section{Uleophytum}

Uleophytum Hieron., Verh. Bot. Vereins Prov. Brandenburg 48: 198. 1906. TYPE: Uleophytum scandens Hieron.

Woody vines, moderately branched. Stems terete, striated. Leaves opposite, sessile; blades broadly oblongovate, bases broadly cordate, margins minutely denticulate, apex acuminate, trinervate with strongly ascending veins from near base, veinlets prominulous below, surfaces glabrous, glandular punctate below. Inflorescence of numerous heads clustered in axils of leaves, without evident pedicels. Involucral bracts ca. 25 , subimbricate, in 3-4 unequal graduated series, lanceolate with sharp tips, mostly 4-costate on outer surface, mostly persistent; receptacle flat, glabrous. Florets ca. 55-60 in a head; corollas whitish?, narrowly funnelform, glabrous on inner and lower outside surfaces; cells of throat elongate with sinuous lateral walls; lobes triangular, slightly longer than wide, smooth on both surfaces, with numerous glands clustered on outer surface; anther collar cylindrical, with numerous subquadrate cells, cell walls with weak but distinct ornate thickenings; anther appendage large, ovate to oblong, longer than wide, with slightly retuse tip; style base not enlarged, glabrous; style appendages narrowly linear, nearly filiform below, slightly broadened distally, mamillose. Achenes prismatic, 4-5-ribbed, glabrous except for few glands near top; carpopodium distinct, with distinct slight upper rim, stopper-shaped, composed of small quadrate cells in ca. 8 tiers, with rather thick walls; pappus of ca. 30 scabrid closely contiguous persistent bristles in 1 series, not or slightly broader and not or slightly more scabrid distally, apical cells obtuse to short-acute. Pollen grains ca. 20-22 $\mu \mathrm{m}$ in diameter. Plate 150.

The generic status given to Uleophyzum by Hieronymus (1906) appears to have been based entirely upon the unique but perhaps questionable character of the sessile axillary inflorescences and the scandent habit. In all of the standard features, the genus fits the traditional generic concept of Eupatorium, having a persistent capillary pappus of essentially uniform bristles, a large anther appendage, and five-ribbed achenes. Uleophytum would have keyed to Eupatorium in the key to the genera of the Eupatorieae by B. Robinson (1913a), a key from which the genus was apparently omitted by accident. A proper re-evaluation of the status and position of Uleophytum in the Eupatorieae did not occur until the present series of studies.

As indicated in the systematic review of the Eupatorieae by H. Robinson and King (1977), Uleophytum proves to be a member of the subtribe Critoniinae. The position is marked best by the simple structure of the style base and branches. The subimbricate involucre is also indicative, though the inner bracts are not as deciduous as in many members of the subtribe. The corolla lobes have rather lax and possibly slightly bulging cells on the inner surface, but the surface is still basically smooth.
The position of Uleophytum in the Critoniinae is possibly reflected in the dense clustering and restriction of glands on the outer surfaces of the corolla lobes, a characteristic of Koanophyllon and some of its closely related genera. The broadly cylindrical base of the corolla and the lanceolate less deciduous bracts of the involucre would also support such a relationship. The longer corollas, corolla lobes, achenes, and bristles of the pappus easily distinguish Uleophytum from Koanophyllon, but do not necessarily indicate great phyletic distance. The best distinguishing key characters of the genus remain the broad sessile pairs of leaves with clusters of subsessile heads in their axils.

Uleophytum seems to be known as yet only from the original collection from Cerro de Escalar, at $1,200 \mathrm{~m}$ altitude, Department of Loreto, Peru.

The generic name honors the well-known botanist, Ernst H. G. Ule, 1854-1915, best known for his extensive collections of Brazilian and Peruvian plants.

The following single species is recognized in the genus: Uleophytum scandens Hieron., Peru. 


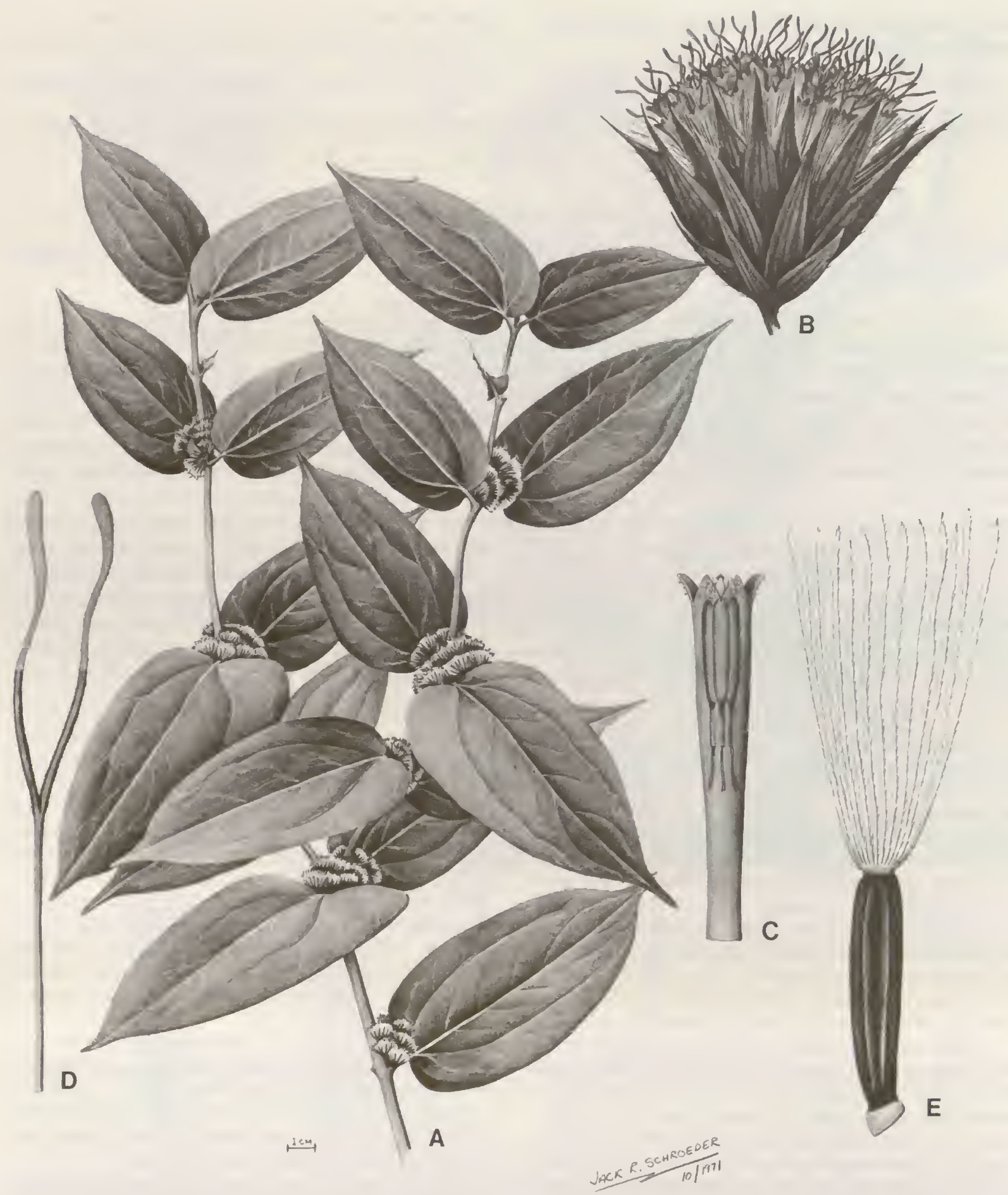

PLATE 150. Uleophytum scandens Hieron. -A. Habit, $\times 4 \% .-$ B. Head, $\times 5 .-$ C. Corolla showing anthers, $\times 14 .-D$. Style, $\times 14 .-E$. Achene, $\times 14$. 


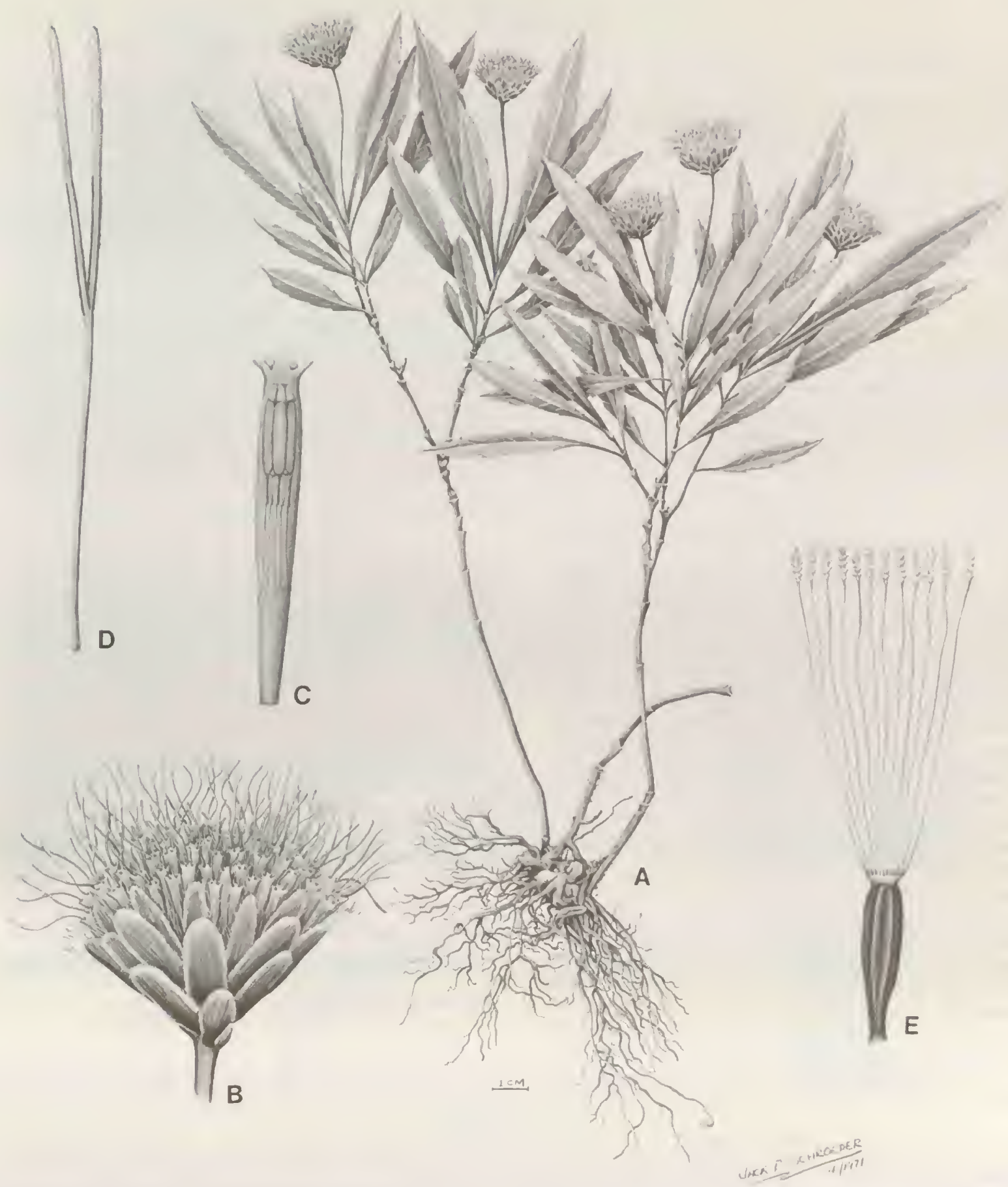

PlATE 151. Amboroa wurdackii R. King \& H. Robinson. - A. Habit, $\times 3 / 5 .-B$. Head, $\times 3 .-$ C. Corolla showing anthers, $\times 9,-D$. Style, $\times 9 .-$ E. Achene, $\times 9$. 


\section{Amboroa}

Amboroa Cabrera, Bol. Soc. Argent. Bot. 6: 91. 1956. TYPE: Amboroa geminata Cabrera.

Small erect subshrubs or shrubs, with several stems sometimes arising from base, few branched. Stems terete, striated, subcarnose, glabrous. Leaves opposite, petioles short and poorly delimited above; blades narrowly elliptical, base cuneate, margins remotely serrulate, apex sharply acute, venation pinnate with ascending secondary veins, without glandular punctations below. Inflorescences borne on separate slender peduncles, with 1 head or a pair of sessile heads. Involucral bracts ca. $25-40$, strongly subimbricate, in ca. 4-5 unequal graduated series, broadly to narrowly oblong, apices rounded to obtuse, with numerous weak longitudinal veins, scarcely prominulous on outer surface, inner bracts persistent; receptacle convex, alveolate, glabrous. Florets 50 to more than 80 in a head; corollas white, narrowly funnelform, with long cylindrical basal tube and rather cylindrical throat, glabrous on inner and outer surfaces; cells of limb laxly oblong with weak non-sinuous or scarcely sinuous walls; lobes triangular, short compared to length of corolla, longer than wide, smooth on both surfaces; anther collar cylindrical, composed of many subquadrate cells below, with weakly beaded thickenings on walls; anther appendage large, oblong-ovate, ca. 1.5 times as long as wide; style base not enlarged, glabrous; style appendages narrowly linear, becoming nearly filiform, with dense short-erect papillae. Achenes prismatic, 5-6-ribbed, glabrous; carpopodium indistinct on cylindrical base of achene, with a few scattered large firm-walled cells; pappus of ca. 15-25 non-contiguous slender bristles in 1 series, with bases broad and flattened, smooth, extremely slender and smooth for most of length, becoming greatly enlarged and subplumose distally with many large densely projecting obtuse or short-acute cells. Pollen grains ca. $20 \mu \mathrm{m}$ in diameter. Plate 151.

The Peruvian and Bolivian genus Amboroa is distinct from all other members of the tribe Eupatorieae by the pappus bristles that are smooth and extremely slender for most of their length, but which bear greatly enlarged projecting cells in the distal part. Cabrera (1956) referred to the tips of the pappus bristles as plumose. The expanded tips are somewhat reminiscent of those seen on the pappus bristles of male plants of Baccharis in the Astereae or Antennaria in the Inuleae, but the bristles are much finer and more flexuous. In less mature heads, the pappus bristles exceed the unopened corollas in length, and evidently form a solid mass of expanded tips across the top of the compressed head.

Amboroa has the technical characters of the subtribe Critoniinae, with a subimbricate involucre, a simple style base, and smooth corolla lobes. Structurally, besides the pappus, only the long-pedunculate heads with numerous flowers and the multiveined persistent involucral bracts are notably unusual in the subtribe. The habitat of the genus is unusal in the subtribe. Both species have been recorded from elevations below $1,000 \mathrm{~m}$, on or between rocks, in ravines or beside rivers. Both the pappus and the habitat of Amboroa thoroughly distinguish the genus within the subtribe, but many other characters such as the long-pedunculate solitary or paired heads from the apices of short leafy stems, and the broad thin multiveined involucral bracts further the impression that the genus is not closely related to any other member of the Critoniinae.

Amboroa was originally described on the basis of a species from Cerro del Amboro, after which the genus is named, in the Department of Santa Cruz in central Bolivia. The second species is from the same general floristic zone along the Amazonian side of the Andes, but occurs approximately $2,000 \mathrm{~km}$ to the northwest in the Marañon River area of northern Peru. Both of the species are known only from the original collections. The distinctions of the species are given by King and Robinson $(1975 n)$.

The following two species are recognized in the genus: Amboroa geminata Cabrera, Bolivia.

Amboroa wurdackii R. King \& H. Robinson, Peru.

\section{Tuberostylis}

Tuberostylis Steetz in Seemann, Bot. Voy. Herald 142. 1854. TyPE: Tuberostylis rhizophorae Steetz in Seemann.

Creeping to scandent herbs or shrubs, moderately branched. Stems terete, slightly striated when dry, frequently rooting at nodes. Leaves opposite, narrow, petioles not to rather sharply delimited above; blade slightly carnose, glabrous, obovate to elliptical, base acute with usually narrow acumination, margins entire to crenulate, apex obtuse to short-acuminate, veins trinervate from near base, lower surface often with minute non-glandular spots. Inflorescences terminal on lateral branches or sessile in axils of leaves; heads sessile in 

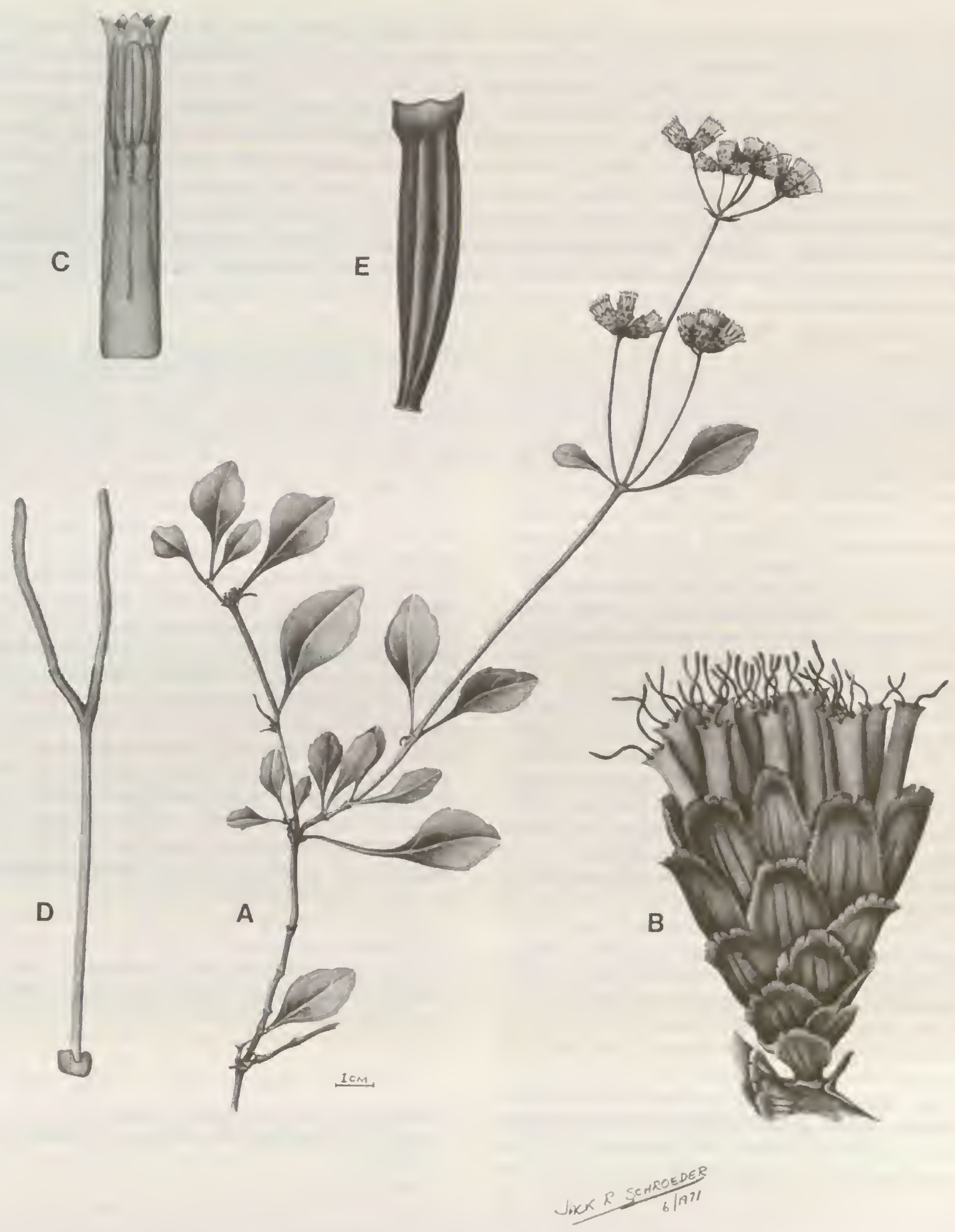
Plate 152. Tuberostyles rhizophorae Steetz. - A. Habit, $\times 2 / 3,-B$. Head, $\times 7 .-$ C. Corolla showing anthers, $\times 15 .-D$. Style with
nectary, $\times 15 .-$ E. Achene, $\times 15$. 
small panicles or in axillary fascicles. Involucral bracts 25-30, subimbricate, in 4-5 unequal graduated series, mostly oblong to oblong-lanceolate, usually 4-costate on outer surface, with rounded or acute apices, bracts spreading at maturity or with inner bracts deciduous; receptacle flat or slightly convex, glabrous or with narrow paleae inside peripheral flowers. Florets ca. 10-20 in a head; corollas white, narrowly tubular with slightly thickened base, glabrous on inner surface and lower outside surface; cells of limb elongate with sinuous lateral walls; lobes triangular to oblong, 1-3 times as long as wide, smooth on both surfaces, mamillose at tips, a few minute glands on outer surface; anther collar cylindrical, composed mostly of short-oblong cells, with weak but distinct scalariform thickenings on walls; anther appendage ovate, about as long as wide; style base not enlarged, glabrous; style appendages narrowly linear, slightly mamillose, slightly broadened distally. Achenes prismatic to cylindrical 5-veined or 5-ribbed, whitish and strongly corticated when mature, glabrous; carpopodium short, indistinct, with rather large thin-walled cells; pappus lacking. Pollen grains ca. $23 \mu \mathrm{m}$ in diameter. Plate 152.

The genus Tuberostylis has the subimbricate involucre, simple style bases, smooth corolla lobes, and other details of the subtribe Critoniinae, but it is placed at the end of the sequence in this treatment because of two unusual features, the epiphytic habit, and the epappose achenes. The genus contains the only epappose members of the subtribe except some in the remotely related eximbricate and exappendiculate Ophryosporus. The combination of epappose achenes and appendiculate anthers in Tuberostylis led to original comparison with the traditional concept of Alomia by Steetz, but the latter genus has been revised to include only a small group of Mexican species in the subtribe Alomiinae having 40-50 flowers in the heads and minute peg-like setulae on the achenes.

Tuberostylis, like Mikania and Neomirandea, is notable for an epiphytic habit, but the three genera are not closely related. Tuberostylis differs from both of the others by its lack of a pappus, and by its tubular or upwardly narrowed corollas. The genus differs further from Mikania by the larger number of flowers in the heads and the numerous subimbricate involucral bracts. It differs further from Neomirandea by the less elongate anther collars with more ornamented cell walls, and by the strictly narrow cells of the corolla. The chromosome number of Tuberostylis is not known, but as a member of the Critoniinae it might be expected to be based on $n=10$, in which case it would be further distinct from Mikania or Neomirandea.

In spite of the placement of Tuberostylis at the end of the Critoniinae, the genus is not necessarily so phyletically distant from Critonia. The habit is somewhat like that of a scandent Critonia, and the cylindrical heads form similar clusters in both genera. Tuberostylis is thoroughly distinct in the lack of internal secretory pockets in the areoles of the leaves, in the lack of a pappus, and in the cortication of the mature achenes. The axillary clusters of heads in Tuberostylis axillaris are reminiscent of Uleophytum, but the two are not closely related, and do not look similar because the leaves in Uleophytum are broad and sessile.

The degree of difference between the two species of Tuberostylis raises a question regarding whether they represent one or two genera. The type species has paniculate inflorescences, involucral bracts with rounded tips, and deciduous inner bracts. Paleae are lacking. The S. F. Blake species, $T$. axillaris, has the heads in axillary clusters, involucral bracts more lanceolate and pointed, and the inner bracts persistent. There are a few paleae in the latter species. Nevertheless, both species share the same habitat that S. F. Blake (1943) regarded as unique in the family, epiphytic on tree trunks or roots in saline tidal thickets. Both species are restricted to the same geographical area from eastern Panama southward along the Pacific coast to northern Ecuador. Both species are ultimately alike in the fleshy habit, and their corticated epappose mature achenes. Corticated achenes have been seen elsewhere in the tribe only in members of the Mikania guaco group (King \& Robinson, 1975y).

The generic name given by Steetz (1854) was evidently in reference to the nectary at the base of the style. Such nectaries are not unusual, being developed to varying extent in all members of the Eupatorieae. Still, the nectary is more obvious on epappose achenes such as those in Tuberostylis.

The following two species are recognized in the genus:

Tuberostylis axillaris S. F. Blake, Colombia.

Tuberostylis rhizophorae Steetz in Seemann, Panama, Colombia, Ecuador.

Subtribe XiI. Praxelinae

Praxelinae R. King \& H. Robinson, Phytologia 46: 448. 1980. TYPE: Praxelis Cass.

Erect to subscandent, annual to perennial herbs or subshrubs, sparsely to densely branched, never rosulate. Leaves mostly opposite, rarely verticillate or alternate, usually petiolate with short to moderately long petioles; blades entire to serrate, sometimes dissected in Lomatozona, ovate or oblong to linear. Inflorescence laxly 
cymose to thyrsoid-paniculate, rarely monocephalic on long erect peduncles, heads pedicellate or sessile; involucral bracts imbricated, graduated in length, totally deciduous; receptacle slightly convex to highly conical, with or without paleae. Flowers 5-65 in a head; corollas white, blue, lavender, or purple, mostly narrowly funnelform, peripheral flowers of Praxeliopsis and to lesser extent in Eitenia and Lomatozona with outer lobes more enlarged; cells of throat elongate with sinuous lateral walls, usually prorulose at upper ends, rarely hair-like in Eitenia; lobes usually longer than wide, usually densely papillose on inner surface, often with sclerified cap of cells outside near tip, without stomata on outer surface; anther collar usually 5 times as long as wide or less, usually distinctly broadened in lower half with subquadrate or shorter cells, strongly ornamented with transverse, vertical, or oblique lines; anther appendage usually longer than wide, shorter in Osmiopsis, obsolete in Praxeliopsis; style base usually not enlarged, enlarged in Praxeliopsis, glabrous; style branches usually narrowly linear and densely papillose, less papillose and with broadened smooth tips in Osmiopsis. Achenes biconvex to trigonous or prismatic, with 2-5 ribs, micropunctations of achene walls not strongly aligned in transverse bands; carpopodium usually distinct, short cylindrical or strongly asymmetrical toward adaxial surface, indistinct in Lomatozona, with or without slight upper rim, cells small, often bistratose, with somewhat thickened walls; pappus usually of numerous capillary scabrid bristles in 1 series, sometimes bristles only $5-8$, with or without intermixed smaller bristles, sometimes pappus reduced to fringe of short unequal bristles, apical cells usually sharply acute. Basic chromosome number $x=10$, polyploidy and apomixis common.

The primary characteristic of the Praxelinae is the totally deciduous involucre, the bracts falling rather than spreading at maturity. The bracts remaining appressed until they fall is a particularly useful feature in herbarium specimens, but is useless in the field, because live members of other subtribes also have the bracts appressed until past maturity. Exceptions within the subtribe are relatively few. Material of Eupatoriopsis hoffmanniana shows tenuously retained outer bracts. The bracts in all of the variants of Chromolaena sinuata may not be totally deciduous, and some species such as $C$. cryptantha and $C$. pulchella have not been seen in a totally ebracteate condition. Totally ebracteate receptacles have been seen in only one species outside of the Praxelinae, in Symphyopappus decussatus of the Disynaphiinae from eastern Brazil. The latter has strictly five-flowered heads, and has differentiated linear outer involucral bracts, and also lacks the specialized anther collars or corolla papillosity of the Praxelinae. It is not regarded as a close relative.

Although the subtribe Praxelinae is one of the most natural groups in the Eupatorieae, there has been no tendency to recognize the relationships between the various included genera in the traditonal systems of classification. Efforts to distinguish much of Chromolaena at various levels of classification have emphasized the cylindrical shape of the heads and have often included members of the related subtribe Critoniinae which have only the inner involucral bracts deciduous. At the same time, other species of Chromolaena and members of Praxelis, which have more campanulate involucres, were not recognized as close relatives. With the exception of a small typical group of Chromolaena, the above elements with their pappus of many capillary bristles were usually placed in the broad concept of Eupatorium. All members of the subtribe with defective forms of pappus, however, were maintained in separate genera. Eupatoriopsis of Brazil was even regarded as a close relative of the North American Trichocoronis by B. Robinson (1906).

The subtribe Praxelinae has a geographical distribution of considerable interest, with most of its genera and its diversity concentrated in Brazil. With one exception, all the genera occur in Brazil, and of those only two extend outside of that country. The only phytogeographic anomaly in the subtribe involves a number of the species of Chromolaena extending north of South America and the genus Osmiopsis which is endemic to Hispaniola. Chro. molaena sinuata of the Greater Antilles, Chromolaena subgenus Osmiella of Mexico and Central America, and Osmiopsis all seem to be the products of complex intersubtribal hybridization between Koanophyllon of the subtribe Critoniinae and Chromolaena. Such hybridization has undoubtedly occurred elsewhere in the tribe and the family, but the present group furnishes the most unmistakable example in the Eupatorieae. The resulting forms showing intergradation with the Critoniinae were erroneously thought to be the more primitive elements of the Chromolaena relationship during the original treatment of the genus in the present series of studies (King \& Robinson, 1970q). If the subtribe were not one of the most strongly characterized in the tribe, the intersubtribal hybridization might not be so evident.

There are two trends of special interest in the Praxelinae. Eupatoriopsis, Praxelis, and Eitenia have distinctly obcompressed achenes, a feature seen elsewhere in the tribe in Barroetea of the Alominae. These same three genera are the only ones in the tribe with tangentially oriented styles (H. Robinson, 1984). In Praxeliopsis, and to a lesser degree in Eitenia and Lomatozona, the peripheral flowers have zygomorphic corollas with longer outer lobes. Greater asymmetry of corollas is seen elsewhere in the tribe only in the genus Microspermum of the Ageratinae. 
Cytologically, the Praxelinae like the Critoniinae are based on $x=10$. The subtribe differs, however, in the great amount of polyploidy and irregular meiosis (R. King et al., 1976). Apomixis appears to be common in the subtribe, as evidenced by the frequency of Type II pollen. Some species such as Praxelis pauciflora and Eitenia polyseta seem to be characteristically apomictic.
The subtribe is known chemically primarily on the basis of the genus Chromolaena (Bohlmann et al., 1979c, 1981e, $1981 h, 1982 a, 1982 f)$. Cadinen-derivatives seem common in the latter genus, and prostaglandin-like fatty acids have been reported from two species.

\section{KEY TO THE GENERA OF THE SUBTRIBE PRAXELINAE}

1. Peripheral flowers of heads with greatly expanded outer lobes; anthers inserted high in corolla near bases of lobes; style base with enlarged node above nectary; pappus with 5 bristles 157. Praxeliopsis

1'. Peripheral flowers of heads without or with moderate expansion of outer lobes; anthers inserted below an elongate throat; style without basal node; pappus of various forms, rarely with 5 bristles

2. Receptacle conical to columnar; carpopodium strongly asymmetrical, borne laterally on base of flattened achene

3. Pappus of 18-20 very short densely barbellate bristles; receptacle columnar; outer involucral bracts slightly persistent

3'. Pappus with long bristles; receptacle conical; involucral bracts all totally deciduous 155. Eupatoriopsis

4. Pappus with 5-8 stout bristles, with or without additional smaller bristles; achenes with only 2 marginal ribs ...... 158. Eitenia

4'. Pappus capillary with $20-40$ bristles; achenes with $3-4$ ribs 153. Praxelis

$2^{\prime}$. Receptacle with flower-bearing portion flat; carpopodium essentially symmetrical or obsolete; achenes prismatic with 35 ribs

5. Pappus of numerous short unequal bristles; carpopodium minute, poorly differentiated; leaves often dissected

156. Lomatozona

5'. Pappus capillary with long bristles; carpopodium distinct, short cylindrical; leaves not dissected

6. Style branches with enlarged tips; anther appendages shorter than wide; corolla lobes broadly triangular, with dense cluster of glands on outer surface 159. Osmiopsis

6:. Style branches linear, without enlarged tips; anther appendages as long as wide or longer; corolla lobes longer than wide, with or without a few glands on outer surface 154. Chromolaena

\section{Praxelis}

Praxelis Cass., Dict. Sci. Nat. 43: 261. 1826. TyPE: Praxelis villosa Cass. [=Praxelis pauciflora (H.B.K.) R. King \& H. Robinson].

Ooclinium DC., Prodr. 5: 133. 1836. LeCtOTYPE: Ooclinium grandiflorum DC. [= Praxelis grandiflora (DC.) Schultz-Bip.].

Eupatorium section Praxelis (Cass.) Benth. ex Baker in C. Martius, Fl. Bras. 6(2): 341. 1876.

Haberlea Pohl ex Baker in C. Martius, Fl. Bras. 6(2): 341. 1876, nom. nud.

Erect to decumbent annual or perennial herbs or subshrubs, sparingly branched. Stems terete, with faint to moderate striations, glabrous or pubescent. Leaves opposite or whorled, sessile or petiolate; blade ovate to elliptical or filiform, margin subentire to sharply serrate, with single vein or trinervate from or near base, with or without glandular punctations below. Inflorescence monocephalic on long erect peduncles to laxly thyrsoid or rather densely corymbose; pedicels mostly long and slender, rarely short; heads usually campanulate. Involucral bracts 15-25, imbricate in 3-4 unequal graduated series, totally deciduous, outer bracts falling first, tips acute to acuminate, outer surface 4-6-costate, glabrous to sparsely pilose; receptacle highly conical, glabrous. Florets 25-30 in a head; corollas white, blue, or lavender, narrowly funnelform or with cylindrical throat and slightly narrower basal tube, outer surface mostly smooth, with a few glands; cells of throat narrow with sinuous lateral walls, prorulose with inwardly projecting upper ends; lobes rather ovate to oblong, 1.5-3 times as long as wide, densely long-papillose on inner surface, usually with some projecting cells on outer surface at tip; anther collars with enlarged bases, narrowed above, with numerous quadrate cells below, elongate above, cell walls with prominent annular thickenings, transverse in longer cells, oblique or vertical in many short cells; anther appendage slightly longer than wide to very narrow and distinctly longer than wide, often toothed at tip; style base not enlarged, glabrous; style branches long, narrowly linear, more broadened in distal half, densely long-papillose. Achenes slightly to strongly obcompressed, 3-4-ribbed, with scattered setulae; carpopodium distinct, broad, highly asymmetrical with opening turned toward inner 


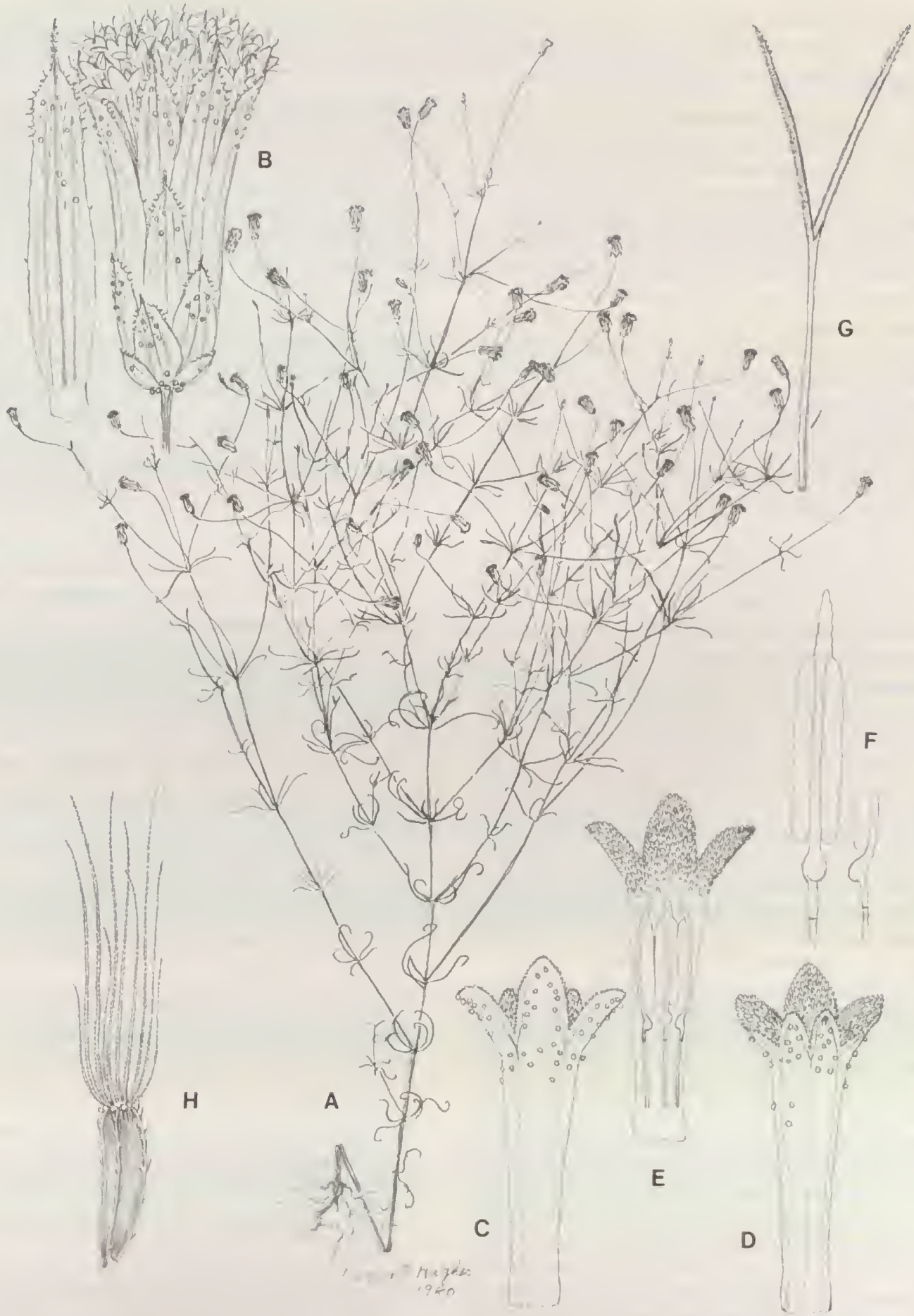

PlATE 153. Praxelis capillaris (DC.) Schultz-Bip. - A. Habit, $\times 1 / 2 .-B$. Head, $\times 8$, with separate enlarged inner involucral bract.C. Corolla outer surface, side facing away from center of head, $\times 14 .-$ D. Corolla, outer surface, side facing toward center of head, $\times 14$. - E. Corolla, inner surface, $\times 14 .-F$. Anthers with inside and lateral views of collar, $\times 28 .-$ G. Style, $\times 14 .-H$. Achene, $\times 14$. 
surface, cells small, in ca. 6 series, with thin walls; pappus of ca. 40 scabrid persistent bristles in 1 series, not or scarcely broadened distally, apical cells acute. Pollen grains ca. 20-22 $\mu \mathrm{m}$ in diameter, often abnormally shaped as result of irregular meiosis. Chromosome numbers $2 n=48,51$, ca. $80, n=7_{11}+26_{1}$. Plate 153.

The genus Praxelis can be distinguished from all others in the tribe by the combination of the pappus of numerous capillary bristles, the deciduous involucre, and the conical receptacle. The characteristics were fully recognized by both Cassini $(1826 b)$ at the time of the original establishment of the genus, and DeCandolle (1836) at the time of establishment of Ooclinium. The distinguishing features have continued to be cited by more recent authors who have recognized the present group at only the sectional level (J. Baker, 1876; B. Robinson, $1918 b$; Barroso, 1950). Some authors such as B. Robinson also note the rather characteristic habit of weed-like annuals, being mostly decumbent with heads few, singly terminating peduncles that are unusually long for species that have been placed in the broad concept of Eupatorium. The latter features, however, are not consistent for the entire genus.

The relationships of Praxelis have not been as accurately recognized in the traditional treatments of the Eupatorieae. As part of Eupatorium. Praxelis was usually placed among the latter sections of the genus rear Campuloclinium and Conoclinium which had similar conical receptacles, while the members of Chromolaena in the section Cylindrocephala were placed first (J. Baker, 1876; B. Robinson, 1918b; Barroso, 1950). DeCandolle (1836) did place his Ooclinium adjacent to his monotypic Chromolaena in the treatment of the tribe, but the proximity is not explained and seems rather accidental. While the receptacle may have been one reason for the separation, the shape of the heads has undoubtedly contributed. The heads in Praxelis are generally campanulate, while most of Chromolaena has cylindrical heads. Species of Chromolaena with campanulate heads on long erect peduncles as in Praxelis, such as $C$. decumbens, have tended to be misidentified as members of the latter genus.

There are three characteristics of Praxelis that appear to be structurally interrelated. The asymmetrical carpopodia and the obcompressed achenes on which they are borne seem to have a shape mandated by the shape of the conical receptacle against which they fit. In various Argentinian specimens of Praxelis clematidea in which the receptacles are less conical, the carpopodia are less asymmetrical.

The fact that some specimens of Praxelis clematidea approach Chromolaena in the form of their receptacles and carpopodia does not seem to reflect close relationship beween the two. The carpopodia of Chromolaena usually have a second layer of cells on the surface, and the cells have thicker walls. Also, the corollas of Chromolaena rarely show the papillosity of the inner surface extending well down into the throat as in Praxelis. The closest relationship of the Praxelis appear to be with some of the smaller Brazilian genera with a reduced pappus such as Eupatoriopsis and Eitenia which also have conical or columnar receptacles and asymmetrical carpopodia.

The genus Praxelis remains comparatively uniform in most of its characters. Some species such as $P$. insignis and $P$. missiona seem to have mostly single heads on long peduncles, and $P$. clematidea seems to have heads rather densely clustered, but other species such as $P$. pauciflora have inflorescences varying between both extremes. The only strikingly distinctive species is $P$. capillaris with its whorls of filiform leaves. The latter species is also notable for its very narrow strongly crenate anther appendages, but such appendages are found in a number of other species.

Most of the species of Praxelis are concentrated in Brazil, with a number also found in adjacent Paraguay, northern Argentina, and eastern Bolivia. Praxelis pauciflora is notable for its mostly Andean distribution, while $P$. asperulacea is one of the few non-scandent Eupatorieae common in the Amazon Basin.

The source of the name Praxelis was not explained by Cassini (1826b). The name Ooclinium of DeCandolle (1836), however, apparently refers to the oval silhouette of the bare receptacle.

The following 14 species are recognized in the genus:

Praxelis asperulacea (Baker) R. King \& H. Robinson, Venezuela, Guyana, Brazil.

Praxelis basifolia (Malme) R. King \& H. Robinson, Brazil.

Praxelis capillaris (DC.) Schultz-Bip., Brazil.

Praxelis chiquitensis (B. Robinson) R. King \& H. Robinson, Bolivia.

Praxelis clematidea (Griseb.) R. King \& H. Robinson, Argentina, Brazil, Paraguay, Bolivia.

Praxelis conoclinanthia (Hieron.) R. King \& H. Robinson, Bolivia.

Praxelis grandiflora (DC.) Schultz-Bip., Brazil.

Praxelis insignis (Malme) R. King \& H. Robinson, Brazil.

Praxelis karuaiensis (V. Badillo) R. King \& H. Robinson, Venezuela.

Praxelis kleinioides (H.B.K.) Schultz-Bip., Colombia, Venezuela. Peru, Bolivia, Brazil.

Praxelis missiona (Malme) R. King \& H. Robinson, Argentina, Brazil.

Praxelis odontodactyla (B. Robinson) R. King \& H. Robinson. Brazil.

Praxelis ostenii (B. Robinson) R. King \& H. Robinson, Paraguay. Praxelis pauciflora (H.B.K.) R. King \& H. Robinson, Colombia, Venezuela, Guyana, Peru, Brazil. 


\section{Chromolaena}

Chromolaena DC., Prodr. 5: 133. 1836. TYPE: Chromolaena horminö̈des DC.

Eupatorium section Cylindrocephala DC., Prodr. 5: 141. 1836. LECTOTYPE: Eupatorium odoratum L. [= Chromolaena odorata (L.) R. King \& H. Robinson].

Osmia Schultz-Bip., Pollichia 22-24: 251. 1866. TyPE: Eupatorium odoratum L.

Eupatorium section Osmia (Schultz-Bip.) Benth. ex Baker in C. Martius, Fl. Bras. 6(2): 275. 1876.

Eupatorium section Chromolaena (DC.) Benth. ex Baker in C. Martius, Fl. Bras. 6(2): 300. 1876.

Erect to somewhat scandent perennial herbs or shrubs, sparingly to densely branched. Stems terete to hexagonal, mostly pubescent. Leaves usually opposite, alternate in such species as $C$. cinereo-viride, $C$. stachyphylla, and $C$. vindex, rarely verticillate, sessile to shortly or moderately petiolate; blades mostly ovate or triangular to elliptical, sometimes linear, margins subentire to lobed, weakly to strongly trinervate from or near base, rarely pinnate with ascending veins as in C. moritziana, unicostate in $C$. pseudinsignis, with or without glandular punctations. Inflorescence usually thyrsoid to candelabriform with laxly to densely corymbose branches, seldom with solitary heads on long erect peduncles as in $C$. pseudinsignis; heads usually pedicellate or pedunculate, in incompletely separated complexes in C. cryptantha. Involucral bracts 18-65, densely imbricated in 4-6 strongly unequal graduated series, totally deciduous, outer bracts falling first, persistent outer bracts in some $C$. sinuata, ovate to lanceolate, often with expanded herbaceous or colored tips; receptacle flat to slightly convex, glabrous, sometimes with paleae. Florets $6-75$ in a head; corollas white, blue, lavender, or purple, rather cylindrical with scarcely narrower base; outer surface smooth below lobes, with few to many short-stalked glands, often with rather stiff hairs; cells of throat elongate with sinuous lateral walls, sometimes prorulose at upper end on inner surface; lobes rather oblong or ovate, slightly to distinctly longer than wide, usually densely papillose on inner surface, smooth in subgenus Osmiella, with cap of thick-walled often projecting cells distally on outer surface; anther collars usually broader below, narrowed above, with numerous subquadrate cells below, elongate cells above, cell walls with prominent annular thickenings on walls, transverse in longer cells, oblique or vertical in many shorter cells, collars not broadened below in subgenus Osmiella; anther appendage large, oblong, ca. 1.5 times as long as wide, entire or crenulate at tip; style base not enlarged, glabrous; style branches narrowly linear to slightly broadened distally, slightly mamillose to densely long-papillose. Achenes prismatic, 5-ribbed, rarely 3-ribbed, with setulae mostly on ribs, sometimes with glands; carpopodium distinct, short-cylindrical or narrowed below, cells small, mostly subquadrate or wider than high, in ca. 7-10 tiers in outer layer of thick-walled cells, with inner layer of larger sclerified cells; pappus of ca. 40 slender scabrid persistent bristles in 1 series, not or scarcely broadened distally, apical cells acute. Pollen grains ca. $20-22 \mu \mathrm{m}$ in diameter, often with larger abnormally shaped grains resulting from irregular meiosis. Chromosome number $n=10,2029$, ca. 40, 50, $2 n=58$. Plate 154 .

Chromolaena is one of the largest genera of the Eupatorieae, as presently recognized, with over 165 known species. The genus is distinct among the Praxelinae by its pappus of numerous capillary bristles, its flat to scarcely convex receptacle, and its slender corollas with lobes longer than wide. The genus differs from Praxelis, which has the only older name in the subtribe, by the prismatic, usually five-ribbed achenes with symmetrical carpopodia, by the presence of an outer layer of cells on the carpopodium, and by the non-conical receptacle. Some species of Chromolaena that show the single heads on long erect peduncles of the type common in Praxelis are regarded as the product of convergent evolution and are not considered evidence of close relationship.

Because of the capillary pappus, most of the species of Chromolaena have been placed in the broad concept of Eupatorium in the traditional systems of classification.
The species have mostly been placed in a section Cylindrocephala that is widely regarded as quite distinctive, and which has occasionally been recognized at the generic level under the name Osmia (Bolick, 1977). The name Chromolaena, which has often been maintained for a separate section in Eupatorium with broader heads and sometimes paleaceous receptacles, is not distinguishable and is an older name at the generic level. A few species with less obviously imbricate involucres, such as the alternate-leaved C. campestris and C. stachyophylla of Brazil, were previously placed in the section Subimbricata of Eupatorium which otherwise consisted almost entirely of other genera. Blake (1938), evidently unaware of typical Chromolaena of Brazil, placed a paleaceous species from Central America in the genus Eupatoriastrum to which there is no close relationship. Other placements of species seem rather incidental, $C$. decumbens having been placed 


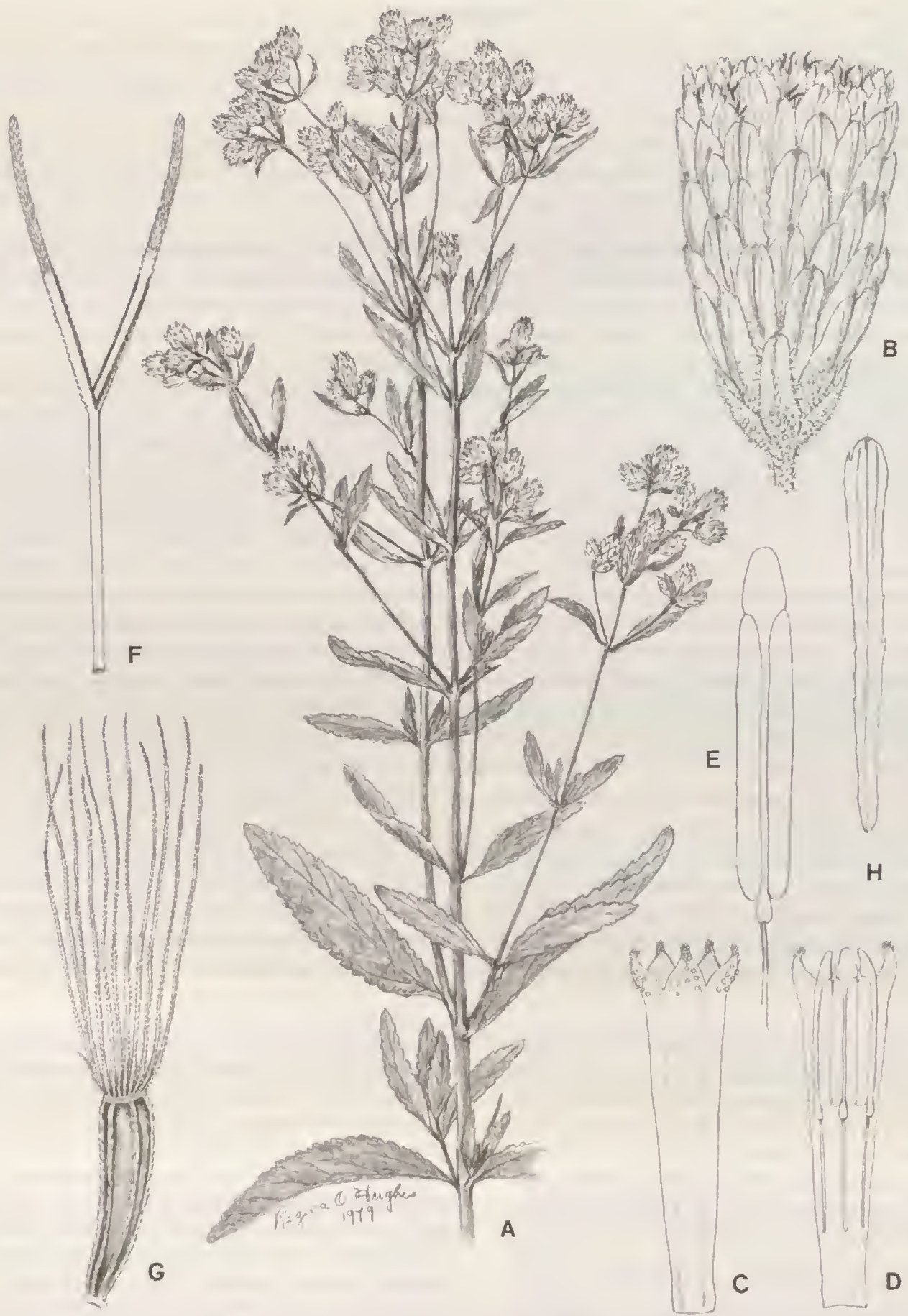

Plate 154. Chromolaena horminioides DC. - A. Habit, $\times 1 / 2,-B$. Head, $\times 4 \frac{1}{2},-$ C. Corolla outer surface, $\times 10 .-D$. Corolla inner surface with anthers, $\times 10 .-E$. Anther, $\times 22 .-F$. Style, $\times 10 .-$ G. Achene, $\times 10 .-$ H. Palea, $\times 7$. 
in the section Praxelis (J. Baker, 1876) apparently on the basis of misidentified material, and $C$. gentianoïdes being placed in Brickellia (B. Robinson, 1923) primarily because of the seemingly evenly 9-10-ribbed achenes.

In spite of the basic uniformity in Chromolaena, some obvious and significant variations are evident in the genus. The type of inflorescence with solitary, thyrsoid, and corymbose forms, and the elaborations on the tips of the involucral bracts, sometimes approaching the form in the Heliantheae, are the most obvious types of variation in the genus. Nevertheless, such variations are scattered widely in the typical elements of the genus in South America and as far north as Mexico and the United States. Some of the more significant variations are evident in the species that range north of South America. A small group native to the Lesser Antilles is notable for having trigonous achenes, but these are in no way obcompressed as in the genus Praxelis. Other northern elements of the genus have comparatively smooth corolla lobes and weakly mamillose style branches and have anther collars not enlarged below. These latter forms, including $C$. sinuata of the Greater Antilles, and the subgenus Osmiella of Mexico and Central America, are more Critoniine in their characters and seem to be part of a swarm resulting from the intersubtribal hybridizations that produced the genus Osmiopsis

The genus Chromolaena has its greatest number of species, and except for the products of the intersubtribal hybridization, has its greatest diversity in Brazil, where the other genera of the subtribe are concentrated. Chromolaena has many species in other parts of South America, however, and northward to Mexico and the southeastern United States. Only Praxelis among the other pure Praxelinae has species outside of Brazil. In addition to the many species of Chromolaena endemic to various parts of tropical America, there are three extremely widespread species, C. laevigata which ranges from Mexico to Argentina, C. ivaefolia which ranges from the United States south to Argentina, and $C$. odorata, the best known species of the genus, which ranges from the United States south to Argentina with introductions into Asia and Africa. The latter weedy species has been studied for purposes of biological control (Cock \& Holloway, 1982).

Because of the placement of most species of Chromolaena in the section Cylindricephala in traditional treatments, previous keys under the broad concept of Eupatorium are comparatively useful. Included are the keys by B. Robinson to Mexico (1926b), Colombia (1918b), Venezuela and Ecuador (1918c), Peru (1919b), and Bolivia $(1920 b)$, and the key by Barroso (1950) for the species in Brazil. The only key available under the revised concept is that to the three most common species in the Flora of Panama (King \& Robinson, 1975y). Other papers in the present series dealing with Chromolaena include the original redelimitation of the genus (King \& Robinson, 1970q), and a number of subsequent additions and corrections in which some species distinctions are discussed (King \& Robinson, 1972jj, 1975q, 1975x, 1977b, 1977d, 1978l. 1980o; Huber, 1977).

The genus Chromolaena shows many examples of polyploidy and other high chromosome numbers ( $R$. King et al., 1976). Irregular meiosis and apomixis are apparently common in the genus, as indicated by the wide occurrence of Type II pollen.

Label data on some specimens of Chromolaena odorata indicate use of the plant as a fish poison. The responsible chemicals are not certain. Chemical analysis of that and other species shows that cadinene derivatives, including furocadinenes, are unusually common in the genus (Bohlmann et al., 1979c, 1981h, 1982f). Prostaglandin-like fatty acids have been reported from two Brazilian species, C. chaseae and C. morii (Bohlmann et al., 1981 h, 1982a, 1982f). Phloroglucinol-based anthochlors have been reported from the leaves of C. odorata (Bose et al., 1973), the only reports of anthochlors presently known in the tribe.

The generic name is derived from the Greek words chroma $(=$ color) and laina (= cloak), evidently in reference to the colored involucral bracts found in some species including the type.

The following 165 species are recognized in the genus:

Chromolaena adenolepis (Schultz-Bip. ex Baker) R. King \& H. Robinson, Brazil.

Chromolaena alvimii R. King \& H. Robinson, Brazil.

Chromolaena anachoretica (B. Robinson) R. King \& H. Robinson, Peru.

Chromolaena angusticeps (Malme) R. King \& H. Robinson, Brazil.

Chromolaena aridicola V. Badillo, Venezuela.

Chromolaena arnottiana (Griseb.) R. King \& H. Robinson. Argentina, Bolivia.

Chromolaena arrayana (Gardner) R. King \& H. Robinson, Brazil.

Chromolaena ascendens (Schultz-Bip. ex Baker) R. King \& H. Robinson, Argentina, Brazil, Paraguay.

Chromolaena asperrima (Schultz-Bip. ex Baker) R. King \& H. Robinson, Brazil.

Chromolaena austera (B. Robinson) R. King \& H. Robinson, Bolivia.

Chromolaena bahamensis (Northrop) R. King \& H. Robinson, Bahamas.

Chromolaena bangii (Rusby) R. King \& H. Robinson, Bolivia, Peru.

Chromolaena barbacensis (Hieron.) R. King \& H. Robinson, Brazil.

Chromolaena barranquillensis (Hieron.) R. King \& H. Robinson, Colombia.

Chromolaena barrosoae R. King \& H. Robinson, Brazil.

Chromolaena bathyphlebia (B. Robinson) R. King \& H. Robinson, Venezuela.

Chromolaena beckii R. King \& H. Robinson, Bolivia.

Chromolaena bertholdii (Schultz-Bip.) R. King \& H. Robinson, Mexico. 
Chromolaena bigelovii (A. Gray) R. King \& H. Robinson, Mexico.

Chromolaena borinquensis (Britton) R. King \& H. Robinson, Puerto Rico.

Chromolaena breedlovei R. King \& H. Robinson, Mexico.

Chromolaena brunneola (Baker) R. King \& H. Robinson, Brazil.

Chromolaena bullata (Klatt) R. King \& H. Robinson, Colombia.

Chromolaena caaguazuensis (Hieron.) R. King \& H. Robinson, Brazil, Paraguay.

Chromolaena caldensis (B. Robinson) R. King \& H. Robinson, Colombia.

Chromolaena callilepis (Schultz-Bip, ex Baker) R. King \& H. Robinson, Brazil.

Chromolaena campestris (DC.) R. King \& H. Robinson, Brazil.

Chromolaena chaseae (B. Robinson) R. King \& H. Robinson, Brazil.

Chromolaena christieana (Baker) R. King \& H. Robinson, Argentina, Brazil, Paraguay.

Chromolaena chry'sosticta (B. Robinson) R. King \& H. Robinson, Colombia.

Chromolaena cinereoviridis (Schultz-Bip. ex Baker) R. King \& H. Robinson, Brazil.

Chromolaena collina (DC.) R. King \& H. Robinson, Mexico, Guatemala, El Salvador. Honduras, Costa Rica.

Chromolaena columbiana (Heering) R. King \& H. Robinson, Colombia, Venezuela.

Chromolaena congesta (Hook. \& Arn.) R. King \& H. Robinson, Brazil, Uruguay.

Chromolaena connivens (Rusby) R. King \& H. Robinson, Peru, Bolivia.

Chromolaena corymbosa (Aublet) R. King \& H. Robinson, West Indies, French Guiana.

Chromolaena costatipes (B. Robinson) R. King \& H. Robinson, Brazil.

Chromolaena cryptantha (Schultz-Bip. ex Baker) R. King \& H. Robinson, Brazil.

Chromolaena cylindrocephala (Schultz-Bip. ex Baker) R. King \& H. Robinson, Brazil.

Chromolaena decumbens Gardner, Brazil.

Chromolaena densiflora (Morong) R. King \& H. Robinson, Paraguay.

Chromolaena desmocephala (B. Robinson) R. King \& H. Robinson, Bolivia.

Chromolaena diaphanophlebia (B. Robinson) R. King \& H. Robinson, Colombia.

Chromolaena dussii (Urban) R. King \& H. Robinson, Guadeloupe.

Chromolaena elliptica (Hook. \& Am.) R. King \& H. Robinson, Argentina, Brazil.

Chromolaena epaleacea Gardner, Brazil.

Chromolaena eripsima (B. Robinson) R. King \& H. Robinson, Peru.

Chromolaena extensa (Gardner) R. King \& H. Robinson, Brazil, Bolivia, Peru.

Chromolaena farinosa (B. Robinson) R. King \& H. Robinson, Venezuela.

Chromolaena ferruginea $\mathbf{R}$. King \& $\mathbf{H}$. Robinson, Brazil.

Chromolaena frustrata (B. Robinson) R. King \& H. Robinson, Florida.

Chromolaena gentianoides (B. Robinson) R. King \& H. Robinson, Brazil.
Chromolaena geranifolia (Urban) R. King \& H. Robinson, Puerto Rico.

Chromolaena glaberrima (DC.) R. King \& H. Robinson, Mexico, Guatemala, El Salvador, Belize, Honduras, Nicaragua, Costa Rica.

Chromolaena haenkeana (DC.) R. King \& H. Robinson, Mexico.

Chromolaena haughtii (B. Robinson) R. King \& H. Robinson, Peru.

Chromolaena herzogii (B. Robinson) R. King \& H. Robinson, Bolivia.

Chromolaena heteroclinia (Griseb.) R. King \& H. Robinson, Jamaica.

Chromolaena heterosquamea (Urban \& E. Ekman) R. King \& H. Robinson, Dominican Republic.

Chromolaena hirsuta (Hook. \& Arn.) R. King \& H. Robinson, Argentina, Brazil, Uruguay.

Chromolaena hookeriana (Griseb.) R. King \& H. Robinson, Argentina, Brazil.

Chromolaena horminoides DC., Brazil.

Chromolaena hypericifolia (H.B.K.) R. King \& H. Robinson, Colombia.

Chromolaena hypodictya (B. Robinson) R. King \& H. Robinson, Guatemala.

Chromolaena integrifolia (Bert. ex Sprengel) R. King \& H. Robinson, Guadeloupe.

Chromolaena iridolepis (B. Robinson) R. King \& H. Robinson, Colombia.

Chromolaena ivaefolia (L.) R. King \& H. Robinson, SE United States, Greater Antilles, Lesser Antilles, Mexico, Central America, South America.

Chromolaena jelskii (Hieron.) R. King \& H. Robinson, Peru.

Chromolaena kleinii (Cabrera) R. King \& H. Robinson, Brazil.

Chromolaena laevigata (Lam.) R. King \& H. Robinson, Mexico, Central America, South America.

Chromolaena larensis (V. Badillo) R. King \& H. Robinson, Venezuela.

Chromolaena latisquamulosa (Hieron.) R. King \& H. Robinson, Argentina, Brazil.

Chromolaena leivensis (Hieron.) R. King \& H. Robinson, Colombia.

Chromolaena leptocephala (DC.) R. King \& H. Robinson, Colombia, Ecuador, Peru.

Chromolaena leucocephala Gardner, Brazil.

Chromolaena lilacina (Hieron.) R. King \& H. Robinson, Brazil.

Chromolaena lucayana (Britton) R. King \& H. Robinson, Bahamas.

Chromolaena lundelii $\mathbf{R}$. King \& $\mathbf{H}$. Robinson, Guatemala.

Chromolaena luquensis (Chodat) R. King \& H. Robinson, Paraguay.

Chromolaena macrantha (Sw.) R. King \& H. Robinson, West Indies.

Chromolaena mallota (B. Robinson) R. King \& H. Robinson, Bolivia.

Chromolaena margaritensis (Hassler) R. King \& H. Robinson, Brazil, Paraguay.

Chromolaena mattogrossensis (Hieron.) R. King \& H. Robinson, Brazil.

Chromolaena maximilianii (Schrader ex DC.) R. King \& H. Robinson, Brazil.

Chromolaena mendezii (DC.) R. King \& H. Robinson, Mexico.

Chromolaena meridensis (B. Robinson) R. King \& H. Robinson, Venezuela. 
Chromolaena minasgeraesensis (Hieron.) R. King \& H. Robinson, Brazil.

Chromolaena misella (McVaugh) R. King \& H. Robinson, Mexico.

Chromolaena molina (B. Robinson) R. King \& H. Robinson, Venezuela.

Chromolaena mononeura (Urban) R. King \& H. Robinson, Lesser Antilles (Dominica).

Chromolaena morii R. King \& H. Robinson, Brazil.

Chromolaena moritensis (Aristeg.) R. King \& H. Robinson, Venezuela.

Chromolaena moritziana (Schultz-Bip. ex Hieron.) R. King \& H. Robinson, Venezuela.

Chromolaena mucronata (Gardner) R. King \& H. Robinson, Brazil.

Chromolaena multiflosculosa (DC.) R. King \& H. Robinson, Brazil.

Chromolaena myriadenia R. King \& H. Robinson, Brazil.

Chromolaena inyriocephala (Gardner) R. King \& H. Robinson, Brazil.

Chromolaena odorata (L.) R. King \& H. Robinson, SE United States, West Indies, Mexico, Central America, South America, widely adventive in paleotropics.

Chromolaena oinopolepis (Malme) R. King \& H. Robinson, Brazil.

Chromolaena opadoclinia (S. F. Blake) R. King \& H. Robinson, Mexico.

Chromolaena orbignyana (Klatt) R. King \& H. Robinson, Argentina, Paraguay.

Chromolaena ortegae (B. Robinson) R. King \& H. Robinson, Mexico.

Chromolaena ossaeana (DC.) R. King \& H. Robinson, West Indies.

Chromolaena oteroi (Monach.) R. King \& H. Robinson, Puerto Rico.

Chromolaena oxylepis (DC.) R. King \& H. Robinson, Brazil.

Chromolaena oyadensis (Hieron.) R. King \& H. Robinson, Argentina, Paraguay.

Chromolaena palmaris (Schultz-Bip. ex Baker) R. King \& H. Robinson, Brazil.

Chromolaena paraguariensis (Hieron.) R. King \& H. Robinson, Paraguay.

Chromolaena parviceps (Malme) R. King \& H. Robinson, Brazil.

Chromolaena pedalis (Schultz-Bip. ex Baker) R. King \& H. Robinson, Brazil.

Chromolaena pedunculosa (Hook. \& Am.) R. King \& H. Robinson, Argentina. Brazil.

Chromolaena pellia (Klatt) R. King \& H. Robinson, Venezuela.

Chromolaena perforata (Schultz-Bip. ex Baker) R. King \& H. Robinson, Brazil.

Chromolaena perglabra (B. Robinson) R. King \& H. Robinson, Colombia.

Chromolaena perijaensis R. King \& H. Robinson, Colombia.

Chromolaena persericea R. King \& H. Robinson, Colombia, Venezuela.

Chromolaena pharcidodes (B. Robinson) R. King \& H. Robinson, Venezuela, Guyana.

Chromolaena picta (Gardner) R. King \& H. Robinson, Brazil.

Chromolaena porophylloides (B. Robinson) R. King \& H. Robinson, Bolivia.

Chromolaena porphyrolepis (Baker) R. King \& H. Robinson, Brazil.
Chromolaena pseudinsignis R. King \& H. Robinson, Brazil.

Chromolaena pulchella (H.B.K.) R. King \& H. Robinson, Mexico.

Chromolaena punctulata (DC.) R. King \& H. Robinson, Brazil. Chromolaena pungens (Gardner) R. King \& H. Robinson, Brazil. Chromolaena quercetorum (L. O. Williams) R. King \& H. Robinson, Mexico, Guatemala.

Chromolaena revoluta (Gardner) R. King \& H. Robinson, Brazil. Chromolaena rhinanthacea (DC.) R. King \& H. Robinson. Brazil.

Chromolaena rigida (Sw.) R. King \& H. Robinson, Jamaica.

Chromolaena rojasii (Hassler) R. King \& H. Robinson, Paraguay.

Chromolaena roseorum (B. Robinson) R. King \& H. Robinson, Ecuador.

Chromolaena sagittata (A. Gray) R. King \& H. Robinson, Mexico.

Chromolaena sagittifera (B. Robinson) R. King \& H. Robinson, Brazil.

Chromolaena sanctopaulensis (B. Robinson) R. King \& H. Robinson, Argentina, Brazil.

Chromolaena santanensis (Aristeg.) R. King \& H. Robinson, Venezuela.

Chromolaena scabra (L. f.) R. King \& H. Robinson, Colombia.

Chromolaena serratuloides (H.B.K.) R. King \& H. Robinson, Peru.

Chromolaena sinuata (Lam.) R. King \& H. Robinson, Greater Antilles.

Chromolaena squalida (DC.) R. King \& H. Robinson, Brazil, Peru, Venezuela.

Chromolaena squarroso-ramosa (Hieron.) R. King \& H. Robinson, Argentina, Brazil, Bolivia.

Chromolaena squarrulosa (Hook. \& Arn.) R. King \& H. Robinson, Argentina, Brazil, Paraguay, Uruguay.

Chromolaena stachyophylla (Sprengel) R. King \& H. Robinson, Brazil, Bolivia.

Chromolaena steyermarkiana (V. Badillo) R. King \& H. Robinson, Venezuela.

Chromolaena stillingiaefolia (DC.) R. King \& H. Robinson, Mexico.

Chromolaena subscandens (Hieron.) R. King \& H. Robinson, Colombia, Venezuela.

Chromolaena suratensis (B. Robinson) R. King \& H. Robinson, Colombia.

Chromolaena tacotana (Klatt) R. King \& H. Robinson, Colombia.

Chromolaena tecta (Gardner) R. King \& H. Robinson, Brazil.

Chromolaena tenuicapitulata (Hieron.) R. King \& H. Robinson, Peru.

Chromolaena thurnii (B. Robinson) R. King \& H. Robinson, Venezuela, Brazil.

Chromolaena toldensis (Hieron.) R. King \& H. Robinson, Argentina, Bolivia.

Chromolaena trigonocarpa (Griseb.) R. King \& H. Robinson, Lesser Antilles (Dominica).

Chromolaena trujillensis (B. Robinson) R. King \& H. Robinson, Venezuela.

Chromolaena tunariensis (Hieron.) R. King \& H. Robinson, Bolivia.

Chromolaena tyleri (B. Robinson) R. King \& H. Robinson, Ven. ezuela.

Chromolaena ulei (Hieron.) R. King \& H. Robinson, Brazil. 
Chromolaena umbelliformis (Dusén ex Malme) R. King \& H. Robinson, Brazil.

Chromolaena uromeres (B. Robinson) R. King \& H. Robinson, Colombia.

Chromolaena urticoides (Schultz-Bip. ex Hieron.) R. King \& H. Robinson, Venezuela.

Chromolaena verbenacea (DC.) R. King \& H. Robinson, Argentina, Brazil, Paraguay.

Chromolaena verticillata $\mathrm{R}$. King \& $\mathrm{H}$. Robinson, Brazil.
Chromolaena vindex (DC.) R. King \& H. Robinson, Brazil. Chromolaena voglii (B. Robinson) $\mathrm{H}$. Huber, Venezuela.

Chromolaena xestolepidoides (Wurd.) R. King \& H. Robinson, Venezuela.

Chromolaena xestolepis (B. Robinson) R. King \& H. Robinson, Venezuela.

Chromolaena xylorhiza (Schultz-Bip. ex Baker) R. King \& H. Robinson, Brazil.

\section{Eupatoriopsis}

Eupatoriopsis Hieron., Bot. Jahrb. Syst. 18(Beibl. 43): 46. 1893. TYPE: Eupatoriopsis hoffmanniana Hieron.

Erect annual herbs, sparingly branched. Stems terete, striated, hirsute. Leaves opposite, subsessile to shortpetiolate; blades ovate to rather elliptical, bases narrowly acuminate or cuneate, margins serrate, apex shortacute, trinervate from above base, without obvious glandular punctations on lower surface. Inflorescence laxly cymose; pedicels long and slender, erect. Involucral bracts ca. 12-14, weakly subimbricate in ca. 1-2 slightly unequal to subequal series, mostly membranaceous or scarious, outer bracts somewhat persistent; receptacle very highly conical to columnar, glabrous. Florets ca. 30 in a head; corollas lilac, short-funnelform, with very short basal tube, glabrous on outer surface below lobes; cells of throat elongate often with sinuous lateral walls, prorulose above on inner surface by projecting upper ends of cells, single ducts along veins of throat often with colored resin; lobes broadly triangular, about as long as wide, tips and inner surface densely long-papillose, outer surface with glands; anther collars expanded below, narrower above, with many subquadrate or shorter cells in lower part, elongate cells above, cell walls with prominent beaded or annular thickenings, lines often oblique to vertical in lower cells; anther appendages narrower than thecae, subquadrate; style base not enlarged, glabrous; style branches narrowly linear, slightly broadened in distal half, densely papillose. Achenes broadly obcompressed, slightly obcordate, usually with 2 ribs, with numerous short setulae on ribs; carpopodium distinct, asymmetrical, turned to adaxial side, cells subquadrate in ca. 5 series, with thin slightly porose walls; pappus of ca. 18-20 very short, unequal, densely barbellate bristles in one series, persistent, apical cells acute. Pollen grains ca. $20 \mu \mathrm{m}$ in diameter. Plate 155.

The genus Eupatoriopsis was established by Hieronymus (1893) for the distinctive annual species from Brazil showing a reduced pappus, a highly conical receptacle, and strongly subalately obcompressed achenes. Because of the reduced pappus and the anther appendage that appeared small compared to the broad thecae, the genus was placed in the Piqueriinae. Although, rather similar annual species having conical receptacles and obcompressed achenes were at that time placed in the broad concept of Eupatorium in the section Praxelis because of their pappus of numerous capillary bristles, there was no mention of the latter by Hieronymus. B. Robinson (1906) noted that the anther appendages of the genus were actually quite well developed, and stated that the true affinity was with Trichocoronis of the southwestern United States and Mexico. According to B. Robinson, the only claim to generic separation from Trichocoronis was the broad obovate quasi two-winged achene.

In the review of the Eupatorieae by H. Robinson and King (1977), Eupatoriopsis was placed in the Praxelis group on the basis of the characteristic anther collar with its broadened lower part, the densely papillose inner surfaces of the corolla lobes, and the deciduous bracts of the involucre. It is also in the Praxelinae where Praxelis and the more recently described Eitenia show conical receptacles, obcompressed achenes, and asymmetrical carpopodia similar to those of Eupatoriopsis. Praxelis differs by the less elongate receptacle, the more graduated involucral bracts, the 3-4-ribbed achenes, and the long capillary pappus. It is Eitenia that seems closest with 2-ribbed achenes, but it differs by the same receptacle and involucre characters as Praxelis, as well as the more cylindrical corollas, the asymmetric corolla lobes of the peripheral flowers in the heads, the longer pappus bristles that are sometimes of two types, and the narrower anther thecae.

The subequal thin and somewhat persistent involucral bracts of Eupatoriopsis are unlike other members of the subtribe Praxelinae, but because of the generally specialized nature of the genus, the character is presumed to be derived from more imbricate and totally deciduous types. The short broad corolla also distinguishes Eupatoriopsis from other members of the subtribe, where long cylindrical corollas are most common. The reddish resin ducts in the throat of the corolla are not particularly distinctive, 

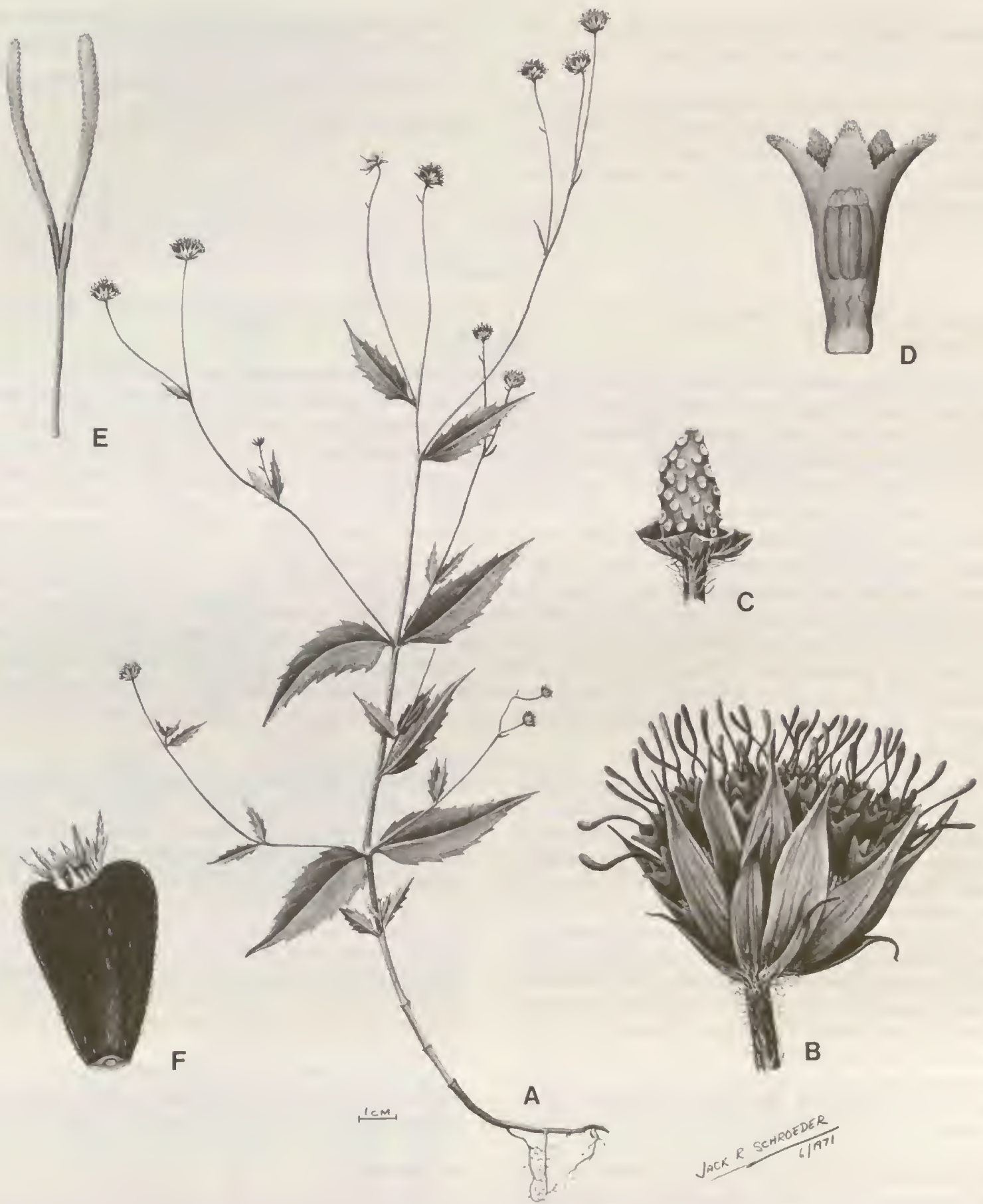

Plate 155. Eupatoriopsis hoffmanniana Hieron. - A. Habit, $\times 3 / 5 .-$ B. Head, $\times 7 .-$ C. Receptacle, $\times 7 .-$ D. Corolla showing anthers, $\times 20,-$ E. Style, $\times 20 .-F$. Achene, $\times 20$. 
such ducts being found to some extent in Eitenia, many species of Praxelis, and even some species of Chromolaena.

The single known species of Eupatoriopsis is known to us from only the type series from near Caldas in Minas Gerais, Brazil, and from a piece mixed in a Peperomia numularifolia collection by Herschen near Caldas during the same Regnell expedition.
The generic name is derived from the name Eupatorium and the Greek suffix -opsis which implies a likeness.

The following single species is recognized in the genus. Eupatoriopsis hoffmanniana Hieron., Brazil.

\section{Lomatozona}

Lomatozona Baker in C. Martius, Fl. Bras. 6(2): 198. 1876. TYPE: Lomatozona artemisiaefolia Baker in C. Martius.

Erect perennial herbs or subshrubs, moderately to densely branched, stems and leaves covered with minute uniseriate, rarely biseriate, stipitate glands. Stems terete, striated. Leaves opposite, petiolate; blades ovate in outline, margins lobed to deeply dissected, trinervate or trilobed from or near base, lower surface with very large sessile globular capitate glands. Inflorescence laxly cymose, pedicels short to long. Involucral bracts ca. 25, strongly imbricated, in ca. 3-4 strongly unequal graduated series, all deciduous, outer usually falling first; receptacle slightly convex, with or without paleae. Florets 10-27 in a head; corollas white or bluish, narrowly funnelform, with occasional glands on outer surface; cells of throat elongate, prorulose on inner surface with projecting upper ends; lobes triangular to rather oblong, up to 1.5 times longer than wide, densely papillose on inner surface, outer lobes of peripheral flowers longer in L. inaequale; anther collars short, slightly broader below, some subquadrate cells in lower part, elongate cells above, cell walls with prominent ornate beaded thickenings; anther appendage large, oblong-ovate, longer than wide; style base not enlarged, glabrous; style branches filiform, densely papillose. Achenes prismatic, mostly 5-ribbed, setuliferous, more densely setuliferous at base and apex; carpopodium lacking or poorly developed, symmetrical; pappus of 15-22 short unequal persistent scabrid bristles in 1 series, apical cells sharply acute. Pollen grains ca. $20-22 \mu \mathrm{m}$ in diameter. Plate 156.

The genus Lomatozona was known for almost a hundred years on the basis of a single species from the interior of Brazil that had a pappus of short bristles, an imbricated involucre, a few paleae among the flowers, and dissected leaves. The genus was keyed by J. Baker (1876) near Ageratum and was placed in the sequence between Ageratum and Stevia. Nevertheless, Baker noted in his treatment of the genus that the involucre was like that of Eupatorium section Praxelis. The key to the genera of the Eupatorieae by B. Robinson (1913a) tended to emphasize the multiseriate unequal involucral bracts as a character and mentioned the bipinnatifid leaves. Formal recognition of relationship to the Praxelis group did not occur until the survey of the tribe by H. Robinson and King (1977).

During the period of the present series of studies, three additional species were added to the genus in rapid succession (King \& Robinson, 1975o, 1978f, 1979d). All three species differed from the type species by their longer pedicels and the epaleaceous receptacles. Still, the three were from the same general area as the type in Goyas and adjacent Mato Grosso in the interior of Brazil, and had all the essential characters of a non-conical receptacle, narrow symmetrical bases on the achenes with indistinct carpopodia, and a pappus of short irregular bristles. The leaves of all the species tended to be weakly to strongly lobed. More convincing evidence of the relationship is obtained from the examination of the glands. In all the species there are unusually large globose sessile glands on the undersurfaces of the leaves. Also, the minute stipitate glands on the leaves and stems in Lomatozona are often entirely uniseriate, a condition scarcely known in the Asteraceae. Glandular hairs in the family seem to be basically biseriate, and the type in Lomatozona seems to be specialized from such types with which they are sometimes intermixed. Only in Paraqueria, elsewhere in the Eupatorieae, are there uniseriate glandular hairs, the latter occurring on the corolla lobes.

Among the more recently described species, $L$. inaequale is distinctive in its asymmetrical peripheral flowers, having longer outer lobes and a more strongly prorulose inside surface of the throat on the side nearest the center of the head.

Label data indicates that all members of the genus are rupestral, occurring on or between rocks. Only the type species is known at present from more than one or two collections. A key to the species has been provided by King and Robinson (1979d).

The generic name is derived from the Greek words loma -tos (= fringe or border) and zone (= belt or girdle). The name refers to the pappus which was described by J. Baker 


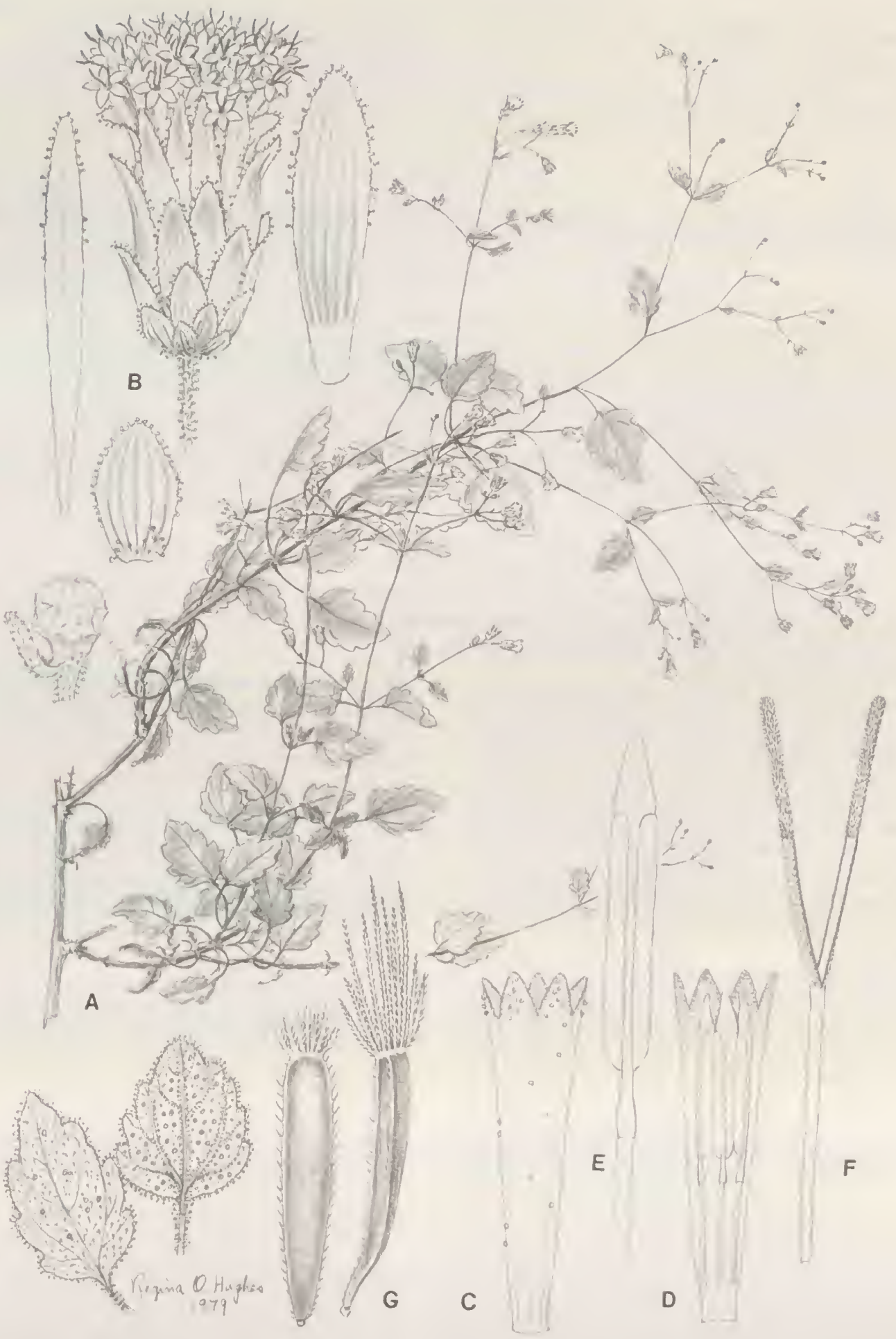

PLATE 156. Lomatozona andersonii R. King \& H. Robinson. - A. Habit, $\times 1 / 2$, with pair of separate enlarged leaves - B. Head, $\times 7$. with separate enlarged receptacle and representative involucral bracts. $-\mathrm{C}$. Corolla outer surface, $\times 20 .-\mathrm{D}$. Corolla inner surface with anthers, $\times 20 .-E$. Anther, $\times 40 .-F$. Style, $\times 20 .-G$. Achenes, outside and lateral views, $\times 20$. 
(1876) as "brevisimus coroniformis, setis inaequalibus basi in annulum confluentius."

The following four species are recognized in the genus:
Lomatozona andersonii R. King \& H. Robinson, Brazil. Lomatozona artemisiaefolia Baker, Brazil. Lomatozona huntii R. King \& H. Robinson, Brazil. Lomatozona inaequale $\mathrm{R}$. King \& H. Robinson, Brazil.

\section{Praxeliopsis}

Praxeliopsis G. Barroso, Arq. Jard. Bot. Rio de Janeiro 9: 176. 1949. TYPE: Praxeliopsis mattogrossensis G. Barroso.

Erect annual or short-lived perennial herbs, with few branches, stems, leaves, branches of inflorescence, and involucral bracts essentially glabrous. Stems terete. Leaves alternate, sessile, linear, entire, with an apical callus, 1-nerved. Inflorescence laxly cymose, pedicels very long. Involucral bracts ca. 20-25, imbricated in ca. 3 strongly unequal series, ca. 7 subequal inner bracts and shorter outer bracts, all easily deciduous; receptacle conical, glabrous. Florets ca. 16 in a head; corollas whitish?, salverform, with elongate narrowly funnelform basal tube, glabrous on both surfaces; throat very short and spreading, with large short-oblong non-bulging cells; lobes unequal, oblong-ovate or with outer lobe oblong-linear, 1.5-3 times as long as wide, densely papillose on inner surface; anthers borne slightly below bases of lobes, exserted above the spreading lobes; anther collars short and broad, broader below, cells mostly subquadrate or shorter, with prominent beaded or annular thickenings on walls, often oblique or vertical in shorter cells; anther appendage rudimentary or lacking; style base enlarged, glabrous; style branches filiform, densely papillose. Achenes prismatic, 5 -ribbed, with numerous long setulae mostly on ribs; carpopodia small, distinct, symmetrical, cells quadrate, in ca. 3 tiers, with thick walls; pappus of 5 stout scabrid persistent bristles, narrowed distally, apical cells acute. Pollen grains ca. $20 \mu \mathrm{m}$ in diameter. Plate 157.

The genus Praxeliopsis has the general appearance of a Praxelis as noted by Barroso (1949) and as reflected in the name given to the genus. Membership in the subtribe Praxelinae is not in doubt since the plant involved shows the totally deciduous involucre, the distinctive anther collar, and the papillose corolla lobes and style branches that are characteristic of that group. The genus is the most individually distinctive member of the subtribe, however, and does not fall close to any of the other members of the group on the basis of the traditional systems of classification of the tribe.

The actual position given to Praxeliopsis by Barroso (1949) was in the subtribe Piqueriinae, because of the absence of an anther appendage. No other genus of the Praxelinae lacks an anther appendage, and only Osmiopsis has an appendage shorter than wide. The pappus, with its reduced number of bristles, also distinguishes the genus from other Praxelinae except Eitenia, and caused Barroso to seek comparisons for Praxeliopsis with the Mexican genus Podophania now placed in Hofmeisteria. Praxeliopsis does not have either the flattened achenes of Eitenia or the pseudoverticillate leaves subtending the inflorescences as in the Hofmeisteriinae. Praxeliopsis does show an enlarged node at the base of the style, a feature not seen in any other members of the Praxelinae or in the related Critoniinae or Hebecliniinae. The corolla is also unique in the tribe by its elongate basal tube and its anthers mounted near the base of the spreading lobes. One feature emphasized by Barroso (1949), the unequal lobes of the corolla, is approached by members of Eitenia and Lomatozona which have longer outer lobes on the peripheral corollas of the head. Still, the outer lobes in Praxeliopsis are very well developed, and are exceeded in zygomorphy in the tribe only in the ray-like peripheral corollas of Microspermum in the Ageratinae. The highly conical receptacle of Praxeliopsis resembles those of Praxelis, Eitenia, and Eupatoriopsis, but the carpopodium does not seem to be asymmetrical as in those genera.

The leaves of the rather depauperate type specimen of Praxeliopsis mattogrossensis have been examined with the thought that they might be only petioles that had lost their blades. The detailed structure and the apical callus seem to indicate that the leaves are complete as seen. Such reduced leaves might be expected on a plant of rather xeric habitats.

The single species of Praxeliopsis is presently known from only one collection from the campos dos Urupós, cab. do Centario, Catagui-iamain, Mato Grosso, in the interior of Brazil.

As indicated by Barroso (1949), the name of the genus is derived from the generic name Praxelis with the Greek suffix -opsis indicating similarity.

The following single species is recognized in the genus: Praxeliopsis mattogrossensis G. Barroso, Brazil. 



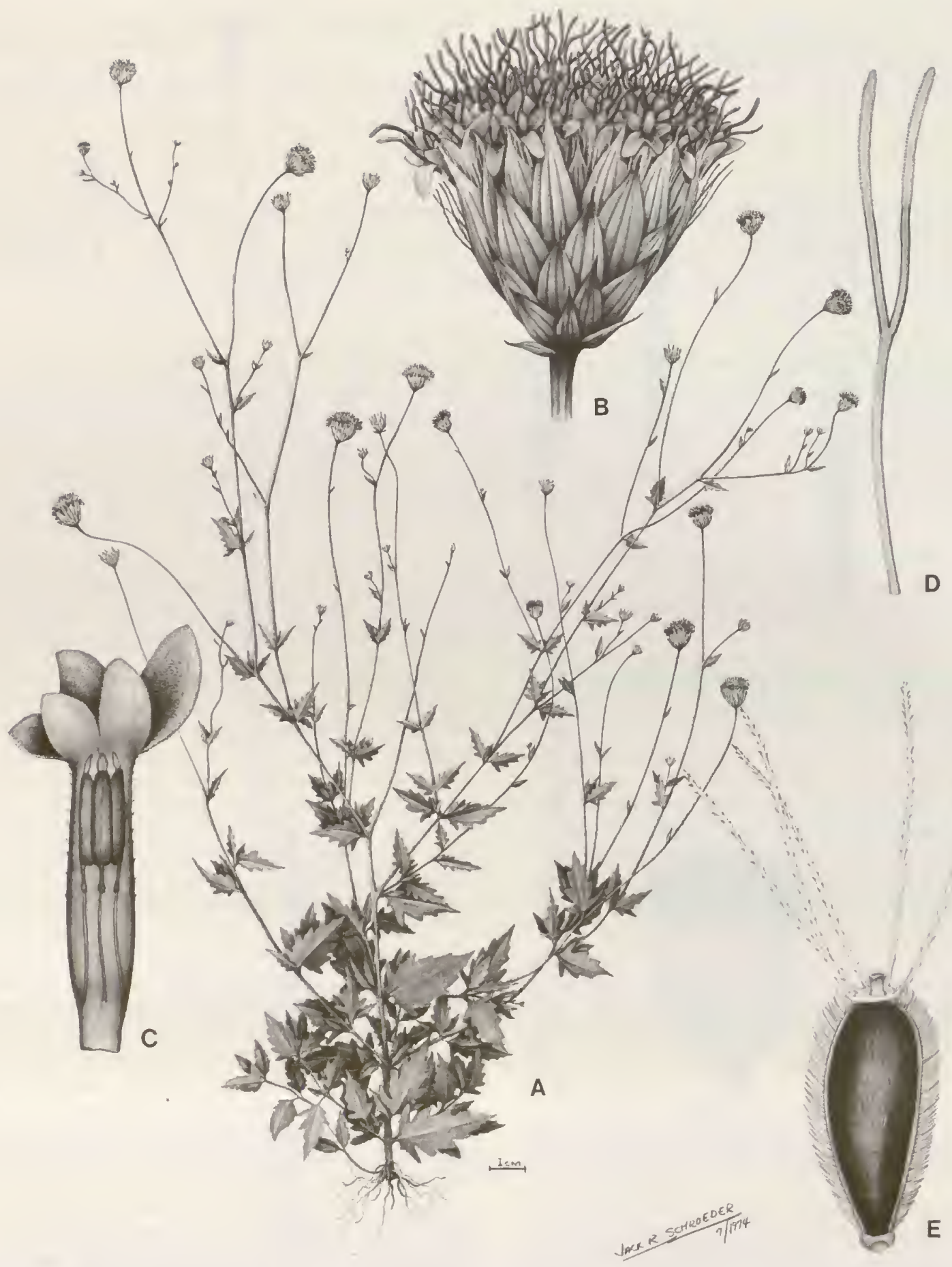

PlATE 158. Eitenia praxeloides R. King \& H. Robinson. - A. Habit, $\times \$ \% .-B$. Head, $\times 5 .-$ C. Corolla showing anthers, $\times 14 .-D$. Style, $\times 14 .-$ E. Achene, $\times 14$. 


\section{Eitenia}

\section{Eitenia R. King \& H. Robinson, Phytologia 28: 282. 1974. TYPE: Eitenia praxeloides R. King \& H. Robinson.}

Erect annual or short-lived perennial herbs, with few to many branches. Stems terete, striated, hirsute. Leaves opposite, short-petiolate; blades ovate, base obtuse, margins coarsely serrate to sublobate, apex acute, trinervate from base, with glandular punctations on lower surface. Inflorescence a rather lax broadly cymose panicle; pedicels long. Involucral bracts ca. 22-35, imbricate in 3-4 strongly unequal graduated series, easily deciduous, outer bracts falling first, most bracts lanceolate; receptacle highly conical, glabrous. Florets ca. 40-50 in a head; corollas violet or white, narrowly funnelform, with long cylindrical throat; cells of throat elongate with sinuous lateral walls, prorulose on inner surface by projecting upper ends of cells, more projecting and often setiform along veins, also somewhat prorulose on outer surface; single narrow resin ducts along veins with intermittent reddish resin; lobes strongly unequal, with outer lobes of peripheral flowers much longer and wider, all lobes oblong, densely long-papillose on inner surface, prorulose and with few glands on outer surface; anther collars distinctly broadened in lower part, with subquadrate cells below, longer cells above, cells with usually prominent ornate banding on walls, transverse above, often oblique or vertical below; anther appendage narrowly oblong, ca. 1.5 times as long as wide; style base not enlarged, glabrous; style branches filiform, densely long-papillose. Achenes obcompressed, usually with 2 or rarely 3 ribs, densely long-setuliferous on ribs, with a few shorter setulae on surfaces; carpopodium distinct, asymmetrical with 8 opening turned adaxially, cells subquadrate in ca. 3 series, walls thin, weakly porose; pappus of usually 28 stout scabrid persistent bristles, sometimes with interspersed weaker bristles, in 1 series, narrowed distally,
apical cells sharply acute. Pollen grains ca. $18-20 \mu \mathrm{m}$ in diameter. Plate 158 .

Eitenia is one of the genera of the Eupatorieae, that has been named during the present series of studies, that would be generically distinct even by the traditional systems of classification. In the key to the traditional generic concepts by B. Robinson (1913a), the species of Eitenia would key variously to Dissothrix, now placed in the Alomiinae, which has pappus bristles of two types, or to Fleischmannia, now placed in the Fleischmanniinae, which was at that time distinguished by having a pappus of only five bristles. Eitenia is easily distinguished from both of these by its conical receptacle, its obcompressed achenes, and the unequal lobes on the corollas of its peripheral flowers.

The only significant comparison possible with any of the genera in the B. Robinson key is with Eupatoriopsis, a genus now placed in the Praxelinae. Eitenia is unquestionably a member of the subtribe, having the totally deciduous involucre and the unique form of anther collar that are characteristic of the Praxelinae. Both Eitenia and Eupatoriopsis show obcompressed achenes with only marginal ribs, an asymmetrical carpopodium, and a conical receptacle. Eupatoriopsis and Eitenia also have a similar trinervate condition of the leaves originating at the bases of the short petioles rather than at the bases of the blades. Eupatoriopsis differs by its short pappus of more numerous bristles, its short and broad corolla with short equal lobes, its broad anther thecae, the shorter uniform prorulosity on the inside of its corolla throats, the more nearly columnar receptacle, and the thinner more subequal somewhat persistent bracts of its involucre. The genus Praxelis is also close to Eitenia, having similar receptacles and carpopodia, and having somewhat obcompressed achenes. Nevertheless, Praxelis has a pappus of numerous equal capillary bristles, achenes with 3-4 ribs, and corollas with equal lobes. The other nembers of the Praxelinae having unequal lobes like Eitenia, the genus Praxeliopsis and Lomatozona inaequale, are plants with prismatic achenes and a number of other differences as detailed under those genera.

A feature of Eitenia noted in the original description (King \& Robinson, 1974h) was the presence of prorulosity on the inner surface of the corolla throat that becomes long and rather hair-like in the cells along the veins. The feature was only weakly developed in the second species, $E$. polyseta (King \& Robinson, 1979d). The resin ducts evident along the same veins, have only intermittent areas of reddish resin. Resin ducts are also evident in the shaft of the style inside of the veins in E. polyseta. Various other differences between the two known species are discussed by King and Robinson (1979d), and a number of these prove to be associated with the apomixis of $E$. polyseta. The latter species has defective pollen, small anthers, white rather than violet corollas, and appressed papillae on the style branches. The contrasting conditions in the type species all indicate maintenance of active pollination mechanisms and a normal sexual reproduction.

Both species of Eitenia occur in the area of Goiás and the Federal District, in the interior of Brazil.

The generic name honors George and Liene T. Eiten, the co-collectors of the original material of the type species.

The following two species are recognized in the genus:

Eitenia polyseta R. King \& H. Robinson, Brazil. Eilenia praxeloides R. King \& H. Robinson, Brazil. 


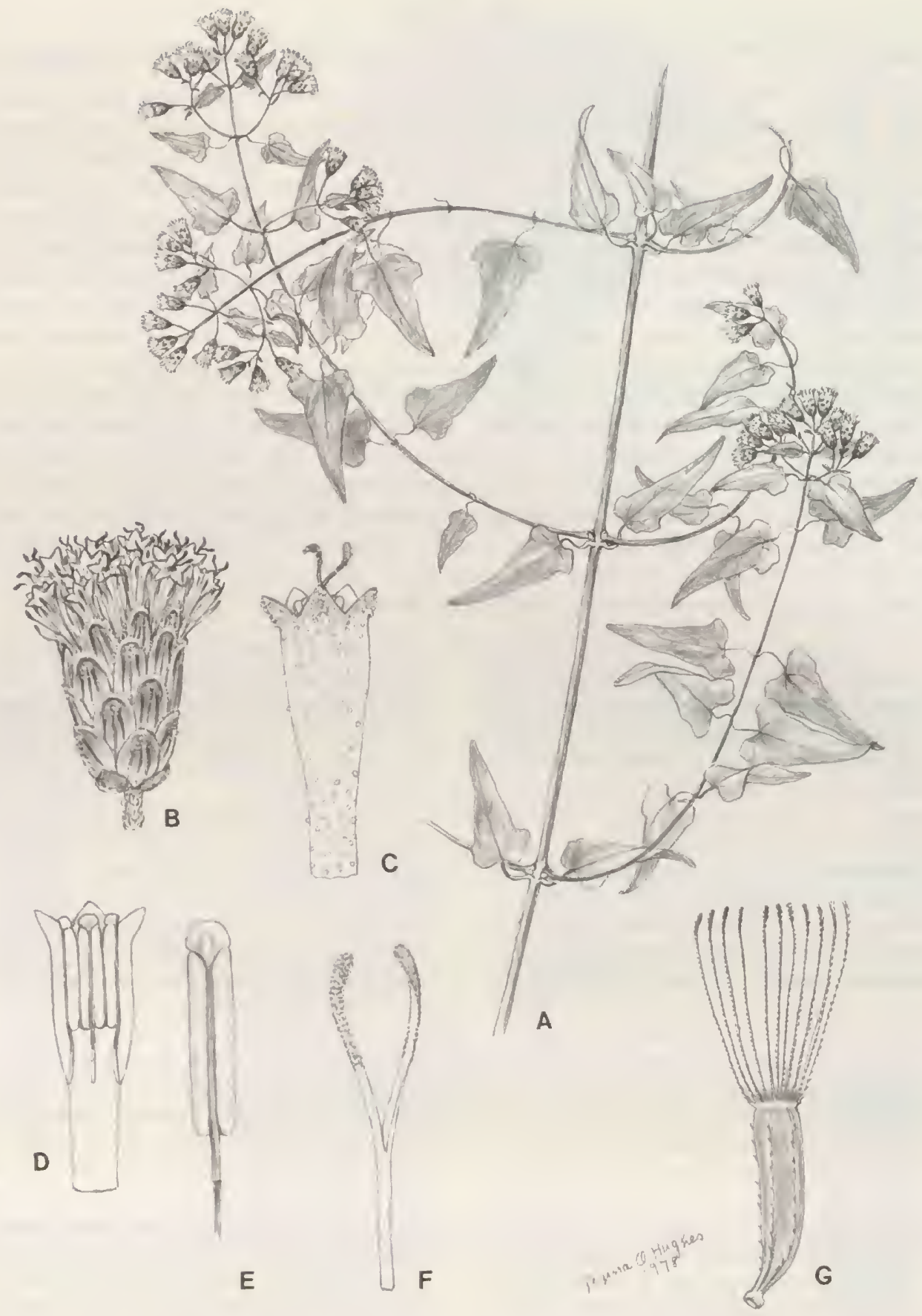

Plate 159. Osmiopsis plumeri (Urban \& E. Ekman) R. King \& H. Robinson. - A. Habit, $\times 1 / 2,-$ B. Head, $\times 5 .-$ C. Corolla outer surface, $\times 12 .-D$. Corolla inner surface with anthers, $\times 12 .-$ E. Anthers, $\times 24 .-F$. Style, $\times 12,-$ G. Achene, $\times 12$. 


\section{Osmiopsis}

Osmiopsis R. King \& H. Robinson, Phytologia 32: 250. 1975. TYPE: Eupatorium plumeri Urban \& E. Ekman.

Weak scandent shrubs, with numerous branches at right angles or slightly retroflexed. Stems terete to slightly angled, glabrous. Leaves opposite, slenderly petiolate; blades ovate to lanceolate often with lobed bases, upper margins entire, trinervate from base, lower surface extremely densely covered with glandular punctations. Inflorescences numerous, terminal on lateral branches, in small corymbose clusters; pedicels rather short. Involucral bracts ca. 20, imbricate, in 4-5 strongly unequal graduated series, all deciduous, mostly broadly oblong, with rounded tips, 4-costate on outer surface; receptacle flat to slightly convex on distal surface, glabrous. Florets 18-26 in a head; corollas white, funnelform with a short broadly cylindrical base, sparsely glandular on outer surface below lobes; cells of throat elongate with sinuous lateral walls; lobes triangular, often broad, as long as wide to 1.5 times as long as wide, smooth on both surfaces, densely glandular on outer surface; anther collar slightly broader below, with numerous subquadrate or shorter cells below, longer cells above, cells with prominent ornate beading on walls; anther appendage semi-circular, wider than long; style base not enlarged, glabrous; style branches narrowly linear with slightly broadened tips, sharply short-papillose. Achenes short-prismatic, slightly narrowed below, 5-ribbed, with few glands and short setulae; carpopodium distinct, short-cylindrical, cells on surface subquadrate, small, in ca. 9 tiers, with thickened walls; pappus of ca. 25-30 stout scabrid persistent bristles in 1 series, somewhat broadened distally, apical cells acute. Pollen grains ca. $22 \mu \mathrm{m}$ in diameter. Plate 159.

The genus Osmiopsis is one of many elements in Mexico, Central America, and the West Indies showing a combination of characters of the Praxelinae and the Critoniinae. All of the elements involved are presumed to have a history that includes intersubtribal hybridization between the genera Chromolaena of the Praxelinae and Koanophyllon of the Critoniinae. It is in Osmiopsis of Haiti on the Island of Hispaniola, that the combination of characters is most obvious, and it is here that the characters are combined in a manner that makes inclusion in either of the parent genera impossible.

The involucral bracts of Osmiopsis are imbricated and totally deciduous in the manner of other Praxelinae, and the habit of the plant is most like various species of Chromolaena, particularly $C$. odorata. In the interior of the head, however, the plants closely resemble Koanophyllon with their short-cylindrical corolla bases, their triangular lobes densely covered outside with glands, their short anther appendages, the somewhat broadened tips of their style branches, and the stout achenes with stout pappus bristles. The only Praxeline tendencies in the florets are the cylindrical shape of the carpopodia and the corolla lobes often distinctly longer than wide. In recognizing such a hybrid at generic rank, the authors acknowledge an evolutionary process in flowering plants that is probably much more common in plants than is generally realized.

The name Osmiopsis is derived from the generic name Osmia, a synonym of Chromolaena, and the Greek suffix -opsis meaning similar.

The following single species is recognized in the genus:

Osmiopsis plumeri(Urban \& E. Ekman) R. King \& H. Robinson, Haiti.

\section{Subtribe XIII, Hebeclininae}

Hebecliniinae R. King \& H. Robinson, Phytologia 46: 448. 1980. TYPE: Hebeclinium DC.

Erect perennial herbs or shrubs to small trees, sparingly to moderately branched, never rosulate. Leaves usually opposite, alternate in Decachaeta, often with long petioles; blades often broad with rounded to cordate bases. Inflorescence laxly cymose to densely corymbose or thyrsoid-paniculate, with heads clustered, pedicellate; involucral bracts usually strongly subimbricated, graduated in length, with inner bracts easily deciduous, eximbricate and persistent in Amolinia; receptacle slightly convex to strongly hemispherical, usually epaleaceous, paleaceous in Matudina, often with hairs. Flowers 4-150 in a head; corollas white, lavender, blue, or purple, narrowly funnelform, rarely with hairs inside of throat; cells of throat elongate with sinuous lateral walls; lobes triangular, usually about as long as wide, smooth on both surfaces, without stomata on outer surface; anther collar usually elongate, 5-10 times as long as wide, of even width, with numerous subquadrate cells in lower half, without obvious ornate thickenings on walls; anther appendage usually longer than wide, short in Decachaeta; style base not enlarged, glabrous; style branches narrowly linear to filiform, 
mamillose to short-papillose, rarely with enlarged tips. Achenes prismatic, 5-ribbed, micropunctations of walls not strongly aligned in transverse bands; carpopodium annuliform to turbinate, procurrent on ribs of achene, cell walls thin or slightly thickened; pappus usually of numerous capillary bristles, usually persistent, deciduous in Decachaeta, obsolete in Erythradenia, apical cells sharply acute. Basic chromosome number $x=10$ or 16 .

The subtribe Hebecliniinae has the general characters of the Critoniinae, smooth corolla lobes, a simple style base, and a usually subimbricate involucre with deciduous inner bracts, and the two subtribes seem unquestionably closely related. The most significant features of the Hebecliniinae are the unusually common occurrence of hairs on the receptacles and the occurrence in some genera of a chromosome base number of $x=16$. Neither character is unique to the subtribe nor consistent within it, but the latter is totally unknown in the subtribe Critoniinae which has a constant base of $x=10$.

While the tendency toward pubescent receptacles and the variation in chromosome number are the primary basis for the recognition of the Hebecliniinae as a separate subtribe, it is other characteristics that seem to properly define the limits of the group. All genera placed in the Hebecliniinae show a carpopodial structure with comparatively thin walls with extensions of the callus formation upward along the bases of the achene ribs. These are poorly developed in some such as Amolinia, but are present to some extent in all members. All the genera also show elongate anther collars with many subquadrate cells and inornate cell walls. Such collars are more reminiscent of Neomirandea or the Oxylobinae than the Critoniinae. The Hebecliniinae as thus defined seems an entirely natural group with strong tendencies toward hairs on the receptacle and rather long petioles. The only question of limits retained at this time involves the genus Critoniella which has similar carpopodia with procurrent upper margins, and has rather long anther collars. The latter is retained in the Critoniinae in this treatment because of its narrow heads with minute receptacles. All members placed here in the Hebecliniinae have the surface of the receptacles broad or highly convex.

Historically, the nearest thing to recognition of the Hebecliniinae as a group was the recognition of a genus or Eupatorium section Hebeclinium based on the presence of hairs on the receptacle. The concept included many of the species still retained here in Hebeclinium plus many now placed in Bartlettina. The concept did not include any of the members of the above genera that lack hairs on the receptacles, or any of the related genus Guayania which also lacks the hairs. The inclusion in the concept of species now placed in Polyanthina of the Ayapaninae and Urolepis of the Gyptidinae was inevitable, but the failure to include most species now placed in Decachaeta, a true member of the Hebecliniinae, seems inexplicable. Most of the species of Decachaeta rested in Eupatorium section Subimbricata, though actually a few Mexican species were placed in the South American genus Ophryosporus by some authors (B. Robinson, 1925) because of their reduced anther appendages. Erythradenia, with its reduced anther appendage and its lack of a pappus, was inevitably placed in the genus Piqueria of the Ageratinae in the traditional system of classification (B. Robinson, 1901). The entire group now placed in the Hebecliniinae was not brought together until the survey of the Eupatorieae by H. Robinson and King (1977).

One genus placed in the Hebeclinium group by H. Robinson and King (1977), Peteravenia, is excluded here. The latter genus has a superficial resemblance to Bartlettina, and occurs in some of the same geographical areas, but lacks the carpopodial structure that is found in all members of the Hebecliniinae. The reports of a chromosome number of ca. 17 in one Peteravenia (R. King et al., 1976) is considered misleading, and the genus is placed in the Critoniinae in the present treatment.

The distribution of the chromosome numbers in the Hebecliniinae is of special interest. The distinctive $x=$ 16 is thus far known only from Mexican and Central American members of the subtribe. The number is recorded from Bartlettina, Matudina, and Decachaeta, and might be expected from Erythradenia which is very close to Decachaeta. The $x=16$ is not known from any of the South American members of the subtribe, not even those placed here in the genus Bartlettina. The only likely candidate for such a number in South America seems to be the genus Guayania which has not yet been counted. The base of $x=10$ is not restricted geographically, being found in at least some Central American species of Hebeclinium.

The subtribe Hebecliniinae is a primarily Mexican, Central American, and Andean group. Guayania does occur outside of that area in the nearby Guayana Highlands of northern South America. The only other extensions of range involve one species of Bartlettina native to eastern Brazil, and the common weedy species Hebeclinium macrophyllum which occurs throughout the Neotropics.

Almost nothing seems to be known of the chemistry of the subtribe Hebecliniinae. A guaianolide, thieleanine, has been described from Decachaeta (Alvarado et al., 1979). The most distinctive compounds in any member of the subtribe appear to be the diterpenes with the structure of Hebeclinolid. The compounds have three separate rings, each distinctively oxygenated, first with a ketone group, the second as a lactone, and the third as a furan group (Bohlmann \& Grenz, 1977). The same species contains acyclic sesquiterpenes of a type widely distributed in the tribe. 
KEY TO THE GENERA OF THE SUBTRIBE HEBECLINIINAE

1. Pappus absent or easily deciduous; anther appendages much shorter than wide; leaves often alternate

2. Pappus absent

2'. Pappus present, with deciduous bristles

$\therefore$ Pappus capillary, persistent; anther appendages as long as wide or longer; leaves opposite

3. Receptacle with paleae; involucre with many series of subfoliaceous bracts at base

3'. Receptacle without paleae; involucre without many series of subfoliaceous bracts at base

4. Involucre of subequal scarcely overlapping bracts; achenes $5-7 \mathrm{~mm}$ long

4'. Involucre with 4-5 rows of graduated subimbricate bracts; achenes less than $4 \mathrm{~mm}$ long

5. Carpopodium strongly asymmetrical, born on side of achene base; receptacle without hairs

5'. Carpopodium symmetrical to scarcely asymmetrical on base of achene; receptacle often with hairs 164. Erythradenia 163. Decachaeta

6. Receptacle highly convex, hemispherical, usually composed of highly sclerified cells throughou

6'. Receptacle shallowly convex, with parenchymatous 166. Matudina to slightly clavate, somewhat flattened

\section{Hebeclinium}

\section{Hebeclinium DC., Prodr. 5: 136. 1836. LeCTOTYPE: Eupatorium macrophyllum L. [= Hebeclinium macro- phyllum (L.) DC.]. \\ Eupatorium section Hebeclinium (DC.) Benth. ex Baker in C. Martius, Fl. Bras. 6(2): 345. 1876.}

Large erect herbs or subshrubs, with moderate branching. Stems terete to faintly angled, slightly striated. Leaves opposite, usually long-petiolate; blades broadly ovate to deltoid or lanceolate, base acute to cordate, margin usually crenate or serrate, pinnate with ascending veins or trinervate from or near base, glands on lower surface often small or indistinct, numerous in $H$. macrophyllum. Inflorescence a lax cyme with widely spreading branches; pedicels short. Involucres broadly campanulate; involucral bracts ca. 25-40, subimbricate, in 3-5 strongly unequal graduated series, narrowly oblong to ovate or ovate-lanceolate, outer bracts persistent, inner bracts deciduous; receptacle hemispherical, often with center broken off, sclerified throughout (parenchymatous internally in $H$. guevarae), glabrous to densely hirsute. Florets $20-80$ in a head; corollas white or pink, narrowly funnelform, outer surface glabrous below, inner surface of throat in some species with numerous hairs; cells of limb elongate with sinuous lateral walls; lobes triangular, slightly longer than wide, smooth on both surfaces, usually with prominent multicellular uniseriate hairs and few glands on outer surface; anther collar usually slender, with many subquadrate cells in lower part, cell walls rather thin with indistinct annular thickenings; anther appendage large, ovate-triangular to oblong, slightly longer than wide; style base not enlarged, glabrous; style appendages narrowly filiform, terete, mamillose, somewhat broadened distally in $H$. beneolens and $H$. vestitum. Achenes prismatic, often slightly curved, 2-3 mm long, narrowed below, 4-5-ribbed, setulae sometimes present; carpopodium scarcely distinct, with only few tiers of short cells at lower margin, area of longer upper cells merging with sides of achene and procurrent on ribs; pappus of ca. 30-40 scabrid slender persistent capillary bristles in 1 series, sometimes broadened distally, apical cells acute. Pollen grains ca. $18-22 \mu \mathrm{m}$ in diameter. Chromosome number $x=10$. Plate 160 .

The genus Hebeclinium was initially established by DeCandolle (1836) to include two elements having rounded pubescent receptacles, and it has continued to be recognized at the sectional level for various species placed in the broad concept of Eupatorium that have that trait. The section came to include a total of nearly 12 species as represented in different treatments. The group as traditionally delimited was of limited value, however, being only a partial representation of the species of Eupatorium sensu lato having pubescent receptacles, and including a number of unrelated species. One of the elements originally included was Urolepis of the subtribe Gyptidinae, and later additions to the section involved diverse species now placed in Polyanthina of the Ayapaninae and Steyermarkina of the Critoniinae. Equally unaccounted for was the lack of hairs on the receptacles of some species unquestionably closely related to the type species which are placed in the naturally delimited Hebeclinium of the present treatment.

In spite of the various problems with the traditional section Hebeclinium, a review of the tribe has shown that there is a tendency toward receptacular pubescence in the relationship of the genus. A number of the species originally placed in the section prove to be members of the genus Hebeclinium as delimited here, or members of the closely related genera Bartlettina or Decachaeta. Even 


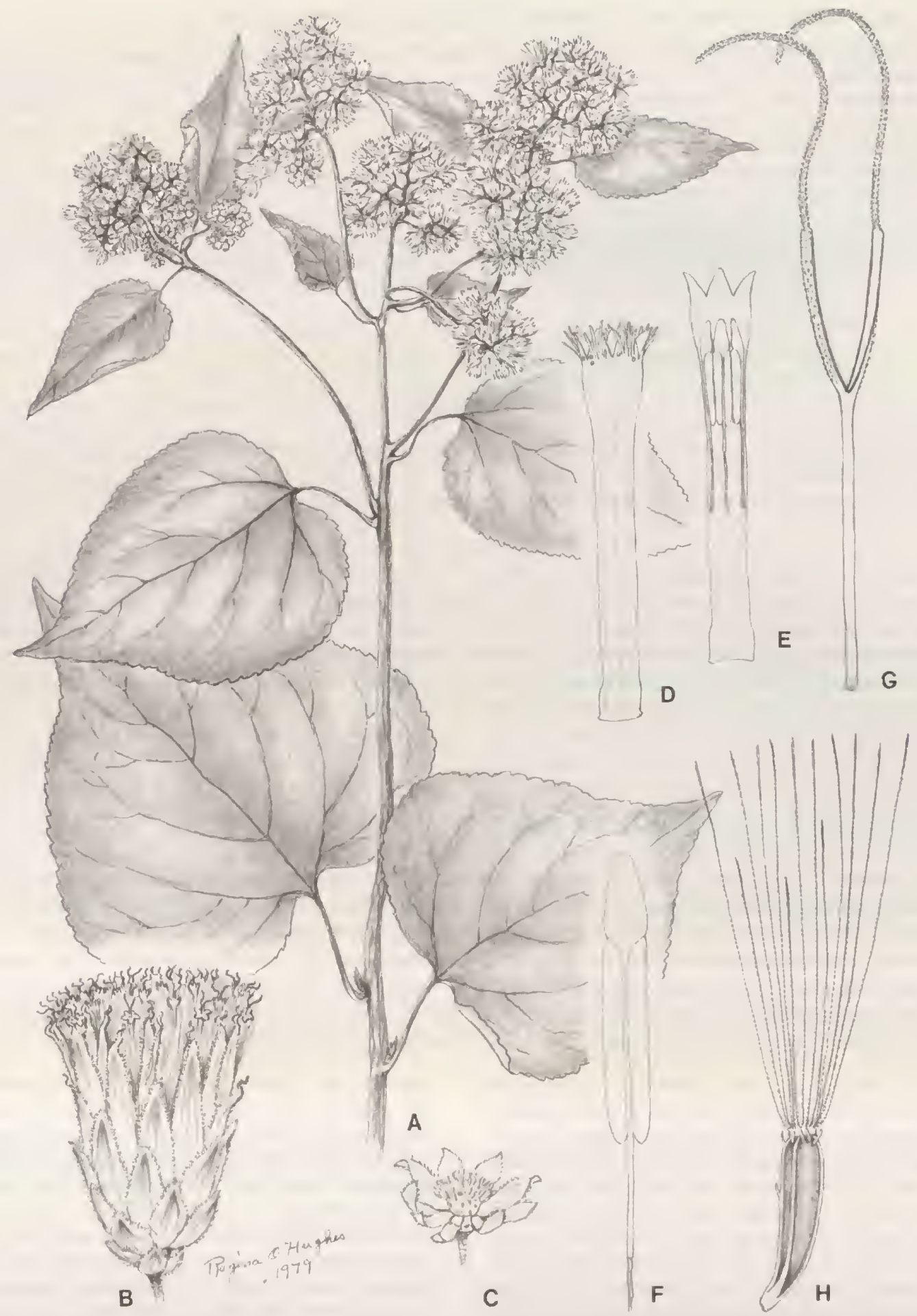

PLATE 160. Hebeclinium macrophyllum (L.) DC. - A. Habil, $\times 1 / 2 .,-$ B. Head, $\times 9,-$ C. Old head showing receptacle, $\times 9 .-$ D. Corolla outer surface, $\times 18 .-$ E. Corolla inner surface with anthers, $\times 18 .-F$. Anther, $\times 50$. -G. Style, $\times 18 .-$ H. Achene, $\times 18$. 
within the limited group, the hairs on the receptacle can not be used to define groups, however. Only Decachaeta, of the genera cited, consistently has hairs. In view of the latter, it is strange that only the one opposite-leaved species of Decachaeta was included in the traditional section $\mathrm{He}$ beclinium.

The present concept of Hebeclinium excludes the related genus Decachaeta which has a very short anther appendage, and which also has mostly alternate leaves. It also excludes such genera as Guayania which has an asymmetrical carpopodium, and Amolinia which has an eximbricate involucre and large achenes $5-7 \mathrm{~mm}$ long. It is Bartlettina which shares most of the traditional characters of Hebeclinium and contains many species that were placed in the section Hebeclinium, but it differs in the broader less strongly convex receptacle having a parenchymatous center, and the broader style branches. All but one species of Hebeclinium have a receptacle sclerified throughout, a feature not found in other genera of the tribe. All the species have the style appendages filiform and terete at least for most of their length, a feature found elsewhere in the subtribe only in Guayania. The inflorescence of Hebeclinium is a rather characteristic spreading lax cymose panicle.

A genus that may be related to Hebeclinium, but which is not placed here in the Hebecliniinae, is Critoniella. The two genera have the same type of carpopodium with thinwalled cells procurrent on the achene ribs, and filiform terete appendages on the styles. Because of the similarity, one species, Eupatorium leucolithogenum, was first placed in Hebeclinium by the present authors (King \& Robinson, $1975 n$ ) and later transferred to Critoniella (King \& Robinson, $1975 w$ ) where it rests uncomfortably. Critoriella differs from Hebeclinium by its small flat receptacles and the ornamented cell walls of its anther collars, and the genus is placed in the subtribe Critoniinae in the present treatment.

The species of Hebeclinium are concentrated in Colombia, Venezuela, and Ecuador, with a few species occurring to the south in Peru and to the west in Costa Rica and Panama. One species, $H$. macrophyllum, is a weedy species found throughout most of the Neotropical Region. The latter species may owe its wider distribution to the comparatively dense cover of glandular punctations on its leaves which should discourage attack by herbivores. A key has been provided to the species of Hebeclinium in Colombia by King and Robinson (1969a) under the section of Eupatorium.

Available chromosome counts for Hebeclinium are all $n=10$ (R. King et al., 1976).

The generic name is derived from the Greek words hebe (= puberty) and $k$ line $(=$ bed), in reference to the pubescent receptacle.

The following 20 species are recognized in the genus:

Hebeclinium beneolens (B. Robinson) R. King \& H. Robinson, Peru.

Hebeclinium bullatissimum (B. Robinson) R. King \& H. Robinson, Ecuador, Peru.

Hebeclinium costaricense $\mathrm{R}$. King \& $\mathrm{H}$. Robinson, Costa Rica, Panama.

Hebeclinium erioclinium (B. Robinson) R. King \& H. Robinson, Colombia.

Hebeclinium guevarae (R. King \& H. Robinson) R. King \& H. Robinson, Colombia.

Hebeclinium hygrohylaeum (B. Robinson) R. King \& H. Robinson, Costa Rica.

Hebeclinium hylophorbum (B. Robinson) R. King \& H. Robinson, Peru.

Hebeclinium jajoense (Aristeg.) R. King \& H. Robinson, Venezuela.

Hebeclinium killipii (B. Robinson) R. King \& H. Robinson, Colombia, Ecuador.

Hebeclinium knappiae R. King \& H. Robinson, Panama.

Hebeclinium lellingeri R. King \& H. Robinson, Colombia.

Hebeclinium macrophyllum (L.) DC., Mexico, Central America, West Indies, South America.

Hebeclinium oblusisquamosum (Hieron. ex Sodiro) R. King \& H. Robinson, Ecuador.

Hebeclinium phoeniclicum (B. Robinson) R. King \& H. Robinson, Colombia.

Hebeclinium recreense (Hieron.) R. King \& H. Robinson, Ecuador.

Hebeclinium reedii $\mathrm{R}$. King \& $\mathrm{H}$. Robinson, Panama.

Hebeclinium sericeum (H.B.K.) R. King \& H. Robinson, Colom. bia.

Hebeclinium letragonum Benth., Ecuador.

Hebeclinium torondoyense (V. Badillo) R. King \& H. Robinson, Colombia, Venezuela.

Hebeclinium vestitum $\mathrm{R}$. King \& H. Robinson, Peru.

\section{Amolinia}

Amolinia R. King \& H. Robinson, Phytologia 24: 265. 1972. TYPE: Eupatorium heydeanum B. Robinson.

Erect shrubs or small trees, sparsely to moderately branched. Stems terete, striated, densely tomentose. Leaves opposite, long-petiolate; blades ovate, base rounded with distinct acumination, margins entire, apex narrowly acuminate, trinervate from near base with strongly ascending veins, densely glandular-punctate on lower surface. Inflorescence a corymbose panicle; pedicels short to moderately long. Involucres narrowly campanulate, spreading when dry; involucral bracts ca. 15, eximbricate, in 2-3 slightly unequal series, linear, outer surface bicostate, with numerous hairs and glandular punctations; receptacle slightly convex, usually 


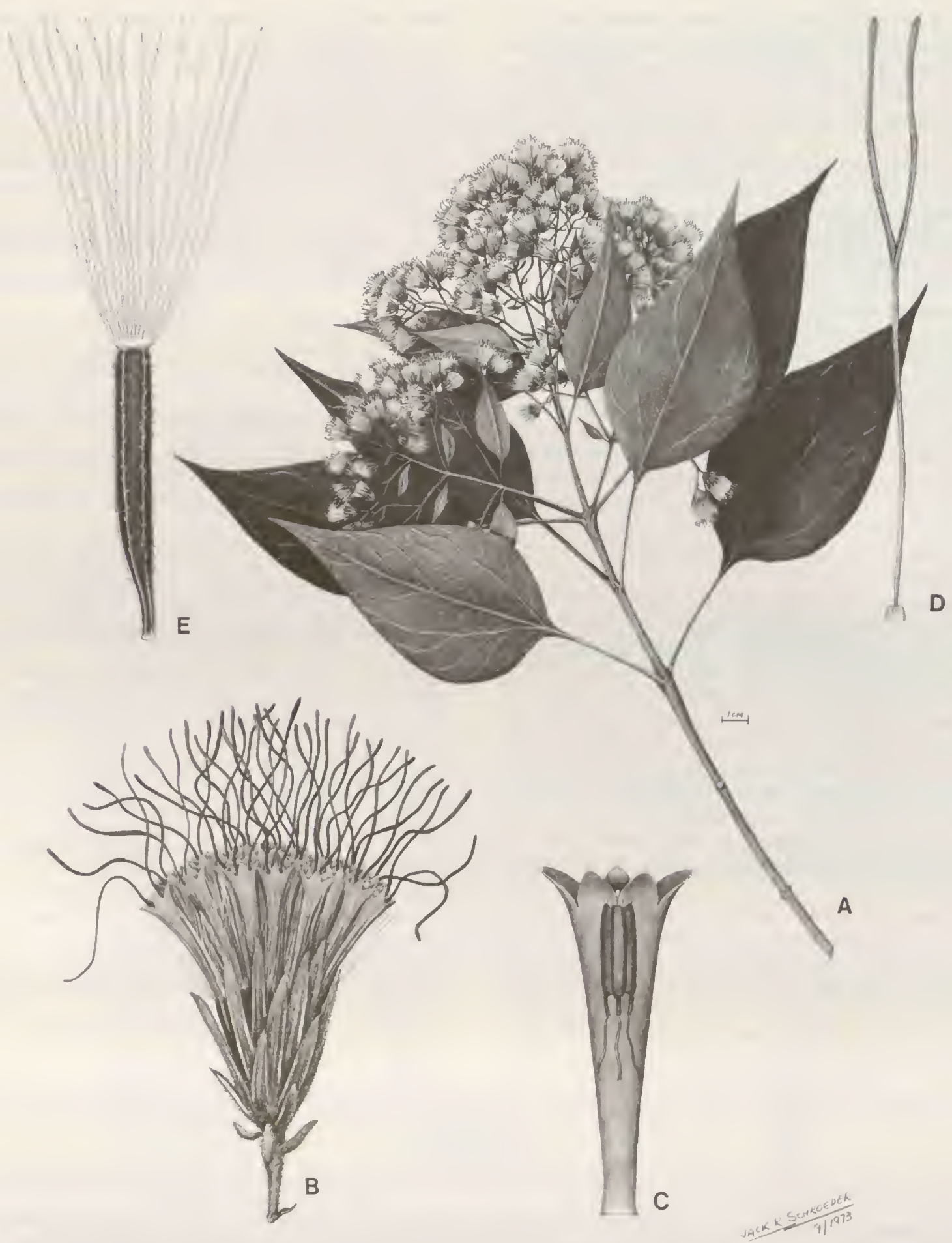

Plate 161, Amolinia heydeana (B. Robinson) R. King \& H. Robinson. - A. Habit, $\times 4 / 9 .-$ B. Head, $\times 5$. - C. Corolla showing anthers, $\times 11 .-D$. Style with nectary, $\times 11 .-E$. Achene, $\times 11$. 
hirtellous. Florets $20-25$ in a head; corollas white, narrowly funnelform, with cylindrical basal tube, outer surface sparsely glanduliferous, inner surface smooth and glabrous; cells of limb broadly to narrowly oblong, with straight or sinuous lateral walls; lobes ovate-triangular, as long as wide, smooth on both surfaces; anther collar slender and elongate, composed of numerous subquadrate cells below, cell walls without ornate annular thickenings; anther appendage large, oblong, slightly longer than wide; style base not enlarged, glabrous; style branches narrowly linear, mamillose. Achenes prismatic, elongate, 5-7 mm long, 5-ribbed, densely glanduliferous and sparsely setuliferous, glands short with minute tips; carpopodium very short, distinct, basal cells small, subquadrate, in 5-7 tiers, with slightly thickened walls, with some thin-walled cells above along bases of ribs; pappus of ca. 30 slender scabrid persistent bristles in 1 series, not broadened distally, apical cells narrowly obtuse to acute. Pollen grains ca. $19 \mu \mathrm{m}$ in diameter. Chromosome number $x=10$. Plate
161 .

Amolinia has the pubescent receptacle, the elongate petioles, and the elongate anther collars with many quadrate cells that indicate a relationship to the genus Hebeclinium. The genus differs from Hebeclinium, however, by the less convex receptacle with a parenchymatous core, and the narrowly linear rather than filiform and terete style appendages. The inflorescence is also more corymbose. The genus is closer to Bartlettina, but lacks the specialized carpopodium seen in most species of the latter genus. Amolinia differs from all the other members of the $\mathrm{He}$ becliniinae by its narrow essentially eximbricate involucral bracts, and its elongate achenes $5-7 \mathrm{~mm}$ long. The dense glandular pubescence of the achene is also rather distinctive.

The genus Amolinia occurs in an area where there are three other genera of the Hebecliniinae, in Guatemala and adjacent Chiapas in Mexico. The area contains many species of Bartlettina and Decachaeta, and the single species of Matudina. All of the latter are notable for their apparently characteristic chromosome number of $x=16$. On the basis of a count by John Strother (1983), Amolinia does not belong to this group of the subtribe with which it is geographically associated.

The involucre of Amolinia is not completely eximbricate. There are some shorter outer bracts, and the proper designation might be weakly subimbricate. The bracts are so narrow, however, that the imbrication is not obvious. Also, the inner bracts are not obviously deciduous.

Label data indicates that Amolinia is a tree 5-6 m tall, occurring in montane cloud forests above $2,000 \mathrm{~m}$.

The generic name honors Prof. Antonio Molina R., well-known Central American botanist.

The following single species is recognized in the genus:

Amolinia heydeana (B. Robinson) R. King \& H. Robinson, Mexico, Guatemala.

\section{Bartlettina}

Bartlettina R. King \& H. Robinson, Phytologia 22: 160. 1971, new name for Neobartlettia R. King \& H. Robinson.

Neobartlettia R. King \& H. Robinson, Phytologia 21: 294. 1971. TYPE: Eupatorium tuerckheimii Klatt, non Neobartlettia Schlechter. (Orchidaceae).

Erect shrubs or small trees, with sparse to moderate branching. Stems terete to subquadrangular or subhexagonal, striated, fistulose or solid. Leaves opposite, often with long slender petioles (short-petiolate in $B$. tuerckheimii and related species), rarely narrowly winged; blades lanceolate to broadly ovate, base cuneate to truncate, cordate in some South American species, trinervately or pinnately veined, lower surface often with glandular punctations. Inflorescence usually corymbose paniculate; pedicels short. Involucres broadly campanulate; involucral bracts ca. 20-50, weakly to strongly subimbricate, in 3-5 unequal graduated series, narrowly lanceolate to broadly ovate, spreading at maturity, inner bracts deciduous; receptacle broadly convex, usually sparsely to densely pubescent, sometimes glabrous. Florets 8-150 in a head; corollas white, lavender, blue, or purple, narrowly funnelform above, inner surface glabrous; cells of limb mostly narrow with sinuous lateral walls; lobes triangular, as long as wide, smooth on both surfaces, outer surface usually densely puberulous, often glanduliferous; anther collars very elongate, with numerous quadrate to shortrectangular cells below, cell walls inornate; anther appendage large, oblong-ovate to long-triangular, longer than wide; style base not enlarged, glabrous; style branches narrowly linear, sometimes slightly broadened distally, nearly smooth to short-papillose. Achenes prismatic, 5-ribbed, 2-3 mm long, glabrous to sparsely setuliferous, rarely with glands; carpopodium slightly to distinctly enlarged, symmetrical, usually with smaller 


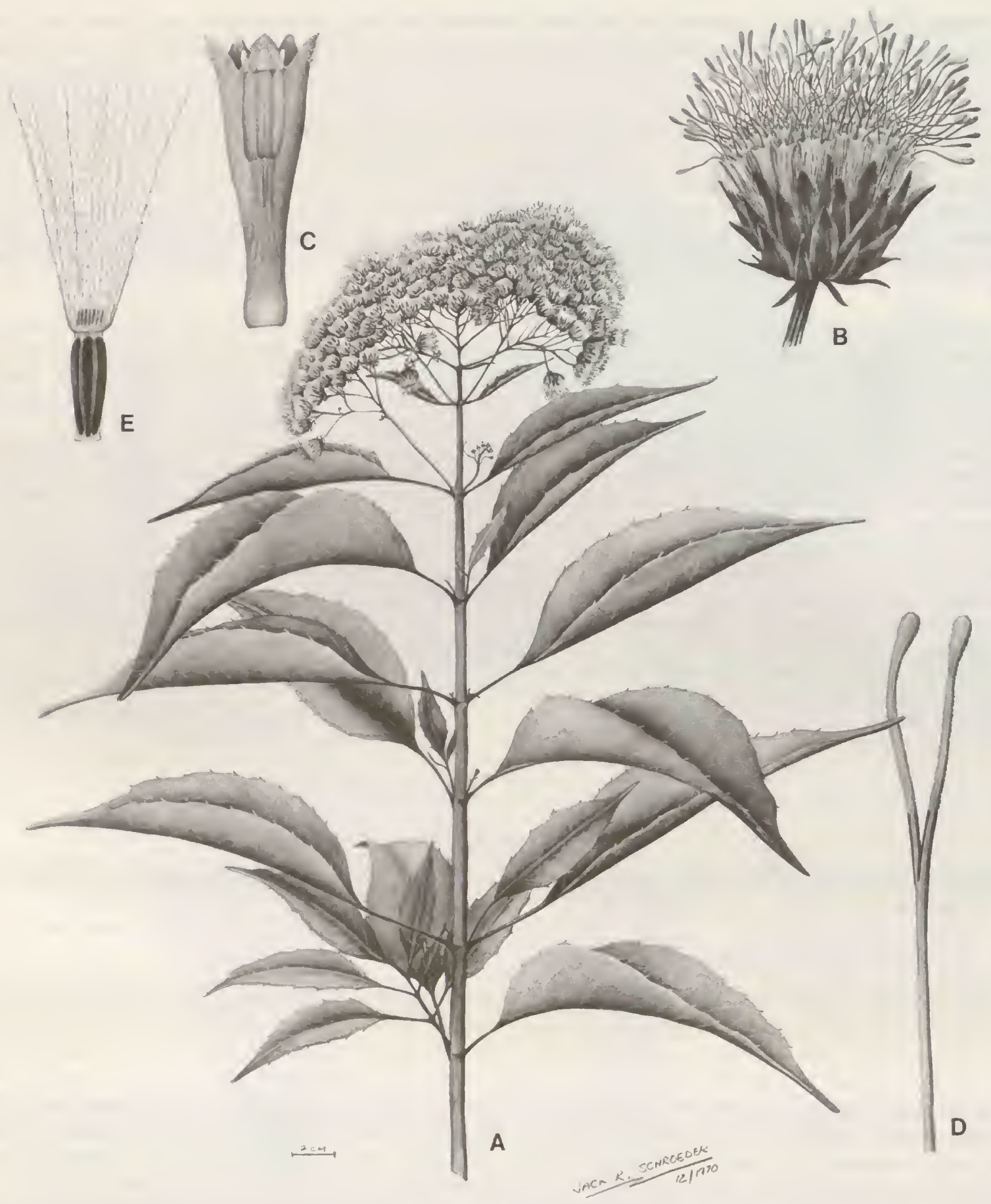

PLATE 162. Bartlettina tuerckheimii (Klatt) R. King \& H. Robinson. - Habit, $\times 1 / 3 .-$ B. Head, $\times 4 .-$ C. Corolla showing anthers, $\times 10 .-D$. Style, $\times 10 .-$ E. Achene, $\times 10$. 
subquadrate cells near base, and larger elongate cells above procurrent into enlarged bases of ribs, cell walls thin; pappus of ca. 30-40 slender scabrid persistent bristles in 1-2 series, rarely broadened distally, apical cells acute. Pollen grains 23-25 $\mathrm{m}$ in diameter. Chromosome number $x=10$ or 16 . Plate 162.

The genus Bartlettina consists of species falling within the traditional broad concept of Eupatorium, and contains many species that have been placed in the section or genus Hebeclinium because of pubescence on the receptacles. Actual relationship to Hebeclinium is evident from the tendency for elongate petioles on the leaves and elongate anther collars with inornate cell walls, along with other features such as the subimbricate involucre with deciduous inner bracts. The genus lacks the specialized hemispherical receptacle sclerified throughout and the filiform terete style branches of Hebeclinium.

Many of the species of Bartlettina have a distinctly enlarged carpopodium with numerous small rather thinwalled cells in the lower tapering part, and more elongate cells in the upper swollen part which is procurrent on the achene ribs. The precise form is not found in any other genus of the tribe, but unfortunately, is not developed in all species of Bartlettina. Many of the species are also notable for the broadly triangular corolla lobes often bearing numerous hairs on the outer surface.

Both the carpopodia and the pubescence on the corolla lobes distinguish Bartlettina from the superficially similar genus Peteravenia of Central America. The latter can be distinguished most easily by its non-contiguous pappus bristles with distinctly enlarged tips, and it never has hairs on the receptacle. The cordate leaf bases, originally mentioned as a distinguishing character of Peteravenia (King \& Robinson, 1971 $i$ ), has proven unreliable in both genera (King \& Robinson, 1979c), but there are no cordate bases on the leaf blades in Central American species of Bartlettina. Peteravenia is placed in the Critoniinae in this treatment.

The Central American species of Bartlettina show considerable variation in the form of their leaves, from lanceolate with pinnate venation in $B$. tuerckheimii to broadly ovate and trinervate in $B$. sordida, and show variation in the inflorescence from pyramidal to corymbose. The series seems to form a natural group, however, and all available chromosome counts of Central American species show $n=16$ (R. King et al., 1976). The only species from the area that may not belong to the group are B. silvicola of Costa Rica and $B$. montigena of Guatemala. The latter is particularly distinct in having only about ten flowers in a head. All other members of the genus have 20 or more flowers in the heads except B. hylobia with 8-16 flowers. Distinctions of a number of Central American species of Bartlettina are discussed by King and Robinson (1974i. $1977 i$ ) in the process of naming new species, and a key is provided by King and Robinson (1975y) to three species in Panama.

The South American members of Bartlettina have general characters as in the typical group, but they seem to form a number of separate elements, none of which relate closely to those of Central America. The only species for which there is a chromosome count, B. paezense, shows $n=10$ (Powell \& Cuatrecasas, 1970; R. King et al., 1976), totally unlike the typical group. That species also has less strongly subimbricate involucral bracts. One complex of species in the northern Andes, containing B. tenorae, has a tendency for cordate bases on the leaf blades, a feature unknown in the typical group. The latter series seems to include $B$. perezoides of Colombia that was erroneously placed in the Critonioid genus Aristeguietia in an earlier paper in the present series of studies (King \& Robinson, 1975e). The highly disjunct B. hemisphaerica of eastern Brazil has a synonym that was placed in the Gyptoid genus Barrosoa in an earlier study in the series (King \& Robinson, $1971 \mathrm{~b}$ ), but which can be distinguished by its distinctly subimbricate involucre. The only Peruvian species, $B$. macromeris, has unusually short-petiolate leaves, and has flowers with uniquely narrow and pointed corolla lobes and anther appendages. It seems notable that the South American species, even though they more closely approach the related genera Hebeclinium and Guayania geographically, they resemble them less than do the more typical members of Bartlettina in Central America.

Both names for the genus, the original which proved to be a later homonym, and the later substitute name, honor Harley Harris Bartlett, botanist, ethnologist, and linguist of the University of Michigan. The life and works of Bartlett have been summarized by Voss (1961).

The following 35 species are recognized in the genus:

Bartlettina breedlovei R. King \& H. Robinson, Mexico.

Bartlettina brevipetiolata (Schultz-Bip. ex Klatt) R. King \& H. Robinson, Mexico.

Bartlettina campii R. King \& H. Robinson, Ecuador.

Bartlettina chiriquensis R. King \& H. Robinson, Panama.

Bartlettina cleefii R. King \& H. Robinson, Colombia.

Bartlettina constipatiflora (Klatt) R. King \& H. Robinson, Mexico.

Bartlettina cronquistii R. King \& H. Robinson, Mexico.

Bartlettina gentryi (R. King \& H. Robinson) R. King \& H. Robinson, Panama, Colombia.

Bartlettina guatemalensis R. King \& H. Robinson, Guatemala.

Bartlettina hastifera (Standley \& Steyerm.) R. King \& H. Robinson, Guatemala.

Bartlettina hemisphaerica (DC.) R. King \& H. Robinson, Brazil.

Bartlettina hintonii R. King \& H. Robinson, Mexico.

Bartlettina hylobia (B. Robinson) R. King \& H. Robinson, Mexico.

Bartlettina karvinskiana (DC.) R. King \& H. Robinson, Mexico. Bartlettina liesneri R. King \& H. Robinson, Venezuela.

Bartlettina luxii (B. Robinson) R. King \& H. Robinson, Guatemala.

Bartlettina macdougallii R. King \& H. Robinson, Mexico. 
Barlettina macrocephala (Benth.) R. King \& H. Robinson, Mexico.

Bartlettina macromeris (B. Robinson) R. King \& H. Robinson, Peru.

Bartlettina matudae R. King \& H. Robinson, Mexico.

Bartlettina maxonii (B. Robinson) R. King \& H. Robinson, Panama.

Bartlettina montigena (Standley \& Steyerm.) R. King \& H. Robinson, Guatemala.

Bartlettina oresbia (B. Robinson) R. King \& H. Robinson, Mexico.

Bartlettina oresbioides (B. Robinson) R. King \& H. Robinson, Guatemala.

Bartlettina paezensis (Hieron.) R. King \& H. Robinson, Colombia.

Bartlettina pansamalensis (B. Robinson) P. King \& H. Robinson, Colombia.
Bartlettina perezioides (B. Robinson) R. King \& H. Robinson, Colombia.

Bartlettina pinabetensis (B. Robinson) R. King \& H. Robinson, Mexico, Guatemala.

Bartlettina platyphylla (B. Robinson) R. King \& H. Robinson, Mexico, Guatemala, Costa Rica, Panama.

Bartlettina prionophylla (B. Robinson) R. King \& H. Robinson, Costa Rica, Panama.

Bartlettina silvicola (B. Robinson) R. King \& H. Robinson, Costa Rica.

Bartlettina sordida (Less.) R. King \& H. Robinson, Mexico, Guatemala, widely introduced.

Bartlettina tenorae (Aristeg.) R. King \& H. Robinson, Venezuela.

Bartlettina tuerckheimil (Klatt) R. King \& H. Robinson, Mexico, Guatemala, Honduras.

Bartlettina williamsii R. King \& H. Robinson, Honduras.

\section{Decachaeta}

\section{Decachaeta DC., Prodr. 5: 133. 1836. TYPE: Decachaeta haenkeana DC.}

Erect or arching subshrubs or shrubs, with sparse to moderate branching, usually with numerous glands on stems, leaves, and inflorescence, without glands in D. haenkeana. Stems terete, striated. Leaves alternate, opposite in $D$. perornata, petioles distinct and often long, sometimes winged; blades elliptical, ovate, or suborbicular, sometimes rather lobed, base acute to broadly rounded, margins serrate or crenate, apex acuminate, venation usually trinervate from near or above base, pinnate in $D$. haenkeana. Inflorescence a thyrsoid panicle, usually leafy; pedicels short. Involucres campanulate; involucral bracts ca. 10-15, subimbricate, in 3-4 strongly unequal graduated series; receptacle slightly to strongly convex, hirsute, paleaceous in D. haenkeana. Florets 4-30 in a head; corollas white, bluish in D. perornata, narrowly funnelform, with cylindrical basal tube, outer surface glabrous or sparsely glanduliferous; cells of limb oblong with sinuous lateral walls; lobes triangular, about as long as wide, smooth on both surfaces; anther collar rather narrow, often long, base with subquadrate cells, without ornate thickenings on walls; anther appendage short, much wider than long, margin strongly reflexed; style base not enlarged, glabrous; style appendages narrowly linear, slightly broadened distally, mamillose. Achenes prismatic, 4-5-ribbed, 2-3 mm long, with numerous setulae mostly on ribs; carpopodium distinct, with or without slight upper rim, short-cylindrical or stopper-shaped, not or distinctly procurrent on achene ribs, cells subquadrate in ca. 5 tiers, walls slightly thickened; pappus of ca. 10-30 slender scabrid rather deciduous bristles in 1 series, often distinctly dilated distally, apical cells acute. Pollen grains ca. 17-20 $\mu \mathrm{m}$ in diameter. Chromosome number $x=16$. Plate 163.

Decachaeta has the pubescent receptacle, subimbricate involucre with deciduous inner bracts, and inornate cell walls of the anther collars that indicate a proper position in the subtribe Hebecliniinae. The placement seems confirmed by the chromosome count of $n=16$ for one of the species, $D$. incompta (R. King et al., 1976), the same number found in many species of Bartlettina and in Matudina. The only feature that is inconsistent with the placement is the comparatively short anther collars of many species, but typically Hebecliniine collars occur in at least $D$. perornata. In one respect, Decachaeta is more Hebecliine than Hebeclinium, being the only genus of the subtribe of any size that has the receptacle consistently pubescent.

The genus Decachaeta has been recognized as distinct by all authors since the original dcscription by DeCandolle (1836), but the delimitation has been totally incorrect.
The supposed character of the genus, the approximately ten bristles of the pappus after which the genus is named, is fiction. The actual number is near 15 to 18 , and counts of less are the result of the deciduous nature of the bristles. The single species usually placed in the genus, cannot be distinguished, on that basis, from others traditionally placed in Eupatorium. A few other species that have been placed in Decachaeta previous to the present series of studies are not closely related. A Mexican species proves to belong in Ageratella in the subtribe Alomiinae, and two South American species are members of Acritopappus in the Gyptidinae.

Decachaeta, as presently delimitcd, is a highly natural group distinguished from other genera of the Hebecliniinae by the short anther appendage and the pappus of rather deciduous bristles. The genus is closest in habit and 


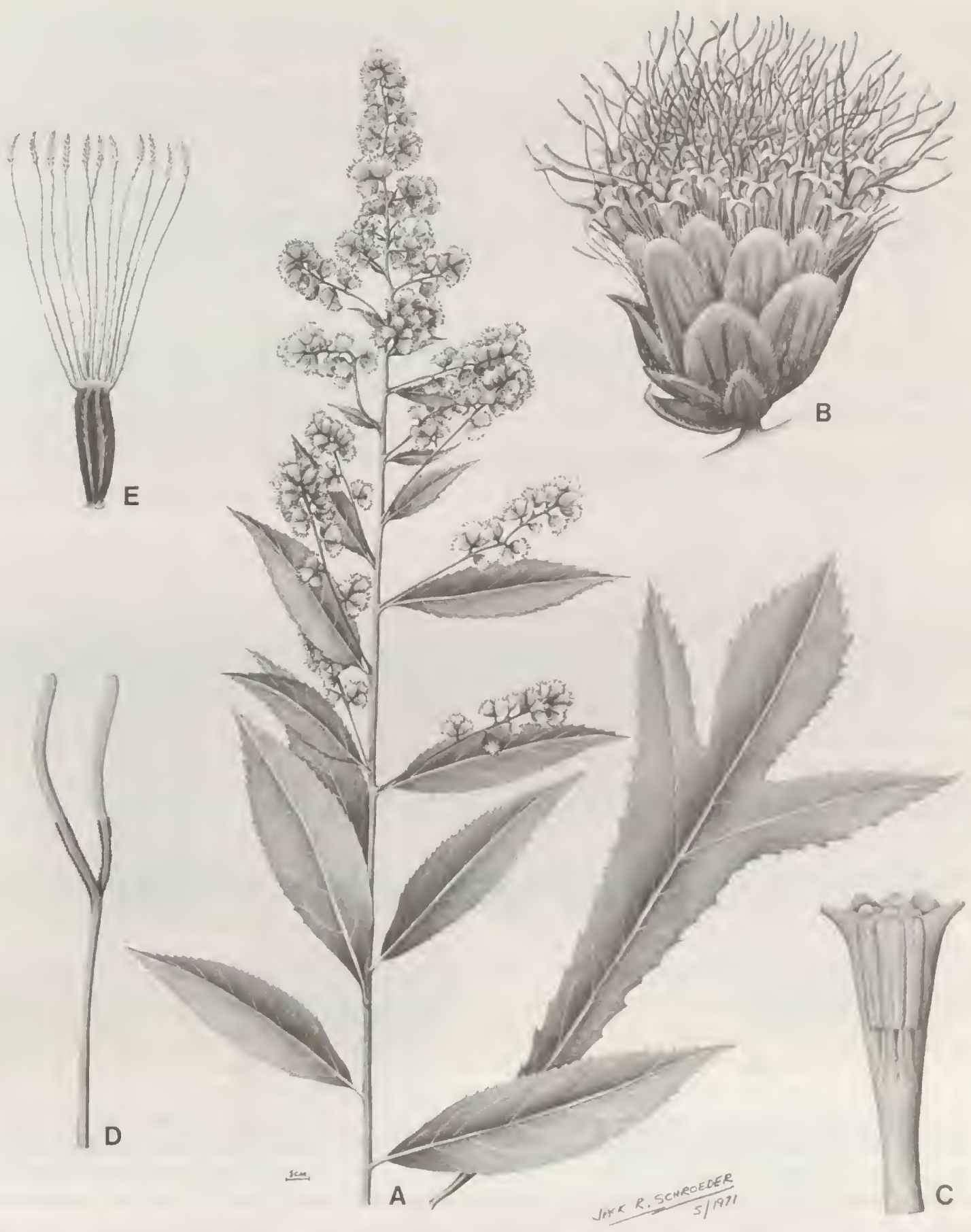

PLATE 163. Decachaeta haenkeana DC. - A. Habit with separate basal leaf, $\times 1 / 3 .-$ B. Head, $\times 7$, - C. Corolla showing anthers, $\times 13$. D. Style, $\times 13 .-E$. Achene, $\times 11$. 
apparently in relationship to Erythradenia, but the latter has the pappus obsolete and the receptacle bare.

In spite of its obvious unity, the genus Decachaeta shows some diversity, although hardly justifying the treatment of the species under three different genera in Standley's Trees and Shrubs of Mexico, Part 5 (B. Robinson, 1926b; Blake, 1926). Nevertheless, the three groups, treated as Decachaeta, Ophryosporus, and Eupatorium in the latter work, represent three basically distinct elements in the genus Decachaeta as presently delimited.

Typical Decachaeta, containing only the type species, has more than ten pappus bristles, but the number is less than most of the other species, ca. 15-18, and the tips are more strongly expanded. Its receptacles bear slender paleae. The plants also have elliptical, pinnately veined leaves with short petioles, and the stems, leaves, and inflorescence lack the glandular punctations seen in all other species of the genus.

The majority of the species of Decachaeta belong to the subgenus Polyadenia (as Polydenia in King \& Robinson, $1969 d)$. The group has leaves alternate as in the type species, but the blades are more trinervate, the pappus has 16-30 bristles with tips not or weakly expanded, and there are glandular punctations on the stems, leaves, and inflorescence. The species of the subgenus have normally been placed in Eupatorium, but include a few that were placed in Ophryosporus by Hemsley (1881-1882) and B. Robinson $(1925 ; 1926 b)$ because of their short anther appendages. The placement of the Mexican species in Ophryosporus by B. Robinson (1925) was with reservations, since he noted that true Ophryosporus of South America had a totally obsolete anther appendage and essentially equal rather than subimbricate involucral bracts.
Other less shrubby species in the subgenus were not transferred to Ophryosporus by B. Robinson but are nevertheless closely related to those that were transferred, and $D$. incompta apparently hybridizes with some of them.

A third group in the genus deserving but not having subgeneric rank, consists of the single species, $D$. perornata. The species differs from others of the genus by its opposite leaves, its bluish flowers, and the distinct procurrence of its carpopodium onto the bases of the achene ribs. The species has been placed in Eupatorium section Hebeclinium, at least by implication, in traditional treatments of the tribe, and one unvalidated synonym is in the genus Hebeclinium (Hemsley, 1881-1882; Hooker \& Jackson, 1895).

The genus Decachaeta has most of its species in Mexico and Guatemala, with one rather isolated in Costa Rica and Panama. A treatment of the genus, including a key, has been provided by King and Robinson (1969d), excluding only $D$. perornata.

The following seven species are recognized in the genus:

Decachaeta haenkeana DC., Mexico.

Decachaeta incompta (DC.) R. King \& H. Robinson, Mexico, Guatemala.

Decachaeta ovandensis (Grashoff \& Beaman) R. King \& H. Robinson, Mexico.

Decachaeta ovatifolia (DC.) R. King \& H. Robinson, Mexico. Decachaeta perornata (Klatt) R. King \& H. Robinson, Mexico. Decachaeta scabrella (B. Robinson) R. King \& H. Robinson, Mexico.

Decachaeta thieleana (Klatt ex T. Durand \& Pittier) R. King \& H. Robinson, Costa Rica, Panama.

\section{Erythradenia}

Erythradenia (B. Robinson) R. King \& H. Robinson, Brittonia 21: 285. 1969.

Piqueria subgenus Erythradenia B. Robinson, Proc. Amer. Acad. Arts 42: 6. 1906. Type: Piqueria pyramidalis $\mathrm{B}$. Robinson.

Erect or arching subshrubs, with sparse to moderate branching, with numerous reddish or yellowish glandular punctations, especially on undersurfaces of leaves and in inflorescences. Stems terete, striated, tomentellous. Leaves alternate, long-petiolate; blades broadly ovate, often aceriform with rounded to cordate base and lobed dentate margins, apex shortly and often broadly acuminate, trinervate from or near base. Inflorescence an elongate leafy thyrsoid panicle, with thyrsoid lateral branches; ultimate branchlets with heads sessile or subsessile in small clusters. Involucres short, broadly campanulate; involucral bracts ca. 10 , weakly subimbricate, in ca. 2 somewhat unequal series, persistent, oblong, weakly bicostate, pubescent and glanduliferous on part or all of outer surface; receptacle slightly convex, glabrous. Florets ca. 6 in a head; corollas white, narrowly funnelform, with broadly cylindrical basal tube, outer surface glanduliferous, inner surface glabrous; cells of limb oblong with sinuous lateral walls; lobes triangular, about as long as wide, smooth on both surfaces, with numerous glands on outer surface; anther collar narrowly cylindrical, with numerous subquadrate cells in lower half, cell walls without ornate thickenings; anther appendage very short, much wider than long, reflexed; style base not enlarged, glabrous; style appendages narrowly linear, slightly broader distally, mamillose. Achenes prismatic, 5-ribbed, ca. $2 \mathrm{~mm}$ long, setuliferous mostly on ribs; car- 

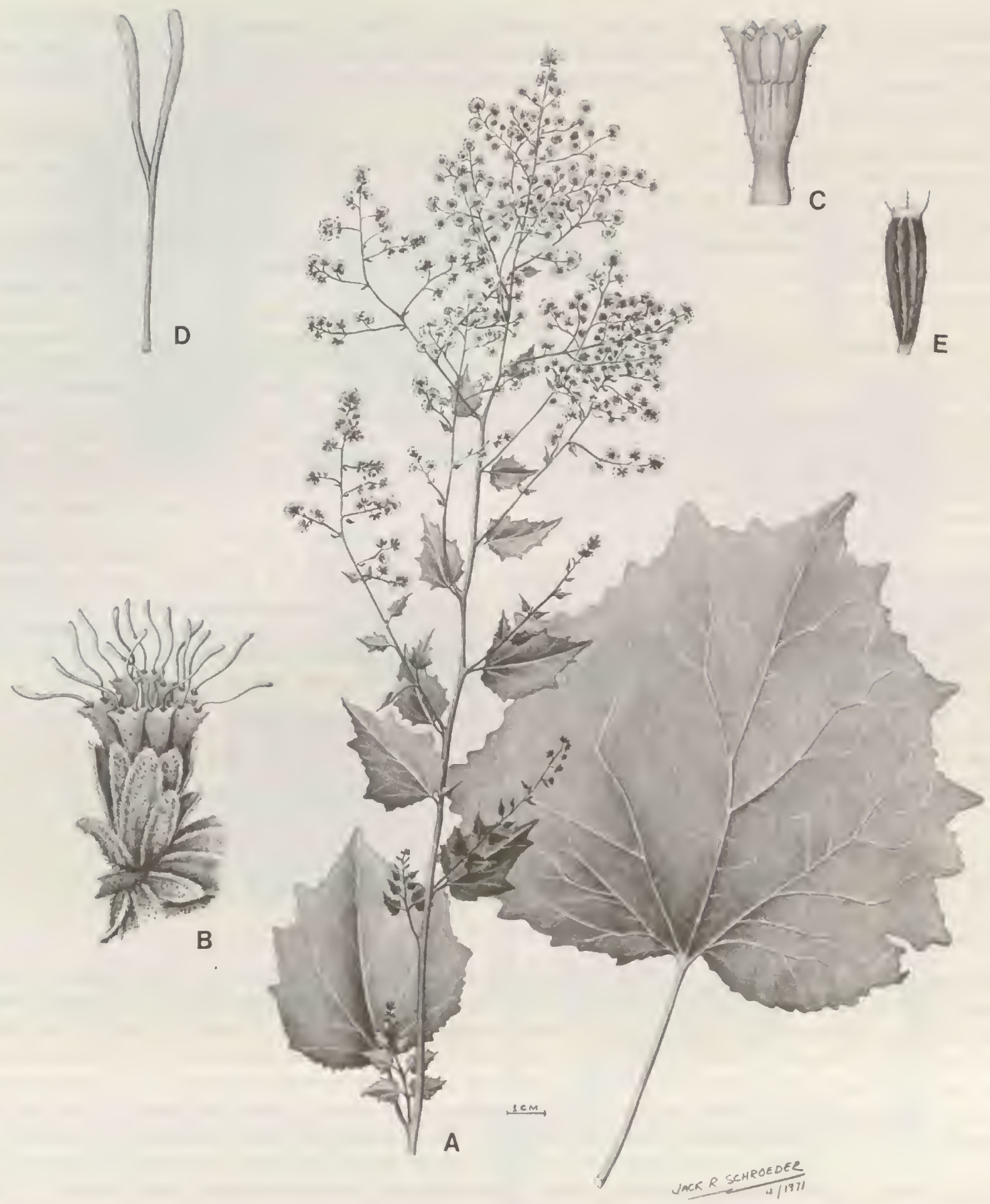

PLATE 164. Erythradenia pyramidalis (B. Robinson) R. King \& H. Robinson. - A. Habit, $\times 3 / 5 .-$ B. Head, $\times 71 / 2 .-$ C. Corolla showing anthers, $\times 13 .-D$. Style, $\times 13 .-E$. Achene, $\times 13$. 
popodium a narrow rim, with small subquadrate cells in ca. 5 tiers, with somewhat thickened walls, not procurrent on ribs, abruptly demarcated above by unsclerified cells; pappus obsolete, of short scabrid persistent bristles or setulae, scarcely distinguishable from setulae of achene ribs, apical cells acute. Pollen grains ca. $16-18 \mu \mathrm{m}$ in diameter. Plate 164 .

Erythradenia was originally described by $\mathrm{B}$. Robinson (1906) as a subgenus of Piqueria because of the obsolete seemingly absent pappus and the very small anther appendage. The latter combination of characters were the basis of the traditional broad concept of Piqueria that prevailed until the present series of studies. Erythradenia was distinguished within the genus by $\mathbf{B}$. Robinson by the broad rather than constricted basal tube of the corolla, and by alternate glanduliferous leaves. It was the colored glands of the leaves and inflorescence after which the subgenus was named.

Even at the time of the study by B. Robinson (1906), Erythradenia might have been recognized at the generic level, if the artificial traditional genera had not been so thoroughly entrenched. The present series of studies have shown that the genus is remote from other elements that have been placed in Piqueria. The purely Andean Piqueria subgenus Artemisioides with its almost totally obsolete anther appendage, eximbricate involucres, and broadly tipped style appendages, has proven to belong to the genus Ophryosporus in the Critoniinae. The species placed by B. Robinson in the other subgenera of Piqueria also show subequal involucral bracts but have papillose inner surfaces of the corolla lobes, and prove to belong to the subtribe Ageratinae. Among these, true Piqueria is particularly distinct, having 3-5 flowers in the head with an equal number of involucral bracts, papillose or pubescent lower parts of the anther filaments, opposite leaves, widely spaced micropunctations in the achene walls, and even the slight remnants of anther appendages incurved rather than reflexed.

As recognized by King and Robinson (1969e), Erythradenia is actually closely related to the genus Decachaeta and must be placed in the subtribe Hebecliniinae. Erythradenia has the same habit with narrowly thyrsoid panicles, alternate leaves, the same type of short anther appendages, identical carpopodia, similar corollas, inornate anther collars, and somewhat subimbricate involucres as in most species of Decachaeta. Actually, it is only the lack of a well-developed pappus and the lack of pubescence on the receptacle that dictate the need for a separate genus for Erythradenia. The subimbrication of the involucre in the genus seems somewhat weaker, and the inner bracts are more persistent, but this seems only part of generally reduced head size in Erythradenia. Contrary to the name given by B. Robinson (1906), the glands of the genus are sometimes yellowish rather than reddish.

The genus Erythradenia is known from comparatively few collections from the Sierra Madre del Sur in the states of Mexico, Guerrero, and Michoacán in Mexico.

The following single species is recognized in the genus: Erythradenia pyramidalis (B. Robinson) R. King \& H. Robinson, Mexico.

\section{Guayania}

\section{Guayania R. King \& H. Robinson, Phytologia 21: 302. 1971. TYPE: Eupatorium roupalifolium B. Robinson.}

Erect perennial herbs or shrubs, with moderate branching, with nearly glabrous and often fleshy stems and leaves. Stems terete, striated. Leaves opposite, shortly or longly petiolate; blades elliptical to broadly ovate, base cuneate to slightly acuminate, margins serrate, venation pinnate with somewhat to strongly ascending secondary veins, glandular punctations apparently lacking. Inflorescence strongly cymose; ultimate branchlets with heads sessile or subsessile in clusters. Involucres campanulate; involucral bracts ca. 12-25, subimbricate, in ca. 3-4 unequal graduated series, rather persistent, lanceolate to oblong, mostly 4-costate on outer surface; receptacle convex to hemispherical, glabrous. Florets 5-25 in a head; corollas bluish-white, lavender, or white, narrowly funnelform, with cylindrical basal tube, outer surface glabrous below lobes, inner surface glabrous; cells elongate with sinuous lateral walls; lobes triangular, about as long as wide, smooth on both surfaces, outer surface densely pilosulous; anther collars slender, composed of numerous subquadrate cells in lower half, cell walls without ornate thickenings; anther appendage large, triangular, longer than wide; style base not enlarged, glabrous; style appendages filiform, essentially terete, densely short-papillose. Achenes prismatic, 5-ribbed, 1.5-2 $\mathrm{mm}$ long, glabrous or with few setulae mostly on ribs; carpopodium distinct, strongly asymmetrical, with lower cells subquadrate, upper cells elongate, cell walls rather thin; pappus of ca. 30-40 slender scabrid persistent bristles in I series, narrowed distally, apical cells acute. Pollen grains ca. $18-20 \mu \mathrm{m}$ in diameter. Plate 165 . 

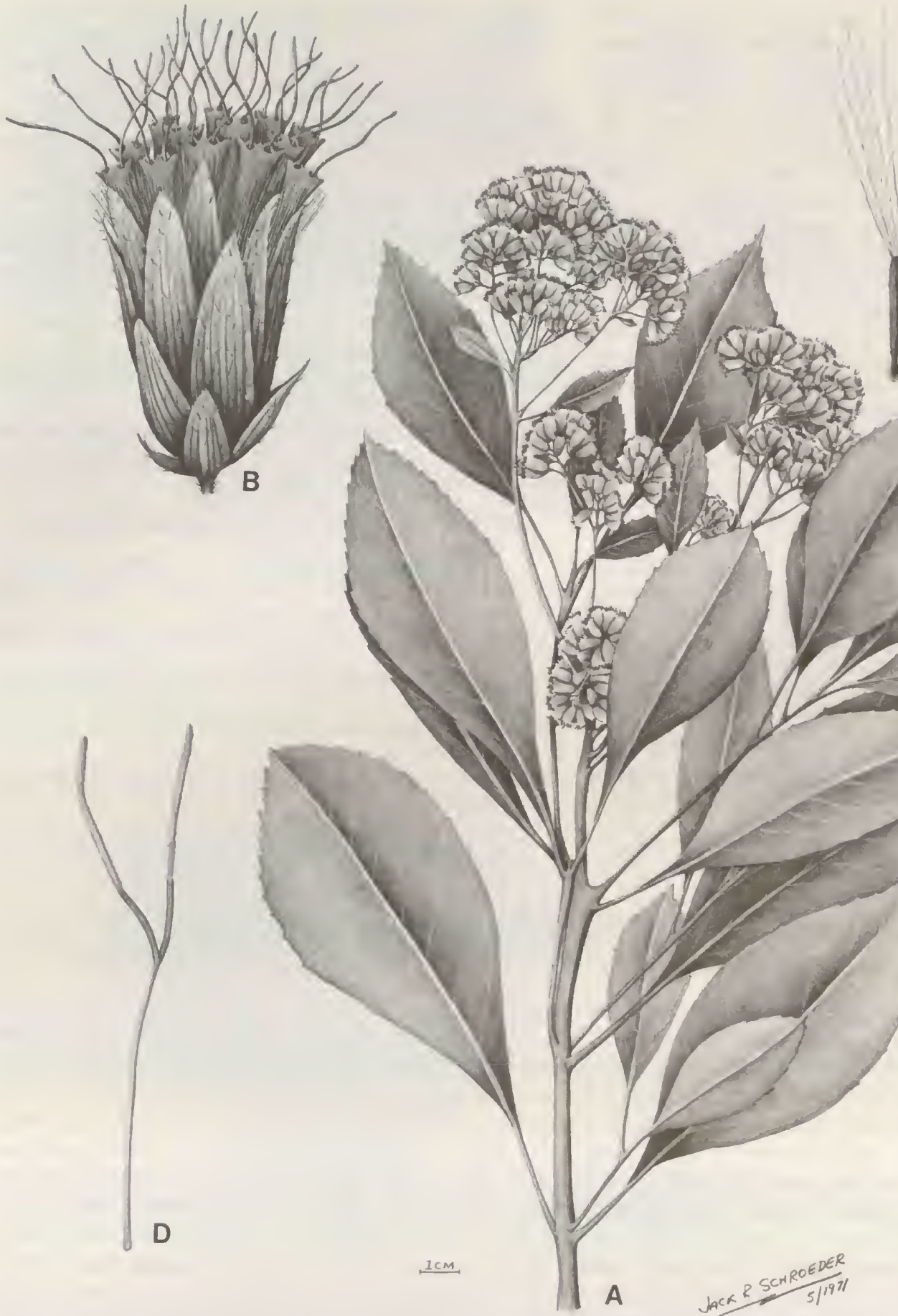
The genus Guayania does not have some of the features that are considered highly characteristic of the Hebecliniinae. It lacks hairs on the receptacle, and it often has less elongate anther collars with some beaded thickenings in the cell walls. Since the genus is South American, it is probable that a chromosome number would not be particularly helpful in assigning the genus, even if one were a vailable. Nevertheless, the receptacle of Guayania is rather prominent, sometimes almost conical, and the anther collars are sometimes elongate and always have numerous quadrate cells unobscured by thickenings. Furthermore, Guayania has a subimbricate involucre, a carpopodium procurrent on the ribs of the achene, and usually dense puberulence on the outer surface of the corolla lobes, all characters found in members of the Hebecliniinae. The filiform essentially terete appendages of the styles actually place the genus close to Hebeclinium itself.

Within the Hebecliniinae, Guayania is immediately distinguishable by the strongly asymmetrical carpopodium, having the outer side in the form of a sclerified shield and the opening born on the inner side. The genus is also some what distinct in the pinnate though sometimes strongly ascending venation of the leaf blade, and the lack of glandular punctations. The genus has a tendency for fleshiness not seen in other members of the subtribe, and seems to be rather specialized in this way for the area of the Guayana Highlands in northern South America where all the species occur.

In spite of the unquestionable unity of the genus, Guayania, between species, shows a high degree of structural variation. The comparatively widely distributed $G$. cer- asifolia, from lower elevations, is the most conventionally Eupatorian in aspect. The more succulent type species from tepuis of the eastern and central Guayana Highlands, has elliptical to obovate leaves with unusual strongly ascending secondary veins. Guayania crassicaulis, from near the base of Cerro Duida, has the leaves tending to be congested near the abruptly terminating fattened erect stems from which the slender inflorescences arise, while G. bulbosa, from Cerro Parú, is subrosulate from a bulbous base. The latter species seems to be the only member of the genus without numerous hairs on the outer surfaces of the corolla lobes. Two of the species, $G$. penninervata and G. yaviana, from tepuis in northern Amazonas in Venezuela, have been described with paniculate or corymbose inflorescences, but the over-all form of the inflorescences is presumed to be cymose.

The generic name refers to the Guayana Highland area of northern South America to which the genus is restricted.

The following six species are recognized in the genus:

Guayania bulbosa (Aristeg.) R. King \& H. Robinson, Venezuela. Guayania cerasifolia (Schultz-Bip. ex Baker) R. King \& H. Robinson, Brazil, Colombia, Venezuela.

Guayania crassicaulis (Steyerm.) R. King \& H. Robinson, Venezuela.

Guayania penninervata (Wurd.) R. King \& H. Robinson, Venezuela.

Guayania roupalifolia (B. Robinson) R. King \& H. Robinson, Venezuela, Guayana.

Guayania yaviana (Lasser \& Maguire) R. King \& H. Robinson, Venezuela.

\section{Matudina}

\section{Matudina R. King \& H. Robinson, Phytologia 26: 171. 1973. TYPE: Eupatorium corvi McVaugh.}

Coarse sprawling to erect calciphilous subshrubs or shrubs, sparingly branched, with dense cover of minutely tipped stipitate glands on stems and inflorescence; roots fleshy, clustered. Stems terete, striated, not fistulose. Leaves opposite, long-petiolate; blades herbaceous, with prominulous veinlets, broadly ovate, aceriform with cordate base, margins dentate-lobate, palmately veined from base, with glandular punctations on lower surface. Inflorescence subcymose, short central head distinctly maturing first; pedicels moderately long; heads broadly campanulate. Subinvolucral and involucral bracts ca. 75-125, subimbricate in 5-6 series, subequal, narrowly lanceolate with progressively shorter part being strongly reflexed and herbaceous; receptacle broadly convex, paleaceous; paleae narrowly linear, sharply acute. Florets ca. 200 in a head; corollas white, very narrowly funnelform, nearly cylindrical, with throat slightly constricted above, glabrous on both surfaces except for few glands on outer surface of lobes; cells of limb oblong with not or slightly sinuous lateral walls; lobes small compared to length of corolla, triangular, about as long as wide, smooth on inner and most of outer surface; anther collar slender, with subquadrate cells in basal fourth, oblong cells above, without ornate thickenings on walls; anther appendage large, oblong, slightly longer than wide, not retuse or grooved; style base not enlarged, glabrous; style appendages narrowly linear, slightly broadened distally, submamillose, apex obtuse. Achenes narrowly fusiform, 5-ribbed, ca. $4 \mathrm{~mm}$ long, with short setulae mostly in ribs; carpopodium symmetrical, shortly stopper-shaped with prominent upper rim, with moderate-sized subquadrate cells in 7-10 tiers, cell walls moderately thickened; pappus of ca. 15-22 slender scabrid non-contiguous or 


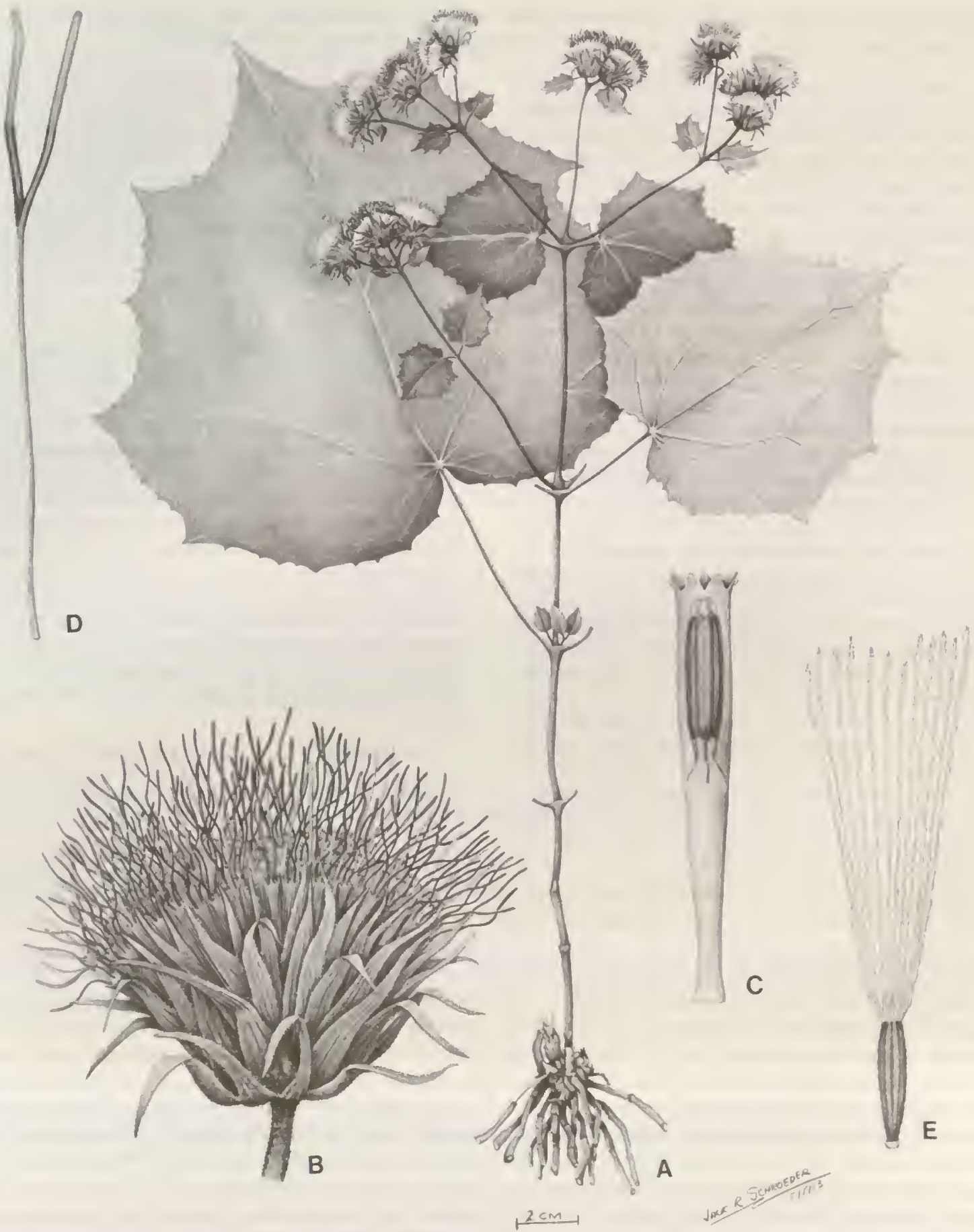

Plate 166. Matudina corvi (McVaugh) R. King \& H. Robinson, - A. Habit, $\times 1 / 2,-B$. Head, $\times 3$. C. Corolla showing anthers, $\times 10 .-D$. Style, $\times 10 .-E$. Achene, $\times 10$. 
scarcely contiguous rather easily deciduous bristles in 1 series, broadened and more scabrid distally, apical cells acute. Pollen grains ca. $20 \mu \mathrm{m}$ in diameter. Chromosome number $x=16$. Plate 166.

The genus Matudina is individually distinctive in the form of its heads with the great number of narrow subinvolucral and involucral bracts. The bracts are subequal in length but appear graduated because of the progressively decreasing proportion that is herbaceous and strongly reflexed. The bracts are subimbricate in approximately five to six series.

The heads of Matudina also contain numerous narrow paleae that are as long as the florets and have tips projecting above the unopened corollas. It is because of the paleae that the species was originally placed among members of the Eupatorieae that were at times placed in an artificial genus Eupatoriastrum. It was on the occasion of the description of the species that McVaugh (1972) noted the artificiality of the concept, and reduced Eupatoriastrum to synonymy under Eupatorium. The latter genus has subscquently been recognized as a natural group consisting of three species (King \& Robinson, 1971 h), without close relationship to other elements once placed in the genus. Matudina differs from true Eupatoriastrum by its solid rather than fistulose stems, the distinctly cymose order of maturation of the heads, and the anther appendage that is longer than wide rather than short, in addition to the involucral bracts. Eupatoriastrum is unquestionably in the relationship of Koanophyllon in the subtribe Critoniinae, which Matudina is not.

Matudina actually shows characteristics that are held in common by members of both the Critoniinae and the Hebecliniinae, subimbricate involucres, smooth surfaces of the corolla lobes, and the lack of strong ornamentation on the cell walls of the anther collars. The receptacles without hairs and with paleae are not like other members of the Hebecliniinac, and the achenes are longer than any in that subtribe except those of Amolinia. The achenes have carpopodia that are not procurrent on the achene ribs, and have non-contiguous distally broadened bristles of the pappus that are reminiscent of Peteravenia placed here in the Critoniinae, but both features also occur in Decachaeta of the Hebecliniinae. Ultimately, the position given to Matudina in the present treatment, is based partly on the chromosome number of $n=16$ (R. King et al., 1976), a number unknown in the Critoniinae, but found in Barlettina and Decachaeta in the Hebecliniinae.

Plants of Matudina have rather distinctive fleshy roots apparently born directly on the surface of limestone ledges. Observations of plants communicated in a letter from Dennis Breedlove indicate that Mantina is a calciphile, always occurring on lime cliff faces, getting a foothold in crevices or eroded pockets. The plant is a sprawling to erect shrub on such cliffs. All known plants are from the state of Chiapas in eastern Mexico, mostly near Chiapa de Corzo, but with one collection from an area $60-70 \mathrm{~km}$ to the north.

The generic name honors the Japanese born Mexican botanist Eizi Matuda (1894-1978), for many years with the Instituto de Biologia, Universidad Nacional Autonoma de Mexico. The species name given by McVaugh (1972) honors Peter H. Raven, of the Missouri Botanical Garden.

The following single species is recognized in the genus:

Matudina corvi (McVaugh) R. King \& H. Robinson, Mexico (Chiapas).

\section{SubTRIBE XIV. NeOMIRANDEINAE}

Neomirandeinae R. King \& H. Robinson, Phytologia 46: 448. 1980. TYPE: Neomirandea R. King \& H. Robinson.

Large herbs or shrubs to small trees, epiphytic or humicolous, moderately branched, never rosulate. Leaves opposite or whorled, petioles short or long; blades deltoid or aceriform to elliptical or oblong, with rounded to cordate bases, often subcarnose. Inflorescence a broadly cymose or corymbose panicle, with heads clustered, pedicels short to moderately long; involucral bracts strongly subimbricate, graduated in length, ecostate, inner bracts somewhat deciduous, outer persistent; receptacle plane or slightly convex, without paleae, with or without hairs. Flowers $2-28$ in a head; corollas white to reddish purple, narrowly funnelform, with or without hairs inside throat; cells of limb often subquadrate with non-sinuous walls; lobes triangular to narrowly oblong. smooth on both surfaces, without stomata on outer surface; anther collar elongate, 5-10 times as long as wide, of even width, with numerous subquadrate cells in lower half, without obvious ornate thickenings on walls; anther appendages longer than wide; style base with or without enlargement, glabrous; style branches narrowly linear, not strongly clavate at tip. Achenes prismatic, 5-ribbed, micropunctations of walls not strongly aligned in transverse bands; carpopodia short, without or with slight projecting upper rim, with small to moderate-sized subquadrate cells, cell walls thin to moderately thickened; pappus of numerous persistent capillary bristles, apical cells obtuse to acute. Basic chromosome number $x=17,20,25$. 
The subtribe Neomirandeinae has a general aspect and preference for moist habitats that is reminiscent of the subtribe Critoniinae, and the two subtribes share a number of the same general features such as the subimbricate involucres with often deciduous inner bracts, smooth corolla lobes, comparatively unornamented cell walls of the anther collars, and glabrous often unenlarged style bases. There is no reason to doubt that the two subtribes sharing these characters are related. The genus Neomirandea has not been placed in the Critoniinae, however, because of the consistent presence in the genus of higher chromosome numbers, and because of the presence in one subgenus of an enlargement at the base of the style. The genus, placed here in the Neomirandeinae, also tends to differ in its greater specialization toward the most moist habitats in the rain forests of Central America. The members of the subtribe are apparently completely restricted to organic substrates, and many are extreme epiphytes. Ultimately, it can be noted that the anther collars of the Neomirandeinae are generally more elongate than those of the Critoniinae, and that the involucral bracts are ecostate and more laxly imbricated than those of similarly shaped involucres in the Critoniinae. Although the subtribes seem closely related, the relationship is not considered immediate, and there are no genera in the Critoniinae that seem particularly close to Neomirandea.

The restriction of the Neomirandeinae to organic substrates, and the high degree of epiphytism, is the most complete in the tribe Eupatorieae. There are other epi- phytes in the tribe, however, perhaps more than in any other tribe of the Asteraceae. One such epiphyte, Tuberostyles, is a member of the Critoniinae, but it is a specialized epappose genus of the brackish mangrove forests along the Pacific Coasts from Panama to Ecuador, and is not related. Another possible epiphyte, the once collected Standleyanthus of Costa Rica, as indicated under that genus, is unquestionably a member of the Oxylobinae, differing by its trifoliate leaves and eximbricate involucre.

A more likely candidate for relationship to the Neomirandeinae on the basis of epiphytism is Mikania of the Mikaniinae. The latter large genus consists mostly of scandent species which are often common in trees in the Neotropical Region. Still, many species of Mikania are terrestrial, and even the scandent forms may germinate or continue to grow on the ground in comparatively inorganic substrates. Mikania also differs greatly in structure, with heads having four subequal involucral bracts and four flowers. Other details of the flowers, including various papillose lobe types and strongly emergent anthers, indicate a group remote from the Neomirandeinae.

There seem to be no reports of the chemical constituents of the subtribe Neomirandeinae. If the group holds to the pattern seen in some other Asteraceae in the more moist habitats, the secondary metabolites are probably not particularly numerous or concentrated.

The subtribe Neomirandeinae contains the single genus Neomirandea, and has other characteristics as in that genus.

\section{Neomirandea}

Neomirandea R. King \& H. Robinson, Phytologia 19: 306. 1970. TYPE: Eupatorium araliaefolium Less.

Large erect herbs, erect or spreading shrubs, or becoming small trees, epiphytic or growing in deep humus, sometimes becoming secondarily terrestrial, with few to many branches. Stems terete or subterete, faintly to strongly striated, glabrous to densely hirsute, fistulose or solid. Leaves usually opposite, ternate in $N$. costaricensis, petioles short to long, longer petioles sometimes with wings or teeth; blades elliptical or oblong to broadly deltoid or aceriform, base cuneate to cordate, margins entire to coarsely lobed and dentate, venation trinervate from base to pinnate, with or without glandular punctations below. Inflorescence broadly corymbose-paniculate; heads densely to laxly clustered on short to moderately long narrow pedicels. Involucres cylindrical to slightly spreading; involucral bracts ca. 9-28, moderately to strongly subimbricate, in 3-4 unequal graduated series, tips laxly appressed, obtuse to short-acute, inner bracts irregularly dentate in some $N$. araliaefolia, outer surface not obviously costate, inner bracts often deciduous; receptacle flat to slightly convex, glabrous or pilosulous. Florets 2-28 in a head; corollas white, lavendar, pink, or reddishpurple, narrowly funnelform or with broadly funnelform throat, shortly to longly cylindrical in basal tube, outer surface with hairs or glands, many hairs inside in subgenus Neomirandea; cells of limb usually laxly subquadrate with non-sinuous walls, rarely oblong with slightly sinuous walls; lobes usually short and triangular, about as long as wide, elongate and oblong to 3 times as long as wide in 4 species; anther collar elongate, with many subquadrate or short-oblong cells in lower part, cell walls without ornate thickenings; anther appendage large, ovate or oblong, slightly longer than wide; style base glabrous, enlarged in subgenus Neomirandea, not enlarged in subgenus Critoniopsis; style branches linear, scarcely broadened in distal part, smooth or nearly smooth. Achenes prismatic, 5-ribbed, glabrous or with few to many setulae; carpopodium 

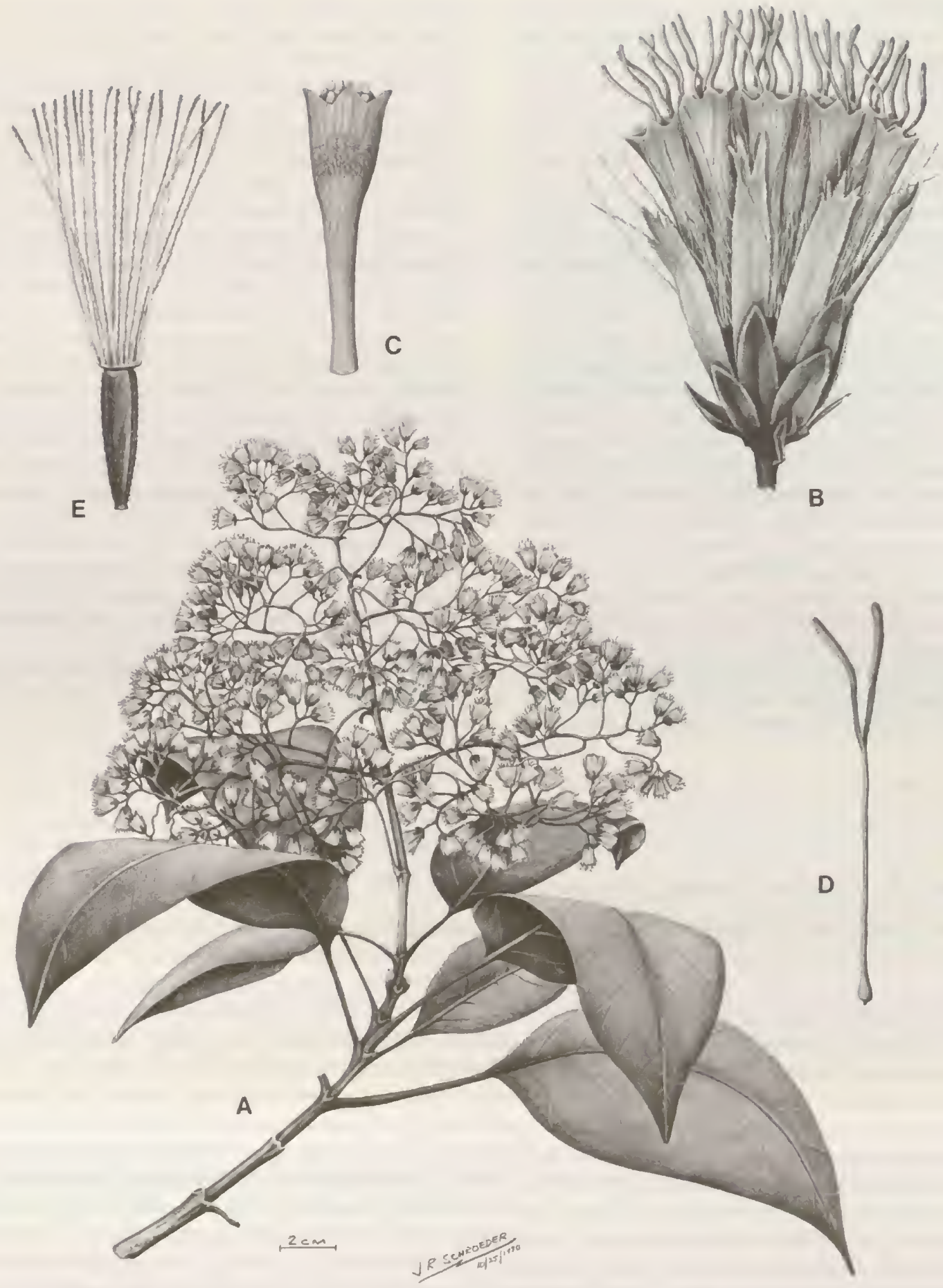

Plate 167. Neomirandea araliaefolia (Less.) R. King \& H. Robinson. - A. Habit, $\times 4 / \% .-B$. Head, $\times 7 .-$ C. Corolla showing anthers and internal hairs, $\times 8 .-D$. Style, $\times 8 .-E$. Achene, $\times 8$. 
annuliform to short-cylindrical, with projecting upper rim in older dried material, with small to mediumsized subquadrate cells in 5-10 tiers, cell walls slightly thickened; pappus of ca. 30-57 scarcely scabrid persistent slender mostly congested bristles mostly in 1 series, often slightly broadened distally, apical cells shortly to sharply acute. Pollen grains ca. $20 \mu \mathrm{m}$ in diameter. Plate 167.

The genus Neomirandea has a number of features in common with the subtribe Critoniinae, but is sufficiently distinct to be treated here in a separate monogeneric subtribe, Neomirandeinae. The distinctions are summarized in the preceding subtribal discussion.

Among the distinctions of Neomirandea, the most noticeable is the extreme specialization for epiphytism and organic substrates. The genus seems to be one of the most successful members of the family in invading the rain forest habitat. One of the species, $N$. allenii, has been noted as an epiphyte in the tops of the tallest trees in an area of central Panama (King \& Robinson, 1972vv), and $N$. araliaefolia has been recorded by collectors such as Skutch (King \& Robinson, $1970 \mathrm{~g}$ ) and Breedlove (pers. comm.) as having the habit of a strangler fig. Breedlove indicates that younger plants appear to be sprawling epiphytic shrubs often with pendent branches, and older individuals become tree-like as roots reach the ground and often replace the host trunk.

A number of the species of Neomirandea are not epiphytes, and one, $N$. angularis, seems to be common along roadsides in Costa Rica at certain times of year. Study of plants in the field, however, shows that such plants grow in deep humus or other organic substrates. Some of the species have extensive prop-root systems, and $N$. burgeri has a distinctive running rhizome, also with prop-roots. The substrate and basal structure of the latter terrestrial species leads to the belief that they are derived from epiphytic ancestors.

The diversity of Neomirandea is evident at both the superficial level noted above and at the anatomical and cytological level, and two subgenera are recognized, dating from the original description of the genus (King \& Robinson, $1970 \mathrm{~g}$ ). The subgenus Neomirandea has enlarged style bases, usually has hairs inside the corolla, and has more tiers of smaller subquadrate cells in the carpopodium. Counts of both epiphytic and terrestrial members indicate chromosome numbers of $n=20-25$ in the subgenus (R. King et al., 1976). The subgenus Critoniopsis has no enlargement at the base of the style, never has hairs inside the corolla, and has fewer tiers of somewhat larger cells in the carpopodium. Counts of three species indicate a rather consistent chromosome number of $n=17$ ( $R$. King et al., 1976). The subgenera, as defined, are regarded as totally natural, but they do not correlate with the most obvious superficial characters of the genus. The type species and its closest relatives are epiphytes with entire-margined leaves as in members of the subgenus Critoniopsis, but have the same subgeneric characters as the strikingly distinctive terrestrial species with sharply toothed leaf mar- gins. The lack of correlation discourages the thought that separate genera are involved.

A number of features of Neomirandea are of interest at the species level. The different basal structures of the stems in some of the terrestrial species seem stable within species, but unfortunately, the structures are rarely noted by collectors. The toothed wings on the petioles of some of the same species, however, seem equally valuable as species characters. The presence of hairs inside the corolla is a significant character both for the distinction of the subgenus Neomirandea, and for distinction within that subgenus of the three terrestrial species, $N$. burgeri, $N$. grosvenorii, and $N$. panamensis, which lack the hairs. The remaining terrestrial and epiphytic members of the subgenus have the hairs. Presence of the hairs usually is correlated in the genus with pubescence on the receptacle which is often more visible. The number of flowers in the heads also seems rather stable at the species level. The reduction series in the typical group is of particular interest, including $N$. turrialbae with mostly three flowers and $N$. biflora with two flowers in a head. Some species among both the epiphytic and terrestrial members of the subgenus Neomirandea have characteristically elongate or deeply cut lobes on the corollas.

The near restriction of Neomirandea to the more moist habitats of the Neotropical Region has had an effect upon the discovery of the species. Such habitats tend to be less habitable and have been comparatively poorly collected in the past. A few of the species are widely distributed such as the type, $N$. araliaefolia ranging from Jalisco in Mexico south to Panama, and $N$. homogama ranging from Panama as far south as the Amazonian side of the Ecuadorian Andes. The widely ranging species are all members of the subgenus Neomirandea. Most members of the genus, in both subgenera, have more restricted distributions concentrated in Costa Rica and western Panama, and many remained uncollected until recently. The problem of collecting is heightened by the seasonality of almost all the species. Even the largest terrestrial species seem to die back extensively, and different series of species are found at different times of year in Costa Rica. Only $N$. araliaefolia and $N$. eximia of the Costa Rican species have been collected in flower throughout the year.

The species of Neomirandea that were named prior to the present series of studies were mostly placed in the broad concept of Eupatorium. The one exception, $N$. homogama, was originally described in the genus Liabum. a member of another tribe. Still, the various factors that limited collecting of the genus in the past have resulted in an unusually large percentage of the species remaining 
undescribed until the start of the present series of studies. A key to the species then known was provided by King and Robinson $(1970 \mathrm{~g})$ at the time the genus was described, but numerous species have been named since (King \& Robinson, 1972kk, 1972vv, 1973e, 1975c, 1975d), with discussions of distinctions. A more recent key has been provided by King and Robinson (1975y) for the species in Panama, but one additional species has been described by Dillon and D'Arcy (1978).

The generic name honors the well-known Mexican botanist Faustino Miranda (1904-1964). The Spanish-born botanist is noted among other things, as author of a flora of Chiapas, and as developer of botanical gardens in Chiapas and Mexico City.

The following 27 species are recognized in the genus:

Neomirandea allenii $\mathrm{R}$. King \& H. Robinson, Panama, Colombia.

Neomirandea angularis (B. Robinson) R. King \& H. Robinson, Costa Rica.

Neomirandea araliaefolia (Less.) R. King \& H. Robinson, Mexico, Central America to Panama.

Neomirandea arthodes (B. Robinson) R. King \& H. Robinson, Costa Rica, Panama.

Neomirandea biflora R. King \& H. Robinson, Costa Rica.

Neomirandea burgeri R. King \& H. Robinson, Costa Rica.

Neomirandea carnosa (Kuntze) R. King \& H. Robinson, Costa Rica.
Neomirandea chiriquensis R. King \& H. Robinson, Panama. Neomirandea costaricensis R. King \& H. Robinson, Costa Rica. Neomirandea croatii R. King \& H. Robinson, Panama.

Neomirandea eximia (B. Robinson) R. King \& H. Robinson, Costa Rica, Panama.

Neomirandea folsomiana Dillon \& D'Arcy, Panama.

Neomirandea gracilis R. King \& H. Robinson, Panama.

Neomirandea grosvenorii $\mathrm{R}$. King \& $\mathrm{H}$. Robinson, Costa Rica.

Neomirandea guevarii R. King \& H. Robinson, Costa Rica.

Neomirandea homogama (Hieron.) H. Robinson \& Brettell, Panama, Colombia, Ecuador.

Neomirandea ovandensis R. King \& H. Robinson, Mexico, Guatemala.

Neomirandea panamensis R. King \& H. Robinson, Panama.

Neomirandea parasitica (Klatt) R. King \& H. Robinson, Costa Rica.

Neomirandea pithecobia (B. Robinson) R. King \& Robinson, Costa Rica.

Neomirandea pseudopsoralea R. King \& H. Robinson, Panama.

Neomirandea psoralea (B. Robinson) R. King \& H. Robinson, Costa Rica.

Neomirandea sciaphila (B. Robinson) R. King \& H. Robinson, Colombia.

Neomirandea standleyi (B. Robinson) R. King \& H. Robinson, Costa Rica, Panama.

Neomirandea terluipes R. King \& H. Robinson, Panama.

Neomirandea ternata R. King \& H. Robinson, Panama.

Neomirandea turrialbae R. King \& H. Robinson, Costa Rica.

\section{SubTribe XV. Mikaninae}

Mikaniinae R. King \& H. Robinson, Phytologia 46: 448. 1980. TYPE: Mikania Willd.

Usually woody vines, sometimes erect perennial herbs or shrubs, moderately branched, never rosulate. Leaves opposite or whorled, sessile to long-petiolate; blades linear to broadly ovate, with narrow to cordate bases, membranaceous to coriaceous. Inflorescence terminal on stems or lateral branches, cymose to corymbose or thyrsoid, with heads clustered, sessile to narrowly pedicellate; involucral bracts eximbricate, 4 , subequal, persistent; receptacle plane, epaleaceous. Flowers 4 in a head; corollas white or pink, funnelform or with variously campanulate limb, with or without distinct basal tube, glabrous to pilosulous or glanduliferous on outer surface, with or without papillae on inside of throat or lobes; cells of limb laxly subquadrate to elongate, with or without sinuous walls; lobes broadly triangular to narrowly oblong, without stomata on outer surface; anther collar broad, with numerous subquadrate cells, walls inornate; thecae distinctly emergent from open corolla; anther appendages as long as or longer than wide; style base thick, without distinct basal node, glabrous or sometimes papillose; style branches narrowly linear, not broadened at tip, scarcely to strongly papillose. Achenes prismatic, 4-10-ribbed, micropunctations of achene walls not strongly aligned in transverse bands; carpopodia short-cylindrical with mostly subquadrate cells, cell walls moderately thickened; pappus of numerous persistent capillary bristles, apical cells obtuse to acute. Basic chromosome numbers $x=$ ca. $16-20$.

The subtribe Mikaniinae is placed in the sequence in the present study on the basis of its high chromosome number and the lack of strong annular thickenings on the cell walls of its anther collars. The scandent habit and the strong representation of members in rain forest habitats is also similar to the preceding Neomirandeinae. Nevertheless, the Mikaniinae do not appear to be closely related to either the preceding Neomirandeinae or the following Oxylobinae. The Mikaniinae are actually remarkably distinct, having no clear close relatives outside of the subtribe.

The subtribe Mikaniinae is immediately distinguishable from others by the structure of the head, having four subequal eximbricate involucral bracts with four enclosed 
flowers. Only a few other members of the Eupatorieae sometimes show heads with parts in fours, and these are not related. Piqueria of the Ageratinae has bracts and flowers in equal numbers from three to five, occasionally including four, but the genus has flowers without anther appendages, with papillose or pubescent anther filaments, with dense annulation on the cell walls of the anther collars, and with sparse internal micropunctations in the achene wall. Ophryosporus of the Critoniinae also has some species with heads like those of Mikania, and specimens are sometimes labelled as Mikania. Still, Ophryosporus is easily distinguished by its exappendiculate anthers and the distinct clavate tips on its style branches. Although specimens of other members of the tribe, such as Hughesia of the Critoniinae, are sometimes labelled as Mikania because of their scandent habit, none possess the head structure of Mikania.

The anthers of the Mikaniinae are somewhat distinctive both in their exsertion and the structure of their collars. Most mature flowers of Mikania have the anthers emergent, and some with deeply cut lobes have the anthers completely exserted. Other members of the tribe, except those with deeply cut lobes, have the anthers included. The collars are usually short and distinctly broadened loward the base in Mikania, a form more reminiscent of the Heliantheae than other members of the Eupatorieae. Longer anther collars do occur in some species of Mikania.

The style base of the Mikaniinae is unusually broad, broadening above the narrow base and remaining thick for the entire length of the shaft. The shape and capacity for papillosity shown by the style bases in the subtribe, exceeds anything seen in the Neomirandeinae or Oxylobinae. The distinctive style base is often accompanied by a large elongate nectary unlike those in other subtribes of the Eupatorieae.

The high chromosome numbers in the Mikaniinae are also rather distinctive. The actual number has not been fixed with certainty. This contrasts with the ease with which most Eupatorieae can be counted. The difficulty in Mikania is partly from irregularity of the chromosome numbers, but is apparently mostly from the lack of clear differential staining between the chromosomes and cytoplasm of the meiotic cells. The staining problem is itself a character that seems to help distinguish the subtribe from others in the Eupatorieae.

The subtribe Mikaniinae is a large and diverse group with a pantropical distribution. The structural, geographical, and chemical diversity of the subtribe are discussed under the single included genus, Mikania.

\section{Mikania}

Mikania Willd., Sp. Pl., ed. 4, 3(3): 1742. 1803. TYPE: Eupatorium scandens L., typ. cons. [= Mikania scandens (L.) Willd.].

Carelia A. L. Juss. ex Cav., Anales Ci. Nat. 6: 317. 1802 (1803). Type: Carelia satureiaefolia Cav. [= Mikania parviflora (Aublet) Karsten], non Carelia Ponted. ex Fabr. 1759.

Corynanthelium Kunze, Linnaea 20: 19. 1847. TYPE: Corynanthelium moronoa Kunze (= Mikania glomerata Sprengel).

Morrenia Kunze, Linnaea 20: 19. 1847, nom. nud. in syn. TYPE: Morrenia odorata Kunze, nom. nud. (= Mikania glomerata Sprengel).

Moronoa Kunze, error for Morrenia.

Kanimia Gardner, London J. Bot. 6: 446. 1847. TYPE: Mikania strobilifera Gardner (= Mikania oblongifolia DC.).

Willoughbya Necker ex Kuntze, Revis. Gen. Pl. 1: 371. 1891. TYPE: Eupatorium scandens L. [= Mikania scandens (L.) Willd.].

Mostly vines, or reclining weak shrubs, sometimes erect perennial herbs or shrubs, with few to many branches. Stems terete to hexagonal, striated to rarely winged, glabrous or variously pubescent. Leaves opposite or in verticels of $3-4$, sessile to long-petiolate; blades narrowly linear to broadly ovate, sometimes dissected into broad or narrow segments, base narrowly cuneate to cordate or hastate, margins entire to toothed or lobed, apex rounded to short-acuminate, venation trinervate to pinnate, lower surface with or without glandular punctations. Inflorescence paniculate with diffuse, thyrsoid, racemose, spicate, corymbose, or subcymose branches; heads sessile or with short pedicels, head usually immediately subtended by subinvolucral bract, head raised above bract on short pedicel in M. houstoniana. Involucral bracts 4, eximbricate, subequal in 1 series, persistent, often with swollen bases; receptacle flat, glabrous. Florets 4 in a head; corollas usually white, sometimes pink, funnelform or with distinct basal tube and variously campanulate limb, glabrous to pilosulous or glanduliferous on outer surface, inner surface of throat smooth or rarely short- 


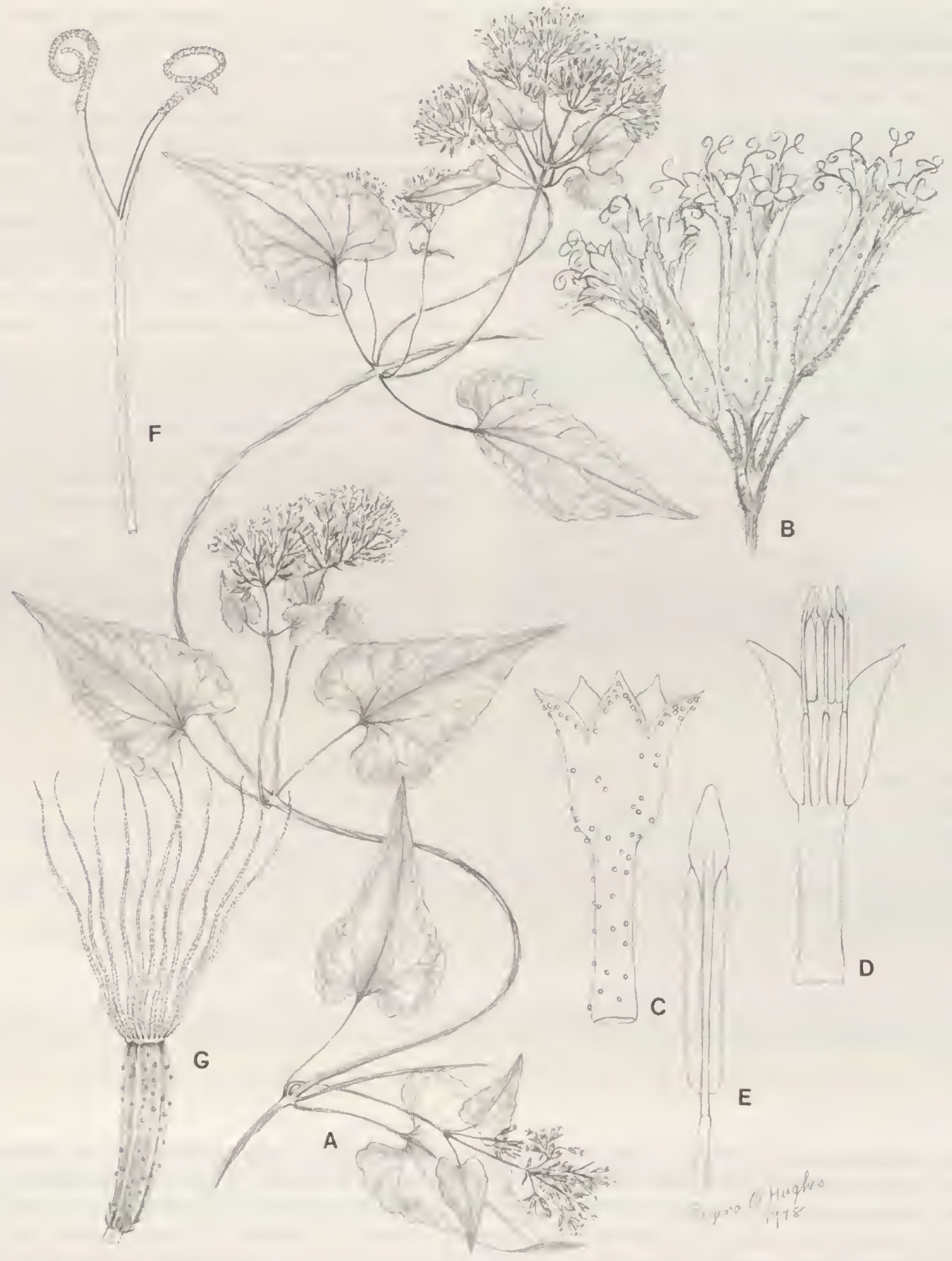

Plate 168. Mikania scandens (L.) Willd. - A. Habit, $\times 1 / 2 .-$ B. Cluster of heads, $\times 7 .-$ C. Corolla outer surface, $\times 15 .-$ D. Corolla inner surface with anthers, $\times 15 .-$ E. Anthers, $\times 35 .-F$. Style, $\times 15 .-G$. Achene, $\times 15$. 
papillose; cells of limb broadly to narrowly oblong, with or without sinuous lateral walls; lobes mostly triangular and as broad as long, sometimes narrowly oblong to 3 times as long as wide, with or without papillae on inner surface, often with fringe of hair-like cells along inside of margin; anther collar usually short, rarely longer, 1-4 times as long as wide, usually tapering from a broader base, composed of subquadrate to short-oblong cells, cell walls firm, with little or no ornate thickening; anther appendage large, ovate to oblong, 1-2 times as long as wide; nectary often large and elongate; style base often stout, not or gradually narrowed upwardly on shaft, usually smooth, papillose in $M$. guaco group; style branches narrowly linear, without enlarged tip, densely papillose, hirtellous with extremely long papillae in $M$. guaco group. Achenes prismatic, 4-10-ribbed, glabrous or with glands or setulae; carpopodium short-cylindrical, with mostly subquadrate cells, cell walls moderately thickened; pappus of ca. 35-60 scabrid persistent contiguous or congested bristles in 1-2 series, often somewhat broadened distally, apical cells usually obtuse. Pollen grains ca. $16-22 \mu \mathrm{m}$ in diameter. Chromosome numbers $n=$ ca. $16-20,2 n=34-38$. Plate 168.

Mikania is the largest genus of the tribe Eupatorieae, with approximately 400 known species. The genus has the general anther and pappus characters of the traditional broad concept of Eupatorium, but has been maintained as a distinct genus by most authors since the time of Willdenow (1803) on the basis of the distinctive heads containing four flowers enclosed in four involucral bracts. The mostly scandent habit of the genus has also probably been a factor in the general acceptance. The only recent suggestion that Mikania be reduced to the synonymy of Eupatorium was by Correll and Johnston (1970), and the last attempt to reduce the genus was by Gomez de la Maza (1889).

The genus Mikania is interpreted here to include all members of the subtribe Mikaniinae, all showing the characteristic head structure and the general trends in anther structure. The genus is in many ways one of the most perfect in the family, even superior to Baccharis of the Astereae in the large and diverse natural group that is sharply isolated from all other genera. The genus Mikania contrasts greatly in its present form from the many comparatively small genera recognized in the subtribe Critoniinae. There is no doubt that the latter genera represent minor groups equivalent to only species groups in $\mathrm{Mi}$ kania. The characters that would allow a broader natural concept within the Critoniinae are lacking however, and the generic treatment of each subtribe must be considered correct on the basis of the available characters.

Although the limits of the genus Mikania and the subtribe are not in doubt, the recognition of the genus is sometimes complicated by two factors. The heads in many of the species are densely clustered, and superficially look like larger heads with more flowers. Also, the involucre is often subtended closely by an additional subinvolucral bract that obscures the characteristic involucral organization.

The structure of the head with four flowers and four involucral bracts can be viewed as an extension of the opposite-leaved condition that is common in the vegetative parts of members of the Eupatorieae. Such an effect would help explain the great stability of the head structure in the genus. The suggestion suffers from the fact that the inflorescence in which the heads are borne is not restricted to such an opposite organization, but shows extreme variation in its form. It is as though the unusually stable organization of the heads had a destabilizing effect on the development of the inflorescence. Even considering the size of the genus, the variation in the branching of the inflorescence is exceptional.

There seems to be a destabilizing influence on the structure of the filower as well. The corolla form is highly erratic, being distinctive within some species groups but variable in others. A particularly extreme example of instability is the variation in the length of the basal tube and the depth to which the lobes are cut within the single species $M$. psilostachya. This is in total contrast to the stability of corolla form seen in other genera of the Eupatorieae including large genera such as Fleischmannia. There is also remarkable variation in papillosity on the inner surface of the corolla, base of the style, and appendages of the style in Mikania, more than in any other genus of the tribe.

Given the size and diversity of Mikania, attempts at generic segregation are to be expected, and a number of generic synonyms exist. Nevertheless, only one of the names, Kanimia, represents a serious attempt to recognize a separate genus, distinguished by an erect habit and tenribbed achenes. The type species, Kanimia strobilifera, might seem thoroughly distinctive to students knowing only the common scandent forms of Mikania having fiveribbed achenes. However, other species of Mikania in the drier open areas of Brazil, such as M. officinalis and $M$. reticulata, are erect without the extra achene ribs, and a number of Andean species are scandent with ten-ribbed achenes. There is no close relationship among the species having these characters. Ultimately, even such species as $M$. oblongifolia (including $K$. strobilifera), $M$. nitida, and $M$. pohlii, all of which have erect habits and ten-ribbed achenes, are not closely related. For this reason, the genus Kanimia has recently been formally reduced to synonymy under Mikania (King \& Robinson, 1980 $\mathrm{m}$ ).

Other attempts to subdivide Mikania have been at sectional and subsectional level, and date from the work of DeCandolle (1836). The sections of DeCandolle, based 
partly on habit, partly on branching of the inflorescence, and partly on leaf-shape, were Erectae, Spiciformes, Stipulatae, Ecordatae, Cordiformes, Angulatae, and Partitae. These were reorganized by J. Baker (1876) into three sections and four series: I. Corymbosae erectae, II. Corymbosae volubiles, with series, a. Ecordatae, b. Angulatae, c. Cordiformes, d. Partitae, and III. Spicato-Racemosae. B. Robinson (1922b) reorganized the genus further into five sections based entirely upon form of the inflorescence: I. Spiciformes DeCandolle, II. Racemosae B. Robinson, III. Thyrsigerae B. Robinson, IV. Corymbosae B. Robinson, and V. Globosae B. Robinson. The most recent rearrangement was by Barroso (1958) who recombined the closely related groups with spicate and racemose branches of the inflorescence and who resurrected the section based on dissected leaf blades as follows: I. SpicatoRacemosae Baker, II. Thyrsigerae B. Robinson, III. Corymbosae B. Robinson, IV. Globosae B. Robinson, and V. Partitae DeCandolle. The various sections are convenient for superficial subdivision of the genus, and the characters on which they are based remain useful for keys, but only the small section Partitae has any claim to being phyletic. The section Globosae is particularly aphyletic, since such species are intimately related to various thyrsoid members of the genus and are sometimes variable in the density of their inflorescences. Although the spicate-racemose species are usually more distinct from other types in the genus, the various species involved, such as $M$. houstoniana, $M$. decora, and $M$. psilostachya, are not closely related. Similarly, the corymbose types such as $M$. scandens and $M$. guaco are not closely related to each other. The last two inflorescence types have undoubtedly evolved more than once within the genus.

Any attempt at a phyletic subdivision of Mikania will require the recognition of far more numerous subgroups, often with comparatively few species. Some of the potential phyletic units that have been noticed include the following. The typical group with $M$. scandens, having cordate leaf blades, corymbose clustering of heads, and short lobes, with the probably related $M$. cordifolia group having longer corolla lobes; the $M$. guaco group with noncordate leaf blades, corymbose clustering of heads, and hirsutely papillose style appendages; the $M$. houstoniana group with spicate-racemose branches of the inflorescences and the inner surface of the corolla throat expanded and rugose; the $M$. psilostachya group with spicate-racemose branches of the inflorescence and numerous very large glands on the undersurfaces of the leaves; the $M$. banisteriae group with thyrsoid inflorescences, solid stems, leaf surfaces with dense pilosity but noglands, and broadly campanulate corolla limbs; the $M$. glomerata-M. hookeriana group with thyrsoid inflorescences, hollow stems, and sparsely pubescent to subglabrous leaves; the $M$. $o b$ ovata group with hair-like papillae along the inside margin of the corolla lobes; the $M$. lindleyana group with a double vein along the margin of the corolla lobes; the $M$. reticulata group with erect habits and sometimes closely spi- rally inserted or ternately inserted leaves; the $M$. ternata group with its dissected leaf blades; and the $M$. nitida group with its single large shrubby coriaceous-leaved maritime species. The listing is not intended to present all the possible groups in the genus, or to provide all of their characters, but does provide a measure of the diversity that is involved.

The chromosome studies of Mikania are not helpful in the subdivision of the genus. Definite counts are comparatively rare, and such counts differ within some of the species. Mikania micrantha alone has counts of $n=17$, 19, and 20 (Powell \& King, 1969a, 1969b; R. King et al., 1976). If the numbers are more stable in other species or species groups, it is not yet evident.

The chemistry of the genus is of some interest, and some of the constituents are cited in the chemical review of the Eupatorieae by Dominguez (1977). A number of subsequent studies (Bohlmann et al., 1981o, 1982d, 1982h, $1982 j, 1982 k$ ) have concentrated on the extensive terpenoid chemistry of the genus. As might be expected in such a large and diverse genus, the chemistry is diverse. There is a tendency for the production of highly oxygenated sesquiterpene lactones of the mikanolide, scandenolide, and miscandenin type (Bohlmann et al., 1982k) having 7-8 rather than the more common 7-6 lactone formation. Such lactones occur in the typical group and somewhat similar species such as $M$. grazielae. It is of particular interest that they also occur in $M$. goyazensis, M. pohlii, and M. purpurascens (Bohlmann et al., 1982 h, $1982 k$ ) three erect species previously placed in the segregate genus Kanimia. It is of further interest that a different series of erect species from Brazil, including $M$. alvimii, $M$. arrojadoi, $M$. luetzelburgii, and $M$. sessilifolia of the $M$. reticulata group (Bohlmann et al., 1981o, 1982d) lack the mikanolide type of lactone but have kaurene type diterpenes that are lacking in the other species. Yet another erect species, $M$. officinalis showed neither the mikanolide type lactones nor the kaurene type diterpenes (Bohlmann et al., 1981o). Kaurene type diterpenes have also been reported from a few scandent species, including $M$. belemii of the $M$. lindleyana group (Bohlmann et al., 1981o) and $M$. monagasensis of the $M$. banisteriae group (Mathur \& Fermin, 1973).

The genus Mikania is pantropical in distribution, with a few species reaching northward into the southeastern United States. The type species, $M$. scandens is restricted to, but widely distributed in the eastern United States. Not only the genus, but also many of the individual species are widely distributed. The pantropical distribution of $M$. micrantha is evidently due to human introduction, but other species, including $M$. microptera, the only transAtlantic species, seem to have attained their distributions naturally. Though wind distribution is probably common in the genus, the extreme success in distribution exhibited by numerous species, and the ability to cross the South Atlantic, are almost certainly the result of distribution by birds. It seems logical that a genus notable for its invasion 
of the habitats of birds, the trees, would have greatly increased opportunities for transport in the feathers of those animals.

The epiphytic nature of many of the species has also resulted in the greater representation of the genus in the Amazon Region, an area unsuited to most members of the Eupatorieae and the Asteraceae. This quality has resulted in many of the common species having distributions including both eastern Brazil and the northern Andes, areas with Asteraceous floras that are mostly very isolated from each other.

There are numerous keys to species of Mikania treating various regions. The typical group has been monographed on a world-wide basis by Holmes (1975, unpubl.). The Mexican species have been treated by B. Robinson (1926b). Treatments for other countries include Guatemala (Williams, 1976), Panama (King \& Robinson, 1975y), Colombia, Venezuela, Ecuador, Peru, and Bolivia (B. Robinson, $1922 b$ ), a more recent treatment of Venezuela (Aristeguieta, 1964), a more recent treatment of Peru, including 20 species described during the study (Holmes \& McDaniel, 1982), and Brazil (Barroso, 1958). Subsequent additions to Mikania in Brazil include ten new species (King \& Robinson, 1980c, 1981c) and six transfers from Kanimia. The Old World species are treated by Holmes (1982). Various notes and additions are found in the series of studies by Holmes and McDaniel (1975-1981) and by Holmes (1982-1986).

The generic name honors Joseph Gottfried Mikan, 17431814, professor at the University of Prague (Fernald, 1950).

The following 415 species are recognized in the genus:

Mikania acuminata DC., Brazil.

Mikania acutissima Rusby ex B. Robinson, Colombia.

Mikania additicia B. Robinson, Brazil.

Mikania alba Norman Taylor, Cuba.

Mikania alexandreae G. Barroso, Brazil.

Mikania allartii B. Robinson, Venezuela.

Mikania alvimii R. King \& H. Robinson. Brazil.

Mikania ambigens Urban, Trinidad.

Mikania amblyolepis B. Robinson, Colombia, Panama.

Mikania andrei B. Robinson, Ecuador.

Mikania anethifolia (DC.) Matzenbacher, Brazil, Uruguay.

Mikania angularis Humb. \& Bonpl., Colombia, Ecuador, Peru.

Mikania anisodora Hassler, Paraguay.

Mikania aquaria B. Robinson, Peru.

Mikania araguensis V. Badillo, Venezuela.

Mikania archeri B. Robinson, Colombia.

Mikania archidonensis Cuatrec., Ecuador.

Mikania areolata W. Holmes \& McDaniel. Peru.

Mikania argyreiae DC., Brazil.

Mikania argyropappa Schultz-Bip. ex Baker, Brazil.

Mikania aristei $\mathbf{B}$. Robinson, Colombia.

Mikania arrojadoi Mattf., Brazil.

Mikania arthroclada B. Robinson. Peru.

Mikania aschersonii Hieron., Costa Rica, Colombia, Ecuador, Peru.
Mikania baccharoidea Rusby, Bolivia.

Mikania bakeri R. King \& H. Robinson, Brazil.

Mikania banisteriae DC., Costa Rica, Panama, Andes S to Bolivia, Brazil.

Mikania barahonensis Urban, Dominican Republic.

Mikania barrosoana G. Barroso, Brazil.

Mikania batalaefolia DC., Florida, Cuba, Bahamas.

Mikania belernii R. King \& H. Robinson, Brazil.

Mikania biformis DC., Brazil.

Mikania bishopii R. King \& H. Robinson, Brazil.

Mikania bogotensis Benth., Costa Rica, Colombia,

Mikania brachycarpa Urban, Jamaica.

Mikania brachyphylla Hieron., Peru.

Mikania bradei B. Robinson, Brazil.

Mikania brevifaucia W. Holmes \& McDaniel, Peru.

Mikania broadwayi B. Robinson, Trinidad.

Mfikania brooksii W. Holmes \& McDaniel, Peru.

Mikania brunnescens B. Robinson. Brazil.

Mikania buchii Urban, Haiti.

Mikania buchtienii B. Robinson, Bolivia.

Mikania buddleiaefolia DC., Brazil.

Mikania bulbisetifera Cuatrec., Peru.

Mikania bullata B. Robinson, Peru.

Mikania burchellii Baker, Argentina, Brazil.

Mikania cabrerae G. Barroso, Brazil.

Mikania cacerensis G. Barroso, Brazil.

Mikania calcarulata B. Robinson, Paraguay.

Mikania caldasana B. Robinson, Colombia.

Mikania callineura Schultz-Bip. ex Baker, Brazil.

Mikania campanulata Gardner, Brazil.

Mikania camporum B. Robinson, Brazil.

Mikania campos-portoana G. Barroso, Brazil.

Mikania candolleana Gardner, Brazil.

Mikania capensis DC., East Africa, South Africa, Malagasy Republic.

Mikania capricorni B. Robinson, Brazil.

Mikania cardiophylla B. Robinson, Brazil.

Mikania carnosa Muschler, Peru.

Mikania carteri Baker, Cameroon, Nigeria.

Mikania casaretloi B. Robinson, Brazil.

Mikania chagalensis Hieron., Ecuador.

Mikania chenopodifolia Willd., tropical West Africa to S Sudan,

Ethiopia, S to Angola. Mozambique, Malagasy Republic, Fernando $\mathrm{Po}$.

Mikania chevalieri (C. Adams) W. Holmes \& McDaniel, Sierra Leone to Nigeria, Cameroon, Zaire, Angola, Zambia.

Mikania chimborazensis Hieron. in Sodiro, Ecuador.

Mikania chlorolepis Baker, Brazil.

Mikania chocensis B. Robinson, Colombia.

Mikania cipoensis $\mathbf{G}$. Barroso, Brazil.

Mikania clematidiflora Rusby ex B. Robinson, Colombia.

Mikania clematidifolia Dusén, Brazil.

Mikania coarctata Gardner, Brazil.

Mikania cochabambana B. Robinson, Bolivia.

Mikania comarapensis B. Robinson, Bolivia.

Mikania concinna Standley \& Steyerm., Guatemala.

Mikania conferta Gardner, Brazil.

Mikania confertissima Schultz-Bip. ex Baker, Brazil.

Mikania congesta DC., Puerto Rico, Lesser Antilles, N South

America to Peru, Bolivia, Brazil.

Mikania conglomerata W. Holmes \& McDaniel, Peru. 
Mikania cordata (Burm. f.) B. Robinson, SE Asia, East Indies, Borneo, New Guinea, Philippines, Taiwan, Hainan.

Mikania cordifolia (L. f.) Willd., SE United States, Mexico, Central America, West Indies, South America.

Mikania cordigera W. Holmes, Colombia.

Mikania corei W. Holmes \& McDaniel, Colombia.

Mikania corymbiifolia (B. Robinson) R. King \& Robinson, Brazil.

Mikania corymbulosa Benth., Colombia.

Mikania crassifolia Hieron., Peru.

Mikania crispiflora E. Wright, Cuba.

Mikania cristata B. Robinson, Costa Rica.

Mikania cuencana Hieron., Ecuador.

Mikania cutervensis Hieron., Peru.

Mikania cuzcoensis W. Holmes \& McDaniel, Peru.

Mikania cyanosma Urban \& E. Ekman, Haiti.

Mikania cynanchifolia (Hook. \& Arn. ex Baker) B. Robinson,

Argentina, Brazil, Paraguay, Uruguay.

Mikania decora Poeppig \& Endl., Ecuador, Peru.

Mikania decumbens Malme, Brazil.

Mikania desmocephala B. Robinson, Peru, Bolivia.

Mikania dictyophylla B. Robinson, Colombia.

Mikania dictyota B. Robinson, Bolivia.

Mikania dioscoreoides (Rusby) B. Robinson, Bolivia.

Mikania dissecta Urban \& E. Ekman, Haiti.

Mikania divaricata Poeppig \& Endl., Brazil, Guyana, Cayenne.

Mikania diversifolia DC., Brazil.

Mikania duckei $\mathrm{G}$. Barroso, Brazil.

Mikania dudleyi W. Holmes \& McDaniel, Peru.

Mikania duidensis B. Robinson in H. A. Gleason, Venezuela.

Mikania dusenii B. Robinson, Argentina, Brazil.

Mikania ecuadorensis W. Holmes \& McDaniel, Ecuador, Peru.

Mikania eggersii Heiron., Ecuador.

Mikania elliptica DC., Brazil.

Mikania erioclada DC., Brazil.

Mikania eriostrepta B. Robinson, Brazil.

Mikania eucosma B. Robinson, Bolivia.

Mikania euryanthela (Malme) W. Holmes, Brazil.

Mikania featherstonei B. Robinson, Ecuador, Peru.

Mikania fendleri Klatt, Panama.

Mikania ferruginea (Rusby) B. Robinson, Bolivia.

Mikania fiebrigii Hieron. in Urban, Bolivia.

Mikania filgueirasii R. King \& H. Robinson, Brazil.

Mikania filicifolia B. Robinson, Peru.

Mikania flabellata Rusby ex B. Robinson, Colombia.

Mikania flaccida B. Robinson, Bolivia.

Mikania florida Aristeg., Venezuela.

Mikania fragilis Urban, Puerto Rico.

Mikania fragrans Klatt, Colombia.

Mikania fulva (Hook. \& Arn.) Baker, Brazil.

Mikania glandulifera W. Holmes \& McDaniel, Peru.

Mikania glauca C. Martius ex Baker, Brazil.

Mikania glaziovii Baker, Brazil.

Mikania gleasonii B. Robinson, Guyana.

Mikania globifera Rusby ex B. Robinson, Colombia.

Mikania globosa (J. Coulter) J. Coulter in J. Sm., Mexico, Guatemala, El Salvador, Honduras.

Mikania glomerata Sprengel, Argentina, Brazil, Paraguay.

Mikania gonzalezii B. Robinson \& Greenman, Mexico.

Mikania goyazensis (B. Robinson) R. King \& H. Robinson, Brazil.

Mikania gracilipes B. Robinson, Venezuela.
Mikania granulata B. Robinson, Colombia, Ecuador.

Mikania grazielae R. King \& H. Robinson, Brazil.

Mikania guaco Humb. \& Bonpl., Mexico, Central America, South

America $\mathrm{S}$ to Bolivia, Brazil.

Mikania guaranitica Hassler, Paraguay.

Mikania guilleminii B. Robinson, Brazil.

Mikania haenkeana DC., Ecuador, Peru, Bolivia, Argentina.

Mikania hagei R. King \& H. Robinson, Brazil.

Mikania harlingii R. King \& H. Robinson, Ecuador.

Mikania hassleriana Chodat in Chodat \& Hassler, Paraguay.

Mikania hastata (L.) Willd., Cuba, Jamaica, Venezuela.

Mikania hastato-cordata Malme, Brazil.

Mikania hastifolia Baker, Brazil.

Mikania hatschbachii $\mathrm{G}$. Barroso, Brazil.

Mikania hemisphaerica Schultz-Bip. ex Baker, Argentina, Brazil.

Mikania hesperia B. Robinson, Colombia.

Mikania hexagonocaulis W. Holmes \& McDaniel, Peru.

Mikania hioramii Britton \& B. Robinson, Cuba.

Mikania hirsutissima DC., Argentina, Brazil.

Mikania hitchcockii B. Robinson, Ecuador.

Mikania hoehnei B. Robinson, Brazil.

Mikania hoffmanniana Dusén ex Malme, Brazil.

Mikania holwayana B. Robinson, Ecuador.

Mikania hookeriana DC., Mexico, Central America, Lesser Antilles, South America S to Bolivia, Brazil.

Mikania hotteana Urban \& E. Ekman, Haiti.

Mikania houstoniana (L.) B. Robinson, Mexico, Central America, Andes from Venezuela to Bolivia.

Mikania huanucoensis W. Holmes \& McDaniel, Peru.

Mikania iltisii R. King \& H. Robinson, Costa Rica.

Mikania incasina B. Robinson, Peru.

Mikania infesta B. Robinson, Peru.

Mikania inornata B. Robinson, Peru.

Mikania involucrata Hook. \& Am., Brazil.

Mikania iodotricha S. F. Blake, Ecuador.

Mikania iquitosensis B. Robinson, Peru.

Mikania iserniana Cuatrec., Ecuador.

Mikania itambama Gardner, Brazil.

Mikania jamaicensis B. Robinson, Jamaica.

Mikania jamesonii B. Robinson, Ecuador.

Mikania javitensis V. Badillo, Venezuela.

Mikania jelskii Hieron., Peru.

Mikania joergensenii B. Robinson, Argentina.

Mikania johnstonii B. Robinson, Venezuela.

Mikania jujuyensis Cabrera, Argentina.

Mikania juninensis W. Holmes \& McDaniel, Peru.

Mikania killipii B. Robinson, Colombia.

Mikania kleiniana Cabrera in Cabrera \& Vittet, Brazil.

Mikania klugii B. Robinson, Peru.

Mikania kubitzkii R. King \& H. Robinson, Brazil.

Mikania laevigata Schultz-Bip. ex Baker, Brazil.

Mikania lagoensis Baker, Brazil.

Mikania lanceolata Hieron. in Sodiro, Ecuador, Peru.

Mikania lancifolia B. Robinson, Peru.

Mikania lanuginosa DC., Venezuela, Brazil, Bolivia.

Mikania lasiandrea DC., Brazil.

Mikania lasiopoda B. Robinson, Peru.

Mikania latifolia Smith in Rees, Lesser Antilles.

Mikania latisquama Cabrera in Cabrera \& Vittet, Brazil.

Mikania laurifolia (L. f.) Willd., Colombia.

Mikania lawrancei B. Robinson, Colombia.

Mikania lehmannii Hieron., Colombia. 
Mikania leiolaena DC., Brazil.

Mikania leiostachya Benth., Guatemala to Panama, Colombia, Ecuador, Peru.

Mikania lepidophora Urban, Dominican Republic.

Mikania leptotricha Baker, Brazil.

Mikania leucophylla (Rusby) B. Robinson, Bolivia.

Mikania ligustrifolia DC., Brazil.

Mikania lindbergii Baker, Brazil.

Mikania lindenii S. Moore, Cuba.

Mikania lindleyana DC., Brazil, Guyana, Peru, Venezuela.

Mikania linearifolia DC., Brazil.

Mikania lloensis Hieron. in Sodiro, Colombia, Ecuador.

Mikania longiacuminata (Rusby) B. Robinson, Bolivia.

Mikania longiflora (Rusby) B. Robinson, Bolivia.

Mikania longipes Baker, Brazil.

Mikania lucida S. F. Blake in H. A. Gleason \& Killip, Venezuela.

Mikania luetzelburgii Mattf., Brazil.

Mikania lundiana DC., Brazil.

Mikania lutescens B. Robinson, Peru.

Mikania macbridei B. Robinson, Peru.

Mikania macedoi G. Barroso, Brazil.

Mikania malacolepis B. Robinson, Brazil.

Mikania marahuacensis Steyerm. \& Maguire, Venezuela.

Mikania marinii Cabrera, Peru.

Mikania mathewsii B. Robinson, Peru, Venezuela.

Mikania mattos-silvae R. King \& H. Robinson, Brazil.

Mikania maxonii Proctor, Jamaica.

Mikania mazanensis W. Holmes \& McDaniel, Peru.

Mikania mazaruniensis W. Holmes \& McDaniel, Guayana.

Mikania megalophylla W. Holmes \& McDaniel, Peru.

Mikania mendocina F. Philippi, Argentina.

Mikania micayensis B. Robinson, Colombia.

Mikania michelangleiana Steyerm., Venezuela.

Mikania miconiö̈des B. Robinson, Costa Rica, Panama, Colombia, Venezuela.

Mikania micrantha H.B.K., Mexico, Central America, West Indies, South America, widely introduced in Asia, Indonesia, Pacific Islands.

Mikania microcephala DC., Brazil.

Mikania microdonta DC., Brazil.

Mikania microlepis Baker, Brazil.

Mikania microphylla Schultz-Bip. ex Baker, Brazil.

Mikania microptera DC., Brazil, Bolivia, Peru, Venezuela, Guy. ana, Suriname, tropical West Africa to Zaire, Angola, Tanzania.

Mikania millei B. Robinson, Ecuador.

Mikania minima Schultz-Bip. ex Baker, Argentina.

Mikania monagasensis V. Badillo, Venezuela.

Mikania montana B. Robinson, Peru.

Mikania montverdensis Proctor, Jamaica.

Mikania morii R. King \& H. Robinson. Brazil.

Mikania mosenii Malme, Brazil.

Mikania mucronulifera B. Robinson, Colombia.

Mikania multinervia Turcz., Colombia, Ecuador.

Mikania myriocephala DC., Brazil.

Mikania natalensis DC., South Africa.

Mikania neblinensis Aristeg., Venezuela.

Mikania neei W. Holmes, Mexico.

Mikania nemorosa Klatt, Colombia.

Mikania neurocaula DC., Brazil.

Mikania nigricans Gardner, Brazil.

Mikania nigropunctulata Hieron., Colombia.
Mikania nitida (DC.) R. King \& H. Robinson, Brazil.

Mikania nodulosa Schultz-Bip. ex Baker, Brazil.

Mikania nummularia DC., Brazil.

Mikania oblongifolia DC., Brazil.

Mikania obovata DC., Brazil.

Mikania obsoleta (Vell.) G. Barroso, Brazil.

Mikania obtusata DC., Brazil.

Mikania ochroleuca B. Robinson, Brazil.

Mikania odoratissima Urban, Puerto Rico.

Mikania officinalis C. Martius, Brazil, Bolivia.

Mikania oopetala Urban \& Niedenzu, Cuba, Jamaica?

Mikania oreimeles B. Robinson, Bolivia.

Mikania oreopola B. Robinson, Peru.

Mikania orleansensis Hieron., Brazil.

Mikania ovalis Griseb., Lesser Antilles.

Mikania oxylepis Schultz-Bip. ex Baker, Brazil.

Mikania pachychaeta (Baker) G. Barroso, Brazil.

Mikania pachydictya B. Robinson, Colombia.

Mikania pachyphylla Urban, Puerto Rico.

Mikania palustris (Gardner) R. King \& H. Robinson, Brazil.

Mikania paniculata DC., Brazil.

Mikania pannosa Baker, Venezuela, Brazil.

Mikania papillosa Klatt, Dominican Republic.

Mikania paranahybensis G. Barroso, Brazil.

Mikania paranensis Dusén, Brazil.

Mikania parvicapitulata Hieron. in Urban, Peru.

Mikania parviflora (Aublet) Karsten, Colombia, Venezuela, Cayenne, Ecuador, Peru, Brazil.

Mikania parvifolia Baker, Brazil.

Mikania pastazae B. Robinson, Ecuador.

Mikania paucifolia W. Holmes, Colombia.

Mikania pendula W. Holmes \& McDaniel, Peru.

Mikania pennellii B. Robinson, Colombia.

Mikania periplocifolia Hook. \& Am., Argentina, Brazil, Bolivia,

Paraguay, Uruguay.

Mikania pernambucensis Gardner, Brazil.

Mikania perstipulara W. Holmes, Bolivia.

Mikania petrina Standley \& Steyerm., Guatemala.

Mikaniaa phaeoclados C. Martius ex Baker, Brazil.

Mikania pichinchensis Hieron., Ecuador.

Mikania pilcomayensis (Hassler) B. Robinson, Argentina, Paraguay.

Mikania pilosa Baker, Brazil.

Mikania pinnatiloba DC., Argentina, Brazil, Uruguay.

Mikania pittieri B. Robinson, Costa Rica, Panama.

Mikania platylepis D. Don ex R. King \& H. Robinson, Peru.

Mikania platyloba Urban \& E. Ekman, Dominican Republic.

Mikania pohliana Schultz-Bip. ex Baker, Brazil.

Mikania pohlii (Baker) R. King \& H. Robinson, Brazil.

Mikania polycephala Urban, Haiti.

Mikania polychaeta Urban, Haiti.

Mikania popayanensis Hieron., Colombia.

Mikania populifolia Gardner, Brazil.

Mikania porosa Urban, Puerto Rico.

Mikania premniflora Gardner, Brazil.

Mikania producta Urban \& E. Ekman, Dominican Republic.

Mikania pseudogracilis R. King \& H. Robinson, Brazil.

Mikania pseudohoffmanniana G. Barroso, Brazil.

Mikania pseudomicrocephala R. King \& H. Robinson, Brazil.

Mikania psilostachya DC., Panama, South America S to Bolivia, Brazil.

Mikania pterocaula Schultz-Bip. ex Klatt, Mexico, Guatemala. 
Mikania pteropoda DC., Brazil.

Mikania pulverulenta Sodiro ex B. Robinson, Ecuador.

Mikania purpurascens (Baker) R. King \& H. Robinson, Brazil.

Mikania pycnadenia B. Robinson, Peru.

Mikania pyramidata J. Smith, Mexico, Guatemala, Honduras. Mikania ramosissima Gardner, Brazil.

Mikania ranunculifolia A. Rich. ex D. Ramon de la Sagra, Cuba.

Mikania reticulata Gardner, Brazil.

Mikania reticulosa $\mathrm{E}$. Wright, Cuba.

Mikania retifolia Schultz-Bip. ex Baker, Brazil.

Mikania rhomboidea Urban \& E. Ekman, Haiti.

Mikania rimachii W. Holmes \& McDaniel, Peru.

Mikania riparia Greenman ex B. Robinson, Costa Rica.

Mikania rivularis $\mathrm{B}$. Robinson, Peru.

Mikania rondonensis V. Badillo, Venezuela.

Mikania rothii $\mathrm{G}$. Barroso, Brazil.

Mikania rotunda Griseb., West Indies.

Mikania rubella Lingelsh., Bolivia.

Mikania rufa Benth., Colombia.

Mikania rufescens Schultz-Bip. ex Baker, Brazil.

Mikania rugosa B. Robinson, Peru.

Mikania rusbyi B. Robinson, Bolivia.

Mikania sagittifera B. Robinson, Zaire, Ruanda, Burundi, Tan-

zania, Zambia, Zimbabwe, Angola, Botswana.

Mikania salicifolia Hassler, Paraguay.

Mikania saltensis Hieron., Argentina.

Mikania salviaefolia Gardner, Brazil.

Mikania salzmanniaefolia DC., Brazil.

Mikania santosii R. King \& H. Robinson, Brazil.

Mikania sarcodes Baker, Brazil.

Mikania scabrida Baker, Brazil.

Mikania scandens (L.) Willd., E North America, NE Mexico, Bahamas.

Mikania schenckii Hieron., Brazil.

Mikania schultzii B. Robinson, Bolivia.

Mikania seemannii B. Robinson, Ecuador.

Mikania selloi Sprengel, Brazil.

Mikania sericea Hook. \& Arn., Brazil.

Mikania sessilifolia DC., Brazil.

Mikania setigera Schultz-Bip. ex Baker, Brazil.

Mikania shushunensis W. Holmes \& McDaniel, Peru.

Mikania siambonensis Hieron., Argentina.

Mikania simpsonii W. Holmes \& McDaniel, Colombia, Peru.

Mikania smaragdina Dusén ex Malme, Brazil.

Mikania smilacina DC., Brazil.

Mikania smithii B. Robinson, Colombia.

Mikania speciosa DC., Peru, Bolivia.

Mikania sprucei Baker, Venezuela, Brazil.

Mikania steinbachii B. Robinson, Bolivia.

Mikania stenomeres B. Robinson, Brazil.

Mikania stereodes B. Robinson, Peru.

Mikania stereolepis B. Robinson, Ecuador.

Mikania stevensiana Britton, Puerto Rico.

Mikania steyermarkii R. King \& H. Robinson, Venezuela.

Mikania stipulacea (M. Vahl) Willd., Brazil.

Mikania stipulifera L. O. Williams, Honduras.
Mikania stuebelii Hieron., Colombia, Venezuela, Peru.

Mikania stygia B. Robinson, Bolivia.

Mikania stylosa Gardner, Brazil.

Mikania subverticillata Schultz-Bip. ex Baker, Brazil.

Mikania sulcata (Hook. \& Am.) B. Robinson, Brazil.

Mikania swartziana Griseb., Cuba, Jamaica?

Mikania sylvatica Klatt, Colombia, Ecuador.

Mikania szyszylowiczii Hieron., Ecuador, Peru.

Mikania tafallana H.B.K., Ecuador.

Mikania tambillensis Hieron., Peru.

Mikania tehuacanensis W. Holmes, Mexico.

Mikania teixeirae R. King \& H. Robinson, Brazil.

Mikania tenax Schultz-Bip. ex B. Robinson, Peru.

Mikania tepuiensis V. Badillo, Venezuela.

Mikania ternata (Vell.) B. Robinson, Argentina, Brazil, Paraguay, Peru.

Mikania ternifolia DC., Brazil, Uruguay.

Mikania testudinaria DC., Brazil.

Mikania thapsoides DC., Argentina, Brazil, Paraguay, Uruguay.

Mikania thyrsoidea Baker, Brazil.

Mikania tillettii R. King \& H. Robinson, Guyana, Venezuela.

Mikania tonduzii B. Robinson, Guatemala, Costa Rica, Panama.

Mikania trachodes B. Robinson, Peru.

Mikania trachypleura B. Robinson, Argentina, Brazil, Paraguay. Mikania triangularis Baker, Brazil.

Mikania trichophila DC., Brazil.

Mikania trifolia (Rusby) B. Robinson, Bolivia.

Mikania trimeria W. Holmes \& McDaniel, Colombia.

Mikania trinervis Hook. \& Arn., Brazil.

Mikania trinitaria DC., Venezuela, Guyana, Trinidad, Brazil.

Mikania tripartita Urban \& Niedenzu, Haiti.

Mikania triphylla Sprengel ex Baker, Brazil.

Mikania troyana Urban, Jamaica.

Mikania turbaricola W. Holmes \& McDaniel, Peru.

Mikania tysonii R. King \& H. Robinson, Panama.

Mikania ulei Hieron., Brazil.

Mikania urticaefolia Hook. \& Am., Argentina.

Mikania vargasii W. Holmes \& McDaniel, Peru.

Mikania variifolia Hieron., Argentina, Brazil.

Mikania vaupesensis W. Holmes \& McDaniel, Colombia.

Mikania vauthieriana Baker, Brazil.

Mikania venosa Alain, Dominican Republic.

Mikania viminea DC., Brazil.

Mikania violaefolia Cuatrec., Peru.

Mikania violascens (B. Robinson) R. King \& H. Robinson, Colombia.

Mikania virgata $\mathrm{B}$. Robinson, Brazil.

Mikania vismiaefolia DC., Brazil.

Mikania vitifolia DC., Mexico, Central America, South America S to Bolivia, Brazil.

Mikania warmingii Schultz-Bip. ex Baker, Brazil.

Mikania weberbaueri Hieron. in Urban, Peru.

Mikania werdermannii B. Robinson, Bolivia.

Mikania williamsii B. Robinson, Bolivia.

Mikania woytkowskii W. Holmes \& McDaniel, Peru.

Mikania zonensis R. King \& H. Robinson, Panama. 


\section{SubTRIBe XVI. OXYLOBINAE}

\section{Oxylobinae R. King \& H. Robinson. Phytologia 38: 323. 1978. TyPE: Oxylobus (Moc. ex DC.) A. Gray.}

Perennial herbs or shrubs to small trees, usually erect, rarely somewhat scandent, moderately to densely branched, never rosulate. Leaves opposite, rarely subopposite, alternate, or ternate, short- to long-petiolate; blades deltoid to narrowly elliptical, membranaceous to coriaceous. Inflorescences terminal on stems or branches, usually pyramidally to corymbosely paniculate, with heads clustered, on short to moderately long pedicels; involucral bracts eximbricate to weakly subimbricate, usually subequal, persistent; receptacle plane to slightly convex, with or without paleae. Flowers 7-75 in a head; corollas white or pink, rarely purple, narrowly funnelform or with slender basal tube and campanulate limb, glabrous to pilosulous or glanduliferous on outer surface; cells of throat and outer surface of lobes usually elongate with sinuous lateral walls; lobes triangular, often distinctly longer than wide, usually densely papillose on inner surface, smooth but cells rather isodiametric in Jaramilloa, Kaunia, and some Piptothrix, outer surface without stomata, usually thickened and seeming cushion-like, smooth, roughened in Pachythamnus and Spaniopappus; anther collar often more than 5 times as long as wide, with numerous subquadrate cells in iower part, cell walls inornate or with weak beaded thickenings; anther appendage as long as wide; style base often with distinct enlarged node, lacking in Jaramilloa, Kaunia, Pachythamnus, Spaniopappus, and Ageratina subg. Apoda, glabrous; style branches narrowly linear, without enlarged tips, usually densely papillose. Achenes prismatic to fusiform, 5-ribbed, micropunctations of achene walls not strongly aligned in transverse bands; carpopodium usually distinct, short-cylindrical or stopper-shaped, cells moderately sized, subquadrate to oblong, walls firm, thin to beaded, indistinct in Piptothrix; pappus of numerous deciduous or persistent capillary bristles, squamellose in Oxylobus, a few short bristles and a fringe of minute squamellae in Spaniopappus ekmanii, apical cells acute. Basic chromosome numbers $x=16,17$, or 20 , with considerable irregularity and apomixis.

The Oxylobinae is a large and distinctive subtribe noted primarily for the major genus Ageratina with approximately 200 species. The subtribe is notable for its usually eximbricate involucres, the essentially inornate cell walls of its anther collars, the commonly enlarged base of its styles, the basically papillose inner surfaces of its corolla lobes, the comparatively large thin-walled cells of its carpopodia, and its well-established high basic chromosome number. The combination of characters leads to the belief that the group is rather isolated in the Eupatorieae, and various members such as Kaunia that approach the subtribe Critoniinae in their smooth corolla lobes and unenlarged style bases are believed to be specialized in the Oxylobinae, reverting from forms more like Ageratina.

The placement of the Oxylobinae in the present system derives primarily from the inornate cell walls of the anther collars and the high chromosome numbers. These features and the eximbricate involucre bring the subtribe into the order after the Mikaniinae, but the Oxylobinae have none of the specialized features of the latter, and the association seems to be without phyletic significance. The preceding subtribe Neomirandeinae is actually a better candidate for close relationship by its longer anther collars and multi-flowered heads, but has distinctly subimbricate involucral bracts and other Critoniine characteristics of the corollas and carpopodia that are totally foreign to the basic pattern in the Oxylobinae. The Oxylobinae may actually be closest to the following subtribes, the Hofmeisteriinae and the Oaxacaniinae, but the latter differ among other things by their distinctly subimbricate involucres and their solitary heads. The latter are actually not considered close relatives in the present treatment.

Some of the comparisons made between members of the Oxylobinae and members of other subtribes in the past, actually involve groups that are totally remote in relationship. There is a particularly close habital resemblance between some members of Ageratina and some species of Fleischmannia of the Fleischmanniinae (Williams, 1975, 1976), but the two can easily be distinguished as indicated under Ageratina. The attempt to relate Ageratina to Stevia of the subtribe Ageratinae (Grashoff et al., 1972) seems to be based mostly on the assumption that some of the $2 n=34$, chromosome counts of the latter can be interpreted as $n=17$ as in Ageratina. The corolla lobes of the two genera do appear similar in their papillose inner surfaces and smooth outer surfaces, but the Stevia counts seem on further examination to be based on $x=11$ or 12 (R. King et al., 1976). Also, Stevia is in a subtribe that seems to basically lack a capillary pappus, and which has strongly annulated cell walls in the anther collars.

As presently circumscribed, the Oxylobinae seems to be a natural group. The genera, however, have been placed very erratically previously. Ageratina, Pachythamnus, Standleyanthus, most of Spaniopappus, and one species of Piptothrix have been placed in the traditional broad concept of Eupatorium. Two species of Jaliscoa have been placed in Piptothrix. Oxylobus and the type species of Spaniopappus have been maintained as distinct genera on 
the basis of their reduced pappus of short bristles or squamellae. Oxylobus was usually associated closely with Ageratum (B. Robinson, 1913b).

Chromosome counts for the subtribe are numerous, but mostly from two genera. Ageratina shows most of the known reports of $n=17$ in the Eupatorieae, but the subgenus Andinia seems to have a base of $x=20$, and $O x y$ lobus has $x=16$ (R. King et al., 1976). Recent efforts to count Kaunia show a number in excess of $n=40$.

The chemistry of the members of the subtribe is not particularly notable, but Ageratina has perhaps the most well-recorded occurrences of benzofurans in the tribe (Hass, 1970). A small quantity of the phyletically significant pyrrolizidine alkaloid group has been isolated from $A$. adenophora by Webb (Everist, 1974). Sesquiterpene lactones have been studied from Oxylobus (Bohlmann et al., 1980b), and monoterpenes seem rather characteristic of the genus Kaunia (Bohlmann et al., 1981q). The chemistry is discussed further under the various genera.

The subtribe Oxylobinae displays a basically western distribution pattern in North and South America, being concentrated in the Mexican highlands and the Andes. Only one species of Ageratina reaches eastward into southern Brazil, and a few species of Ageratina occur in the eastern United States and the West Indies. Spaniopappus is the only strictly eastern genus in the subtribe, being endemic to eastern Cuba. The distribution pattern of the subtribe is in extreme contrast to that of such subtribes as the Eupatoriinae, the Disynaphiinae, and the Gyptidinae which are concentrated in the eastern parts of North and South America.

\section{KEY TO THE GENERA OF THE SUBTRIBE OXYLOBINAE}

1. Leaves trifoliolate

175. Standleyanthus

I'. Leaves simple

73. Pachythamnus

2. Stems thick with fleshy cortex; leaves absent at anthesis

173. Pachythamnus

$2^{\prime}$. Stems not unusually thickened; plants not seasonally defoliated

3. Heads with paleae

172. Jaliscoa

3'. Heads without paleae

4. Corolla lobes papillose on outer surface; style base not enlarged above nectary; plants of eastem Cuba

4'. Corolla lobes smooth on outer surface; style base with or without node above nectary

174. Spaniopappus

5. Pappus reduced to short scales

170. Oxylobus

5'. Pappus of capillary bristles

6. Stems and leaves with yellowish granular pubescence

177. Jaramilloa

6'. Stems and leaves without yellowish granular pubescence

7. Style base with enlarged node above nectary; bristles of pappus often easily deciduous

8. Carpopodium not differentiated; corolla lobes sometimes completely smooth on inner surface ........

171. Piptothrix

8'. Carpopodium differentiated with sclerified cells, sometimes long-cylindrical; corolla lobes never completely smooth on inner surface

169. Ageratina

7'. Style base without enlarged node above nectary; bristles of pappus persistent

9

9. Herbs, with leaves trinervate from near base of blade; inner surfaces of corolla lobes mamillose to papillose 169. Ageratina subgenus Apoda

9'. Shrubs or small trees, with leaves pinnately veined or having ascending secondary veins parallel to basal leaf margin; inner surfaces of corolla lobes smooth 176. Kaunia

\section{Ageratina}

Ageratina Spach, Hist. Nat. Veg. Phan. 10: 286. 1841. LeCTOTYPE: Eupatorium aromaticum L. [= Ageratina aromatica (L.) Spach].

Batschia Moench, Methodus 567. 1794. TYPE: Batschia nivea Moench [= Ageratina altissima (L.) R. King \& H. Robinson], non Batschia J. Gmelin, 1791 (Boraginaceae); Batschia Mutis ex Thunb., 1792 (Menispermaceae); or Batschia M. Vahl, 1794 (Leguminosae).

Ageratiopsis Schultz-Bip. ex Benth. \& Hook., Gen. Pl. 2: 246. 1873, nom. nud. in syn. TyPE: Eupatorium ageratoides L. f. [= Ageratina altissima (L.) R. King \& H. Robinson].

Mallinoa J. Coulter, Bot. Gaz. (Crawfordsville) 20: 47. 1895. TYPE: Mallinoa corymbosa J. Coulter [=Ageratina muelleri (Schultz-Bip. ex Klatt) R. King \& H. Robinson].

Kyrstenia Necker ex E. Greene, Leafl. Bot. Observ. 1: 8. 1903. LectOTYPE: Eupatorium aromaticum L. [= Ageratina aromatica $(\mathrm{L}$.$) Spach].$ 

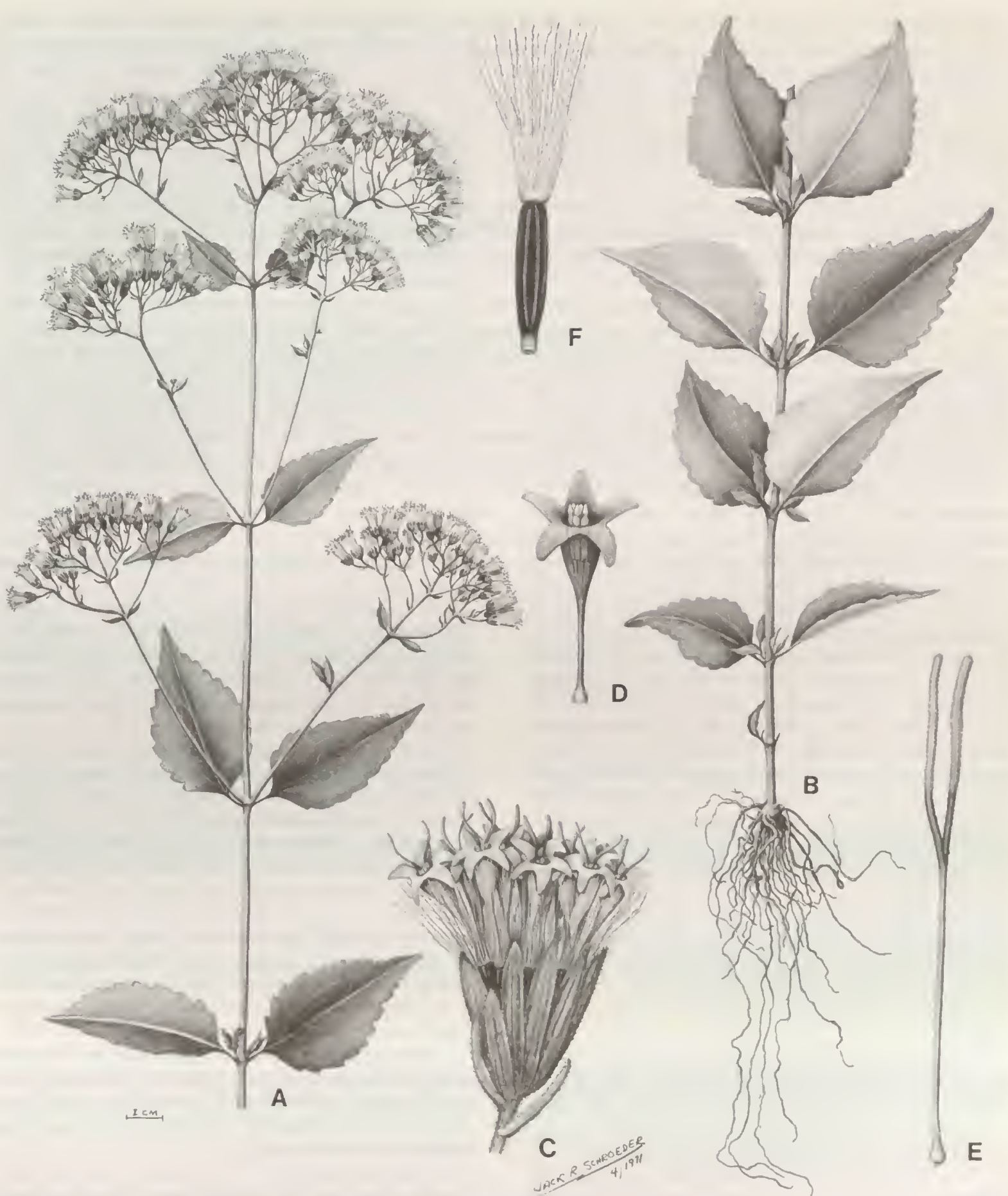

PLATE 169. Ageratina aromatica (L.) Spach. - A, B. Habit, $\times 3 / 5 .-$ C. Head, $\times 6,-$ D. Corolla showing anthers, $\times 10 .-$ E. Style, $\times 17,-$ F. Achene, $\times 10$. 
Perennial herbs or shrubs, usually erect, rarely scandent, sparingly to densely branched. Stems terete, striated. Leaves opposite, ra rely subopposite or alternate, shortly to longly petiolate; blades narrowly elliptical to deltoid, margins entire to toothed or lobed, serrate or crenate in most species, venation trinervate to pinnate, glandular punctations rare in subgenus Ageratina, more common in other subgenera. Inflorescences laxly to densely corymbose; pedicels short to moderately long. Involucral bracts ca. 30, eximbricate to weakly subimbricate, in 2-3 series, mostly subequal, spreading at maturity, bicostate in subgenus Ageratina, mostly indistinctly costate in other subgenera; receptacle usually slightly convex, glabrous or with minute scattered hairs. Florets $10-60$ in a head; corollas white or lavender, usually with slender basal tube and campanulate limb in subgenera Ageratina and Klattiella, others narrowly funnelform; cells of throat and outer surfaces of lobes elongate with sinuous lateral walls; lobes triangular, distinctly longer than wide, inner surface densely papillose, outer surface smooth, glabrous or glanduliferous, usually with hairs in subgenus Ageratina; anther collar cylindrical, usually elongate, composed of numerous subquadrate cells in basal half or more, cell walls with few or no beaded thickenings; anther appendage large, ovate-oblong, longer than wide; style base usually enlarged, not enlarged in subgenus Apoda, glabrous; style branches linear, rarely slightly broadened distally, densely papillose with projecting cells on lateral and outer surface, papillae usually long, often with glands along adaxial surface. Achenes prismatic or fusiform, usually 5-ribbed, setuliferous or glanduliferous or both; carpopodium distinct, symmetrical, without prominent upper rim, cylindrical in subgenus Ageratina, others rounded or shortly stopper-shaped, composed of moderately large cells in many tiers, cells oblong in subgenus Ageratina, others subquadrate, walls thin and beaded; pappus of 5-40 scabrid elongate often easily deciduous capillary bristles in 1 series, often enlarged distally, apical cells acute, often with shorter outer series of setulae. Pollen grains 20-30 $\mu \mathrm{m}$ in diameter. Chromosome numbers $n=$ ca. 16, 17, 18, 20, ca. 25, ca. 40, ca. $42,48,2 n=48,50,51,55+2$ frag., $68-69$, ca. 80 , ca. 85 , with frequent triploidy, irregular meiosis, and apomixis. Plate 169.

The genus Ageratina is the largest and most diverse in the subtribe Oxylobinae, and forms a seemingly central element from which most of the other genera might have been derived. This is especially true of Oxylobus with its reduced squamellose pappus. The papillose inner surfaces of the corolla lobes, and the enlarged bases of the styles are considered here to be represented in Ageratina in the form that is probably primitive for the subtribe. Only Jaramilloa and Kaunia of South America seem to represent an early divergence in the subtribe that might not have arisen from Ageratina type ancestors. The only other members of the subtribe in South America are species of Ageratina itself, including the widely distributed typical subgenus, and one obviously recently distributed species of Oxylobus. Other generic differences are discussed under the various related genera, and further details on the distribution of Ageratina are discussed under the various subgenera.

It is odd, but not inexplicable, that all the synonyms of the genus represent the subgenus Ageratina. All but one of the generic synonyms are based upon the two most common species in eastern North America where the genus has been most available to most taxonomists. The long nomenclatural history of the genus represents attempts to recognize a distinct group well before any knowledge of anatomical or cytological differences. The efforts were undoubtedly encouraged by the fact that the extreme forms in eastern North America offer a marked contrast to the numerous typical Eupatorium species of that area. In that area Eupatorium can easily be distinguished from
Ageratina by the shorter basal tube of the corolla, the smooth corolla lobes, the hairy style base, the indistinct carpopodium, the presence of only glands on the corolla and achene, the blunt-tipped pappus bristles, and the basic chromosome number of $x=10$.

Of the efforts to distinguish Ageratina, that of E. L. Greene (1903) deserves special notice. Among various comments, he offered the following, "These two plants (i.e., E. ageratoides and E. aromaticum), and with them a host of their congeners are so unlike true Eupatorium and at the same time so like Ageratum in foliage, inflorescence, uniserial involucre, and even as to flowers and fruits, that nothing but the fine-bristly rather than paleaceous pappus could have kept them apart from the genus last named, where, as already noted, Linnaeus did actually place the first species. They differ from Eupatorium by a set of characters exactly corresponding to those by which Erigeron is held separate from Aster."

"One must needs assume the Atlantic North American species mentioned to be the proper type of Kyrstenia. They are herbaceous perennials with opposite leaves and a corymbose inflorescence; their thin almost uniserial involucral bracts notably pointed."

Greene goes on to say, "This typical group has many representatives beyond our borders in Mexico, Central and even South America, some herbaceous, others shrubby, of which I cite but few."

Greene showed an amazing insight into the group for that time, but three errors are significant. Necker names such as Kyrstenia, which he used, are not now accepted 
except through validation by other authors at later dates. Also, Ageratina and Ageratum are not as closely related as suggested by Greene. The latter genus has high papillae on the backs of the corolla lobes, strong annulations on the cell walls of the anther collars, a very different carpopodial structure, a conical receptacle, and a basic chromosome number of $x=10$ in addition to the pappus character. Finally, among the species cited by Greene are some members of the genus Fleischmannia. This group is one most frequently confused with Ageratina, and with its chromosome numbers of $x=10$ and $x=4$, it has been especially frustrating to the efforts of cytotaxonomists. While similar to typical Ageratina in habit, leaf form, and the tendency for hairy corollas, Fleischmannia is distinct in the short thin corolla lobes prorulosely papillose on both surfaces, the strongly annular thickenings on the cell walls of the anther collar, the complete lack of enlargement of the style base, and the thick-walled cells of the strongly rimmed carpopodium.

There is some additional confusion regarding the eastern North American types of the various generic names. This results from the fact that Linnaeus (1753) initially described one of the species in Ageratum with the species name altissimum. There was, of course, a transfer of the name into Eupatorium (Murray, 1774) which created a later homonym of Eupatorium altissima, a totally different Linnaean species. Then, in rapid succession, three substitute names were provided for the species in Eupatorium, E. rugosum Houttuyn (1779), E. urticaefolium Reichard (1780), and $E$. ageratoides Linnaeus f. (1781). It was unfortunate that these substitute names came into use in the literature in the reverse order of their priority, and $E$. rugosum did not come into proper usage until the study by Merrill (1938). The entire sequence has proven futile, however, with the recognition of the genus Ageratina where there is no previous use of the name altissima. In spite of Spach's own use of the name ageratoides (1841), the Linnaean name altissima again takes priority. The eastern North American species, including $A$. altissima and the generic type, A. aromatica, are reviewed by Clewell and Wooten (1971).

The only generic synonym not based on eastern North American material was Mallinoa of Coulter, based on a specimen from Guatemala (1895). Coulter's generic concept was uninsightful, since he placed the genus tentatively in the Inuloideae. The species involved actually belongs to a not particularly exceptional Mexican and Central American series in subgenus Ageratina noted for their reduced upper leaves and lax inflorescences (Grashoff \& Beaman, 1969a).

The typical subgenus to which all of the above elements belong has the following characters: herbs and subshrubs; leaf blades trinervate to subpinnate, without obvious glandular punctations; involucre eximbricate with bicostate bracts; corollas usually with long narrow basal tubes, usually with hairs on outer surface of lobes, rarely with a few long-stalked glands or glabrous; cells on inner surface of corolla lobes and on style appendages densely long-projecting; achenes without glands; carpopodium cylindrical with mostly elongate cells; and pappus bristles easily deciduous.

Reports of chromosome numbers indicate that subgenus Ageratina has a base of $x=17$. Variation is found in a number of the individual species, but is particularly common in $A$. bustamenta (= A. aschenborniana), which

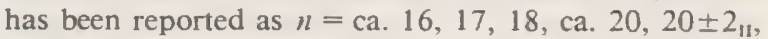
and recently as $2 n=20$ and ca. $70_{1}$ (Grashoff et al., 1972) and ca. 10 (R. King et al., 1976). Polyploidy occurs in the subgenus, for example $2 n=48$ in A. riparia, $2 n=51$ in $A$. adenophora and $A$. pazcuarensis, $n=30-34$ in $A$. pichinchensis, $2 n=68_{1}$ in $A$. muelleri, and $2 n=51$ and over 80 in $A$. rothrockii. Some of these represent triploids reproducing by apomixis. Meiotic irregularities accompanying apomixis are evidenced by the presence of modified Type II pollen in some species. For additional reports see R. King et al. (1976).

Two species of the subgenus Ageratina are widely introduced weeds, $A$. adenophora and $A$. riparia, and both appear to be triploid apomicts. They have become troublesome in places such as Australia (Everist, 1974) and Hawaii. Both species have been studied extensively in Hawaii and Mexico by William Rose and others for the purposes of biological control, with the discovery of specific gall-forming Tephritids of the genus Procecidochares (Steyskal, 1974).

The natural distribution of the subgenus Ageratina is concentrated in Mexico, Central America, and the Andes of South America with a few eastern extensions to the eastern United States, the West Indies, and in one species to southern Brazil.

The subgenus Klattiella R. King \& H. Robinson, Phytologia 19: 218. 1970. Type: Eupatorium anisochromum Klatt, is characterized by the plants being shrubs; the leaf blades pinnately to weakly trinervately veined; the involucre eximbricate without prominent costae; the corollas with a very narrow basal tube which is distinctly pubescent, with the lobes as long as or longer than the throat, the lobes with broad low mamillae on inner surface, with glands on outer surface; the style appendages strongly papillose; the achenes with glands and setulae; the carpopodia rather shortly rounded with quadrate to short-oblong cells; and the pappus persistent. The chromosome number is $x=17$. The subgenus consists primarily of the Central American type species, but the $\mathrm{Cu}$ ban $A$. paucibracteata seems to be a thoroughly distinct related species.

The subgenus Neogreenella R. King \& H. Robinson, Phytologia 19: 218. 1970. Type: Eupatorium wrightii A. Gray, is characterized by the plants being mostly shrubs, rarely perennial herbs or vines with leaf blades trinervate to pinnate; the involucre eximbricate, without prominent 
costae; the corollas with the basal tube rarely very narrow; the lobes shorter than the throat, with the inner surface densely papillose, the outer surface with glands or hairs or glabrous; the style appendages strongly papillose; the achenes with glands or setulae; the carpopodium shortly rounded with the cells mostly quadrate; and the pappus bristles rather persistent. The chromosome number is $x=$ 17 , with comparatively few variations. Polyploidy has been reported in $A$. cardiophylla at $n=$ ca. 68 (Grashoff et al., 1972).

The subgenus Neogreenella is distributed almost entirely in Mexico and the southwestern United States with a few species extending as far south as Costa Rica, and east into the Greater Antilles. South American species originally placed in the subgenus by King and Robinson $(1970 b)$ have subsequently been transferred to the subgenera Andinia and Apoda (King \& Robinson, 1978a). A few Mexican members of subgenus Ageratina, including $A$. ixiocladon, $A$. kupperi, and $A$. lasia, were originally misplaced in the subgenus Neogreenella by error.

The subgenus Andinia R. King \& H. Robinson, Phytologia 38: 324. 1978. Type: Eupatorium exerto-venosum Klatt, consists of shrubs with leaf blades mostly coriaceous, with pinnate venation, sometimes with more prominent veins near base; the involucre weakly subimbricate; the corollas with the basal tube not narrow, the outer surface with glands or glabrous; the lobes shorter than the throat with the inner surface densely papillose; the style appendages strongly papillose; the achenes with glands, sometimes with short setulae; the carpopodium shortly rounded with cells mostly quadrate; and the pappus bristles rather persistent. The chromosome numbers are $n=$ ca. 40 and 42 , and are probably based ultimately on 20 (R. King et al., 1976).

The subgenus Andinia is the predominent element of the genus in the northern Andes, often forming large populations. The species were orginally included in the subgenus Neogreenella (King \& Robinson, 1970b), but the texture of the leaves, the imbrication of the involucre, the chromosome numbers, and the geographical distribution all indicate a significant separate group.

The subgenus Apoda R. King \& H. Robinson, Phytologia 38: 325. 1978. Type: Eupatorium pentlandianum DC., consists of subshrubs with leaf blades trinervately veined; the involucre weakly subimbricate; the corollas with the basal tube not narrow, the outer surface with glands; the lobes shorter than the throat with the inner surface weakly papillose; the style base not enlarged; the style appendages with short pointed papillae; the achenes with glands; the carpopodia shortly rounded with mostly quadrate cells; and the pappus bristles rather persistent. The chromosome number is unknown.

The subgenus Apoda is restricted to Peru and adjacent Bolivia, mostly to the south of the range of subgenus Andinia. The subgenus is unique in Ageratina by the lack of an enlargement on the base of the style, and is immediately distinguishable from the closely associated subgenus Andinia by its distinctly trinervate leaves.

The chemistry of Ageratina is rather diverse, showing numerous benzofurans, chromenes, flavonoids, polyacetylenes, thymol derivatives, sesquiterpenes of three types, diterpenes, and triterpenoids (Dominguez, 1977). A small quantity of pyrrolizidine alkaloid has been isolated from A. adenophora by L. J. Webb (Everist, 1974) confirming the presence of this distinctive group in divergent elements of the Eupatorieae. Many of the chemicals are types common in the Eupatorieae and Asteraceae, but a few deserve special mention.

Although benzofurans are common in the Eupatorieae, it is in Ageratina altissima that their effects are best known. The plants were common in the newly cleared pastures of the early nineteenth century, and the various benzofurans such as tremetone and toxol caused trembling disease in the cattle and were transmitted to humans through milk. The poisoned milk apparently caused many deaths including that of the mother of Abraham Lincoln (Hass, 1970).

Among the polyacetylenes, pentaynene is common, representing a basic pathway in the tribe. Reports in Ageratina include $A$. altissima and $A$. exertovenosa (Bohlmann et al., 1973). The only example of a thiophene in the tribe outside of Mikania is from Ageratina glabrata (Bohlmann et al., 1977b).

Various sesquiterpenes include acyclic forms from Ageratina bustamenta (as $A$. aschenborniana. Bohlmann \& Fiedler, 1978), cadinene derivatives from $A$. adenophora (Bohlmann \& Gupta, 1981), and the common germacrane $\mathrm{D}$ in both of the preceding. As might be expected, the sesquiterpene lactones have been reported from members of the subgenus Neogreenella, A. glabrata, $A$. ligustrina, and $A$. petiolaris (Seaman, 1982) which have distinct glandular punctations on the leaves, but are not reported from members of the subgenus Ageratina which lacks such glands.

Chemicals of unspecified nature, according to Weberbauer (B. Robinson, 1919b), are extracted from the fresh roots of $A$. sternbergiana in Peru, and employed as an abortive. Also a tea from leaves is used for kidney and bladder troubles.

Many keys are available for members of the genus $\mathrm{Ager}$ atina as a result of the fact that the genus constitutes most members that have been placed in the Eupatorium section eximbricata in earlier treatments to Mexico (B. Robinson, 1926b), Colombia (B. Robinson, $1918 b$ ), Venezuela and Ecuador (B. Robinson, 1918c), Peru (B. Robinson, 1919b), and Bolivia (B. Robinson, 1920b). The Eupatorium bellidifolium group was revised under the old generic concept by Grashoff and Beaman (1969a). Treatments under the name Ageratina include the species of eastern North America (Clewell \& Wooten, 1971), Costa Rica (King \& Robinson, 1972u), and Panama (King \& Robinson, 1975y). 
Since the reestablishment of the genus Ageratina (King \& Robinson $1970 b$ ), various new species have been described by Adams (1971), McVaugh (1972), and Turner (1977) under Eupatorium and these have been transferred and other species described in the genus in various papers by King and Robinson (1972u, 1974k, 1975b, 1977b, 1977d, 1978a).

The name Ageratina is a diminutive form of Ageratum. The name, unfortunately, approximates in its form the name of the subtribe Ageratinae, creating a possible source of confusion between the two totally different groups. Of the synonyms, Batschia honors August Johann Georg Carl Batsch, 1761-1802, while the sources of the names $K y r$ stenia and Mallinoa are not known.

The genus Ageratina $\mathrm{O}$. Hoffmann is a totally different entity belonging to the tribe Vernonieae. This later homonym has subsequently been renamed Ageratinastrum Mattfeld.

The following five subgenera and 248 species are recognized in the genus:

\section{Subgenus Ageratina}

Ageratina adenophora (Sprengel) R. King \& H. Robinson, Mexico, adventive in California, West Indies, South America, Portugal, Pacific Islands, Australia.

Ageratina allenii (Standley) R. King \& H. Robinson, Costa Rica. Ageratina almedae R. King \& H. Robinson, Costa Rica.

Ageratina altissima (L.) R. King \& H. Robinson, E United States, E Canada.

Ageratina amblyolepis (B. Robinson) R. King \& H. Robinson, Mexico.

Ageratina anchistea (Grashoff \& Beaman) R. King \& H. Robinson, Guatemala, Honduras.

Ageratina apollinairei (B. Robinson) R. King \& H. Robinson, Colombia.

Ageratina aristeguietii R. King \& H. Robinson, Venezuela.

Ageratina aromatica $(\mathrm{L}$.$) Spach, E United States.$

Ageratina arsenei (B. Robinson) R. King \& H. Robinson, Mexico. Ageratina articulata (Schultz-Bip. ex Hieron.) R. King \& H. Robinson, Colombia, Venezuela, Ecuador, Peru.

Ageratina atrocordata (B. Robinson) R. King \& H. Robinson, Mexico, Guatemala.

Ageratina austin-smithii R. King \& H. Robinson, Costa Rica.

Ageratina azangaroensis (Schultz-Bip. ex Wedd.) R. King \& H.

Robinson, Ecuador, Peru, Bolivia.

Ageratina badia (Klatt) R. King \& H. Robinson, Costa Rica.

Ageratina barbensis R. King \& H. Robinson, Costa Rica.

Ageratina bellidifolia (Benth.) R. King \& H. Robinson, Mexico.

Ageratina bishopii R. King \& H. Robinson, Peru.

Ageratina burgeri R. King \& H. Robinson, Costa Rica.

Ageratina bustamenta (DC.) R. King \& H. Robinson, Mexico, Central America to Panama.

Ageratina calderillensis (Hieron.) R. King \& H. Robinson, Bolivia.

Ageratina camachensis (Hieron.) R. King \& H. Robinson, Bolivia.

Ageratina carmonis (Standley \& Steyerm.) R. King \& H. Robinson, Mexico, Guatemala.
Ageratina cartagoensis R. King \& H. Robinson, Costa Rica. Ageratina chiriquensis (B. Robinson) R. King \& H. Robinson, Panama.

Ageratina choricephala (B. Robinson) R. King \& H. Robinson, Mexico.

Ageratina choricephaloides (B. Robinson) R. King \& H. Robinson, Peru.

Ageratina ciliata (Less.) R. King \& H. Robinson, Mexico. Ageratina contigua $\mathrm{R}$. King \& H. Robinson, Costa Rica. Ageratina corylifolia (Griseb.) R. King \& H. Robinson, Cuba. Ageratina costaricensis R. King \& H. Robinson, Costa Rica. Ageratina croatii R. King \& H. Robinson, Panama.

Ageratina cuencana (B. Robinson) R. King \& H. Robinson, Ecuador.

Ageratina cuteriensis (Hieron.) R. King \& H. Robinson, Peru.

Ageratina dasyneura (B. Robinson) R. King \& H. Robinson, Colombia.

Ageratina davidsei R. King \& H. Robinson, Colombia.

Ageratina diversipila R. King \& H. Robinson, Costa Rica.

Ageratina dolichobasis (McVaugh) R. King \& H. Robinson, Mexico.

Ageratina enixa (B. Robinson) R. King \& H. Robinson, Mexico. Ageratina funckii (B. Robinson) R. King \& H. Robinson, Colombia.

Ageratina geminata (McVaugh) R. King \& H. Robinson, Mexico. Ageratina gilbertii (B. Robinson) R. King \& H. Robinson, Peru. Ageratina glabrata (H.B.K.) R. King \& H. Robinson, Mexico.

Ageratina glandulifera (Hieron.) R. King \& H. Robinson, Ecuador.

Ageratina glechonophylla (B. Robinson) R. King \& H. Robinson, Chile, Peru, Ecuador?

Ageratina gracilenta (B. Robinson) R. King \& H. Robinson, Peru. Ageratina gracilis (H.B.K.) R. King \& H. Robinson, Colombia, Venezuela, Ecuador.

Ageratina grandifolia (Regel) R. King \& H. Robinson, Mexico. Ageratina helenae R. King \& H. Robinson, Guatemala.

Ageratina hintonii R. King \& H. Robinson, Mexico.

Ageratina ibaguensis (Schultz-Bip. ex Hieron.) R. King \& H. Robinson, Colombia, Venezuela.

Ageratina infiernillensis R. King \& H. Robinson. Peru.

Ageratina iodotricha (B. Robinson) R. King \& H. Robinson, Ecuador.

Ageratina isolepis(B. Robinson) R. King \& H. Robinson, Mexico. Ageratina ixiocladon (Benth. ex Oersted) R. King \& H. Robinson, Costa Rica, Panama.

Ageratina jucunda (E. Greene) Clewell \& Wooten, SE United States.

Ageratina kupperi (Suesseng.) R. King \& H. Robinson, Costa Rica.

Ageratina lasia (B. Robinson) R. King \& H. Robinson, Mexico. Ageratina lemmonii (B. Robinson) R. King \& H. Robinson, Mexico.

Ageratina lobulifera (B. Robinson) R. King \& H. Robinson, Peru. Ageratina lorentzii (Hieron.) R. King \& H. Robinson, Argentina. Ageratina luciae-brauniae (Fern.) R. King \& H. Robinson, Kentucky.

Ageratina malacolepis (B. Robinson) R. King \& H, Robinson, Mexico.

Ageratina mariarum (B. Robinson) R. King \& H. Robinson, Mexico.

Ageratina modesta (Kunth) R. King \& H. Robinson, Mexico.

Ageratina molinae R. King \& H. Robinson, Honduras, El Salvador, Costa Rica, Panama. 
Ageratina muelleri (Schultz-Bip. ex Klatt) R. King \& H. Robinson, Mexico, Honduras.

Ageratina multiserrata (Schultz-Bip.) R. King \& H. Robinson, Mexico.

Ageratina nelsonii R. King \& H. Robinson, Mexico.

Ageratina nesomii B. Turner, Mexico.

Ageratina oligocephala (DC.) R. King \& H. Robinson, Mexico.

Ageratina pacifica (B. Robinson in I. M. Johnston) R. King \& H. Robinson, Mexico.

Ageratina pampalcensis (B. Robinson) R. King \& H. Robinson, Peru.

Ageratina paupercula (A. Gray) R. King \& H. Robinson, Arizona, Mexico.

Ageratina pazcuarensis (H.B.K.) R. King \& H. Robinson, Mexico, Guatemala.

Ageratina peracuminata R. King \& H. Robinson, Mexico.

Ageratina photina (B. Robinson) R. King \& H. Robinson, Mexico.

Ageratina pichinchensis (H.B.K.) R. King \& H. Robinson, Colombia, Ecuador, Peru.

Ageratina proba (N. E. Br.) R. King \& H. Robinson, Peru.

Ageratina prunellaefolia (H.B.K.) R. King \& H. Robinson, Mexico, Guatemala, Ecuador.

Ageratina psilodora (B. Robinson) R. King \& H. Robinson, Colombia.

Ageratina purpusii (Brandegee) R. King \& H. Robinson, Baja California.

Ageratina ramonensis (B. Robinson) R. King \& H. Robinson, Mexico.

Ageratina remyana (Philippi) R. King \& H. Robinson, Chile.

Ageratina repens (B. Robinson) R. King \& H. Robinson, Mexico.

Ageratina rhodopappa (B. Robinson) R. King \& H. Robinson, Colombia.

Ageratina rhypodes (B. Robinson) R. King \& H. Robinson, Ecuador.

Ageratina rhytidodes (B. Robinson) R. King \& H. Robinson, Peru.

Ageratina riparia (Regel) $\mathrm{R}$. King \& H. Robinson, Mexico, adventive in West Indies, Peru, Ceylon, Pacific Islands, Australia. Ageratina rivalis (Greenman) R. King \& H. Robinson, Mexico. Ageratina roraimensis (N. E. Br.) R. King \& H. Robinson, Guyana, Venezuela.

Ageratina rothrockii (A. Gray) R. King \& H. Robinson, Arizona, New Mexico, W Texas, $N$ Mexico.

Ageratina rufa (E. Greene) R. King \& H. Robinson, Mexico.

Ageratina salicifolia $\mathrm{R}$. King \& H. Robinson, Mexico.

Ageratina schaffneri (Schultz-Bip. ex B. Robinson) R. King \& H. Robinson, Mexico.

Ageratina scopulorum (Wedd.) R. King \& H. Robinson, Peru, Bolivia.

Ageratina sinaloensis R. King \& H. Robinson, Mexico.

Ageratina skutchii (B. Robinson) R. King \& H. Robinson, Mexico, Guatemala.

Ageratina sodiroi (Hieron.) R. King \& H. Robinson, Ecuador.

Ageratina sotarensis (Hieron.) R. King \& H. Robinson, Colombia.

Ageratina standleyi R. King \& H. Robinson, Costa Rica.

Ageratina sternbergiana (DC.) R. King \& H. Robinson, Peru, Bolivia.

Ageratina subcordata (Benth. ex Oersted) R. King \& H. Robinson, Costa Rica.

Ageratina subglabra R. King \& H. Robinson, Costa Rica.
Ageratina tambillensis (Hieron.) R. King \& H. Robinson, Peru. Ageratinatarmensis (B. Robinson) R. King \& H. Robinson, Peru. Ageratina tenuis (R. E. Fries) R. King \& H. Robinson, Argentina. Ageratina tonduzii (Klatt) R. King \& H. Robinson, Costa Rica. Ageratina trapezoidea (Kunth) R. King \& H. Robinson, Mexico. Ageratina vallincola (DC.) R. King \& H. Robinson, Peru. Ageratina viscosissima (Rolfe) R. King \& H. Robinson, Mexico. Ageratina whitei $\mathrm{R}$. King \& H. Robinson, Panama.

Ageratina zinniifolia (B. Robinson) R. King \& H. Robinson, Colombia.

Ageratina zunilana (Standley \& Steyerm.) R. King \& H. Robinson, Guatemala.

\section{Subgenus Klattiella}

Ageratina anisochroma (Klatt) R. King \& H. Robinson, Nicaragua, Costa Rica, Panama.

Ageratina paucibracteata (Alain) R. King \& H. Robinson, Cuba

\section{Subgenus Neogreenella}

Ageratina acutidentata (B. Robinson) R. King \& H. Robinson, Mexico.

Ageratina adenachaenia (Schultz-Bip. ex Klatt) R. King \& H. Robinson, Mexico.

Ageratina aegirophylla (B. Robinson) R. King \& H. Robinson, Mexico.

Ageratina betulaefolia (E. Greene) R. King \& H. Robinson, Mexico.

Ageratina blepharilepis (Schultz-Bip.) R. King \& H. Robinson, Mexico.

Ageratina brandegeana (B. Robinson) R. King \& H. Robinson, Mexico.

Ageratina breedlovei R. King \& H. Robinson, Mexico. Ageratina brevipes (DC.) R. King \& H. Robinson, Mexico.

Ageratina caeciliae (B. Robinson) R. King \& H. Robinson, Guatemala.

Ageratina calaminthaefolia (H.B.K.) R. King \& H. Robinson, Mexico.

Ageratina calophylla (B. Robinson) R. King \& H. Robinson, Mexico.

Ageratina campyloclada (B. Robinson) R. King \& H. Robinson, Mexico.

Ageratina cardiophylla (B. Robinson) R. King \& H. Robinson, Mexico.

Ageratina cerifera (McVaugh) R. King \& H. Robinson, Mexico. Ageratina collodes (B. Robinson \& Greenman) R. King \& H. Robinson, Mexico.

Ageratina contorta (C. Adams) R. King \& H. Robinson, Jamaica. Ageratina cremasta (B. Robinson) R. King \& H. Robinson, Mexico.

Ageratina crenaea (B. Robinson) R. King \& H. Robinson, Mexico.

Ageratina cronquistii R. King \& H. Robinson, Mexico.

Ageratina cylindrica (McVaugh) R. King \& $\mathrm{H}$. Robinson, Mexico. Ageratina deltoidea (N. J. Jacquin) R. King \& H. Robinson, Mexico.

Ageratina desquamans (B. Robinson) R. King \& H. Robinson, Mexico.

Ageratina dictyoneura (Urban) R. King \& H. Robinson, Haiti. Ageratina durangensis (B. Robinson) R. King \& H. Robinson, Mexico. 
Ageratina ernstii R. King \& H. Robinson, Mexico.

Ageratina espinosarum (A. Gray) R. King \& H. Robinson, Mexico.

Ageratina etlensis (B. Robinson) R. King \& H. Robinson, Mexico. Ageratina flourensifolia (B. Turner) R. King \& H. Robinson, Mexico.

Ageratina glauca (Schultz-Bip. ex Klatt) R. King \& H. Robinson, Mexico.

Ageratina glischra (B. Robinson) R. King \& H. Robinson, Mexico.

Ageratina gonzalezorum B. Turner, Mexico.

Ageratina gypsophila B. Tumer, Mexico.

Ageratina halbertiana (McVaugh) R. King \& H. Robinson, Mexico.

Ageratina hartii (Urban) R. King \& H. Robinson, Jamaica.

Ageratina havanensis (H.B.K.) R. King \& H. Robinson, Texas, Mexico, West Indies.

Ageratina hebes (B. Robinson) R. King \& H. Robinson, Mexico. Ageratina hederaefolia (A. Gray) R. King \& H. Robinson, Mexico.

Ageratina herbacea (A. Gray) R. King \& H. Robinson, SW United States.

Ageratina hidalgensis (B. Robinson) R. King \& H. Robinson, Mexico.

Ageratina hyssopina (A. Gray) R. King \& H. Robinson, Mexico. Ageratina illita (Urban) R. King \& H. Robinson, Dominican Republic.

Ageratina intercostulata (B. Robinson) R. King \& H. Robinson, Colombia.

Ageratina intibucensis R. King \& H. Robinson, Honduras.

Ageratina irrasa (B. Robinson) R. King \& H. Robinson, Mexico. Ageratina lasioneura (Hook. \& Arn.) R. King \& H. Robinson, Mexico.

Ageratina leptodictyon (A. Gray) R. King \& H. Robinson, Mexico.

Ageratina liebmannii (Schultz-Bip. ex Klatt) R. King \& H. Robinson, Mexico.

Ageratina ligustrina (DC.) R. King \& H. Robinson, Mexico, Guatemala, El Salvador, Costa Rica.

Ageratina loeseneri (B. Robinson) R. King \& H. Robinson, Mexico.

Ageratina lucida (Ortega) R. King \& H. Robinson, Mexico.

Ageratina macvaughii R. King \& H. Robinson, Mexico.

Ageratina mairetiana (DC.) R. King \& H. Robinson, Mexico.

Ageratina miquihuana (B. Turner) R. King \& H. Robinson, Mexico.

Ageratina mortoniana (Alain) R. King \& H. Robinson, Cuba.

Ageratina mygindaefolia (A. Gray) R. King \& H. Robinson, Mexico.

Ageratina oaxacana (Klatt) R. King \& H. Robinson, Mexico.

Ageratina occidentalis (Hook.) R. King \& H. Robinson, W United States.

Ageratina ovilla (Standley \& Steyerm.) R. King \& H. Robinson, Mexico, Guatemala.

Ageratina pachypoda (B. Robinson) R. King \& H. Robinson, Mexico.

Ageratina pelotropha (B. Robinson) R. King \& H. Robinson, Mexico.

Ageratina petiolaris (Mociño \& Sessé ex DC.) R. King \& H. Robinson, Mexico.

Ageratina plethadenia (Standley \& Steyerm.) R. King \& H. Robinson, Guatemala.
Ageratina porriginosa (B. Robinson) R. King \& H. Robinson, Mexico.

Ageratina pringlei (B. Robinson \& Greenman) R. King \& H. Robinson, Mexico.

Ageratina prionobia(B. Robinson) R. King \& H. Robinson, Mexico.

Ageratina resiniflua (Urban) R. King \& H. Robinson, Puerto Rico.

Ageratina reticulifera (Standley \& L. O. Williams) R. King \& H. Robinson, Costa Rica.

Ageratina rhodopoda (B. Robinson) R. King \& H. Robinson, Mexico.

Ageratina rhomboidea (H.B.K.) R. King \& H. Robinson, Mexico. Ageratina rollinsii B. Turner, Mexico.

Ageratina rubricaulis (H.B.K.) R. King \& H. Robinson, Mexico. Ageratina rupicola (B. Robinson \& Greenman) R. King \& H. Robinson, Mexico.

Ageratina saltillensis (B. Robinson) R. King \& H. Robinson, Mexico.

Ageratina salvadorensis R. King \& H. Robinson, El Salvador.

Ageratina scorodonioides(A. Gray) R. King \& H. Robinson, Mexico.

Ageratina shastensis (D. W. Taylor \& Stebb.) R. King \& H, Robinson, California.

Ageratina stricta (A. Gray) R. King \& H. Robinson, Mexico.

Ageratina subinclusa (Klatt) R. King \& H. Robinson, Mexico. Guatemala.

Ageratina subintegra (E. Greene) R. King \& H. Robinson, Mexico.

Ageratina tetragona (Schrader) R. King \& H. Robinson, Mexico. Ageratina thyrsiflora (E. Greene) R. King \& H. Robinson, Mexico.

Ageratina tomentella (Schrader) R. King \& H. Robinson, Mexico. Ageratina triniona (McVaugh) R. King \& H. Robinson, Mexico. Ageratina tristis (DC.) R. King \& H. Robinson, Jamaica.

Ageratina urbanii (E. Ekman ex Urban) R. King \& H. Robinson, Haiti.

Ageratina venulosa (A. Gray) R. King \& H. Robinson, Mexico. Ageratina vernalis (Vatke \& Kurtz) R. King \& H. Robinson, Mexico, Guatemala.

Ageratina vernicosa (Schultz-Bip. ex Greenman) R. King \& H. Robinson, Mexico.

Ageratina viburnoides (DC.) R. King \& H. Robinson, Mexico. Ageratina wrightii (A. Gray) R. King \& H. Robinson, SW United States, Mexico.

\section{Subgenus Andinia}

Ageratina ampla (Benth.) R. King \& H. Robinson, Colombia. Ageratina arbutifolia (Benth.) R. King \& H. Robinson, Colombia. Ageratina aristei (B. Robinson) R. King \& H. Robinson, Colombia.

Ageratina asclepiadea (L.f.) R. King \& H. Robinson, Colombia Ageratina baccharoides (H.B.K.) R. King \& H. Robinson, Colombia.

Ageratina barclayae R. King \& H. Robinson, Colombia Ageratina boekei R. King \& H. Robinson, Peru.

Ageratina boyacensis R. King \& H. Robinson, Colombia. Ageratina chachapoyasensis (Cuatrec.) R. King \& H. Robinson, Peru.

Ageratina crassiceps (B. Robinson) R. King \& H. Robinson, Colombia. 
Ageratina cuatrecasasii R. King \& H. Robinson, Colombia. Ageratina dendroides (Sprengel) R. King \& H. Robinson, Ecuador.

Ageratina elegans (H.B.K.) R. King \& H. Robinson Colombia. Ageratina exserto-venosa (Klatt) R. King \& H. Robinson, Ecuador, Peru.

Ageratina fastigiata (H.B.K.) R. King \& H. Robinson, Colombia. Ageratina flaviseta (B. Robinson) R. King \& H. Robinson, Colombia.

Ageratina gloeoclada (B. Robinson) R. King \& H. Robinson, Bolivia.

Ageratina glyptophlebia (B. Robinson) R. King \& H. Robinson, Colombia.

Ageratina gynoxoides (Wedd.) R. King \& H. Robinson, Colombia.

Ageratina jahnii (B. Robinson) R. King \& H. Robinson, Venezuela.

Ageratina latipes (Benth.) R. King \& H. Robinson, Colombia. Ageratina lopez-mirandae R. King \& H. Robinson, Peru.

Ageratina macbridei (B. Robinson) R. King \& H. Robinson, Peru. Ageratina mutiscuensis (B. Robinson) R. King \& H. Robinson, Colombia.

Ageratina neriifolia (B. Robinson) R. King \& H. Robinson, Venezuela.

Ageratina ocanensis (B. Robinson) R. King \& H. Robinson, Colombia.

Ageratina paramensis (Aristeg.) R. King \& H. Robinson, Venezuela.
Ageratina piurae (B. Robinson) R. King \& H. Robinson, Peru. Ageratina popayanensis (Hieron.) R. King \& H. Robinson, Colombia.

Ageratina prunifolia (H.B.K.) R. King \& H. Robinson, Ecuador. Ageratina pseudochilca (Benth.) R. King \& H. Robinson, Ecuador.

Ageratina subferruginea (B. Robinson) R. King \& H. Robinson, Peru.

Ageratina theaefolia (Benth.) R. King \& H. Robinson, Colombia, Venezuela.

Ageratina tinifolia (H.B.K.) R. King \& H. Robinson, Colombia, Venezuela.

Ageratina vacciniaefolia (Benth.) R. King \& H. Robinson, Colombia.

Ageratina viscosa (H.B.K.) R. King \& H. Robinson, Colombia. Ageratina wurdackii R. King \& H. Robinson, Peru.

\section{Subgenus Apoda}

Ageratina cuzcoensis (Hieron.) R. King \& H. Robinson, Peru. Ageratina dombeyana (DC.) R. King \& H. Robinson, Peru. Ageratina pentandiana (DC.) R. King \& H. Robinson, Peru, Bolivia.

Ageratina simulans (B. Robinson) R. King \& H. Robinson, Peru. Ageratina stictophylla (B. Robinson) R. King \& H. Robinson, Peru.

\section{Oxylobus}

Oxylobus (Mociño ex DC.) A. Gray, Proc. Amer. Acad. Arts 15: 25. 1879.

Phania section Oxylobus Mociño ex DC., Prodr. 5: 115. 1836. TYPE: Ageratum arbutifolium H.B.K. [= Oxylobus arbutifolius (H.B.K.) A. Gray].

Decumbent herbs to low shrubs, moderately to densely branched. Stems terete, striated. Leaves opposite, short-petiolate; blades small, ovate to oblong, margins crenate to subentire, venation trinervate, surface usually with glandular punctations. Inflorescence laxly to densely corymbose to subcymose; pedicels moderately long. Involucral bracts ca. 10-15, eximbricate, in 2-3 series, mostly subequal, spreading at maturity; receptacle slightly convex, epaleaceous, glabrous. Florets $20-75$ in a head; corollas white or pink, with a long narrow basal tube and a narrowly campanulate limb, cells of throat elongate with sinuous lateral walls; lobes triangular, longer than wide, inner surface densely papillose, outer surface smooth with stalked glands or glabrous; anther collar cylindrical, elongate, composed of numerous subquadrate cells, cell walls with few or no annular thickenings; anther appendage large, ovate, longer than wide; style base enlarged, glabrous; style branches linear, densely long-papillose with strongly projecting cells on lateral and outer surfaces. Achenes fusiform, 5-ribbed, bearing short setulae; carpopodium distinct, often stipitate, shortly rounded, composed of short and subquadrate cells in many tiers, cell walls thin with beaded thickenings; pappus of a few short laciniate persistent squamellae, apical cells of pappus squamellae sharply acute. Pollen grains ca. $25 \mu \mathrm{m}$ in diameter. Chromosome number $x=16$. Plate 170.

The members of the genus Oxylobus have usually been placed in or near the genera Ageratum or Phania in the traditional treatments of the Eupatorieae, a position based on the reduced form of pappus. B. Robinson (1913a), in his summary of the traditional generic concepts of the tribe, distinguished Oxylobus from Ageratum by the subfiliform basal tubes and ampliate limbs of its corollas, and its subcoriaceous leaves. The suffruticose habit was also mentioned. The two genera Ageratum and Phania are close relatives to each other, but are thoroughly distinct from Oxylobus, having conical receptacles, strongly annulated cell walls in the anther collars, roughened outer surfaces of the corolla lobes, unusually obvious recessed glandular punctations on the leaf undersurfaces, and a 


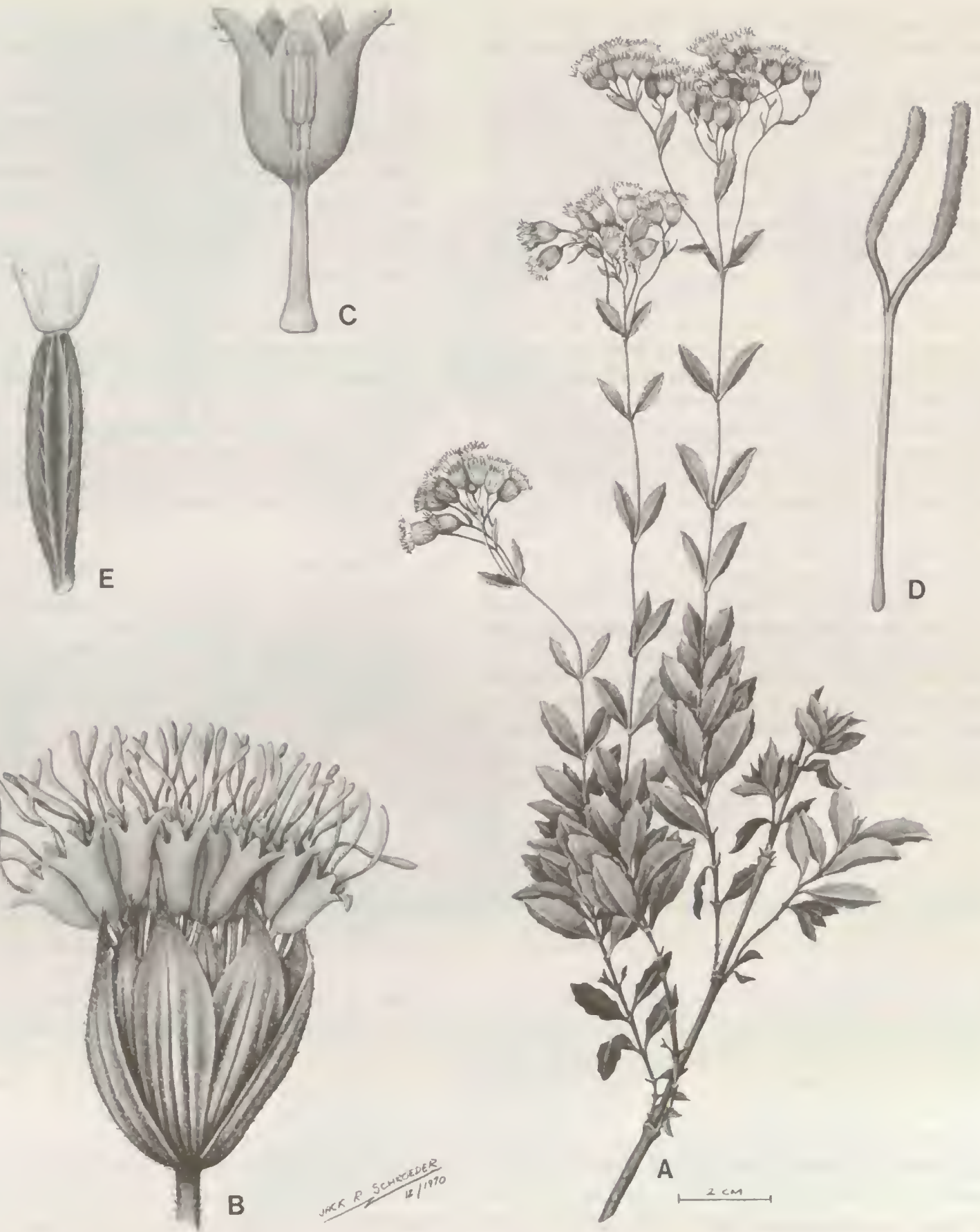

Plate 170. Oxylobus arbutifolius (H.B.K.) A. Gray. - A. Habit, $\times 233,-$ B. Head, $\times 8 .-$ C. Corolla showing anthers, $\times 15 .-$ D. Style, $\times 15 .-E$. Achene, $\times 15$.

basic chromosome number of $x=10$. The two belong to the subtribe Ageratinae as presently delimited.

The position of Oxylobus was first properly recognized in the present series of studies during the revision of the generic limits of Ageratina (King \& Robinson, 1970b). A subtribe Oxylobinae was formally established by King and Robinson (1978a) for the generic series. Oxylobus is particularly close to Ageratina, having the same densely pa- 
pillose inner surfaces and smooth outer surfaces of the corolla lobes, the same enlarged base on the style, and the same form of long anther collar with numerous subquadrate scarcely ornamented cells. Oxylobus differs primarily by the short squamiform pappus, with shorter and usually broader segments than any of the somewhat shortened forms in Ageratina subgenus Neogreenella. The carpopodium is distinct and the pappus persistent, unlike the related genus Piptothrix, and the heads have no paleae as in Jaliscoa, two other closely related genera with sometimes defective pappus.

Not only is Oxylobus closely related to Ageratina, but the habit, including the form of the leaves, the form of the carpopodium, and the presence of sesquiterpene lactones (Bohlmann et al., 1980b) are all features shared with Ageratina subgenus Neogreenella which occurs in much of the same area. They are different from the subgenus Ageratina. A position close to subgenus Neogreenella is not certain, however, since the corollas have slender basal tubes as in the subgenus Ageratina, and the glands containing the sesquiterpene lactones tend to be stalked and protuberant rather than punctate. It also seems notable that Oxylobus has one species $O$. glanduliferus, which extends its range from Mexico south to Colombia and Venezuela, exceeding the range of the subgenus Neogreenella which does not reach South America.

The chromosome number of Oxylobus, as seen in four of the species, is $x=16$ (R. King et al., 1976). The number tends to confirm the relationship to Ageratina but is consistently different from the $x=17$ that is basic to most of the latter genus. The lower number of Oxylobus is easily derived from that in Ageratina, but the derivation is sufficiently matured to stabilize at a level below that in any other stable element counted in the subtribe.

Paray (1958) described a species, Oxylobus macrocephalus, which has a habit similar to members of the genus. The latter species, however, has structural details of the subtribe Ageratinae close to the genus Carphochaete, and has been transferred to the genus Revealia (King \& Robinson, 1976a, 1976d).

Keys to most of the species of Oxylobus can be found in the revision by B. Robinson $(1913 b)$ and the treatment of the Mexican species by Blake (1926). Three of the species are also treated for Guatemala by Williams (1976). Distinctions of the only species not in any keys, O. subglabrus of Oaxaca, Mexico, are given by King and Robinson (1974a).

The name Oxylobus apparently refers to the sharply pointed lobes of the corolla. The corolla lobes in Oxylobus and most related members of the Oxylobinae are distinct from those of Ageratum and Phania by being clearly longer than wide.

The following five species are recognized in the genus:

Oxylobus adscendens (Schultz-Bip.) B. Robinson \& Greenman in B. Robinson, Mexico, Guatemala.

Oxylobus arbutifolius (H.B.K.) A. Gray, Mexico, Guatemala. Oxylobus glanduliferus (Schultz-Bip. ex Benth. \& Hook. f.) A.

Gray, Mexico, Guatemala, Colombia, Venezuela.

Oxylobus oaxacanus S. F. Blake, Mexico.

Oxylobus subglabrus R. King \& H. Robinson, Mexico.

\section{Piptothrix}

Piptothrix A. Gray, Proc. Amer. Acad. Arts 21: 383. 1886. TyPE: Piptothrix palmeri A. Gray.

Erect herbs or weak shrubs, sparingly branched. Stems terete, not or scarcely striated, glabrous to puberulous or hirtellous. Leaves opposite, rarely subopposite, subsessile to short petiolate; blades ovate to narrowly ovate, bases rounded to obtuse, rather abrupt, margins serrulate to serrate, apex narrowly acute to acuminate, trinervate from or near base, often with minute reticulum of prominulous veinlets, with or without minute glandular punctations. Inflorescence a thyrsoid panicle with rather densely corymbose branches; pedicels mostly short. Involucral bracts ca. 7-15, eximbricate, in 2 equal to subequal series, persistent, spreading at maturity; receptacle slightly convex, epaleaceous, glabrous to spinose. Florets 7-18 in a head; corollas white, with narrow basal tube and funnelform to slightly campanulate limb, outer surface glabrous; cells of throat elongate with sinuous lateral walls; lobes triangular, ca. 1.5-2 times as long as wide, inner surface mamillose to nearly smooth, outer surface smooth; anther collar cylindrical, narrow, composed of numerous subquadrate cells below, elongate cells above, cell walls with little or no ornate thickening; anther appendage large, ovate or oblong, longer than wide; style base enlarged, glabrous; style branches narrowly linear, scarcely broadened distally, densely papillose. Achenes prismatic, 5-ribbed, setuliferous; carpopodium indistinct; pappus of ca. 15-25 scabrid deciduous bristles, sometimes only half as long as corolla, apical cells acute, with a very short outer series of small setulae. Pollen grains ca. 20-23 $\mu \mathrm{m}$ in diameter. Plate 171.

Piptothrix is one of the remarkable examples of a genus established and consistently maintained within the traditional system of classification without any reliable dis- tinguishing character. As suggested by the name, pipto (= fall) and thrix (= hair), the pappus bristles of the traditional species tend to be very deciduous, but not or 


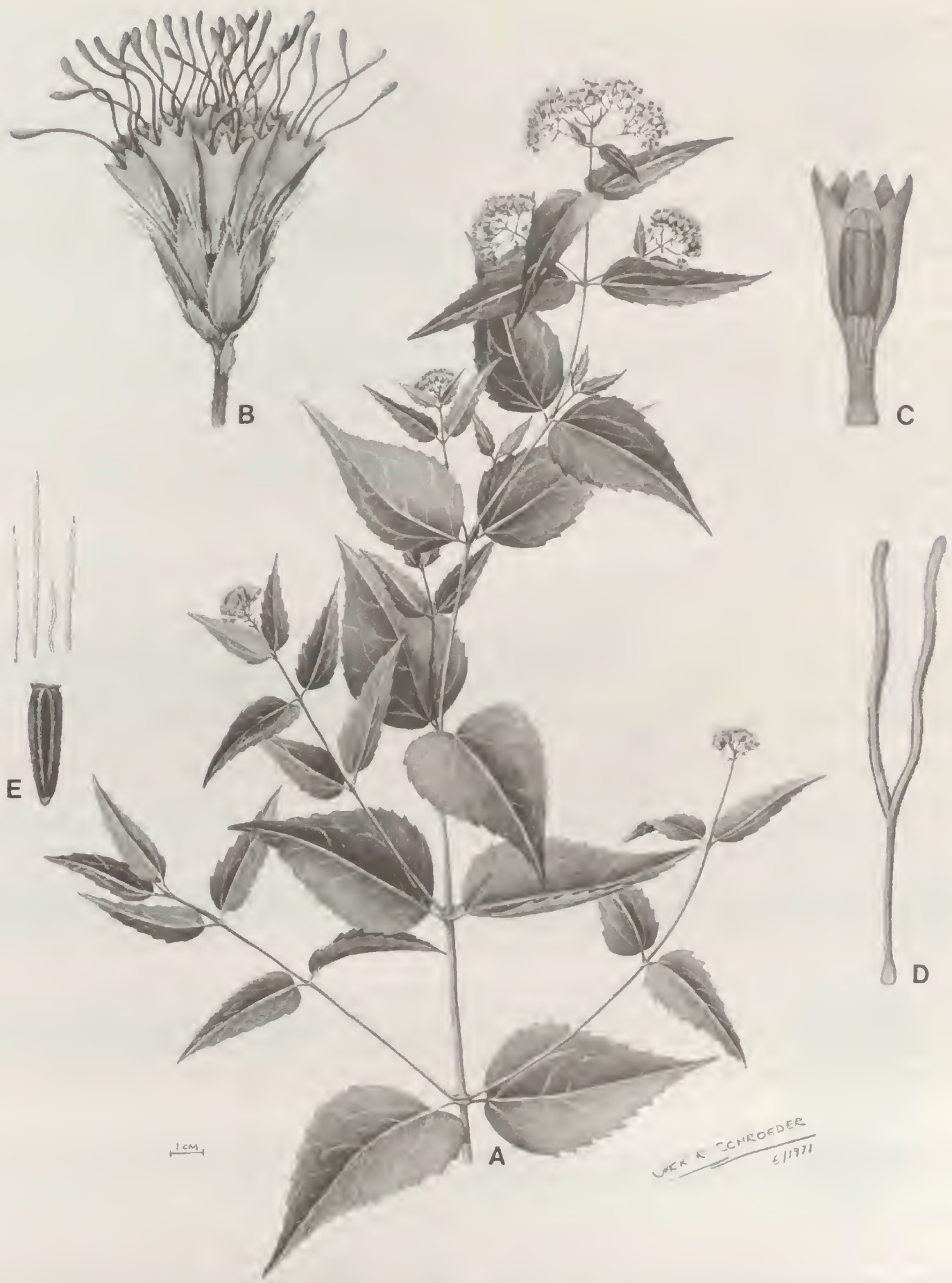

Plate 171. Piptothrix palmeri A. Gray. - A. Habit, $\times 1 / 2 .-$ B. Head, $\times 7 .-$ C. Corolla showing anthers, $\times 14 .-$ D. Style, $\times 14 .-$ E. Achene with a few representative deciduous pappus bristles, $\times 11$. 
scarcely more than those of many in the closely related genus Ageratina that were traditionally retained in Eupatorium. The shortness of the bristles in some of the traditional species did not provide a consistent difference either. It is hardly necessary to say that the traditional concept of the genus Piptothrix was also somewhat unnatural, including as it did two paleaceous species that properly belong in Jaliscoa, and excluding one species, Eupatorium areolare that belonged in the genus. All of the included species did belong to the subtribe Oxylobinae.

The present reasons for recognizing Piptothrix as a distinct genus are totally different from those used in the past. The most important feature delimiting the genus is the lack of a differentiated carpopodium. The latter feature is visible with normal approaches with a dissecting microscope. The mamillose to nearly smooth inner surfaces of the corolla lobes are more difficult to see, but are considered here as a more important technical distinction from Ageratina. The corolla lobe condition is considered as specialized in the generic group. It should be noted that papillosity survives on the style appendages.

The species added to the genus during the present series of studies, $P$. areolaris (King \& Robinson, 1970j), has a superficial resemblance to the others, and the relationship was anticipated to some extent by the passing comment of Cronquist (1965). The species is actually the most common member of the genus as presently delimited, ranging from Jalisco in Mexico southeastward through Chiapas to Guatemala. The other species all have more limited distributions in western Mexico from Jalisco northward to Chihuahua.

There is no key to the species of Piptothrix as presently delimited. A key to the traditional concept of the genus by Blake (1926) includes the four less common species. The excluded species, $P$. areolaris, is usually a more robust plant, and often has distinct spines on the receptacles that are absent in the rest of the genus.

The following five species are recognized in the genus:

Piptothrix areolaris (DC.) R. King \& H. Robinson, Mexico, Guatemala.

Piptothrix jaliscensis B. Robinson, Mexico.

Piptothrix palmeri A. Gray, Mexico.

Piptothrix pubens A. Gray in S. Watson, Mexico.

Piptothrix sinaloae S. F. Blake, Mexico.

\section{Jaliscoa}

\section{Jaliscoa S. Watson, Proc. Amer. Acad. Arts 25: 153. 1890. TYPE: Jaliscoa pringlei S. Watson.}

Erect perennial herbs or shrubs, sparingly branched. Stems terete, without distinct striations, glabrous to minutely puberulous, fistulose in part, usually clathrate in J. pringlei. Leaves opposite, rarely subopposite or ternate, petioles sharply demarcated, moderately long; blades ovate to deltoid, base rounded to truncate, margins crenulate-serrulate to sharply serrate, apex shortly and often narrowly acuminate, trinervate from or near base, lower surface with reticulum of somewhat darkened non-prominulous veinlets. Inflorescence a lax pyramidal panicle, with rather densely corymbose lateral branches; pedicels short. Involucral bracts ca. 15-20, eximbricate, in 2 subequal to equal series, spreading with age, persistent; receptacle slightly convex, paleaceous. Florets 11-25 in a head; corollas white, with narrow basal tube and funnelform to slightly campanulate limb, outer surface glabrous; cells of throat elongate with sinuous lateral walls; lobes ca. 1.5 times as long as wide, mamillose to short-papillose on inner surface, smooth on outer surface; anther collar elongate, cylindrical, composed of subquadrate cells below, elongate cells above, with little or no ornate thickening on walls; anther appendage large, ovate or triangular, slightly longer than wide; style base sometimes enlarged, glabrous; style branches narrowly linear, densely papillose. Achenes prismatic, 4-5-ribbed, glabrous or bearing a few setulae near top; carpopodium usually distinct, symmetrical, annuliform to stoppershaped, composed of 1-10 tiers of rather small subquadrate cells, with slightly thickened cell walls; pappus an obscure callus border or a lacerate-fimbriate crown or of rather short deciduous bristles, apical cells of bristles acute. Pollen grains ca. 18-23 $\mu \mathrm{m}$ in diameter. Plate 172.

The genus Jaliscoa was established and maintained in the traditional system of classification on the basis of its reduced or lacking pappus and its paleaceous receptacle. The former character caused Watson (1890) to place the genus near Alomia, and the latter character provided distinction from that genus. The paleae were not as important to B. Robinson (1913a), who distinguished the genus instead by the shrubby habit and the fistulose often clathrate stems. The genus was originally monotypic, and a second species described by Blake (1924) has proven to be a minor variant of the type species (King \& Robinson, 1970h).

Shortly after their first study, King and Robinson (1970b, $1970 j, 1970 k$ ) recognized a related group of genera including Ageratina, Oxylobus, Piptothrix, and Jaliscoa, among others, a group now recognized as the Oxylobinae. The genus Jaliscoa was found to be distinct within the 


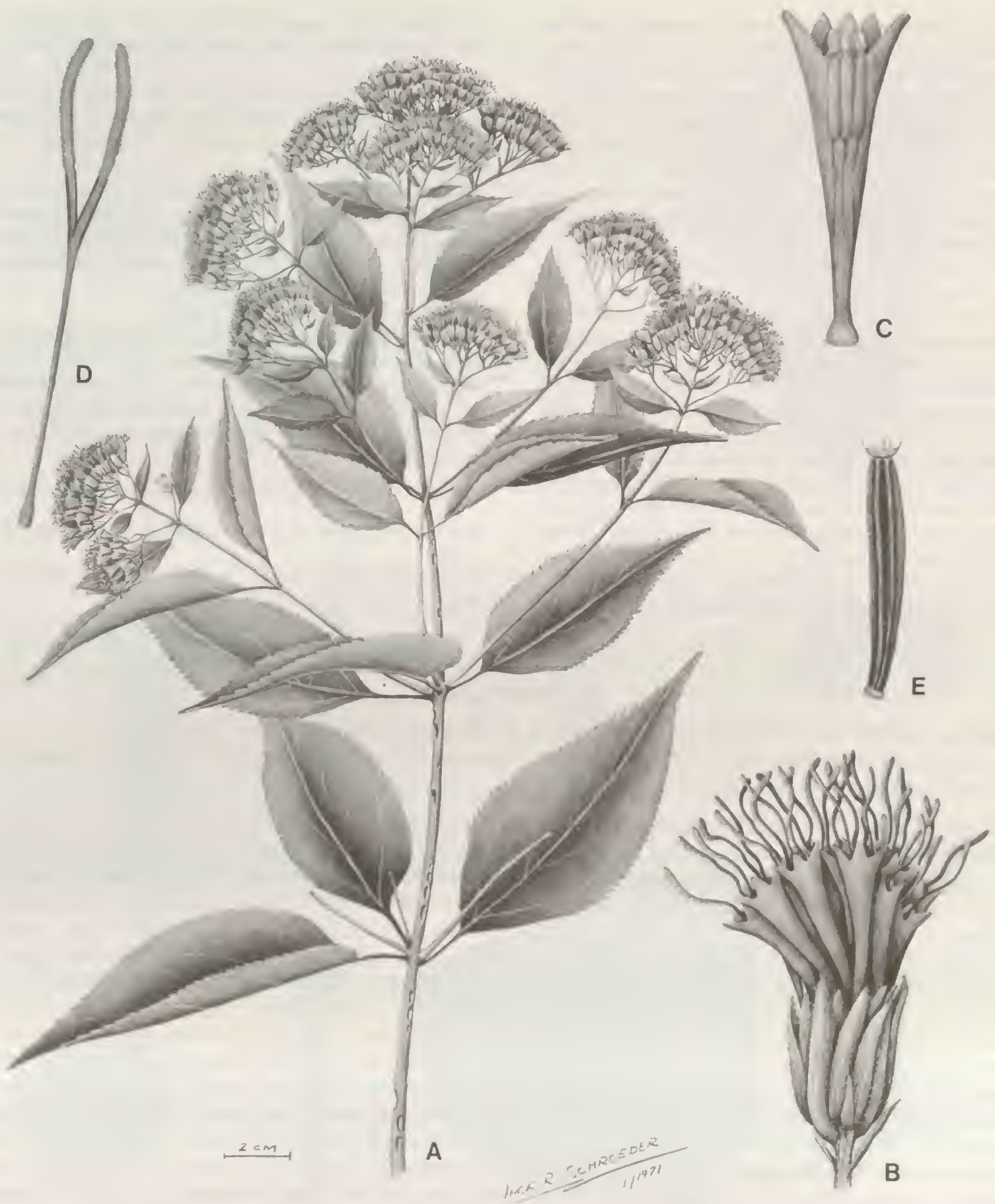

Plate 172. Jaliscoa pringlei S. Watson. - A. Habit, $\times 1 / 2 .-$ B. Head, $\times 6 .-$ C. Corolla showing anthers, $\times 12,-D$. Style, $\times 12,-E$. Achene, $\times 12$ 
group by the presence of paleae on the receptacle, and two paleaceous species were transferred into the genus from the related Piptothrix. The two latter species, in addition to being paleaceous, differed from true Piptothrix by having distinct carpopodia, shorter pappus bristles, a tendency for more broadly ovate, longer petiolate leaves, nonprominulous veinlets, and more flowers in the heads. The distinction of Jaliscoa from Piptothrix seems clearly natural, but the two genera are undoubtedly each other's closest relatives.

The reduction of the pappus in Jaliscoa remains a feature of interest. The pappus in the type species was originally described as a callus border, but Blake (1924) described his species, which is a variant of the type, as having a lacerate-fimbriate crown. Examination shows that the actual pappus of the latter material is in the form of minute narrow projections that are essentially bristles. The latter type of pappus is not considered to be significantly different in basic structure from the longer forms seen in the two species transferred from Piptothrix. The pappus reduction series in Jaliscoa seems to be totally separate within the subtribe from those seen in the related genera Oxylobus and Spaniopappus.

The holes in the stems of the type species of Jaliscoa are the kind of structure that would seem highly artifac- tual. Blake (1924) suggested that they were made by weevils. Nevertheless, at least some holes have been seen in the larger stems of every fully matured specimen, a fact that seems to justify B. Robinson's (1913a) use of them as a key character. It would seem that the holes reflect some basic structural weakness that is characteristic in the stems of the species.

The genus Jaliscoa is known from the State of Jalisco in Mexico, after which it is named, but the type species ranges eastward to Guerrero and Morelos along the southern side of the Central Plateau of Mexico. The other two species also occur in Jalisco, but $J$. goldmanii extends north into Chihuahua.

Keys to the species of Jaliscoa are found in Standley's Trees and Shrubs of Mexico (Blake, 1926) under the generic names Jaliscoa and Piptothrix. Two species belonging to Jaliscoa are recognized under each of the generic names, and in each case these are presently considered to be a single species.

The following three species are recognized in the genus:

Jaliscoa goldmanii (B. Robinson) R. King \& H. Robinson, Mexico.

Jaliscoa paleacea (Cronq.) R. King \& H. Robinson, Mexico. Jaliscoa pringlei $\mathrm{S}$. Watson, Mexico.

\section{Pachythamnus}

Pachythamnus (R. King \& H. Robinson) R. King \& H. Robinson, Phytologia 23: 153.1972.

Ageratina subgenus Pachythamnus R. King \& H. Robinson, Phytologia 19: 228. 1970. TYPE: Eupatorium crassirameum B. Robinson.

Shrubs or small trees, with few branches mostly innovating from below old inflorescences. Stems terete, swollen or somewhat succulent, becoming wrinkled when dry, glabrous, with large somewhat chambered pith. Leaves opposite, lacking at anthesis, with narrow moderately long petioles; blades broadly ovate to deltoid, base rather truncate with slight acumination, margins with a few blunt teeth, apiculate at tip, venation subtrinervate from above base, without glandular punctations. Inflorescence terminal, rather abrupt, densely corymbose; pedicels mostly rather short. Involucral bracts ca. 15, eximbricate to scarcely subimbricate, in 2-3 mostly subequal series, persistent, spreading with age, oblong to narrowly oblong with obtuse tips, mostly bicostate; receptacle slightly convex, with minute scattered hairs. Florets ca. 15 in a head; corollas white or lavender, narrowly funnelform, with narrowly cylindrical basal tubes, puberulous on upper tube and lower throat, glabrous inside; cells of throat oblong with sinuous lateral walls; lobes triangular, longer than wide, densely papillose on inner surface, outer surface and margins smooth below and with projecting cells above, without hairs or glands; anther collar cylindrical, composed of numerous subquadrate cells below, elongate cells above, cell walls with few or no ornate thickenings; anther appendage large, ovate, slightly longer than wide; style base not enlarged, glabrous; style appendages narrowly linear, not broadened distally, densely papillose. Achenes prismatic, usually 5 -ribbed, setuliferous on ribs and sides; carpopodium distinct, shortly rounded or stopper-shaped, without upper rim, with moderately large subquadrate cells in ca. 5 tiers, cell walls rather thin with beaded thickenings; pappus of ca. 25 scabrid slender rather easily deciduous bristles in 1 series, not broadened distally, apical cells acute. Pollen grains ca. $20 \mu \mathrm{m}$ in diameter. Plate 173.

The genus Pachythamnus is thoroughly distinct in its habit, with fattened stems that are leafless at anthesis. Such a habit is not seen in any other member of the
Eupatorieae. Elsewhere in the Asteraceae the habit seems to be matched only in the Senecioneae, especially in the genus Pittocaulon which is distinct in its alternate leaves 

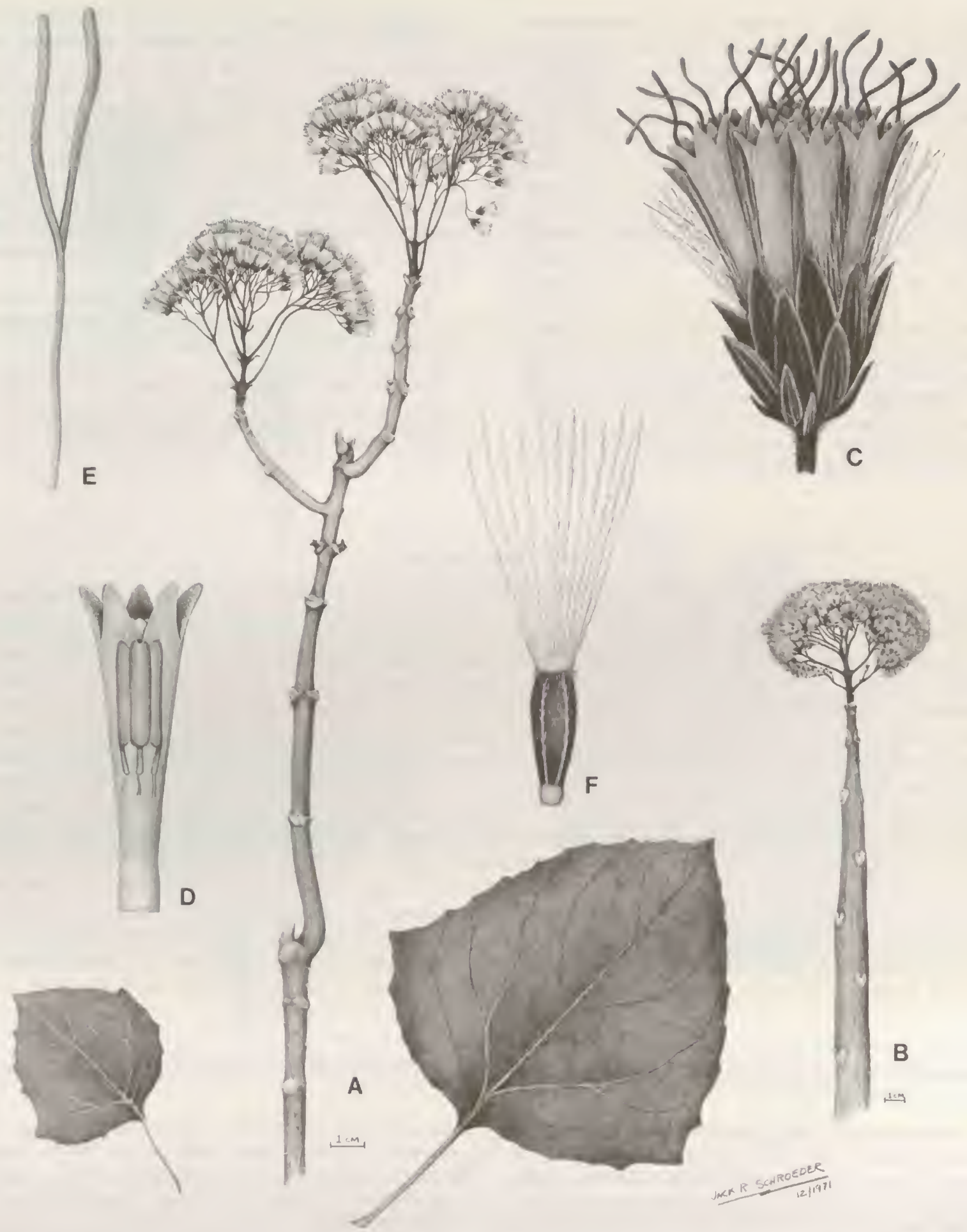

Plate 173. Pachythammus crassirameus (B. Robinson) R. King \& H. Robinson. - A. Habit with separate leaves, $\times 3 / s,-B$. Branch with thickened stem, $\times 1 / 3,-$ C. Head, $\times 8 .-$ D. Corolla showing anthers, $\times 12 .-$ E. Style, $\times 12 .-$ F. Achene, $\times 10$. 
and resiniferous stems. The habits of both genera are reminiscent of the common Mexican and Central American species of Cnidoscolus of the Euphorbiaceae.

In spite of the distinctive habit, the details of the corolla lobes and anthers show that Pachythamnus is closely related to Ageratina, and the genus was originally treated in this series of studies as a subgenus of Ageratina (King \& Robinson, 1970b). The habit, the roughened distal outside surfaces of the corolla lobes, and the lack of a basal enlargement on the style caused the elevation to generic level. All species of Ageratina have characteristically smooth rather cushion-like outer surfaces of the corolla lobes, and all but the members of the small Andean subgenus Apoda have an enlarged style base. The carpopodium of Pachythamnus is like those in Ageratina subgenus Neogreenella, but the lack of glandular punctations and the rather distinct costae of the involucral bracts are more like the subgenus Ageratina. The involucral bracts are more unequal than those of either of the subgenera of Ageratina in Mexico or Central America.
The genus Pachythamnus is comparatively xerophytic. According to Breedlove (pers. comm.), in Chiapas, the thick-stemmed shrub occurs on bare exposed lime outcrops. It flowers when leafless and is in leaf in the wet season. Williams (1976) cites a Nicaraguan specimen on a dry sun-heated lava flow. Williams comments on variation in the species and suggests that there is more than one species, but the higher elevation vegetative specimen cited by him from Guatemala (Steyermark 51920), on examination proves to be the distinctive epiphytic $\mathrm{Nel}$ sonianthus epiphyticus Robinson \& Brettell of the Senecioneac.

The generic name is from the Greek, pachys (= thick) and thamnos (= shrub), in reference to the shrubby habit with thickened stems of the plants.

The following single species is recognized in the genus:

Pachythamnus crassirameus (B. Robinson) R. King \& H. Robinson, Mexico, Guatemala, El Salvador, Nicaragua.

\section{Spaniopappus}

Spaniopappus B. Robinson, Contr. Gray Herb. n.s. 77: 45. 1926. TYPE: Spaniopappus ekamnii B. Robinson.

Erect perennial herbs or shrubs, moderately branched. Stems terete, striated, fistulose, sparsely puberulous to hirtellous, often glabrous in aspect. Leaves opposite, slenderly petiolate, sometimes with slight wings; blades oblong-ovate to elliptical, base acute to acuminate, margins entire to remotely serrate or lobatecrenate, apex acute to slightly acuminate, with immediate tip often rather blunt, venation ascending-pinnate, lower pairs stronger and subtrinervate in aspect, without glandular punctations. Inflorescence rather broadly and laxly corymbose; pedicels moderately long. Involucral bracts ca. 15, weakly subimbricate, in 2-3 somewhat unequal series, persistent, spreading with age, narrowly oblong to linear, mostly bicostate; receptacle slightly convex, epaleaceous, glabrous. Florets 25-60 in a head; corollas purple distally, narrowly funnelform with basal tube narrowly cylindrical or constricted above nectary, inner and outer surfaces glabrous; cells of throat oblong with sinuous lateral walls; lobes triangular, longer than wide, inner surface densely papillose with broad papillae, margins and outer surface papillose with strongly projecting cells; anther collar cylindrical, elongate, composed of subquadrate cells below, elongate cells above, cell walls with few or no ornate thickenings; anther appendage large, ovate, slightly longer than wide; style base not or scarcely enlarged, glabrous; style appendages linear, scarcely broadened above base, mamillose to slightly papillose. Achenes prismatic, usually 5-ribbed, glabrous to sparsely setuliferous; carpopodium poorly to distinctly differentiated, with isolated sclerified cells or with 5-10 tiers of laxly subquadrate rather thin-walled cells, sometimes appearing rimmed by collapse of thin-walled cells above; pappus of ca. 40 persistent scabrid slender bristles in 1 series, apical cells acute, a few short bristles and a fringe of minute squamellae in S. ekmanii. Pollen grains ca. 25 $\mu \mathrm{m}$ in diameter. Plate 174.

As indicated in the redelimitation of the genus by King and Robinson (1970f), Spaniopappus consists of a small group of closely related species in Cuba that are notable for their fistulose stems, lack of glands, weakly subimbricate involucres, corolla lobes that are papillose on both surfaces, and style bases without enlargements. The leaves are subcarnose or rather flaccid in appearance as seen in dried material, with the pinnately disposed secondary veins rather decurrent at their bases. The flowers in all the species seem to be characteristically purplish distally on the lobes and style branches. Most of the species are from the mountains of southern Oriente Province in eastern Cuba, but one species, $S$. iodostylus, is from the Trinidad Mountains in central Cuba.

Spaniopappus owes its recognition under the traditional classification of the Eupatorieae to the fact that one of the species has a reduced pappus. The remaining species were all placed under the broad concept of Eupatorium pre- 


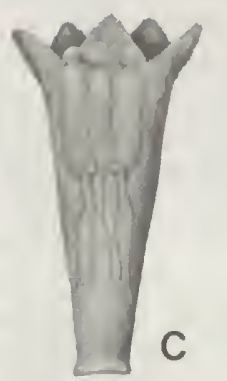

और
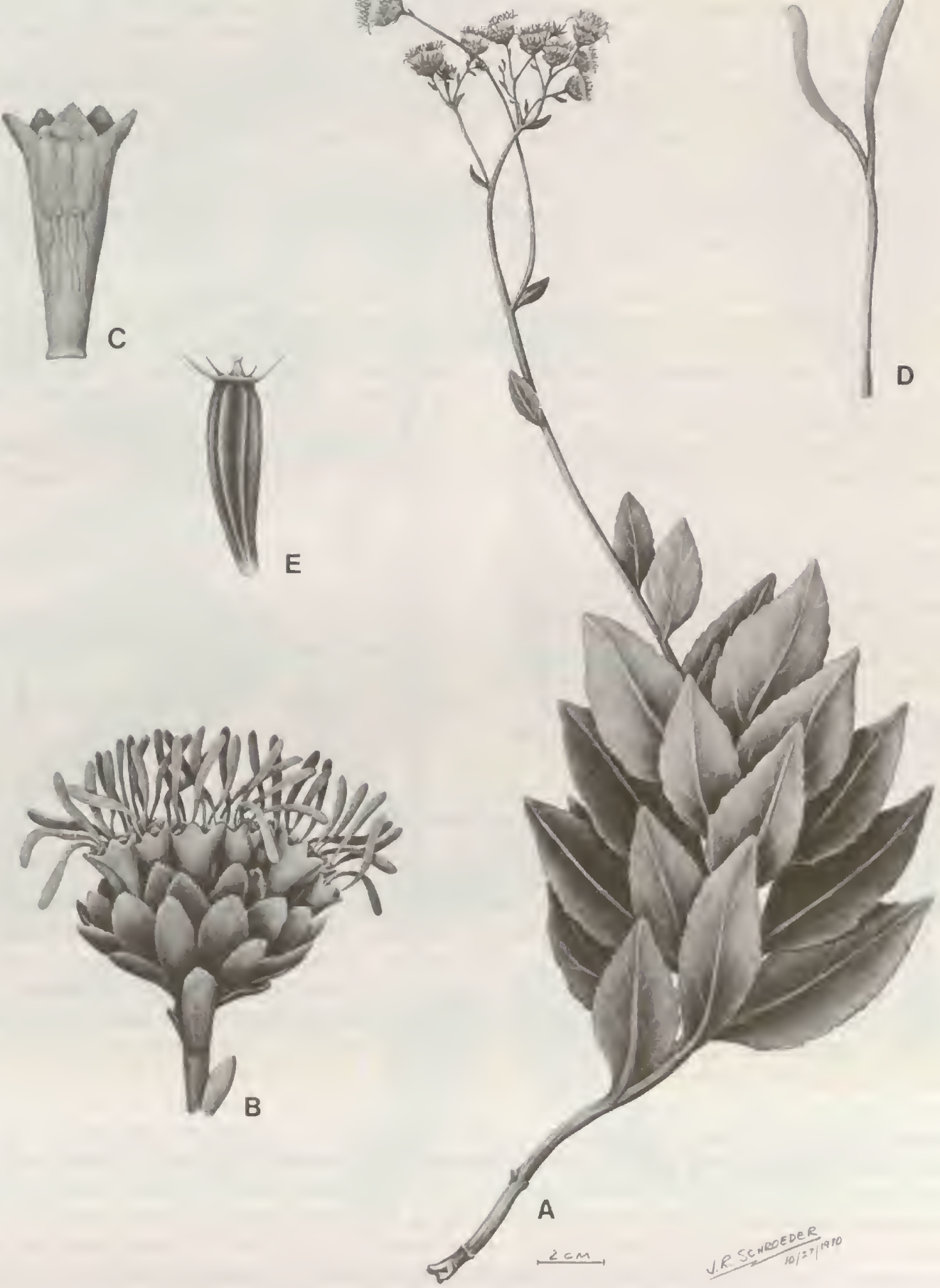

Plate 174. Spaniopappus ekmanii B. Robinson. - A. Habit, $\times 1 / 2 .-$ B. Head, $\times 7 .-$ C. Corolla showing anthers, $\times 15 .-D$, Style, $\times 15$. E. Achene, $\times 15$. 
vious to the present series of studies. In the original description of the genus, B. Robinson (1926a) noted the pappus with bristles of different lengths in the type species, S. ekmanii, and made casual comparisons to Dissothrix, now placed in the Alomiinae, and Fleischmannia, now placed in the Fleischmanniinae. It is remarkable that B. Robinson did not notice the close similarity of his species to the closely related members of "Eupatorium" in Cuba with which it shares so many features. This is especially true since B. Robinson was the author of three of the related species, one being described in the same paper with the genus Spaniopappus. Except for the pappus, $S$. ekmanii seems to differ basically from the others only in the shorter base of the achene, and by the carpopodium with only a few scattered sclerified cells.

The actual question about Spaniopappus at this time is its true relationship to Ageratina in the Oxylobinae. The genus is technically distinguished from Ageratina in the key only by the papillose outer surfaces of the corolla lobes and the unenlarged bases of the styles, but observation of floral details indicates that the two genera are more than technically distinct. Spaniopappus is not a member of the definite Ageratina group within the subtribe, the group that usually has enlarged style bases. The involucre of Spaniopappus is part of the problem, being basically subimbricate but with narrow bracts and a rather eximbricate appearance. The involucre is distinct in its details from other weakly subimbricate forms in the Oxylobinae, but it cannot be easily described for use as a key character.

The distribution pattern of Spaniopappus seems rather anomalous in the Oxylobinae. Some species of Ageratina are endemic to the West Indies, but Spaniopappus is the only genus in the subtribe centered in or endemic to an area outside of the generally western parts of the American land mass. The geography adds to the impression of divergence from other members of the subtribe.

Specimens of the genus Spaniopappus have a distinctly mesophytic appearance, and B. Robinson (1926a) referred to the type as seeming to be a shy denizen of an exceptionally secluded habitat. Actual collection data indicated the plant was rare, in very dense low woods at the top of the mountain spur El Yunque. Material of $S$. iodostylus is cited from moist ground or limestone, and the type of $S$. shaferi is said to be on rocks by water near the top of a waterfall. The only suggestion of common occurrence is in S. buckeri which is labelled a "tall weed" in windfall, Loma Cardero, Pico Tarquino. There is no key to the species.

As indicated by B. Robinson (1926a) the generic name is from the Greek spanios (= scanty) and pappos (= coma).

The following five species are recognized in the genus:

Spaniopappus buckeri (B. Robinson) R. King \& H. Robinson, Cuba.

Spaniopappus ekmanii B. Robinson, Cuba.

Spaniopappus hygrophilus (Alain) R. King \& H. Robinson, Cuba. Spaniopappus iodostylus (B. Robinson) R. King \& H. Robinson, Cuba.

Spaniopappus shaferi (B. Robinson) R. King \& H. Robinson, Cuba.

\section{Standleyanthus}

Standleyanthus R. King \& H. Robinson, Phytologia 22: 41. 1971. TYPE: Eupatorium triptychum B. Robinson.

Large flaccid shrub, with few branches, glabrous. Stems rather fleshy, terete, striated, fistulose. Leaves opposite, petioles long; blades divided into 3 leaflets, leaflets oblong-ovate, petiolulate, margins remotely crenate-undulate, apex narrowly acuminate, venation pinnate. Inflorescence terminal in branches, pyramidally paniculate; pedicels slender, short to moderately long. Involucral bracts ca. 12, eximbricate, in ca. 2 subequal series, narrowly oblong, persistent, spreading with age, scarcely bicostate on outer surface; receptacle slightly convex, epaleaceous, glabrous. Florets ca. 12 in a head; corollas whitish?, narrowly funnelform with long cylindrical basal tube, outer and inner surfaces glabrous; cells of throat oblong with sinuous lateral walls; lobes triangular, slightly longer than wide, with dense prominent mamillae on inner surface, outer surface smooth below and somewhat mamillose above; anther collar cylindrical, composed of numerous subquadrate cells below, cell walls without ornate thickenings; anther appendage large, oblong-ovate, slightly longer than wide; style base scarcely thickened, glabrous; style appendages narrowly linear, scarcely broadened distally, slightly mamillose. Achenes prismatic, 4-5-ribbed, ribs prominent and usually pale, setuliferous, greatly expanded at base; carpopodium indistinct, sometimes with 1-2 tiers of subquadrate cells with firm thin walls; pappus of ca. 20 scabrid mostly persistent contiguous slender bristles in 1 series, not broadened distally, apical cells acute. Pollen grains ca. $21 \mu \mathrm{m}$ in diameter. Plate 175.

The genus Standleyanthus is easily distinguished from all other members of the Eupatorieae by the compound leaves having three large pinnately veined petiolulate leaflets. The leaflets themselves look like leaves to a greater extent than in any other dissected leaf type in the tribe. The petiolules are distinct and about $1 \mathrm{~cm}$ long. They appear unwinged but have the slight margin that is present in the petioles and petiolules of all members of the As- 


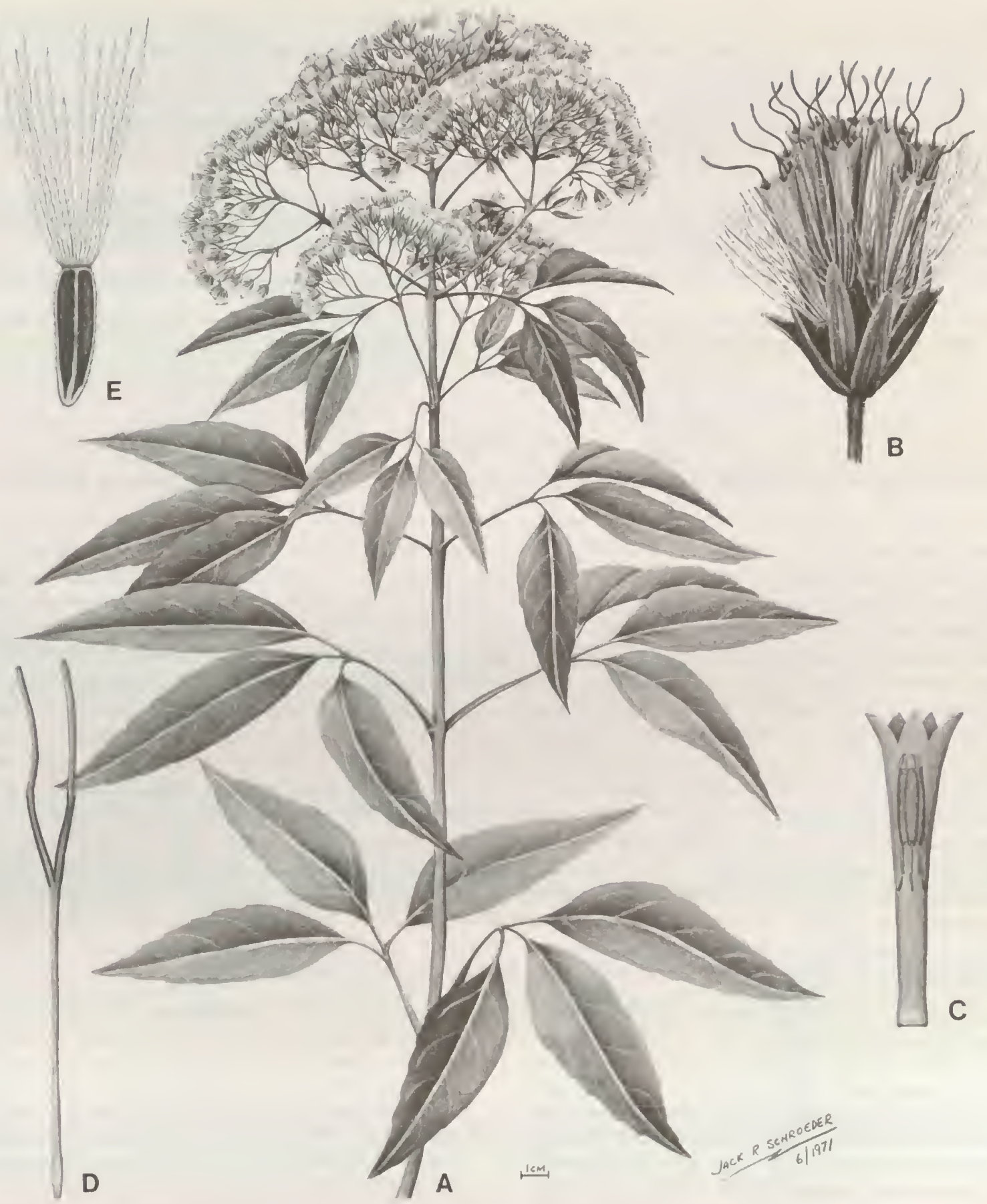

Plate 175. Standleyanthus triptychus (B. Robinson) R. King \& H. Robinson. - A. Habit, $\times 4 / \% .-$ B. Head, $\times 4$. - C. Corolla showing anthers, $\times 9 .-$ D. Style, $\times 9 .-$ E. Achene, $\times 9$.

teraceae. The petiole is long and becomes narrow distally, but as seen in a single leaf, the basal half of the petiole is quite broad before drying.

The relationship of the genus Standleyanthus is not what might be thought on superficial observation. The flaccid plant from moist woods has some of the appearance of a Neomirandea of the subtribe Neomirandeinae, and Standleyanthus may have been an epiphyte or hum- 
icolous like Neomirandea. The habit is not certain, however, and in any case the floral details are different. The in volucre is essentially eximbricate with only a few shorter outer bracts, and the inner surface of the corolla lobes is mamillose. The latter characters combined with the anther collar indicate a position for the genus in the subtribe Oxylobinae. The fistulose stems and generally flaccid appearance may indicate closest relationship to the Cuban genus Spaniopappus in the subtribe. The very slight enlargement of the style bases is not significant, and is not comparable to that noted in Ageratina, Oxylobus, and their closest relatives.

Standleyanthus is presently known from a single specimen with a single stem. The Standley collection is cited from El Muñeco, south of Navarro, in the Province of Cartago, Costa Rica, at an altitude of about $1,400 \mathrm{~m}$. The collection data indicates the plant was a large shrub in a wet forest. Recent attempts to collect the genus by R. King have found that any such habitat at the locality has been destroyed, and it is possible that the genus Standleyanthus is now extinct.

The generic name honors Paul C. Standley, collector of the type specimen, specialist in Rubiaceae, and author of floras of Costa Rica, Guatemala, and Mexico.

The following single species is recognized in the genus:

Standleyanthus triptychus (B. Robinson) R. King \& H. Robinson, Costa Rica.

\section{Kaunia}

\section{Kaunia R. King \& H. Robinson, Phytologia 47: 258. 1980. TYPE: Eupatorium eucosmoides B. Robinson.}

Erect shrubs or small trees, to $4 \mathrm{~m}$ tall, moderately branched. Stems terete, striated, glabrous to tomentellous. Leaves opposite, distinctly petiolate, petioles short in $K$. pachanoi; blades usually ovate, base rounded to acuminate, margins entire to serrate, apex broadly to narrowly acute, venation pinnate to subtrinervate from above base, with or without small dark immersed glandular punctations, often with small reticulum of slightly insculpate veinlets. Inflorescences terminal on branches, thyrsoid to corymbose with densely corymbose branches, branches opposite, branchlets with few to many small bracts; pedicels short. Involucral bracts ca. 12-21, weakly subimbricate, in ca. 2-3 series, subequal to unequal, persistent, spreading with age, with two short narrow costae outside; receptacle slightly convex, epaleaceous, glabrous. Florets (10-)16-50 in a head; corollas usually white or violet, narrowly funnelform, glabrous inside and on lower outer surface; cells of throat laxly oblong, with weakly to strongly sinuous lateral walls; lobes triangular, slightly longer than wide, inner surface nearly smooth with subquadrate to short-oblong cells, outer surface smooth and somewhat padded, with occasional glands; anther collar cylindrical, elongate, composed of numerous subquadrate cells below, cell walls with few or no ornate thickenings; anther appendage large, ovate, slightly longer than wide; style base not enlarged, glabrous; style branches narrowly linear, smooth to slightly mamillose. Achenes prismatic, 5-ribbed, base and apex usually densely setuliferous or glanduliferous; carpopodium distinct, symmetrical, annuliform to shortly stopper-shaped, composed of ca. 5 tiers of subquadrate cells, with cell walls not thickened; pappus of ca. 25-30 scabrid persistent contiguous slender bristles in 1 series, not broadened distally, apical cells acute. Pollen grains ca. 20-22 $\mu \mathrm{m}$ in diameter. Plate 176.

The genus Kaunia has the general lack of specializations of style base and corolla lobes that is normally characteristic of the subtribe Critoniinae, and a position in that subtribe might initially seem most likely. Certain details such as the unenlarged tips of the style branches, the weakly subimbricate involucres, the narrow anther collars with essentially unornamented cell walls, and the carpopodial cells with scarcely thickened walls form a combination not known in the Critoniinae, however. The true relationship of Kaunia is ultimately seen in the detailed structure of the corolla lobes, with the rather cushion-like outer surface and the shortened nearly isodiametric cells of the inner surface. Except for the lack of papillae on the inner surface, the corolla lobes are like those of Ageratina in the Oxylobinae, and a position in that subtribe is supported by most structural features and the geography of the genus.
The general lack of specialization in the style base and corolla lobes in Kaunia, that cause confusion in its subgeneric placement, prove highly useful as distinguishing characters within the Oxylobinae. Neither of the unspecialized features is unique to Kaunia in the subtribe. Unenlarged style bases are found in Ageratina subgenus Apoda, and Jaramilloa of South America, Pachythamnus and Standleyanthus of Mexico and Central America, and Spaniopappus of Cuba. The non-papillose or non-mamillose inner surface of the corolla lobes is more restricted, occurring elsewhere in the subtribe in Jaramilloa and Piptothrix. The only other member of the subtribe sharing both features, Jaramilloa, is geographically isolated in northern Colombia, has specialized granular pubescence on the stems and leaves, and has corollas with campanulate throats. 


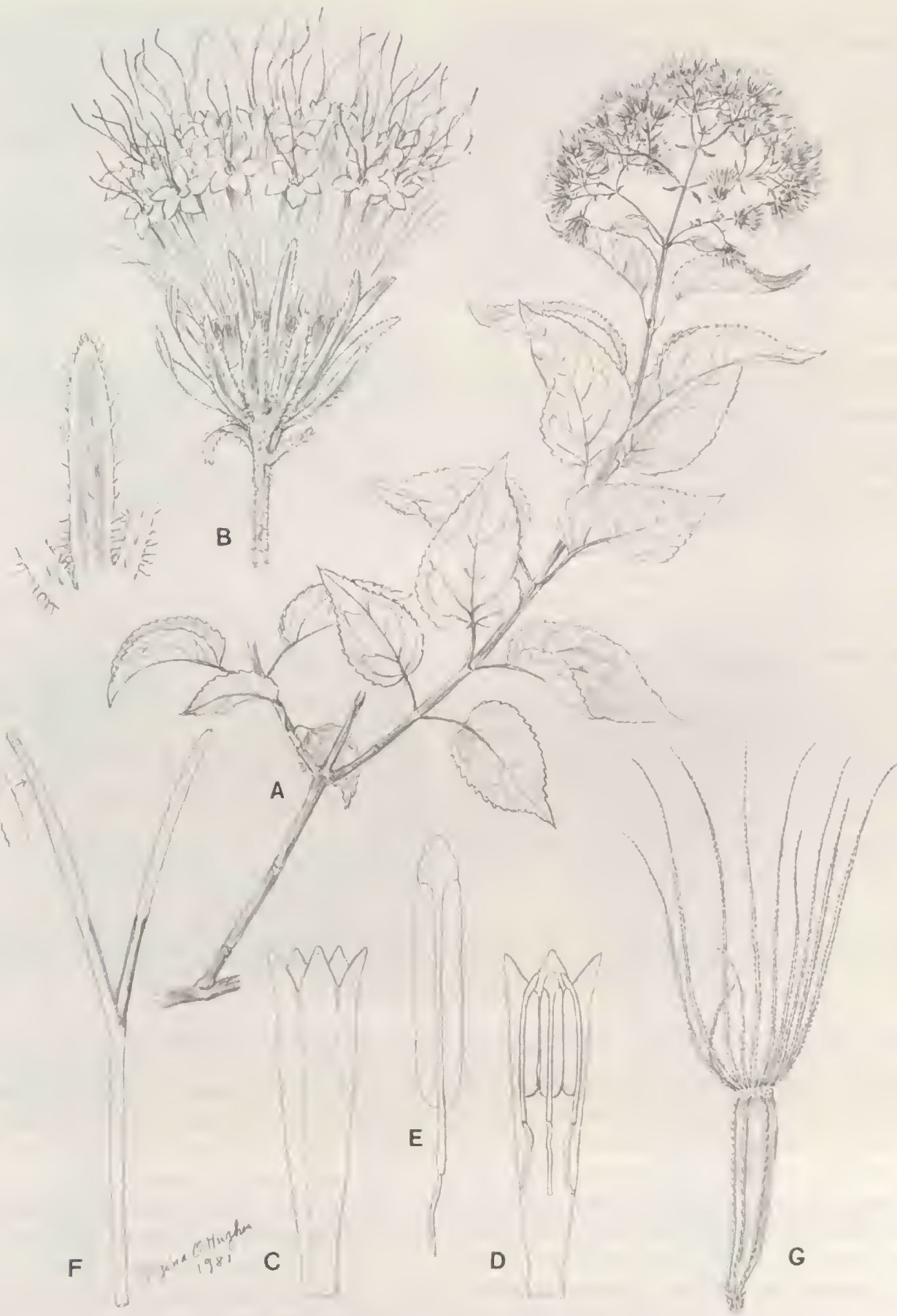

Plate 176. Kaunia salsensis (Hieron.) R. King \& H. Robinson. - A. Habit, $\times 1 / 2 .-$ B. Head, $\times 7$, with separate enlarged segment of involucre. - C. Corolla outer surface, $\times 15 .-$ D. Corolla inner surface with anthers, $\times 15 .-$ E. Anther, $\times 30 .-F$. Style, $\times 15$, with enlarged section of appendage. $-\mathrm{G}$. Achene, $\times 15$. 
Kaunia is believed to be most closely related in the subtribe to Jaramilloa, and the two seem to represent an early divergence in the subtribe restricted to South America. The Ageratina subgenus Apoda, which is sympatric, is a more herbaceous group that seems to represent a more recent extension of the Oxylobinae into South America. In considering Kaunia to represent an early divergence in the subtribe, there is no conclusion as to whether the unenlarged style bases and non-papillose inner surfaces of the corolla lobes were primitive or derived within the subtribe, but it is definitely felt at this time that Kaunia and Jaramilloa are not transitional in the subtribe to the Critoniinae, and relationship to the latter group is considered remote.

Kaunia, a genus of shrubs and small trees, seems geographically concentrated in the area of Bolivia, with species in Peru, Argentina, and eastward into southern Brazil. The northernmost species, $K$. pachanoi of central Ecuador, differs from others by the comparatively few flowers (ca. ten) in the heads, and by the small elliptical leaves with very short petioles. The more typical element of the genus has broader leaves on distinct petioles, and has an unusual degree of variation within species as to the pinnate or subtrinervate form of leaf-venation. The more typical element also reaches southernmost Ecuador in the form of $K$. arbuscularis.

Only one attempt has been made to count the chromosomes of Kaunia, by Royce Oliver, who obtained an uncertain high number near 45 (King \& Robinson, 1980q). The chemistry of three species has been examined (Bohlmann et al., 1981) with reports of thymol derivatives in all three. Guaianolides have been reported from $K$. arbuscularis.
Kaunia was named and delimited by King and Robinson $(1980 q)$ to include species that had been previously placed in the broad traditional concept of Eupatorium. The generic name was selected to honor Edward Kaun of Baltimore, Maryland, who has greatly aided the present authors in the preparation of this treatment of the Eupatorieae.

The following 14 species are recognized in the genus:

Kaunia arbuscularis (B. Robinson) R. King \& H. Robinson, Ecuador.

Kaunia camataguiensis (Hieron.) R. King \& H. Robinson, Bolivia.

Kaunia endyta (B. Robinson) R. King \& H. Robinson, Peru. Kaunia eucosmoides (B. Robinson) R. King \& H. Robinson, Peru. Kaunia grossidentata (Hieron.) R. King \& H. Robinson, Bolivia. Kaunia gynoximorpha (Rusby ex B. Robinson) R. King \& H. Robinson, Bolivia.

Kaunia hosanensis (B. Robinson) R. King \& H. Robinson, Bolivia.

Kaunia ignorata (Hieron.) R. King \& H. Robinson, Bolivia.

Kaunia lasiophthalma (Hieron.) R. King \& H. Robinson, Argentina, Bolivia.

Kaunia longipetiolata (Schultz-Bip. ex Rusby) R. King \& H. Robinson, Bolivia.

Kaunia pachanoi (B. Robinson) R. King \& H. Robinson, Ecuador.

Kaunia rufescens (Lund ex DC.) R. King \& H. Robinson, Bolivia, Brazil.

Kaunia saltensis (Hieron.) R. King \& H. Robinson, Argentina, Bolivia.

Kaunia uber (B. Robinson) R. King \& H. Robinson, Peru.

\section{Jaramilloa}

Jaramilloa R. King \& H. Robinson, Phytologia 47: 117. 1980. TYPE: Eupatorium hylibates B. Robinson.

Erect shrubs or small trees, to $3 \mathrm{~m}$ tall, moderately branched. Stems terete to slightly hexagonal, scarcely striated, sometimes thickened, fistulose or non-fistulose, younger parts with dense granular yellowish pilosity. Leaves opposite, with rather long sharply delimited petioles; blades often large, broadly oblong, base often truncate to cordate, margins serrulate to scarcely undulate, apex short-acute, venation pinnate, widely spreading, often congested near base, glandular punctate above, sparsely to densely granulate-pilose below. Inflorescences terminal on branches, broadly corymbose with ascending opposite lower branches; heads shortpedicellate or sessile in glomerules. Involucral bracts ca. 12-23, weakly subimbricate, in ca. 3 unequal series, persistent, spreading with age, not obviously costate outside; receptacle slightly convex, epaleaceous, glabrous. Florets 14-20 in a head; corollas whitish, with narrow cylindrical basal tube and narrowly campanulate limb, glabrous on inner and lower outside surfaces; cells of throat oblong with laxly sinuous lateral walls; lobes scarcely to strongly longer than wide, slightly mamillose on inner surface with short cells, smooth and glanduliferous on outer surface; anther collar cylindrical, elongate, composed of numerous subquadrate cells below, elongate cells above, cell walls without or with slight beaded thickenings; anther appendages large, subquadrate to shortly oblong-ovate; style base without node, glabrous, style shaft slightly thickened; style appendages narrowly linear, strongly prorulose. Achenes prismatic, 5-ribbed, setuliferous or glanduliferous; 


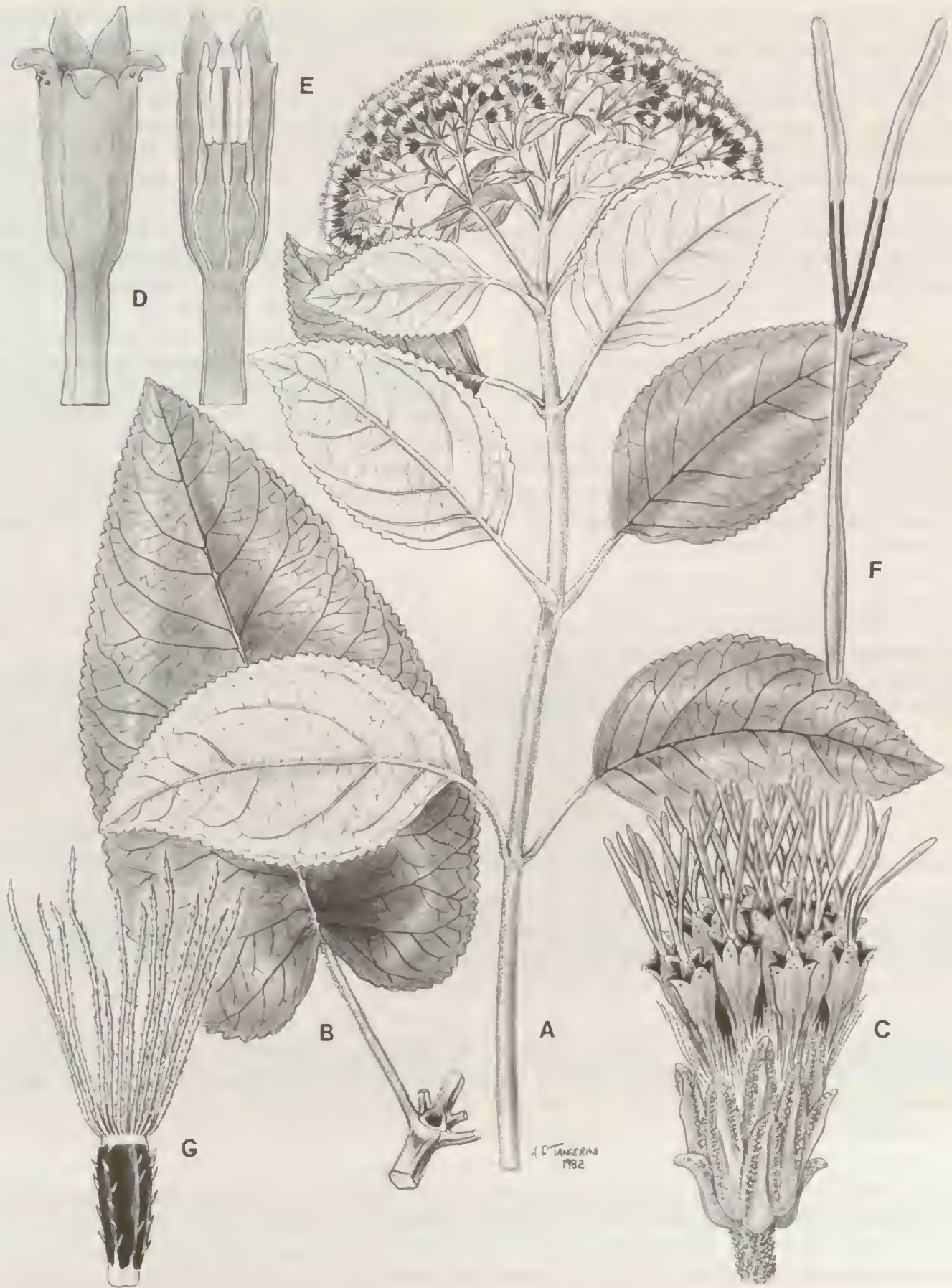

PLATE 177. Jaramilloa hylibates (B. Robinson) R. King \& H. Robinson. - A. Habit, $\times 1 / 2 .-$ B. Lower leaf, $\times 1 / 2 .-$ C. Head, $\times 5 .-D$. Corolla outer surface, $\times 11 .-$ E. Corolla inner surface with anthers, $\times 11 .-F$. Style, $\times 11 .-$ G. Achene, $\times 11$.

carpopodium short-cylindrical, broader than high, symmetrical, without or with slight upper rim, cells quadrate to short-oblong in ca. 7 tiers, cell walls scarcely thickened; pappus of ca. 25-50 scabrid rather easily deciduous slender contiguous bristles in 1-2 series, sometimes borne on outer surface of callus, not broadened distally, apical cells acute. Pollen grains ca. $25 \mu \mathrm{m}$ in diameter. Plate 177. 
The genus Jaramilloa is placed here in the subtribe Oxylobinae near the genus Kaunia. Both genera appear to represent a South American element of the subtribe differing from other members of the Oxylobinae by the unenlarged style bases and the non-papillose or non-mamillose inner surfaces of the corolla lobes. The latter Critoniine features are dismissed as evidence of relationship because of the elongate anther collars with numerous subquadrate cells and the distinct carpopodia with rather thin-walled cells which are more indicative of the Oxylobinae. The genus Jaramilloa seems easier to accept than Kaunia as a member of the Oxylobinae because of its campanulate corolla limbs superficially resembling those of typical Ageratina. Nevertheless, relationship of Jaramilloa within the subtribe seems clearly with Kaunia rather than with Ageratina.

Both species of Jaramilloa have a rather distinctive form of pubescence on the stems and leaves unlike that of any other genera in the subtribe. The yellowish hairs have many short broad thin-walled cells in a single series, and look granular as a result of their short stout shape. The nearest approximation of the hair-type in the Eupatorieae is in the Critoniine genus Corethamnium, also of Colombia, but the hairs of the latter have the cells thickwalled and partially biseriate. Other features of corolla shape, carpopodial structure, and style appendage indicate that the latter genus has no close relationship. The style appendages of Corethamnium are actually more papillose than those of Jaramilloa, a situation that is the reverse of that in most Oxylobinae and Critoniinae.

The species of Jaramilloa are restricted to northern Colombia. They share a similar appearance with large pinnately veined leaves, and broad subimbricate involucres. The species are even alike in such details as the prorulose surface of the style appendages. As such, it is not surprising that the species were treated for years in herbaria as members of a single species. The two species are actually very distinct, however. Jaramilloa sanctaemartae differs from the type species by having fistulose stems, the heads in sessile clusters, the corolla lobes more deeply cut and twice as long as wide, the achenes bearing glands rather than short setulae, and the pappus being apical and biseriate. The pappus of the type species is inserted in a single series below the margin on the outer surface of the apical callus of the achene. A key to the species is provided by King and Robinson (1980k).

The generic name honors R. Jaramillo Mejia of the staff at the Instituto de Ciencias Naturales in Bogotá.

The following two species are recognized in the genus:

Jaramilloa hylibates (B. Robinson) R. King \& H. Robinson, Colombia.

Jaramilloa sanctae-martae R. King \& H. Robinson, Colombia.

\section{SubTRIBE XVII. HoFmeISTERIINAE}

Hofmeisteriinae R. King \& H. Robinson, Phytologia 46: 449. 1980. TYPE: Hofmeisteria Walp.

Perennial herbs or small shrubs, moderately to densely branched, never rosulate. Leaves alternate, congested to subverticillate at bases of inflorescences; petioles usually elongate; blades usually lobed to dissected, glabrous or with small stipitate glands, without glandular punctations. Inflorescences of numerous erect long peduncles bearing single heads; involucres broadly campanulate; involucral bracts strongly subimbricate in 4-6 unequal graduated series, appressed, mostly persistent; receptacle slightly convex, epaleaceous. Flowers 100-250 in a head; corollas white or pink, very narrowly funnelform, glabrous; cells of throat elongate with sinuous lateral walls; lobes triangular to oblong, longer than wide, smooth on both surfaces, outer surface without stomata; anther collar narrowly cylindrical, poorly differentiated at base, cells oblong with weak beaded thickenings on walls; anther appendage usually slightly longer than wide, very short in two species; style base not enlarged, glabrous; style appendages slightly broadened and flattened distally, smooth or slightly mamillose. Achenes prismatic, 5-ribbed, micropunctations of achene walls not strongly aligned in transverse bands; carpopodium distinct, symmetrical, with slight upper rim, shortly stopper-shaped, with small broad cells in many tiers and ranks, rather thick-walled; pappus of 3-15 tapering persistent bristles, sometimes with intervening squamellae, apical cells acute. Pollen grains with numerous slight spinules, appearing nearly smooth under light microscope. Basic chromosome numbers $x=18$ or 19 .

The subtribe Hofmeisteriinae with the single genus $\mathrm{Hof}$ meisteria is placed in the sequence of subtribes in the present treatment mostly on the basis of its narrow anther collars with weakly ornamented cell walls and its high basic chromosome number. Actual relationships are somewhat uncertain, but the following subtribe Oaxaca- niinae seems closest, differing most obviously by its paleaceous receptacles and its more spinulose pollen. The Hofmeisteriinae, with its strongly subimbricate involucres, is not considered closely related to the preceding Oxylobinae.

In spite of few species and general uniformity, the mem- 
bers of the subtribe Hofmeisteriinae show remarkable variation in two features, the pappus and the anther appendage, once commonly used to distinguish genera in the Eupatorieae. None of the species have more than 15 bristles in the pappus, and none have been placed in the broad concept of Eupatorium. However, two species with only five pappus bristles have been placed in Fleischmannia of the Fleischmanniinae, and others with alternating bristles and squamellae have been closely associated with species of Malperia and Pleurocoronis of the Alomiinae. These elements are properly distinguished by King and Robinson (1966). The Hofmeisteriinae has none of the corolla prorulosity or the anther collar annulation of the Fleischmanniinae, and does not have the upwardly narrowed corollas or greatly broadened style branches of the Alomiinae. The short form of anther appendage found in two species of the Hofmeisteriinae has caused a placement of one of these among the so-called Piqueriinae, but the members of Hofmeisteria lack the papillosity of the corolla lobes found in most members of the Ageratinae to which Piqueria belongs.

The members of the Hofmeisteriinae seem distinguishable from the Ageratinae, the Alomiinae, and the Fleisch- manniinae by the higher basic chromosome number. The other subtribes all have a basic number of $x=9$ or 10 . The numbers in the Hofmeisteriinae, however, are based upon reports of a single species, and other species are not counted (R. King et al., 1976).

The pollen grains of the Hofmeisteriinae are characteristic of the group and unique in the Eupatorieae. Although spinulose like others in the tribe, the spinules are more numerous and much smaller than those of most other members of the subfamily Asteroideae. The pollen grains do not appear spinulose under the light microscope. only slightly roughened. The spinules can be seen clearly using the scanning electron microscope (H. Robinson \& King, 1977).

Chemical study of the Hofmeisteriinae has been minimal, involving only material admixed with a sample of Carterothamnus (Bohlmann et al., 1979a). Only benzofurans are reported, a type of compound common in the Eupatorieae.

The single included genus, Hofmeisteria, is restricted to Mexico, occurring mostly in the western part of that country.

\section{Hofmeisteria}

Hofmeisteria Walp., Repert. Bot. Syst. 6: 106. 1846. TYPE: Helogyne fasciculata Benth.

Helogyne Benth., Bot. Voy. Sulphur 20. 1844. TYPE: Helogyne fasciculata Benth., non Helogyne Nutt., 1841.

Podophania Baillon, Bull. Mens. Soc. Linn. Paris 1: 268. 1880. TYPE: Podophania ghiesbreghtiana Baillon [= Hofmeisteria dissecta (Hook. \& Arn.) R. King \& H. Robinson].

Perennial herbs or woody subshrubs, moderately to densely branched, glabrous or with small stipitate glands. Stems terete, scarcely or not striated. Leaves alternate in two-fifths phyllotaxy, usually congested at flowering nodes and appearing whorled, not congested in $H$. filifolia, petioles usually distinct and rather long, not distinct from undivided blade in some $H$. filifolia; blades broadly ovate to filiform in outline, margin entire to lobed or greatly dissected into cuneate or filiform segments, basically trinervate, sometimes unicostate. Inflorescences monocephalic, with heads on long erect scapiform peduncles; heads broadly campanulate. Involucral bracts ca. 50-100, subimbricate, in 4-6 strongly unequal graduated series, appressed, with apices acute to pungent, outer surface with 4 low costae; receptacle convex, epaleaceous, glabrous. Florets (100-)150-175(-250) in a head; corollas white, pink, or lavender, very narrowly funnelform, nearly tubular, glabrous on inner and outer surfaces; cells of throat elongate with sinuous lateral walls; lobes triangular to oblong, longer than wide, smooth on both surfaces, with papillae at tip; anther collar narrowly cylindrical, poorly differentiated, cells oblong with weak beaded thickenings on walls; anther appendage usually large, ovate, as long as wide, short in $H$. dissecta and $H$. sinaloensis; style base not enlarged, glabrous; style appendages slightly enlarged and flattened distally, smooth or slightly mamillose. Achenes prismatic, 5 ribbed, setuliferous on ribs; carpopodium distinct, symmetrical, broadly stopper-shaped, composed of ca. 7-8 tiers of rather thick-walled subquadrate to broadly oblong cells; pappus of 3-15 scabrid tapering bristles, with 6-10 intervening lacerate squamellae in species with less bristles, persistent, apical cells acute. Pollen grains ca. $11-18 \mu \mathrm{m}$ in diameter, scarcely spinulose. Plate 178.

The genus Hofmeisteria has a distinctive appearance with its usually lobed or dissected leaves congested at the bases of the inflorescences, and with its numerous erect long peduncles bearing solitary heads. The naturalness of the genus is confirmed by such details as the appressed strongly subimbricate involucral bracts, the narrow gla- 


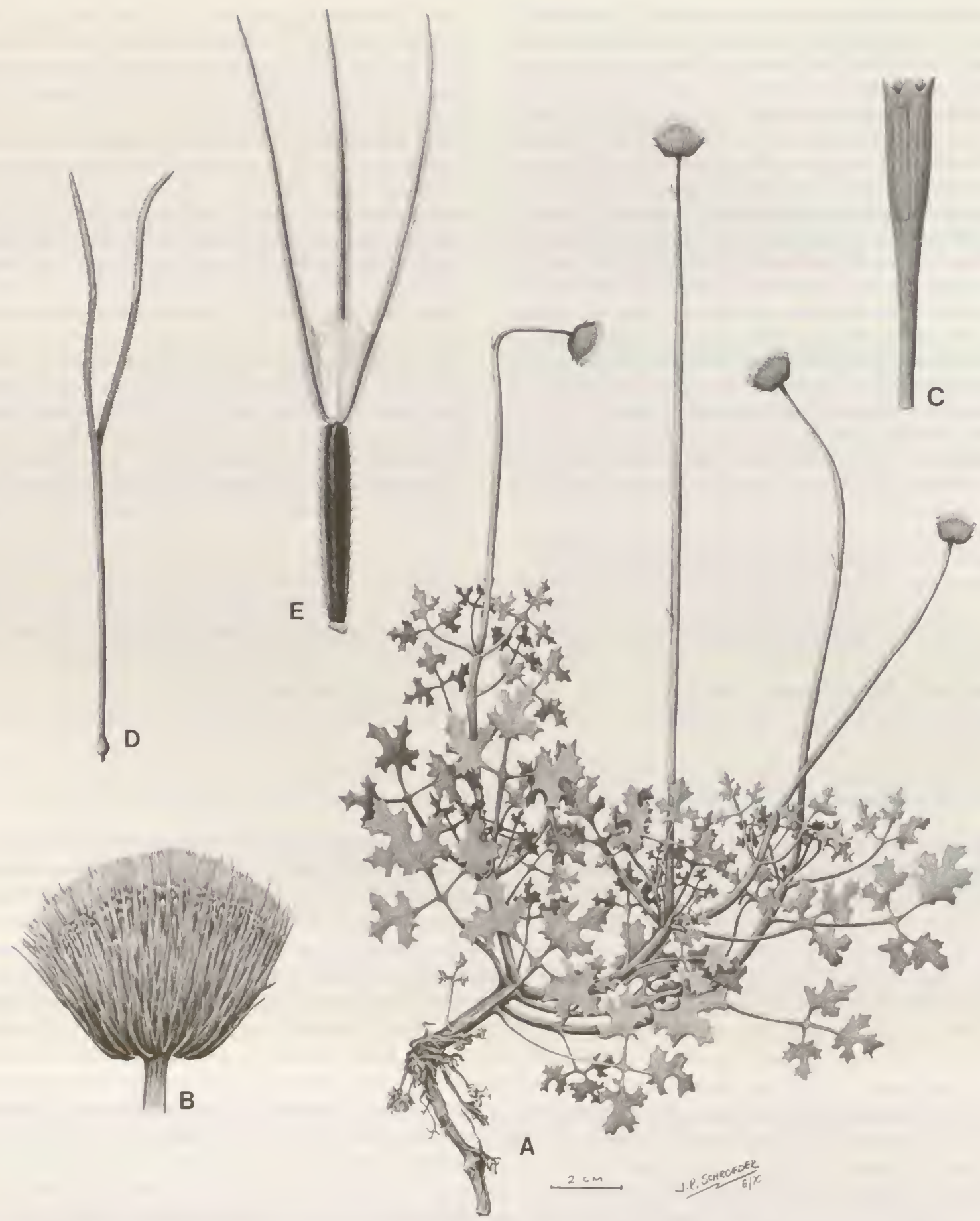

Plate 178. Hofmeisteria fasciculata (Benth.) Walp. - A. Habit, $\times 5 / \% .-$ B. Head, $\times 3 \frac{13}{3} .-$ C. Corolla showing anthers, $\times 12 .-$ D. Style, $\times 12 .-$ E. Achene, $\times 12$.

brous corollas, the shortly stopper-shaped carpopodia with tiered and ranked broadly oblong cells, and the unique minutely spinulose pollen that appears nearly smooth. The genus should have presented no problems to taxonomists.
In two respects, the genus was treated properly in older treatments. As a result of the comparatively few bristles in the pappus, none of the species have been placed in the broad concept of Eupatorium. Also, Bentham (1844), who first recognized the group at generic level, mentioned 
two possible congeners, Phania? urenifolia and Phania? dissecta, representing much of the presently recognized diversity of the genus. Unfortunately, the very natural and distinctive genus Hofmeisteria shows variation in two of its structures, the pappus and the anther appendage, and these two structures were used to define genera in the later traditional systems of classification (Bentham \& Hooker, 1873; B. Robinson, 1913a). At the time the present series of studies began, the species of Hofmeisteria were distributed among three genera, and members of two other genera were placed in Hofmeisteria.

The traditional concept of Hofimeisteria came to be based on the pappus having alternate squamellae and bristles. Foreign elements included in the genus on this basis were the genus Pleurocoronis, and sometimes the genus $\mathrm{Mal}$ peria, both of the subtribe Alomiinae. The latter differ in essential details of habit, corolla pubescence, achene and carpopodium form, and pollen surface, and were excluded by King and Robinson (1966). Species of Hofmeisteria excluded in the traditional classification were two types lacking squamellae in the pappus. Two species, $H$. standleyi and $H$. urenifolia, have only five bristles in the pappus and were placed on that basis in the traditional concept of Fleischmannia. Phania? dissecta, with more bristles in the pappus and a short anther appendage, was placed in a separate genus Podophania. These three non-squamellabearing species were placed in Hofmeisteria by King and Robinson (1966). It seems notable that a second species with a short anther appendage, $H$. sinaloensis, was already placed in Hofmeisteria.

The members of the genus Hofmeisteria are known only from Mexico, mostly in the western part, especially around the Gulf of California. A few specimens have been recorded from as far east as Chiapas. The most frequently cited habitats are on or among rocks, or in crevices on cliffs, usually near streams or seepage. A number of the more xeric and exposed species, including the type, are rather succulent. The two groups, including $H$. standleyi and $H$. urenifolia with five bristles in the pappus, and $H$. dissecta and $H$. sinaloensis with short anther appendages. have thinner leaves and apparently occur in more shaded habitats.

The genus Hofmeisteria was redelimited by King and Robinson (1966) and was monographed and a key provided by $R$. King (1967c).

The generic name is said by Walpers (1846-1847) to honor Fr. Hofmeister, bibliopolae Lipsiensis viri de re herbaria meritissimi. This is evidently Wilhelm Friedrich Benedict Hofmeister, 1824-1877 of Leipzig.

The following eight species are recognized in the genus:

Hofmeisleria crassifolia S. Watson, Mexico.

Hofmeisteria dissecta (Hook. \& Arn.) R. King \& H. Robinson, Mexico.

Hofmeisteria fasciculala (Benth.) Walp., Mexico.

Hofmeisteria filifolia I. M. Johnston, Mexico.

Hofmeisteria schaffneri (A. Gray) R. King \& H. Robinson, Mexico.

Hofmeisteria sinaloensis H. Gentry. Mexico.

Hofmeisteria standleyi (S. F. Blake) R. King \& H. Robinson, Mexico.

Hofmeisleria urenifolia (Hook. \& Arn.) Walp., Mexico.

\section{Subtribe XVIII. OAXacaniInaE}

Oaxacaniinae R. King \& H. Robinson, Phytologia 46: 449. 1980. TYPE: Oaxacania B. Robinson \& Greenman.

Sprawling subshrubs or shrubs, moderately to densely branched, not rosulate. Leaves alternate, distinctly petiolate; blades palmate, cleft with 3-7 oblong lobes, viscid with minutely stipitate or sessile glands. Inflorescences with solitary heads on long erect peduncles or a laxly branching leafy cyme with few heads; involucres broadly campanulate; bracts strongly subimbricate, in ca. 5 strongly unequal graduated series, appressed, mostly persistent, with innermost somewhat deciduous, with 4 broad costae, fringed at tip; receptacle slightly convex, with well-developed paleae, paleae with florets easily deciduous. Flowers $50-100$ in a head; corollas white, narrowly funnelform with narrow basal tube, stipitate-glandular or glabrous on outer surface; cells of throat elongate with sinuous lateral walls; lobes triangular, slightly to distinctly longer than wide, smooth on both surfaces or somewhat papillose on inner surface, outer surface without stomata; anther collar narrowly cylindrical, poorly differentiated or with numerous subquadrate cells below, cell walls without ornate thickenings on walls; anther appendage large, as long as wide to twice as long as wide; style base with enlarged cone or annulus, glabrous; style appendages either narrowly linear and papillose or filiform with distinct broadened and thickened smooth tip. Achenes prismatic or compressed, with 2 or 5 ribs, micropunctations of achene walls not strongly aligned in transverse bands; carpopodium distinct with slight upper rim, symmetrical, shortly stopper-shaped, with small cells in ranks and tiers, cell walls somewhat thick-walled; pappus obsolete or a short laciniate crown, or with one long bristle, persistent, with apical cells rounded to acute. Basic chromosome number $x=18$. 
The subtribe Oaxacaniinae has a number of features that can serve as the basis for interesting speculation. The subtribe consists of two unquestionably related although very different genera, each with a very localized distribution in widely separated xeric parts of Mexico. The obvious impression is of a relictual group of some age. The opportunities for speculation are increased by the characteristic paleaceous receptacles in both genera, and the reduced form of pappus that is found in each. It is notable that one of the genera, Oaxacania, also has a compressed achene, one of two genera in the Eupatorieae with this form. The Oaxacaniinae are at least a remarkable parallelism of the tribe Heliantheae. The opposite-leaved condition that seems basic to most members of both the Eupatorieae and the Heliantheae, however, is not found in the Oaxacaniinae. Also, there can be no doubt that the Oaxacaniinae is a totally characteristic member of the tribe Eupatorieae, with probable closest relationship to the preceding subtribe, Hofmeisteriinae.

The subtribe Oaxacaniinae has the general habit and many structural details as in the Hofmeisteriinae, including alternate leaves with lobed or dissected blades, a tendency for solitary heads on erect peduncles, and strongly subimbricate involucral bracts. Neither subtribe shows the glandular punctations that are widely distributed elsewhere in the Asteraceae, but both have small glandular hairs that are subsessile to stipitate. Both subtribes have similar stopper-shaped carpopodia. These features support the idea of close relationship between the two groups. The Oaxacaniinae is thoroughly distinct, however, in the presence of paleae on the receptacle, the enlargement at the base of the style, and the pollen surface with larger less numerous spinules. Also, the corollas of the Oaxacaniinae are more funnelform.

A more remote relationship of the Oaxacaniinae may be to the subtribes Ayapaninae and Alominae. The style appendage of Carterothamnus has a broadened and thickened fusiform tip, similar to that in Gongrostylus of the Ayapaninae. Style branches that are thickened as well as broadened seem to be characteristic of the Alomiinae, the close relative of the subtribe Ayapaninae. The Oaxacaniinae also has an enlarged style base, a feature found in many Ayapaninae and Alomiinae. Still, the stylar enlargement in the Oaxacaniinae is more conical with a rim of more differentiated cells, and the cell walls of the anther collars do not have the annulations characteristic of the latter subtribes.

The paleae of the Oaxacaniinae are of particular interest. Although various other Eupatorieae have paleae, those paleae are of a comparatively superficial type easily dismissed as secondarily derived from epaleaceous ancestors. In the Oaxacaniinae, the paleae seem to enclose the florets at the base, and the two structures are usually extracted as a unit. Such paleae are the only ones in the tribe that seem possibly primitive in form.

Considering the generally close relationship, the two genera of the Oaxacaniinae, Oaxacania and Carterothamnus differ in a number of significant features. The contrasts in form of the achenes, papillosity of the inner surface of the corolla lobes and style, and the shape of the style tips seem particularly striking. The pollen is also remarkably different in size, although pollen of the Oaxacania size has been seen adherent to the styles of Carterothamnus (King \& Robinson, 1970e). There prove to be many other Eupatorieae with the same large size, however.

Oaxacania and Carterothammus are both restricted to Mexico, but the genera are separated within that country by a distance of over $2,000 \mathrm{~km}$. Each of the genera is known from only a small area, and both seem to be restricted to rather vertical rock faces where collecting is difficult.

Chemistry has been studied only in Carterothamnus.

\section{KEY TO THE GENERA OF THE SUBTRIBE OAXACANIINAE}

1. Achene flattened; pappus obsolete or with a short laciniate crown; corolla tube with numerous stalked glands on outer surface; style branches thin with scarcely enlarged tips 179. Oaxacania

1'. Achene prismatic; pappus of numerous scales and one long bristle; corolla glabrous on outer surface; style branches strongly clavate 180. Carterothamnus

\section{Oaxacania}

Oaxacania B. Robinson \& Greenman, Amer. J. Sci., Ser. 3, 50: 151. 1895. TYPE: Oaxacania malvaefolia B. Robinson \& Greenman.

Sprawling subshrubs or shrubs, moderately to densely branched. Stems terete, striated, covered with long, minutely gland-tipped hairs. Leaves alternate, petiole distinct, moderately long; blade herbaceous, orbicular to reniform, 3-7 cleft to two-thirds or more toward base, lobes oblong, trinervate at base, surfaces with numerous stipitate minutely tipped glands. Inflorescence terminal on leafy branches, laxly cymose; peduncles moderately long, hirsute with stipitate glands; heads broadly campanulate. Involucral bracts ca. 30-40, 

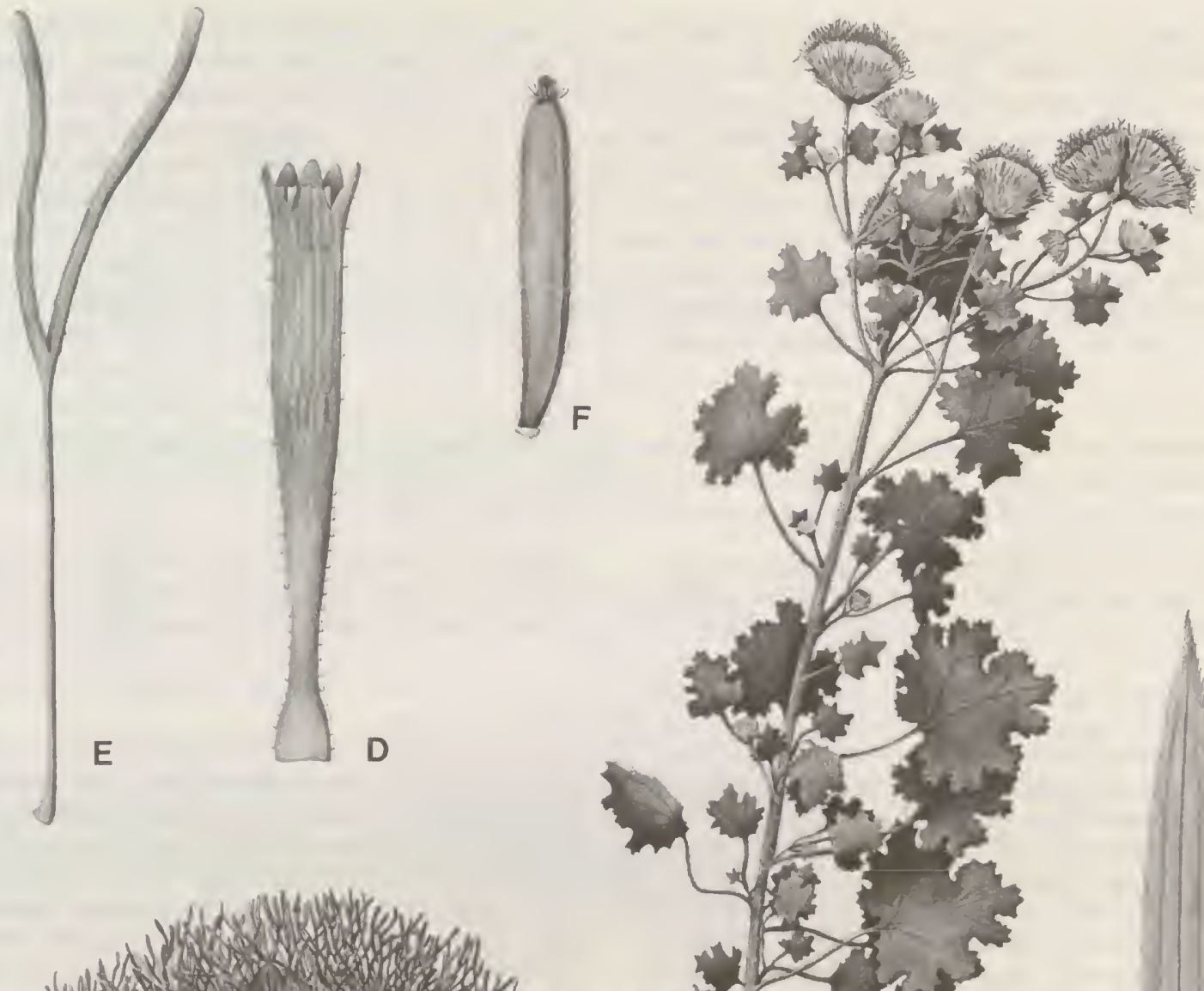

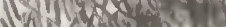

Inturing

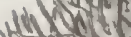

was 0

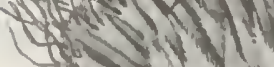

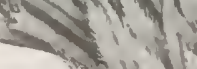

है

11

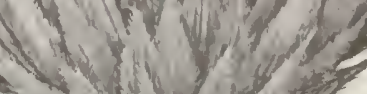

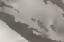
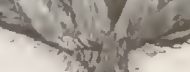

in

B
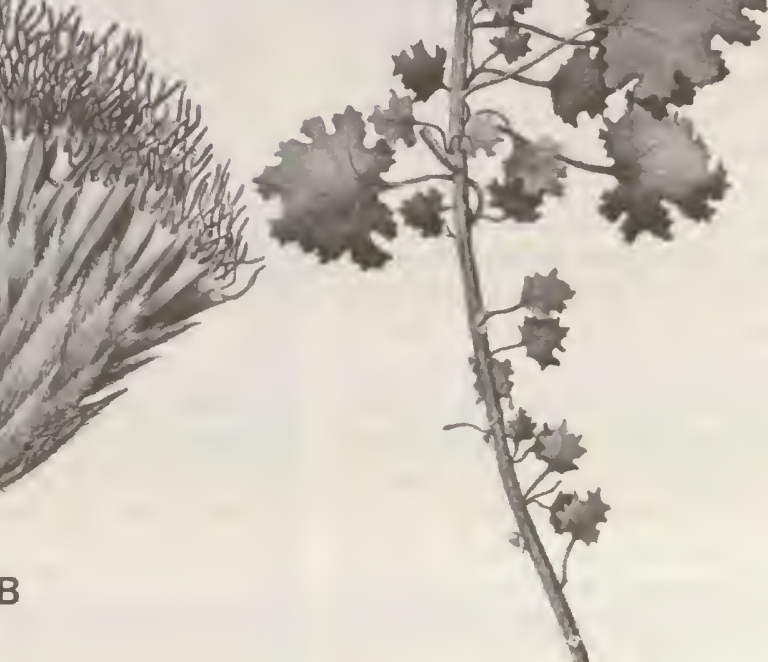

C

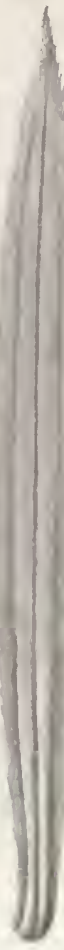

\section{A}

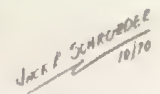

Plate 179. Oaxacania malvaefolia B. Robinson \& Greenman. - A. Habil, $\times 3 / 5 .-$ B. Head, $\times 4$. - C. Palea, $\times 15 .-$ D. Corolla showing anthers, $\times 12 .-E$. Style, $\times 12 .-F$. Achene, $\times 10$. 
subimbricate, in ca. 4-6 strongly unequal graduated series, appressed, mostly persistent, inner bracts somewhat deciduous, apices narrowly acuminate and densely fringed, outer surface with 4 costae; receptacle slightly convex, paleaceous; paleae deciduous, linear-lanceolate, with single floret partially enclosed by base of each palea. Florets ca. 100 in a head; corollas white, narrowly funnelform, with basal tube long and slender with enlarged base and apex, outer surface of tube with numerous stipitate glands, a few smaller stipitate glands distally on limb; cells of throat elongate with sinuous lateral walls; lobes triangular-oblong, ca. 1.5 times as long as wide, papillose on inner surface, smooth and somewhat thickened on outer surface; anther collar long-cylindrical, with numerous subquadrate or shorter cells in basal half, oblong above, cell walls somewhat thickened without distinct ornamentation; anther appendage large, ovate, ca. 2.5 times as long as wide, rounded to truncate at tip; style base enlarged, conical, truncate below against nectary, with retrorsely projecting rim of marginal cells, glabrous; style appendages narrowly linear, densely long-papillose. Achenes compressed, linear-oblong, with 2 ribs or 2 pairs of ribs, with slender base, blunt-tipped setulae on ribs; carpopodium distinct, with slight upper rim, symmetrical, shortly stopper-shaped, composed of short-oblong cells in ranks and in ca. 5 tiers, cell walls moderately thickened; pappus obsolete or a short laciniate crown, apical cells of segments blunt. Pollen grains ca. $25 \mu \mathrm{m}$ in diameter. Plate 179.

The genus Oaxacania is distinctive in its alternate petiolate leaves with palmately lobed blades, its stipitate glandular pubescence, its flattened achenes, and its obsolete pappus, the characters emphasized by B. Robinson and Greenman (1895) when they compared the genus with the broad traditional concept of Alomia. The paleae of the receptacle were also noted by those authors, but were not considered different from paleae in other members of the Eupatorieae. There was no appreciation of the extremely isolated position of Oaxacania in the Eupatorieae.

The only reasonably close relative of Oaxacania seems to be the comparatively recently described Carterothamnus of southern Baja California. The latter genus has a similar phyllotaxy and leaf form, and also has elongate peduncles, subimbricate involucres, paleaceous receptacles, and a reduced pappus. Nevertheless, the two genera differ in a number of important characters. Carterothamnus has subsessile rather than long-stipitate glands, the peduncles are completely solitary, the involucral bracts have blunt apices, the corollas are glabrous on the outer surface, the inner surfaces of the corolla lobes are not papillose, the style appendages are nearly smooth with greatly enlarged nodular apices, the achenes are not flattened, and the pappus retains distinct squamellae and a single long bristle. It is considered significant that the closest relative of Oaxacania is itself so different.

The paleae of the receptacle in Oaxacania and Carterothamnus are the most important feature on which the subtribe is based. They seem to have a more basic struc- ture than the various other paleae found in the Eupatorieae, and they are more closely associated with the adjacent flowers. The paleae and florets seem to detach from the receptacle as a unit. This is most strongly developed in Oaxacania, where the base of the palea somewhat encloses the achene.

The achene of Oaxacania is one of the two examples in the Eupatorieae that is compressed. The compression in Oaxacania is incomplete, with two ribs surviving along each margin. The other genus of the Eupatorieae with compressed achenes, Macvaughiella (= Schaetzellia Schultz-Bip.), is a member of the subtribe Ageratinae, apparently near Stevia, having an eximbricate subequal involucre, comparatively few-flowered heads, no paleae, two-ribbed achenes, and a two-bristled pappus.

The pappus in Oaxacania is reduced to a small fringe of setulae that closely resemble those along the ribs of the achene. Such setulae do not necessarily represent a true pappus, and the achenes are probably best regarded as epappose.

The genus Oaxacania appears to be restricted to steep rocks or cliffs in northern Oaxaca and immediately adjacent southern Puebla, in eastcentral Mexico. The type locality in Tomellin Canyon is recorded as 3,000 ft. in elevation. The generic name refers to the state of Oaxaca from which the plant was originally described.

The following single species is recognized in the genus: Oaxacania malvaefolia B. Robinson \& Greenman, Mexico.

\section{Carterothamnus}

\section{Carterothamnus R. King, Rhodora 69: 45. 1967. TYPE: Carterothamnus anomalochaeta R. King.}

Sprawling to pendent subshrubs or shrubs, moderately to densely branched. Stems terete, striated, with minute subsessile glandular hairs in younger parts. Leaves alternate, petioles distinct, moderately long; blades subcoriaceous, broadly 3-7 cleft two-thirds or more to base, lobes oblong, often narrow, trinervate at base, surfaces smooth with minute essentially sessile glandular dots releasing viscid fluid on surfaces when mature. 

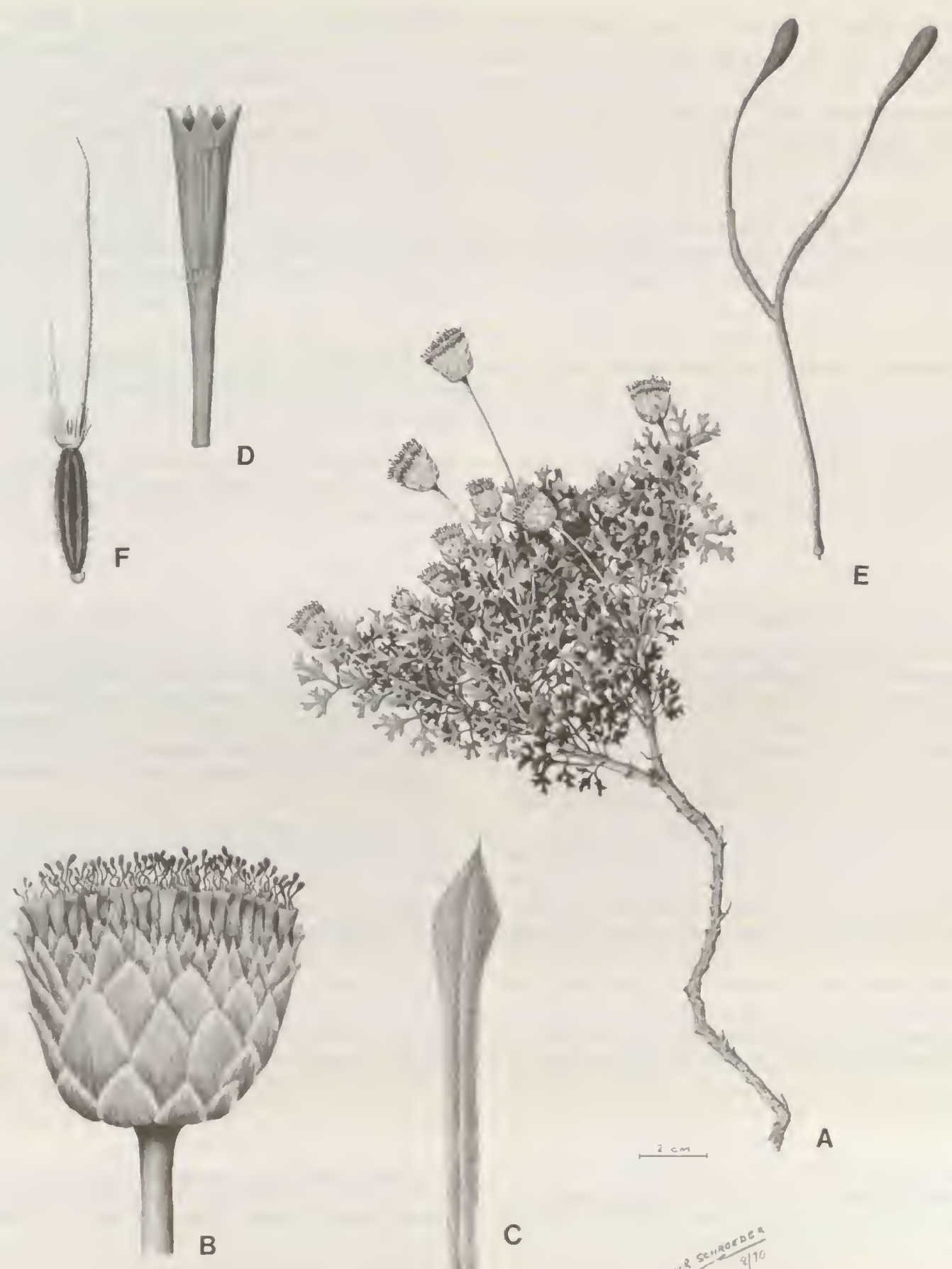
Inflorescences terminal on leafy shoots, heads solitary on moderately long erect peduncles; heads broadly campanulate. Involucral bracts ca. 30-40, subimbricate, in 4-6 strongly unequal graduated series, appressed, mostly persistent, inner bracts somewhat deciduous, apices obtuse and fringed, outer surface with 4 costae; receptacle convex with slight central depression, paleaceous; paleae deciduous, linear with slightly broadened fringed tips, basally appressed to and usually extracted with florets. Florets ca. 50 in a head; corollas white, narrowly funnelform with slender basal tube enlarged slightly at base and apex, glabrous on both surfaces; cells of throat elongate with sinuous lateral walls; lobes triangular, slightly longer than wide, with large slightly bulging cells on inner surface, smooth and somewhat thickened on outer surface; anther collar cylindrical, poorly differentiated, cell walls not sclerified or ornamented; anther appendage large, as wide as long, truncated to somewhat retuse; style base enlarged in small node, with girdle of large firm-walled cells in ca. 2 series, glabrous; style appendages slender and scarcely mamillose below, with large smooth fusiform broadened and thickened apex. Achenes prismatic, 5-ribbed, with setulae on ribs; carpopodium distinct, with slight upper rim, symmetrical, shortly stopper-shaped, with many tiers of ranked shortly subquadrate cells, cell walls thickened; pappus of ca. 10-12 narrow short squamellae and with 1 long barbed bristle with a bent or contorted tip, apical cells acute. Pollen grains ca. 13-15 $\mu \mathrm{m}$ in diameter. Plate 180.

As suggested to the authors years ago by J. Rzedowski of Instituto Politécnico Nacional in Mexico (pers. comm.), Carterothamnus is evidently related to Oaxacania. Both genera have alternate petiolate leaves with palmately lobed blades, long peduncles, subimbricate apically fringed involucral bracts, paleaceous receptacles, corolla lobes with smooth thickened outer surfaces, a basal node on the style, and an obsolete or reduced pappus. Carterothamnus differs by its glands not being obviously stipitate, its peduncles being solitary, its involucral bracts having blunt apices, its corollas being glabrous, its corolla lobes not being papillose inside, its stylar node being less conical with a more differentiated band of outer cells, its stylar appendages non-papillose with greatly enlarged tips, and its pappus having squamellae and a long bristle.

At the time of its description (R. King, 1967a), the relationship of Carterothamnus to Oaxacania was not suspected. The obvious comparison was with Hofmeisteria which is common in the same area of Baja California where Carterothamnus grows. Hofmeisteria also has alternate leaves with lobed or dissected blades, lacks true glandular punctations, has solitary heads on erect peduncles, has subimbricate involucres, and has glabrous corollas. Hofmeisteria is undoubtedly related to Carterothamnus, but is placed here in a separate subtribe, outside of the Carterothamnus-Oaxacania relationship, primarily because of the lack of paleae on the receptacle, the lack of a basal stylar node, and the scarcely spinulose surface on the pollen grains.

The glands of Carterothamnus are similar to those of Oaxacania in having small tips, but they have short rather than long stalks, being nearly sessile. The glands seem to quickly degenerate, leaving a viscid fluid on the stem and leaf surfaces. The fluid apparently contains labdane derivatives (Bohlmann et al., 1979a). The lack of true large capitate glandular punctations seems to be reflected in the lack of sesquiterpene lactones.

The anther collar of Carterothamnus seems to be unsclerified, and the cell structure is difficult to determine. An area of shorter cells does seem to be present, however. Sclerified walls may be present in some specimens.

The pollen in Carterothaminus is the smallest in the Eupatorieae. The contrast between the pollen and the much larger type in Oaxacania was noted by King and Robinson (1970e).

The chromosome report of $n=18$ has been furnished by A. M. Powell (pers. comm.). The one count, correlated with a few similar counts in Hofmeisteria, suggests that such numbers are basic in both of the related subtribes.

Carterothamnus is known only from various Arroyos and vertical cliffs in the Sierra de la Giganta in southern Baja California, Mexico. The elevations given are between $375-780 \mathrm{~m}$. One specimen is recorded as growing at the point of contact of grayish tuff with the uppermost stratum of black conglomerate (?).

The generic name honors Annetta Carter, botanist at the University of California at Berkeley. Dr. Carter was the collector of the type specimen.

The following single species is recognized in the genus: Carterothamnus anomalochaeta R. King, Baja California. 


\section{Literature Cited}

Aaron, I. 1974. The Blazing Star Prairies of Western Pennsylvania. Butler, Pennsylvania.

ADAMS, C. D. 1971. Miscellaneous additions and revisions to the flowering plants of Jamaica, 1II. Phytologia 21: 405-410.

Alain, H. 1960. Novedades en la flora Cubana, XII. Contr. Ocas. Mus. Hist. Nat. Colegio "De La Salle" 18: 1-16.

Alvarado, S., J. F. Ciccio, J. Calzada, V. Zabel \& W. H. WATSON. 1979. Thieleanine, a new guaianolide from Decachaeta thieleana. Phytochemistry 18: 330.

Aristeguieta, L. 1964. Compositae. In Flora de Venezuela 10: 91-243 (Eupatorieae), 523, 525-531 (Isocarpha and Lepidesmia).

Arruda da Camara, M. 1810. Discurso Sobre Utilidade da Instituicâo de Jardins nas Principaes Provincias do Brazil. Rio de Janeiro.

Atkinson, R. E. \& R. F. Curtis. 1971. A thiophen from Liatris pycnostachya. Phytochemistry 10: 454-455.

BAdillo, V. M. 1943. Dos nuevas compuestas de Venezuela. Bol. Soc. Venez. Ci. Nat. 8: 237-239.

- $1944 a$ Compuestas venezolanas notables o nuevas. Bol. Soc. Venez. Ci. Nat. 9: 131-137.

- 1944b. Tamayoa, genero nuevo de las compuestas (Asteraceae). Bol. Soc. Venez. Ci. Nat. 9: 139-140.

- 1946. Contribucion al conocimiento de la sistematica y distribucion geografica de las compuestas en Venezuela. Bol. Soc. Venez. Ci. Nat. 10: 279-320.

- 1962. Mikania araguensis, una nueva compuesta del parque nacional de Rancho Grande. Noved. Ci., Ser. Bot. 2: $1-4$.

- 1976. Novedades venezolanas en Asteraceae (Compositae). Bol. Soc. Venez, Ci. Nat. 22: 35-41.

- 1978. Tres Compuestas de Venezuela. Acta Bot. Venez. 13: $109-115$.

-1981. Mikania solidinervia sp. nov. y Vernonia karstenii Sch. Bipp. [sic] nuevas en Venezuela. Ernstia 7: 20 24.

- 1982. Una nueva combinación en Crilonia (Compositac). Ernstia 10: 10-12.

—_ 1985. Dos nuevos Compuestas del sur de Venezuela. Ernstia 30: 1-3.

BAKER, H. G. 1967. The evolution of weedy taxa in the $E u$ patorium microstemon species aggregate. Taxon 16: 293300.

BAKER, J. G. 1876. Compositae 1I. Eupatoriaceae. In C. Martius, Fl. Bras. 6(2): 181-374, pl. 51-102.

BAKER, M. M. \& B. L. TURner. 1986. Taxonomy of Flyriella (Asteraceae-Eupatorieae). SIDA 11: 300-317.

Barroso, G. M. 1949. Praxeliopsis-Um novo gênero de Compositae. Arq. Jard. Bot. Rio de Janeiro 9: 175-178.

- 1950. Consideraçōes sôbre o gênero Eupatorium. Arq. Jard. Bot. Rio de Janeiro 10: 13-116, pl. 1, 2, foto 1-19.

-1951. Estudos das espécies brasileiras de "Trichogonia" Gardn. Arq. Jard. Bot. Rio de Janeiro 11: 7-18, pl. 1-13.

-1957. Compositae-O gênero Stylotrichium Mattfeld. Arq. Jard. Bot. Rio de Janeiro 15: 23-25.

- 1958. Mikaniae do Brasil. Arq. Jard. Bot. Rio de Janeiro 16: 239-333, pl. 1-31, foto 1-57.

83.
1969. Novitates compositarum, 11. Loefgrenia 36: 13, foto $1-6$

- \& R. M. KING. 1971. New taxa of Compositac (Eupatorieae) from Brazil. Brittonia 23: 118-121.

Bartram, W. 1791. Travels through North and South Carolina. James and Johnson, Philadelphia.

BeNTHAM, G. 1844. The Botany of the Voyage of H.M.S. Sulphur. Smith, Elder \& Co., London.

- 1873. Notes on the classification, history, and geographical distribution of Compositae. J. Linn. Soc., Bot. 13: 335-577.

— \& J. D. Hooker. 1873. Genera Plantarum. 2: 1-554. Lovell Reeve \& Co., London.

BLAKE, S. F. 1924. New American Asteraceae. Contr. U.S. Natl. Herb. 22(8): 587-661, pl. 54-63.

- 1926. 157. Asteraceae. Aster Family. In P. C. Standley, Trees and Shrubs of Mexico. Contr. U.S. Natl. Herb. 23: 1418-1432 (3. Piqueria-15. Piptothrix), 1470-1484 (18. Mikania-21. Dyscritolhamnus).

- 1938. Eleven new American Asteraceae. J. Wash. Acad. Sci. 28: $478-492$.

- 1941. Note on the name Eupatorium rugosum. Rhodora 43: 557-558.

- 1943. Ten new American Asteraceac. J. Wash. Acad. Sci. 33: $265-272$.

- 1958. Two new genera of Compositae from Peru and Costa Rica. J. Wash. Acad. Sci. 47: 407-410.

Bohlmann, F. \& L. N. DutTA. 1979. Neue Germacranolide aus Liatris cylindracea. Phytochemistry 18: 847-850.

- \& L. FIEDLER. 1978. Neue Nerolidol-Derivate aus Ageratina aschenbornia. Phytochemistry 17: 566-567.

- \& M. Grenz. 1977. Über neue Inhaltsstoffe aus Vertretern der Eupalorium-Gruppe. Chem. Ber. 110:1321-1329.

\& R. K. GuptA. 1981. Six cadinene derivatives from Ageratina adenophora. Phytochemistry 20: 1432-1433.

- \& C. ZDERo. 1975. Uber neue Sesquiterpene aus Polypteris texana (DC.) A. Gray. Chem. Ber. 108: 3543-3549. - \& - 1976. Über Inhaltsstoffe der Gattung Brickellia. Chem. Ber. 109: 1436-1445.

—, T. BURKHARDT \& C. ZDERO. 1973. Naturally Occurring Acetylenes. Academic Press, London and New York.

- - C. ZDERo, R. M. King \& H. ROBinson. 1977a. A new Ageratone derivative from Isocarpha oppositifolia. Phytochemistry 16: 768.

- J. Jakupovic \& M. Lonitz. 1977b. Über lnhaltsstoffe der Eupatorium-Gruppe. Chem. Ber. 110: 301-314.

- C. Zdero, R. M. King \& H. Robinson. 1979a. Neue Labdan-Derivate aus Canterothamnus anomalochaeta. Phytochemistry 18: 621-624.

- L. N. DUtTA, W. DORNer, R. M. King \& H. Robinson. 1979b. Zwei neue Guajanolide sowie weitere Longipinenester aus Stevia-Arten. Phytochemistry 18: 673-675.

- C. Zdero, R. M. King \& H. Robinson. 1979c. Neue Cadinen-Derivate und Andere Inhaltsstoffe aus Chromolaena-Arten. Phytochenistry 18: 1177-1179.

$\longrightarrow$ - $\longrightarrow$ \& $\longrightarrow$. 1979d. Ein neues LabdanDerivate und neue Thymol-derivate aus Bishovia boliviensis. Phytochemistry 18: 1234-1235.

- A. Suwita, H. Robinson \& R. M. King. 1979e. Ein 
neues Toxol-derivate aus Austrobrickellia patens. Phytochemistry 18: 2055.

,-- R. M. King \& H. Robinson. 1980a. Neue entlabdan-derivate aus Austroeupatorium chaparense. Phytochemistry 19: 111-114.

- L. DUtTA \& K. KERR. 1980b. Sesquiterpenlactone aus Oxylobus oaxacanus. Phytochemistry 19: 691-692.

- E. Rosenberg, R. M. King \& H. Robinson. $1980 \mathrm{c}$. Neue Labdan-Derivate aus Aristeguietia buddleaefolia. Phytochemistry 19: 977-979.

- A. Suwita, R. M. King \& H. Robinson. 1980d. Neue Guajanolide aus Eupatorium rotundifolium. Phytochemistry 19: 1233-1234.

- C. Zdero, R. M. KING \& H. Robinson. 1980e. New heliangolides from Conocliniopsis prasiifolia. Phytochemistry 19: 1547-1549.

$\longrightarrow,-$ H. Robinson \& R. M. KING. 1980f. Guaianolides from Agrianthus pungens. Phytochemistry 19: 18731874.

$\longrightarrow,-$, R. K. GuptA, R. M. King \& H. Robinson. $1980 \mathrm{~g}$. Diterpenes and tetranorditerpenes from Acritopappus species. Phytochemistry 19: 2695-2705.

- R. K. GuptA, R. M. KiNG \& H. Robinson. 1981a. A clerodane lactone and a tremetone derivative from Bahianthus viscidus. Phytochemistry 20: 331-332.

- J. JAKuponic, A. K. DhAR, R. M. King \& H. RoBinson. 1981b. Heliangolides and diterpenes from Hartwrightia floridana. Phytochemistry 20: 843-845.

$\longrightarrow$, C. ZDERO, R. M. King \& H. ROBinson. 1981c. Germacranolides, a guaianolide with a $\beta$-lactone ring and further constituents from Grazielia species. Phytochemistry 20: 10691075.

- A. K. DhaR, J. JaKupovic, R. M. King \& H. Robinson. 1981d. Two sesquiterpene lactones with an additional propiolactone ring from Disynaphia halimifolia. Phytochemistry 20: 1077-1080.

-, C. Zdero, L. Fiedler, H. Robinson \& R. M. King. 1981e. A labdane derivative from Chromolaena collina and a p-hydroxyacetophenone derivative from Stomatanthes corumbensis. Phytochemistry 20: 1141-1143.

—, A. K. DAHR, R. M. King \& H. RoBinson. 1981f. A guaianolide from Guevaria sodiroi. Phytochemistry 20: 1144 1145.

$\longrightarrow$, C. Zdero, J. Pickard, H. Robinson \& R. M. King. 1981g. New types of sesquiterpene lactones and other constituents from Trichogonia species. Phytochemistry 20: 13231333.

$\longrightarrow$, R. K. Gupta, R. M. King \& H. RoBinson. $1981 h$. Prostaglandin-like fatty acid derivative from Chromolaena morii. Phytochemistry 20: 1417-1418.

-, A. K. DhaR, J. JAKupovic, R. M. King \& H. Robinson, 1981 i. A caryophyllene derivative from Fleischmannia pycnocephaloides. Phytochemistry 20: 1425-1426.

- M. Ahmed, H. Robinson \& R. M. King. 1981j. A kolavane derivative from Liatris scariosa. Phytochemistry 20: 1439-1440.

- J. JAKupovic, R. M. King \& H. Robinson. 1981k. New germacranolides, guaianolides and rearranged guaianolides from Lasiolaena santosii. Phytochemistry 20: 1613-1622.

- W. Abraham, H. Robinson \& R. M. King. 1981l. Heliangolides and other constituents from Bejaranoa semistriata. Phytochemistry 20: 1639-1642.

- C. ZDERO, R. M. KING \& H. ROBINSON. $1981 \mathrm{~m}$. Thir- teen kolavane derivatives from Symphyopappus species. Phytochemistry 20: 1657-1663.

— A. Suwita, H. Robinson \& R. M. King. 1981n. Six guaianolides from Stylotrichium rotundifolium. Phytochemistry 20: 1887-1890.

—, A. Adler, A. Schuster, R. K. Gupta, R. M. King \& H. Robinson. 1981o. Diterpenes from Mikania species. Phytochemistry 20: 1899-1902.

—, W.-R. Abraham, R. M. King \& H. Robinson. 1981 p. New diterpenes from Koanophyllon species. Phytochemistry 20: 1903-1906.

- W. Kramp, R. K. Gupta, R. M. King \& H. Robinson. 1981q. Four guaianolides and other constituents from three Kaunia species. Phytochemistry 20: 2375-2378.

- , N. BORTHAKUR, R. M. KING \& H. Robinson. $1982 a$. Further prostaglandin-like fatty acids from Chromolaena morii. Phytochemistry 21: 125-127.

- C. ZDERO, R. M. KING \& H. RoBinson. 1982b. Humulene derivatives from Acritopappus prunifolius. Phytochemistry $21: 147-150$.

- J. Jakupovic, A. Schuster, R. M. King \& H. Robinson. 1982c. Guaianolides and homoditerpenes from Lasiolaena morii. Phytochemistry 21: 161-165.

- A. Adler, R. M. King \& H. Robinson. 1982d. Entlabdanes from Mikania alvimii. Phytochemistry 21: 173176.

—, M. BAPUj, R. M. King \& H. Robinson. 1982e. Unusual diterpenes from Brickellia eupatorioides. Phytochemistry $21: 181-186$.

- P. Singh, J. Jakupovic, R. M. King \& H. Robinson. 1982f. Three cadinene derivatives and a prostaglandin-like acid from Chromolaena species. Phytochemistry 21: 371374.

- C. Zdero, H. Robinson \& R. M. King. 1982g. Labdane derivatives from Planaltoa lychnophoroides. Phytochemistry 21: 465-467.

- , P. Singh, J. Jakupovic, H. Robinson \& R. M. King. 1982h. An epoxygermacranolide and further constituents from Mikania species. Phytochemistry 21: 705-707.

- - M. Bapuji, R. M. King \& H. Robinson. 1982i. New kolavenol derivatives from Goyazianthus tetrastichus. Phytochemistry 21: 939-941.

- A. Adler, R. M. King \& H. Robinson. 1982j. Germacranolides from Mikania grazielae. Phytochemistry 21: 1169-1170.

- - - J. JAKupovic, R. M. KING \& H. Robinson. 1982k. A dimeric germacranolide and other sesquiterpene lactones from Mikania species. Phytochemistry 21: 13491355.

- C. Zdero, R. M. King \& H. RoBinson. 1984. A new hydroxygermacrene and other constituents from Pseudobrickellia pinnifolia. Phytochemistry 23: 1798-1799.

Bolick, M. R. 1977. Observations on style branch exposure in Eupatorium havanense H.B.K. (Eupatoricae-Compositae). Taxon 26: 239-240.

Borhidi, A. 1983. New names and new species in the flora of Cuba and Antilles, 1Il. Acta Bot. Acad. Sci. Hung. 29: 181215.

— \& O. Muñız. 1971. New plants in Cuba 1. Act. Bot. Acad. Sci. Hung. 17: 1-36.

\&-1973. New plants in Cuba II. Act. Bot. Acad. Sci. Hung. 18: 29-48.

Bose, P. K., P. Chakrabarti, S. Chakravarti, S. P. Dutra \& 
A. K. BARUA. 1973. Flavonoid constituents of Eupatorium odoratum. Phytochemistry 12: 667-668.

Boulter, D., J. T. Gleaves, B. G. Haslett, D. Peacock \& U. JENSEN. 1978. The relationships of 8 tribes of the Compositae as suggested by plastocyanin amino acid sequence data. Phytochemistry 7: 1585-1589.

- J. A. M. Ramshaw, E. W. Thompson, M. Richardson \& R. H. BROwN. 1972. A phylogeny of higher plants based on the amino acid sequences of cytochrome $c$ and its biological implications. Proc. Roy. Soc. London, Ser. B, Biol. Sci. 181: 441-455.

Bowers, W. S., T. Ohta, J. S. Cleere \& P. A. Marsella. 1976. Discovery of insect anti-juvenile hormones in plants. Science 193: 542-547.

BRITTEN, J. 1896. Arruda's Brazilian plants. J. Bot. 34: 242250.

Brown, K. S., JR. 1984. Adult-obtained pyrrolizidine alkaloids defend ithomiine butterflies against a spider predator. Nature (London) 309: 707-709.

Brown, R. 1817-1818. Some observations on the natural family of plants called Compositae. Trans. Linn. Soc. London 12: 76-142.

Browne, P. 1756. The Civil and Natural History of Jamaica in Three Parts. London.

Buban1, P. 1900. Flora pyrenaea. 2: 1-718. Milan.

Cabrera, A. L. 1941. Compuestas Bonaerensis. (II. Adenostemma Forst.-V1. Mikania Willd.) Revista Mus. La Plata, Sec. Bot. n.s. 4: 21-49.

1945. Cuatro compuestas nuevas del Peru. Revista Univ. (Cuzco) 33(87): 1 I 7-122.

- 1956. Un nuevo genero de Eupatorieas (Compositae) de Bolivia. Bol. Soc. Argent. Bot. 6: 91-93.

- 1957. El genero Carelia (Compositae). Bol. Soc. Argent. Bot. 6: 239-242.

- 1959a. Compositae Catarinenses novae. Bol. Soc. Argent. Bot. 7: 187-200.

- $1959 \mathrm{~b}$. Notas sobre tipos de compuestas sudamericanas en herbarios europeos, I. Bol. Soc. Argent. Bot. 7: 233-246.

- 1959c. Notas sobre tipos de compuestas sudamericanas en herbarios europeos, II. Bol. Soc. Argent. Bot. 8: 26-35.

—_. 1959d. Ocho compuestas sudamericanas nuevas. Univ. Nac. La Plata, Notas Mus. 19(92): 191-210.

- 1962. Compuestas andinas nuevas. Bol. Soc. Argent. Bot. 10: 21-45.

-1973. Notas sobre tipos de compuestas sudamericanas en herbarios europeos, IV. Bol. Soc. Argent. Bot. 15: 113125.

-1974. Especies nuevas o criticas de la flora Jujeña, VI. Bol. Soc. Argent. Bot. 15: 319-339.

- 1976. Una segunda especie del genera Ascidiogyne (Compositae). Hickenia 1: 1-3.

- 1978. Parte X-Compositae. Pp. 1-726 in Flora de la Provincia de Jujuy. Coleccion Cientifica del Inta, Buenos Aires.

— \& N. VitTET. 1954. Catalogo de las Eupatoricas Argentinas. Revista Mus. Univ. Eva Peron n.s. 8: 179-263.

\& 1 1961. Compositae Catharinensis 1. Vernonieae. Sellowia 13: 143-193.

\& -1963 . Compositae Catharinensis 1I. Eupatorieae. Sellowia 15: 149-258.

CARLQUIST, S. 1965. Wood anatomy of Eupatorieae (Compositae). Aliso 6(1): 89-103.

ㄴ. 1966. Wood anatomy of Compositae: a summary with comments on factors controlling wood evolution. Aliso 6(2): 25-44.

- 1976. Tribal interrelationships and phylogeny of the Asteraceae. Aliso 8(4): 465-492.

Cassini, H, 1812. Extrait d'un premier mémoire de M. Henri Cassini, sur les Synanthérées. Bull. Soc. Philom. Paris 1812: 189-191.

- 1813. Observations sur le style, et le stigmate des Synanthérées. J. Phys. Chim. Hist. Nat. Arts 76: 97-128, 181201, 249-275, pl. 1.

- 1814a. Second mémoire de M. Henri Cassini, sur les Synanthérées. Bull. Soc. Philom. Paris 1814: 9-11, pl. 1, 2.

1814b. Précis d'un secund mémoire sur les Synanthérées. J. Phys. Chim. Hist. Nat. Arts 78: 272-291.

- 1815. Extrait d'un troisième mémoire de M. Henri Cassini, sur le Synanthérées. Bull. Soc. Philom. Paris 1815: $171-175$.

- 1816a. Troisième mémoire sur les Synanthérées, analyse de la corolle. J. Phys. Chim. Hist. Nat. Arts 82: 116146.

- 1816b. Aperçu des genres nouveaux formés par M. Henri Cassini, dans la famille des Synanthérées. Bull. Soc. Philom. Paris 1816: 198-200.

— 1817a. Extrait d'un quatrième mémoire de M. Henri Cassini, sur les Synanthérées. Bull. Soc. Philom. Paris 1817: 115-118.

. 1817b. Quatrième mémoire sur la famille des Synanthérées, contenant l'analyse de l'ovaire et de ses accessoires. J. Phys. Chim. Hist. Nat. Arts 85: 5-21.

- 1817c. Caelestina. In G. Cuvier, Dict. Sci. Nat. 6(suppl.): 8 .

- 1817d. Carphephore. In G. Cuvier, Dict. Sci. Nat. 7: $148-150$.

- 1818a. Cinquième mémoire, sur la famille des Synanthérées, contenant les fondemens de la Synantherographie. J. Phys. Chim. Hist. Nat. Arts 86: 120-129, 173-189.

-18186. Coleosanthus, In G. Cuvier, Dict. Sci. Nat. 10: 36-37.

- 1818c. Composées. In G. Cuvier, Dict. Sci. Nat. 10: $131-159$.

—_. 1818d. Aperçu des genres nouveaux formés par M. Henri Cassini dans la famille des Synanthérées, neuvième fascicule. Bull. Soc. Philom. Paris 1818: 139-142.

- 1819a. Sixième mémoire sur la famille des Synanthérées, contenant les caracteres des tribus. J. Phys. Chim. Hist. Nat. Arts 88: 150-169, 189-204.

- 1819b. Critonia. In G. Cuvier, Dict. Sci. Nat. 12: $1-2$.

- 1820a. Eupatoire. In G. Cuvier, Dict. Sci. Nat. 16: $2-4$.

- 1820b. Eupatorées. In G. Cuvier, Dict. Sci. Nat. 16: 5-8.

. 1820c. Eupatoriées. In G. Cuvier, Dict. Sci. Nat. 16: 9-10.

- 1821a. Gyptide. In G. Cuvier, Dict. Sci. Nat. 20: 177179.

- $1821 \mathrm{~b}$. Hélianthées (with discussion of tribes). In G. Cuvier, Dict. Sci. Nat. 20: 354-385.

- 1822a. 1socarphe. In G. Cuvier, Dict. Sci. Nat. 24: 1820. 520. $1822 b . \quad$ Kuhnie. In G. Cuvier, Dict. Sci. Nat. 24:515- 
1822c. Lavenie. In G. Cuvier, Dict. Sci. Nat. 25: 360365.

1823a. Le catalogue des plantes du Jardin medical de Paris (comments). In G. Cuvier, Dict. Sci. Nat. 26: 223235.

- 1823b. Liatris. In G. Cuvier, Dict. Sci. Nat. 26: 235239.

- 1825. Nothite. In G. Cuvier, Dict. Sci. Nat. 35: 163167.

1826-1834. Opuscules Phytologiques. 3 Volumes. Paris. 1826a. Piquerie. In G. Cuvier, Dict. Sci. Nat. 41: 115119.

- 1826b. Praxelide. In G. Cuvier, Dict. Sci. Nat. 43: 261262.

1827a. Sclerolepe. In G. Cuvier, Dict. Sci. Nat. 48: 155-156.

- 1827b. Suprage. In G. Cuvier, Dict. Sci. Nat. 51: 384 388.

- 1827c. Synanthérologie. In G. Cuvier, Dict. Sci. Nat. 51: 443-455.

. 1828a. Traganthes. In G. Cuvier, Dict. Sci. Nat. 55: 129-131.

—. 1828b. Trilise. In G. Cuvier, Dict. Sci. Nat. 55: 310 311 .

1829. Wikstromia. In G. Cuvier, Dict. Sci. Nat. 59: 60.

- 1830. Zyégée (with tableau synoptique des Synanthérées). In G. Cuvier, Dict. Sci. Nat. 60: 560-619.

Cavanilles, A. J. 1794-1797. Icones et Descriptiones Plantarum. Volumes 3, 4. Typographia Regia, Madrid.

Chamberlain, J. S. 1891. A comparative study of the styles of Compositae. Bull. Torrey Bot. Club 18: 175-209, pl. 117120.

Chevalier, A. 1910. Alkaloids in Ageratum conyzoides and $A$. mexicanum. Pharm. J. 84: 760.

Chung, I. 1967. New taxa of South American Compositae. Phytologia 14: 321-324.

Clarke, C. B. 1876. Compositae Indicae, Descriptae et Secus Genera Benthamii Ordinatae. Thacker Spink, Calcutta.

Clewell, A. F. \& J. W. Wooten. 1971. A revision of Ageratina (Compositae: Eupatorieae) from eastern North America. Brittonia 23: 123-143.

Cock, M. J. W. \& J. D. Holloway. 1982. The history of, and prospects for, the biological control of Chromolaena odorata (Compositae) by Pareuchaetes pseudoinsulata Rego Barros and allies (Lepidoptera: Arctiidae). Bull. Entomol. Res. 72: 193-205.

CoL, M. A. 1904. Recherches sur l'appareile secreteur interne des Composées. J. Bot. (Morot) 18: 110-133, 153-175.

Coleman, J. 1970. Additional chromosome numbers in Brazilian Compositae. Rhodora 20: 94-99.

Correa A., M. D. \& R. L. Wilbur. 1969. A revision of the genus Carphephorus (Compositae-Eupatorieae). J. Elisha Mitchell Sci. Soc. 85(3): 79-91.

Correll, D. S. \& M. C. Johnston. 1970. Manual of the Vascular Plants of Texas. Texas Research Foundation, Renner, Texas.

COUlter, J. M. 1895. New or noteworthy Compositae from Guatemala. Bot. Gaz. (Crawfordsville) 20:41-52, pl. 5, 6.

Cronquist, A. 1955. Phylogeny and taxonomy of the Compositae. Amer. Midl. Naturalist 53: 478-511.

-1965. Studies in Mexican Compositae, I. Miscellaneous new species. Mem. New York Bot. Gard. 12: 286-292.
1977. The Compositae revisited. Brittonia 29: 137240.

1980. Asteraceae. In Vascular Flora of the Southeastern United States 1: i-xvi, 1-261. Univ. North Carolina Press, Chapel Hill.

Cuatrecasas, J. 1964. Studies on Andean Compositae: VI. Proc. Biol. Soc. Wash. 77: 127-156.

1965. Some new Compositae from Peru. Ann. Missouri Bot. Gard. 52: 304-313.

DAlla Torre, K. W. von \& H. A. T. HARMS. 1900-1907. Genera Siphonogamarum ad Systema Englerianum Conscripta. Wilhelm Engelmann, Leipzig.

DeCandolle, A. P. 1836. Eupatoriaceae. In Prodr. 5: 103-211.

- 1838. Mantissa Compositarum. In Prodr. 7: 262-307.

Dillon, M. O. \& W. G. D’ARCY. 1978 (1979). New and noteworthy Asteraceae from Panama. Ann. Missouri Bot. Gard. 65: 766-769.

Dominguez, X. A. 1977. Chapter 16. Eupatorieae-chemical review. Pp. 487-502 in V. H. Heywood, J. B. Harborne \& B. L. Turner (editors), The Biology and Chemistry of the Compositae. Academic Press, London, New York, San Francisco.

Esteves, A., M. A. Castellano, J. Brovetto-Cruz \& W. FieLITZ. 1981. Indigenous plants used in Uruguay for fertility control. Phytologia 49: 421-424.

Everist, S. L. 1974. Poisonous Plants of Australia. Angus and Robertson, Sydney.

FERNALD, M. L. 1950. Gray's Manual of Botany. 8th edition. American Book Company, New York.

Ferreira, A. G. 1968. Contribuição ao estudio da nervação foliar das Compositae dos cerrados-IV-tribo Eupatorieae. Arq. Bot. Estado São Paulo 4: 153-170.

Fischer, N. H., E. J. Olivier \& H. D. Fischer, 1979. The biogenesis and chemistry of sesquiterpene lactones. P. 48 in W. Herz, H. Grisebach \& G. W. Kirby (editors), Progress in the Chemistry of Organic and Natural Products. SpringerVerlag, New York.

Fletcher, H. G. 1955. The sweet herb of Paraguay. Chem. Digest 7: 18

FLYR, D. 1968. New names and records in Brickellia (Compositae). Sida 3: 252-256.

Forster, J. R. \& J. G. A. Forster. 1776. Characters Generum Plantarum. London.

Gaertner, J. 1791. De Fructibus et Seminibus Plantarum. 2(3): 353-504, pl. 157-180. G. H. Schramm, Tübingen.

GAGE, D. 1985. Chemical data and their bearing upon generic delineations in the Eupatorieae. Taxon 34:61-71.

GaISER, L. O. 1946. The genus Liatris. Rhodora 48: 165-183, 216-263, 273-326, 331-382, 393-412.

- 1949. Chromosome studies in Liatris. I. Spicatae and Pycnostachyae. Amer. J. Bot. 36: 122-135.

- 1950a. Chromosome studies in Liatris. II. Graminifolia and Pauciflorae. Amer. J. Bot. 37: 414-423.

- 1950b. Chromosome studies in Liatris. 11I. Punctatae. Amer. J. Bot. 37: 763-777.

- 1953. Chromosome studies in Kuhniinae (Eupatorieae). I. Brickellia. Rhodora 55: 253-267, 269-288, 297$321,328-345$.

-1954. Studies in the Kuhniinae (Eupatorieae), II. J. Arnold Arbor. 35: 87-133.

Gardner, G. 1846. Contributions towards a flora of Brazil, being the characters of several new species of Compositae, 
belonging to the tribe Eupatorieae (part). London J. Bot. 5: $455-491$.

-1847. Contributions towards a flora of Brazil, being the characters of several new species of Compositae, belonging to the tribes Vernonieae and Eupatorieae, from the Province of Goyaz (part). London J. Bot. 6: 417-463.

Gleason, H. A. 1952. The New Britton and Brown lllustrated Flora of the Northeastern United States and Adjacent Canada, Volume 3. Lancaster Press, Lancaster, Pennsylvania.

Gomez de LA MAZA, M. 1889. Diccionario Botanico de los Nombres Vulgares Cubanos y Puerto-riquenos. Habana.

Godfrey, R. K. 1950. Studies in the Compositae of North Carolina, III. J. Elisha Mitchell Sci. Soc. 66: 186-194.

- 1961. Liatris provincialis, sp. nov., (Compositae), endemic in western Florida. Amer. Midl. Naturalist 66: 466470.

Goodw1N, T. W. 1980, 5.3 Carotenoids. In E. A. Bell \& B. V. Charlwood (editors), Secondary Plant Products. Encycl. Pl. Physiol. n.s. 8: 257-287.

Grant, W. F. 1953. A cytotaxonomic study in the genus $E u$ patorium. Amer. J. Bot. 40: 729-742.

GrashofF, J. L. 1972. A Systematic Study of the North and Central American Species of Stevia. Ph.D. dissertation, Univ. of Texas, Austin.

—_. 1974. Novelties in Stevia (Compositae: Eupatorieae). Brittonia 26: 347-384.

-1975. Metastevia (Compositae: Eupatorieae): a new genus from Mexico. Brittonia 27: 69-73.

\& J. H. BEAMAN, 1969a. Studies in Eupatorium (Compositae), I. Revision of Eupatorium bellidifolium and allied species. Rhodora 71: 566-576.

- \& - 1969b. Studies in Eupatorium (Compositae), II. A new species of Eupatorium (section Hebeclinium). Rhodora 71: 577-579.

— \& 1970. Studies in Eupatorium (Compositae), III. Apparent wing pollination. Brittonia 22: 77-84.

- M. W. Bierner \& D. K. Northington. 1972. Chromosome numbers in North and Central American Compositae. Brittonia 24: 379-394.

Gray, A. 1849. Plantae Fendlerianae Novi-Mexicanae: An account of a collection of plants made chiefly in the vicinity of Santa Fé, New Mexico, by Augusta Fendler; with descriptions of new species, critical remarks, and characters of other undescribed or little known plants from surrounding regions. Mem. Amer. Acad. Arts n.s. 4: 1-116.

- 1851. Characters of a new genus of Compositae-Eupatoriaceae, with remarks on some other genera of the same tribe. Hooker's J. Bot. Kew Gard. Misc. 3: 223-225.

- 1852. Compositae. In Plantae Wrightianae TexanoNeo-mexicanae. I. Smithsonian Contr. Knowl. 3: 82-129, pl. 6-10.

- $1879 a$. On the genus Garberia. Proc. Acad. Sci. Philadelphia 1879: 379-380.

- $1879 b(1880)$. Botanical contributions. 2. Some new North American genera, species, \&c. Proc. Amer. Acad. Arts 15: 41-52.

1880. Contributions to North American botany. 1. Notes on some Compositae. Proc. Amer. Acad. Arts 16: 78-102.

- 1882. Contributions to North American botany, 11. Novitiae Arizonicae, etc.: characters of the new plants of certain recent collections, mainly in Arizona and adjacent districts, etc. Proc. Amer. Acad. Arts 17: 199-230.
Greene, E. L. 1889-1892. Biolettia, a new genus of Compositae. Pittonia 2: 215-216.

- 1893. Observations on the Compositae-Tribe 11. Eupatoriaceae. Erythea 1: 41-45.

- 1903. Neglected Eupatoriaceous genera. Leafl. Bot. Observ. 1: 7-13.

Greeneman, J. N. 1912. II.-Diagnoses of new species and notes on other Spermatophytes, chiefly from Mexico and Central America. Publ. Field. Columbian Mus., Bot. Ser. 2: 329-350.

Grierson, A. J. C. 1972. Critical notes on the Compositae of Ceylon. Ceylon J. Sci. 10: 42-60.

HARBORNe, J. B. 1977. Chapter 12. Flavonoid profiles in the Compositae. Pp. 359-384 in V. H. Heywood, J. B. Harborne \& B. L. Turner (editors), The Biology and Chemistry of the Compositae. Academic Press, London, New York, San Francisco.

Harcombe, P. A. \& J. H. Beaman. 1967. Transfer of two Mexican species of Eupatorium to Brickellia (Compositae). Southw. Naturalist 12: 127-133.

HASs, E. 1970. White snakeroot and a frontier tragedy. Gard. J. New York Bot. Gard. 20(5): 138-139.

Hebert, H. J.-C. 1968. Generic considerations concerning Carphephorus and Trilisa (Compositae). Rhodora 70: 474-485.

Hegnauer, R. 1977. Chapter 10. The chemistry of the Compositae. Pp. 283-335 in V. H. Heywood, J. B. Harborne \& B. L. Tumer (editors), The Biology and Chemistry of the Compositae. Academic Press, London, New York. San Francisco.

HeMSLEY, W. B. 1881-1882. Enumeration of the Gamopetalae, with descriptions of new species. In F. D. Godman \& O. Salvin (editors). Biol. Cent.-Amer., Bot. 2: 1-576.

Herout, V. 1974. A chemical compound as a taxonomic character. In G. Bendz \& J. Santesson (editors), Chemistry in Botanical Classification. Nobel Symposia: Medicine and Natural Sciences 25: 55-62.

Herz, W. 1974. Pseudoguaianolides in Compositae. In G. Bendz. \& J. Santesson (editors), Chemistry in Botanical Classification. Nobel Symposia: Medicine and Natural Sciences 25: 153-172.

-1977. Chapter 11. Sesquiterpene lactones in the Compositae, Pp. 337-357 in V. H. Heywood, J. B. Harborne \& B. L. Tumer (editors), The Biology and Chemistry of the Compositae. Academic Press, London, New York, San Francisco.

Herz, W., P. Kulanthaivel, P. S. Subramanian, C. C. J. CulVENOR \& J. A. EDGAR. 1981. Alkaloids of Conoclinium coelestinum (L.) DC., Eupatorium compositifolium Walt., and $E$. altissimum L.: isolation of crystalline intermedine from C. coelestinum. Experimentia 37: 683.

- P. S. Santhanam, H. Wagner, R. Hoer, L. Horhammer \& L. FARKAS. 1969a. Isolation, structure and synthesis of 4'5, 6, 7-tetrahydroxy-3'-methoxyflavone (Batafolia), a new flavone from Mikania batatafolia DC. Tetrahedron Lett. 39: 3419-3421.

- P. S. Subramanian, P. S. Santhanam, K. Aota \& A. HaLl. $1969 b$. Structure elucidation of sesquiterpene dilactones from Mikania scandens (L.) Willd. J. Org. Chem. 35: 1453-1464.

— \& S. GiBAJA. 1972a. Compositae 5-hydroxy-6,7,4'-trimethoxyflavone from Ageratina gilbertii. Phytochemistry 11: 2625 .

$\longrightarrow,-$ S. V. Bhat \& A. Srinivasan. 1972b. Dihy- 
droflavonols and other flavonoids from Eupatorium species. Phytochemistry 11: 2859-2863.

- \& 1. WAHLberG. 1973a. Provincialin, a cytotoxic germacradienolide from Liatris provincialis Godfrey with an unusual ester side chain. J. Org. Chem. 38: 2485-2489.

— \& 1973b. Punctatin: a new germacradienolide from Liatris punctata. Phytochemistry 12: 1421-1426.

Hieronymus, G. 1893. Über Eupatoriopsis, eine neue Compositen-gattung. Bot. Jahrb. Syst. 18(Beibl. 43): 46-47.

- 1901. Plantae Lehmannianae praesertim in Columbia [sic] et Ecuador collectae, additis quibusdam ab aliis collectoribus ex iisdem regionibus allatis determinatae et descriptae. Compositae 11. Bot. Jahrb. Syst. 28: 558-659.

-1906. Uleophytum. In E. Ule, II. Beiträge zur Flora der Hylaea nach den Sammlungen von Ule's Amazonas-Expedition. Verh. Bot. Vereins Prov. Brandenburg 48: 198.

HiNTON, J. \& J. RzEDOwSKı. 1972. George B. Hinton, collector of plants in southwestern Mexico. J. Arnold Arbor. 53: 140181.

Hoffmann, O. 1890-1894. Compositae. In A. Engler \& K. Prantl (editors), Nat. Pflanzenfam. 4(5): 87-387.

Holmes, W. C. 1975. A Revision of Mikania scandens and Relatives (Compositae). Ph.D. dissertation. Mississippi State Univ., University.

- 1982. Revision of the Old World Mikania (Compositae). Bot. Jahrb. Syst. 103: 211-246.

- 1982. Studies on Mikania (Compositae)-V1I1. Phytologia 51: 233-239.

- 1983. Studies on Mikania (Compositae)-IX. Phytologia 54: 115-118.

- 1985a. Studies on Mikania (Compositae)-X. Phytologia 57: 441-444.

—_. 1985b. Studies on Mikania (Compositae)-X1. Phytologia 58: 165-166.

—_. 1985c. Studies on Mikania (Compositae)-XII. Phytologia 58: 243-244.

- 1986. Studies on Mikania (Compositae)-XI11. Phytologia 59: 441-442.

— \& S. MCDANiel. 1975. Notes on Mikania (Compositae). Phytologia 31: 273-278.

— \& - 1976. Notes on Mikania (Compositae)-II. Phytologia 33: 1-3.

- \& 1977a. Notes on Mikania (Compositae)III. Phytologia 35: 329-331.

— \& 1977b. Notes on Mikania (Compositae)IV. Phytologia 37: 467-475.

— \& 1979. Notes on Mikania (Compositae)-V. Phytologia 41: 183-197.

_ \& - 1980. Notes on Mikania (Compositae)-V1. Phytologia 45: 297-300.

- \& 1981. Studies on Mikania (Compositae)VII. Phytologia 50: 3-11.

— \& - 1982. Genus Mikania-Tribe Eupatorieae. In J. F. Macbride \& collaborators, Flora of Peru. Fieldiana, Bot. n.s. 9: 1-57.

HOLZINGER, J. M. 1893. The systematic position of Hartwrightia floridana. Bull. Torrey Bot. Club 20: 287-288, pl. 160.

HOOKER, J. D. \& B. D. JACKSON. 1895. Index Kewensis. 2 Volumes. Oxford.

HOOKER, W. J. \& W. G. ARnotT. 1835 (1836). Contributions towards a flora of South America and the islands of the Pacific (part). Companion Bot. Mag. 1: 234-244.
Houttuyn, M. 1779. Natuurlijke Historie. 10: i-viii, 1-828, pl. 61-69. Leiden.

Huber, H. 1977. Gehölzflora der Anden von Merida. Teil 1. Mitt. Bot. München 13: 1-128.

Humboldt, F. H. A. von, A. J. Bonpland \& C. S. Kunth. 1818. Sectio III. Eupatoreae. In Nov. Gen. Sp. Folio edition, 4: 82-120, pl. 339-354.

JAmES, C. W. 1958. Generic considerations concerning Carphephorus, Trilisa and Litrisa (Compositae). Rhodora 60: 117-122.

Johnson, M. F. 1971 a. A monograph of the genus Ageratum L. (Compositae-Eupatorieae). Ann. Missouri Bot. Gard. 58: 6-88.

- 1971b. The genera Carphephorus, Mikania and Kuhnia (Eupatorieae-Asteraceae) in Virginia. Virginia J. Sci. 22: 38-41.

- 1971c. The genus Liatris in Virginia. Castanea 36:137147.

- 1972. Eupatorieae (Asteraceae) in Virginia: Eupatoriadelphus, Ageratina, Fleischmannia and Conoclinium. Virginia J. Sci. 23: 48-55.

- 1974. Eupatorieae (Asteraceae) in Virginia: Eupatorium L. Castanea 39: 205-228.

Johnston, I. M. 1924. Expedition of the California Academy of Sciences to the Gulf of California in 1921. The Botany. Proc. Calif. Acad. Sci., Ser. 4, 12: 951-1218.

Karlsson, K., I. Wahlberg \& C. R. Enzell. 1972a. Volatile constituents of Carphephorus odoratissimus (J. F. Gmel) Hebert. Acta Chem. Scand. 26: 2837-2846.

- - $\quad$ - 1972b. Volatile constituents of Carphephorus corymbosus and Carphephorus paniculatus. Acta Chem. Scand. 26: 3839-3848.

Keil, D. J. \& D. J. Pinkava. 1976. Chromosome counts and taxonomic notes for Compositae from the United States and Mexico. Amer. J. Bot. 63: 1393-1403.

- \& 1977. Reinstatement of Carminatia DC. (Compositae: Eupatorieae). Phytologia 35: 323.

— \& T. F. Stuessy. 1975. Chromosome counts of Compositae from the United States, Mexico, and Guatemala. Rhodora 77: 171-195.

_ \& - 1981. Systematics of Isocarpha (Compositae: Eupatorieae). Syst. Bot. 6: 258-287.

KING, R. M. 1965. Piqueriopsis, a new genus of Compositae from southwestern Mexico. Brittonia 17: 352-353.

- 1967a. Studies in the Eupatorieae (Compositae), I-1II. Rhodora 69: 35-47, 240.

- 1967b. Studies in the Compositae-Eupatorieae V, notes on the genus Piqueria. Sida 3: 107-109.

- 1967c. Studies in the Compositae-Eupatorieae IV. Rhodora 67: 352-371.

- 1967d. Studies in the Compositae-Eupatorieae V1I Sida 3: 163-164

- 1968. Studies in the Compositae-Eupatorieae VI. Brittonia 20: 11-12.

- \& V. KRANTZ. 1975. Ultraviolet reflectance patterns in the Asteraceae. 1. Local and cultivated species. Phytologia 31: 66-114.

— \& H. Robinson. 1966. Generic limitations in the Hofmeisteria complex (Compositae-Eupatorieae). Phytologia 12: $465-476$.

\& \& 1967. Multiple pollen forms in two species of the genus Stevia (Compositae). Sida 3: 165-169. 
- \& 1968a. Studies in the Compositae-Eupatorieae VIII. Observations on the microstructure of Stevia. Sida 3: 257-269.

— \& - 1968b. Macvaughiella King \& Robinson, nomen novum for Schaetzellia Sch.-Bip., not Klotzsch (Compositae). Sida 3: 282.

— \& I $1969 a$. Studies in the Compositae-Eupatorieae, IX. A review of the genus Eupatorium section $\mathrm{He}$ beclinium in Colombia. Sida 3: 321-326.

— \& 1969b. Studies in the Compositae-Eupatorieae, X. A new species of Helogyne Nuttall. Sida 3: 327 328.

- \& I - I969c. Studies in the Compositae-Eupatorieae, XI. Typification of genera. Sida 3: 329-342.

— \& 1969d. Studies in the Eupatorieae (Compositae). XVI. A monograph of the genus Decachaeta DC. Brittonia 21: 275-284, 397.

— \& 1969e. Studies in the Eupatorieae (Compositae). XVII. The genus Erythradenia (B. L. Robinson) R. M. King \& H. Robinson. Brittonia 21: 285.

— \& 1970a. Studies in the Eupatorieae (Compositae). XVIII. New combinations in Fleischınannia. Phytologia 19: 201-207.

— \& $1970 b$. Studies in the Eupatorieae (Compositae). XIX. New combinations in Ageratina. Phytologia 12: $208-229$.

- \& - 1970c. Studies in the Eupatorieae (Compositae). XII. A new genus, Shinnersia. Phytologia 19: 297298.

- \& - 1970d. Studies in the Eupatorieae (Compositae). XIII. The genus Conoclinium. Phytologia 19: 299300.

- \& 1970e. Studies in the Eupatorieae (Compositae). XIV. Another example of dimorphic pollen? Phytologia 19: 301-302.

- \& 1970f. Studies in the Eupatorieae (Compositae). XX. New combinations in Spaniopappus. Phytologia 19: 303-304.

— \& $-1970 \mathrm{~g}$. Studies in the Eupatorieae (Compositae). XXI. A new genus, Neomirandea. Phytologia 19: 305-310.

- \& $1970 h$. Studies in the Compositae-Eupatorieae, XV. Jaliscoa, Macvaughiella, Oaxacania, and Planalioa. Rhodora 72: 100-105.

\&-1970i. The new Synantherology. Taxon 19: $6-11$.

— \& 1970j. Studies in the Eupatorieae (Compositae). XXII. The genus Piptothrix. Phytologia 19: 425-426.

\& $-1970 k$. Studies in the Eupatorieae (Compositae). XXIII. New combinations in Jaliscoa. Phytologia 19: 427-428.

— \& 1970/. Studies in the Eupatorieae (Compositae). XXIV. A new genus Stomatanthes. Phytologia 19:429430.

— \& $1970 \mathrm{~m}$. Studies in the Eupatorieae (Compositae). XXV. A new genus Eupatoriadelphus. Phytologia 19: $431-432$.

- \& 1970n. Studies in the Eupatorieae (Compositae). XXVI. A new genus Austroeupatorium. Phytologia 19: 433-435.

- \& 19700 . Studies in the Eupatorieae (Com- positae). XXVII. A monograph of the genus, Trichocoronis. Phytologia 19: 497-500.

— \& 1970p. Studies in the Eupatorieae (Compositae). XXVIII. The genus Praxelis. Phytologia 20: 193195.

— \& - 1970q. Studies in the Eupatorieae (Compositae). XXIX. The genus Chromolaena. Phytologia 20: 196-209.

- \& - 1970r. Studies in the Eupatoricae (Compositae). XXX. The genus Ayapana. Phytologia 20: 210-212.

- \& 1970s. Studies in the Eupatorieae (Compositae). XXXI. A new genus, Polyanthina. Phytologia 20: $213-$ 214.

$-\&-1970 t$. Studies in the Eupatorieae (Compositae). XXXII. A new genus, Neocuatrecasia. Phytologia 20: 332-333.

- \&-1970u. Eupatorium, a Composite genus of arcto-tertiary distribution. Taxon 19: 769-774.

__ \& 1971a. Studies in the Eupatorieae (Compositae). XXXIII. The genus Gyptis. Phytologia 21: 22-25.

\& $1971 b$. Studies in the Eupatorieae (Compositae). XXXIV. A new genus, Barrosoa. Phytologia 21: 26-27.

- \& $1971 c$. Studies in the Eupatorieae (Compositae). XXXV. A new genus, Lourteigia. Phytologia 21 : 28-30.

$-\&-1971$. Studies in the Eupatorieae (Compositae). XXXVI. A new genus. Neobartlettia. Phytologia 21: 294-297.

- \& 1971e. Studies in the Eupatorieae (Compositae). XXXVII. The genus Hebeclinium. Phytologia 21: 298-301.

- \& 1 . 1971f. Studies in the Eupatorieae (Compositae). XXXIX. A new genus, Guayania. Phytologia 21: $302-$ 303.

- \& $1971 \mathrm{~g}$. Studies in the Eupatorieae (Compositae). XL. The genus, Urolepis. Phytologia 21: 304-305.

- \& $-1971 \mathrm{~h}$. Studies in the Eupatorieae (Compositae). XLI. The genus, Eupatoriastrum. Phytologia 21: 306-307.

— \& - 1971i. Studies in the Eupatorieae (Asteraceae). XXXVIII. A new genus, Peteravenia. Phytologia 21: 394-395.

- \& $1971 j$. Studies in the Eupatorieae (Asteraceae). XLII. A new genus, Eupatorina. Phytologia 21: 396397.

- \& - 1971k. Studies in the Eupatorieae (Asteraceae). XLIII. A new genus, Antillia. Phytologia 21: 398-399.

- \& 1971l. Studies in the Eupatorieae (Asteraceae). XLIV. The genus, Radlkoferotoma. Phytologia 21: 400-401.

- \& - $1971 \mathrm{~m}$. Studies in the Eupatorieae (Asteraceae). XLV. A new genus, Fleischmanniopsis. Phytologia 21: $402-404$.

— \& $1971 n$. Studies in the Eupatoricae (Asteraceae). XLVI. A new genus, Standleyanthus. Phytologia 22: $41-42$.

- \& 1971o. Studies in the Eupatorieae (Asteraceae). XLVII. A new genus, Steyermarkina. Phytologia 22: 43-45.

- \& $1971 p$. Studies in the Eupatorieae (Asteraceae). XLVIII. The genus, Critonia. Phytologia 22: 46-51. 
\& —. 1971q. Studies in the Eupatorieae (Asteraceae). XLIX. A new genus, Critoniadelphus. Phytologia 22: 52-53.

\& \& 1971r. Studies in the Eupatorieae (Asteraceac). L. A new genus, Urbananthus. Phytologia 22: 54-55. _ \& 1 1971s. Studies in the Eupatorieae (Asteraceae). LI. The Disynaphioid complex. Phytologia 22: 109110.

- \& - 1971t. Studies in the Eupatorieae (Asteraceae). LII. A new genus, Acanthostyles. Phytologia 22: 111112.

— \& $1971 u$. Studies in the Eupatorieae (Asteraceae). LIII. A new genus, Raulinoreitzia. Phytologia 22: 113114.

- \& - $1971 v$. Studies in the Eupatorieae (Asteraceae). LIV. The genus, Symphyopappus. Phytologia 22: 115117.

— \& $1971 w$. Studies in the Eupatorieae (Asteraceae). LV. The genus, Dimorpholepis. Phytologia 22: 118120.

- \& - 1971x. Studies in the Eupatorieae (Asteraceae). LVI. A new genus, Campovassouria. Phytologia 22: 121-122.

- \& $1971 y$. Studies in the Eupatorieae (Asteraceae). LVII. The genus, Disynaphia. Phytologia 22: 123-125.

— \& - 1971z. Studies in the Eupatorieae (Asteraceae). LXII. A new genus, Neohintonia. Phytologia 22: 143144.

— \& 1971aa. Studies in the Eupatorieae (Asteraceae). LXIII. A new genus, Kyrsteniopsis. Phytologia 22: 145-146.

— \& $1971 b b$. Studies in the Eupatorieae (Asteraceae). LXIV. The genus, Koanophyllon. Phytologia 22: $147-$ 152.

- \& - - $1971 \mathrm{cc}$. Studies in the Eupatorieae (Asteraceae). LVIII. A new genus, Tamaulipa. Phytologia 22: 153155.

— \& $1971 d d$. Studies in the Eupatorieae (Asteraceae). LIX. A new genus, Steviopsis. Phytologia 22: 156157.

- \& 1971ee. Studies in the Eupatorieae (Asteraceae). LX. A new genus, Dyscritogyne. Phytologia 22: 158159.

— \& . 1971ff. Studies in the Eupatorieae (Asteraceae). LXI. Additions to the Hebeclinium complex with Bartlettina, a new generic name. Phytologia 22: 160-162.

—_ \& - 1972a. Studies in the Eupatorieae (Asteraceae). LXV. A new genus, Neocabreria. Phytologia 23: 151152.

— \& 1972b. Studies in the Eupatorieae (Asteraceae). LXVI. The genus, Pachythamnus. Phytologia 23: 153154.

- \& - 1972c. Studies in the Eupatorieae (Asteraceae). LXVII. Grazielia nom. nov. for Dimorpholepis. Phytologia 23: 305-306.

— \& 1972d. Studies in the Eupatorieae (Asteraceae). LXVIII. A new genus, Conocliniopsis. Phytologia 23: 307-309.

— \& - 1972e. Studies in the Eupatorieae (Asteraceae). LXIX. A new genus, Gyptidium. Phytologia 23: $310-$ 311 .
\& - 1972f. Studies in the Eupatorieae (Asteraceae). LXX. A new genus, Bahianthus. Phytologia 23: 312 313.

— \& 1972g. Studies in the Eupatorieae (Asteraceae). LXXI. A new genus, Hatschbachiella. Phytologia 23: 393-394.

- \& 1972h. Studies in the Eupatorieae (Asteraceae). LXXII. Notes on the genus Koanophyllon. Phytologia 23: 395-396.

\& 1 . 1972i. Studies in the Eupatorieae (Asteraceae). LXXIII. The genus, Ophryosporus. Phytologia 23: 397400.

— \& $1972 j$. Studies in the Eupatorieae (Asteraceae). LXXIV. New species of Critonia, Fleischmannia and Hebeclinium. Phytologia 23: 405-408.

— $\&$. 1972k. Studies in the Eupatorieae (Asteraceae). LXXV. A new genus, Cronquistianthus. Phytologia 23: 409-412.

- \& - 1972l. Studies in the Eupatorieae (Asteraceae). LXXVI. Additions to the genus Kyrsteniopsis. Phytologia 24: 57-59.

— \& $1972 \mathrm{~m}$. Studies in the Eupatorieae (Asteraceae). LXXVII. Additions to the genus Steviopsis. Phytologia 24: 60-62.

— \& $1972 n$. Studies in the Eupatorieae (Asteraceae). LXXVIII. A new genus, Brickelliastrum. Phytologia 24: 63-64.

- \& 19720 . Studies in the Eupatorieae (Asteraceae). LXXIX. A new genus, Asanthus. Phytologia 24: 6566.

- \& 1972p. Studies in the Eupatorieae (Asteraceae). LXXX. A new genus, Flyriella. Phytologia 24: 67-69.

_ \& 1972q. Studies in the Eupatorieae (Asteraceae). LXXXI. The genus, Phanerostylis. Phytologia 24: 7071.

\& $\&$ 1972r. Studies in the Eupatorieae (Asteraceae). LXXXII. A new genus, Austrobrickellia. Phytologia 24: 72-73.

— \& 1972s. Studies in the Eupatorieae (Asteraceae). LXXXIII. A new genus, Pseudobrickellia. Phytologia 24: 74-76.

- \& 1 1972t. Studies in the Eupatorieae (Asteraceae). LXXXIV. A new genus, Crossothammus. Phytologia 24: $77-78$.

- \& 1972u. Studies in the Eupatoricae (Asteraceae). LXXXV. Additions to the genus Ageratina with a key to the Costa Rican species. Phytologia 24: 79-104.

— \& 1972v. Studies in the Eupatorieae (Asteraceae). LXXXVI. Additions to the genus, Neocuatrecasia. Phytologia 24: 105-107.

— \& 1972w. Studies in the Eupatorieae (Asteraceae). LXXXVII. The genus, Alomia. Phytologia 24: 108111.

- \& - 1972x. Studies in the Eupatorieae (Asteraceae). LXXXVIII. Additions to the genus, Ageratum. Phytologia 24: 112-117.

— \& - 1972y. Studies in the Eupatorieae (Asteraceae). LXXXIX. A new genus, Blakeanthus. Phytologia 24 118-119.

- \& - 1972z. Studies in the Eupatorieae (Asteraceae). XC. The genus, Campuloclinium. Phytologia 24: 170172. 
\& $1972 a a$. Studies in the Eupatorieae (Asteraceae). XCI. A new genus, Macropodina. Phytologia 24: 173175.

- \& — . 1972bb. Studies in the Eupatorieae (Asteraceae). XCII. The genus, Trichogonia. Phytologia 24: 176179.

- \& 1 1972cc. Studies in the Eupatorieae (Asteraceae). XCIII. A new genus, Trichogoniopsis. Phytologia 24: 180-181.

- \& $-1972 d d$. Studies in the Eupatorieae (Asteraceae). XCIV. A new genus, Platypodanthera. Phytologia 24: 182-183.

- \& 1972ee. Studies in the Eupatorieae (Asteraceae). XCV. Additions to the genus Barrosoa. Phytologia 24: 184 .

— \& 1972ff. Studies in the Eupatorieae (Asteraceae). XCVI. A new genus, Lasiolaena. Phytologia 24: 185186.

— \& 1972gg. Studies in the Eupatorieae (Asteraceae). XCVII. A new genus, Dasycondylus. Phytologia 24: 187-191.

- \& $-1972 \mathrm{hh}$. Studies in the Eupatorieae (Asteraceae). XCVIII. A new genus, Diacranthera. Phytologia 24: 192-194.

- \& 1972ii. Studies in the Eupatorieae (Asteraceac). XCIX. A new genus, Amolinia, and a new combination in Bartlettina. Phytologia 24: 265-266.

- \& - 1972jj. Studies in the Eupatorieae (Asteraceae). C. A key to the genera of Nueva Galicia, Mexico. Phytologia 24: 267-280.

- \& 1972kk. Studies in the Eupatorieae (Asteraceae). CI. New species of Fleischmannia and Neomirandea. Phytologia 24: 281-284.

- \& 1972/l. Studies in the Eupatorieae (Asteraceae). CII. A new genus, Condylidium. Phytologia 24: 380381 .

- \& $1972 \mathrm{~mm}$. Studies in the Eupatorieae (Asteraceae). CIII. A new genus, Ayapanopsis. Phytologia 24: 382-386.

- \& $\&$ - 1972nn. Studies in the Eupatorieae (Asteraceae). CIV. A new genus, Gongrosty/lus. Phytologia 24: 387388.

— \& 197200. Studies in the Eupatorieae (Asteraceae). CV. A new genus, Heterocondy/us. Phytologia 24: 389-392.

—_ \& $1972 p p$. Studies in the Eupatorieae (Asteraceae). CVI. A new genus, Gymnocondylus. Phytologia 24: 393-394.

— \& 1972qq. Studies in the Eupatorieae (Asteraceae). CVII. A new genus, Alomiella. Phytologia 24: 395396

— \& 1972rr. Studies in the Eupatorieae (Asteraceae). CVIII. A new genus, Condylopodium. Phytologia 24: $397-400$.

— \& 1972ss. Studies in the Eupatorieae (Asteraceae). CIX. A new genus, Acritopappus. Phytologia 24: 401403.

— \& - 1972tt. Studies in the Eupatorieae (Asteraceae). CX. Additions to the genus, Campuloclinium. Phytologia 24: 404-406.

— \& 1972uน. Studies in the Eupatorieae (Aster- aceae). CXI. Additions to the genus, Ophryosporus. Phytologia 25: 65-67.

— \& 1972w. Neomirandea allenii, a new epiphytic Composite of the American rain forest. Rhodora 74: 272-275.

- \& - 1973a. Studies in the Eupatorieae (Asteraceae). CXI1. A new species of Ferreyrella. Phytologia 26: $167-169$.

- \& $-1973 b$. Studies in the Eupatorieac (Asteraceae). CXIII. A new genus, Matudina. Phytologia 26: 170173.

- \& - 1973c. Studies in the Eupatorieae (Asteraceae). CXIV. The genera of Barro Colorado Island, Panama. Phytologia 27: 233-240.

- \& - 1973d. Studies in the Eupatorieae (Asteraceae). CXV. A new genus and species, Pseudokyrsteniopsis perpetiolata. Phytologia 27: 241-244.

- \& $1973 e$. Studies in the Eupatorieae (Asteraceae). CXVI. New species of Neomirandea. Phytologia 27: 245-251.

- \& 1974a. Studies in the Eupatorieae (Asteraceae). CXVII. A new species of Oxylobus from Oaxaca. Mexico. Phytologia 27: 385-386.

- \& $-1974 b$. Studies in the Eupatorieae (Asteraceae). CXVIII. New species of Ageratum, Fleischmannia and Hebeclinium from northern South America. Phytologia 27: 387-394.

_ $\&$ - 1974c. Studies in the Eupatorieae (Asteraceae). CXIX. Additions to the genera Cronquistianthus, Helogyne and Neocualrecasia from Peru. Phytologia 27: 395401.

— \& - 1974d. Studies in the Eupatorieae (Asteraceae). CXX. Additions to the genus Koanophyllon in Panama. Phytologia 28: 67-72.

_ \& 1974e. Studies in the Eupatorieae (Asteraceae). CXX1. Additions to the genus Fleischmannia. Phytologia 28: 73-96.

- \& 1974f. Studies in the Eupatorieae (Asteraceae). CXXII. A new genus, Sartorina. Phytologia 28: 97100.

\& - 1974g. Studies in the Eupatorieae (Asteraceae). CXXIll. Additions to the genus Mikania. Phytologia 28: $272-281$.

- \& $-1974 h$. Studies in the Eupatorieae (Asteraceae). CXXIV. A new genus, Eitenia. Phytologia 28: 282285.

- \& $-1974 i$. Studies in the Eupatorieae (Asteraceae). CXXV. Additions to the genus, Bartlettina. Phytologia 28: 286-293.

- $\&$ - 1974j. Studies in the Eupatorieae (Asteraceae). CXXVI. A new species of Ageratum. Phytologia 28: 491-493.

- \& - 1974k. Studies in the Eupatorieae (Asteraceae). CXXVIII. Four additions to the genus Ageratina from Mexico and Central America. Phytologia 28: 494-502.

- \& - 1974l. Studies in the Eupatorieac (Asteraceae). CXXVII. Additions to the American and Pacific Adenostenmatinac. Adenostemma, Gymnocoronis and Sciadocephala. Phytologia 29: 1-20.

- \& - 1974m. Studies in the Eupatorieae (Asteraceae). CXX1X. A new genus, Vittetia. Phytologia 29: 121122. 
\& $1974 n$. Studies in the Eupatorieae (Asteraceae). CXXX. Notes on Campuloclinium, Koanophyllon, Mikania and Symphyopappus. Phytologia 29: 123-129.

— \& 19740. Studies in the Eupatorieae (Asteraceae). CXXXII. The genus, Phalacraea. Phytologia 29: 251256.

- \& 1974p. Studies in the Eupatorieae (Asteraceae). CXXXI. A new genus, Guevaria. Phytologia 29: 257263.

- \& 1974q. Studies in the Eupatorieae (Asteraceae). CXXXIII. A new genus, Piqueriella. Phytologia 29: 264-266.

— \& $1975 a$. Studies in the Eupatorieae (Asteraceae). CXXXIV. A new species of Sciadocephala from Panama. Phytologia 29: 343-346.

- \& $1975 b$. Studies in the Eupatorieae (Asteraceae). CXXXV. A new species of Ageratina from Panama. Phytologia 29: 347-350.

- \& $1975 c$. Studies in the Eupatorieae (Asteraceae). CXXXVI. Four new species of Neomirandea. Phytologia 29: 351-361.

— \& 1975d. Studies in the Eupatorieae (Asteraceae). CXXXVII. Two new species of Neomirandea. Phytologia 30: 9-14.

— \& 1975e. Studies in the Eupatorieae (Asteraceae). CXXXIX. A new genus, Aristeguietia. Phytologia 30: 217-220.

- \& - 1975f. Studies in the Eupatorieae (Asteraceae). CXL. A new genus, Grosvenoria. Phytologia 30: 221222.

- \& 1975g. Studies in the Eupatorieae (Asteraceae). CXLI. A new genus, Asplundianthus. Phytologia 30: 223-228.

- \& 1 1975h. Studies in the Eupatorieae (Asteraceae). CXLII. A new genus, Badilloa. Phytologia 30: 229234.

\& $-1975 i$. Studies in the Eupatorieae (Asteraceae). CXXXVIII. A new genus, Critoniella. Phytologia 30: 284-285.

— \& $1975 j$. Studies in the Eupatorieae (Asteraceae). CXLV. A new species of Bartlettina. Phytologia 31: $62-65$.

- \& 1 . 1975k. Studies in the Eupatorieae (Asteraceae). CXLIII. A new genus, Austrocritonia. Phytologia 31: $115-117$.

- \& 1 1975l. Studies in the Eupatorieae (Asteraceae). CXLIV. A new genus, Viereckia. Phytologia 31: 118121.

- \& $1975 \mathrm{~m}$. Studies in the Eupatorieae (Asteraceae). CXLVI. Two new species of Fleischmannia from Central America. Phytologia 31: 305-310.

— \& $1975 n$. Studies in the Eupatorieae (Asteraceae). CXLVII. Additions to the genera Amboroa, Ayapanopsis, and Hebeclinium in South America. Phytologia 31: $311-316$.

- \& - 19750. Studies in the Eupatorieae (Asteraceae). CXLVIII. A new species of Lomatozoma. Phytologia 32: $246-249$.

— $\&$ 1975p. Studies in the Eupatorieae (Asteraceae). CXLIX. A new genus, Osmiopsis. Phytologia 32: 250251.

$\&$ _ 1975q. Studies in the Eupatorieae (Astera- ceae). CL. Limits of the genus Koanophyllon. Phytologia 32: 252-267.

- \& 1 1975r. Studies in the Eupatorieae (Asteraceae). CLI. A new genus, Grisebachianthus. Phytologia 32: 268-270.

_ \& 1 1975s. Studies in the Eupatorieae (Asteraceae). CLII. A new genus, Imeria. Phytologia 32: 271-272.

- \& 1 . 1975t. Studies in the Eupatorieae (Asteraceae). CLIII. A new genus, Lorentzianthus. Phytologia 32: 273-274.

\& \& 1975u. Studies in the Eupatorieae (Asteraceae). CLIV. A new genus, Chacoa. Phytologia 32: 275-276. - \& - 1975v. Studies in the Eupatorieae (Asteraceae). CLV. A new genus, Idiothammus. Phytologia 32: 277282.

\& 1 . 1975w. Studies in the Eupatorieae (Asteraceae). CLVI. Various new combinations. Phytologia 32: 283285.

— \& $1975 x$ (1976). New species of Stomatanthes from Africa (Eupatorieae, Compositae). Kew Bull. 30: 463465.

— \& - 1975y. (1976). Eupatorieae. Pp. 888-1004.

In R. E. Woodson, Jr., R. W. Schery, and collaborators, Flora of Panama, part IX, family 184. Compositae. Ann. Missouri Bot. Gard. 62: 835-1322.

- \& $-1976 a$. Studies in the Eupatorieae (Asteraceae). CLVII. A new genus, Revealia from Mexico. Phytologia 33: 277-280.

\& 1 - 1976b. Studies in the Eupatorieae (Asteraceae). CLVIII. A new genus, Adenocritonia from Jamaica. Phytologia 33: 281-284.

- \& - 1976c. Studies in the Eupatorieae (Asteraceae). CLIX. Additions to the genus, Ayapana. Phytologia 34: 57-66.

\& -1976 d. Studies in the Eupatorieae (Asteraceae). CLX. A new species of Sciadocephala from Ecuador. Phytologia 34: 375-377.

- \& \& 1977a. Studies in the Eupatorieae (Asteraceae). CLXI. A new species of Stevia from Costa Rica. Phytologia 35: 229-232.

- \& - 1977b. Studies in the Eupatorieae (Asteraceae). CLXII. New species and combinations from Venezuela. Phytologia 35: 497-504.

— \& 1 1977c. Studies in the Eupatorieae (Asteraceae). CLXIII. Additions to the genus Fleischmanniopsis. Phytologia 36: 193-200.

- \& - 1977d. Studies in the Eupatorieae (Asteraceae). CLXIV. Various notes and additions. Phytologia 37: 455-460.

- \& - 1977e. Studies in the Eupatorieae (Asteraceae). CLXV. A new genus, Goyazianthus. Phytologia 37 : $461-466$.

- \& 1 1977f. Compositae in the Flora of Guatemala: a review. Taxon 26: 435-441.

— \& 1977g. Guayania davidsei and Hebeclinium gentryi, new species from northern South America (Eupatorieae-Asteraceae). Ann. Missouri Bot. Gard. 64: 366370.

- \& - 1977h. Studies in the Eupatorieae (Asteraceae). CLXVI. A new genus Scherya and additions to ACritopappus. Phytologia 38: 99-105.

- \& - 1977i. Studies in the Eupatorieac (Astera- 
ceae). CLXVII. Four new speeies of Barlettina. Phytologia 38: 106-117.

- \& 1978a. Studies in the Eupatorieae (Asteraceae). CLXVIII. Additions to the genus Ageratina. Phytologia 38: 323-355.

— \& 1978b. Studies in the Eupatorieae (Asteraceae). CLXIX. Two new species of Fleischmannia from Guatemala. Phytologia 38: 417-423.

- \& - 1978c. Studies in the Eupatorieae (Asteraceae). CLXX. Additions to the genus Neocabreria. Phytologia 38: 424-428.

— \& $-1978 d$. Studies in the Eupatorieae (Asteraeeae). CLXXI. A new genus, Corethamnium. Phytologia 39: 54-57.

- \& 1978e. Studies in the Eupatorieae (Asteraceae). CLXXII. A new genus, Castenedia. Phytologia 39: $58-60$.

- \& 1 1978f. Studies in the Eupatorieae (Asteraceae). CLXXIII. A new speeies of Lomatozonı. Phytologia 39: 129-131.

- \& - 1978g. Studies in the Eupatorieae (Asteraeeae). CLXXIX. Notes on the genus Symphyopappus. Phytologia 39: 132-135.

- \& - 1978h. Studies in the Eupatorieae (Asteraceae). CLXXX. Three new Critonioid species from Tropical America. Phytologia 39: 136-142.

- \& - 1978i. Studies in the Eupatorieae (Asteraceae). CLXXXI. Two new species of Trichogonia. Phytologia 39: 334-338.

- \& $1978 j$. Studies in the Eupatorieac (Asteraceae). CLXXXII. A new genus, Bishovia. Phytologia 39: 339342 .

$-\&-1978 k$. Studies in the Eupatorieae (Asteraceae). CLXXXIII. a new genus, Bejaranoa. Phytologia 40: $51-53$.

- \& 1 1978l. New records and new speeies of Central American Eupatorieae (Asteraceae). Wrightia 6: 41-42.

- \& - 1979a. Studies in the Eupatorieae (Asteraeeae). CLXXIV. A new genus, Nothobaccharis. Phytologia 41: 396-397.

- \& - 1979b. Studies in the Eupatorieae (Asteraeeae). CLXXV. A new genus from Bahia, Litothammus. Phytologia 44: 79-83.

- \& 1979c. Studies in the Eupatorieae (Asteraceae). CLXXVI. The relationship of Eupatorium cyrili-nelsonii. Phytologia 44: 84-88.

— \& 1979d. Studies in the Eupatorieae (Asteraceae). CLXXVIII. Additions to Eitenia and Lomatozoma. Phytologia 44: 455-462.

- \& 1979e. Studies in the Eupatorieae (Asteraceae). CLXXXIV. A new speeies of Arrojadocharis. Phytologia 44: 463-465.

- \& - 1979f. Studies in the Eupatorieae (Asteraceae). CLXXXV. Additions to the genus Lasiolaena. Phytologia 44: 466-472.

- \& - 1980a. Studies in the Eupatorieae (Asteraceae). CLXXXVI. A review of the genus Stylotrichum. Phytologia 45: 101-104.

- \& $1980 \mathrm{~b}$. Studies in the Eupatorieae (Asteraceae). CLXXXV1I. Additions to Trichogonia and Trichogoniopsis. Phytologia 45: 105-123.

\& $-1980 c$. Studies in the Eupatorieae (Astera- eeae). CLXXXVIII. New species of Mikania from Brasil. Phytologia 45: 124-141.

- \& 1 1980d. Studies in the Eupatorieae (Asteraceae). CLXXXIX. Additions to Acritopappus. Phytologia 45: 142-157.

\& $1980 e$. Studies in the Eupatorieae (Asteraeeae). CXC. A new genus, Santosia. Phytologia 45: 463466.

— \& 1980f. Studies in the Eupatorieae (Asteraeeae). CXCI. Various new speeies from Brasil. Phytologia 46: 295-307.

- \& 1980g. Studies in the Eupatorieae (Asteraceae). CXCII. Validation of subtribes. Phytologia 46: 446450.

- \& $1980 h$. Studies in the Eupatorieae (Asteraceae). CXC1II. A new genus, Teixeiranthus. Phytologia 47: $108-109$.

- \& - 1980i. Studies in the Eupatorieae (Asteraeeae). CXCIV. A new genus, Parapiqueria. Phytologia 47: $110-112$.

- \& - 1980j. Studies in the Eupatorieae (Asteraceae). CXCV. A new genus, Cavalcantia. Phytologia 47: 113116.

- \& 1 1980k. Studies in the Eupatorieae (Asteraceae). CXCVI. A new genus, Jaramilloa. Phytologia 47: 117120.

_ \& 1980l. Studies in the Eupatorieae (Asteraeeae). CXCVIJ. Three additions to Bartlettina. Phytologia 47: $121-125$.

- \& $1980 \mathrm{~m}$. Studies in the Eupatorieae (Asteraceae). CXCVIII. Reduetion of the genus Kanimia. Phytologia 47: 126-127.

- \& - 1980n. Studies in the Eupatorieae (Asteraceae). CIC. A new genus, Malmeanthus. Phytologia 47: 225229.

- \& 1 1980o. Studies in the Eupatorieac (Asteraceae). CC. Additions to the genus Chromolaena. Phytologia 47: 230-251.

- \& 1980 p. Studies in the Eupatorieae (Asteraceae). CCI. A new genus, Hughesia. Phytologia 47: 252-256.

- \& 1980q. Studies in the Eupatorieae (Asteraceae). CCII. A new genus, Kaunia. Phytologia 47: 257-260.

_ \& 1981a. Studies in the Eupatorieae (Asteraceae). CCIII. A new genus, Bishopiella. Phytologia 48: 218220.

\& 1981 b. Studies in the Eupatorieae (Asteraeeae). CCIV. New combinations in Brasilian and Mexican species. Phytologia 48: 221-222.

- \& - 1981c. Studies in the Eupatorieae (Asteraceae). CCV. Two new species of Mikania from Brasil. Phytologia 48: 223-228.

- \& $-1981 d$. Studies in the Eupatorieae (Asteraceae). CCVI. A new genus. Gardnerina. Phytologia 49: 1-2.

_ \& 1981e. Studies in the Eupatorieae (Asteraeeae). CCVII. Additional new combinations. Phytologia 49: $3-6$.

- \& 1981f. Studies in the Eupatorieae (Asteraceae). CCVIIl. Additions to Badilloa and Bartlettina from Ecuador. Phytologia 49: 7-9.

- \& $-1981 \mathrm{~g}$. Studies in the Eupatorieae (Asteraceae). CCX. A second species of Vittetia from Brasil. Phytologia 49: 281-283. 
_ \& 1981h. Studies in the Eupatorieae (Asteraceae). $\mathrm{CClX}$. Two new species of Grazielia from Brasil. Phytologia 49: 284-290.

- \& 1 1981i. Studies in the Eupatorieae (Asteraceae). CCXI. Three new species of Mikania from Brasil. Phytologia 49: 488-495.

— \& $1982 a$. Studies in the Eupatorieae (Asteraceae). CCXI1. Additions to Austroeupatorium, Flyriella, and Teixeiranthus. Phytologia 50: 379-384.

— \& - 1982b. Studies in the Eupatorieae (Asteraceae). CCXIII. A new genus, Prolobus, from Bahia. Phytologia 50: 385-387.

- \& $-1982 c$. Studies in the Eupatorieae (Asteraceae). CCXIV. New species of Chromolaena and Stevia from Bolivia. Phytologia 51: 172-178.

- \& - 1982d. Studies in the Eupatorieae (Asteraceae). CCXV. Additions to Austroeupatorium and Cronquistianthus. Phytologia 51: 179-186.

\& 1 1983a. Studies in the Eupatorieae (Asteraceae). CCXVII. Three new species of Adenostemina. Phytologia 54: 29-35.

- \& - 1983b. Studies in the Eupatorieae (Asteraceae). CCXV1. Various new species from the Andes and Panama. Phytologia 54: 36-51.

- \& G. M. Barroso. 1979. Studies in the Eupatorieae (Asteraceae). CLXXVII. A new genus, Morithamnus. Phytologia 44: 451-454.

- D. W. Kyhos, A. M. Powell, P. H. Raven \& H. Robinson. 1976 (1977). Chromosome numbers in Compositae, X111. Eupatorieae. Ann. Missouri Bot. Gard. 63: 862-888.

Klatt, F. W. 1896. Amerikanische Compositen (aus dem Herbarium der Universität Zürich). Bull. Herb. Boissier 4: 479480.

Koster, H. 1816. Travels in Brazil. 2 Volumes. London.

Koster, J. T. 1935. The Compositae of the Malay Archipelago 1. Blumea 1: 351-536.

KunTZE, C. E. O. 1891. Revisio Generum Plantarum. Volume 1. Arthur Felix, Leipzig.

Lagasca y Segura, M. 1816. Genera et Species Plantarum. Madrid.

Lessing, C. F. 1832. Synopsis Generum Compositarum. Berlin. LinNaEus, C. 1753. Species Plantarum. 2 Volumes. Stockholm.

- 1754. Genera Plantarum. 5th edition. Stockholm.

- 1762-1763. Species Plantarum. 2nd edition. 2 Volumes. Stockholm.

LinNaEus, C., F. 1781. Supplementum Plantarum. Brunsvigae.

Mabry, T. J. \& F. Bohlmann. 1977. Chapter 41. Summary of the chemistry of the Compositae. Pp. 1097-1104 in V. H. Heywood, J. B. Harbome \& B. L. Tumer (editors), The Biology and Chemistry of the Compositae. Academic Press, London, New York, San Francisco.

— , B. N. TimmermanN, N. Heil \& A. M. Powell. 1981. Systematic implications of the flavonoids and chromosomes of Flyriella (Compositae-Eupatorieae). Pl. Syst. Evol. 137: $275-280$.

MCVAUGH, R. 1972. Tribe II1. Eupatorieae. In Compositarum Mexicanarum Pugillus. Contr. Univ. Michigan Herb. 9: 378408.

-1982. The new synantherology vs. Eupatorium in Nueva Galicia. Contr. Univ. Michigan Herb. 15: 181-190.

Malme, G. O. A. 1899. Die Compositen der ersten Regnell' schen Expedition. Kongl. Svenska Vetenskapsakad. Handl. 32(5): $1-90$.

- 1933. Eupatorieae. In Compositae Paranenses Dusenianae. Kongl. Svenska Vetenskapsakad. Handl., Ser. 3, 12(2): 28-62.

Mathur, S. B. \& C. M. Fermin. 1973. Terpenes of Mikania mongenansis. Phytochemistry 12: 226-227.

Matrfeld, J. 1923. Compositae. In R. Pilger (editor), Plantae Lützelburgianae brasiliensis. Notizbl. Bot. Gart. Mus. Berlin-Dahlem 8: 428-451.

- 1930. Arrojadocharis Mattf. nom. nov. In IX. Vermischte Diagnosen VI. Notizbl. Bot. Gart. Mus. Berlin-Dahlem 10: 1053.

- 1938. Compositae. In L. Diels, I1. Neue Arten aus Ecuador. Notizbl. Bot. Gart. Mus. Berlin-Dahlem 14: 4144.

Matthews, J. V., JR. 1980. Tertiary land bridges and their climate: backdrop for development of the present Canadian insect fauna. Canad. Entomol. 112: 1089-1103.

MATZENBACHER, N. I. 1978. Uma nova combinação no gênero Mikania Willd. (Compositae). Bradea 2(37): 258-259.

Mazzei Planas, G. \& J. Kuć. 1968. Contraceptive properties of Stevia rebaudiana. Science 162: 1007.

Merrill, E. D. 1938. On Houttuyn's overlooked binomials for native or introduced plants in eastern North America. Rhodora 40: 288-293.

-1945. In defense of the validity of William Bartram's binomials. Bartonia 23: 10-35.

Miller, J. A. 1980. Chemical fruits of the desert. Sci. News 118: 189.

MoEnCH, C. 1794. Methodis. Marburg.

Montgomery, J. D. \& D. E. Fairbrothers. 1970. A biosystematic study of the Eupatorium rotundifolium complex (Compositae). Brittonia 22: 134-150.

Mues, R., B. N. Timmermann, N. Ohno \& T. J. Mabry. 1979. 6-methoxyflavonols from Brickellia californica. Phytochemistry 18: 1379-1383.

MurRay, J. A. (EDITOR). 1774. Systema Vegetabilium. 13th edition. Göttingen.

NECKER, N. J. DE 1790. Elementa Botanica. 3 Volumes. Neuwied.

Nuttall, T. 1822. A catalogue of a collection of plants made in East Florida, 1821. Amer. J. Sci. 5: 286-304.

Oliver, D. 1892. CCLV-Paraguay indigo. Bull. Misc. Inform. 1892(67/68): 179-180.

Paray, L. 1953. Las Compuestas del Valle Central de México. Bol. Soc. Bot. México 15: 1-12.

-1954. Nuevas Fanerogamas de Mexico. Bol. Soc. Bot. México 16: 20-25.

- 1956. El genero Eupatorium en la Valle Central de México. Bol. Soc. Bot. México 19: 1-15.

- 1958. Neuvas Compuestas de México. Bol. Soc. Bot. México 22: 1-12.

Pezzuto, J. M., N. P. Dhammika Nanayakkara \& A. D. KingHORN, 1983. Steviol, the aglycone of the commercial sweetening agent stevioside, is mutagenic. In AACR Abstracts. Proc. Amer. Assoc. Cancer Res. 24: 83.

Philippi, R. A. 1860. Florula Atacamensis. Halle.

-1891. Catalogus praevius plantarum in itinere ad Tarapaca a Friderico Philippi lectarum. Ann. Mus. Nac. Chile, Sect. 2, Bot. 8: 1-94, 2 pl. 
Poljakov, P. P. 1967. Sisematika i Proischoždenie Složnocvetnykh. Alma-Ata.

PoWel., A. M. 1972. Artificial hybridizations in the subtribe Peritylinae (Compositae-Helenieae). Amer. J. Bot. 59: 760768.

- \& J. Cuatrecasas. 1970. Chromosome numbers in Compositae: Colombian and Venezuelan species. Ann. Missouri Bot. Gard. 57: 374-379.

- \& R. M. KING. 1969a. Chromosome numbers in the Compositae: Colombian species. Amer. J. Bot. 56: 116-121.

- \& 1969b. Chromosome numbers in the Compositae: West Indian species. Sida 3: 319-320.

RAFINESQUe, C. S. 1838 . Neobotanon. In New F1. 4: 1-1 12.

Raven, P. H. \& D. 1. Axelrod. 1974. Angiosperm biogeography and past continental movements. Ann. Missouri Bot. Gard. 61: 539-673.

RAY, J. 1704. Historia Plantarum. 3 Volumes. London.

Reichard, D. J. J. (EDITOR). 1780. Systema Plantarum. Volume 3. Frankfurt.

Rios, T., A. Romo de Vivar \& J. Romo. 1967. Stevin, a new pseudoguaianolide isolated from Stevia rhombifolia HBK. Tetrahedron 23: 4265 .

Roberts, M. F., B. N. Timmermann \& T. J. Mabry. 1980. 6-methoxyflavonoids from Brickellia veronicaefolia (Compositae). Phytochemistry 19: 127-129.

Robinson, B. L. 1892. Descriptions of new plants collected in Mexico by C. G. Pringle in 1890 and 1891 , with notes on a few other species. Proc. Amer. Acad. Arts 27: 165-185.

- 1900. New phanerogams, chiefly Gamopetalae, from Mexico and Central America. Proc. Amer. Acad. Arts 35: 323-342.

- 1901. New species and newly noted synonymy among the spermatophtyes of Mexico and Central America. Proc. Amer. Acad. Arts 36: 471-488.

- 1903. Eupatorium hypomalacum. In J. D. Smith, Undescribed plants from Guatemala and other Central American Republics. Bot. Gaz. (Crawfordsville) 35: 4 .

-1904a. Diagnoses and synonymy of some Mexico and Central American Eupatoriums. Proc. Boston Soc. Nat. Hist. 31: 247-254.

- 1904b. Synopsis of the Mikanias of Costa Rica. Proc. Boston Soc. Nat. Hist. 31: 254-257.

- 1905. Diagnoses and notes relating to American Eupatorieae. Proc. Amer. Acad. Arts 41: 271-278.

- 1906. Studies in the Eupatorieae. I. Revision of the genus Piqueria. II. Revision of the genus Ophryosporus. III. The genus Helogyne and its synonyms. IV. Diagnoses and synonymy of Eupatorieae and of certain other Compositae which have been classed with then. Proc. Amer. Acad. Arts 42: 3-48 (I: 4-16; II: 17-27; III: 27-32; IV: 32-48).

- 1907. New or otherwise noteworthy spermatophytes chiefly from Mexico. Proc. Amer. Acad. Arts 43: 21-48.

-1909. Diagnoses and transfers of tropical American Phanerogams. Proc. Amer. Acad. Arts 44: 613-626.

- 1911a. On the classification of certain Eupatorieae. Proc. Amer. Acad. Arts 47: 191-202.

- $1911 b$. Revision of the genus Barroetea. Proc. Amer. Acad. Arts 47: 202-206.

- 1913a. A key to the genera of the Compositae-Eupatorieae. Proc. Amer. Acad. Arts 49: 429-437.
- 1913b. Revisions of Alomia, Ageratum and Oxylobus. Proc. Amer. Acad. Arts 49: 438-491.

- 1916. New, reclassified or otherwise noteworthy spermatophytes. Proc. Amer. Acad. Arts 51: 527-540.

- 1917. A monograph of the genus Brickellia. Mem. Gray Herb. 1: 3-151.

- $1918 a$. Diagnoses and notes relating to tropical American Eupatorieae. Proc. Amer. Acad. Arts 54: 235-263.

- 1918b. A descriptive revision of the Colombian Eupatoriums. Proc. Amer. Acad. Arts 54: 264-330.

- 1918c. Keyed recensions of the Eupatoriums of Venezuela and Ecuador. Proc. Amer. Acad. Arts 54: 331-367.

- $1919 a$. On tropical American Compositae, chiefly Eupatorieae. Proc. Amer. Acad. Arts 55: 3-41.

- 1919b. A recension of the Eupatoriums of Peru. Proc. Amer. Acad. Arts 55: 42-88.

- 1920a. Further diagnoses and notes on tropical American Eupatorieae. Contr. Gray Herb. n.s. 61: 3-30.

- 1920b. The Eupatoriums of Bolivia. Contr. Gray Herb. n.s. $61: 30-80$.

—_. 1922a. Records preliminary to a general treatment of the Eupatorieae, 1. Contr. Gray Herb. n.s. 64: 3-21.

- 1922b. The Mikanias of northern and western South America. Contr. Gray Herb. n.s. 64: 21-116.

- 1922c. Dyscritothamnus, a new genus of Compositae. Contr. Gray Herb. n.s. 65: 24-28, 1 pl.

- $1922 d$. Records preliminary to a general treatment of the Eupatorieae, II. Contr. Gray Herb. n.s. 65: 46-54.

- 1923. Records preliminary to a general treatment of the Eupatorieae, III. Contr. Gray Herb. n.s. 68: 3-43.

- 1924. Records preliminary to a general treatment of the Eupatorieae, IV. Contr. Gray Herb. n.s. 73: 3-31.

- 1925. Records preliminary to a general treatment of the Eupatorieae, V. Contr. Gray Herb. n.s. 75: 3-15.

- 1926a. Records preliminary to a general treatment of the Eupatorieae, VI. Contr. Gray Herb. n.s. 77: 3-62.

- 1926b. 16. Eupatorium-17. Ophryosporus. In P. C. Standley (editor), Trees and Shrubs of Mexico. Contr. U.S. Natl. Herb. 23: 1432-1470.

- 1928. Records preliminary to a general treatment of the Eupatorieae, VII. Contr. Gray Herb. n.s. 80: 3-42.

- 1930a. Ageratum (Coelestina) Siandleyi. In P. C. Standley (editor), Woody Plants of Siguatepeque, Honduras. J. Arnold Arbor. 11: 44.

- 1930b. Eupatorium (Subimbricata) hondurense. In P. C. Standley (editor), Woody Plants of Siguatepeque, Honduras. J. Arnold Arbor. 11: 44-45.

- 1930c. Records preliminary to a general treatment of the Eupatorieae, VIII. Contr. Gray Herb. n.s. 90: 3-36.

- 1930d. Observations on the genus Stevia. Contr. Gray Herb. n.s. 90: 36-58, 1 pl.

- 1930e. The Stevias of the Argentine Republic. Contr. Gray Herb. n.s. 90: 58-79.

- 1930f. The Stevias of Paraguay. Contr. Gray Herb. n.s. 90: 79-90.

- $1930 \mathrm{~g}$. The Stevias of North America. Contr. Gray Herb. n.s. 90: 90-160.

_. 1931a. Compositae-Eupatorieae. In H, A. Gleason (editor), Botanical Results of the Tyler-Duida Expedition. Bull. Torrey Bot. Club 58: 482-485. 
1931b. Records preliminary to a general treatment of the Eupatorieae, IX. Contr. Gray Herb. n.s. 96: 3-27.

- 1931c. The Stevias of Colombia. Contr. Gray Herb. n.s. 96: 28-36.

- 1931d. The Stevias of Venezuela. Contr. Gray Herb. n.s. 96: $37-43$.

. 1931e. The Stevias of Ecuador. Contr. Gray Herb. n.s. 96: $43-49$.

- 1932a. Records preliminary to a general treatment of the Eupatorieae, X. Contr. Gray Herb. n.s. 100: 3-19.

- 1932b. The Stevias of Peru. Contr. Gray Herb. n.s. 100: 20-36.

- 1932c. The Stevias of Bolivia. Contr. Gray Herb. n.s. 100: 36-39.

-1933. Taxonomic notes on several South American Eupatoriums. Pp. 349-358 in Ostenia, Coleccion de Trabajos Botanicos Dedicados a Don Cornelio Osten en Ocasion del LXX Aniversario de su Nacimiento. Montevideo.

- 1934a. Records preliminary to a general treatment of the Eupatorieae, XI. Contr. Gray Herb. n.s. 104: 3-49.

- $1934 \mathrm{~b}$. The variability of two wide-ranging species of Mikania. Contr. Gray Herb. n.s. 104: 49-55.

-1934c. Mikania scandens and its near relatives. Contr. Gray Herb. n.s. 104: 55-71.

- 1934d. New Compositae-Eupatorieae from Brazil. Candollea 5: 170-174.

\& J. M. Greenman. 1895. II. New and noteworthy plants, chiefly from Oaxaca, collected by Messrs. C. G. Pringle, L. C. Smith, and E. W. Nelson. Amer. J. Sci., Ser. 3, 50: 150-168.

- \& 1896. Synopsis of the Mexican and Central American species of the genus Mikania. Proc. Amer. Acad. Arts 32: 10-13.

$-\&-$ 1899. Supplementary notes upon Calea, Tridax, and Mikania. Proc. Boston Soc. Nat. Hist. 29: 105108.

- \& H. E. SEATON. 1893. Additions to the phanerogamic flora of Mexico discovered by C. G. Pringle in 1891-1892. Proc. Amer. Acad. Arts 28: 103-115.

Robinson, H. 1970. South American species of Stomatanthes (Eupatorieae, Compositae). Phytologia 20: 334-338.

-1977. An analysis of the characters and relationships of the tribes Eupatorieae and Vernonieae (Asteraceae). Syst. Bot. 2: 199-208.

- 1979. Two new genera of Vernonieae (Asteraceae) from Brasil, Heterocypsela and Pseudostifftia. Phytologia 44: 442450.

-1980. Notes on the Lychnophorine genera Chresta and Eremanthus. Phytologia 45: 89-100.

-1981. A revision of the tribal and subtribal limits of the Heliantheae (Asteraceae). Smithsonian Contr. Bot. 51: $1-102$.

- 1983. A generic review of the Tribe Liabeae (Asteraceae). Smithsonian Contr. Bot. 54: 1-69.

- 1984. Style rotation in the Asteraceae. Taxon 33:400404.

— \& R. D. Brettell. 1974. Studies in the Senecioneae (Asteraceae). V. The genera Psacaliopsis, Barkleyanthus, Telanthophora and Roldana. Phytologia 27: 402-439.

- \& R. M. King. 1977. Chapter 15. Eupatorieae-systematic review. Pp. 437-485 in V. H. Heywood, J. B. Harborne \& B. L. Turner (editors), The Biology and Chemistry of the Compositae. Academic Press, London, New York, San Francisco.

\& - 1980. Phytogeographical patterns in the tribe Eupatorieae (Asteraceae). Bol. Soc. Argent. Bot. 19: 45-52.

- F. Bohlmann \& R. M. King. 1979. Chemosystematic notes on the Asteraceae II. Acyclic sesquiterpenes. Phytologia 41: 387-395.

- A. M. Powell, R. M. King \& J. F. Weedin. 1981. Chromosome numbers in Compositae, XII: Heliantheae. Smithsonian Contr. Bot. 52: 1-28.

RusBy, H. H. 1893. New genera of plants from Bolivia. Bull. Torrey Bot. Club 20: 429-434.

Rydberg, P. A. 1914. Family 2. Carduaceae. Tribe 10. Helenieae. In N. L. Britton, W. L. Murrill \& T. H. Barnhart (editors), N. Amer. Fl. 34(1): 1-80.

RzEDOwsKı, J. 1970. Estudio sistematico del genero Microspermum (Compositae). Bol. Soc. Bot. México 31: 49-107.

-1972. Dos especies nuevas del genero Microspermum (Compositae) del Estado de Jalisco (Mexico). Bol. Soc. Bot. México 32: 77-86.

- 1978. Claves para la identificación de los géneros de la Familia Compositae en México. Acta Ci. Potos. 7: 5-145.

SCHreber, J. C. D. von (EDITOR). 1791. Genera Plantarum. 8th edition. 2 Volumes. Frankfurt.

Schulte-Bipontinus, C. H. 1850. Fleischmannia novum plantarum genus. Flora 27: 417-418.

- 1856. Tribus II, Eupatoriaceae. In B. C. Seemann (editor), Bot. Voy. Herald (Flora of northwestern Mexico) 7,8: 298-301.

Seaman, F. C. 1982. Sesquiterpene lactones as taxonomic characters in the Asteraceae. Bot. Rev. (Lancaster) 48: 121-595.

SeEmanN, B. C. 1852-1857. The Botany of the Voyage of H.M.S. Herald. London.

SHINNERS, L. H. 1943. A revision of the Liatris scariosa complex. Amer. Midl. Naturalist 29: 27-41.

1946. Revision of the genus Kuhnia L. Wrightia 1: $122-144$.

- 1951. Notes on Texas Compositae-VII. Field \& Lab. 19: 74-82.

- 1955. Notes on Compositae-X. Field \& Lab. 23: 3436.

. 1971. Kuhnia L. transferred to Brickellia Ell. (Compositae). Sida 4: 274.

Skvarla, J. J., B. L. Turner, V. C. Patel \& A. S. Tomb. 1977. Chapter 8. Pollen morphology in the Compositae and in morphologically related families. Pp. 141-248 In V. H. Heywood, J. B. Harborne \& B. L. Turner (editors), The Biology and Chemistry of the Compositae. Academic Press, London, New York, San Francisco.

Small, J. 1917a. The origin and development of the Compositae. New Phytologist 16: 157-177.

- $1917 \mathrm{~b}$. The origin and development of the Compositae. Chapter II. New Phytologist 16: 198-221.

- 1917c. The origin and development of the Compositae. Chapter 11I. New Phytologist 16: 253-276.

- $1918 a$. The origin and development of the Compositae. Chapter 1V. New Phytologist 17: 13-40.

- $1918 \mathrm{~b}$. The origin and development of the Compositae. Chapter V. New Phytologist 17: 69-94.

- 1918c. The origin and development of the Compositae. Chapters VI-V11I. New Phytologist 17: 114-142. 
1918d. The origin and development of the Compositae. Chapter IX. New Phytologist 17: 200-230.

- $1919 a$. The origin and development of the Compositae. Chapter X. New Phytologist 18: 1-35.

- $1919 b$. The origin and development of the Compositae. Chapter XI. New Phytologist 18: 65-89.

- $1919 c$. The origin and development of the Compositae. Chapter XII. New Phytologist 18: 129-176.

- $1919 d$. The origin and development of the Compositae. Chapter XIII. New Phytologist 18: 201-234.

Small, J. K. 1924. Plant novelties from Florida. Bull. Torrey Bot. Club 51: 379-393.

SoARes Nunes, J. M. 1981. Contribuição ao conhecimento das Compostas Brasileiras. Bradea 3(18): 129-138.

Soejarto, D. D., C. M. Compadre \& A. D. Kinghorn. 1983. Ethnobotanical notes on Stevia. Bot. Mus. Leafl. 29: 1-25.

- A. D. Kinghorn \& N. R. Farnsworth. 1982. Potential sweetening agents of plant origin. III. Organoleptic evaluation of Stevia leaf herbarium samples for sweetness. J. Nat. Prod. (Lloydia) 45: 590-599.

Sørensen, N. A. 1977. Chapter 13. Polyacetylenes and conservatism of chemical characters in the Compositae. $\mathrm{Pp}$. 385-409 in V. H. Heywood, J. B. Harborne \& B. L. Turner (editors), The Biology and Chemistry of the Compositae. Academic Press, London, New York, San Francisco.

Solbrig, O. T. 1963. Subfamilial nomenclature of Compositae. Taxon 12: 229-235.

SOLEREDER, H. 1908. Systematic Anatomy of the Dicotyledons (translation). Clarendon Press, Oxford.

SPACH, E. 1841. Histoire Naturelle des Végétaux. Phanérogames. Volume 10. Paris.

Standley, P. C. 1938. Compositae. In Flora of Costa Rica. Field Mus. Nat. Hist., Bot. Ser 18(4): 1418-1538.

Steetz, J. 1854. Tribus II. Eupatoriaceae. In B. C. Seemann (editor), Bot. Voy. Herald, Flora of the Isthmus of Panama 4: 142-151, pl. 29.

Steyermark, J. A. 1953. III. Compositae. In Botanical exploration in Venezuela. Fieldiana, Bot. 28: 620-678.

Steyskal, G. C. 1974. A new species of Procecidochares (Diptera: Tephritidae) causing galls on stems of Hamakua $\mathrm{Pa}-$ makani (Ageratina riparia: Asteraceae) in Hawaii. U.S. Dept. Agric., Coop. Econ. Ins. Rep. 24(32): 639-641.

Stone, A. 1947. A new Procecidochares from Eupatorium stems (Diptera: Tephritidae). Proc. Hawaiian Entomol. Soc. 13: 97-98.

Strother, J. L. 1983. More chromosome studies in Compositae. Amer, J. Bot. 70: 1217-1224.

Stuessy, T. F. 1977. Chapter 23. Heliantheae-systematic review. Pp. 621-671 in V. H. Heywood, J. B. Harborne \& B. L. Turner (editors), The Biology and Chemistry of the Compositae. Academic Press, London, New York. San Francisco.

Sullivan, V. I. 1975. Pollen and pollination in the genus Eupatorium (Compositae). Canad. J. Bot. 53: 582-589.

- 1976. Diploidy, polyploidy, and agamospermy among species of Eupatorium (Compositae). Canad. J. Bot. 54: 29072917.

TAUBERT, P. 1896. Beiträge zur Kenntnis der Flora des central brasilianischen Staates Goyaz mit einer pflanzengeographischen Skizze von E. Ule. Bot. Jahrb. Syst. 21: 402-457.

Timmermann, B. N., R. Mues, T. J. Mabry \& A. M. Powell. 1979. 6-methoxyflavonoids from Brickellia laciniala (Compositae). Phytochemistry 18: 1855-1858.
Toman, J., J. Harmatha \& L. Novotny. 1968. Verwandschaftsbeziehungen der Gattung Adenostyles und bie Berechtigung ihrer Einreihung in die Tribus Senecioneae. Preslia 40: 122-132.

TOURNEFORT, J.P. DE. 1700. Institutiones rei Herbariae, Editio Altero. 3 Volumes. Paris.

Turczaninow, N. 1847-1848. Decades 3, 4, et 5 generum adhuc non descriptorum, adjectis descriptionibus nonnullarum specierum Myrtacearum xerocarpicarum atque Umbelliferarum imperfectarum. Bull. Soc. Imp. Naturalistes Moscou 20: 148-174; 21: 570-591.

TURNER, B. L. 1966. Taxonomy of Eutetras. Southw. Naturalist 11: $118-122$.

-1977. New species of Eupatorium (Asteraceae) from northcentral Mexico. Wrightia 5: 352-354.

- 1978. A new species of Brickellia. subgenus Phanerostylis (Asteraceae). Brittonia 30: 342-344.

- 1983a. A new species of Critonia (Asteraceae-Eupatorieae) from Belize. Phytologia 52: 491-492.

- 1983b. Two new species of Koanophyllon (AsteraceaeEupatorieae) from northeastern Mexico. Phytologia 52: $495-$ 498.

- 1983c. Two new species of Ageratina (AsteraceaeEupatorieae) from northcentral Mexico. Phytologia 53: 241244.

- 1985. A new species of Brickellia subgenus Phanerostylis (Asteraceae) from Nuevo León, Mexico. Phytologia 58: $492-496$.

— \& D. FIYR. 1966. Chromosome numbers in the Compositae. X. North American species. Amer. J. Bot. 53: 2433.

— \& A. M. Powell. 1977. Chapter 25. Helenieae-systematic review. Pp. 699-737 In V. H. Heywood, J. B. Harborne \& B. L. Tumer (editors), The Biology and Chemistry of the Compositae. Academic Press, London, New York, San Francisco.

- - \& R. M. KING. 1962. Chromosome numbers in the Compositae VI. Additional mexican and guatemalan species. Rhodora 64: 251-271.

$\longrightarrow,-$ \& J. Cuatrecasas. 1967. Chromosome numbers in Compositae. XI. Peruvian species. Ann. Missouri Bot. Gard. 54: 172-177.

Ulubelen, A., B. N. Timmermann \& T. J. Mabry. 1980. Flavonoids from Brickellia chlorolepis and B. dentata. Phytochemistry 19: 905-908.

URBAN, I. 1900. V. Species nova, praesertim portoricensis (part). Symbolae Antillanae seu Fundamenta Forae Indiae Occidentalis 1(3): 385-481.

- 1925. Ciceronia. In Sertum Antillarum, XXIII. Repert. Spec. Nov. Regni Veg. 21: 224-225.

- 1931. Compositae. In Plantae Haitienses et Domingenses novae vel rariores IX. a cl. E. L. Ekman 1924-1930 lectae, Ark. Bot. 23A(11): 1-103, pl. 1-5.

Vichnew'SkI, W., P. Kulanthaival, V. L. Goedken \& W. Herz. 1985. Two sesquiterpene lactones from Trichogonia gardneri. Phytochemistry 24: 291-296.

ViS, E. \& H. G. Fletcher, JR. 1957. Stevioside. IV. Evidence that Stevioside is a sophoroside, J. Amer. Chem. Soc. 78: 4709-4710 (1956?).

Voss, E. G. 1961. Harley Harris Bartlett. Bull. Torrey Bot. Club 88: 47-56. 
WAGENITz, G. 1976. Systematics and phylogeny of the Compositae (Asteraceae). PI. Syst. Evol. 125: 29-46.

WAGNer, H., M. A. IYengar, L. Horhammer \& W. Herz. 1972. Flavonol-3-glycosides in eight Eupatorium species. Phytochemistry 11: 1504-1505.

- \& W. HERZ. 1973. Flavonoids in ten Liatris species. Phytochemistry 12: 2063-2064.

Wahlberg, I., K. Karlsson \& C. R. Enzell. 1972. Non-volatile constituents of Deertongue leaf. Acta Chem. Scand. 26: 1383-1388.

WALPERS, W. G. 1846-1847. Repertorium Botanices Systematicae. Volume 6. Leipzig.

Watson, S. 1890. Contributions to American botany. 2. Descriptions of new species of plants from northem Mexico, collected chiefly by Mr. C. G. Pringle in 1888 and 1889. Proc. Amer. Acad. Arts 25: 141-163.

Watson, T. J. 1973. Chromosome numbers in Compositae from the southwestern United States. Southw. Naturalist 18: 117-124.
WIEGAND, K. M. 1920. Eupatorium purpureum and its allies. Rhodora 22: 57-70.

WIEGAND, K. M. \& C. A. WEATHERBy, 1937. The nomenclature of the verticillate Eupatoria. Rhodora 39: 297-306.

Willdenow, C. L. (EDitor). 1803. Species Plantarum. 4th edition. 3(3): 1475-2409.

Williams, L. O. 1961. Tropical American plants II. Fieldiana, Bot. 29: 345-372.

- 1975. Tropical American plants XVII. Fieldiana, Bot. 36: $77-100$.

- 1976. Tribe II. Eupatorieae. In D. L. Nash \& L. O. Williams (editors), Flora of Guatemala. Fieldiana, Botany 24(12): i-x, 1-603.

Wooten, J. W. \& A. E. Clewell. 1971. Fleischmannia and Conoclinium (Compositae, Eupatorieae) in eastern North America. Rhodora 73: 566-574.

YAPP, R. H. 1906. Fruit dispersal of Adenostemma viscosum. Ann. Bot. (London) 20(79): 311-316, pl. 23. 


\section{NOMENCLATOR OF THE EUPATORIEAE}

The following list of names includes all those known for the Eupatorieae and all that have been proposed under genera that are now recognized as Eupatorieae. The publication data is provided for each name, and when the name is a synonym, the present disposition is provided. The list will allow users to discover the identity in the present system of any name from previous systems. Use will be limited by the extensive misapplication of names in past systems. Varieties are included in the list only in the rare instances where they are basionyms of taxa later elevated to species level.

The form of citation below of literature and authors is mostly according to standardized abbreviations in the Kew draft list, B-P-H (Botanico-Per-

Acam hostyles buniifolius (Hook. \& Arn.) R. King \& H. Robinson, Phytologia 22: 111. 1971.

Acanthostyles sancechicoensis (Hieron.) R. King \& H. Robinson, Phytologia 22: 112. 1971.

Acritopappus confertus (Gardner) R. King \& H. Robinson, Phytologia 24: 402. 1972.

Acritopappus connatifolius (Soares Nunes) R. King \& H. Robinson, Phytologia 48: 22I. 1981.

Acritopappıs hagei R. King \& H. Robinson, Phytologia 45: 142. 1980.

Acritopappus harleyi R. King \& H. Robinson, Phytologia 38: 100. 1977.

Acritopappus heterolepis (Baker) R. King \& H. Robinson, Phytologia 45: 147. 1980.

Acritopappus irwinii R. King \& H. Robinson, Phytologia 24: 402. 1972.

Acritopappus longifolins (Gardner) R. King \& H. Robinson, Phytologia 24: 403. 1972.

Acritopappus micropappus (Baker) R. King \& H. Robinson, Phytologia 38: 100. 1977.

Acritopappus morii R. King \& H. Robinson, Phytologia 45: 143. 1980.

Acritopappus prunifolius R. King \& H. Robinson, Phytologia 45: 144. 1980.

Acritopappus santosii R. King \& H. Robinson, Phytologia 45: 145. 1980.

Acritopappus subtomentosus R. King \& H. Robinson. Phytologia 45: 146. 1980.

Acritopappns teixeirae R. King \& H. Robinson, Phytologia 45: 146. 1980.

Addisonia boliviana Rusby, Descr. S. Amer. PI. 147. 1920. = Helogyne straminea (DC.) B. Robinson.

Addisonia virgata Rusby, Bull. Torrey Bot. Club 20: 432. 1893. = Helogyne straminea (DC.) B. Robinson.

Adenocritonia adainsii R. King \& H. Robinson, Phytologia 33: 281(-282). 1976

Adenostemma angustifolium Arn., Nova Acta Phys.-Med. Acad. Caes. Leop.-Carol. Nat. Cur. 18(1): 347. 1836.

Adenostemma aquaticum D. Don, Prodr. FI. Nepal. 181. 1825. = Adenostemina laveria (L.) Kuntze.

Adenostemma berterii DC., Prodr. 5: 110. 1836.

Adenostemma biflorum Less., Syn. Gen. Compos. 156. 1832. = Wollastonia biflora (Less.) DC. HellantheAE.
iodicum-Huntianum) and TL-2 (Taxonomic Literature, 3d. 2). In this way, the familiar B. L. Robinson, a leading botanist of the first third of the century, author of the seventh edition of Gray's Manual, professor to students like S. F. Blake, L. B. Smith, and Julian Steyermark, and specialist in the Eupatorieae, becomes B. Robinson.

Omitted from the list are five species described under the genus name Eupatorium Bubani (1900), E. dioscoridis Bubani, E. hirsutum Nieuwl., E. molle Nieuwl., E. parviflorum Nieuwl, and E. rostellatum Nieuwl. This latter genus is a synonym of Agrimonia in the Rosaceac. The species do not belong to the Asteraceae, but they preoccupy combinations under the name Eupatorium.

Adenostemma brasilianum Cass., Dict. Sci. Nat. 25: 363. 1822. Adenostemma caffrum DC., Prodr. 5: 112. 1836.

Adenostemma cuatrecasasii R. King \& H. Robinson, Phytologia 29: 5(-6). 1974.

Adenostemma decumbens Don ex Heynh., Nom. Bot. Hort. I: 19. 1840. = Adenostemma berterii DC.

Adenostemma dregei DC., Prodr. 5: 111. 1836. = Adenostemma viscosium Forster.

Adenostemma elatuin D. Don, Prodr. Fl. Nepal. 181. 1825. = Adenostemma lavenia (L.) Kuntze.

Adenostemma erectum DC., Prodr. 5: 113. 1836. = Adenostemma lavenia (L.) Kuntze.

Adenostemma fastigiatmm (Blume) DC., Prodr. 5: 111. 1836. = Adenostemma lavenia (L.) Kuntze.

Adenosiemma flintii R. King \& H. Robinson, Phytologia 54: 29. 1983.

Adenostemma fosbergii R. King \& H. Robinson, Phytologia 29: 6(-7). 1974.

Adenostemma glntinosnm DC., Prodr. 5: 111. 1836. = Adenostemtma viscosum Forster.

Adenostemma goyazense R. King \& $\mathrm{H}$. Robinson, Phytologia 54: 30. 1983.

Adenostemma gymnocoronis Schultz-Bip. ex Baker, Fl. Bras. 6(2): 183. 1876, nom. nud. = Gymnocoronis spilanthoides DC Adenostemma hirsutum (Blume) DC., Prodr. 5: 113. 1836. Adenostemma hirtiflorum Benth., Pl. Hartw. 75. 1841.

Adenostemma involucratum R. King \& H. Robinson, Phytologia 29: 7(-8). 1974.

Adenostemma lanceolatum Miq., Fl. Ned. Ind. 2: 24. 1856.

Adenostemma latifolium D. Don, Prodr. Fl. Nepal. 181. 1825. = Adenosteinma lavenia (L.) Kuntze.

Adenostemma lavenia (L.) Kuntze, Revis. Gen. Pl. 1: 304. 1891. Adenostemma leiocarpum DC. in Wight, Contr. Bot. India 9. 1834. = Adenostemma lavenia (L.) Kuntze.

Adenostemma macrophyllum (Blume) DC., Prodr. 5: 113. 1836. = Adenostemma viscosum Forster.

Adenostemma madurense DC. in Wight, Contr. Bot. India 9. 1834.

Adenostemma mauritiannm DC., Prodr. 5: 110. 1836.

Adenostemma microcephalum DC., Prodr. 5: $111.1836 .=\mathrm{Ad}-$ enostemma viscosum Forster.

Adenostemma natalense DC., Prodr. 5: 112. 1836. = Adenostemma viscosum Forster. 
Adenostemma nutans Greenman, Publ. Field Columbian Mus., Bot. Ser. 2: 344. 1912. = Gymnocoronis nutans (Greenman) R. King \& H. Robinson.

Adenostemma ovatum Miq., Fl. Ned. Ind. 2: 25. 1856. $=\mathrm{Ad}$ chostemma viscosum Forster.

Adenostemma pakaraimae Maguire \& Wurd., Mem. New York Bot. Gard. 9: 366. 1957. = Sciadocephala pakaraimae (Maguire \& Wurd.) R. King \& H. Robinson.

Adenostemma pariflorum (Blume) DC., Prodr. 5: 111. 1836. = Adenostemma viscosum Forster.

Adenostemma perrottetii DC., Prodr. 5: 110. 1836. = Adenostemma viscosum Forster.

Adenostemma platyphyllum Cass., Dict. Sci. Nat. 25: 363.1822.

Adenostemma renschii Koster, Blumea 1: 482. 1935.

Adenostemma reticulatum DC. in Wight, Contr. Bot. India 8. 1834. = Adenostemma mauritianum DC.

Adenostemma rivale Dalz., Hooker's J. Bot. Kew Gard. Misc. 3: 231. 1851. = Adenostemma lavenia (L.) Kuntze.

Adenostemma roylei DC., Prodr. 5: 112. 1836. = Adenostemma madurense DC. in Wight.

Adenostemma rufescens Schultz-Bip., Syst. Verzeich. 120. 18541855 , ignota.

Adenostemma rugosum DC. in Wight, Contr. Bot. India 8. 1834. = Adenostemma lavenia (L.) Kuntze.

Adenostemma scaevolifolium Martius ex Baker, Fl. Bras. 6(2): 186. 1876. = Adenostemma suffruticosum Gardner.

Adenostemma schimperi Schultz-Bip. ex A. Rich., Tent. Fl. Abyss. 4: 382. 1847.

Adenostemma suffruticosum Gardner, London J. Bot. 6: 433. 1847.

Adenostemma swartzii Cass., Dict. Sci. Nat. 25: 362. 1822. = Adenostemma verbesina (L.) Kuntze.

Adenostemma tinctorimm (Lour.) Cass.. Dict. Sci. Nat. 25: 364. 1822.

Adenostemma triangulare DC., Prodr. 5: 113. 1836. = Adenostemma brasilianum Cass.

Adenostemma vargasii $\mathrm{R}$. King \& H. Robinson, Phytologia 54: 31. 1983.

Adenostemma verbesina (L.) Kuntze, Revis. Gen. PI. 1: 304. 1891.

Adenostemma viscosum Forster, Char. Gen. PI. 90. 1776.

Adenostemma vitiense H. Robinson, Phytologia 29: 8(-9). 1974.

Ageratella microphylla (Schultz-Bip.) A. Gray ex S. Watson, Proc. Amer. Acad. Arts 22: 419. 1887.

Ageratella palmeri (A. Gray) B. Robinson, Proc. Amer. Acad. Arts 41: 272. 1905

Ageratina abronia (Klatt) R. King \& $\mathrm{H}$. Robinson, Phytologia 24: 80. 1972. = Ageratina prumellaefolia $($ H. B. K.) R. King \& H. Robinson.

Ageratina acutidentata (B. Robinson) R. King \& H. Robinson, Phytologia 19: 219. 1970.

Ageratina adenachaenia (Schultz-Bip. ex Klatı) R. King \& H. Robinson, Phytologia 19: 219. 1970.

Ageratina adenophora (Sprengel) R. King \& H. Robinson, Phytologia 19: 211. 1970.

Ageratina aegirophylla (B. Robinson) R. King \& H. Robinson, Phytologia 19: 219. 1970.

Ageratina ageratoides (L. f.) Spach. Hist. Nat. Veg. 10:286. 1841. $=$ Ageratina altissima (L.) R. King \& H. Robinson.

Ageratina allenii (Standley) R. King \& H. Robinson, Phytologia 24: 80.1972.

Ageratina almedae R. King \& H. Robinson, Phytologia 38: 326. 1978.

Ageratina altissima (L.) R. King \& H. Robinson, Phytologia 19: 212. 1970

Ageratina amblyolepis (B. Robinson) R. King \& H. Robinson, Phytologia 19: 212. 1970.

Ageratina ampla (Benth.) R. King \& H. Robinson, Phytologia 19: 219.1970
Ageratina anchistea (Grashoff \& Beaman) R. King \& H. Robinson, Phytologia 24: 80. 1972.

Ageratina angustifolia (H. B. K.) R. King \& H. Robinson, Phytologia 19: 219. 1970. = Ageratina asclepiadea (L. f.) R. King \& H. Robinson.

Ageratina anisochroma (Klatt) R. King \& H. Robinson, Phytologia 19: 218. 1970.

Ageratina apollinairei (B. Robinson) R. King \& H. Robinson, Phytologia 19: 212. 1970.

Ageratina arbutifolia (Benth.) R. King \& H. Robinson, Phytologia 19: 219.1970.

Ageratina aristeguictii R. King \& H. Robinson, Phytologia 35: 497. 1977.

Ageratina aristei (B. Robinson) R. King \& H. Robinson, Phytologia 19: 219. 1970.

Ageratina aromatica (L.) Spach, Hist. Nat. Veg. 10: 286. 1841.

Ageratina arsenei (B. Robinson) R. King \& H. Robinson, Phytologia 19: 212. 1970.

Ageratina articulata (Schultz-Bip. ex Hieron.) R. King \& H. Robinson, Phytologia 19: 212. 1970.

Ageratina aschenborniana (Schauer) R. King \& H. Robinson, Phytologia 19: 212. 1970. = Ageratina bustamenta (DC.) $\mathbf{R}$. King \& H. Robinson.

Ageratina asclepiadea (L. f.) R. King \& H. Robinson, Phytologia 60:80. 1986

Ageratina atrocordata (B. Robinson) R. King \& H. Robinson, Phytologia 19: 212. 1970.

Ageratina austin-smithii R. King \& $\mathrm{H}$. Robinson, Phytologia 28: 494. 1974.

Ageratina azangaroensis (Schultz-Bip. ex Wedd.) R. King \& H. Robinson, Phytologia 19: 212. 1970.

Ageratina baccharoides (H. B. K.) R. King \& H. Robinson, Phytologia 19: 219. 1970.

Ageratina badia (Klatt) R. King \& H. Robinson, Phytologia 19: 212. 1970.

Ageratina barbensis R. King \& H. Robinson, Phytologia 24: 83. 1972.

Ageratina barclayae R. King \& H. Robinson, Phytologia 54: 38. 1983.

Ageratina bellidifolia (Benth.) R. King \& H. Robinson, Phytologia 19: 212.1970.

Ageratina betulaefolia (E. Greene) R. King \& H. Robinson, Phytologia 19: 219. 1970.

Ageratina bimatra (Standley \& L. O. Williams) R. King \& H. Robinson, Phytologia 19: 212. 1970. = Fleischmannia microstemon (Cass.) R. King \& H. Robinson.

Ageratina bishopii R. King \& H. Robinson, Phytologia 54: 37. 1983.

Ageratina blepharilepis (Schultz-Bip.) R. King \& H. Robinson, Phytologia 19: 219. 1970.

Ageratina boekei R. King \& H. Robinson, Phytologia 54: 39. 1983.

Ageratina boyacensis R. King \& H. Robinson, Phytologia 24: 84 1972.

Ageratina brandegeana (B. Robinson) R. King \& H. Robinson, Phytologia 19: 219. 1970.

Ageratina breedlovei R. King \& H. Robinson, Phytologia 58: 259. 1985.

Ageratina brevipes (DC.) R. King \& H. Robinson, Phytologia 19: 219. 1970.

Ageratina burgeri R. King \& H. Robinson, Phytologia 24: 85. 1972.

Ageratina bustamenta (DC.) R. King \& H. Robinson, Phytologia 19: 213. 1970.

Ageratina caeciliae (B. Robinson) R. King \& H. Robinson, Phytologia 19: 220. 1970.

Ageratina calaminthacfolia (H. B. K.) R. King \& H. Robinson. Phytologia 19: 220. 1970. 
Ageratina calderillensis (Hieron.) R. King \& H. Robinson, Phytologia 19: 213. 1970.

Ageratina calophylla (B. Robinson) R. King \& H. Robinson, Phytologia 19: 220. 1970.

Ageratina camachensis (Hieron.) R. King \& H. Robinson, Phytologia 19: 213. 1970.

Ageratina campyloclada (B. Robinson) R. King \& H. Robinson, Phytologia 19: 220. 1970.

Ageratina cardiophylla (B. Robinson) R. King \& H. Robinson, Phytologia 19: 220. 1970.

Ageratina carmonis (Standley \& Steyerm.) R. King \& H. Robinson, Phytologia 49: 3. 1981.

Ageratina cartagoensis R. King \& H. Robinson, Phytologia 24: 85. 1972.

Ageratina cerifera (McVaugh) R. King \& H. Robinson, Phytologia 24: 86. 1972.

Ageratina chachapoyasensis (Cuatrec.) R. King \& H. Robinson, Phytologia 19: 220. 1970.

Ageratina chapalensis (S. Watson) R. King \& H. Robinson, Phytologia 19: 220. 1970. = Ageratina lasioneura (Hook. \& Arn.) R. King \& H. Robinson.

Ageratina chiapensis (B. Robinson) R. King \& H. Robinson, Phytologia 19: 213. 1970. = Ageratina vernalis (Vatke \& Kurtz) R. King \& H. Robinson.

Ageratina chiriquensis (B. Robinson) R. King \& H. Robinson, Phytologia 19: 213. 1970.

Ageratina choricephala (B. Robinson) R. King \& H. Robinson, Phytologia 19: 213. 1970.

Ageratina choricephaloides (B. Robinson) R. King \& H. Robinson, Phytologia 19: 213. 1970.

Ageratina ciliata (Less.) R. King \& H. Robinson, Phytologia 19: 213. 1970.

Ageratina collodes (B. Robinson \& Greenman) R. King \& H. Robinson, Phytologia 19: 220. 1970.

Ageratina conspicua [Kunth \& Bouche] R. King \& H. Robinson, Phytologia 19: 213. 1970. ="Ageratina grandifolia (Regel) R. King \& H. Robinson.

Ageratina comigua R. King \& H. Robinson, Phytologia 58: 258. 1985.

Ageratina contorna (C. Adams) R. King \& H. Robinson, Phytologia 24: 87. 1972.

Ageratina cordata (Walter) Spach, Hist. Nat. Veg. 10: 286. 1841. = Ageratina aromatica (L.) Spach.

Ageratina corylifolia (Griseb.) R. King \& H. Robinson, Phytologia 19: 213. 1970.

Ageratina costaricensis R. King \& H. Robinson, Phytologia 24: 87. 1972.

Ageratina crassiceps (B. Robinson) R. King \& H. Robinson, Phytologia 19: 220. 1970.

Ageratina crassiramea (B. Robinson) R. King \& H. Robinson, Phytologia 19: 228. 1970. = Pachythannus crassirameus (B. Robinson) R. King \& H. Robinson.

Ageratina cremasta (B. Robinson) R. King \& H. Robinson, Phytologia 19: 220. 1970.

Ageratina crenaea (B. Robinson) R. King \& H. Robinson, Phytologia 19: 220. 1970.

Ageratina croatii R. King \& H. Robinson, Phytologia 29: 347(348). 1975.

Ageratina cronquistii R. King \& H. Robinson, Phytologia 38: 334. 1978.

Ageratina cuatrecasasii R. King \& H. Robinson, Phytologia 24: 88. 1972.

Ageratina cuencana (B. Robinson) R. King \& H. Robinson, Phytologia 19: 213. 1970.

A geratilla cupressorum (Standley \& Steyerm.) R. King \& H. Robinson. Phytologia 24: 89. 1972. = Piptothrix areolaris (DC.) R. King \& H. Robinson.
Ageratina cutervensis (Hieron.) R. King \& H. Robinson. Phytologia 19: 213. 1970.

Ageratina cuzcoensis (Hieron.) R. King \& H. Robinson, Phytologia 19: 220. 1970.

Ageratina cylindrica (McVaugh) R. King \& H. Robinson, Phytologia 24: 89. 1972.

Ageratina dasyneura (B. Robinson) R. King \& H. Robinson, Phytologia 19: 213. 1970.

Ageratina davidsei R. King \& H. Robinson, Phytologia 38: 327. 1978.

Ageratina deltoidea (Jacq.) R. King \& H. Robinson, Phytologia 19: 221. 1970.

Ageratina dendroides (Sprengel) R. King \& H. Robinson, Phytologia 19: 221. 1970.

Ageratina desquamans (B. Robinson) R. King \& H. Robinson, Phytologia 19: 221. 1970.

Ageratina dictyoneura (Urban) R. King \& H. Robinson, Phytologia 19: 221. 1970.

Ageratina diversipila R. King \& H. Robinson, Phytologia 24: 89. 1972.

Ageratina dolichobasis (McVaugh) R. King \& H. Robinson, Phytologia 24: 90. 1972.

Ageratina dombeyana (DC.) R. King \& H. Robinson, Phytologia 19: 221. 1970.

Ageratina durangensis (B. Robinson) R. King \& H. Robinson, Phytologia 19: 221. 1970.

Ageratina elegans (H. B. K.) R. King \& H. Robinson, Phytologia 19: 221. 1970.

Ageratina enixa (B. Robinson) R. King \& H. Robinson, Phytologia 19: 214. 1970.

Ageratina ernstii R. King \& H. Robinson, Phytologia 38: 336. 1978.

Ageratina esmeraldae (Cuatrec.) R. King \& H. Robinson. Phytologia 24: 90. 1972. = Ageratina rhypodes (B. Robinson) R. King \& H. Robinson.

Ageratina espinosarum (A. Gray) R. King \& H. Robinson, Phytologia 19: 221. 1970.

Ageratina etlensis (B. Robinson) R. King \& H. Robinson, Phytologia 19: 221. 1970.

Ageratina exserto-venosa (Klatt) R. King \& H. Robinson, Phytologia 19: 221. 1970.

Ageratina fastigiata (H. B. K.) R. King \& H. Robinson, Phytologia 19:221. 1970.

Ageratina flaviseta (B. Robinson) R. King \& H. Robinson, Phytologia 19: 221. 1970.

Ageratina flourensifolia (B. Turner) R. King \& H. Robinson, Phytologia 48: 221. 1981 .

Ageratina fosbergii R. King \& H. Robinson, Phytologia 28: 495. 1974. = Ageratina atrocordata (B. Robinson) R. King \& H. Robinson.

Ageratina funckii (B. Robinson) R. King \& H. Robinson, Phytologia 19: 214. 1970.

Ageratina geminata (McVaugh) R. King \& H. Robinson, Phytologia 24: 90. 1972.

Ageratina gilbertii (B. Robinson) R. King \& H. Robinson, Phytologia 19: 214. 1970.

Ageratina glabrata (H. B. K.) R. King \& H. Robinson, Phytologia 19: 214. 1970.

Ageratina glandulifera (Hicron.) R. King \& H. Robinson, Phytologia 19: 214. 1970.

Ageratina glauca (Schultz-Bip. ex Klatt) R. King \& H. Robinson, Phytologia 19: 221. 1970.

Ageratina glechonophylla (Less.) R. King \& H. Robinson, Phytologia 19: 214. 1970.

Ageratina glischra (B. Robinson) R. King \& H. Robinson, Phytologia 19: 222. 1970.

Ageratina glococlada (B. Robinson) R. King \& H. Robinson, Phytologia 19: 222. 1970. 
Ageratina glyptophlebia (B. Robinson) R. King \& H. Robinson, Phytologia 19: 222. 1970.

Ageratina gonzalezorum B. Turner, Phytologia 58: 498. 1985.

Ageratina gracilenta (B. Robinson) R. King \& H. Robinson, Phytologia 19: 214. 1970.

Ageratina gracilis (H. B. K.) R. King \& H. Robinson, Phytologia 19: 214. 1970.

Ageratina grandidentata (DC.) R. King \& H. Robinson, Phytologia 19: 214. 1970. = Ageratina pazcuarensis (H. B. K.) R. King \& H. Robinson.

Ageratina grandifolia (Regel) R. King \& H. Robinson, Phytologia 60: 80. 1986.

Ageratina grashoffii B. Turner, Phytologia 61: 77. 1986.

Ageratina gynoxoides (Wedd.) R. King \& H. Robinson, Phytologia 19: 222. 1970.

Ageratina gypsophila B. Turner, Phytologia 57: 130. 1985.

Ageratina halbertiana (McVaugh) R. King \& H. Robinson, Phytologia 24: 90.1972.

Ageratina hartii (Urban) R. King \& H. Robinson, Phytologia 19: 222. 1970.

Ageratina havanensis (H. B. K.) R. King \& H. Robinson, Phytologia 19: 222. 1970.

Ageratina hebes (B. Robinson) R. King \& H. Robinson, Phytologia 19: 222. 1970.

Ageratina hederaefolia (A. Gray) R. King \& H. Robinson, Phytologia 19: 222. 1970.

Ageratina helenae R. King \& H. Robinson, Phytologia 24: 90. 1972.

Ageratina herbacea (A. Gray) R. King \& H. Robinson, Phytologia 19: 222. 1970.

Ageratina hidalgensis (B. Robinson) R. King \& H. Robinson, Phytologia 19: 222. 1970.

Ageratina hintonii R. King \& H. Robinson, Phytologia 28: 496. 1974.

Ageratina humboldtii (Hieron.) R. King \& H. Robinson, Phytologia 19: 222. 1970. = Ageratina asclepiadea (L. f.) R. King \& H. Robinson.

Ageratina hyssopina (A. Gray) R. King \& H. Robinson, Phytologia 19: 222, 1970.

Ageratina ibaguensis (Schultz-Bip. ex Hieron.) R. King \& H. Robinson, Phytologia 19: 214. 1970.

Ageratina illita (Urban) R. King \& H. Robinson, Phytologia 19: 222. 1970.

Ageratina infiernillensis R. King \& H. Robinson, Phytologia 24: 91. 1972.

Ageratina intercostulata (B. Robinson) R. King \& H. Robinson, Phytologia 19: 223. 1970.

Ageratina intibucensis R. King \& H. Robinson, Phytologia 38: 337. 1978.

Ageratina iodotricha (B. Robinson) R. King \& H. Robinson, Phytologia 19: 214. 1970 .

Ageratina irrasa (B. Robinson) R. King \& H. Robinson, Phytologia 19: 223. 1970

Ageratina isolepis (B. Robinson) R. King \& H. Robinson, Phytologia 19: 223. 1970.

Ageratina ixiocladon (Benth. ex Oersted) R. King \& H. Robinson, Phytologia 19: 223. 1970.

Ageratina jahnii (B. Robinson) R. King \& H. Robinson, Phytologia 19: 223. 1970.

Ageratina jucunda (E. Greene) A. Clewell \& Wooton, Brittonia 23: 142. 1971.

Ageratina kupperi (Suesseng.) R. King \& H. Robinson, Phytologia 19: 223, 1970.

Ageratina lasia (B. Robinson) R. King \& H. Robinson, Phytologia 19: 223. 1970

Ageratina lasioneura (Hook. \& Arn.) R. King \& H. Robinson, Phytologia 24: 92. 1972.
Ageratina latipes (Benth.) R. King \& H. Robinson, Phytologia 37: 455.1977.

Ageratina lemmonii (B. Robinson) R. King \& H. Robinson, Phytologia 19: 223. 1970.

Ageratina leptodictyon (A. Gray) R. King \& H. Robinson, Phytologia 19: 223. 1970.

Ageratina liebmannii (Schultz-Bip. ex Klatt) R. King \& H. Robinson, Phytologia 19: 223. 1970.

Ageratina ligustrina (DC.) R. King \& H. Robinson, Phytologia 19: 223. 1970.

Ageratina lobulifera (B. Robinson) R. King \& H. Robinson, Phytologia 19: 214. 1970.

Ageratina loeseneri (B. Robinson) R. King \& H. Robinson, Phytologia 19: 223. 1970.

Ageratina longipetiolata (Schultz-Bip. ex Rusby) R. King \& H. Robinson, Phytologia 24: 92. 1972. = Kauria longipetiolata (Schultz-Bip. ex Rusby) R. King \& H. Robinson.

Ageratina lopez-mirandae R. King \& H. Robinson, Phytologia 38: 331.1978

Ageratina lorentzii (Hieron.) R. King \& H. Robinson, Phytologia 19: 215.1970.

Ageratina luciae-brauniae (Fern.) R. King \& H. Robinson, Phytologia 19: 215. 1970.

Ageratina lucida (Ortega) R. King \& H. Robinson, Phytologia 19: 224. 1970.

Ageratina macbridei (B. Robinson) R. King \& H. Robinson, Phytologia 19: 224. 1970.

Ageratina macvanghii R. King \& H. Robinson, Phytologia 38: 335. 1978.

Ageratina mairetiana (DC.) R. King \& H. Robinson, Phytologia 19: 224. 1970.

Ageratina malacolepis (B. Robinson) R. King \& H. Robinson, Phytologia 19: 215. 1970.

Ageratina mariarum (B. Robinson) R. King \& H. Robinson, Phytologia 19: 215. 1970.

Ageratina miquihuana (B. Turner) R. King \& H. Robinson, Phytologia 37: 455. 1977.

Ageratina modesta (Kunth) R. King \& H. Robinson, Phytologia 24: 93.1972

Ageratina molinae R. King \& H. Robinson, Phytologia 24: 93. 1972.

Ageratina mortoniana (Alain) R. King \& H. Robinson, Phytologia 19: 224. 1970.

Ageratina muelleri (Schultz-Bip. ex Klatt) R. King \& H. Robinson, Phytologia 19: 215. 1970.

Ageratina multiserrata (Schultz-Bip.) R. King \& H. Robinson, Phytologia 24: 94. 1972.

Ageratina mutiscuensis (B. Robinson) R. King \& H. Robinson, Phytologia 24: 94. 1972

Ageratina mygindaefolia (A. Gray) R. King \& H. Robinson, Phytologia 19: 224. 1970.

Ageratina nelsonii R. King \& H. Robinson, Phytologia 24: 94. 1972.

Ageratina neriifolia (B. Robinson) R. King \& H. Robinson, Phytologia 19: 224. 1970.

Ageratina nesomii B. Turner, Phytologia 53: 241. 1983.

Ageratina oaxacana (Klatt) R. King \& H. Robinson, Phytologia 32: 284. 1975

Ageratina ocanensis (B. Robinson) R. King \& H. Robinson, Phytologia 19: 224. 1970.

Ageratina occidentalis (Hook.) R. King \& H. Robinson, Phytologia 19: 224. 1970.

Ageratina oligocephala (DC.) R. King \& H. Robinson, Phytologia 19: 215. 1970.

Ageratina ovilla (Standley \& Steyerm.) R. King \& H. Robinson, Phytologia 19: 224. 1970.

Ageratina pachypoda (B. Robinson) R. King \& H. Robinson, Phytologia 19: 224. 1970. 
Ageratina pacifica (B. Robinson in I. M. Johnston) R. King \& H. Robinson, Phytologia 19: 215. 1970.

Ageratina pampalcensis (B. Robinson) R. King \& H. Robinson, Phytologia 19: 215. 1970.

Ageratina paramensis (Aristeg.) R. King \& H. Robinson, Phytologia 19: 224. 1970.

Ageratina paucibracteata (Alain) R. King \& H. Robinson, Phytologia 19: 218. 1970.

Ageratina paupercula (A. Gray) R. King \& H. Robinson, Phytologia 19: 215. 1970.

Ageratina pazcuarensis (H. B. K.) R. King \& H. Robinson, Phytologia 19: 215. 1970.

Ageratina pelotropha (B. Robinson) R. King \& H. Robinson, Phytologia 19: 224. 1970.

Ageratina pentlandiana (DC.) R. King \& H. Robinson, Phytologia 19: 225. 1970.

Ageratina peracuminata R. King \& H. Robinson, Phytologia 38: 328. 1978.

Ageratina petiolaris (Mocino \& Sesse ex DC.) R. King \& H. Robinson, Phytologia 19: 225. 1970.

Ageratina photina (B. Robinson) R. King \& H. Robinson, Phytologia 19: 215. 1970.

Ageratina pichinchensis (H. B. K.) R. King \& H. Robinson, Phytologia 19: 215. 1970.

Ageratina piurae (B. Robinson) R. King \& H. Robinson, Phytologia 19: 225. 1970.

Ageratina plethadenia (Standley \& Steyerm.) R. King \& H. Robinson, Phytologia 24: 95. 1972.

Ageratina pomaderrifolia (Benth.) R. King \& H. Robinson, Phytologia 19: 225. 1970. = Ageratina angustifolia (H. B. K.) R. King \& H. Robinson.

Ageratina popayanensis (Hicron.) R. King \& H. Robinson, Phytologia 19: 225. 1970.

Ageratina porriginosa (B. Robinson) R. King \& H. Robinson, Phytologia 19: 225. 1970.

Ageratina pringlei (B. Robinson \& Greenman) R. King \& H. Robinson, Phytologia 19: 225. 1970.

Ageratina prionobia (B. Robinson) R. King \& H. Robinson, Phytologia 19: 225. 1970.

Ageratina proba (N. E. Br.) R. King \& H. Robinson, Phytologia 37: 455.1977.

Ageratina prunellaefolia (H. B. K.) R. King \& H. Robinson, Phytologia 19: 215. 1970.

Ageratina prunifolia (H. B. K.) R. King \& H. Robinson, Phytologia 19: 225. 1970.

Ageratina pseudochilca (Benth.) R. King \& H. Robinson, Phytologia 19: 225. 1970.

Ageratina psilodora (B. Robinson) R. King \& H. Robinson, Phytologia 19: 216. 1970.

Ageratina purpusii (Brandegee) R. King \& H. Robinson, Phytologia 19: 216. 1970.

Ageratina rafaelensis (Coulter) R. King \& H. Robinson, Phytologia 19: 225. 1970. = Ageratina mairetiana (DC.) R. King \& H. Robinson.

Ageratina ramonensis (B. Robinson) R. King \& H. Robinson, Phytologia 19: 216. 1970.

Ageratina remyana (Philippi) R. King \& H. Robinson, Phytologia 49: 3. 1981.

Ageratina repens (B. Robinson) R. King \& H. Robinson, Phytologia 19: 216. 1970.

Ageratina resiniflua (Urban) R. King \& H. Robinson, Phytologia 19: 225. 1970

Ageratina reticulifera (Standley \& L. O. Williams) R. King \& H. Robinson, Phytologia 19: 226. 1970.

Ageratina rhodopappa (13. Robinson) R. King \& H. Robinson, Phytologia 19: 216, 1970.

Ageratina rhodopoda (B. Robinson) R. King \& H. Robinson, Phytologia 19: 226. 1970.
- Ageratina rhomboidea (H. B. K.) R. King \& H. Robinson, Phytologia 19: 226. 1970.

Ageratina rhypodes (B. Robinson) R. King \& H. Robinson, Phytologia 19: 216. 1970.

Ageratina rhytidodes (B. Robinson) R. King \& H. Robinson, Phytologia 19: 216. 1970.

Ageratina riparia (Regel) R. King \& H. Robinson, Phytologia 19: 216. 1970

Ageratina rivalis (Greenman) R. King \& H. Robinson, Phytologia 19: 216. 1970.

Ageratina rollinsii B. Turner, Phytologia 53: 242. 1983.

Ageratina roraimensis (N. E. Br.) R. King \& H. Robinson, Phytologia 19: 216. 1970.

Ageratina rothrockii (A. Gray) R. King \& H. Robinson, Phytologia 19: 216. 1970.

Ageratina rubricaulis (H. B. K.) R. King \& H. Robinson, Phytologia 19: 226. 1970.

Ageratina rufa (E. Greene) R. King \& H. Robinson. Phytologia 19: 216. 1970

Ageratina rupicola (B. Robinson \& Greenman) R. King \& H. Robinson, Phytologia 19: 226. 1970.

Ageratina salicifolia R. King \& H. Robinson, Phytologia 38: 329. 1978.

Ageratina saltillensis (B. Robinson) R. King \& H. Robinson, Phytologia 19: 226. 1970.

Ageratina salvadorensis R. King \& H. Robinson, Phytologia 38: 337(-338). 1978.

Ageratina schaffineri (Schultz-Bip. ex B. Robinson) R. King \& H. Robinson, Phytologia 19: 217. 1970.

Ageratina scopulorum (Wedd.) R. King \& H. Robinson, Phytologia 19: 217. 1970.

Ageratina scorodonioides (A. Gray) R. King \& H. Robinson, Phytologia 19: 226. 1970.

Ageratina shastensis (Taylor \& Stebb.) R. King \& H. Robinson, Phytologia 45: 464. 1980.

Ageratina simulans (B. Robinson) R. King \& H. Robinson, Phytologia 19: 226. 1970.

Ageratina sinaloensis R. King \& H. Robinson, Phytologia 38 : 330. 1978.

Ageratina skutchii (B. Robinson) R. King \& H. Robinson, Phytologia 19: 217, 1970.

Ageratina sodiroi (Hieron.) R. King \& H. Robinson, Phytologia 19: 217.1970.

Ageratina sotarensis (Hieron.) R. King \& H. Robinson, Phytologia 19: 217. 1970.

Ageratina standleyi R. King \& H. Robinson, Phytologia 24: 95. 1972.

Ageratina stembergiana (DC.) R. King \& H. Robinson, Phytologia 19: 217. 1970.

Ageratina stevioides (Steyerm.) R. King \& H. Robinson, Phytologia 19: 226. 1970. = Agerarina jahmii (B. Robinson) R. King \& H. Robinson.

Ageratina stictophylla (B. Robinson) R. King \& H. Robinson, Phytologia 19: 226. 1970.

Ageratina stricta (A. Gray) R. King \& H. Robinson, Phytologia 19: 226. 1970.

Ageratina subcordata (Benth. ex Oersted) R. King \& H. Robinson, Phytologia 19: 217. 1970.

Ageratina subferruginea (B. Robinson) R. King \& H. Robinson, Phytologia 19: 226. 1970.

Ageratina subglabra R. King \& H. Robinson, Phytologia 24: 97. 1972.

Ageratina subinclusa (Klatt) R. King \& H. Robinson, Phytologia 38: 339. 1978.

Ageratina subintegra (E. Greene) R. King \& H. Robinson. Phytologia 19: 226. 1970.

Ageratina subpenninervia (Klatt) R. King \& H. Robinson, Phy- 
tologia 37: 455. 1977. = Ageratina subinclusa (Klatt) R. King \& H. Robinson.

Ageratina sundbergii B. Tumer, Phytologia 61: 78. 1986.

Ageratina tambillensis (Hieron.) R. King \& H. Robinson, Phytologia 19: 217. 1970.

Ageratina tarmensis (B. Robinson) R. King \& H. Robinson, Phytologia 19: 217. 1970.

Ageratina tenuis (R. E. Fries) R. King \& H. Robinson, Phytologia 19: 217.1970.

Ageratina tetragona (Schrader) R. King \& H. Robinson, Phytologia 19: 227. 1970.

Ageratina theaefolia (Benth.) R. King \& H. Robinson, Phytologia 19: 227.1970.

Ageratina thyrsiflora (E. Greene) R. King \& H. Robinson, Phytologia 19: 227. 1970.

Ageratina tinifolia (H. B. K.) R. King \& H. Robinson, Phytologia 19: 227. 1970.

Ageratina tomentella (Schrader) R. King \& H. Robinson, Phytologia 19: 227. 1970.

Ageratina tonduzii (Klatt) R. King \& H. Robinson, Phytologia 19: 217. 1970.

Ageratina trapezoidea (Kunth) R. King \& H. Robinson, Phytologia 24: 98. 1972.

Ageratina triniona (McVaugh) R. King \& H. Robinson, Phytologia 24: 98. 1972.

Ageratina tristis (DC.) R. King \& H. Robinson, Phytologia 19: 227. 1970.

Ageratina urbanii (Ekman ex Urban) R. King \& H. Robinson, Phytologia 19: 227. 1970.

Ageratina vacciniaefolia (Benth.) R. King \& H. Robinson, Phytologia 19: 227. 1970.

Ageratina vallincola (DC.) R. King \& H. Robinson, Phytologia 19: 217. 1970.

Ageratina ventillana (Cuatrec.) R. King \& H. Robinson, Phytologia 19:217. 1970. = Ageratina riparia (Regel) R. King \& H. Robinson.

Ageratina venulosa (A. Gray) R. King \& H. Robinson, Phytologia 19: 227. 1970.

Ageratina vernalis (Vatke \& Kurtz) R. King \& H. Robinson, Phytologia 19: 227. 1970.

Ageratina vernicosa (Schultz-Bip. ex Greenman) R. King \& H. Robinson, Phytologia 19: 227. 1970.

Ageratina viburnoides (DC.) R. King \& H. Robinson, Phytologia 19:227. 1970.

Ageratina viscosa (H. B. K.) R. King \& H. Robinson, Phytologia 19: 228. 1970.

Ageratina viscosissima (Rolfe) R. King \& H. Robinson, Phytologia 49: 3. 1981 .

Ageratina vulcanica (Benth. ex Oersted) R. King \& H. Robinson, Phytologia 19: 218. 1970. = Ageratina bustamenta (DC.) R. King \& H. Robinson.

Ageratina whitei R. King \& H. Robinson, Phytologia 28: 496. 1974.

Ageratina wrightii (A. Gray) R. King \& H. Robinson, Phytologia 19: 228. 1970.

Ageratina wurdackii R. King \& H. Robinson, Phytologia 38: 332. 1978.

Ageratina xanthochlora (B. Robinson) R. King \& H. Robinson, Phytologia 19: 218. 1970. = Ageratina malacolepis (B. Robinson) R. King \& H. Robinson.

Ageratina zinniifolia (B. Robinson) R. King \& H. Robinson, Phytologia 19:218. 1970.

Ageratina zunilana (Standley \& Steyerm.) R. King \& H. Robinson, Phytologia 19: 218. 1970.

Ageratiopsis apiculata Schultz-Bip. ex Baker, Fl. Bras. 6(2): 362. 1876, nom. nud. = Barrosoa apiculata (Gardner) R. King \& H. Robinson.

Ageratum adscendens Schultz-Bip. ex Hemsley, Biol. Cent.-Amer.,
Bot. 2: 80. 1881. = Oxylobus adscendens (Schultz-Bip.) B. Robinson \& Greenman in B. Robinson.

Ageratım agrianthus O. Hoffm., Nat. Pflanzenfam. 4, Abt. 5: 134. 1890. = Agrianthus corymbosus DC.

Agerat um albidum (DC.) Hemsley, Biol. Cent.-Amer., Bot. 2: 81 . 1881.

Ageratum albidum var. nelsonii B. Robinson, Contr. Gray Herb. 42: 471. 1913. = Ageratum nelsonii (B. Robinson) M. Johnson. Ageratum album Steudel, Nomencl. Bot. 1: 18. 1821. = Ageratum conyzoides $\mathrm{L}$.

Ageratum alternifolium (Gardner) Baker, Fl. Bras. 6(2): 195. 1876. = Campuloclinium alternifolium Gardner.

Ageratum altissimum L., Sp. PI. 839. 1753. = Ageratina altissima (L.) R. King \& H. Robinson.

Ageratum angustifolium Sprengel, Syst. Veg. Fl. Peruv. Chil. 3: 446. 1826. = Calea angusta Blake. Heliantheae.

Ageratım aquaticum Roxb., Hort. Bengal. 61. 1814, nom. nud.

Fl. Ind. 3: 416. 1832. = Adenostemma lavenia (L.) Kuntze.

Ageratum arbutifolium H. B. K., Nov. Gen. Sp. 4: 117. Ed. Folio. 1818. = Oxylobus arbutifolius (H. B. K.) A. Gray.

Ageratum arsenei B. Robinson, Contr. Gray Herb. 64: 3. 1922. = Ageratum conyzoides $\mathrm{L}$.

Ageratum ballotaefolium (Maguire, Steyerm. \& Wurd.) R. King \& H. Robinson, Phytologia 24: 113. 1972.

Ageratum benjamin-lincolnii R. King \& H. Robinson, Phytologia 24: 113. 1972, nom. nov. = Ageratum platylepis (B. Robinson) R. King \& H. Robinson.

Ageratum brachystephanum Regel, Gartenflora 3: 245. T. 108. 1854. = Ageratum conyzoides $\mathrm{L}$.

Ageratum caeruleum Hort. ex Poiret, Encycl. Suppl. 1: 241.1810. = Hebeclinium macrophyllum (L.) DC., ?

Ageratum callosum S. Watson, Proc. Amer. Acad. Arts 25: 153. 1889. = Alomia callosa (S. Watson) B. Robinson.

Ageratum campuloclinioides Baker, Fl. Bras. 6(2): 196. $1876 .=$ Campuloclinium campuloclinioides (Baker) R. King \& H. Robinson.

Ageratum candidum G. Barroso, Sellowia 17: 83. 1965.

Ageratum chiriquense (B. Robinson) R. King \& H. Robinson, Phytologia 24: 113. 1972.

Ageratum chortianum Standley \& Steyerm., Fieldiana, Bot. 23: 98. 1944.

Ageratum ciliare L., Sp. Pl. 839. 1753, ignota.

Ageratum ciliare Lour., F. Cochinch. 484. 1790. = Ageratum conyzoides $\mathrm{L}$.

Ageratum coelestinum Sims, Bot. Mag. T. 1730. 1815. = Ageratum corymbosum Zuccagni.

Ageratum coeruleum Desf., Tabl. Ecole Bot. 1, 98. 1804, nom. nud. = Ageratum conyzoides $\mathbf{L}$.

Ageratum coeruleum Sieber ex Baker, F. Bras. 6(2): 345.1876. = Hebeclinium macrophyllum (L.) DC.

Ageratum confertum (Gardner) Benth. ex Baker, Fl. Bras. 6(2): 196. 1876. = Acritopappus confertus (Gardner) R. King \& H. Robinson.

Ageratum connatifolium Soares Nunes, Bradea 3: 130. 1981. = Acritopappus connatifolius (Soares Nunes) R. King \& H. Robinson.

Ageratum conspicuum K. Koch \& Fintelm., Wochenschr. 1: 33. 1858. = Ageratina glechonophylla (Less.) R. King \& H. Robinson.

Ageratum conyzoides L., Sp. Pl. 839. 1753.

Ageratum conyzoides Sieber ex Steudel, Nomencl. Bot. 1: 37. 1840. = Chromolaena corymbosa (Aublet) R. King \& H. Robinson.

Ageratum cordatum (Blake) L. O. Williams, Fieldiana, Bot. 36: 78. 1975. = Blakeanthus cordatus (Blake) R. King \& H. Robinson.

Ageratum cordifolium Roxb., F. Ind. 3: 416. 1832. = Ageratum conyzoides $\mathbf{L}$. 
Ageratum corymbosum Zuccagni, Cent. Prim. Obs. Bot. 1: 40. (Spec. No. 85). 1806.

Ageratum corymbosum Zuccagni ex Pers., Syn. PI. 2: 402.1807. = Ageratum corymbosum Zuccagni.

Ageratum corymbosum (DC.) Benth. ex Baker, Fl. Bras, 6(2): 196. 1876. = Stylotrichium corymbosum (DC.) Mattf. in Pilger.

Ageratum domingense Sprengel, Syst. Veg. Fl. Peruv. Chil. 3: 446. 1826. = Phania domingensis (Sprengel) Griseb.

Ageratum echioides (Less.) Hemsley, Biol. Cent.-Amer., Bot. 2: 81,1881 .

Ageratum elachycarpum B. Robinson, Proc. Amer. Acad. Arts 49: 477. 1913. = Ageratum rugosum Coulter ex J. D. Smith.

Ageratum elassocarpum S. F. Blake, Contr. U. S. Natl. Herb. 22: 588. 1924.

Ageratum ellipticum B. Robinson, Contr. Gray Herb. 90: 5. 1930. Ageratum fastigiatum (Gardner) R. King \& H. Robinson, Phytologia 24: 114. 1972.

Ageratum febrifugum Sesse ex DC., Prodr. 5: 104. 1836, nom. inval. = Piqueria trinervia Cav.

Ageratum febrifugum Sesse, PI. Nov. Hisp. 135. 1889, Naturaleza (Mexico City), ser. 2(1): 126. App. Ed. 2. 1893. = Piqueria trinervia Cav.

Ageratum gaumeri B. Robinson, Proc. Amer. Acad. Arts 47: 191. 1911.

Ageratnm glanduliferum Schultz-Bip. ex Benth. \& Hook. f., Gen. Pl. 2: 242. 1873. = Oxylobus glanduliferus (Schultz-Bip. ex Benth. \& Hook. f.) A. Gray.

Ageratum glaucum Hort. ex Sieber \& Voss, Vilm. Blumengaert., ed. 3, 1: 448. 1896, nom. nud. = Ageratina ligustrina $($ DC.) R. King \& H. Robinson.

Ageratum glomeratum G. Barroso \& R. King, Brittonia 23: 121. 1971. = Cavalcantia glomerata (G. Barroso \& R. King) R. King \& H. Robinson.

Ageratum guatemalense M. Johnson, Ann. Missouri Bot. Gard. 58: 64. 1971.

Ageratum guianense Aublet, Hist. Pl. Guiane 2: 800. 1775. = Hebeclininm macrophyllum (L.) DC.

Ageratum heterolepis Baker, Fl. Bras. 6(2): 198. 1876. = Acritopappus heterolepis (Baker) R. King \& H. Robinson.

Ageratum hirsutum Poiret, Encycl. Suppl. 1: 242. 1810. = Ageratum conyzoides $\mathrm{L}$.

Ageratum hirtum Lam., Encycl. I: 54. 1783. = Ageratum conyzoides $\mathrm{L}$.

Ageratum houstonianum Miller, Gard. Dict, ed. 8, N. 2. 1768.

Ageratum hudsonii Hort. ex Vilm., Fl. Pleine Terre, ed. 2. 43. 1866, nom. nud. = Ageralum corymbosum Zuccagni.

Ageratum humile Salisb., Prodr. 188. 1796, nom. illeg. = Ageratum conyzoides $\mathrm{L}$.

Ageratum hnmile Larran., Escr. D. A. Larranaga 1: 406.1922. = Ageranum conyzoides $\mathbf{L}$.

Ageratum iltisii R. King \& H. Robinson. Phytologia 27: 387. 1974.

Ageratum intermedium Hemsley, Biol. Cent.-Amer., Bot. 4: 102. 1887. = Ageratum maritimum H. B. K.

Ageratum isocarphoides (DC.) Hemsley, Biol. Cent.-Amer., Bot. 2: 82.1881 .

Ageratnm isocarphoides (DC.) L. O. Williams, Fieldiana, Bot. 36: 78. 1975 , comb. superfl. = Ageratum isocarphoides (DC.) Hemsley.

Ageratnm laciniatum Sesse \& Mocino, PI. Nov. Hisp. 136. 1889, Naturaleza (Mexico City), ser. 2(1): 126. App. Ed. 2. 1893. = Stevia trifida Lagasca.

Ageratnm lasseauxii Carriere, Rev, Hort. 90. 1870-1871. = Barrosoa candolleana (Hook. \& Am.) R. King \& H. Robinson.

Ageratum latifolium Cav., Icon. 4: 33. 1797. = Ageratum conyzoides L.

Ageratum latifolium (Benth.) Hemsley, Biol. Cent.-Amer., Bot.

2: 82.1881 , = Ageratum nelsonii (B. Robinson) M. Johnson.
Ageratum lineare Cav., Icon. 3: 3 T. 205. 1794. = Palafoxia linearis (Cav.) Lagasca. Heliantheae.

Ageratnm littorale A. Gray, Proc. Amer. Acad. Arts 16: 78, 1880. Ageratum longifolium (Gardner) Benth. ex Baker, F. Bras. 6(2): 197. 1876. = Acrilopappus longifolizus (Gardner) R. King \& H. Robinson.

Ageratum lucidum B. Robinson, Proc. Amer. Acad. Arts 36: 475. 1901.

Ageratum lundellii R. King \& H. Robinson, Wrightia 6(2): 23. 1978.

Ageratum maritimum H. B. K., Nov. Gen. Sp. 4: 117 . Ed. Folio. 1818.

Ageratum matricarioides (Spreng.) Less., Syn. Gen. Compos. 155. 1832. = Phania matricarioides (Sprengel) Griseb.

Ageratum melissaefolium DC., Prodr. 5: 109. 1836. = Platypodanthera melissaefolia (DC.) R. King \& H. Robinson.

Ageratum meridanum V. Badillo, Ernstia 17: 19. 1983.

Ageratum mexicanum Sims, Bot. Mag. T. 2524. 1825. = Ager atum houstonianum Miller.

Ageratum mexicanum Sweet, Brit. Fl. Gard. 1. T. 89. 1825. = Ageratum houstonianum Miller.

Ageratum microcarptum (Benth. ex Oersted) Hemsley, Biol. Cent.Amer., Bot. 2: 82. 1881.

Ageratum microcephalum Hemsley, Biol. Cent.-Amer., Bot. 2: 82. 1881 .

Ageratum micropappum Baker, F. Bras. 6(2): 198. 1876. = ACnitopappus micropappus (Baker) R. King \& H. Robinson.

Ageratum microphyllum Schultz-Bip., Bot. Voy. Herald 298. 1856. = Ageratella microphylla (Schultz-Bip.) A. Gray ex S. Watson.

Ageratum muticum Griseb., F. Brit. W. 1. 356. 1861. = Ageratum conyzoides $\mathrm{L}$.

Ageratum myriadenium (Schultz-Bip. ex Baker) R. King \& H. Robinson, Phytologia 24: 115. 1972.

Ageratum nanum Schultz-Bip. in Koch \& Fintelm., Wochenschr. Gartnerei Pflanzenk. 1:26. 1858, nom. nud. = Ageratum conyzoides L.

Ageratum nelsonii (B. Robinson) M. Johnson, Ann. Missouri Bot. Gard. 58: 42. 1971.

Ageratum oblusifolium Lam., Encycl. 1: 54. 1783. = Ageratum conyzoides L.

Ageratum odoratum Vilm. Fl. Pleine Terre, ed. 2. 42. 1866. = Ageratuin conyzoides L.

Ageratum oerstedii B. Robinson, Proc. Amer. Acad. Arts 49: 472. 1913.

Ageratum oliveri R. King \& H. Robinson, Phytologia 28: 491. 1974.

Ageratum paleaceum (DC.) Hemsley, Biol. Cent.-Amer., Bot. 2: 83. 1881 .

Ageratum panamense B. Robinson, Contr. Gray Herb. 104: 5. 1934.

Ageratum paniculatum Hort. ex Steudel, Nomencl. Bot. 2. 1: 37. 1840. = Brickellia paniculata (Miller) B. Robinson.

Ageratum peckii B. Robinson, Proc. Amer. Acad. Arts 47: 191. 1911.

Ageratum pedatum Ortega, Nov. Pl. Descr. Dec. 38. 1797. = Florestina pedata (Cav.) Cass. Heliantheae.

Ageratum perplexans M. Johnson, Ann. Missouri Bot. Gard. 58: 80. 1971. = Galinsoga quadriradiata Ruiz Lopez \& Pavon. HELIANTHEAE.

Ageratum petiolatum (Hook. \& Am.) Hemsley, Biol. Cent.-Amer., Bot. 2: 83. 1881

Ageratum pinetorum (L. O. Williams) R. King \& H. Robinson, Phytologia 24: 115. 1972. = Ageratum corymbosum Zuccagni. Ageratum platylepis (B. Robinson) R. King \& H. Robinson, Phytologia 24: 115. 1972.

Ageratum platypodum B. Robinson, Proc. Amer. Acad. Arts 49: 464. 1913. 
Ageratum pohlianum Baker, Fl. Bras. 6(2): 197. 1876. = Calea? Hel.jantHEAE.

Ageratum polyphyllum Baker, Kew Bull. 148. 1898. = AgeratiItasirum polyphyllum (Baker) Mattf. VERNONIEAE.

Ageratum punctatum Ortega, Nov. Pl. Descr. Dec. 37. 1797. = Stevia eupatoria (Sprengel) Willd.

Ageratum punctatlin Jacq., Pl. Hort. Schoenbr. 3: 28. T. 300. 1798. = Stevia serrata Cav.

Ageralum purpureum Vitman, Summa Pl. 4: 474. 1790, ignota. Ageratum purpureum Sesse \& Mocino ex DC., Prodr. 5: 122. 1836. = Stevia viscida $\mathrm{H}$. B. K.

Ageratum purpureum Sesse \& Mocino, Pl. Nov. Hisp. 135. 1889 , Naturaleza (Mexico City), ser. 2(1): 126. App. Ed. 2. 1893. = Stevia viscida $\mathrm{H}$. B. K.

Agerat um quadriflorum Blanco, F. Filip. (ed. 1) 1 624. 1837. = Pseudelephantopus spicatus (Juss.) Baker. Vernonieae.

Ageratum radicans B. Robinson, Proc. Amer. Acad. Arts 47: 192. 1911.

Ageratum reedii $\mathrm{R}$. King \& $\mathrm{H}$. Robinson, Phytologia 24: 115. 1972. = Ageratum petiolatum (Hook. \& Arn.) Hemsley.

Ageratum rhytidophyllum B. Robinson, Proc. Amer. Acad. Arts 36: 476. 1901. = Ageratum paleaceum (DC.) Hemsley.

Ageratum riparium B. Robinson, Proc. Amer. Acad. Arts 49: 473. 1913.

Ageratum rivale Sessc \& Mocino, Pl. Nov. Hisp. 136. 1889, Naturaleza (Mexico City), ser. 2(1): 126. App. Ed. 2. 1893. = ? Stevia.

Ageraum rivale B. Robinson, Contr. Gray Herb. 61: 3. 1920. = Ageratum panamense $\mathrm{B}$. Robinson.

Ageratum robinsonianum (L. O. Williams) L. O. Williams, Fieldiana, Bot. 36: 81. 1975. = Ageratum rugosum Coulter ex J. D. Smith.

Ageratum rubens Viv., Elench. PI. 9. 1802. ignota.

Ageratum rugosum Coulter cx J. D. Smith, Bot. Gaz. (Crawfordsville) 20: 42.1895.

Ageratum salicifolium Hemsley, Biol. Cent.-Amer., Bot. 2: 83. 1881.

Ageratum sandwicense Leveille, Feddes Repert. 11: 63. 1912, ignota.

Ageratum scabriusculum Hemsley, Biol. Cent.-Amer., Bot. 2: 83. 1881. = Ageratum petiolatum (Hook. \& Arn.) Hemsley.

Ageratum scorpioideum Baker, Fl. Bras. 6(2): 197. 1876.

Ageratum serratum Glaz., Bull. Soc. Bot. France Mem. 3. 56: 382. 1909, nom. nud. ignota.

Ageratum sessilifolium Schauer, Linnaea 19: 715. 1847. = Trichocoronis sessilifolia (Schauer) B. Robinson.

Ageraium sordidum S. F. Blake, Contr. U. S. Natl. Herb. 20: 534. 1924. = Oxylobus glanduliferus (Schultz-Bip. ex Benth. \& Hook. f.) A. Gray.

Ageratum stachyofolium B. Robinson, Proc. Amer. Acad. Arts 36: 476. 1901

Ageratum standleyi B. Robinson, J. Arnold Arbor. 11: 44. 1930. Ageratum striatum Sesse \& Mocino, Pl. Nov. Hisp. 136. 1889, Naturaleza (Mexico City), ser. 2(1): 127. App. Ed. 2. 1893. = Stevia serrata Cav.

Ageratum strictum Sims, Bot. Mag. T. 2410. 1823. = Adenostemma viscosum Forster.

Ageratum strictum Hemsley, Biol. Cent.-Amer., Bot. 2: 83, 1881. = Ageratum corymbostm Zuccagni.

Ageratum suffruticosum Regel, Gartenflora 3: 389. T. 108. 1854. = Ageratum conyzoides $\mathrm{L}$.

Ageraum tomentosum (Benth. ex Oersted) Hemsley, Biol. Cent.Amer., Bot. 2: 84. 1881.

Ageratum viscosum Ortega, Nov. Pl. Descr. Dec. 36. 1797. = Stevia salicifolia Cav.

Ageratum viscosum Sesse \& Mocino, Pl. Nov. Hisp. 135. 1889, Naturaleza (Mexico City), ser. 2(1): 127. App. Ed. 2. 1893. = Stevia elatior H. B. K. or Stevia pilosa Lagasca.
Ageratum wendlandii compactum nanum coeruleum Vilm. ex Voss, Vilm. Blumengaert., ed. 3, 46. 1894, nom. illeg. = Ageratum houstonianum Miller.

Ageratum wrightii Torrey \& A. Gray, Proc. Amer. Acad. Arts 1: 46. 1846. = Trichocoronis wrightii (Torrey \& A. Gray) A. Gray. Agrianthus campestris Martius ex DC., Prodr. 5: 125. 1836.

Agrianthus corymbosus DC., Prodr. 7: 266. 1838. = Stylotrichium corymbosum (DC.) Mattf. in Pilger.

Agrianthus empetrifolius Martius ex DC., Prodr. 5: 126. 1836.

Agrianthus leutzelburgii Mattf. in Pilger, Notizbl. Bot. Gart. Berlin-Dahlem 8: 441. 1923.

Agrianthus microlicioides Mattf. in Pilger, Notizbl. Bot. Gart. Berlin-Dahlem 8: 442.1923.

Agrianthus myrtoides Mattf. in Pilger, Notizbl. Bot. Gart. BerlinDahlem 8: 444. 1923.

Agrianthus pungens Mattf. in Pilger, Notizbl. Bot. Gart. BerlinDahlem 8: 443. 1923.

Alomia ageratoides H. B. K., Nov. Gen. Sp. 4: 119. Ed. Folio. 1818.

Alomia alata Hemsley, Biol. Cent.-Amer., Bot. 2: 79. 1881.

Alomia angustata (Gardner) Benth. ex Baker, Fl. Bras. 6(2): 190. 1876. = Gardnerina angustata (Gardner) R. King \& H. Robinson.

Alomia armani (Balbis) Baker, Fl. Bras. 6(2): 191. 1876. = Clibadium armanii (Balbis) Baker. HeLIANTHEAE.

Alomia ballotaefolia Maguire, Steyerm. \& Wurd., Mem. New York Bot. Gard. 9: 425. 1957. = Ageratum ballotaefolium (Maguire, Steyerm. \& Wurd.) R. King \& H. Robinson.

Alomia callosa (S. Watson) B. Robinson, Proc. Amer. Acad. Arts 49: 443. 1913.

Alomia chiriquensis B. Robinson, Contr. Gray Herb. 61: 4. 1920. = Ageratum chiriquense (B. Robinson) R. King \& H. Robinson.

Alomia cinerea (Gardner) Benth. ex Baker, Fl. Bras. 6(2): 191. 1876. = Trichogonia cinerea (Gardner) R. King \& H. Robinson.

Alomia coelestina (Regel) B. Robinson, Contr. Gray Herb. 90: 4. 1930. = Ageratum microcarpum (Benth. ex Oersted) Hemsley.

Alomia cordata Blake, Proc. Biol. Soc. Wash. 60: 41. 1947. = Blakeanthus cordatus (Blake) R. King \& H. Robinson.

Alomia dubia B. Robinson, Proc. Amer. Acad. Arts 42: 33.1906. $=$ Trichogonia dubia (B. Robinson) R. King \& H. Robinson.

Alomia echioides (Less.) B. Robinson, Proc. Amer. Acad. Arts 49: 449. 1913. = Ageratum echioides (Less.) Hemsley.

Alomia fastigiata (Gardner) Benth. ex Baker, Fl. Bras. 6(2): 192. 1876. = Ageratum fastigiatum (Gardner) R. King \& H. Robinson.

Alomia foliosa Benth. \& Hook. f., Gen. PI. 2: 240. 1873. = Teixeiranthus foliosus (Gardner) R. King \& H. Robinson.

Alomia glutinosa Kraschen., Bot. Mater. Gerb. Glavn. Bot. Sada RSFSR 3: 161. 1922. = Acritopappus longifolius (Gardner) R. King \& H. Robinson.

Alomia guatemalensis B. Robinson, Proc. Amer. Acad. Arts 49: 448. 1913. = Ageratum platylepis (B. Robinson) R. King \& H. Robinson.

Alomia heterolepis (Baker) B. Robinson, Proc. Amer. Acad. Arts 49: 447. 1913. = Acritopappus heterolepis (Baker) R. King \& H. Robinson.

Alomia hintonii R. King \& H. Robinson, Phytologia 24: 110. 1972.

Alomia isocarphoides (DC.) B. Robinson, Proc. Amer. Acad. Arts 49: 449. 1913. = Ageratun isocarphoides (DC.) Hemsley.

Alomia longifolia (Gardner) B. Robinson, Proc. Amer. Acad. Arts 49: 447. 1913. = Acritopappus longifolius (Gardner) R. King \& H. Robinson.

Alomia microcarpa (Benth. ex Oersted) B. Robinson, Proc. Amer. Acad. Arts 49: 452. 1913. = Ageratum microcarpum (Benth. ex Oersted) Hemsley. 
Alomia microcephala (Hemsley) B. Robinson, Proc. Amcr. Acad. Arts 49: 448. 1913. = Ageratuin inicrocephalum Hemsley.

Alomia myriadenia Schultz-Bip. ex Baker, Fl. Bras. 6(2): 192. 1876. = Ageratum myriadenium (Schultz-Bip. ex Baker) R. King \& $\mathrm{H}$. Robinson.

Alomia pinetornm L. O. Williams, Fieldiana, Bot. 31: 25.1964. = Ageratum corymbosum Zuccagni.

Alomia platylepis B. Robinson, Proc. Amer. Acad. Arts 49: 448. 1913. = Ageratum platylepis (B. Robinson) R. King \& H. Robinson.

Alomia pohlii Baker, F1. Bras. 6(2): 190. 1876. incertae sedis.

Alomia polyphylla Baker, Fl. Bras. 6(2): 191. 1876. = Ageratum fastigiatum (Gardner) R. King \& H. Robinson.

Alomia regnellii Malme, Kongl. Svenska Vetenskapsakad. Handl. 32(5): 32. 1899. = Alomiella regnellii (Malme) R. King \& H. Robinson.

Alomia robinsoniana L. O. Williams, Ficldiana, Bot. 31: 27.1964. = Ageratum rugosum Coulter ex J. D. Smith.

Alomia spilanthoides D. Don ex Hook., Companion Bot. Mag. 1: 238. 1835. = Gymnocoronis spilanthoides DC.

Alomia stenolepis Blake, J. Wash. Acad. Sci. 27: 375. 1937.

Alomia wendlandii B. Robinson, Proc. Amer. Acad. Arts 49: 452. 1913. = Ageratum migosum Coulter ex J. D. Smith.

Alomiella hatschbachii R. King \& H. Robinson, Phytologia 56: 256. 1984.

Alomiella regnellii (Malme) R. King \& H. Robinson, Phytologia 24: 396. 1972.

Amboroa geminata Cabrera, Bol. Soc. Argent. Bot. 6: 92. 1956.

Amboroa wurdackii R. King \& H. Robinson, Phytologia 31: 311 (312). 1975.

Ainmopursus ohlingerae (Blake) Small, Bull. Torrey Bot. Club 51: 393. 1924. = Liatris ohlingerae (Blake) B. Robinson.

Amolinia heydeana (B. Robinson) R. King \& H. Robinson, Phytologia 24: 266. 1972.

Anisopappus candelabrum Leveille, Feddes Repert. 8: 451.1910. = Adenostemmina tinctorimm (Lour.) Cass.

Anonvmos ciliatus Walter, F. Carol. 197. 1788, nom. illeg. = Liatris graminifolia [Walter] Willd., ?

Anonymos graminifolius Walter, Fl. Carol. 197. 1788, nom. illeg. = Liatris graminifolia [Walter] Willd.

Anoulymos odoratissimus Walter. Fl. Carol. 198. 1788, nom. illeg. = Trilisa odoratissima (J. Gmelin) Cass.

Anonyunos paniculatus Walter, Fl. Carol. 198. 1788, nom. illeg. = Trilisa paniculata (J. Gmelin) Cass.

Anonymos pilosus Walter, Fl. Carol. 197. 1788, nom. illeg. = Liatris pycnostachya Michaux.

Anonymos racemosus Walter, Fl. Carol. 198. 1788, nom. illeg. ignota.

Anonymos ramosa Walter, Fl. Carol. 198. 1788, nom. illeg. = Liatris scariosa Willd.

Antillia brachychaeta (B. Robinson) R. King \& H. Robinson. Phytologia 21: 399. 1971.

Aristeguietia amethystina (B. Robinson) R. King \& H. Robinson, Phytologia 30: 219. 1975.

Aristegniletia anisodonta (B. Robinson) R. King \& H. Robinson, Phytologia 30: 219. 1975.

Aristeguietia arborea (H. B. K.) R. King \& H. Robinson, Phytologia 30: 219. 1975.

Aristeguictia ballii (Oliver) R. King \& H. Robinson, Phytologia 30: 219.1975.

Aristeguletia buddleaefolia (Benth.) R. King \& H. Robinson, Phytologia 30: 219. 1975.

Aristeguietia cacalioides (H. B. K.) R. King \& H. Robinson, Phytologia 30: 219. 1975.

Aristeguietia chimborazensis (Hieron.) R. King \& H. Robinson, Phytologia 30: 219. 1975.

Aristeguietia cursonii (B. Robinson) R. King \& H. Robinson, Phytologia 30: 219. 1975.
Aristeguietia dielsii (B. Robinson) R. King \& H. Robinson, Phytologia 30: 219. 1975.

Aristeguietia diplodictyon (B. Robinson) R. King \& H. Robinson, Phytologia 30: 219. 1975.

Aristeguietia discolor (DC.) R. King \& H. Robinson, Phytologia 30: 220. 1975.

Aristeguietia gascae (B. Robinson) R. King \& H. Robinson, Phytologia 30: 220. 1975.

Aristeguietia gay:ana (Wedd.) R. King \& H. Robinson, Phytologia 30: 220. 1975.

Aristeguietia glutinosa (Lam.) R. King \& H. Robinson, Phytologia 30: 220.1975.

Aristeguietia lainiifolia (H. B. K.) R. King \& H. Robinson, Phytologia 30: 220. 1975.

Aristeguietia perezioides (B. Robinson) R. King \& H. Robinson, Phytologia 30: 220. 1975. = Bartlettina perezioides (B. Robinson) R. King \& H. Robinson.

Aristeguietia persicifolia (H. B. K.) R. King \& H. Robinson, Phytologia 30: 220. 1975.

Aristeguietia psendarborea (Hieron.) R. King \& H. Robinson, Phytologia 30: 220. 1975.

Aristeguietia salvia (Colla) R. King \& H. Robinson, Phytologia 30: 220. 1975.

Aristeguietia tahonensis (Hicron.) R. King \& H. Robinson. Phytologia 30: 220. 1975.

Aristeguietia tatamensis (B. Robinson) R. King \& H. Robinson, Phytologia 30: 220. 1975.

Aristeguietia uribei R. King \& H. Robinson, Phytologia 54: 36. 1983.

Arrojadoa praxeloides Mattf. in Pilger, Notizbl. Bot. Gart. BerlinDahlem 8: 435. 1923. = Arrojadocharis praxeloides (Mattf.) Mattf.

Arrojadocharis praxeloides (Mattf.) Mattf., Notizbl. Bot. Gart. Berlin-Dahlem 10: 1053. 1930.

Arrojadocharis santosii R. King \& H. Robinson, Phytologia 44: 464. 1979.

Artemisia tenuifolia Willd., Sp. P1. 3: 1819. 1803. = Eupatorium capillifolium (Lam.) Small.

Asanthus solidaginifolius (A. Gray) R. King \& H. Robinson, Phytologia 24: 66. 1972.

Asamthus squamulosus (A. Gray) R. King \& H. Robinson, Phytologia 24: 66. 1972.

Asamthus thrysiflorus (A. Gray) R. King \& H. Robinson, Phytologia 24: 66. 1972.

Aschenbornia heteropoda Schauer, Linnaea 19:716. 1847. = Calea ternifolia H. B. K. HeliantheAE.

Ascidiogyne sanchezvegae Cabrera, Hickenia 1: 2-3. 1976.

Ascidiogyne w'urdackii Cuatrec., Ann. Missouri Bot. Gard. 52: 310. 1965.

Asplundianthus arcuans (B. Robinson) R. King \& H. Robinson, Phytologia 30: 224. 1975.

Asplundianthus densus (Benth.) R. King \& H. Robinson, Phytologia 30: 225. 1975.

Asplundianthus pseudoglotneratus (Hieron. in Sodiro) R. King \& H. Robinson, Phytologia 30: 225. 1975.

Asplundianthus pseudostuebelii R. King \& H. Robinson, Phytologia 30: 225. 1975.

Asplundianthus sagasteguii R. King \& H. Robinson, Phytologia 39: 136. 1978.

Asplundianthus scabrifolius (B. Robinson) R. King \& H. Robinson, Phytologia 30: 226. 1975.

Asplundianthus smilacims (H. B. K.) R. King \& H. Robinson, Phytologia 30: 226. 1975.

Asplundianthus stuebelii (Hieron.) R. King \& H. Robinson, Phytologia 30: 226. 1975.

Asplundianthus toroi (B. Robinson) R. King \& H. Robinson, Phytologia 30: 226. 1975. 
Asplundianthus trachyphyllus (Hieron.) R. King \& H. Robinson, Phytologia 30: 226. 1975.

Austrobrickellia arnottii (Baker) R. King \& H. Robinson, Phytologia 24: 73. 1972.

Austrobrickellia bakerianum (B. Robinson) R. King \& H. Robinson, Phytologia 24: 73. 1972.

Austrobrickellia patens (Don ex Hook. \& Am.) R. King \& H. Robinson, Phytologia 24: 73. 1972.

Austrocritonia angulicaulis (Schultz-Bip. ex Baker) R. King \& H. Robinson, Phytologia 31: 116. 1975.

Austrocritonia rosea (Gardner) R. King \& H. Robinson, Phytologia 31: 116. 1975.

Austrocritonia taunayana (Glaz. ex B. Robinson) R. King \& H. Robinson, Phytologia 37: 456. 1977.

Austrocritonia velutina (Gardner) R. King \& H. Robinson, Phytologia 31: 117. 1975.

Austroeupatorium apensis (Chodat) R. King \& H. Robinson, Phytologia 5I: 179. 1982.

Austroeupatorium chaparense (B. Robinson) R. King \& H. Robinson, Phytologia 19: 433. 1970.

Austroeupatorium decemflorum (DC.) R. King \& H. Robinson, Phytologia 45: 465. 1980.

Austroeupatorium entreriense (Hieron.) R. King \& H. Robinson, Phytologia 19: 434. 1970.

Austroeupatorium inulaefolium (H. B. K.) R. King \& H. Robinson, Phytologia 19: 434. 1970.

A ustroeupatorium laete-virens (Hook. \& Am.) R. King \& H. Robinson, Phytologia 19: 434. 1970.

Austroeupatorium mapiriense (Hieron.) R. King \& H. Robinson, Phytologia 19: 434. 1970. = Austroeupatorium decemflorum (DC.) R. King \& H. Robinson.

Austroeupatorium monardaefolium (Walp.) R. King \& H. Robinson, Phytologia 19: 434. 1970. = Austroeupatorium silphiifolium (Martius) R. King \& H. Robinson.

Austroeupatorium morii R. King \& H. Robinson, Phytologia 50: 379. 1982.

Austroeupatorium neglectum (B. Robinson) R. King \& H. Robinson, Phytologia 19: 434. 1970.

Austroeupatorium paulinum (DC.) R. King \& H. Robinson, Phytologia 19: 434. 1970.

Austroeupatorium petrophilum (B. Robinson) R. King \& H. Robinson, Phytologia 19: 434. 1970.

Austroeupatorium picturatum (Malme) R. King \& H. Robinson, Phytologia 19: 434. 1970.

Austroelupatorium rosmarinaceum (Cabrera \& Vittet) R. King \& H. Robinson, Phytologia 49: 3. 1981.

Austroeupatorium rosmarinifolium (Sesse \& Mocino) R. King \& H. Robinson, Phytologia 19: 434. 1970. = Brickellia scoparia (DC.) A. Gray, ?

Austroeupatorium silphiifolium (Martius) R. King \& H. Robinson, Phytologia 51: 179. 1982.

Austroeupatorium tweedieanum (Hook. \& Arn.) R. King \& H. Robinson, Phytologia 19: 434. 1970. = Hatschbachiella tweedieana (Hook. \& Am.) R. King \& H. Robinson.

Ayapana amygdalina (Lam.) R. King \& H. Robinson, Phytologia 20: 211.1970.

Ayapana ecuadorensis R. King \& H. Robinson, Phytologia 34: 57(-58). 1976.

Avapana elata (Steetz) R. King \& H. Robinson, Phytologia 27: 235. 1973.

A)apana haughtii R. King \& H. Robinson, Phytologia 34: 58(59). 1976

Ayapana hylophila (B. Robinson) R. King \& H. Robinson, Phytologia 20: 211. 1970.

Ayapana jaramillii R. King \& H. Robinson, Phytologia 20: 211. 1970.

Ayapana lanceolata R. King \& H. Robinson, Phytologia 34: 59(60). 1976
Ayapana officinalis Spach, Hist. Nat. Veg. 10: 290. 1841. =Ayapana triplinervis (Vahl) R. King \& H. Robinson.

Ayapana ornatiloba (B. Robinson) R. King \& H. Robinson, Phytologia 20: 212. 1970. = Lourteigia ornatiloba (B. Robinson) R. King \& H. Robinson.

Ayapana ornithophora (B. Robinson) R. King \& H. Robinson, Phytologia 20: 333. 1970.

Ayapana pilluanensis (Hieron.) R. King \& H. Robinson, Phytologia 34: 60. 1976.

Ayapana pyramidalis (Klatt) R. King \& H. Robinson, Phytologia 20: 212. 1970. = Ayapana stenolepis (Steetz) R. King \& H. Robinson.

Ayapana squarrosa (Klatt) R. King \& H. Robinson, Phytologia 20: 212. 1970. = Lepidesmia squarrosa Klatt.

Ayapana stenolepis (Steetz) R. King \& H. Robinson, Phytologia 32: 284. 1975.

Ayapana tovarensis (B. Robinson) R. King \& H. Robinson, Phytologia 20: 212. 1970.

Ayapana trinitensis (Kuntze) R. King \& H. Robinson, Phytologia 20: 212.1970.

Ayapana triplinervis (Vahl) R. King \& H. Robinson, Phytologia 20: 212.1970

Ayapana turbacensis (Hieron.) R. King \& H. Robinson, Phytologia 20: 212. 1970.

Ayapanopsis adenophora R. King \& H. Robinson, Phytologia 24: 383. 1972

Ayapanopsis andina (B. Robinson) R. King \& H. Robinson, Phytologia 24: 384. 1972.

Ayapanopsis cuchabensis (B. Robinson) R. King \& H. Robinson, Phytologia 31: 312. 1975.

Ayapanopsis didyma (Klatt) R. King \& H. Robinson, Phytologia 24: 384. 1972.

Ayapanopsis esperanzae (Hassler) R. King \& H. Robinson, Phytologia 24: 384. 1972.

Ayapanopsis euphyes (B. Robinson) R. King \& H. Robinson, Phytologia 24: 384. 1972.

Ayapanopsis ferreyrii R. King \& H. Robinson, Phytologia 31: 312. 1975.

Ayapanopsis garcia-barrigae R. King \& H. Robinson, Phytologia 24: 384. 1972. = Ayapanopsis cuchabensis (B. Robinson) R. King \& H. Robinson.

Ayapanopsis latipaniculata (Rusby) R. King \& H. Robinson, Phytologia 24: 385. 1972.

Ayapanopsis mathewsii (B. Robinson) R. King \& H. Robinson, Phytologia 24: 385. 1972.

Ayapanopsis oblongifolia (Gardner) R. King \& H. Robinson, Phytologia 49: 3. 1981.

Ayapanopsis tarapotensis (B. Robinson) R. King \& H. Robinson, Phytologia 24: 385. 1972.

Ayapanopsis triosteifolia (Rusby) R. King \& H. Robinson, Phytologia 24: 385. 1972.

Ayapanopsis trixioides (Martius ex Baker) R. King \& H. Robinson, Phytologia 24: 385. 1972. = Ayapanopsis oblongifolia (Gardner) R. King \& H. Robinson.

Ayapanopsis tucumanensis (Lillo \& B. Robinson) R. King \& H. Robinson, Phytologia 24: 385. 1972.

Ayapanopsis vargasii R. King \& H. Robinson, Phytologia 24: 385. 1972.

Baccharis microphylla DC., Prodr. 5: 406. 1836. = Nothobaccharis candolleana (Steudel) R. King \& H. Robinson.

Baccharis oppositifolia Kuntze, Revis. Gen. Pl. 138. 1891. = Polyanthina nernorosa (Klatt) R. King \& H. Robinson.

Baccharis squamulosa M. E. Jones, Contr. W. Bot. 18: 71. 19331935, nom. nud. = Asanthus squamulosus (A. Gray) R. King \& H. Robinson.

Badilloa atrescens (B. Robinson) R. King \& H. Robinson, Phytologia 49: 7. 1981. 
Badilloa drepanoides (B. Robinson) R. King \& H. Robinson, Phytologia 30: 230. 1975.

Badilloa helianthifolia (H. B. K.) R. King \& H. Robinson, Phytologia 30: 230. 1975.

Badilloa herrerae (B. Robinson) R. King \& H. Robinson, Phytologia 30: 230. 1975.

Badilloa procera (B. Robinson) R. King \& H. Robinson, Phytologia 30: 230. 1975.

Badilloa salicina (Lam.) R. King \& H. Robinson, Phytologia 30: 230. 1975.

Badilloa sonsonensis R. King \& H. Robinson, Phytologia 30: 231. 1975.

Badilloa sphagnophila (B. Robinson) R. King \& H. Robinson, Phytologia 30: 231. 1975.

Badilloa steetzii (B. Robinson) R. King \& H. Robinson, Phytologia 30: 231. 1975.

Badilloa venezuelensis (V. Badillo) R. King \& H. Robinson, Phytologia 30: 232. 1975

Bahianthus viscosus (Sprengel) R. King \& H. Robinson, Phytologia 23: 313. 1972.

Barroetea brevipes B. Robinson, Proc. Amer. Acad. Arts 47: 205. 1911.

Barroetea glutinosa Brandegee, Zoe 5: 262. 1908. = Phanerostylis glutinosa (Brandegee) R. King \& H. Robinson.

Barroetea laxiflora Brandegee, Univ. Calif. Publ. Bot. 4:93. 1910.

Barroetea pavonii A. Gray, Proc. Amer. Acad. Arts 17:206. 1882.

Barroetea sessilifolia Greenman, Proc. Amer. Acad. Arts 40: 35. 1904.

Barroetea setosa A. Gray, Proc. Amer. Acad. Arts 15: 29. 1880.

Barroetea subuligera (Schauer) A. Gray, Proc. Amer. Acad. Arts 15: 29. 1880.

Barrosoa apiculata (Gardner) R. King \& H. Robinson, Phytologia 24: 184. 1972

Barrosoa betonicaeformis (DC.) R. King \& H. Robinson, Phytologia 21: 27. 1971.

Barrosoa cabrerae (B. Robinson) R. King \& H. Robinson, Phytologia 21: 27. 1971.

Barrosoa candolleana (Hook. \& Arn.) R. King \& H. Robinson, Phytologia 21: 27. 1971.

Barrosoa confluentis (B. Robinson) R. King \& H. Robinson, Phytologia 49: 3. 1981.

Barrosoa metensis (B. Robinson) R. King \& H. Robinson, Phytologia 24: 184. 1972.

Barrosoa morichalana (Aristeg.) R. King \& H. Robinson, Phytologia 21: 27. 1971. = Barrosoa metensis (B. Robinson) R. King \& $\mathrm{H}$. Robinson.

Barrosoa organensis (Gardner) R. King \& H. Robinson, Phytologia 24: 184. 1972.

Barrosoa ramboi (Cabrera) R. King \& H. Robinson, Phytologia 21: 27. 1971.

Barrosoa trianae (B. Robinson) R. King \& H. Robinson, Phytologia 24: 184. 1972.

Barrosoa viridiflora (Baker) R. King \& H. Robinson, Phytologia 24: 184. 1972. = Barlettina hemisphaerica (DC.) R. King \& H. Robinson.

Bartlettina breedlovei R. King \& H. Robinson, Phytologia 28: 286. 1974.

Barlletina brevipetiolata (Schultz-Bip. ex Klatt) R. King \& H. Robinson, Phytologia 22: 160. 1971.

Bartlettina campii R. King \& H. Robinson, Phytologia 49: 7. 1981.

Bartlettina chiriquensis R. King \& H. Robinson, Phytologia 38: 109. 1977.

Barllettina cleefii R. King \& H. Robinson, Phytologia 47: 122. 1980.

Bartlettina constipatiflora (Klatt) R. King \& H. Robinson, Phytologia 22: 160. 1971.
Bartlettina cronquistii R. King \& H. Robinson, Phytologia 38: 108. 1977.

Bartlettina ehrenbergii (Hemsley) R. King \& H. Robinson, Phytologia 22: 160. 1971. = Barlettina macrocephala (Benth.) R. King \& $\mathrm{H}$. Robinson.

Bartlettina guatemalensis R. King \& H. Robinson. Phytologia 28: 287. 1974.

Bartlettina hastifera (Standley \& Steyerm.) R. King \& H. Robinson, Phytologia 22: 160. 1971.

Bartlettina hemisphaerica (DC.) R. King \& H. Robinson, Phytologia 22: 160. 1971.

Barlettina hintonii R. King \& H. Robinson, Phytologia 31: 62. 1975.

Barlettina hylobia (B. Robinson) R. King \& H. Robinson, Phytologia 22: 161. 1971.

Bartlettina karvinskiana (DC.) R. King \& H. Robinson, Phytologia 22: 161. 1971.

Bartlettina liesneri R. King \& H. Robinson, Phytologia 47: 121. 1980.

Barlettina luxii (B. Robinson) R. King \& H. Robinson, Phytologia 22: 161. 1971.

Bartlettina macdougallii R. King \& H. Robinson, Phytologia 38: 107. 1977.

Bartlettina macrocephala (Benth.) R. King \& H. Robinson, Phytologia 24: 266. 1972.

Barllettina macromeris (B. Robinson) R. King \& H. Robinson, Phytologia 49: 3. 1981.

Bartlettina matudae R. King \& H. Robinson, Phytologia 28: 288. 1974.

Bartlettina maxonii (B. Robinson) R. King \& H. Robinson, Phytologia 22: 161. 1971.

Bartlettina montigena (Standley \& Steyerm.) R. King \& H. Robinson, Phytologia 38: 111. 1977.

Bartlettina oresbia (B. Robinson) R. King \& H. Robinson, Phytologia 22: 161. 1971.

Bartlettina oresbioides (B. Robinson) R. King \& H. Robinson, Phytologia 22: 161. 1971.

Bartlettina paezensis (Hieron.) R. King \& H. Robinson, Phytologia 22: 161. 1971.

Barllettina pansamalensis (B. Robinson) R. King \& H. Robinson, Phytologia 22: 161, 1971.

Bartlettina perezioides (B. Robinson) R. King \& H. Robinson, Phytologia 47: 121. 1980.

Bartlettina pinabetensis (B. Robinson) R. King \& H. Robinson, Phytologia 22: 161. 1971.

Bartlettina platyphylla (B. Robinson) R. King \& H. Robinson, Phytologia 22: 161. 1971.

Bartlettina prionophylla (B. Robinson) R. King \& H. Robinson, Phytologia 22: 161. 1971.

Bartlettina ruae (Standley) R. King \& H. Robinson, Phytologia 22: 161. 1971. = Bartlettina pansamalensis (B. Robinson) R. King \& H. Robinson.

Bartlettina silvicola (B. Robinson) R. King \& H. Robinson, Phytologia 38: 111. 1977.

Bartlettina sordida (Less.) R. King \& H. Robinson, Phytologia 22: 161. 1971.

Bartlettina tenorae (Aristeg.) R. King \& H. Robinson, Phytologia 35: 498.1977.

Bartlettina tuerckheimii (Klatt) R. King \& H. Robinson, Phytologia 22: 162. 1971.

Bartlettina williamsii R. King \& H. Robinson, Phytologia 38: 106. 1977.

Batschia nivea Moench, Methodus 567. 1794. = Ageratina altissima (L.) R. King \& H. Robinson.

Bejaranoa balansae (Hieron.) R. King \& H. Robinson, Phytologia 40: 53. 1978.

Bejaranoa semistriata (Baker) R. King \& H. Robinson, Phytologia 40: 53. 1978. 
Bembicium gracile Martius ex Baker, F1. Bras. 6(2): 343. 1876, nom. nud. = Praxelis kleinioides (H. B. K.) Schultz-Bip.

Biasolettia elliptica Pohl ex Baker, Fl. Bras. 6(2): 311. 1876, nom. nud. = Ayapanopsis trixioides (Martius ex Baker) R. King \& H. Robinson.

Bidens atriplicifolia L., Cent. P1. 1 30. 1756. = Isocarpha atriplicifolia (L.) R. Br. ex DC.

Bigelowia oppositifolia A. Gray, Proc. Amer. Acad. Arts 15: 32. 1880. = Ageratina mygindaefolia (A. Gray) R. King \& H. Robinson.

Biolettia riparia E. Greene, Pittonia 2: 216. 1891 = Trichocoronis urightii (Torrey \& A. Gray) A. Gray.

Bishopiella elegans R. King \& H. Robinson, Phytologia 48: 218. 1981.

Bishovia boliviensis R. King \& H. Robinson, Phytologia 39: 340. 1978.

Bishovia mikaniifolia (B. Robinson) R. King \& H. Robinson, Phytologia 39: 341. 1978.

Blakeanthus cordatus (Blake) R. King \& H. Robinson, Phytologia 24: 119. 1972.

Brachyandra macrogyne Philippi, Fl. Atacam. 34. T. 4. $1860 .=$ Helogyne macrogyne (Philippi) B. Robinson.

Brachyandra tenuifolia Reiche, Fl. Chile 3: 263. 1902. = Helogyne apaloidea Nutt.

Brickellia adenocarpa B. Robinson, Mem. Gray Herb. 1: 93. 1917. = Brickellia argyrolepis B. Robinson.

Brickellia adenolepis (B. Robinson) Shinn., Sida 4: 274. 1971.

Brickellia albicaulis (Rydb.) Nelson in Coulter \& Nelson, New Man. Bot. Centr. Rocky Mt. 487. 1909. = Brickellia californica (Torrey \& A. Gray) A. Gray.

Brickellia ambigens (E. Greene) Nelson, New Man. Bot. Centr. Rocky Mt. 486. 1909. = Brickelliastrum fendleri (A. Gray) R. King \& H. Robinson.

Brickellia amblyolepis B. Robinson, Proc. Amer. Acad. Arts 36: 485. 1901. = Steviopsis amblyolepis (B. Robinson) R. King \& H. Robinson.

Brickellia amplexicanlis B. Robinson, Proc. Amer. Acad. Arts 47: 199. 1911.

Brickellia arguta B. Robinson, Mem. Gray Herb. 1: 102.1917.

Brickellia argyrolepis B. Robinson, Mem. Gray Herb. 1: 90. 1917.

Brickellia arsenei B. Robinson, Proc. Amer. Acad. Arts 55: 40. 1919. = Dyscritogyne adenosperma (Schultz-Bip.) R. King \& H. Robinson.

Brickellia atractyloides A. Gray, Proc. Amer. Acad. Arts 8: 290. 1870.

Brickellia baccharidea A. Gray, Pl. Wright. 1: 87. 1850.

Brickellia betonicaefolia A. Gray, Pl. Wright. 2: 72. 1852.

Brickellia betonicaefolia var. conduplicata B. Robinson, Proc. Amer. Acad. Arts 43: 37. 1907. = Brickellia conduplicata B. Robinson.

Brickellia botterii B. Robinson, Mem. Gray Herb. 1: 93.1917.

Brickellia brachiata A. Gray, Proc. Amer. Acad. Arts 21: 385. 1886.

Brickellia brachiata var. glabrata Rose, Contr. U. S. Natl. Herb. 1: 83. 1890. = Brickellia glabrata (Rose) B. Robinson.

Brickellia brachyphylla (A. Gray) A. Gray, Pl. Wright. 1: 84. 1852.

Brickellia brandegei B. Robinson, Mem. Gray Herb. 1: 106. 1917. Brickellia brasiliensis (Sprengel) B. Robinson, Proc. Amer. Acad. Arts 47: 199. 1911. = Pseudobrickellia brasiliensis (Sprengel) R. King \& H. Robinson.

Brickellia californica (Torrey \& A. Gray) A. Gray, Pl. Fendler. 64. 1848.

Brickellia cardiophylla B. Robinson, Proc. Amer. Acad. Arts 36: 485. 1901 .

Brickellia cavanillesii (Cass.) A. Gray, Pl. Wright. 1: 85. 1850.

Brickellia cayucensis M. E. Jones, Contr. W. Bot. 18: 71. 19331935 , nom. nud. = Brickellia coulteri A. Gray, ?
Brickellia cedrosensis E. Greene, Bull. Torrey Bot. Club 10: 86. 1883. = Brickellia microphylla (Nutt.) A. Gray.

Brickellia chenopodina (Greene ex Wooton \& Standley) B. Robinson, Mem. Gray Herb. 1: 99. 1917.

Brickellia chlorolepis (Wooton \& Standley) Shinn., Sida 4: 274. 1971.

Brickellia coahuilensis (A. Gray) Harc. \& Beaman, Southw. Naturalist 12: 129. 1967. = Phanerostylis coahuilensis (A. Gray) R. King \& H. Robinson.

Brickellia colimae Rose, Contr. U. S. Natl. Herb. 1: 333. 1895. = Brickellia hebecarpa (DC.) A. Gray.

Brickellia conduplicata B. Robinson, Mem. Gray Herb. I: 79. 1917.

Brickellia cordifolia Elliott, Sketch Bot. S. Carolina 2: 290. 1824.

Brickellia coridifolia (DC.) B. Robinson, Proc. Amer. Acad. Arts 47: 200. 1911. = Pseudobrickellia? .

Brickellia corymbosa (DC.) A. Gray, Pl. Wright. 1: 84. 1850.

Brickellia coulteri A. Gray, P1. Wright. 1: 86. 1850.

Brickellia cumingii Klatt, Abh. Naturf. Ges. Halle 15:325. 1882. = Chrysopsis oregana (Nutt.) A. Gray. AstereAE.

Brickellia cuspidata S. Watson in A. Gray, Proc. Amer. Acad. Arts 22: 421.1887.

Brickellia cylindracea A. Gray \& Engelm., Proc. Amer. Acad. Arts 1: 46. 1846.

Brickellia cymulifera B. Robinson, Proc. Amer. Acad. Arts 51: 538. 1916. = Kyrsteniopsis cymulifera (B. Robinson) R. King \& H. Robinson.

Brickellia dentata (DC.) Schultz-Bip., Bot. Voy. Herald 301. 1856. Brickellia desertorum Cov., Proc. Biol. Soc. Wash. 7: 68. 1892.

Brickellia diffusa (Vahl) A. Gray, Pl. Wright. 1: 86. 1850.

Brickellia diffusa M. E. Jones, Contr. W. Bot. 18: 71. 1933-1935, nom. nud. = Brickellia cardiophylla B. Robinson, ?

Brickellia eupatorioides (L.) Shinn., Sida 4: 274. 1971.

Brickellia extranea McVaugh, Contr. Univ. Michigan Herb. 9: 378. 1972.

Brickellia fendleri A. Gray, Mem. Amer. Acad. Arts 4: 63. 1849. = Brickelliastrum fendleri (A. Gray) R. King \& H. Robinson. Brickellia filipes B. Robinson, Mem. Gray Herb. 1: 26. 1917.

Brickellia floribunda A. Gray, P1. Wright. 2: 73. 1852.

Brickellia frutescens A. Gray, Proc. Amer. Acad. Arts 17: 207. 1882.

Brickellia galeottii A. Gray, Pl. Wright. 1: 85. 1850. = Brickellia veronicaefolia (H. B. K.) A. Gray.

Brickellia gentianoides B. Robinson, Contr. Gray Herb. 68: 42. 1923. = Chromolaena gentianoides (B. Robinson) R. King \& H. Robinson.

Brickellia glabrata (Rose) B. Robinson, Mem. Gray Herb. 1: 63. 1917.

Brickellia glandulosa (Llave in Llave \& Lex.) McVaugh, Contr. Univ. Michigan Herb. 9: 380. 1972.

Brickellia glomerata Fern., Proc. Amer. Acad. Arts 36: 504. 1901.

Brickellia glutinosa A. Gray, Proc. Amer. Acad. Arts 21: 385. 1886.

Brickellia grandiflora (Hook.) Nutt., Trans. Amer. Philos. Soc. ser. 2, 7: 287. 1841.

Brickellia grandiflora var. petiolaris A. Gray, Proc. Amer. Acad. Arts 17:207. 1882. = Brickellia grandiflora (Hook.) Nutt.

Brickellia grayanae Hieron., Bot. Jahrb. Syst. 28: 583. 1901. = Brickellia microphylla (Nutt.) A. Gray.

Brickellia greenei A. Gray, Proc. Amer. Acad. Arts 12: 58. 1876.

Brickellia guatemalensis B. Robinson, Mem. Gray Herb. 1: 92. 1917. = Brickellia argyrolepis B. Robinson.

Brickellia hartwegi A. Gray, Pl. Wright. 1: 85. 1850. = Brickellia paniculata (Miller) B. Robinson.

Brickellia hastata Benth., Bot. Voy. Sulphur 21. 1844.

Brickellia hebecarpa (DC.) A. Gray, Pl. Wright. 1: 85. 1850.

Brickellia hebecarpoides B. Robinson, Proc. Amer. Acad. Arts 36: 486. 1901. = Brickellia pacayensis Coulter. 
Brickellia hinckleyi Standley, Publ. Field Mus. Nat. Hist., Bot. Ser. 22: 61. 1940. = Brickellia brachyphylla A. Gray.

Brickellia hintoniorum B. Turner, Phytologia 58: 493. 1985. = Phallerostylus hintoniorum (B. Turner) R. King \& H. Robinson.

Brickellia humilis (E. Greene) Nelson in Coulter \& Nelson, New Man. Bot. Centr. Rocky Mt. 487. 1909, comb. inval. = Brickellia oblongifolia Nutt.

Brickellia hymenochlaena A. Gray, Proc. Amer. Acad. Arts 15: 29. 1879.

Brickellia incana A. Gray, Proc. Amer. Acad. Arts 7: 350.1867

Brickellia jalisceusis McVaugh, Contr. Univ. Michigan Herb. 9: 380. 1972.

Brickellia kellermanii Greenman, Publ. Field Columbian Mus., Bot. Ser. 2: 265. 1907.

Brickellia knappiana Drew in Greene, Pittonia 1: 260. 1888.

Brickellia laccata Flyr, Sida 3: 252. 1968.

Brickellia laciniata A. Gray, P1. Wright. 1: 87. 1850.

Brickellia lanata (DC.) A. Gray, PI. Wright. 1: 84. 1850.

Brickellia lancifolia B. Robinson \& Greenman, Amer. J. Sci. Arts Ser. 3. 1: 152. 1895.

Brickellia lemmonii A. Gray, Proc. Amer. Acad. Arts 17: 206. 1882.

Brickellia leptophylla (Scheele) Shinn., Sida 4: 274. 1971.

Brickellia lewisii B. Turncr, Phytologia 57: 167. 1985.

Brickellia linearifolia Klatt, Abh. Naturf. Ges. Halle 15: 325. 1882. = Bigelowia visciflora. AsterEAE.

Brichellia linifolia D. Eaton in S. Watson, Bot. U. S. Geol. Exped. 137. T. 15, f. 1-6. 1871. = Brickellia oblongifolia Nutt.

Brickellia longifolia S. Watson, Amer. Naturalist 7: 301. 1873.

Brickellia macromera B. Robinson, Mem. Gray Herb. 1: 107. 1917.

Brickellia inagnifica McVaugh, Contr. Univ. Michigan Herb. 9: 382. 1972.

Brickellia mcdonaldii B. Turner, Phytologia 58: 219. 1985.

Brickellia ulegalodonta Greenman, Proc. Amer. Acad. Arts 40: 34. 1904. = Brickellia coulteri A. Gray.

Brickellia megaphylla M. E. Jones ex B. Robinson in Blake, Contr. U. S. Natl. Herb. 29: 125. 1945.

Brickellia microphylla (Nutt.) A. Gray, Pl. Wright. 1: 85. 1850.

Brickellia microphylla (DC.) Hieron., Bot. Jahrb. Syst. 28: 583. 1901. = Nothobaccharis candolleana (Steudel) R. King \& H. Robinson.

Brickellia microphylla var. scabra A. Gray, Proc. Amer. Acad. Arts 11: 74. 1876. = Brickellia scabra (A. Gray) Nelson in Coulter \& Nelson.

Brickellia mohavensis A. Gray, Syn. Fl. N. Amer. 1(2): 104. 1886. = Brickellia oblongifolia Nutt.

Brickellia monocephala B. Robinson, Proc. Boston Soc. Nat. Hist. 31: 268. 1904.

Brickellia mosieri (Small) Shinn., Sida 4: 274. 1971.

Brickellia multiflora Kellogg, Proc. Calif. Acad. Sci. 7: 49. 1876.

Brickellia llelsonii B. Robinson, Mem. Gray Herb. 1: 79. 1917.

Brickellia nesonnii B. Turner, Brittonia 30: 342. 1978. = Phauerostylis nesomii (B. Turner) R. King \& H. Robinson.

Brickellia nevinii A. Gray, Proc. Amer. Acad. Arts 20: 297. 1884.

Brickellia nutans B. Robinson \& Greenman, Amer. J. Sci. Arts 50: 152. 1895. = Brickellia orizabaensis Klatt.

Brickellia mutans (H. B. K.) B. Robinson, Mem. Gray Herb. 1: 85. 1917. = Brickellia nutanticeps S. F. Blake.

Brickellia nutanticeps S. F. Blake, J. Wash. Acad. Sci. 33: 266. 1943.

Brickellia oblongifolia Nutt., Trans. Amer. Philos. Soc. ser. 2, 7: 288. 1841.

Brickellia odontophylla A. Gray, Proc. Amer. Acad. Arts 17: 206. 1882.

Brickellia oliganthes (Less.) A. Gray, P1. Wright. 1: 84. 1850.

Brickellia oreithales (B. Robinson) Shinn., Sida 4: 274. 1971.
Brickellia orizabaensis Klatt, Ann. K. K. Naturhist. Hofmus. 9: 358. 1894.

Brickellia pacayensis Coulter, Bot. Gaz. (Crawfordsville) 16: 98. 1891. = Brickellia glandulosa (Llave in Llave \& Lex.) McVaugh.

Brickellia palıneri A. Gray, Proc. Amer. Acad. Arts 15: 30. 1879. Brickellia paniculata (Miller) B. Robinson, Proc. Amer. Acad. Arts 42: 48. 1906.

Brickellia parryi A. Gray, Proc. Amer. Acad. Arts 15: 31. 1879.

Brickellia parvula A. Gray, PI. Wright. 1: 84. 1850.

Brickellia paucidentata Klatt, Abh. Naturf. Ges. Halle 15: 326 1882 , ignota.

Brickellia pedunculosa (DC.) Harc. \& Beaman, Southw. Naturalist 12: 128. 1967. = Phanerostylis pedunculosa (DC.) R. King \& H. Robinson

Brickellia pendula (Schrader) A. Gray, PI. Wright. 1: 85. 1850.

Brickellia peninsularis Brandegee, Zoe 5: 160. 1903.

Brickellia petrophila B. Robinson, Proc. Amer. Acad. Arts 36: 486. 1901 . = Brickellia verouicaefolia (H. B. K.) A. Gray.

Brickellia pinifolia (Gardner) A. Gray, PI. Wright. 1: 84. 1850. = Pseudobrickellia brasiliensis (Sprengel) R. King \& H. Robinson.

Brickellia pringlei A. Gray, Proc. Amer. Acad. Arts 17: 206. 1882.

Brickellia pulcherrima B. Robinson, Proc. Boston Soc. Nat. Hist. 31: 268. 1904. = Steviopsis vigintiseta (DC.) R. King \& H. Robinson.

Brickellia rapunculoides (DC.) McVaugh, Contr. Univ. Michigan Herb. 9: 383. 1972. = Steviopsis rapunculoides (DC.) R. King \& H. Robinson.

Brickellia recondita (McVaugh) Keil \& Pinkava, Amer. J. Bot. 63(10): 1393. 1976. = Carninatia recondita McVaugh.

Brickellia reniformis A. Gray, Pl. Wright. 1:86. 1850.= Brickellia californica (Torrey \& A. Gray) A. Gray.

Brickellia reticulata (DC.) A. Gray, PI. Wright. 1: 84. 1850.

Brickellia rhomboidea E. Greene, Pittonia 2: 103. 1890.

Brickellia riddellii (Torrey \& A. Gray) A. Gray, Pl. Wright. 1: 83. 1850. = Brickellia dentata (DC.) Schultz-Bip.

Brickellia robinsoniana S. F. Blake, Proc. Biol. Soc. Wash. 54: 17. 1941.

Brickellia rosalesia Benth. \& Hook. f. ex Hemsley, Biol. Cent.Amer., Bot. 2: 106. 1881. = Brickellia glandulosa (Llave in Llave \& Lex.) McVaugh.

Brickellia rusbyi A. Gray, Syn. Fl. N. Amer. 2. 1: 106. 1886.

Brickellia saltillensis B. Robinson, Proc. Amer. Acad. Arts 43: 37. 1907

Brickellia scabra (A. Gray) Nelson in Coulter \& Nelson, New Man. Bot. Centr. Rocky Mt. 487. 1909.

Brickellia schaffneri (A. Gray) Shinn., Sida 4: 274. 1971.

Brickellia scoparia (DC.) A. Gray, PI. Wright. 1: 84. 1850.

Brickellia secundiflora (Lagasca) A. Gray, Pl. Wright. 1: 85. 1850.

Brickellia seemannii A. Gray, Proc. Amer. Acad. Arts 15: 30. 1879.

Brickellia shineri M. E. Jones ex Flyr, Sida 3: 254. 1968. = Flyriella parryi (A. Gray) R. King \& H. Robinson.

Brickellia simplex A. Gray, PI. Wright. 2: 73. 1852.

Brickellia solidaginifolia A. Gray, Proc. Amer. Acad. Arts 22: 306. 1886. = Asauthus solidaginifolius (A. Gray) R. King \& H. Robinson.

Brickellia spinulosa A. Gray, PI. Wright. 1: 84. 1850.

Brickellia squarmulosa A. Gray, Proc. Amer. Acad. Arts 15: 30. 1879. = Asanthus squamulosus (A. Gray) R. King \& H. Robinson.

Brickellia squarrosa B. Robinson \& Seaton, Proc. Amer. Acad. Arts 28: 108. 1893. = Brickellia pendula (Schrader) A. Gray. Brickellia squarrosa (Cav.) B. Robinson, Mem. Gray Herb. 1: 90. 1917. = Brickellia cavanillesii (Cass.) A. Gray.

Brickellia stolonifera B. Tumer, Phytologia 52: 252. 1982.

Brickellia subsessilis B. Robinson, Mem. Gray Herb. 1: 56. 1917. 
Brickellia tenera A. Gray, Pl. Wright. 2: 72. 1852. = Brickellia californica (Torrey \& A. Gray) A. Gray.

Brickellia tenuiflora (DC.) Keil \& Pinkava, Amer. J. Bot. 63(10): 1393. 1976. = Carminatia tenuiflora DC.

Brickellia thyrsiflora A. Gray, Proc. Amer. Acad. Arts 15: 30. 1879. = Asanthus thyrsiflorus (A. Gray) R. King \& H. Robinson.

Brickellia tomentella A. Gray, Pl. Wright. 1: 85. 1850.

Brickellia umbellata (E. Greene) Nelson in Coulter \& Nelson, New Man. Bot. Centr. Rocky Mt. 486. 1909, comb. inval. = Brickellia grandiflora (Hook.) Nutt.

Brickellia umbellata (E. Greene) Rydb., Brittonia 1: 98. 1931. = Brickellia grandiflora (Hook.) Nutt.

Brickellia undonis M. E. Jones, Contr. W. Bot. 18: 71. 19331935 , nom. nud. = Brickellia peninsularis Brandegee, ?

Brickellia urolepis S. F. Blake, J. Wash. Acad. Sci. 32: 146. 1942.

Brickellia venosa (Wooton \& Standley) B. Robinson, Mem. Gray Herb. 1: 50. 1917.

Brickellia verbenacea (E. Greene) B. Robinson, Mem. Gray Herb. 1: 53. 1917.

Brickellia vernicosa B. Robinson, Proc. Amer. Acad. Arts 36: 487. 1901.

Brickellia veronicaefolia (H. B. K.) A. Gray, Pl. Wright. 1: 85. 1850.

Brickellia viejensis Flyr, Sida 3: 253. 1968.

Brickellia vollmeri Wiggins, Contr. Dudley Herb. 3: 286. 1943.

Brickellia watsonii B. Robinson, Mem. Gray Herb. 1: 42.1917.

Brickellia wislizeni A. Gray, Pl. Fendler. 64. 1848.

Brickellia wrightii A. Gray, Pl. Wright. 2: 72. 1852. = Brickellia californica (Torrey \& A. Gray) A. Gray.

Brickelliastrum fendleri (A. Gray) R. King \& H. Robinson, Phytologia 24: 64. 1972

Bulbostylis anmua Nutt., J. Acad. Nat. Sci. Philadelphia Ser. 2. 1: 179. 1847. = Psathyrotes annua (Nutt.) A. Gray. HELIANTHEAE.

Bulbostylis californica Torrey \& A. Gray, Fl. N. Amer. 2: 79. 1841 . = Brickellia californica (Torrey \& A. Gray) A. Gray.

Bulbostylis cassiniana Gardner, London J. Bot. 5: 471. 1846. = Heterocondylus alatus (Vell. Conc.) R. King \& H. Robinson, in part.

Bulbostylis cavanillesii (Cass.) DC., Prodr. 5: 138. 1836. = Brickellia caranillesii (Cass.) A. Gray.

Bulbostylis deltoides Buckley, Proc. Acad. Nat. Sci. Philadelphia 13: 456. 1861. = Ageratina havanensis (H. B. K.) R. King \& H. Robinson.

Bulbostylis diffusa (Vahl) DC., Prodr. 7: 268. 1838. = Brickellia diffisa (Vahl) A. Gray.

Bulbostylis elegans Gardner, London J. Bot. 5: 467. 1846. = Ayapana amy'gdalina (Lam.) R. King \& H. Robinson.

Bulbostylis glabra DC., Prodr. 5: 139. 1836. = Heterocondylus alatus (Vell. Conc.) R. King \& H. Robinson.

Bulbostylis glabriuscula K. Koch, App. Sem. Hort. Berol. 13. 1855. = Ayapana?

Bulbostylis glandulosa Gardner, London J. Bot. 5: 469. 1846.= Ayapana anygdalina (Lam.) R. King \& H. Robinson.

Bulbostylis hastata (Benth.) Walp., Repert. Bot. Syst. 4: 279. 1847, nom. nud. = Brickellia hastata Benth.

Bulbostylis hebecarpa DC., Prodr. 5: 138. 1836. = Brickellia hebecarpa (DC.) A. Gray.

Bulbostylis lanata DC., Prodr. 7: 268. 1838. = Brickellia lanata (DC.) A. Gray.

Bulbostylis micrantha Gardner, London J. Bot. 6: 449. 1847, nom. nud. = Ayapana amygdalina (Lam.) R. King \& H. Robinson.

Bulbostylis microcephala Gardner, London J. Bot. 5: 468.1846. = Ayapana amygdalina (Lam.) R. King \& H. Robinson.

Bulbostylis microphylla Nutt., Trans. Amer. Philos. Soc. 2, 7: 286. 1841. = Brickellia microphylla (Nutt.) A. Gray.
Bulbostylis nepetaefolia (H. B. K.) DC., Prodr. 5: 139. 1836. = Brickellia scabra (A. Gray) Nelson in Coulter \& Nelson.

Bulbostylis oblongifolia Gardner, London J. Bot. 5: 469. 1846. = Ayapanopsis oblongifolia (Gardner) R. King \& H. Robinson.

Bulbostylis oliganthes (Less.) DC., Prodr. 5: 139. 1836. = Brickellia oliganthes (Less.) A. Gray.

Bulbostylis pauciflora (H. B. K.) DC., Prodr. 5: 139. $1836 .=$ Praxelis pauciflora (H. B. K.) R. King \& H. Robinson.

Bulbostylis pedunculosa DC., Prodr. 5: 138. 1836. = Phanerostylis pedunculosa (DC.) R. King \& H. Robinson.

Bulbostylis pendula (Schrader) DC., Prodr. 5: 138. 1836. = Brickellia pendula (Schrader) A. Gray.

Bulbostylis pumila Gardner, London J. Bot. 5: 470. 1846. = Heterocondylus pumilus (Gardner) R. King \& H. Robinson.

Bulbostylis ramosissima Gardner, London J. Bot. 5: 471. 1846. $=$ Heterocondylus alatus (Vell. Conc.) R. King \& H. Robinson.

Bulbostylis reticulata DC., Prodr. 7: 268. 1838. = Brickellia reticulata (DC.) A. Gray.

Bulbostylis rigida Hook. \& Am., Bot. Beechey Voy. 297. 1838. = Brickellia lanata (DC.) A. Gray.

Bulbostylis scandens Gardner, London J. Bot. 5: 470. 1846. = Heterocondylus vitalbae (DC.) R. King \& H. Robinson.

Bulbostylis scorodoniaefolia Kunth, Ind. Sem. Hort. Berol. 12. 1846. = Brickellia secundiflora (Lagasca) A. Gray.

Bulbostylis secundiflora (Lagasca) DC., Prodr. 5: 138. 1836. = Brickellia secundiflora (Lagasca) A. Gray.

Bulbostylis spinaciaefolia DC., Prodr. 5: 139. 1836. = Critonia spinaciaefolia (DC.) R. King \& H. Robinson.

Bulbostylis subuligera S. Schauer, Linnaea 19: 718. 1847.= Barroetea subuligera (Schauer) A. Gray.

Bulbostylis tomentosa Gardner, London J. Bot. 5: 468. 1846. = Ayapana amygdalina (Lam.) R. King \& H. Robinson.

Bulbostylis triangularis DC., Prodr. 7: 268. 1838. = Eupatoriastrum triangulare (DC.) B. Robinson.

Bulbostylis veronicaefolia (H. B. K.) DC., Prodr. 5: 139. 1836. = Brickellia veronicaefolia (H. B. K.) A. Gray.

Bustainenta cordata Alaman ex DC., Prodr. 5: 166. 1836, nom. nud. = Ageratina petiolaris (Mocino \& Sesse ex DC.) R. King \& H. Robinson.

Bustamenta ovata Mairet ex DC., Prodr. 5: 168. 1836, nom. nud. = Ageratina bustamenta (DC.) R. King \& H. Robinson.

Cacalia angulata Vell. Conc., Fl. Flum. 315. 1825. = Mikania cordifolia (L. f.) Willd.

Cacalia asclepiadea L. f., Suppl. PI. 352. 1781. = Ageratina asclepiadea (L. f.) R. King \& H. Robinson.

Cacalia cor-jesu Vell. Conc., Fl. Flum. 318. 1825. = Mikania officinalis Martius.

Cacalia cordata Vell. Conc., Fl. Flum. 314. 1825. = Mikania cordifolia (L. f.) Willd.

Cacalia cordifolia L. f., Suppl. Pl. 351. 1781 . = Mikania cordifolia (L. f.) Willd.

Cacalia crenata Vell. Conc., Fl. Flum. 314. 1825. = Stomatanthes?.

Cacalia ernarginata Vell. Conc., Fl. Flum. 314. 1825 = Grazielia?.

Cacalia heterophylla Bartram, Travels Carolina 164. 1791. = Garberia heterophylla (Bartram) Merr. \& Harper.

Cacalia laeta Vell. Conc., Fl. Flum. 319. 1825. = Flosculi coccinei. EUPATORIEAE?

Cacalia laurifolia L. f., Suppl. PI. 351. 1781. = Mikania laurifolia (L. f.) Willd.

Cacalia mentrasto Vell. Conc., F1. Flum. 339. 1825. = Ageratum houstonianum Miller.

Cacalia nitida Vell. Conc., Fl. Flum. 316, 1825 = Mikania laevigata Schultz-13ip. ex Baker or Mikania lindbergii Bakcr?

Cacalia pilosa Vell. Conc., Fl. Flum. 316. 1825. = Mikania cordifolia (L. f.) Willd. 
Cacalia pubescens Raf., Fl. Ludov. 61. 1817. = Mikania corymbulosa Benth.

Cacalia punctulata Vell. Conc., F1. Flum. 317. 1825. = Critonia?

Cacalia reticulata Vell. Conc., Fl. Flum. 316. 1825. = Ophryosporus?.

Cacalia septemnata Vell. Conc., Fl. Flum. 316. 1825. = Mikania ternata (Vell. Conc.) B. Robinson.

Cacalia ternata Vell. Conc., Fl. Flum. 315. 1825. = Mikania ternata (Vell. Conc.) B. Robinson.

Cacalia triangularis Vell. Conc., Fl. Flum. 316. 1825. = Mikania cordifolia (L. f.) Willd.

Cacalia trilobata Vell. Conc., F1. Flum. 315. 1825. = Mikania glomerata Sprengel or Mikania vitifolia DC.

Cacalia villosa Vell. Conc., Fl. Flum. 315. 1825. = Mikania sp.

Caelestina ageratoides H. B. K., Nov. Gen. Sp. 4: 118 . Ed. Folio. 1818. = Ageratum corymbosum Zuccagni.

Caelestina albida DC., Prodr. 5: 107. 1836. = Ageratum albidum (DC.) Hemsley.

Caclestina caerilea Cass., Dict. Sci. Nat. 6. Suppl. 8. 1817. = Ageratum corymbosum Zuccagni.

Caelestina cordata Pohl ex Baker, Fl. Bras. 6(2): 345. 1876, nom. nud. = Hebeclinium macrophyllum (L.) DC.

Caelestina corymbosa (Zuccagni) DC., Prodr. 5: 108. 1836. = Ageratum corymbosum Zuccagni.

Caelestina hartwegi Walp., Repert. Bot. Syst. 2: 545. 1843. = Conoclinium betonicum DC.

Caelestina hastata Pohl ex Baker, Fl. Bras. 6(2): 363. 1876, nom. nud. = Barrosoa betonicaeformis (DC.) R. King \& H. Robinson.

Caelestina isocarphoides DC., Prodr. 5: 107. 1836. = Ageratum isocarphoides (DC.) Hemsley.

Caelestina latifolia Benth. ex Oersted, Vidensk. Meddel. Dansk Naturhist. Foren. Kjobenhavn 71. 1852. = Ageratum nelsonii (B. Robinson) M. Johnson.

Caelestina lessingiana Klotzsch ex Walp., Repert. Bot. Syst. 2: 545. 1843. = Ageratum corymbosum Zuccagni.

Caelestina linearifolia Schultz-Bip. ex Baker, Fl. Bras. 6(2): 191. 1876, nom. nud. = Ageratum fastigiatum (Gardner) R. King \& H. Robinson.

Caclestina longifolia Pohl ex Baker, Fl. Bras. 6(2): 361. 1876, nom. nud. = Barrosoa organensis (Gardner) R. King \& H. Robinson.

Caclestina maritima Torrey \& A. Gray, F1. N. Amer. 2: 64. 1841. = Ageratum littorale A. Gray.

Caelestima micrantha Sprengel, Syst. Veg. Fl. Peruv. Chil. 3: 446. 1826. = Ageratum corymbosum Zuccagni.

Caclestina microcarpa Benth. ex Oersted, Vidensk. Meddel. Dansk Naturhist. Foren. Kjobenhavn 72. 1852. = Ageratum microcarpum (Benth. ex Ocrsted) Hemsley.

Caelestina paleacea Gay ex DC., Prodr. 5: 107. 1836. = Ageratum paleaceum (DC.) Hemsley.

Caclestina parvifolia DC., Prodr. 5: 108. 1836, ignota.

Caelestina petiolata Hook. \& Am., Bot. Beechey Voy. 433. 1841. = Ageratum petiolatum (Hook. \& Arn.) Hemsley.

Caelestina pohlii Schultz-Bip. ex Baker, Fl. Bras. 6(2): 190. 1876, nom. nud. = Alomia pohlii Baker.

Caelestina repanda Pohl ex Baker, Fl. Bras. 6(2): 309. 1876, nom. nud. = Bartlettina hemisphaerica (DC.) R. King \& H. Robinson.

Caelestina repens Schultz-Bip. ex Schomb., Faun. Fl. Brit.-Guian. 1134. 1849, nom. nud. ignota.

Caclestina scabriuscula Benth. ex Oersted, Vidensk. Meddel. Dansk Naturhist. Foren. Kjobenhavn 72. 1852. = Ageratum petiolatum (Hook. \& Am.) Hemsley.

Caclestina suffruticosa Sweet, Hort. Brit. 229. 1826, nom. illeg. = Ageratum conyzoides $\mathrm{L}$.

Caelestina tomentosa Benth. ex Oersted, Vidensk. Meddel. Dansk
Naturhist. Foren. Kjobenhavn 71. 1852. = Ageratum tornentosum (Benth. \& Oersted) Hemsley.

Caelestina urticaefolia Pohl ex Baker, Fl. Bras. 6(2): 362. 1876 , nom. nud. = Barrosoa betonicaeformis (DC.) R. King \& $\mathrm{H}$. Robinson.

Caelestina viscosa Pohl ex Baker, Fl. Bras. 6(2): 362. 1876, nom. nud. = Barrosoa apiculata (Gardner) R. King \& H. Robinson.

Calea oppositifolia L., Sp. Pl., ed. 2, 1179. 1763. = Isocarpha oppositifolia (L.) Cass.

Calostelma elegans (Walter) D. Don in Sweet, Brit. Fl. Gard. Ser. 2, T. 184. 1833. = Liatris elegans (Walter) Michaux.

Calydermos atriplicifolius (L.) Sprengel, Syst. Veg. Fl. Peruv. Chil. 3: 457. 1826. = Isocarpha atriplicifolia (L.) R. Br. ex DC.

Calydermos jamaicensis Sprengel, Syst. Veg. Fl. Peruv. Chil. 3: 457. 1826. = Critonia dalea (L.) DC.

Campovassouria bupleurifolia (DC.) R. King \& H. Robinson, Phytologia 22: 122. 1971. = Campovassouria cruciata (Vell. Conc.) R. King \& H. Robinson.

Campovassouria cruciata (Vell. Conc.) R. King \& H. Robinson, Phytologia 49: 3. 1981

Campuloclinium alternifolium Gardner, London J. Bot. 6: 438. 1847.

Campuloclinium arenarium Gardner, London J. Bot. 5: 467. 1846, ignota.

Campuloclinium ascendens Schultz-Bip. ex Baker, Fl. Bras. 6(2): 363. 1876 , nom. nud. = Conocliniopsis prasifolia $(\mathrm{DC}.) \mathrm{R}$. King \& H. Robinson.

Campuloclinium barrosoana (G. Barroso) R. King \& H. Robinson, Phytologia 24: 404. 1972. = Campuloclinium cainpuloclinioides (Baker) R. King \& H. Robinson.

Campuloclinium burchellii (Baker) R. King \& H. Robinson, Phytologia 24: 171. 1972.

Campuloclinium campuloclinioides (Baker) R. King \& H. Robinson, Phytologia 29: 123. 1974.

Campuloclinium chlorolepis (Baker) R. King \& H. Robinson, Phytologia 24: 171. 1972.

Campuloclinium corymbosum Schultz-Bip. ex Baker, Fl. Bras. 6(2): 356.1876 , nom. nud. = Campuloclinium burchellii (Baker) R. King \& H. Robinson.

Campuloclinium crenatum Schlechtend. ex Martius, Flora 24, 2 Beibl. 105. 1841. = Diacranthera crenata (Schlechtend. in Martius) R. King \& H. Robinson.

Campuloclinium decumbens (Gardner) Schultz-Bip. ex Baker, Fl. Bras. 6(2): 344. 1876, nom. nud. = Chromolaena decumbens Gardner.

Campuloclinium eiteniorum $\mathrm{R}$. King \& H. Robinson, Phytologia 46: 295. 1980.

Campuloclinium frutescens Bartling, Ind. Sem. Hort. Acad. Gott. 15. 1843, ignota.

Camıpuloclinium hickenii (Cabrera \& Vittet) R. King \& H. Rob. inson, Phytologia 24: 171. 1972.

Campuloclinium hirsutum Gardner, London J. Bot. 6:438. 1847.

Campuloclinium irwinii R. King \& H. Robinson, Phytologia 24: 405. 1972.

Campuloclinium kleinioides (H. B. K.) DC., Prodr. 5: 137. 1836. $=$ Praxelis kleinioides $($ H. B. K.) Schultz-Bip.

Campuloclinium macrocephalum (Less.) DC., Prodr. 5: 137. 1836.

Campuloclinium megacephalum (Martius ex Baker) R. King \& H. Robinson, Phytologia 24: 172. 1972.

Campuloclinium palustre DC., Prodr. 5: 137. 1836. = Barrosoa betonicaeformis (DC.) R. King \& H. Robinson.

Campuloclinium parvulum (Glaz.) R. King \& H. Robinson, Phytologia 24: 172. 1972. = Campuloclinium parvulum (Glaz. ex B. Robinson) R. King \& H. Robinson.

Campuloclinium parrulum (Glaz. ex B. Robinson) R. King \& H. Robinson, Phytologia 37: 457. 1977

Campuloclinium pohlianum Schultz-Bip. ex Baker, F. Bras. 6(2): 
358. 1876, nom. nud. = Campuloclinium macrocephalum (Less.) DC.

Campuloclinium polyphyllum Schultz-Bip. ex Baker, Fl. Bras. 6(2): 354. 1876, nom. nud. = Campuloclinium megacephalum (Martius ex Baker) R. King \& H. Robinson.

Campuloclinium purpurascens (Schultz-Bip. ex Baker) R. King \& H. Robinson, Phytologia 24: 172. 1972.

Campuloclinium riedelii (Baker) R. King \& H. Robinson, Phytologia 24: 172. 1972.

Campuloclinium siegesbeckioides Schultz-Bip. ex Baker, Fl. Bras. 6(2): 359. 1876, nom. nud. = Campuloclinium hirsutum Gardner.

Campuloclinium strigosum Schultz-Bip. ex Baker, Fl. Bras. 6(2): 358. 1876 , nom. nud. = Campuloclinium macrocephalum (Less.) DC.

Campuloclinium subpaniculatum DC., Prodr. 5: 137. 1836. = Dasycondylus resinosus (Sprengel) R. King \& H. Robinson.

Campuloclinium surinamense Miq., Linnaea 17: 69. 1843. = Heterocondylus vitalbae (DC.) R. King \& H. Robinson.

Campuloclinium tubaraoense (Hieron.) R. King \& H. Robinson, Phytologia 24: 172. 1972.

Campuloclinium turbinatum Schultz-Bip. ex Baker, Fl. Bras. 6(2): 357. 1876 , nom. nud. = Campuloclinium chlorolepis $($ Baker) R. King \& H. Robinson.

Campuloclinium urticaefolium [L. f.] DC., Prodr. 5: 137. 1836. $=$ Praxelis pauciflora (H. B. K.) R. King \& H. Robinson.

Campuloclinium viridiflorum Bartling ex Baker, Fl. Bras. 6(2): 309. 1876, nom. nud. = Bartletina hemisphaerica (DC.) R. King \& H. Robinson.

Caradesia pauciflora Raf., New Fl. 4: 80. 1836, nom. illeg. prov. = Fleischmannia?

Carelia adscendens (Schultz-Bip. ex Benth. \& Hook.) Kuntze, Revis. Gen. Pl. 325. 1891. = Oxylobus adscendens (SchultzBip.) B. Robinson \& Greenman in B. Robinson.

Carelia agrianthus (O. Hoffm.) Kuntze, Revis. Gen. P1. 325. 1891. = Agrianthus corymbosus DC.

Carelia albida (DC.) Kuntze, Revis. Gen. Pl. 325. 1891. = Ageratum albidum (DC.) Hemsley.

Carelia arbutifolia (H. B. K.) Kuntze, Revis. Gen. PI. 325. 1891. $=$ Oxylobus arbutifolius (H. B. K.) A. Gray.

Carelia berroi Hutch., Kew Bull. 1916: 189. 1916. = Radlkoferotoma berroi (Hutch.) R. King \& H. Robinson.

Carelia brachystephana (Regel) Kuntze, Revis. Gen. PI. 325. 1891. = Agerat tum conyzoides $\mathbf{L}$.

Carelia cistifolia Less., Syn. Gen. Compos. 156. 1832. = Radlkoferotoma cistifolium (Less.) Kuntze.

Carelia conferta (Gardner) Kuntze, Revis. Gen. Pl. 325. 1891. = Acritopappus confertus (Gardner) R. King \& H. Robinson.

Carelia conyzoides (L.) Kuntze, Revis. Gen. P1. 325. 1891. = Ageratum conyzoides $\mathrm{L}$.

Carelia corymbosa (Zuccagni) Kuntze, Revis. Gen. Pl. 325. 1891. = Ageratum corymbosum Zuccagni.

Carelia domingensis (Sprengel) Kuntze, Revis. Gen. P1. 325. 1891. $=$ Phania domingensis (Sprengel) Griseb.

Carelia echioides (Less.) Kuntze, Revis. Gen. PI. 325. 1891. = Ageratum echioides (Less.) Hemsley.

Carelia glandulifera (Schultz-Bip.) Kuntze, Revis. Gen. Pl. 325. 1891.= Oxylobus glanduliferus (Schultz-Bip. ex Benth. \& Hook.) A. Gray.

Carelia houstoniana (Miller) Kuntze, Revis. Gen. Pl. 325. 1891. = Ageratum houstonianum Miller.

Carelia isocarphoides (DC.) Kuntze, Revis. Gen. Pl. 325. 1891. = Ageratum isocarphoides (DC.) Hemsley.

Carelia latifolia (Benth.) Kuntze, Revis. Gen. Pl. 325. 1891. = Ageratum nelsonii (B. Robinson) M. Johnson.

Carelia littorale (A. Gray) Kuntze, Revis. Gen. Pl. 325. 1891. = Ageratum littorale A. Gray.
Carelia longifolia (Gardner) Kuntze, Revis. Gen. P1. 325. 1891. $=$ Acritopappus longifolius (Gardner) R. King \& H. Robinson. Carelia maritima (H. B. K.) Kuntze, Revis. Gen. PI. 325. 1891. = Ageratum maritimum $\mathrm{H}$. B. K.

Carelia matricarioides (Sprengel) Kuntze, Revis. Gen. Pl. 325. 1891. = Phania matricarioides (Sprengel) Griseb.

Carelia melissaefolia (DC.) Kuntze, Revis. Gen. P1. 325. 1891. = Ageratum melissaefolium DC.

Carelia microcephala (Hemsley) Kuntze, Revis. Gen. PI. 325. 1891. = Ageratum microcephalum Hemsley.

Carelia mutica (Griseb.) Kuntze, Revis. Gen. Pl. 325. 1891. = Ageratum conyzoides $\mathbf{L}$.

Carelia paleacea (DC.) Kuntze, Revis. Gen. P1. 325. 1891. = Ageratum paleaceum (DC.) Hemsley.

Carelia petiolata (Hook. \& Arn.) Kuntze, Revis. Gen. PI. 325. 1891. = Ageratum petiolatum (Hook. \& Am.) Hemsley.

Carelia purpurea (Vitman) Kuntze, Revis. Gen. P1. 325. 1891, ignota.

Carelia ramboi Cabrera, Bol. Soc. Argent. Bot. 6: 240. 1957. = Radlkoferotoma ramboi (Cabrera) R. King \& H. Robinson.

Carelia salicifolia (Hemsley) Kuntze, Revis. Gen. Pl. 325. 1891. = Ageratum salicifolium Hemsley.

Carelia saturiaefolia Cav., Anales Ci. Univ. Madrid 6: 317. 1803, nom. nud. = Mikania parviflora (Aublet) Karsten.

Carelia scabriuscula (Benth.) Kuntze, Revis. Gen. Pl. 325. 1891. = Ageratum petiolatum (Hook. \& Arn.) Hemsley.

Carelia sessilifolia (Schauer) Kuntze, Revis. Gen. Pl. 325. 1891. = Trichocoronis greggii A. Gray.

Carelia stricta (Hemsley) Kuntze, Revis. Gen. Pl. 325. 1891. = Ageratum corymbosum Zuccagni.

Carelia tomentosa (Benth. ex Oersted) Kuntze, Revis. Gen. Pl. 325. 1891. = Ageratum tomentosum (Benth. ex Oersted) Hemsley.

Carminatia recondita $\mathrm{McVaugh,} \mathrm{Contr.} \mathrm{Univ.} \mathrm{Michigan} \mathrm{Herb.}$ 9: 384. 1972.

Carminatia tenuiflora DC., Prodr. 7: 267. 1838.

Carminatia tenuifolia Steudel, Nomencl. Bot. 1:299. 1840, nom. nud. = Carminatia tenuiflora DC

Carphephorts atriplicifolius A. Gray, Proc. Amer. Acad. Arts 5: 159. 1861. = Bebbia atriplicifolia (A. Gray) E. Greene, HELIANTHEAE.

Carphephorus baicalensis (Adams) DC., Prodr. 5: 132. 1836. = Saussurea pycnocephala Ledeb. CYNAREAE.

Carphephorus bellidifolius Torrey \& A. Gray, Fl. N. Amer. 2: 66. 1841.

Carphephorus carnosiss (Small) C. James, Rhodora 60: 120. 1958. = Litrisa carnosa Small.

Carphephorus coridifolius DC., Prodr. 7: 267. 1838. = Pseudob rickellia?.

Carphephorus corymbosus (Nutt.) Torrey \& A. Gray, Fl. N. Amer. 2: 67. 1841.

Carphephorus junceus Benth., Bot. Voy. Sulphur 21. 1844. = Aster squamatus (Sprengel) Hieron. AstereaE.

Carphephorus odoratissimus (J. Gmelin) Hebert, Rhodora 70: 483. 1968. = Trilisa odoratissima (Willd.) Cass.

Carphephorus paniculatus (J. Gmelin) Hebert, Rhodora 70: 483. 1968. = Trilisa paniculata (Willd.) Cass.

Carphephorus pseudoliatris Cass., Bull. Sci. Soc. Philom. Paris 198. 1816.

Carphephorus revolutifolius DC., Prodr. 5: 133. 1836. = Pleocarphus revolutus D. Don. MutisieaE.

Carphephorus tomentosus (Michaux) Torrey \& A. Gray, Fl. N. Amer. 2: 66. 1841.

Carphephorus triangularis (DC.) A. Gray, PI. Wright. 1: 86. 1852, nom. nud. = Eupatoriastrum triangulare (DC.) B. Robinson.

Carphochaete bigelovii A. Gray, Pl. Wright. 1: 89. 1852.

Carphochaete grahamii A. Gray, P1. Wright. 1: 89. 1852. 
Carphochaete gummifera McVaugh, Contr. Univ, Michigan Herb. 9: 385. 1972.

Carphochaete macrocephala (Paray) Grashoff ex B. Turner \& Kerr, P1. Syst. Evol. 151: 86. 1985. = Revealia macrocephala (Paray) R. King \& H. Robinson.

Carphochaete schaffneri Greenman. Proc. Amer. Acad. Arts 40: 34. 1904.

Carphochaete wislizeni A. Gray, Mem. Amer. Acad. Arts 4: 65. 1849.

Carterothammus anomalochaeta R. King, Rhodora 69: 45. 1967.

Castenedia santamartensis R. King \& H. Robinson, Phytologia 39: 58. 1978.

Cavalcantia glomerata (G. Barroso \& R. King) R. King \& H. Robinson, Phytologia 47: 114. 1980.

Cavalcantia percymosa R. King \& H. Robinson, Phytologia 47: 114. 1980.

Chacoa mikaniifolia (B. Robinson) R. King \& H. Robinson, Phytologia 32: 276. 1975. = Bishovia mikaniifolia (B. Robinson) R. King \& H. Robinson.

Chacoa pseudo-prasiifolia (Hassler) R. King \& H. Robinson, Phytologia 32: 276. 1975.

Chondrilla rhombifolia (Willd.) Poiret, Encycl. Suppl. 2: 329. 1811. = Brickellia diffusa (Vahl) A. Gray.

Chone heterophylla Dulac, FI. Hautes-Pyrenees 512. 1867. = Eupatorium cannabinum L.

Chromolaena adenolepis (Schultz-Bip. ex Baker) R. King \& H. Robinson, Phytologia 20: 198. 1970.

Chromolaena alternifolia Gardner, London J. Bot. 5: 465.1846. $=$ Chromolaena stachyophylla (Sprengel) R. King \& H. Robinson.

Chromolaena alvimii R. King \& H. Robinson, Phytologia 47: 231. 1980.

Chromolaena anachoretica (B. Robinson) R. King \& H. Robinson, Phytologia 47: 230. 1980.

Chromolaena angusticeps (Malme) R. King \& H. Robinson, Phytologia 49: 4. 1981.

Chromolaena aridicola V. Badillo, Ernstia 33: 6. 1985.

Chromolaena arnottiana (Griseb.) R. King \& H. Robinson, Phytologia 20: 198. 1970.

Chromolaena arrayana (Gardner) R. King \& H. Robinson, Phytologia 20: 198. 1970.

Chromolaena ascendens (Schultz-Bip. ex Baker) R. King \& H. Robinson, Phytologia 20: 199. 1970.

Chromolaena asperrima (Schultz-Bip. ex Baker) R. King \& H. Robinson, Phytologia 47: 230. 1980.

Chromolaena austera (B. Robinson) R. King \& H. Robinson, Phytologia 20: 199. 1970.

Chroinolaena bahamensis (Northrop) R. King \& H, Robinson, Phytologia 20: 199. 1970.

Chromolaena bangii (Rusby) R. King \& H. Robinson, Phytologia 20: 199. 1970.

Chromolaena barbacensis (Hieron.) R. King \& H. Robinson, Phytologia 20: 199. 1970.

Chromolaena barranquillensis (Hieron.) R. King \& H. Robinson, Phytologia 20: 199. 1970.

Chromolaena barrosoae R. King \& H. Robinson, Phytologia 47: 232. 1980

Chromolaena bathyphlebia (B. Robinson) R. King \& H. Robinson, Phytologia 20: 199. 1970.

Chromolaena beckii R. King \& H. Robinson, Phytologia 51: 172. 1982.

Chromolaena bertholdii (Schultz-Bip.) R. King \& H. Robinson, Phytologia 20: 208. 1970.

Chromolaena bigelovii (A. Gray) R. King \& H. Robinson, Phytologia 20: 208. 1970.

Chromolaena borinquensis (Britton) R. King \& H. Robinson. Phytologia 20: 199. 1970.
Chromolaena breedlovei R. King \& H. Robinson, Phytologia 47: 233. 1980.

Chromolaena brunneola (Baker) R. King \& H. Robinson, Phytologia 47: 230. 1980.

Chromolaena bullata (Klatt) R. King \& H. Robinson, Phytologia 20: 199. 1970.

Chromolaena caaguazuensis (Hieron.) R. King \& H. Robinson, Phytologia 20: 199. 1970.

Chromolaena calainocephala (Baker) R. King \& H. Robinson, Phytologia 20: 199. 1970. = Chromolaena lencocephala Gardner.

Chromolaena caldensis (B. Robinson) R. King \& H. Robinson, Phytologia 49: 4. 1981.

Chromolaena callilepis (Schultz-Bip. ex Baker) R. King \& H. Robinson, Phytologia 20: 199. 1970.

Chromolaena campestris (DC.) R. King \& H. Robinson, Phytologia 20: 200. 1970.

Chromolaena candolleana Gardner, London J. Bot. 5: 464. 1846. = Chromolaena horminoides DC.

Chromolaena chaseae (B. Robinson) R. King \& H. Robinson, Phytologia 20: 200. 1970.

Chromolaena christieana (Baker) R. King \& H. Robinson, Phytologia 20: 200. 1970.

Chromolaena chrysosticta (B. Robinson) R. King \& H. Robinson, Phytologia 20: 200. 1970.

Chromolaena cinereo-viridis (Schultz-Bip. ex Baker) R. King \& H. Robinson, Phytologia 20: 200. 1970.

Chromolaena collina (DC.) R. King \& H. Robinson, Phytologia 20: 208. 1970.

Chromolaena columbiana (Heering) R. King \& H. Robinson, Phytologia 20: 200. 1970.

Chromolaena congesta (Arn. \& Hook.) R. King \& H. Robinson, Phytologia 20: 200. 1970.

Chromolaena connivens (Rusby) R. King \& H. Robinson, Phytologia 20: 200. 1970.

Chromolaena corymbosa (Aublet) R. King \& H. Robinson, Phytologia 20: 200. 1970.

Chromolaena costatipes (B. Robinson) R. King \& H. Robinson, Phytologia 49: 4. 1981.

Chromolaena cryptantha (Schultz-Bip. ex Baker) R. King \& H. Robinson, Phytologia 47: 230. 1980.

Chromolaena cylindrocephala (Schultz-Bip. ex Baker) R. King \& H. Robinson, Phytologia 47: 230. 1980.

Chromolaena decumbens Gardner, London J. Bot. 5: 466, 1846.

Chromolaena densiflora (Morong) R. King \& H. Robinson, Phytologia 20: 200. 1970.

Chromolaena desmocephala (B. Robinson) R. King \& H. Robinson, Phytologia 49: 4. 1981.

Chromolaena diaphanophlebia (B. Robinson) R. King \& H. Robinson, Phytologia 47: 231. 1980.

Chromolaena dussii (Urban) R. King \& H. Robinson, Phytologia 20: 200. 1970.

Chromolaena elliptica (Hook. \& Am.) R. King \& H. Robinson, Phytologia 20: 200. 1970.

Chromolaena epaleacea Gardner, London J. Bot. 6: 436. 1847.

Chromolaena eripsima (B. Robinson) R. King \& H. Robinson, Phytologia 20: 201. 1970.

Chromolaena extensa (Gardner) R. King \& H. Robinson, Phytologia 20: 201. 1970.

Chromolaena farinosa (B. Robinson) R. King \& H. Robinson, Phytologia 20: 201. 1970.

Chromolaena ferruginea [Gardner] R. King \& H. Robinson, Phytologia 49: 4. 1981.

Chromolaena foliata (Schultz-Bip. ex Baker) R. King \& H. Robinson, Phytologia 20: 201. 1970. = Chromolaena pedunculosa (Hook. \& Am.) R. King \& H. Robinson.

Chromolaena frustrata (B. Robinson) R. King \& H. Robinson, Phytologia 20: 201. 1970. 
Chromolaena furcata (Lam.) R. King \& H. Robinson, Phytologia 20: 201. 1970. = Chromolaena ivaefolia (L.) R. King \& H. Robinson.

Chromolaena gentianoides (B. Robinson) R. King \& H. Robinson, Phytologia 47: 231. 1980.

Chromolaena geranifolia (Urban) R. King \& H. Robinson, Phytologia 20: 201. 1970.

Chromolaena glaberrima (DC.) R. King \& H. Robinson, Phytologia 20: 208. 1970.

Chromolaena haenkeana (DC.) R. King \& H. Robinson, Phytologia 20: 208. 1970.

Chromolaena haughtii (B. Robinson) R. King \& H. Robinson, Phytologia 20: 201. 1970.

Cliromolaena herzogii (B. Robinson) R. King \& H. Robinson, Phytologia 20: 201. 1970.

Chromolaena heteroclinia (Griseb.) R. King \& H. Robinson, Phytologia 20: 201. 1970.

Chromolaena heterosquamea (Urban \& Ekman) R. King \& H. Robinson, Phytologia 32: 283. 1975.

Chromolaena hirsma (Hook. \& Arn.) R. King \& H. Robinson, Phytologia 20: 201. 1970.

Cliromolaena holquinensis (B. Robinson) R. King \& H. Robinson, Phytologia 20: 208. 1970. = Grisebachianthus holquinensis (B. Robinson) R. King \& H. Robinson.

Chromolaena hookeriana (Griseb.) R. King \& H. Robinson, Phytologia 47: 231. 1980.

Chromolaena horminoides DC., Prodr. 5: 133. 1836.

Chromolaena hypericifolia (H. B. K.) R. King \& H. Robinson, Phytologia 20: 202. 1970.

Chromolaena hypodictya (B. Robinson) R. King \& H. Robinson, Phytologia 49: 4. 1981.

Chromolaena impetiolaris (Griseb.) Nicolson, Phytologia 62: 164. 1987.

Chromolaena integrifolia (Bertero ex Sprengel) R. King \& H. Robinson, Phytologia 20: 202. 1970.

Chromolaena iridolepis (B. Robinson) R. King \& H. Robinson, Phytologia 20: 202. 1970.

Chromolaena ivaefolia (L.) R. King \& H. Robinson, Phytologia 20: 202. 1970.

Chromolaena jelskii (Hieron.) R. King \& H. Robinson, Phytologia 20: 202. 1970.

Chromolaena jujuiensis (Hieron.) R. King \& H. Robinson, Phytologia 20: 202. 1970. = Cliromolaena hookeriana (Griseb.) R. King \& H. Robinson.

Chromolaena kleinii (Cabrera) R. King \& H. Robinson, Phytologia 20: 202. 1970

Chromolaena laevigata (Lam.) R. King \& H. Robinson. Phytologia 20: 202. 1970.

Chromolaena larensis (V. Badillo) R. King \& H. Robinson, Phytologia 35: 498. 1977.

Chromolaena latisquamulosa (Hieron.) R. King \& H. Robinson, Phytologia 20: 202. 1970.

Chromolaena leivensis (Hieron.) R. King \& H. Robinson, Phytologia 20: 202. 1970.

Chromolaena leptocephala (DC.) R. King \& H. Robinson, Phytologia 20: 202. 1970

Chromolaena leucocephala Gardner, London J. Bot. 5: 465. 1846.

Chromolaena lilacina (Hieron.) R. King \& H. Robinson, Phytologia 20: 202. 1970

Chromolaena linearis (Malme) R. King \& H. Robinson, Phytologia 20: 203. 1970.

Chromolaena lucayana (Britton) R. King \& H. Robinson, Phytologia 20: 203. 1970.

Chromolaena lundellii R. King \& H. Robinson, Wrightia 6(2): 24. 1978.

Chromolaena luquensis (Chodat) R. King \& H. Robinson, Phytologia 20: 203. 1970.
Chromolaena macrantha (Sw.) R. King \& H. Robinson, Phytologia 20: 203. 1970.

Chromolaena macrodon(DC.) Nicolson, Phytologia 62: 164. 1987.

Chromolaena mallota (B. Robinson) R. King \& H. Robinson, Phytologia 20: 203. 1970.

Chromolaena margaritensis (Hassler) R. King \& H. Robinson, Phytologia 20: 203. 1970.

Chromolaena mattogrossensis (Hieron.) R. King \& H. Robinson, Phytologia 20: 203. 1970.

Chromolaena maximilianii (Schrader ex DC.) R. King \& H. Robinson, Phytologia 49: 4. 1981.

Chromolaena mendezii (DC.) R. King \& H. Robinson, Phytologia 32: 283. 1975.

Chromolaena meridensis (B. Robinson) R. King \& H. Robinson, Phytologia 20: 203. 1970.

Chromolaena minasgeraesensis (Hieron.) R. King \& H. Robinson, Phytologia 47: 231. 1980.

Chromolaena misella (McVaugh) R. King \& H. Robinson, Phytologia 24: 275. 1972.

Chromolaena molina (B. Robinson) R. King \& H. Robinson, Phytologia 20: 203. 1970.

Chromolaena mononeura (Urban) R. King \& H. Robinson, Phytologia 20: 203. 1970.

Chromolaena morii R. King \& H. Robinson, Phytologia 47: 234. 1980.

Chromolaena moritensis (Aristeg.) R. King \& H. Robinson, Phytologia 35: 498. 1977.

Chromolaena moritziana (Schultz-Bip. ex Hieron.) R. King \& H. Robinson, Phytologia 20: 203. 1970.

Chromolaena mornicola (Urban \& Ekman) R. King \& H. Robinson, Phytologia 20: 208. 1970. = Koanophyllon mornicola (Urban \& Ekman) R. King \& H. Robinson.

Chromolaena mucronata (Gardner) R. King \& H. Robinson, Phytologia 37: 457. 1977.

Chromolaena multiflosculosa (DC.) R. King \& H. Robinson, Phytologia 20: 203. 1970.

Chromolaena myriadenia R. King \& H. Robinson, Phytologia 47: 235. 1980.

Chromolaena myriocephala (Gardner) R. King \& H. Robinson, Phytologia 20: 203. 1970.

Chromolaena odorata (L.) R. King \& H. Robinson, Phytologia 20: 204. 1970.

Chromolaena oerstediana (B. Robinson ex Oersted) R. King \& H. Robinson, Phytologia 20: 208. 1970. = Chromolaena glaberrima (DC.) R. King \& H. Robinson.

Chromolaena oinopolepis (Malme) R. King \& H. Robinson, Phytologia 20: 204. 1970.

Chromolaena opadoclinia (Blake) R. King \& H. Robinson, Phytologia 20: 208. 1970.

Chromolaena orbignyana (Klatt) R. King \& H. Robinson, Phytologia 20: 204. 1970.

Chromolaena ortegae (B. Robinson) R. King \& H. Robinson, Phytologia 20: 209. 1970.

Chromolaena ossaeana (DC.) R. King \& H. Robinson, Phytologia 20: 204. 1970.

Chromolaena oteroi (Monach.) R. King \& H. Robinson, Phytologia 20: 204. 1970.

Chromolaena ovaliflora (Hook. \& Arn.) R. King \& H. Robinson, Phytologia 20: 209. 1970. = Chromolaena glaberrima (DC.) R. King \& H. Robinson.

Chromolaena oxylepis (DC.) R. King \& H. Robinson, Phytologia 20: 204. 1970.

Chromolaena oyadensis (Hieron.) R. King \& H. Robinson, Phytologia 20: 204. 1970.

Chromolaena palmaris (Schultz-Bip. ex Baker) R. King \& H. Robinson, Phytologia 20: 204. 1970.

Chromolaena paraguariensis (Hieron.) R. King \& H. Robinson, Phytologia 20: 204. 1970. 
Chromolaena parviceps (Malme) R. King \& H. Robinson, Phytologia 20: 204. 1970.

Chromolaena pedalis (Schultz-Bip. ex Baker) R. King \& H. Robinson, Phytologia 20: 204. 1970.

Chromolaena pedunculosa (Hook. \& Am.) R. King \& H. Robinson, Phytologia 47: 231. 1980.

Chromolaena pellia (Klatt) R. King \& H. Robinson, Phytologia 20: 204. 1970.

Chromolaena perforata (Schultz-Bip. ex Baker) R. King \& H. Robinson, Phytologia 20: 205. 1970.

Chromolaena perglabra (B. Robinson) R. King \& H. Robinson, Phytologia 20: 205. 1970.

Chromolaena perijaensis R. King \& H. Robinson, Phytologia 47: 236. 1980.

Chromolaena persericea $\mathrm{R}$. King \& H. Robinson, Phytologia 47: 237. 1980.

Chromolaena pharcidodes (B. Robinson) R. King \& H. Robinson, Phytologia 20: 205. 1970.

Chromolaena picta (Gardner) R. King \& H. Robinson, Phytologia 47: 231. 1980.

Chromolaena plumeri (Urban \& Ekman) R. King \& H. Robinson, Phytologia 20: 209. 1970. = Osmiopsis plumeri (Urban \& Ekman) R. King \& H. Robinson.

Chromolaena polyamha [Schultz-Bip. \& Baker] R. King \& H. Robinson, Phytologia 20: 205. 1970, nom. nud. = Chromolaena inucronata (Gardner) R. King \& H. Robinson.

Chromolaena porophylloides (B. Robinson) R. King \& H. Robinson, Phytologia 49: 4. 1981.

Chromolaena porphyrolepis (Baker) R. King \& H. Robinson, Phytologia 20: 205. 1970 .

Chromolaena pratensis Gardner, London J. Bot. 1: 176. 1842. = Campuloclinium macrocephalum (Less.) DC.

Chromolaena pseudinsignis R. King \& H. Robinson, Phytologia 47: 238. 1980.

Chromolaena pulchella (H. B. K.) R. King \& H. Robinson, Phytologia 20: 209. 1970.

Chromolaena punctata (Lam.) R. King \& H. Robinson, Phytologia 20: 205. 1970. = Chromolaena mononeura (Urban) R. King \& H. Robinson.

Chromolaena punctulata (DC.) R. King \& H. Robinson, Phytologia 20: 205. 1970.

Cliromolaena pungens (Gardner) R. King \& H. Robinson, Phytologia 47: 231. 1980.

Chromolaena quercetorum (L. O. Williams) R. King \& H. Robinson, Phytologia 37: 457. 1977.

Chromolaena revoluta (Gardner) R. King \& H. Robinson, Phytologia 20: 205. 1970.

Chromolaena rhinamhacca (DC.) R. King \& H. Robinson, Phytologia 20: 205. 1970.

Chromolaena rigida (Sw.) R. King \& H. Robinson, Phytologia 49: 4. 1981 .

Chromolaena rojasii (Hassler) R. King \& H. Robinson, Phytologia 20: 205. 1970.

Chromolaena roseorum (B. Robinson) R. King \& H. Robinson, Phytologia 20: 205. 1970.

Chromolaena sagittata (A. Gray) R. King \& H. Robinson, Phytologia 20: 205. 1970.

Chromolaena sagittifera (B. Robinson) R. King \& H. Robinson, Phytologia 20: 206. 1970.

Chromolaena sanctopaulensis (B. Robinson) R. King \& H. Robinson, Phytologia 20: 206. 1970.

Chromolaena samanensis (Aristeg.) R. King \& H. Robinson, Phytologia 20: 206. 1970.

Chromolaena scabra (L. f.) R. King \& H. Robinson, Phytologia 20: 206. 1970.

Chromolaena serratuloides (H. B. K.) R. King \& H. Robinson, Phytologia 49: 4. 1981.
Chromolaena sinuata (Lam.) R. King \& H. Robinson, Phytologia 32: 283. 1975.

Chromolaena squalida (DC.) R. King \& H. Robinson, Phytologia 20: 206. 1970.

Chromolaena squarroso-ramosa (Hieron.) R. King \& H. Robinson, Phytologia 20: 206. 1970.

Chromolaena squarrulosa (Hook. \& Arn.) R. King \& H. Robinson, Phytologia 20: 206. 1970.

Chromolaena stachyophylla (Sprengel) R. King \& H. Robinson, Phytologia 20: 206. 1970.

Chromolaena steyermarkiana (V. Badillo) R. King \& H. Robinson, Phytologia 35: 498. 1977.

Chromolaena stillingiaefolia (DC.) R. King \& H. Robinson, Phytologia 32: 283. 1975.

Chromolaena subscandens (Hieron.) R. King \& H. Robinson, Phytologia 20: 206. 1970.

Chromolaena suratensis (B. Robinson) R. King \& H. Robinson, Phytologia 20: 206. 1970.

Chromolaena tacotana (Klatt) R. King \& H. Robinson, Phytologia 20: 206. 1970.

Chromolaena tecta (Gardner) R. King \& H. Robinson, Phytologia 20: 206. 1970.

Chromolaena tenuicapitulata (Hieron.) R. King \& H. Robinson, Phytologia 20: 207. 1970.

Chromolaena thurnii (B. Robinson) R. King \& H. Robinson, Phytologia 20: 207. 1970.

Chromolaena toldensis (Hieron.) R. King \& H. Robinson, Phytologia 20: 207. 1970.

Chromolaena trigonocarpa (Griseb.) R. King \& H. Robinson, Phytologia 20: 207. 1970.

Chromolaena irujillensis (B. Robinson) R. King \& H. Robinson, Phytologia 20: 207. 1970.

Chromolaena tunariensis (Hieron.) R. King \& H. Robinson, Phytologia 20: 207. 1970.

Chromolaena tyleri (B. Robinson) R. King \& H. Robinson, Phytologia 20: 207. 1970.

Chromolaena ulei (Hieron.) R. King \& H. Robinson, Phytologia 20: 207. 1970.

Chromolaena umbelliformis (Dusen ex Malme) R. King \& H. Robinson, Phytologia 20: 207. 1970.

Chromolaena uromeres (B. Robinson) R. King \& H. Robinson, Phytologia 20: 207. 1970.

Chromolaena urticoides (Schultz-Bip. ex Hieron.) R. King \& H. Robinson, Phytologia 20: 207. 1970.

Chrornolaena verbenacea (DC.) R. King \& H. Robinson, Phytologia 20: 207. 1970.

Chromolaena verticillata R. King \& H. Robinson, Phytologia 47: 239. 1980.

Chromolaena vindex (DC.) R. King \& H. Robinson, Phytologia 47: 231. 1980.

Chromolaena voglii (B. Robinson) H. Huber, Mitt. Bot. Staatssamml. Munchen 13: 103. 1977.

Chromolaena xestolepidoides (Wurd.) R. King \& H. Robinson, Phytologia 35: 499. 1977.

Chromolaena xestolepis (B. Robinson) R. King \& H. Robinson, Phytologia 20: 207. 1970.

Chromolaena xylorhiza (Schultz-Bip. ex Baker) R. King \& H. Robinson, Phytologia 20: 208. 1970.

Chrysocoma alata Vell. Conc., Fl. Flum. 313. 1825. = Heterocondylus alatus (Vell. Conc.) R. King \& H. Robinson.

Chrysocoma capillacea Michaux, Fl. Bor.-Amer. 2: 101, 1803. = Eupatorium capillifolium (Lam.) Small.

Chrysocoma coronopifolia Michaux, Fl. Bor.-Amer. 2: 102. 1803. = Eupatorium compositifolium Walter.

Chrysocoma cruciata Vell. Conc., Fl. Flum. 306. 1825. = Campovassonria cruciala (Vell. Conc.) R. King \& H. Robinson.

Chrysocoma maculata Vell. Conc., Fl. Flum. 305. 1825. = 
Cliromolaena hookeriana (Griseb.) R. King \& H. Robinson, or Chromolaena odorata (L.) R. King \& H. Robinson.

Chrysocoma odoratissima [Walter] J. Gmelin, Syst. Nat. 2: 1204. 1792. = Trilisa odoratissima (J. Gmelin) Cass.

Chrysocoma oppositifolia Vell. Conc., Fl. Flum. 307. 1825. = Ayapana amygdalina (Lam.) R. King \& H. Robinson, ?

Clirysocoma paniculata [Walter] J. Gmelin, Syst. Nat. 2: 1204. 1792. = Trilisa paniculata (J. Gmelin) Cass.

Chrysocoma panciflora Vell. Conc., Fl. Flum. 305. 1825. = Praxelis clematidea (Griseb.) R. King \& H. Robinson.

Chrysocoma pilosa [Walter] J. Gmelin, Syst. Nat. 2: 1203. 1792. $=$ Liatris pynostachya Michaux.

Chrysocoma punctata Vell. Conc., Fl. Flum. 313. 1825. = Chromolaena laevigata (Lam.) R. King \& H. Robinson.

Chrysocoma purpurascens Vell. Conc., Fl. Flum. 310. 1825. = Ayapana amygdalina (Lam.) R. King \& H. Robinson.

Clirysocoma serrata Vell. Conc., Fl. Flum. 308. 1825. = Stomatanthes?

Chrysocoma volubilis Vell. Conc., F1. Flum. 309. 1825. = Chromolaena odorata (L.) R. King \& H. Robinson.

Ciceronia chaptalioides Urban, Feddes Repert. 21: 225. 1925.

Clavigera brachyphylla A. Gray, PI. Fendler. 63. 1848. = Brickellia brachyphylla (A. Gray) A. Gray.

Clavigera corymbosa DC., Prodr. 5: 128. 1836. = Brickellia corymbosa (DC.) A. Gray.

Clavigera dentata DC., Prodr. 5: 128. 1836. = Brickellia dentata (DC.) Schultz-Bip.

Clavigera pinifolia Gardner, London J. Bot. 5: 461. 1846. = Pseudobrickellia brasiliensis (Sprengel) R. King \& H. Robinson.

Clavigera riddellii Torrey \& A. Gray, Fl. N. Amer. 2: 77.1841. = Brickellia dentata (DC.) Schultz-Bip.

Clavigera scabra Benth., Pl. Hartw. 19. 1839. = Brickellia scoparia (DC.) A. Gray.

Clavigera scoparia DC., Prodr. 5: 128. 1836. = Brickellia scoparia (DC.) A. Gray.

Clavigera spinulosa A. Gray, Pl. Fendler. 63. 1848. = Brickellia spinulosa A. Gray.

Coelestina scleropliylla Wooton \& Standley, Contr. U. S. Natl. Hcrb. 16: 176. 1913. = Ageratum corymbosum Zuccagni.

Coleosantlus abbreviatus E. Greene, Pittonia 4: 125. 1900. = Brickellia oblongifolia Nutt.

Coleosanthus adenocarpus (B. Robinson) Arthur, Torreya 22: 30. 1922. = Brickellia argyrolepis B. Robinson.

Coleosanthus albicaulis Rydb., Bull. Torrey Bot. Club 31: 646 1904. = Brickellia californica (Torrey \& A. Gray) A. Gray.

Coleosanthus ambigens E. Greene, Bull. Torrey Bot. Club 25: 118. 1898. = Brickelliastrum fendleri (A. Gray) R. King \& H. Robinson.

Coleosanthus amplexicaulis (B. Robinson) Ortega, Cat. Sist. PI. Sinaloa 27. 1929. = Brickellia amplexicaulis B. Robinson.

Coleosanthus argutus (B. Robinson) Blake, Contr. U. S. Natl. Herb. 23: 1483. 1926. = Brickellia arguta B. Robinson.

Coleosanthus atractyloides (A. Gray) Kuntze, Revis. Gen. Pl. 328. 1891. = Brickellia atractyloides A. Gray.

Coleosanthus axillaris E. Greene, Leafl. W. Bot. 1: 149. 1905. = Brickellia californica (Torrey \& A. Gray) A. Gray.

Coleosanthus baccharideus (A. Gray) Kuntze, Revis. Gen. PI. 328. 1891. = Brickellia baccharidea A. Gray.

Coleosanthus betonicifolius (A. Gray) Kuntze, Revis. Gen. Pl. 328. 1891. = Brickellia betonicaefolia A. Gray.

Coleosanthus botterii (B. Robinson) Blake, Contr. U. S. Nat1. Herb. 23: 1482. 1926. = Brickellia botterii B. Robinson.

Coleosanthus brachiatus (A. Gray) Blake, Contr. U.S. Natl. Herb. 23: 1477. 1926. = Brickellia brachiata A. Gray.

Coleosanthus brachyphyllus (A. Gray) Kuntze, Revis. Gen. Pl. 328. 1891. = Brickellia brachyphylla (A. Gray) A. Gray.
Coleosanthus brandegei (B. Robinson) Blake, Contr. U. S. Natl. Herb. 23: 1483. 1926. = Brickellia brandegei B. Robinson.

Coleosanthus californicus (Torrey \& A. Gray) Kuntze, Revis. Gen. Pl. 328. 1891. = Brickellia californica (Torrey \& A. Gray) A. Gray.

Coleosantluus cavanillesii Cass., Dict. Sci. Nat. 10: 37. 1818. = Brickellia cavanillesii (Cass.) A. Gray.

Coleosanthus cedrosensis (E. Greene) E. Greene, Erythea 1: 54. 1893. = Brickellia microphylla (Nutt.) A. Gray.

Coleosanthus chenopodinus E. Greene in Wooton \& Standley, Contr. U. S. Natl. Herb. 16: 177. 1913. = Brickellia chenopodina (E. Greene ex Wooton \& Standley) B. Robinson.

Coleosanthus congestus Nelson, Bot. Gaz. (Crawfordsville) 31: 401. 1901 . = Brickellia grandiflora (Hook.) Nutt.

Coleosanthus cordifolius (Elliott) Kuntze, Revis. Gen. Pl. 328. 1891. = Brickellia cordifolia Elliott.

Coleosanthus corymbosus (DC.) Kuntze, Revis. Gen. Pl. 328. 1891. = Brickellia corymbosa (DC.) A. Gray.

Coleosanthus coulteri (A. Gray) Kuntze, Revis. Gen. PI. 328. 1891. = Brickellia coulteri A. Gray.

Coleosanthus cuspidatus (A. Gray) E. Greene, Erythea 1: 54. 1893. = Brickellia cuspidata S. Watson in A. Gray.

Coleosanthus cylindraceus (A. Gray \& Engelm.) Kuntze, Revis. Gen. Pl. 328. 1891. = Brickellia cylindracea A. Gray \& Engelm.

Coleosanthus cymuliferus (B. Robinson) Blake, Contr. U. S. Natl. Herb. 23: 1477. 1926. = Kyrsteniopsis cymulifera (B. Robinson) R. King \& H. Robinson.

Coleosanthus densus E. Greene, Pittonia 4: 126. 1900. = Brickellia lemmonii A. Gray.

Coleosanthus dentatus (DC.) Kuntze, Revis. Gen. PI. 328. 1891. = Brickellia dentata (DC.) Schultz-Bip.

Coleosanthus desertorum (Cov.) Cov., Contr. U. S. Natl. Herb. 4: 119. 1893. = Brickellia desertorum Cov.

Coleosanthus diffusus (Vahl) Kuntze, Revis. Gen. PI. 328. 1891. = Brickellia diffusa (Vahl) A. Gray.

Coleosanthus fendleri (A. Gray) E. Greene, Pittonia 4: 237. 1901, nom. nud. = Brickelliastrum fendleri (A. Gray) R. King \& H. Robinson.

Coleosanthus floribundus (A. Gray) Kuntze, Revis. Gen. PI. 328. 1891. = Brickellia floribunda A. Gray.

Coleosanthus frutescens (A. Gray) Kuntze, Revis. Gen. PI. 328. 1891. = Brickellia frutescens A. Gray.

Coleosanthus galeotiii (A. Gray) Kuntze, Revis. Gen. P1. 328. 1891. = Brickellia veronicaefolia (H. B. K.) A. Gray.

Coleosanthus garrettii Nelson, Proc. Biol. Soc. Wash. 20: 38. 1907. = Brickellia grandiflora (Hook.) Nutt.

Coleosanthus glabratus (Rose) Blake, Contr. U. S. Natl. Herb. 23: 1477. 1926. = Brickellia glabrata (Rose) B. Robinson.

Coleosanthus glandulosis (Llave in Llave \& Lex.) Kuntze, Revis. Gen. Pl. 328, 1891. = Brickellia glandulosa (Llave in Llave \& Lex.) McVaugh.

Coleosanthus glomeratus (Fern.) Blake, Contr. U. S. Natl. Herb. 23: 1479. 1926. = Brickellia glomerata Fern.

Coleosanthus glutinosus (A. Gray) Blake, Contr. U. S. Natl. Herb. 23: 1478. 1926. = Brickellia glutinosa A. Gray.

Coleosanthus gracilipes E. Greene, Pittonia 4:237. 1901.= Brickellia grandiflora (Hook.) Nutt.

Coleosanthus grandiflorus (Hook.) Kuntze, Rcvis. Gen. Pl. 328. 1891. = Brickellia grandiflora (Hook.) Nutt.

Coleosanthus greenei (A. Gray) Kuntze, Revis. Gen, PI. 328. 1891. = Brickellia greenei A. Gray.

Coleosanthus hastatus (Benth.) Kuntze, Revis. Gen. Pl. 328. 1891. = Brickellia hastata Benth.

Coleosanthus hebecarpus (DC.) Kuntze, Revis. Gen. Pl. 328. 1891. = Brickellia hebecarpa (DC.) A. Gray.

Coleosanthus humilis E. Greene, Pittonia 4: 124. 1900. = Brickellia oblongifolia Nutt. 
Colcosanthus hymenochlaenus (A. Gray) Kuntze, Revis. Gen. Pl. 328. 1891. = Brickellia hymenochlaena A. Gray.

Coleosanthus incanus (A. Gray) Kuntze, Revis. Gen. Pl. 328. 1891. = Brickellia incana A. Gray.

Coleosanthus knappianus E. Greene, Erythea 1: 54. 1893. = Brickellia knappiana Drew in Greene.

Coleosanthus laciniatus (A. Gray) Kuntze, Revis. Gen. Pl. 328. 1891. = Brickellia laciniata A. Gray.

Coleosanthus lanatus (DC.) Kuntze, Revis. Gen. P1. 328. 1891. = Brickellia lanata (DC.) A. Gray.

Coleosanthus lancifolius (B. Robinson \& Greenman) Blake, Contr. U. S. Natl. Herb. 23: 1480. 1926. = Brickellia lancifolia B. Robinson \& Greenman.

Coleosanthus lemmonii (A. Gray) Kuntze, Revis. Gen. PI. 328. 1891. = Brickellia lemmonii A. Gray.

Coleosanthus limifolius (Eaton) Kuntze, Revis. Gen. Pl. 328. 1891. = Brickellia oblongifolia Nutt.

Coleosanthus longifolius (S. Watson) Kuntze, Revis. Gen. Pl. 328. 1891. = Brickellia longifolia S. Watson.

Coleosanthus macromerus (B. Robinson) Blake, Contr. U. S. Natl. Herb. 23: 1483. 1926. = Brickellia macromera B. Robinson.

Coleosanthus megalodontus (Greenman) Arthur, Torreya 21: 12. 1921. = Brickellia coulteri A. Gray.

Coleosanthus melissaefolius E. Greene, Leafl. Bot. Observ. Crit. 1: 150. 1905. = Brickellia californica (Torrey \& A. Gray) A. Gray.

Coleosanthus microphyllus (Nutt.) Kuntze, Revis. Gen. PI. 328. 1891. = Brickellia microphylla (Nutt.) A. Gray.

Coleosanthus minor (A. Gray) Daniels, Univ. Missouri Stud., Sci. Ser. 2. 2: 225. 1911, = Brickellia grandiflora (Hook.) Nutt.

Colcosanthus modestus E. Greene, Pittonia 4:236. 1901.= Brickelliastrum fendleri (A. Gray) R. King \& H. Robinson.

Coleosanthus mollavensis (A. Gray) Kuntze, Revis. Gen. Pl. 328. 1891. = Brickellia oblongifolia Nutt.

Coleosanthus multiflorus (Kellogg) Kuntze, Revis. Gen. PI. 328. 1891. = Brickellia muliflora Kellogg.

Coleosanthus nelsonii (B. Robinson) Blake, Contr. U. S. Natl. Herb. 23: 1479. 1926. = Brickellia nelsonii B. Robinson.

Coleosamthus nepctacfolius E. Greene, Pittonia 4: 237. 1901. = Brickelliastrum fendleri (A. Gray) R. King \& H. Robinson.

Coleosanthus nevinii (A. Gray) A. A. Heller, Cat. N. Amer. Pl. 8. 1898. = Brickellia nevinii A. Gray.

Coleosanthus oblongifolius (Nutt.) Kuntze, Revis. Gen. Pl. 328. 1891. = Brickellia oblongifolia Nutt.

Coleosanthus oliganthus (Less.) Kuntze, Revis. Gen. P1. 328. 1891. = Brickellia oliganthes (Less.) A. Gray.

Colcosanthus orizabaensis (Klatt) Blake, Contr. U. S. Natl. Herb. 23: 1481. 1926. = Brickellia orizabaensis Klatt.

Coleosanthns pacavensis (Coulter) Coulter, Bot. Gaz. (Crawfordsville) 20: 46. 1895. = Brickellia glandulosa (Llave in Llave \& Lex.) McVaugh.

Coleosamthus pacavensis (Coulter) Standley in Standley \& Calderon, Lista PI. Salvador 219. 1925, comb. superfl. = Brickellia glandulosa (Llave in Llave \& Lex.) McVaugh.

Coleosanthus palmeri (A. Gray) Kuntze, Revis. Gen. Pl. 328. 1891. = Brickellia palmeri A. Gray.

Coleosanthus paniculatus (Miller) Standley in Standley \& Calderon, Lista Pl. Salvador 219. 1925, nom. nud. = Brickellia paniculata (Miller) B. Robinson.

Coleosanthus parryi (A. Gray) Kuntze, Revis. Gen. PI. 328. 1891. = Brickellia parryi A. Gray.

Coleosanthus parvulus (A. Gray) Kuntze, Revis. Gen. P1. 328. 1891. = Brickellia parvula A. Gray.

Coleosanthus pendulus (Schrader) Kuntze, Revis. Gen. Pl. 328. 1891. = Brickellia pendula (Schrader) A. Gray.

Coleosanthus peninsularis (Brandegee) Blake. Contr. U. S. Natl. Herb. 23: 1483. 1926. = Brickellia peninsularis Brandegee.
Coleosanthus petiolaris (A. Gray) E. Greene, Bull. Torrey Bot. Club 25: 117. 1898. = Brickellia grandiflora (Hook.) Nutt.

Coleosanthus pinifolius (Gardner) Kuntze, Revis. Gen. Pl. 328. 1891. = Pseudobrickellia brasiliensis (Sprengel) R. King \& H. Robinson.

Coleosanthus polyanthemus E. Greene, Pittonia 4: 126. 1900.= Brickellia oliganthes (Less.) A. Gray.

Coleosanthus populifolius E. Greene, Pittonia 4: 238. 1901.= Brickellia grandiflora (Hook.) Nutt.

Coleosanthus pringlei (A. Gray) Kuntze, Revis. Gen. PI. 328. 1891. = Brickellia pringlei A. Gray.

Coleosanthus reniformis (A. Gray) Rydb., Bull. Torrey Bot. Club 31: 646. 1904. = Brickellia californica (Torrey \& A. Gray) A. Gray.

Coleosanthus reticulatus (DC.) Kuntze, Revis. Gen. Pl. 328. 1891. = Brickellia reticulata (DC.) A. Gray.

Coleosanthus rhomboideus (E. Greene) E. Greene, Erythea I: 54. 1893. = Brickellia rhomboidea E. Greene.

Coleosanthus riddellii (Torrey \& A. Gray) Kuntze ex Small, Fl. S. E. U.S. 1177. 1903. = Brickellia dentata (DC.) Schultz-Bip. Coleosanthus rigidus (Benth.) Kuntze, Revis, Gen. P1. 328. 1891. = Brickellia paniculata (Miller) B. Robinson.

Coleosanthus rusbyi (rustyi) (A. Gray) Kuntze, Revis. Gen. Pl. 328. 1891 . = Brickellia rusbyi A. Gray.

Coleosanthus saltillensis (B. Robinson) S. F. Blake, Contr. U. S. Natl. Herb. 23: 1481. 1926. = Brickellia saltillensis B. Robinson.

Coleosanthus scaber (A. Gray) E. Greene, Pittonia 3: 100. 1896. = Brickellia scabra (A. Gray) Nelson in Coulter \& Nelson.

Coleosanthus scoparius (DC.) Kuntze, Revis. Gen. P1. 328. 1891. = Brickellia scoparia (DC.) A. Gray.

Coleosanthus secundiflorus (Lagasca) Kuntze, Revis. Gen. P1. 328. 1891. = Brickellia secundiflora (Lagasca) A. Gray.

Coleosanthus seemannii (A. Gray) Kuntze, Revis. Gen. P1. 328. 1891. = Brickellia seemannii A. Gray.

Coleosanthus seemannii (A. Gray) Blake, Contr. U. S. Natl. Herb. 23: 1481. 1926, comb. superfl. = Brickellia seemannii A. Gray. Coleosanthus simplex (A. Gray) Kuntze, Revis. Gen. Pl. 328. 1891. = Brickellia simplex A. Gray .

Coleosantlus spinulosus (A. Gray) Kuntze, Revis. Gen. Pl. 328. 1891. = Brickellia spinulosa A. Gray.

Coleosantlius squammlosus (A. Gray) Kuntze, Revis. Gen. PI. 328. 1891. = Asanthus squamulosus (A. Gray) R. King \& H. Robinson.

Coleosamthus squarrosus (Cav.) Kuntze, Revis. Gen. Pl. 327. 1891. = Brickellia cavanillesii (Cass.) A. Gray.

Coleosanthus squarrosus (Cav.) Blake, Contr. U. S. Natl. Herb. 23: 1481. 1926, comb. superf. = Brickellia cavanillesii (Cass.) A. Gray.

Coleosanthus tener (A. Gray) Kuntze, Revis. Gen. Pl. 328. 1891. = Brickellia californica (Tortey \& A. Gray) A. Gray.

Coleosanthus thyrsiflonus (A. Gray) Kuntze, Revis. Gen. Pl. 328. 1891. = Asantlius thyrsiflorus (A. Gray) R. King \& H. Robinson.

Coleosanthus tiliaefolius Cass., Dict. Sci. Nat. 24: 519. 1822.= Hebeclinium macrophyllum (L.) DC.

Coleosanthus tomentellus (A. Gray) Kuntze, Revis. Gen. Pl. 328. 1891. = Brickellia tomentella A. Gray.

Colcosanthus umbellatus E. Greene, Pittonia 4: 238. 1901. = Brickellia grandiflora (Hook.) Nutt.

Coleosanthus venosus Wooton \& Standley, Contr. U. S. Natl. Herb. 16: 177. 1913. = Brickellia venosa (Wooton \& Standley) B. Robinson.

Coleosanthus venulosus Nelson, Bot. Gaz. (Crawfordsville) 37: 262. 1904. = Brickellia atractyloides A. Gray.

Coleosanthus verbenaceus E. Greene, Pittonia 4: 125. 1900. = Brickellia verbenacea (E. Greene) B. Robinson. 
Colcosanthus vernicosus (B. Robinson) Blake, Contr. U. S. Natl. Herb. 23: 1475. 1926. = Brickellia vernicosa B. Robinson.

Coleosanthus veronicifolius (H. B. K.) Kuntze, Revis. Gen. Pl. 328. 1891. = Brickellia veronicacfolia (H. B. K.) A. Gray.

Coleosanthus watsonii (B. Robinson) Rydb., Fl. Rocky Mts. 843. 1917. = Brickellia watsonii B. Robinson.

Coleosanthus wislizenii (A. Gray) Kuntze, Revis. Gen. Pl. 328. 1891. = Brickellia wislizeni A. Gray.

Colcosanthus wootoni E. Greene, Bull. Torrey Bot. Club 24: 511. 1897. = Brickellia lemmonii A. Gray.

Coleosanthus wrightii (A. Gray) Britton, Trans. New York Acad. Sci. 14: 43. 1894. = Brickellia californica (Torrey \& A. Gray) A. Gray.

Condylidium cuatrecasasii R. King \& H. Robinson, Phytologia 24: 381.1972.

Condylidium iresinoides (H. B. K.) R. King \& H. Robinson, Phytologia 24: 381. 1972.

Condylopodium cuatrecasasii R. King \& H. Robinson, Phytologia 24: 398. 1972.

Condylopodium fuliginosum (H. B. K.) R. King \& H. Robinson, Phytologia 24: 399. 1972.

Condylopodium killipii R. King \& H. Robinson, Phytologia 24: 399. 1972.

Condylopodium pennellii R. King \& H. Robinson, Phytologia 24: 399. 1972.

Conocliniopsis prasiifolia (DC.) R. King \& H. Robinson, Phytologia 23: 308. 1972.

Conoclinium acuminatum Schultz-Bip. ex Baker, Fl. Bras. 6(2): 361. 1876, nom. nud. = Barrosoa organensis (Gardner) R. King \& H. Robinson.

Conoclinium adenolepis Schultz-Bip. ex Baker, F. Bras. 6(2): 361. 1876, nom. nud. = Eupatorium selloi Baker, Barrosoa?

Conoclinium affine Gardner, London J. Bot. 5: 466. 1846. = Barrosoa betonicaeformis (DC.) R. King \& H. Robinson.

Conoclinium album Martius, Del. Sem. Hort. Monac. 4. 1848, ignota.

Conoclinium ballotaefolium (H. B. K.) Schultz-Bip. ex Baker, F. Bras. 6(2): 360. 1876, nom. nud. = Lourteigia ballotaefolia $(\mathrm{H}$. B. K.) R. King \& H. Robinson.

Conoclinium betonicaeforme DC., Prodr. 5: 135. 1836. = Barrosoa betonicaeformis (DC.) R. King \& H. Robinson.

Conoclinium betonicifolium (Miller) R. King \& H. Robinson, Phytologia 19: 300. 1970.

Conoclinium betonicum DC., Prodr. 5: 135. 1836. = Conoclinium betonicifolium (Miller) R. King \& H. Robinson.

Conoclinium cerasifolium Schultz-Bip. ex Baker, Fl. Bras. 6(2): 308. 1876, nom. nud. = Guayania cerasifolia (Baker) R. King \& H. Robinson.

Conoclinium coelestinum (L.) DC., Prodr. 5: 135. 1836.

Conoclinium dichotomum Chapman, Bot. Gaz. (Crawfordsville) 3: 5. 1878. = Conoclinium coelestinum (L.) DC.

Conoclinium dissectum A. Gray, Pl. Wright. 1: 88. 1852. = Conocliniuın greggii (A. Gray) Small.

Conoclinium flaccidum E. Greene, Pittonia 4: 274. 1901. = Conoclinium coelestinum (L.) DC.

Conoclinium grandiflorum Hort. ex Vilm., Vilm. Blumengaert., ed. 3, 1: 448. 1896, nom. nud. = Ageratina vernalis $($ Vatke \& Kurtz) R. King \& H. Robinson.

Conoclinium greggii (A. Gray) Small, Fl. S. E. U. S. 1169. 1903.

Conoclinium hirsutissimum Schultz-Bip. ex Baker, Fl. Bras. 6(2):

311. 1876, nom. nud. = Dasycondylus hirsutissimus (Baker) R. King \& $H$. Robinson.

Conoclinium humile Benth., Pl. Hartw. 199. 1845. = Lourteigia humilis (Benth.) R. King \& H. Robinson.

Conoclinium ianthinum Morren, Ann. Acad. Gand. 5: 173.1849.

$=$ Bartlettina sordida (Less.) R. King \& H. Robinson.

Conoclinium integrifolium (A. Gray) Small, Fl. S. E. U. S. 1170.
1903. = Conoclinium betonicifolium (Miller) R. King \& H. Robinson.

Conoclinium lasseauxii Durand, Ind. Sem. Hort. Burdigala 15. 1872. = Barrosoa candolleana (Hook. \& Am.) R. King \& H. Robinson.

Conoclinium maritimum Schultz-Bip. ex Baker, F. Bras. 6(2): 362. 1876 , nom. nud. = Barrosoa apiculata (Gardner) R. King \& H. Robinson.

Conoclinium microcephalum Schultz-Bip. ex Baker, Fl. Bras. 6(2): 364. 1876, nom. nud. = Barrosoa candolleana (Hook. \& Arn.) R. King \& H. Robinson.

Conoclinium microphyllum (L. f.) DC., Prodr. 5: 135. 1836. = Lourteigia microphylla (L. f.) R. King \& H. Robinson.

Conoclinium mikanioides Schultz-Bip. ex Baker, F. Bras. $6(2)$ : 306. 1876, nom. nud. = Diacranthera crenata (Schlechtend in Martius) R. King \& H. Robinson.

Conoclinium nepetaefolium E. Greene, Pittonia 4: 274. 1901. = Conoclinium coelestinum (L.) DC.

Conoclinium oligolepis Kunze, Linnaea 20: 19. 1847. = Conoclinium betonicifolium (Miller) R. King \& H. Robinson, ?

Conoclinium organense (Gardner) Schultz-Bip. ex Baker, Fl. Bras. 6(2): 361. 1876, nom. nud. = Barrosoa organensis (Gardner) R. King \& H. Robinson.

Conoclinium palustre Schultz-Bip. ex Baker, Fl. Bras. 6(2): 363. 1876 , nom. nud. = Barrosoa betonicaeformis (DC.) R. King \& H. Robinson.

Conoclinium platylepis Schultz-Bip. ex Baker, Fl. Bras. 6(2): 355. 1876 , nom. nud. $=$ Dasycondylus platylepis $($ Baker) R. King \& H. Robinson.

Conoclinium prasiifolium DC., Prodr. 5: 135. 1836. = Conocliniopsis prasiifolia (DC.) R. King \& H. Robinson.

Conoclinium resinosum (Sprengel) Schultz-Bip. ex Baker, Fl. Bras. 6(2): 306. 1876, nom. nud. = Dasycondylus resinosus $($ Sprengel) R. King \& H. Robinson.

Conoclinium rigidum (DC.) Chapman, Bot. Gaz. (Crawfordsville) 3: 6. 1878. = Chromolaena rigida (Sw.) $\mathrm{R}$. King \& H. Robinson.

Conoclinium rugosum Turcz., Bull. Soc. Imp. Naturalistes Moscou 24(1): 168. 1851. = Aristeguietia glutinosa (Lam.) R. King \& H. Robinson.

Conoclinium scandens Gardner, London J. Bot. 6: 437. 1847. = Sphaereupatorium scandens (Gardner) R. King \& H. Robinson.

Conoclinium semistriatum Schultz-Bip. ex Baker, Fl. Bras. 6(2): 318. 1876, nom. nud. = Bejaranoa semistriata $($ Baker) R. King \& H. Robinson.

Conoclinium subglutinosum A. Gray, Proc. Amer. Acad. Arts 5: 115. 1861. = Barrosoa apiculata (Gardner) R. King \& H. Robinson.

Conoclinium subglutinosum (A. Gray) Schultz-Bip. ex Baker, Fl. Bras. 6(2): 362. 1876, nom. nud. = Barrosoa apiculata (Gardner) R. King \& H. Robinson.

Conoclinium subviscosum (error for subglutinosum) A. Gray ex Baker, Fl. Bras. 6(2): 362. 1876, nom. nud. = Barrosoa apiculata (Gardner) R. King \& H. Robinson.

Conoclinium venulosum E. Greene, Pittonia 4: 273. 1901.= Conoclinium coelestinum (L.) DC.

Conoclinium vindex Schultz-Bip. ex Baker, Fl. Bras. 6(2): 312 1876 , nom. nud. = Chromolaena vindex (DC.) R. King \& H. Robinson.

Conyza oblongifolia Sprengel, Syst. Veg. Fl. Peruv. Chil. 3: 512 1826. = Stomatanthes oblongifolius (Sprengel) H. Robinson.

Corethannium chocoensis R. King \& H. Robinson, Phytologia 39: 55.1978.

Corynanthelium moronoa Kunze, Linnaea 20: 19. 1847. = Mikania glomerata Sprengel, ?

Cotula verbesina L., Amoen. Acad. 5:407. 1760. = Adenostemma verbesina (L.) Kuntze. 
Critonia arachnoidea (Legn.) R. King \& H. Robinson, Phytologia 49: 4. 1981.

Critonia aromatisans (DC.) R. King \& H. Robinson, Phytologia 22: 48. 1971 .

Critonia bartlettii (B. Robinson) R. King \& H. Robinson, Phytologia 22: 48. 1971.

Critonia belizeana B. Turner, Phytologia 52: 491, 1983. = Critonia lanicallis (B. Robinson) R. King \& H. Robinson.

Critonia billbergiana (Beurlin) R. King \& H. Robinson, Phytologia 22: 48. 1971.

Critonia breedlovei R. King \& H. Robinson, Phytologia 58: 260. 1985.

Critonia campechensis (B. Robinson) R. King \& H. Robinson, Phytologia 22: 48. 1971.

Critonia chrysocephala (Klatt) R. King \& H. Robinson, Phytologia 22: 48. 1971. = Neurolaena lobata (L.) R. Br. HELIANTHEAE.

Critonia conzattii (Greenman) R. King \& H. Robinson, Phytologia 22: 48. 1971.

Critonia dalea (L.) DC., Prodr. 5: 140. 1836.

Critonia daleoides DC., Prodr. 5: 141. 1836.

Critonia dominicensis R. King \& H. Robinson, Phytologia 23: 405. 1972.

Critonia eggersii (Hieron.) R. King \& H. Robinson, Phytologia 22: 49. 1971.

Critonia elliptica Raf. ex DC., Prodr. 5: 178. 1836, nom. nud. = Eupatorium rotundifolium $\mathrm{L}$.

Critonia eriocarpa (B. Robinson \& Greenman) R. King \& H. Robinson, Phytologia 22: 49. 1971.

Critonia eupatorioides Gaertner ex Steudel, Nomencl. Bot. 1: 441. 1840, nom. nud. = Brickellia eltpatorioides (L.) Shinn.

Critonia hebebotrya DC., Prodr. 5: 141. 1836.

Critonia hemipteropoda (B. Robinson) R. King \& H. Robinson, Phytologia 22: 49. 1971.

Critonia heteroneura Ernst, Flora 57: 210. 1874.

Critonia hospitalis (B. Robinson) R. King \& H. Robinson, Phytologia 22: 49. 1971.

Critonia iltisii R. King \& H. Robinson, Phytologia 39: 137. 1978.

Critonia imbricata Griseb., Mem. Amer. Acad. Arts n. s. 8: 512. 1863.

Critonia inaequidens (Urban) R. King \& H. Robinson, Phytologia 22: 49.1971.

Critonia kuhnia Gaertner, Fruct. Sem. PI. 2: 411 . T. 174, f. 7. 1791. = Brickellia eupatorioides (L.) Shinn.

Critonia lanicaulis (B. Robinson) R. King \& H. Robinson, Phytologia 22: 49. 1971.

Critonia laurifolia (B. Robinson) R. King \& H. Robinson, Phytologia 22: 49. 1971.

Critonia lozanoana (B. Robinson) R. King \& H. Robinson, Phytologia 22: 49.1971.

Critonia macropoda DC., Prodr. 5: 140. 1836.

Critonia magistri (L. O. Williams) R. King \& H. Robinson, Phytologia 37: 457. 1977.

Critonia megaphylla (Baker) R. King \& H. Robinson, Phytologia 49: 4. 1981.

Critonia morifolia (Miller) R. King \& H. Robinson, Phytologia 22: 49. 1971 .

Critonia naiguatensis (V. Badillo) R. King \& H. Robinson, Phytologia 35: 499. 1977.

Critonia nicaraguensis (B. Robinson) R. King \& H. Robinson, Phytologia 22: 50. 1971.

Critonia parviflora [Sw.] DC., Prodr. 5: 140. 1836.

Critonia peninsularis (Brandegee) R. King \& H. Robinson, Phytologia 22: 50.1971.

Critoria platychaeta (Urban) R. King \& H. Robinson, Phytologia 23: 405.1972.

Critonia portoricensis (Urban) Britton \& P. Wilson, Sci. Surv. Porto Rico \& Virgin 1sl. 6: 291. 1925.
Critonia pseudo-dalea DC., Prodr. 5: 140. 1836.

Critonia quadrangularis (DC.) R. King \& H. Robinson, Phytologia 22: 50. 1971.

Critonia sexangularis (Klatt) R. King \& H. Robinson, Phytologia 22: 50.1971

Critonia spinaciaefolia (DC.) R. King \& H. Robinson, Phytologia 22: 50.1971 .

Critonia stiginatica (Urban \& Ekman) R. King \& H. Robinson, Phytologia 22: 50. 1971.

Critonia tenuifolia (H. B. K.) V. Badillo, Ernstia 10: 10. 1982. = Critoniella tenuifolia (H. B. K.) R. King \& H. Robinson.

Critonia thyrsigera (Hieron.) R. King \& H. Robinson, Phytologia 22: 50.1971 .

Critonia thyrsoidea (Mocino ex DC.) R. King \& H. Robinson, Phytologia 22: 50. 1971.

Critonia tuxtiae R. King \& H. Robinson, Phytologia 58: 262. 1985.

Critoniadelphus microdon (B. Robinson) R. King \& H. Robinson, Phytologia 22: 53. 1971.

Critoniadelphus nubigenus (Benth.) R. King \& H. Robinson, Phytologia 22: 53. 1971.

Critoniella acuminata (H. B. K.) R. King \& H. Robinson, Phytologia 30: 285. 1975.

Critoniella albertosmithii (B. Robinson) R. King \& H. Robinson, Phytologia 30: 285. 1975.

Critoniella lebrijensis (B. Robinson) R. King \& H. Robinson, Phytologia 30: 285. 1975.

Critoniella leucolithogena (B. Robinson) R. King \& H. Robinson, Phytologia 32: 284. 1975.

Critoniella tenuifolia (H. B. K.) R. King \& H. Robinson, Phytologia 53: 392. 1983.

Critoniella vargasiana (DC.) R. King \& H. Robinson, Phytologia 30: 285. 1975.

Cronquistia pringlei(S. Watson) R. King, Brittonia 20: 12. 1968.

Cronquistianthus bishopii R. King \& H. Robinson, Phytologia 54: 40.1983.

Cronquistianthus bulliferus (Blake) R. King \& H. Robinson, Phy* tologia 49: 4. 1981.

Cronquistianthus callacatensis (Hieron.) R. King \& H. Robinson, Phytologia 32: 284. 1975.

Cronquistianthus celendinensis R. King \& H. Robinson, Phytologia 51: 179. 1982.

Cronquistianthus chachapoyensis R. King \& H. Robinson, Phytologia 51: 180. 1982.

Cronquistianthus chamaedrifolius (H. B. K.) R. King \& H. Robinson, Phytologia 23: 410. 1972.

Cronquistiauthus chotensis (Hieron.) R. King \& H. Robinson, Phytologia 23: 410.1972.

Cronquistianthus desmophyllus (B. Robinson) R. King \& H. Robinson, Phytologia 23: 411. 1972.

Cronquistianthus determinatus (B. Robinson) R. King \& H. Robinson, Phytologia 51: 181. 1982.

Cronquistianthus ferreyrii R. King \& H. Robinson, Phytologia 27: 395.1974.

Cronquistianthus glomeratus (DC.) R. King \& H. Robinson, Phytologia 23: 411.1972.

Cronquistianthus infantesii R. King \& H. Robinson, Phytologia 51: 181. 1982.

Cronquistianthus kalenbornianus (B. Robinson) R. King \& H. Robinson, Phytologia 23: 411. 1972.

Cronquistianthus lavandulaefolius (DC.) R. King \& H. Robinson. Phytologia 23: 411.1972.

Cronquistianthus leucophyllus (H. B. K.) R. King \& H. Robinson, Phytologia 23: 411. 1972.

Cronquistiamthus lopezmirandae (Cabrera) R. King \& H. Robinson, Phytologia 54: 40. 1983.

Cronquistianthus macbridei R. King \& H. Robinson, Phytologia 51: 182. 1982. 
Cronquistianthus marrubiifolius (Hieron.) R. King \& H. Robinson, Phytologia 27: 396. 1974.

Cronquistianthus niveus (H. B. K.) R. King \& H. Robinson, Phytologia 23: 411. 1972.

Cronquistianthus origanoides (H. B. K.) R. King \& H. Robinson, Phytologia 23: 411 . 1972.

Cronquistianthus pseudoriganoides (Hieron.) R. King \& H. Robinson, Phytologia 23: 411. 1972.

Cronquistianthus rosei $\mathrm{R}$. King \& H. Robinson, Phytologia 51: 182. 1982

Cronquistianthus rugosus [H. B. K.] R. King \& H. Robinson, Phytologia 23:411.1972. = Cronquistianthus bulliferus (Blake) R. King \& H. Robinson.

Cronquistianthus trianae R. King \& H. Robinson, Phytologia 56: 252. 1984.

Cronquistianthus urubambensis (B. Robinson) R. King \& H. Robinson, Phytologia 23: 411. 1972.

Cronquistianthus volkensii (Hieron.) R. King \& H. Robinson, Phytologia 23: 411. 1972.

Crossothamnus weberbaueri (Hieron.) R. King \& H. Robinson, Phytologia 24: 78. 1972.

Cunigunda perfoliata (L.) Lunell, Amer. Midl. Naturalist 5: 35. 1917. = Eupatorium perfoliatum $\mathrm{L}$.

Cunigunda purpurea (L.) Lunell, Amer. Midl. Naturalist 5: 35. 1917. = Eupatorium purpureum L.

Cunigunda vulgaris Bubani, F. Pyren. 2: 273. 1899. = Eupatorium cannabinum $\mathrm{L}$.

Dasycondylus debeauxii (B. Robinson) R. King \& H. Robinson, Phytologia 24: 189. 1972.

Dasycondylus dusenii R. King \& H. Robinson, Phytologia 24: 189. 1972.

Dasycondylus hirsutissimus (Baker) R. King \& H. Robinson, Phytologia 60: 80. 1986.

Dasycondylus lobbii (Klatt) R. King \& H. Robinson, Phytologia 24: 190.1972.

Dasycondylus platylepis (Baker) R. King \& H. Robinson, Phytologia 24: 190. 1972.

Dasycondylus regnellii $\mathrm{R}$. King \& H. Robinson, Phytologia 24: 190. 1972.

Dasycondylus resinosus (Sprengel) R. King \& H. Robinson, Phytologia 24: 191. 1972.

Dasycondylus riedelii $\mathrm{R}$. King \& $\mathrm{H}$. Robinson, Phytologia 24: 191. 1972.

Dasycondylus santosii R. King \& H. Robinson, Phytologia 46: 296. 1980. = Dasycondylus hirsutissimus (Baker) R. King \& H. Robinson.

Decachaeta conferta Gardner, London J. Bot. 5: 463. $1846 .=$ Acritopappus confertus (Gardner) R. King \& H. Robinson.

Decachaeta haenkeana DC., Prodr. 5: 133. 1836.

Decachaeta incompta (DC.) R. King \& H. Robinson, Brittonia 21: 280. 1969.

Decachaeta longifolia Gardner, London J. Bot. 5: 462 . 1846. = Acritopappus longifolius (Gardner) R. King \& H. Robinson.

Decachaeta ovandensis (Grashoff \& Beaman) R. King \& H. Robinson, Brittonia 21: 397. 1969(1970).

Decachaeta ovatifolia (DC.) R. King \& H. Robinson, Brittonia 21: 282. 1969.

Decachaeta perornata (Klatt) R. King \& H. Robinson, Phytologia 21: 301. 1971.

Decachaeta pyramidalis (B. Robinson) Sundberg, R. Cowan \& B. Turner, Amer. J. Bot. 73: 37. 1986. = Erythradenia pyramidalis (B. Robinson) R. King \& H. Robinson.

Decachaeta scabrella (B. Robinson) R. King \& H. Robinson, Brittonia 21: 283. 1969.

Decachaeta seemanni Benth. \& Hook. f., Gen. Pl. 2: 239.1873. = Ageratella microphylla (Schultz-Bip.) A. Gray ex S. Watson. Decachaeta thieleana (Klatt ex T. Durand \& Pittier) R. King \& H. Robinson, Brittonia 21: 281. 1969.
Diacranthera crenata (Schlechtend, in Martius) R. King \& $\mathrm{H}$. Robinson, Phytologia 24: 193. 1972.

Diacranthera ulei R. King \& H. Robinson, Phytologia 24: 193. 1972.

Dimorpholepis anethifolia (DC.) R. King \& H. Robinson, Phytologia 22: 119. 1971. = Mikania anethifolia (DC.) Matzenbacher.

Dimorpholepis coriacea R. King \& H. Robinson, Phytologia 22: 119. 1971. = Symphyopappus reticulatus Baker.

Dimorpholepis gaudichaudeana (DC.) R. King \& H. Robinson, Phytologia 22: 119. 1971. = Grazielia gaudichaudeana (DC.) R. King \& H. Robinson.

Dimorpholepis grazielae R. King \& H. Robinson, Phytologia 22: 119. 1971, nom. nov. = Grazielia dimorpholepis (Baker) R. King \& H. Robinson.

Dimorpholepis intermedia (DC.) R. King \& H. Robinson, Phytologia 22: 119. 1971. = Grazielia intermedia (DC.) R. King \& H. Robinson.

Dimorpholepis mollissima (Schultz-Bip. ex Baker) R. King \& H. Robinson, Phytologia 22: 119. 1971. = Grazielia mollissima (Schultz-Bip. ex Baker) R. King \& H. Robinson.

Dimorpholepis multifida (DC.) R. King \& H. Robinson, Phytologia 22: 119. 1971. = Grazielia multifida (DC.) R. King \& H. Robinson.

Dimorpholepis nummularia (Hook. \& Am.) R. King \& H. Robinson, Phytologia 22: 119. 1971. = Grazielia nummularia (Hook. \& Arn.) R. King \& H. Robinson.

Dimorpholepis serrata (Sprengel) R. King \& H. Robinson, Phytologia 22: 119. 1971. = Grazielia serrata (Sprengel) R. King \& H. Robinson.

Dissothrix gardneri A. Gray, Hooker's J. Bot. Kew Gard. Misc. 3: 223. T. 5. 1851. = Dissothrix imbricata (Gardner) B. Robinson.

Dissothrix hassleriana Chodat, Bull. Herb. Boissier Ser. 2. 1: 411. 1901. = Stevia aristata D. Don ex Hook. \& Arn.

Dissothrix imbricata (Gardner) B. Robinson, Proc. Amer. Acad. Arts 42: 35.1906.

Disynaphia achillaea (Chodat) R. King \& H. Robinson, Phytologia 22: 124. 1971.

Disynaphia albissima (Hassler) R. King \& H. Robinson, Phytologia 22: 124. 1971.

Disynaphia calyculata (Hook. \& Am.) R. King \& H. Robinson, Phytologia 22: 124. 1971 .

Disynaphia ericoides (DC.) R. King \& H. Robinson, Phytologia 22: 124. 1971.

Disynaphia filifolia (Hassler) R. King \& H. Robinson, Phytologia 22: 124. 1971

Disynaphia halimifolia (DC.) R. King \& H. Robinson, Phytologia 37: 457.1977.

Disynaphia ligulaefolia (Hook. \& Arn.) R. King \& H. Robinson, Phytologia 22: 124. 1971.

Disynaphia littoralis (Cabrera) R. King \& H. Robinson, Phytologia 22: 124. 1971.

Disynaphia minutiflora R. King \& H. Robinson, Phytologia 46: 296. 1980.

Disynaphia montevidensis DC., Prodr. 7: 267. 1838. = Disynaphia calyculata (Hook. \& Arn.) R. King \& H. Robinson.

Disynaphia multicrenulata (Schultz-Bip. ex Baker) R. King \& H. Robinson, Phytologia 22: 124. 1971.

Disynaphia praeficta (B. Robinson) R. King \& H. Robinson, Phytologia 32: 284. 1975.

Disynaphia radula (Chodat) R. King \& H. Robinson, Phytologia 22: 124. 1971.

Disynaphia senecionidea (Baker) R. King \& H. Robinson, Phytologia 22: 124. 1971 .

Disynaphia spathulata (Hook. \& Arn.) R. King \& H. Robinson, Phytologia 22: 125. 1971. 
Disynaphia lacuarembensis (Hieron. \& Arechav.) R. King \& H. Robinson, Phytologia $60: 80.1986$.

Disynaphia variolata (B. Robinson) R. King \& H. Robinson, Phytologia 22: 125. 1971.

Dunantia achyranthes DC., Prodr. 5: 627. 1836. = Isocarpha oppositifolia (L.) Cass.

Dunantia microcephala DC., Prodr. 5: 627. 1836. = Isocarpha microcephala (DC.) S. F. Blake.

Dyscritogyne adenosperma (Schultz-Bip.) R. King \& H. Robinson, Phytologia 22: 159. 1971.

Dyscrilogyne dryophila (B. Robinson) R. King \& H. Robinson, Phytologia 22: 159. 1971.

Eitenia polyseta R. King \& H. Robinson, Phytologia 44: 455. 1979.

Eitenia praxeloides R. King \& H. Robinson, Phytologia 28: 282. 1974.

Ellenbergia glandulata Cuatrec., Proc. Biol. Soc. Wash. 77: 142. 1964.

Eriopappus paniculatus Hort. ex Loudon, Encycl. Pl. 688. 1836, nom. nud. = Brickellia paniculata (Miller) B. Robinson.

Erythradenia pyramidalis (B. Robinson) R. King \& H. Robinson, Brittonia 21: 285. 1969.

Eupatoriadelphus dubius (Willd. ex Poiret) R. King \& H. Robinson, Phytologia 19: 432. 1970. = Eupatorium dubium Willd. ex Poiret.

Eupatoriadelphus fistulosus (J. Barratt) R. King \& H. Robinson, Phytologia 19: 432. 1970. = Eupatorium fistulosum J. Barratt.

Eupatoriadelphus maculatus (L.) R. King \& H. Robinson. Phytologia 19:432. 1970. = Eupatorium maculatum L.

Eupatoriadelphus purpureus (L.) R. King \& H. Robinson, Phytologia 19:432. 1970. = Eupatorium purpureum L.

Eupatoriastrum angulifolium (B. Robinson) R. King \& H. Robinson, Phytologia 21: 306. 1971.

Eupatoriastrum chlorostylum B. Turner. Phytologia 59: 323.1986.

Eupatoriastrum clavisetum V. Badillo, Bol. Soc. Venez. Ci. Nat. 238. 1943. = Idiothamnus clavisetus (V. Badillo) R. King \& H. Robinson.

Eupatoriastrum nelsonii Greenman, Proc. Amer. Acad. Arts 39: 93. 1903.

Eupatoriastrum opadoclinium Blake, J. Wash. Acad. Sci. 28: 479. 1938. = Chromolaena opadoclinia (Blake) R. King \& H. Robinson.

Eupatoriastrum triangulare (DC.) B. Robinson, Contr. Gray Herb. 68: 34. 1923.

Eupatorina sophiaefolia (L.) R. King \& H. Robinson, Phytologia 21: 397. 1971.

Eupatoriopsis hoffinamiana Hieron., Bot. Jahrb. Syst. 18: Beibl. 43: 46. 1893.

Eupatorium aboriginum E. Greene, Pittonia 4: 277. 1901. = Ageratina altissima (L.) R. King \& H. Robinson.

Eupatorium abronium Klatt, Ann. K. K. Naturhist. Hofmus. 9: 355. 1894. = Ageraina prunellaefolia (H. B. K.) R. King \& H. Robinson.

Eupatorium achillaea Chodat, Bull. Herb. Boissier Ser. 2. 1:411. 1901. = Disynaphia achillaea (Chodat) R. King \& H. Robinson.

Eupatorium acuminatum H. B. K., Nov. Gen. Sp. 4: 84. Ed. Folio. 1818. = Critoniella acuminata (H. B. K.) R. King \& H. Robinson.

Eupatorium acuminatum D. Don, Prodr. Fl. Nepal. 171. 1825. = Vermonia divergens (Roxb.) Edgewood. VERNONIEAE.

Eupatorium acuminatum Hook. \& Am., Companion Bot. Mag. 1: 241.1835 . = Neocabreria serrulata (DC.) R. King \& H. Robinson.

Eupatorium acuminatum Sprengel ex DC., Prodr. 5: 33. 1836 , nom. nud. = Vemonia saligna $($ Roxb.) DC. VERNONIEAE.

Eupatorium acuminatum Wallich ex DC., Prodr. 5: 32. 1836, non. nud. = Vernorila arborea Buch.-Ham. VERNONIEAE.
Eupatorium acutidentatum B. Robinson, Proc. Amer. Acad. Arts 43: 29. 1907. = Ageratina acutidentata (B. Robinson) R. King \& H. Robinson.

Eupatorium adamantium Gardner, London J. Bot. 5: 477. 1846. = Koanophyllon adamantium (Gardner) R. King \& H. Robinson.

Eupatorium adenachaenium Schultz-Bip. ex Klatt, Leopoldina 20: 75. 1884. = Ageratina adenachaenia $($ Schultz-Bip. ex Klatt) R. King \& H. Robinson.

Eupatorium adenanthum DC., Prodr. 5: 164. 1836. = Trichogoniopsis adenawtha (DC.) R. King \& H. Robinson.

Eupatorium adenochaetum Schuitz-Bip. ex Hemsley, Biol. Cent. Amer., Bot. 2: 91. 1881, nom. nud. = Ageratina adenachaenia (Schultz-Bip. ex Klatt) R. King \& H. Robinson.

Eupatorium adenolepis Schultz-Bip. ex Baker, F. Bras. 6(2): 291. 1876. = Chromolaena adenolepis (Schultz-Bip. ex Baker) R. King \& H. Robinson.

Eupatorium adenophorum Sprengel, Syst. Veg. Fl. Peruv. Chil. 3: 420. 1826. = Ageratina adenophora (Sprengel) R. King \& H. Robinson.

Eupatorium adenospermum Schultz-Bip., Bot. Voy. Herald 299. 1856. = Dyscritogyne adenosperma (Schultz-Bip.) R. King \& H. Robinson.

Eupatorium adspersum Klatt, Compos. Nov. Costaric. [Bot. Beibl. Leopoldina] 1895: 1. 1895. = Ageratina anisochroma (Klatt) R. King \& H. Robinson.

Eupatorium adspersum Klatt in T. Durand \& Pittier, Bull. Soc. Roy. Bot. Belgique 35: 279. 1896. = Ageratina anisochroma (Klatt) R. King \& H. Robinson.

Eupatorium aegirophyllum B. Robinson, Proc. Amer. Acad. Arts 35: 329. 1900. = Ageratina aegirophylla (B. Robinson) R. King \& H. Robinson.

Eupatorium aequinoctiale B. Robinson, Contr. Gray Herb. 61: 4. 1920. = Fleischmannia aequinoctialis (B. Robinson) R. King \& H. Robinson.

Eupatorium affine H. B. K., Nov. Gen. Sp. 4: 98. Ed. Folio. 1818. = Ophryosportus chilca (H. B. K.) Hieron.

Eupatorium affine Wender., Schriften Ges. Beford. Gesammten Naturwiss. Marburg 2: 261. 1831, ignota.

Eupatorium affine Hook. \& Arn., Companion Bot. Mag. 1: 240. 1835. = Chromolaena odorata (L.) R. King \& H. Robinson.

Eupatorium affine Mairet ex DC., Prodr. 7: 66. 1838, nom. nud. = Acourtia hebeclada DC. MutisieAE.

Eupatorium affine Wender., Linnaea 16. Litt. 111. 1842, ignota.

Eupatorium africanum Oliver \& Hieron., Fl. Trop. Afr. 3: 301. 1877. = Stomatanthes africamus (Oliver \& Hieron.) R. King \& H. Robinson.

Eupatorium ageratifolizm DC., Prodr. 5: 173. 1836. = Ageratina havanensis (H. B. K.) R. King \& H. Robinson.

Eupatorium ageratifolium var, acuminatum Coulter, Contr. U. S. Natl. Herb. 1: 39. 1890. = Tamaulipa azurea (DC.) R. King \& H. Robinson.

Eupatorium ageratifolium var. herbaceum A. Gray, Pl. Wright. 1: 87.1852 .

Eupatorium ageratoides L. f., Suppl. Pl. 355. 1781. = Ageratina altissima (L.) R. King \& H. Robinson.

Eupatorium ageratoides Bertero ex DC., Prodr. 5: 173. 1836, nom. nud. = Ageratina havanensis $(\mathrm{H}$. B. K.) R. King \& H. Robinson.

Eupatorium ageratoides var. angustatum A. Gray, Syn. Fl. N. Amer. 1(2): 101. 1884. = Ageratina altissima (L.) R. King \& H. Robinson.

Eupatorium albertinae A. Molina, Ceiba 16: 53. 1970. = Campuloclinium macrocephalum (Less.) DC.

Eupatorium albertosmithii B. Robinson, Contr. Gray Herb. 80: 12. 1928 . = Critoniella albertosmithii (B. Robinson) R. King \& H. Robinson.

Eupatorium albescens Gardner, London J. Bot. 6: 445. 1847.= 
Austroeupatorium silphiifolium (Martius) R. King \& H. Robinson.

Enpatorium albicaule Schultz-Bip. ex Hemsley, Biol. Cent.-Amer., Bot. 2: 92. 1881. = Koanophyllon albicaulis (Schultz-Bip. ex Klatt) R. King \& H. Robinson.

Eupatorium albifrons E. H. Krause, Sturm's Fl. Deutchl., ed. 2, 13: 34. 1905. = Adenostyles alliariae (Gouan) A. Kerner. SEnECIONEAE.

Eupatorium albissimum Hassler, Feddes Repert. 11: 172. 1912. $=$ Disynaphia albissima (Hassler) R. King \& H. Robinson.

Eupatorium album L., Mant. PI. 1: 111. 1767.

Eupatorium album Thunb., Fl. Jap. 308. 1784. = Eupatorium chinense $\mathbf{L}$.

Eupatorium album Hemsley, Biol. Cent.-Amer., Bot. 2:92. 1881 , nom. nud. ignota.

Eupatorium allaisii Sennen, Bol. Soc. Iber. Ci. Nat. 28: 73. 1929. = Eupatorium cannabinum L.

Eupatorium allenii Standley, Publ. Field Mus. Nat. Hist., Bot. Ser. 18: 1457. 1938. = Ageratina allenii (Standley) R. King \& H. Robinson.

Eupatoritum alpestre Gardner, London J. Bot. 4: 116. 1845. = Grazielia serrata (Sprengel) R. King \& H. Robinson.

Eupatorium alternans DC., Prodr. 5: 144. 1836. = Chromolaena laevigata (Lam.) R. King \& H. Robinson.

Eupatorium alternifolium Ard., Animadv. Bot. Spec. Alt. 2: 40. 1764. = Brickellia eupatorioides (L.) Shinn.

Eupatorium alternifolium Schultz-Bip. ex Baker, Fl. Bras. 6(2): 333. 1876, = Gyptis crassipes (Hieron.) R. King \& H. Robinson.

Eupatorium altiscandens McVaugh, Contr. Univ. Michigan Herb. 9: 390. 1972. = Neomirandea araliaefolia (Less.) R. King \& H. Robinson.

Eupatorium altissinum L., Sp. P1. 837. 1753.

Eupatorium altissimum (L.) Murray, Syst. Nat., ed. 13, 614. 1774, nom. illeg. = Ageratina altissima (L.) R. King \& H. Robinson.

Eupatorium anabile Kitam., Acta Phytotax. Geobot. 1: 283. 1932.

Eupatorium arnarum Vahl, Symb. Bot. 3: 93. 1794. = Mikania parviflora (Aublet) Karsten.

Eupatorium ambiguum $\times$ Hook., Companion Bot. Mag. 1: 96. 1835. = Eupatorium semiserratum DC., and Eupatorium serotinum Michaux.

Eupatorium a mblyolaenum Schultz-Bip. ex Baker, Fl. Bras. 6(2): 332. 1876, nom. nud. = Campovassouria cruciata (Vell. Conc.) R. King \& H. Robinson.

Eupatorium amblyolepis B. Robinson, Proc. Amer. Acad. Arts 35: 330. 1900. = Ageratina amblyolepis (B. Robinson) R. King \& H. Robinson.

Eupatorium amethystinum B. Robinson, Contr. Gray Herb. 77: 8. 1926. = Aristeguietia amethystina (B. Robinson) R. King \& H. Robinson.

Eupatorium amoenum Pursh, Fl. Amer. Sept. 2: 514. 1814. = Eupatorium dubium Willd. ex Poiret.

Eupatorium amori Cuatrec., Anales Ci. Univ. Madrid 4(2): 219. 1935. = Ayapanopsis?

Eupatorium amphidyctium DC., Prodr. 5: 163. 1836. = Heterocondylus amphidictyus (DC.) R. King \& H. Robinson.

Eupatorium amplifolium A. Gray, Proc. Amer. Acad. Arts 15: 28. 1879. = Ageratina rubricaulis (H. B. K.) R. King \& H. Robinson.

Eupatorium amplum Benth., Pl. Hartw. 200. 1845. = Ageratina ampla (Benth.) R. King \& H. Robinson.

Eupatorium ainygdalinum Lam., Encycl. 2: 408. 1788. = Ayapana amygdalina (Lam.) R. King \& H. Robinson.

Eupatorium anachoreticum B. Robinson, Contr. Gray Herb. 104: 9. 1934. = Chromolaena anachoretica (B. Robinson) R. King \& H. Robinson.

Eupatorium anastomosans DC. ex Steudel, Nomencl. Bot. 1: 606.
1840, nom. nud. = Critonia aromatisans (DC.) R. King \& H. Robinson.

Eupatorium anchisteum Grashoff \& Beaman, Rhodora 71: 567. 1969. = Ageratina anchistea (Grashoff \& Beaman) R. King \& H. Robinson.

Eupatorium andinum B. Robinson, Contr. Gray Herb. 77: 9. 1926. = Ayapanopsis andina (B. Robinson) R. King \& H. Robinson.

Eupatorium anethifolium DC., Prodr. 5: 182. 1836. = Mikania anethifolia (DC.) Matzenbacher.

Eupatorium angosturae Polak., Linnaea 41: 575. 1877. = Erechtites valerianae (Wolf) DC. SENECIONEAE.

Eupatorium angulare B. Robinson, Contr. Gray Herb. 96: 19. 1931, nom. nov. = Neomirandea angularis (B. Robinson) R. King \& H. Robinson.

Eupatorium angulicaule Schultz-Bip. ex Baker, Fl. Bras. 6(2): 287. 1876. = Austrocritonia angulicaulis (Schultz-Bip. ex Baker) R. King \& H. Robinson.

Eupatorium angulicaulis Lasser \& Maguire, Brittonia 7: 88. 1950. = Guavania yaviana (Lasser \& Maguire) R. King \& H. Robinson.

Eupatorium angulifolium B. Robinson, Contr. Gray Herb. 65: 46. 1922. = Eupatoriastrum angulifolium (B. Robinson) R. King \& H. Robinson.

Eupatorium angulosum Glaz., Bull. Soc. Bot. France Mem. 3. 56: 390. 1909, nom. nud. = Heterocondylus grandis (SchultzBip. ex Baker) R. King \& H. Robinson.

Eupatorium angustatum (A. Gray) E. Greene, Pittonia 4: 277. 1901. = Ageratina altissima (L.) R. King \& H. Robinson.

Eupatorium angusticeps Malme, Ark. Bot. 24a(6): 25. 1932. = Chromolaena angusticeps (Malme) R. King \& H. Robinson.

Eupatorium angustifolium (H. B. K.) Sprengel, Syst. Veg. 3: 415. 1826. = Ageratina asclepiadea (L. .) R. King \& H. Robinson.

Eupatorium angustissimum Sprengel ex Baker, Fl. Bras. 6(2): 325. 1876. = Pseudobrickellia angustissima (Sprengel ex Baker) R. King \& H. Robinson.

Eupatorium anisochromum Klatt in T. Durand \& Pittier, Bull. Soc. Roy. Bot. Belgique 31: 186. 1892. = Ageratina anisochroma (Klatt) R. King \& H. Robinson.

Eupatorium anisodontum B. Robinson, Proc. Amer. Acad. Arts 55: 6. 1919. = Aristeguietia anisodonta (B. Robinson) R. King \& H. Robinson.

Eupatorium anisopodum B. Robinson, Proc. Amer. Acad. Arts 36: 477. 1901. = Fleischmannia anisopoda (B. Robinson) R. King \& $\mathrm{H}$. Robinson.

Eupatorium anomalum Nash, Bull. Torrey Bot. Club 23: 106. 1896.

Eupatorium antiquorum Standley \& Steyerm., Publ. Field Mus. Nat. Hist., Bot. Ser. 22: 302. 1940. = Fleischmannia antiquorum (Standley \& Steyerm.) R. King \& H. Robinson.

Eupatorium apense Chodat, Bull. Herb. Boissier Ser. 2. 3: 708. 1903. = Austroeupatorium apense (Chodat) R. King \& H. Robinson.

Eupatorium apiculatum Gardner, London J. Bot. 5: 476.1846. = Barrosoa apiculata (Gardner) R. King \& H. Robinson.

Eupatorium apollinairei B. Robinson, Proc. Amer. Acad. Arts 54: 236. 1918. = Ageratina apollinairei (B. Robinson) R. King \& H. Robinson.

Eupatorium appendiculatum Less, ex Baker, F. Bras. 6(2): 365. 1876 , nom. nud. = Urolepis hecatantha (DC.) R. King \& H. Robinson.

Eupatorium arachnoideum Legn., Lilloa 34: 51(-53). 1975. = Critonia arachnoidea (Legn.) R. King \& H. Robinson.

Eupatorium araliaefolium Less., Linnaea 6: 403. 1831. = Neomirandea araliaefolia (Less.) R. King \& H. Robinson.

Eupatorium arborescens M. E. Jones, Contr. W. Bot. 12: 43. 1908. = Koanophyllon palmeri (A. Gray) R. King \& H. Robinson.

Eupatorium arboreum H. B. K., Nov. Gen. Sp. 4: 103. Ed. Folio. 
1818. = Aristeguietia arborea (H. B. K.) R. King \& H. Robinson.

Eupatorium arboreum Reinw. ex Vriese, PI. Ind. Bat. Orient. 129. 1857. = Vernonia cinerea (L.) Less. VERNONIEAE.

Eupatorium arbutifolium Benth., Pl. Hartw. 199. 1845. = Ageratina arbutifolia (Benth.) R. King \& H. Robinson.

Eupatorium arcuans B. Robinson, Proc. Amer. Acad. Arts 54: 237. 1918. = Asphundianthus arcuans (B. Robinson) R. King \& H. Robinson.

Eupatorium arechavaletae Baker, J. Bot. 16: 78. 1878. = Vernonia echioides Less. VERNONIEAE.

Eupatorium areolare DC., Prodr. 5: 169. 1836. = Piptothrix areolaris (DC.) R. King \& H. Robinson.

Eupatorium areolatum Perr. ex DC., Prodr. 5: 12. 1836, nom. nud. = Piptothrix areolaris (DC.) R. King \& H. Robinson.

Eupatorium argenteum Wallich, Num. List Dr. Pl. 3166.1831 , nom. nud. = Eupatorium cannabinım L., ?

Eupatorium argutum H. B. K., Nov. Gen. Sp. 4: 94. Ed. Folio. 1818. = Fleischmannia arguta (H. B. K.) B. Robinson.

Eupatorium aristei B. Robinson, Proc. Amcr. Acad. Arts 55: 6. 1919. = Ageratina aristei (B. Robinson) R. King \& H. Robinson.

Eupatorium arizonicum (A. Gray) E. Grecne, Pittonia 4: 280. 1901. = Ageratina herbacea (A. Gray) R. King \& H. Robinson.

Eupatorium arizonicum (A. Gray) Nelson, Bot. Gaz. (Crawfordsville) 53: 226. 1912, comb. superfl. = Ageratina herbacea (A. Gray) R. King \& H. Robinson.

Eupatorium armani Balbis, Hort. Taur. Stirp. 27. PI. 6. 1810. = Clibadium armanii (Balbis) Baker. HeliantheAe.

Eupatorium arnottianum Griseb., Goett. Abh. 24: 169. 1879. = Chromolaena arnottiana (Griseb.) R. King \& H. Robinson.

Eupatorium arnottii Bakcr. Fl. Bras. 6(2): 323. 1876. = Austrobrickellia arnottii (Baker) R. King \& $\mathrm{H}$. Robinson.

Eupatorium aromaticum L., Sp. PI. 839. 1753. = Ageratina aromatica (L.) Spach.

Eupatorium aromaticum Sieber ex Steudel, Nomencl. Bot. 1: 606. 1840, nom. nud. = Brickellia diffusa (Vahl) A. Gray.

Eupatorium aromatisans DC., Prodr. 5: 150.1836. = Critonia aromalisans (DC.) R. King \& H. Robinson.

Eupatorium arrayanum Gardner, London J. Bot. 6: 439.1847. = Chromolaena arrajana (Gardner) R. King \& H. Robinson.

Eupatorium arsenei B. Robinson. Contr. Gray Herb. 104: 10. 1934. = Ageratina arsenei (B. Robinson) R. King \& H. Robinson.

Eupatorium artemisiifolinm Griscb., Goctt. Abh. 24: 171. 1879.

$=$ Gyptis artemisifolia (Griseb.) R. King \& H. Robinson.

Eupatorium arthrodes B. Robinson, Contr. Gray Herb. 68: 8. 1923. = Neomirandea arthodes (B. Robinson) R. King \& H. Robinson.

Eupatorium articulatum Schultz-Bip. ex Hieron. in Urban, Bot. Jahrb. Syst. 40: 385. 1908. = Ageratina articulata (SchultzBip. ex Hieron.) R. King \& H. Robinson.

Eupatorium ascendens Martius ex Baker, Fl. Bras. 6(2): 344. 1876, nom. nud. = Chromolaena decumbens Gardner.

Eupatorium ascendens Schultz-Bip. cx Baker, Fl. Bras. 6(2): 296. 1876. = Chromolaena ascendens (Schultz-Bip. ex Baker) R. King \& H. Robinson.

Eupatoritm aschenbornianum Schaucr, Linnaea 19: 720. 1847. = Ageratina bustamenta (DC.) R. King \& H. Robinson.

Eupatorium asclepiadem DC., Prodr. 5: 148. 1836. = Campovassouria cruciata (Vell. Conc.) R. King \& H. Robinson.

Eupatorium asperifolium Schultz-Bip.. Linnaea 30: 182. 1859 1860. = Austroeupatorium silphiffolinm (Martius) R. King \& H. Robinson.

Eupatorium asperrimum Schultz-Bip. ex Bakcr. F1. Bras. 6(2): 292. 1876. = Chromolaena asperrima (Schultz-Bip. ex Baker) R. King \& H. Robinson.
Eupatorium asperulaceum Baker, FI. Bras. 6(2): 342. 1876. = Praxelis asperulacea (Baker) R. King \& H. Robinson.

Eupatorium asperum Roxb., Fl. Ind. 3: 415. 1832. = Vemonia aspera (Roxb.) Ham. VernoNiEAE.

Eupatorium astillerum B. Turncr, Wrightia 5: 353. 1977. = Ageratina miquihuana (B. Turner) R. King \& H. Robinson.

Eupatorium atrescens B. Robinson, Contr. Gray Herb. 77: 9. 1926. = Badilloa atrescens (B. Robinson) R. King \& H. Robinson.

Eupatorium alriplicifolimm Hort. ex Lam., Encycl. 2: 407. 1788. = Chromolaena corymbosa (Aublct) R. King \& H. Robinson.

Eupatorium atriplicifolium Vahl, Bidr. Beskr. Ste Croix 302. 1793 , Symb. Bot. 3: 96. 1794. = Chromolaena odorata (L.) R. King \& H. Robinson.

Eupatorium alrocordatum B. Robinson. Contr. Gray Herb. 104: 12. 1934. = Ageratina atrocordata (B. Robinson) R. King \& H. Robinson.

Eupatorium atroglandulosum Alain, Contr. Ocas. Mus. Hist. Nat. Colegio "De La Salle" 18: 3. 1960. = Koanophyllon atroglandulosum (Alain) R. King \& H. Robinson.

Eupatorium atromontanum Nelson, Bot. Gaz. (Crawfordsville) 31: 400. 1901. = Eupatorium maculatum L.

Eupatorium atropurpureum Sesse \& Mocino, Pl. Nov. Hisp. 135. 1889, Naturaleza (Mexico City), ser. 2(1): 126. App. Ed. 2. 1893. = Vemonia alamanii DC. VERNONIEAE.

Eupatorium atrorubens Nicholson, III. Dict. Gard. 1: 540. 1885. = Bartlettina sordida (Less.) R. King \& H. Robinson.

Eupatorium aureo-viride Chodat, Bull. Herb. Boissier Ser. 2. 2: 309. 1902. = Gyptis vernoniopsis (Schultz-Bip. ex Baker) R. King \& H. Robinson.

Eupatorium auriculatum Lam., Encycl. 2: 411. 1788. = Senecio deltoideus Less. Senecioneae.

Eupatorium auriculatum Vahl, Symb. Bot. 3: 95. 1794. = Senecio penicillatus (Cass.) Schultz-Bip. SenecioneaE.

Eupatorium austerum B. Robinson, Contr. Gray Herb. 68: 9. 1923. = Chromolaena austera (B. Robinson) R. King \& H. Robinson.

Eupatorium australe Thunb., PI. Bras. 2: 26. 1818. = Chromolaena laevigata (Lam.) R. King \& H. Robinson.

Eupatorium australe Bartling, Ind. Sem. Hort. Acad. Gott. 9: t. 310. 1837, Linnaea 12. Litt. 81. 1839. = Ageratina glechonophylla (Less.) R. King \& H. Robinson, ?

Eupatorium axillare (Torrey \& A. Gray) Mocino \& Sesse ex DC., Prodr. 5: 138. 1836, nom. nud. = Brickellia californica (Torrey \& A. Gray) A. Gray.

Eupatorium axilliflorum Griseb.. Goett. Abh. 19: 121. 1874. = Ophrn:sporus axilliflorus (Griseb.) Hieron.

Eupatorium aya-pana Vent., Jard. Malmaison 3. T. 3. 1803.= Ayapana triplinervis (Vahl) R. King \& H. Robinson.

Eupatorium avapanoides Griseb., Cat. PI. Cub. 146. 1866. = Koanophyllon ayapanoides (Griseb.) R. King \& H. Robinson.

Eupatorium azangaroense Schultz-Bip. ex Wcdd., Chlor. And. 1: 217.1857. = Ageratina azangaroensis (Schultz-Bip. ex Wedd.) R. King \& H. Robinson.

Eupatorium azureum DC., Prodr. 5: 168, 1836. = Tamaulipa azurea (DC.) R. King \& H. Robinson.

Eupatorium baccharifolium Gardner, London J. Bot. 4: 117. 1845. = Koanophyllon baccharifolium (Gardner) R. King \& H. Robinson.

Eupatorium baccharoides H. B. K., Nov. Gen. Sp. 4: 132. Ed. Folio. 1818. = Ageratina baccharoides (H. B. K.) R. King \& H. Robinson.

Eupatorium hacleamum DC., Prodr. 5: 157. 1836. = Gypt is com= mersonii Cass.

Eupatorium badium Klatt in T. Durand \& Pittier, Bull. Soc. Roy. Bot. Belgique 31: 186. 1892. = Ageratina badia (Klatt) R. King \& H. Robinson.

Eupatorium bahamense Northrop, Mem. Torrey Bot. Club 12: 
70. Pl. 19. 1902. = Chromolaena bahamensis (Northrop) R. King \& H. Robinson.

Eupatorium bahamense Urban, Symb. Antill. 3: 391. 1903. = Chromolaena bahamensis (Northrop) R. King \& H. Robinson.

Eupatorium bakerianum B. Robinson, Contr. Gray Herb. 75: 5. 1925, nom. nov. = Austrobrickellia bakerianum (B. Robinson) R. King \& H. Robinson.

Eupatorium balansae Hieron., Bot. Jahrb. Syst. 22: 778. 1897. = Bejaranoa balansae (Hieron.) R. King \& H. Robinson.

Eupatorium ballii Oliver, Hooker's Icon. Pl. 15: 49. 1884. = Aristeguietia ballii (Oliver) R. King \& H. Robinson.

Eupatorimm ballotaefolium H. B. K., Nov. Gen. Sp. 4: 95. Ed. Folio. 1818. = Lourteigia ballotaefolia (H. B. K.) R. King \& H. Robinson.

Eupatorium bangii Rusby, Mem. Torrey Bot. Club 6: 56. 1896. $=$ Chromolaena bangii (Rusby) R. King \& H. Robinson.

Eupatorium barahonense Urban, Feddes Repert. 17: 10. 1921. = Koanophyllon barahonense (Urban) R. King \& H. Robinson.

Eupatorium barbacense Hieron., Bot. Jahrb. Syst. 22: 750. 1897. = Chromolaena barbacensis (Hieron.) R. King \& H. Robinson.

Eupatorium barclayanum Benth., Bot. Voy. Sulphur 112.1845. = Avapana amygdalina (Lam.) R. King \& H. Robinson.

Eupatorium barranquillense Hieron., Bot. Jahrb. Syst. 28: 564. 1901 . = Chromolaena barranquillensis (Hieron.) R. King \& H. Robinson.

Eupatorium bartlettii B. Robinson, Contr. Gray Herb. 100: 11. 1932. = Critonia bartlettii (B. Robinson) R. King \& H. Robinson.

Eupatorium bartlingianum Steudel, Nomencl. Bot. 1: 606. 1840, nom. nud. = Ageratina glechonophylla (Less.) R. King \& H. Robinson,?

Eupatorium bartsiaefolium DC., Prodr. 5: 147. 1836. = Chromolaena hirsuta (Hook. \& Arn.) R. King \& H. Robinson.

Eupatorium bartsioides Schultz-Bip. ex Baker, F1. Bras. 6(2): 295. 1876, nom. nud. = Chromolaena hirsuta (Hook. \& Arn.) R. King \& H. Robinson.

Eupatorium basifolium Malme, Ark. Bot. 24a(8): 30. 1932. = Praxelis basifolia (Malme) R. King \& H. Robinson.

Eupatorium bathyphlebium B. Robinson, Contr. Gray Herb. 100: 12. 1932. = Chrornolaena bathyphlebia (B. Robinson) R. King \& H. Robinson.

Eupatorium bellidifolium Benth., Pl. Hartw. 43. 1840. = Ageratina bellidifolia (Benth.) R. King \& H. Robinson.

Eupatorium beneolens B. Robinson, Contr. Gray Herb. 73: 5. 1924. = Hebeclinium beneolens (B. Robinson) R. King \& H. Robinson.

Eupatorium benguetense C. Robinson, Philipp. J. Sci. 3: 217. 1908.

Eupatorium benjamin-lincolnii Steyerm., Fieldiana, Bot. 28(3): 635. 1953, nom. nov. = Symphyopappus reticulatus Baker.

Eupatorimm benthamii Klatt, Leopoldina 20: 90. 1884. = Bartlettina macrocephala (Benth.) R. King \& H. Robinson.

Eupatorium bergantinense V. Badillo, Bol. Soc. Venez. Ci. Nat. 10: 294. 1946. = Fleischmannia bergantinensis (V. Badillo) R. King \& H. Robinson.

Eupatorium berlandieri DC., Prodr. 5: 167. 1836. = Ageratina havanensis (H. B. K.) R. King \& H. Robinson.

Etpatorium berlandieri A. Gray, Rep. U. S. Mex. Bound., Bot. 76. 1859 . = Ageratina occidentalis (Hook.) R. King \& H. Robinson.

Eupatorium berterianum (Sprengel) Colla, Mem. Reale Acc. Sci. Torino 33: 130. 1829. = Fleischmannia microstemon (Cass.) R. King \& H. Robinson.

Eupatorium bertholdii Schultz-Bip., Bot. Voy. Herald 299. 1856. = Chromolaena bertholdii (Schultz-Bip.) R. King \& H. Robinson.

Eupatorium betonicaeforme (DC.) Baker, Fl. Bras. 6(2): 362.1876. $=$ Barrosoa betonicaeformis (DC.) R. King \& H. Robinson.
Eupatorium betonicifolium Miller, Gard. Dict, ed. 8, 9. 1768. = Conoclinium betonicifolium (Miller) R. King \& H. Robinson.

Eupatorium betonicum Hemsley, Biol. Cent.-Amer., Bot. 2: 93. 1881, nom. nud. = Conoclinium betonicifolium (Miller) R. King \& H. Robinson.

Eupatorium betulaefolium (E. Greene) B. Robinson, Proc. Amer. Acad. Arts 43: 29. 1907. = Ageratina betulaefolia (E. Greene) R. King \& H. Robinson.

Eupatorium biceps Klotzsch ex Vatke, Bot. Zeitung (Berlin) 30: 719. 1872. = Ageratina ligustrina (DC.) R. King \& H. Robinson.

Eupatorium bicolor Lam. ex DC., Prodr. 6: 326. 1837, nom. nud. = Gynoxys buxifolia (H. B. K.) Cass. SenecioneAE.

Eupatorium bigelovii A. Gray, Rep. U. S. Mex. Bound., Bot. 75. 1859. = Chromolaena bigelovii (A. Gray) R. King \& H. Robinson.

Eupatorium billbergianum Beurlin, Kongl. Vetensk. Acad. Handl. 134. 1854. = Critonia billbergiana (Beurlin) R. King \& H. Robinson.

Eupatorium bimatrum Standley \& L. O. Williams, Ceiba 3: 64. 1952. = Fleischmannia microstemon (Cass.) R. King \& H. Robinson.

Eupatorium birmanicum DC., Prodr. 5: 179. 1836. = Eupatorium cannabinum L., ?

Eupatorium blakei B. Robinson, Contr. Gray Herb. 61: 5. 1920. =Fleischmannia blakei (B. Robinson) R. King \& H. Robinson.

Eupatorium blanchetii Schultz-Bip. ex Baker, F1. Bras. 6(2): 351. 1876. = Lasiolaena blanchetii (Schultz-Bip. ex Baker) R. King \& H. Robinson.

Eupatoriuin blepharilepis Schultz-Bip., Bot. Voy. Herald 300. 1856. = Ageratina blepharilepis (Schultz-Bip.) R. King \& H. Robinson.

Eupatorium blumenavii Hieron., Bot. Jahrb. Syst. 22: 784. 1897. = Macropodina blumenavii (Hieron.) R. King \& H. Robinson.

Eupatoriurn bogotense DC., Prodr. 5: 181. 1836. = Ageratina baccharoides (H. B. K.) R. King \& H. Robinson.

Eupatorium bonplandianum Schultz-Bip. ex Hieron., Bot. Jahrb. Syst. 29: 4. 1900, nom. nud. = Koanophyllon solidaginoides (H. B. K.) R. King \& H. Robinson.

Eupatorium boreale E. Greene, Rhodora 3: 83. 1901. = Ageratina altissima (L.) R. King \& H. Robinson.

Eupatorium borinquense (Britton) B. Robinson, Contr. Gray Herb. 80: 15. 1928. = Chromolaena borinquensis (Britton) R. King \& H. Robinson.

Eupatorium borregoianum M. Gomez, Dicc. Bot. Nom. Vulg. Cub. Pue.-Riq. 55. 1889, nom. nud. = Mikania ranunculifolia Rich. ex Sagra.

Eupatorium boyacense B. Robinson, Contr. Gray Herb. 104: 13. 1934. = Agcratina boyacensis R. King \& H. Robinson.

Eupatorium brachiatum Sw. ex Wikstr., Kongl. Vetensk. Acad. Handl. 71. 1827. = Chromolaena odorata (L.) R. King \& H. Robinson.

Eupatorium brachychaetum B. Robinson, Proc. Amer. Acad. Arts 51: 532. 1916. = Antillia brachychaeta (B. Robinson) R. King \& H. Robinson.

Eupatorium bracteatum Hook. \& Arn., Companion Bot. Mag. 1: 239. 1835. = Chromolaena congesta (Hook. \& Arn.) R. King \& H. Robinson.

Eupatorium bracteatum Gardner, London J. Bot. 5: 472.1846. = Stomatamthes pernambucensis (B. Robinson) H. Robinson.

Eupatorium brandegeanum B. Robinson, Contr. Gray Herb. 68: 10. 1923. = Ageratina brandegeana (B. Robinson) R. King \& H. Robinson.

Eupatorium brasiliense Sprengel, Syst. Veg. Fl. Peruv, Chil. 3: 417. 1826. = Pseudobrickellia brasiliensis (Sprengel) R. King \& H. Robinson.

Eupatorium braunii Polak., Linnaea 41: 576. 1877. = Baccharis pedunculata (Miller) Cabrera. AstereAE. 
Eupatorium brenesii Standley, Publ. Field Mus. Nat. Hist., Bot. Ser. 18: 1461. 1938. = Neomirandea Standleyi (B. Robinson) R. King \& H. Robinson.

Eupatorium breviflorum Alain, Contr. Ocas. Mus. Hist. Nat. Colegio "De La Salle" 18: 4. 1960. = Koanophyllon breviflorum (Alain) R. King \& H. Robinson.

Eupatorium brevipes DC., Prodr. 5: 168. 1836. = Ageratina brevipes (DC.) R. King \& H. Robinson.

Eupatorium brevipetiolatum Schultz-Bip. ex Baker, Fl. Bras. 6(2): 335 , In Obs. 1876, nom. nud. = Grazielia.

Eupatorium brevipetiolatum Schultz-Bip. ex Klatt, Leopoldina 20: $90.1884 .=$ Bartlettina brevipetiolata (Schultz-Bip. ex Klatt) R. King \& H. Robinson.

Eupatorium brevisetum DC., Prodr. 5: 169. 1836. = Piptothrix areolaris (DC.) R. King \& H. Robinson.

Eupatorium brickellia DC., Prodr. 5: 182. 1836. = Brickellia cordifolia Elliott.

Eupatorium brickellioides Klatt, Arbeiten Bot. Mus. Hamb. 2. 1890, Jahrb. Hamb. Wiss. Anstalt. 9: 124. 1892. = Heterocondylus or Vernonia? Affinity Heterocondylus alatus (Vell. Conc.) R. King \& H. Robinson? (Cabrera \& Vittet, 1961.).

Eupatorium bridgesii B. Robinson, Proc. Amer. Acad. Arts 55: 7. 1919. = Fleischmannia bridgesii (B. Robinson) R. King \& H. Robinson.

Elupatorium brineri A. Gray, Syn. Fl. N. Amer. 1(2): 96. 1884. = Eupatorium maculatum L.

Eupatorium brumneolum Baker, F. Bras. 6(2): 288. $1876 .=$ Chromolaena brunneola (Baker) R. King \& H. Robinson.

Eupatorium bucheri B. Robinson, Contr. Gray Herb. 77: 35. 1926, as "ruckeri." = Spaniopappus bucheri (B. Robinson) R. King \& $\mathrm{H}$. Robinson.

Eupatorium bucheri B. Robinson, Contr. Gray Herb. 80: 15. 1928, correction for E. ruckeri. = Spaniopappus buckeri (B. Robinson) R. King \& H. Robinson.

Eupatorium buchii Urban, Feddes Repert. 17: 9. 1921. = Koanophyllon?

Eupatorium huddleaefolium Benth., Pl. Hartw. 135. 1844. = Ar. isteguietia buddleaefolia (Benth.) R. King \& H. Robinson.

Eupatorium bulbosum Aristeg., Mem. New York Bot. Gard. 9: 367. 1957. = Guayania bulbosa (Aristeg.) R. King \& H. Robinson.

Eupatorium bullatissimum B. Robinson, Contr. Gray Herb. 73: 6. 1924. = Hebeclinium bullatissimum (B. Robinson) R. King \& H. Robinson.

Eupatorium bullatum Klatt, Bot. Jahrb. Syst. 8: 34. 1886. = Chromolaena bullata (Klatt) R. King \& H. Robinson.

Eupatorium bullescens B. Robinson, Proc. Amer. Acad. Arts 51: 533. 1916. = Koanophyllon bullescens (B. Robinson) R. King \& H. Robinson.

Eupatorium bulliferum Blake, Rhodora 43: 558. 1941, nom. nov. = Cronquistianthus bulliferus (Blake) R. King \& H. Robinson.

Eupatorium bullulatum Urban \& Ekman, Ark. Bot. 23a(11): 67. 1931, ignota, sterile.

Eupatorium buniifolium Hook. \& Arn., Companion Bot. Mag. 1: 240. 1835. = Acanthostyles buniifolius (Hook. \& Am.) R. King \& H. Robinson.

Eupatorium bupleurifolium DC., Prodr. 5: 149. 1836. = Cainpovassouria cruciata (Vell. Conc.) R. King \& H. Robinson.

Eupatorium burchellii Baker, Fl. Bras. 6(2): 356. 1876. = Campuloclinium burchellii (Baker) R. King \& H. Robinson.

Eupatorium burgeri (R. King \& H. Robinson) L. O. Williams, Fieldiana, Bot. 36: 84. 1975. = Neomirandea burgeri R. King \& H. Robinson.

Eupatorium bustamenta DC., Prodr. 5: 168. 1836. = Ageratina bustamenta (DC.) R. King \& H. Robinson.

Eupatorium caaguazuense Hicron., Bot. Jahrb. Syst. 22: 760. 1897. = Chromolaena caaguazuensis (Hieron.) R. King \& H. Robinson.
Eupatorium cabaionum Urban \& Ekman, Ark. Bot. 23a(11): 65. 1931. = Koanophyllon cabaionum (Urban \& Ekman) R. King \& H. Robinson.

Eupatorium cabrerae B. Robinson, Contr. Gray Herb. 90: 21. 1930. = Barrosoa cabrerae (B. Robinson) R. King \& H. Robinson.

Eupatorium cacalioides H. B. K., Nov. Gen. Sp. 4: 101. Ed. Folio. 1818. = Aristeguietia cacalioides (H. B. K.) R. King \& H. Robinson.

Eupatorium caducisetum DC., Prodr. 5: 165. 1836. = Ageratina gracilis (H. B. K.) R. King \& H. Robinson.

Eupatorium caeciliae B. Robinson, Contr. Gray Herb. 90: 23. 1930. = Ageratina caeciliae (B. Robinson) R. King \& H. Robinson.

Eupatorium caespitosum Migo, J. Shanghai Sci. Inst. 3(3): 7. 1934, ignota.

Eupatorium calaminthaefolium H. B. K., Nov. Gen. Sp. 4: 101, Ed. Folio. 1818. = Ageratina calaminihaefolia $($ H. B. K.) R. King \& H. Robinson.

Eupatorium calaminthaefolium var. irrasum B. Robinson, Contr. Gray Herb. 68: 11. 1923. = Ageratina irrasa (B. Robinson) R. King \& H. Robinson.

Eupatorium calamocephalum (Baker) Hieron., Bot. Jahrb. Syst. 22: 761. 1897. = Chromolaena leucocephala Gardner.

Eupatorium calcicolum Urban, Symb. Antill. 5: 524. 1908. = Koanophyllon calcicola (Urban) R. King \& H. Robinson.

Eupatorium caldense B. Robinson, Contr. Gray Herb. 73: 7. 1924. = Chromolaena caldensis (B. Robinson) R. King \& H. Robinson.

Eupatorium calderillense Hieron. in Urban, Bot. Jahrb. Syst. 40: 381. 1908. = Ageratina calderillensis (Hieron.) R. King \& H. Robinson.

Eupatorium callacatense Hieron., Bot. Jahrb. Syst. 36: 468. 1905. = Cronquistiam hus callacatensis (Hieron.) R. King \& H. Robinson.

Eupatorium callilepis Schultz-Bip. ex Baker, Fl. Bras. 6(2): 285. 1876. = Chromolaena callilepis (Schultz-Bip. ex Baker) R. King \& H. Robinson.

Eupatorium calocephalum (Nutt.) Nutt., Trans. Amer. Philos. Soc. 7: 286. 1841. = Eupatorium ivaefolium L.

Eupatorium calophyllum (E. Greene) B. Robinson, Contr. Gray Herb. 75: 5. 1925. = Ageratina calophylla (B. Robinson) R. King \& $\mathrm{H}$. Robinson.

Eupatorium calycimum Schultz-Bip. ex Baker, Fl. Bras. 6(2): 326. 1876. = Disynaphia calyculata (Hook. \& Am.) R. King \& H. Robinson.

Eupatorium calyculatum Hook. \& Am., Companion Bot. Mag. 1: 242. 1835. = Disynaphia calyculata (Hook. \& Arn.) R. King \& H. Robinson.

Eupatorium camachense Hieron. in Urban, Bot. Jahrb. Syst. 40: 386. 1908. = Ageratina camachensis (Hieron.) R. King \& H. Robinson.

Eupatorium camataquiense Hieron, in Urban, Bot. Jahrb. Syst. 40: 377. 1908. = Kaunia camataguiensis (Hieron.) R. King \& H. Robinson.

Eupatorium camiguinense Merr., Philipp. J. Sci. 7: 355. 1912.

Eupatorium campechense B. Robinson, Proc. Amer. Acad. Arts 43: 30. 1907. = Critonia campechensis (B. Robinson) R. King \& H. Robinson.

Eupatorium campestre DC., Prodr. 5: $152.1836 .=$ Chromolaena campestris (DC.) R. King \& H. Robinson.

Eupatorium campylocladum B. Robinson, Proc. Boston Soc. Nat. Hist. 31: 247. 1904. = Ageratina campyloclada (B. Robinson) R. King \& H. Robinson.

Eupatorium candicans Wallich, Num. List Dr. PI. 2999. 1831, nom. nud. = Leucomeris spectabilis D. Don. MutISIEAE.

Eupatorium candolleamum Hook. \& Am., Companion Bot. Mag. 
1: 243. 1835. = Barrosoa candolleana (Hook. \& Arn.) R. King

\& H. Robinson.

Eupatorium canescens Vahl, Bidr. Beskr. Ste Croix 302. 1793, Symb. Bot. 3: 95. 1794. = Chromolaena sinuata (Lam.) R. King \& H. Robinson.

Eupatorium canescens Ortega, Nov. Pl. Descr. Dec. 34. 1797. = Kuhnia rosmarinifolia Vent., Brickellia?

Eupatorium cannabifolium Salisb., Prodr. Stirp. Chap. Allerton 187. 1796, nom. nud. = Eupatorium cannabinum L.

Eupatorium cannabinum L., Sp. PI. 838. 1753.

Eupatorium cannabis-folium Gilib., F1. Lit. Inch. 1: 172. 1781, nom. illeg. = Eupatorium cannabinum L.

Eupatoritum capense A. Sprengel, Tent. Suppl. 22. 1828. = Vernonia mespilifolia Less. VERNONIEAE.

Eupatorium capillare Desv., Prodr. Pl. Ind. Occid. 51. 1825. = Brickellia diffusa (Vahl) A. Gray.

Eupatorium capillare (DC.) Baker, F1. Bras. 6(2): 341 . 1876. = Praxelis capillaris (DC.) Schultz-Bip.

Eupatorium capillifolium (Lam.) Small, Mem. Torrey Bot. Club 5: 311.1894.

Eupatorium capillipes Benth. ex Oersted, Vidensk. Meddel. Dansk Naturhist. Foren. Kjobenhavn 79. 1852. = Fleischmannia capillipes (Benth. ex Oersted) R. King \& H. Robinson.

Eupatorium capitatum Rusby, Bull. New York Bot. Gard. 4: 380. 1907. = Trichogonia capitata (Rusby) B. Robinson.

Eupatorium capnoresbium B. Robinson, Proc. Amer. Acad. Arts 35: 331. 1900. = Ageratina lucida (Ortega) R. King \& H. Robinson.

Eupatorium caracasanum Schultz-Bip. ex Hieron., Bot. Jahrb. Syst. 28: 567. 1901, nom. nud. = Chromolaena oxylepis (DC.) R. King \& H. Robinson.

Eupatorium cardiophyllum B. Robinson, Proc. Amer. Acad. Arts 35: 331 . 1900. = Ageratina cardiophylla (B. Robinson) R. King \& H. Robinson.

Eupatorium carletonii B. Robinson, Contr. Gray Herb. 73: 7. 1924. = Fleischmannia carletonii (B. Robinson) R. King \& H. Robinson.

Eupatorium carmonis Standley \& Steyerm., Publ. Field Mus. Nat. Hist., Bot. Ser. 22: 303. 1940. = Ageratina carmonis (Standley \& Steyerm.) R. King \& H. Robinson.

Eupatorium carnosifolium B. Robinson, Contr. Gray Herb. 80: 15. 1928. = Diacranthera crenata (Schlechtend. in Martius) R. King \& H. Robinson.

Eupatorium carnosum Kuntze, Revis. Gen. Pl. 337. 1891. = Neomirandea carnosa (Kuntze) R. King \& H. Robinson.

Eupatorium carolinianum Hort. Vind. ex Stev., Bull. Soc. Imp. Naturalistes Moscou 29(2): 372. 1856, ignota.

Eupatorium carsticola Borh. \& Muniz, Acta Bot. Hung. 18: 45. 1973. = Grisebachianthus carsticola (Borh. \& Muniz) R. King \& H. Robinson.

Eupatorium casarettoi (B. Robinson) Steyerm., Fieldiana, Bot. 28(3): 635. 1953. = Symphyopappus casarettoi B. Robinson.

Eupatorium cassinaefolium Bertol., Misc. Bot. 5: 17. 1846. = Eupatoriurn cuneifolium Willd.

Eupatorium catense Elmer, Leafl. Philipp. Bot. 7: 2584. 1915. = Eupatorium camiguinense Merr.

Eupatorium catharinense Cabrera, Sellowia No. 15, 197. 1963. $=$ Neocabreria catharinensis (Cabrera) R. King \& H. Robinson.

Eupatorium caucasicum Steven, Bull. Soc. Imp. Naturalistes Moscou 29(2): 371. 1856. = Eupatorillm cannabinum L.

Eupatorium ceanothifolium Muhlenb. ex Willd., Sp. Pl. 3: 1755. 1804. = Ageratina aromatica $($ L.) Spach.

Eupatorium ceanothifolium Sprengel, Syst. Veg. Fl. Peruv. Chil. 3: 418. 1826. = Ageratina tristis (DC.) R. King \& H. Robinson.

Eupatorium celebicum Blume, Bijdr. F1. Ned. Ind. 903. 1826. = Vernomia arborea Buch.-Ham. VERNONIEAE.

Eupatorium celestini Cuatrec., Trab. Mus. Nac. Ci. Nat., Ser. Bot. 27: 12. 1934. = Ageratina .
Eupatorium celtidifolium Lam., Encycl. 2: 406. 1788. = Koanophyllon celtidifolia (Lam.) R. King \& H. Robinson.

Eupatorium cerasifolium Baker, Fl. Bras. 6(2): 308. 1876. = Guayania cerasifolia (Baker) R. King \& H. Robinson.

Eupatorium ceratophyllum Hook. \& Arn., Companion Bot. Mag. 1: $240.1835 .=$ Gyptis pinnatifida Cass.

Eupatorium ceriferım McVaugh, Contr. Univ. Michigan Herb. 9: 390. 1972. = Ageratina cerifera $(\mathrm{McVaugh}) \mathrm{R}$. King \& H. Robinson.

Eupatorium chabrense Urban \& Ekman, Ark. Bot. 23a(11): 58. 1931. = Koanophyllon chabrense (Urban \& Ekman) R. King \& H. Robinson.

Eupatorium chachapoyasense Cuatrec., Ann. Missouri Bot. Gard. 52: $306.1965 .=$ Ageratina chachapoyasensis (Cuatrec.) R. King \& H. Robinson.

Eupatorium chalceorithales B. Robinson, Contr. Gray Herb. 77: 10. 1926. = Koanophyllon chalceorithales (B. Robinson) R. King \& H. Robinson.

Eupatorium chamaedrifolium H. B. K., Nov. Gen. Sp. 4: 88. Ed. Folio. 1818. = Cronquistianthus chamaedrifolius (H. B. K.) R. King \& H. Robinson.

Eupatorium chapalense S. Watson, Proc. Amer. Acad. Arts 26: 138. 1891. = Ageratina lasioneura (Hook. \& Arn.) R. King \& H. Robinson.

Eupatorium chaparense B. Robinson, Contr. Gray Herb. 90: 24. 1930. = Austroeupatorium chaparense (B. Robinson) R. King \& H. Robinson.

Eupatorium chapmanii Small, Fl. S. E. U. S. 1168, 1338. 1903. = Eupatorium perfoliatum $\mathrm{L}$.

Eupatorium chaseae B. Robinson, Contr. Gray Herb. 104: 14. 1934. = Chromolaena chaseae (B. Robinson) R. King \& H. Robinson.

Eupatorium chenopodifolium (Willd.) Poiret, Encycl. Suppl. 2: 606. 1812. = Mikania chenopodifolia Willd.

Eupatorium chiapense B. Robinson, Proc. Amer. Acad. Arts 35: 332. 1900. = Ageratina vernalis (Vatke \& Kurtz) R. King \& H. Robinson.

Eupatorium chilca H. B. K., Nov. Gen. Sp. 4: 98. Ed. Folio. 1818. = Ophryosporus chilca (H. B. K.) Hieron.

Eupatorium chilense Molina, Sag. Stor. Nat. Chili 142.354. 1782. $=$ Flaveria trinervia (Sprengel) C. Mohr. HeliantheaE.

Eupatorium chilense Bertero, Mercurio Chileno 13: 616. 1829. = Ageratina glechonophylla (Less.) R. King \& H. Robinson.

Eupatorium chimborazense Hieron. in Sodiro, Bot. Jahrb. Syst. 29: 7. 1900. = Aristeguietia chimborazensis (Hieron.) R. King \& H. Robinson.

Eupatorium chinense L., Sp. P1. 837. 1753.

Eupatorium chiquitense B. Robinson, Contr. Gray Herb. 68: 11. 1923. = Praxelis chiquitensis (B. Robinson) R. King \& H. Robinson.

Eupatorium chiriquense B. Robinson, Proc. Amer. Acad. Arts 54: 238. 1918. = Ageratina chiriquensis $(\mathrm{B}$. Robinson) R. King \& H. Robinson.

Eupatorium chlorolepis Baker, Fl. Bras. 6(2): 357. 1876. = Campuloclinium chlorolepis (Baker) R. King \& H. Robinson.

Eupatorium chlorophyllum Klatt in T. Durand \& Pittier, Bull. Soc. Roy. Bot. Belgique 31: 187. 1892. = Ageratina badia (Klatt) R. King \& H. Robinson.

Eupatorium chodati Hassler, Feddes Repert. 11: 169. 1912. = Trichogonia chodatii (Hassler) R. King \& H. Robinson.

Eupatorium choricephaloides B. Robinson, Proc. Amer. Acad. Arts 55: 8. 1919. = Ageratina choricephaloides (B. Robinson) R. King \& H. Robinson.

Eupatorium choricephalum B. Robinson, Proc. Amer. Acad. Arts 54:239. 1918. = Ageratina choricephala (B. Robinson) R. King \& H. Robinson.

Eupatorium chotense Hieron., Bot. Jahrb. Syst. 36: 466. 1905. 
$=$ Cronquistianthus chotensis (Hieron.) R. King \& H. Robinson.

Eupatorium christicanum Baker, F. Bras. 6(2): 298. 1876. = Chromolaena christieana (Baker) R. King \& H. Robinson.

Eupatorium chrysocephalum Klatt, Compos. Nov. Costaric. [Bot. Beibl. Leopoldina] 2. 1895. = Neurolaena lobata (L.) R. Br. Heliantheae.

Eupatorium chrysostictum B. Robinson, Proc. Amer. Acad. Arts 54: 240. 1918. = Chromolaena chrysosticta (B. Robinson) $R$. King \& H. Robinson.

Eupatorium chrysostyloides B. Robinson, Proc. Amer. Acad. Arts 43: 30. 1907. = Flyriella leonensis (B. Robinson) R. King \& H. Robinson.

Eupatorium chrysostylum B. Robinson, Proc. Amer. Acad. Arts 41: 274. 1905. = Flyriella chrysostyla (B. Robinson) R. King \& H. Robinson.

Eupatorium cicatricosum Schultz-Bip. ex Baker, F. Bras. 6(2): 326. 1876, nom. nud. = Pseudobrickellia angustissima (Sprengel ex Baker) R. King \& H. Robinson.

Eupatorium ciliatum Less., Linnaea 6: 404. 1831. = Ageratina ciliata (Less.) R. King \& H. Robinson.

Eupatorium ciliatum Hook. \& Arn., Companion Bot. Mag. 1: 240. 1835. = Chromolaena hookeriana (Griseb.) R. King \& H. Robinson.

Eupatorium cinerascens Wallich, Num. List Dr. Pl. 3066. 1831, nom. nud. = Aster albescens (C. B. Clarke) Hand.-Mazz. AstereaE.

Eupatorium cinereo-viride Schultz-Bip. ex Baker, F1. Bras. 6(2): 294. 1876. = Chromolaena cinereo-viridis (Schultz-Bip. ex Baker) R. King \& H. Robinson.

Eupatorium cinereum L. f., Suppl. PI. 354. 1781. = Pteronia incana (Burman) DC. AstereAE.

Eupatorinm cinereum Raf., New Fl. 4: 80. 1836, ignota.

Eupatorium cinereum Wallich ex Steudel, Nomencl. Bot. 1: 606. 1840, nom. nud. = Aster albescens (Clarke) Hand.-Mazz. AsTEREAE.

Eupatorium cinereum Griseb.. F. Brit. W. I. 359. 1861. = Austroeupatorium inulaefolium (H. B. K.) R. King \& H. Robinson.

Eupatorium cinereum Baker, J. Bot. 20: 226. 1882. = Austrobrickellia bakerianum (B. Robinson) R. King \& H. Robinson.

Eupatorium claussenii Gardner, London J. Bot. 6: 445. 1847. = Chromolaena stachyophylla (Sprengel) R. King \& H. Robinson.

Eupatorium clavisetum (V. Badillo) V. Badillo, Bol. Soc. Venez. Ci. Nat. 10: 292. 1946, = Idiothamnus clavisetus (V. Badillo) R. King \& H. Robinson.

Eupatoriun clanulatum Griseb., Goett. Abh. 19: 168. 1874. = Ophryosporus piquerioides (DC.) Benth. ex Baker.

Eupatoriun clematideum (Wallich ex DC.) Schultz-Bip., Jahresber. Pollichia 22-24:258. 1866. = Eupatorimn reevesii Wallich ex DC.

Eupatorium clenatideum Less. ex Baker, Fl. Bras. 6(2): 256. 1876, nom. nud. = Mikania phacoclados Martius ex Baker.

Eupatorium clematideum Griscb., Goett. Abh. 24: 172. 1879. = Praxelis clematidea (Griseb.) R. King \& H. Robinson.

Eupatorium clematitis DC., Prodr. 5: 144. 1836. = Chronolaena odorata (L.) R. King \& H. Robinson.

Eupatorium clementis Alain, Contr. Ocas. Mus. Hist. Nat. Colegio "De La Salle" 4. 1960. = Koanophyllon clement is (Alain) R. King \& H. Robinson.

Eupatorium clibadioides Baker, Kew Bull. 105. 1895. incertae sedis.

Eupatorium coahnilense A. Gray, Proc. Amer. Acad. Arts 17: 205. 1882. = Phanerosiylis coahuilensis (A. Gray) R. King \& H. Robinson.

Eupatorium cochabambense Hieron., Bot. Jahrb. Syst. 22: 745. 1897. = Chromolaena connivens (Rusby) R. King \& H. Robinson.
Eupatorium coelestinum L., Sp. Pl. 838. 1753. = Conoclinium coclestinum (L.) DC.

Eupatorium coelocaule B. Robinson, Proc. Amer. Acad. Arts 55: 8. 1919. = Grosvenoria coclocaulis (B. Robinson) R. King \& H. Robinson.

Eupatorium coeruleum Sesse \& Mocino, Pl. Nov. Hisp. 134. 1889, Naturaleza (Mexico City), ser. 2(1): 125. App. Ed. 2. 1893. = Ageratum corymbosum Zuccagni, ?

Eupatorium cognatum Kunth \& Bouche, Ind. Sem. Hort. Berol. 13. 1847. = Ageratina mairetiana (DC.) R. King \& H. Robinson.

Eupatorium collinum DC., Prodr. 5: 164. 1836. = Chrornolaena collina (DC.) R. King \& H. Robinson.

Eupatorium collodes B. Robinson \& Greenman, Amer. J. Sci. Arts Ser. 3. 50: 152. 1895. = Ageratina collodes (B. Robinson \& Greenman) R. King \& H. Robinson.

Eupatorium coloratum Willd., Sp. Pl., ed. 5, 3: 1768. 1804. = Gymnanthernum coloratum (Willd.) H. Robinson \& Kahn. VERNONIEAE.

Eupatorium coloratum Sprengel ex DC., Prodr. 5: 343. 1836 , nom. nud. = Aster albescens (Clarke) Hand.-Mazz. AsterEAE.

Eupatorium coloratum Larran., Escr. D. A. Larranaga 1: 26. 1922, ignota.

Eupatorium columbianum Heering, Mem. Soc. Sci. Nat. Neuchatel 5: 421. 1913. = Chromolaena columbiana (Heering) $R$. King \& H. Robinson.

Eupatorium cornmersonii (Cass.) Hieron., Bot. Jahrb. Syst. 22: 771. 1897. = Gyptis commersonii Cass.

Eupatorium compactum Benth., Bot. Voy. Sulphur 112. 1845. = Aristeguietia persicifolia (H. B. K.) R. King \& H. Robinson.

Eupatorium compositifolium Walter, Fl. Carol. 199. 1788.

Eupatorium compressuin Gardner, London J. Bot. 5: 473. 1846. = Symphyopappus compressus (Gardner) B. Robinson.

Eupatorium comptoniaefolium DC., Prodr. 5: 148. 1836. = Grazielia serrata (Sprengel) R. King \& H. Robinson.

Eupatorium concinnitas Herter, Revista Sudamer, Bot. 7: 233. 1943. = Neocabreria concinna R. King \& H. Robinson.

Eupatorium concinnum Hook. \& Arn., Companion Bot. Mag. 1: 239. 1835. = Chromolaena ivaefolia (L.) R. King \& H. Robinson.

Eupatorium concinnum DC., Prodr. 5: 156. 1836. = Neocabreria concinna R. King \& H. Robinson.

Eupatorium condensatum Reichb. ex Less., Linnaea 4: 337. 1829 , nom. nud. = Pollalesta condensata (Less.) Aristeg. VERNONIEAE.

Eupatorium confertifolium Klatt, Abh. Naturf. Ges. Halle 15: 324. 1882 . = Ageratina vacciniaefolia (Benth.) $R$. King \& $H$. Robinson.

Eupatorium confertum Gardner, London J. Bot. 4: 116. 1845. = Grazielia serrata (Sprengel) R. King \& H. Robinson.

Eupatorinm confluentis B. Robinson, Contr. Gray Herb. 77: 11. 1926. = Barrosoa confluentis (B. Robinson) R. King \& H. Robinson.

Eupatorium congestum Hook. \& Arn., Companion Bot. Mag. 1: 239. 1835. = Chromolaena congesta (Hook. \& Am.) R. King \& H. Robinson.

Eupatorium conglobatum DC., Prodr. 5: 165. 1836. = Koanophyllon conglobatum (DC.) R. King \& H. Robinson.

Eupatorium connatum Michaux, F1. Bor.-Amer. 2: 99. 1803. = Eupatorium perfoliatum $\mathrm{L}$.

Eupatorium connivens Rusby, Mem. Torrey Bot. Club 6: 57. 1896. = Chromolaena connivens (Rusby) R. King \& H. Robinson.

Eupatorium conoclinanthium Hieron. in Urban, Bot. Jahrb. Syst. 40: 388. 1908, = Praxelis conoclinanthia (Hieron.) R. King \& H. Robinson.

Eupatorium conoclinioides Gardner, London J. Bot. 5: 475.1846. = Trichogonia salviaefolia Gardner,? 
Eupatoriun consanguineum DC., Prodr. 5: 166. 1836. = Koanophyllon consanguineum (DC.) R. King \& H. Robinson.

Eupatorium conspicuum Martius ex Colla, Herb. Pedem. 3: 283. 1834, ignota.

Eupatorium conspicuum Kunth \& Bouche, Ind. Sem. Hort. Berol. 13. 1847. = Ageratina grandifolia (Regel) R. King \& H. Robinson.

Eupatorium constanzae Urban, Symb. Antill. 7: 422. 1912. = Grisebachianthus? .

Eupatorium constipatiflormm Klatt, Ann. K. K. Naturhist. Hofmus. 9: 355. 1894. = Bartlettina constipatiflora (Klatt) R. King \& H. Robinson.

Eupatorium contortum C. Adams, Phytologia 21: 408. 1971. = Ageratina contorta (C. Adams) R. King \& H. Robinson.

Eupatorium conyzoides Miller, Gard. Dict, ed. 8, 14. 1768. = Vernonia arborescens (L.) Sw. VERNONIEAE.

Eupatorium conyzoides Vahl, Symb. Bot. 3: 96. 1794. = Chromolaena odorata (L.) R. King \& H. Robinson.

Eupatorium conyzoides (L.) E. H. Krause, Sturm's Fl. Deutchl., ed. 2, 13: 32. 1905. = Ageratum conyzoides $\mathrm{L}$.

Eupatorium conyzoides var. foliatum Schultz-Bip. ex Baker, Fl. Bras. 6(2): 278. 1876. = Chromolaena pedunculosa (Hook. \& Arn.) R. King \& H. Robinson.

Eupatorium conyzoides var. tunariensis Hieron., Bot. Jahrb. Syst. 22: 742. 1897. = Chromolaena tunariensis (Hieron.) R. King \& H. Robinson.

Eupatorium conzattii Greenman, Proc. Amer. Acad. Arts 34: 574. 1899. = Critonia conzattii (Greenman) R. King \& H. Robinson.

Eupatorium conzattii Gand., Bull. Soc. Bot. France 65: 40. 1918. = Piptothrix areolaris (DC.) R. King \& H. Robinson, ?

Eupatorium cookii B. Robinson, Proc. Amer. Acad. Arts 55: 9. 1919. = Fleischmannia cookii (B. Robinson) R. King \& H. Robinson.

Eupatorium coperense Hieron., Bot. Jahrb. Syst. 21: 330. 1895. = Ageratina asclepiadea (L. f.) R. King \& H. Robinson.

Eupatorium cordatum Burm. f., Fl. Indica 176. 1768. = Mikania cordata (Burm. f.) B. Robinson.

Eupatorium cordatum Walter, F. Carol. 199. 1788. = Ageratina aromatica (L.) Spach.

Eupatorium cordatum Mutis, Diario 2: 275. 1958, ignota.

Eupatorium cordifolium Sw., Prodr. 111.1788. = Koanophyllon?

Eupatorium cordiforme Poiret, Encycl. Suppl. 2: 600. 1812. = Ageratina aromatica (L.) Spach.

Eupatorium cordigerum $\times($ Fern.) Fern., Rhodora 47: 192. 1945. $=$ Eupatorium perfoliatum L., and Eupatorium rotundifolium L.

Eupatorium coriaceum Vahl, Symb. Bot. 3: 94. 1794. = Gymnanthemum fimbrilliferum Cass. VERNONIEAE.

Eupatorium coriaceum Sprengel, Syst. Veg. Fl. Peruv. Chil. 3: 410. 1826. = Koanophyllon villosum (Sw.) R. King \& H. Robinson.

Eupatorium coriaceum Scheele, Linnaea 18: 457. 1844. = Symphyopappus reticulatus Baker.

Eupatorium cornifolium Willd. ex Less., Linnaea 4: 337. 1829, nom. nud. = Pollalesta acuminata (H. B. K.) Aristeg. VERNONIEAE.

Eupatorium coronopifolium (Michaux) Willd., Sp. Pl. 3: 1750. 1804. = Eupatorium compositifolium Walter.

Eupatorium correlliorum Plettman, Brittonia 29: 85. 1977. = Koanophyllon correlliorum (Plettman) R. King \& H. Robinson.

Eupatorium corsicum Req. ex Loisel, Mem. Soc. Linn. Paris 6: 428. 1827. = Eupatorium cannabinum L.

Eupatorium corumbense B. Robinson, Contr. Gray Herb. 104: 15. 1934. = Stomatanthes corumbensis (B. Robinson) H. Robinson.
Eupatorium corvi McVaugh, Contr. Univ. Michigan Herb. 9: 389. 1972. = Matudina corvi (McVaugh) R. King \& H. Robinson. Eupatorium corylifolium Griseb., Fl. Brit. W. I. 361. 1861. = Ageratina corylifolia (Griseb.) R. King \& H. Robinson.

Eupatorium corymbosum Aublet, Hist. Pl. Guiane 2: 799. 1775. = Chromolaena corymbosa (Aublet) R. King \& H. Robinson. Eupatorium costaricense Kuntze, Revis. Gen. P1. 337. 1891. = Gongrostylus costaricensis (Kuntze) R. King \& H. Robinson.

Eupatorium costatipes B. Robinson, Contr. Gray Herb. 68: 12. 1923. = Chromolaena costatipes (B. Robinson) R. King \& H. Robinson.

Eupatorium cotacachense Hieron., Bot. Jahrb. Syst. 21: 331. 1895. = Ageratina pseudochilca (Benth.) R. King \& H. Robinson.

Eupatorium cotinifolium Willd., Phytographia 11. T. 7, f. 1. 1794. = Baccharis cotinifolium (Willd.) Urban. AsterEAE.

Eupatorium coulteri B. Robinson, Proc. Amer. Acad. Arts 36: 477. 1901. = Koanophyllon coulteri (B. Robinson) R. King \& H. Robinson.

Eupatorium cowleyanum M. Gomez \& Molinet, Ensayo Farm. Cub. 84. 1889, nom. nov, = Mikania cordifolia (L. f.) Willd.

Eupatorium crassicaule Steyerm., Fieldiana, Bot. 28(3): 629. 1953. = Guayania crassicaulis (Steyerm.) R. King \& H. Robinson.

Eupatorium crassiceps B. Robinson, Contr. Gray Herb. 80: 17. 1928. = Ageratina crassiceps (B. Robinson) R. King \& H. Robinson.

Eupatorium crassifolium Raf., Fl. Ludov. 62. 1817. = Eupatorium hyssopifolium $\mathrm{L}$.

Eupatorium crassifolium Shuttlew. ex A. Gray, Syn. Fl. N. Amer. 1(2): 97. 1884, nom. nud. = Eupatorium mikanioides Chapman.

Eupatorium crassipes Hieron., Bot. Jahrb. Syst. 22: 780. 1897. = Gyptis crassipes (Hieron.) R. King \& H. Robinson.

Eupatorium crassirameum B. Robinson, Proc. Amer. Acad. Arts 35: 332. 1900. = Pachythamnus crassirameus (B. Robinson) R. King \& H. Robinson.

Eupatorium cremastum B. Robinson, Proc. Amer. Acad. Arts 42: 38. 1906. = Ageratina cremasta (B. Robinson) R. King \& H. Robinson.

Eupatorium crenaeum B. Robinson, Proc. Amer. Acad. Arts 35: 333. 1900. = Ageratina crenaea (B. Robinson) R. King \& H. Robinson.

Eupatorium crenatum B. A. Gomes, Mem. Math. Phis. Acad. Real Sci. Lisboa 3: 23. 1812. = Mikania cordifolia (L. f.) Willd.

Eupatorium crenatum DC., Prodr. 5: 191. 1836, nom. nud. = Mikania stipulacea (Vahl) Willd.

Eupatorium crenatum Gardner, London J. Bot. 6: 441. 1847. = Chromolaena squalida (DC.) R. King \& H. Robinson.

Eupatorium crenulatum Gardner, London J. Bot. 5: 474. 1846. = Trichogonia hirtiflora (DC.) Schultz-Bip. ex Baker.

Eupatorium crenulatum Sprengel ex Hieron., Bot. Jahrb. Syst. 22: 776. 1897. = Raulinoreitzia crenulata (Sprengel) R. King \& H. Robinson.

Eupatorium crispiflorum (Wright) Molinet \& M. Gomez, Dicc. Bot. Nom. Vulg. Cub. Pue.-Riq. 55. 1889. = Mikania crispiflora Wright.

Eupatorium cristalense Urban, Feddes Repert. 26: 102, 1929. = Koanophyllon rhexioides (B. Robinson) R. King \& H. Robinson.

Eupatorium crithmifolium Griseb., Abh. Konigl. Ges. Wiss. Gottingen 19: 121. 1874. = Acanthostyles buniifolius (Hook. \& Arn.) R. King \& H. Robinson.

Eupatorium crithmifolium Less. ex Baker, Fl. Bras. 6(2): 262. 1876, nom. nud. = Mikania anethifolia (DC.) Matzenbacher. Eupatorium critoniforme Urban, Symb. Antill. 1: 458. 1899. = Urbananthus critoniformis (Urban) R. King \& H. Robinson.

Eupatorium critonioides Steetz, Bot. Voy. Herald 145. 1854. = Critonia morifolia (Miller) R. King \& H. Robinson.

Eupatorium crocodilium Standley \& Steyerm., Publ. Field Mus. 
Nat. Hist., Bot. Ser. 23: 182. 1944. = Fleischmannia crocodilia (Standley \& Steyerm.) R. King \& H. Robinson.

Eupatorim cryptanthum Schultz-Bip. ex Baker, Fl. Bras. 6(2): 296. 1876. = Chromolaena cryptantha (Schultz-Bip. ex Baker) R. King \& H. Robinson.

Empatorium cuadrasense V. Badillo, Bol. Soc. Venez. Ci. Nat. 10: 288. 1946. = Ayapana tovarensis (B. Robinson) R. King \& H. Robinson.

Eupatorium cuatrecasasii R. King \& H. Robinson, Sida 3: 324. 1969. = Hebeclinium killipii (B. Robinson) R. King \& H. Robinson.

Eupatorium cubense Pers., Syn. P1. 2: 402. 1807. = Kuhnia rosmarinifolia Vent., Brickellia?

Eupatorium cubense DC., Prodr. 5: 172. 1836. = Koanophyllon villosum (Sw.) R. King \& H. Robinson.

Eupatorium cuchabense B. Robinson, Contr. Gray Herb. 100: 13. 1932. = Ayapanopsis cuchabensis (B. Robinson) R. King \& H. Robinson.

Eupatorium chencanmm B. Robinson, Proc. Amer. Acad. Arts 54: 241. 1918. = Ageratina cuencana (B. Robinson) R. King \& H. Robinson.

Empatorium cujabense S. Moore, Trans. Linn. Soc. London, Bot. 2. 4: 395. 1895. = Ayapana amygdalina (Lam.) R. King \& H. Robinson, ?

Eupatorim cuneatum DC., Prodr. 5: 149. 1836. = Symphyopappus cuneatus (DC.) Schultz-Bip. ex Baker.

Eupatorim cuneatum Engelm. ex Torrey \& A. Gray, Fl. N. Amer. 2: 88. 1841, nom. nud. = Eupatorium perfoliatum L.

Eupatorium cuneifolium Willd., Sp. Pl. 3(3): 1753. 1804.

Eupatorium cupressorum Standley \& Steyerm., Publ. Field Mus. Nat. Hist.. Bot. Ser. 23: 183. 1944. = Piptothrix areolaris (DC.) R. King \& H. Robinson.

Eupatorium ctrsonii B. Robinson, Proc. Amer. Acad. Arts 42: 38. 1906. = Aristeguietia cursonii (B. Robinson) R. King \& H. Robinson.

Enpatorium cuspidatum Willd. ex Less., Linnaea 4: 315. 1829, nom. nud. = Pollalesta discolor (H. B. K.) Aristeg. VERnONIEAE.

Eupatorium cuspidatmm Sprengel ex DC., Prodr. 5: 32. 1836, nom. nud. = Vernonia volkameriifolia DC. VERNONIEAE.

Empatorium chspidatum Pavon ex A. Gray, Proc. Amer. Acad. Arts 17: 206. 1881-1882. = Barroetea pavonii A. Gray.

Eupatorium cuspidatum Sesse \& Mocino, Pl. Nov. Hisp. 134. 1889, Naturaleza (Mexico City), ser. 2(1): 125. App. Ed. 2. 1893 = Barroctea pavonii A. Gray.

Eupatorium cutervense Hieron. in Urban, Bot. Jahrb. Syst. 40: 383. 1908 . = Ageratina cutervensis (Hieron.) R. King \& H. Robinson.

Enpatorium cuzcoense Hieron. in Urban, Bot. Jahrb. Syst. 40: 376. 1908. = Ageratina cuzcoensis (Hieron.) R. King \& H. Robinson.

Elmpatorium cydoniae folium Willd. ex Less., Linnaea 4: 269. 1829, nom. nud. = Pollalesta vernonioides H. B. K. VERNONIEAE.

Eipatorium cylindrictm McVaugh, Contr. Univ. Michigan Herb. 9: 393. 1972. = Ageratina cylindrica $($ McVaugh) R. King \& H. Robinson.

Eupatorimm cylindrocephalmm Schultz-Bip. ex Baker, Fl. Bras. 6(2): 283. 1876. = Chromolaena cylindrocephala (Schultz-Bip. ex Baker) R. King \& H. Robinson.

Eupatorium cynanchifolium DC., Prodr. 5: 172. 1836. = Koanophyllon villosum (Sw.) R. King \& H. Robinson.

Eupaioritsm cyrili-nelsonii A. Molina, Ceiba 22(1): 39. 1978. = Peteravenia cyrili-nelsonii (A. Molina) R. King \& H. Robinson.

Empatoritm dalea L., Syst. Nat. ed. 10, 1204. 1740. = Critonia dalea (L.) DC.

Eupatorim dalea H. B. K., Nov, Gen. Sp. 4: 83. Ed. Folio. 1818. = Critonia psendo-dalea DC

Eupatoritm daleoides (DC.) Hemsley in Godman \& Salvin, Biol. Cent.-Amer., Bot. 2: 94. 1881. = Critoria daleoides DC.
Enpatorium dasycarpum A. Gray ex S. Watson, Proc. Amer. Acad. Arts 22: 420. 1887. = Sieviopsis rapmnculoides (DC.) R. King \& H. Robinson.

Eupatorimm dasyneurum B. Robinson. Proc. Amer. Acad. Arts 55: 10. 1919. = Ageratina dasyneura (B. Robinson) R. King \& H. Robinson.

Eupatorim debeauxii B. Robinson, Contr. Gray Herb. 68: 13. 1923. = Dasycondylus debeauxii (B. Robinson) R. King \& H. Robinson.

Eupatorium decentlorum DC., Prodr. 5: 154. 1836. = Austroeupatorium decemflorum (DC.) R. King \& H. Robinson.

Eupatorium decipiens Hook. \& Arn.. Companion Bot. Mag. 1: 240. 1835. = Ophryosporus triangularis Meyen.

Eupatorium decipiens Baker, Fl. Bras. 6(2): 347. 1876. = Helerocondylus decipiens (Baker) R. King \& H. Robinson.

Eupatorimm decumbens (Gardner) Baker, Fl. Bras. 6(2): 344. 1876. = Chromolaena decumbens Gardner.

Eupatorium decurrens Sesse \& Mocino, Pl. Nov. Hisp. 134. 1889, Naturaleza (Mexico City), ser. 2(1): 125. App. Ed. 2. $1893=$ Pluchea salicifolia (Miller) Blake. INULEAE.

Enpatorium decussatum Sieber ex Steudel, Nomencl. Bot. 1: 607. 1840, nom. nud. = Eupatorium cordifolimm Sw.

Eupatorium decussatum Klatt in T. Durand \& Pittier, Bull. Soc. Roy. Bot. Belgique 35: 295. 1896. = Koanophyllon solidaginoides (H. B. K.) R. King \& H. Robinson.

Eupatorium dejectum B. Robinson, Contr. Gray Herb. 77: 12. 1926. = Helogyne tacaquirensis Hieron. in Urban.

Eupatorium delpechianum Urban \& Ekman, Ark. Bot. 23a(11): 60. 1931. = Koanophyllon delpechianum (Urban \& Ekman) R. King \& $\mathrm{H}$. Robinson.

Eupatorium deltifolium Raf. ex DC., Prodr. 5: 135. 1836. nom. nud. = Conocliniurn coelestinmm (L.) DC.

Eupatorinm deltoides E. Braun, Rhodora 42: 50. 1940. = Ageratina luciae-branniae (Fern.) R. King \& H. Robinson.

Eupatorium delooideum Jacq., Pl. Hort. Schoenbr. 3: 63. T. 369. 1798. = Ageratina deltoidea (Jaca.) R. King \& H. Robinson.

Eupatorim delioideum Poeppig ex Sprengel, Syst. Veg. Fl. Peruv. Chil. 3: 415. 1826. = Koanophyllon villostm (Sw.) R. King \& H. Robinson, ?

Eupatorimm deltoideum Steudel, Nomencl. Bot. 1: 607.1840. nom. nud. = Conoclinium coelestimum (L.) DC.

Eupatorimm dendroides Sprengel, Syst. Veg. Fl. Peruv. Chil. 3: 415. 1826. = Ageratina dendroides (Sprengel) R. King \& H. Robinson.

Eupatorium densiflomm Morong ex Morong \& Britton, Ann. New York Acad. Sci. 7: 136. 1892. = Chromolaena densiflora (Morong) R. King \& H. Robinson.

Eupatorimm densifolimm Martius ex Baker, Fl. Bras. 6(2): 281. 1876, nom. nud. $=$ Chromolaena inultiflosculosa (DC.) R. King \& H. Robinson.

Enpatorium densum Benth., Pl. Hartw. 200. 1845. = Asplumdianthus densus (Benth.) R. King \& H. Robinson.

Eupatorium dentaimm Gardner, London J. Bot. 6: 443. 1847. = Stomatanthes dentatus (Gardner) H. Robinson.

Eupatorium denticulatum Vahl, Symb. Bot. 3: 93. 1794. = Mi. kania micrantha H. B. K., ?

Eupatorium denndatum Chodat, Bull. Herb. Boissier Ser. 2. 1: 413. 1901. = Campuloclinium macrocephalmm (Less.) DC.

Eupatorium desmocephalmm B. Robinson, Contr. Gray Herb. 68: 14. 1923. = Chromolaena desmocephala (B. Robinson) R. King \& H. Robinson.

Eupatorimm desmophyllum B. Robinson, Contr. Gray Herb. 73: 9. 1924. = Cronquistianthus desmophyllis (B. Robinson) R. King \& $\mathrm{H}$. Robinson.

Enpatorium desquamans B. Robinson, Proc. Amer. Acad. Arts 35: 333. 1900. = Ageratina desquamans (B. Robinson) R. King \& H. Robinson.

Eupatorium diaphanophlebium B. Robinson, Proc. Amer. Acad. 
Arts 54: 242. 1918. = Chromolaena diaphanophlebia (B. Robinson) R. King \& H. Robinson.

Eupatortum dichotomum Schultz-Bip. ex Miq., Stirp. Surinam. Seleet. 184. 1850. = Chromolaena squalida (DC.) R. King \& H. Robinson.

Enpatorium dichotomum Larran., Escr. D. A. Larranaga 2: 251. 1923, ignota.

Fupatorium dichroum B. Robinson, Contr. Gray Herb. 73: 10. 1924. = Lourteigia dichroa (B. Robinson) R. King \& H. Robinson.

Eupatorium dicline Edgewood, Trans. Linn. Soc. London 20: 63. 1851. = Eupatoriuın cannabinuın L.

Eupatorium dictyoneurum Urban. Symb. Antill. 3: 402. 1903. = Ageratina dictyoneura (Urban) R. King \& H. Robinson.

Eupatorium didymtım Klatt, Ann. K. K. Naturhist. Hofmus. 9: 356. 1894. = Ayapanopsis didyma (Klatt) R. King \& H. Robinson.

Eupatorium dielsii B. Robinson in Diels, Biblioth. Bot. 116: 159. 1937. = Aristeguietia dielsii (B. Robinson) R. King \& H. Robinson.

Eupatorium diffusum Vahl, Symb. Bot. 3: 94. 1794. = Brickellia difficsa (Vahl) A. Gray.

Eupatorium dimorpholepis Baker, F. Bras. 6(2): 331. 1876. = Graziclia dimorpholepis (Baker) R. King \& H. Robinson.

Eupatorium diplodictyon B. Robinson, Proc. Amer. Aead. Arts 54: 242. 1918. = Aristeguietia diplodictyon (B. Robinson) R. King \& $\mathrm{H}$. Robinson.

Eupatorium discolor Sprengel, Syst. Veg. Fl. Peruv. Chil. 3: 412. 1826. = Vernonia discolor (Sprengel) Less. VeRNONIEAE.

Eupatorium discolor DC., Prodr. 5: 161. 1836, nom. illeg. = Aristeguietia discolor $\mathrm{R}$. King \& H. Robinson.

Eupatorium dispalatum Gardner, London J. Bot. 4: 117. 1845. = Stejermarkina dispalata (Gardner) R. King \& H. Robinson.

Eupatorium dispar B. Robinson, Contr. Gray Herb. 77: 14. 1926. $=$ Neocuatrecasia dispar (B. Robinson) R. King \& H. Robinson.

Eupatorium dissectum (Hook. \& Arn.) Benth., Bot. Voy. Sulphur 113. 1845. = Hofineisteria dissecta (Hook. \& Am.) R. King \& H. Robinson.

Enpatorium dissectum A. Gray, Proc. Amer. Acad. Arts 18: 100. 1883, nom. nud. = Conoclinium greggii (A. Gray) Small.

Eupatorium dissolvens Baker, Fl. Bras. 6(2): 308. 1876. = Fleischmannia dissolvens (Baker) R. King \& H. Robinson.

Eupatorium divaricantu, P. Bergius, Descr. Pl. Cap. 229. 1767, Thundb., Prod. Pl. Cap. 142. 1800. = Pteronia divaricata (P. Bergius) Less. AstereaE.

Eupatorium divaricatım Schultz-Bip., Linnaea 22: 571. 1849, nom. nud. = Fleisclmmannia laxa (Gardner) R. King \& H. Robinson.

Eupatorium divergens Less., Linnaea 5: 138. 1830. = Chromolaena odorata (L.) R. King \& H. Robinson.

Eupatorium divergens Roxb., Fl. Ind. 3: 415. 1832.=Vernonia divergens (DC.) Edgewood. VERNONIEAE.

Eupatorium diversifolium Sehrader, Ind. Sem. Hort. Acad. Gott. 1134. 1829. = Fleischmannia pycnocephala (Less.) R. King \& H. Robinson.

Eupatorium dodoneaefolium DC., Prodr. 5: 161. 1836. = Ayapana ainygdalina (Lam.) R. King \& H. Robinson.

Eupatorium dadoneaefolium Hook. \& Arn., Companion Bot. Mag. 2: 44. 1836. = Pluchea dodoneaefolia (Hook. \& Arn.) H. Robinson \& Cuatree. INULEAE.

Eupatorium dolichobasis MeVaugh, Contr. Univ. Michigan Herb. 9: 395. 1972. = Ageratina dolichobasis (McVaugh) R. King \& H. Robinson.

Eupatorium dolicholepis (Urban) Britton, Sei. Surv. Porto Rico \& Virgin Isl. 6: 289. 1925. = Koanophyllon dolicholepis (Urban) R. King \& H. Robinson.

Eupatorium dolichopus Urban, Feddes Repert. 17: 52. 1921. = Koanophyllon .
Eupatorium dolphini Urban. Symb. Antill. 5: 522. 1908. = Koanophyllon dolphinii (Urban) R. King \& H. Robinson.

Eupatorium dombeyanum DC., Prodr. 5: 167. 1836. = Ageratina dombeyana (DC.) R. King \& H. Robinson.

Eupatorium domingense Sprengel, Syst. Veg. Fl. Peruv. Chil. 3: 412. 1826. = Piptocoma rufescens Cass. VernoniEAE.

Eupatorium donianurn Hook. \& Arn., Companion Bot. Mag. 1: 243. 1835. = Campuloclinium macrocephalum (Less.) DC.

Eupatorium donnell-smithii Coulter, Bot. Gaz. (Crawfordsville) 16: 95. 1891. = Ageratina bustamenta (DC.) R. King \& H. Robinson.

Eupatorium drepanoides B. Robinson, Proc. Amer. Acad. Arts 55: 12. 1919. = Badilloa drepanoides (B. Robinson) R. King \& H. Robinson.

Eupatorium drepanophyllum Klatt, Ann. K. K. Naturhist. Hofmus. 9: 356. 1894. = Koanophyllon albicaulis (Sehultz-Bip. ex Klatt) R. King \& H. Robinson.

Eupatorium droserolepis B. Robinson, Proc. Amer. Aead. Arts 54: 243. 1918. = Koanophyllon droserolepis (B. Robinson) R. King \& H. Robinson.

Eupatorium dryadeum DC., Prodr. 7: 269. 1838. = Hebeclinium macrophyllum (L.) DC.

Eupatorium dryophilum B. Robinson, Proc. Amer. Acad. Arts 36: 478. 1901.= Dyscritogyne dryophila (B. Robinson) R. King \& H. Robinson.

Eupatorium dubium Willd. ex Poiret, Eneycl. Suppl. 2: 606. 1812.

Eupatorium dubium Sesse \& Mocino, Fl. Mexie. (ed. 2) 182. 1894. = Brickellia? .

Eupatorium duidense V. Badillo, Bol. Soc. Venez. Ci. Nat. 10: 292. 1946. = Koanophyllon kavanayense (V. Badillo) R. King \& H. Robinson.

Eupatorium dumosum Schultz-Bip., Bull. Soc. Bot. France 12: 81. 1865, Linnaea 34: 535. Feb. 1866. ignota.

Eupatorium duodecimiflorum Sehultz-Bip. ex Baker, Fl. Bras. 6(2): 318. 1876, nom. nud. = Austroeupatorium inulaefolium (H. B. K.) R. King \& H. Robinson, ?

Eupatorium durandi Klatt in T. Durand \& Pittier, Bull. Soc. Roy. Bot. Belgique 31: 189. 1892. = Ageratina anisochroma (Klatt) R. King \& H. Robinson.

Eupatorium durangense B. Robinson, Proc. Amer. Acad. Arts 43: 31. 1907. = Ageratina durangensis (B. Robinson) R. King \& H. Robinson.

Eupatorium dusenii Malme, Kongl. Svenska Vetenskapsakad. Handl. Ser. 3. 2(12): 38. 1933. = Steyermarkina dusenii (Malme) R. King \& H. Robinson.

Eupatorium dussii Urban, Symb. Antill. 5: 521 . 1908. = Chromolaena dussii (Urban) R. King \& H. Robinson.

Eupatorium dyctiophyllum DC., Prodr. 5: 153. $1836 .=$ Stomatanthes dyctiophyllus (DC.) H. Robinson.

Eupatorium ecuadorae Klatt, Ann. K. K. Naturhist. Hofmus. 9: 356. 1894. = Heterocondylus vitalbae (DC.) R. King \& H. Robinson.

Eupatorium eggersii Hieron., Bot. Jahrb. Syst. 28: 566. 1901.= Critonia eggersii (Hieron.) R. King \& H. Robinson.

Eupatorium ehrenbergii Hemsley, Biol. Cent.-Amer., Bot. 2: 94. 1881. = Bartlettina macrocephala (Benth.) R. King \& H. Robinson.

Eupatorium ejidense V. Badillo, Bol. Soe. Venez. Ci. Nat. 10: 289. 1946. = Fleischmannia ejidensis (V. Badillo) R. King \& H. Robinson.

Eupatorium ekmanii B. Robinson, Contr. Gray Herb. 77: 15. 1926. = Koanophyllon ekmanii (B. Robinson) R. King \& H. Robinson.

Eupatorium elaeagnifolium Hort. ex DC., Prodr. 5: 22. 1836 , nom. nud. = Vernonia elliptica DC. VERNONIEAE.

Eupatorium elatum Salisb., Prodr. Stirp. Chap. Allerton 187. 1796, nom. nud. = Eupatorium altissimum L. 
Eupatorium elatum Steetz, Bot. Voy. Herald 148. 1854. $=A y$ apana elata (Steetz) R. King \& H. Robinson.

Eupatorium elegans H. B. K., Nov. Gen. Sp. 4: 104. Ed. Folio. 1818. = Ageratina elegans (H. B. K.) R. King \& H. Robinson.

Eupatorium elegans (Walter) Vent. ex Steudel, Nomencl. Bot. 1: 607. 1840. = Liatris elegans (Walter) Michaux.

Eupatorium elegans Gardner, London J. Bot. 5: 467. 1846. = Ayapana amygdalina (Lam.) R. King \& H. Robinson.

Eupatorium eleutherantherum Rusby, Men. Torrey Bot. Club 3(3): 53. 1893. = Ophryosporus eleutherantherus (Rusby) B. Robinson.

Eupatorium ellipticum Hook. \& Arn., Companion Bot. Mag. 1: 240. 1835. = Chromolaena elliptica (Hook. \& Arn.) R. King \& H. Robinson.

Eupatorium ellipticum DC., Prodr. 5: 156. 1836. = Vernonia scandens DC. VERNONIEAE.

Eupatorium elongatum Hook. \& Arn., Companion Bot. Mag. 1: 241. 1835. = Stomatanthes oblongifolius (Sprengel) H. Robinson.

Eupatorium elongatum Willd. ex Hieron., Bot. Jahrb. Syst. 29: 6. 1900 , nom. nud. in syn. = Chromolaena subscandens $(\mathrm{Hi}-$ eron.) R. King \& H. Robinson.

Eupatorium endytum B. Robinson, Proc. Amer. Acad. Arts 55: 13. 1919. = Kaunia endyta (B. Robinson) R. King \& H. Robinson.

Eupatorium engelmannianum Link ex Torrey \& A. Gray, Fl. N. Amer. 2: 502. 1843, nom. nud. = Ageratina aromatica (L.) Spach.

Eupatorium enixum B. Robinson, Contr. Gray Herb. 68: 15. 1923. = Ageratina enixa (B. Robinson) R. King \& H. Robinson.

Eupatorium ensifolium Griseb., Goett. Abh. 24: 170. 1879. = Campovassouria cruciata (Vell. Conc.) R. King \& H. Robinson.

Eupatorium entreriense Hieron., Bot. Jahrb. Syst. 22: 767. 1897. = Austroenpatorium entreriense (Hieron.) R. King \& H. Robinson.

Enpatorium epalcaceum (Gardner) B. Robinson, Proc. Amer. Acad. Arts 51: 534. 1916. = Chromolaena epaleacea Gardner.

Eupatorium epilobioides H. B. K., Nov. Gen. Sp. 4: 97. Ed. Folio. 1818. = Ageratina gracilis (H. B. K.) R. King \& H. Robinson.

Eupatorium erectum Rojas, Cat. Nat. Hist. Corriente 68. 1897, ignota, Tessaria? InULEAE?

Eupatorium ericoides DC., Prodr. 5: 150. 1836. = Disynaphia ericoides (DC.) R. King \& H. Robinson.

Eupatorium erigeroides DC., Prodr. 5: 171. 1836. = Hatschbachiella tweedieana (Hook. \& Arn.) R. King \& H. Robinson.

Eupatorium eriocarpum B. Robinson \& Greenman, Proc. Amer. Acad. Arts 32: 42. 1896. = Critonia eriocarpa (B. Robinson \& Greenman) R. King \& H. Robinson.

Eupatorium erioclinium B. Robinson, Proc. Amer. Acad. Arts 54: 243. 1918. = Hebeclinium erioclinium (B. Robinson) R. King \& H. Robinson.

Eupatorium eripsimum B. Robinson, Proc. Amer. Acad. Arts 55: 14. 1919. = Chromolaena eripsima (B. Robinson) R. King \& H. Robinson.

Eupatorium erodiifolium DC. Prodr. 5: 158. 1836. = Gyptis pinnatifida Cass.

Eupatorium er ythrocomum B. Robinson, Proc. Amer. Acad. Arts 43: 31. 1907. = Ageratina oligocephala (DC.) R. King \& H. Robinson.

Eupatorium erythrolepis Schultz-Bip., Linnaea 34: 535. 18651866, nom. nud. = Lorentzianthus viscidus (Hook. \& Am.) R.

King \& H. Robinson.

Eupatorium erythropappum B. Robinson, Proc. Boston Soc. Nat. Hist. 31: 248. 1904. = Ageratina ligustrina (DC.) R. King \& H. Robinson.

Eupatorium esmeraldae Cuatrec., Anales Ci. Univ. Madrid 4(2):
221. 1935. = Ageratina rhypodes (B. Robinson) R. King \& H. Robinson.

Eupatorium esperanzae Hassler, Feddes Repert. 11: 170. 1912. = Ayapanopsis esperanzae (Hassler) R. King \& H. Robinson.

Eupatorium espinosarum A. Gray, Proc. Amer. Acad. Arts 15: 28. 1879. = Ageratina espinosarum (A. Gray) R. King \& H. Robinson.

Eupatorium estrellense Hassler, Feddes Repert. 11: 173. 1912. $=$ Heterocondylus lysimachioides (Chodat) R. King \& H. Robinson.

Eupatorium etlense B. Robinson, Contr. Gray Herb. 75: 6. 1925. = Ageratina etlensis (B. Robinson) R. King \& H. Robinson.

Eupatorium encosmoides B. Robinson, Contr. Gray Herb. 75: 6. 1925. = Kaunia eucosmoides (B. Robinson) R. King \& H. Robinson.

Eupatorium eucosmum B. Robinson, Contr. Gray Herb. 61: 6. 1920. = Kaunia saltensis (Hicron.) R. King \& H. Robinson.

Eupatorium eugenei Small, Fl. S. E. U. S. 1165,1338 . 1903. = Eupatorium pinnatifidum Ellis.

Eupatorium euonymifolium E. Greene, Pittonia 3: 31. 1896.= Ageratina lemmonii (B. Robinson) R. King \& H. Robinson.

Eupatorium euphyes B. Robinson, Contr. Gray Herb. 68: 16 1923. = Ayapanopsis euphyes (B. Robinson) R. King \& H. Robinson.

Eupatorium eurybiaefolium E. Greene, Pittonia 4: 275. 1901.= Ageratina altissima (L.) R. King \& H. Robinson.

Eupatorium exacoides G. Don ex Baker, Fl. Bras. 6(3): 154. 1882, nom. nud. = Ichthyothere terminalis (Sprengel) Blake. HELIANTHEAE.

Eupatorium exiguum Klotzsch ex Stectz, Bot. Voy. Herald 145. 1854, nom. nud. $=$ Condylidium iresinoides (H. B. K.) R. King \& H. Robinson.

Eupatorium eximium B. Robinson, Contr. Gray Herb. 73: 11. 1924. = Neomirandea eximia (B. Robinson) R. King \& H Robinson.

Eupatorium exserto-venosum Klatt, Abh. Naturf. Ges. Halle 15: 324. 1882, = Ageratina exserto-venosa (Klatt) R. King \& H. Robinson.

Eupatorium extensum Gardner, London J. Bot. 6: 440. 1847.= Chromolaena extensa (Gardner) R. King \& H. Robinson.

Eupatorium extrorsurn Schultz-Bip. ex Baker, Fl. Bras. 6(2): 290. 1876, nom. nud. = Chromolaena ivaefolia (L.) R. King \& H. Robinson.

Eupatorium falcatum Michaux, F. Bor.-Amer. 2: 99. 1803. = Eupatorium purpureum L.

Eupatorium farinosum B. Robinson ex Pittier, Man. PI. Usual. Venez. 340. 1926. = Chromolaena farinosa (B. Robinson) R. King \& H. Robinson.

Eupatorium farinosum B. Robinson, Contr. Gray Herb. 80: 19. 1928. = Chromolaena farinosa (B. Robinson) R. King \& H. Robinson.

Eupatorium fasciculare Poeppig \& Endl., Nov. Gen. Sp. Pl. 3: 54. 1845 . = Chromolaena ivacfolia (L.) R. King \& H. Robinson.

Eupatorium fastigiatum $\mathrm{H}$. B. K., Nov. Gen. Sp. 4: 98. Ed. Folio. 1818. = Ageratina fastigiata (H. B. K.) R. King \& H. Robinson.

Eupatorium fendleri (A. Gray) A. Gray. Proc. Amer. Acad. Arts 17: 205. 1882. = Brickelliastrum fendleri (A. Gray) R. King \& H. Robinson.

Eupatorium fermaldii Godfrey, J. Elisha Mitchell Sci. Soc. 66: 187. 1950 , nom. nov, = Eupatorium album L.

Eupatorium ferruginascens Schultz-Bip. ex Baker, F. Bras. 6(2): 348. 1876, nom. nud. = Barrosoa candolleana (Hook, \& Am.) R. King \& H. Robinson.

Eupatorium ferrugineum Labill., Nov. Holl. Pl. 2: 88. T. 180. 1806. = Helichrysum ferrugineum (Labill.) Less. INULEAE.

Eupatorium ferrugineum Gardner, London J. Bot. 6: 442.1847. = Chromolaena ferruginea [Gardner] R. King \& H. Robinson. 
Eupatorium fiebrigii Hieron. in Urban, Bot. Jahrb. Syst. 40: 371. 1908. = Fleischmannia .

Eupatorium fiebrigii Hassler, Feddes Repert. 11: 174. 1912. = Chacoa pseudoprasiifolia (Hassler) R. King \& H. Robinson.

Eupatorium filicaule Schultz-Bip. ex A. Gray, Proc. Amer. Acad. Arts 21: 384. 1886. = Koanophyllon solidaginoides (H. B. K.) R. King \& H. Robinson.

Eupatorium filifolium Hassler, Feddes Repert. 11:171. 1912.= Disynaphia filifolia (Hassler) R. King \& H. Robinson.

Eupatorium finlaysonianum Wallich ex DC., Prodr. 5: 179. 1836. = Eupatorium cannabinum L., ?

Eupatorium firmum Glaz., Bull. Soc. Bot. France Mem. 3. 56: 385. 1909, nom. nud. ignota.

Eupatorium fissifolium Larran., Escr. D. A. Larranaga 2: 251. 1923, ignota.

Eupatorium fistulosum J. Barratt, Class-book Bot., ed. 41, 314. 1849.

Eupatorium fistulosum B. Robinson, Proc. Boston Soc. Nat. Hist. 31:249. 1904. = Neomirandea angularis (B. Robinson) R. King \& H. Robinson.

Eupatorium flaccidum Sprengel ex DC., Prodr. 5: 174. 1836, nom. nud. = Brickellia diffusa (Vahl) A. Gray.

Eupatorium flavidulum Urban \& Ekman, Ark. Bot. 23a(11): 61 . 1931. = Koanophyllon flavidultm (Urban \& Ekman) R. King \& H. Robinson.

Eupatorium flavisetum B. Robinson, Proc. Amer. Acad. Arts 54: 244. 1918. = Ageratina flaviseta (B. Robinson) R. King \& H. Robinson.

Eupatorium flexile B. Robinson, Proc. Amer. Acad. Arts 55: 14. 1919. = Koanophyllon flexilis (B. Robinson) R. King \& H. Robinson.

Eupatorium flexuosum Lam., Encycl. 2: 411. 1788. = Faujasia flexuosa (Lam.) Benth. \& Hook. f. ex Hook. f. \& Jackson. SENECIONEAE.

Eupatorium floribundum H. B. K., Nov. Gen. Sp. 4: 92. Ed. Folio. 1818. = Chromolaena odorata (L.) R. King \& H. Robinson.

Eupatorium floridanum Raf. ex Torrey \& A. Gray, Fl. N. Amer. 2: 86. 1841 , nom. nud. = Eupatorium altissimum $\mathrm{L}$.

Eupatorium flourensifolium B. Turner, Wrightia 5: 353. 1977. = Ageratina flourensifolia (B. Tumer) R. King \& H. Robinson.

Eıpatorium foeniculaceum Willd., Sp. Pl., ed. 5, 3: 1750.1804. = Eupatorium capillifolium (Lam.) Small.

Eupatorium foeniculoides Walter, FI. Carol. 199. 1788. =Eupatorium capillifolium (Lam.) Small.

Eupatorium foliatum (Schultz-Bip.) Hieron., Bot. Jahrb. Syst. 22: 748. 1897. = Chromolaena pedunculosa (Hook. \& Arn.) R. King \& H. Robinson.

Eupatorium foliolosum DC., Prodr. 5: 174. 1836. = Ophryosporus triangularis Meyen.

Eupatorium foliolosum Wallich ex DC., Prodr. 5: 451. 1836, nom. nud. = Pluchea indica (L.) Less. INULEAE.

Eupatorium formosanum Hayata, J. Coll. Sci. Imp. Univ. Tokyo 25: 122. 1908.

Eupatorium fortunei Turcz., Bull. Soc. Imp. Naturalistes Moscou 24(1): 170. 1851.

Eupatorium fragile B. Robinson, Contr. Gray Herb. 100: 13. 1932. = Fleischmannia fragilis (B. Robinson) R. King \& H. Robinson.

Eupatorium frasieri Poiret, Encycl. Suppl. 2: 600. 1812. = Ageratina altissima (L.) R. King \& H. Robinson.

Eupatorium fraternum DC., Prodr. 5: 163. 1836. = Ayapana amygdalina (Lam.) R. King \& H. Robinson.

Eupaiorium freyreysi Thunb., Pl. Bras. 2: 25. 1818. = Ophryosports freyreysii (Thunb.) Baker.

Eupatorium frustratum B. Robinson, Proc. Amer. Acad. Arts 47: 193. 1911. = Chromolaena frustrata (B. Robinson) R. King \& H. Robinson.

Eupatorium fruticosum L., Syst. Nat. ed. 10, 1204. 1759, ignota.
Eupatorium fruticosum Miller, Gard. Dict, ed. 8, 6. 1768. = Mikania houstoniana (L.) B. Robinson.

Eupatorium fruticosum Desf., Tabl. Ecole Bot. 98. 1804, = Kuhnia frutescens Hornem., ignota.

Eupatorium fuertesii Urban, Feddes Repert. 17: 9. 1921. = Vernonia fuertesii (Urban) H. Robinson. VERNONIEAE.

Eupatorium fuliginosum H. B. K., Nov. Gen. Sp. 4: 86. Ed. Folio. 1818. = Condylopodium fuliginosum (H. B. K.) R. King \& H. Robinson.

Eupatorium fulvum Hook. \& Arn., Companion Bot. Mag. 1: 241. 1835. = Mikania fulva (Hook. \& Arn.) Baker.

Eupatorium fulvum Raf., New Fl. 4: 80. 1836, ignota.

Elıpatorium funckii B. Robinson, Contr. Gray Herb. 68: 16.1923. = Ageratina funckii (B. Robinson) R. King \& H. Robinson.

Eupatorium furcatum Lam., Encycl. 2: 407. 1788. = Chromolaena ivaefolia (L.) R. King \& H. Robinson.

Eupatorium fuscorubrum Walter, Fl. Carol. 199. 1788. = Eupatorium purpureum L.

Eupatorium fuscum N. E. Br., Trans. Linn. Soc. London, Bot. 2. 6: 39. 1901. = Koanophyllon fuscum (N. E. Br.) R. King \& H. Robinson.

Eupatorium gabbii Urban, Feddes Repert. 17: 50. 1921.= Koanophyllon gabbii (Urban) R. King \& H. Robinson.

Eupatorium galeopsifolium Gardner, London J. Bot. 6: 446.1847. = Gymnocondy/us galeopsifolius (Gardner) R. King \& H. Robinson.

Eupatorium galeottii B. Robinson, Contr. Gray Herb. 68: 17. 1923. = Koanophyllon galeottii (B. Robinson) R. King \& H. Robinson.

Eupatorium ganophyllum Mattf. ex Pilger, Notizbl. Bot. Gart. Berlin-Dahlem 9: 379. 1925. = Morithamnus ganophyllus (Mattf.) R. King \& H. Robinson.

Eupatorium gardnerianum Hieron., Bot. Jahrb. Syst. 22: 758. 1897, nom. nov. = Campuloclinium hirsutum Gardner.

Eupatorium gascae B. Robinson, Proc. Amer. Acad. Arts 55: 15. 1919. = Aristeguietia gascae (B. Robinson) R. King \& H. Robinson.

Eupatorium gaudichaudianum DC., Prodr. 5: 148. 1836. = Grazielia gaudichaudeana (DC.) R. King \& H. Robinson.

Eupatorium gayanum Wedd., Chlor. And. 1: 216. 1857. = Aristeguietia gayana (Wedd.) R. King \& H. Robinson.

Eupatorium geminatum McVaugh, Contr. Univ. Michigan Herb. 9: 396. 1972. = Ageratina gerninata (McVaugh) R. King \& H. Robinson.

Eupatorium gentianoides (B. Robinson) B. Robinson, Contr. Gray Herb. 100: 14. 1932. = Chromolaena gentianoides (B. Robinson) R. King \& H. Robinson.

Eupatorium geranifolium Urban, Symb. Antill. 1: 458. 1899. = Chromolaena geranifolia (Urban) R. King \& H. Robinson.

Eupatorium gibbosum Urban, Feddes Repert. 17: 49. 1921. = Koanophyllon gibbosum (Urban) R. King \& H. Robinson.

Eupatorium gibertii Baker ex Herter, Estud. Bot. Reg. Uruguay 4: 119. 1930, nom. nud. ignota.

Eupatorium gilbertii B. Robinson, Proc. Amer. Acad. Arts 55; 16. 1919. = Ageratina gilbertii (B. Robinson) R. King \& H. Robinson.

Eupatorium glabellum Hort. ex Sieber \& Voss, Blumengartner 1: 448. 1894, nom. nud. = Ageratina ligustrina (DC.) R. King \& H. Robinson.

Eupatorium glaberrimum DC., Prodr. 5: 144. 1836. = Chromolaena glaberrima (DC.) R. King \& H. Robinson.

Eupatorium glabratum H. B. K., Nov. Gen. Sp. 4: 100. Ed. Folio. 1818. = Ageratina glabrata $($ H. B. K.) R. King \& H. Robinson.

Eupatorium glabratum Hort. Berol., Hort. Berol. 61. 1832.= Ageratina modesta (Kunth) R. King \& H. Robinson.

Eupatorium glabratum Hort. ex Kunth, Ind. Sem. Hort. Berol. 13. 1847. = Ageratina modesta (Kunth) R. King \& H. Robinson. 
Eupatorium glabriusculum DC., Prodr. 5: 161. 1836. = Heterocondylus alatus (Vell. Conc.) R. King \& H. Robinson.

Eupatorium glabrum Heyne ex Wallich, Num. List Dr. Pl. 3283. 1831 , nom. nud. = Vernonia bracteata Wallich ex Hook. f. ? VERNONIEAE.

Eupatorium glanduliferum Hieron. in Sodiro, Bot. Jahrb. Syst. 29: 13. 1900. = Ageratina glandulifera (Hieron.) R. King \& H. Robinson.

Eupatorium glandulosissimum Malme, Kongl. Svenska Vetenskapsakad. Handl. 32(5): 40. 1899. = Ayapana amygdalina (Lam.) R. King \& H. Robinson.

Eupatorium glandulosum Michaux, Fl. Bor.-Amer. 2: 98. 1803. = Eupatorium album L.

Eupatorium glandulosum H. B. K., Nov. Gen. Sp. 4: 96. Ed. Folio. 1818. = Ageratina adenophora (Sprengel) R. King \& H. Robinson.

Eupatorium glandulosum Hort. ex Kunth, Ind. Sem. Hort. Berol, 13. 1847. = Ageratina mairetiana (DC.) R. King \& H. Robinson.

Eupatorium glandulosum Schultz-Bip. ex Baker, Fl. Bras. 6(2): 314. 1876, nom. nud. = Ayapana amygdalina (Lam.) R. King \& H. Robinson.

Eupatorium glastifolium Bertol., Misc. Bot. 5: 16. 1846. = Trilisa odoratissima (Willd.) Cass.

Eupatorium glaucescens Ellis, Sketch Bot. S. Carolina 2: 297. 1822. = Eupatorium cuneifolium Willd.

Eupatorium glaucum Schultz-Bip. ex Klatt, Leopoldina 20: 89. 1884. = Ageratina glauca (Schultz-Bip. ex Klatt) R. King \& H. Robinson.

Eupatorium glaziovii Baker, Fl. Bras. 6(2): 357. 1876. = Campuloclinium purpurascens (Schultz-Bip. ex Baker) R. King \& H. Robinson.

Eupatorium glechomaefolium Mocino ex DC., Prodr. 5: 139. 1836, nom. nud. = Brickellia veronicaefolia $($ H. B. K.) A. Gray.

Eupatorium glechonophyllum Less., Linnaea 6: 105. 1831. = Ageratina glechonophylla (Less.) R. King \& H. Robinson.

Eupatorium glehni F. Schmidt ex Trautv., Trudy Imp. S.-Peterburgsk. Bot. Sada 8: 432. 1883. = Eupatorium chinense L.

Eupaiorium glischrum B. Robinson, Proc. Amer. Acad. Arts 54: 245. 1918. = Ageratina glischra (B. Robinson) R. King \& H. Robinson.

Eupatorium gloeocladum B. Robinson, Proc. Amer. Acad. Arts 55: 17. 1919. = Ageratina glococlada (B. Robinson) R. King \& H. Robinson.

Eupatorium glomeratum DC., Prodr. 5: 154. 1836. = Cronquislianthus glomeratus (DC.) R. King \& H. Robinson.

Eupatorium glumaceum DC., Prodr. 5: 181. 1836. = Condylidium iresinoides (H. B. K.) R. King \& H. Robinson.

Eupatorium glutinosum Lam., Encycl. 2: 408. 1788. = Aristeguieria glutinosa (Lam.) R. King \& H. Robinson.

Eupatorium glyptophlebium B. Robinson, Proc. Amer. Acad. Arts 54: 245. 1918. = Agcratina glyptophlebia (B. Robinson) R. King \& H. Robinson.

Eupatorium gnidioides DC., Prodr. 5: 150. 1836. = Disynaphia ligulaefolia (Hook. \& Am.) R. King \& H. Robinson.

Eupatorium godfreyanum Cronq., Brittonia 37: 238. 1985.

Eupatorium gongorae Cuatrec., Trab. Mus. Nac. Ci. Nat., Ser. Bot. 29: 17. 1935. = Asplundianthus arcuans (B. Robinson) R. King \& H. Robinson.

Eupatorium gonocladum DC., Prodr. 5: 171, 1836. = Ageratina glabrata (H. B. K.) R. King \& H. Robinson.

Eupatorium gonzalezii B. Robinson, Proc. Amer. Acad. Arts 36: 479. 1901. = Fleischmannia gonzalezii (B. Robinson) R. King \& H. Robinson.

Eupatorium gouani Hort. ex Sprengel, Novi Provent 23. 1819. = Salmea eupatoria DC. HellantheAE.

Eupatorium goyazense Glaz., Bull. Soc. Bot. France Mem. 3. 56:
386. 1909 , nom. nud. = Ayapana amygdalina $($ Lam.) R. King \& H. Robinson.

Eupatorium gracile H. B. K., Nov. Gen. Sp. 4: 97. Ed. Folio. 1818. = Ageratina gracilis (H. B. K.) R. King \& H. Robinson.

Eupatorium gracile D. Don ex Hook. \& Arn., Companion Bot. Mag. I: 243. 1835, nom. nud. = Ageratina glechonophylla (Less.) R. King \& H. Robinson.

Eupatorium gracilentum B. Robinson, Proc. Amer. Acad. Arts 55: 18. 1919. = Ageratina gracilenta (B. Robinson) R. King \& H. Robinson.

Eupatorium gracilicaule Schultz-Bip. ex B. Robinson. Proc. Amer. Acad. Arts 42: 39. 1906. = Koanophyllon gracilicaule (SchultzBip. ex B. Robinson) R. King \& H. Robinson.

Eupatorium graciliflorum DC., Prodr. 5: 145. 1836. = Chromolaena odorata (L.) R. King \& H. Robinson.

Eupatorium gracilipes Urban, Symb. Antill. 5: 522. 1908. = Koanophyllon gracilipes (Urban) R. King \& H. Robinson.

Eupatorium gracillimum Hayata, Icon. PI. Formosan. 3: 124. 1913. = Eupatorium tashiroi Hayata.

Eupatorium graminifolium Chodat, Bull. Herb. Boissier Ser. 2. 1: 411. 1901. = Campovassouria cruciata (Vell. Conc.) R. King \& H. Robinson, ?

Eupatorium grande Schultz-Bip. ex Baker, Fl. Bras. 6(2): 347. 1876. = Heterocondylus grandis (Schultz-Bip. ex Baker) R. King \& H. Robinson.

Eupatorium grandiceps Wright, Anales Acad. Ci. Med. Habana 6: 178. 1869. = Koanophyllon grandiceps (Wright) R. King \& H. Robinson

Eupatorium grandiceps Wright, F. Cub. 76. 1873. = Koanophyllon grandiceps (Wright) R. King \& H. Robinson.

Eupatorium grandidentatum DC., Prodr. 5: 167. 1836. = Ageratina pazcuarensis (H. B. K.) R. King \& H. Robinson.

Eupatorium grandiflorum Hook., Fl. Bor.-Amer. 2: 26. 1834. = Brickellia grandiflora (Hook.) Nutt.

Eupatorium grandiflorum Andre, Rev. Hort. 384. 1882. = Barllettina sordida (Less.) R. King \& H. Robinson.

Eupatorium grandifolium Regel, Gartenflora 1: 102. T. 12. 1852. = Ageratina grandifolia (Regel) R. King \& H. Robinson.

Eupaiorium greggii A. Gray, Syn. F. N. Amer. 1(2): 102. 1884. = Conoclinium greggii (A. Gray) Small.

Eupatorium grisebachi Molt. \& Gomez, Anales Hist. Nat. 19: 272. 1890. = Critonia imbricata Griseb.

Eupatorium grisebachianum Alain, Candollea 17: 121. 1960, nom. nov. = Koanophyllon grisebachianum (Alain) R. King \& H. Robinson.

Eupatorium griseo-viride Schultz-Bip. ex Baker, F. Bras. 6(2): 353. 1876, nom. nud. = Koanophyllon adamantitum (Gardner) R. King \& H. Robinson.

Eupatorium griseopubescens Dusen ex Malme, Kongl. Svenska Vetenskapsakad. Handl. Ser. 3. 12(2): 49. 1933. = Campuloclinium burchellii (Baker) R. King \& H. Robinson.

Eupatorium griseum Coulter, Bot. Gaz. (Crawfordsville) 20: 43 . 1895. = Peteravenia grisea (Coulter) R. King \& H. Robinson.

Eupatorium grossedentatum Martius ex Colla, Herb. Pedem. 3: 284. 1834, ignota.

Eupatorium grossidentatum Hieron. in Urban, Bot. Jahrb. Syst. 40: 377. 1908. = Kaunia grossidemtata (Hieron.) R. King \& H. Robinson.

Eupatorium guadalupense Sprengel, Syst. Veg. F. Peruv. Chil. 3: 414. 1826. = Fleischmannia microstemon (Cass.) R. King \& H. Robinson.

Eupatorium guanaiense Britton, Bull. Torrey Bot. Club 18: 333. 1891. = Chromolaena ivaefolia (L.) R. King \& H. Robinson.

Eupatorium guapulense Klat, Leopoldina 20: 90. 1884, nom. nov. = Hebeclinium tetragonum Benth.

Eupatorium guatemalense Regel, Ind. Sem. Turic. 4. 1850, ignota. 
Eupatorium guatemalense Regel cx Walp., Ann. Bot. Syst. 2: 816. 1852, ignota.

Eupatorium guevarae R. King \& H. Robinson, Sida 3: 322.1969. = Hebeclinium guevarae (R. King \& H. Robinson) R. King \& H. Robinson.

Eupatorium gundlachii Urban, Symb. Antill. 3: 399. 1903. = Koanophyllon gundlachii (Urban) R. King \& H. Robinson.

Eupatorium gynoxioides Rusby, Bull. New York Bot. Gard. 4: 380. 1907. = Kaunia gynoximorpha (Rusby ex B. Robinson) R. King \& H. Robinson.

Eupatorium gynoxoides Wedd., Chlor. And. 1: 216. 1857. = Ageratina gynoxoides (Wedd.) R. King \& H. Robinson.

Eupatorium gynoxymorphum Rusby ex B. Robinson, Contr. Gray Herb. 61: 7. 1920. = Kaunia gynoximorpha (Rusby ex B. Robinson) R. King \& H. Robinson.

Eupatorium haageanum Regel \& Koern., Ind. Sem. Hort. Petrop. 40. 1857, ignota.

Eupatorium haenkeanum DC., Prodr. 5: 158. 1836. = Chromolaena haenkeana (DC.) R. King \& H. Robinson.

Eupatorium hakonense Nakai, Bot. Mag. (Tokyo) 41: 512, 1927. = Eupatorium chinense L.

Eupatorium halbertianum McVaugh, Contr. Univ. Michigan Herb. 9: 398. 1972. = Ageratina halbertiana (McVaugh) R. King \& H. Robinson.

Eupatorium halimifolium DC., Prodr. 5: 150. 1836. = Disynaphia halimifolia (DC.) R. King \& H. Robinson.

Eupatoriun hammatocladum Britton \& B. Robinson, Proc. Amer. Acad. Arts 54: 246. 1918. = Koanophyllon hainmatocladum (B. Robinson \& Britton) R. King \& H. Robinson.

Eupatorium hardwarense Proctor ex C. Adams, Phytologia 21: 409. 1971. = Koanophyllon hardwarense (Proctor ex C. Adams) R. King \& H. Robinson.

Eupatorium harnedii Steele ex Harned, Wild. Fl. Alleghanies 501. 1931. = Eupatorium purpureurn L.

Eupatorium harrisii Urban, Symb. Antill. 1: 460. 1899. = Ageratina riparia (Regel) R. King \& H. Robinson.

Eupatorium hartii Urban, Symb. Antill. 3: 395. 1903. = Ageratina hartii (Urban) R. King \& H. Robinson.

Eupatorium hartwegi Benth., Pl. Hartw. 19. 1839. = Conoclinium betonicifolium (Miller) R. King \& H. Robinson.

Eupatorium harvardianum Steyerm., Ficldiana, Bot. 28(3): 636. 1953, nom. nov. = Bahianthus viscosus (Sprengel) R. King \& H. Robinson.

Eupatorium hasslerianum Chodat, Bull. Herb. Boissier Ser. 2. 3: 711. 1903. = Ayapana ainygdalina (Lam.) R. King \& H. Robinson.

Eupatorium hastatum L., Syst. Nat. ed. 10, 1204. 1759. = Mikania hastata (L.) Willd.

Eupatorium hastiferum Standley \& Steyerm., Publ. Field Mus. Nat. Hist., Bot. Ser. 22: 303. 1940. = Bartlettina hastifera (Standley \& Steycrm.) R. King \& H. Robinson.

Eupatorium hastile Schauer, Linnaea 19: 719. 1847. = Critonia spinaciaefolia (DC.) R. King \& H. Robinson.

Eupatorium haughtii B. Robinson, Contr. Gray Herb. 90: 25. 1930. = Chromolaena liaughtii (B. Robinson) R. King \& H. Robinson.

Eupatorium havanense H. B. K., Nov. Gen. Sp. 4: 100. Ed. Folio. 1818. = Ageratina havanensis (H. B. K.) R. King \& H. Robinson.

Eupatorium hebebotrya (DC.) Hemsley, Biol. Ccnt.-Amer., Bot. 2: 95. 1881. = Critonia liebebotrya DC.

Eupatorium hebecladum DC., Prodr. 5: 164. 1836. = Barrosoa candolleana (Hook. \& Arn.) R. King \& H. Robinson.

Eupatorium hebes B. Robinson, Contr. Gray Herb. 75: 7. 1925. = Ageratina hebes (B. Robinson) R. King \& H. Robinson.

Eupatorium hecatanthum Schultz-Bip., Linnaea 30: 182. 1859. 1860, nom. nud. = Ayapanopsis didyma (Klatt) R. King \& H. Robinson.
Eupatorium hecatanthum (DC.) Baker, Fl. Bras. 6(2): 365. 1876. $=$ Urolepis hecatantha (DC.) R. King \& H. Robinson.

Eupatorium hederaefolium A. Gray, Pl. Fendler. 65. 1848. = Ageratina hederaefolia (A. Gray) R. King \& H. Robinson.

Eupatorium helenae Buscal. \& Muschler, Bot. Jahrb. Syst. 49: 505. 1913, ignota, American material falsely credited to Africa. Eupatorium helianthemoides B. Robinson, Contr. Gray Herb. 77: 17. 1926. = Koanophyllon helianthemoides (B. Robinson) R. King \& H. Robinson.

Eupatorium helianthifolium H. B. K., Nov. Gen. Sp. 4: 99. Ed. Folio. 1818. = Badilloa helianthifolia (H. B. K.) R. King \& H. Robinson.

Eupatorium hemipteropodum B. Robinson, Proc. Amer. Acad. Arts 42: 39. 1906. = Critonia hemipteropoda (B. Robinson) R. King \& H. Robinson.

Eupatorium hemisphaericum DC., Prodr. 5: 158. 1836. = Bartlettina hemisphaerica (DC.) R. King \& H. Robinson.

Eupatorium heptaneurum Urban, Symb. Antill. 7: 554. 1913.= Koanophyllon heptaneurum (Urban) R. King \& H. Robinson.

Eupatoriuin heptanthuin Schultz-Bip. ex Wedd., Chlor. And. 1: 217. 1857. = Ophryosporus heptanthus (Schultz-Bip. ex Wedd.) R. King \& H. Robinson.

Eupatorium heptanthum Schultz-Bip. ex Rusby, Bull. New York Bot. Gard. 4: 378. 1907. = Ageratina sternbergiana (DC.) R. King \& $\boldsymbol{H}$. Robinson.

Eupatorium herbaceum (A. Gray) E. Greene, Pittonia 4: 279. 1901. = Ageratina herbacea (A. Gray) R. King \& H. Robinson.

Eupatorium herrerae B. Robinson, Contr. Gray Herb. 80: 20. 1928. = Badilloa herrerae (B. Robinson) R. King \& H. Robinson.

Eupatorium herzogii B. Robinson, Contr. Gray Herb. 68: 19. 1923. = Chromolaena herzogii (B. Robinson) R. King \& H. Robinson.

Eupatorium heteroclinium Griseb., F1. Brit. W. I. 358. 1861. = Chromolaena heteroclinia (Griseb.) R. King \& H. Robinson.

Eupatorium heterolaenum Schultz-Bip. ex Baker, Fl. Bras. 6(2): 328. 1876 , nom. nud. = Grazielia serrata (Sprengel) R. King \& H. Robinson.

Eupatorium heterolepis B. Robinson, Proc. Amer. Acad. Arts 35: 335. 1900. = Neomirandea araliaefolia (Less.) R. King \& H. Robinson.

Eupatorium heteroneurum (Ernst) B. Robinson, Contr. Gray Herb. 80: 21. 1928. = Critonia heteroneura Ernst.

Eupatorium heterophyllum DC., Prodr. 5: 180. 1836. = Eupatorium cannabinum L.

Eupatorium heterophyllum A. Rich. in Sagra, Hist. Fis. Cuba, Bot. 3: 39. 1853. = Grisebachianthus holquinensis (B. Robinson) R. King \& H. Robinson.

Eupatorium heterosquameum Urban \& Ekman, Ark. Bot. 23a(11): 54. 1931. = Chromolaena heterosquamea (Urban \& Ekman) R. King \& H. Robinson.

Eupatorium hexanthum DC., Prodr. 5: 148. 1836. = Chromolaena hirsuta (Hook. \& Am.) R. King \& H. Robinson.

Eupatorium heydeanum B. Robinson, Proc. Amer. Acad. Arts 35: 335. 1900. = Amolinia heydeana (B. Robinson) R. King \& H. Robinson.

Eupatorium hickenii Cabrera \& Vittet, Revista Mus. Eva Peron, Secc. Bot. 8: 246. 1954. = Campuloclinium hickenii (Cabrera \& Vittet) R. King \& H. Robinson.

Eupatorium hidalgense B. Robinson, Contr. Gray Herb. 75: 8. 1925. = Ageratina hidalgensis (B. Robinson) R. King \& H. Robinson.

Eupatorium hidrodes B. Robinson, Contr. Gray Herb. 73: 12. 1924. = Koanophyllon hidrodes (B. Robinson) R. King \& H. Robinson.

Eupatorium hiemale Lillo, Prim. Reun. Nac. Soc. Argent. Ci. Nat. 218. 1919. = Kaunia lasiophthalma (Hieron.) R. King \& H. Robinson. 
Eupatorium hilarii B. Robinson, Contr. Gray Herb. 68: 19. 1923. $=$ Malmeanthius hilarii (B. Robinson) R. King \& H. Robinson. Eupatorium hirsutissimum Baker, Fl. Bras. 6(2): 311. 1876. = Dasycondylus hirsutissimus (Baker) R. King \& H. Robinson.

Eupatorium hirsutum Hook. \& Arn., Companion Bot. Mag. 1: 239. 1835. = Chromolaena hirsuta (Hook. \& Arn.) R. King \& H. Robinson.

Eupatorium hirsutum DC., Prodr. 5: 170. 1836. = Ageratina liebmannii (Schultz-Bip. ex Klatt) R. King \& H. Robinson.

Eupatorium hirsutum (Gardner) Baker, F. Bras. 6(2): 359. 1876. = Campuloclinium hirsutum Gardner.

Eupatorium hirtum Less. ex Baker, Fl. Bras. 6(2): 260. 1876, nom. nud. = Mikania hirsutissima DC.

Eupatorium hispidulum (DC.) Malme, Ark. Bot. 24a(8): 20.1932. = Chromolaena maximilianii (Schrader ex DC.) R. King \& H. Robinson.

Eupatorium hispidum Pers., Syn. PI. 2: 402. 1807. = Vernonia ? VERNONIEAE?

Eupatorium hitchcockii B. Robinson, Contr. Gray Herb. 73: 14. 1924. = Neomirandea homogama (Hieron.) H. Robinson \& Brettell.

Eupatorium hoffinannii Kuntze, Revis. Gen. Pl. 3(2): 147. 1898. = Sphaereupatorium scandens (Gardner) R. King \& H. Robinson.

Eupatorium holguinense B. Robinson, Contr. Gray Herb. 77; 18. 1926. = Grisebachianthus holquinensis (B. Robinson) R. King \& H. Robinson.

Eupatorium holwayanum B. Robinson, Proc. Amer. Acad. Arts 42: 40. 1906. = Fleischmannia holwayana (B. Robinson) $R$. King \& H. Robinson.

Eupatorium holzingeri Rydb., Brittonia I: 97. 1931. = Eupatorium purpureum L.

Eupatorium hondurense B. Robinson in B. Robinson \& Standley, J. Arnold Arbor. 11: 44. 1930. = Koanophyllon hondurensis (B. Robinson) R. King \& H. Robinson.

Eupatorium hookerianum Griseb., Goett. Abh. 19: 118. 1874. = Chromolaena hookeriana (Griseb.) R. King \& H. Robinson.

Eupatorium horminoides (DC.) Baker, Fl. Bras. 6(2): 300. 1876. = Chromolaena horminoides DC.

Eupatorium horsfieldii Miq., F. Ned. Ind. 2: 27. 1856. = Austroeupatorium inulaefolium (H. B. K.) R. King \& H. Robinson.

Eupatorium hosanense B. Robinson, Contr. Gray Herb. 100: 14. 1932. = Kaunia hosanensis (B. Robinson) R. King \& H. Robinson.

Eupatorium hospitale B. Robinson, Proc. Amer. Acad. Arts 43: 32. 1907. = Critonia hospitalis (B. Robinson) R. King \& H. Robinson.

Eupatorium hotteamum Urban \& Ekman, Ark. Bot. 23a(11): 63. 1931. = Koanophyllon hotteanum (Urban \& Ekman) R. King \& H. Robinson.

Eupatorium houstonianum L., Sp. P1. 836. 1753. = Mikania houstoniana (L.) B. Robinson.

Eupatorium houstonis L., Syst. Nat. ed. 10, 1204. 1759. = Mikania houstoniana (L.) B. Robinson.

Eupatorium huambutiense Cabrera, Revista Univ. (Cuzco) 33(87): 117(-122). 1945. = Helogyne tacaquirensis Hieron. in Urban.

Eupatorium huantae B. Robinson, Contr. Gray Herb. 104: 16. 1934. = Koanophyllon huantae (B. Robinson) R. King \& H. Robinson.

Eupatorium huehuetecum Standley \& Steyerm., Publ. Field Mus. Nat. Hist., Bot. Ser. 22: 304. 1940. = Ageratina bustamenta (DC.) R. King \& H. Robinson.

Eupatorium huigrense B. Robinson, Contr. Gray Herb. 61: 7. 1920. = Fleischmannia obscurifolia (Hieron, in Sodiro) R. King \& H. Robinson.

Eupatorium humboldtii Hieron., Bot. Jahrb. Syst. 28: 571. 1901. = Ageratina asclepiadea (L. f.) R. King \& H. Robinson.

Eupatorium humile (Benth.) B. Robinson, Proc. Amer. Acad. Arts 54: 322. 1918. = Lourteigia humilis (Benth.) R. King \&
H. Robinson.

Eupatorium hunzigeri Hieron., Bot. Jahrb. Syst. 22: 779. 1897. $=$ Gyptis crassipes (Hieron.) R. King \& H. Robinson.

Eupatorium hy'grohylaeum B. Robinson, Contr. Gray Herb. 77 . 19. 1926. = Hebeclinium hygrohylaeum (B. Robinson) R. King
\& H. Robinson.

Eupatorium hygrophilum Alain, Contr. Ocas. Mus. Hist. Nat. Colegio "De La Salle" 18: 6. 1960. = Spaniopappus hygrophilus (Alain) R. King \& H. Robinson.

Eupatorium hylibates B. Robinson, Proc. Amer. Acad. Arts 54: 246. 1918. = Jaramilloa hylibates (B. Robinson) R. King \&
H. Robinson.

Eupatorium hylobium B. Robinson, Proc. Boston Soc. Nat. Hist. 31: 249. 1904. = Bartlettina hylobia (B. Robinson) R. King \& H. Robinson.

Eupatorium hylonomum B. Robinson, Proc. Boston Soc. Nat. Hist. 31: 250. 1904. = Koanophyllon hylonoma (B. Robinson) R. King \& H. Robinson.

Eupatorium hylophilum B. Robinson, Proc. Amer. Acad. Arts 55: 18. $1919 .=$ Ayapana hylophila (B. Robinson) R. King \&
H. Robinson.

Eupatorium hylophorbum B. Robinson, Contr. Gray Herb. 104: 16. 1934. = Hebeclinium hylophorbum (B. Robinson) R. King \& H. Robinson.

Eupatorium hymenolepis B. Robinson, Proc. Amer. Acad. Arts 43: 33. 1907. = Fleischmannia pycnocephala (Less.) R. King \& H. Robinson.

Eupatorium hymenophyllum Klatt in T. Durand \& Pittier, Bull. Soc. Roy. Bot. Belgique 31: 190. 1892. = Fleischmannia hymenophylla (Klatt) R. King \& H. Robinson.

Eupatorium hypargyrum B. Robinson, Proc. Amer. Acad. Arts 55: 19. 1919. = Grosvenoria hypargyra (B. Robinson) R. King \& H. Robinson.

Eupatorium hypericifolium H. B. K., Nov. Gen. Sp. 4: 93. Ed. Folio. 1818. = Chromolaena hypericifolia (H. B. K.) R. King
\& H. Robinson.

Eupatorium hypodictyon B. Robinson, Proc. Boston Soc. Nat. Hist. 3 I : 250. 1904. = Chromolaena hypodictya (B. Robinson) R. King \& H. Robinson.

Eupatorium hypoleucum Griseb., Mem. Amer. Acad. Arts 8: 512. 1863. = Grisebachianthus hypoleucus (Griseb.) R. King \& H. Robinson.

Eupatorium hypomalacum B. Robinson ex J. D. Smith. Bot. Gaz. (Crawfordsville) 35: 4. 1903. = Koanophyllon hypomalaca (B. Robinson ex J. D. Smith) R. King \& H. Robinson.

Eupatorium hypomalacum var. wetmorei B. Robinson, Contr. Gray Herb. 104: 17. 1934. = Koanophyllon wetmorei (B. Robinson) R. King \& H. Robinson.

Eupatorium hyrcanicum Steven, Bull. Soc. Imp. Naturalistes Moscou 29(2): 371. 1856. = Eupatorium cannabinum L.

Eupatorium hyssopifolimm L., Sp. PI. 836. 1753.

Eupatorium hyssopinum A. Gray, Proc. Amer. Acad. Ars 15: 28. 1880. = Ageratina hyssopina (A. Gray) R. King \& H. Robinson.

Eupatorium ianthinum (Hook.) Hemsley, Biol. Cent.-Amer., Bot. 2: 96. 1881. = Bartlettina sordida (Less.) R. King \& H. Robinson.

Eupatorium ibaguense Schultz-Bip. ex Hieron. in Urban, Bot. Jahrb. Syst. 40: 384. 1908. = Ageratina ibaguensis (SchultzBip. ex Hieron.) R. King \& H. Robinson.

Eupatorium ignoratum Hieron. in Urban, Bot. Jahrb. Syst. 40: 379. 1908. = Kaunia ignorata (Hieron.) R. King \& H. Robinson.

Eupatorium ignotum V. Badillo, Bol. Soc. Venez. Ci. Nat. 10: 290. 1946. = Fleischmannia ignota (V. Badillo) R. King \& H. Robinson. 
Eupatorium illitum Urban, Symb. Antill. 3: 401. 1901. = Ageratina illita (Urban) R. King \& H. Robinson.

Enpatorium imbricatum (Griseb.) Urban, Symb. Antill. 1: 460. 1900. = Critonia imbricata Griseb.

Eupatorium imitans B. Robinson, Contr. Gray Herb. 68: 20. 1923. = Fleischmannia imitans (B. Robinson) R. King \& H. Robinson.

Eupatorium impetiolare Griseb., Fl. Brit. W. 1. 357. 1861. = Chromolaena impetiolaris (Griseb.) Nicolson.

Eupatorium inaequidens Urban, Symb. Antill. 1: 460. 1899. = Critonia inaequidens (Urban) R. King \& H. Robinson.

Eupatorium inamoenum Martius ex Baker, Fl. Bras. 6(2): 213. 1876, nom. nud. = Trichogonia villosa Schultz-Bip. ex Baker.

Eupatorium incanum Schultz-Bip. ex Baker, Fl. Bras. 6(2): 327. 1876, nom, nud. = Disynaphia halimifolia (DC.) R. King \& H. Robinson.

Eupatorium incarnatum Walter, Fl. Carol. 200, 1788. = Fleischmannia incarnata (Walter) R. King \& H. Robinson.

Eupatorium incarum B. Robinson, Mem. Gray Herb. 1: 122. 1917. = Nothobaccharis candolleana (Steudel) R. King \& H. Robinson.

Eupatorium incasicum Wedd., Chlor. And. 1:217. 1857. = Ageratina pentlandiana (DC.) R. King \& H. Robinson.

Eupatorium incisum Rich., Actes Soc. Hist. Nat. Paris 1: 112. 1792, ignota.

Eupatorium incisum Griseb., Cat. Pl. Cub. 146. 1866. =Koanophyllon grisebachianum (Alain) R. King \& H. Robinson.

Eupatorium incisum Chapman, Fl. South. U. S., ed. 3, 216.1897. = Ageratina jucunda (E. Greene) A. Clewell \& Wooten.

Eupatorium incompt um DC., Prodr. 5: 173. 1836. = Decachaeta incompta (DC.) R. King \& H. Robinson.

Eupatorium inconspicuum Schultz-Bip., Linnaea 34: 535. 1865. 1866. = Ageratina azangaroensis (Schultz-Bip. ex Wedd.) R. King \& $\mathrm{H}$. Robinson.

Eupatorium indigofera Parodi, Anales Soc. Ci. Argent. 5: 39. 1877. = Koanophyllon tinctorilun Arruda.

Eupatorium innumerosum DC., Prodr. 5: 164. 1836. = Ageratina?.

Eupatorium insigne Malme, Ark. Bot. 24a(8): 28. 1932. = Praxelis insignis (Malme) R. King \& H. Robinson.

Eupatorium integerrimum Sprengel ex Baker, Fl. Bras. 6(2): 324. 1876, nom. nud. = Alustrocritonia velutina (Gardner) R. King \& H. Robinson.

Eupatorium integrifolium Bertcro ex Sprengel, Syst. Veg. Fl. Peruv. Chil. 3: 410. 1826. = Chromolaena integrifolia (Bertero ex Sprengel) R. King \& H. Robinson.

Eupatorium intercostulatum B. Robinson, Proc. Amer. Acad. Arts 54: 247. 1918. = Ageratina intercostulata (B. Robinson) R. King \& H. Robinson.

Eupatorium intermedium DC., Prodr. 5: 148. 1836. = Grazielia intermedia (DC.) R. King \& H. Robinson.

Eupatorium inulaefolium H. B. K., Nov. Gen. Sp. 4: 85. Ed. Folio. 1818. = Austroeupatorium inulaefolium (H. B. K.) R. King \& H. Robinson.

Eupatorium involucratum Schultz-Bip., Linnaea 22: 572. 1849 , nom. nud. = Grazielia schultzii R. King \& H. Robinson.

Eupatorium iodostylum B. Robinson, Proc. Amer. Acad. Arts 47: 194. 1911. = Spaniopappus iodostylus (B. Robinson) R. King \& H. Robinson.

Eupatorium iodotrichum B. Robinson, Proc. Amer. Acad. Arts 55: 19. 1919. = Ageratina iodotricha (B. Robinson) R. King \& H. Robinson.

Eupatorium iresinoides H. B. K., Nov. Gen. Sp. 4: 83. Ed. Folio. 1818. = Condylidium iresinoides (H. B. K.) R. King \& H. Robinson.

Eupatorium iridolepis B. Robinson, Proc. Amer. Acad. Arts 54: 247. $1918 .=$ Chromolaena iridolepis (B. Robinson) R. King \& H. Robinson.
Eupatorium irrasum (B. Robinson) B. Robinson, Contr. Gray Herb. 75: 8. 1925. = Ageratina irrasa (B. Robinson) R. King \& H. Robinson.

Eupatorium isillumense B. Robinson, Proc. Amer. Acad. Arts 55: 20. 1919. = Koanophyllon isillurnense (B. Robinson) $\mathbf{R}$. King \& H. Robinson.

Eupatorium isolepis B. Robinson, Proc. Amer. Acad. Arts 43: 33. 1907. = Ageratina isolepis (B. Robinson) R. King \& H. Robinson.

Eupatorium itacolumiense Schultz-Bip. ex Baker, Fl. Bras. 6(2): 310. 1876. = Heterocondylus itacolumiensis (Schultz-Bip. ex Baker) R. King \& H. Robinson.

Eupatorium itatiayense Hieron., Bot. Jahrb. Syst. 22: 764. 1897. = Symphyopappus itatiayensis (Hieron.) R. King \& H. Robinson.

Eupatorium iteophyllum Urban \& Ekman, Ark. Bot. 23a(11): 57. 1931. = Koanophyllon iteophyllum (Urban \& Ekman) R. King \& H. Robinson.

Eupatorium ivaefolium L., Syst. Nat. ed. 10, 1205. 1759. = Chromolaena ivaefolia (L.) R. King \& H. Robinson.

Eupatorium ixiocladon Benth. ex Oersted, Vidensk. Meddel. Dansk Naturhist. Foren. Kjobenhavn 77. 1852. = Ageratina ixiocladon (Benth. ex Oersted) R. King \& H. Robinson.

Eupatorium ixodes Benth., J. Bot. (Hooker) 2: 41. 1840. =Ayapana amygdalina (Lam.) R. King \& H. Robinson.

Eupatorium jacquemontii Urban, Feddes Repert. 17: 50. 1921. = Koanophyllon?.

Eupatorium jaegerianum Urban, Symb. Antill. 3: 394. 1903.= Koanophyllon jaegerianum (Urban) R. King \& H. Robinson.

Eupatorium jahnii B. Robinson, Proc. Amer. Acad. Arts 54: 248. 1918. = Ageratina jahtınii (B. Robinson) R. King \& H. Robinson.

Eupatorium jajoense Aristeg., Fl. Venezuela 10: 200. 1964. = Hebeclinium jajoense (Aristeg.) R. King \& H. Robinson.

Eupatorium jamesonii Turcz., Bull. Soc. Imp. Naturalistes Moscou 24(1): 169. 1851. = Badilloa salicina (Lam.) R. King \& H. Robinson, some Jameson specimens = Cronquistianthus niveus (H. B. K.) R. King \& H. Robinson.

Eupatorium japonicum Thunb., Fl. Jap. 308. 1784. = Eupatorium chinense $\mathrm{L}$.

Eupatorium jaraguense B. Robinson, Contr. Gray Herb. 80: 23. 1928. = Heterocondylus jaraguensis (B. Robinson) R. King \& H. Robinson.

Eupatorium javanicum Blume, Bijdr. Fl. Ned. Ind. 903. 1826. = Vernonia arborea Ham. VernONIEAE.

Eupatorium jejunum Standley \& Steyerm., Publ. Field Mus. Nat. Hist., Bot. Ser. 23: 183. 1944. = Fleischmannia capillipes (Benth. ex Oersted) R. King \& H. Robinson.

Eupatorium jelskii Hieron., Bot. Jahrb. Syst. 36: 464. 1905. = Chromolaena jelskii (Hieron.) R. King \& H. Robinson.

Eupatorium jenssenii Urban, Arch. Bot. *PICK CORRECT ENTRY 17(7): 64. 1922. = Koanophyllon jenssenii (Urban) R. King \& H. Robinson.

Eupatorium jucundum E. Greene, Pittonia 3: 180. 1897, nom. nov. = Ageratina jucunda (E. Greene) A. Clewell \& Wooten.

Eupatorium jugipaniculatum Rusby, Bull. New York Bot. Gard. 4: 379. 1907. = Koanophyllon jugipaniculatum (Rusby) R. King \& H. Robinson.

Eupatorium jujuiense Hieron., Bot. Jahrb. Syst. 22: 744. 1897. = Chromolaena hookeriana (Griseb.) R. King \& H. Robinson.

Eupatorilum juninense B. Robinson, Contr. Gray Herb. 77: 20. 1926. = Koanophyllon juninense (B. Robinson) R. King \& H. Robinson.

Eupatorium junquitense V. Badillo, Bol. Soc. Vencz. Ci. Nat. 10: 291. 1946. = Ageratina ibaguensis (Schultz-Bip. ex Hieron.) R. King \& H. Robinson.

Eupatorium kalenbornianum B. Robinson, Contr. Gray Herb. 
61:8. 1920. = Cronquistianthus kalenbornianus (B. Robinson) R. King \& H. Robinson.

Eupatorium karuaiense V. Badillo, Bol. Soc. Venez. Ci. Nat. 10: 294. 1946. = Praxelis karuaiensis (V. Badillo) R. King \& H. Robinson.

Eupatorium karvinskianum DC., Prodr. 5: 163. 1836. = Bartlettina karvinskiana (DC.) R. King \& H. Robinson.

Eupatorium kavanavense V. Badillo, Bol. Soc. Venez. Ci. Nat. 10: 293. 1946. = Koanophyllon kavanayense (V. Badillo) R. King \& H. Robinson.

Eupatorium killipii B. Robinson, Contr. Gray Herb. 77: 21 . 1926. = Hebeclinium killipii (B. Robinson) R. King \& H. Robinson.

Enpatorium kirilowii Turcz., Bull. Soc. Imp. Naturalistes Moscou 7: 153. 1837. = Eupatorium lindleyanum DC.

Eupatorium klattianum Hieron., Bot. Jahrb. Syst. 28: 573. 1901, nom. nov. = Fleischmannia klattiana (Hieron.) R. King \& H. Robinson.

Eupatorium klattii Millsp., Publ. Field Columbian Mus., Bot. Ser. 2: 105. 1900. = Chromolaena odorata (L.) R. King \& H. Robinson.

Eupatorium kleinii Cabrera, Bol. Soc. Argent. Bot. 7: 187. 1959. = Chromolaena kleinii (Cabrera) R. King \& H. Robinson.

Eupatorium kleinioides H. B. K., Nov. Gen. Sp. 4: 94. Ed. Folio. 1818. = Praxelis kleinioides $($ H. B. K.) Schultz-Bip.

Eupatorium koelliaefolium E. Greene, Pittonia 3: 31. 1896. = Ageratina hyssopina (A. Gray) R. King \& H. Robinson.

Eupatorium kuhnia Crantz, Inst. Rei Herb. 1:264. 1766. = Brickellia eupatorioides (L.) Shinn.

Eupatoriım kunthianum Schultz-Bip. ex Hieron., Bot. Jahrb. Syst. 28: 568. 1901. = Chromolaena bullatum (Klatt) R. King \& H. Robinson.

Eupatorium kuntzei Hieron., Bot. Jahrb. Syst. 22: 766. 1897. = Ophryosporus macrodon Griseb.

Eupatorium kupperi Suesseng., Bot. Jahrb. Syst. 72: 288.1942. = Ageratina kupperi (Suesseng.) R. King \& H. Robinson.

Eupatorium laciniatum Kitam., Acta Phytotax. Geobot. 5: 245. 1936. = Eupatorium chinense L.

Eupatorium laete-virens Hook. \& Arn., Companion Bot. Mag. 1: 240.1835 . = Austroeupatorium laete-virens (Hook. \& Am.) R. King \& H. Robinson.

Eupatorium laeve DC., Prodr. 5: 169. 1836. = Koanophyllon tinctorium Arruda.

Eupatorium laevigatulum B. Robinson, Contr. Gray Herb. 77: 21. 1926. = Chromolaena christieana (Baker) R. King \& H. Robinson.

Eupatorium laevigatum Lam., Encycl. 2: 408. 1788. = Chromolaena laevigala (Lam.) R. King \& H. Robinson.

Eupatorium laevigatum Torrey, Cat. PI. New York 92. 1819. = Eupatorium purpureum L.

Eupatorium lallavei Baillon, Hist. Pl. 8: 296. 1882, nom. nud. ignota.

Eupatorium lambertianum Wallich, Num. List Dr. Pl. 3288. 1831, nonı. nud. = Eupatorium cannabinum L., ?

Eupatorium lamiifolium H. B. K., Nov. Gen. Sp. 4: 88. Ed. Folio. 1818. = Aristeguietia lamiifolia (H. B. K.) R. King \& H. Robinson.

Eupatorium lamiifolium Link, Enum. Hort. Berol. Alt. 2: 306. 1822. = Dasycondy/us resinosus (Sprengel) R. King \& H. Robinson.

Eupatorinm lanatum Sprengel ex DC., Prodr. 5: 469. 1836, nom. nud. = Imula cappa (Ham. ex D. Don) DC. INULEAE.

Eupatorium lanceolatum Muhlenb. ex Willd., Sp. PI., ed. 5, 3: 1752. 1804. = Eupatorium pilosum Walter.

Eupatorinm lanceolatum Sesse \& Mocino, Pl. Nov. Hisp. 133. 1889. Naturaleza (Mexico City), ser. 2(1): 125. App. Ed. 2. 1893. = Fleischmanniopsis leucocephala (Benth.) R. King \& H. Robinson.
Eupatorium lancifolium (Torrey \& A. Gray) Small, Fl. S. E. U. S. $1167,1338.1903$

Eupatorium lanicaule B. Robinson, Proc. Amer. Acad. Arts 35: 336. 1900. = Critonia lanicaulis (B. Robinson) R. King \& H. Robinson.

Eupatorium lanigerum Hook. \& Arn., Companion Bot. Mag. 1: 242. $1835 .=$ Gyptis crassipes (Hieron.) R. King \& H. Robinson.

Eupatorium lantanifolium Griseb., Mem. Amer. Acad. Arts 8: 511. 1863. = Grisebachianthus lantanifolius (Griseb.) R. King \& H. Robinson.

Eupatorium lanulatum B. Robinson, Proc. Amer. Acad. Arts 54: 249. 1918. = Lourteigia lanulata (B. Robinson) R. King \& H. Robinson.

Eupatorium larcheanum Urban, Feddes Repert. 17: 52. 1921. = Koanophyllon

Eupatorium larense V. Badillo, Bol. Soc. Venez. Ci. Nat. 10:287. 1946. = Chromolaena larensis (V. Badillo) R. King \& H. Robinson.

Eupatorium lasiolepis B. Robinson, Contr. Gray Herb. 96: 21. 1931. = Gyptis crassipes (Hieron.) R. King \& H. Robinson.

Eupatorium lasioneuron Hook. \& Arn., Bot. Beechey Voy. 297. 1838. = Ageratina lasioneura (Hook. \& Arn.) R. King \& H. Robinson.

Eupatorium lasiophthalmum Griseb., Goett. Abh. 19: 119. 1874. = Kaunia lasiophthalma (Hieron.) R. King \& H. Robinson.

Eupalorium lasium B. Robinson, Contr, Gray Herb. 68: 21. 1923. = Ageratina lasia (B. Robinson) R. King \& H. Robinson.

Eupatorium lasseauxii (Carriere) Wittmack, Gartenflora 44:625, 653. 1895. = Barrosoa candolleana (Hook. \& Am.) R. King \& H. Robinson.

Eupatorium lasseanxii (Carriere) Olmsted, Cov. \& Kelsey, Stand PI. Nam. 8. 1923, comb. superfi. = Barrosoa candolleana (Hook \& Arn.) R. King \& H. Robinson.

Eupatorium lasseauxii (Carriere) Herter, Revista Sudamer. Bot. 4: 199. 1937, comb. superfl. = Barrosoa candolleana (Hook. \& Am.) R. King \& H. Robinson.

Eupatorium latidens Small, Man. S. E. Fl. 1327. 1933. = Ageratina aromatica (L.) Spach.

Eupatorium latifolium Less. ex Baker, F1. Bras. 6(2): 257. 1876, nom. nud. = Mikania argyreiae DC.

Eupatorium latipaniculatum Rusby, Bull. New York Bot. Gard. 4: 380. 1907. = Ayapanopsis latipaniculata (Rusby) R. King \& H. Robinson.

Eupatorium latipes Benth., PI. Hartw. 200. 1845. = Ageratina latipes (Benth.) R. King \& H. Robinson.

Eupatorium latisquamulosum (Hieron.) Malme, Kongl. Svenska Vetenskapsakad. Handl. Ser. 3. 12(2): 34. 1933. = Chromolaena latisquamulosa (Hieron.) R. King \& H. Robinson,

Eupatorium laurifolitum B. Robinson, Proc. Boston Soc. Nat. Hist. 31: 251. 1904. = Critonia laurifolia (B. Robinson) R. King \& H. Robinson.

Eupatorium lavandulaefolium DC., Prodr. 5: 154. 1836. = Cronquistianthus lavandulaefolius (DC.) R. King \& H. Robinson.

Eupatorium laxicephalum Cabrera, Sellowia 15: 196. 1963. = Fleischmannia laxicephala (Cabrera) R. King \& H. Robinson.

Eupatorium laxım Gardner, London J. Bot. 5: 476. 1846. = Fleischmannia laxa (Gardner) R. King \& H. Robinson.

Eupatorium lebrijense B. Robinson, Contr. Gray Herb. 80: 24. 1928. = Critoniella lebrijensis (B. Robinson) R. King \& H. Robinson.

Eupatorium lecheaefolium E. Greene, Pittonia 3: 177. 1897. = Eupatorium hyssopifolium L.

Eupatorium lehmannianum Klatt, Bot. Jahrb. Syst. 8: 34. 1886. $=$ Ageratina tinifolia (H. B. K.) R. King \& H. Robinson.

Eupatorium leiophyllum Less., Linnaea 6:402.1831. = Ageratina havanensis $(\mathrm{H}, \mathrm{B}, \mathrm{K}$.) R. King \& H. Robinson.

Eupatorium leivense Hieron., Bot. Jahrb. Syst. 21: 329. 1895. = Chromolaena leivensis (Hieron.) R. King \& H. Robinson. 
Eupatorium lemassonii Biau, Bull. Soc. Bot. France 57: 201. 1910. = Eupatorium cannabinum L.

Eupatorium lemmoni B. Robinson, Proc. Amer. Acad. Arts 27: 171. 1892. = Ageratina lemmonii (B. Robinson) R. King \& H. Robinson.

Eupatoriurn leonense B. Robinson, Proc. Amer. Acad. Arts 36: 479. 1901. = Flyriella leonensis (B. Robinson) R. King \& H. Robinson.

Eupatorium leptocephalum DC., Prodr. 5: 148. 1836. = Chromolaena leptocephala (DC.) R. King \& H. Robinson.

Eupatorium leptodictyon A. Gray in S. Watson, Proc. Amer. Acad. Arts 22: 420. 1887. = Ageratina leptodictyon (A. Gray) R. King \& H. Robinson.

Eupatorium leptolepis Baker, Fl. Bras. 6(2): 359. $1876 .=$ Heterocondylus leptolepis (Baker) R. King \& H. Robinson.

Eupatorium leptophlebium (B. Robinson) Steyerm., Fieldiana, Bot. 28(3): 636. 1953. = Raulinoreitzia leptophlebia (B. Robinson) R. King \& H. Robinson.

Eupatorium leptophyllum DC., Prodr. 5: 176. 1836.

Eupatorium leptopodum Gardner, London J. Bot. 5: 478.1846. = Brickellia diffusa (Vahl) A. Gray.

Eupatorium leucanthum Klotzsch ex Walp., Repert. Bot. Syst. 6: 133. 1846, nom. nud. = Conyza modesta Kunth. Astereae.

Eupatorium leucocephalum Benth., Pl. Hartw. 86. 1841. = Fleischmanniopsis leucocephala (Benth.) R. King \& H. Robinson.

Eupatorium leucocephalum (Gardner) Malme, Ark. Bot. 24a(8): 26. 1932. = Chromolaena leucocephala Gardner.

Eupatorium leucoderme B. Robinson, Proc. Amer. Acad. Arts 41: 274. 1905. = Koanophyllon albicaulis (Schultz-Bip. ex Klatt) R. King \& H. Robinson.

Eupatorium leucolepis Torrey \& A. Gray, F1. N. Amer. 2: 84. 1841.

Eupatorium leucolithogenum B. Robinson, Contr. Gray Herb. 80: 25. 1928. = Critoniella leucolithogena $(\mathrm{B}$. Robinson) R. King \& H. Robinson.

Eupatorium leucomyelum B. Robinson, Contr. Gray Herb. 68: 22. 1923. = Ageratina neriifolia (B. Robinson) R. King \& H. Robinson.

Eupatorium leucophyllum H. B. K., Nov. Gen. Sp. 4: 90. Ed. Folio. 1818. = Cronquistianthusleucophyllus (H. B. K.) R. King \& H. Robinson.

Eupatorium leucotrichium Schultz-Bip. ex Baker, Fl. Bras. 6(2): 292. 1876 , nom. nud. = Chromolaena verbenacea $(\mathrm{DC}.) \mathrm{R}$. King \& H. Robinson.

Eupatorium liatrideum DC., Prodr. 5: 142. 1836. = Chromolaena squarrulosa (Hook. \& Am.) R. King \& H. Robinson.

Eupatorium libanoticum Schultz-Bip., J. Bot. 1: 234. 1863. = Grisebachianthus libanotica (Schultz-Bip.) R. King \& H. Robinson.

Eupatorium liebmannii Hemsley, Biol. Cent.-Amer., Bot. 2: 96. 1881, nom. nud. = Decachaeta perornata (Klatt) R. King \& H. Robinson.

Eupatorium liebmannii Schultz-Bip. ex Klatt, Leopoldina 20: 75. 1884. = Ageratina liebmannii (Schultz-Bip. ex Klatt) R. King \& H. Robinson.

Eupatorium ligulaefolium Hook. \& Arn., Companion Bot. Mag. 1: 242. 1835. = Disynaphia ligulaefolia (Hook. \& Am.) R. King \& H. Robinson.

Eupatorium ligustrinum DC., Prodr. 5: 181, 1836. = Ageratina ligustrina (DC.) R. King \& H. Robinson.

Eupatorium lilacinum Hieron., Bot. Jahrb. Syst. 22: 757. 1897 = Chromolaena lilacina (Hieron.) R. King \& H. Robinson.

Eupatorium lilloi B. Robinson, Contr. Gray Herb. 90: 27. 1930. = Idiothamnus lilloi (B. Robinson) R. King \& H. Robinson.

Eupatorium lindenianum A. Rich. in Sagra, Hist. Fis. Cuba, Bot. 3: 42. 1853. = Koanophyllon villosum (Sw.) R. King \& H. Robinson.
Eupatorium lindheimerianum Scheele, Linnaea 21: 599. 1848. = Ageratina havanensis (H. B. K.) R. King \& H. Robinson.

Eupatorium lindleyanum DC., Prodr. 5: 180. 1836.

Eupatorium lindleyanum F. Muell., Fragm. 5: 62. 1865. = Eupatorium cannabinum $\mathrm{L}$.

Eupatorium lineare Malme, Ark. Bot. 24a(8): 23. 1932. = Chromolaena ivaefolia (L.) R. King \& H. Robinson.

Eupatorium linearifolium Walter, Fl. Carol. 199. 1788. = Eupatorium cuneifolium Willd.

Eupatoritm linearifolium Michaux, F1. Bor.-Amer. 2: 97. 1803. = Eupatorium hyssopifolium L.

Eupatorium lineatum Schultz-Bip. ex Baker, F1. Bras. 6(2): 336 1876. = Chromolaena?

Eupatorium linifolium DC., Prodr. 5: 149. 1836. = Campovas souria cruciata (Vell. Conc.) R. King \& H. Robinson.

Eupatorium lithophilum B. Robinson, Contr. Gray Herb. 73: 14. 1924. = Fleischmannia lithophila (B. Robinson) R. King \& H. Robinson.

Eupatorium littorale Cabrera, Bol. Soc. Argent. Bot. 7: 189. 1959. = Disynaphia littoralis (Cabrera) R. King \& H. Robinson.

Eupatorium littorale Alain, Contr. Ocas. Mus. Hist. Nat. Colegio "De La Salle" 18: 4. 1960. = Koanophyllon littorale R. King \& H. Robinson.

Eupatorium lloense Hieron. in Sodiro, Bot. Jahrb. Syst. 29: 11. 1901. = Fleischmannia lloensis (Hieron.) R. King \& H. Robinson.

Eupatorium lobatifolium Cabrera, Sellowia 15: 192. 1963. = Koanophyllon lobatifolia (Cabrera) R. King \& H. Robinson.

Eupatorium lobatum B. Robinson, Proc. Amer. Acad. Arts 55: 21. 1919. = Neocuatrecasia lobata (B. Robinson) R. King \& H. Robinson.

Eupatorium lobbii Klatt, Ann. K. K. Naturhist. Hofmus. 9: 356. 1894. = Dasycondylus lobbii (Klatt) R. King \& H. Robinson.

Eupatorium lobuliferum B. Robinson, Contr. Gray Herb. 77: 24. 1926. = Ageratina lobulifera (B. Robinson) R. King \& H. Robinson.

Eupatorium loefgrenii B. Robinson, Contr. Gray Herb. 104: 18. 1934. = Stomatanthes loefgrenii (B. Robinson) H. Robinson.

Eupatorium loesenerii B. Robinson, Proc. Amer. Acad. Arts 35: 336. 1900. = Ageratina loeseneri (B. Robinson) R. King \& H. Robinson.

Eupatorium longepetiolatum Schultz-Bip., Linnaea 34: 535. Feb. 1866, nom. nud. = Kaunia longipetiolata (Schultz-Bip. ex Rusby) R. King \& H. Robinson.

Eupatorium longicaule Wallich ex DC., Prodr. 5: 178. 1836. = Eupatorium cannabinum L., ?

Eupatorium longifolium B. Robinson, Proc. Amcr. Acad. Arts 36: 480. 1901. = Koanophyllon longifolia (B. Robinson) R. King \& $\mathrm{H}$. Robinson.

Eupatorium longipes A. Gray, Proc. Amer. Acad. Arts 15: 26. 1880. = Phanerostylis pedunculosa (DC.) R. King \& H. Robinson.

Eupatorium longipetiolatum Schultz-Bip., Bull. Soc. Bot. France 12: 81. 1865, nom. nud. = Kaunia longipetiolata (Schultz-Bip. ex Rusby) R. King \& H. Robinson.

Eupatorium longipetiolatum Martius ex Baker, Fl. Bras. 6(2): 217. 1876, nom. nud. = Trichogonia salviaefolia Gardner.

Eupatorium longipetiolatum Schultz-Bip. ex Rusby, Mem. Torrey Bot. Club 3(3): 52. 1893. = Kaunia longipetiolata (SchultzBip. ex Rusby) R. King \& H. Robinson.

Eupatorium longipetiolatum var. arbusculare B. Robinson, Contr. Gray Herb. 61: 9. 1920. = Kaunia arbuscularis (B. Robinson) R. King \& H. Robinson.

Eupatorium loniceroides H. B. K., Nov. Gen. Sp. 4: 91. Ed. Folio. 1818. = Ayapana amygdalina (Lam.) R. King \& H. Robinson. Eupatorium lopezmirandae Cabrera, Bol. Soc. Argent. Bot. 10: 21. 1962. = Cronquistianthus lopezmirandae (Cabrera) R. King \& H. Robinson. 
Eupatorium lorentzii Hieron., Bot. Jahrb. Syst. 22: 787. 1897. = Ageratina lorentzii (Hieron.) R. King \& H. Robinson.

Eupatorium loxense Klatt, Ann. K. K. Naturhist. Hofmus. 9: 357. 1894, = ignota, Baccharis?

Eupatorium loxense Hieron., Bot. Jahrb. Syst. 21: 331. 1895.= Ageratina exserto-venosa (Klatt) R. King \& H. Robinson.

Eupatorium lozanoanum B. Robinson, Proc. Amer. Acad. Arts 41: 275. 1905. = Critonia lozanoana (B. Robinson) R. King \& H. Robinson.

Eıpatorium lozanoi Cuatrec., Trab. Mus. Nac. Ci. Nat., Ser. Bot. 29: 18. 1935. = Lourteigia ballotaefolia (H. B. K.) R. King \& H. Robinson.

Eupatoritm lucayanum Britton, Bahama Fl. 439. 1920. = Chromolaena licayana (Britton) R. King \& H. Robinson.

Eupatorium Iucentifolium L. O. Williams, Fieldiana, Bot. 36: 88. 1975. = Critoniadelphus microdon (B. Robinson) R. King \& H. Robinson.

Eupatorium luchmense Nakai, Bot. Mag. (Tokyo) 30: 147. 1916.

Eupatorium luciae-brauniac Fern., Rhodora 44: 463. 1942, nom. nov. = Ageratina luciae-brauniae (Fern.) R. King \& H. Robinson.

Eupatorium hucidum Ortega, Nov. PI. Descr. Dec. 35. 1797. = Ageratina lucida (Ortega) R. King \& H. Robinson.

Eupatorium lucidum Colla, Herb. Pedem. 3: 283. 1834, ignota.

Eupatorium ludovicianım DC., Prodr. 5: 183. 1836, nom. nud. = Mikania cordifolia (L. f.) Willd.

Eupatorium lundianum DC., Prodr. 5: 170. 1836. = Dasycondylus resinosus (Sprengel) R. King \& H. Robinson.

Eupatorium lupulinum Baker, F1. Bras. 6(2): 301. 1876. = Chromolaena epaleacea Gardner.

Eupatorium luquense Chodat, Bull. Herb. Boissier Ser. 2. 1: 413. 1901. = Chromolaena luquensis (Chodat) R. King \& H. Robinson.

Eupatorium luteum Raf., Med. Repos. 5: 361. 1808, ignota.

Eupatorium luxii B. Robinson, Proc. Amer. Acad. Arts 36: 480. 1901. = Barlettina luxii (B. Robinson) R. King \& H. Robinson.

Eupatorium luzoniense Llanos, Fragm. Pl. Filip. 88. 1851. = Alyana triplinervis (Vahl) R. King \& H. Robinson.

Eupatorium lymansmithii (B. Robinson) Steyerm., Fieldiana, Bot. 28(3): 636. 1953. = Symphyopappus lymansmithii B. Robinson.

Eupatorium lyratum Coulter, Bot. Gaz. (Crawfords ville) 16: 96. 1891. Blumea viscosa (Miller) V. Badillo. InUleAe.

Eupatorium lysimachioides Chodat, Bull. Herb. Boissier Ser. 2. 2: 310. 1902. = Heterocondylus lysimachioides (Chodat) R. King \& $\mathrm{H}$. Robinson.

Eupatorium macbridei B. Robinson, Contr. Gray Herb. 68: 23. 1923. = Ageratina macbridei (B. Robinson) R. King \& H. Robinson.

Eupatorium macranthum Sw. F1. Ind. Occid. 3: 1315. 1806.= Chrornolaena macramlia (Sw.) R. King \& H. Robinson.

Eupatorium macrocephalum Less., Linnaea 5: 136. 1830. = Campuloclinium macroceplualum (Less.) DC.

Eupatorium ınacrodon DC., Prodr. 5: 145. 1836. = Chromolaena macrodon (DC.) Nicolson.

Eupatorium macromeris B. Robinson, Contr. Gray Herb. 68: 24. 1923. = Barlettina macromeris (B. Robinson) R. King \& H. Robinson.

Eupatorium macrophylloides B. Robinson, Proc. Amer. Acad. Arts 54: 249. 1918. = Critoniella vargasiana (DC.) R. King \& H. Robinson.

Eupatorium macrophyllum L., Sp. PI., ed. 2, 1175. 1762-1763. = llebeclinium macrophyllum (L.) DC.

Eupatorium macropodum Baker, Fl. Bras. 6(2): 279. 1876. = Chromolaena.

Eupatorium macropus (DC.) Urban, Symb. Antill. 1: 460. 1899, nom. illeg. = Critonia macropoda DC.

Eupatorium macrum Standley \& Steyerm., Publ. Field Mus. Nat.
Hist., Bot. Ser. 23: 184. 1944. = Condylidium tresinoides $(\mathrm{H}$. B. K.) R. King \& H. Robinson.

Eupatorium maculatum L., Cent. PI. 1. 1: 27. 1755, Amoen. Acad. 4: 288. 1759.

Eupatorium madrense S. Watson, Proc. Amer. Acad. Arts 26: 137. 1891. = Chromolaena bigelovii (A. Gray) R. King \& H. Robinson.

Eupatorium maestrense Urban, Symb. Antill. 3: 397. 1903. = Koanophyllon maestrense (Urban) R. King \& H. Robinson.

Eupatorium magdalenae Stehle. Adansonia 2: 349. 1962, nom. nov. = Critonia macropoda DC.

Eupatorium magdalenense B. Robinson, Proc. Amer. Acad. Arts 54: 250. 1918. = Fleischmannia magdalenensis (B. Robinson) R. King \& H. Robinson.

Eupatorium magistri L. O. Williams. Ficldiana, Bot. 36: 90(-91). 1975. = Critonia magistri (L. O. Williams) R. King \& H. Robinson.

Eupatorium mairei Leveille, Bull. Acad. Int. Geogr. Bot. 25: 14. 1915. = Eupatorium chinense L., ?

Eupatorium mairetiamum DC., Prodr. 5: 167. 1836. = Ageratina mairetiana (DC.) R. King \& H. Robinson.

Eupatorium malachophyllum Klatt, Jahrb. Hamburg. Wiss. Anst. 9: 125. 1892, Arb. Bot. Mus. Ham. 3. 1890. = Neocabreria malachophylla (Klatt) R. King \& H. Robinson.

Eupatorillm malacolepis B. Robinson. Proc. Amer. Acad. Arts 44: 618. 1909. = Ageratina malacolepis (B. Robinson) R. King \& H. Robinson.

Eupatorium mallotum B. Robinson, Proc. Amer. Acad. Arts 55: 22. 1919. = Chromolaena mallota (B. Robinson) R. King \& H. Robinson.

Eupatorium malvaefolium DC., Prodr. 5: 160. 1836. = Peteravenia malvaefolia (DC.) R. King \& H. Robinson.

Eupatorium mancoanum B. Robinson, Contr. Gray Herb. 90: 28. 1930. = Neocuatrecasia mancoana (B. Robinson) R. King \& H. Robinson.

Eupatorium mandowii Schultz-Bip., Linnaca 34: 533. 1865-1866. = Camporassouria cruciata (Vell. Conc.) R. King \& H. Robinson.

Eupatorium mapiriense Hieron. in Urban, Bot. Jahrb. Syst. 40: 374. 1908. = Austroeupatorium decenflorum (DC.) R. King \& H. Robinson.

Eupatorium maracayuense Chodat, Bull. Herb. Boissier Ser. 2. 3: 710. 1903, ignota.

Eupatorium margaritense Hassler, Feddes Repert. 14: 279. 1916. = Cliromolaena margaritensis (Hassler) R. King \& H. Robinson.

Eupatorium marginatum Poeppig \& Endl., Nov. Gen. Sp. 3: 54. 1845. = Fleischmannia marginata (Poeppig \& Endl.) R. King \& H. Robinson.

Eupatorium mariarum B. Robinson, Proc. Amer. Acad. Arts 36: 481. 1901. = Ageratina mariarum (B. Robinson) R. King \& H. Robinson.

Eupatorium marquezianum M. Gomez, Dicc. Bot. Nom. Vulg. Cub. Pue.-Riq. 54. 1889, nom. nud. = Mikania cordifolia (L. f.) Willd.

Eupatorium marrubiifolium Hieron., Bot. Jahrb. Syst. 36: 466. 1905. = Cronquistianthus marrubilfolizus (Hicron.) R. King \& H. Robinson.

Eupatorium marrubium Walter, F7. Carol. 199. 1788. = Eupatorium rotundifolium $\mathrm{L}$.

Eupatorium martii Martius. Flora 21(2): 88. 1838. = Chromolaena squalida (DC.) R. King \& H. Robinson.

Eupatorium martiusii DC., Prodr. 7: 269. 1838. = Chromolaena squalida (DC.) R. King \& H. Robinson.

Eupatorium mathewsii B. Robinson, Proc. Amer. Acad. Arts 55: 23. 1919. = Alapanopsis mathensii (B. Robinson) R. King \& H. Robinson.

Eupatorium mattogrossense Hieron., Bot. Jahrb. Syst. 22: 761. 
1897. = Chromolaena mattogrossensis (Hieron.) R. King \& H. Robinson.

Eupatorium maximiliani Schrader ex DC., Prodr. 5: 143. 1836. = Chromolaena maximilianii (Schrader ex DC.) R. King \& H. Robinson.

Eupatorium maxonii B. Robinson, Proc. Amer. Acad. Arts 54: 251. 1918. = Bartlettina maxonii (B. Robinson) R. King \& H. Robinson.

Eupatorium maxwelliae S. Moore, J. Bot. 66: 165. 1928. = Chromolaena heteroclinia (Griseb.) R. King \& H. Robinson.

Eupatorium mayarense Alain, Contr. Ocas. Mus. Hist. Nat. Colegio "De La Salle"18: 5. 1960. = Grisebachianthus mayarensis (Alain) R. King \& H. Robinson.

Eupatorium mayorii B. Robinson, Contr. Gray Herb. 68: 24. 1923. = Fleischmannia mayorii (B. Robinson) R. King \& H. Robinson.

Eupatorium medullosum Urban, Symb. Antill. 3: 393. 1903. = Chromolaena.

Eupatorium megacephalum Martius ex Baker, F1. Bras. 6(2): 354. 1876. = Campuloclinium megacephalum (Martius ex Baker) R. King \& H. Robinson.

Eupatorium megalophyllum (Lemaire) Klatt, Leopoldina 20: 90. 1884. = Bartlettina sordida (Less.) R. King \& H. Robinson, ? Eupatorium megaphyllum Baker, Fl. Bras. 6(2): 322. 1876. = Critonia megaphyila (Baker) R. King \& H. Robinson.

Eupatorium megaphyllum M. E. Jones, Contr. W. Bot. 18. 70. 1935?. = Critonia quadrangularis (DC.) R. King \& H. Robinson.

Eupatorium megapotamicum Sprengel, Syst. Veg. Fl. Peruv. Chil. 3: 420. 1826, ignota.

Eupatorium melanadenium Hance, J. Bot. 23: 325. 1885. = Eupatorium chinense L., ?

Eupatorium melanolepis Schultz-Bip. ex Klatt, Leopoldina 20: 89. 1884. = Ageratina subinclusa (Klatt) R. King \& H. Robinson.

Eupatorium melarhabdotrichum Gilli, Feddes Repert. 94: 308. 1983. = Polyanthina nemorosa (Klatt) R. King \& H. Robinson.

Eupatorium melissaefolium Lam., Encycl. 2: 411. 1788. = Stevia melissaefolia (Lam.) Schultz-Bip.

Eupatorium melissaefolium D. Dietr., Syn. Pl. 4: 1394. 1847, ignota.

Eupatorium melissoides Willd., Sp. Pl., ed. 5, 3:1754. 1804. = Ageratina aromatica (L.) Spach.

Eupatorium memorabile Maguire \& Wurd., Mem. New York Bot. Gard. 9: 366. 1957. = Imeria memorabilis (Maguire \& Wurd.) R. King \& H. Robinson.

Eupatorium mendax Standley \& Steyerm., Publ. Field Mus. Nat. Hist., Bot. Ser. 23: 185. 1944. = Fleischmanniopsis mendax (Standley \& Steyerm.) R. King \& H. Robinson.

Eupatorium mendezii DC., Prodr. 5: 160. 1836. = Chromolaena mendezii (DC.) R. King \& H. Robinson.

Eupatorium menthaefolitum Poeppig ex Sprengel, Syst. Veg. Fl. Peruv. Chil. 3: 412. 1826, ignota.

Eupatorium menthaefolium Wallich ex C. B. Clarke, Compos. Ind. 18. 1876, nom. nud. in syn. = Vernonia chinensis Less. VERNONIEAE.

Eupatorium mercedense B. Robinson, Contr. Gray Herb. 104: 19. 1934. = Fleischmannia mercedensis (B. Robinson) R. King \& H. Robinson.

Eupatorium meridense B. Robinson, Proc. Amer. Acad. Arts 54: 252. 1918. = Chromolaena meridensis (B. Robinson) R. King \& H. Robinson.

Eupatoritum mesoreopolum B. Robinson, Contr. Gray Herb. 73: 15. 1924. = Koanophyllon mesoreopolum (B. Robinson) R. King \& H. Robinson.

Eupatorium metense B. Robinson, Proc. Amer. Acad. Arts 55: 24. 1919. = Barrosoa metensis (B. Robinson) R. King \& H Robinson.
Eupatorium mexiae B. Robinson, Contr. Gray Herb. 104: 20. 1934. = Bartlettina hemisphaerica (DC.) R. King \& H. Robinson.

Eupatorium meyeri Pilger, Bot. Jahrb. Syst. 30: 202. 1901. = Chromolaena asperrima (Schultz-Bip. ex Baker) R. King \& H. Robinson, ?

Eupatorium michelianum B. Robinson, Proc. Amer. Acad. Arts 41: 276. 1905. = Chromolaena glaberrima (DC.) R. King \& H. Robinson.

Eupatorium micrachaenium Schultz-Bip. ex Baker, Fl. Bras. 6(2): 319. 1876, nom. nud. = Hatschbachiella tweedieana (Hook. \& Arn.) R. King \& H. Robinson.

Eupatorium micranthon J. Gmelin, Syst. Nat. 1198. 1792, nom. superfl. = Mikania parviflora (Aublet) Karsten.

Eupatorium micranthum Lagasca, Gen. Sp. Pl. 25. 1816. = Ager atum corymbosum Zuccagni.

Eupatorium micranthum Less., Linnaea 5: 138. 1830. = Ageratina ligustrina (DC.) R. King \& H. Robinson.

Eupatorium microcephalum Regel, Ind. Sem. Hort. Petrop. 35. 1860. = Ageratina .

Eupatorium microcephalum A. Gray, Proc. Amer. Acad. Arts 21: 384. 1886. = Decachaeta scabrella (B. Robinson) R. King \& H. Robinson.

Eupatorium microchaeteum Urban \& Ekman, Ark. Bot. 23a(1 1): 62. 1931. = Koanophyllon microchaetum (Urban \& Ekman) R. King \& H. Robinson.

Eupatorium microdon B. Robinson, Proc. Amer. Acad. Arts 54: 252. 1918. = Critoniadelphus microdon (B. Robinson) R. King \& H. Robinson.

Eupatorium microphyllum L. f., Suppl. PI. 355. 1781. = Lourteigia microphylla (L. f.) R. King \& H. Robinson.

Eupatorium microstemon Cass., Dict. Sci. Nat. 25: 432 . 1822. = Fleischmannia microstemon (Cass.) R. King \& H. Robinson.

Eupatorium mikaniifolium B. Robinson, Contr. Gray Herb. 104: 22. 1934. = Bishovia mikaniifolia (B. Robinson) R. King \& H. Robinson.

Eupatorium mikanioides Chapman, Fl. South. U. S. 195. 1860.

Eupatorium militare B. Robinson, Contr. Gray Herb. 65: 50. 1922. = Gyptidium militare (B. Robinson) R. King \& H. Robinson.

Eupatorium milleri Steudel, Nomencl. Bot. 1: 608. 1840, nom. nov. = Porophyllum punctatum (Miller) Blake. HELIANTHEAE.

Eupatorium mimicum Standley \& Steyerm., Publ. Field Mus. Nat. Hist., Bot. Ser. 23: 186. 1944. = Koanophyllon minica (Standley \& Steyerm.) R. King \& H. Robinson.

Eupatorium minasgeraesense Hieron., Bot. Jahrb. Syst. 22: 749. 1897. = Chromolaena minasgeraesensis (Hieron.) R. King \& H. Robinson.

Eupatorium minutifolium Alain, Contr. Ocas. Mus. Hist. Nat. Colegio "De La Salle" 18: 5. 1960. = Koanophyllon minutifolium (Alain) R. King \& H. Robinson.

Eupatorium miquihuanum B. Turner, Wrightia 5: 352. 1977. = Ageratina miquihuana (B. Turner) R. King \& H. Robinson.

Eupatorium miradorense Hieron., Bot. Jahrb. Syst. 28: 576. 1901, nom. nud. = Bartlettina brevipetiolata (Schultz-Bip. ex Klatt) R. King \& H. Robinson.

Eupatorium miragoanae Urban, Feddes Repert. 17: 11. 1921. = Koanophyllon miragoanae (Urban) R. King \& H. Robinson.

Eupatorium misellum McVaugh, Contr. Univ. Michigan Herb. 9: 400. 1972. = Chromolaena misella (McVaugh) R. King \& H. Robinson.

Eupatorium miserum B. Robinson, Proc. Amer. Acad. Arts 54: 253. 1918. = Fleischmannia misera (B. Robinson) R. King \& H. Robinson.

Eupatorium missionum Malmc, Ark. Bot. 24a(6): 35. 1932. = Praxelis missiona (Malme) R. King \& H. Robinson.

Eupatorium modestum Kunth, Ind. Sem. Hort. Berol. 13. 1847. = Ageratina modesta (Kunth) R. King \& H. Robinson. 
Eupatorium mohrii E. Greene, Contr. U. S. Natl. Herb. 6: 762. 1901.

Eupatorium molinae L. O. Williams, Fieldiana, Bot. 36: 91.1975 , nom. nov. = Neomirandea ovandensis R. King \& H. Robinson.

Eupatorium molinum B. Robinson, Contr. Gray Herb. 68: 25. 1923. = Chromolaena molina (B. Robinson) R. King \& H. Robinson.

Eupatorium molle Sw., Prodr. 111. 1788. = Hebeclinium macrophyllum (L.) DC.

Eupatorium molle H. B. K., Nov. Gen. Sp. 4: 85. Ed. Folio. 1818. = Austroeupatorium inulaefolium (H. B. K.) R. King \& H. Robinson.

Eupatorium molle Bertero ex DC., Prodr. 5: 172. 1836, nom. nud. = Koanophyllon puberulum (DC.) R. King \& H. Robinson.

Eupatorium molle Mutis, Diario 2: 275. 1958, ignota.

Eupatorium mollicomum B. Robinson, Contr. Gray Herb. 68: 26. 1923. = Grazielia mollicoma (B. Robinson) R. King \& H. Robinson.

Eupatorium mollissimum Baker, F1. Bras. 6(2): 331. 1876. = Grazielia mollissima (Schultz-Bip. ex Baker) R. King \& H. Robinson.

Eupatorium monagasense V. Badillo, Bol. Soc. Venez. Ci. Nat. 10:293. 1946. = Fleischmannia monagasensis (V. Badillo) R. King \& H. Robinson.

Eupatorium monanthum Schultz-Bip., Bot. Voy. Herald 299. 1856. = Neohintonia monantha (Schultz-Bip.) R. King \& H. Robinson.

Eupatorium monardacfolium Walp., Linnaea 14: 505. 1840. = Austroeupatorium silphiifolium (Martius) R. King \& H. Robinson.

Eupatorium mononeurum Urban, Symb. Antill. 3: 392. 1903.= Chromolaena mononeura (Urban) R. King \& H. Robinson.

Eupatorium montanum Sw., Prodr. 111, 1788. = Koanophyllon montanum (Sw.) R. King \& H. Robinson.

Eupatorium montevidense Sprengel, Syst. Veg. Fl. Peruv, Chil. 3: 417.1826 . = Baccharis coridifolia DC. AsTEREAE.

Eupatorium monticola L. O. Williams, Fieldiana, Bot. 36: 91(93). 1975. = Ageratina subinclusa (Klatt) R. King \& H. Robinson.

Eupatorium montigenum Standley \& Steyerm., Publ. Field Mus. Nat. Hist., Bot. Ser. 23: 258. 1947. = Bartlettina montigena (Standley \& Steyerm.) R. King \& H. Robinson.

Eupatorium morelense B. Robinson, Contr. Gray Herb. 104: 22. 1934, nom. nov. = Ageratina rufa (E. Greene) R. King \& H. Robinson.

Eumatorium morichalanum Aristeg., Mem. New York Bot. Gard. 9: 367. 1957. = Barrosoa metensis (B. Robinson) R. King \& H. Robinson.

Eupatorium morifolium Miller, Gard. Dict, ed. 8, n. 10. 1768. = Critonia morifolia (Miller) R. King \& H. Robinson.

Eupatorium morisii H. Pat. ex Vis., Ort. Bot. Padov. 80. 1842 , nom, nud. ignota.

Eupatorium moritense Aristeg., Fl. Venezuela 10: 129. 1964. = Chromolaena moritensis (Aristeg.) R. King \& H. Robinson.

Eupatorium moritibense B. Robinson, Contr. Gray Herb. 104: 23. 1934. = Prolobus nitidulus (Baker) R. King \& H. Robinson.

Eupatorium moritzianum Schultz-Bip. ex Hieron., Bot. Jahrb. Syst. 28: 565. 1901. = Chromolaena moritziana (Schultz-Bip. ex Hieron.) R. King \& H. Robinson.

Eupatorium mornicola Urban \& Ekman, Ark. Bot. 23a(11): 65. 1931. = Koanophvllon mornicola (Urban \& Ekman) R. King \& H. Robinson.

Eupatorium mortonianum $\times$ Alain, Contr. Ocas. Mus. Hist. Nat. Colegio "De La Salle" 18: 8. 1960. = Ageratina mortoniana (Alain) R. King \& H. Robinson.

Euputorium mucronatum Gardner, London J. Bot. 6: 440.1847. = Chromolaena mucronata (Gardner) R. King \& H. Robinson.
Eupatorium muelleri Schultz-Bip. ex Klatt, Leopoldina 20: 90. 1884. = Ageratina muelleri (Schultz-Bip. ex Klatt) R. King \& H. Robinson.

Eupatorium multicaulum (DC.) M. Gomez, Anales Hist. Nat. 19: 270. 1890. = Phania multicaulis DC.

Eupatorium multicrenulatum Schultz-Bip. ex Baker, F. Bras. 6(2): 335. 1876. = Disynaphia multicrenulata (Schultz-Bip. ex Baker) R. King \& H. Robinson.

Eupatorium multifidum DC., Prodr. 5: 182. 1836. = Grazielia multifida (DC.) R. King \& H. Robinson.

Eupatorium multiflorum Less. ex Baker, F. Bras. 6(2): 231, 235. 1876, nom. nud. = Mikania buddleiaefolia DC., and Mikania nodulosa Schultz-Bip. ex Baker.

Eupatorium multiflorum Martius ex Baker, F. Bras. 6(2): 361. 1876, nom. nud. = Barrosoa organernsis (Gardner) R. King \& H. Robinson.

Eupatorium multiflorum Larran., Escr. D. A. Larranaga 2: 251. 1923, ignota.

Eupatorium multiflosculosum DC., Prodr. 5: 141. 1836. = Chromolaena multiflosculosa (DC.) R. King \& H. Robinson.

Eupatorium multifolium B. Robinson, Contr. Gray Herb. 68: 27. 1923. = Disynaphia ligulaefolia (Hook. \& Arn.) R. King \& H. Robinson, ?

Elupatorium multinerve Benth., Pl. Hartw. 76. 1841. = Fleischmannia multinervis (Benth.) R. King \& $\mathrm{H}$. Robinson.

Eupatorium multiserratum Schultz-Bip., Bot. Voy. Herald 301. 1856. = Ageratina multiserrata (Schultz-Bip.) R. King \& H. Robinson.

Eupatorium muricatum Alain, Contr. Ocas. Mus. Hist. Nat. Colegio "De La Salle" 18: 6. 1960. = Koanophyllon muricatum (Alain) R. King \& H. Robinson.

Eupatorium mutiscuense B. Robinson, Contr. Gray Herb. 80: 25. 1928. = Ageratina mutiscuensis (B. Robinson) R. King \& H Robinson.

Eupatorium mygindaefolium A. Gray, Proc. Amer. Acad. Arts 16: 101. 1880. = Ageratina mygindaefolia (A. Gray) R. King \& H. Robinson.

Eupatorium myosotifolium Jacq., Icon. Pl. Rar. 3: 15. T. 582. 1789 , ignota.

Eupatorium myriadenium Schauer, Linnaea 19: 721, 1847. = Ageratina ligustrina (DC.) R. King \& H. Robinson.

Eupatorium myrianthum Less. ex Baker, Fl. Bras. 6(2): 230. 1876. nom. nud. = Mikania myriocephala DC.

Eupatorium myrianthum Klatt, Compos. Nov. Costaric. [Bot. Beibl. Leopoldina] 3. 1895. = Decachaeta thieleana (Klatt ex T. Durand \& Pittier) R. King \& H. Robinson.

Eupatorium inyricifolium (B. Robinson) Steyerm., Fieldiana, Bot. 28(3): 636. 1953. = Symphyopappus myricifolius B. Robinson.

Eupatorium myriocephalum Gardner, London J. Bot. 6: 442. 1847. = Chromolaena myriocephala (Gardner) R. King \& H. Robinson.

Eupatorium myriocephalum Klatt, Leopoldina 25: 104. 1889. = Decachaeta thieleana (Klatt ex T. Durand \& Pittier) R. King \& H. Robinson.

Eupatorium myrtilloides DC., Prodr. 5: 165. 1836. = Koanophyllon myrtilloides (DC.) R. King \& H. Robinson.

Eupatorium mysorense Heyne ex DC., Prodr. 5; 451. 1836, nom. nud. $=$ Pluchea tomentosa DC. in Wight. InULEAE.

Eupatorium naiguatensis (V. Badillo) Steyerm., Pittieria 7: 23. 1978. = Critonia naiguatensis (V. Badillo) R. King \& H. Robinson.

Eupatorium neaeanum DC., Prodr. 5: 160. 1836. = Chromolaena collina (DC.) R. King \& H. Robinson.

Eupatorium neglectum B. Robinson, Contr. Gray Herb. 68: 28. 1923. = Austroeupatorium neglectum (B. Robinson) R. King \& H. Robinson.

Eupatorium nelsonii B. Robinson, Proc. Amer. Acad. Arts 35: 
337. 1900. = Kyrsteniopsis nelsonii (B. Robinson) R. King \& H. Robinson.

Eupatorium nemorale E. Greene, Pittonia 4: 278. 1901. = Ageratina aromatica (L.) Spach.

Eupatorium nemorense Schultz-Bip., Linnaea 34: 535. 1865-1866, nom. nud. = Lorentzianthus viscidus (Hook. \& Arn.) R. King \& H. Robinson.

Eupatorium nemorense Schultz-Bip. ex Baker, Fl. Bras. 6(2): 304. 1876, nom. nud. = Heterocondylus alatus (Vell. Conc.) R. King \& H. Robinson.

Eupatorium nemorosum Klatt, Bot. Jahrb. Syst. 8: 35. $1886 .=$ Polyanthina nemorosa (Klatt) R. King \& H. Robinson.

Eupatorium nepalense Sprengel, Syst. Veg. 3: 412. 1826. = Vernonia divergens (DC.) Edgewood. VeRNONIEAE.

Eupatorium nepetaefolium H. B. K., Nov. Gen. Sp. 4: 87. Ed. Folio. 1818. = Brickellia secundiflora (Lagasca) A. Gray.

Eupatorium nepetaefolium Wawra, Oesterr. Bot. Z. 13: 219. 1863, ignota.

Eupatorium nepetoides Lindley ex Baker, Fl. Bras. 6(2): 360. 1876 , nom. nud. = Conocliniopsis prasiifolia (DC.) R. King \& H. Robinson.

Eupatorium neriifolium B. Robinson, Contr. Gray Herb. 65: 49. 1922. = Ageratina neriifolia (B. Robinson) R. King \& H. Robinson.

Eupatorium nervosum Sw., Prodr. 111. 1788. = Koanophyllon nervosum (Sw.) R. King \& H. Robinson.

Eupatorium nervosum Sieber ex DC., Prodr. 5: 399. 1836, nom. nud. = Baccharis nervosa DC. AstEREAE.

Eupatorium neurolepis Torrey ex Torrey \& A. Gray, Fl. N. Amer. 2: 81.1841 , nom. nud. = Chromolaena ivaefolia (L.) R. King \& H. Robinson

Eupatorizm neurophyllum Schultz-Bip. ex Baker, FI. Bras. 6(2): 321. 1876, nom. nud. = Raulinoreitzia crenulata (Sprengel) R. King \& H. Robinson.

Eupatorium nicaraguense B. Robinson, Contr. Gray Herb. 61: 29. 1920. = Critonia nicaraguensis (B. Robinson) R. King \& H. Robinson.

Eupatorium niederleinii Hieron., Bot. Jahrb. Syst. 22: 763. 1897. $=$ Neocabreria malachophylla (Klatt) R. King \& H. Robinson.

Eupatorium nigrescens Hook. \& Arn., Bot. Beechey Voy. 297. 1838. = Chromolaena collina (DC.) R. King \& H. Robinson.

Eupatorium nigrum Baillon, Hist. P1. 8: 31. 1882, nom. nud. ignota.

Eupatorium nipense B. Robinson, Contr. Gray Herb. 77: 25. 1926. = Grisebachianthus mipensis (B. Robinson) R. King \& H. Robinson.

Eupatorium nitidulum Baker, Fl. Bras. 6(2): 351. 1876. = Prolobus nitidulus (Baker) R. King \& H. Robinson.

Eupatorium nitidum DC., Prodr. 5: 180. 1836. = Mikania nitida (DC.) R. King \& H. Robinson.

Eupatorium niveum H. B. K., Nov. Gen. Sp. 4: 90. Ed. Folio. 1818. = Cronquistianthus niveus (H. B. K.) R. King \& H. Robinson.

Eupatorium nodiflorum Wallich ex DC., Prodr. 5: 179. 1836.

Eupatorium mibigenoides B. Robinson, Proc. Amer. Acad. Arts 42: 42. 1906. = Fleischmanniopsis nubigenoides (B. Robinson) R. King \& $\mathrm{H}$. Robinson.

Eupatorium nubigenum Benth., Pl. Hartw. 85. 1841. = Critoniadelphus nubigenus (Benth.) R. King \& H. Robinson.

Eupatorium nubivagum L. O. Williams, Fieldiana, Bot. 36: 94(96). 1975. = Ageratina prunellaefolia (H. B. K.) R. King \& H. Robinson.

Eupatorium nudiflorum A. Rich. in Sagra, Hist. Fis. Cuba, Bot. 3: 41. 1853. = Koanophyllon nudiflorum (A. Rich.) R. King \& H. Robinson.

Eupatorium nudispermum Sesse \& Mocino, Fl. Mexic. (ed. 2) 181. 1894. = Ageratum maritimum H. B. K.
Eupatorium nudosum (Sprengel) M. Gomez, Anales Hist. Nat. 19: 269. 1890. = Mikania nodosa Sprengel.

Eupatorium nudum Gardner, London J. Bot. 5: $475.1846 .=$ Platypodanthera melissaefolia (DC.) R. King \& H. Robinson.

Eupatorium nummularium Hook. \& Arn., Companion Bot. Mag. 1: 241. 1835. = Grazielia nummularia (Hook. \& Arn.) R. King \& H. Robinson.

Eupatorium nutans H. B. K., Nov. Gen. Sp. 4: 82. Ed. Folio. 1818. = Brickellia nutanticeps S. F. Blake.

Eupatorium oaxacanum Klatt, Abh. Naturf. Ges. Halle 15: 324. 1882. = Ageratina oaxacana (Klatt) R. King \& H. Robinson. Eupatorium oblongifolium (Sprengel) Baker, Fl. Bras. 6(2): 333. 1876. = Stomatanthes oblongifolius (Sprengel) H. Robinson.

Eupatorium obovatum Raf., Med. Repos. 5: 359. 1808. =Eupatorium rotundifolium L., ?

Eupatorium obovatum Willd. ex Less., Linnaea 4: 271. 1829, nom. nud. = Vernonia brasiliana (L.) Druce. VERNONIEAE.

Eupatorium obscurifolium Hieron. in Sodiro, Bot. Jahrb. Syst. 29: 9. 1900. = Fleischmannia obscurifolia (Hieron.) R. King \& H. Robinson.

Eupatorium obscurum DC., Prodr. 5: 142, 1836. = Chromolaena ivaefolia (L.) R. King \& H. Robinson.

Eupatoriuin obtusifolium Willd., Sp. PI. 3: 1768. 1804. = Vernonia albicaulis Pers. VernoniEAE.

Eupatorium obtusisquamosum Hieron. ex Sodiro, Bot. Jahrb. Syst. 29: 14. 1900. = Hebeclinium obtusisquamosum (Hieron. ex Sodiro) R. King \& H. Robinson.

Eupatorium obtusissimum DC., Prodr. 5: 173. 1836. = Koanophyllon obtusissimum (DC.) R. King \& H. Robinson.

Eupatorium ocanense B. Robinson, Contr. Gray Herb. 68: 27. 1923. = Ageratina ocanensis (B. Robinson) R. King \& H. Robinson.

Eupatorium occidentale Hook., Fl. Bor.-Amer. 1: 305. 1833. = Ageratina occidentalis (Hook.) R. King \& H. Robinson.

Eupatorium occidentale var. arizonicum A. Gray, Syn. Fl. N. Amer. 1: 101. 1886. = Ageratina herbacea (A. Gray) R. King \& H. Robinson.

Eupatorium odontodactylum B. Robinson, Contr. Gray Herb. 75: 10. 1925. = Praxelis odontodactyla (B. Robinson) R. King \& H. Robinson.

Eupatorium odoratissimum Hort. ex Sieber \& Voss, Vilm. Blumengaert., ed. 3, 1:448. 1894, nom. nud. = Ageratina ligustrina (DC.) R. King \& H. Robinson.

Eupatorium odoratum L., Syst. Nat. ed. 10, 1205. 1759. = Chromolaena odorata (L.) R. King \& H. Robinson.

Eupatorium odoratum Walter, Fl. Carol. 200. 1788. = Ageratina altissima (L.) R. King \& H. Robinson, ?

Eupatorium oerstedianum Benth. ex Oersted, Vidensk. Meddel. Dansk Naturhist. Foren. Kjobenhavn 74. 1852. = Chromolaena glaberrima (DC.) R. King \& H. Robinson.

Eupatorium officinale (Martius) Baillon, Traite Bot. Med. Phan. 2: 1127. 1884. = Mikania officinalis Martius.

Eupatorium oinopolepis (Malme) Cabrera, Sellowia 15: 196. 1963. = Chromolaena oinopolepis (Malme) R. King \& H. Robinson.

Eupatorium oligadenium Alain, Contr. Ocas. Mus. Hist. Nat. Colegio "De La Salle" 18: 7. 1960. = Koanophyllon oligadenium (Alain) R. King \& H. Robinson.

Eupatorium oliganthes Less., Linnaea 5: 137. 1830. = Brickellia oliganthes (Less.) A. Gray.

Eupatorium oligocephalum DC., Prodr. 5: 166. 1836. = Ageratina oligocephala (DC.) R. King \& H. Robinson.

Eupatorium oligolepis Hemsley, Biol. Cent.-Amer., Bot. 2: 98. 1881. = Conoclinium betonicifolium (Miller) R. King \& H. Robinson.

Eupatorium omphaliaefolium Kunth \& Bouche, Ind. Sem. Hort. Berol. Adnat. N. 13. 1844. = Neomirandea araliaefolia (Less.) R. King \& H. Robinson.

Eupatorium oinphaliaefolium Kunth \& Bouche ex Walp., Repert. 
Bot. Syst. 6: 113. 1846. = Neomirandea araliaefolia (Less.) R. King \& H. Robinson.

Eupatorium opiferum (Martius) Baillon, Traite Bot. Med. Phan. 2: 1127. 1884. = Mikania cordifolia (L. f.) Willd.

Eupatorium oppositifolium Hoffsgg., Verz. Pfl.-Kult. (ed. 2) 3: 36. 1824 , ignota.

Eupatorium orbiculatum DC., Prodr. 5: 172. 1836. = Vittetia orbiculata (DC.) R. King \& H. Robinson.

Eupatorium orbignyanum Klatt, Abh. Naturf. Ges. Halle 15: 323. 1882. = Chromolaena orbignyana (Klatt) R. King \& H. Robinson.

Eupatorium oregonum Nutt., Trans. Amer. Philos. Soc. 7: 286. 1841. = Ageratina occidentalis (Hook.) R. King \& H. Robinson.

Eupatorium oreithales Greenman, Proc. Amer. Acad. Arts 32: 308. 1897. = Ageratina prunellaefolia (H. B. K.) R. King \& H. Robinson.

Eupatorium oreophilum L. O. Williams, Fieldiana, Bot. 36: 96(97). 1975. = Neomirandea biflora R. King \& H. Robinson.

Eupatorium oresbioides B. Robinson, Proc. Amer. Acad. Arts 44: 618. 1909. = Bartlettina oresbioides (B. Robinson) R. King \& H. Robinson.

Eupatorium oresbium B. Robinson, Proc. Amer. Acad. Arts 35: 337. 1900. = Bartlettina oresbia (B. Robinson) R. King \& H. Robinson.

Eupatorium organense Gardner, London J. Bot. 4: 117. 1845. = Barrosoa organensis (Gardner) R. King \& H. Robinson.

Eupatorium orguale DC., Prodr. 5: 174. 1836. = Austroeupatorium imulaefolium (H. B. K.) R. King \& H. Robinson, ?

Eupatorium orgyaloides B. Robinson, Proc. Amer. Acad. Arts 55:24. 1919. = Idiothamnus orgyaloides (B. Robinson) R. King \& H. Robinson.

Eupatorium origanoides H. B. K., Nov. Gen. Sp. 4: 89. Ed. Folio. 1818. = Cronquistianthus origanoides (H. B. K.) R. King \& H. Robinson.

Eupatorium origanoides Meyen \& Walp., Nova Acta Phys.-Med. Acad. Caes. Leop.-Carol. Nat. Cur. 19, Suppl. 1: 257. 1843. $=$ Ophryosporus heptanthus (Schultz-Bip. ex Wedd.) R. King \& H. Robinson.

Eupatorium orinocense (H. B. K.) M. Gomez, Dicc. Bot. Nom. Vulg. Cub. Pue.-Riq. 55. 1889. = Mikania micrantha $\mathrm{H}$. B. K.

Eupatorium orizabae Schultz-Bip. ex Hemsley, Biol. Cent.-Amer., Bot. 2: 98. 1881, nom. nud. = Ageratina glauca (Schultz-Bip. ex Klatt) R. King \& H. Robinson.

Eupatorium ornatilobum B. Robinson, Contr. Gray Herb. 80: 27. 1928. = Lourteigia ornatiloha (B. Robinson) R. King \& H. Robinson.

Eupatorium ornithophorum B. Robinson, Proc. Amer. Acad. Arts 54:254. 1918. = Ayapana ornithophora (B. Robinson) R. King \& H. Robinson.

Eupatorium orogenes L. O. Williams, Fieldiana, Bot. 36: 97(98). 1975. = Neomirandea parasitica (Klatt) R. King \& H. Robinson.

Eupatorium orphaliaefolium Kunth \& Bouche ex Regel, Gartenflora 2: 4. 1853. = Neomirandea araliaefolia (Less.) R. King \& H. Robinson.

Eupatorium ortegae B. Robinson, Contr. Gray Herb. 75: 10. 1925. = Chromolaena ortegae (B. Robinson) R. King \& H. Robinson.

Eupatorium ossaeanum DC., Prodr. 5: 144. 1836. = Chromolaena ossaeana (DC.) R. King \& H. Robinson.

Eupatorium osseanum Schultz-Bip. ex Baker. Fl. Bras. 6(2): 287. 1876 , nom. nud. = Chromolaena laevigata (Lam.) R. King \& H. Robinson.

Eupatorium ostenii B. Robinson, Ostenia 356. 1933. = Praxelis ostenii (B. Robinson) R. King \& H. Robinson.
Eupatorium oteroi Monach., Phytologia 2: 406. 1948. = Chromolaena oteroi (Monach.) R. King \& H. Robinson.

Eupatorium ovaliflorum Hook. \& Am., Bot. Beechey Voy. 297. 1838. = Chromolaena glaberrima (DC.) R. King \& H. Robinson.

Eupatorium ovandense Grashof \& Beaman, Rhodora 71: 577. 1969. = Decachaeta ovandensis (Grashoff \& Beaman) R. King \& H. Robinson.

Eupatorium ovatifolium Hieron. in Urban, Bot. Jahrb. Syst. 40: 387. 1908 . = Hebeclinium

Eupatorium ovatum J. Bigelow, F1. Boston., ed. 2, 296. 1824. = Eupatorium rotundifolium L.

Eupatorium ovillum Standley \& Steyerm., Publ. Field Mus. Nat. Hist., Bot. Ser. 22: 305. 1940. = Ageratina ovilla (Standley \& Steyerm.) R. King \& H. Robinson.

Eupatorium oxychlaenum DC., Prodr. 5: 162. 1836. = Ayapana amygdalina (Lam.) R. King \& H. Robinson.

Eupatorium oxyhedrum Baker, F. Bras. 6(2): 359. 1876. = Campuloclimium macrocephalum (Less.) DC., ?

Eupatorium oxylepis DC., Prodr. 5: 145. 1836. = Chromolaena oxylepis (DC.) R. King \& H. Robinson.

Eupatorium oxylepis Schultz-Bip. ex Baker, Fl. Bras. 6(2): 339. 1876 , nom. nud. = Stomatanthes warmingii (Baker) H. Robinson.

Eupatorium oyadense Hieron., Bot. Jahrb. Syst. 22: 755. 1897. = Chromolaena oyadensis (Hieron.) R. King \& H. Robinson.

Eupatorium pabstii Regel, Ann. Sci. Nat. Bot. 4,12: 375. 1859. = Ageratina .

Eupatorium pacacanum Klatt, Compos. Nov. Costaric. [Bot. Beibl. Leopoldina] 3. 1895. = Fleischmannia pratensis (Klatt) R. King \& H. Robinson.

Eupatorium pachanoi B. Robinson, Proc. Amer. Acad. Arts 55: 25. 1919. = Kaunia pachanoi (B. Robinson) R. King \& H. Robinson.

Eupatorium pachyneurum Urban, Feddes Repert. 17: 10. 1921. $=$ Koanophyllon pachyneurum (Urban) R. King \& H. Robinson.

Eupatorium pachypodum B. Robinson, Proc. Amer. Acad. Arts 36: 481. 1901. = Ageratina pachypoda (B. Robinson) R. King \& H. Robinson.

Eupatorium pacificum B. Robinson in I. M. Johnston, Proc. Calif. Acad. Sci. Ser. 4. 20: 99. 1931. = Ageratina pacifica (B. Robinson ex I. M. Johnston) R. King \& H. Robinson.

Eupatorium pacificum B. Robinson, Contr. Gray Herb. n.s. 100: 15. 1932. = Ageratina pacifica (B. Robinson) R. King \& H. Robinson.

Eupatorium paezense Hieron., Bot. Jahrb. Syst. 28: 574. 1901. = Bartlettina paezensis (Hieron.) R. King \& H. Robinson.

Eupatorium palaeforme Klatt, Leopoldina 20: 76. 1884. = Ageratina?.

Eupatorium paleaceum Sesse \& Mocino, Fl. Mexic. (ed. 2) . 181. 1894. = Ageratum conyzoides L.

Eupatorium pallescens DC., Prodr. 5: 154. 1836. = Austroeupatorium inulaefolium (H. B. K.) R. King \& H. Robinson.

Eupatorium pallidum Hook. \& Am., Companion Bot. Mag. 1: 241. 1835. = Austroeupatorium inulaefolium (H. B. K.) R. King \& H. Robinson.

Eupatorium palmare Schultz-Bip. ex Baker, Fl. Bras. 6(2): 294. 1876. = Chromolaena palmaris (Schultz-Bip. ex Baker) R. King \& H. Robinson.

Eupatorium palmeri A. Gray, Proc. Amer. Acad. Arts 21: 383. 1886. = Koanophyllon palmeri (A. Gray) R. King \& H. Robinson.

Eupatorium palustre (DC.) Baker, F. Bras. 6(2): 363. 1876. = Barrosoa betonicaeformis (DC.) R. King \& H. Robinson.

Eupatorium pampalcense B. Robinson, Contr. Gray Herb. 104: 24. 1934. = Ageratina pampalcensis (B. Robinson) R. King \& H. Robinson. 
Eupatorium pandurifolium Baker, Fl. Bras. 6(2): 310. 1876. = Heterocondylus pandurifolius (Baker) R. King \& H. Robinson. Eupatorium paniculatum Miller, Gard. Dict, ed. 8, 15. 1768. = Brickellia paniculata (Miller) B. Robinson.

Eupatorium paniculatum Schrader, Ind. Sem. Hort. Acad. Gott. 2. 1832, Linnaea 8. Litt. 26. 1833. = Fleischmannia microstemon (Cass.) R. King \& H. Robinson.

Eupatorium paniculatum Lindley ex DC., Prodr. 5: 23. 1836 , nom. nud. = Vernonia paniculata DC. VeRNONIEAE.

Eupatorium pansamalense B. Robinson, Proc. Amer. Acad. Arts 36: 482. 1901. = Bartlettina pansamalensis (B. Robinson) R. King \& H. Robinson.

Eupatorium papantlense Less., Linnaea 6:403.1831. = Ageratina havanensis (H. B. K.) R. King \& H. Robinson, ?

Eupatorium paradoxum Hook. \& Am., Companion Bot. Mag. 1: 240. 1835. = Ophryosporus paradoxus (Hook. \& Arn.) Benth. \& Hook. ex Hook. f. \& Jackson.

Eupatorium paraguariense Hieron., Bot. Jahrb. Syst. 22: 752. 1897. = Chromolaena paraguariensis (Hieron.) R. King \& H. Robinson.

Eupatorium paramense Aristeg., Fl. Venezuela 10: 171. 1964. = Ageratina paramensis (Aristeg.) R. King \& H. Robinson.

Eupatorium paranense Hook. \& Arn., Companion Bot. Mag. 1: 241. 1835. = Austroeupatorium inulaefolium (H. B. K.) R. King \& H. Robinson.

Eupatorium parasiticum Klatt, Ann. K. K. Naturhist. Hofmus. 9: 357. 1894. = Neomirandea parasitica (Klatt) R. King \& H. Robinson.

Eupatorium parietariaefolium Scheele, Linnaea 18: 458. 1844. = Ageratina?.

Eupatorium parryi A. Gray, Rep. U. S. Mex. Bound., Bot. 75. 1859. = Flyriella parni (A. Gray) R. King \& H. Robinson.

Eupatorium pariceps Malme, Ark. Bot. 24a(8): 24. 1932. = Chromolaena parviceps (Malme) R. King \& H. Robinson.

Eupatorium parviflorum Aublet, Hist. Pl. Guiane 2: 797. 1775. = Mikania parviflora (Aublet) Karsten.

Eupatorium parviflorum Sw., Prodr. 111. 1788. = Critonia parviflora [Sw.] DC.

Eupatorium parviflorum Elliott, Sketch Bot. S. Carolina 2: 299. 1822?. = Eupatorium semiserratum DC.

Eupatorium parviflorum var. lancifolium Torrey \& A. Gray, Fl. N. Amer. 2: 85. 1841. = Eupatorium lancifolium (Torrey \& A. Gray) Small.

Eupatorium parvulum Glaz., Bull. Soc. Bot. France Mem. 3. 56: 390. 1909, nom. nud. = Campuloclinium parulum (Glaz. ex B. Robinson) R. King \& H. Robinson.

Eupatorium parvulum Glaz. ex B. Robinson, Contr. Gray Herb. 73: 16. 1924. = Campuloclinium parrulum (Glaz. ex B. Robinson) R. King \& H. Robinson.

Eupatorium pasadenense Parish, Zoe 5: 75. 1900. = Ageratina adenophora (Sprengel) R. King \& H. Robinson.

Eupatorium pastazae B. Robinson, Biblioth. Bot. 29 (Heft. 116): 160. 1937. = Fleischmannia pastazae (B. Robinson) R. King \& H. Robinson.

Eupatorium patagonicum Klatt, Abh. Naturf. Ges. Halle 15: 324. 1882. = Austrobrickellia patens (Don ex Hook. \& Arn.) R. King \& H. Robinson.

Eupatorium patens Don ex Hook. \& Arn., Companion Bot. Mag. 1:242. 1835. = Austrobrickellia patens (Don ex Hook. \& Arn.) R. King \& H. Robinson.

Eupatorium patens Philippi, Sert. Mendoc. Alt. 21. 1870. = Austrobrickellia patens (Don ex Hook. \& Arn.) R. King \& H. Robinson.

Eupatorium paucibracteatum Alain, Contr. Ocas. Mus. Hist. Nat. Colegio "De La Salle" 18: 8. 1960. = Ageratina paucibracteata (Alain) R. King \& H. Robinson.

Eupatorium paucicapitulatum Hieron., Bot. Jahrb. Syst. 22: 756. 1897. = Chromolaena .
Eupatorium paucicrenatum Urban \& Ekman, Ark. Bot. 23a(11): 59. 1931. = Koanophyllon paucicrenatum (Urban \& Ekman) R. King \& H. Robinson.

Eupatorium paucidentatum Schultz-Bip., Linnaea 34: 535. 1865 1866 , nom. nud. = Chromolaena connivens (Rusby) R. King \& H. Robinson.

Eupatorium paucidentatum Schultz-Bip. ex Baker, F1. Bras. 6(2): 297. 1876. = Chromolaena congesta (Hook. \& Arn.) R. King \& H. Robinson.

Eupatoriuın pauciflorum H. B. K., Nov. Gen. Sp. 4: 94. Ed. Folio. 1818. = Praxelis pauciflora (H. B. K.) R. King \& H. Robinson.

Eupatorium pauciflorum Raf., New Fl. 4: 80. 1836, nom. illeg. prov. = Caradesia pauciflora Raf., Fleischmannia?

Eupatorium pauciflorum Wallich ex DC., Prodr. 5: 15. 1836. nom. nud. = Vernonia teres Wallich ex DC. VERNONIEAE.

Eupatorium paulense Loefgren, Bol. Commiss. Geogr. Estado Sao Paulo 1 (12): 242. 1897. = Campuloclinium megacephalum (Martius ex Baker) R. King \& H. Robinson.

Eupatorium panlinum DC., Prodr. 5: 158. 1836. = Austroeupatorium paulinum (DC.) R. King \& H. Robinson.

Eupatorium paulinum Martius ex Baker, Fl. Bras. 6(2): 282. 1876, nom. nud. = Chromolaena squalida (DC.) R. King \& H. Robinson.

Eupatorium pauperatum H. B. K., Nov. Gen. Sp. 4: 95. Ed. Folio. 1818. = Lourteigia ballotaefolia (H. B. K.) R. King \& H. Robinson, ?

Eupatorium pauperculum A. Gray, Proc. Amer. Acad. Arts 17: 205. 1882. = Ageratina paupercula (A. Gray) R. King \& H. Robinson.

Eupatorium pavoniaefolium Schultz-Bip., Flora 33: 30. 1850 , nom. nud. = Symphyopappus decussatus Turcz.

Eupatorium pazcuarense H. B. K., Nov. Gen. Sp. 4:96. Ed. Folio. 1818. = Ageratina pazcuarensis (H. B. K.) R. King \& H. Robinson.

Eupatorium pectinatum Wallich, Num. List Dr. Pl. 3172. 1831, nom. nud. = Vernonia pectinata DC. VERNONIEAE.

Eupatorium pectinatum Raf., Atlantic J. 17. 1832, ignota.

Eupatorium pectinatum Small, Fl. S. E. U. S. 1165, 1338. 1903. = Eupatorium pinnatifidum Ellis.

Eupatorium pedale Schultz-Bip. ex Baker, Fl. Bras. 6(2): 295. 1876. = Chromolaena pedalis (Schultz-Bip. ex Baker) R. King \& H. Robinson.

Eupatorium pedunculosum Hook. \& Arn., Companion Bot. Mag. 1: 240. 1835.= Chromolaena pedunculosa (Hook. \& Arn.) R. King \& H. Robinson.

Eupatorium pedunculosum (DC.) A. Gray, PI. Wright. 1: 86. 1852, nom. illeg. = Phanerostylis pedunculosa (DC.) R. King \& H. Robinson.

Eupatorium pellium Klatt, Ann. K. K. Naturhist. Hofmus. 9: 357. 1894. = Chromolaena pellia (Klatt) R. King \& H. Robinson.

Eupatorium pellucidum H. B. K., Nov. Gen. Sp. 4: 84. Ed. Folio. 1818. = Critoniella acuminata (H. B. K.) R. King \& H. Robinson.

Eupatorium pelotrophum B. Robinson, Proc. Amer. Acad. Arts 42: 44. 1906. = Ageratina pelotropha (B. Robinson) R. King \& H. Robinson.

Eupatoritum pendulum Schrader, Ind. Sem. Hort. Acad. Gott. 76. 1830, Linnaea 6. Litt. 72.1831. = Brickellia pendula (Schrader) A. Gray.

Eupatorium peninsulare Brandegee, Erythea 7: 4. 1899. = Critonia peninsularis (Brandegee) R. King \& H. Robinson.

Eupatorium pennellii B. Robinson, Proc. Amer. Acad. Arts 54: 254. 1918. = Fleischmannia pennellii (B. Robinson) R. King \& H. Robinson.

Eupatorium penninervatum Wurd., Mem. New York Bot. Gard. 8: 145. 1953. = Guayania penninervata (Wurd.) R. King \& H. Robinson. 
Eupatorium pennivenium (B. Robinson) Steyerm., Fieldiana, Bot. 28(3): 636. 1953. = Neocabreria pennivenia (B. Robinson) $R$. King \& H. Robinson.

Eupatorium pentaflorum Larran., Escr. D. A. Larranaga 2: 251. 1923 , ignota.

Eupatorium pentanthum Schultz-Bip., Linnaea 22: 572. 1849 , nom. nud. = Raulinoreitzia crenulata (Sprengel) R. King \& H. Robinson.

Eupatorium pentlandianum DC., Prodr. 5: 157. 1836. = Ageratina pentlandiana (DC.) R. King \& H. Robinson.

Eupatorium perczioides B. Robinson, Proc. Amer. Acad. Arts $54: 255.1918 .=$ Bartlettina perezioides (B. Robinson) R. King \& H. Robinson.

Eupatorium perfoliatum L., Sp. PI. 838. 1753.

Eupatorium perforatum Schultz-Bip. ex Baker, Fl. Bras. 6(2): 289. 1876. = Chromolaena perforata (Schultz-Bip. ex Baker) R. King \& H. Robinson.

Eupatorium perglabrum B. Robinson, Contr. Gray Herb. 80: 28. 1928, = Chromolaena perglabra (B. Robinson) R. King \& H. Robinson.

Eupatorium pernambucense B. Robinson, Contr. Gray Herb. 90: 31. 1930, nom. nov. = Stomatanthes pernambucensis $(\mathrm{B}$. Robinson) H. Robinson.

Eupatorium perornatum Klatt, Leopoldina 20: 90. 1884. = Decachaeta perornata (Klatt) R. King \& H. Robinson.

Eupatorium perpetiolatum (R. King \& H. Robinson) L. O. Williams, Fieldiana, Bot. 36: 99. 1975. = Pseudokyrsteniopsis perpetiolata R. King \& H. Robinson.

Eupatorium perrinianum Sprengel, Syst. Veg. Fl. Peruv. Chil. 3: 412. 1826, ignota.

Eupatorium persicifolium H. B. K., Nov. Gen. Sp. 4: 130. Ed. Folio. 1818. = Aristegnictia persicifolia (H. B. K.) R. King \& H. Robinson.

Eupatorium petalodium Britton ex Small, Bull. Torrey Bot. Club 24: 492. 1897. = Eupatorium album L.

Eupatorium petaloideum Britton ex Small, Fl. S. E. U. S. 1168. 1903. = Eupatorium album L.

Eupatorium petasites Griseb., Ind. Sem. Hort. Acad. Gott. 8. 1877. = Bartlettina sordida (Less.) R. King \& H. Robinson.

Eupatorium petiolare Mocino \& Sesse ex DC., Prodr. 5: 166. 1836. = Ageratima petiolaris (Mocino \& Sesse ex DC.) R. King \& H. Robinson.

Eupatorium petraeum B. Robinson, Proc. Amer. Acad. Arts 41: 275. 1905. = Decachaeta ovatifolia (DC.) R. King \& H. Rob-

inson.
Eupatorium petrophilum B. Robinson, Contr. Gray Herb. 77: 27. 1926. = Austroeupatorium petrophilum (B. Robinson) R. King \& H. Robinson.

Eupatorium phanioides Urban \& Ekman, Ark. Bot. 23a(11): 54. 1931. = Koanophyllon phanioides (Urban \& Ekman) R. King \& H. Robinson.

Eupatorium pharcidodes B. Robinson ex Gleason, Bull. Torrey Bot. Club 58: 483. 1931. = Chromolaena pharcidodes (B. Robinson) R. King \& H. Robinson.

Eupatorium phlebodes B. Robinson, Contr. Gray Herb. 100: 16. 1932. = Trichogonia phlebodes (B. Robinson) R. King \& H. Robinson.

Eupatorium phlogifolium DC., Prodr. 5: 147. 1836. = Campo vassouria cruciata (Vell. Conc.) R. King \& H. Robinson.

Eupatorium phocnicolepis B. Robinson, Proc. Amer. Acad. Arts 35: 338. 1900. = Peteravenia phoenicolepis (B. Robinson) R. King \& H. Robinson.

Eupatorium phocnicticum B. Robinson, Proc. Amer. Acad. Arts 55: 26. 1919. = Hebeclinium phoenicticum (B. Robinson) R. King \& $\mathrm{H}$. Robinson.

Eupatorium photinum B. Robinson, Proc. Amer. Acad. Arts 35: 338. 1900. = Ageratina photina (B. Robinson) R. King \& H. Robinson.
Eupatorium phyllocephahum Klatt, Ann. K. K. Naturhist. Hofmus. 9: 358. 1894. = Chromolaena.

Eupatorium piauhyense Gardner, London J. Bot. 5: 472.1846 $=$ Raulinoreitzia crenulata (Sprengel) R. King \& H. Robinson. Eupatorium picardae Urban, Feddes Repert. 17: 51. 1921. = Koanophyllon picardae (Urban) R. King \& H. Robinson.

Eupatorium pichinchense H. B. K., Nov, Gen. Sp. 4: 95. Ed Folio. 1818. = Ageratina pichinchensis (H. B. K.) R. King \& H. Robinson.

Eupatorium pictum Gardner, London J. Bot. 6: 443. 1847. = Chromolaena picta (Gardner) R. King \& H. Robinson.

Eupatorium picturatum Malme. Kongl. Svenska Vetenskapsakad. Handl. 32(5): 41. 1899. = Austrocupatorium picturatum (Malme) R. King \& H. Robinson.

Eupatorium pilluanense Hieron. in Ule, Verh. Bot. Vereins Prov. Brandenburg 48: 201. 1907. = Ayapana pilluanensis (Hieron.) R. King \& H. Robinson.

Eupatorium pilosum Walter. Fl. Carol. 199. 1788.

Eupatorium pinabetense B. Robinson, Proc. Amer. Acad. Arts 36: 482. 1901. = Barlettina pinabetensis (B. Robinson) R. King \& H. Robinson.

Eupatorium pinctorum L. O. Williams \& A. Molina, Fieldiana. Bot. 36: 99(-100). 1975. = Critonia hebebotrya DC.

Eupatorium pinnangense V. Badillo, Bol. Soc. Venez. Ci. Nat. 10: 290. 1946. = Badilloa venezuelensis (V. Badillo) R. King \& H. Robinson.

Eupatorium pinnatifidum Ellis, Sketch Bot. S. Carolina 2: 295. 1822 ?.

Eupatorium pinnatifidum DC., Prodr. 5: 149. 1836. = Acanthostyles buniifolius (Hook. \& Am.) R. King \& H. Robinson.

Eupatorium piunatifissum Buek, Gen. Sp. Synon. Cand. 2: 5 . 1840. = Acanthostyles buniifolius (Hook. \& Am.) R. King \& H. Robinson.

Eupatorium pinnatipartitum Schultz-Bip. ex Baker, Fl. Bras. 6(2): 338. 1876. = Stomatanthes pinnatipartitus (Schultz-Bip. ex Baker) H. Robinson.

Eupatorium pinnatisectum Steudel, Nomencl. Bot. 1: 608. 1840. nom. nov, = Acanthostyles buniifolius (Hook. \& Am.) R. King \& H. Robinson.

Eupatorium pintobambense Cabrera, Revista Univ. (Cuzco) 33(87): 118-119. 1945. = Critonia?

Eupatorium piperitum Sesse \& Mocino, Fl. Mexic. (ed. 2) 182. 1894. = Ageratina glabrata (H. B. K.) R. King \& H. Robinson.

Eupatorium piptolepis Schultz-Bip. ex Baker, FI. Bras. 6(2): 346. 1876 , nom. nud. = Sicyermarkina pyrifolia (DC.) R. King \& H. Robinson.

Eupatorium piptopappum Schultz-Bip., Bull. Soc. Bot. France 12: 82. 1865, Linnaea 34: 535. Feb. 1866. ignota.

Eupatorium piquerioides DC., Prodr. 5: 175. 1836. = Ophryosportus piquerioides (DC.) Benth. ex Baker.

Eupatorium pithecobium B. Robinson, Contr. Gray Herb. 77: 28. 1926. = Neomirandea pithecobia (B. Robinson) R. King \& H. Robinson.

Eupatorium pitonianum Urban \& Ekman. Ark. Bot. 23a(11): 64 1931. = Koanophyllon pitonianum (Urban \& Ekman) R. King \& H. Robinson.

Eupatorium pittieri Klatt in T. Durand \& Pittier, Bull. Soc. Roy Bot. Belgique 31: 192. 1892. = Koanophyllon pittieri (Klatt) R. King \& H. Robinson.

Eupatorium piurae B. Robinson, Contr. Gray Herb. 77: 28. 1926. = Ageratina piurae (B. Robinson) R. King \& H. Robinson.

Eupatorium planellasianum Gomez \& Molt., Anales Hist. Nat. 19: 271. 1890. = Phania domingensis (Sprengel) Griseb.

Eupatorium platychaetum Urban, Notizbl. Bot. Gart. BerlinDahlem 8: 23. 1921. = Critonia platychacta (Urban) R. King \& H. Robinson.

Eupatorium platylepis Baker, Fl. Bras. 6(2): 355. 1876. = Dasycondy/us platylepis (Baker) R. King \& H. Robinson. 
Eupatorium platyphyllum B. Robinson, Proc. Amer. Acad. Arts 35: 339. 1900. = Bartlettina platyphylla (B. Robinson) R. King \& H. Robinson.

Eupatorium plectrauthifolium Benth. ex Oersted, Vidensk. Meddel. Dansk Naturhist. Foren. Kjobenhavn 76. 1852. = Fleischmannia plectranthifolia (Benth. ex Oersted) R. King \& H. Robinson.

Eupatorium pleianthum B. Robinson, Proc. Amer. Acad. Arts 36: 483, 1901. = Dyscritogyne dryophila (B. Robinson) R. King \& H. Robinson.

Eupatorium plethadeniuin Standley \& Steyerm., Publ. Field Mus. Nat. Hist., Bot. Ser. 23: 186. 1944. = Ageratina plethadenia (Standley \& Steyerm.) R. King \& H. Robinson.

Eupatorium plicatum Urban, Symb. Antill. 5: 523. 1908. = Koanophyllon tinctorium Arruda.

Eupatorium plucheoides Griseb., Mem. Amer. Acad. Arts 8: 511. 1863. = Grisebachianthus plucheoides (Griseb.) R. King \& H. Robinson.

Eupatorium plumeri Urban \& Ekman, Ark. Bot. 23a(11): 52. 1931. = Osmiopsis phumeri (Urban \& Ekman) R. King \& H. Robinson.

Eupatorium pluriseriatum B. Robinson, Proc. Amer. Acad. Arts 47: 195. 1911. = Urbanauthus pluriseriatus (B. Robinson) R. King \& H. Robinson.

Eupatorium podachaenium Schultz-Bip. ex Baker, Fl. Bras. 6(2): 356. 1876, nom. nud. = Campuloclinium purpurascens (SchultzBip. ex Baker) R. King \& H. Robinson.

Eupatorium poeppigii Sprengel, Syst. Veg. Fl. Peruv. Chil. 3: 415. 1826. = Koanophyllon villosum (Sw.) R. King \& H. Robinson, $?$

Eupatorium polant hum Klatt, Compos. Nov. Costaric. [Bot. Beibl. Leopoldina] 3. 1895. = Ageratina anisochroma (Klatt) R. King \& H. Robinson.

Eupatorium polopolense B. Robinson, Contr. Gray Herb. 61: 10. 1920. = Fleischmannia polopolensis (B. Robinson) R. King \& H. Robinson.

Eupatorium polyarthes Sprengel, Syst. Veg. Fl. Peruv. Chil. 3: 414. 1826. = Veruonia polyanthes (Sprengel) Less. VERNONIEAE.

Eupatorium polyanthes Less. ex Baker, Fl. Bras. 6(2): 258. 1876, nom. nud. = Mikania callineura Schultz-Bip. ex Baker.

Eupatorium polvanthum Wallich, Num. List Dr. PI. 3171.1831, nom. nud. = Vernonia divergens (DC.) Edgewood. VerNONIEAE.

Eupatorium polyanthum Schultz-Bip. ex Baker, Fl. Bras. 6(2): 279. 1876, nom. nud. = Chromolaena mucronata (Gardner) R. King \& H. Robinson.

Eupatorium polyathum Schultz-Bip. ex Baker, Fl. Bras. 6(2): 285. 1876. = Chromolaena ivaefolia (L.) R. King \& H. Robinson.

Eupatorium polybotryum DC., Prodr. 5: 174. 1836. = Decachaeta ovatifolia (DC.) R. King \& H. Robinson.

Eupatorium polycephalum Schultz-Bip. ex Baker, Fl. Bras. 6(2): 338. 1876, nom. nud. = Stomatanthes polycephalus (SchultzBip. ex B. Robinson) H. Robinson.

Eupatorium polycephalum Schultz-Bip. ex B. Robinson, Contr. Gray Herb. 77: 30. 1926. = Stomatanthes polycephalus (SchultzBip. ex B. Robinson) H. Robinson.

Eupatorium polycladum Dusen ex Malme, Kongl. Svenska Vetenskapsakad. Handl. 3. 12(2): 39. 1933. = Hatschbachiella polyclada (Dusen ex Malme) R. King \& H. Robinson.

Eupatorium polyneuron $\times($ F. J. Herm.) Wunderlin, Ann. Missouri Bot. Gard. 59: 472. 1972. = Eupatorium perfoliatum L. Eupatorium serotinum Michaux.

Eupatorium polyodon Urban, Symb. Antill. 1: 462. 1899. = Koanophyllon polyodon (Urban) R. King \& H. Robinson.

Eupatorium polystachyum Willd. ex Less., Linnaea 4: 283. 1829, nom. nud. = Vernonia canescens H. B. K. VernoniEAE.

Eupatorium polystachyum DC., Prodr. 5: 149. 1836. = Symphyopappus compressus (Gardner) B. Robinson.
Eupatorium polystictum Urban, Symb. Antill. 3: 400. 1903. = Koanophyllon polystictum (Urban) R. King \& H. Robinson.

Eupatorium pomaderrifolium Benth., Pl. Hartw. 199. 1845. = Ageratina asclepiadea (L. f.) R. King \& H. Robinson.

Eupatorium ponticum Pallas ex Georgi, Beschr. Russ. Reich. 8: 306. 1797-1802. = Eupatorium cannabinum L.

Eupatorium popayanense Hieron. in Urban, Bot. Jahrb. Syst. 40: 373. 1908. = Ageratina popayanensis (Hieron.) R. King \& H. Robinson.

Eupatorium popocatapetlense Schlechtend. ex Hemsley, Biol. Cent.-Amer., Bot. 2: 99. 1881, nom. nud. = Ageratina ligustrina (DC.) R. King \& H, Robinson.

Eupatorium populifolium H. B. K., Nov. Gen. Sp. 4: 87. Ed. Folio. 1818. = Critonia morifolia (Miller) R. King \& H. Robinson.

Eupatorium populifolium Hook. \& Arn., Companion Bot. Mag. 1: $242.1835 .=$ Urolepis hecatantha (DC.) R. King \& H. Robinson.

Eupatorium populifolium Martius, Flora 20, 2 Beibl. 105. 1837. = Hebeclinium macrophyllum (L.) DC.

Eupatorium porophylloides B. Robinson, Contr. Gray Herb. 68: 29. 1923. = Chromolaena porophylloides (B. Robinson) R. King \& H. Robinson.

Eupatorium porphyranthemum A. Gray, Proc. Amer. Acad. Arts 15: 27. 1880. = Fleischmannia porphyranthema (A. Gray) R. King \& H. Robinson.

Eupatorium porphyrocladum Urban \& Ekman, Ark. Bot. 23a(11): 56. 1931. = Koanophyllon porphyrocladum (Urban \& Ekman) R. King \& H. Robinson.

Eupatorium porphyrolepis Baker, Fl. Bras. 6(2): 280. 1876. = Chromolaena porphyrolepis (Baker) R. King \& H. Robinson.

Eupatorium porriginosum B. Robinson, Contr. Gray Herb. 75: 11. 1925. = Ageratina porriginosa (B. Robinson) R. King \& H. Robinson.

Eupatorium portoricense Urban, Symb. Antill. 1: 459. 1899. = Critonia portoricensis (Urban) Britton \& P. Wilson.

Eupatorium poterioides Schultz-Bip., Linnaea 22: 571 . 1849, nom. nud. = Sphaereupatorium scandens (Gardner) R. King \& H. Robinson.

Eupaiorium praefictum B. Robinson, Contr. Gray Herb. 68: 30. 1923. = Disynaphia praeficta (B. Robinson) R. King \& H. Robinson.

Eupatorium prasiifolium Griseb., Goett. Abh. 19: 119. 1874. = Fleischmannia prasiifolia (Griseb.) R. King \& H. Robinson.

Eupatorium pratense Klatt in T. Durand \& Pittier, Bull. Soc. Roy. Bot. Belgique 31: 193. 1892. = Fleischmannia pratensis (Klatt) R. King \& H. Robinson.

Eupatorium pringlei B. Robinson \& Greenman, Amer. J. Sci. Arts Ser. 3. 50: 152. 1895. = Ageratina pringlei (B. Robinson \& Greenman) R. King \& H. Robinson.

Eupatorium prinodes B. Robinson, Contr. Gray Herb. 77: 30. 1926. = Koanophyllon prinodes (B. Robinson) R. King \& H. Robinson.

Eupatorium prionobium B. Robinson, Proc. Amer. Acad. Arts 36: 483. 1901. = Ageratina prionobia (B. Robinson) R. King \& H. Robinson.

Eupatorium prionophyllum B. Robinson, Proc. Amer. Acad. Arts 36: 484. 1901. = Bartlettilta prionophylla (B. Robinson) R. King \& H. Robinson.

Eupatorium probum N. E. Br., Gard. Chron. ser. 3. 7: 321. Fig. 48. 1890. = Ageratina proba (N. E. Br.) R. King \& H. Robinson.

Eupatorium procerum B. Robinson, Contr. Gray Herb. 73: 17. 1924. = Badilloa procera (B. Robinson) R. King \& H. Robinson.

Eupatorium propinquum DC., Prodr. 5: 146. 1836. = Chromolaeula laevigata (Lam.) R. King \& H. Robinson.

Eupatorium prunellaefolium H. B. K., Nov. Gen. Sp. 4: 96. Ed. 
Folio. 1818. = Ageratina prumellaefolia (H. B. K.) R. King \& H. Robinson.

Eupatorium prunifolium H. B. K., Nov. Gen. Sp. 4: 104. Ed. Folio. 1818. = Ageratina prunifolia (H. B. K.) R. King \& H. Robinson.

Eupatorium pseudarboreum Hieron., Bot. Jahrb. Syst. 36: 469. 1905. = Aristeguietia pseudarborea (Hieron.) R. King \& H. Robinson.

Eupatorimm pseudo-dalea (DC.) Gomez \& Molt., Anales Hist. Nat. 19: 272. 1890. = Critonia pseudo-dalea DC.

Eupatorium pseudo-hirsutum Hieron., Bot. Jahrb. Syst. 22: 758. 1897, nom. nov. = Ageratina liebmannii (Schultz-Bip. ex Klatt) R. King \& H. Robinson.

Eupatorium pseudo-prasiifolium Hassler, Feddes Repert. 16: 25. 1919, nom. nov. = Chacoa pseudo-prasiifolia $($ Hassler) R. King \& H. Robinson.

Eupatorium pseudochilca Benth., Pl. Hartw. 198. 1845. = Ageratina pseudochilca (Benth.) R. King \& H. Robinson.

Eupatorium pseudofastigiatum Hieron., Bot. Jahrb. Syst. 36: 467. 1905. = Ageratina exserto-venosa (Klatt) R. King \& H. Robinson.

Eupatorium pseudoglomeratum Hieron. in Sodiro, Bot. Jahrb. Syst. 29: 8. 1900. = Asplundianthus pseudoglomeratus(Hieron. in Sodiro) R. King \& H. Robinson.

Eupatorium psendolaeve Soares Nunes, Bradea 3: 130(-131). 1981. = Santosia talmonii R. King \& H. Robinson.

Eupatorium pseudoperfoliatum Schultz-Bip. ex Klatt, Leopoldina 20: 75. 1884. = Koanophyllon pseudoperfoliata (Schultz-Bip. ex Klatt) R. King \& H. Robinson.

Eupatorium pseudopraxelis Hieron. in Ule, Verh. Bot. Vereins Prov. Brandenburg 48: 200. 1907. = Praxelis asperulacea $($ Baker) R. King \& H. Robinson.

Eupatorium pseudoriganoides Hieron, in Sodiro, Bot. Jahrb. Syst. 29: 10. 1900. = Cronquistianthus pseudoriganoides (Hieron.) R. King \& H. Robinson.

Eupatorium psiadiaefolium DC., Prodr. 5: 144. 1836. = Chromolaena laevigata (Lam.) R. King \& H. Robinson.

Eupatorium psilodorum B. Robinson, Proc. Amer. Acad. Arts 55: 27. 1919. = Ageratina psilodora (B. Robinson) R. King \& H. Robinson.

Eupatorium psoraleum B. Robinson, Proc. Boston Soc. Nat. Hist. 31:253. 1904. = Neomirandea psoralea (B. Robinson) R. King \& H. Robinson.

Eupatorium ptaretepuiense V. Badillo, Bol, Soc. Venez. Ci. Nat. 10:291. 1946. = Ageratina ibaguensis (Schultz-Bip. ex Hieron.) R. King \& H. Robinson.

Eupatorium pteropodum Hieron. in Sodiro, Bot. Jahrb. Syst. 29: 15. 1900. = Polyanthina nemorosa (Klatt) R. King \& H. Robinson.

Eupatorium puberulum DC., Prodr. 5: 172. 1836. = Koanophyllon puberulum (DC.) R. King \& H. Robinson.

Eupatorium pubescens Muhlenb. ex Willd., Sp. PI. 3: 1755. 1804. $=$ Eupatorium rotundifolium $\mathrm{L}$.

Eupatorium pubescens Wallich ex DC., Prodr. 6: 281. 1837, nom. nud. = Carpesium glossophyllum Maxim. INULEAE.

Eupatorium pulchellum H. B. K.. Nov. Gen. Sp. 4: 93. Ed. Folio. 1818. = Chromolaena pulchella (H. B. K.) R. King \& H. Robinson.

Eupatorium pulchrum Gardner, London J. Bot. 6: 444. 1847. = Chromolaena stachyophylla (Sprengel) R. King \& H. Robinson.

Eupatorium pumilum Wender., Schriften Ges. Beford. Gesammten Naturwiss. Marburg 2: 262. 1831, ignota.

Eupatorium pumilum (Gardner) B. Robinson, Contr. Gray Herb. 68: 30. 1923. = Heterocondylus pumilus (Gardner) R. King \& H. Robinson.

Eupatorium punctatum Miller, Gard. Dict, ed. 8, 11. $1768 .=$ Porophyllum punctatum (Miller) Blake. HeliantheaE.
Eupatorium punctatum Lam., Encycl. 2: 408. 1788. = Chromolaena mononeura (Urban) R. King \& H. Robinson.

Eupatorium punctatum Willd, Enum. Pl. Hort. Berol. 853. 1809. = Eupatorium dubium Willd. ex Poiret.

Eupatorium punctatum Miq., Linnaea 17:66. 1843. = Eupatorium purpureum $\mathrm{L}$.

Eupatorium punctulatum DC., Prodr. 5: 147. 1836. = Chromolaena punctulata (DC.) R. King \& H. Robinson.

Eupatorium punduanum Wallich ex DC., Prodr. 5: 179. 1836. = Eupatorium cannabinum L., ?

Eupatorium pungens Gardner, London J. Bot. 5: 474. 1846. = Chromolaena pungens (Gardner) R. King \& H. Robinson.

Eupatorium purpurascens Schultz-Bip. ex Baker, Fl. Bras. 6(2): 356. $1876 .=$ Campuloclinium purpurascens (Schultz-Bip. ex Baker) R. King \& H. Robinson.

Eupatorium purpureum L., Sp. Pl. 838. 1753.

Eupatorium purpureum Lour., Fl. Cochinch. 487. 1790. = Eupatorium quaternum $\mathrm{DC}$.

Eupatorium purpusi Brandegee, Erythea 7: 3. 1899. = Ageratina purpusii (Brandegee) R. King \& H. Robinson.

Eupatorium pycnocephaloides B. Robinson, Proc. Amer. Acad. Arts 51: 534. 1916. = Fleischmannia pycnocephaloides $(\mathrm{B}$. Robinson) R. King \& H. Robinson.

Eupatorium pycnocephalum Less., Linnaea 6: 404. 1831. = Fleischmannia pycnocephala (Less.) R. King \& H. Robinson.

Eupatorium pyramidale D. Don, Prodr. Fl. Nepal. 170. 1825. = Vernonia aspera (Roxb.) Ham. VernONIEAE.

Eupaiorium pyramidale Klatt, Abh. Naturf. Ges. Halle 15: 323. 1882. = Ayapana stenolepis (Steetz) R. King \& H. Robinson.

Eupatorium pyrifoliu in DC., Prodr. 5: 153. 1836. = Steyermarkina pyrifolia (DC.) R. King \& H. Robinson.

Eupatorium quadrangulare DC., Prodr. 5: 150.1836. = Critonia quadrangularis (DC.) R. King \& H. Robinson.

Eupatorium quadriflorum Larran., Escr. D. A. Larranaga 2: 251. 1923, ignota.

Eupatorium quasitripartitum Hayata, Icon. PI. Formosan. 8: 44. 1919. = Eupatorium formosamum Hayata.

Eupatorium quaternum DC., Prodr. 5: 183. 1836.

Eupatorium quercetorum L. O. Williams, Fieldiana, Bot. 36: 101(102). 1975. = Chromolaena quercetorum (L. O. Williams) R. King \& H. Robinson.

Eupatorium quinqueflorum Urban \& Ekman, Ark. Bot. 23a(11): 57. 1931. = Eupatorium mohrii E. Greene.

Eupatorium quinquesetosum Hemsley, Biol. Cent.-Amer., Bot. 2: 90.1881 . = Fleischmannia arguta $($ H. B. K.) B. Robinson.

Eupatorium quinquesetum Benth. ex Oersted, Vidensk. Meddel. Dansk Naturhist. Foren. Kjobenhavn 79. 1852. = Fleischmannia arguta (H. B. K.) B. Robinson.

Eupatorium quintuplinerve Less. ex Baker, Fl. Bras. 6(2): 240. 1876, nom. nud. = Mikania trinervis Hook. \& Am.

Eupatorium quisqueyanum Alain, Moscosoa 1(1): 48-49. 1976. = Koanophyllon quisquejanum (Alain) R. King \& H. Robinson.

Eupatorium racemosum Bertol., Misc. Bot. 6: 26. 1845?. = Eupatorium compositifolium Walter.

Eupatorium racemosum Schultz-Bip. ex Baker, F. Bras. 6(2): 339. 1876, nom. nud. = Stomatamthes polycephalus (SchultzBip. ex B. Robinson) H. Robinson.

Eupatorium radula Chodat. Bull. Herb. Boissier Ser. 2. 2: 311. 1902. = Disynaphia radula (Chodat) R. King \& H. Robinson. Eupatorium rafaelense Coulter, Bot. Gaz. (Crawfordsville) 16: 97. 1891. = Ageratina mairetiana (DC.) R. King \& H. Robinson.

Eupatorium raffllii Hemsley, Bot. Mag. 8227. 1908. = Bartlettina sordida (Less.) R. King \& H. Robinson.

Eupatorium ramboi Cabrera, Sellowia 15:207. 1963. = Barrosoa ramboi (Cabrera) R. King \& H. Robinson.

Eupatorium ramonense B. Robinson, Proc. Amer. Acad. Arts 
44: 619. 1909. = Ageratina ramonensis (B. Robinson) R. King \& H. Robinson.

Eupatorium ramosissimum Gardner, London J. Bot. 6: 441. 1847. = Chromolaena squalida (DC.) R. King \& H. Robinson.

Eupatorium ramosum Miller, Gard. Dict, ed. 8, 13. $1768 .=$ Eupatorium altissimum L.

Eupatorium ranunculifolium (Rich. ex Sagra) M. Gomez, Anales Hist. Nat. 19: 270. 1890. = Mikania ranunculifolia Rich. ex Sagra.

Eupatorium rapunculoides (DC.) B. Robinson, Proc. Amer. Acad. Arts 42: 45. 1906. = Steviopsis rapunculoides (DC.) R. King \& H. Robinson.

Eupatorium rebaudianum Bertoni, Revista Agron. Asuncion 2: 35. 1899. Stevia rebaudiana (Bertoni) Bertoni.

Eupatorium recreense Hieron. in Urban, Bot. Jahrb. Syst. 40: 389. 1908. = Hebeclinium rereense (Hieron. in Urban) R. King \& H. Robinson.

Eupatorium recurvans Small, Fl. S. E. U. S. 1167, 1338. 1903. = Eupatorium mohrii E. Greene.

Eupatorium reevesii Wallich ex DC., Prodr. 5: 179. 1836. Eupatorium squamosum D. Don.

Eupatorium reflexum Moench, Suppl. Meth. 234. 1802. = Blumea chinensis (L.) DC. INULEAE.

Eupatorium regnellii Schultz-Bip., Linnaea 30: 182. 1859-1860, nom. nud. = Dasycondy/us regnellii $\mathrm{R}$. King \& H. Robinson.

Eupatorium reitzii Cabrera, Sellowia 15: 191. 1963, nom. nov. = Symphyopappus reitzii (Cabrera) R. King \& H. Robinson.

Eupatorium remotifolium DC., Prodr. 5: 165. 1836. = Fleischmannia remotifolia (DC.) R. King \& H. Robinson.

Eupatorium remyanum Philippi, Fl. Atacam. 29. 1860. = Ageratina remyana (Philippi) R. King \& H. Robinson.

Eupatorium repandum Willd., Sp. Pl. 3: 1767. 1804. = Chromolaena corymbosa (Aublet) R. King \& H. Robinson.

Eupaiorium resinifluum Urban, Symb. Antill. 1: 461 . 1899. = Ageratina resiniflıa (Urban) R. King \& H. Robinson.

Eupatorium resinosum Torrey ex DC., Prodr. 5: 176. 1836.

Eupatorium resinosum Poeppig \& Endl., Nov. Gen. Sp. 3: 54. 1845. = Chromolaena laevigata (Lam.) R. King \& H. Robinson.

Eupatorium reticulatum Desv., Prodr. Pl. Ind. Occid. 51. 1825, ignota, branches pentagonal.

Eupatorium reticulatum Hook. \& Arn., Bot. Beechey Voy. 29. 1830. = Aristeguietia salvia (Colla) R. King \& H. Robinson.

Eupatorium reticulatum A. Rich. in Sagra, Hist. Fis. Cuba, Bot. 3: 39. 1853. = Grisebachianthus libanotica (Schultz-Bip.) R. King \& H. Robinson.

Eupatorium reticuliferum (as reticuliforum) Standley \& L. O. Williams, Ceiba 1: 254. 1951. = Ageratina reticulifera (Standley \& L. O. Williams) R. King \& H. Robinson.

Eupatorium reticulosum (C. Wright) Molinet \& M. Gómez, Dicc. Bot. Nom. Vulg. Cub. Pue.-Riq. 55. 1889. = Mikania reticulosa Wright.

Eupatorium retifolium Schultz-Bip., Flora 33: 30. 1850, nom. nud. = Mikania sessilifolia DC.

Eupatorium retrofractum Thunb., Prodr. Pl. Cap. 142. 1800. = Pegolettia retrofracta (Thunb.) Kies. InULEAE.

Eupatorium reversuin Urban, Arch. Bot. 17(7): 64. 1922.=Koanophyllon reversum (Urban) R. King \& H. Robinson.

Eupatorium revolutum Gardner, London J. Bot. 6: 444. 1847. = Chromolaena revoluta (Gardner) R. King \& H. Robinson.

Eupatorium revolutum Pohl ex Baker, Fl. Bras. 6(2): 314. 1876, nom. nud. = Ayapana stenolepis (Steetz) R. King \& H. Robinson, ?

Eupatorium rhexioides B. Robinson, Proc. Amer. Acad. Arts 51: 535. $1916 .=$ Koanophyllon rhexioides (B. Robinson) R. King \& H. Robinson.

Eupatorium rhinanthaceum DC., Prodr. 5: 146. 1836. = Chromolaena rhinanthacea (DC.) R. King \& H. Robinson.
Eupatorium rhodanthum Schultz-Bip. ex Baker, Fl. Bras. 6(2): 314. 1876 , nom. nud. = Ayapana amygdalina $($ Lam.) R. King \& H. Robinson.

Eupatorium rhodochlamydeum A. Gray, Proc. Amer. Acad. Arts 15:26. 1880. = Peteravenia rhodochlamydea (A. Gray) R. King \& H. Robinson.

Eupatorium rhodolaenum Hieron. in Urban, Bot. Jahrb. Syst. 40: 369. 1908. = Austrobrickellia patens (Don ex Hook. \& Arn.) R. King \& H. Robinson.

Eupatorium rhodolepis Chodat, Bull. Herb. Boissier Ser. 2. 3: 705. 1903. = Chromolaena verbenacea (DC.) R. King \& H. Robinson.

Eupatorium rhodopappum B. Robinson, Contr. Gray Herb. 77: 31. 1926. = Ageratina rhodopappa (B. Robinson) R. King \& H. Robinson.

Eupatorium rhodopodum B. Robinson, Contr. Gray Herb. 75: 12. 1925. = Ageratina rhodopoda (B. Robinson) R. King \& H. Robinson.

Eupatorium rhodotephrum B. Robinson, Contr. Gray Herb. 77: 32. 1926. = Fleischmannia rhodotephra (B. Robinson) R. King \& H. Robinson.

Eupatorium rhodotrichum Dusen ex Malme, Kongl. Svenska Vetenskapsakad. Handl. 3. 12(2): 30. 1933, nom. nud. = Trichogonia rhodotricha Malme.

Eupatorium rhomboideum H. B. K., Nov. Gen. Sp. 4: 99. Ed. Folio. 1818. = Ageratina rhomboidea $($ H. B. K.) R. King \& H. Robinson.

Eupatorium rhypodes B. Robinson, Proc. Amer. Acad. Arts 55: 28. 1919. = Ageratina rhypodes (B. Robinson) R. King \& H. Robinson.

Eupatorium rhytidodes B. Robinson, Contr. Gray Herb. 77: 33. 1926. = Ageratina rhytidodes (B. Robinson) R. King \& H. Robinson.

Eupatorium riedelianum Gardner, London J. Bot. 5: 478.1846. = Ophryosporus freyreysii (Thunb. \& Dallm.) Baker.

Eupatorium riedelii Baker, F. Bras. 6(2): 355. 1876. = Campuloclinium riedelii (Baker) $\mathrm{R}$. King \& H. Robinson.

Eupatorium rigidulum Miq., Ann. Mus. Bot. Lugduno-Batavum 2: 167. 1866. = Pertya rigidula (Miq.) Makino. MutisieAE.

Eupatorium rigidum Sw., Prodr. 111. 1788. = Chromolaena rigida (Sw.) R. King \& H. Robinson.

Eupatorium rigidum Wallich, Num. List Dr. Pl. 2925. 1831, nom. nud. = Vernonia teres Wallich ex DC. VernONIEAE.

Eupatorium rigidum Benth., PI. Hartw. 88. 1841. = Brickellia paniculata (Miller) B. Robinson.

Eupatorium rimbachii B. Robinson, Contr. Gray Herb. 96: 21. 1931. = Grosvenoria rimbachii (B. Robinson) R. King \& H. Robinson.

Eupatoriltm riparium Regel, Gartenflora 15: 324. T.525. 1866. = Ageratina riparia (Regel) R. King \& H. Robinson.

Eupatorium rivale Greenman, Zoe 5: 186. 1904. = Ageratina rivalis (Greenman) R. King \& H. Robinson.

Eupatorium rivulorum B. Robinson, Contr. Gray Herb. 77: 34. 1926, = Fleischmannia rivulorum (B. Robinson) R. King \& H. Robinson.

Eupatorium roanense Small, Man. S. E. F1. 1326. 1933. = Ageratina alissima (L.) R. King \& H. Robinson.

Eupatorium robinsonianum E. Greene, Erythea 1: 150. 1893. = Ageratina espinosarum (A. Gray) R. King \& H. Robinson.

Eupatorium robustum Glaz., Bull. Soc. Bot. France Mem. 3. 56: 384. 1909, nom. nud. = Brasilia sickii G. Barroso. HELIANTHEAE.

Eupatorium rojasianum Standley \& Steyerm., Publ. Field Mus. Nat. Hist., Bot. Ser. 23: 188. 1944. = Fleischmannia pycnocephala (Less.) R. King \& H. Robinson.

Eupatorium rojasii Hassler, Feddes Repert. 11: 168. 1912. = Chromolaena rojasii (Hassler) R. King \& H. Robinson.

Eupatorium roraimense N. E. Br., Trans. Linn. Soc. London, 
Bot. 2. 6: 38. 1901. = Ageratina roraimensis (N. E. Br.) R. King \& H. Robinson.

Eupatorium rorule llum B. Robinson, Proc. Amer. Acad. Arts 54: 255. 1918. = Ageratina elegans (H. B. K.) R. King \& H. Robinson.

Eupatorium rosalesia DC., Prodr. 5: 183. 1836. = Brickellia glandulosa (Llave in Llave \& Lex.) McVaugh.

Eupatorium roseorum B. Robinson, Proc. Amer. Acad. Arts 55: 29. 1919. = Chromolaena roseorum (B. Robinson) R. King \& H. Robinson.

Eupatorium roseum Gardner, London J. Bot. 4: 116. 1845. = Austrocritonia rosea (Gardner) R. King \& H. Robinson.

Eupatorium roseum Klatt in T. Durand \& Pittier, Bull. Soc. Roy. Bot. Belgique 31: 194. 1892. = Fleischmannia pratensis $($ Klatt) R. King \& H. Robinson.

Eupatorium rosmarinaceum Cabrera \& Vittet, Sellowia 15: 195. 1963, nom. nov. = Austroeupatorium rosmarinaceum (Cabrera \& Vittet) R. King \& H. Robinson.

Eupatoriuın rosmarinifolium Labill., Nov. Holl. Pl. 2: 38. 1806. = Helichrysum rosmarinifolium (Labill.) Less. INULEAE.

Eupatorium rosmarinifolium Schultz-Bip. ex Baker, Fl. Bras. 6(2): 319. 1876, nom. nud. = Austroeupatorium rosinarinaceum (Cabrera \& Vittet) R. King \& H. Robinson.

Eupatorium rosmarinifolium Sesse \& Mocino, Pl. Nov. Hisp. 133. 1889, Naturaleza (Mexico City), ser. 2(1): 124. App. Ed. 2. 1893. = Brickellia scoparia (DC.) A. Gray,?

Eupatorium rothrockii A. Gray, Syn. FI. N. Amer. 1(2): 102. 1884. = Ageratina rothrockii (A. Gray) R. King \& H. Robinson. Eupatorium rotundifolium L., Sp. Pl. 837. 1753.

Eupatorium rolundifolium Fern., Rhodora 45: 477. 1943. = Eupatorium rotundifolium $\mathrm{L}$.

Eupatorium roupalifolium B. Robinson, Proc. Amer. Acad. Arts 55: 30. 1919. = Guayania roupalifolia (B. Robinson) R. King \& H. Robinson.

Eupatoriutn ruae Standley, Ceiba 1: 49. 1950. = Barlettina pansamalensis (B. Robinson) R. King \& H. Robinson.

Eupatorium rubricaule H. B. K., Nov. Gen. Sp. 4: 97. Ed. Folio. 1818. = Ageratina rubricaulis (H. B. K.) R. King \& H. Robinson.

Eupatorium rubroviolaceum Urban \& Ekman, Ark. Bot. 23a(11): 62. 1931. = Koaliophyllon rubroviolaceun (Urban \& Ekman) R. King \& H. Robinson.

Eupatorium rufescens Lund ex DC., Prodr. 5: 168. 1836. = Kannia rufescens (Lund ex DC.) R. King \& H. Robinson.

Eupatorium rufidulum Hook. \& Arn., Companion Bot. Mag. 1: 243. 1835, ignota.

Eupatorium rufum Sprengel ex DC., Prodr. 5: 33. 1836. = VernOIIIa extellsa DC. VERNONIEAE.

Eupatorium rugosmu Houtt., Nat. Hist. 2 10: 558. 1779. = Ageratina altissima (L.) R. King \& H. Robinson.

Eupatorium rugosum H. B. K., Nov. Gen. Sp. 4: 89. Ed. Folio. 1818 . = Cronquistianthus bulliferus (Blake) R. King \& H. Robinson.

Eupatorium rıgosum Sprengel, Neue Entd. 3: 39. 1822, = Eupatorium sprengelianum DC., ignota.

Eupatorium rugosun Schrader ex DC., Prodr. 5: 174. 1836. = Ageratina liebmannii (Schultz-Bip. ex Klatt) R. King \& H. Robinson, ?

Eupatorium rupestre Raf., Atlantic J. 17. 1832. = Eupatorium altissimum $\mathrm{L}$.

Eupatorium rupestre Gardner, London J. Bot. 5: 474. 1846. = Gyinnocondylus galeopsifolius (Gardner) R. King \& H. Robinson, ?

Eupatorium rupicola B. Robinson \& Greenman, Proc. Amer. Acad. Arts 32: 42. 1896, = Ageratina rupicola (B. Robinson \& Greenman) R. King \& H. Robinson.

Eupatorium rusbyi Britton, Bull. Torrey Bot. Club 18: 334.1891. $=$ Polyamhina nemorosa (Klatt) R. King \& H. Robinson.
Eupatoriıun rydbergt Britton, Man. F. N. States 921. 1901. = Eupatorium inaculatum L.

Eupatoriun! sabeanum Buckley, Proc. Acad. Nat. Sci. Philadelphia 13: 456. 1861. = Chromolaena odorata (L.) R. King \& H. Robinson.

Eupatoriım sachalinense (F. Schmidt) Makino, Bot. Mag. (Tokyo) 23: 90. 1909, noin. nov. = Eupatorium chinense L.

Eupatorium sagittatum A. Gray, PI. Wright. 1: 88. 1852. = Chromolaena sagittata (A. Gray) R. King \& H. Robinson.

Eupatorium sagittiferum B. Robinson, Contr, Gray Herb. 65: 52. 1922. = Chromolaena sagittifera (B. Robinson) R. King \& H. Robinson.

Eupatorium salicinum Lam., Encycl. 2: 409. 1786. = Badilloa salicina (Lam.) R. King \& H. Robinson.

Eupatorium salinum Standley \& Steyerm., Publ. Ficld Mus. Nat. Hist., Bot. Ser. 23: 188. 1944. = Ageratina prunellaefolia (H. B. K.) R. King \& H. Robinson.

Eupatoriunl saltense Hieron., Bot. Jahrb. Syst. 22: 786. 1897. = Kaunia saltensis (Hieron.) R. King \& H. Robinson.

Eupatorium saltillense 13. Robinson, Proc. Amer. Acad. Arts 43: 34. 1907. = Ageratina saltillensis (B. Robinson) R. King \& H. Robinson.

Eupatoriull saltivarii Schultz-Bip. ex B. Robinson \& Seaton, Proc. Amer, Acad. Arts 28: 108. 1893. = Ageratina prunellaefolia (H. B. K.) R. King \& H. Robinson.

Eupatorium saltuense Fern., Rhodora 44: 461. 1942. = Eupatorium altissimum L.

Eupatorium sahıberrimum Larran., Escr. D. A. Larranaga 2: 251. 1923, ignota.

Eupatorium salvia Colla, Mem. Reale Acc. Sci. Torino 38: 8. 1835. = Aristeguietia salvia (Colla) R. King \& H. Robinson.

Eupatorium salviaefolium H. B. K.. Nov. Gen. Sp. 4: 102. Ed. Folio. 1818. = Aristeguietia dielsii (B. Robinson) R. King \& H. Robinson.

Eupatoriunt salviaefolium Sims, Bot. Mag. 45: 2010. 1818. = Eupatorium perfoliatum L.

Eupatorium salvifolium Balbis ex Sprengel, Neue Entd. 3: 40. 1822 , ignota.

Eupatorium salvifolium Bertero ex Sprengel, Syst. Veg. 3: 412. 1826. nom. nud. = Koanophyllon puberulum (DC.) R. King \& H. Robinson.

Eupatorium salvifolium Kunth ex Sprengel, Syst. Veg. Fl. Peruv. Chil. 3: 412. 1826. = Aristeguietia dielsii (B. Robinson) R. King \& $\mathbf{H}$. Robinson.

Eupatoriuın salzmannianum DC., Prodr. 5: 159. 1836. = Ayapana alnygdalina (Lam.) R. King \& H. Robinson.

Eupatorium sambucifolium Elmer, Leaf. Philipp. Bot. 1: 102. 1906.

Eupatorium sampaionis Herter ex Samp., Arq. Mus. Nac. Rio de Janeiro 18: 15,33. 1916, nom. nud. ignota.

Eupatorium sanctopaulense B. Robinson, Contr. Gray Herb. 68 : 32. 1923. = Chromolaena sanctopaulensis (B. Robinson) R. King \& H. Robinson.

Eupatorium santacruzense Hieron., Bot. Jahrb. Syst. 22: 762. 1897. = Lorentzianthus viscidus (Hook. \& Arn.) R. King \& H. Robinson.

Eupatorium santanense Aristeg., Acta Bot. Venez. 3: 45.1968. = Chromolaena santanensis (Aristeg.) R. King \& H. Robinson.

Eupatorium sartorii Schultz-Bip. ex Klatt, Leopoldina 20: 91. 1884, nom. nud. = Critonia morifolia (Miller) R. King \& H. Robinson.

Eupatoriun satureiaefoliuu (Lam.) Lam., Encycl. 2: 411. 1786. = Stevia satureifolia Lam.

Eupatorium saucechicoense Hieron., Bot. Jahrb. Syst. 22: 775. 1897. = Acauthostyles saucechicoensis (Hieron.) R. King \& H. Robinson.

Eupatorium saxatile Larran., Escr. D. A. Larranaga 2: 251. 1923, ignota. 
Eupatorium saxorum Standley \& Steyerm., Publ. Field Mus. Nat. Hist., Bot. Ser. 23: 189. 1944. = Fleischmannia saxorum (Standley \& Steyerm.) R. King \& H. Robinson.

Eupatorium scaberrimum Walp., Linnaea 14: 505. 1840. = Chromolaena stachyophylla (Sprengel) R. King \& H. Robinson.

Eupatorium scabrellum B. Robinson, Proc. Amer. Acad. Arts 35: 339. 1900. = Decachaeta scabrella (B. Robinson) R. King \& H. Robinson.

Eupatorium scabridum Ellis, Sketch Bot. S. Carolina 2: 299. 1822?. $=$ Eupatorium rotundifolitum L.

Eupatorium scabrifolium B. Robinson, Contr. Gray Herb. 77: 36. 1926. = Asplundianthus scabrifolius (B. Robinson) R. King \& H. Robinson.

Eupatoritmm scabriusculum Urban \& Ekman, Ark. Bot. 23a(11): 59. 1931. = Koanophyllon scabriusculum (Urban \& Ekman) R. King \& H. Robinson.

Eupatorium scabrum L. f., Suppl. P1. 354. 1781. = Chromolaena scabra (L. f.) R. King \& H. Robinson.

Eupatorium scandens L., Sp. Pl. 836. 1753. = Mikania scandens (L.) Willd.

Eupatorium scandens Thunb., Prodr. Pl. Cap. 142. 1800. $=\mathrm{Mi}$ kania capensis DC.

Eupatorium scandens Link, Enum. Hort. Berol. Alt. 2: 307. 1821 1822. = Senecio delioideus Less. SenecioneaE.

Eupatorium scandens Hook. \& Am., Companion Bot. Mag. 1: 242. 1835. = Mikania lagoensis Baker.

Eupatorium scariosum Wallich ex DC., Prodr. 5: 138. 1836, nom. nud. = Brickellia pendula (Schrader) A. Gray.

Eupatorium schaffneri Schultz-Bip. ex Hemsley, Biol. Cent.Amer., Bot. 2: 100. 1881, publ. inval. = Ageratina schaffneri (Schultz-Bip. ex B. Robinson) R. King \& H. Robinson.

Eupatorium schaffneri Schultz-Bip. ex B. Robinson, Proc. Amer. Acad. Arts 27: 171. 1892. = Ageratina schaffneri (Schultz-Bip. ex B. Robinson) R. King \& H. Robinson.

Eupatoriutm schickendantzii Hieron., Bot. Jahrb. Syst. 22: 769. 1897. = Fleischmannia schickendantzii (Hieron.) R. King \& H. Robinson.

Eupatorium schiedeanoides Schultz-Bip. ex A. Gray, Rep. U. S. Mex. Bound., Bot. 76. 1859, nom. nud. = Fleischmannia pycnocephala (Less.) R. King \& H. Robinson.

Eupatorium schiedeanum Schrader, Ind. Sem. Hort. Acad. Gott. 3. 1832, Linnaca 8. Litt. 26. 1833. = Fleischmannia pycnocephala (Less.) R. King \& H. Robinson.

Eupatorium schimperianum Scheele, Linnaea 18: 458. 1844, = ignota. INULEAE.

Eupatorintm schininii Cabrera, Darwiniana 20: 411(-413). 1976, affinity Ayapanopsis esperanzae (Hassler) R. King \& H. Robinson.

Eupatorium schizanthum Griseb., Fl. Brit. W. I. 361. 1861. = Ageratina .

Eupatoritm schlechtendalii DC., Prodr. 7: 269. 1838. = Dasycondylus resinosus (Sprengel) R. King \& H. Robinson.

Eupatorium schomburgkii Benth., J. Bot. (Hooker) 2: 41. 1840, ignota.

Eupatorium schraderi DC., Prodr. 5: 174. 1836. = Ageratina liebmannii (Schultz-Bip. ex Klatt) R. King \& H. Robinson, ?

Eupatorium schultzii Schnittsp.. Z. Gartenbau (Darmstadt) 6 1857. = Peteravenia schultzii (Schnittsp.) R. King \& H. Robinson.

Eupatorium sciaphilum B. Robinson, Proc. Amer. Acad. Arts 54: 256. 1918. = Neomirandea sciaphila(B. Robinson) R. King \& H. Robinson.

Eupatorium sciatraphes B. Robinson, Proc. Amer. Acad. Arts 54: 257. 1918. = Koanophyllon sciatraphes (B. Robinson) R. King \& H. Robinson.

Eupatoriurn scoparioides L. O. Williams, Fieldiana, Bot. 36: 102(103). 1975. = Koanophyllon solidaginoides (H. B. K.) R. King \& H. Robinson.
Eupatorium scopulorum Wedd., Chlor. And. 1: 216. 1857. = Ageratina scopulorum (Wedd.) R. King \& H. Robinson.

Eupatorium scorodonioides A. Gray, Proc. Amer. Acad. Arts 15: 27. 1880. = Ageratina scorodonioides (A. Gray) R. King \& H. Robinson.

Eupatorium secundiflorum Lagasca, Gen. Sp. Pl. 25. 1816. = Brickellia secundiflora (Lagasca) A. Gray.

Eupatorium secundiflorum Bertero ex DC., Prodr. 5: 48. 1836, nom. nud. = Vernonia arborescens Sw. VERNONIEAE.

Eupatorium selerianum B. Robinson, Proc. Amer. Acad. Arts 35: $340.1900 .=$ Fleischmannia seleriana (B. Robinson) R. King \& H. Robinson.

Eupatorium selleanum Urban, Feddes Repert. 17: 9. 1921. = Koanophyllon selleanum (Urban) R. King \& H. Robinson.

Eupatorium selleanum Urban, Ark. Bot. 23a(11): 53. 1931. = Koanophyllon selleanum (Urban) R. King \& H. Robinson.

Eupatorium selloi Baker, Fl. Bras. 6(2): 361. 1876. = Barrosoa?

Eupatorium semialatum Benth., P1. Hartw. 76. 1841.= Ageratina ligustrina (DC.) R. King \& H. Robinson.

Eupatorium semicrenatum Urban, Symb. Antill. 3: 398. 1903. = Koanophyllon semicrenatum (Urban) R. King \& H. Robinson.

Eupatorium serniserratum DC., Prodr. 5: 177. 1836.

Eupatorium sernistriatum Baker, Fl. Bras. 6(2): 318. 1876. = Bejaranoa semistriata (Baker) R. King \& H. Robinson.

Eupatorium senecionideum Baker, Fl. Bras. 6(2): 335. $1876 .=$ Disynaphia senecionidea (Baker) R. King \& H. Robinson.

Eupatorium septuplinervium Klatt, Leopoldina 20: 90. 1884. = Bartlettina sordida (Less.) R. King \& H. Robinson.

Eupatorium sericeum H. B. K., Nov. Gen. Sp. 4: 86. Ed. Folio. 1818. = Hebeclinium sericeum (H. B. K.) R. King \& H. Robinson.

Eupatorium serotinum Michaux, Fl. Bor.-Amer. 2: 100. 1803.

Eupatorium serratifolium (H. B. K.) DC., Prodr. 5: 181.1836. = Ophryosporus serratifolius (H. B. K.) B. Robinson.

Eupatorium serratuloides H. B. K., Nov. Gen. Sp. 4: 91 . Ed. Folio. 1818. = Chromolaena serratuloides (H. B. K.) R. King \& H. Robinson.

Eupatorium serratum Sprengel, Syst. Veg. Fl. Peruv. Chil. 3: 415. 1826. = Grazielia serrata (Sprengel) R. King \& H. Robinson.

Eupatorium serrulatum DC., Prodr. 5: 147. 1836. = Neocabreria serrulata (DC.) R. King \& H. Robinson.

Eupatoriurn sessile Sesse \& Mocino, Fl. Mexic. (ed. 2) 182. 1894. = Vernonia sericea Rich. VERNONIEAE.

Eupatorium sessilifolium L., Sp. PI. 837. 1753.

Eupatorium setiferum Pavon ex A. Gray, Proc. Amer. Acad. Arts 17: 206. 1882, nom. nud. = Barroetea pavonii A. Gray.

Eupatorium sexangulare (Klatt) B. Robinson, Proc. Amer. Acad. Arts 43: 35. 1907. = Critonia sexangularis (Klatt) R. King \& H. Robinson.

Eupatorium sexcostatum E. H. Krause, Beih. Bot. Centralbl. 32(2): 340. 1914, ignota.

Eupatorium shaferi B. Robinson, Proc. Amer. Acad. Arts 51: 537. 1916. = Spaniopappus shaferi (B. Robinson) R. King \& H. Robinson.

Eupatorium shastense Taylor \& Stebb., Madroño 25: 218(-220). 1978. = Ageratina shastensis (Taylor \& Stebb.) R. King \& H Robinson.

Eupatorium shimadai Kitam., Acta Phytotax. Geobot. 1: 284. 1932.

Eupatorium sideritidis Benth. ex Oersted, Vidensk. Meddel. Dansk Naturhist. Foren. Kjobenhavn 77. 1852. = Fleischmannia sideritides (Benth. ex Oersted) R. King \& H. Robinson.

Eupatorium sieberianum DC., Prodr. 5: 181. 1836. = Condylidium iresinoides (H. B. K.) R. King \& H. Robinson.

Eupatorium silenifolium Martius ex Baker, F1. Bras. 6(2): 215. 1876, nom. nud. = Trichogonia campestris Gardner. 
Eupatorium sillense Hieron. in Urban, Bot. Jahrb. Syst. 40: 382. 1908. = Ageratina ibaguensis (Schultz-Bip. ex Hieron.) R. King \& H. Robinson.

Eupatorium silphiifolium Martius, Flora 20(2): 105. 1837. = Austroeupatorium silphiifolium (Martius) R. King \& H. Robinson.

Eupatorium silvaticum B. Robinson, Contr. Gray Herb. 77: 37. 1926. = Koanophyllon silvaticum (B. Robinson) R. King \& H. Robinson.

Eupatorium silvicola B. Robinson, Proc. Boston Soc. Nat. Hist. 31: 254. 1904. = Bartlettina silvicola (B. Robinson) R. King \& H. Robinson.

Eupatorium simile Proctor, Bull. Inst. Jamaica Sci. Ser. 16: 71. 1967. = Koanophyllon simile (Proctor) R. King \& H. Robinson.

Eupatorium simillimum B. Robinson, Contr. Gray Herb. 77: 38. 1926. = Koanophyllon simillima (B. Robinson) R. King \& H. Robinson.

Eupatorium simonsii C. B. Clarke, Compos. Ind. 32. 1876. = Eupatorium cannabinum L., ?

Eupatorium simulans B. Robinson, Proc. Amer. Acad. Arts 55: 31. 1919. = Ageratina simulans (B. Robinson) R. King \& H. Robinson.

Eupatorium sinaloense B. Robinson, Contr. Gray Herb. 77: 39. 1926. = Fleischmannia sinaloensis (B. Robinson) R. King \& H. Robinson.

Eupatorium sinclairii Benth. ex Oersted, Vidensk. Meddel. Dansk Naturhist. Foren. Kjobenhavn 79. 1852. = Fleischmannia sinclairii (Benth. ex Oersted) R. King \& H. Robinson.

Eupatorium sinense (error for chinense) J. Gmelin, Syst. Nat. 1198. 1791(1792). = Eupatorium chinense $\mathrm{L}$

Eupatorium sinuatum Lam., Encycl. 2: 407. 1788. = Chromolaena sinuata (Lam.) R. King \& H. Robinson.

Eupatorium simuatum Lour., Fl. Cochinch. 487. 1790. $=E u$ patorium hispidum Pers., Vernonia? VeRnONIEAE?

Eupatorium sitiense Hieron., Bot. Jahrb. Syst. 22: 751. 1897. = Chromolaena squalida (DC.) R. King \& H. Robinson.

Eupatorium skutchii B. Robinson, Contr. Gray Herb. 104: 27. 1934. = Ageratina skutchii (B. Robinson) R. King \& H. Robinson.

Eupatorium sladenianum S. Moore, J. Bot. 42: 36. 1904. = Cainpuloclinium macrocephalum (Less.) DC., ?

Eupatorium smilacinum H. B. K., Nov. Gen. Sp. 4: 87. Ed. Folio. 1818. = Asplundianthus smilacinus (H. B. K.) R. King \& H. Robinson.

Eupatorium smithii B. Robinson, Proc. Amer. Acad. Arts 35: 340. 1900. = Ageratina tomentella (Schrader) R. King \& H. Robinson.

Eupatorium smithii E. Greene \& C. Mohr, Contr. U. S. Natl. Herb. 6: 761. Pl. 10. 1901. = Eupatorium pinnatifidum Ellis.

Eupatorium sodali L. O. Williams, Fieldiana, Bot. 36: 103. 1975, nom. nov. = Koanophyllon standleyi (B. Robinson) R. King \& H. Robinson.

Eupatorium sodiroi Hieron, ex Sodiro, Bot. Jahrb. Syst. 29: 12. 1900. = Ageratina sodiroi (Hieron.) R. King \& H. Robinson.

Eupatorium solanifolium Sesse \& Mocino, PI. Nov. Hisp. 134. 1889, Naturaleza (Mexico City), ser. 2(1): 125. App. Ed. 2. 1893 . = Vernonia morelana Gleason. VERNONIEAE,

Eupatorium soleirolii Loisel, Mem. Soc. Linn. Paris 6: 428. 1827. $=$ Eupatorium cannabinum $\mathbf{L}$.

Eupatorium solidaginifolium A. Gray, Pl. Wright. 1:87. 1852. $=$ Koanophyllon solidaginifolia (A. Gray) R. King \& H. Robinson.

Eupatorium solidaginoides H. B. K., Nov. Gen. Sp. 4: 99. Ed. Folio. 1818. = Koanophyllon solidaginoides (H. B. K.) R. King \& H. Robinson.

Eupatorium sonderi Schuliz-Bip., Linnaea 22: 571 . 1849. = Campovassouria cruciata (Vell. Conc.) R. King \& H. Robinson.

Eupatorium sonorae A. Gray, Pl. Wright. 2: 74. 1853. = Fleischmannia sonorae (A. Gray) R. King \& H. Robinson.
Eupatorium sophiaefolium L., Sp. Pl., ed. 2, 1175. 1763. =Eupatorina sophiaefolia (L.) R. King \& H. Robinson.

Eupatorium sophioides DC., Prodr. 5: 170. 1836. = Eupatorina sophiaefolia (L.) R. King \& H. Robinson.

Eupatorium soratae Schultz-Bip. ex B. Robinson, Contr. Gray Herb. 61: 51, 1920. = Fleischmannia soratae (Schultz-Bip. ex B. Robinson) R. King \& H. Robinson.

Eupatorium soratense Hieron., Bot. Jahrb. Syst. 21: 333. 1895. = Ageratina sotarensis (Hieron.) R. King \& H. Robinson.

Eupatorium sordescens DC., Prodr. 5: 167. 1836. = Dasycondylus resinosus (Sprengel) R. King \& H. Robinson.

Eupatorium sordidum Less., Linnaea 6: 403. 1831. = Bartlettina sordida (Less.) R. King \& H. Robinson.

Eupatorium sorensenii (R. King \& H. Robinson) L. O. Williams, Fieldiana, Bot. 36: 104. 1975. = Koanophyllon sorensenii $\mathrm{R}$. King \& $\mathrm{H}$. Robinson.

Eupatorium sotarense Hieron., Bot. Jahrb. Syst. 28: 574. 1895. = Ageratina sotarensis (Hieron.) R. King \& H. Robinson.

Eupatorium sotorum C. Nelson, Ceiba 25: 175. 1984, = Critonia sexangularis (Klatt) R. King \& H. Robinson.

Eupatorium spathulatum Hook. \& Arn., Companion Bot. Mag. 1: 242. 1835. = Disynaphia spathulata (Hook. \& Arn.) R. King \& H. Robinson.

Eupatorium speciosum Vent., Descr. Pl. Nouv. 79. 1804. = Liatris elegans (Walter) Michaux.

Eupatorium spectabile (Don) Sprengel, Syst. Veg. Fl. Peruv. Chil. 3: 410. 1826. = Gochnatia spectabilis (Don) Less. MUTISIEAE.

Eupatorium sphaerocephalum Schultz-Bip., Linnaea 30: 182. 1859-1860, nom. nud. = Sphaereupatorium scandens (Gardner) R. King \& H. Robinson.

Eupatorium sphaerocephalum Schultz-Bip. ex Baker, F. Bras. 6(2): 317. 1876. = Sphaereupatorium scandens (Gardner) R. King \& H. Robinson.

Eupatorium sphagnophilum B. Robinson, Contr. Gray Herb. 73: 18. 1924. = Badilloa sphagnophila (B. Robinson) R. King \& H. Robinson.

Eupatorium sphenopodum B. Robinson, Proc. Amer. Acad. Arts 43: 35. 1907. = Flyriella sphenopoda (B. Robinson) R. King \& H. Robinson.

Eupatorium spicatum Lam., Encycl. 2: 409. 1786. = Baccharis spicata (Lam.) Baillon. Astereae.

Eupatorium spinaciaefolium (DC.) A. Gray, Rep. U. S. Mex. Bound., Bot. 75. 1859. = Critonia spinaciaefolia (DC.) R. King \& H. Robinson.

Eupatorium spiraeifolium Schultz-Bip. ex O. Hoffm., Bull. Herb. Boissier 3: 624. 1895. = Ageratina espinosarum (A. Gray) R. King \& $\mathrm{H}$. Robinson.

Eupaiorium splendens Klotzsch ex Polak., Linnaea 41: 575. 1877, nom . nud. = Fleischmannia splendens R. King \& H. Robinson.

Eupatorium sprengelianum DC., Prodr. 5: 184. 1836, ignota.

Eupatorium spruce $i$ B. Robinson, Proc. Amer. Acad. Arts 55: 33. 1919. = Ayapana elata (Steetz) R. King \& H. Robinson.

Eupatorium squalidum DC., Prodr. 5: 142. 1836. = Chromolaena squalida (DC.) R. King \& H. Robinson.

Eupatorium squamosum D. Don, Prodr. Fl. Nepal. 170. 1825

Eupatorium squarroso-ramosum Hieron., Bot. Jahrb. Syst. 22: 753. 1897. = Chromolaena squarroso-ramosa (Hieron.) R. King \& H. Robinson.

Eupatorium squarrosum Cav,, Icon. 1: 66. 1791. = Brickellia cavanillesii (Cass.) A. Gray.

Eupatorium squarrosum Sesse \& Mocino, Pl. Nov. Hisp. 135. 1889, Naturaleza (Mexico City), ser. 2(1): 126. App. Ed. 2. 1893. = Brickellia cavanillesii (Cass.) A. Gray.

Eupatorium squarrulosum Hook. \& Am., Companion Bot. Mag. 1: 239. 1835. = Chromolaena squarrulosa (Hook. \& Arn.) R. King \& H. Robinson.

Eupatorium squiresii Rusby in B. Robinson, Proc. Amer. Acad. 
Arts 54: 258. 1918. = Ayapana trinitensis (Kuntze) R. King \& H. Robinson.

Eupatorium stachyophyllum Sprengel, Syst. Veg. Fl. Peruv. Chil. 3: 420. 1826. = Chromolaena stachyophylla (Sprengel) R. King \& H. Robinson.

Eupatorium standleyi B. Robinson, Contr. Gray Herb. 77: 40. 1926. = Neomirandea standleyi (B. Robinson) R. King \& H. Robinson.

Eupatoritm steetzii B. Robinson, Proc. Amer. Acad. Arts 55: 36. 1919. = Badilloa steetzii (B. Robinson) R. King \& H. Robinson.

Eupatorium stenolepis Steetz, Bot. Voy. Herald 148. 1854. = Ayapana stenolepis (Steetz) R. King \& H. Robinson.

Eupatorium sternbergianum DC., Prodr. 5: 167. 1836. = Ageratina sternhergiana (DC.) R. King \& H. Robinson.

Eupatorium steviaefolium DC., Prodr. 5: 158. 1836. = Hatschbachiella tweedieana (Hook. \& Arn.) R. King \& H. Robinson.

Eupatorium stevioides Steyerm., Fieldiana, Bot. 28(3): 637. 1953. - Ageratina jahnil (B. Robinson) R. King \& H. Robinson.

Eupatorium stevermarkianum V. Badillo, Bol. Soc. Venez. Ci. Nat. 10: 287. 1946. = Chromolaena steyermarkiana (V. Badillo) R. King \& H. Robinson.

Elupatorium stictophyllum B. Robinson, Proc. Amer. Acad. Arts 55: 36. 1919. = Ageratina stictophylla (B. Robinson) R. King \& H. Robinson.

Eupatorium stigmaticum Urban \& Ekman, Ark. Bot. 23a(11): 67. 1931. = Critonia stigmatica (Urban \& Ekman) R. King \& H. Robinson.

Eupatorium stigmatosum Meyen \& Walp., Nova Acta Phys.Med. Acad. Caes. Leop.-Carol. Nat. Cur. 19, Suppl. 1: 257. 1843. = Chromolaena odorata (L.) R. King \& H. Robinson.

Enpatorium stigmatosum Bertol., Misc. Bot. 5: 15. 1846. = Eupatorium album $\mathrm{L}$.

Eupatorium stigmatosum Chodat, Bull. Herb. Boissier Ser. 2. 1: 413. 1901. = Campuloclinium macrocephalum (Less.) DC.

Eupatorium stillingiaefolium DC., Prodr. 5: 160. 1836. = Chromolaena stillingiaefolia (DC.) R. King \& H. Robinson.

Eupatorium stipulaceum Vahl, Symb. Bot. 3: 94. 1794. $=\mathrm{Mi}$ kania stipulacea (Vahl) Willd.

Eupatorium stipuliferum Rusby, Mem. Torrey Bot. Club 4: 210. 1895. = Koanophyllon stipulifera (Rusby) R. King \& H. Robinson.

Eupatorium stoechadifolium L. f., Suppl. Pl. 355. 1781 . = Lourteigia stoechadifolia (L. f.) R. King \& H. Robinson.

Eupatorium stoechadosnmum Hance, Ann. Sci. Nat. Bot. 4. 18: 222. 1862. = Eupatoritum fortunei Turcz.

Eupatorium stramineum DC., Prodr. 5: 150. 1836. = Helogyne straminea (DC.) B. Robinson.

Eupatorium strictum A. Gray, Proc. Amer. Acad. Arts 21: 384. 1886. = Ageratina stricta (A. Gray) R. King \& H. Robinson.

Eupatorium strobilanthum Martius ex Baker, F1. Bras. 6(2): 300. 1876, nom. nud. = Chromolaena horminoides DC.

Eupatorium stuebelii Hieron., Bot. Jahrb. Syst. 21: 329. 1895. = Asplundianthus stuebelii (Hieron.) R. King \& H. Robinson.

Eupatorimm suaveolens H. B. K., Nov. Gen. Sp. 4: 86. Ed. Folio. 1818. = Austroeupatorimm inulaefolium (H. B. K.) R. King \& H. Robinson.

Eupatorium suaveolens Wallich, Num. List Dr. Pl. 3290. 1831, nom. nud. = Eupatorium cannabinum L., ?

Eupatorium suaveolens Chapman, Bot. Gaz. (Crawfordsville) 3: 5. 1878. = Ageratina jucunda (E. Greene) A. Clewell \& Wooton.

Eupatorium subalternifolium DC., Prodr. 5: 152. 1836. = Chromolaena stachyophylla (Sprengel) R. King \& H. Robinson.

Eupatorium subcapitatum Malme, Kongl. Svenska Vetenskapsakad. Handl. 3. 12(2): 45. 1933. = Siomatanthes subcapitatus (Malme) H. Robinson.

Eupatorium subcordatum Benth. ex Oersted, Vidensk. Meddel. Dansk Naturhist. Foren. Kjobenhavn 77. 1852. = Ageratina subcordata (Benth. ex Oersted) R. King \& H. Robinson.
Eupatorium subdentatum Gardner, London J. Bot. 5: 478.1846. = Koanophyllon adamantium (Gardner) R. King \& H. Robinson.

Eupatorium subferrugineum B. Robinson, Contr. Gray Herb. 96: 22. 1931. = Ageratina subferruginea (B. Robinson) R. King \& H. Robinson.

Eupatorium subglabratum (Hieron.) Cabrera \& Vittet, Revista Mus. Eva Peron, Secc. Bot. 8: 243. 1954. = Chromolaena?.

Eupatorium subhastatum Hook. \& Arn., Companion Bot. Mag. 1: 239. 1835. = Chromolaena hirsuta (Hook. \& Arn.) R. King \& H. Robinson.

Eupatorium subinclusum Klatt, Leopoldina 20: 75. 1884. = Ager atina subinclusa (Klatt) R. King \& H. Robinson.

Eupatorium subintegerrimum Malme, Ark. Bot. 24a(6): 30.1932. = Malmeanthus subintegerrimus (Malme) R. King \& H. Robinson.

Eupatorium subintegrum (E. Greene) B. Robinson, Contr. Gray Herb. 75: 13. 1925. = Ageratina subintegra (E. Greene) R. King \& H. Robinson.

Eupatorium subobtusum DC., Prodr. 5: 161. 1836. = Ayapana amygdalina (Lam.) R. King \& H. Robinson.

Eupatorium subpenninervium Schultz-Bip. ex Klatt, Leopoldina 20: 89. 1884. = Ageratina subinclusa $($ Klatt) $\mathrm{R}$. King \& H. Robinson

Eupatorium subplumosum D. Don ex Hook. \& Arn., Companion Bot. Mag. 1: 242. 1835, nom. nud. = Gyptis pinnatifida Cass.

Eupatorium subpurpureum Urban \& Ekman, Ark. Bot. 23a(11): 66. 1931. = Koanophyllon subpurpureum (Urban \& Ekman) R. King \& H. Robinson.

Eupatorium subscandens Hieron., Bot. Jahrb. Syst. 22: 742.1897. = Chromolaena subscandens (Hieron.) R. King \& H. Robinson.

Eupatorium subserratum Gardner, London J. Bot. 6: 440.1847. = Chromolaena mucronata (Gardner) R. King \& H. Robinson.

Eupatorium subtetragonum Miq., J. Bot. Neerl. 1: 99. 1861. = Eupatorium lindleyanum DC.

Eupatorium subtriplinerve Schultz-Bip., Linnaea 30: 182. 1859 1860 , nom. nud. = Kaunia rufescens (Lund ex DC.) R. King \& H. Robinson.

Eupatorium subtruncatum Gardner, London J. Bot. 6: 443. 1847. = Chromolaena.

Eupatorium subulatum Sesse \& Mocino, Pl. Nov. Hisp. 135. 1889, Naturaleza (Mexico City), ser. 2(1): 126. App. Ed. 2. 1893. = Brickellia?

Eupatorium subuligenum (Schauer) A. Gray, Pl. Wright. 1: 86. 1852. = Barroetea subuligera (Schauer) A. Gray.

Eupatorium subvelutinum DC., Prodr. 7: 268. 1838. = Chromolaena squalida (DC.) R. King \& H. Robinson.

Eupatorium subverticillatum Less. ex Baker, Fl. Bras. 6(2): 225. 1876 , nom. nud. = Mikania subverticillata Schultz-Bip. ex Baker.

Eupatorium succulentum Sol. ex Baker, F]. Bras. 6(2): 362. 1876. nom. nud. = Barrosoa apiculata (Gardner) R. King \& H. Robinson.

Eupatorium suffruticosum Sesse \& Mocino, Pl. Nov. Hisp. 133. 1889, Naturaleza (Mexico City), ser. 2(1): 124. App. Ed. 2. 1893. ignota.

Eupatorium sulcatum Hook. \& Arn., Companion Bot. Mag. 1: 243. 1835. = Mikania sulcata (Hook. \& Am.) B. Robinson.

Eupatorium suratense B. Robinson, Contr. Gray Herb. 80: 29. 1928. = Chromolaena suratensis (B. Robinson) R. King \& H. Robinson.

Eupatorium surinamense Schultz-Bip. ex Miq., Stirp. Surinam. Select. 185. 1851. = Ayapana amygdalina (Lam.) R. King \& H. Robinson.

Eupatorium symphyo pappus Steyerm., Fieldiana, Bot. 28(3): 636. 1953, nom. nov. = Symphyopappus decussatus Turcz.

Eupatorium syriacum Jaca., Icon. PI. Rar. 1: 17. 1782, Misc. 2: 349. 1781 or 1782 . = Eupatorium cannabinum L. 
Eupatorium syriacum Steven, Bull. Soc. Imp. Naturalistes Moscou 29(2): 372. 1856, ignota.

Eupatorium syringaefolium Turcz., Bull. Soc. Imp. Naturalistes Moscou 24(1): 169. 1851. = Koanophyllon solidaginoides $(\mathrm{H}$. B. K.) R. King \& H. Robinson.

Eupatorium tacaquirense (Hieron.) B. Robinson, Contr. Gray Herb. 90: 31. 1930. = Helogyne tacaquirensis Hieron. in Urban.

Eupatorium tacotanum Klatt, Bot. Jahrb. Syst. 8: 35. $1886 .=$ Chromolaena tacotana (Klatt) R. King \& H. Robinson.

Eupatorium tacuarembense Hieron. \& Arechav. in Arechav., Anales Mus. Nac. Montevideo Ser. 2. 1: 8. PI. 1. 1904. Disynaphia tacuarembensis (Hieron. \& Arechav.) R. King \& H. Robinson.

Eupatorium taltonense Hieron. in Urban, Bot. Jahrb. Syst. 40: 372. 1908. = Arist eguietia tahonensis (Hieron.) R. King \& H. Robinson.

Eupatorium tamaulipanum B. Turner, Brittonia 37: 374. 1985. = Bartlettina brevipetiolata (Schultz-Bip. ex Klatt) R. King \& H. Robinson.

Eupatorium tambillense Hieron. in Urban, Bot. Jahrb. Syst. 40: 380. 1908. = Ageratina Lambillensis (Hieron.) R. King \& H. Robinson.

Eupatorium tamboense Hieron., Bot. Jahrb. Syst. 22: 770. 1897. = Fleischmannia tamboensis (Hieron.) R. King \& H. Robinson.

Eupatorium tanacetifolium Gill. ex Hook. \& Arn., Companion Bot. Mag. 1: 242. 1835. = Gyptis pinnatifida Cass.

Eupatorium tapeinanthum Urban, Feddes Repert. 17: 51. 1921. = Koanoplyllon tapeinamhum (Urban) R. King \& H. Robinson.

Eupatorium tarapotense B. Robinson, Proc. Amer. Acad. Arts 55: 37. 1919. = Ayapanopsis tarapotensis (B. Robinson) R. King \& H. Robinson.

Eupatorium tarmense B. Robinson, Contr. Gray Herb. 104: 28. 1934. = Ageratina tarmensis (B. Robinson) R. King \& H. Robinson.

Eupatorituntashiroi Hayata, J. Coll. Sci. Imp. Univ. Tokyo 18(8): 9. 1904.

Eupatorium tatamense B. Robinson, Contr. Gray Herb. 77: 41, 1926. = Aristeguietia tatamensis (B. Robinson) R. King \& H. Robinson.

Eupatorium tatei B. Robinson ex Gleason, Bull. Torrey Bot. Club 58: 484. 1931, = Koanophvllon tatei (B. Robinson) R. King \& H, Robinson.

Eupatorium taunayanum Glaz., Bull. Soc. Bot. France Mem. 3. 56: 385. 1909, nom. nud. = Austrocritonia taunayana (Glaz. ex B. Robinson) R. King \& $\mathrm{H}$. Robinson.

Eupatorium taunayanum Glaz. ex B. Robinson, Contr. Gray Herb. 73: 8. 1924. = Austrocritonia taunayana (Glaz. ex B. Robinson) R. King \& H. Robinson.

Eupatorium tawadae $\times$ Kitam. ex Masam., Enum. Trach. 7: 108. 1955.

Eupatorium tectum Gardner, London J. Bot. 4: 117. 1845. = Chromolaena tecta (Gardner) R. King \& H. Robinson.

Eupatorium tenorae Aristeg., Fl. Venezuela 10: 189. 1964. = Bartlettina tenorae (Aristeg.) R. King \& H. Robinson.

Eupatorium tenue R. E. Fries, Arch. Bot. *PICK CORRECT ENTRY 5(13): 9. 1906. = Ageratina tenuis (R. E. Fries) R. King \& H. Robinson.

Eupatorium temicapitulatum Hieron., Bot. Jahrb. Syst. 36: 465 1905. = Chromolaena tenuicapitulata (Hieron.) R. King \& H. Robinson.

Eupatorium tenuiflorum (Griseb.) Hieron., Bot. Jahrb. Syst. 22: 772. 1897. = Austrobrickellia arnottii (Baker) R. King \& H. Robinson.

Eupatorium tenuifolium H. B. K., Nov. Gen. Sp. 4: 84. Ed. Folio. 1818 = Critoniella teruifolia (H. B. K.) R. King \& H. Robinson.
Eupatorium tenuifolium Rojas, Cat. Nat. Hist. Corriente 69. 1897. = Eupatorium subglabratum (Hieron.) Cabrera \& Vittet, ?

Eupatorium tepicanum (Hook. \& Arn.) Hemsley, Biol. Cent.Amer., Bot. 2: 101. 1881. = Critonia hebebotrya DC.

Eupatorium tepuianum Steyerm., Fieldiana, Bot. 28(3): 638. 1953. = Guayania roupalifolia (B. Robinson) R. King \& H. Robinson.

Eupatorium tequendamense Hieron. ex Sodiro, Bot. Jahrb. Syst. 29: 6. 1900. = Chromolaena subscandens (Hieron.) R. King \& H. Robinson.

Eupatorium ternatum Sesse \& Mocino, Pl. Nov. Hisp. 133. 1889. Naturaleza (Meixco City), ser. 2(1): 124. App. Ed. 2. 1893. = Hofmeisteria urenifolia (Hook. \& Arn.) Walp., ?

Eupatorium ternifolium Elliott, Sketch Bot. S. Carolina 2: 306. 1824. = Eupatorium dubium Willd. ex Poiret.

Eupatorium tetragonum Schrader, Ind. Sem. Hort. Acad. Gott. 9: T. 310. 1830, Linnaea 6. Litt. 72. 1831. = Ageratina tetra gona (Schrader) R. King \& H. Robinson.

Eupatorium tetranthum Griseb., F. Brit. W. 1, 360. 1861. = Koanophyllon tetranthum (Griseb.) R. King \& H. Robinson.

Eupatorium tetranthum Schultz-Bip. ex Baker, Fl. Bras. 6(2): 337 1876, nom. nud. = Stomatanthes dentatus (Gardner) H. Robinson.

Eupatorium tetrasticlum (B. Robinson) Steyerm., Fieldiana, Bot. 28(3): 636. 1953. = Goyazianthus tetrastichus (B. Robinson) R. King \& H. Robinson.

Eupatorium teucrifolium Willd., Sp. Pl. 3(3): 1753. 1804. = Eupatorium rotundifolium $\mathrm{L}$.

Eupatorium teucriifolium D. Don ex Hook. \& Am., Companion Bot. Mag. 1: 239. 1835, nom. nud. = Chromolaena hirsuta (Hook. \& Am.) R. King \& H. Robinson.

Eupatorium teucriifolium (Sprengel) Herter, Revista Sudamer. Bot. 7: 234. 1943. = Grazielia gaudichaudeana (DC.) R. King \& H. Robinson.

Eupatoriuin teucrioides Hook. \& Am. ex Hieron., Bot. Jahrb. Syst. 22: 746. 1897, nom. nud. = Chromolaena arnottiana (Griseb.) R. King \& H. Robinson.

Eupatorium texense (Torrey \& A. Gray) Rydb., F. Colorado 335. 1906. = Ageratina havanensis (H. B. K.) R. King \& H. Robinson.

Eupatorium thapsoides (DC.) Niederl., Bol. Mens. Mus. Prod. Argent. 3(31): 309. 1890. = Mikania thapsoides DC.

Eupatorium theaefolium Benth., Pl. Hartw. 199. 1845. = Ageratina theaefolia (Benth.) R. King \& H. Robinson.

Eupatorium thermarum B. Robinson, Biblioth. Bot. 29 (Heft. 116): 161. 1937. = Ayapanopsis?

Eupatorium thespesiaefolium DC., Prodr. 5: 164. 1836. = Barllettina sordida (Less.) R. King \& H. Robinson.

Eupatorium thieleanum Klatt in T. Durand \& Pittier, Bull. Soc. Roy. Bot. Belgique 31: 191. 1892. = Decachaeta thieleana (Klatt ex T. Durand \& Pittier) R. King \& H. Robinson.

Eupatoriurn thurnii B. Robinson, Contr. Gray Herb. 80: 30. 1928. = Chromolaena thurnii (B. Robinson) R. King \& H. Robinson.

Eupatorium thymifolizem Britton, Bull. Torrey Bot. Club 19: 1. 1892. = Neocuatrecasia thymifolia (Britton) R. King \& H. Robinson.

Eupatoriun thyrsiflorum (E. Greene) B. Robinson, Proc. Amer. Acad. Arts 43: 36. 1907. = Ageratina thyrsiflora (E. Greene) R. King \& H. Robinson.

Eupatorium thyrsigerum Hieron., Bot. Jahrb. Syst. 28: 570. 1901. = Critonia ilyrsigera (Hieron.) R. King \& H. Robinson.

Eupatorium thyrsoideum Mocino ex DC., Prodr. 5: 150. 1836. = Critonia thyrsoidea (Mocino ex DC.) R. King \& H. Robinson.

Eupatorium thyrsoideum Sesse \& Mocino, Fl. Mexic. (ed. 2) 182. 1894. = Critonia thyrsoidea (Mocino ex DC.) R. King \& H. Robinson.

Eupatorium thysanolepis B. Robinson, Contr. Gray Herb. 75: 13. 1925. = Koanophyllon thysanolepis (B. Robinson) R. King \& H. Robinson. 
Eupatorium tinctorium Pohl ex Baker, Fl. Bras. 6(2): 352. 1876, nom. nud. = Koanophyllon tinctorium Arruda.

Eupatorium tinifolium H. B. K., Nov. Gen. Sp. 4: 104. Ed. Folio. 1818. = Ageratina tinifolia (H. B. K.) R. King \& H. Robinson.

Eupatorium toldense Hieron. in Urban, Bot. Jahrb. Syst. 40: 378. 1908. = Chromolaena toldensis (Hieron.) R. King \& H. Robinson.

Enpatorium tolimense Hieron., Bot. Jahrb. Syst. 19: 45. 1894. = Critoniella acuminata (H. B. K.) R. King \& H. Robinson.

Eupatorium tomentellum (A. Gray) Schrader, Ind. Sem. Hort. Acad. Gott. 3. T. 3. 1833, Linnaea 10: Litt. 70. 1836. = Ageratina tomentella (Schrader) R. King \& H. Robinson.

Eupatorium tomentosum Lam., Encycl. 2: 410. 1788. = Senecio penicillatus (Cass.) Schultz-Bip. SenecroneaE.

Eupatorium tomentosum DC. ex Steudel, Nomencl. Bot. 1: 609. 1840, nom. nud. = Ageratina tomentella (Schrader) R. King \& H. Robinson.

Eupatorium tomentosum Sesse \& Mocino, Pl. Nov. Hisp. 134. 1889, Naturaleza (Mexico City), ser. 2(1): 125. App. Ed. 2. 1893. = Brickellia tomentella A. Gray.

Eupatorium tonduzii Klatt, Compos. Nov. Costaric. [Bot. Beibl. Leopoldina] 4. 1895. = Ageratina tonduzii (Klatt) R. King \& H. Robinson.

Eupatorium toppingianum Elmer, Leafl. Philipp. Bot. 1: 101. 1906.

Eupatorium toroi B. Robinson, Contr. Gray Herb. 104: 28.1934. = Asplundianthus toroi (B. Robinson) R. King \& H. Robinson.

Eupatorium torondoyense V. Badillo, Bol. Soc. Venez. Ci. Nat. 9: 189. 1944. = Hebeclinium torondoyense (V. Badillo) R. King \& H. Robinson.

Eupatorium torreyanum Short \& Peter, Transylvania J. Med. Assoc. Sci. 8(32): 575. 1836. = Eupatorium hyssopifolium L.

Eupatorium torreyanum Short ex Torrey \& A. Gray, F. N. Amer. 2: 84. 1841. = Eupatorium hyssopifolium L.

Eupatorium tortifolium Chapman, Bot. Gaz. (Crawfordsville) 3: 5. 1878. = Eupatorium cuneifolium Willd.

Eupatorium tovarense B. Robinson, Proc. Amer. Acad. Arts 54: 259. 1918. = Ayapana tovarensis (B. Robinson) R. King \& H. Robinson.

Eupatorium tozanense Hayata, Icon. Pl. Formosan. 8: 44.1919. = Eupatorium chinense L.

Eupatorium tozziaefolium DC., Prodr. 5: 146. 1836. = Chromolaena congesta (Hook. \& Arn.) R. King \& H. Robinson.

Eupatorium trachyphyllum Hieron., Bot. Jahrb. Syst. 36: 467. 1905. = Asplundianthus trachyphyllus (Hieron.) R. King \& H. Robinson.

Eupatorium tracyi E. Greene, Pittonia 4: 278. 1901. = Ageratina aromatica (L.) Spach.

Eupatorium tranninense Glaz., Bull. Soc. Bot. France Mem. 3. 56: 385. 1909, nom. nud. ignota.

Eupatorium trapezoideum Kunth, Ind. Sem. Hort. Berol. 13. 1847. = Ageratina trapezoidea (Kunth) R. King \& H. Robinson.

Eupatorium tremulım Hook. \& Am., Companion Bot. Mag. 1: 241. 1835. = Raulinoreitzia tremula (Hook. \& Am.) R. King \& H. Robinson.

Eupatorium trianae B. Robinson, Proc. Amer. Acad. Arts 54: 260. 1918. = Barrosoa trianae (B. Robinson) R. King \& H. Robinson.

Eupatorium triangulare Poiret, Encycl. Suppl. 2: 604. 1812. = Chromolaena corymbosa (Aublet) R. King \& H. Robinson.

Eupatorium triangulare Mocino ex DC., Prodr. 5: 166. 1836 , nom. nud. = Ageratina deltoidea (Jacq.) R. King \& H. Robinson.

Eupatorium triangulare Mocino ex Sesse \& Mocino, Pl. Nov. Hisp. 134. 1889, Naturaleza (Mexico City), ser. 2(1): 125. App. Ed. 2. 1893. = Ageratina deltoidea (Jacq.) R. King \& H. Robinson.
Eupatorium triangulatum Alaman \& DC., Prodr. 5: 172. 1836. = Ageratina rubricaulis (H. B. K.) R. King \& H. Robinson.

Eupatorium tricephalotes Schultz-Bip. ex Baker, Fl. Bras. 6(2): 322. 1876. = Koanophyllon tricephalotes (Schultz-Bip. ex Baker) R. King \& H. Robinson.

Eupatorium trichobasis Baker, F1. Bras. 6(2): 364. 1876. = Gyptidium trichobasis (Baker) R. King \& H. Robinson.

Eupatorium trichophorum DC., Prodr. 5: 147. 1836. = Chromolaena hirsuta (Hook. \& Arn.) R. King \& H. Robinson.

Eupatorium trichosanthum A. Rich. in Sagra, Hist. Fis. Cuba, Bot. 3: 41. 1853. = Brickellia diffusa (Vahl) A. Gray.

Eupatorium trichotomum Schultz-Bip., Linnaea 34: 535. 1865 1866, nom. nud. = Ageratina gloeoclada (B. Robinson) R. King \& H. Robinson.

Eupatorium trichotomum Schultz-Bip. ex Baker, Fl. Bras. 6(2): 305. 1876, nom. nud. = Heterocondylus alatus (Vell. Conc.) R. King \& H. Robinson.

Eupatorium trifidum Vahl, Symb. Bot. 3: 94. 1794. = Eupatorium cannabinum L., ?

Eupatorium triflorum Aublet, Hist. P1. Guiane 2: 795. 1775. = Piptocarpha triflora (Aublet) Bennett ex Baker. VeRnonieAe.

Eupatorium trifoliatum L., Sp. PI. 837. 1753, Syst. Nat., ed. 10. 1204. 1759. = Eupatorium purpureum L.

Eupatorium trifoliatum Luces, Topogr. Nachr. Insel Oesel 270. 1823. = Eupatorium cannabinum $\mathrm{L}$.

Eupatorium irifoliatum Hort. Dorp. ex Stev., Bull. Soc. Imp. Naturalistes Moscou 29(2): 371. 1856. = Eupatorium cannabinum L.

Eupatorium trigonocarpum Griseb., Fl. Brit. W. I. 359. 1861. = Chromolaena trigonocarpa (Griseb.) R. King \& H. Robinson.

Eupatorium trigonum Gardner, London J. Bot. 6: 446. 1847. = Stomatanthes trigonus (Gardner) H. Robinson.

Eupatorium trinervatum Sesse \& Mocino, Pl. Nov. Hisp. 134. 1889, Naturaleza (Mexico City), ser. 2(1): 125. App. Ed. 2. 1893. = Baccharis trinervis (Lam.) Pers. AstereAe.

Eupatorium trinervium Schultz-Bip., Bot. Voy. Herald 300.1856. = Fleischmannia trinervia (Schultz-Bip.) R. King \& H. Robinson.

Eupatorium trinionum McVaugh, Contr. Univ. Michigan Herb. 9: 402. 1972. = Ageratina triniona (McVaugh) R. King \& H. Robinson.

Eupatorium trinitarium (DC.) M. Gomez, Anales Hist. Nat. 19: 270. 1890. = Mikania trinitaria DC.

Eupatorium trinitense (Kuntze) Rusby \& B. Robinson, Contr. Gray Herb. 61: 11. 1920. = Ayapana trinitensis (Kuntze) R. King \& H. Robinson.

Eupatorium triosteifolium Rusby, Bull. New York Bot. Gard. 4: 379. 1907. = Ayapanopsis triosteifolia (Rusby) R. King \& H. Robinson.

Eupatorium triplinerve Vahl, Symb. Bot. 3: 97. 1794. = Ayapana triplinervis (Vahl) R. King \& H. Robinson.

Eupatorium triplinerve Vahl ex Blume, Bijdr. Fl. Ned. Ind. 903. 1826. = Ayapana triplinervis (Vahl) R. King \& H. Robinson.

Eupatorium triptychum B. Robinson, Contr. Gray Herb. 77: 43. 1926. = Standleyanthus triptychus (B. Robinson) R. King \& H. Robinson.

Eupatorium triradiatum Urban, Symb. Antill. 3: 396. 1903. = Koanophyllon triradiatum (Urban) R. King \& H. Robinson.

Eupatorium trisectum Hook. \& Arn., Companion Bot. Mag. 1: 242. 1835. = Stevia .

Eupatorium triste DC., Prodr. 5: 166. 1836. = Ageratina tristis (DC.) R. King \& H. Robinson.

Eupatorium trixoides Martius ex Baker, Fl. Bras. 6(2): 311.1876. = Ayapanopsis oblongifolia (Gardner) R. King \& H. Robinson.

Eupatorium trujillense B. Robinson, Contr. Gray Herb. 104: 29. 1934. = Chromolaena trujillensis (B. Robinson) R. King \& H. Robinson. 
Eupatorium truncatum Muhlenb. ex Willd., Sp. Pl. 3: 1751. 1803. Eupatorium perfoliatum L.

Eupatorium truncatum Muhlenb. ex Elliott, Sketch Bot. S. Carolina 2: 298. 1824. = Eupatorium sessilifolinm L.

Eupatorium tubaraoense Hieron., Bot. Jahrb. Syst. 22: 784. 1897. = Campuloclinium tubaraoense (Hieron.) R. King \& H. Robinson.

Eupatorium tubiflorum Benth., PI. Hartw. 76. 1841. = Piptothrix areolaris (DC.) R. King \& H. Robinson.

Enpatorium tucumanense Lillo \& B. Robinson, Contr. Gray Herb. 90: 32. 1930. = Ayapanopsis tucumanensis (Lillo \& B. Robinson) R. King \& H. Robinson.

Eupatorium tuerckheimii Klatt, Leopoldina 20:95. 1884. = Bartlettina tuerckheimii (Klatt) R. King \& H. Robinson.

Eupatorium tulanum Klatt, Abh. Naturf. Gcs. Halle 15: 323. 1882. = Vernonia liatroides DC. VERNONIEAE.

Eupatorium tunariense (Hieron.) B. Robinson, Contr. Gray Herb. 61: 39. 1920. = Chromolaena tunariensis (Hieron.) R. King \& H. Robinson.

Eupatorinm tunii L. O. Williams, Fieldiana, Bot. 36: 106(-107). 1975. = Critoria bartlettii (B. Robinson) R. King \& H. Robinson.

Eupatorium turbacense Hieron., Bot. Jahrb. Syst. 21: 332. 1895. = Avapana turbacensis (Hieron.) R. King \& H. Robinson.

Eupatorium turbinaturn A. Gray, Proc. Amer. Acad. Arts 15: 26. 1879. = Chromolaena bigelovii (A. Gray) R. King \& H. Robinson.

Enpatorium turczaninowii B. Robinson, Proc. Amer. Acad. Arts 54: 364. 1918, nom. nov. = Aristeguietia glutinosa (Lam.) R. King \& H. Robinson.

Enpatorium turquinense Alain, Contr. Ocas. Mus. Hist. Nat. Colegio "De La Salle" 18: 7. 1960. = Koanophyllon turquinense (Alain) Borh.

Enpatorium iweedieanum Hook. \& Arn., Companion Bot. Mag. 1: 242. 1835. = Hatschbachiella tweedieana (Hook. \& Am.) R. King \& H. Robinson.

Eupatorium tyleri B. Robinson ex Gleason. Bull. Torrey Bot. Club 58: 482. 1931. = Chrornolaena tyleri (B. Robinson) R. King \& H. Robinson.

Enpatorium uber B. Robinson, Proc. Amer. Acad. Arts 55: 37. 1919. = Kaunia uber (B. Robinson) R. King \& H. Robinson.

Eupatorium ulei Hieron., Bot. Jahrb. Syst. 22: 751. 1897. = Chromolaena ulei (Hieron.) R. King \& H. Robinson.

Eupatorium umbelliforme Dusen ex Malme, Kongl. Svenska Vetenskapsakad. Handl. 3. 12(2): 33. 1933. = Chromolaena umbelliformis (Dusen cx Malme) R. King \& H. Robinson.

Eupatorium umbellulatum Sprengel, Syst. Veg. Fl. Peruv. Chil. 4: 409. App. 1827. = Piptocarpha umbellulata (Sprengel) Baket. VERNONIEAE.

Eupatorium umbrosum Benth., PI. Hartw. 198. 1845. = Ageratina pseudochilca (Benth.) R. King \& H. Robinson,?

Eupatorium umbrosum Klatt, Bot. Jahrb. Syst. 8: 35. 1886. = Fleischmannia klattiana (Hieron.) R. King \& H. Robinson.

Eupatorium uniflorum Sesse \& Mocino, Pl. Nov. Hisp. 132. 1889, Naturaleza (Mexico City), ser. 2(1): 123. App. Ed. 2. 1893. = Vermonia salicifolia (DC.) Schultz-Bip. VernONIEAE.

Eupatorium urbanii Ekman ex Urban, Ark. Bot. 23a(11): 55. 1931. = Ageratina urbanii (Ekman cx Urban) R. King \& H. Robinson.

Eupatorium urolepis Daveau, Dict. Hort. 1: 524.1896.=Urolepis hecatantha (DC.) R. King \& H. Robinson.

Eupatorinull uromeres B. Robinson, Proc. Amer. Acad. Arts 54: 260. 1918. = Chromolaena uromeres (B. Robinson) R. King \& H. Robinson.

Eupatorimm urticaefolium Reichard, Syn. PI. 3: 719. 1780. = Ageratina altissima (L.) R. King \& H. Robinson.

Eupatorium urticaefolium L. f., Suppl. Pl. 354. 1781. = Praxelis pauciflora $(\mathrm{H}, \mathrm{B}$. K.) R. King \& H. Robinson.
Eupatorium urticifoliun Banks ex Griscb., F. Brit. W. 1. 362. 1861. nom. nud. in syn. = Fleischmannia microstemon (Cass.) R. King \& H. Robinson.

Eupatorium urticoides Schultz-Bip, ex Hicron., Bot. Jahrb. Syst. 28: 568. 1901. = Chromolaena uricoides (Schultz-Bip. ex Hieron.) R. King \& H. Robinson.

Eupatorium urubambense B. Robinson, Proc. Amer. Acad. Ars 55: 38. 1919. = Cronquistianthis urubanbensis (B. Robinson) R. King \& H. Robinson.

Eupatorium urubambense var. determinatum B. Robinson, Contr. Gray Herb. 68: 33. 1923. = Cronquistianthus determinatus (B. Robinson) R. King \& H. Robinson.

Eupatorinm vacciniaefolium Benth., Pl. Hartw. 200. 1845. = Ageratina vacciniaefolia (Benth.) R. King \& H. Robinson.

Eupatorium vagans Wallich. Nun. List Dr. Pl. 3040. 1831, nom. nud. = Vernonia scandens DC. VERNONIEAE.

Eupatorium vagum Gardner, London J. Bol. 5: 477. 1846. = Grazielia gaudichaudeana (DC.) R. King \& H. Robinson.

Eupatorium vahlianum Urban in Duss, Ann. Inst. Bot.-Geol. Colon. Marscille 3: 355. 1897. = Chromolaena trigonocarpa (Griseb.) R. King \& H. Robinson.

Eupatorium valerianum Standley, Publ. Ficld Mus. Nat. Hist., Bot. Ser. 18: 1474. 1938. = Fleischmannia hymenophylla (KJatt) R. King \& H. Robinson.

Eupatorium vallincola DC.. Prodr. 5: 168. 1836. = Ageratina vallincola (DC.) R. King \& H. Robinson.

Eupatorium valverdeanum Klatt in T. Durand \& Pittier, Bull. Soc. Roy. Bot. Belgique 31: 188. 1892. = Neurolaena lobata (L.) R. Br. Heliantheae.

Eupatorimm vanillosmoides Schultz-Bip. cx Baker, Fl. Bras. 6(2): 346. 1876, nom. nud. = Steyermarkina pyrifolia (DC.) R. King \& H. Robinson.

Eupatorium vargasianum DC., Prodr. 5: 155.1836. = Critoniella vargasiana (DC.) R. King \& H. Robinson.

Eupatorium variabile Makino, Bot. Mag. (Tokyo) 24: 59. 1910.

Eupatorium variegatum (DC.) Malmc, Kongl. Svenska Vetenskapsakad. Handl. 3. 12(2): 46. 1933, nom. nov. = Praxchs grandiflora (DC.) Schultz-Bip.

Eupatorium variifolium Bartling, Linnaca 15. Litt. 93. 1841. = Eupatorium cannabinum L.

Eupatorium variolatum B. Robinson. Contr. Gray Herb. 73: 20. 1924. = Disynaphia variolata (B. Robinson) R. King \& H. Robinson.

Eupatorium vasey i Porter, Bull. Torrey Bot. Club 19: 128. 1892. $=$ Eupatorium sessilifolium L.

Eupatorium vattuonei Hicken. Darwiniana 1: 146. 1924. = Austrobrickellia patens (Don ex Hook. \& Am.) R. King \& H. Robinson.

Eupatorium vautherianum DC., Prodr. 5: 159. 1836. = Heterocondylus alatns (Vell. Conc.) R. King \& H. Robinson.

Eupatorium velutinum Gardner, London J. Bot. 5: 473. 1846. = Austrocritonia velutina (Gardner) R. King \& H. Robinson.

Eupatorium venezuelense V. Badillo, Bol. Soc. Vencz. Ci. Nat. 9: 131. 1944. = Badilloa venezuelensis (V. Badillo) R. King \& H. Robinson.

Eupatorium venosissimum Rusby, Mem. Torrey Bot. Club 6: 57 1896. = Ophryosporus venosissimus (Rusby) B. Robinson.

Eupatorium venosum Martius ex Baker. F. Bras. 6(2): 281. 1876, nom. nud. = Chromolaena squalida (DC.) R. King \& H. Robinson.

Eupatorium ventillanum Cuatrec., Ann. Missouri Bot. Gard. 52: 305. 1965. = Ageratina riparia (Regel) R. King \& H. Robinson. Eupatorium venulosum A. Gray. Proc. Amer. Acad. Arts 21: 384. 1886. = Ageratina venulosa (A. Gray) R. King \& H. Robinson. Eupatorium veraecrucis Steudel, Nomcncl. Bot. 1: 609. 1840 , nom. nud. = Brickellia paniculata (Miller) B. Robinson.

Eupatorium verbenacetum DC.. Prodr. 5: 146. 1836. = Chromolaena verbenacea (DC.) R. King \& H. Robinson. 
Eupatorium verbenaefolium Michaux, Fl. Bor.-Amer. 2: 98. 1803. = Eupatorium rolundifolium $\mathrm{L}$.

Eupatorium vernale Vatke \& Kurtz, Ind. Sem. Hort. Berol. App. 2. 1871, Gartenfl. 36. 1873. = Ageratina vernalis (Vatke \& Kurtz.) R. King \& H. Robinson.

Eupatorium vernicosum Schultz-Bip. cx Greenman, Zoe 5: 186. 1904. = Ageratina vernicosa (Schultz-Bip. ex Greenman) R. King \& $\mathrm{H}$. Robinson.

Eupatorium vernonioides Coulter, Bot. Gaz. (Crawfordsville) 20: 45. 1895 . = Chromolaena glaberrima (DC.) R. King \& H. Robinson.

Eupatorium vernoniopsis Schultz-Bip. ex Baker, Fl. Bras. 6(2): 334. 1876. = Gyptis vernoniopsis (Schultz-Bip. ex Baker) R. King \& H. Robinson.

Eupatorium veronicaefolium H. B. K., Nov. Gen. Sp. 4: 88. Ed. Folio. 1818. = Brickellia veronicaefolia (H. B. K.) A. Gray.

Eupatorium versicolor Wallich, Num. List Dr. P1. 3167. 1831, nom. nud. nom. nud. = Vernonia divergens (DC.) Edgewood. VERNONIEAE.

Eupatorium verticillatum Lam., Encycl. 2: 405. 1786. = Eupatorium dubium Willd. ex Poiret.

Eupatorium verticillatum Sesse \& Mocino, Pl. Nov. Hisp. 135. 1889, Naturaleza (Mcxico City), ser. 2(1): 126. App. Ed. 2. 1893. ignota.

Eupatorium vestitum Sprengel, Syst. Veg. Fl. Peruv. Chil. 3: 416. 1826, ignota.

Eupatorium vestitum Pocppig \& Endl., Nov. Gen. Sp. 3: 55. 1845. $=$ Hebeclinimm vestitum $\mathrm{R}$. King \& $\mathrm{H}$. Robinson.

Eupatorium vetularum Standley \& Steyerm., Publ. Field Mus. Nat. Hist., Bot. Ser. 23: 190. 1944. = Ageratina caeciliae (B. Robinson) R. King \& H. Robinson.

Eupatorium viburnifolium E. Greene, Pittonia 4: 276. 1901. = Ageratina aromatica (L.) Spach.

Eupatorium viburnoides DC., Prodr. 5: 171. 1836. = Ageratina viburnoides (DC.) R. King \& H. Robinson.

Eupatorium villosum Sw., Prodr. 111. 1788. = Koanophyllon villosum (Sw.) R. King \& H. Robinson.

Eupatorium villosum Bertero ex DC., Prodr. 5: 173. 1836, nom. nud. = Koanophyllon obtusissimum (DC.) R. King \& H. Robinson.

Eupatorium vincaefolium Lam., Encycl. 2: 410. 1786. = Mikania parviflora (Aublet) Karsten.

Eupatorium vindex DC., Prodr. 5: 160. 1836. = Chromolaena vindex (DC.) R. King \& H. Robinson.

Ellpatorium violaceum Raf., Fl. Ludov. 62.1817. = Conoclinium coelestinum (L.) DC., ?

Eupatorium violaceum Bertcro ex Sprengel, Syst. Veg. Fl. Peruv. Chil. 3: 414. 1826. = Fleischmannia microstemon (Cass.) R. King \& H. Robinson.

Eupatorium virgatum Schrader, Ind. Sem. Hort. Acad. Gott. 9: T. 310. 1829. DC., Prod. 5: 159. 1836.= Fleischmannia pycnocephala (Less.) R. King \& H. Robinson.

Eupatorium virgatum D. Don ex Hook. \& Arn., Companion Bot. Mag. 1: 241. 1835. = Acanthostyles buniifolius (Hook. \& Arn.) R. King \& H. Robinson.

Eupatorium viride E. H. Krause, Sturm's Fl. Deutchl., ed. 2, 13: 34. 1905. = Adenostyles alpina (L.) Bluff \& Fingcrh. SENECIONEAE.

Eupatorium viridiflorum Baker, Fl. Bras. 6(2): 309. 1876. = Bartlettina hemisphaerica (DC.) R. King \& H. Robinson.

Eupatorium viscidipes B. Robinson, Proc. Amer. Acad. Arts 36: 484. 1901. = Fleischmannia viscidipes (B. Robinson) R. King \& H. Robinson.

Eupatorium viscidum Hook. \& Arn., Companion Bot. Mag. 1: 241. 1835. = Lorentzianthus viscidus (Hook. \& Am.) R. King \& H. Robinson.

Eupatorium viscosissimum Rolfe, Gard. Chron. Ser. 3. 39: 274. 1906. = Ageratina viscosissima (Rolfe) R. King \& H. Robinson.
Eupatorium viscosum H. B. K., Nov. Gen. Sp. 4: 101. Ed. Folio. 1818. = Ageratina viscosa (H. B. K.) R. King \& H. Robinson.

Eupatorium viscosum Wallich, Num. List Dr. Pl. 3287. 1831, nom. nud. = Eupatorium cannabinum L., ?

Eupatorium vitalbae DC., Prodr. 5: 163. 1836.= Heterocondylus vitalbae (DC.) R. King \& H. Robinson.

Eupatorium vitifolium Klatt, Leopoldina 20: 90. 1884. = Eupatoriastrum triangulare (DC.) B. Robinson.

Eupatorium voglii B. Robinson, Contr. Gray Herb. 104: 29.1934. = Chromolaena voglii (B. Robinson) Huber.

Eupatorium volckmanni Philippi, Anales Univ. Chile USE \#1415 51. 1861. = Ophryosporus triangularis Meyen.

Eupatorium volkameriaefolium Wallich, Num. List Dr. P1. 3001. 1831 , nom. nud. = Vernonia volkameriaefolia DC. VERNONIEAE.

Eupatorium volkensii Hieron. in Urban, Bot. Jahrb. Syst. 40: 370. 1908. = Cronquistianthus volkensii (Hieron.) R. King \& H. Robinson.

Eupatorium volubile Vahl, Symb. Bot. 3: 93. 1794. = Mikania cordata (Burm. f.) B. Robinson.

Eupatorium vulcanicum Benth. ex Oersted, Vidensk. Meddel. Dansk Naturhist. Foren. Kjobenhavn 78. 1852. = Ageratina bustamenta (DC.) R. King \& H. Robinson.

Eupatorium wageneri Hieron. in Urban, Bot. Jahrb. Syst. 40: 375. 1908. = Condylidium iresinoides (H. B. K.) R. King \& H. Robinson.

Eupatorium wallichii DC., Prodr. 5: 179. 1836. = Eupatorium chinense L.

Eupatorium warmingii Baker, F1. Bras. 6(2): 339. 1876. = Stomatanthes warmingii (Baker) $\mathrm{H}$. Robinson.

Eupatorium warmingii Schultz-Bip. ex Baker, Fl. Bras. 6(2): 340. 1876 , nom. nud. = Stomatanthes dyctiophyllus (DC.) H. Robinson.

Eupatorium weberbaueri Hieron. in Urban, Bot. Jahrb. Syst. 40: 369. 1908. = Crossothamnus weberbaueri (Hieron.) R. King \& H. Robinson.

Eupatorium weddellii B. Robinson, Contr. Gray Herb. 77: 44. 1926. = Neocuatrecasia weddellii (B. Robinson) R. King \& H. Robinson.

Eupatorium weinmannianum Regel \& Koern., Ind. Sem. Hort. Petrop. 41. 1857. = Ageratina ligustrina (DC.) R. King \& H Robinson.

Eupatorium williamsii A. Clewell, Ceiba 19(2): 194. 1975, nom nud. = Barlettina williamsii $\mathrm{R}$. King \& $\mathrm{H}$. Robinson.

Eupatorium wrightii A. Gray, Pl. Wright. 1:87.1852.=Ageratina wrightii (A. Gray) R. King \& H. Robinson.

Eupatorium xalapanum B. Turner, Brittonia 37: 376. 1985. = Bartlettina brevipetiolata (Schultz-Bip. ex Klatt) R. King \& H. Robinson.

Eupatorium xalapense H. B. K., Nov. Gen. Sp. 4: 100. Ed. Folio. 1818. = Ageratina glabrata (H. B. K.) R. King \& H. Robinson.

Eupatorium xanthochlorum B. Robinson, Contr. Gray Herb. 77: 44. 1926. = Ageratina malacolepis (B. Robinson) R. King \& H. Robinson.

Eupatorium xerolepis Schultz-Bip. ex Baker, FI. Bras. 6(2): 323. 1876, nom. nud. = Austrobrickellia patens (Don ex Hook. \& Arn.) R. King \& H. Robinson.

Eupatorium xestolepidoides Wurd., Mem. New York Bot. Gard. 8: 145. 1953. = Chromolaena xestolepidoides (Wurd.) R. King \& H. Robinson.

Eupatorium xestolepis B. Robinson, Proc. Amer. Acad. Arts 54: 261. 1918. = Chromolaena xestolepis (B. Robinson) R. King \& H. Robinson.

Eupatorium xylophylloides DC., Prodr. 5: 149. 1836. = Raulinoreitzia crenulata (Sprengcl) R. King \& H. Robinson.

Eupatorium xylorhizum Schultz-Bip. ex Baker, Fl. Bras. 6(2): 292. 1876. = Chromolaena xylorhiza (Schultz-Bip. ex Baker) R. King \& H. Robinson. 
Eupatorium yakushimaense Masam. \& Kitam., Acta Phytotax. Geobot. 2: 43. 1933.

Eupatoritm yavianum Lasser \& Maguire, Bol. Soc. Venez. Ci. Nat. 15: 106. 1954. = Guayania yaviana (Lasser \& Maguire) R. King \& H. Robinson.

Eupatorium ymalense B. Robinson, Contr. Gray Herb. 75: 14. 1925. = Koanophyllon albicanlis (Schultz-Bip. ex Klatt) R. King \& H. Robinson.

Eupatorium yungasense B. Robinson, Contr. Gray Herb. 104: 30. 1934. = Fleischmannia yungasensis $(\mathrm{B}$. Robinson) $\mathrm{R}$. King \& H. Robinson.

Eupatoriun zeylanicum L., Sp. PI. 837. 1753. = Vernonia zeylanicuin (L.) LesS. VERNONIEAE.

Eupatoriun zibellinum Sesse \& Mocino, Pl. Nov. Hisp. Ed. 1 135. 1889. = Fleischmannia arguta (H. B. K.) B. Robinson.

Eupatorium zinniifolinm B. Robinson, Proc. Amer. Acad. Arts 54: 261. 1918. = Ageratina zinniifolia (B. Robinson) R. King \& H. Robinson.

Eupatorium zunilanum Standley \& Steyerm., Publ. Field Mus. Nat. Hist., Bot. Ser. 23: 191. 1944. = Ageratina zunilana (Standley \& Steyerm.) R. King \& H. Robinson.

Ferreyrella cuatrecasasii R. King \& H. Robinson, Phytologia 26: 167. 1973

Ferreyrella peruviana Blake, J. Wash. Acad. Sci. 47: 407. 1957.

Flaveria peruviana [Juss.] Gmelin, Syst. Nat. ed. 10, 2: 1269. 1791. = Ophryosporus peruvianus (Gmelin) R. King \& H. Robinson.

Fleischmannia aequinoctialis (B. Robinson) R. King \& H. Robinson, Phytologia 19: 202. 1970.

Fleischmannia allenii R. King \& H. Robinson, Phytologia 28: 73. 1974.

Fleischmannia anisopoda (B. Robinson) R. King \& H. Robinson, Phytologia 19: 202. 1970.

Fleischmannia antiquorum (Standley \& Steyerm.) R. King \& H. Robinson, Phytologia 49: 5. 1981.

Fleischmannia arguta (H. B. K.) B. Robinson, Proc. Amer. Acad. Arts 42: 35. 1906.

Fleischmannia bergantinensis (V. Badillo) R. King \& H. Robinson, Phytologia 19: 202. 1970.

Fleischmannia blakei (B. Robinson) R. King \& H. Robinson, Phytologia 19: 202. 1970.

Fleischmannia bohlmanmiana R. King \& H. Robinson. Phytologia $38: 418.1978$.

Fleischmannia bridgesii (B. Robinson) R. King \& H. Robinson, Phytologia 19: 203. 1970.

Fleischmannia capillipes (Benth. ex Oersted) R. King \& H. Robinson, Phytologia 28: 74. 1974.

Fleischmaunia carletonii (B. Robinson) R. King \& H. Robinson, Phytologia 19: 203. 1970.

Fleischmannia chiriquensis R. King \& H. Robinson, Phytologia 28: 74. 1974.

Fleischmannia ciliolifera R. King \& H. Robinson, Phytologia 28: 75. 1974.

Fleischmannia cookii (B. Robinson) R. King \& H. Robinson. Phytologia 19: 203. 1970.

Fleischmannia croatii R. King \& H. Robinson, Phytologia 28: 76. 1974.

Fleischmannia crocodilia (Standley \& Steyerm.) R. King \& H. Robinson, Phytologia 19: 203. 1970.

Fleischmannia cuatrecasasii R. King \& H. Robinson, Phytologia 23: 406. 1972

Fleischmannia deborabellae R. King \& H. Robinson, Phytologia 38: 417.1978.

Fleischmannia dissolvens (Baker) R. King \& H. Robinson, Phytologia 19: 203. 1970.

Fleischmannia ejidensis (V. Badillo) R. King \& H. Robinson, Phytologia 35: 499. 1977.
Fleischmannia ferreyrii R. King \& H. Robinson, Phytologia 27: 388. 1974.

Fleischmannia fragilis (B. Robinson) R. King \& H. Robinson, Phytologia 19: 203. 1970.

Fleischmannia gentryi R. King \& H. Robinson, Phylologia 31: 305. 1975.

Fleischmannia gonzalezii (B. Robinson) R. King \& H. Robinson. Phytologia 19: 203. 1970.

Fleischmannia granatensis R. King \& H. Robinson, Phytologia 28: 76. 1974.

Fleischmannia guatemalensis R. King \& H. Robinson, Phytologia 31: 306. 1975.

Fleischmannia harlingii R. King \& H. Robinson, Pliytologia 60 : 81. 1986.

Fleischmannia haughtii R. King \& H. Robinson, Phytologia 28 77. 1974.

Fleischmannia holwayana (B. Robinson) R. King \& H. Robinson. Phytologia 19: 203. 1970.

Fleischrnannia huigrensis (B. Robinson) R. King \& H. Robinson. Phytologia 19: 203. 1970. = Fleischmannia obscurifolia (Hieron. in Sodiro) R. King \& H. Robinson.

Fleischmannia hymenophylla (Klatt) R. King \& H. Robinson, Phytologia 19: 203. 1970.

Fleischmannia ignota (V. Badillo) R. King \& H. Robinson, Phytologia 35: 499. 1977.

Fleischmannia imitans (B. Robinson) R. King \& H. Robinson, Phytologia 19: 203. 1970.

Fleischmannia incarnata (Walter) R. King \& H. Robinson, Phytologia 19: 203, 1970.

Fleischmannia jejuna (Standley \& Steyerm.) R. King \& H. Robinson, Phytologia 19: 203. 1970. = Fleischmannia capillipes (Benth. ex Oersted) R. King \& H. Robinson.

Fleischmannia klattiana (Hieron.) R. King \& H. Robinson, Phytologia 19: 204. 1970.

Fleischmannia langlassei B. Robinson, Proc. Amer. Acad. Arts 41: 273. 1905. = Hofmeisteria urenifolia (Hook. \& Arn.) Walp.

Fleischmannia laxa (Gardner) R. King \& H. Robinson, Phytologia 19: 204. 1970.

Fleischmannia laxicephala (Cabrera) R. King \& H. Robinson, Phytologia 19: 204. 1970.

Fleischmannia lellingeri R. King \& H. Robinson, Phytologia 27: 389. 1974.

Fleischmannia lithophila (B. Robinson) R. King \& H. Robinson. Phytologia 19: 204. 1970.

Fleischmannia lloensis (Hieron.) R. King \& H. Robinson, Phytologia 19: 204. 1970.

Fleischmannia inagdalenensis (B. Robinson) R. King \& H. Robinson, Phytologia 19: 204. 1970.

Fleischmannia inarginata (Poeppig \& Endl.) R. King \& H. Robinson, Phytologia 19: 204. 1970.

Fleischmannia matudae R. King \& H. Robinson, Phytologia 28: 78. 1974.

Fleischmannia mayorii (B. Robinson) R. King \& H. Robinson, Phytologia 19: 204. 1970.

Fleischmannia mercedensis (B. Robinson) R. King \& H. Robinson. Phytologia 19: 204. 1970.

Fleischmannia microsiemon (Cass.) R. King \& H. Robinson, Phytologia 19: 204. 1970.

Fleischmannia misera (B. Robinson) R. King \& H. Robinson, Phytologia 19: 204. 1970.

Fleischmannia monagasensis (V. Badillo) R. King \& H. Robinson, Phytologia 28: 79. 1974.

Fleischmannia multinenis (Benth.) R. King \& H. Robinson, Phytologia 19: 204. 1970.

Fleischmannia nix R. King \& H. Robinson, Phytologia 28: 79. 1974.

Fleischinannia obscurifolia (Hieron.) R. King \& H. Robinson, Phytologia 19: 205. 1970. 
Fleischmannia panamensis R. King \& H. Robinson, Phytologia 28: 80. 1974.

Fleischmannia pastazae (B. Robinson) R. King \& H. Robinson, Phytologia 49: 5. 1981.

Fleischmannia pennellii (B. Robinson) R. King \& H. Robinson, Phytologia 19: 205. 1970.

Fleischmannia plectranthifolia (Benth. ex Oersted) R. King \& H. Robinson, Phytologia 19: 205. 1970.

Fleischmannia polopolensis (B. Robinson) R. King \& H. Robinson, Phytologia 19: 205. 1970.

Fleischmannia porphyranthema (A. Gray) R. King \& H. Robinson, Phytologia 19: 205. 1970.

Fleischmannia prasiifolia (Griseb.) R. King \& H. Robinson, Phytologia 19: 205. 1970.

Fleischmannia pratensis (Klatt) R. King \& H. Robinson, Phytologia 19: 205. 1970.

Fleischmannia purpusii R. King \& H. Robinson, Phytologia 28: 81. 1974.

Fleischmannia pycnocephala (Less.) R. King \& H. Robinson, Phytologia 19: 205. 1970.

Fleischmannia pycnocephaloides (B. Robinson) R. King \& H. Robinson, Phytologia 19: 205. 1970.

Fleischmannia remotifolia (DC.) R. King \& H. Robinson, Phytologia 19: 205. 1970.

Fleischmannia repens B. Robinson, Proc. Amer. Acad. Arts 54: 262. 1918 . = Ageratina repens (B. Robinson) $\mathrm{R}$. King \& $\mathbf{H}$. Robinson.

Fleischmannia rhodostyla Schultz-Bip., Flora 33: 417. 1850. = Fleischmannia arguta (H. B. K.) B. Robinson.

Fleischmannia rhodotephra (B. Robinson) R. King \& H. Robinson, Phytologia 19: 205. 1970.

Fleischmannia rivulorum (B. Robinson) R. King \& H. Robinson, Phytologia 19: 205. 1970.

Fleischmannia saxorum (Standley \& Steyerm.) R. King \& H. Robinson, Phytologia 49: 5. 1981.

Fleischinannia schaffneri A. Gray, Proc. Amer. Acad. Arts 16: 101. 1881. = Hofmeisteria schaffneri (A. Gray) R. King \& H. Robinson.

Fleischmannia schickendantzii (Hieron.) R. King \& H. Robinson, Phytologia 19: 205. 1970.

Fleischmannia seleriana (B. Robinson) R. King \& H. Robinson, Phytologia 19: 206. 1970.

Fleischmannia sideritides (Benth. ex Oersted) R. King \& H. Robinson, Phytologia 19: 206. 1970.

Fleischmannia sinaloensis (B. Robinson) R. King \& H. Robinson, Phytologia 19: 206. 1970.

Fleischmannia sinclairii (Benth. ex Oersted) R. King \& H. Robinson, Phytologia 19: 206. 1970.

Fleischmannia sonorae (A. Gray) R. King \& H. Robinson, Phytologia 28: 82. 1974.

Fleischmannia soratae (Schultz-Bip. ex B. Robinson) R. King \& H. Robinson, Phytologia 19: 206. 1970.

Fleischmannia splendens R. King \& H. Robinson, Phytologia 24: 281. 1972.

Fleischmannia standleyi S. F. Blake, Contr. U. S. Natl. Herb. 22: 590. 1924. = Hofmeisteria standleyi (Blake) R. King \& H. Robinson.

Fleischmannia steyermarkii R. King \& H. Robinson, Phytologia 35: 499. 1977.

Fleischmannia tamboensis (Hieron.) R. King \& H. Robinson, Phytologia 19: 206. 1970.

Fleischmannia trinervia (Schultz-Bip.) R. King \& H. Robinson, Phytologia 19: 206. 1970.

Fleischmannia tysonii R. King \& H. Robinson, Phytologia 28: 82. 1974.

Fleischmannia urenifolia (Hook. \& Am.) Benth. \& Hook. f. ex Jackson \& Hook. f., Index Kew. 1: 970. 1893. = Hofmeisteria urenifolia (Hook. \& Arn.) Walp.
Fleischmannia valeriana (Standley) R. King \& H. Robinson, Phytologia 19: 206. 1970. = Fleischmannia hymenophylla (Klatt) R. King \& H. Robinson.

Fleischmannia viscidipes (B. Robinson) R. King \& H. Robinson, Phytologia 19: 206. 1970.

Fleischmannia yungasensis (B. Robinson) R. King \& H. Robinson, Phytologia 19: 206. 1970.

Fleischmanniopsis anomalochaeta R. King \& H. Robinson, Phytologia 36: 195. 1977.

Fleischmanniopsis langmaniae R. King \& H. Robinson, Phytologia 36: 196. 1977.

Fleischmanniopsis leucocephala (Benth.) R. King \& H. Robinson, Phytologia 21: 403. 1971.

Fleischmanniopsis mendax (Standley \& Steyerm.) R. King \& H. Robinson, Phytologia 21: 403. 1971.

Fleischmanniopsis nubigenoides (B. Robinson) R. King \& H. Robinson, Phytologia 21: 404. 1971.

Flyriella chrysostyla (B. Robinson) R. King \& H. Robinson, Phytologia 24: 69. 1972.

Flyriella harrimanii R. King \& H. Robinson, Phytologia 50: 380. 1982.

Flyriella leonensis (B. Robinson) R. King \& H. Robinson, Phytologia 24: 69. 1972.

Flyriella parryi (A. Gray) R. King \& H. Robinson, Phytologia 24: 69. 1972.

Flyriella sphenopoda (B. Robinson) R. King \& H. Robinson, Phytologia 24: 69. 1972.

Flyriella stanfordii R. King \& H. Robinson, Phytologia 24: 69. 1972.

Garberia fruticosa (Nutt.) A. Gray, Proc. Acad. Nat. Sci. Philadelphia 380. 1879. = Garberia heterophylla (Bartram) Merr. \& Harper.

Garberia heterophylla (Bartram) Merr. \& Harper, Bartonia 23: 24. 1945.

Gardnerina angustata (Gardner) R. King \& H. Robinson, Phytologia 49: 2 . 1981.

Gongrostylus costaricensis (Kuntze) R. King \& H. Robinson, Phytologia 24: 388. 1972.

Goyazianthus tetrastichus (B. Robinson) R. King \& H. Robinson, Phytologia 37: 462. 1977.

Grazielia anethifolia (DC.) R. King \& H. Robinson, Phytologia 23: 305. 1972. = Mikania anethifolia (DC.) Matzenbacher.

Grazielia bishopii R. King \& H. Robinson, Phytologia 49: 285. 1981.

Grazielia coriacea (Scheele) R. King \& H. Robinson, Phytologia 23: 305. 1972. = Symphyopappus reticulatus Baker.

Grazielia dimorpholepis (Baker) R. King \& H. Robinson, Phytologia 23: 306. 1972.

Grazielia gaudichaudeana (DC.) R. King \& H. Robinson, Phytologia 23: 306. 1972.

Grazielia intermedia (DC.) R. King \& H. Robinson, Phytologia 23: 306. 1972.

Grazielia mollicoma (B. Robinson) R. King \& H. Robinson, Phytologia 49: 5. 1981.

Grazielia mollissima (Schultz-Bip. ex Baker) R. King \& H. Robinson, Phytologia 23: 306. 1972.

Grazielia multifida (DC.) R. King \& H. Robinson, Phytologia 23: 306. 1972.

Grazielia nummularia (Hook. \& Arn.) R. King \& H. Robinson, Phytologia 23: 306. 1972.

Grazielia schultzii R. King \& H. Robinson, Phytologia 49: 286. 1981.

Grazielia serrata (Sprengel) R. King \& H. Robinson, Phytologia 23: 306. 1972.

Grisebachianthus carsticola (Borh. \& Muniz) R. King \& H. Robinson, Phytologia 32: 270. 1975.

Grisebachianthus holquinensis (B. Robinson) R. King \& H. Robinson, Phytologia 32: 270. 1975. 
Grisebachianthus hypoleucus (Griseb.) R. King \& H. Robinson, Phytologia 32: 270. 1975.

Grisebachianthus lantanifolius (Griseb.) R. King \& H. Robinson, Phytologia 32: 270. 1975.

Grisebachianthus libanotica (Schultz-Bip.) R. King \& H. Robinson, Phytologia 32: 270. 1975.

Grisebachianthus mayarensis (Alain) R. King \& H. Robinson, Phytologia 32: 270. 1975.

Grisebachianthus nipensis (B. Robinson) R. King \& H. Robinson, Phytologia 32: 270. 1975.

Grisebachianthus plucheoides (Griseb.) R. King \& H. Robinson, Phytologia 32: 270. 1975.

Grosvenoria campii R. King \& H. Robinson, Phytologia 39: 138. 1978.

Grosvenoria coelocaulis (B. Robinson) R. King \& H. Robinson, Phytologia 30: 222. 1975.

Grosvenoria hypargyra (B. Robinson) R. King \& H. Robinson, Phytologia 30: 222, 1975.

Grosvenoria rimbachii (B. Robinson) R. King \& H. Robinson, Phytologia 30: 222. 1975.

Guayania bulbosa (Aristeg.) R. King \& H. Robinson, Phytologia 22: 162.1971

Guayania cerasifolia (Baker) R. King \& H. Robinson, Phytologia 21: 303. 1971 .

Guayania crassicaulis (Steyerm.) R. King \& H. Robinson, Phytologia 49: 5. 1981.

Guayania davidsei R. King \& H. Robinson, Ann. Missouri Bot. Gard. 64: 366(-368). 1977. = Guayania crassicaulis (Steyerm.) R. King \& H. Robinson.

Guayania pelinimervata (Wurd.) R. King \& H. Robinson, Phytologia 21: 303. 1971.

Guayania roupalifolia (B. Robinson) R. King \& H. Robinson, Phytologia 21: 303. 1971.

Guayania yaviana (Lasser \& Maguire) R. King \& H. Robinson, Phytologia 21: 303. 1971.

Guevaria alvaroi R. King \& H. Robinson, Phytologia 29: 260. 1974.

Guevaria loxensis (Blake \& Steyerm.) R. King \& H. Robinson, Phytologia 29: 261. 1974.

Guevaria sodiroi (Hieron. in Sodiro) R. King \& H. Robinson, Phytologia 29: 261. 1974.

Guevaria vargasii (Chung) R. King \& H. Robinson, Phytologia 29: 261.1974.

Gymnocondylus galeopsifolius (Gardner) R. King \& H. Robinson, Phytologia 24: 394. 1972.

Gymnocoronis atlenuata DC., Prodr. 5: 106. 1836. = Gymnocoronis spilanthoides DC.

Gymnocoronis latifolia Hook. \& Am., Bot. Beechey Voy. 296. 1838.

Gymnocoronis matudae R. King \& H. Robinson, Phytologia 29: 10. 1974

Gyminocoronis nutans (Greenman) R. King \& H. Robinson, Phytologia 29: 10. 1974.

Gymnocoronis sessilis S. F. Blake, Proc. Biol. Soc. Wash. 36: 179. 1923.

Gymnocoronis spilanthoides DC., Prodr. 7: 266. 1838.

Gi:mnocoronis subcordata DC., Prodr. 5: 106. 1836. = Gymnocoronis spilanthoides DC.

Gyptidiun militare (B. Robinson) R. King \& H. Robinson, Phytologia 23: 311.1972.

Gyptidium trichobasis (Baker) R. King \& H. Robinson, Phytologia 23: 311.1972.

Gyptis alternifolia [Schultz-Bip. ex Baker] R. King \& H. Robinson, Phytologia 21: 23. 1971. = Gyptis crassipes (Hieron.) R. King \& H. Robinson.

Gyptis artemisifolia (Griseb.) R. King \& H. Robinson, Phytologia 21: 23. 1971 .

Gyptis baccharoides Schultz-Bip. ex Baker, Fl. Bras. 6(2): 366.
1876, nom. nud. = Bahianthus viscosus (Sprengel) R. King \& H. Robinson.

Gyptis commersonii Cass., Dict. Sci. Nat. 20; 178. 1821.

Gypris crassipes (Hieron.) R. King \& H. Robinson, Phytologia 37: 458.1977

Gyptis inornata R. King \& H. Robinson, Phytologia 21: 24. 1971.

Gyptis lanigera (Hook. \& Arn.) R. King \& H. Robinson. Phytologia 21: 24. 1971.

Gyptis oblongifolia (Sprengel) Schultz-Bip. ex Baker, F. Bras. 6(2): 333. 1876, nom. nud. = Stomatanthes oblongifolius (Sprengel) H. Robinson.

Gyptis peucedanifolia Schultz-Bip. ex Baker, F. Bras. 6(2): 315. 1876, nom. nud. = Gyptis pinnatifida Cass.

Gyptis pinnatifida Cass., Dict. Sci. Nat. 20: 178. 1821.

Gyptis vernoniopsis (Schultz-Bip. ex Baker) R. King \& H. Robinson, Phytologia 21: 24. 1971.

Haberlea affinis Pohl ex Baker, F7. Bras. 6(2): 343. 1876. nom. nud. = Prarelis kleinioides (H. B. K.) Schultz-Bip.

Haberlea dentata Pohl ex Baker, F. Bras. 6(2): 343. 1876, nom. nud. = Praxelis kleinioides (H. B. K.) Schultz-Bip.

Haberlea divaricata Pohl ex Baker. F. Bras. 6(2): 344. 1876. nom. nud. = Praxelis pauciflora $($ H. B. K.) R. King \& H. Robinson.

Haberlea pinnara Pohl ex Baker, F. Bras. 6(2): 199. 1876, nom. nud. = Lomalozona arternisiaefolia Baker.

Haberlea sperguloides Pohl ex Baker, F. Bras. 6(2): 341. 1876, nom. nud. = Praxelis capillaris (DC.) Schultz-Bip.

Hartwrightia floridana A. Gray ex S. Watson, Proc. Amer. Acad. Arts 23: 265. 1888.

Hatschbachiella polyclada (Dusen ex Malme) R. King \& H. Robinson, Phytologia 23: 394. 1972.

Hatschbachiella iweedieana (Hook. \& Am.) R. King \& H. Robinson, Phytologia 23: 394. 1972.

Hebeclinium atrorubens Lemaire, 111. Hor. 9: T. 310. 1862. = Barletrina sordida (Less.) R. King \& H. Robinson.

Hebeclinium beneolens (B. Robinson) R. King \& H. Robinson. Pliytologia 31: 313. 1975.

Hebeclinium brevipetiolatum Schultz-Bip. ex Klatt, Leopoldina 20:90. 1884. = Bartlettina brevipetiolata (Schultz-Bip. ex Klatt) R. King \& H. Robinson.

Hebeclinium bullatissimum (B. Robinson) R. King \& H. Robinson, Phytologia 21: 299. 1971.

Hebeclinium costaricense R. King \& $\mathrm{H}$. Robinson, Phytologia 23: 407. 1972.

Hebeclinium cuatrecasasii (R. King \& H. Robinson) R. King \& H. Robinson, Phytologia 21:299. 1971. = Hebeclinium killipii (B. Robinson) R. King \& H. Robinson.

Hebeclinium ehrenbergii Schultz-Bip. ex Hemsley, Biol, Cent.Amer., Bot. 2: 94. 1881, nom. nud. = Barlettina macrocephala (Benth.) R. King \& H. Robinson.

Hebeclinium erioclinium (B. Robinson) R. King \& H. Robinson. Phytologia 21: 299. 1971.

Hebeclinium gentryi R. King \& H. Robinson, Ann. Missouri Bot. Gard. 64: 368(-370). 1977.

Hebeclinium guapulense (Klatt) R. King \& H. Robinson, Phytologia 21: 299. 1971. = Hebeclinium tetragonum Benth.

Hebeclinium guevarae (R. King \& H. Robinson) R. King \& H. Robinson, Phytologia 21: 299.1971.

Hebeclinium hecatanthum DC., Prodr. 5: 136. 1836. = Urolepis hecatantha (DC.) R. King \& H. Robinson.

Hebeclinium hygrohylacum (B. Robinson) R. King \& H. Robinson, Phytologia 21: 299. 1971.

Hebeclinium hylophorbum (B. Robinson) R. King \& H. Robinson. Phytologia 22: 162. 1971.

Hebeclinium ianthinum (Morren) Hook., Bot. Mag. T. 4574. 1851.

$=$ Bartlettina sordida (Less.) R. King \& H. Robinson.

Hebeclinium jajoense (Aristeg.) R. King \& H. Robinson. Phytologia 21: 299. 1971. 
Hebeclinium killipii (B. Robinson) R. King \& H. Robinson, Phytologia 32: 284. 1975.

Ilebeclinium knappiae R. King \& H. Robinson, Phytologia 54: 41. 1983, as "knappii."

Hebeclinium lellingeri R. King \& H. Robinson, Phytologia 27: 389. 1974.

Hebeclinium leucolithogenum (B. Robinson) R. King \& H. Robinson, Phytologia 31: 313. 1975. = Critoniella leucolithogena (B. Robinson) R. King \& H. Robinson.

Hebeclinium liebmannii Schultz-Bip. ex Hemsley, Biol. Cent.Amer., Bot. 2: 96. 1881, nom. nud. = Decachaeta perornata (Klatt) R. King \& H. Robinson.

Hebeclinium macrocephalum Benth., Pl. Hartw. 42. 1840. = Bartlettina macrocephala (Benth.) R. King \& H. Robinson.

Hebeclinium macrophyllum (L.) DC., Prodr. 5: 136. 1836.

Hebeclinium megalophyllum Lemaire, Ill. Hort. 9: misc. 73. 1862. = Bartlettina sordida (Less.) R. King \& H. Robinson, ?

Ilebeclinium obtusisquamosum (Hieron. ex Sodiro) R. King \& H. Robinson, Phytologia 49: 5. 1981.

Hebeclinium panamense Carriere, Rev. Hort. 330. 1877. = Bartlettina sordida (Less.) R. King \& H. Robinson.

Hebeclinium phoenicticum (B. Robinson) R. King \& H. Robinson, Phytologia 21: 300. 1971.

Hebeclinium recreense (Hieron. in Urban) R. King \& H. Robinson, Phytologia 53: 392. 1983.

Hebeclinium reedii R. King \& H. Robinson, Phytologia 23: 406. 1972.

Hebeclinium sericeum (H. B. K.) R. King \& H. Robinson, Phytologia 21: 300. 1971

Hebeclinium sordidum (Less.) Schultz-Bip. ex Koster, Blumea 1: 494. 1935 , nom. nud. = Bartlettina sordida (Less.) R. King \& H. Robinson.

Hebeclinium tepicanum Hook. \& Arn., Bot. Beechey Voy. 434. 1841. = Critonia hebebotrya DC.

Hebeclinium tetragonum Benth., Pl. Hartw. 198. 1845.

Hebeclinium torondoyense (V. Badillo) R. King \& H. Robinson, Phytologia 21: 300. 1971.

Hebeclinium urolepis DC., Prodr. 5: 136. 1836. = Urolepis hecatantha (DC.) R. King \& H. Robinson.

Hebeclinium vestitum $\mathrm{R}$. King \& H. Robinson, Phytologia 31: 313. 1975, nom. nov.

Hebeclinium vitifolium Schultz-Bip. ex Klatt, Leopoldina 20: 90. 1884 , nom. nud. in syn. = Eupatoriastrum triangulare (DC.) B. Robinson.

Helogyne apaloidea Nutt., Trans. Amer. Philos. Soc. 7: 449. 1841.

IVlogyne calocephala Mattf., Feddes Repert. 19: 78. 1923.

IIelogyne fasciculata Benth., Bot. Voy. Sulphur 20. T. 14. 1844. = Hofmeisteria fasciculata (Benth.) Brandegee.

Helogyne ferreyrii R. King \& H. Robinson, Phytologia 27: 396. 1974.

Ilelogyne fiebrigii Hieron. in Urban, Bot. Jahrb. Syst. 40: 368. 1908. = Helogyne straminea (DC.) B. Robinson.

Helogyne hutchisonii R. King \& H. Robinson, Sida 3(5): 327. 1969.

Helogyne macrogyne (Philippi) B. Robinson, Proc. Amer. Acad. Arts 42: 31. 1906.

Helogyne straminea (DC.) B. Robinson, Proc. Amer. Acad. Arts 55: 88.1919.

Helogyne tacaquirensis Hieron. in Urban, Bot. Jahrb. Syst. 40 369. 1908.

Helogyne urenifolia (Hook. \& Am.) Benth. Walp., Repert. Bot. Syst. 4: 457. 1847, nom. nud. in syn.= Hofmeisteria urenifolia (Hook. \& Am.) Walp.

Helogyne virgata (Rusby) B. Robinson, Proc. Amer. Acad. Arts 42: 31. 1906.

Helogyne weberbaueri B. Robinson, Proc. Amer. Acad. Arts 42: 32. 1906. = Ilelogyne straminea (DC.) B. Robinson.
Heterocondylus alatus (Vell. Conc.) R. King \& H. Robinson, Phytologia 49: 5. 1981.

Heterocondylus amphidictyus (DC.) R. King \& H. Robinson, Phytologia 24: 390. 1972

Heterocondylus decipiens (Baker) R. King \& H. Robinson, Phytologia 24: 390. 1972.

Heterocondylus grandis (Schultz-Bip. ex Baker) R. King \& H. Robinson, Phytologia 24: 390. 1972.

Heterocondylus itacolumiensis (Schultz-Bip. ex Baker) R. King \& H. Robinson, Phytologia 24: 390. 1972

Heterocondylus jaraguensis (B. Robinson) R. King \& H. Robinson, Phytologia 24: 390. 1972.

Heterocondylus leptolepis (Baker) R. King \& H. Robinson, Phytologia 24: 390. 1972.

Heterocondylus lysimachioides (Chodat) R. King \& H. Robinson, Phytologia 24: 391. 1972.

Heterocondylus pandurifolius (Baker) R. King \& H. Robinson, Phytologia 24: 391. 1972.

Heterocondylus pumilus (Gardner) R. King \& H. Robinson, Phytologia 24: 391. 1972.

Heterocondylus reitzii $\mathrm{R}$. King \& H. Robinson, Phytologia 24: 391. 1972.

Heterocondylus vauthierianus (DC.) R. King \& H. Robinson, Phytologia 24: 391. 1972. = Heterocondylus alatus (Vell. Conc.) R. King \& H. Robinson.

Heterocondylus vitalbae (DC.) R. King \& H. Robinson, Phytologia 24: 391(-392). 1972.

Heterolaena alpestris Schultz-Bip. ex Baker, Fl. Bras. 6(2): 328. 1876 , nom. nud. = Grazielia serrata (Sprengel) R. King \& H. Robinson.

Heterolaena anethifolia Schultz-Bip. ex Baker, Fl. Bras. 6(2): 330 1876, nom. nud. = Mikania anethifolia (DC.) Matzenbacher.

Ileterolaena conferta Schultz-Bip. ex Baker, Fl. Bras. 6(2): 328. 1876 , nom. nud. = Grazielia serrata (Sprengel) R. King \& H. Robinson.

Heterolaena gaudichaudiana Schultz-Bip. ex Baker, Fl. Bras. 6(2): 329. 1876 , nom. nud. = Grazielia gaudichaudeana (DC.) R. King \& H. Robinson.

Heterolaena intermedia Schultz-Bip. ex Baker, Fl. Bras. 6(2): 329. 1876, nom. nud. = Grazielia intermedia (DC.) R. King \& H. Robinson.

Heterolaena involucrata Schultz-Bip. ex Baker, F. Bras. 6(2): 331. 1876, nom. nud. = Grazielia schultzii R. King \& H. Robinson.

Heterolaena itapingensis Schultz-Bip. ex Baker, Fl. Bras. 6(2): 329. 1876 , nom. nud. = Grazielia intermedia $(\mathrm{DC}$.) R. King \& H. Robinson.

Heterolaena leucodon Schultz-Bip. ex Baker, Fl. Bras. 6(2): 330. 1876 , nom. nud. = Grazielia gaudichaudeana (DC.) R. King \& H. Robinson.

Heterolaena mollissima Schultz-Bip. ex Baker, Fl. Bras. 6(2): 331. 1876, nom. nud. = Grazielia mollissima (Schultz-Bip. ex Baker) R. King \& H. Robinson.

Heterolaena nitida Schultz-Bip. ex Baker, Fl. Bras. 6(2): 370. 1876, nom. nud. = Mikania nitida (DC.) R. King \& H. Robinson.

Heterolaena orgyalis Schultz-Bip. ex Baker, Fl. Bras. 6(2): 328. 1876, nom. nud. = Grazielia serrata (Sprengel) R. King \& H. Robinson.

Heterolaena serrata Schultz-Bip. ex Baker, Fl. Bras. 6(2): 328. 1876 , nom. nud. = Grazielia serrata (Sprengel) R. King \& H. Robinson.

IIofmeisteria crassifolia S. Watson, Proc. Amer. Acad. Arts 24: 53. 1889.

Hofmeisteria dissecta (Hook. \& Arn.) R. King \& H. Robinson, Phytologia 12: 466. 1966.

Hofineisteria fasciculata (Benth.) Walp., Repert. Bot. Syst. 6: 106. 1847. 
Hofmeisteria fasciculata (Benth.) Brandegee, Proc. Calif. Acad. Sci. Ser. 2. 2: 167. 1889, comb. superfl. = Hofineisteria fasciculata (Benth.) Walp.

Hofmeisteria flifolia I. M. Johnston, Proc. Calif. Acad. Sci. Ser. 4. 12: 1185.1924.

Hofineisteria gentryi Wiggins, Contr. Dudley Herb. 4: 25. 1950. $=$ Plenrocoronis gentryi (Wiggins) R. King \& H. Robinson.

Hofmeisteria laphamioides Rose in Vasey \& Rose, Contr. U. S. Natl. Herb. 1: 79. 1890. = Pleurocoronis laphamioides (Rose) R. King \& H. Robinson.

Hofmeisteria pluriseta A. Gray in Torrey, Pacif. Rail. Rep. 4: 96. T. 9. 1857. = Pleurocoronis pluriseta (A. Gray) R. King \& H. Robinson.

Hofmeisteria pubescens S. Watson. Proc. Amer. Acad. Arts 24: 54. 1889 . = Hofmeisteria fasciculata (Benth.) Walp.

Hofmeisteria schaffneri (A. Gray) R. King \& H. Robinson, Phytologia 12: 467. 1966.

Hofmeisteria sinaloensis H. Gentry, Brittonia 6: 329. 1948.

Hofmeisteria standleyi (Blake) R. King \& H. Robinson, Phytologia 12: 467. 1966.

Hofmeisteria tenuis (S. Watson) I. M. Johnston, Proc. Calif. Acad. Sci. Ser. 4. 12: 1188. 1924. = Malperia tenuis S. Watson.

Hofmeisteria urenifolia (Hook. \& Am.) Walp., Repert. Bot. Syst. 6: $106,1847$.

IIofineisteria viscosa Nelson, Bot. Gaz. (Crawfordsville) 37: 263. 1904. = Pleurocoronis pluriseta (A. Gray) R. King \& H. Robinson.

IInghesia reginae R. King \& H. Robinson, Phytologia 47: 252. 1980.

Hymenopappus matricarioides Sprengel, Syst. Veg. 3: 450. 1826. = Phania matricarioides (Sprengel) Griseb.

Idiothammus clavisetus (V. Badillo) R. King \& H. Robinson, Phytologia 32: 279. 1975.

Idiothamnus lilloi (B. Robinson) R. King \& H. Robinson, Phytologia 32: 279. 1975.

Idiothamnus orgy aloides (B. Robinson) R. King \& H. Robinson, Phytologia 32: 279. 1975.

Idiothamnus psendorgvalis R. King \& H. Robinson, Phytologia 32: 279.1975.

Iltisia echandiensis R. King \& H. Robinson, Phytologia 56: 249. 1984.

Ilicisia repens S. F. Blake, J. Wash. Acad. Sci. 47: 409. 1957.

Imeria memorabilis (Maguire \& Wurd.) R. King \& H. Robinson, Phytologia 32: 272. 1975.

Imeria serratifolia V. Badillo, Enstia 30: 2. 1985.

Ismaria glandulosa Raf. Sylva Tellur. 117. 1838. = Brickellia glandulosa (Llave in Llave \& Lex.) McVaugh.

glandulosa (Llave in Llave \& Lex.) McVaugh. $19.1822 .=I s-$ acarpha atriplicifolia (L.) R. Br. ex DC.

Isocarpha amellus Sprengel ex DC.. Prodr. 5: 493. 1836, nom. nud. = Salmea scandens (DC.) DC. HELIANTHEAE,

Isocarpha amplexicaulis B. Robinson ex C. Baker, W. Amer. Pl. 2: 21. 1903. nom. nud.

Isocarpha angustata Griseb., F. Brit. W. I. 376. 186I. = Isocarpha oppositifolia (L.) Cass.

Isocarpha atriplicifolia (L.) R. Br. ex DC., Prodr. 5: 106.1836.

Isocarpha berterii Balbis ex DC. Prodr. 5: 140. 1836. nom. nud. = Critonia dalea (L.) DC.

Isocarpha bilhergiana Less. in Schlechtend. \& Cham., Linnaea $6: 405.1831$. = Isocarpha atriplicifolia (L.) R. Br. ex DC.

socarpha blepharolepis Greenman, Publ. Field Mus. Nat. Hist., Bot. Ser. 2: 347. 1912. = Isocarpha microcephala (DC.) S. F. Blake.

Isocarpla cubana S. F Blake, Contr. U. S. Natl. Herb. 22: 613. 1924 = Isocarpha atriplicifolia (L.) R. Br. ex DC.

1924. = Isocarpha atriplicifolia (L.) R. Br. ex DC. 41.1845. Isocarpha divaricata Benth., Bot. Voy. Sulphur
Isocarpha echioides Less. in Schlechtend. \& Cham., Linnaea 5: 141. T. 2. 1830. = Ageratum echioides (Less.) Hemsley.

Isocarpha eupatorioides Gardner, London J. Bot. 5: 456. 1846. = Trichogonia menthaefolia Gardner.

Isocarpha fastigiata Gardner, London J. Bot. 5: 455. 1846. = Ageratum fastigiatum (Gardner) R. King \& H. Robinson.

Isocarpha fistulosa Keil \& Stuessy, Syst. Bot. 6: 273. 1981.

Isocarpha foliosa Gardner, London J. Bot. 5: 457. 1846. = Teixeiranthus foliosus (Gardner) R. King \& H. Robinson.

Isocarpha glabrata S. F. Blake, Contr. U. S. Natl. Herb. 22: 614. 1924. = Isocarpha oppositifolia (L.) Cass.

Isocarpha kumthii Cass., Dict. Sci. Nat. 24: 19. 1822. = Spilanthes leucantha H. B. K. HeliantheaE.

Isocarpha megacephala Mattf., Notizbl. Bot. Gart. Berlin-Dahlem 9: 385. 1925.

Isocarpha microcephala (DC.) S. F. Blake, Proc. Biol. Soc. Wash. 39: 144. 1926.

Isocarpha oppositifolia (L.) Cass., Dict. Sci. Nat. 24: 19. 1822.

Isocarpha pyrethraria (L.) Cass., Dict. Sci. Nat. 26: 280. 1823. - Spilanthes oleracea L. HeliantheAe.

Isocarpha tricephala Cass., Dict. Sci. Nat. 26: 280. 1823. =Isocarpha oppositifolia (L.) Cass.

Jaliscoa goldmanii (B. Robinson) R. King \& H. Robinson, Phy tologia 19: 427. 1970.

Jaliscoa paleacea (Cronq.) R. King \& H. Robinson, Phytologia 19: 428. 1970.

Jaliscoa pappifera S. F. Blake, Contr. U. S. Natl. Herb. 22: 587. 1924. = Jaliscoa pringlei $\mathrm{S}$. Watson.

Jaliscoa pringlei S. Watson, Proc. Amer. Acad. Arts 25: 153. 1890.

Jaramilloa hylibales (B. Robinson) R. King \& H. Robinson, Phytologia 47: 118. 1980.

Jaramilloa sanctae-martae R. King \& H. Robinson, Phytologia 47: 119,1980

Jaumea ienuifolia Klatt, Leopoldina 23: 146. 1887. = Bartlettina karvinskiana (DC.) R. King \& H. Robinson.

Kallophyllon crenatum Pohl ex Baker, Fl. Bras. 6(2): 367. 1876 nom. nud. = Symphyopappus reticulatus Baker.

Kallophyllon ovatum Pohl ex Baker, F. Bras. 6(2): 368, 1876. nom. nud. = Symphyopappus reticulatus Baker.

Kanimia celestini Cuatrec., Trab. Mus. Nac. Ci. Nat., Ser. Bot 29: 15. 1935, nom. nud. = Eupatorium celestini Cuatrec.. Ager alina?

Kanimia colombiana Rusby, Descr. S. Amer. Pl. 148. 1920. = Ophryosporus heptanthus (Schultz-Bip. ex Wedd.) R. King \& H. Robinson.

Kanimia corymbifolia B. Robinson. Proc. Amer. Acad. Arts 47: 198. 1911 . = Mikania

Kanimia corymbulosa (Benth.) Jackson \& Hook. f., Index Kew. 2:3. 1894. = Mikania corymbulosa Benth.

Kanimia cutervensis (Hieron.) Hieron. in Urban, Bot. Jahrb. Syst. 40: 394. 1908. = Mikania cuteriensis Hieron.

Kanimia erithalina (DC.) Benth. \& Hook. ex Jackson \& Hook. f., Index Kew. 2: 3. 1894, as "erythralina." = Mikania nitida (DC.) R. King \& H. Robinson.

Kanimia goyazensis B. Robinson, Contr. Gray Herb. 75: 14. 1925. = Mikania goyazensis (B. Robinson) R. King \& H. Robinson.

Kanimia gracilis Baker, Fl. Bras. 6(2): 371. 1876. = Mfikanid bakeri R. King \& H. Robinson.

Kanimia microphylla B. Robinson, Contr. Gray Herb. 65: 54. 1922 = Mikania

Kanimia nitida Baker, Fl. Bras. 6(2): 370. 1876. = Mikania nitida (DC.) R. King \& H. Robinson.

Kanimia oblongifolia (DC.) Baker. Fl. Bras. 6(2): 369. 1876. = Mikania oblongifolia DC.

Kanimia palustris Gardner, London J. Bot. 6: 447. 1847. = Mikania palustris (Gardner) R. King \& H. Robinson. 
Kanimia pohlii Baker, Fl. Bras. 6(2): 370. 1876. = Mikania pohlit (Baker) R. King \& H. Robinson.

Kanimia purpurascens Baker, Fl. Bras. 6(2): 371. 1876. = Mikania purpurascens (Baker) R. King \& H. Robinson.

Kanimia rufescens (Schultz-Bip.) Hieron. in Urban, Bot. Jahrb. Syst. 40: 394. 1908. = Mikania rufescens Schultz-Bip. ex Baker. Kanimia strobilifera Gardner, London J. Bot. 6: 447. 1847. = Mikania oblongifolia DC.

Kanimia thapsoides (DC.) Jackson \& Hook. f., Index Kew. 2: 3. 1894. = Mikania thapsoides DC.

Kanimia thapsoides (DC.) Hieron., Bot. Jahrb. Syst. 22: 797. 1897, comb. superf. = Mikania thapsoides DC.

Kanimia violascens B. Robinson, Proc. Amer. Acad. Arts 47: 198. $1911 .=$ Mikania.

Kaunia arbuscularis (B. Robinson) R. King \& H. Robinson, Phytologia 47: 259. 1980.

Kaunia camataguiensis (Hieron.) R. King \& H. Robinson, Phytologia 47: 259. 1980.

Kannia endyta (B. Robinson) R. King \& H. Robinson, Phytologia 47: 259. 1980.

Kaunia eucosmoides (B. Robinson) R. King \& H. Robinson, Phytologia 47: 259. 1980.

Kaumia grossidentata (Hieron.) R. King \& H. Robinson, Phytologia 47: 259. 1980.

Kaunia gynoximorpha (Rusby ex B. Robinson) R. King \& H. Robinson, Phytologia 47: 259. 1980.

Kaunia hosanensis (B. Robinson) R. King \& H. Robinson, Phytologia 47: 259. 1980.

Kannia ignorata (Hieron.) R. King \& H. Robinson, Phytologia 47: 259. 1980.

Kannia lasiophthalma (Hieron.) R. King \& H. Robinson, Phytologia 47: 259. 1980.

Kaunia longipetiolata (Schultz-Bip. ex Rusby) R. King \& H. Robinson, Phytologia 47: 259. 1980.

Kannia pachanoi (B. Robinson) R. King \& H. Robinson, Phytologia 47: 260. 1980.

Kalnia rufescens (Lund ex DC.) R. King \& H. Robinson, Phytologia 47: 260. 1980.

Kannia saltensis (Hieron.) R. King \& H. Robinson, Phytologia 47: 260. 1980.

Kamia uber (B. Robinson) R. King \& H. Robinson, Phytologia 47: $260,1980$.

Kleinia alata G. Meyer, Prim. Fl. Esseq. 249. 1818. = Mikania micrantha $\mathrm{H}$. B. K.

Kleinia selloi Sprengel, Syst. Veg. Fl. Peruv. Chil. 3: 438. 1826. = Stevia selloi (Sprengel) B. Robinson.

Koanophyllon adamantitm (Gardner) R. King \& H. Robinson, Phytologia 32: 254. 1975

Koanophyllon albicanlis (Schultz-Bip. ex Klatt) R. King \& H. Robinson, Phytologia 22: 149. 1971.

Koanophyllon andersonii R. King \& H. Robinson, Phytologia 46: 297. 1980.

Koanophyllon atroglandulosum (Alain) R. King \& H. Robinson, Phytologia 32: 254. 1975.

Koanophyllon avapanoides (Griseb.) R. King \& H. Robinson, Phytologia 32: 254. 1975

Koanophyllon baccharifolium (Gardner) R. King \& H. Robinson, Phytologia 32: 255. 1975.

Koanophyllon barahonense (Urban) R. King \& H. Robinson, Phytologia 32: 255. 1975.

Koanophyllon breviflorum (Alain) R. King \& H. Robinson, Phytologia 32: 255. 1975.

Koanophyllon bullescens (B. Robinson) R. King \& H. Robinson, Phytologia 32: 255. 1975.

Koanophyllon cabaionum (Urban \& Ekman) R. King \& H. Robinson, Phytologia 32: 255. 1975.

Koanophyllon calcicola (Urban) R. King \& H. Robinson, Phytologia 32: 255. 1975.
Koanophyllon celtidifolia (Lam.) R. King \& H. Robinson, Phytologia 22: 149. 1971.

Koanophyllon chabrense (Urban \& Ekman) R. King \& H. Robinson, Phytologia 32: 255. 1975.

Koanophyllon chalceorithales (B. Robinson) R. King \& H. Robinson, Phytologia 32: 255. 1975.

Koanophyllon clementis (Alain) R. King \& H. Robinson, Phytologia 32: 255. 1975.

Koanophyllon conglobatum (DC.) R. King \& H. Robinson, Phytologia 45: 465. 1980.

Koanophyllon consanguineum (DC.) R. King \& H. Robinson, Phytologia 32: 256. 1975.

Koanophyllon correllionum (Pletıman) R. King \& H. Robinson, Phytologia 37: 458. 1977.

Koanophyllon coulteri (B. Robinson) R. King \& H. Robinson, Phytologia 22: 149. 1971.

Koanophyllon cubense (DC.) R. King \& H. Robinson, Phytologia 32: 256. 1975. = Koanophyllon villosum (Sw.) R. King \& H. Robinson.

Koanophyllon cynanchifolitm (DC.) R. King \& H. Robinson, Phytologia 32: 256. 1975. = Koanophyllon villosum (Sw.) R. King \& H. Robinson.

Koanophyllon delpechianum (Urban \& Ekman) R. King \& H. Robinson, Phytologia 32: 256. 1975.

Koanophyllon dolicholepis (Urban) R. King \& H. Robinson, Phytologia 32: 256. 1975.

Koanophyllon dolphinii (Urban) R. King \& H. Robinson, Phytologia 32: 256. 1975.

Koanophyllon droserolepis(B. Robinson) R. King \& H. Robinson, Phytologia 32: 256. 1975.

Koanophyllon dukei R. King \& H. Robinson, Phytologia 28: 68. 1974.

Koanophyllon eitenii R. King \& H. Robinson, Phytologia 32: 256. 1975.

Koanophyllon ekmanii (B. Robinson) R. King \& H. Robinson, Phytologia 32: 257. 1975.

Koanophyllon flavidulum (Urban \& Ekman) R. King \& H. Robinson, Phytologia 32: 257. 1975.

Koanophyllon flexilis (B. Robinson) R. King \& H. Robinson, Phytologia 22: 150. 1971.

Koanophyllon fuscum (N. E. Br.) R. King \& H. Robinson, Phytologia 32: 257. 1975.

Koanophyllon gabbii (Urban) R. King \& H. Robinson, Phytologia 32: 258. 1975.

Koanophyllon galeottii (B. Robinson) R. King \& H. Robinson, Wrightia 6(2): 25. 1978.

Koanophyllon gibbosum (Urban) R. King \& H. Robinson, Phytologia 32: 258. 1975.

Koanophyllon gracilicaule (Schultz-Bip. ex B. Robinson) R. King \& H. Robinson, Phytologia 32: 258. 1975.

Koanophyllon gracilipes (Urban) R. King \& H. Robinson, Phytologia 32: 258. 1975.

Koanophyllon grandiceps (Wright) R. King \& H. Robinson, Phytologia 49: 5. 1981.

Koanophyllon grisebachianum (Alain) R. King \& H. Robinson, Phytologia 49: 5. 1981.

Koanophyllon gundlachii (Urban) R. King \& H. Robinson, Phytologia 32: 258. 1975.

Koanophyllon hammatocladım (B. Robinson \& Britton) R. King \& H. Robinson, Phytologia 32: 258. 1975.

Koanophyllon hardwarense (Proctor ex C. Adams) R. King \& H. Robinson, Phytologia 32: 258. 1975.

Koanophyllon helianthernoides (B. Robinson) R. King \& H. Robinson, Phytologia 32: 258. 1975.

Koanophyllon heptaneurum (Urban) R. King \& H. Robinson, Phylologia 32: 258. 1975.

Koanophyllon hidrodes (B. Robinson) R. King \& H. Robinson, Phytologia 32: 258. 1975. 
Koanophyllon hondurensis (B. Robinson) R. King \& H. Robinson, Phytologia 22: 150. 1971.

Koanophyllon hotteanum (Urban \& Ekman) R. King \& H. Robinson, Phytologia 32: 259. 1975.

Koanophyllon hwantae (B. Robinson) R. King \& H. Robinson, Phytologia 22: 150. 1971.

Koanophyllon hylonoma (B. Robinson) R. King \& H. Robinson, Phytologia 22: 150. 1971.

Koanophyllon hypomalaca (B. Robinson ex D. Sm.) R. King \& H. Robinson, Phytologia 22: 150. 1971.

Koanophyllon incisum R. King \& H. Robinson, Phytologia 32: 259.1975, nom. nov. = Koanophyllon grisebachianum (Alain) R. King \& H. Robinson.

Koanophyllon isillumense (B. Robinson) R. King \& H. Robinson, Phytologia 32: 259. 1975.

Koanophyllon iteophyllum (Urban \& Ekman) R. King \& H. Robinson, Phytologia 32: 259. 1975.

Koanophyllon jaegerianum (Urban) R. King \& H. Robinson, Phytologia 32: 259. 1975.

Koanophyllon jenssenii (Urban) R. King \& H. Robinson, Phytologia 32: 259. 1975.

Koanophyllon jugipaniculatum (Rusby) R. King \& H. Robinson, Phytologia 32: 259. 1975.

Koanophyllon juninense (B. Robinson) R. King \& H. Robinson, Phytologia 32: 259. 1975

Koanophyllon kavanayense (V. Badillo) R. King \& H. Robinson, Phytologia 32: 260. 1975.

Koanophyllon lindenianum (A. Rich.) R. King \& H. Robinson, Phytologia 32: 260. 1975. = Koanophyllon villosum (Sw.) R. King \& H. Robinson.

Koanophyllon littorale R. King \& H. Robinson, Phytologia 32: 260. 1975, nom. nov.

Koanophyllon lobatifolia (Cabrera) R. King \& H. Robinson, Phytologia 29: 123. 1974.

Koanophyllon longifolia (B. Robinson) R. King \& H. Robinson, Phytologia 22: 150. 1971.

Koanophyllon maestrense (Urban) R. King \& H. Robinson, Phytologia 32: 260. 1975.

Koanophyllon mesoreopolum (B. Robinson) R. King \& H. Robinson, Phytologia 32: 260. 1975.

Koanophyllon microchactum (Urban \& Ekman) R. King \& H. Robinson. Phytologia 32: 260. 1975.

Koanophyllon mimica (Standley \& Steyerm.) R. King \& H. Robinson, Phytologia 22: 150.1971.

Koanophyllon minutifolium (Alain) R. King \& H. Robinson, Phytologia 32: 260. 1975.

Koanophyllon miragoanae (Urban) R. King \& H. Robinson, Phytologia 32: 260. 1975.

Koanophyllon montanum (Sw.) R. King \& H. Robinson, Phytologia 32: 261. 1975.

Koanophyllon mornicola (Urban \& Ekman) R. King \& H. Robinson, Phytologia 32: 261. 1975.

Koanophyllon muricatum (Alain) R. King \& H. Robinson, Phytologia 32: 261. 1975.

Koanophyllon myrtilloides (DC.) R. King \& H. Robinson, Phytologia 32: 261. 1975.

Koanophyllon nervosum (Sw.) R. King \& H. Robinson, Phytologia 32: 261. 1975.

Koanophyllon nudiflorum (A. Rich.) R. King \& H. Robinson, Phytologia 32: 261. 1975.

Koanophyllon obtusissimum (DC.) R. King \& H. Robinson, Phytologia 32: 261. 1975.

Koanophyllon oligadenium (Alain) R. King \& H. Robinson, Phytologia 32: 261. 1975.

Koanophyllon pachyneurum (Urban) R. King \& H. Robinson, Phytologia 32: 261. 1975

Koanophyllon palmeri (A. Gray) R. King \& H. Robinson, Phytologia 22: 150. 1971.
Koanophyllon panamensis R. King \& H. Robinson, Phytologia 28: 67. 1974.

Koanophyllon paucicrenatum (Urban \& Ekman) R. King \& H. Robinson, Phytologia 32: 261. 1975.

Koanophyllon phanioides (Urban \& Ekman) R. King \& H, Robinson, Phytologia 32: 262. 1975.

Koanophyllon picardae (Urban) R. King \& H. Robinson, Phytologia 32: 262. 1975.

Koanophyllon pitonianum (Urban \& Ekman) R. King \& H. Robinson, Phytologia 32: 262. 1975.

Koanophyllon pittieri (Klatt) R. King \& H. Robinson, Phytologia 22: 150. 1971

Koanophyllon plicata (Urban) R. King \& H. Robinson, Phytologia 22: 150. 1971. = Koanophyllon tinctorium Arruda.

Koanophy'llon polyodon (Urban) R. King \& H. Robinson, Phytologia 32: 262. 1975.

Koanophyllon polystictum (Urban) R. King \& H. Robinson, Phytologia 32: 262. 1975.

Koanophyllon porphyrocladum (Urban \& Ekman) R. King \& H. Robinson, Phytologia 32: 262. 1975.

Koanophyllon prinodes (B. Robinson) R. King \& H. Robinson, Phytologia 32: 262. 1975.

Koanophyllon pseudoperfoliata (Schultz-Bip. ex Klatt) R. King \& H. Robinson, Phytologia 22: 150. 1971.

Koanophyllon puberulum (DC.) R. King \& H. Robinson, Phytologia 32: 262. 1975.

Koanophyllon quisqueyanum (Alain) R. King \& H. Robinson, Phytologia 49: 5. 1981.

Koanophyllon ravenit $\mathrm{R}$. King \& $\mathrm{H}$. Robinson, Phytologia 22: 150. 1971.

Koanophyllon reversum (Urban) R. King \& H. Robinson, Phytologia 32: 263. 1975.

Koanophyllon reyrobinsonii B. Tumer, Phytologia 52: 495.1983. = Koanophyllon longifolia (B. Robinson) R. King \& H. Robinson.

Koanophyllon rhexioides (B. Robinson) R. King \& H. Robinson, Phytologia 32: 263. 1975.

Koanophyllon richardsonii B. Turner, Phytologia 52: 496. 1983. =Koanophyllon gracilicaule (Schultz-Bip. ex B. Robinson) R. King \& H. Robinson.

Koanophyllon rubroviolaceum (Urban \& Ekman) R. King \& H. Robinson, Phytologia 32: 263. 1975.

Koanophyllon sagasteguii R. King \& H. Robinson, Phytologia 54: 42.1983.

Koanophyllon scabriusculum (Urban \& Ekman) R. King \& H. Robinson, Phytologia 32: 263. 1975.

Koanophyllon sciatraphes (B. Robinson) R. King \& H. Robinson, Phytologia 32: 263. 1975.

Koanophyllon selleanum (Urban) R. King \& H. Robinson, Phytologia 32: 263. 1975.

Koanophyllon semicrenatum (Urban) R. King \& H. Robinson, Phytologia 32: 263. 1975.

Koanophyllon silvaticum (B. Robinson) R. King \& H. Robinson, Phytologia 32: 263. 1975.

Koanophyllon simile (Proctor) R. King \& H. Robinson, Phytologia 32: 263. 1975.

Koanophyllon simillima (B. Robinson) R. King \& H. Robinson, Phytologia 22: 151. 1971.

Koanophyllon solidaginifolia (A. Gray) R. King \& H. Robinson, Phytologia 22: 151. 1971.

Koanophyllon solidaginoides (H. B. K.) R. King \& H. Robinson, Phytologia 22: 151. 1971.

Koanophyllon sorensenii R. King \& H. Robinson, Phytologia 23: 395. 1972.

Koanophyllon standleyi (B. Robinson) R. King \& H. Robinson, Phytologia 22: 151. 1971.

Koanophyllon stipulifera (Rusby) R. King \& H. Robinson, Phytologia 22: 151. 1971. 
Koanophyllon subpurpurcum (Urban \& Ekman) R. King \& H. Robinson, Phytologia 32: 264. 1975.

Koanophyllon tapeinanthum (Urban) R. King \& H. Robinson, Phytologia 32: 264. 1975.

Koanophyllon tatci (B. Robinson) R. King \& H. Robinson, Phytologia 32: 264. 1975.

Koanophyllon tetranthum (Griseb.) R. King \& H. Robinson, Phytologia 32: 264. 1975.

Koanophyllon thysanolepis (B. Robinson) R. King \& H. Robinson. Phytologia 32: 264. 1975.

Koanophyllon tinctorium Arruda, Diss. PI. Brazil 38. 1810.

Koanophyllon tricephalotes (Schultz-Bip. ex Baker) R. King \& H. Robinson, Phytologia 32: 265. 1975.

Koanophyllon triradiatum (Urban) R. King \& H. Robinson, Phytologia 32: 265. 1975.

Koanophyllon turquiensis (Alain) Borh., ERROR 29: 210.1983.

Koanophyllon villosum (Sw.) R. King \& H. Robinson, Phytologia 32: 265. 1975.

Koanophyllon wetmorei (B. Robinson) R. King \& H. Robinson, Phytologia 28: 67. 1974.

Kuhnia adenolepis B. Robinson, Proc. Amer. Acad. Arts 47: 201. 1911. = Brickellia adenolepis (B. Robinson) Shinn.

Kuhnia albicaulis Raf., New FI. 4: 105. 1838, ignota.

Kuhnia altaica Raf., New F1. 1: 79. 1836, nom. superfl. = Brickellia eupatorioides (L.) Shinn.

Kíhnia arabica Hochst. \& Steudel ex DC., Prodr. 7: 267. 1838. = Pegolettia senegalenisis Cass. InULEAE.

Kuhnia arguta H. B. K., Nov. Gen. Sp. 4: 82. Ed. Folio. 1818. $=$ Trichogonia arguta $($ H. B. K.) Benth. \& Hook. f. ex Klatt.

Kuhnia baccharoides DC., Prodr. S: 127. 1836. = Bahianthus viscosus (Sprengel) R. King \& H. Robinson.

Kúhrita chlorolepis Wooton \& Standley, Contr. U. S. Natl. Herb. 16: 177. 1913. = Brickellia chlorolepis (Wooton) Shinn.

Kuhnia cinerea Raf., New Fl. 4: 106. 1838. = Brickellia eupatorioides (L.) Shinn.

Kuhnia critonia Willd., Sp. PI. 3: 1773. 1803. = Brickellia eupatorioides (L.) Shinn.

Kuhnia dasypia Raf.. Herb. Raf. 30. 1833, New F. I: 79.1836. = Brickellia eltpatorioides (L.) Shinn.

Kuhnia divaricata Raf., New FI. 4: 105. 1838. = Brickellia eupatorioides (L.) Shinn.

Kuhnia elliptica Raf., New F1, 1: 76,79. 1836. = Brickellia eupatorioides (L.) Shinn.

Kuhmia eupalorioides L., Sp. Pl., ed. 2, 1662. 1762-1 763. = Brickellia etupatorioides (L.) Shinn.

Kuhria fizpatricki Nelson, Bot. Gaz. (Crawfordsville) 31: 402. 1901 , = Brickellia ellpatorioides (L.) Shinn.

Kuhnia frutescens Hornem., Hort. Bot. Hafn. 2: 79. 1815, ignota.

Kuhria fruticosa Vent. ex Steudel, Nomencl. Bot. 1: 322. 1821, nom. nud. = Kuhnia frutescens Hornem.

Kuhnia fulva Raf., New F1. 1:80. 1836. = Brickellia eupatorioides (L.) Shinn.

Kuhnia glabra Raf., Herb. Raf. 29. 1833, New F. 1: 79. 1836. = Brickellia eupatorioides (L.) Shinn.

Kuhnia glabrata DC., Prodr. 5: 127. 1836. = Stomatanthes oblongifolius (Sprengel) H. Robinson.

Kuhnia glomerata Raf., New Fl. 4: 105. 1838. = Brickellia eupatorioides (L.) Shinn.

Kuhria glutinosa Ellis, Sketch 13ot. S. Carolina 2: 292. 1822?. = Brickellia eupatorioides (L.) Shinn.

Kuhnia gooddingi Nelson, Bot. Gaz. (Crawfordsville) 31: 402. 1901. = Brickellia cupatorioides (L.) Shinn.

Kuhnia hirtiflora DC., Prodr. 5: 127. 1836. = Trichogonia hirtiflora (DC.) Schultz-Bip. ex Baker.

Kuhnia hitchcocki Nelson, Bot. Gaz. (Crawfordsville) 31: 403. 1901. = Brickellia eupatorioides (L.) Shinn.

Kuhnia icosantha Schultz-Bip., Linnaea 22: 572. 1849, nom. nud. = Trichogoniopsis podocarpa (DC.) R. King \& H. Robinson.
Kuhnia jacobaea Lunell, Amer. Midl. Naturalist 5: 36. 1917. = Brickellia eupatorioides (L.) Shinn.

Kuhnia kuhnia (Gaertner) Mohr, Bull. Torrey Bot. Club 24: 28. 1897, taut. illeg. = Brickellia eupatorioides (L.) Shinn.

Kuhnia latifolia Raf., New Fl. 4: 105. 1838. = Brickellia eupatorioides (L.) Shinn.

Kuhnia leptophylla Scheele, Linnaea 21: 598. 1848. = Brickellia leptophylla (Scheele) Shinn.

Kuhnia linearifolia Sprengel, Syst. Veg. Fl. Peruv. Chil. 3: 439. 1826. = Jaumea linearis Pers. HeliantheAe.

Kuhnia macrantha Buckley, Proc. Amer. Acad. Arts 13(1861): 456. 1861. = Brickellia eupatorioides (L.) Shinn.

Kuhnia maximiliani Sinning, Allg. Gartenzeitung 7: 138. 1839. = Brickellia eupatorioides (L.) Shinn.

Kuhnia media Raf., Herb. Raf. 30. 1833, New Fl. 1: 76. 1836. = Brickellia eupatorioides (L.) Shinn.

Kuhnia microphylla Shinn., Wrightia 1: 127. 1946. = Brickellia schaffieri (A. Gray) Shinn.

Kuhnia mosieri Small, Man. S. E. Fl. 1329. 1933. = Brickellia mosieri (Small) Shinn.

Kuhnia multiramea Turcz., Bull. Soc. Imp. Naturalistes Moscou 24(1): 168. 1851. = Ophryosporus triangularis Meyen.

Kuhnia oreithales B. Robinson, Proc. Amer. Acad. Arts 54: 263. 1918. = Brickellia oreithales (B. Robinson) Shinn.

Kuhnia paniculata Cass., Dict. Sci. Nat. 24: 516. 1822. = Brickellia eupatorioides (L.) Shinn.

Kulmia pinnata J. Gmelin, Syst. Nat. 375. 1791. = Petalostemum corymbosum Michaux. LeguminosAE.

Kuhnia podocarpa DC., Prodr. 5: 127. 1836. = Trichogoniopsis podocarpa (DC.) R. King \& H. Robinson.

Kuhnia pubescens Raf., New Fl. 1: 80. 1836. = Brickellia ellpatorioides (L.) Shinn.

Kuhnia pyrifolia Martius, P1. Hort. Erlang. 175. 1840. = Kuhnia rosmarinifolia Vent.

Kuhnia pyrifolia Martius ex Steudel, Nomencl. Bot. 1: 851. 1840 , nom. nud. = Kuhnia rosmarinifolia Vent.

Kuhnia reticulata Nelson, Bot. Gaz. (Crawfordsville) 31: 403. 1901. = Brickellia eupatorioides (L.) Shinn.

Kuhnia rosmarinifolia Vent., Descr. P1. Nouv. T. 91. 1803-1804, ignota.

Kuhnia schaffneri A. Gray, Proc. Amer. Acad. Arts 17: 207.1882. = Brickellia schaffneri (A. Gray) Shinn.

Kuhnia spicata (L.) Baillon, Hist. Pl. 8: 298. 1882. = Liatris spicata (L.) Willd.

Kuhnia suaveolens Fresen., Enum. Sem. Hort. Francof. 22. 1838?. = Brickellia eupatorioides (L.) Shinn.

Kuhnia suaveolens Fresen., Linnaea 13. Litt. 94. 1839. = Brickellia eupatorioides (L.) Shinn.

Kuhnia triplinervis S. F. Blake, Contr. U. S. Natl. Herb. 22: 591. 1924. = Brickellia oreithales (B. Robinson) Shinn.

Kuhnia tuberosa Raf., Herb. Raf. 30. 1833, New Fl. 1: 80. 1836. = Brickellia eupatorioides (L.) Shinn.

Kuhnia villosa Sprengel, Syst. Veg. Fl. Peruv. Chil. 3: 439. 1826. = Trichogonia villosa Schultz-Bip. ex Baker.

Kuhnia virgata Raf., New Fl. 4: 105. 1838. = Brickellia eupatorioides (L.) Shinn.

Kyrstenia aboriginum (E. Greene) E. Greene, Leafl. Bot. Observ. Crit. 1: 8. 1903. = Ageratina altissima (L.) R. King \& H. Robinson.

Kyrstenia acuta E. Greene, Leaf. Bot. Observ. Crit. 1: 11. 1903. = Tamaulipa azurea (DC.) R. King \& H. Robinson.

Kyrstenia ageratifolia (DC.) E. Greene, Leaf. Bot. Observ. Crit. 1: 9. 1903. = Ageratina havanensis $($ H. B. K.) R. King \& H. Robinson.

Kyrstenia altissima (L.) E. Greene, Leafl. Bot. Observ. Crit. 1: 8. 1903. = Ageratina altissima (L.) R. King \& H. Robinson.

Kyrstenia amplifolia (A. Gray) E. Greene, Leafl. Bot. Observ. 
Crit. 1: 9. 1903. = Ageratina rubricaulis (H. B. K.) R. King \& H. Robinson.

Kyrstenia amplissima E. Greene, Leafl. Bot. Observ. Crit. 1: 10. 1903. = Ageratina crenaea (B. Robinson) R. King \& H. Robinson.

Kurstenia angustata (A. Gray) E. Greene, Leafl. Bot. Observ. Crit. 1: 8. 1903. = Ageratina altissima (L.) R. King \& H. Robinson.

Kyrstenia arizonica (A. Gray) E. Greene, Leafl. Bot. Observ. Crit. 1: 9. 1903. = Ageratina herbacea (A. Gray) R. King \& H. Robinson.

Kyrstenia aromatica (L.) E. Greene, Leafl. Bot. Observ. Crit. 1: 8. 1903. = Ageratina aromatica (L.) Spach.

Kyrstenia bellidifolia (Benth.) E. Greene, Leafl. Bot. Observ. Crit. 1: 9. 1903. = Ageratina bellidifolia (Benth.) R. King \& H. Robinson.

Kyrstenia benthami (Klatt) E. Greene, Leafl. Bot. Observ. Crit. I: 9. 1903. = Bartlettina macrocephala (Benth.) R. King \& H. Robinson.

Kyrstenia betulaefolia E. Greene, Leafl. Bot. Observ. Crit. I: 10. 1903. = Ageratina betulaefolia (E. Greene) R. King \& H. Robinson.

Kyrstenia borealis (E. Greene) E. Greene, Leafl. Bot. Observ. Crit. 1: 8. 1903. = Ageratina altissima $($ L.) R. King \& H. Robinson.

Kyrstenia brevipes (DC.) E. Greene, Leafl. Bot. Observ. Crit. I: 9. 1903. = Ageratina brevipes (DC.) R. King \& H. Robinson.

Kyrstenia calaminthaefolia (H. B. K.) E. Greene, Leafl. Bot. Observ. Crit. 1: 9. 1903. = Ageratina calaminthaefolia (H. B. K.) R. King \& H. Robinson.

Kyrstenia calophylla E. Greene, Leafl. Bot. Observ. Crit. 1: 11. 1903. = Ageratina calophylla (B. Robinson) R. King \& H. Robinson.

Kyrstenia ceanothifolia (Muhlenb. in Willd.) E. Greene, Leafl. Bot. Observ. Crit. 1: 8. 1903. = Ageratina aromatica (L.) Spach.

Kyrstenia ciliata (Less.) E. Greene, Leaft. Bot. Observ. Crit. 1: 9. 1903. = Ageratina ciliata (Less.) R. King \& H. Robinson.

Kyrstenia coahuilensis (A. Gray) E. Greene, Leafl. Bot. Observ. Crit. 1:9. 1903. = Phanerostylis coahuilensis (A. Gray) R. King \& H. Robinson.

Kurstenia collina (DC.) E. Greene, Leaft. Bot. Observ. Crit. 1: 9. 1903. = Chromolaena collina (DC.) R. King \& H. Robinson.

Kyrstenia deltoidea (Jacq.) E. Greene, Leafl. Bot. Observ. Crit. 1: 9. 1903. = Ageratina delioidea (Jacq.) R. King \& H. Robinson.

Kyrstenia donmell-smithii (Coulter) E. Greene, Leafl. Bot. Observ. Crit. 1: 9. 1903. = Ageratina bustamenta (DC.) R. King \& H. Robinson.

Kyrstenia espinosarum (A. Gray) E. Greene, Leafl. Bot. Observ. Crit. 1: 9. 1903. = Ageratina espinosarum (A. Gray) R. King \& H. Robinson.

Kyrstenia cuonymyfolia (E. Greene) E. Greene, Leafl. Bot. Observ. Crit. 1:9. 1903. = Ageratina lemmonii (B. Robinson) R. King \& H. Robinson.

Kyrstenia glechonophylla (Less.) E. Greene, Leaf. Bot. Observ. Crit. 1: 9, 1903. = Ageratina glechonophylla (Less.) R. King \& H. Robinson.

Kyrstenia grandidemata (DC.) E. Greene, Leafl. Bot. Observ. Crit. 1: 9. 1903. = Ageratina pazcuarensis (H. B. K.) R. King \& H. Robinson.

Kyrstenia grandifolia (Regel) E. Greene, Leaf. Bot. Observ. Crit. 1: 9. 1903. = Ageratina grandifolia (Regel) R. King \& H. Robinson.

K'yrstenia guadalupensis (Sprengel) E. Greene, Leafl. Bot. Observ Crit. 1: 9, 1903 = Fleischmannia microstemon (Cass.) R. King \& H. Robinson.

Kurstevia herhacea (A Gray) E. Greene, Leafl. Bot. Observ. Crit. 1: 9. 1903. = Ageratina herbacea (A. Gray) R. King \& H Robinson.

Kyrstenia incarnata (Walter) E. Greene, Leafl. Bot. Observ. Crit.
1: 8. 1903. = Fleischmannia incarnata (Waiter) R. King \& H. Robinson.

Kyrstenia jucunda (E. Greene) E. Greene, Leaft. Bot. Observ. Crit. 1: 8. 1903. = Ageratina jucunda (E. Greene) A. Clewell \& Wooten.

Kyrstenia koelliaefolia (E. Greene) E. Greene, Leafl. Bot, Observ. Crit. 1: 9. 1903. = Ageratina hyssopina (A. Gray) R. King \& H. Robinson.

Kyrstenia laeta E. Greene, Leaft. Bot. Observ. Crit. I: 11. 1903. = Ageratina espinosarum (A. Gray) R. King \& H. Robinson.

Kyrstenia melissoides (Willd.) E. Greene, Leafl. Bot. Observ. Crit. 1: 8. 1903. = Ageratina aromatica $($ L.) Spach.

Kyrstenia nemoralis (E. Greene) E. Greene, Leafl. Bot. Observ. Crit. 1: 8. 1903. = Ageratina aromatica (L.) Spach.

Kyrstenia occidentalis(Hook.) E. Greene, Leafl. Bot. Observ. Crit. 1: 9. 1903. = Ageratina occidentalis (Hook.) R. King \& H. Robinson.

Kirstenia oreithales (Greenman) E. Greene, Leafl. Bot. Observ. Crit. 1: 9. 1903. = Ageratina prunellaefolia (H. B. K.) R. King \& H. Robinson.

Kurstenia parvifolia E. Greene, Leafl. Bot. Observ. Crit. 1: 12 1903. = Ageratina wrightii (A. Gray) R. King \& H. Robinson.

Kyrstenia paupercula (A. Gray) E. Greene, Leaf. Bot. Observ. Crit. 1: 9. 1903. = Ageratina paupercula (A. Gray) R. King \& H. Robinson.

Kyrstenia pazcuarensis (H. B. K.) E. Greene, Leafl. Bot. Observ. Crit. 1: 9. 1903. = Ageratina pazcuarensis (H. B. K.) R. King \& H. Robinson.

Kurstenia rothrockii (A. Gray) E. Greene, Leafl. Bot. Observ. Crit. I: 9. 1903. = Ageratina rothrockii (A. Gray) R. King \& H. Robinson.

Kyrstenia rufa E. Greene, Leafl. Bot. Observ. Crit. 1: 10. 1903. = Ageratina rufa (E. Greenc) R. King \& H. Robinson.

Ḱyrstenia subintegra E. Greene, Leafl. Bot. Observ. Crit. 1: 10. 1903. = Ageratina subintegra $($ E. Greene) R. King \& H. Robinson.

Kyrstenia thyrsiflora E. Greene, Leafl. Bot. Observ. Crit. 1: 9. 1903. = Ageratina thyrsiflora (E. Greene) R. King \& H. Robinson.

K'yrstenia tracyi (E. Greene) E. Greene, Leaf. Bot. Observ. Crit. 1: 8. 1903. = Ageratina aromatica (L.) Spach.

Kyrstenia viburnifolia (E. Greene) E. Greene, Leafl. Bot. Observ. Crit. 1: 8. 1903. = Ageratina aromatica (L.) Spach.

Kyrsteniopsis congesta R. King \& H. Robinson. Phytologia 24: 57(-58). 1972.

Kyrsteniopsis cymulifera (B. Robinson) R. King \& H. Robinson, Phytologia 24: 58. 1972.

Kyrsteniopsis dibollii R. King \& H. Robinson. Phytologia 24: 58. 1972.

Kyrsteniopsis nelsonii (B. Robinson) R. King \& H. Robinson, Phytologia 22: 146. 1971

Lacinaria acidota (Engelm. \& A. Gray) Kuntze, Revis. Gen. Pl. 349. 1891. = Liatris acidota Engelm. \& A. Gray.

Lacinaria alata Nelson, Bot. Gaz. (Crawfordsville) 31: 404. 1901 = Liatris alata (Nelson) Schumann.

Lacinaria angustifolia Bush, Amer. Midl. Naturalist 12: 315. 1931. = Liatris angustifolia (Bush) Gaiser.

Lacinaria arenicola Bush, Amer. Midl. Naturalist 12: 314. 1931. = Liatris densispicata (Bush) Gaiser.

Lacinaria aspera E. Greene, Pittonia 4: 318. 1901. = Liatris aspera Michaux.

Lacinaria boykinii $\times$ (Torrey \& A. Gray) Kuntze, Revis. Gen. PI. 349. 1891. = Liatris elegans $($ Walter $)$ Michaux $\times$ Liatris tennifolia Nutt.

Lacinaria brachyphylla Bush, Amer. Midl. Naturalist 12: 317. 1931 . = Liatris acidota Engelm. \& A. Gray.

Lacinaria carinata Small, Fl. S. E. U. S. 1174. 1903. = Liatris regimontis (Small) Schumann. 
Lacinaria chapmanii (Torrey \& A. Gray) Kuntze, Revis. Gen. Pl. 349. 1891. = Liatris chapmanii Torrey \& A. Gray.

Lacinaria chlorolepis Small, Man. S. E. Fl. 1333. 1933. = Liatris garberi A. Gray.

Lacinaria cylindracea (Michaux) Kuntze, Revis. Gen. Pl. 349. 1891. = Liatris cylindracea Michaux.

Lacinaria cymosa Nessel, Bull. Torrey Bot. Club 26: 21.1899. = Liatris cymosa (Nessel) Schumann.

Lacinaria deamiae Lunell, Amer. Midl. Naturalist 2: 163. 1912. = Liatris chapmanii Torrey \& A. Gray.

Lacinaria deamii Lunell, Amer. Midl. Naturalist 2: 169. 1912. $=$ Liatris spheroidea $\times$ Michaux.

Lacinaria densispicata Bush, Amer. Midl. Naturalist 12: 313. 1931. = Liatris densispicata (Bush) Gaiser.

Lacinaria earlei E. Greene, Pittonia 4:316. 1901. = Liatris squarrulosa Michaux.

Lacinaria elegans (Walter) Kuntze, Revis. Gen. Pl. 349. 1891. = Liatris elegans (Walter) Michaux.

Lacinaria elegantula E. Greene, Pittonia 4: 316. 1901. = Liatris pilosa (Aiton) Willd.

Lacinaria elongata E. Greene, Pittonia 5: 57. 1902. = Liatris spicata (L.) Willd.

Lacinaria fallacior Lunell, Amer. Midl. Naturalist 5: 38.1917. $=$ Liatris fallacior $\times$ (Luncll) Rydb.

Lacinaria flabellata Small, Bull. Torrey Bot. Club 25: 472.1898. = Liatris elegans (Walter) Michaux.

Lacinaria formosa E. Greene, Leafl. Bot. Observ. Crit. 1: 149. 1905. = Liatris ligulistylis (Nelson) Schumann.

Lacinaria garberi (A. Gray) Kuntze, Revis. Gen. Pl. 349. 1891 $=$ Liatris garberi A. Gray.

Lacinaria gladewitzii $\times$ Farw., Amer. Midl. Naturalist 10: 43 . 1926. = Liatris cylindracea Michaux $\times$ Liatris sphaeroidea $\times$ Michaux.

Lacinaria gracilis (Pursh) Kuntze, Revis. Gen. Pl. 349. 1891 . = Liatris gracilis Pursh.

Lacinaria graminifolia (Walter) Kuntze, Revis. Gen. Pl. 349. 1891. = Liatris pilosa (Aiton) Willd.

Lacinaria halei Small, Bull. Torrey Bot. Club 27: 281. 1900. = Liatris acidota Engelm. \& A. Gray.

Lacinaria helleri (Porter) Porter in A. A. Heller, Muhlenbergia 1: 6. 1900. = Liatris helleri (Porter) Porter.

Lacinaria herrickii Stchlc ex Rydb., Brittonia 1: 99. 1931, nom. nud. = Liatris ligulistylis (Nelson) Schumann.

Lacinaria kansana Britton, Man. Fl. N. States 927. 1905. = Liatris lancifolia (E. Greene) Kittel in Tidestrom \& Kittel.

Lacinaria laevigata (Nutt.) Small, Fl. S. E. U. S. 1175. 1903. = Liatris laevigata Nutt.

Lacinaria lancifolia E. Greene, Bull. Torrcy Bot. Club 25: 118. 1898. = Liatris lancifolia (E. Greenc) Kittel in Tidestrom \& Kittel.

Lacinaria langloisii E. Greene, Pittonia 5: 58. 1902. = Liatris pycnostachya Michaux.

Lacinaria laxa Small, Bull. Torrey Bot. Club 25: 472. 1898. = Liatris gracilis Pursh.

Lacinaria leptostachya Bush, Amer. Midl. Naturalist 12: 314. 1931. = Liatris inucronata DC.

Lacinaria ligulistylis Nelson, Bot. Gaz. (Crawfordsville) 31: 405. 1901. = Liatris ligulistylis (Nelson) Schumann.

Lacinaria macilenta Small, Man. S. E. Fl. 1333. 1933, nom. nud. in syn, = Liatris pycnostachya Michaux.

Lacinaria microcephala Small, Bull. Torrey Bot. Club 25: 473. 1898. = Liatris microcephala (Small) Schumann.

Lacinaria nashii Small, Fl. S. E. U. S. 1175. 1903. = Liatris garberi A. Gray.

Lacinaria nervata E. Greene, Pittonia 4: 317. 1901. = Liatris cylindracea Michaux.

Lacinaria ohlingerae S. F. Blake, Bull. Torrey Bot. Club 50: 203. 1923. = Liatris ohlingerae (Blakc) B. Robinson.
Lacinaria pauciflora (Pursh) Kuntze, Revis. Gen. Pl. 349. 1891. $=$ Liatris pauciflora Pursh.

Lacinaria pilosa (Aiton) A. A. Heller, Muhlenbergia 1: 6. 1900. = Liatris pilosa (Aiton) Willd.

Lacinaria platylepis Small, Bull. Torrey Bot. Club 27: 281. 1900. $=$ Liatris platylepis $\times$ ? (Schumann) Small.

Lacinaria polyphylla Small, Fl. S. E. U. S. 1173. 1903. = Liatris microcephala (Small) Schumann.

Lacinaria punctata (Hook.) Kuntze, Revis, Gen. Pl. 349. 1891. = Liatris punctata Hook

Lacinaria pycnosiachya (Michaux) Kuntze, Revis. Gen. Pl. 349. 1891. = Liatris pycnostachya Michaux.

Lacinaria regimontis Small, Bull. Torrey Bot. Club 25:473. 1898. = Liatris regimontis (Small) Schumann.

Lacinaria ruthii Bush, Amer. Midl. Naturalist 12: 316. 1931. = Liatris angustifolia (Bush) Gaiser.

Lacinaria ruthii Alexander in Small, Man. S. E. Fl. 1335. 1933. = Liatris squarrulosa Michaux.

Lacinaria scabra E. Greenc, Pittonia 4: 317. 1901. = Liatris squarrulosa Michaux.

Lacinaria scariosa (L.) Hill, Hort. Kew. 70. 1768. = Liatris scariosa (L.) Willd.

Lacinaria scariosa var. nieuwlandii Lunell, Amer. Midl. Naturalist 2: 169(-177). 1912. = Liatris nieuwlandii $\times($ Lunell) Gaiscr.

Lacinaria scariosa var. novae-angliae Lunell, Amer. Midl. Naturalist 2: 172, 177. 1912. = Liatris borealis Nutt. ex MacNab.

Lacinaria secunda (Elliott) Small, Man. S. E. Fl. 1333. 1933. = Liatris pauciflora Pursh.

Lacinaria serotina E. Greene, Pittonia 4: 315. 1901. = Liatris serotina $\times(E$. Greene) Schumann.

Lacinaria shortii Alexander in Small, Man. S. E. Fl. 1335. 1933. = Liatris squarrulosa Michaux.

Lacinaria smallii Britton, Man. Fl. N. States 927. 1905. = Liatris regimontis (Small) Schumann.

Lacinaria spicata (L.) Kuntze, Revis. Gen. Pl. 349. 1891. = Liatris spicata (L.) Willd.

Lacinaria squarrosa (L.) Hill, Hort. Kew. 70. 1768. = Liatris squarrosa (L.) Willd.

Lacinaria tenuifolia (Nutt.) Kuntze, Revis. Gen. Pl. 349. 1891. = Liatris tenuifolia Nutt.

Lacinaria tracyi Alexander in Small, Man. S. E. Fl. 1335. 1933. = Liatris squarrulosa Michaux.

Lacinaria vittata E. Greene, Pittonia 4: 315. 1901. = Liatris spicata (L.) Willd.

Lasiolaena blanchetii (Schultz-Bip. ex Baker) R. King \& H. Robinson, Phytologia 24: 186. 1972.

Lasiolaena duartei R. King \& H. Robinson, Phytologia 24: 186. 1972.

Lasiolaena morii R. King \& H. Robinson, Phytologia 44: 467. 1979.

Lasiolaena pereirae R. King \& H. Robinson, Phytologia 46: 298. 1980.

Lasiolaena santosii R. King \& H. Robinson, Phytologia 44: 468. 1979.

Lavenia alba Wallich, Num. List Dr. Pl. 3220. 1831. = Adenosiemma lavenia (L.) Kuntze.

Lavenia aquatica Sprengel, Syst. Veg. 3: 445. 1826. = Adenostemma lavenia (L.) Kuntze.

Lavenia carnosa Wallich, Num. List Dr. Pl. 3219. 1831, nom. nud. = Adenostemma lavenia (L.) Kuntze.

Lavenia decumbens Sw., Prodr. 112. 1788. = Adenostemma verbesina (L.) Kuntze.

Lavenia decumbens Sprengel, Syst. Veg. Fl. Peruv. Chil. 3: 445. 1826. = Adenostemma berterii DC

Lavenia dentata Wallich, Num. List Dr. Pl. 3216. 1831, nom. nud. = Adenostemma lavenia (L.) Kuntze. 
Lavenia divaricata Ham. in DC., Prodr. 5: 111. 1836, nom. nud. = Adenostemma lavenia (L.) Kuntze.

Lavenia elata Sprengel, Syst. Veg. 3: 445. 1826. = Adenostemma lavenia (L.) Kuntze.

Lavenia erecta Sw., Prodr. 112. 1788. = Adenostemma lavenia (L.) Kuntze.

Lavenia fastigiata Blume, Bijdr. Fl. Ned. Ind. 905. 1826. $=A d-$ enostemma lavenia (L.) Kuntze.

Lavenia glutinosa Gaudich., Voy. Uranie 471. 1830. = Adenostemima viscosum Forster.

Lavenia hirsuta Blume, Bijdr. F. Ned. Ind. 905. 1826. = Adenostemma hirsutum (Blume) DC.

Lavenia latifolia Sprengel, Syst. Veg. 3:445. 1826. = Adenostemma lavenia (L.) Kuntze.

Lavenia macrophylla Blume, Bijdr. Fl. Ned. Ind. 905. $1826 .=$ Adenostemina macrophyllum (Blume) DC.

Lavenia montana Martius ex Baker, Fl. Bras. 6(2): 185. 1876, nom. nud. = Adenostemma brasilianum Cass.

Lavenia nudiflora Hort. ex DC., Prodr. 5: 112. 1836, nom. nud. = Adenostemma lavenia (L.) Kuntze.

Lavenia parviflora Blume, Bijdr. Fl. Ned. Ind. 906. 1826. = Adenostemma viscosum Forster.

Lavenia rigida Wallich, Num. List Dr. Pl. 3215. 1831, nom. nud. = Rhynchospermum verticillatum Reinw. ASTEREAE.

Lavenia rugosa Wight, Num. List Dr. PI. 3221. 1831, nom. nud. = Adenostemma lavenia (L.) Kuntze.

Lavenia sphoerantha Wallich, Num. List Dr. PI. 3217. 1831, nom. nud. = Myriactis nepalensis Less. AsTEREAE.

Lavenia viscida Buch.-Ham., Num. List Dr. Pl. 3222. 1831. = Adenostemina viscosum Forster.

Lepidesmia squarrosa Klatt, Bull. Herb. Boissier 4: 479. 1896.

Leptoclinium brasiliense (Gardner) Benth. \& Hook. ex Gaiser, Rhodora 48: 410. 1946. = Symphyopappus brasiliensis (Gardner) R. King \& H. Robinson.

Leptoclinium fruticosum (Nutt.) A. Gray, Proc. Amer. Acad. Arts 15: 48. 1880. = Garberia heterophylla (Bartram) Merr. \& Harper.

Leptoclinium trichotomum (Gardner) Benth. ex Baker, Fl. Bras. 6(2): 272.1876.

Leto tennifolia Philippi, Anales Univ. Chile 33. T. 1, f. 3. 1891. = Helogyne apaloidea Nutt.

Liabum homogamum Hieron., Bot. Jahrb. Syst. 28: 626. 1901. = Neomirandea homogama (Hieron.) H. Robinson \& Brettell.

Lialris acidota Engelm. \& A. Gray, Boston J. Nat. Hist. 5: 218. 1845, nom. nov.

Liatris alata (Nelson) Schumann, Just's Bot. Jahresber. 29(1): 569. 1903, ignota.

Lialris amplexicaulis Raf., New Fl. 4: 76. 1838. = Trilisa odoratissima (J. Gmelin) Cass.

Lialris angustifolia (Bush) Gaiser. Rhodora 48: 368. 1946.

Liatris aspera Michaux, Fl. Bor.-Amer. 2: 92. 1803.

Liatris baicalensis Adams, Mem. Soc. Imp. Naturalistes Moscou 5: 115.1817 = Saussurea pycnocephala Ledeb. CYNAREAE.

Liatris bebbiana Rydb., Brittonia 1: 99. 1931. = Liatris pycnoslachya Michaux.

Liatris bellidifolia Michaux, F1. Bor-Amer. 2: 93. 1803. = Carphephorus bellidifolius (Michaux) Torrey \& A. Gray.

Liatris borealis Nutt. ex MacNab, Edinburgh New Philos. J. 19: 60. 1835 .

Liatris borealis Nutt., Paxton's Mag. Bot. 5: 27. 1838. = Liatris borealis Nutt. ex MacNab.

Lialris botrys Raf. New Fl. 4: 76. 1838, ignota.

Liatris boykinii $\times$ Torrey \& A. Gray, F. N. Amer. 2: 70. 1841 $=$ Liatris elegans (Walter) Michaux $\times$ Liatris tenuifolia Nutt.

Liatris brachystachya Nutt., J. Acad. Nat. Sci. Philadelphia 7: 72. $1834=$ Liatris pycnostachya Michaux

Liatris bracteata Gaiser, Rhodora 48: 371. 1946.
Liatris brasiliensis Gardner, London J. Bot. 5: 461. 1846. = Symphyopappus brasiliensis (Gardner) R. King \& H. Robinson.

Liairis carinata (Small) Coker, PI. Life Hartsville 108. 1912. = Liatris regimontis (Small) Schumann.

Liatris chapmanii Torrey \& A. Gray, F. N. Amer. 2: 502. 1843.

Liatris compacta (Torrey \& A. Gray) Rydb., Brittonia 1: 98. 1931. = Liatris squarrosa (L.) Willd.

Liatris cordata Royle ex C. B. Clarke, Compos. Ind. 247. 1876. = Ainsliaea aptera DC. MUTISIEAE.

Liatris corymbosa Nutt., Gen. N. Amer. Pl. 2: 132. 1818. = Carphephorus corymbosus (Nutt.) Torrey \& A. Gray.

Liatris creditonensis $\times$ Gaiser, Rhodora 48: 409. 1946.

Liatris cylindracea Michaux, F. Bor.-Amer. 2: 93. 1803.

Liatris cylindrica Torrey, Ann. Lyceum Nat. Hist. New York 2: 210. 1828. = Liatris punctata Hook.

Liatris cymosa (Nessel) Schumann, Just's Bot. Jahresber. 27(1): 528. 1901 .

Liatris deamii $\times$ (Lunell) Shinn., Amcr. Midl. Naturalist 29: 31 . 1943. = Liatris spheroidea $\times$ Michaux.

Liatris densispicata (Bush) Gaiser, Rhodora 48: 363. 1946.

Liatris dubia Barton, Veg. Mater. Med. U. S. 2: 223. T. 49. 1818. $=$ Liatris pilosa (Aiton) Willd.

Liatris earlei (E. Greene) Schumann, Just's Bot. Jahresber. 29(1): 569. 1903. Liatris squarrulosa Michaux.

Liatris elegans (Walter) Michaux, Fl. Bor.-Amer. 2: 91. 1803.

Liatris elegans Willd., Sp. Pl. 3: 1635. 1803. = Liatris elegans (Walter) Michaux.

Liauris elegantula (E. Greene) Schumann, Just's Bot. Jahresber. 29(1): 569. 1903. = Liatris pilosa (Aiton) Willd.

Liarris fallacior $\times$ (Lunell) Rydb., Fl. Plains N. Amer. 780. 1932.

Liatris flabellata (Small) Schumann, Just's Bot. Jahresber. 26(1): 378. 1900. = Liatris elegans (Walter) Michaux.

Lialris flexuosa D. Thomas, Amer. J. Sci. Arts 37: 338. 1839. = Liatris cylindracea Michaux.

Liatris frostii $\times$ Gaiser, Rhodora 48: 245. 1946.

Liatris fruticosa Nutt., Amer. J. Sci. Arts 5: 299. 1822. = Garberia heterophylla (Bartram) Merr. \& Harper.

Liatris garberi A. Gray, Proc. Amer. Acad. Arts 15: 48. 1880.

Liatris glabrata Rydb., Brittonia 1:98. 1931. = Liatris squarrosa (L.) Willd.

Liatris gladewitzii $\times$ (Farw.) Farw. in Shinn., Amcr. Midl. Naturalist 29: 37. 1943. = Liatris cylindracea Michaux $\times$ Lialris sphaeroidea $\times$ Michaux.

Liatris gracilis Pursh, Fl. Amer. Sept. 2: 508. 1814.

Liatris graminifolia [Walter] Willd., Sp. PI. 3: 1636. 1803. = Liatris pilosa (Aiton) Willd.

Liatris graminifolia Pursh, Fl. Amer. Sept. 2: 508. 1814. = Liatris pilosa (Aiton) Willd.

Liarris halei (Small) Schumann, Just's Bot. Jahresber. 28(1): 477. 1902. = Liatris acidota Engelm. \& A. Gray.

Liatris haywardii Rydb., Brittonia 1: 99. 1931. = Liatris ligulistylis (Nelson) Schumann

Liarris helleri (Porter) Porter, Bull. Torrey Bot. Club 18: 147. 1891.

Liatris herrickii (Steele) Rydb., Brittonia 1: 99. 1931. = Liatris ligulistylis (Nelson) Schumann.

Liatris heterophylla R. Br. in Aiton, Hort. Kew. 2. 4: 503. 1812, ignota.

Liatris hirsuta Rydb., Brittonia 1: 98. 1931. = Liatris squarrosa (L.) Willd.

Liatris hirsutiflora (Poiret) Kostel., Allg. Med.-Pharm. Fl. 2: 651. 1833. = Liatris squarrosa (L.) Willd.

Liatris hirsutissima Poiret ex Steudcl, Nomencl. Bot. 2: 40, 1841, nom. nud. = Liatris pycnostachya Michaux.

Liatris intermedia Lindley, Bot. Reg. 948. 1826. = Liatris cylindracea Michaux.

Liatris kansana (Britton) Rydb., F. Plains N. Amer. 781. 1932. $=$ Liatris lancifolia (E. Grecne) Kittel in Tidestrom \& Kittel. 
Liatris laevigata Nutt., Trans. Amer. Philos. Soc. 7: 285. 1841. Liatris lanata Sprengel ex DC., Prodr. 6: 540. 1838, nom. nud. = Saussurea albescens Hook. f. \& Thomson. CynareaE.

Liatris lanceolata Bertol., Misc. Bot. 5: 11. 1846. = Liatris gracilis Pursh.

Liatris lancifolia (E. Greene) Kittel in Tidestrom \& Kittel, Fl. Ariz. New Mex. 370. 1941.

Liatris langloisii (E. Greene) Cory, Rhodora 38: 407. 1936. = Liatris pycnostachya Michaux.

Liatris latifolia D. Don, Prodr. Fl. Nepal. 169. 1825. = Ainsliaea pteropoda DC. MUTISIEAE.

Liatris laxa (Small) Schumann, Just's Bot. Jahresber. 26(1): 378. 1900. = Liatris gracilis Pursh.

Liatris ligulistylis (Nelson) Schumann, Just's Bot. Jahresber. 29(1): 569. 1903.

Liatris linaria Raf., Fl. Ludov. 61. 1817. = Liatris pycnostachya Michaux, ?

Liatris lobelioides Wallich ex C. B. Clarke, Compos. Ind. 246. 1876 , nom. nud. in syn. = Ainsliaea pteropoda DC. MuTISIEAE.

Liatris macrostachya Michaux, Fl. Bor.-Amer. 2: 91. 1803. = Liatris spicata (L.) Willd.

Liatris magnifica Hort. ex Gardner, Kew Herb. Pl. 263. 1895. = Liatris spicata (L.) Willd.

Liatris marginata Cass., Dict. Sci. Nat. 26: 236. 1823. = Liatris cylindracea Michaux.

Liatris microcephala (Small) Schumann, Just's Bot. Jahresber. 26(1): 378. 1900.

Liatris monocephala Cass., Dict. Sci. Nat. 26: 237. 1823. = Liatris cylindracea Michaux.

Liatris mucronata DC., Prodr. 5: 129. 1836.

Liatris mucronata sensu Torrey \& A. Gray, Fl. N. Amer. 2: 70. 1841. = Liatris acidota Engelm. \& A. Gray.

Liatris nervata (E. Greene) Schumann, Just's Bot. Jahresber. 29(1): 569. 1903. = Liatris cylindracea Michaux.

Liatris nienwlandii $\times$ (Lunell) Gaiser, Rhodora 48: 325. 1946. $=$ Liatris ligulistylis (Nelson) Schumann $\times$ Liastris borealis Nutt. ex Macnab.

Liatris novae-angliae (Lunell) Shinn., Amer. Midl. Naturalist 29: 29. 1943. = Liatris borealis Nutt. ex MacNab.

Liatris odoratissima (J. Gmelin) Willd., Sp. Pl. 3: 1637. 1803. = Trilisa odoratissima (J. Gmelin) Cass.

Liatris ohlingerae (Blake) B. Robinson, Contr. Gray Herb. 104: 49. 1934.

Liatris oppositifolia Nutt.. Amer. J. Sci. Arts 5: 299. 1822. = Chromolaena ivaefolia (L.) R. King \& H. Robinson.

Liatris paniculata (J. Gmelin) Michaux, F. Bor.-Amer. 2: 93. 1803. = Trilisa paniculata (J. Gmelin) Cass.

Liatris pauciflora Pursh, Fl. Amer. Sept. 2: 510. 1814.

Liatris pauciflosculosa Nutt., J. Acad. Nat. Sci. Philadelphia 7: 71. 1834. = Liatris gracilis Pursh.

Liatris picta Barton ex DC., Prodr. 5: 130. 1836, nom. nud. = Liatris spicata (L.) Willd.

Liatris pilosa (Aiton) Willd., Sp. Pl. 3: 1636. 1803.

Liatris pilosa Ker Gawler, Bot. Reg. 595. 1821. = Liatris spicata (L.) Willd.

Liatris platylepis $\times$ ? (Schumann) Small, Just's Bot. Jahresber. 28(1): 477. 1902.

Liatris propinqua Hook., Bot. Mag. 3829. 1841. = Liatris pilosa (Aiton) Willd.

Liatris provincialis Godfrey, Amer. Midl. Naturalist 66: 466. 1961.

Liatris pumila Lodd., Bot. Cab. 2. T. 147. 1818. = Liatris spicata (L.) Willd.

Liatris punctata Hook., Fl. 13or.-Amer. 1: 306 T. 105. 1833.

Liatris pycnostachya Michaux, Fl. Bor.-Amer. 2: 91. 1803.

Liatris radians Bertol., Misc. Bot. 5: 9. 1846. = Liatris elegans (Walter) Michaux.
Liatris regimont is (Small) Schumann, Just's Bot. Jahresber. 26(1): 378. 1900.

Liatris resinosa Nutt., Gen. N. Amer. Pl. 2: 131. 1818. = Liatris spicata (L.) Willd.

Liatris ridgwayi $\times$ Standley, Rhodora 31: 37. 1929.

Liatris rosendahlii Rydb., Brittonia 1: 100. 1931. = Liatris ligulistylis (Nelson) Schumann.

Liatris scabra (E. Greene) Schumann, Just's Bot. Jahresber. 29(1): 569. 1903. = Liatris squarrulosa Michaux.

Liatris scariosa (L.) Willd., Sp. Pl. 3: 1635. 1803

Liatris secunda Elliott, Sketch Bot. S. Carolina 2: 278. 1822?. = Liatris pauciflora Pursh.

Liatris serotina $\times($ E. Greene) Schumann, Just's Bot. Jahresber. 29(1): 569.1903.

Liatris sessiliflora Bertol., Misc. Bot. 5: 10. 1846. = Liatris spicata (L.) Willd.

Liatris spheroidea $\times$ Michaux, Fl. Bor.-Amer. 2: 92.1803.

Liatris spicata (L.) Willd., Sp. Pl. 3: 1636. 1803.

Liatris squamosa Nutt., J. Acad. Nat. Sci. Philadelphia 7: 73. 1834. = Carphephorus pseudoliatris Cass.

Liatris squarrosa (L.) Willd., Sp. Pl. 3: 1634. 1803.

Liatris squarrulosa Michaux, Fl. Bor.-Amer. 2: 92.1803.

Liatris stellei $\times$ Gaiser, Rhodora 48: 227. 1946. = Liatris sphaeroidea Michaux, $\times$ Liatris spicata $(\mathrm{L}$.$) Willd.$

Liatris stricta MacNab, Edinburgh New Philos. J. 19: 60. 1835. = Liatris cylindracea Michaux.

Liatris tenuifolia Nutt., Gen. N. Amer. Pl. 2: 131. 1818

Liatris tenuis Shinn., Southw. Naturalist 4: 208. 1959.

Liatris tomentosa Michaux, Fl. Bor.-Amer. 2: 93. 1803. = Carphephorus tomentosus (Michaux) Torrey \& A. Gray.

Liatris trichotoma Gardner, London J. Bot. 6: 435. 1847. = Leptoclinium trichotomum (Gardner) Benth. ex Baker.

Liatris turbinata Sweet, Hort. Brit. 220. 1827, nom. nud. = Liatris spicata (L.) Willd.

Liatris turgida Gaiser, Rhodora 48: 261. 1946.

Liatris umbellata Bertol., Misc. Bot. 5: 13. 1846. = Vernonia angustifolia Michaux. VERNONIEAE.

Liatris uniflora Raf., New F1. 4: 76. 1838. = Liatris squarrosa (L.) Willd.

Liatris varia Banks ex Pursh, Fl. Amer. Sept. 2: 508. 1814. = Liatris scariosa Willd.

Liatris virgata Nutt., J. Acad. Nat. Sci. Philadelphia 7: 72. 1834. = Liatris pilosa (Aiton) Willd.

Liatris vittata (E. Greene) Schumann, Just's Bot. Jahresber. 29(1): 569. 1903. = Liatris spicata (L.) Willd.

Liatris waheri Elliott, Sketch Bot. S. Carolina 2: 285. 1822?. = Carphephorus tomentosus (Michaux) Torrey \& A. Gray.

Liatris weaveri $\times$ Shinn., Amer. Midl. Naturalist 29: 38.1943.

Litothamnus ellipticus R. King \& H. Robinson, Phytologia 44: 80. 1979.

Litrisa carnosa Small, Bull. Torrey Bot. Club 51: 392. 1924.

Lomatozona andersonii R. King \& H. Robinson, Phytologia 32: 246. 1975.

Lomatozona artemisiaefolia Baker, Fl. Bras. 6(2): 199. 1876.

Lomatozona huntii R. King \& H. Robinson, Phytologia 39: 129. 1978 .

Lomatozona inaequale R. King \& H. Robinson, Phytologia 44: 457. 1979

Lorentzianthus viscidus (Hook. \& Arn.) R. King \& H. Robinson, Phytologia 32: 274. 1975.

Lourteigia ballotaefolia (H. B. K.) R. King \& H. Robinson, Phytologia 23: 308. 1972.

Lourteigia dichroa (B. Robinson) R. King \& H. Robinson, Phytologia 21: 29. 1971.

Lourteigia fimbriata V. Badillo, Acta Bot. Venez. 13: 111. 1976.

Lourteigia humilis (Benth.) R. King \& H. Robinson, Phytologia 21: 29. 1971. 
Lourteigia lanulata (B. Robinson) R. King \& H. Robinson, Phytologia 21: 29. 1971.

Lourteigia microphylla (L. f.) R. King \& H. Robinson, Phytologia 21: 29. 1971.

Laurteigia ornatilaba (B. Robinson) R. King \& H. Robinson, Phytologia 21: 29. 1971.

Lourteigia scandens V. Badillo, Ernstia 29: 11. 1985.

Lourteigia stoechadifolia (L. f.) R. King \& H. Robinson, Phytologia 21: 29. 1971.

Macropodina blumenavii (Hieron.) R. King \& H. Robinson. Phytologia 24: 174. 1972.

Macropodina bradei R. King \& H. Robinson, Phytologia 24: 174. 1972

Macropodina reizzii R. King \& H. Robinson, Phytologia 24: 175. 1972.

Macvaughiella mexicana (Schultz-Bip.) R. King \& H. Robinson, Sida 3(4): 282. 1968.

Macvaughiella standlevi (Steyerm.) R. King \& H. Robinson, Sida 3(4): 282. 1968. = Macvaughiella mexicana (Schultz-Bip.) R. King \& H. Robinson.

Mallinoa corymbosa Coulter, Bot. Gaz. (Crawfordsville) 20: 47. 1895. = Ageratina muelleri (Schultz-Bip. ex Klat1) R. King \& H. Robinson.

Malmeam hus catharinensis R. King \& H. Robinson, Phytologia 47: 226. 1980.

Malmeanthus hilarii (B. Robinson) R. King \& H. Robinson, Phytologia 47: 226, 1980.

Malmeanthus subintegerrimus (Malme) R. King \& H. Robinson, Phytologia 47: 226. 1980.

Malperia tenuis S. Watson, Proc. Amer. Acad. Arts 24: 54. 1889.

Margacola parvula Buckley, Proc. Acad. Nat. Sci. Philadelphia 13: 457. 1861. = Trichocoronis wrightii (Torrey \& A. Gray) A. Gray.

Matudina coni (McVaugh) R. King \& H. Robinson, Phytologia 26: 171.1973.

Metastevia hintonii Grashoff, Brittonia 27: 69. 1975.

Mexianthus mexicamus B. Robinson, Contr. Gray Herb. 80: 5. 1928.

Microspermum debile Benth., Pl. Hanw. 64. 1840.

Microspernum flaccidum P. Wilson, Kew Bull. 13: 167.1958.

Microspermum gonzalezii Rzed., Bol. Soc. Bot. Mexico 32: 77(80). 1972.

Microspermum gracillimum Rzed., Bol. Soc. Bot. Mexico 32: 80(-86). 1972.

Microspermum hintonii Rzed., Bol. Soc. Bot. Mexico 31: 99. 1970.

Microspermum numulariaefolium Lagasca, Gen. Sp. PI. 25. 1816.

Microspermum repens (Blake) L. O. Williams, Fieldiana, Bo1. 29: 371. 1961 = Ilisia repens S. F. Blake.

Microspermum tenue P. Wilson, Kew Bull. 13: 166. 1958.

Mikania acrensis B. Robinson, Contr. Gray Herb. 104: 31.1934. = Mikania lindleyana DC.

Mikania acuminata DC., Prodr. 7: 270. 1838

Mikania acutissima Rusby ex B. Robinson, Contr. Gray Herb. 64: 5.1922.

Mikania additicia B. Robinson, Contr. Gray Herb. 104: 3 I. 1934.

Mikania affinis Gardner, London J. Bot. 4: 120. 1845. = Mikania lanuginosa DC.

Mikania alata (G. Meyer) DC., Prodr. 5: 197. 1836. = Mikania micrantha H. B. K.

Mikania alba Taylor. Torreya 7: 185. 1907.

Mikania alexandreae G. Barroso, Arch. Jard. Bot. Rio de Janeiro 16: 281.1959.

Mikania allartii B. Robinson, Contr. Gray Herb. 96: 23. 1931.

Mikania almagroi Cuatrec., Anales Ci. Univ. Madrid 4(2): 233. 1935. = Mikania banisteriae DC.

Mikania alvimii R. King \& H. Robinson, Phytologia 45: 124. 1980.
Mikania amara Willd., Sp. Pl. 3: 1744. 1803. = Mikania parviflora (Aublet) Karsten.

Mikania amara Bertero ex DC., Prodr. 5: 199. 1836, nom. nud. = Mikania cordifolia (L. f.) Willd.

Mikania amazonica Baker, F. Bras. 6: (2): 266. 1876, = Mikania sprucei Baker.

Mikania ambigens Urban, Symb. Antill. 2: 460. 1901.

Mikania ambigua DC., Prodr. 5: 187, 1836. = Mikania sulcala (Hook. \& Arn.) B. Robinson.

Mikania amblyolepis B. Robinson, Contr. Gray Herb. 61: 11. 1920.

Mikania andrachne DC.. Prodr. 5: 192. 1836. = Mikania trinervis Hook. \& Arn.

Mikania andrei B. Robinson, Contr. Gray Herb. 6I: 12. 1920.

Mikania anethifolia (DC.) Matzenbacher, Bradea 2(37): 259. 1978.

Mikania angularis Humb. \& Bonpl., PI. Aequin. 2: 87. T. 106. 1810.

Mikania angulata Llave, Mosaico Mexicano 2: 299. 1837-1838. = Mikania pyramidata J. D. Smith, ?

Mikania angulosa Raf., Fl. Ludov. 62. 1817. = Mikania scandens (L.) Willd.

Mikania angustifolia H. B. K., Nov. Gen. Sp. 4: 108. Ed. Folio. 1818. = Ageratina asclepiadea (L. f.) R. King \& H. Robinson. Mikania angustifolia (O. Hoffm.) R. E. Fries, Wiss. Ergebn. Schwed. Rhodesia-Kongo Exped. 1: 328. 1916. = Mikania sagittifera B. Robinson.

Mikania anisodora Hassler, Feddes Repert. 14: 172. 1915

Mikania anomala M. E. Jones, Contr. W. Bot. 18: 70. 1933. = Piqueria trinervia Cav.

Mikania antennaria Schultz-Bip., Linnaca 30: 182. 1859-1860, nom. nud. = Mikania microdanta DC.

Mikania antioquiensis Hieron.. Bot. Jahrb. Sys1. 28: 580. 1901. = Mikania banisteriae DC.

Mikania anzoatiguensis V. Badillo, Bol. Soc. Venez. Ci. Nat. 10: 301. 1946. = Mikania vitifolia DC.

Mikania apiifolia DC.. Prodr. 5: 202. 1836. = Mikania ternata (Vell. Conc.) B. Robinson.

Mikania aquaria B. Robinson. Contr. Gray Herb. 73: 21.1924. Mikania araguensis V. Badillo, Noved. Ci., Ser. Bot. 1: 2. 1952.

Mikania araucana Philippi, Anales Univ. Chile USE \$1415 87: 330. 1887. = Mikania mendocina Philippi.

Mikania arborea Beatson, Tracts St. Helena 313. 1816. = Senecio prenanthiflorus Benth. \& Hook. f. SENECIONEAE.

Mikania arborea H. B. K., Nov. Gen. Sp. 4: 109. Ed. Folio. 1818 = Ageratina dendroides (Sprengel) R. King \& H. Robinson.

Mikania archeri B. Robinson, Contr. Gray Herb. 96: 24. 1931.

Mikania archidonensis Cuatrec., Anales Ci. Univ, Madrid 4(2): 234. 1935.

Mikania areolata Holmes \& McDaniel, Phytologia 37: 467. 1977

Mikania argyreiae DC.. Prodr. 5: 193. 1836.

Mikania argyropappa Schultz-Bip. ex Baker, Fl. Bras. 6(2): 268. 1876.

Mikania argyrostigma Miq.. Linnaea 17: 69. 1843. = Mikania guaco Humb. \& Bonpl.

Mikania aristei B. Robinson, Contr. Gray Herb. 64: 6. 1922

Mikania armigera Poeppig \& Endl., Nov. Gen. Sp. 3: 52. pl. 260. 1843. = Mikania laxa DC

Mikania aromatica Oersted, Overs. Kongel. Danske Vidensk. Selsk. Forh. Medlemmers Arbeider 10. 1863.

Mikania arrojadoi Mattf., Notizbl. Bot. Gart. Berlin-Dahlem 9: 381. 1925.

Mikania artemisioides Cass., Dict. Sci. Nat. 55: 130. 1828. = Eupatorium capillifolium (Lam.) Small.

Mikania arthroclada B. Robinson. Contr. Gray Herb. 80: 34. 1928.

Mikania aschersonii Hicron., Bot. Jahrb. Syst. 28: 577. 1901.

Mikania asparagoides Lichtenst. ex Less., Syn. Gen. Compos. 
394. 1832. = Euryops asparagoides (Lichtenst. ex Less.) DC. SEnectoneae.

Mikania aspera Miq., Linnaea 17: 68. 1843. = Mikania guaco Humb. \& Bonpl.

Mikania asperifolia Schultz-Bip. ex Baker, Fl. Bras. 6(2): 256. 1876, nom. nud. = Mikania phaeoclados Martius ex Baker.

Mikania atriplicifolia Schultz-Bip. ex Miq., Stirp. Surinam. Select. 189. 1851. = Mikania congesta DC.

Mikania attenuata DC., Prodr. 5: 195. 1836. = Mikania guaco Humb. \& Bonpl., ?

Mikania auricularis Griseb., Abh. Konigl. Ges. Wiss. Gottingen 19: 122. 1874. = Mikania periplocifolia Hook. \& Arn.

Mikania auriculata Willd., Sp. Pl. 3: 1745. 1803. = Senecio deltoideus Less. SENECIONEAE.

Mikania auyantepuensis Blake in Gleason \& Killip, Brittonia 3: 198. 1939. = Mikania sprucei Baker.

Mikania baccharoidea Rusby, Bull. New York Bot. Gard. 8: 127. 1912.

Mikania badieri DC., Prodr. S: 194. 1836. = Mikania hookeriana DC.

Mikania bakeri R. King \& H. Robinson, Phytologia 47: 126. 1980, nom. nov.

Mikania banisteriae DC., Prodr. 5: 193. 1836.

Mikania barahonensis Urban, Symb. Antill. 7: 424. 1912.

Mikania barrosoana G. Barroso, Arch. Jard. Bot. Rio de Janeiro 16: 296. 1959.

Mikania batataefolia DC., Prodr. 5: 197. 1836.

Mikania belemii R. King \& H. Robinson, Phytologia 45: 125. 1980.

Mikania bergantinensis V. Badillo, Bol. Soc. Venez. Ci. Nat. 10: 303. 1946. = Mikania banisteriae DC.

Mikania berteriana Sprengel, Syst. Veg. Fl. Peruv. Chil. 3: 423. 1826. = Fleischınannia microstemon (Cass.) R. King \& H. Robinson.

Mikania biformis DC., Prodr. 5: 202. 1836.

Mikania biformis Schultz-Bip. ex Baker, Fl. Bras. 6(2): 254. 1876, nom. nud. = Mikania cordifolia (L. f.) Willd.

Mikania bishopii R. King \& H. Robinson, Phytologia 48: 223. 1981.

Mikania bogotensis Benth., PI. Hartw. 201. 1845.

Mikania bolivarensis V. Badillo, Bol. Soc. Venez, Ci. Nat. 10: 299. 1946. = Mikania pannosa Baker.

Mikania boliviensis Schultz-Bip., Linnaea 34: 535. 1865-1866, nom. nud. = Mikania schnltzii B. Robinson.

Mikania boliviensis Lingelsh., Feddes Repert. 7: 251. 1909. = Mikania vitifolia DC.

Mikania brachiata Pocppig \& Endl., Nov. Gen. Sp. 3: 53. 1845. = Mikania guaco Humb. \& Bonpl.

Mikania brachycarpa Urban, Symb. Antill. 5: 220. 1907.

Mikania brachyphylla Hieron., Bot. Jahrb. Syst. 36: 472.1905.

Mikania brachypoda DC., Prodr. 5: 201 . 1836. = Mikania officinalis Martius.

Mikania bracteosa DC., Prodr. 5: 194. 1836. = Mikania involucrata Hook. \& Am.

Mikania bradei B. Robinson, Contr. Gray Herb. 104: 32.1934

Mikania brevifancia Holmes \& McDaniel, Phytologia 37: 468. 1977

Mikania brevipetiolata Schultz-Bip. ex Baker, FI. Bras, 6(2): 230. 1876, nom. nud. = Mikania myriocephala DC.

Mikania broadwayi B. Robinson, Contr. Gray Herb. 68: 35.1923.

Mikania brooksii Holmes \& McDaniel, Phytologia 41: 193(-194). 1978.

Mikania brunnescens B. Robinson, Contr. Gray Herb. 77: 48. 1926.

Mikania buchii Urban, Feddes Repert. 13: 480. 1915.

Mikania buchtienii B. Robinson, Contr. Gray Herb. 64: 7. 1922.

Mikania buddleiaefolia DC., Prodr. 5: 192. 1836.
Mikania bulbisetifera Cuatrec., Ann. Missouri Bot. Gard. 52: 308. 1965.

Mikania bullata B. Robinson, Contr. Gray Herb. 61: 13. 1920.

Mikania burchellii Baker, Fl. Bras. 6(2): 232. 1876.

Mikania cabrerae G. Barroso, Arch. Jard. Bot. Rio de Janeiro 16: 295.1959.

Mikania cacerensis G. Barroso, Arch. Jard. Bot. Rio de Janeiro 16: 303. 1959.

Mikania calcarulata B. Robinson, Contr. Gray Herb. 104: 33. 1934.

Mikania caldasana B. Robinson, Contr. Gray Herb. 77: 49. 1926.

Mikania callineura Schultz-Bip. ex Baker, Fl. Bras. 6(2): 258. 1876.

Mikania campanulata Gardner, London J. Bot. 5: 489.1846.

Mikania camporum B. Robinson, Contr. Gray Herb. 104: 33. 1934.

Mikania campos-portoana G. Barroso, Arch. Jard. Bot. Rio de Janeiro 16: 294. 1959.

Mikania canaguensis V. Badillo, Bol. Soc. Venez. Ci. Nat. 9: 132. 1944. = Mikania banisteriae DC.

Mikania candolleana Gardner, London J. Bot. 5: 484. 1846.

Mikania capayensis V. Badillo, Bol. Soc. Venez. Ci. Nat. 10: 304. 1946. = Mikania trinitaria DC.

Mikania capensis DC., Prodr. 5: 198. 1836.

Mikania capricorni B. Robinson, Contr. Gray Herb. 104: 34. 1934.

Mikania cardiophylla B. Robinson, Candollea 5: 171. 1934.

Mikania carnosa Muschler, Bot. Jahrb. Syst. 50: Beibl. 3: 76. 1913.

Mikania carnosula DC., Prodr. 5: 197. 1836. = Mikania cordifolia (L. f.) Willd.

Mikania carteri Baker, Kew Bull. 106. 1895.

Mikania carvifolia Hieron. ex Arechav., Anales Mus. Nac. Montevideo Ser. 2. 1: 9. Pl. 3. 1904. = Mikania anethifolium (DC.) Matzenbacher.

Mikania casarettoi B. Robinson, Candollea 5: 172. 1934.

Mikania catharinensis Hieron., Bot. Jahrb. Syst. 22: 796. 1897. = Mikania lundiana DC.

Mikania caudata Benth., PI. Hartw. 201. 1845. = Mikania banisteriae DC.

Mikania caustolepis B. Robinson, Contr. Gray Herb. 77: 49. 1926. = Mikania vitifolia $\mathrm{DC}$

Mikania cercifolia Holmes, Phytologia 51: 233. 1982.

Mikania chagalensis Hieron., Bot. Jahrb. Syst. 19: 47. 1894.

Mikania charua Griseb., Abh. Konigl. Ges. Wiss. Gottingen 24: 174. 1879. = Ophryosporus charua (Griseb.) Hieron.

Mikania chaseae B. Robinson, Contr. Gray Herb. 104: 35. 1934. = Mikania additicia B. Robinson.

Mikania chenopodifolia Willd., Sp. Pl. 3: 1745. 1803.

Mikania chenopodioides Wallich, Num. List Dr. Pl. 3175. 1831, nom. nud. = Senecio chenopodifolius DC. SENECIONEAE.

Mikania chevalieri (C. Adams) Holmes \& McDaniel, Phytologia 31: 274. 1975.

Mikania chimborazensis Hieron. in Sodiro, Bot. Jahrb. Syst. 29: 15. 1900

Mikania chlorolepis Baker, Fl. Bras. 6(2): 247. 1876

Mikania chocensis B. Robinson, Contr. Gray Herb. 100: 17. 1932.

Mikania cinerea Schultz-Bip. ex Baker, Fl. Bras. 6(2): 236. 1876 , nom. nud. = Mikania sericea Hook. \& Am.

Mikania cinnamornifolia Lingelsh., Feddes Repert. 7: 251. 1909. = Mikania dioscoreoides (Rusby) B. Robinson, ?

Mikania cipoensis G. Barroso, Arch. Jard. Bot. Rio de Janeiro 16: 309. 1959.

Mikania cissampelina DC., Prodr. 5: 195. 1836. = Mikania cordifolia H. B. K.

Mikania claussenii Schultz-Bip., Linnaea 30: 182. 1859-1860, nom. nud. = Mikania nummularia DC 
Mikania clavellata DC., Prodr. 5: 192. 1836. = Ophryosporus freyreysii (Thunb. \& Dallm.) Baker.

Mikania clematidea Wallich ex DC., Prodr. 5: 19. 1836. =Eupatorium squamosum $\mathrm{D}$. Don.

Mikania clematidiflora Rusby ex B. Robinson, Contr. Gray Herb. 6I: 13. 1920.

Mikania clematidifolia Dusen, Arch. Bot. *PICK CORRECT ENTRY 9(15): 20. 1910.

Mikania coarctata Gardner, London J. Bot. 5: 483. 1846.

Mikania cocaensis Gardner, London J. Bot. 5: 487. 1846. = Mikania cordifolia (L. f.) Willd.

Mikania cochabambana B. Robinson, Contr. Gray Herb. 90: 33. 1930.

Mikania comarapensis B. Robinson, Contr. Gray Herb. 90: 34. 1930.

Mikania complanata Gardner, London J. Bot. 5: 485 . $1846 .=$ Mikania obovata DC.

Mikania concinna Standley \& Steyerm., Publ. Field Mus. Nat. Hist., Bot. Ser. 23: 260. 1947.

Mikania conferta Gardner, London J. Bot. 4: 119. 1845

Mikania confertissima Schultz-Bip. ex Baker, F1. Bras. 6(2): 242. 1876.

Mikania congesta DC., Prodr. 5: 197. 1836.

Mikania conglomerata Holmes \& McDaniel, Phytologia 37: 469. 1977.

Mikania consanguinea Gardner, London J. Bot. 6: 448. 1847. = Mikania psilostachy: DC.

Mikania convolvulacea DC.. Prodr. 5: 199. 1836. = Mikania cordifolia (L. f.) Willd.

Mikania copayensis (error for capayensis) V. Badillo, Bol. Soc. Venez, Ci. Nat. 10: 304. 1946. = Mikania trinitaria DC.

Mikania cordata (Burm. f.) B. Robinson, Contr. Gray Herb. 104: 65. 1934.

Mikania cordata var, chevalieri C. Adams. J. W. Afr. Sci. Assoc. 8: 136. 1964. = Mikania chevalieri (C. Adams) Holmes \& McDaniel.

Mikania cordifolia (L. f.) Willd., Sp. Pl. 3: 1746. 1803.

Mikania cordiformes Gardner, Lond on J. Bot. 5: 487. 1846. error for (cordiformes) cocaensis. = Mikania cordifolia (L. f.) Willd.

Mikania cordigera W. Holmes, Phytologia 57: 441. 1985.

Mikania corei Holmes \& McDaniel, Phytologia 50(1): 5. 1981.

Mikania coriacea Llave, Mosaico Mexicano 2: 299. 1837-1838, ignota.

Mikania cornifolia G. Don ex Baker, Fl. Bras. 6(2): 237. 1876, nom nud. = Mikania parviflora (Aublet) Karsten.

Mikania corvdalifolia Griseb., Mem. Amer. Acad. Arts 8: 5 I2. 1863 = Mikania rammculifolia Rich. ex Sagra.

Mikania corvmbiifolia (B. Robinson) R. King \& H. Robinson, Phytologia 53: 392. 1983

Mikania corymbulosa Benth., PI. Hartw. 21 I. 1845.

Mikania crassifolia Hieron., Bot. Jahrb. Syst. 36: 471. 1905.

Mikania crispiflora Wright, Anales Acad. Ci. Med. Habana 6 : 179. 1869.

Mikania cristata B. Robinson, Proc. Amer. Acad. Arts 47: 195. 1911.

Mikania cryptodonta B. Robinson, Contr. Gray Herb. 73: 22. 1924 = Mikania vitifolia DC

Mikania cuencana Hieron., Bot. Jahrb. Syst. 28: 581. 1901.

Mikania cumingii Schultz-Bip., Linnaea 34: 535. 1865-1866, nom. nud = Ophryosporis cumingii Benth. ex Baker.

Mikania cuneata Schultz-Bip., Bonplandia 4: 54. 1856, nom. nud. = Mikania guaco Humb. \& Bonpl.

Mikania cutervensis Hieron., Bot. Jahrb. Syst. 36: 473. 1905.

Mikania cuzcoensis Holmcs \& McDaniel, Phytologia 35: 329 $(-330) .1977$

Mikania cyanosma Urban \& Ekman, Ark. Bot. 23a(11):69.1931.

Mikania cyanosma Urban \& Ek. \& Arn. ex Baker) B. Robinson, Contr. Gray Herb. 104: 63. 1934.
Mikania decora Poeppig \& Endl., Nov. Gen. Sp. 3: 53. 1845.

Mikania decumbens Malme, Kongl. Svenska Vetenskapsakad. Handl. Ser. 3. 12(2): 52. 1933.

Mikania deflexa Gardner, London J. Bot. 5: 482. 1846. = Mikania lundiana DC.

Mikania deltoides Poeppig ex Sprengel, Syst. Veg. Fl. Peruv. Chil. 3: 423. 1826. = Ageratina havanensis (H. B. K.) R. King \& H. Robinson.

Mikania dentata Sprengel, Syst. Veg. F. Peruv. Chil. 3: 422. 1826. = Mikania ternata (Vell. Conc.) B. Robinson.

Mikania dentata G. Barroso, Arch. Jard. Bot. Rio de Janeiro 16: 275. 1959. hom. illeg.

Mikania denticulata (Vahl) Willd., Sp. PI. 3: 1744. I803. = Mikania micrantha H. B. K. or Mikania cordifolia (L. f.) Willd.? Mikania desmocephala B. Robinson, Contr. Gray Herb. 64: 7. 1922.

Mikania dictyophylla B. Robinson, Contr. Gray Herb. 64: 8. 1922.

Mikania dictyota B. Robinson, Contr. Gray Herb. 68: 37. 1923.

Mikania dioscoreaefolia DC., Prodr. 5: 198. 1836. = Mikania capensis DC.

Mikania dioscoreoides (Rusby) B. Robinson, Contr. Gray Herb. 64: 97. 1922.

Mikania discolor Baker, FI. Bras. 6(2): 234. 1876. = Mikania buddleiaefolia DC.

Mikania dissecta Urban \& Ekman, Ark. Bot. 23a(11): 73. 1931.

Mikania divaricata Poeppig \& Endl., Nov. Gen. Sp. 3: 53. 1845.

Mikania divaricata Gardner, London J. Bot. 5: 488 . 1846. = Mikania microcephala DC.

Mikania diversifolia DC., Prodr. 5: 201. 1836.

Mfikania duckei G. Barroso, Arch. Jard. Bot. Rio de Janciro 16 : 255. 1959.

Mikania dudleyi Holmes \& McDanicl, Phytologia 45: 297(-298). 1980.

Mikania duidensis B. Robinson in Gleason, Bull. Torrey Bot. Club 58: 485. 1931.

Mikania dusenii B. Robinson, Contr. Gray Herb. 96: 24. 1931.

Mikania ecuadorensis Holmes \& McDaniel, Phytologia 31: 274 $(-275) .1975$.

Mikania eggersii Hieron.. Bot. Jahrb. Syst. 28: 582. 1901.

Mikania elliptica DC., Prodr. 7: 270. 1838.

Mikania ericoides Martius ex Baker, FI. Bras. 6(2): 372. 1876 nom. nud. = Pseudobrickellia angustissima (Sprengel ex Baker) R. King \& H. Robinson.

Mikania erioclada DC., Prodr. 5: 192.1836.

Mikania eriophora Schultz-Bip. ex Hensley in Godman, Biol. Cent.-Amer., Bot. 2: 103. 1881, nom. nud. = Mikania pyramidata J. D. Smith.

Mikania eriostrepta B. Robinson, Contr. Gray Herb. 104: 35. 1934.

Mikania erithalina DC., Prodr. 5: 193. 1836. = Mikania nitida (DC.) R. King \& H. Robinson.

Mikania estrellensis Baker, Fl. Bras. 6(2): 231. 1876. = Mikania trinervis Hook. \& Arn.

Mikania eucosma B. Robinson, Contr. Gray Herb. 64: 9. 1922

Mikania eupatorioides Blake, J. Wash. Acad. Sci. 28: 481. 1938 = Mikania aschersonii Hieron.

Mikania fastuosa Lemaire. F. Serres Jard. Eur. 3(8): sub PI. $10(262)$, n. 42. 1847, cult., ignot.

Mikania featherstonei B. Robinson, Contr. Gray Herb. 68: 38 1923.

Mikaria fendleri Klatı, Abh. Naturf. Ges. Halle 15: 324. 1882

Mikania ferruginea (Rusby) B. Robinson, Contr. Gray Herb. 64 101. 1922.

Mikania fiebrigii Hieron, in Urban, Bot. Jahrb. Syst. 40: 390. 1908.

Mikania filgucirasii R. King \& H. Robinson, Phytologia 49: 488. I98I. 
Mikania flicifolia B. Robinson, Contr. Gray Herb. 61: 14. 1920. Mikania fimbriata Gardner, London J. Bot. 4: 119. 1845. = Mikania cordifolia (L. f.) Willd.

Mikania firmula Baker, Fl. Bras. 6(2): 266. 1876. = Mikania iigricans Gardner.

Mikania flabellata Rusby ex B. Robinson, Contr. Gray Herb. 61: 14. 1920.

Mikania flaccida B. Robinson, Contr. Gray Herb. 64: 9. 1922.

Mikania flavescens Gardner, London J. Bot. 5: 481. 1846. = Mikania nummularia DC.

Mikania floribunda Bojer ex DC., Prodr. 5: 198. 1836. = Mikania capensis DC.

Mikania florida Aristeg., Mem. New York Bot. Gard. 9: 426. 1957.

Mikania fockeana Miq., Linnaea 17: 68. 1843. = Mikania psilostachya DC.

Mikania fragilis Urban, Symb. Antill. 1: 464. 1899.

Mikania fragrans Ten. ex Lemaire, Fl. Serres Jard. Eur. 3(8): sub Pl. 10(272), n. 42.1847, nom. nud. in syn. = Mikania fastuosa Lemaire.

Mikania fragrans Klatt, Bot. Jahrb. Syst. 8: 36. 1886.

Mikania fulva (Hook. \& Arn.) Baker, Fl. Bras. 6(2): 222.1876.

Mikania gabrieli Baker, F. Bras. 6(2): 235. 1876. = Mikania banisteriae DC.

Mikania glandulifera Holmes \& MeDaniel, Phytologia 37: 470. 1977.

Mikania glastifolia Martius ex Baker, F. Bras. 6(2): 321.1876 , nom. nud. = Raulinoreitzia crenulata (Sprengel) R. King \& H. Robinson.

Mikania glauca Martius ex Baker, Fl. Bras. 6(2): 224. 1876.

Mikania glaziovii Baker, Fl. Bras. 6(2): 251. 1876.

Mikania gleasonii B. Robinson, Contr. Gray Herb. 73: 23.1924.

Mikania glechomaefolia Schultz-Bip. ex Baker, F. Bras. 6(2): 249. 1876, nom. nud. = Mikania micrantha H. B. K.

Mikania globifera Rusby ex B. Robinson, Contr. Gray Herb. 61: 15. 1920.

Mikania globosa Coulter, Bot. Gaz. (Crawfordsville) 20: 46. 1895, nom. nud. in syn. = Mikania aromatica Oersted.

Mikania glomerata Sprengel, Syst. Veg. Fl. Peruv. Chil. 3: 421. 1826.

Mikania glumiflora Martius ex Baker, F1. Bras. 6(2): 369.1876 , nom. nud. = Mikania oblongifolia DC.

Mikania gonoclada DC., Prodr. 5: 199. 1836. = Mikania cordifolia (L. f.) Willd.

Mikania gonzalezii B. Robinson \& Greenman, Proc. Boston Soc. Nat. Hist. 29: 107. 1899.

Mikania goyazensis (B. Robinson) R. King \& H. Robinson, Phytologia 47: 126. 1980.

Mikania gracilipes B. Robinson, Contr. Gray Herb. 61: 15. 1920.

Mikania gracilis Schultz-Bip. ex Miq., Stirp. Surinam. Select. 187. 1851. = Mikania vitifolia DC.

Mikania gracillima Dusen ex Malme, Kongl. Svenska Vetenskapsakad. Handl. Ser. 3. 12(2); 61. 1933, nom. nud. in syn. = Mikania termata (Vell. Conc.) B. Robinson.

Mikania grandifolia Schultz-Bip. ex Baker, Fl. Bras. 6(2): 246. 1876, nom. nud. = Mikania vitifolia DC.

Mikania granulata B. Robinson, Contr. Gray Herb. 77: 51.1926.

Mikania grazielae R. King \& H. Robinson, Phytologia 45: 126. 1980.

Mikania guaco Humb. \& Bonpl., Pl. Aequin. 2: 84. T. 105. 18101811 .

Mikania guaranitica Hassler, Feddes Repert. 14: 172. 1915.

Mikania guatemalensis Standley \& Steyerm., Publ. Field Mus. Nat. Hist., Bot. Ser. 23: 105. 1944. = Mikania houstoniana (L.) B. Robinson.

Mikania guilleminii B. Robinson, Contr. Gray Herb. 96: 26. 1931.

Mikania haenkeana DC., Prodr. 5: 196. 1836.
Mikania hagei R. King \& H. Robinson, Phytologia 45: 128.1980.

Mikania harlingii R. King \& H. Robinson, Phytologia 60: 82. 1986.

Mikania hassleriana Chodat in Chodat \& Hassler, Bull. Herb. Boissier Ser. 2. 3: 712.1903.

Mikania hastata (L.) Willd., Sp. PI. 3: 1742. 1803.

Mikania hastato-cordata Malme, Ark. Bot. 24a(6): 39. 1932.

Mikania hastifolia Baker, Fl. Bras. 6(2): 270. 1876.

Mikania hatschbachii G. Barroso, Arch. Jard. Bot. Rio de Janeiro 16: 326. 1959.

Mikania hederaefolia DC., Prodr. 5: 202. 1836. = Mikania glomerata Sprengel.

Mikania hederaefolia Schultz-Bip., Linnaea 30: 182. 1859-1860, nom. nud. = Mikania triangularis Baker.

Mikania hemisphaerica Schultz-Bip. ex Baker, Fl. Bras. 6(2): 254. 1876.

Mikania hesperia B. Robinson, Contr. Gray Herb. 73: 24. 1924.

Mikania hexagona B. Robinson, Proc. Amer. Acad. Arts 47: 196. 1911. = Mikania microptera DC.

Mikania hexagonocaulis Holmes \& McDaniel, Phytologia 37: 471. 1977.

Mikania hioramii Britton \& B. Robinson, Contr. Gray Herb. 61: 16. 1920.

Mikania hirsutissima DC., Prodr. 5: 200. 1836.

Mikania hispida Gardner, London J. Bot. 5: 490. 1846. = Mikania conferta Gardner.

Mikania hitchcockii B. Robinson, Contr. Gray Herb. 73: 25. 1924.

Mikania hoehnei B. Robinson, Contr. Gray Herb. 104: 36. 1934.

Mikania hoffmanniana Dusen ex Malme, Kongl. Svenska Vetenskapsakad. Handl. Ser. 3. 12(2): 54. 1933.

Mikania holwayana B. Robinson, Contr. Gray Herb. 64: 11. 1922.

Mikania hookeriana DC., Prodr. 5: 195. 1836.

Mikania hostmanii Miq., Stirp. Surinam. Select. 189. 1851. = Mikania cordifolia (L. f.) Willd.

Mikania hotteana Urban \& Ekman, Ark. Bot. 23a(11): 72. 1931.

Mikania houstoniana (L.) B. Robinson, Proc. Amer. Acad. Arts 42: 47. 1906.

Mikania houstonis Willd., Sp. Pl. 3: 1742. 1803. = Mikania houstoniana (L.) B. Robinson.

Mikania huaco Rieux ex Sprengel, Syst. Veg. Fl. Peruv. Chil. 3: 422. 1826 , nom. nud. = Mikaria guaco Humb. \& Bonpl.

Mikania huanucoensis Holmes \& McDaniel, Phytologia 41: 190 (-191). 1978

Mikania huitzensis Standley \& Stcyerm., Publ. Field Mus. Nat. Hist., Bot. Ser. 23: 260. 1947. = Mikania cordifolia (L. f.) Willd.

Mikania humilis Kuntze ex Hieron., Bot. Jahrb. Syst. 22: 792. 1897, nom. nud. = Mikania mendocina Philippi.

Mikania hylibates B. Robinson, Contr. Gray Herb. 77: 52. 1926. = Mikania hookeriana DC.

Mikania ildefonsiana Gardner, London J. Bot. 5: 484. 1846. = Mikania argyreiae DC.

Mikania iltisii R. King \& H. Robinson, Phytologia 29: 124. 1974, nom. nov.

Mikania imrayana Griseb., Fl. Brit. W. I. 363. 1861. = Mikania hookeriana DC.

Mikania incasina B. Robinson, Contr. Gray Herb. 64: 11. 1922.

Mikania infesta B. Robinson, Contr. Gray Herb. 104: 37.1934

Mikania inordinata R. King \& H. Robinson, Phytologia 45: 129. 1980. = Mikania campanulata Gardner.

Mikania inornata B. Robinson, Contr. Gray Herb. 73: 26.1924.

Mikania involucrata Hook. \& Arn., Companion Bot. Mag. 1: 243. 1835.

Mikania iodotricha Blake, J. Wash. Acad. Sci. 28: 483. 1938.

Mikania iquitosensis B. Robinson, Contr. Gray Herb. 104: 38. 1934. 
Mikania iserniana Cuatrec., Anales Ci. Univ. Madrid 4(2): 235. 1935.

Mikania itambana Gardner, London J. Bot. 5: 481. 1846, see M. stambana.

Mikania jamaicensis B. Robinson, Contr. Gray Herb. 64: 12. 1922.

Mikania jamesomii B. Robinson, Contr. Gray Herb. 61: 17. 1920.

Mikania javitensis V. Badillo, Bol. Soc. Venez. Ci. Nat. 9: 133. 1944.

Mikania jelskii Hieron., Bot. Jahrb. Syst. 36: 475. 1905.

Mikania joergensenii B. Robinson, Contr. Gray Herb. 64: 13. 1922.

Mikania johnstonii B. Robinson, Contr. Gray Herb. 64: 14. 1922.

Mikania jujuyensis Cabrera, Fl. Prov. Jujuy 10: 105. 1978.

Mikania juninensis Holmes \& McDaniel, Phytologia 41: 185 (-186). 1978

Mikania karsteniana Klotzsch, Bot. Jahrb. Syst. 28: 581. 1901. = Mikania pannosa Baker.

Mikania karuaiensis V. Badillo, Bol. Soc. Venez. Ci. Nat. 10: 296. 1946. = Mikania psilostachya DC.

Mikania kavanayensis V. Badillo, Bol. Soc. Venez. Ci. Nat. 10: 300. 1946. = Mikania banisteriae DC.

Mikania killipii B. Robinson, Contr. Gray Herb. 77: 53.1926.

Mikania kleiniana Cabrera, Sellowia 15: 236. Fig. 8. 1963.

Mikania klugii B. Robinson, Contr. Gray Herb. 104: 38. 1934.

Mikania kubitzkii R. King \& H. Robinson, Phytologia 48: 224. 1981.

Mikania laevigata Schultz-Bip. ex Baker, Fl. Bras. 6(2): 241. 1876

Mikania laevis DC. Prodr. 5: 194. 1836. = Mikania trinervis Hook. \& Arn.

Mikania lagoeusis Baker, Fl. Bras. 6(2): 220. 1876.

Mikania lanceolata Hieron. in Sodiro, Bot. Jahrb. Syst. 29: 17. 1900.

Mikania lancifolia B. Robinson, Contr. Gray Herb. 61: 17. 1920.

Mikania lanigera Gardner, London J. Bot. 5: 479. 1846. = Mikania leiolaena DC.

Mikania lanuginosa DC., Prodr. 5: 201. 1836.

Mikania larensis V. Badillo, Bol. Soc. Venez. Ci. Nat. 10: 298. 1946. = Mikaria stuebelii Hieron.

Mikania lasiandrae DC. Prodr. 5: 189. 1836.

Mikania lasiopoda B. Robinson, Contr. Gray Herb. 73: 27. 1924.

Mikania latifolia Smith in Rees, Cycl. 23. Mikania N. 8. 1819.

Mikania larisquama Cabrera, Sellowia 15: 241. Fig. 9. 1963.

Mikania laurifolia (L. f.) Willd., Sp. PI. 3: 1746. 1803.

Mikania lawrancei B. Robinson, Contr. Gray Herb. 104: 39. 1934.

Mikania laxa DC., Prodr. 5: 200. 1836. = Mikania angularis Humb. \& Bonpl.

Mikaria laxa A. Chev, Expl. Bot. Afr. Occ. Franc. 1: 360. 1920, nom. nud. = Mikania chevalieri (C. Adams) Holmes \& McDaniel.

Mikania lechleri Schultz-Bip. ex B. Robinson, Contr. Gray Herb. 90: 35.1930 = Mikania vitifolia.

Mikania lehmannii Hieron., Bot. Jahrb. Syst. 19: 46. 1894.

Mikania leiolaena DC. Prodr. 5: 188. 1836.

Mikania leiostach'a Benth., Pl. Hartw. 201. 1845.

Mikania levidophora Urban, Symb. Antill. 7: 423. 1912

Mikania leptotricha Baker, Fl. Bras. 6(2): 234. 1876.

Mikania leucophylla (Rusby) B. Robinson, Proc. Amer. Acad. Arts 47: 196. 1911.

Mikania liervalii Herincq. Horticulteur Franc. 18. 1866, ignota, cult.

Mikania ligustrifolia DC., Prodr. 5: 191. 1836.

Mikania lima Schlechtend, ex Martius, Flora 24, 2 Beibl. 110. 1841. = Mikania psilostachya DC.

Mikania lindbergii Baker, F. Bras. 6(2): 232. 1876

Mikania lindenii S. Moore, J. Bot. 66: 166. 1928.
Mikania lindleyana DC., Prodr. 5: 195. 1836.

Mfikania linearifolia DC.. Prodr. 5: 187. 1836.

Mikania lloensis Hieron. in Sodiro, Bot. Jahrb. Syst. 29: 18. 1900.

Mfikania longiacuminata (Rusby) B. Robinson, Contr. Gray Herb. 64: 103. 1922

Mikania longicaulis Wallich, Num. List Dr. Pl. 3073. 1831, nom. nud. = Eupatorium cannabinum L.

Mikania longiflora (Rusby) B. Robinson, Proc. Amer. Acad. Arts 47: 196. 1911

Mikania longifolia Larran., Escr. D. A. Larranaga 1: 408. 1922. ignota.

Mikania longipes Baker, Fl. Bras. 6(2): 233. 1876.

Mikania loretensis B. Robinson. Contr. Gray Herb. 64: 15. 1922. = Mikania parviflora (Aublet) Karsten.

Mikania loxensis H. B. K., Nov. Gen. Sp. 4: 106. Ed. Folio. 1818. = Mikania cordifolia (L. f.) Willd.

Mikania lucida Blake in Gleason \& Killip, Brittonia 3: 199. 1939.

Mikania luetzelburgii Mattf., Notizbl. Bot. Gart. Berlin-Dahlem 9: 381.1925

Mikania lundiana DC., Prodr. 7: 270. 1838.

Mikania lutescens B. Robinson, Contr. Gray Herb. 80: 37.1928.

Mikania macbridei B. Robinson, Contr. Gray Herb. 73: 27. 1924.

Mikania macedoi G. Barroso, Arch. Jard. Bot. Rio de Janeiro 16: 247. 1959.

Mikania malacolepis B. Robinson, Contr. Gray Herb. 104: 40. 1934.

Mikania manaosensis Hieron. in Ule, Verh. Bot. Vereins Prov. Brandenburg 48: 201. 1907. = Mikania sprucei Baker.

Mikaria mandonii Schultz-Bip., Linnaea 34: 536. 1865-1866. = Ophryosporus piquerioides (DC.) Benth. ex Baker.

Mikania manettiae DC., Prodr. 5: 191. 1836. = Mikania stipulacea (Vahl) Willd.

Mikania marahuacensis Steyerm. \& Maguire, Acta Bot. Venez. 14: 28.1984

Mikania marinii Cabrera, Bol. Soc. Argent. Bot. 5: 37. 1953.

Mikania maritima Gardner, London J. Bot. 5: 489. 1846. = Mikania stipulacea (Vahl) Willd.

Mikania martiana Gardner, London J. Bot. 5: 484. 1846. = Mikania hirsutissima DC.

Mikania mathewsii B. Robinson, Contr. Gray Herb. 61: 18. 1920.

Mikania mattos-silvae R. King \& H. Robinson, Phytologia 49: 489. 1981 .

Mikania Maxonii Proctor, Bull. Inst. Jamaica Sci. Ser. 16: 72. 1967.

Mikania mazanensis Holmes \& McDaniel, Phytologia 31: 275 (-276). 1975 .

Mikania mazaruniensis Holmes \& McDaniel, Phytologia 50: 7. 1981.

Mikania megalophylla Holmes \& McDaniel, Phytologia 31: 276 (-277). 1975.

Mikania melastomacea Blake, J. Wash. Acad. Sci. 28:480. 1938. = Mikania decora Poeppig \& Endl., ?

Mikania melissaefolia (Lam.) Willd., Sp. PI. 3: 1747. 1803. = Stevia melissaefolia (Lam.) Schultz-Bip.

Mikania mendocina Philippi, Sert. Mendoc. Alt. 20. 1870.

Mikania menispermea DC., Prodr. 5: 200. 1836. = Mikania scandens (L.) Willd.

Mikania meridana V. Badillo, Bol. Soc. Venez. Ci. Nat. 10: 303. 1946. = Mikania banisteriae DC.

Mikania meridensis V. Badillo, Bol. Soc. Venez. Ci. Nat. 9: 134. 1944. = Mikania stuebelii Hieron.

Mikania micajensis B. Robinson, Contr. Gray Herb. 77: 54. 1926.

Mikania michelangeliana Steyerm., Ann. Missouri Bot. Gard. 71: 339. 1984.

Mikania miconioides B. Robinson, Contr. Gray Herb. 61: 19. 1920. 
Mikania micramtha H. B. K., Nov. Gen. Sp. 4: 105. Ed. Folio. 1818.

Mikania microcephala DC., Prodr. 5: 200. 1836.

Mikania microdonta DC., Prodr. 5: 200. 1836.

Mikania microlepis Baker, Fl. Bras. 6(2): 259. 1876.

Mikania microphylla Schultz-Bip. ex Baker, Fl. Bras. 6(2): 219. 1876.

Mikania microptera DC., Prodr. 5: 196. 1836.

Mikania millei B. Robinson, Contr. Gray Herb. 77: 55. 1926.

Mikania minima (Baker) B. Robinson, Contr. Gray Herb. 104: 60. 1934

Mikania molinensis V. Badillo, Bol. Soc. Venez. Ci. Nat. 10: 296. 1946. = Mikania banisteriae DC.

Mikania mollis H. B. K., Nov. Gen. Sp. 4: 105. Ed. Folio. 1818.

= Mikania cordifolia (L. f.) Willd.

Mikania monagasensis V. Badillo, Bol. Soc. Venez. Ci. Nat. 10: 300. 1946.

Mikania montana B. Robinson, Contr. Gray Herb. 73: 29. 1924.

Mikania montevidensis Sprengel ex Baker, Fl. Bras. 6(2): 222. 1876 , nom. nud. in syn. = Mikania ternifolia DC

Mikania montverdensis Proctor, Bull. Inst. Jamaica Sci. Ser. 16: 75. 1967.

Mikania monzonensis Hieron. in Urban, Bot. Jahrb. Syst. 40: 391. 1908. = Mikania haenkeana DC.

Mikania morii R. King \& H. Robinson, Phytologia 45: 130.1980.

Mikania mosenii Malme, Kongl. Svenska Vetenskapsakad. Handl. Ser. 3. 12(2): 53. 1933.

Mikania mossambicensis Steetz, Naturw. Reise Mossambique 377. 1852-1882, ignota.

Mikania moyobambensis Hieron. in Urban, Bot. Jahrb. Syst. 40: 393. 1908. = Mikania psilostachya DC.

Mikania inucronulifera B. Robinson, Contr. Gray Herb. 77: 55. 1926.

Mikania multinervia Turcz., Bull. Soc. Imp. Naturalistes Moscou 24(2): 59.1851.

Mikania mutisiana Cuatrec., Trab. Mus. Nac. Ci. Nat., Ser. Bot. 29: 18. 1935. = Mikania caldasana B. Robinson.

Mikania myricaefolia Bojer ex DC., Prodr. 5: 188. 1836. = Senecio myricaefolius (Bojer ex DC.) Humbert. SEnecioneaE.

Mikania myriocephala DC., Prodr. 5: 191. 1836.

Mikania napensis Blake, J. Wash. Acad. Sci. 28: 484. 1938. = Mikania guaco Humb. \& Bonpl.

Mikania natalensis DC., Prodr. 5: 198. 1836.

Mikania neblinensis Aristeg., Mem. New York Bot. Gard. 9: 368. 1957.

Mikania nebularum Dusen ex Malme, Kongl. Svenska Vetenskapsakad. Handl. Ser. 3. 12(2): 56. 1933, nom. nud. in syn. = Mikania smaragdina Dusen ex Malme.

Mikania neei W. Holmes, Phytologia 58: 165. 1985.

Mikania neglecta B. Robinson, Candollea 5: 173. 1934. = Mikania warmingii Schultz-Bip. ex Baker.

Mikania nemorosa Klatt, Bot. Jahrb. Syst. 8: 36. 1886.

Mikania neurocaula DC., Prodr. 5: 188. 1836.

Mikania niederleinii Hieron., Bot. Jahrb. Syst. 22: 792. 1897. = Mikania periplocifolia Hook. \& Arn.

Mikania nigricans Gardner, London J. Bot. 5: 486. 1846.

Mikania nigropunctulata Hieron., Bot. Jahrb. Syst. 28: 578. 1901.

Mikania nitida (DC.) R. King \& H. Robinson, Phytologia 47: 126. 1980.

Mikania nitidula Baker, F]. Bras. 6(2): 243. 1876. = Mikania lindbergii Baker.

Mikania nodosa Sprengel, Syst. Veg. Fl. Peruv. Chil. 3: 423. 1826, ignota.

Mikania nodulosa Schultz-Bip. ex Baker, Fl. Bras. 6(2): 235. 1876.

Mikania nubigena B. Robinson, Contr. Gray Herb. 77: 57.1926. = Mikania pittieri $\mathrm{B}$. Robinson.

Mikania nummularia DC., Prodr. 5: 188. 1836
Mikania oblongifolia DC., Prodr. 5: 188. 1836.

Mikania obovata DC., Prodr. 5: 192. 1836.

Mikania obscura Sprengel ex Baker, Fl. Bras. 6(2): 362.1876, nom. nud. in syn. = Barrosoa betonicaeformis (DC.) R. King \& H. Robinson.

Mikania obsoleta (Vell. Conc.) G. Barroso, Arch. Jard. Bot. Rio de Janeiro 16: 291. 1959.

Mikania obtusata DC., Prodr. 5: 192.1836.

Mikania ochroleuca B. Robinson, Contr. Gray Herb. 80: 38. 1928.

Mikania odorata Lehm., Garten \& Blumen (Hamburg) Gartenz. 5: 369. 1849. = Mikania fastuosa Lemaire.

Mikania odoratissima Urban, Symb. Antill. 1: 464. 1899.

Mikania officinalis Martius, Reise Bras. 1: 283. 1820.

Mikania olivacea Klatt in T. Durand \& Pittier, Bull. Soc. Roy. Bot. Belgique 31: 195. 1892. = Mikania guaco Humb. \& Bonpl.

Mikania oniaensis V. Badillo, Bol. Soc. Venez. Ci. Nat. 10: 297. 1946. = Mikania banisteriae DC.

Mikania oopetala Urban \& Niedenzu, Symb. Antill. 2: 461. 1901.

Mikania opifera Martius, Reise Bras. 1: 279. 1820. = Mikania cordifolia (L. f.) Willd.

Mikania oreimeles B. Robinson, Contr. Gray Herb. 68: 39. 1923.

Mikania oreopola B. Robinson, Contr. Gray Herb. 64: 16. 1922.

Mikania orinocensis H. B. K., Nov. Gen. Sp. 4: 105. Ed. Folio. 1818. = Mikania micrantha H. B. K.

Mikania orleansensis Hieron., Bot. Jahrb. Syst. 22: 790. 1897.

Mikania ovalis Griseb., Fl. Brit. W. I. 363. 1861.

Mikania oxylepis Schultz-Bip. ex Baker, Fl. Bras. 6(2): 220.1876.

Mikania oxyota DC., Prodr. 5: 198. 1836. = Mikania capensis DC.

Mikania pachychaeta (Baker) G. Barroso, Arch. Jard. Bot. Rio de Janeiro 16: 272. 1959.

Mikania pachydictya B. Robinson, Contr. Gray Herb. 80: 38. 1928.

Mikania pachylepis Schultz-Bip. ex Baker, Fl. Bras. 6(2): 239. 1876. = Mikania rufescens Schultz-Bip. ex Baker.

Mikania pachyphylla Urban, Symb. Antill. 1: 463. 1899.

Mikania paezensis B. Robinson, Proc. Amer. Acad. Arts 47: 197. 1911. = Mikania popayanensis Hieron.

Mikania palustris (Gardner) R. King \& H. Robinson, Phytologia 47: 126. 1980.

Mikania panamensis B. Robinson, Contr. Gray Herb. 104: 41. 1934. = Mikania amblyolepis B. Robinson.

Mikania paniculata DC., Prodr. 5: 194. 1836

Mikania pannosa Baker, Fl. Bras. 6(2): 261. 1876.

Mikania papillosa Klatt, Abh. Naturf. Ges. Halle 15: 325.1882.

Mikania paranahybensis G. Barroso, Arch. Jard. Bot. Rio de Janeiro 16: 289. 1959.

Mikania paranensis Dusen, Arch. Bot. *PICK CORRECT ENTRY 9(15): 21. 1910.

Mikania parkeriana DC., Prodr. 5: 199. 1836. = Mikania congesta DC

Mikania parodii Cabrera, Revista Mus. La Plata, Secc. Bot. 4: 46. 1941. = Mikania mendocina Philippi.

Mikania parvicapitulata Hieron. in Urban, Bot. Jahrb. Syst. 40: 392. 1908.

Mikania parviflora (Aublet) Karsten, Deut. Fl. 1061. 1880-1883.

Mikania parvifolia Baker, Fl. Bras. 6(2); 226. 1876.

Mikania pastazae B. Robinson, Contr. Gray Herb. 73: 29. 1924.

Mikania paucifolia W. Holmes, Phytologia 57: 442. 1985.

Mikania pellucidivenia Hieron., Bot. Jahrb. Syst. 36: 474. 1905. = Mikania haenkeana DC.

Mikaria pendula Holmes \& McDaniel, Phytologia 37: 472. 1977.

Mikania pennellii B. Robinson, Contr. Gray Herb. 61: 19. 1920.

Mikania penstemonoides DC., Prodr. 5: 189. 1836. = Mikania sulcata (Hook. \& Am.) B. Robinson.

Mikania periplocifolia Hook. \& Arn., Companion Bot. Mag. 1: 243. 1835. 
Mikania pernambucensis Gardner, London J. Bot. 5: 490. 1846. Mikania perstipulata W. Holmes, Phytologia 58: 243. 1985.

Mikania petrina Standley \& Steyerm., Publ. Field Mus. Nat. Hist., Bot. Ser. 23: 261. 1947.

Mikania phaeoclados Martius ex Baker, Fl. Bras. 6(2): 256. 1876.

Mikania phelpsii Maguire \& Steyerm. in Lasser \& Maguire, Brittonia 7:89. 1950. = Mikania lucida Blake in Gleason \& Killip.

Mikania phyllopoda Griseb., Abh. Konigl. Ges. Wiss. Gottingen 19: 122. 1874. = Mikania urticaefolia Hook. \& Arn.

Mikania pichinchensis Hieron., Bot. Jahrb. Syst. 28: 576. 1901.

Mikania pilcomayensis (Hassler) B. Robinson, Contr. Gray Herb. 104: 64. 1934.

Mikania pilosa Baker, Fl. Bras. 6(2): 234. 1876.

Mikania pinnatiloba DC., Prodr. 5: 187. 1836.

Mikania pittieri B. Robinson, Proc. Boston Soc. Nat. Hist. 31: 255. 1904.

Mikania platylepis D. Don ex R. King \& H. Robinson, Phytologia 58: 263. 1985.

Mikania platyloba Urban \& Ekman, Ark. Bot. 23a(11): 72. 1931.

Mikania platyphylla DC., Prodr. 5: 195. 1836. = Mikania hookeriana DC.

Mikania poeppigii Sprengel, Syst. Veg. F1. Peruv. Chil. 3: 422. 1826. = Mikania cordifolia (L. f.) Willd.

Mikania polliana Schultz-Bip. ex Baker, Fl. Bras. 6(2): 232. 1876.

Mikania pohlii (Baker) R. King \& H. Robinson, Phytologia 47: 126. 1980.

Mikania polybotrys G. Don ex Baker, F1. Bras. 6(2): 266. 1876. nom. nud. in syn. = Mikania psilostachya DC.

Mikania polycepliala Urban, Symb. Antill. 2: 459. 1901.

Mikaria polycephala Dusen ex Malme, Kongl. Svenska Vetenskapsakad. Handl. 3: 12(2): 55. 1933, nom. nud. in syn. = Mikania hoffinanniana Dusen ex Malme.

Mikania polychaeta Urban, Feddes Repert. 16: 146. 1919.

Mikania polystachva DC., Prodr. 5: 190. 1836. = Mikania psilostachya DC.

Mikania popavanensis Hieron., Bot. Jahrb. Syst. 28: 579. 1901.

Mikania populifolia Gardner, London J. Bot. 5: 485. 1846.

Mikania porosa Urban, Symb. Antill. 1: 465. 1899.

Mikania premnifolia Gardner, London J. Bot. 5: 480. 1846.

Mikania producta Urban \& Ekman, Ark. Bot. 23a(11): 70. 1931.

Mikania pseudogracilis R. King \& H. Robinson, Phytologia 53: 392. 1983.

Mikania pseudohoffmanniana G. Barroso, Arch. Jard. Bot. Rio de Janeiro 16: 285. 1959.

Mikania pseudomicrocephala R. King \& H. Robinson, Phytologia 49: 490. 1981.

Mikania psilostachya DC., Prodr. 5: 190. 1836

Mikania psychotrioides DC., Prodr. 5: 193. 1836. = Mikania obovata DC.

Mikania ptaretepuiensis V. Badillo, Bol. Soc. Venez. Ci. Nat. 10: 302. 1946. = Mikania banisteriae DC.

Mikania pterocaula Schultz-Bip. ex Klatt, Leopoldina 20: 91. 1884.

Mikania pteropoda DC., Prodr. 5: 191. 1836.

Mikania puberula Gardner, London J. Bot. 5: 482. 1846. = Mikania selloi Sprengel.

Mikania pubescens Muhlenb., Cat. Pl. Amer. Sept. 71. $1813 .=$ Mikaria scandens (L.) Willd.

Mikania pulverulenta Sodiro ex B. Robinson, Contr. Gray Herb. 77: 58.1926.

Mikania punctala Gardner, London J. Bot. 4: 118. 1845. = Mikania pteropoda DC.

Mikania punctata Klatt in T. Durand \& Pittier, Bull. Soc. Roy. Bot. Belgique 31: 195. 1892. = Mikania vitifolia DC,

Mikania purpurascens Schultz-Bip. ex Baker, Fl. Bras. 6(2): 371. 1876, nom. nud. in syn. = Mikania purpurascens (Baker) R. King \& H. Robinson.
Mikania purpurascens (Baker) R. King \& H. Robinson, Phytologia 47: 126. 1980.

Mikania pycnadenia B. Robinson, Contr. Gray Herb. 64: 18. 1922.

Mikania pyramidata J. D. Smith, Bot. Gaz. (Crawfordsville) 13: 188. 1888.

Mikania pyrifolia DC., Prodr. 5: 195. 1836, = Senecio curvatus Baker. SENECIONEAE.

Mikania racemosa Martius ex Baker, F. Bras. 6(2): 270. 1876, nom. nud. in syn. = Mikania ligustrifolia DC

Mikania racemulosa Benth., J. Bot. (Hooker) 2: 41. 1840. = Mikania psilostachya DC.

Mikania racemulosa Klatt, Abh. Naturf. Ges. Halle 15: 325. 1882. = Mikania nigropunctulata Hicron.

Mikania ramiziana Glaz., Bull. Soc. Bot. France Mem. 3. 56 : 393. 1910 , nom. nud. = Mikania pteropoda DC.

Mikania rainosissima Gardner, London J. Bot. 5: 483. 1846.

Mikania ranunculifolia Rich. ex Sagra, Hist. Fis. Cuba, Bot. 3: 45. 1853.

Mikania regnellii Schultz-Bip., Linnaea 22: 572. 1849, nom. nud. Linnaea 30: 182. 1859-60. = Mikania sessilifolia DC.

Mikania repanda Llave, Mosaico Mexicano 2: 299. 1837-1838. = Mikania pyramidata J. D. Smith, ?

Mikania resinosa Sprengel, Neue Entd. 2: 134. 1820. = Dasycondy/us resinosus (Sprengel) R. King \& H. Robinson.

Mikania reticulata Gardner, London J. Bot. 5: 480.1846.

Mikania reticulosa Wright, Anales Acad. Ci. Med. Habana 6: 180. 1869.

Mikania retifolia Schultz-Bip. ex Baker, F. Bras. 6(2): 242. 1876.

Mikania rhomboidea Urban \& Ekman, Ark. Bot. 23a(11): 71. 1931.

Mikania riedeliana Casar. ex B. Robinson, Candollea 5: 174 1934. = Mikania rufescens Schultz-Bip. ex Baker.

Mikania rimachii Holmes \& McDaniel, Phytologia 41: 195 (-196). 1978.

Mikania riparia Greenman ex B. Robinson. Proc. Boston Soc. Nat. Hist. 31: 255. 1904.

Mikania rivularis B. Robinson, Contr. Gray Herb. 73: 30. 1924.

Mikania robinsoniana Steyerm., Fieldiana. Bot. 28(3): 660. 1953. nom. nov. = Mikania nigropunctulata Hieron.

Mikania rondonensis V. Badillo, Bol. Soc. Venez. Ci. Nat. 10: 297. 1946.

Mikania roraimensis B. Robinson, Contr. Gray Herb. 80: 39. 1928. = Mikania sprucei Baker.

Mikania rothii G. Barroso, Arch. Jard. Bot. Rio de Janeiro 16 : 271. 1959.

Mikania rotunda Griseb., F. Brit. W. 1. 364. 1861.

Mikania rotundifolia G. Barroso, Arch. Jard. Bot. Rio de Janeiro 16:251. 1959. = Mikania salzmanniaefolia DC.

Mikania rubella Lingelsh., Feddes Repert. 7: 250. 1909.

Mikania rubiginosa Smith in Rees, Cycl. 23. Mikania N. 12. 1819. = Mikania cordifolia (L. f.) Willd.

Mikania rufa Benth., P1. Hartw. 201. 1845.

Mikania nufescens Schultz-Bip. ex Baker, Fl. Bras. 6(2): 238 1876.

Mikania rugosa B. Robinson, Contr. Gray Herb. 61: 20. 1920.

Mikania ruiziana Poeppig \& Endl., Nov. Gen. Sp. 3: 53. 1845. = Mikania banisteriae DC.

Mikania rusbyi B. Robinson, Contr. Gray Herb. 64: 18. 1922.

Mikania sagittata Blanco, Fl. Filip. (ed. 2) 54. 1837. = Mikania cordata (Burm. f.) B. Robinson.

Mikania sagittifera B. Robinson, Contr. Gray Herb. 104: 68. 1934.

Mikania salicifolia Hassler, Feddes Repert. 12: 367. 1913.

Mikania saltensis Hieron., Bot. Jahrb. Syst. 22: 794. 1897.

Mikania salviacfolia Gardner, London J. Bot. 5: 487. 1846.

Mikania salzmanniacfolia DC.. Prodr. 5: 193. 1836. 
Mikania sanderi Sander, Cat. 22. 1899. = Mikania liervalii Herincq,?

Mikania sanjacintensis V. Badillo, Bol. Soc. Venez. Ci. Nat. 10: 298. 1946. = Mikania hookeriana DC.

Mikania santamensis V. Badillo, Bol. Soc. Venez. Ci. Nat. 9: 135. 1944. = Mikania trinitaria DC.

Mikania santosii R. King \& H. Robinson, Phytologia 45: 131. 1980.

Mikania sapucayensis Hassler, Feddes Repert. 14: 171. 1915. = Mikania variifolia Hieron.

Mikania sarcodes Baker, Fl. Bras. 6(2): 269. 1876.

Mikania saturejaefolia (Lam.) Willd., Sp. Pl. 3: 1747. 1803. = Stevia satureifolia Lam.

Mikania scabra DC., Prodr. 5: 190. 1836. = Mikania psilostachya DC.

Mikania scabrida Baker, Fl. Bras. 6(2): 258. 1876.

Mikania scandens (L.) Willd., Sp. Pl. 3: 1743. 1803.

Mikania scandens var. cynanchifolia Hook. \& Arn. ex Baker, F. Bras. 6(2): 249. 1876. = Mikania cynanchifolia (Hook. \& Am. ex Baker) B. Robinson.

Mikania scandens var. minima Baker, Fl. Bras. 6(2): 250. 1876. = Mikania minima (Baker) B. Robinson.

Mikania scandens var. pilcomayensis Hassler, Feddes Repert. Spec. Nov. Regni Veg. 12.368. 1913.= Mikania pilcomayensis (Hassler) B. Robinson.

Mikania scausoria DC., Prodr. 5: 202. 1836. = Mikania glomerata Sprengel.

Mikania schenckii Hieron., Bot. Jahrb. Syst. 22: 797. 1897.

Mikania schultzii B. Robinson, Contr. Gray Herb. 64: 19. 1922.

Mikania seemannii B. Robinson, Contr. Gray Herb. 61: 20.1920.

Mikania selloi Sprengel, Syst. Veg. Fl. Peruv. Chil. 3: 421. 1826.

Mikania senecioides Schultz-Bip. ex Baker, F. Bras. 6(2): 223. 1876 , nom. nud. in syn. = Mikania ternifolia DC.

Mikania sepiaria Gardner, London J. Bot. 5: 488. 1846. = Mikania hirsutissima DC.

Mikania sericea Hook. \& Am., Companion Bot. Mag. 1: 243. 1835.

Mikania serratifolia H. B. K., Nov. Gen. Sp. 4: 108. Ed. Folio. 1818. = Ophryosporus serratifolius (H. B. K.) B. Robinson.

Mikania serratifolia Sieber ex DC., Prodr. 5: 181. 1836, nom. nud. = Condylidium iresinoides (H. B. K.) R. King \& H. Robinson.

Mikania serrulata Schultz-Bip. ex Baker, Fl. Bras. 6(2): 230. 1876, nom. nud. in syn. = Mikania myriocephala DC.

Mikania sessilifolia DC., Prodr. 5: 188. 1836.

Mikania setigera Schultz-Bip. ex Baker, Fl. Bras. 6(2): 259. 1876.

Mikania shushuensis Holmes \& McDaniel, Phytologia 45: 298 (-299). 1980.

Mikania siambonensis Hieron., Bot. Jahrb. Syst. 22: 790. 1897.

Mikania sieberiana DC., Prodr. 5: 196. 1836. = Mikania congesta DC.

Mikania simpsonii Holmes \& McDaniel, Phytologia 37: 473. 1977.

Mikania simuata Rusby, Bull. New York Bot. Gard. 8: 127. 1912. = Mikania micrantha $\mathrm{H}$. B. K.

Mikania skutchii Blake, Brittonia 2: 333. 1937. = Mikania banisteriae DC.

Mikania smaragdina Dusen ex Malme, Kongl. Svenska Vetenskapsakad. Handl. Ser. 3. 12(2): 55. 1933.

Mikania smilacina DC., Prodr. 5: 192. 1836.

Mikania smithii B. Robinson, Contr. Gray Herb. 80: 40. 1928.

Mikania sodiroi Hieron. in Sodiro, Bot. Jahrb. Syst. 29: 16.1900. = Mikania leiostachya Benth.

Mikania solidinervia V. Badillo, Emstia 7: 22. 1981.

Mikania sophiaefolia (L.) Sprengel, Syst. Veg. F. Peruv. Chil. 3: 423. 1826. = Eupatorina sophiaefolia (L.) R. King \& H. Robinson.

Mikania speciosa DC., Prodr. 5: 196. 1836.
Mikania spiraeastrum Martius ex Baker, Fl. Bras. 6(2): 243. 1876, nom. nud. in syn. = Mikania obtusata DC.

Mikania sprucei Baker, Fl. Bras. 6(2): 264. 1876.

Mikania stambana Gardner, London J. Bot. 5: 481. 1846, error for "itambana." = Mikania itambana Gardner.

Mikania standleyi B. Robinson, Contr. Gray Herb. 77: 59. 1926. = Mikania holwayana $\mathrm{B}$. Robinson.

Mikania standleyi R. King \& H. Robinson, Phytologia 28: 272. 1974. = Mikania iltisii R. King \& H. Robinson.

Mikania steinbachii B. Robinson, Contr. Gray Herb. 80: 40. 1928.

Mikania stenocephala Schultz-Bip. ex Baker, Fl. Bras. 6(2): 249. 1876, nom. nud. in syn. = Mikania cynanchifolia (Hook. \& Arn. ex Baker) B. Robinson.

Mikania stenomeres B. Robinson, Contr. Gray Herb. 104: 43. 1934.

Mikania stenophylla Holmes, Phytologia 51: 234. 1982.

Mikania stereodes B. Robinson, Contr. Gray Herb. 77: 60. 1926.

Mikania stereolepis B. Robinson, Contr. Gray Herb. 104: 44. 1934.

Mikania stevensiana Britton, Bull. Torrey Bot. Club 43: 458. 1916.

Mikania steyermarkii R. King \& H. Robinson, Phytologia 28: 273. 1974.

Mikania stictophora Steyerm., Fieldiana, Bot. 28(3): 660. 1953. = Mikania sprucei Baker.

Mikania stipitata Schultz-Bip. ex Miq., Stirp. Surinam. Select. 191. 1851. = Mikania parviflora (Aublet) Karsten.

Mikania stipulacea (Vahl) Willd., Sp. Pl. 3: 1745. 1803.

Mikania stipulifera L. O. Williams, Fieldiana, Bot. 36: 109. 1975.

Mikania strigosa Gardner, London J. Bot. 4: 119. 1845. = Mikania lasiandrae DC.

Mikania strobilifera Gardner, London J. Bot. 5: 479. 1846. = Mikania oblongifolia DC.

Mikania stuebelii Hieron., Bot. Jahrb. Syst. 21: 333. 1895.

Mikania stygia B. Robinson, Contr. Gray Herb. 90: 36. 1930.

Mikania stylosa Gardner, London J. Bot. 5: 486. 1846.

Mikania suaveolens H. B. K., Nov. Gen. Sp. 4: 106. Ed. Folio. 1818. = Mikania cordifolia (L. f.) Willd.

Mikania subcordata Gardner, London J. Bot. 4: 118. 1845. = Mikania argyreiae DC

Mikania subcrenata Hook. \& Arn., Companion Bot. Mag. 1: 243. 1835. = Mikania micrantha H. B. K.

Mikania subcymosa Gardner, London J. Bot. 6: 448. 1847. = Mikania micrantha $\mathrm{H}$. B. K.

Mikania sublaxa Malme, Kongl. Svenska Vetenskapsakad. Handl. Ser. 3. 12(2): 58. 1933. = Mikania campanulata Gardner.

Mikania subverticillata Schultz-Bip. ex Baker, Fl. Bras. 6(2): 224. 1876.

Mikania sulcata (Hook. \& Arn.) B. Robinson, Proc. Amer. Acad. Arts 47: 197. 1911.

Mikania surinamensis Miq., Stirp. Surinam. Select. 188. 1851. = Mikania cordifolia (L. f.) Willd.

Mikania swartziana Griseb., Fl. Brit. W. I. 363. 1861.

Mikania sylvatica Klatt, Bot. Jahrb. Syst. 8: 37. 1886.

Mikania szyszylowiczii Hieron., Bot. Jahrb. Syst. 36: 475. 1905.

Mikania tafallae Sprengel, Syst. Veg. Fl. Peruv. Chil. 3: 422. 1826. = Mikania tafallana H. B. K.

Mikania tafallana H. B. K., Nov. Gen. Sp. 4: 107. Ed. Folio. 1818.

Mikania tambillensis Hieron., Bot. Jahrb. Syst. 36: 470. 1905.

Mikania tamoides DC., Prodr. 5: 197. 1836. = Mikania batataefolia DC.

Mikania tarapotensis B. Robinson, Contr. Gray Herb. 61: 21. 1920. = Mikania decora Poeppig \& Endl.

Mikania tehuacanensis W. Holmes, Phytologia 59: 442. 1986.

Mikania teixeirae R. King \& H. Robinson, Phytologia 45: 132. 1980. 
Mikania tenax Schultz-Bip. ex B. Robinson, Contr. Gray Herb. 80: 41. 1928.

Mikania tenuiflora Griseb., Abh. Konigl. Ges. Wiss. Gottingen 24: 174. 1879. = Austrobrickellia patens (Don ex Hook. \& Am.) R. King \& H. Robinson.

Mikania tepuiensis V. Badillo, Bol. Soc. Venez. Ci. Nat. 10: 302. 1946.

Mikania ternata (Vell. Conc.) B. Robinson, Proc. Amer. Acad. Arts 47: 198. 1911.

Mikania ternifolia DC., Prodr. 5: 188. 1836.

Mikania testudinaria DC., Prodr. 5: 197. 1836.

Mikania tencriifolia Sprengel, Neue Entd. 2: 134. 1820. = Grazielia gaudichaudeana (DC.) R. King \& H. Robinson.

Mikania thapsoides DC., Prodr. 5: 189. 1836.

Mikania thunbergiaefolia Gardner, London J. Bot. 6: 448. 1847. = Mikania cordifolia (L. f.) Willd.

Mikania thumbergioides DC., Prodr. 5: 198. 1836. = Mikania capensis DC.

Mikania thyrsoidea Baker, Fl. Bras. 6(2): 267. 1876.

Mikania tillettii R. King \& H. Robinson, Phytologia 28: 274. 1974.

Mikania Ilalixcoyan Llave, Mosaico Mexicano 2: 299. 1837. 1838, ignota, sterile.

Mikania tomentosa Willd., Sp. Pl. 3: 1744. 1803. = Senecio penicillatus (Cass.) Schultz-Bip. Senecioneae.

Mikania tonduzii B. Robinson, Proc. Boston Soc. Nat. Hist. 31: 256. 1904.

Mikania trachodes B. Robinson, Contr. Gray Herb. 61: 22. 1920.

Mikania Irachypleura B. Robinson, Contr. Gray Herb. 104: 46. 1934.

Mikania triangularis Baker, Fl. Bras. 6(2): 246. 1876.

Mikania irichophila DC., Prodr. 5: 200. 1836.

Mikaria trifolia Schultz-Bip., Linnaea 34: 535. 1865-1866, nom. nud. = Mfikania trifolia (Rusby) B. Robinson.

Mikania trifolia (Rusby) B. Robinson, Contr. Gray Herb. 64: 107. 1922.

Afikania trimeria Holmes \& McDaniel, Phytologia 50: 8. 1981.

Mikania trinervis Hook. \& Am., Companion Bot. Mag. 1: 244. 1835.

Mikania trinitaria DC., Prodr. 5: 194. 1836.

Mikania tripartita Urban \& Niedenzu, Symb. Antill. 2: 462. 1901.

Mikania tripltylla Sprengel ex Baker, Fl. Bras. 6(2): 263.1876.

Mikania tropaeolifolia O. Hoffm., Bot. Jahrb. Syst. 24: 468. 1898.

= Mikania carteri Baker.

Mikania troyana Urban, Symb. Antill. 5: 226. 1907.

Mikania turbaricola Holmes \& McDaniel, Phytologia 37: 474. 1977.

Mikania tysonii R. King \& H. Robinson, Phytologia 28: 275. 1974.

Mikania ulei Hieron., Bot. Jahrb. Syst. 22: 795. 1897.

Mikania Immbellifera Gardner, London J. Bot. 4: 119. 1845. = Mikania micrantha H. B. K.

Mikania ursina Martius ex Baker, Fl. Bras. 6(2): 261. 1876, nom. nud. in syn. = Mikania hirsutissima DC.

Mikania urticaefolia Hook. \& Arn., Companion Bot. Mag. 1: 244. 1835.

Mikania vargasii Holmes \& McDaniel, Phytologia 35: 330(-331). 1977.

Mikania variabilis Meyen \& Walp., Nova Acta Phys.-Med. Acad. Caes. Leop.-Carol. Nat. Cur. 19, Suppl. 1: 257. 1843. $=$ Mikania micrantha H. B. K.

Mikanlia variabilis Gardner, London J. Bot. 5: $486.1846 .=$ Mikania congesta DC.

Mikania variifolia Hieron., Bot. Jahrb. Syst. 22: 793. 1897.

Mikania vaupesensis Holmes \& McDaniel, Phytologia 50: 9. 1981.

Mikania vauthieriana Baker, FI. Bras. 6(2): 269. 1876.
Mikania vellosiana Barb. Rodr., Hort. Flumen. 276. 1894. = Mikania cordifolia (L. f.) Willd.

Mikania venosa Alain, Mem. New York Bot. Gard. 21(2): 151. 1971.

Mikania verrucosa Sprengel, Syst. Veg. F. Peruv. Chil. 3: 423. 1826. = Koanophyllon celtidifolia (Lam.) R. King \& H. Robinson.

Mikania verticillata Schultz-Bip.. Bonplandia 9: 175. 1861. = Mikania anethifolia (DC.) Matzenbacher.

Mikania viminaria Steudel, Nomend. Bot. 2: 145. 1841. = Mikania viminea DC.

Mikania viminea DC., Prodr. 5: 187. 1836.

Mikania violacea Regel, Cat. PI. Horl. Aksakov. 93. 1860, nom. nud. ignota, cult.

Mikania violaefolia Cuatrec., Ann. Missouri Bot. Gard. 52: 307. 1965.

Mikania violascens (B. Robinson) R. King \& H. Robinson, Phytologia 53: 392. 1983.

Mrikania virgata B. Robinson, Contr. Gray Herb. 68: 41. 1923.

Mikania viscosa Sprengel, Neue Entd. 1: 277. 1820. = Bahianthus viscosus (Sprengel) R. King \& H. Robinson.

Mikania vismiaefolia DC. Prodr. 5: 189. 1836.

Mikania vitifolia DC.. Prodr. 5: 202. 1836.

Mikamia vitrea B. Robinson. Contr. Gray Herb. 61: 22. 1920. = Mikania hookeriana DC.

Mikania volubilis (Vahl) Willd., Sp. PI. 3: 1743. 1803. = Mikania cordata (Burm. f.) B. Robinson.

Mikania warmingii Schultz-Bip. ex Baker, Fl. Bras. 6(2): 242. 1876.

Mikania weberbaueri Hieron. in Urban, Bot. Jahrb. Syst. 40: 389. 1908.

Mikania wedelii Holmes \& McDaniel, Phytologia 33: 1(-2). 1976. = Mikania tysonii R. King \& H. Robinson.

Mikania werdermannii B. Robinson, Contr. Gray Herb. 104: 47. 1934.

Mikania widgrenii B. Robinson, Contr. Gray Herb. 96: 27. 1931. = Mikania campanulata Gardner.

Mikania williamsii B. Robinson, Contr. Gray Herb. 64: 19. 1922.

Mikania woytkowskii Holmes \& McDanicl, Phytologia 37: 475. 1977.

Mikania yapasensis B. Robinson, Contr. Gray Herb. 104: 48. 1934. = Mikania cordifolia (L. f.) Willd.

Mikania ypacarayensis Holmes \& McDaniel, Phytologia 31: 277. 1975, nom. nov. = Mikania trachypleura B. Robinson.

Mikania zonensis R. King \& H. Robinson, Phytologia 28: 275 $(-276) .1974$.

Miradoria sartorii Schultz-Bip. ex Benth.. Gen. PI. 2: 407. 1873 , nom. nud. in syn. = Microspermum debile Benth.

Monogereion carajensis G. Barroso \& R. King, Brittonia 23: 118. 1971.

Morithamnus crassus R. King, H. Robinson \& G. Barroso, Phytologia 44: 452. 1979.

Morithaminus ganophyllus (Mattf.) R. King \& H. Robinson, Phytologia 46: 300. 1980.

Morrenia odorata Hort. ex Kunze, Linnaea 20: 19. 1847. = Mi kania glomerata Sprengel.

Mustelia eupatoria Sprengel, Bot. Gart. Halle 1: 28. 1801. = Stevia cupatoria (Sprengel) Willd.

Myriactis candelabrum (Leveille) Leveille, Feddes Repert. 11: 303. 1912. = Adenostemma tinctorium (Lour.) Cass.

Neobartlettia bresipetiolata (Schultz-Bip. ex Klatt) R. King \& H. Robinson, Phytologia 21: 295. 1971. = Barlettina brevipe tiolata (Schultz-Bip. ex Klatt) R. King \& H. Robinson.

Ncohartletia constipatiflora (Klatt) R. King \& H. Robinson, Phytologia 21: 295. 1971. = Barlettina constipatifora (Klatt) R. King \& H. Robinson.

Neohartlettia eltrenbergii (Hemsley) R. King \& H. Robinson, 
Phytologia 21: 295. 1971. = Bartletina macrocephala (Benth.) R. King \& H. Robinson.

Neobartletlia hastifera (Standley \& Steyerm.) R. King \& H. Robinson, Phytologia 21: 295. 1971. = Bartlettina hastifera (Standley \& Steyerm.) R. King \& H. Robinson.

Neobartlettia hylobia (B. Robinson) R. King \& H. Robinson, Phytologia 21: 295. 1971. = Bartlettina hylobia (B. Robinson) R. King \& H. Robinson.

Neobartlettia karvinskiana (DC.) R. King \& H. Robinson, Phytologia 21:296. 1971. = Bartlettina karvinskiana (DC.) R. King \& H. Robinson.

Neobartletia luxii (B. Robinson) R. King \& H. Robinson, Phytologia 21: 296. 1971. = Bartlettina luxii (B. Robinson) R. King \& H. Robinson.

Neobartlettia maxonii (B. Robinson) R. King \& H. Robinson, Phytologia 21:296. 1971. = Bartlettina maxonii (B. Robinson) R. King \& H. Robinson.

Neobartlettia mexiae (B. Robinson) R. King \& H. Robinson, Phytologia 21: 296. 1971. = Bartlettina hemisphaerica (DC.) R. King \& H. Robinson.

Neobartlettia oresbia (B. Robinson) R. King \& H. Robinson, Phytologia 21: 296. 1971. = Bartlettina oresbia (B. Robinson) R. King \& H. Robinson.

Neobartletia oresbioides (B. Robinson) R. King \& H. Robinson, Phytologia 21: 296. 1971. = Bartlettina oresbioides (B. Robinson) R. King \& H. Robinson.

Neobartlettia paezerse (Hieron.) R. King \& H. Robinson, Phytologia 21:296. 1971. = Bartlettina paezensis(Hieron.) R. King \& H. Robinson.

Neobartlettia pansamalensis (B. Robinson) R. King \& H. Robinson, Phytologia 21: 296. 1971. = Bartlettina pansamalensis (B. Robinson) R. King \& H. Robinson.

Neobarllettia pinabetensis (B. Robinson) R. King \& H. Robinson, Phytologia 21: 296. 1971. = Barlettina pinabetensis (B. Robinson) R. King \& H. Robinson.

Neobarlettia platyphylla (B. Robinson) R. King \& H. Robinson, Phytologia 21: 296. 1971. = Barlettina platyphylla (B. Robinson) R. King \& H. Robinson.

Neobartlettia prionophylla (B. Robinson) R. King \& H. Robinson, Phytologia 21: 296. 1971. = Bartlettina prionophylla (B. Robinson) R. King \& H. Robinson.

Neobartlettia rnae (Standley) R. King \& H. Robinson, Phytologia 21: 296. 1971. = Barlentina pansamalensis (B. Robinson) R. King \& H. Robinson.

Neobartlettia sordida (Less.) R. King \& H. Robinson, Phytologia 21: 296. 1971. = Bartlettina sordida (Less.) R. King \& H. Robinson.

Neobartlettia tuerckheimii (Klatt) R. King \& H. Robinson, Phytologia 21: 297. 1971. = Barlettina tuerckheimii (Klatt) R. King \& $\mathrm{H}$. Robinson.

Neocabreria catharinensis (Cabrera) R. King \& H. Robinson, Phytologia 38: 425. 1978.

Neocabreria concinna R. King \& H. Robinson, Phytologia 23: 152. 1972. nom. nov.

Neocabreria malachophylla (Klatt) R. King \& H. Robinson, Phytologia 23: 152. 1972.

Neocabreria mexiae R. King \& H. Robinson, Phytologia 38: 425. 1978. = Neocabreria pennivenia (B. Robinson) R. King \& H. Robinson, ?

Neocabreria pennivenia (B. Robinson) R. King \& H. Robinson, Phytologia 49: 5. 1981.

Neocabreria serrulata (DC.) R. King \& H. Robinson, Phytologia 23: 152. 1972.

Neocuatrecasia cuzcoensis R. King \& H. Robinson, Phytologia 60: 83. 1986.

Neocuatrecasia dispar (B. Robinson) R. King \& H. Robinson, Phytologia 20: 332. 1970.
Neocuatrecasia hirtella R. King \& H. Robinson, Phytologia 27: 397. 1974.

Neocuatrecasia lobata (B. Robinson) R. King \& H. Robinson, Phytologia 20: 332. 1970.

Neocuatrecasia mancoana (B. Robinson) R. King \& H. Robinson, Phytologia 20: 333. 1970.

Neocuatrecasia sessilifolia R. King \& H. Robinson, Phytologia 24: 106. 1972.

Neocuatrecasia thymifolia (Britton) R. King \& H. Robinson, Phytologia 20: 333. 1970.

Neocuatrecasia weddellii (B. Robinson) R. King \& H. Robinson, Phytologia 24: 107. 1972.

Neohintonia monantha (Schultz-Bip.) R. King \& H. Robinson, Phytologia 22: 144. 1971.

Neomirandea allerii R. King \& H. Robinson, Rhodora 74: 273. 1972.

Neomirandea angularis (B. Robinson) R. King \& H. Robinson, Phytologia 19: 307. 1970.

Neomirandea araliaefolia (Less.) R. King \& H. Robinson, Phytologia 19: 307. 1970.

Neomirandea arthodes (B. Robinson) R. King \& H. Robinson, Phytologia 19: 308. 1970.

Neomirandea biflora R. King \& H. Robinson, Phytologia 29: 351. 1975.

Neomirandea burgeri R. King \& H. Robinson, Phytologia 24: 282. 1972.

Neomirandea carnosa (Kuntze) R. King \& H. Robinson, Phytologia 19: 308. 1970.

Neomirandea chiriquensis R. King \& H. Robinson, Phytologia 27: 245.1973.

Neomirandea costaricensis R. King \& H. Robinson, Phytologia 19: 308. 1970.

Neomirandea croatii R. King \& H. Robinson, Phytologia 29: 352 1975.

Neomirandea eximia (B. Robinson) R. King \& H. Robinson, Phytologia 19: 309. 1970.

Neomirandea folsomiana Dillon \& D'Arcy, Ann. Missouri Bot Gard. 65(2): 766(-768). 1978.

Neomirandea gracilis R. King \& H. Robinson, Phytologia 29: 353. 1975.

Neomirandea grosvenorii R. King \& H. Robinson, Phytologia 29: 354. 1975.

Neomirandea guevarii R. King \& H. Robinson, Phytologia 24: 283. 1972.

Neomirandea hitchcockii (B. Robinson) R. King \& H. Robinson, Phytologia 19: 308. 1970. = Neomirandea homogama $(\mathrm{Hi}-$ eron.) H. Robinson \& Brettell.

Neomirandea homogama (Hieron.) H. Robinson \& Brettell, Phytologia 28: 62. 1974.

Neomirandea ovandensis R. King \& H. Robinson, Phytologia 19: 309. 1970.

Neomirandea panamensis R. King \& H. Robinson, Phytologia 27: 246. 1973.

Neomirandea parasitica (Klatt) R. King \& H. Robinson, Phytologia 19: 309. 1970.

Neomirandea pithecobia (B. Robinson) R. King \& H. Robinson, Phytologia 19: 309. 1970.

Neomirandea pseudopsoralea R. King \& H. Robinson, Phytologia 30: 9. 1975.

Neomirandea psoralea (B. Robinson) R. King \& H. Robinson, Phytologia 19: 308. 1970.

Neomirandea sciaphila (B. Robinson) R. King \& H. Robinson, Phytologia 19: 310. 1970.

Neomirandea standleyi (B. Robinson) R. King \& H. Robinson, Phytologia 19: 308. 1970.

Neomirandea tenuipes R. King \& H. Robinson, Phytologia 58: 264. 1985. 
Neomirandea ternata R. King \& H. Robinson, Phytologia 58: 265. 1985.

Neomirandea turrialbae R. King \& H. Robinson, Phytologia 30: 10. 1975.

Neurolaena tenuifolia Schultz-Bip. ex Klatt, Leopoldina 23: 146. 1887 , nom. nud. = Bartlettina karvinskiana (DC.) R. King \& H. Robinson.

Nothites angustifolia Cass., Dict. Sci. Nat. 35: 164. 1825. = Stevia satureifolia Lam.

Nothites baccharidea DC., Prodr. 5: 187. 1836. = Ophryosporus paradoxus (Hook. \& Arn.) Benth. \& Hook. ex Hook. f. \& Jackson.

Nothites breviflora Cass., Dict. Sci. Nat. 35: 165. 1825. = Stevia breviflora (Cass.) Klotzsch.

Nothites latifolia Cass., Dict. Sci. Nat. 35: 163. 1825. = Stevia melissacfolia (Lam.) Schultz-Bip.

Nothites melissaefolia DC., Prodr. 5: 186. 1836. = Stevia melissaefolia (Lam.) Schultz-Bip.

Nothites ovatifolia DC., Prodr. 5: 187. 1836. = Decachaeta ovatifolia (DC.) R. King \& H. Robinson.

Nothites petiolata Cass., Dict. Sci. Nat. 35: 166. 1825. = Steria petiolata (Cass.) Schultz-Bip.

Nothites satureiaefolia (Lam.) DC., Prodr. 5: 186. 1836. = Stevia satureifolia Lam.

Nothobaccharis candolleana (Steudel) R. King \& H. Robinson, Phytologia 41: 397. 1979.

Oaxacania malvaefolia B. Robinson \& Greenman, Amer. J. Sci. Arts Ser. 3. 50: 151. 1895.

Ooclinium capillare DC., Prodr. 5: 134. 1836. = Praxelis capillaris (DC.) Schultz-Bip.

Ooclinium clavatum Benth., Ann. Nat. Hist. 1(2): 108. 1839. = Chromolaena ivaefolia (L.) R. King \& H. Robinson.

Ooclinium depressum Gardner, London J. Bot. 6: 437. 1847. = Praxelis pauciflora (H. B. K.) R. King \& H. Robinson.

Ooclinium grandiflorum DC.. Prodr. 5: 134. 1836. = Praxelis grandiflora (DC.) Schultz-Bip.

Ooclinium paucidentatum DC., Prodr. 5: 134. 1836. = Praxelis kleinioides (H. B. K.) Schultz-Bip.

Ooclinium pedunculare DC., Prodr. 5: 134. 1836. = Praxelis kleinioides (H. B. K.) Schultz-Bip.

Ooclinium quinqueparitum Gardner ex Baker, Fl. Bras. 6(2): 341. 1876 , nom. nud. in syn. = Praxelis capillaris (DC.) SchultzBip.

Ooclinium rigidum (Sw.) DC., Prodr. 5: 134. 1836. = Chromolaena rigida $(\mathrm{Sw},) \mathrm{R}$. King \& $\mathrm{H}$. Robinson.

Ooclinium rupestre Gardner ex Baker, F1. Bras. 6(2): 343. 1876, nom. nud. in syn. = Praxelis kleinioides (H. B. K.) SchultzBip.

Ooclinium sideritis DC., Prodr. 5: 134. 1836. = Praxelis kleinioides (H. B. K.) Schultz-Bip.

Ooclinium villosum (Cass.) DC., Prodr. 5: 134. 1836. = Praxelis pauciflora (H. B. K.) R. King \& H. Robinson.

Ophrosporus angustifolius B. Robinson, Contr. Gray Herb. 90: 3. 1930.

Ophryosporus anomalus R. King \& H. Robinson. Phytologia 25: 66. 1972, nom. nov.

Ophryosporus apricus B. Robinson, Contr. Gray Herb. 73: 3. 1924.

Ophryosporus axilliflorus (Griseb.) Hieron., Bot. Jahrb. Syst. 22:
(1924. 706. 1897.

Ophryosporus bipinnatifidus B, Robinson, Proc. Amer. Acad. Arts 55: 5. 1919.

Ophryosporus burchellii Baker, F. Bras. 6(2): 187. 1876. = Stomatainthes dentatus (Gardner) H. Robinson.

Ophryosporus burkartii Cabrera, Bol. Soc. Argent. Bot. 15: 114. 1973.

Ophryosporus charua (Griseb.) Hieron., Bot. Jahrb. Syst. 22: 705. 1897.
Ophryosporus chilca (H. B. K.) Hieron., Bot. Jahrb. Syst. 22: 706. 1897.

Ophryosporus clavulatus Griseb., Goett. Abh. 24: 173. 1879. = Ophryosporus piquerioides (DC.) Benth. ex Baker.

Ophryosporus cumingii Benth. ex Baker, F. Bras. 6(2): 188. 1876.

Ophryosporis densiflorus (Benth.) R. King \& H. Robinson, Phytologia 25: 66, 1972.

Ophryosporus eleutherantherus (Rusby) B. Robinson, Contr. Gray Herb. 61: 27. 1920.

Ophryosporus floribundus (DC.) R. King \& H. Robinson, Phytologia 25: 66. 1972.

Ophrvosporus foliolosus (DC.) Reiche, Anales Univ. Chile USE \#1415 109: 9. 1901. = Ophryosporus triangularis Meyen.

Ophryosporus freyreysii (Thunb. \& Dallm.) Baker, F. Bras. 6(2): 188. 1876.

Ophryosporus galioides (DC.) R. King \& H. Robinson, Phytologia 25: 66.1972

Ophryosporus hartwegii (B. Robinson) R. King \& H. Robinson, Phytologia 25: 66. 1972.

Ophryosporus heptanthus (Schultz-Bip.) R. King \& H. Robinson, Phytologia 58: 258. 1985.

Ophryosporus hoppii (B. Robinson) R. King \& H. Robinson, Phytologia 23: 399. 1972.

Ophryosporus johnstonii B. Robinson, Contr. Gray Herb. 77: 4. 1926.

Ophryosponus kuntzei Hieron., Bot. Jahrb. Syst. 22: 707. 1897.

Ophryosporus laxiflorus Baker, F. Bras. 6(2): 189. 1876.

Ophryosporus lorentzii Hieron., Bot. Jahrb. Syst. 22: 706. 1897.

Ophryosponis macbridei B. Robinson, Contr. Gray Herb. 73: 4. 1924.

Ophryosporus macrodon Griseb., Goett. Abh. 24: 173. 1879.

Ophryosponus mandonii (Schultz-Bip.) Benth. \& Hook. f. ex Hook. f. \& Jackson. Index Kew. 2: 354. 1895. = Ophryosporus piquerioides (DC.) Benth. ex Baker.

Ophryosporus mathewsii (B. Robinson) R. King \& H. Robinson, Phytologia 25: 66. 1972.

Ophryosponusorganensis Cabrera, Arch. Jard. Bot. Rio de Janeiro 15: 74. 1957.

Ophryosporus origanoides [Meyen \& Walp.] Hieron., Bot. Jahrb. Syst, 22: 707. 1897. = Ophryosporus heptanthus (Schultz-Bip. ex Wedd.) R. King \& H. Robinson.

Ophryosporus ovatifolius (DC.) Benth. \& Hook. f. ex Hemsley, Biol. Cent.-Amer., Bot. 2: 79. 1881. = Decachaeta ovatifolia (DC.) R. King \& H. Robinson.

Ophryosporus ovatus B. Robinson, Proc. Amer. Acad. Arts 55: 5. 1919.

Ophryosporus pachychaeta Baker, Fl. Bras. 6(2): 187. 1876. = Mikania pachychaeta (Baker) G. Barroso.

Ophryosporus paradoxus (Hook. \& Arn.) Benth. \& Hook. ex Hook. f. \& Jackson. Index Kew. 2: 354. 1895.

Ophryosporus penuvianus (Gmelin) R. King \& H. Robinson, Phytologia 25: 66. 1972.

Ophryosporus petraeus (B. Robinson) B. Robinson, Contr. Gray Herb. 75: 4. 1925. = Decachaeta ovatifolia (DC.) R. King \& H. Robinson.

Ophryosporus pinifolius (Philippi) R. King \& H. Robinson, Phytologia 25: 66. 1972.

Ophryosponus piquerioides (DC.) Benth. ex Baker, Fl. Bras. 6(2): 188.1876.

Ophryosporus pubescens (Smith) R. King \& H. Robinson, Phytologia 25: 66. 1972.

Ophryosporus regnellii Baker, F. Bras. 6(2): 188. 1876.

Ophryosporus saltensis Hieron., Bot. Jahrb. Syst. 22: 705. 1897. = Ophryosporus piquerioides (DC.) Benth. ex Baker.

Ophryosporus scabrellus (B. Robinson) B. Robinson, Contr. Gray Herb. 75: 4. 1925. = Decachaeta scabrella (B. Robinson) R. King \& H. Robinson. 
Ophryosporus serratifolius (H. B. K.) B. Robinson, Contr. Gray Herb. 90: 3. 1930.

Ophryosporus sodiroi Hieron. in Sodiro, Bot. Jahrb. Syst. 29: 3. 1900.

Ophryosporus solidaginoides (H. B. K.) Hieron. in Sodiro, Bot. Jahrb. Syst. 29: 4. 1900. = Koanophyllon solidaginoides $($ H. B. K.) R. King \& H. Robinson.

Ophryosporus steinbachii B. Robinson, Contr. Gray Herb. 77: 5. 1926.

Ophryosporus triangularis Meyen, Reise Erde 1: 402.1834.

Ophryosporus venosissimus (Rusby) B. Robinson, Proc. Amer. Acad. Arts 41: 271. 1905.

Orsinia eupatoria DC., Prodr. 5: 104. 1836. = Clibadium armanii (Balbis) Baker. HeliantheaE.

Osmia alternans (DC.) Schultz-Bip.. Jahresber. Pollichia 22-24: 252. 1866. = Chromolaena laevigata (Lam.) R. King \& $\mathbf{H}$. Robinson.

Osmia arrayana (Gardner) Schultz-Bip., Jahresber. Pollichia 2224: 253. 1866. = Chromolaena arrayana (Gardner) R. King \& H. Robinson.

Osmia ascendens Schultz-Bip. ex Baker, Fl. Bras. 6(2): 296. 1876, nom. nud. in syn, = Chromolaena ascendens (Schultz-Bip. ex Baker) R. King \& H. Robinson.

Osmia asclepiadea (DC.) Schultz-Bip., Jahresber. Pollichia $22-$ 24: 253. 1866. = Campovassouria cruciata (Vell. Conc.) R. King \& $\mathrm{H}$. Robinson.

Osmia asperrima Schultz-Bip. ex Baker, Fl. Bras. 6(2): 293. 1876, nom. nud. il syn. = Chromolaena asperrima (Schultz-Bip. ex Baker) R. King \& $\mathrm{H}$. Robinson.

Osmia atriplicifolia (Vahl) Schultz-Bip., Jahresber. Pollichia 2224: 252. 1866. = Chromolaena odorata (L.) R. King \& H. Robinson.

Osmia bartsiaefolia (DC.) Schultz-Bip., Jahresber. Pollichia 2224: 253. 1866. = Chromolaena hirsuta (Hook. \& Arn.) R. King \& H. Robinson.

Osmia bertholdii (Schultz-Bip.) Schultz-Bip., Jahresber. Pollichia 22-24: 253. 1866. = Chromolaena bertholdii (Schultz-Bip.) R. King \& H. Robinson.

Osmia borinquensis Britton in Britton \& P. Wilson, Sci. Surv. Porto Rico \& Virgin Isl. 6: 288. 1925. = Chromolaena borinquensis (Britton) R. King \& H. Robinson.

Osmia caleoides Schultz-Bip. ex Baker, Fl. Bras. 6(2): 282. 1876, nom. nud. in syn. = Chrornolaena squalida (DC.) R. King \& H. Robinson.

Osmia cinereo-Viridis Schultz-Bip. ex Baker, Fl. Bras. 6(2): 294. 1876 , nom. nud. in syn. = Chromolaena cinereoviridis (SchultzBip. ex Baker) R. King \& H. Robinson.

Osmia clematitis (DC.) Schultz-Bip., Jahresber. Pollichia 22-24: 252. 1866 . = Chromolaena odorata (L.) R. King \& H. Robinson.

Osmia conyzoides (Miller) Schultz-Bip., Jahresber. Pollichia 2224: 252. 1866. = Vernonia arborescens (L.) Sw. VERNONIEAE.

Osmia conyzoides (Vahl) Small, Fl. S. E. U. S. 1164, 1338. 1903. = Chromolaena odorata (L.) R. King \& H. Robinson.

Osmia corymbosa (Aublet) Britton \& P. Wilson, Sci. Surv. Porto Rico \& Virgin Isl. 6: 288. 1925. = Chromolaena corymbosa (Aublet) R. King \& H. Robinson.

Osmia crenata [Gardner] Schultz-Bip., Jahresber. Pollichia 22 24: 253. 1866. = Chromolaena squalida (DC.) R. King \& H. Robinson.

Osmia divergens (Less.) Schultz-Bip., Jahresber. Pollichia 22-24: 252. 1866 . = Chromolaena odorata (L.) R. King \& H. Robinson.

Osmia extensa (Gardner) Schultz-Bip., Jahresber. Pollichia 22 24: 253. 1866. = Chromolaena extensa (Gardner) R. King \& H. Robinson.

Osmia ferruginea Schultz-Bip., Jahresber. Pollichia 22-24: 253.
1866. = Chromolaena ferruginea (Gardner) R. King \& H. Robinson.

Osmia floribunda (H. B. K.) Schultz-Bip., Jahresber. Pollichia 22-24: 252. 1866. = Chromolaena odorata $($ H. B. K.) R. King \& H. Robinson.

Osmia foliata Schultz-Bip. ex Baker, Fl. Bras. 6(2): 278. 1876, nom. nud. in syn. = Chromolaena pedunculosa (Hook. \& Arn.) R. King \& H. Robinson.

Osinia frustrata (B. Robinson) Small, Fl. Florida Keys 147. 1913. = Chromolaena frustrata (B. Robinson) R. King \& H. Robinson.

Osmia furcata (Lanı.) Schultz-Bip., Jahresber. Pollichia 22-24: 252. 1866. = Chromolaena furcata (Lam.) R. King \& H. Robinson.

Osmia geranifolia (Urban) Britton \& P. Wilson, Sci. Surv. Porto Rico \& Virgin Isl. 6: 288. 1925. = Chromolaena geranifolia (Urban) R. King \& H. Robinson.

Osinia glaberrima (DC.) Schultz-Bip., Jahresber. Pollichia 2224: 252. 1866. = Chromolaena glaberrima (DC.) R. King \& H. Robinson.

Osmia graciliflora (DC.) Schultz-Bip., Jahresber. Pollichia 2224: 252 . 1866 . = Chromolaena odorata (L.) R. King \& H. Robinson.

Osmia gracillima Schultz-Bip. ex Baker, Fl. Bras. 6(2): 290. 1876, nom. nud. in syn. = Chromolaena ivaefolia (L.) R. King \& H. Robinson.

Osinia gracillima Schultz-Bip. ex Malme, Ark. Bot. 24a(8): 23. 1932 , nom. nud. in syn. = Chromolaena ivaefolia (L.) R. King \& H. Robinson.

Osmia heteroclina (Griseb.) Small, Fl. S. E. U. S. 1164, 1338. 1903. = Chromolaena heteroclinia (Griseb.) R. King \& H. Robinson.

Osmia hexantha (DC.) Schultz-Bip., Jahresber. Pollichia 22-24: 253. 1866. = Chromolaena hirsuta (Hook. \& Arn.) R. King \& H. Robinson.

Osmia hypericifolia (H. B. K.) Schultz-Bip., Jahresber. Pollichia 22-24: 252. 1866. = Chromolaena hypericifolia (H. B. K.) R. King \& H. Robinson.

Osmia integrifolia (Bertero ex Sprengel) Schultz-Bip., Jahresber. Pollichia 22-24: 252. 1866. = Chromolaena integrifolia (Bertero ex Sprengel) R. King \& H. Robinson.

Osmia ivaefolia (L.) Schultz-Bip., Jahresber. Pollichia 22-24: 250 , 252. 1866. = Chrornolaena ivaefolia (L.) R. King \& H. Robinson.

Osmia laevigata (Lam.) Schultz-Bip., Jahresber. Pollichia 22-24: 252. 1866. = Chromolaena laevigata (Lam.) R. King \& H. Robinson.

Osmia leptocephala (DC.) Schultz-Bip., Jahresber. Pollichia 2224: 253. 1866. = Chromolaena leptocephala (DC.) R. King \& H. Robinson

Osmia liatridea (DC.) Schultz-Bip., Jahresber. Pollichia 22-24: 252. 1866. = Chromolaena squarrulosa (Hook. \& Arn.) R. King \& H. Robinson.

Osmia macrantha (Sw.) Schultz-Bip., Jahresber. Pollichia 22-24: 252. 1866. = Chromolaena macrantha (Sw.) R. King \& H. Robinson.

Osmia macrodon (DC.) Schultz-Bip., Jahresber. Pollichia 22-24: 252. $1866 .=$ Chromolaena macrodon (DC.) Nicolson.

Osmia martiusii (DC.) Schultz-Bip., Jahresber. Pollichia 22-24: 252. 1866. = Chromolaena squalida (DC.) R. King \& H. Robinson.

Osmia maximiliani (Schrader ex DC.) Schultz-Bip., Jahresber. Pollichia 22-24: 252. 1866. = Chromolaena maximilianii (Schrader ex DC.) R. King \& H. Robinson.

Osmia mucronata (Gardner) Schultz-Bip., Jahresber. Pollichia 22-24: 253. 1866. = Chromolaena mucronata (Gardner) $R$ King \& $\mathrm{H}$. Robinson.

Osmia multiflosculosa (DC.) Schultz-Bip., Jahresber. Pollichia 
22-24: 252. 1866. = Chromolaena multiflosculosa (DC.) R. King \& H. Robinson.

Osmia myriocephala (Gardner) Schultz-Bip., Jahresber. Pollichia 22-24: 253. 1866. = Chromolaena myriocephala (Gardner) R. King \& H. Robinson.

Osmia obscura (DC.) Schultz-Bip., Jahresber. Pollichia 22-24: 252. 1866 . = Chromolaena ivaefolia (L.) R. King \& H. Robinson.

Osmia odorata (L.) Schultz-Bip., Jahresber. Pollichia 22-24: 250 , 252. 1866. = Chromolaena odorata (L.) R. King \& H. Robinson.

Osmia osseana (DC.) Schultz-Bip., Jahresber. Pollichia 22-24: 252. 1866. = Chromolaena ossaeana (DC.) R. King \& H. Robinson.

Osmia oxylepis (DC.) Schultz-Bip., Jahresber. Pollichia 22-24: 252. 1866. = Chromolaena oxylepis (DC.) R. King \& H. Robinson.

Osmia palmaris Schultz-Bip. ex Baker, Fl. Bras. 6(2): 294. 1876 , nom. nud. in syn. = Chromolaena palmaris (Schultz-Bip. ex Baker) R. King \& H. Robinson.

Osmia pedalis Schultz-Bip. ex Baker, Fl. Bras. 6(2): 295. 1876 , nom. nud. in syn. = Chromolaena pedalis (Schultz-Bip. ex Baker) R. King \& H. Robinson.

Osmia perforata Schultz-Bip. ex Baker, Fl. Bras. 6(2): 289. 1876 , nom. nud. in syn. = Chromolaena perforata (Schultz-Bip. ex Baker) R. King \& H. Robinson.

Osmia phlogifolia (DC.) Schultz-Bip., Jahresber. Pollichia 22-24: 253. 1866. = Campovassouria cruciata (Vell. Conc.) R. King \& H. Robinson.

Osmia picta (Gardner) Schultz-Bip., Jahresber. Pollichia 22-24: 253. 1866. = Chromolaena picta (Gardner) R. King \& H. Robinson.

Osmia polyantha Schultz-Bip. ex Baker, Fl. Bras. 6(2): 285. 1876 , nom. nud. in syn. = Chromolaena ivaefolia (L.) R. King \& H. Robinson.

Osmia propinqua (DC.) Schultz-Bip., Jahresber. Pollichia 22-24: 252. 1866. = Chromolaena laevigata (Lam.) R. King \& H. Robinson.

Osmia pulchella (H. B. K.) Schultz-Bip., Jahresber. Pollichia 2224: 253. 1866. = Chromolaena pulchella $($ H. B. K.) R. King \& H. Robinson.

Osmia punctata (Lam.) Schultz-Bip., Jahresber. Pollichia 22-24: 252. 1866. = Chromolaena mononeura (Urban) R. King \& H. Robinson.

Osmia punctulata (DC.) Schultz-Bip., Jahresber. Pollichia 22-24: 253. 1866. = Chroinolaena punctulata (DC.) R. King \& H. Robinson.

Osmia ramosissima (Gardner) Schultz-Bip., Jahresber. Pollichia 22-24: 253. 1866. = Chromolaena squalida (DC.) R. King \& H. Robinson.

Osmia repanda (Willd.) Schultz-Bip,, Jahresber. Pollichia 22-24: 252. 1866. = Chromolaena corymbosa (Aublet) R. King \& H. Robinson.

Osmia rhinanthacea (DC.) Schultz-Bip., Jahresber. Pollichia 2224: 253. 1866. = Chromolaena rhinanthacea (DC.) R. King \& H. Robinson.

Osmia scabra (L. f.) Schultz-Bip., Jahresber. Pollichia 22-24: 253. 1866. = Chromolaena scabra (L. f.) R. King \& H. Robinson.

Osmia sericea (H. B. K.) Schultz-Bip., Jahresber. Pollichia 2224: 252. 1866. = Hebeclinium sericeum (H. B. K.) R. King \& H. Robinson.

Osmia serratuloides (H. B. K.) Schult7-Bip., Jahresber. Pollichia 22-24: 252. 1866. = Chromolaena serratuloides $(\mathrm{H}$. B. K.) R. King \& H. Robinson.

Osmia serrulata (DC.) Schultz-Bip., Jahresber. Pollichia 22-24: 253. 1866 . $=$ Neocabreria sernulata (DC.) R. King \& H. Robinson.

Osmia sinuata (Lam.) Britton \& P. Wilson, Sci. Surv. Porto Rico
\& Virgin Isl. 6: 288. 1925. = Chromolaena simuata (Lam.) R. King \& H. Robinson.

Osmia smilacina (H. B. K.) Schultz-Bip., Jahresber. Pollichia $22-$ 24: 252. 1866. = Asplundianthus smilacinus (H. B. K.) R. King \& H. Robinson.

Osmia squalida (DC.) Schultz-Bip., Jahresber. Pollichia 22-24: 252. 1866. = Chromolaena squalida (DC.) R. King \& H. Robinson.

Osmia stenocephala Schultz-Bip. ex Baker, F. Bras. 6(2): 299. 1876 , nom. nud. in syn. = Chromolaena punctulata (DC.) R. King \& H. Robinson.

Osmia stenophylla Schultz-Bip. ex Baker, Fl. Bras. 6(2): 290. 1876, nom. nud. in syn. = Chromolaena ivaefolia (L.) R. King \& H. Robinson.

Osmia subserrata (Gardner) Schultz-Bip., Jahresber. Pollichia 22-24: 253. 1866. = Chromolaena imucronata (Gardner) R. King \& H. Robinson.

Osmia subtruncata (Gardner) Schultz-Bip., Jahresber. Pollichia 22-24: 253. 1866. = Chromolaena

Osmia subvelutina (DC.) Schultz-Bip.. Jahresber. Pollichia 2224: 252. 1866. = Chromolaena squalida (DC.) R. King \& H. Robinson.

Osmia tecta (Gardner) Schultz-Bip., Jahresber. Pollichia 22-24: 253. 1866. = Chromolaena tecta (Gardner) R. King \& H. Robinson.

Osmia tomentosa Schultz-Bip. ex Baker, Fl. Bras. 6(2): 282. 1876, nom. nud. in syn. = Chromolaena squalida (DC.) R. King \& H. Robinson.

Osmia tozziaefolia (DC.) Schultz-Bip., Jahresber. Pollichia 2224: 253. 1866. = Chromolaena congesta (Hook. \& Arn.) R. King \& H. Robinson.

Osmia trichophora (DC.) Schultz-Bip., Jahresber. Pollichia $22-$ 24: 253. 1866. = Chromolaena hirsuta (Hook. \& Arn.) R. King \& H. Robinson.

Osmia trifoliata Schultz-Bip. ex Baker, Fl. Bras. 6(2): 282. 1876. nom. nud. in syn. = Chromolaena squalida (DC.) R. King \& H. Robinson.

Osmia verbenacea (DC.) Schultz-Bip., Jahresber. Pollichia 2224: 253. 1866 . = Chromolaena verbenacea (DC.) R. King \& H. Robinson.

Osmiopsis plumeri (Urban \& Ekman) R. King \& H. Robinson. Phytologia 32: 251. 1975.

Oxylobus adscendens (Schultz-Bip.) B. Robinson \& Greenman in B. Robinson, Proc. Amer. Acad. Arts 41: 272. 1905.

Oxylobus arbutifolius (H. B. K.) A. Gray, Proc. Amer. Acad. Arts 15:26. 1880.

Oxylobus glanduliferus (Schultz-Bip. ex Benth. \& Hook.) A. Gray, Proc. Amer. Acad. Arts 15: 26. 1880.

Oxylobus macrocephalus Paray, Bol. Soc. Bot. Mexico 22: 1. 1958. = Revealia macrocephala (Paray) R. King \& H. Robinson.

Oxylobus oaxacamus Blake, Proc. Biol. Soc. Wash. 55: 113.1942.

Oxylobus subglabrus R. King \& H. Robinson, Phytologia 27: 385. 1974.

Oxylobus trinervius Mocino ex DC., Prodr. 5: 115. 1836, nom. inval. = Phania trinervia DC

Pachychaeta eupatorioides Schultz-Bip. ex Baker, F. Bras. 6(2): 187. 1876, nom. nud. = Mikania pachychaeta $($ Baker) G. Barroso.

Pachythamnus crassirameus (B. Robinson) R. King \& H. Robinson, Phytologia 23: 154. 1972.

Parapiqueria cavalcantei R. King \& H. Robinson, Phytologia 47: 111. 1980.

Pectis violacea Griseb., Goett. Abh. 24: 200. 1879. = Stevia multiaristata Sprengel.

Peteravenia cyrili-nelsonii (A. Molina) R. King \& H. Robinson, Phytologia 44: 86. 1979. 
Peteravenia grisea (Coulter) R. King \& H. Robinson, Phytologia 21: 395. 1971.

Peteravenia malvaefolia (DC.) R. King \& H. Robinson, Phytologia 21: 395. 1971.

Peteravenia phoenicolepis (B. Robinson) R. King \& H. Robinson, Phytologia 21: 395. 1971.

Peteravenia rhodochlamydea (A. Gray) R. King \& H. Robinson, Phytologia 21: 395. 1971. = Peteravenia malvaefolia (DC.) R. King \& H. Robinson.

Peteravenia schultzii (Schnittsp.) R. King \& H. Robinson, Phytologia 21: 395. 1971.

Phalacraea callitricha (B. Robinson) R. King \& H. Robinson, Phytologia 29: 253. 1974.

Phalacraea coelestina Regel, Gartenflora 3: 388. T. 107. 1854. = Ageratum microcarpum (Benth. ex Oersted) Hemsley.

Phalacraea ecuadorensis R. King \& H. Robinson, Phytologia 29: 253. 1974.

Phalacraea latifolia DC., Prodr. 5: 106. 1836.

Phalacraea lindenii Schultz-Bip. ex Benth. \& Hook., Gen. PI. 2: 240. 1873, nom. nud. in syn. = Alomia ageratoides H. B. K.

Phalacraea longipetiolata (B. Robinson) R. King \& H. Robinson, Phytologia 49: 5. 1981.

Phalacraea pittieri (R. King) R. King \& H. Robinson, Phytologia 29: 254. 1974. = Phalacraea longipetiolata (B. Robinson) R. King \& H. Robinson.

Phalacraea wendlandii Schultz-Bip. ex Klatt, Leopoldina 20: 74. 1884, nom. nud. in syn. = Ageratum rugosum Coulter ex J. D. Smith.

Phanerostylis coahuilensis (A. Gray) R. King \& H. Robinson, Phytologia 24: 71. 1972.

Phanerostylis glutinosa (Brandegee) R. King \& H. Robinson, Phytologia 24: 71.1972.

Phanerostylis hintoniorum (B. Turner) R. King \& H. Robinson, Phytologia 60: 80. 1986.

Phanerostylis nesomii (B. Turner) R. King \& H. Robinson, Phytologia 48: 221. 1981.

Phanerostylis pedunculosa (DC.) R. King \& H. Robinson, Phytologia 24: 71. 1972.

Phania arbutifolia (H. B. K.) DC., Prodr. 5: 115. 1836. =Oxylobus arbutifolius (H. B. K.) A. Gray.

Phania cajalbanica Borh. \& Muniz, Acta Bot. Hung. 17: 35.1972.

Phania curtissii B. Robinson, Proc. Amer. Acad. Arts 44: 616. 1909.

Phania dissecta Hook. \& Am., Bot. Beechey Voy. 433. 1841. = Hofmeisteria dissecta (Hook. \& Arn.) R. King \& H. Robinson.

Phania domingensis (Sprengel) Griseb., Cat. Pl. Cub. 145. 1866.

Phania matricarioides (Sprengel) Griseb., Cat. Pl. Cub. 145. 1866.

Phania multicaulis DC., Prodr. 5: 114. 1836.

Phania trinervia DC., Prodr. 5: 115. 1836, ignota.

Phania urenifolia Hook. \& Am., Bot. Beechey Voy. 297. 1838. = Hofmeisteria urenifolia (Hook. \& Am.) Walp.

Piptocarpha sexangularis Klatt, Compos. Nov. Costaric. [Bot. Beibl. Leopoldina] 1. 1895. = Critonia sexangularis (Klatt) R. King \& H. Robinson.

Piptothrix aegiroides B. Robinson \& Greenman in B. Robinson, Proc. Amer. Acad. Arts 41: 273. 1905. = Jaliscoa goldmanii (B. Robinson) R. King \& H. Robinson.

Piptothrix areolaris (DC.) R. King \& H. Robinson, Phytologia 19: 426. 1970.

Piptothrix arizonica Nelson, Amer. J. Bot. 25: 117. 1938. = Ageratina paupercula (A. Gray) R. King \& H. Robinson.

Piptothrix goldmanii B. Robinson, Proc. Amer. Acad. Arts 35: 328. 1900. = Jaliscoa goldmanii (B. Robinson) R. King \& H. Robinson.

Piptothrix jaliscensis B. Robinson, Proc. Boston Soc. Nat. Hist. 31: 268. 1904.

Piptothrix paleacea Cronq., Mem. New York Bot. Gard. 12(3):
289. 1965. = Jaliscoa paleacea (Cronq.) R. King \& H. Robinson.

Piptothrix palmeri A. Gray, Proc. Amer. Acad. Arts 21: 383. 1886.

Piptothrix pubens A. Gray in S. Watson, Proc. Amer. Acad. Arts 22: 419.1887.

Piptothrix sinaloae S. F. Blake, Proc. Biol. Soc. Wash. 32: 190. 1919.

Piqueria ageratoides (H. B. K.) Gardner, London J. Bot. 6: 430. 1847. = Alomia ageratoides H. B. K.

Piqueria angustata Gardner, London J. Bot. 6: 432. 1847. = Gardnerina angustata (Gardner) R. King \& H. Robinson.

Piqueria artemisioides H. B. K., Nov. Gen. Sp. 4: 120. Ed. Folio. 1818. = Ophryosporus peruvianus (Gmelin) R. King \& H. Robinson.

Piqueria attenuata (DC.) Gardner, London J. Bot. 6: 430.1847. = Gymnocoronis spilanthoides DC.

Piqueria callitricha B. Robinson, Proc. Amer. Acad. Arts 42: 15. 1906. = Phalacraea callitricha (B. Robinson) R. King \& H. Robinson.

Piqueria cinerea Gardner, London J. Bot. 6: 432. 1847. = Trichogonia cinerea (Gardner) R. King \& H. Robinson.

Piqueria coelestina (Regel) Hieron., Bot. Jahrb. Syst. 29: 3. 1900, ex B. Robinson, Proc. Amer. Acad. Arts 42: 16. 1906. = Ageratum microcarpum (Benth. ex Oersted) Hemsley.

Piqueria cumingii B. Robinson, Proc. Amer. Acad. Arts 42: 11. 1906. = Ophryosporus anomalus R. King \& H. Robinson.

Piqueria densiflora Benth., Bot. Voy. Sulphur 110. 1845. = Ophryosporus densiflorus (Benth.) R. King \& H. Robinson.

Piqueria eupatorioides (Gardner) Gardner, London J. Bot. 6: 431. 1847. = Trichogonia menthaefolia Gardner.

Piqueria eupatorium (DC.) Gardner, London J. Bot. 6: 430. 1847. = Clibadium armanii (Balbis) Baker. HeliantheAE.

Piqueria fastigiata (Gardner) Gardner, London J. Bot. 6: 431. 1847. = Ageratum fastigiatum (Gardner) R. King \& H. Robinson.

Piqueria floribunda DC., Prodr. 5: 105. 1836. = Ophryosporus foribundus (DC.) R. King \& H. Robinson.

Piqueria foliosa (Gardner) Gardner, London J. Bot. 6: 432.1847. = Teixeiranthus foliosus (Gardner) R. King \& H. Robinson.

Piqueria galioides DC., Prodr. 5: 105. 1836. = Ophryosporus galioides (DC.) R. King \& H. Robinson.

Piqueria glutinosa Schultz-Bip. ex Kraschen., Bot. Mater. Gerb. Glavn. Bot. Sada RSFSR 3: 161. 1922, nom. nud. in syn. = Acritopappus longifolius (Gardner) R. King \& H. Robinson.

Piqueria hartwegi B. Robinson, Proc. Amer. Acad. Arts 42: 14. 1906. = Ophryosporus hartwegii (B. Robinson) R. King \& H. Robinson.

Piqueria hintonii R. King, Sida 3: 107. 1967.

Piqueria latifolia (DC.) Gardner, London J. Bot. 6: 430. 1847.= Phalacraea latifolia DC.

Piqueria laxiflora B. Robinson \& Seaton, Proc. Amer. Acad. Arts 28: 107.1893.

Piqueria longipetiolata Schultz-Bip. ex Baker, Fl. Bras. 6(2): 183. 1876, nom. nud. in syn. = Gymnocoronis spilanthoides DC.

Piqueria longipetiolata B. Robinson, Proc. Amer. Acad. Arts 43: 27. 1907. = Phalacraea longipetiolata (B. Robinson) R. King \& H. Robinson.

Piqueria loxensis Blake \& Steyerm., J. Wash. Acad. Sci. 40: 47. 1950. = Guevaria loxensis (Blake \& Steyerm.) R. King \& H. Robinson.

Piqueria luxurians B. Robinson ex Volkens, Verh. Bot. Vereins Prov. Brandenburg 65: 118. 1923. = Piqueria trinervia Cav.

Piqueria mathewsii B. Robinson, Proc. Amer. Acad. Arts 42: 12. 1906. = Ophryosporus mathewsii (B. Robinson) R. King \& H. Robinson.

Piqueria myriadenia Schultz-Bip. ex Baker, Fl. Bras. 6(2): 192. 
1876, nom. nud. in syn. = Ageratum myriadenium (SchultzBip. ex Baker) R. King \& H. Robinson.

Piqueria ovata G. Don ex Loudon, Hort. Brit. 337. 1830. = Piqueria trinervia Cav.

Piqueria peruviana (Gmelin) B. Robinson, Proc. Amer. Acad. Arts 42: 13. 1906. = Ophryosporus peruvianus (Gmelin) R. King \& $\mathrm{H}$. Robinson.

Piqueria pilosa H. B. K., Nov. Gen. Sp. 4: 120. Ed. Folio. 1818. Piqueria pinifolia (Philippi) Hieron. ex B. Robinson, Proc. Amer. Acad. Arts 42: 11. 1906. = Ophryosporus pinifolius (Philippi) R. King \& H. Robinson.

Piqueria pittieri R. King, Sida 3: 107. 1967, nom. nov. = Phalacraea longipetiolata (B. Robinson) R. King \& H. Robinson.

Piqueria polyphylla Schultz-Bip. ex Baker, Fl. Bras. 6(2): 191. 1876, nom. nud. in syn. = Ageratum fastigiatum (Gardner) R. King \& $\mathrm{H}$. Robinson.

Piqueria pringlei B. Robinson \& Seaton, Proc. Amer. Acad. Arts 28: 107. 1893.

Piqueria pubescens Small in Rees, Cycl. 27. Piqueria N. 2. 1814. = Ophryosporus pubescens (Smith) R. King \& H. Robinson.

Piqueria pyramidalis B. Robinson, Proc. Amer. Acad. Arts 36: 475. $1901 .=$ Erythradenia pyramidalis (B. Robinson) R. King \& H. Robinson.

Piqueria quinqueflora Cass., Bull. Sci. Soc. Philom. Paris 1819: 128. 1819. = Ophryosporus pubescens (Smith) R. King \& H. Robinson.

Piqueria serrata A. Gray, Proc. Amer. Acad. Arts 15: 25. 1880.

Piqueria setifera Chung, Phytologia 14: 324. 1967. = Ellenbergia glandulata Cuatrec.

Piqueria sodiroi Hieron. in Sodiro, Bot. Jahrb. Syst. 29: 3. 1900. = Guevaria sodiroi (Hieron. in Sodiro) R. King \& H. Robinson.

Piqueria standlevi B. Robinson, Contr. Gray Herb. 104: 4. 1934. = Koanophyllon standleyi (B. Robinson) R. King \& H. Robinson.

Piqueria subcordata (DC.) Gardner, London J. Bot. 6: 430.1847. = Gymnocoronis spilanthoides DC.

Piqueria triflora Hemsley in Godman \& Salvin, Biol. Cent.-Amer., Bot. 2: 77. 1881.

Piqueria trinervia Cav., Icon. 3: 19. T. 235. 1795.

Piqueria vargasii Chung, Phytologia 14: 325. 1967. = Guevaria vargasii (Chung) R. King \& H. Robinson.

Piqueriella brasiliensis R. King \& H. Robinson, Phytologia 29: 264, 1974.

Piqueriopsis michoacana R. King, Brittonia 17: 352. 1965.

Planaltoa lychnophoroides G. Barroso, Sellowia 17: 79. 1965.

Planaltoa salviifolia Taubert, Bot. Jahrb. Syst. 21: 454. 1896.

Platypodanthera melissaefolia (DC.) R. King \& H. Robinson, Phytologia 24: 183. 1972.

Pleurocoronis gentryi (Wiggins) R. King \& H. Robinson, Phytologia 12: 470. 1966.

Pleurocoronis laphamioides (Rose) R. King \& H. Robinson, Phytologia 12: 470. 1966.

Pleurocoronis pluriseta (A. Gray) R. King \& H. Robinson, Phytologia 12: 469. 1966.

Podophania dissecta (Hook. \& Arn.) B. Robinson, Proc. Amer. Acad. Arts 47: 192. 1911. = Hofmeisteria dissecta (Hook. \& Arn.) R. King \& H. Robinson.

Podophania ghiesbreghtiana Baillon, Bull. Mens. Soc. Linn. Paris 1: 268. 1880. = Hofmeisteria dissecta (Hook. \& Am.) R. King \& H. Robinson.

Polvanthina nemorosa (Klatt) R. King \& H. Robinson, Phytologia 20: 213. 1970.

Praveliopsis mattogrossensis G. Barroso, Arch. Jard. Bot. Rio de Janeiro 9: 176. 1949.

Praxelis asperulacea (Baker) R. King \& H. Robinson, Phytologia 20: 194. 1970.

Praxelis basifolia (Malme) R. King \& H. Robinson, Phytologia 20: 194. 1970.
Praxelis capillaris (DC.) Schultz-Bip., Jahresber. Pollichia 22-24: 254. 1866.

Praxelis chiquitensis (B. Robinson) R. King \& H. Robinson, Phytologia 37: 458.1977.

Praxelis clematidea (Griseb.) R. King \& H. Robinson, Phytologia 20: 194. 1970.

Praxelis conoclinanthia (Hieron.) R. King \& H. Robinson, Phytologia 20: 194. 1970.

Praxelis grandiflora (DC.) Schultz-Bip., Jahresber. Pollichia 22 24: 254. 1866.

Praxelis grandiflora (DC.) R. King \& H. Robinson, Phytologia 20: 194. 1970, comb. superf. = Praxelis grandiflora (DC.) Schultz-Bip.

Praxelis hecatantha Schultz-Bip. ex Baker, F. Bras. 6(2): 343. 1876, nom. nud. in syn. = Praxelis kleinioides (H. B. K.) SchulıBip.

Praxelis insignis (Malme) R. King \& H. Robinson. Phytologia 20: 195.1970.

Praxelis karuaiensis (V. Badillo) R. King \& H. Robinson, Phytologia 20: 195. 1970.

Praxelis kleinioides (H. B. K.) Schultz-Bip., Jahresber. Pollichia 22-24: 254. 1866.

Praxelis missiona (Malme) R. King \& H. Robinson, Phytologia 20: 195. 1970.

Praxelis odontodactyla (B. Robinson) R. King \& H. Robinson, Phytologia 20: 195. 1970.

Praxelis ostenii (B. Robinson) R. King \& H. Robinson, Phytologia 20: 195. 1970.

Praxelis paucidentata (DC.) Schultz-Bip., Jahresber. Pollichia 22 24: 254. 1866. = Praxelis kleinioides (H. B. K.) Schultz-Bip.

Praxelis pauciflora (H. B. K.) R. King \& H. Robinson, Phytologia 20: 195.1970.

Praxelis peduncularis (DC.) Schultz-Bip., Jahresber. Pollichia 22 24: 254. 1866. = Praxelis kleinioides (H. B. K.) Schultz-Bip.

Praxelis riedelii Schultz-Bip. ex Baker, F. Bras. 6(2): 342. 1876, nom. nud. in syn. = Praxelis capillaris (DC.) Schultz-Bip.

Praxelis sideritis (DC.) Schultz-Bip., Jahresber. Pollichia 22-24: 254. 1866. = Praxelis kleinioides (H. B. K.) Schultz-Bip.

Praxelis villosa Cass., Dict. Sci. Nat. 43: 261. 1826. = Praxelis pauciflora (H. B. K.) R. King \& H. Robinson.

Prenanthes rhombifolia Humb. ex Willd., Sp. Pl. 3: $1535(-1536)$. 1803. = Brickellia diflusa (Vahl) A. Gray.

Prolobus nitidulus (Baker) R. King \& H. Robinson, Phytologia 50(5): 387. 1982.

Pseudobrickellia angustissima (Sprengel ex Baker) R. King \& H. Robinson, Phytologia 24: 75. 1972.

Pseudobrickellia brasiliensis (Sprengel) R. King \& H. Robinson, Phytologia 24: 75. 1972.

Pseudobrickellia irwinii R. King \& H. Robinson. Phytologia 24: 75. 1972. = Pseudobrickellia brasiliensis (Sprengel) R. King \& H. Robinson.

Pseudokyrsteniopsis perpetiolata R. King \& H. Robinson, Phytologia 27: 241. 1973.

Radlkoferotoma berroi (Hutch.) R. King \& H. Robinson, Phytologia 21: 401. 1971.

Radlkoferotoma cistifolium (Less.) Kuntze, Revis. Gen. PI. I: 358. 1891.

Radlkoferotoma ramboi (Cabrera) R. King \& H. Robinson, Phytologia 21: 401. 1971.

Raulinoreitzia crenulata (Sprengel) R. King \& H. Robinson, Phytologia 22: 114. 1971.

Raulinoreitzia leptophlebia (B. Robinson) R. King \& H. Robinson, Phytologia 37: 458. 1977.

Raulinoreitzia tremula (Hook. \& Arn.) R. King \& H. Robinson, Phytologia 22: 114. 1971.

Revealia macrocephala (Paray) R. King \& H. Robinson, Phytologia 34: 376. 1976.

Revealia stevioides R. King \& H. Robinson, Phytologia 33: 277. 
1976. = Revealia macrocephala (Paray) R. King \& H. Robinson.

Rosalesia glandulosa Llave in Llave \& Lex., Nov. Veg. Descr. 1: 9. 1824. = Brickellia glandulosa (Llave in Llave \& Lex.) McVaugh.

Samtolina oppositifolia L., Syst. Nat. ed. 10, 1207. 1759. = Isocarpha oppositifolia (L.) Cass.

Santosia talmonii R. King \& H. Robinson, Phytologia 45: 463. 1980.

Sartorina schultzii R. King \& H. Robinson, Phytologia 28: 98. 1974.

Schaetzellia mexicana Schultz-Bip., Flora 33: 419. 1850. = Macraughiella mexicana (Schultz-Bip.) R. King \& H. Robinson.

Schaetzellia standleyi Steyerm., Publ. Field Mus. Nat. Hist., Bot. Ser. 23: 107. 1944. = Macvanghiella mexicana (Schultz-Bip.) R. King \& H. Robinson.

Scherya bahiensis R. King \& H. Robinson, Phytologia 38: 101. 1977.

Sciadocephala amazonica R. King \& H. Robinson, Phytologia 29: 12. 1974.

Sciadocephala asplundii R. King \& H. Robinson, Phytologia 34: 375. 1976.

Sciadocephala dressleri R. King \& H. Robinson, Phytologia 29: 343. 1975.

Sciadocephala pakaraimae (Maguire \& Wurd.) R. King \& H. Robinson, Phytologia 29: 12. 1974.

Sciadocephala schultze-rhonhofiae Mattf. in Diels, Notizbl. Bot. Gart. Berlin-Dahlem 14: 42. 1938.

Sclerolepis uniflora (Walter) Britton, Sterns \& Pogg., Prelim. Cat. 25. 1888 .

Sclerolepis uniflora (Walter) Poiret, Mem. Torrey Bot. Club 5: 311. 1894, comb. superfl. = Sclerolepis uniflora (Walter) Britton, Sterns \& Pogg.

Sclerolepis verticillata (Michaux) Cass., Dict. Sci. Nat. 48: 155. 1827. = Sclerolepis uniflora (Walter) Britton, Sterns \& Pogg.

Serratula elegans (Walter) Aiton f., Hort. Kew. 3: 138. 1811. = Liatris elegans (Walter) Michaux.

Serratula pilosa Aiton, Hortus Kew. 3: 138. 1789. = Liatris pilosa (Aiton) Willd.

Serratula scariosa L., Sp. Pl. 2: 818. 1753. = Liatris scariosa (L.) willd.

Serratula speciosa Aiton, Hortus Kew. 3: 138. 1789, nom. superfl. $=$ Liatris clegans (Walter) Michaux.

Serratula spicata L., Sp. PI. 2: 819. 1753. = Liatris spicata (L.) Willd.

Serratula squarrosa L., Sp. Pl. 2: 818. 1753. = Liatris squarrosa (L.) Willd.

Shinnersia rivularis (A. Gray) R. King \& H. Robinson, Phytologia 19: 297. 1970.

Spariopappus bucheri (B. Robinson) R. King \& H. Robinson, Phytologia 19: 304. 1970, as "ruckeri."

Spaniopappus ekmanii B. Robinson, Contr. Gray Herb. 77: 45. 1926.

Spaniopappus hygrophilus (Alain) R. King \& H. Robinson, Phytologia 19: 304. 1970.

Spaniopappus iodostylus (B. Robinson) R. King \& H. Robinson, Phytologia 19: 304. 1970.

Spaniopappus ruckeri (B. Robinson) R. King \& H. Robinson, Phytologia 19: 304. 1970, error for "bucheri."

Spaniopappus shaferi (B. Robinson) R. King \& H. Robinson, Phytologia 19: 304. 1970.

Sparganophorus ageratoides Lagasca, Gen. Sp. PI. 25. 1816. = Ageratum corymbosum Zuccagni.

Sparganophorus obtusifolius Lagasca, Gen. Sp. PI. 25. 1816. = Ageratum conyzoides L.

Sparganophorus verticillatus Michaux, F. Bor.-Amer. 2: 95 . T.42 1803. = Sclerolepis uniflora (Waiter) Britton, Sterns \& Pogg.
Sphaereupatorium hoffimannii (Kuntze) B. Robinson, Contr. Gray Herb. 61: 25. 1920. = Sphaereupatorium scandens (Gardner)

R. King \& H. Robinson.

Sphaereupatorium scandens (Gardner) R. King \& H. Robinson, Phytologia 53: 392. 1983.

Sphaereupatorium sphaerocephalum (Schultz-Bip. ex Baker) R. King \& H. Robinson, Phytologia 49: 6. 1981. = Sphaereupatorium scandens (Gardner) R. King \& H. Robinson.

Spilanthes tinctorius Lour., Fl. Cochinch. 484. 1790. = Aden ostemma tinctorium (Lour.) Cass.

Spilanthus atriplicifolius (L.) L., Syst. Nat., ed. 12, 3: 236.1768. = Isocarpha atriplicifolia (L.) R. Br. ex DC.

Staehelina elegans Walter, Fl. Carol. 202. 1788. = Liatris elegans (Walter) Michaux.

Standleyanthus triptychus (B. Robinson) R. King \& H. Robinson, Phytologia 22: 42. 1971.

Steleocodon gracilis Gilli, Feddes Repert. 94: 311. 1983. = Phalacraea longipetiolata (B. Robinson) R. King \& H. Robinson, ?

Stevia achalensis Hieron., Bot. Jahrb. Syst. 22: 712.1897.

Stevia adenophora Lagasca, Gen. Sp. PI. 27. 1816.

Stevia alatipes B. Robinson, Proc. Amer. Acad. Arts 43: 28. 1907.

Stevia alpina Griseb., Abh. Konigl. Ges. Wiss. Gottingen 19: 116.1874.

Stevia alternifolia Hieron., Bot. Jahrb. Syst. 22: 740. 1897.

Stevia amabilis Lemmon ex A. Gray, Proc. Amer. Acad. Arts 19: 1. 1884. = Stevia viscida H. B. K.

Stevia amambayensis B. Robinson, Contr. Gray Herb. 90: 6. 1930.

Stevia amblyolepis (B. Robinson) B. Robinson, Contr. Gray Herb. 90: 6. 1930.

Stevia ammotropha B. Robinson, Contr. Gray Herb. 90: 7. 1930.

Stevia amplexicaulis Hassler, Feddes Repert. 11: 165. 1912.

Stevia andina B. Robinson, Contr. Gray Herb. 96: 3. 1931.

Stevia angustifolia H. B. K., Nov. Gen. Sp. 4: 116. Ed. Folio. 1818. = Stevia salicifolia Cav.

Stevia anisostemma Turcz., Bull. Soc. Imp. Naturalistes Moscou 24(1): 167. 1851.

Stevia apensis B. Robinson, Contr. Gray Herb. 90: 7. 1930.

Stevia arachnoidea B. Robinson, Proc. Amer. Acad. Arts 35: 326. 1900. = Stevia polycephala Baker.

Stevia arbutifolia (H. B. K.) Willd. ex DC., Prodr. 5: 115. 1836, nom. nud. = Oxylobus arbutifolius (H. B. K.) A. Gray.

Stevia aristata D. Don ex Hook. \& Arn., Companion Bot. Mag. 1: 238.1835.

Stevia aristata var, villaricensis B. Robinson, Contr. Gray Herb. 90: 8. 1930. = Stevia villaricensis (B. Robinson) Cabrera \& Vittet.

Stevia arnottiana Baker, F. Bras. 6(2): 201. 1876. = Stevia gilliesii Hook. \& Arn.

Stevia aschenborniana Schultz-Bip. ex Klotzsch, Linnaea 25: 269. 1852.

Stevia baccharoides (DC.) F. Meigen, Bot. Jahrb. Syst. 17: 283. 1893. = Ophryosporus paradoxus (Hook. \& Arn.) Benth. \& Hook. ex Hook. f. \& Jackson.

Stevia balansae Hieron., Bot. Jahrb. Syst. 22: 739. 1897.

Stevia bangii Rusby, Mem. Torrey Bot. Club 4: 209. 1895.

Stevia batesii B. Robinson, Contr. Gray Herb. 104: 6. 1934.= Stevia tornentosa H. B. K.

Stevia beckii R. King \& H. Robinson, Phytologia 51: 173.1982.

Stevia benderi Perkins, Bot. Jahrb. Syst. 49: 221. 1913.

Stevia benthamiana Hieron., Bot. Jahrb. Syst. 28: 561 . 1901. = Stevia ovata Willd.

Stevia berlandieri A. Gray, Rep. U. S. Mex. Bound., Bot. 73. 1859.

Stevia bermejensis Hieron. in Urban, Bot. Jahrb. Syst. 40: 361. 1908.

Stevia bertholdii B. Robinson, Contr. Gray Herb. 96: 4. 1931. 
Stevia bicrenata Klatt, Bot. Jahrb. Syst. 8: 32. 1886. = Stevia elatior H. B. K.

Stevia bisecta M. E. Jones, Contr. W. Bot. 18: 70. 1933. = Ageralella palmeri (A. Gray) B. Robinson.

Stevia boliviensis Schultz-Bip. ex Rusby, Mem. Torrey Bot. Club 3(3): 51. 1893.

Stevia breviaristata Hook. \& Arn., Companion Bot. Mag. 1: 238. 1835.

Stevia breviflora (Cass.) Schultz-Bip., Linnaea 25: 291. 1852.

Stevia brevipapposa Hieron., Bot. Jahrb. Syst. 22: 718. 1897. = Stevia boliviensis Schultz-Bip. ex Rusby.

Stevia bridgesii Rusby, Bull. New York Bot. Gard. 4: 377.1907.

Stevia brunetii Hieron., Bot. Jahrb. Syst. 22: 723. 1897.

Stevia burkartii B. Robinson, Contr. Gray Herb. 96: 4. 1931.

Stevia cajabambensis Hieron, in Urban, Bot. Jahrb. Syst. 40: 367. 1908.

Stevia calderillensis Hieron. in Urban, Bot. Jahrb. Syst. 40: 356. 1908.

Stevia callosa Nutt., J. Acad. Nat. Sci. Philadelphia 2: 121. 1821. = Palafoxia callosa (Nutt.) Torrey \& A. Gray. Heliantheae.

Stevia callosa Cerv, in Loudon, Hort. Brit. 335. 1830?, nom. nud. ignota.

Stevia calycina DC., Prodr. 5: 124. 1836. = Disynaphia calyculata (Hook. \& Arn.) R. King \& H. Robinson.

Stevia camachensis Hicron. in Urban, Bot. Jahrb. Syst. 40: 359. 1908.

Stevia camporum Baker, Fl. Bras. 6(2): 202. 1876.

Stevia canescens H. B. K., Nov. Gen. Sp. 4: 112. Ed. Folio. 1818.

= Stevia serrata Cav.

Stevia caracasana DC., Prodr. 5: 119. 1836.

Stevia carapariensis Cabrera \& Vittet, Revista Mus. Eva Peron, Secc. Bot. 8: 188. 1954.

Stevia cardiatica Perkins, Bot. Jahrb. Syst. 49: 222. 1913.

Stevia catharinensis Cabrera in Cabrera \& Vittet, Sellowia 15: 157. 1963.

Stevia cathartica Poeppig \& Endl., Nov. Gen. Sp. 3: 55.1845.

Stevia centinelae Cabrera. Bol. Soc. Argent. Bot. 15: 319. 1974.

Stevia chacoensis R. E. Fries, Arch. Bot. *PICK CORRECT ENTRY 5(13): 7. 1906.

Stevia chamaedrys Griseb., Abh. Konigl. Ges. Wiss. Gottingen 24: 167.1879.

Stevia chiapensis Grashoff, Brittonia 26: 348. 1974.

Stevia chortiana Standley \& Steyerm., Publ. Field Mus. Nat.

Hist., Bot. Ser. 23: 108. 1944, = Stevia deltoidea E. Grecne.

Stevia cinerascens Schultz-Bip. ex Baker, Fl. Bras. 6(2): 209. 1876.

Stevia clausseni Schultz-Bip. ex Baker, Fl, Bras. 6(2): 203.1876.

Stevia clinopodia DC., Prodr. 5: 116. 1836. = Stevia jorullensis H. B. K.

Stevia clinopodioides Grcenman, Proc. Amer. Acad. Arts 32: 307. 1897.

Stevia clivicola B. Robinson, Contr. Gray Herb. 100: 4. 1932.

Stevia cochabaimbensis Hieron., Bot. Jahrb. Syst. 22: 726, 1897.

Stevia collina Gardner, London J. Bot. 5: 458. 1846.

Stevia collodes Grecnman, Proc. Amer. Acad. Arts 39: 93.1903. = Stevia salicifolia Cav.

Stevia commixta B. Robinson. Contr. Gray Herb. 90: 9. 1930.

Stevia compacta Benth., Pl. Hartw. 197. 1845. = Stevia triflora DC.

Stevia conferta DC., Prodr. 5: 116. 1836. = Stevia pilosa Lagasca.

Stevia congesta Hook. \& Am., Companion Bot. Mag. 1: 238. 1835. = Stevia satureifolia Lam.

Stevia connata Lagasca, Gen. Sp. Pl. 27. 1816.

Stevia copiosa Koster, Blumea 5: 645. 1945.

Stevia cordifolia Benth., PI. Hartw. 39. 1840.

Stevia coriacea Lagasca, Gen. Sp. Pl. 28. 1816. = Stevia lucida Lagasca, ?

Stevia coronata Schultz-Bip., Bot. Zeitung (Berlin) 3: 155. 1845 , nom. nud. = Stevia urticacfolia Billb, in Thunb.
Stevia coronifera DC., Prodr. 5: 115. 1836. = Stevia jorullensis H. B. K.

Stevia crassicephala Cabrera, Bol. Soc. Argent. Bot. 15: 320. 1974.

Stevia crenata Benth., Pl. Hartw. 197. 1845.

Stevia crenata Schultz-Bip. ex Baker, Fl. Bras. 6(2): 205. 1876. nom. nud. in syn. = Stevia menthaefolia Schultz-Bip.

Stevia crenulata Baker, Fl. Bras. 6(2): 211. 1876.

Stevia cruziana Malme, Kongl. Svenska Vetenskapsakad. Handl. 32(5): 33. 1899.

Stevia cruzii Grashoff, Brittonia 26: 348(-351). 1974.

Stevia cryptantha Baker, F. Bras. 6(2): 204. 1876.

Stevia cuncata Hassler, Feddes Repert. 11: 166. 1912.

Stevia cuzcoensis Hicron. in Urban, Bot. Jahrb. Syst. 40: 363. 1908.

Stevia decumbens (B. Robinson \& Greenman) E. Greene, Pittonia 3: 32.1896.

Sievia decussala Bakcr, Fl. Bras. 6(2): 203. 1876.

Stevia deltoidea E. Greene, Pittonia 3: 31. 1896.

Stevia dianthoidea Hieron. in Sodiro, Bot. Jahrb. Syst. 29: 4. 1900.

Stevia dictyophylla B. Robinson, Proc. Amer. Acad. Arts 44:617. 1909.

Stevia diffusa Greenman, Proc. Amer. Acad. Arts 32: 307. 1897. = Sievia aschenborniana Schultz-Bip. ex Klotzsch.

Stevia discolor B. Robinson, Contr. Gray Hcrb. 100: 5. 1932.

Stevia dissitifolia DC., Prodr. 5: 121. 1836. = Stevia origanoides H. B. K.

Stevia dissoluta Schlechtend., Hort. Hal. 16. 1841-1853. = Stevia elatior H. B. K.

Stevia divaricata DC., Prodr. 5: 123. 1836.

Stevia diversipapposa Hieron., Bot. Jahrb. Syst. 22: 708. 1897. = Stevia raga Griseb.

Stevia dodecachaeta DC., Prodr. 5: 122. 1836. = Stevia melissaefolia (Lam.) Schultz-Bip.

Stevia dubia B. Robinson, Contr. Gray Herb. 104: 7. 1934.

Stevia eclipes B. Robinson, Contr. Gray Herb. 96: 5. 1931.

Stevia effiusa Hieron., Bot. Jahrb. Syst. 22: 710. 1897.

Stevia ehrenbergiana Schlechtend., Linnaea 16: 370. 1842. = Stevia ovata Willd.

Stevia elatior H. B. K., Nov. Gen. Sp. 4: 113. Ed. Folio. 1818.

Stevia elatior var. decumbens B. Robinson \& Greenman, Amer. J. Sci. Arts 3, 50: 152. 1895. = Stevia decumbens (B. Robinson \& Greenman) E. Greene.

Stevia elliptica Hook. \& Arn., Bot. Beechey Voy. 434. 1841. = Stevia caracasana DC.

Stevia elongata H. B. K., Nov. Gen. Sp. 4: 113. Ed. Folio. 1818. = Stevia elatior H. B. K.

Stevia elongata $\beta$ moritziana I pallida Schultz-Bip. in Klotzsch, Linnaea $25: 275.1853$. = Stevia ovata Willd.

Stevia elongata $\beta$ moritziana II purpurescens Schultz-Bip. in Klotzsch, Linnaea 25: 275. 1853. = Stevia elatior H. B. K.

Stevia enarthotricha Lagasca, Gen. Sp. PI. 27. 1816. = Stevia elatior H. B. K., ?

Stevia entreriensis Hieron., Bot. Jahrb. Syst. 22: 739. 1897.

Stevia entreriensis Hieron. ex Arechav., Analcs Mus. Nac. Montevideo 6: 139. 1907. = Stevia entreriensis Hieron

Stevia ephemera Grashoff, Brittonia 26: 351. 1974.

Stevia erecta Walp., Repcrt. Bot. Syst. 2: 548. 1843. = Stevia ovata Willd.

Stevia estrellensis Hassler ex B. Robinson, Contr. Gray Herb. 90: 83. 1930.

Stevia eupatoria (Sprengel) Willd., Sp. Pl. 3: 1775. 1804.

Stevia fascicularis Less. in Schlechtend. \& Cham., Linnaea 5: 140. $1830 .=$ Stevia orata Willd.

Stevia fastigiata H. B. K., Nov. Gen. Sp. 4: 116. Ed. Folio. 1818. = Steria lucida Lagasca. 
Stevia febrifuga Mocino ex DC., Prodr. 5: 104. 1836, nom. inval. = Piqueria trinervia Cav.

Stevia ferruginea Schultz-Bip. ex Baker, Fl. Bras. 6(2): 211. 1876, nom. nud. in syn. = Stevia tenuis Hook. \& Am.

Stevia fiebrigii Hieron. in Urban, Bot. Jahrb. Syst. 40: 365.1908. Stevia filipes Rusby, Bull. New York Bot. Gard. 8: 126. 1912.

Stevia flourensioides S. F. Blake, Contr. U. S. Natl. Herb. 22: 589. 1924. = Stevia salicifolia Cav.

Stevia foliosa Small, F. S. E. U. S. 1163., 1338. 1903. = Stevia salicifolia Cav.

Stevia fruticosa Griseb., Abh. Konigl. Ges. Wiss. Gottingen 24: 167. 1879.

Stevia galeopsidifolia Hieron., Bot. Jahrb. Syst. 22: 719. 1897.

Stevia gardneriana Baker, Fl. Bras. 6(2): 207. 1876.

Stevia gilliesii Hook. \& Arn., Companion Bot. Mag. 2: 251.1836.

Stevia glabra Mocino ex DC., Prodr. 5: 117. 1836, nom. inval. = Stevia connata Lagasca.

Stevia glandulifera Schlechtend., Ind. Sem. Hort. Hal. 19. 1839. = Stevia jorullensis H. B. K.

Stevia glandulosa Hook. \& Arn., Bot. Beechey Voy. 296. 1838.

Stevia glanduloso-pubescens Hieron. in Urban, Bot. Jahrb. Syst. 40: 360. 1908.

Stevia glomerata Hieron. in Urban, Bot. Jahrb. Syst. 40: 357. 1908.

Stevia glutinosa H. B. K., Nov. Gen. Sp. 4: 116. Ed. Folio. 1818. = Stevia lucida Lagasca.

Stevia gracilipes Martius ex Baker, Fl. Bras. 6(2): 210. 1876, nom. nud. in syn. = Stevia lundiana DC.

Stevia grandidentata Schultz-Bip. ex Klatt, Leopoldina 20: 75. 1884. = Stevia lucida Lagasca.

Stevia grandidentata Schultz-Bip. ex Rusby, Mem. Torrey Bot. Club 6: 55. 1896. = Stevia soratensis Hieron.

Stevia grandidentata Schultz-Bip. ex Hieron., Bot. Jahrb. Syst. 22: 714. 1897. = Stevia soratensis Hieron. in Urban.

Stevia gratioloides Hook. \& Am., Companion Bot. Mag. 1: 238. 1835. = Stevia tenuis Hook. \& Arn.

Stevia grisebachiana Hieron., Bot. Jahrb. Syst. 22: 716. 1897.

Stevia guaranitica Chodat, Bull. Herb. Boissier Ser. 2. 3: 704. 1903. = Stevia leptophylla Schultz-Bip. ex Baker.

Stevia haenkeana DC., Prodr. 5: 122. 1836.

Stevia hassleriana Chodat, Bull. Herb. Boissier Ser. 2. 2: 305. 1902. = Stevia balansae Hieron.

Stevia heptachaeta DC., Prodr. 5: 122. 1836.

Stevia herrerae B. Robinson, Contr. Gray Herb. 100: 5. 1932.

Stevia hilarii B. Robinson, Contr. Gray Herb. 96: 7. 1931.

Stevia hirsuta Hook. \& Arn., Companion Bot. Mag. 1:239. 1835. = Stevia satureifolia Lam.

Stevia hirsuta DC., Prodr. 5: 121. 1836. = Stevia deltoidea E. Greene.

Stevia hirtiflora Schultz-Bip. in Klotzsch, Linnaea 25: 274.1853. = Stevia caracasana DC.

Stevia hispidula DC., Prodr. 5: 122.1836.

Stevia hoppii B. Robinson, Contr. Gray Herb. 100: 6. 1932.

Stevia humilis Hieron., Bot. Jahrb. Syst. 22: 730. 1897. = Stevia obovata Rusby.

Stevia hymenoppa Mocino ex DC., Prodr. 5: 117. 1836, nom. inval. = Stevia lucida Lagasca.

Stevia hypericifolia Hieron., Bot. Jahrb. Syst. 22: 732. 1897.

Stevia hypomalaca B. Robinson, Contr. Gray Herb. 90: 13. 1930.

Stevia hyptifolia Gardner, London J. Bot. 6: 434. 1847.

Stevia hyssopifolia Cav., Descr. P1. 190. 1802. = Stevia eupatoria (Sprengel) Willd.

Stevia hyssopifolia Sims, Bot. Mag. T. 1861. 1817. = Stevia ovata Willd.

Stevia hyssopifolia H. B. K., Nov. Gen. Sp. 4: 109. Ed. Folio. 1818. = Stevia viscida H. B. K.

Stevia hyssopifolia Philippi, F. Atacam. 29. 1860. = Stevia philippiana Hieron. in Urban.
Stevia iltisiana Grashoff, Brittonia 26: 354(-357). 1974.

Stevia imbricata Gardner, London J. Bot. 5: 458. 1846. = Dissothrix imbricata (Gardner) B. Robinson.

Stevia incanescens Lagasca, Gen. Sp. P1. 27. 1816. = Stevia tomentosa H. B. K., ?

Stevia incognita Grashoff, Brittonia 26: 357(-360). 1974.

Stevia integra S. F. Blake, Contr. U. S. Natl. Herb. 22: 589.1924. = Stevia salicifolia Cav.

Stevia involucrata Schultz-Bip. ex Baker, Fl. Bras. 6(2): 211.1876.

Stevia isomeca Grashoff, Brittonia 26: 360(-362). 1974.

Stevia ivaefolia Willd., Ges. Naturf. Freunde Berlin Mag. Neuesten Entdeck. Gesammten Naturk. 1: 137. 1807. = Stevia serrata Cav.

Stevia jaliscensis B. Robinson, Contr. Gray Herb. 80: 8. 1928.

Stevia jorullensis H. B. K., Nov. Gen. Sp. 4: 112. Ed. Folio. 1818.

Stevia jujuyensis Cabrera, Bol. Soc. Argent. Bot. 15: 322.1974.

Stevia karwinskyana Steudel, Nomencl. Bot. 2: 641. 1841.

Stevia kuhnioides Rusby ex B. Robinson, Contr. Gray Herb. 96: 7. 1931.

Stevia kuntzei Hieron., Bot. Jahrb. Syst. 22: 733. 1897.

Stevia lanceolata Lagasca, Gen. Sp. P1. 26. 1816. = Stevia serrata Cav.

Stevia lanceolata Hook. \& Arn., Companion Bot. Mag. 1: 238. 1835. = Stevia gilliesii Hook. \& Arn.

Stevia lanceolata Mocino ex DC., Prodr. 5: 116. 1836, nom. inval. = Stevia subpubescens Lagasca.

Stevia lanceolata Walp., Linnaea 14: 319. 1840. = Stevia karwinskyana Steudel.

Stevia lasioclada Grashoff, Brittonia 26: 362(-363). 1974.

Stevia latifolia Benth., PI. Hartw. 40. 1840.

Stevia lavandulaefolia Willd. ex DC., Prodr. 5: 125. 1836, nom. inval. = Palafoxia linearis (Cav.) Lagasca. HeliantheAE.

Stevia laxa Hook. \& Arn., Companion Bot. Mag. 1: 238.1835. = Stevia satureifolia Lam.

Stevia laxa B. Robinson \& Seaton, Proc. Amer. Acad. Arts 28: 107. 1893. = Stevia micradenia B. Robinson.

Stevia laxiflora DC., Prodr. 5: 122. 1836. = Stevia viscida H. B. K.

Stevia lechleri Hieron., Bot. Jahrb. Syst. 22: 727. 1897.

Stevia lehmannii Hieron., Bot. Jahrb. Syst. 28: 562. 1901.

Stevia lemmoni A. Gray, Proc. Amer. Acad. Arts 17: 204. 1882.

Stevia leptophylla Schultz-Bip. ex Baker, Fl. Bras. 6(2): 205.1876.

Stevia leucantha Schlechtend., Hort. Hal. 16.1841-1853. = Stevia suaveolens Lagasca.

Stevia leuconeura DC., Prodr. 5: 121. 1836. = Stevia viscida $\mathrm{H}$. B. K.

Stevia leucosticta B. Robinson, Contr. Gray Herb. 96: 8. 1931.

Stevia liebmannii Schultz-Bip. ex Klatt, Leopoldina 20: 75.1884.

Stevia lilloi B. Robinson, Contr. Gray Herb. 90: 14. 1930.

Stevia linariaefolia DC., Prodr. 5: 123. 1836. = Stevia satureifolia Lam.

Stevia linearifolia Walp., Linnaea 14: 320. 1840. = Stevia salicifolia Cav., ?

Stevia linearifolia Steudel, Nomencl. Bot. 2: 641. 1841. = Stevia satureifolia Lam., ?

Stevia linearis (Cav.) Willd., Sp. Pl. 3: 1774. 1804. = Palafoxia linearis (Cav.) Lagasca. HeliantheAe.

Stevia linearis Gill. ex Baker, Fl. Bras. 6(2): 208. 1876, nom. nud. in syn. = Stevia satureifolia Lam.

Stevia linoides Schultz-Bip. in Klotzsch, Linnaea 25: 284.1853. = Stevia serrata Cav.

Stevia lita Grashoff, Brittonia 26: 364. 1974.

Stevia longifolia Mocino ex DC., Prodr. 5: 118. 1836, nom. inval. = Stevia connata Lagasca.

Stevia longiseta Mocino ex DC., Prodr. 5: 121. 1836, nom. inval. = Stevia viscida H. B. K.

Stevia lorentzii Griseb., Abh. Konigl. Ges. Wiss. Gottingen 19: 117. 1874. = Stevia breviaristata Hook. \& Arn. 
Stevia lozanoi B. Robinson, Proc. Amer. Acad. Arts 43: 28. 1907. = Stevia viscida H. B. K.

Stevia lucida Lagasca, Gen. Sp. Pl. 28. 1816.

Stevia Iundiana DC., Prodr. 5: 122. 1836.

Stevia macbridei B. Robinson, Contr. Gray Herb. 96: 9. 1931.

Stevia macella A. Gray, PI. Wright. 2: 70. 1853. = Stevia micrantha Lagasca.

Stevia macvaughii Grashoff, Brittonia 26: 365(-367). 1974.

Stevia madrensis A. Gray, Proc. Amer. Acad. Arts 21: 382.1886. = Stevia plumimerae A. Gray.

Stevia maimarensis (Hieron.) Cabrera, Fl. Prov. Jujuy 10: 81. 1978.

Stevia mandonii Schultz-Bip., Bull. Soc. Bot. France 12:81. 1865, Linnaea 34: 535. Feb. 1866.

Stevia megapotamica DC., Prodr. 5: 123. 1836. = Stevia multiaristata Sprengel.

Stevia melancholica B. Robinson, Contr. Gray Herb. 90: 15. 1930.

Stevia melissaefolia (Lam.) Schultz-Bip., Linnaea 25: 291. 1852.

Stevia menthaefolia Schultz-Bip., Linnaea 25: 282. 1852.

Stevia menthaefolia Philippi, Fl. Atacam. 203. 1860. = Stevia philippiana Hieron. in Urban.

Stevia mercedensis Hieron., Bot. Jahrb. Syst. 22: 735. 1897.

Stevia mercedensis var. pereyrae B. Robinson, Contr. Gray Herb. 90: 16. 1930. = Stevia pereyrae (B. Robinson) Cabrera.

Stevia micradenia B. Robinson, Contr. Gray Herb. 64: 3. 1922.

Stevia micrantha Lagasca, Gen. Sp. PI. 27. 1816.

Stevia microcephala DC., Prodr. 5: 118. 1836. = Stevia serrata Cav., or Stevia tephra B. Robinson.

Stevia microchaeta Schultz-Bip., Linnaea 25: 291.1852.

Stevia micropappa Schultz-Bip., Bull. Soc. Bot. France 12: 81. 1865. = Stevia soratensis Hieron.

Stevia microphylla H. B. K., Nov. Gen. Sp. 4: 109. Ed. Folio. 1818. = Stevia trifida Lagasca.

Stevia minor Griseb., Abh. Konigl. Ges. Wiss. Gottingen 19: 118. 1874.

Stevia mitopoda B. Robinson, Contr. Gray Herb. 80: 8. 1928.

Stevia mollis Schrader, Ind. Sem. Hort. Acad. Gott. 1831: 5. 1831. = Stevia suaveolens Lagasca.

Stevia monardaefolia H. B. K., Nov. Gen. Sp. 4: 115. Ed. Folio. 1818.

Stevia monardifolia var. amblyolepis B. Robinson, Proc. Amer. Acad. Arts 35: 326. 1900. = Stevia amblyolcpis (B. Robinson) B. Robinson.

Stevia morii R. King \& H. Robinson, Phytologia 46: 299. 1980.

Stevia multiaristata Sprengel, Syst. Veg. Fl. Peruv. Chil. 3: 449. 1826.

Stevia multifida Mocino ex DC., Prodr. 5: 121. 1836. = Stevia triflora DC.

Stevia myriadenia Schultz-Bip. ex Baker, Fl. Bras. 6(2): 206. 1876.

Stevia myricoides McVaugh, Contr. Univ. Michigan Herb. 9: 403. 1972.

Stevia neglecta Rusby, Mem. Torrey Bot. Club 4: 209. 1895.

Stevia nelsonii B. Robinson, Contr. Gray Herb. 80: 9. 1928.

Stevia nepetacfolia H. B. K., Nov. Gen. Sp. 4: 114. Ed. Folio. 1818. = Stevia suaveolens Lagasca.

Stevia nervosa DC., Prodr. 5: 117. 1836. = Stevia ovata Willd.

Stevia neurophylla B. Robinson \& Greenman in B. Robinson, Proc. Amer. Acad. Arts 35: 327. 1900.

Stevia nevadensis Hieron., Bot. Jahrb. Syst. 22: 729. 1897. = Stevia chamaedrys Griseb.

Stevia nitida Walp., Linnaea 14: 320. 1840. = Stevia lucida Lagasca.

Stevia oaxacana Schultz-Bip. ex Klatt, Leopoldina 20: 75. 1884.

= Stevia lucida Lagasca.

Stevia obovata Rusby, Mem. Torrey Bot. Club 6: 55. 1896.
Stevia odorata Regel, Gartenflora 40: 107. 1891. = Stevia salicifolia Cav., ?

Stevia okadae Cabrera, Hickenia 1(3): 13(-15). 1976.

Stevia oligocephala DC., Prodr. 5: 117. 1836.

Stevia ophiomaches B. Robinson, Contr. Gray Herb. 96: 10. 1931

Stevia ophryodonta B. Robinson, Contr. Gray Herb. 104: 7, 1934.

Stevia ophryophylla B. Robinson, Contr. Gray Herb, 90: 17. 1930.

Stevia organensis Gardner, London J. Bot. 4: 115. 1845.

Stevia origanifolia Walp., Linnaea 14: 321. 1840. = Stevia jorullensis $\mathrm{H}$. B. K.

Stevia origanoides H. B. K., Nov. Gen. Sp. 4: 115. Ed. Folio. 1818.

Stevia orizabensis B. Robinson, Contr. Gray Herb. 80: 10. 1928.

Stevia ovalis (B. Robinson) B. Robinson, Contr. Gray Herb. 90: 119. 1930.

Stevia ovata Willd., Enum. Pl. Hort. Berol, 855. 1809.

Stevia ovata Dum.-Cours., Bot. Cult., ed. 2, 4: 93.1811 , nom. superfl. = Stevia salicifolia Cav., ?

Stevia ovata Lagasca, Gen. Sp. Pl. 27. 1816. = Stevia ovata Willd.

Stevia orata Raf., New Fl. 4: 73. 1838, ignota, not Stevia

Stevia oxylaena DC., Prodr. 5: 123. 1836. = Stevia selloi $($ Sprengel) B. Robinson.

Stevia pabloensis Hieron. in Urban, Bot. Jahrb. Syst. 40: 364. 1908.

Stevia pallida Martius ex Baker, Fl. Bras. 6(2): 206. 1876, nom. nud. in syn. = Stevia collina Gardner.

Stevia pallida (Schultz-Bip.) Hieron., Bot. Jahrb. Syst. 21: 328. 1895. = Stevia ovata Willd.

Stevia palmeri A. Gray, Proc. Amer. Acad. Arts 21: 382. 1886.

Stevia paniculata Lagasca, Gen. Sp. Pl. 27. 1816. = Stevia ovata Willd.

Stevia paniculigera Martius ex Baker. Fl. Bras. 6(2): 201. 1876 , nom. nud. in syn. = Stevia urticaefolia Billb. in Thunb.

Stevia parvifolia Hassler, Feddes Repert. 11: 165. 1912.

Stevia pauciflora Koster, Blumea 6: 266. 1948.

Stevia pauciradiata Baker ex Glaz., Bull. Soc. Bot. France Mem. 3. 56: 383. 1909, nom. nud. ignota.

Stevia pearcei B. Robinson, Contr. Gray Herb. 100: 7. 1932.

Stevia pedata Cav., Icon. 4:33. T. 356. 1797. = Florestina pedata (Cav.) Cass. Heliantheae.

Stevia pelophila S. F. Blake, Contr. U. S. Natl. Herb. 22: 589. 1924.

Stevia pennellii B. Robinson, Contr. Gray Herb. 100: 7. 1932.

Stevia pereyrae (B. Robinson) Cabrera, Fl. Prov. Jujuy 10: 83 1978.

Stevia perfoliata Cronq., Mem. New York Bot. Gard. 12: 292. 1965.

Stevia petiolata (Cass.) Schultz-Bip. in Klotzsch, Linnaea 25: 291. 1853.

Sievia philippiana Hieron. in Urban, Bot. Jahrb. Syst. 40: 364. 1908.

Stevia phlebophylla A. Gray in S. Watson, Proc. Amer. Acad. Arts 22: 419.1887

Stevia pilosa Lagasca, Gen. Sp. PI. 26. 1816.

Stevia pinifolia Philippi, Anales Univ. Chile 37. 1891. = Ophryosporus pinifolius (Philippi) R. King \& H. Robinson.

Stevia plummerae A. Gray, Proc. Amer. Acad. Arts 17: 204. 1882.

Stevia podocephala DC., Prodr. 5: 121. 1836. = Stevia elatior H. B. K.

Stevia podocephala Schauer, Linnaca 19: 718. 1847. = Stevia aschenborniana Schultz-Bip. ex KJotzsch.

Stevia pohliana Baker, Fl. Bras. 6(2): 21 I. 1876.

Stevia polycephala Bertol., F. Guatimal. 32. 1840.

Stevia polycephala Baker, F1. Bras. 6(2): 207. 1876, nom. illeg. ignota.

Stevia polyphylla DC., Prodr. 5: 123. 1836. 
Stevia porphyrea McVaugh, Contr. Univ. Michigan Herb. 9: 404. 1972, nom. nud. = Stevia stricta Hornem.

Stevia potosiensis R. King \& H. Robinson, Phytologia 51: 173. 1982.

Stevia potrerensis Hieron., Bot. Jahrb. Syst. 22: 715. 1897.

Stevia pringlei S. Watson, Proc. Amer. Acad. Arts 23: 276. 1888. $=$ Cronquistia pringlei (S. Watson) R. King.

Stevia procumbens Hieron., Bot. Jahrb. Syst. 22: 728. 1897.

Stevia puberula Hook., Bot. Misc. 2: 225. 1831.

Stevia puberula D. Don ex Hook. \& Arn., Companion Bot. Mag. 1: 238. 1835. = Stevia gilliesii Hook. \& Arn.

Stevia pubescens Lagasca, Gen. Sp. P1. 26. 1816. = Stevia eupatoria (Sprengel) Willd.

Stevia pubescens Mocino ex DC., Prodr. 5: 119. 1836, nom. inval. = Steria suaveolens Lagasca.

Stevia pubigera Hieron., Bot. Jahrb. Syst. 22: 720. 1897. = Stevia breviaristata Hook. \& Arn.

Stevia pulcherrima (B. Robinson) M. E. Jones, Contr. W. Bot. 18: 71. 1933. = Steviopsis vigintiseta (DC.) R. King \& H. Robinson.

Stevia punctata (Ortega) Pers., Syn. P1. 2: 403. 1807. = Stevia serrata Cav.

Stevia punctata (Jacq.) Schultz-Bip. in Klotzsch, Linnaea 25: 286. 1853. = Stevia serrata Cav.

Stevia punensis B. Robinson, Contr. Gray Herb. 100: 8. 1932.

Stevia purdiei B. Robinson, Contr. Gray Herb. 96: 13. 1931.

Stevia purpurascens (Schultz-Bip.) Hieron., Bot. Jahrb. Syst. 21: 328. 1895. = Stevia elatior H. B. K.

Stevia purpurea Pers., Syn. PI. 2: 402. 1807. = Stevia eupatoria (Sprengel) Willd.

Stevia purpurea Lagasca, Gen. Sp. Pl. 26. 1816. = Stevia viscida H. B. K.

Stevia purpurea sensu B. Robinson, Contr. Gray Herb. 90: 120. 1930. = Stevia stricta Hornem.

Stevia purpusii B. Robinson, Contr. Gray Herb. 90: 18. 1930.

Stevia pyrolaefolia Schlechtend., Linnaca 16: 326. 1842.

Stevia quitensis H. B. K., Nov. Gen. Sp. 4: 113. Ed. Folio. 1818. = Stevia ovata Willd.

Stevia rapunculoides DC., Prodr. 5: 124. 1836. = Steviopsis rapunculoides (DC.) R. King \& H. Robinson.

Stevia rebaudiana (Bertoni) Bertoni, Anales Ci. Parag. 1(5): 3. 1905.

Stevia rebaudiana (Bertoni) Hemsley, Hooker's Icon. P1. 2816. 1906 , comb. superfl. = Stevia rebaudiana (Bertoni) Bertoni.

Stevia reclinata Rusby, Bull. New York Bot. Gard. 8: 127. 1912.

Stevia reglensis Benth., Pl. Hartw. 40. 1840. = Stevia ovata Willd.

Stevia regnellii Schultz-Bip., Linnaea 22: 572 . 1849, Linnaea 25:

272. 1853. = Stevia tenuis Hook. \& Arn.

Stevia resinosa Gardner, London J. Bot. 5: 457.1846.

Stevia reticulata Grashoff, Brittonia 26: 370(-373). 1974.

Stevia revoluta B. Robinson, Proc. Amer. Acad. Arts 44: 617. 1909.

Stevia rhombifolia H. B. K., Nov. Gen. Sp. 4: 112. Ed. Folio. 1818. = Stevia ovata Willd.

Stevia riedelii Schultz-Bip. ex Baker, Fl. Bras. 6(2): 204. 1876.

Stevia rojasii Hassler, Feddes Repert. 11: 167. 1912.

Stevia rosei B. Robinson. Proc. Amer. Acad. Arts 35: 327. 1900.

Stevia rzedowskii McVaugh, Contr. Univ. Michigan Herb. 9: 404. 1972.

Stevia sabulonis B. Robinson, Contr. Gray Herb. 96: 14. 1931.

Stevia salicifolia Cav., Icon. 4: 32. T. 354. 1797.

Stevia saltensis Hieron., Bot. Jahrb. Syst. 22: 725. 1897. = Stevia yaconensis Hieron.

Stevia salviaefolia G. Don, Hort. Brit. 335. 1830?, ignota.

Stevia samaipatensis B. Robinson, Contr. Gray Herb. 96: 15. 1931.

Stevia sanguinea Hieron., Bot. Jahrb. Syst. 22: 714. 1897.

Stevia santacruzensis Hieron., Bot. Jahrb. Syst. 22: 731. 1897.
Stevia sarensis B. Robinson, Contr. Gray Herb. 100: 9. 1932.

Stevia satureiaefolia (Lam.) Schultz-Bip. in Klotzsch, Linnaea 25: 291. 1853, comb. superfl. = Stevia satureifolia (Lam.) Lam.

Stevia satureifolia (Lam.) Lam., Anales Ci. Nat. 6: 317. 1802.

Stevia satureifolia var. maimarensis Hieron., Bot. Jahrb. Syst. 22: 737. 1897. = Stevia maimarensis (Hieron.) Cabrera.

Stevia scabrella Benth., Pl. Hartw. 19. 1839.

Stevia scabridula B. Robinson, Contr. Gray Herb. 90: 19. 1930. = Stevia origanoides H. B. K. × Stevia stricta Hornem. ?

Stevia schickendantzii Hieron., Bot. Jahrb. Syst. 22: 717. 1897. Stevia schreiteri B. Robinson, Contr. Gray Herb. 90: 19. 1930.

Stevia schultzii Hieron., Bot. Jahrb. Syst. 22: 721. 1897. = Stevia boliviensis Schultz-Bip. ex Rusby.

Stevia seemanioides Grashoff, Brittonia 26: 373(-375). 1974.

Stevia seemannii Schultz-Bip. in Seemann, Bot. Voy. Herald 298. 1856.

Stevia seleriana B. Robinson, Proc. Amer. Acad. Arts 35: 327. 1900.

Stevia selloi (Sprengel) B. Robinson, Contr. Gray Herb. 90: 88. 1930.

Stevia semperflorens Ten. ex DC., Prodr. 5: 117. 1836, nom. inval. = Stevia salicifolia Cav.

Stevia sempervirens Steudel, Nomencl. Bot. 2:641 . 1841. = Stevia salicifolia Cav.

Stevia serrata Cav., Icon. 4: 33. T. 355. 1797.

Stevia serrata var. ovalis B. Robinson, Proc. Amer. Acad. Arts 29: 317. 1894. = Stevia ovalis (B. Robinson) B. Robinson.

Stevia setifera Rusby ex B. Robinson, Contr. Gray Herb. 100: 10. 1932.

Stevia simplicitatis Herter, Revista Sudamer. Bot. 4: 200. 1937, nom. nud. ignota.

Stevia simulans B. Robinson, Proc. Amer. Acad. Arts 42: 34. 1906. = Cronquistia pringlei (S. Watson) R. King.

Stevia soratensis Hieron., Bot. Jahrb. Syst. 28: 560. 1901.

Stevia soratensis Hieron. in Urban, Bot. Jahrb. Syst. 40: 356. 1908. = Stevia soratensis Hieron.

Stevia sphacelata Nutt. ex Torrey, Ann. Lyceum Nat. Hist. New York 2: 214. 1828. = Palafoxia sphacelata (Nutt. ex Torrey) Cory. Heliantheae.

Stevia stenocephala Schultz-Bip., Bull. Soc. Bot. France 12: 81. 1865. = Stevia soratensis Hieron.

Stevia stenophylla A. Gray, Proc. Amer. Acad. Arts 15: 25. 1880. = Stevia salicifolia Cav.

Stevia stricta Hornem., Hort. Bot. Hafn. 2: 792. 1813-1815.

Stevia stuebelii Hieron., Bot. Jahrb. Syst. 21: 328. 1895.

Stevia suaveolens Lagasca, Gen. Sp. Pl. 27. 1816.

Stevia subhirsuta Lagasca cx Reichb., Iconogr. Bot. Pl. Crit. 2: 33. T. 188. 1828. = Stevia stricta Hornem., ?

Stevia suboctoaristata Lagasca, Gen. Sp. Pl. 27. 1816, ignota.

Stevia subpubescens Lagasca, Gen. Sp. Pl. 28. 1816.

Stevia talpensis Grashoff, Brittonia 26: 375. 1974.

Stevia tapacariensis Hieron., Bot. Jahrb. Syst. 22: 734. 1897. = Stevia bangii Rusby.

Stevia tarijensis Hieron. in Urban, Bot. Jahrb. Syst. 40: 362. 1908.

Stevia tenella Mocino ex DC., Prodr. 5: 121. 1836, nom. inval. $=$ Stevia micrantha Lagasca.

Stevia tenuifolia D. Don ex Hook. \& Arn., Companion Bot. Mag. 1: 238. 1835. = Stevia satureifolia Lam.

Stevia tenuifolia Philippi, Anales Univ. Chile USE \#1415 2: 397. 1862, Linnaea 33: 128. 1864-1865. = Stevia gilliesii Hook. \& Arn.

Stevia temuis Hook. \& Arn., Companion Bot. Mag. 1: 239. 1835.

Stevia tephra B. Robinson, Proc. Amer. Acad. Arts 35: 328. 1900.

Stevia tephrophylla S. F. Blake, Contr. U. S. Natl. Herb. 22: 590. 1924.

Stevia ternifolia H. B. K., Nov. Gen. Sp. 4: 115. Ed. Folio. 1818. = Stevia ovata Willd. 
Steviatomentosa H. B. K., Nov. Gen. Sp. 4: 114. Ed. Folio. 1818. Stevia tomentosa Schauer, Linnaea 19: 719. 1847. = Stevia suaveolens Lagasca.

Stevia totorensis B. Robinson, Contr. Gray Herb. 96: 16. 1931.

Stevia trachelioides DC., Prodr. 5: 115. 1836. = Stevia monar. daefolia H. B. K.

Stevia trachelioides Hook., Bot. Mag. T. 3856. 1841. = Stevia jorullensis H. B. K.

Stevia triangularis Grashoff, Brittonia 26: 375(-376). 1974.

Stevia triaristata Hieron. in Urban, Bot. Jahrb. Sysi. 40: 358. 1908.

Stevia trichopoda Harvey \& A. Gray ex A. Gray, Mem. Amer. Acad. Arts 4: 64. 1849. = Stevia elatior H. B. K.

Stevia trifida Lagasca, Gen. Sp. Pl. 27. 1816.

Stevia triflora DC., Prodr. 5: 115. 1836.

Stevia tunariensis Hieron., Bot. Jahrb. Syst. 22: 713. 1897.

Stevia tunguraguensis Hieron., Bot. Jahrb. Syst. 28: 563. 1901.

Stevia umbellata Alaman ex DC., Prodr. 5: 118. 1836, nom. inval. = Stevia connata Lagasca.

Stevia uniaristata DC., Prodr. 5: 120. 1836. = Stevia ovata Willd.

Stevia urceolata Grashoff, Brittonia 26: 379(-381). 1974.

Stevia urticaefolia Billb. in Thunb., PI. Bras. 1: 13. 1817.

Stevia vaccinioides Koster, Blumea 5: 646. 1945.

Stevia vaga Griseb., Abh. Konigl. Ges-Wiss. Gottingen 19: 116. 1874.

Stevia velutinella Grashoff, Brittonia 26: 381, 1974.

Stevia venosa A. Gray, Proc. Amer. Acad. Arts 21: 382.1886.

Stevia vernicosa Greenman, Proc. Amer. Acad. Arts 40: 33.1904.

Stevia veronicae DC., Prodr. 5: 123. 1836. = Stevia tenuis Hook. \& Arn.

Stevia verticillata Schlechtend., Linnaca 16: 372.1842.

Stevia villaregalis McVaugh, Contr. Univ. Michigan Herb. 9: 407. 1972.

Stevia villaricensis (B. Robinson) Cabrera \& Vittet, Revista Mus. Eva Peron, Secc. Bot. 8: 197. 1954.

Stevia villosa Mocino ex DC., Prodr. 5: 122. 1836, nom. inval. = Stevia viscida $\mathrm{H}$. B. K.

Stevia viminea Schrader, Ind. Sem. Hort. Acad. Gott. 1832, ex DC., Prodr. 5: 117. 1836. = Sievia connata Lagasca.

Stevia violacea Cerv, in Loudon, Hort. Brit. Suppl. 2: 675. 1832?, ignota.

Stevia violacea (Griseb.) Hieron. ex Kuntze, Revis. Gen. Pl. 3: 180. 1898. = Stcvia multiaristata Sprengel.

Stevia virgata H. B. K., Nov. Gen. Sp. 4: 111. Ed. Folio. 1818. = Stevia serrata Cav.

Stevia virgintiseta DC., Prodr. 5: 123. 1836. = Steviopsis vigintiseta (DC.) R. King \& H. Robinson.

Stevia viscida H. B. K.. Nov. Gen. Sp. 4: 110. Ed. Folio. 1818.

Stevia viscosa Hort. ex Steudel, Nomencl. Bot. 2: 642. 1841, nom. nud. = Stevia viscida $\mathrm{H}$. B. K.

Stevia vulcanicola Standley \& Steyerm., Publ. Field Mus. Nat. Hist., Bot. Ser. 23: 27. 1943. = Stevia microchaeta SchultzBip.

Stevia wageneri Hieron., Bot. Jahrb. Syst. 28: 562. 1901.

Stevia weberbaueri B. Robinson, Contr. Gray Herb. 96: 16. 1931.

Stevia westonii R. King \& H. Robinson, Phytologia 35: 229.1977.

Stevia williamsii Standley in Standley \& L. O. Williams, Ceiba 1: $95.1950 .=$ Stevia tephrophylla S. F. Blake.

Stevia yaconensis Hieron., Bot. Jahrb. Syst. 22: 724. 1897.

Stevia yalae Cabrera, Bol. Soc. Argent. Bot. 15: 324. 1974.

Stevia zacatecana McVaugh, Contr. Univ. Michigan Herb. 15: 196. 1982.

Stevia zephyramtha Grashoff, Brittonia 26: 381(-384). 1974.

Steviopsis amblyolepis (B. Robinson) R. King \& H. Robinson,

Phytologia 24: 61. 1972.

Steviopsis arsenei R. King \& H. Robinson, Phytologia 24: 61. 1972.

Steriopsis pulcherrima (B. Robinson) R. King \& H. Robinson,
Phytologia 24:61. 1972. = Steviopsis vigintiseta (DC.) R. King \& H. Robinson.

Steviopsis rapunculoides (DC.) R. King \& H. Robinson, Phytologia 22: 157. 1971.

Steriopsis rigintiseta (DC.) R. King \& H. Robinson, Phytologia 49: 6. 1981.

Steyermarkina dispalata (Gardner) R. King \& H. Robinson, Phytologia 22: 44. 1971.

Steyermarkina dusenii (Malme) R. King \& H. Robinson, Phytologia 22: 44. 1971.

Steyermarkina naiguatensis V. Badillo, Bol. Soc. Venez. Ci. Nat. 22: $35.1976 .=$ Critonia naiguatensis (V. Badillo) R. King \& H. Robinson.

Steyermarkina pyrifolia (DC.) R. King \& H. Robinson, Phytologia 22: 44. 1971.

Steyermarkina triflora R. King \& H. Robinson, Phytologia 22: 44. 1971.

Stomatanthes africanus (Oliver \& Hieron.) R. King \& H. Robinson, Phytologia 19: 430. 1970.

Stomatanthes corumbensis (B. Robinson) H. Robinson, Phytologia 20: 336. 1970.

Stomatanthes dentatus (Gardner) H. Robinson, Phytologia 20: 336. 1970.

Stomatanthes dyctiophyllus (DC.) H. Robinson, Phytologia 20: 336. 1970.

Stomatanthes hirsutus H. Robinson, Phytologia 20: 336. 1970.

Stomatanthes loefgrenii (B. Robinson) H. Robinson, Phytologia 20: 337. 1970.

Stomatanthes meyeri R. King \& H. Robinson, Kew Bull. 30(3): 463. 1975.

Stomatanthes oblongifolius (Sprengel) H. Robinson, Phytologia 20: 337. 1970.

Stomatanthes pernambucensis (B. Robinson) H. Robinson, Phytologia 20: 337. 1970.

Stomatanthes pinnatipartitus (Schultz-Bip. ex Baker) H. Robinson, Phytologia 20: 337. 1970.

Stomatanthes polycephalus (Schultz-Bip. ex B. Robinson) $\mathbf{H}$. Robinson. Phytologia 20: 337. 1970.

Stomatanthes subcapitatus (Malme) H. Robinson, Phytologia 20: 337. 1970.

Stomatanthes trigonus (Gardner) H. Robinson, Phytologia 20: 337. 1970.

Stomatanthes warmingii (Baker) H. Robinson, Phytologia 20: 337. 1970.

Stomatanthes zambiensis R. King \& H. Robinson, Kew Bull 30(3): 465. 1975.

Stylotrichium corymbosum (DC.) Mattf. in Pilger, Notizbl. Bot. Gart. Berlin-Dahlem 8: 437. 1923.

Stylotrichium edmundoi G. Barroso, Arch. Jard. Bot. Rio de Janeiro 15: 24. 1957.

Stylotrichium rotundifolium Mattf. in Pilger, Notizbl. Bot. Gart. Berlin-Dahlem 8: 438.1923.

Stylotrichium sucrei R. King \& H. Robinson, Phytologia 45: 102. 1980.

Suprago sphaerocephala Cass., Dict. Sci. Nat. 51: 386. 1827.= Liatris scariosa Willd.

Suprago spicata (L.) Gaertner, Fruct. Sem. PI. 2: 402. 1791. = Liatris spicata (L.) Willd.

Symphyopappus angustifolius Cabrera, Revista Mus. La Plata, Secc. Bot. 19: 191. 1959.

Symphyopappus brasiliensis (Gardner) R. King \& H. Robinson, Phytologia 39: 134. 1978.

Symphyopappus casarettoi B. Robinson, Candollea 5: 170. 1934.

Symphyopappus cal harinensis (Cabrera) R. King \& H. Robinson, Phytologia 29: 124. 1974. = Neocabreria catharinensis (Cabrera) R. King \& H. Robinson.

Symphyopappus compressus (Gardner) B. Robinson, Contr. Gray Herb. 80: 12. 1928. 
Symphyopappus cuneatus (DC.) Schultz-Bip. ex Baker, Fl. Bras. $6(2): 367.1876$.

Symphyopappus decussatus Turcz., Bull. Soc. Imp. Naturalistes Moscou 21: 584. 1848.

Symphyopappus itatiayensis (Hieron.) R. King \& H. Robinson, Phytologia 22: 116. 1971.

Symphyopappus leptophlebius B. Robinson, Contr. Gray Herb. 96: 18. 1931. = Raulinoreitzia leptophlebia (B. Robinson) R. King \& H. Robinson.

Symphyopappus lymansmithii B. Robinson, Contr. Gray Herb. 96: 19.1931.

Symphyopappus myricifolius B. Robinson, Contr. Gray Herb. 68: 6. 1923. incertae sedis.

Symphyopappus pennivenius B. Robinson, Contr. Gray Herb. 68: 7. 1923. = Neocabreria pennivenia (B. Robinson) R. King \& H. Robinson.

Symphyopappus polystachyus Baker, Fl. Bras. 6(2): 368. 1876. = Symphyopappus compressus (Gardner) B. Robinson.

Symphyopappus reitzii (Cabrera) R. King \& H. Robinson, Phytologia 22: 116. 1971.

Symphyopappus reticulatus Baker, Fl. Bras. 6(2): 367. 1876.

Symphyopappus tetrastichus B. Robinson, Contr. Gray Herb. 104: 8. 1934. = Goyazianthus tetrastichus (B. Robinson) R. King \& H. Robinson.

Symphyopappus vernicosus Schultz-Bip. ex Baker, Fl. Bras. 6(2): 368. 1876, nom. nud. in syn. = Symphyopappus reticulatus Baker.

Symphyopappus viscosus Schultz-Bip., Fl. Bras. 6(2): 367. 1876, nom. nud. = Symphyopappus reticulatus Baker.

Tainaulipa azurea (DC.) R. King \& H. Robinson, Phytologia 22: 154. 1971.

Tamayoa paraguanensis V. Badillo, Bol. Soc. Venez. Ci. Nat. 9: 139. 1944. = Lepidesmia squarrosa Klatt.

Teixeiranthus foliosus (Gardner) R. King \& H. Robinson, Phytologia 47: 109. 1980.

Teixeiranthus pohlii (Baker) R. King \& H. Robinson, Phytologia 50: 379. 1982.

Traganthes compositifolia (Walter) E. Greene, Leafl. Bot. Observ. Crit. 1: 13. 1903. = Eupatorium compositifolium Walter.

Traganthes eugenei (Small) E. Greene, Leaf. Bot. Observ. Crit. 1: 13. 1903. = Eupatorium pinnatifidum Ellis.

Traganthes leptophylla (DC.) E. Greene, Leafl. Bot. Observ. Crit. 1: 13. 1903. = Eupatorium leptophyllum DC.

Traganthes pectinata (Small) E. Greene, Leafl. Bot. Observ. Crit. 1: 13. 1903. = Eupatorium pinnatifidum Ellis.

Traganthes pinnatifida (Elliott) E. Greene, Leafl. Bot. Observ.

Crit. 1: 13. 1903. = Eupatorium pinnatifidum Elliott.

Traganthes tenuifolia Wallr., Sched. Crit. 1: 456, in nota. 1822. $=$ Eupatorium capillifolium (Lam.) Small.

Trichocoronis greggii A. Gray, Smithsonian Contr. Knowl. 3: 89. $1850 .=$ Trichocoronis sessilifolia (Schauer) B. Robinson.

Trichocoronis riparia (E. Greene) E. Greene, Erythea 1: 42.1893. $=$ Trichocoronis wrightii (Torrey \& A. Gray) A. Gray.

Trichocoronis rivularis A. Gray, Mem. Amer. Acad. Arts n. s. 4: 66. 1849. = Shinnersia rivularis (A. Gray) R. King \& H. Robinson.

Trichocoronis sessilifolia (Schauer) B. Robinson, Proc. Amer. Acad. Arts 42: 35. 1906.

Trichocoronis wrightii (Torrey \& A. Gray) A. Gray, Mem. Amer. Acad. Arts n. s. 4: 65. 1849.

Trichogonia alba V. Badillo, Bol. Soc. Venez. Ci. Nat. 10: 295. 1946. = Trichogonia rhadinocarpa B. Robinson.

Trichogonia apparicioi G. Barroso, Arch. Jard. Bot. Rio de Janeiro 11: 14. 1951. = Trichogonia hirtiflora (DC.) Schultz-Bip. ex Baker.

Trichogonia arguta (H. B. K.) Benth. \& Hook. f. ex Klatt, Bot. Jahrb. Syst. 8: 33.1886.
Trichogonia attenuata G. Barroso, Arch. Jard. Bot. Rio de Janeiro 11: 14. 1951.

Trichogonia barrosoana G. Barroso, Arch. Jard. Bot. Rio de Janeiro 11: 13. 1951.= Campuloclinium campuloclinioides (Baker) R. King \& H. Robinson.

Trichogonia bishopii R. King \& H. Robinson, Phytologia 39: 334. 1978 .

Trichogonia campestris Gardner, London J. Bot. 5: 459. 1846.

Trichogonia capitata (Rusby) B. Robinson, Proc. Amer. Acad. Arts 47: 193. 1911.

Trichogonia chodatii (Hassler) R. King \& H. Robinson, Phytologia 24: 178. 1972.

Trichogonia cinerea (Gardner) R. King \& H. Robinson, Phytologia 24: 178. 1972.

Trichogonia dubia (B. Robinson) R. King \& H. Robinson, Phytologia 24: 178. 1972.

Trichogonia eupatorioides (Gardner) R. King \& H. Robinson, Phytologia 45: 106. 1980. = Trichogonia menthaefolia Gardner.

Trichogonia fiebrigii Mattf. in Pilger, Notizbl. Bot. Gart. BerlinDahlem 8: 450. 1923.

Trichogonia gardneri A. Gray, Hooker's J. Bot. Kew Gard. Misc. 3: 224. 1851. = Trichogoniopsis adenantha (DC.) R. King \& H. Robinson.

Trichogonia grazielae R. King \& H. Robinson, Phytologia 45: 106. 1980.

Trichogonia harleyi R. King \& H. Robinson, Phytologia 39: 335. 1978.

Trichogonia hassleri Mattf. in Pilger, Notizbl. Bot. Gart. BerlinDahlem 8: 449. 1923.

Trichogonia heringeri R. King \& H. Robinson, Phytologia 45: 107. 1980.

Trichogonia hirtiflora (DC.) Schultz-Bip. ex Baker, Fl. Bras. 6(2): 214. 1876.

Trichogonia laxa Gardner, London J. Bot. 6: 435. 1847

Trichogonia leiantha Schultz-Bip. ex Baker, Fl. Bras. 6(2): 215. 1876, nom. nud. in syn. = Trichogoniopsis adenantha (DC.) R. King \& H. Robinson.

Trichogonia macrolepis Baker, Fl. Bras. 6(2): 215. 1876. = Trichogoniopsis podocarpa (DC.) R. King \& H. Robinson.

Trichogonia margarethi Soares Nunes, Bradea 3: 131(-132). 1981.

Trichogonia martii Baker, Fl. Bras. 6(2): 216. 1876.

Trichogonia melissaefolia (DC.) Mattf. in Pilger, Notizbl. Bot. Gart. Berlin-Dahlem 8: 450. 1923. = Platypodanthera melissaefolia (DC.) R. King \& H. Robinson.

Trichogonia menthaefolia Gardner, London J. Bot. 6: 434.1847.

Trichogonia multiflora Gardner, London J. Bot. 5: 460. 1846. = Trichogonia villosa Schultz-Bip. ex Baker.

Trichogonia phlebodes (B. Robinson) R. King \& H. Robinson, Phytologia 24: 178. 1972.

Trichogonia podocarpa (DC.) Schultz-Bip. ex Baker, Fl. Bras. 6(2): 216. 1876. = Trichogoniopsis podocarpa (DC.) R. King \& H. Robinson.

Trichogonia prancii G. Barroso, Loefgrenia 36: 3. 1969.

Trichogonia pseudocampestris R. King \& H. Robinson, Phytologia 45: 108. 1980.

Trichogonia rhadinocarpa B. Robinson, Proc. Amer. Acad. Arts 42: 36. 1906.

Trichogonia rhodotricha Malme, Kongl. Svenska Vetenskapsakad. Handl. Ser. 3. 12(2): 30. 1933.

Trichogonia salviaefolia Gardner, London J. Bot. 5: 460. 1846.

Trichogonia santosii R. King \& H. Robinson, Phytologia 45: 110. 1980.

Trichogonia scabra Klatt, Arbeiten Bot. Mus. Hamb. 3. 1890. = Campuloclinium tubaraoense (Hieron.) R. King \& H. Robinson.

Trichogonia scottmorii R. King \& H. Robinson, Phytologia 45: 110. 1980. 
Trichogonia selloi Schultz-Bip. ex Baker, Fl. Bras. 6(2): 215. 1876, nom. nud. in syn. = Trichogoniopsis adenantha (DC.) R. King \& H. Robinson.

Trichogonia spathulaefolia Mattf. in Pilger, Notizbl. Bot. Gart. Berlin-Dahlem 8: 445. 1923.

Trichogonia tombadorensis R. King \& H. Robinson, Phytologia 45: 111. 1980.

Trichogonia villosa Schultz-Bip. ex Baker, Fl. Bras. 6(2): 213. 1876.

Trichogonia viscosa Schultz-Bip. ex Kraschen., Bot. Mater. Gerb. Glavn. Bot. Sada RSFSR 3: 161. 1922, nom. nud. in syn. = Acritopappus longifolius (Gardner) R. King \& H. Robinson.

Trichogonia zehntneri Mattf. in Pilger, Notizbl. Bot. Gart. BerlinDahlem 8: 446. 1923.

Trichogoniopsis adenantha (DC.) R. King \& H. Robinson, Phytologia 24: 181. 1972.

Trichogoniopsis grazielae Soares Nunes, Bradea 3: 132. 1981.

Trichogoniopsis macrolepis (Baker) R. King \& H. Robinson, Phytologia 24: 181. 1972. = Trichogoniopsis podocarpa (DC.) R. King \& H. Robinson.

Trichogoniopsis morii R. King \& H. Robinson, Phytologia 45: 113. 1980.

Trichogoniopsis podocarpa (DC.) R. King \& H. Robinson, Phytologia 45: 113.1980.

Trilisa carnosa (Small) B. Robinson, Contr. Gray Herb. 104: 49. 1934. = Litrisa carnosa Small.

Trilisa odoratissima (J. Gmelin) Cass., Bull. Sci. Soc. Philom. Paris 1818: 140. 1818.

Trilisa paniculata (J. Gmelin) Cass., Dict. Sci. Nat. 55: 310.1828.

Trychinolepis hoppii B. Robinson, Contr. Gray Herb. 80: 6. 1928. = Ophryosporus hoppii (B. Robinson) R. King \& H. Robinson.

Tuberostyles axillaris Blake, J. Wash. Acad. Sci. 33: 265.1943.

Tuberostyles rhizophorae Steetz in Seemann, Bot. Voy. Herald 142. 1854.

Uleophytum scandens Hieron. in Ule, Verh. Bot. Vereins Prov. Brandenburg 48: 199. 1907.

Uncasia alba (L.) E. Greene, Leafl. Bot. Observ. Crit. 1: 13.1903. = Eupatorium album L.

Uncasia altissima (L.) E. Greene, Leafl. Bot. Observ. Crit. 1: 13. 1903. = Eupatorimm altissimum L.

Uncasia anomala (Nash) E. Greene, Leafl. Bot. Observ. Crit. 1: 13. 1903. = Eupatorium anomalum Nash.

Uncasia cuneata (Engelm. ex Torrey \& A. Gray) E. Greene, Leafl. Bot. Observ. Crit. 1: 13. 1903, nom. nud. = Eupatorium perfoliatum L.

Uncasia cuneifolia (Willd.) E. Greene, Leafl. Bot. Observ. Crit. 1: 13. 1903. = Eupatorium cuneifolium Willd.

Uncasia glomerata (DC.) E. Greene, Leafl. Bot. Observ. Crit. 1: 13. 1903. = Cronquistianthus glomeratus (DC.) R. King \& H. Robinson.

Uncasia hyssopifolia (L.) E. Greene, Leafl. Bot. Observ. Crit. 1: 13. 1903. = Eupatorium hyssopifolium L.

Uncasia lecheaefolia (E. Greene) E. Greene, Leafl. Bot. Observ. Crit. 1: 13. 1903. = Enpatorium hyssopifolium L.

Uncasia lencolepis (Torrey \& A. Gray) E. Grcene, Leafl. Bot. Observ. Crit. 1: 13. 1903. = Eupatorium lencolepis Torrey \& A. Gray.

Uncasia linearifolia (Walter) E. Greene, Leafl. Bot. Observ. Crit. 1: 13. 1903. = Eupatorium cuneifolium Willd.

Uncasia mikanioides (Chapman) E. Greene, Leafl. Bot. Observ. Crit. 1: 13. 1903. = Eupatorium mikanioides Chapman.

Uncasia mohrii (E. Greene) E. Greene, Leafl. Bot. Observ. Crit. 1: 13. 1903. = Eupatorium mohrii E. Greene.

Uncasia pallescens (DC.) E. Greenc, Leafl. Bot. Observ. Crit. 1: 13. 1903. = Austroeupatorium imulaefolium (H. B. K.) R. King \& H. Robinson.

Uncasia perfoliata (L.) E. Greene, Leaft. Bot. Observ. Crit. 1: 13. 1903. = Eupatorium perfoliatum L.
Uncasia petaloidea (Britton ex Small) E. Greene, Leafl. Bot. Observ. Crit. 1: 13. 1903. = Eupatorium album L.

Uncasia pubescens (Muhlenb. ex Willd.) E. Greene, Leafl. Bot. Observ. Crit. 1: 13. 1903. = Eupatorium rot undifolium L.

Uncasia resinosa (Torrey) E. Greene, Leafl. Bot. Observ. Crit. 1: 13. 1903. = Eupatorium resinosum Torrey ex DC.

Uncasia rotundifolia (L.) E. Greene, Leafl. Bot. Observ. Crit. 1: 13. 1903. = Eupatorium rotundifolium L.

Uncasia salvia (Colla) E. Greene, Leafl. Bot. Observ. Crit. 1: 13. 1903. = Aristeguietia salvia (Colla) R. King \& H. Robinson.

Uncasia scabrida (Elliott) E. Greene, Leafl. Bot. Observ. Crit. 1: 13. 1903. = Eupatorium rotundifolium $\mathrm{L}$.

Uncasia semiserrata (DC.) E. Greene, Leafl. Bot. Observ. Crit. 1: 13. 1903. = Eupatorium semiserratum DC.

Uncasia serotina E. Greene, Leafl. Bot. Observ. Crit. 1: 13. 1903. = Eupatorium serotinum Michaux.

Uncasia sessilifolia (L.) E. Greene, Leafl. Bot. Observ. Crit. 1: 13. 1903. = Eupatorium sessilifolium L.

Uncasia torreyana (Short \& Peter) E. Greene, Leafl. Bot. Observ. Crit. 1: 13. 1903. = Eupatorium hyssopifolium L.

Uncasia tortifolia $\times$ (Chapman) E. Greene, Leafl. Bot. Observ. Crit. 1: 13. 1903. = Eupatorium cuneifolium Willd.

Uncasia truncata (Muhlenb. ex Willd.) E. Greene, Leaf. Bot. Observ. Crit. 1: 13. 1903. Eupatorium perfoliatum L.

Uncasia verbenaefolia (Michaux) E. Greene, Leafl. Bot. Observ. Crit. 1: 13. 1903. = Eupatorium rotundifolium L.

Urbananthus critoniformis (Urban) R. King \& H. Robinson, Phytologia 22: 55. 1971.

Urbananthus pluriseriatus (B. Robinson) R. King \& H. Robinson, Phytologia 22: 55. 1971.

Urolepis hecatantha (DC.) R. King \& H. Robinson, Phytologia 21: 305.1971

Vernonia hirsutiflora Poiret, Encycl. 8: 502. 1808. = Liatris squarrosa (L.) Willd.

Vernonia humilis C. H. Wright, Kew Bull. 1897: 269. 1897. = Stomatanthes africanus (Oliver \& Hieron.) R. King \& H. Robinson.

Vernonia lychnophoroides Glaz., Mem. Soc. Bot. France 56, Mem. 3: 368. 1909, nom. nud. = Planaltoa lychnophoroides G. Barroso.

Vernonia malosana Baker, Kew Bull. 1898: 148. 1898. = Stomatanthes africanus (Oliver \& Hieron.) R. King \& H. Robinson.

Viereckia tamaulipasensis R. King \& H. Robinson, Phytologia 31: 118. 1975.

Vittetia bishopii R. King \& H. Robinson, Phytologia 49: 281. 1981.

Vittetia orbiculata (DC.) R. King \& H. Robinson, Phytologia 29: 122. 1974.

Wikstroemia glandulosa Sprengel, Kongl. Vetensk. Acad. Handl. 1821: 167, pl. 3. 1821. = Critonia dalea (L.) DC.

Willoughbya acuminata (DC.) Kuntze, Revis. Gen. Pl. 372.1891. = Mikania acuminata DC.

Willoughbya amazonica (Baker) Kuntze, Revis. Gen. PI. 372. 1891. = Mikania sprucei Baker.

Willoughbya ambigua (DC.) Kuntze, Revis, Gen. PI. 372. 1891.

= Mikania sulcata (Hook. \& Am.) B. Robinson.

Willoughbya andrachne (DC.) Kuntze, Revis. Gen. Pl. 372. 1891.

= Mikania trinervis Hook. \& Am.

Willoughbya angularis (Humb. \& Bonpl.) Kuntze, Revis. Gen.

P1. 372. 1891. = Mikania angularis Humb. \& Bonpl.

W'illonghby'a angulata (Llave) Kuntze, Revis. Gen. PI. 372. 1891.

= Mikania pyramidata J. D. Smith, ?

Willoughbya argyreia (DC.) Kuntze, Revis. Gen. P1. 372. 1891.

= Mikania argyreiae DC.

Willoughbya argyrostigma (Miq.) Kuntze, Revis. Gen. Pl. 372. 1891. = Mikania guaco Humb. \& Bonpl. 
Willoughbya armigera (Poeppig \& Endl.) Kuntze, Revis. Gen. Pl. 372. 1891. = Mikania laxa DC.

Willoughbya aspera (Miq.) Kuntze, Revis. Gen. Pl. 372. 1891. = Mikania guaco Humb. \& Bonpl.

W'illoughbva attentrata (DC.) Kuntze, Revis. Gen. Pl. 372. 1891. = Mikania guaco Humb. \& Bonpl., ?

Willoughbya auriculata (Lam.) Kuntze, Revis. Gen. P1. 372. 1891. = Senecio deltoideus Less. SenecioneAE.

Willoughbya badieri (DC.) Kuntze, Revis. Gen. Pl, 372. 1891. = Mikania hookeriana DC.

Willonghbya bangii Rusby, Mem. Torrey Bot. Club 3(3): 53. 1893. = Mikania decora Poeppig \& Endl.

Willoughbya banisteriae (DC.) Kuntze, Revis. Gen. PI. 372. 1891. - Mikania banisteriae DC

Willoughbya bogotensis (Benth.) Kuntze, Revis. Gen. PI. 372. 1891. = Mikania bogotensis Benth.

Willoughbya brachiata (Poeppig \& Endl.) Kuntze, Revis. Gen. Pl. 372. 1891. = Mikania brachiata Poeppig \& Endl.

Willoughbya bracteosa (DC.) Kuntze, Revis. Gen. Pl. 372. 1891. = Mikania involucrata Hook. \& Arn.

Willoughbya buddleiaefolia (DC.) Kuntze, Revis. Gen. Pl. 372. 1891. = Mikania buddleiaefolia DC.

Willoughbya burchellii (Baker) Kuntze, Revis. Gen. Pl. 372. 1891. = Mikania burchellii Baker.

Willoughbya callineura (Schultz-Bip. ex Baker) Kuntze, Revis. Gen. Pl. 372. 1891. = Mikania callineura Schultz-Bip. ex Baker.

Willoughbya campanulata (Gardner) Kuntze, Revis. Gen. Pl. 372. 1891. = Mikania campanulata Gardner.

Willoughbya candolleana (Gardner) Kuntze, Revis. Gen. Pl. 372. 1891. = Mikania candolleana Gardner.

Willoughbya caudata (Benth.) Kuntze, Revis. Gen. P1. 372. 1891. = Mikania banisteriae DC.

Willoughbya chagalensis Hieron., Bot. Jahrb. Syst. 19: 47. 1895, nom. nud. in syn. = Mikania chagalensis Hieron.

IVilloughbya charna (Griseb.) Kuntze, Revis. Gen. Pl. 372. 1891. = Oplirvosporus charua (Griseb.) Hieron.

Willoughby'a chlorolepis (Baker) Kuntze, Revis. Gen. PI. 372. 1891. = Mikania chlorolepis Baker.

Willoughbya cissampelina (DC.) Kuntze, Revis. Gen. P1. 372. 1891 = Mikania cordifolia (L. f.) Willd.

Willonghbya clavellata (DC.) Kuntze, Revis. Gen. PI. 372. 1891. = Ophryosporus freyreysii (Thunb. \& Dallm.) Baker.

Willoughbya coarctata (Gardner) Kuntze, Revis. Gen. Pl. 372. 1891. = Mikania coarctata Gardner.

Willoughbya complanata (Gardner) Kuntze, Revis. Gen. PI. 372 1891. = Mikania obovata DC.

Willoughbya conferta (Gardner) Kuntze, Revis. Gen. Pl. 372 1891. = Mikania conferta Gardner.

Willoughbya confertissima (Schultz-Bip. ex Baker) Kuntze, Revis. Gen. Pl. 372. 1891 = Mikania confertissima Schultz-Bip. ex Baker.

Willoughbya cordifolia (L. f.) Kuntze, Revis. Gen. PI. 372. 1891 = Mikania cordifolia (L. f.) Willd.

Willoughbya coriacea (Llave) Kuntze, Revis. Gen. Pl. 372. 1891. = Mikania coriacea Llave.

Willoughbya corydalifolia (Griseb.) Kuntze, Revis. Gen. Pl. 372 1891. = Mikania ranunculifolia Rich. ex Sagra.

Willoughbya corymbulosa (Benth.) Kuntze, Revis. Gen. Pl. 372. 1891. = Mikania corymbulosa Benth.

Willoughbya dentata (Sprengel) Kuntze, Revis. Gen. Pl. 372. 1891 . = Mikania ternata (Vell. Conc.) B. Robinson.

Willonghbya dioscoreoides Rusby, Mem. Torrey Bot. Club 6: 58. 1896-1899. = Mikania dioscoreoides (Rusby) B. Robinson.

Willoughbya discolor (Baker) Kuntze, Revis. Gen. PI. 372. 1891. = Mikania buddleiaefolia DC.

Willoughbya divaricata (Poeppig \& Endl.) Kuntze, Revis. Gen. P1. 372. 1891. = Mikania divaricata Poeppig \& Endl.
Willoughbya diversifolia (DC.) Kuntze, Revis. Gen. Pl. 372. 1891. = Mikania diversifolia DC.

Willoughbya erioclada (DC.) Kuntze, Revis. Gen. P1. 372. 1891. = Mikania erioclada DC.

Willoughbya eriophora (Schultz-Bip.) Kuntze, Revis. Gen. Pl. 372. 1891. = Mikania pyramidata J. D. Smith.

Willoughbya erithalina (DC.) Kuntze, Revis. Gen. P1. 372. 1891. = Mikania nitida (DC.) R. King \& H. Robinson.

Willoughbya estrellensis (Baker) Kuntze, Revis. Gen. P1. 372. 1891. = Mikania trinervis Hook. \& Arn.

Willoughbya ferruginea Rusby, Mem. Torrey Bot. Club 6: 58. 1896-1899. = Mikania ferruginea (Rusby) B. Robinson.

Willoughbya firmula (Baker) Kuntze, Revis. Gen. P1. 372. 1891. = Mikania nigricans Gardner.

Willoughbya flavescens (Gardner) Kuntze, Revis. Gen. Pl. 372. 1891. = Mikania nummularia DC.

Willoughbya fulva (Hook. \& Arn.) Kuntze, Revis. Gen. PI. 372. 1891. = Mikania fulva (Hook. \& Arn.) Baker.

Willoughbya gabrieli (Baker) Kuntze, Revis. Gen. P1. 372. 1891. = Mikania banisteriae DC.

Willoughbya gardneriana Kuntze, Revis. Gen. Pl. 372. 1891, nom. nov. = Mikania microcephala DC.

Willoughbya glauca (Martius ex Baker) Kuntze, Revis. Gen. Pl. 372. 1891. = Mikania glauca Martius ex Baker.

Willoughbya glaziovii (Baker) Kuntze, Revis. Gen. Pl. 372. 1891. = Mikania glaziovii Baker.

Willoughbya globosa Coulter, Bot. Gaz. (Crawfordsville) 20: 46. 1895. = Mikania aromatica Oersted.

Willoughbya glomerata (Sprengel) Kuntze, Revis. Gen. PI. 372. 1891. = Mikania glomerata Sprengel.

Willoughbya gracilis (Schultz-Bip. \& Miq.) Kuntze, Revis. Gen. P1. 372. 1891. = Mikania vitifolia DC.

Willoughbya guaco (H. B. K.) Kuntze, Revis. Gen. Pl. 372. 1891. = Mikania guaco Humb. \& Bonpl.

Willoughbya haenkeana (DC.) Kuntze, Revis. Gen. Pl. 372. 1891. = Mikania haenkeana DC.

Willoughbya halei Small, Fl. S. E. U. S. 1170. 1903. = Mikania cordifolia (L. f.) Willd.

Willoughbya hastata (L.) Kuntze, Revis. Gen. P1. 372. 1891. = Mikania hastata (L.) Willd.

Willoughbya hastifolia (Baker) Kuntze, Revis. Gen. Pl. 372. 1891. = Mikania hastifolia Baker.

Willoughbya hemisphaerica (Schultz-Bip. ex Baker) Kuntze, Revis. Gen. Pl. 372. 1891. = Mikania hernisphaerica SchultzBip. ex Baker.

Willoughbya heterophylla Smal1, Fl. S. E. U. S. 1170. 1903. = Mikania batataefolia DC.

Willoughbya hieronymi Rusby, Bull. New York Bot. Gard. 4: 383. 1907. = Mikania speciosa DC.

Willoughbya hirsutissima (DC.) Kuntze, Revis. Gen. PI. 372 1891. = Mikania hirsutissima DC.

Willoughbya hispida (Gardner) Kuntze, Revis. Gen. Pl. 372. 1891. = Mikania conferta Gardner.

Willoughbya houstonis (Willd.) Kuntze, Revis. Gen. Pl. 372.1891. = Mikania houstoniana (L.) B. Robinson.

Willoughbya imrayana (Griseb.) Kuntze, Revis. Gen. Pl. 372. 1891. = Mikania hookeriana DC.

Willonghbya itambana (Gardner) Kuntze, Revis. Gen. Pl. 372. 1891. = Mikania itambana Gardner.

Willoughbya lagoensis (Baker) Kuntze, Revis. Gen. Pl. 372.1891. = Mikania lagoensis Baker.

Willoughbya lanuginosa (DC.) Kuntze, Revis. Gen. Pl. 372.1891 = Mikania lanuginosa DC.

Willoughbya lasiandra (DC.) Kuntze, Revis. Gen PI. 372. 1891. = Mikania lasiandrae DC.

Willoughbya latifolia (Smith) Kuntze, Revis. Gen. P1. 372. 1891. = Mikania latifolia Smith in Rees. 
Willoughbya laurifolia (L. f.) Kuntze, Revis. Gen. PI. 372. 1891. = Mikania laurifolia (L. f.) Willd.

Willoughbya laxa (DC.) Kuntze, Revis. Gen. Pl. 372. 1891. = Mikania laxa DC.

Willoughbya lehmannii Hieron., Bot. Jahrb. Syst. 19: 46. 1895, nom. nud. in syn. = Mikania lehmannii Hieron.

Willoughbya leiolaena (DC.) Kuntze, Revis. Gen. Pl. 372. 1891 = Mikania leiolaena DC.

Willoughbya leiostachya (Benth.) Kuntze, Revis. Gen. PI. 372. 1891. = Mikania leiostachya Benth.

Willoughbya leptotricha (Baker) Kuntze, Revis. Gen. Pl. 372. 1891. = Mikania leptotricha Baker.

Willoughbya lencophylla Rusby, Bull. New York Bot. Gard. 4: 382. 1907. = Mikania leucophylla (Rusby) B. Robinson.

Willoughbya ligustrifolia (DC.) Kuntze, Revis. Gen. Pl. 372. 1891. = Mikania ligustrifolia DC.

Willoughbya lindbergii (Baker) Kuntze, Revis. Gen. PI. 372. 1891. = Mikania lindbergii Baker.

Willoughbya lindleyana (DC.) Kuntze, Revis. Gen. PI. 372. 1891. = Mikania lindleyana DC.

Willoughbya linearifolia (DC.) Kuntze, Revis. Gen. PI. 372. 1891. = Mikania linearifolia DC.

Willoughbya longiacuminata Rusby, Mem. Torrey Bot. Club 6: 59. 1896-1899. = Mikania longiacuminata (Rusby) B. Robinson.

Willoughbya longiflora Rusby, Bull. New York Bot. Gard. 4: 382. 1907. = Mikania longiflora (Rusby) B. Robinson.

Willoughbya longipes (Baker) Kuntze, Revis. Gen. P1. 372. 1891. = Mikania longipes Baker.

Willonghbya loxensis (H. B. K.) Kuntze, Revis. Gen. Pl. 372. 1891. = Mikania cordifolia (L. f.) Willd.

Willoughbva Iundiana (DC.) Kuntze, Revis. Gen. PI. 372. 1891. = Mikaria lundiana DC.

Willoughbya micrantha(H. B. K.) Rusby, Mem. Torrey Bot. Club 4: 211. 1895. = Mikania micrantha H. B. K.

Willoughbya microcephala (DC.) Kuntze, Revis. Gen. PI. 372. 1891. = Mikania microcephala DC

Willoughbya microdonta (DC.) Kuntze, Revis. Gen. PI. 372. 1891. = Mikania microdonta DC.

Willoughby'a microlepis (Baker) Kuntze, Revis. Gen. PI. 372. 1891. = Mikania microlepis Baker.

Willonghbya microphylla (Schultz-Bip. ex Baker) Kuntze, Revis. Gen. PI. 372. 1891. = Mikania microphylla Schultz-Bip. ex Baker.

Willouglibya moronoa (Kuntze) Kuntze, Revis. Gen. Pl. 372. 1891. = Mikania glomerata Sprengel.

Willoughbya multinenia (Turcz.) Kuntze, Revis. Gen. PI. 372. 1891. = Mikania multinersia Turcz.

Willonghbya myriocephala (DC.) Kuntze, Revis. Gen. PI. 372. 1891. = Mikania myriocepliala DC.

Willoughbya neurocaula (DC.) Kuntze, Revis. Gen. PI. 372. 1891. = Mikania neurocaula DC.

Wrillonghbya nigricans (Gardner) Kuntze, Revis. Gen. PI. 372. 1891. = Mikania nigricans Gardner.

Willoughbya nitidula (Baker) Kuntze, Revis. Gen. P1. 372.1891. = Mikania lindhergii Baker.

Willoughbya nodosa (Sprengel) Kuntze, Revis. Gen. PI. 372.1891. = Mikania nodosa Sprengel.

Willouglbbya nodulosa (Schultz-Bip. ex Baker) Kuntze, Revis. Gen.PI. 372. 1891. = Mfikania nodulosa Schultz-Bip. ex Baker.

Willoughbya nummularia (DC.) Kuntze, Revis. Gen. PI. 372. 1891. = Mikania numumularia DC.

Willonghbva oblongifolia (DC.) Kuntze, Revis. Gen. PI. 372. 1891. = Mikania oblongifolia DC.

Willoughbya obovata (DC.) Kuntze, Revis. Gen. Pl. 372.1891.

= Mikania obovata DC.

Willoughbya obtusata (DC.) Kuntze, Revis. Gen. Pl. 372.1891.

= Mikania obtusata DC.
W'illoughbya odorata (Lehm.) Kuntze, Revis. Gen. Pl. 372. 1891 = Mikania fastuosa Lemaire.

Willoughbya odorata Rusby, Bull. New York Bot. Gard. 4: 381 . 1907. = Mikania haenkeana DC.

Willoughbya officinalis (Martius) Kuntze, Revis. Gen. Pl. 372. 1891. = Mikania officinalis Martius.

Willoughbya ovalis (Griseb.) Kuntze, Revis. Gen. Pl. 372. 1891. = Mikania ovalis Griseb.

Willoughbya oxylepis (Schultz-Bip. ex Baker) Kuntze, Revis. Gen. Pl. 372. 1891. = Mikania oxylepis Schultz-Bip. ex Baker.

Willoughbya pachylepis (Schultz-Bip. ex Baker) Kuntze. Revis. Gen. Pl. 372. 1891. = Mikania rufescens Schultz-Bip. ex Baker. Willoughbya pannosa (Baker) Kuntze, Revis. Gen. PI. 372. 1891. = Mikania pamosa Baker.

Willoughbya parviflora (Aublet) Kuntze, Revis. Gen. PI. 372. 1891. = Mikania pariflora (Aublet) Karsten.

Willonghbya panifolia (Baker) Kuntze, Revis. Gen. PI. 372. 1891. = Mikania parvifolia Baker.

Willouglibya pernambucensis (Gardner) Kuntze, Revis. Gen. PI. 372. 1891. = Mikania pernambucensis Gardner.

Willoughbya phaeoclados (Martius) Kuntze, Revis. Gen. PI. 372. 1891. = Mikania phaeoclados Martius ex Baker.

Willonghbya phyllopoda (Griseb.) Kuntze, Revis. Gen. Pl. 3(2): 184. 1898. = Mikania urticaefolia Hook. \& Arn.

Willoughbya pilosa (Baker) Kuntze, Revis. Gen. Pl. 372. 1891. = Mikania pilosa Baker.

Willoughbya pinnatiloba (DC.) Kuntze, Revis. Gen. PI. 372. 1891. = Mikania pinnatiloba DC.

Willoughbya platyphylla (DC.) Kuntze, Revis. Gen. PI. 372. 1891. = Mikania hookeriana DC.

Willoughbya pohliana (Schultz-Bip. ex Baker) Kuntze, Revis. Gen. P1. 372. 1891. = Mikania pohliana Schultz-Bip. ex Baker.

Willoughbya polystaclyya (DC.) Kuntze, Revis. Gen. PI. 372. 1891. = Mikania psilostachya DC.

Willoughbya populifolia (Gardner) Kuntze, Revis. Gen. Pl. 372. 1891. = Mikania populifolia Gardner.

Willonghbya premnifolia (Gardner) Kuntze, Revis. Gen. Pl. 372. 1891. = Mikania premnifolia Gardner.

Willoughbya psilostachya (DC.) Kuntze, Revis. Gen. PI. 372. 1891. = Mikania psilostachya DC.

Willoughbya pteropoda (DC.) Kuntze, Revis. Gen. PI. 372. 1891. = Mikania pteropoda $\mathrm{DC}$.

Willonghbya ramosissima (Gardner) Kuntze, Revis. Gen. Pl. 372. 1891. = Mikania ramosissima Gardner.

Willoughbya ranunculifolia (Rich. ex Sagra) Millsp., Publ. Field Columbian Mus., Bot. Ser. 2: 106. 1900. = Mikania ranun. culifolia Rich. ex Sagra.

Willoughbya repanda (Llave) Kuntze, Revis. Gen. P1. 372. 1891. = Mikania pyramidata J. D. Smith, ?

Willoughbya resinosa (Sprengel) Kuntze, Revis. Gen. PI. 372. 1891. = Dasycondylus resinosus (Sprengel) R. King \& H. Robinson.

Willonghbya reticulata (Gardner) Kuntze, Revis. Gen. PI. 372. 1891. = Mikania reticulata Gardner.

Willoughbya retifolia (Schultz-Bip. ex Baker) Kuntze, Revis. Gen. PI. 372. 1891. = Mikania retifolia Schultz-Bip. cx Baker.

Willouglibya rotunda (Griseb.) Kuntze, Revis. Gen. PI. 372. 1891. = Mikania rotunda Griseb.

Willoughbya nufa (Benth.) Kuntze, Revis. Gen. Pl. 372. 1891. = Mikania rufa Benth.

Willoughby'a rufescens (Schultz-Bip. ex Baker) Kuntze, Revis. Gen. Pl, 372. 1891. = Mikania rufescens Schultz-Bip. ex Baker.

Willoughbya ruiziana (Poeppig \& Endl.) Kuntze, Revis. Gen. Pl. 373. 1891. = Mikania banisteriae DC.

Willoughbya salviaefolia (Gardner) Kuntze, Revis. Gen. PI. 373. 1891. = Mikania salviaefolia Gardner.

Willoughbya salzmanniaefolia (DC.) Kuntze, Revis. Gen. PI. 373. 1891. = Mikania salzınanniaefolia DC. 
Willoughbya sarcodes (Baker) Kuntze, Revis. Gen. Pl. 373.1891. - Mikania sarcodes Baker.

Willoughbya scabra (DC.) Kuntze, Revis. Gen. Pl. 372. 1891. = Mikania psilostachya DC.

Willoughbya scabrida (Baker) Kuntze, Revis. Gen. Pl. 373. 1891. - Mikamia scabrida Baker.

Willoughbya scandens (L.) Kuntze, Revis. Gen. PI. 372. 1891. = Mikania scandens (L.) Willd.

Willoughbya selloi (Sprengel) Kuntze, Revis. Gen. Pl. 373. 1891. = Mikania selloi Sprengel.

Willonghbya sericea(Hook. \& Arn.) Kuntze, Revis. Gen. Pl. 373. 1891. = Mikania sericea Hook. \& Arn.

Willoughbya sessilifolia (DC.) Kuntze, Revis. Gen. Pl. 373. 1891. = Mikania sessilifolia DC.

Willoughbya setigera (Schultz-Bip. ex Baker) Kuntze, Revis. Gen. PI. 373. 1891. = Mikania setigera Schultz-Bip. ex Baker.

Willoughbya smilacina (DC.) Kuntze, Revis. Gen. Pl. 373. 1891. = Mikania smilacina DC.

Willoughbya speciosa (DC.) Kuntze, Revis. Gen. P1. 373. 1891. = Mikania speciosa DC.

Willonghbya sprucei (Baker) Kuntze, Revis. Gen. Pl. 373. 1891. = Mikania sprucei Baker.

Willoughbya stipitata (Schultz-Bip. ex Miq.) Kuntze, Revis. Gen. Pl. 373. 1891. = Mikania parviflora (Aublet) Karsten.

W'illoughbya stipulacea (Willd.) Kuntze, Revis. Gen. Pl. 373. 1891. = Mikania stipulacea (Vahl) Willd.

Willoughbya strigosa (Gardner) Kuntze, Revis. Gen. Pl. 373. 1891. = Mikania lasiandrae DC.

W'illoughbya strobilifera (Gardner) Kuntze, Revis. Gen. Pl. 373. 1891. = Mikania oblongifolia DC.

Willoughbya subverticillata (Schultz-Bip.) Kuntze, Revis. Gen. P1. 373. 1891. = Mikania subverticillata Schultz-Bip. ex Baker.

Willoughbya swartziana (Griseb.) Kuntze, Revis. Gen. Pl. 373. 1891. = Mikania swartziana Griseb.

Willonghbya tafallana (H. B. K.) Kuntze, Revis. Gen. PI. 373. 1891. = Mikania tafallana H. B. K.

W'illoughbya tenuiflora (Griseb.) Kuntze, Revis. Gen. P1. 373. 1891. = Austrobrickellia patens (Don ex Hook. \& Arn.) R. King \& H. Robinson.

W'illoughbya ternata (Vell. Conc.) Kuntze, Revis. Gen. Pl. 372. 1891. = Mikania ternata (Vell. Conc.) B. Robinson.

Willoughbya ternifolia (DC.) Kuntze, Revis. Gen. Pl. 373. 1891. = Mikania ternifolia DC.
Willoughbya testudinaria (DC.) Kuntze, Revis. Gen. PI. 373. 1891. = Mikania testudinaria DC.

Willoughbya teucriifolia (Sprengel) Kuntze, Revis. Gen. P1. 373. 1891. = Grazielia gaudichaudeana (DC.) R. King \& H. Robinson.

Willoughbya thapsodes (DC.) Kuntze, Revis. Gen. Pl. 373. 1891. = Mikania thapsoides DC.

Willoughbya thyrsoidea (Baker) Kuntze, Revis. Gen. P1. 373. 1891. = Mikania thyrsoidea Baker.

Willoughbya tlalixcoyan (Llave) Kuntze, Revis. Gen. Pl. 373. 1891. = Mikania tlalixcoyan Llave.

Willoughbya triangularis (Baker) Kuntze, Revis. Gen. PI. 373. 1891. = Mikania triangularis Baker.

Willoughbyatrichophila(DC.) Kuntze, Revis. Gen. Pl. 373. 1891. = Mikania trichophila DC.

Willoughbya trifolia Rusby, Bull. New York Bot. Gard. 4: 382. 1907. = Mikania trifolia (Rusby) B. Robinson.

Willoughbya trinervis (Hook. \& Arn.) Rusby, Bull. New York Bot. Gard. 4: 381. 1907. = Mikania trinervis Hook. \& Arn.

Willoughbya trinitaria (DC.) Kuntze, Revis. Gen. Pl. 373. 1891. = Mikania trinitaria DC.

Willoughbya triphylla (Sprengel ex Baker) Kuntze, Revis. Gen. Pl. 373. 1891. = Mikania triphylla Sprengel ex Baker.

Willoughbya variabilis (Meyen \& Walp.) Kuntze, Revis. Gen. PI. 373. 1891. = Mikania micrantha H. B. K.

Willoughbya vauthierana (Baker) Kuntze, Revis. Gen. Pl. 373. 1891. = Mikania vauthieriana Baker.

Willoughbya verticillata (Schultz-Bip.) Kuntze, Revis. Gen. Pl. 373. 1891. = Mikania anethifolia (DC.) Matzenbacher.

Willoughbya viminea (DC.) Kuntze, Revis. Gen. Pl. 373. 1891. = Mikania viminea $\mathrm{DC}$.

Willoughbya viscosa (Sprengel) Kuntze, Revis. Gen. Pl. 373. 1891. = Bahianthus viscosus (Sprengel) R. King \& H. Robinson.

Willoughbya vismiaefolia (DC.) Kuntze, Revis. Gen. PI. 373. 1891. = Mikania vismiaefolia DC.

Willoughbya vitifolia (DC.) Kuntze, Revis. Gen. PI. 373. 1891. = Mikania vitifolia $\mathrm{DC}$.

Willonghbya warmingii (Schultz-Bip. ex Baker) Kuntze, Revis. Gen. Pl. 373. 1891. = Mikania warmingii Schultz-Bip. ex Baker.

Xetoligus brevifolius Raf., New Fl. 4: 74. 1836, ignota.

Xetoligus salicifolius (Cav.) Raf., New Fl. 4: 74. 1836. = Stevia salicifolia Cav. 


\section{INDEX TO GENERA}

The index lists genera of the Asteraceae, homonyms, names of presently accepted subtribes, subgenera, and sections used in the text and illustrations. Synonyms are in italics. Numbers in bold face indicate main entries of Eupatorian taxa.

Acanthostyles $16,41,55,56,73,74,77$, pl. 8

Acmella 217

Acritopappus 8, 9, 17, 33, 34, 53, 56, 136, 137, 138, 139, 142, $144,145,152,163,218,241,406$, pl. 41

Addisonia 264, 266

Adenocaulon 3, 18

Adenocritonia 32, 40, 48, 57, 292, 294, 297, 300, 302, 304, pl. 116

Adenostemma 1, 2, 3, 4, 7, 20, 25, 29, 30, 48, 49, 51, 56, 58, $59,60,61,62,284, \mathrm{pl} .1$, frontispiece

Adenostemmatinae 4, 9, 17, 20, 24, 44, 56, 58, 159, 284

Adenostyles 3, 4, 8

Adenostylinae 178

Ageratella 4, 20, 31, 45, 57, 219, 233, 406, pl. 86

Ageratina Spach 1, 2, 3, 5, 6, 7, 9, 11, 18, 20, 22, 27, 29, 36, 37, $40,41,47,49,50,52,57,108,126,135,144,183,245$, $287,341,354,427,428,430,431,432,433,434,435,436$, $437,438,440,444,446,448,452$, figs. $3 \mathrm{H}, 4 \mathrm{D}-\mathrm{F}, 5 \mathrm{E}-\mathrm{G}$, pl. 169

subg. Andinia 354, 428, 432, 435

subg. Apoda 427, 428, 432, 436, 444, 448, 450

subg. Klattiella 431,434

subg. Neogreenella 7, 431, 432, 434, 438, 444

subg. Pachythamnus $\mathbf{4 4 2}$

Ageratina O. Hoffm. 433

Ageratinae 9, 10, 17, 18, 20, 22, 26, 27, 29, 44, 56, 85, 120, 136, $137,142,149,152,159,161,163,166,168,170,182,184$, $186,188,213,218,241,249,291,293,337,379,392,398$, $410,419,427,433,437,438,453,458$

Ageratinastrum 433

Ageratiopsis $\mathbf{4 2 8}$

Ageratum 1, 2, 3, 4, 5, 6, 10, 16, 17, 22, 24, 27, 29, 33, 34, 46, $49,53,56,85,106,108,120,124,126,132,136,137,138$, $139,142,144,145,147,149,152,154,156,159,163,188$, $190,192,233,241,390,428,430,431,433,436,438, \mathrm{pl}$. 43

sect. Coelestina 142

sect. Pectinellum 145

sect. Perplexans 145

sect. Stachyofolium 142

subg. Coelestina 142

Agrianthus $3,4,27,34,36,39,54,56,85,86,113,118,122$, $124,126, \mathrm{pl} .31$

Ainsliaca 249,272

Alciope 3

Alomia 1, 2, 3, 4, 5, 22, 27, 33, 46, 57, 104, 137, 139, 144, 149, $156,159,208,218,219,231,239,241,243,262.264,284$, $378,440,458, \mathrm{pl} .90$

subg. Geissanthodium 241

Alomiella 33, 52, 56, 194, 195, 208, 210, 215, 241, pl. 76

Alominae $8,9.11,17,18,20,22,24,26,27,44,56,77,84$, $104,137,178,194,201,206,208,218,222,224,228,233$,
$235,237,239,240,245,247,249,251,252,253,256,258$, $260,262,264,265,266,268,272,282,285,291,293,312$, $337,379,395,406,446,453,455,456$

Amboroa 4, 24, 42, 57, 292, 294, 376, pl. 151

Ambrosia 64

Ambrosiinae 20

Ammopursus 270, 272, 273

Amolinia 37, 39, 48, 57, 397, 398, 399, 401, 403, 414, pl. 161

Anisochaeta 3

Anonymos 275

Antennaria 376

Antillia 16, 34, 48, 57, 125, 292, 293, 304, 306, 308, pl. 117

Apodocephala 4

Aristeguietia 17, 24, 42, 50, 57, 85, 292, 293, 294, 343, 345, 346, $350,352,366,405$, pl. 136

Arnica 20

Arnoglossum 3

Arrojadoa Mattf. 4, 118, 120

Arrojadoa Britton \& Rose 118

Arrojadocharis 4, 24, 27, 30, 39, 54, 56, 85, 86, 118, 120, pl. 32

Asanthus 24, 32, 47, 57, 219, 222, 233, 235, 249, pl. 87

Aschenbornia 4, 215

Ascidiogyne 4, 20, 22, 30, 56, 137, 152, 154, 213, pl. 48

Asplundianthus $43,51,57,292,295,345,346,347,350$, pl. 137

Aster 430

Austrobrickellia 27, 38, 52, 57, 220, 253, 256, 266, pl. 97

Austrocritonia 43. 55, 57, 292, 293, 295, 349, 361, pl. 138

Austroeupatorium $6,16,29,38,51,53,56,64,65,67,69,71$, fig. $4 \mathrm{~B}, \mathrm{pl} .5$

Ayapana 1, 3, 22, 35, 38, 49, 51, 53, 56, 128, 194, 195, 197, $199,201,208,210,213,215,217$, pl. 69

Ayapaninae 16, 17, 20, 22, 26, 44, 45, 56, 128, 136, 154, 156. $161,163,190,194,197,201,204,206,208,210,213,215$, $217,218,241,284,293,310,398,399,456$

Ayapanopsis 20, 22, 38, 51, 53, 56, 195, 197, 199, 201, fig. 4I, pl. 70

Baccharis 1, 74, 77, 199, 326, 376, 421

Badilloa 42, 50, 57, 292, 294, 345, 346, 350, 351, 352, 357, 366, pl. 139

Bahianthus $8,39,54,56,85,86,112,113,115,122$, pl. 29

Barroetea 4, 11, 32, 35, 38, 46, 56, $218,220,222,223,224,227$, 379 , pl. 82

Barrosoa 22, 29, 40, 51, 55, 56, 85, 87, 92, 94, 97, 102, 122, $126,128,130,405, \mathrm{pl} .17$

Bartlettina 18, 28, 37, 43, 48, 51, 55, 57, 92, 341, 345, 398, 399, $401,403,405,406,414$, fig. $3 \mathrm{~F}$, pl. 162

Batschia J. Gmelin 428

Batschia Moench 2, 3, 428, 433

Batschia Mutis ex Thunb. 428

Batschia M Vahl 428

Bejaranoa 40, 42, 55, 56, 85, 87, 97, 99, 100, 102, pl. 21

Biolettia 188

Bishopiella 16, 39. 53, 56, 84, 86, 124, 125, 126, 306, 324, pl. 35

Bishovia 7, 40, 57, 292, 293, 314, 324, 332, pl. 125

Blakeanthus $17,33,46,56,138,149,241$, pl. 46

Brachyandra 4, 264, 266

Brachyglottis 3

Brickellia 1. 2, 3. 4. 5, 6, 7, 9, 11, 16, 17, 22, 24, 27, 29, 32, 38, 
$46,49,51,52,56,137,149,156,194,218,219,220,222$, $223,224,227,228,231,233,235,239,241,243,245,247$, $249,250,251,252,253,256,262,264,326,285$, fig. $4 C$, pl. 81

sect. Bulbostylis 222

sect. Eubrickellia 222, 228

sect. Gemmipedium 222, 235

sect. Leptanthodium $\mathbf{2 2 2}$

sect. Macrobrickellia 222

sect. Pityophyllum 222, 256

sect. Pseudocarphephorus 222, 256

sect. Steviastrum 222, 235, 249

subg. Phanerostylis 227

Brickelliastrum 41, 56, 219, 222, 228, 231, 245, fig. 5A, pl. 84

Bulbostylis DC. 3, 194, 218, 220, 222

Bulbostylis Kunth 220

Cacalia 282

Caelestina 144

Calea $4,215,217$

Calostelma 270, 272, 273

Campovassouria $41,55,56,73,77,79$, pl. 11

Campuloclinium 1, 3, 20, 22, 34, 38, 40, 46, 52, 54, 56, 85, 86, $97,104,126,128,130,144,194,204,382$, pl. 36

Caradesia 288

Carelia A. L. Juss. ex Cav. 142, 419

Carelia Less. 3, 4, 142

Carelia Ponted. ex Fabr. 142

Carminatia 4, 24, 35, 46, 57, 219, 249, 250, pl. 95

Carphephorus 2, 3, 4, 32, 57, 256, 270, 272, 275, 277, 279, 280, 282 , pl. 108

Carphochaete $4,10,18,20,22,24,32,33,45,56,138,178,180$, $182,218,438, \mathrm{pl} .60$

Carterothamnus $4,16,17,24,28,34,46,57,453,456,458,460$, pl. 180

Castenedia 22, 43, 51, 57, 295, 343, 354, 357, 359, pl. 142

Cavalcantia 33.53,56,138, 154, 156, pl. 49

Celmisia 3

Chacoa $39,42,57,292,294,316,324,332$, pl. 130

Chaenactidinae 20,173, 217

Chaenactis 20

Chamaechaenactis 20

Chone 64

Chromolaena 3, 6, 7, 8, 11, 16, 17, 29, 36, 46, 49, 50, 52, 57, $79,272,312,314,316,319,359,379,380,382,383,385$, $386,387,388,390,397$, fig. 3E, pl. 154

subg. Osmiella $379, \mathbf{3 8 3}, 385$

Chrysactinium 18

Ciceronia 4, 16, 20, 31, 48, 57, 125, 293, 304, 306, 308, pl. 118

Clavigera $3,220,222$

Coelestina 3, 142

Coleosanthus 3, 220, 222

Condylidium 16, 22, 38, 49, 51, 56, 195, 206, pl. 74

Condylopodium $37,38,50,57,220,266,268$, pl. 104

Conocliniopsis $26,29,40,51,54,56,85,87,92,97,100,102$, $122,126,128,130,135, \mathrm{pl} .20$

Conoclinium $2,3,7,11,22,26,40,47,56,85,86,92,97,130$, $132,135,382, \mathrm{pl} .38$

Coreopsidinae 25, 60

Corethamnium 18,41, 50, 57, 292, 294, 354, 357, 359, 452, pl. 141

Corynanthelium 419

Critonia 2, 3, 16, 40, 47, 48, 50, 55, 57, 243, 292, 293, 294, 295,
$297,298,300,301,302,304,310,316,330,343,346,349$, $350,363,370,378, \mathrm{pl} .113$

Critoniadelphus 22, 32, 41, 47, 57, 292, 294, 297, 298, 300, 301, $302,304,310$, pl. 114

Critoniella 22, 43, 51, 57, 292, 295, 341, 343, 346, 357, 398, 401 , pl. 135

Critoniinae $11,17,18,20,22,26,27,28,44,45,57,84,85$, $100,125,130,135,136,137,149,161,168,194,201,243$, $245,247,268,284,291,292,293,297,300,304,306,308$, $310,311,312,314,316,326,332,337,339,340,341,343$, $345,346,349,350,352,354,357,359,361,363,365,366$, $370,371,373,376,378,379,380,392,397,398,401,405$, $410,414,415,417,419,421,427,448,450,452$

Cronquistia $4,10,35,45,56,138,171,178,180,182,368$, pl. 61

Cronquistianthus $9,18,22,42,50,57,135,180,292,294,345$, $365,366,367,368,370$, pl. 147

Crossothamnus 27, 37, 57, 220, 262, 264, 268, pl. 102

Cunigunda 64

Dahlia 20

Dalea L. 295

Dalea P. Browne 295, 297

Dasycondylus $20,22,38,53,56,87,92,94,97,126$, pl. 18

Decachaeta $3,4,16,20,28,31,47,57,138,139,316,341,365$, $397,398,399,401,403,406,408,410,414$, pl. 163 subg. Polyadenia $\mathbf{4 0 8}$

Diacranthera $20,31,38,53,56,87,94,97,102,113$, pl. 19

Dichaeta Nutt. 182

Dichaeta Sch.-Bip. 182

Dimorpholepis (Barroso) King \& Robinson 79, 81

Dimorpholepis A. Gray 79

Dissothrix 4, 27, 35, 52, 57, 219, 251, 253, 395, 446, pl. 96

Disynaphia $8,42,55,56,73,77,79,81,84,217,256$, pl. 10

Disynaphiinae $9,22,24,25,26,45,56,64,73,77,85,113,258$, $260,272,285,349,371,379,428$

Dunantia 215

Dyscritogyne $41,47,57,219,241,243,247,249,268$, pl. 91

Dyscritothamnus 4

Ecliptinae 22, 156

Eitenia $18,35,52,57,252,379,380,382,388,392,395$, pl. 158

Ellenbergia $4,18,20,28,31,56,136,137,159,161,163,166$, 168,213, pl. 52

Eremanthus 20,62

Erigeron 430

Erythradenia 30, 45, 57, 168, 398, 399, 408, 410, pl. 164

Eupatoriadelphus 5, 65

Eupatoriastrum 16, 17, 31, 36, 46, 57, 292, 293, 314, 319, 321, $335,383,414$, pl. 123

Eupatoriinae $9,20,24,25,26,44,45,56,64,73,85,89,285$, 293,428

Eupatorina 16, 42, 48, 57, 292, 293, 304, 306, 308, 310, pl. 119

Eupatoriopsis 4, 5, 17, 22, 33, 35, 52, 57, 128, 188, 379, 380, $382,388,390,392,395, \mathrm{pl} .155$

Eupatorium 1, 2, 3, 4, 6, 7, 10, 11, 16, 18, 22, 25, 26, 30, 38, $46,49,56,64,65,67,69,71,73,74,79,81,84,85,87,89$, $92,94,97,99,100,104,106,108,110,113,120,124,125$, $126,128,130,132,137,144,188,194,195,197,199,200$, $201,204,206,208,222,227,231,241,243,245,247,249$, $253,256,262,266,272,285,287,291,292,293,295,297$, $298,300,304,306,308,310,317,319,321,326,328,330$, $332,337,339,341,343,346,349,350,352,357,359,361$, $365,366,368,370,371,373,379,382,383,385,388,390$, $397,399,401,405,406,408,410,412,414,415,419,421$, 
$427,428,430,431,432,433,440,442,444,446,448,450$, 453,454 , pl. 4

sect. Campuloclinium 126

sect. Conoclinium 130, 135

sect. Cylindrocephala 382, 383, 385

sect. Dimorpholepis 73, 79

sect. Eximbricata 432

sect. Hebeclinium 200, 201, 398, 399, 401, 408

sect. Osmia 383

sect. Subimbricata 383, 398

sect. Praxelis 120, 380, 385, 388, 390

sect. Traganthes 26

sect. Urolepis $\mathbf{8 9}$

subg. Gyptis $\mathbf{8 7}$

subg. Phanerostylis 227

Eutrochium 64, 65, 67

Ferreyrella 4, 17, 18, 28, 30, 56, 136, 137, 149, 159, 161, 163, $168,186,213, \mathrm{pl} .54$

Fitchia 25

Fleischmannia $4,5,11,16,18,22,23,29,36,37,39,41,47$, $49,51,55,57,135,284,285,287,288,289,310,395,421$, $427,431,446,453,455$, figs. 3B, C, 5C. pl. 111

Fleischmanniinae 17, 18, 20, 27, 44, 57, 124, 135, 284, 285, 310, $395,427,446,453$

Fleischmanniopsis 22, 31, 47, 57, 292, 294, 300, 304, 308, 310, $311,312,314,341,370$, pl. 120

Flyriella $7,22,38,46,57,206,220,231$, pl. 85

Galinsoga 145

Galinsoginae 184

Garberia 4, 32, 57, 260, 270, 272, 279, 280, 282, pl. 109

Gardnerina 18, 31, 53, 56, 137, 157, 159, 161, 241, pl. 51

Gongrostylus 16, 20, 22, 31, 38, 50, 56, 194, 195, 201, 456, pl. 72

Goyazianthus $8,32,35,52,57,84,219,253,256,258,260$, pl. 99

Grazielia 16, 41, 55, 56, 73, 77, 79, 81, 84, pl. 12

Grisebachianthus 42, 48, 57, 292, 294, 316, 328, 330, pl. 128

Grosvenoria $42,57,294,345,346,350,352,357$, pl. 140, frontispiece

Guayania 22, 42, 51, 55, 57, 359, 398, 399, 401, 405. 410, 412, pl. 165

Guevaria 16, 28, 31, 56, 138, 149, 159, 161, 163, 166, 168, pl. 53

Guizotia 25

Gymnocondylus 37, 53, 56, 195, 206, 208, pl. 75

Gymnocoronis 3, 4, 30, 45, 51, 56, 58, 62, 284, pl. 3

Gyptidinae $8,9,17,18,20,22,24,25,26,27,29,44,56,64$, $73,77,84,85,89,97,100,102,108,110,111,113,115$, $118,120,122,124,125,126,128,130,132,135,136,137$, $194,217,219,241,284,285,287,291,293,306,312,324$, $349,398,399,406,428$

Gyptidium 17, 36, 37, 39, 55, 56, 87, 89, 92, pl. 15

Gyptis 2, 3, 16, 40, 54, 56, 84, 85, 87.89, 113, pl. 14

Haberlea $\mathbf{3 8 0}$

Hartwrightia 4, 8, 30, 33, 57, 58, 270, 282, 283, 284, pl. 110

Hatschbachiella $38,53,56,64,71$, pl. 7

Hcbecliniinae 9, 16, 17, 18, 20, 22, 28, 44, 57, 92, 168, 292, $316,319,332,341,343,359,361,365,370,392,397,398$, $399,403,406,410,412,414$

Hebeclinium $3,17,18,22,28,29,37,43,48,49,51,55,57,89$, $341,343,357,361,370,397,398,399,401,403,405,408$, 412 , pl. 160 sect. Urolepis 89

Helogyne Benth. 453

Helogyne Nutt. 4, 24, 27, 35, 39, 41, 57, 104, 219, 251, 264, 265,266, pl. 103

Heterocondylus 16, 20, 37, 38, 51, 53, 56, 126, 194, 195, 204. 208, pl. 73

Hieraceum 124

Hofmeisteria 4, 5, 17, 18, 20, 22, 23, 24, 31, 34, 36, 45, 57. 237 , $239,287,392,452,453,455,460$, fig. $5 \mathrm{H}, \mathrm{pl} .178$

Hofmeisteriinae $9,16,17,26,44,57,392,427,452,453,456$

Homogyne 3

Hughesia 16, 43, 57, 295, 361, 363, 370, 419, pl. 145

Idiothamnus $17,28,29,36,39,42,55,57,292,294,316,319$, 335. pl. 131

Iltisia $4,18,30,56,137,138,186,213, \mathrm{pl} .65$

Imeria $43,57,295,354,357,359$, pl. 143

Inula 3

Ismiaria $\mathbf{2 2 0}$

Isocarpha Less. 142

Isocarpha R. Br. 2, 3, 4, 7, 17, 18, 20, 22, 33, 44, 46, 48, 49, 52 , $56,156,194,195,213,215,217$, pl. 80

Isotypus 184

Jaliscoa 17, 33, 34, 35, 36, 46, 57, 427, 428, 438, 440, 442, pl. 172

Jaramilloa $36,39,41,50,57,427,428,430,448,450,452$, pl 177

Kallophyllon 81

Kanimia 4, 5, 22, 113, 218, 419, 421, 422

Kaunia 7, 16, 36, 39. 42, 57. 427, 428, 430, 448, 450, 452, pl. 176

Koanophyllon $6,8,11,17,20,24,27,31,32,40,42,43,45$, $47,48,50,51,54,57,100,243,245,292,293,294,304$. $308,311,314,316,317,318,319,321,324,326,328,330$, $332,335,337,339,349,357,365,366,367,373,379,397$, $414, \mathrm{pl}, 122$

Kuhnia 2, 3, 4, 5, 102, 104, 106, 113, 218, 219, 220, 222, 223, $249,250,297$

sect. Leiogonia 102, 104, 106

sect. Trichogonia 3, 102

Kuhniinae 4, 168, 178, 218

Kyrstenia 2, 245, 428, 430, 433

Kyrsteniopsis 41, 47, 57, 219, 222, 228, 231, 243, 245, 247, pl. 92

Lacinaria $270,272,273$

Lasiolaena $8,20,39,54,56,85,86,120,122,124$, pl. 33

Lasthenia 20

Lavenia 58

Lepidesmia 4, 17, 22, 34, 48, 56, 194, 195, 197, 213, 215, 217. pl. 79

Leptoclinium Benth. 4, 27, 35, 52, 57, 219, 256, 258, 260, 272, 282, pl. 100

Leptoclinium (Nutt.) A. Gray $\mathbf{2 8 0}$

Leto 264, 266

Liabum 417

Liatrinae $9,16,22,24,26,44,57,58,125,178,218,219,268$. $270,279,280,282,284,306$

Liatris $2,3,4,6,8,9,16,22,24,25,32,57,218,219,249,258$, $260,268,270,272,273,275,277,279,280,282,284$, pl. 105 , frontispiece

sect. Letoclinium 280

sect. Suprago 270, 272, 279

sect. Trilisa 275 
subg. Corymbilis 277

subg. Euthyrsis 275

subg. Osmilis 275

subg. Trilisa 275, 277

Litothamnus $40,54,56,86,97,102,110,111,112,113$, pl. 28

Litrisa $32,57,270,272,273,275,277,279,280,282,306, \mathrm{pl}$. 106

Lomatozona 4, 16, 34, 52, 57, 210, 213, 378, 379, 380, 390, 392, $395, \mathrm{pl} .156$

Lorentzianthus $36,43,57,292,295,316,330,332$, pl. 129

Lourteigia 17, 22, 26, 39, 41, 50, 56, 85, 86, 97, 130, 132, 134, $135,136, \mathrm{pl} .40$

Lycapsus 240

Macropodina 38, 53, 56, 86, 106, 128, 130, pl. 37

Macvaughiella 4, 10, 22, 34, 45, 56, 136, 138, 182, 183, 184, 458 , pl. 63

Mallinoa 428, 431, 433

Malmeanthus 43, 55, 57, 292, 293, 295, 349, 359, 360, 361, pl. 144

Malperia $24,34,46,57,219,235,237,239,453,455$, pl. 88

Margacola 188

Matudina 16, 17, 28, 35, 36, 46, 57, 319, 397, 398, 399, 403, $406,412,414$, pl. 166

Melampodium 20

Melanthera 25

Metastevia 20, 32, 46, 56, 138, 171, 175, 182, pl. 59

Mexianthus 16, 17, 34, 45, 57, 292, 293, 314, 321, 335, 337, 339 , pl. 132

Microconia 70

Microspermum 2, 4, 10, 14, 18, 20, 30, 45, 56, 137, 163, 184, $186,379,392$, pl. 64

Mikania 1, 2, 3, 4, 5, 6, 7, 8, 9, 16, 17, 18, 22, 24, 25, 27, 29, $32,36,47,48,50,52,57,81,113,218,282,328,361,365$, $378,415,418,419,421,422,423,424,425,426$, fig. $3 \mathrm{G}$, pl. 168

sect. Corymbosae $\mathbf{4 2 2}$

sect. Globosae $\mathbf{4 2 2}$

sect. Partitae $\mathbf{4 2 2}$

sect. Racemosae $\mathbf{4 2 2}$

sect. Spiciformes $\mathbf{4 2 2}$

sect. Thyrsigerae $\mathbf{4 2 2}$

Mikaniinae 9, 44, 57, 178, 218, 418, 419, 421, 427

Milleriinae 25

Miradoria 184

Monogereion 34, 53, 56, 154, 194, 195, 208, 210, 213, 215, pl. 77

Morithamnus 16, 24, 27, 34, 40, 54, 56, 85, 86, 102, 112, 113, 115,122 , pl. 30 , frontispiece

Moronoa 419

Morrenia 419

Munnozia subg. Kastnera 20

Mustelia 170

Nardosmia 3

Nelsonianthus 444

Neobartlettia King \& Robinson 403

Neobartlettia Schlechter 403

Neocabreria $17,18,31,37,43,54,57,84,292,294,349,350$, $370,371,373$, pl. 149

Neocuatrecasia 26, 35, 38, 56, 85, 86, 108, 110, pl. 26

Neohintonia 16, 17, 36, 45, 57, 292, 293, 314, 316, 321, 337, 339 , pl. 133
Neomirandea $9,16,17,18,37,39,42,47,50,57,370,378,398$, $414,415,417,418,447,448$, pl. 167

subg. Critoniopsis $9,415,417$

Neomirandeinae $9,26,28,44,57,292,414,415,417,418,427$, 447

Neurolaena 1

Nothites 3, 170

Nothobaccharis 43, 57, 292, 293, 314, 324, 326, pl. 126

Oaxacania $17,22,24,28,33,45,57,182,455,456,458,460$, pl. 179

Oaxacaniinae $9,26,28,44,57,182,427,452,455,456$

Olearia 3

Onoseris 184

Ooclinium 3, 380, 382

Ophryosporus 4, 16, 20, 22, 31, 54, 57, 136, 137, 161, 168, 292, $293,306,316,326,337,363,364,365,366,370,378,398$, $408,410,419$, pl. 146

Orsinia 3

Osmia 383, 397

Osmiopsis 11, 27, 36, 48, 57, 316, 379, 380, 385, 392, 397, pl. 159

Oxylobinae $9,17,18,20,26,27,29,44,57,108,144,147,182$, $183,194,245,284,285,287,354,398,415,418,419,427$, $428,430,437,440,446,448,450,452$

Oxylobus 9, 27, 35, 45, 49, 57, 144, 147, 182, 183, 427, 428, $430,436,437,438,440,442,448$, pl. 170

Pachythamnus $36,40,47,57,427,428,442,444,448$, pl. 173

Palafoxia 3, 173

Paleolaria 3

Parapiqueria $17,30,52,56,136,154,161,163,194,195,210$, $213,215,390$, pl. 78

Petasites 3

Peteravenia 35, 43, 48, 57, 295, 339, 340, 341, 398, 405, 414, pl. 134

Phalacraea $3,20,31,49,56,138,147,149,161,168,192$, pl. 45

Phanerostylis $11,38,46,56,220,222,224,227,228,231,285$, fig. 5B, pl. 83

Phania $3,4,18,20,31,49,56,120,137,144,145,147,149$, $436,438,455$, pl. 44

sect. Oxylobus $\mathbf{4 3 6}$

Pinillosa 18,20

Piptothrix 17, 36, 37, 47, 57, 427, 428, 438, 440, 442, 448, pl. 171

Piqueria $1,2,3,4,5,10,17,18,20,22,30,45,48,56,85,120$, $136,137,147,157,159,161,166,168,170,186,194,213$, $249,292,316,361,364,365,398,408,410,419$, 453, fig. $4 \mathrm{H}$, pl. 57

sect. Artemisioides 363, 365, 410

subg. Erythradenia 408

subg. Eupiqueria 168,170

Piqueriella 28, 31, 53, 56, 138, 159, 161, 163, 166, 168, pl. 55

Piqueriinae 136, 137, 147, 168, 170, 266, 284, 306, 337, 339, $363,388,392,453$

Piqueriopsis $4,18,20,28,30,31,45,56,136,138,159,161$, $163,166,168,186,213$, pl. 56

Pittocaulon 442

Planaltoa 4, 27, 33, 52, 57, 219, 260, 262, pl. 101

Platypodanthera $34,54,56,85,86,104,106,108,144$, pl. 25

Pleurocoronis 22, 24, 34, 46, 57, 219, 237, 239, 453, 455, fig. 5I, pl. 89 
Pluchea 1, 199

Podophania 4, 392, 453, 455

Polyanthina 17, 18, 37, 38, 51, 56, 195, 199, 200, 201, 398, 399, pl. 71

Praxelinae 11, 17, 18, 20, 26, 27, 28, 29, 44, 57, 128, 163, 184, $188,210,213,253,272,291,292,293,312,316,319,359$, $378,379,380,383,385,388,392,395,397$

Praxeliopsis 4, 14, 18, 20, 31, 52, 57, 184, 379, 380, 392, 395 pl. 157

Praxelis 3, 17, 20, 22, 29, 35, 36, 50, 52, 57, 126, 379, 380, 382, $383,385,388,390,392,395$, figs. 3D, 5D, pl. 153

Prolobus 40, 54, 56, 87, 100, 102, 112 , pl. 22

Pseudobrickellia 32, 38, 52, 57, 77, 219, 222, 256, 258, 260, pl. 98

Pseudokyrsteniopsis 41, 47, 57, 219, 245, 247, pl. 93, frontispiece Psilosanthus 270, 272

Radlkoferotoma 34, 53, 56, 136, 137, 138, 142, pl. 42

Raulinoreitzia $41,55,56,73,74,77,84$, pl. 9

Revealia $33,45,56,138,178,180,182,438$, pl. 62 , frontispiece Rosalesia 220

Rudbeckiinae 20

Santosia 42, 55, 57, 292, 293, 316, 326, 328, pl. 127

Sartoria 291

Sartorina 20, 22, 41, 47, 57, 124, 285, 287, 291, pl. 112

Saussurea 272

Schaetzellia Klotz 182, 184

Schaetzellia Sch.-Bip. 4, 182, 458

Scherya 34, 53, 56, 138, 150, 152, 156, pl. 47

Schistocarpha 1

Sciadocephala 4, 20, 29, 30, 49, 56, 58, 60, 61, 62, fig. 4A, pl. 2 Sclerolepis 2, 3, 4, 16, 34, 56, 188, 192, 193, pl. 68

Serratula 270, 272

Shawia 3

Shinnersia 33, 46, 56, 188, 190, 191, 192, pl. 67

Sigesbeckia 25

Spaniopappus $4,24,35,40,41,49,57,427,428,442,444,446$, 448 , fig. 31, pl. 174

Sparganophorus 192

Sphaereupatorium 16, 36, 54, 57, 292, 294, 314, 321, 337, pl. 124

Spilanthes 217

Staehelina 270,272

Standleyanthus $16,40,57,415,427,428,446,447,448, p l .175$

Steleocodon 147

Stevia $1,2,3,4,6,8,10,17,18,20,25,29,32,46,48,49,52$, $56,136,137,138,161,170,171,172,173,174,175,178$, $180,182,186,233,247,249,251,253,390,427,458$, pl. 58

sect. Breviaristatae 172

sect. Corymbosae 172 sect. Eustevia 172

sect. Fruticosae 172

sect. Multiaristatae 172

sect. Podocephalae 172

Steviopsis $32,47,57,219,222,235,243,245,247,249,268$, pl. 94

Steyermarkina 18, 28, 43, 55, 57, 292, 295, 349, 350, 363, 368, $370,371,399, \mathrm{pl} .148$

Stokesia 22

Stomatanthes $18,26,38,53,56,64,69,70,71,89$, pl. 6 subg. verticifolium 69

Stylotrichium 4, 8, 20, 22, 33, 34, 52, 56, 85, 86, 118, 122, 124 , pl. 34

Suprago 3, 270, 272, 273

Symphyopappus $4,8,41,55,56,73,77,79,81,84,113,135$, $258,260,272,349,371,379$, pl. 13

Tagetinae 184

Tamaulipa $6,26,40,42,48,56,85,87,132,312$, pl. 39

Tamayoa 213, 215

Teixeiranthus $18,33,53,56,136,138,152,156,217,241$, pl. 50

Traganthes $64,65,67$

Trichocoroniinae $10,26,44,56,85,144,188,197$

Trichocoronis 4, 34, 46, 56, 144, 188, 190, 191, 192, 197, 379, $388, \mathrm{pl} .66$

Trichogonia 4. 7, 18. 22, 33, 35, 50, 53, 56, 85, 86, 102, 104, $106,108,128,130,135,219,241,287$. figs. $3 \mathrm{~A}, 4 \mathrm{G}$, pl. 23

Trichogoniopsis $7,20,31,35,53,56,86,102,104,106,130$, 219 , pl. 24

Trilisa $2,3,4,6,32,57,270,272,275,277,279,280,306$, pl. 107

Trychinolepis $337,361,364,365$

Tuberostyles 4, 16, 22, 33, 49, 57, 292, 293, 376, 378, 415, pl. 152

Tussilago 3

Uleophytum $4,42,57,292,293,363,373,378$, pl. 150

Uncasia 65,67

Urbananthus $18,32,41,48,57,292,294,297,300,301,302$, 304 , pl. 115

Urolepis $17,37,39,54,56,87,89,92,398,399$, pl. 16

Ursinia 12

Verbesina 2

Vernonia 2, 272

Viereckia $43,48,57,295,312,314$, pl. 121

Vittetia $32,54,56.85,87,110, \mathrm{pl} .27$

Wikstroemia Endl. 295

Wikstroemia Schrader 295

Wikstroemia Spreng. 295

Willoughbya 419

Xetoligus 170 
Acanthostyles 74

Acritopappus 138

Adenocritonia 302

Adenostemma 58

Ageratella 233

Ageratina 428

Ageratum 142

Agrianthus 118

Alomia 239

Alomiella 208

Amboroa 376

Amolinia 401

Antillia 304

Aristeguietia 343

Arrojadocharis 118

Asanthus 233

Ascidiogyne 152

Asplundianthus 346

Austrobrickellia 253

Austrocritonia 349

Austrocupatorium 67

Ayapana 195

Ayapanopsis 195

Badilloa 350

Bahianthus 113

Barroetea 224

Barrosoa 92

Bartlettina 403

Bejaranoa 99

Bishopiella 124

Bishovia 324

Blakeanthus 149

Brickellia 220

Brickelliastrum 228

Campovassouria 79

Campuloclinium 126

Carminatia 249

Carphephorus 277

Carphochaete 178

Carterothamnus 458

Castanedia 354

Cavalcantia 154

Chacoa 332

Chromolaena 383

Ciceronia 306

Condylidium 206

Condylopodium 266

Conocliniopsis 97

Conoclinium 130
Corethamnium 354

Critonia 295

Critoniadelphus 298

Critoniella 341

Cronquistia 178

Cronquistianthus 366

Crossothamnus 262

Dasycondylus 94

Decachaeta 406

Diacranthera 94

Dissothrix 25!

Disynaphia 77

Dyscritogyne 241

Eitenia 395

Ellenbergia 159

Erythradenia 408

Eupatoriastrum 319

Eupatorina 308

Eupatoriopsis 388

Eupatorium 64

Ferreyella 163

Fleischmannia 285

Fleischmanniopsis 310

Flyriella 231

Garberia 280

Gardnerina 157

Gongrostylus 201

Goyazianthus 258

Grazielia 79

Grisebachianthus 328

Grosvenoria 352

Guayania 410

Guevaria 161

Gymnocondylus 206

Gymnocoronis 62

Gyptidium 89

Gyptis 87

Hartwrightia 282

Hatschbachiella 71

Hebeclinium 399

Helogyne 264

Heterocondylus 204

Hofmeisteria 453

Hughesia 361

Idiothamnus 335

Iltisia 186

Imeria 357

Isocarpha 215

Jaliscoa 440
Jaramilloa 450

Kaunia 448

Koanophyllon 314

Kyrsteniopsis 243

Lasiolaena 120

Lepidesnia 213

Leptoclinium 258

Liatris 270

Litothamnus 110

Litrisa 273

Lomatozona 390

Lorentzianthus 330

Lourteigia 132

Macropodina 128

Macvaughiella 182

Malmeanthus 359

Malperia 235

Matudina 412

Metastevia 175

Mexianthus 335

Microspermum 184

Mikania 419

Monogereion 210

Morithamnus 115

Neocabreria 371

Neocuatrecasia 108

Neohintonia 337

Neomirandea 415

Nothobaccharis 324

Oaxacania 456

Ophryosporus 363

Osmiopsis 397

Oxylobus 436

Pachythamnus 442

Parapiqueria 210

Peteravenia 339

Phalacraea 147

Phanerostylis 227

Phania 145

Piptothrix 438

Piqueria 168

Piqueriella 166

Piqueriopsis 166

Planaltoa 260

Platypodanthera 106

Pleurocoronis 237

Polyanthina 199

Praxcliopsis 392

Praxelis 380 
Prolobus 100

Pseudobrickellia 256

Pseudokyrsteniopsis 245

Radlkoferotoma 142

Raulinoreitzia 74

Revealia 180

Santosia 326

Sartorina 287

Scherya 150

Sciadocephala 60

Sclerolepis 192
Shinnersia 190

Spaniopappus 444

Sphaereupatorium 321

Standleyanthus 446

Stevia 170

Steviopsis 247

Steyermarkina 368

Stomatanthes 69

Stylotrichium 122

Symphyopappus 81

Tamaulipa 132
Teixeiranthus 156

Trichocoronis 188

Trichogonia 102

Trichogoniopsis 104

Trilisa 275

Tuberostyles 376

Uleophytum 373

Urbananthus 300

Urolepis 89

Viereckia 312

Vittetia 100 
